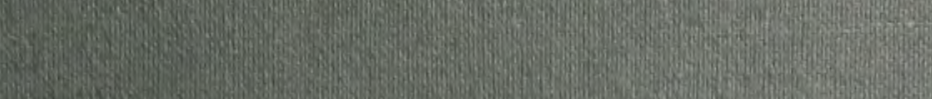

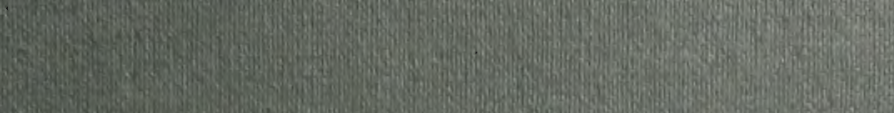
Whing

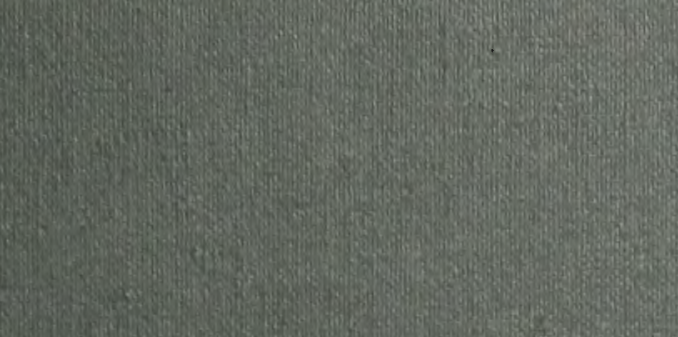

wowing

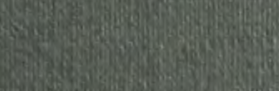

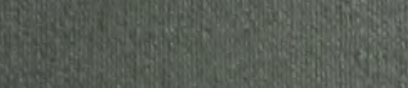

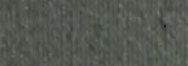

45.

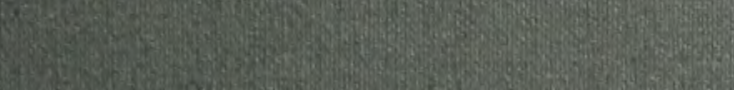

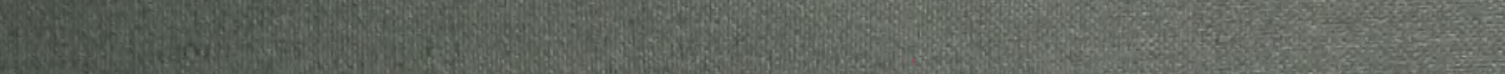

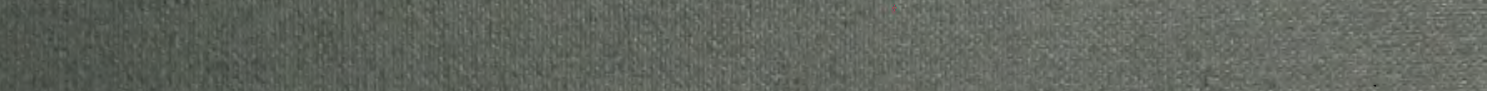

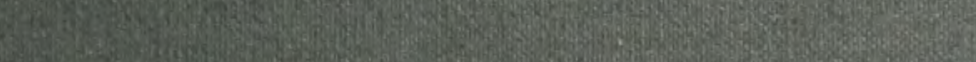

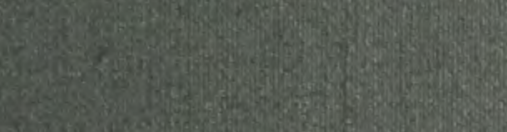

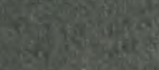

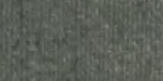

17.

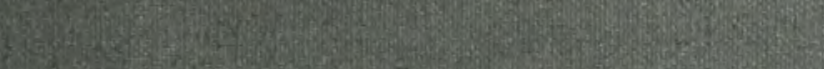

(20)

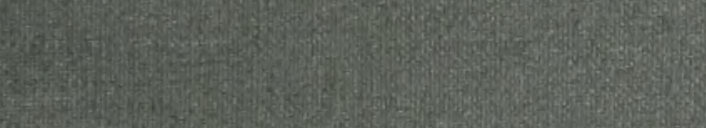

7.5.

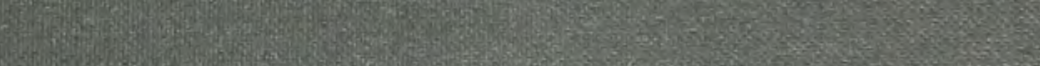

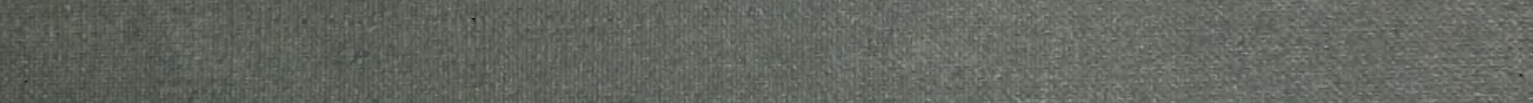

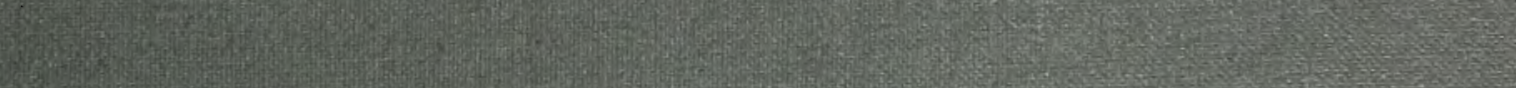

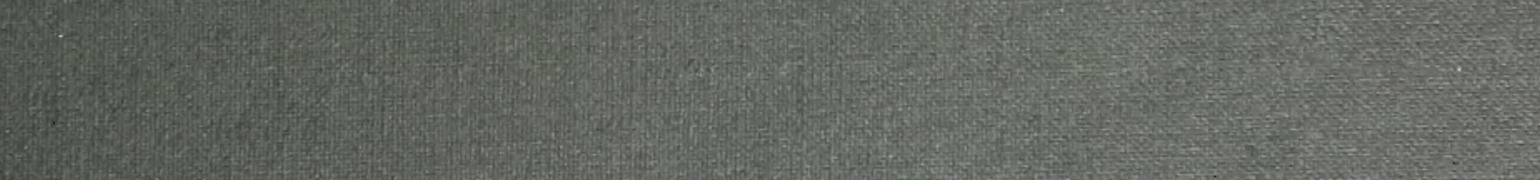

(1)

The

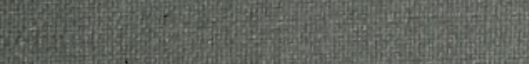

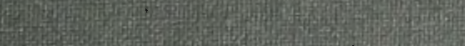

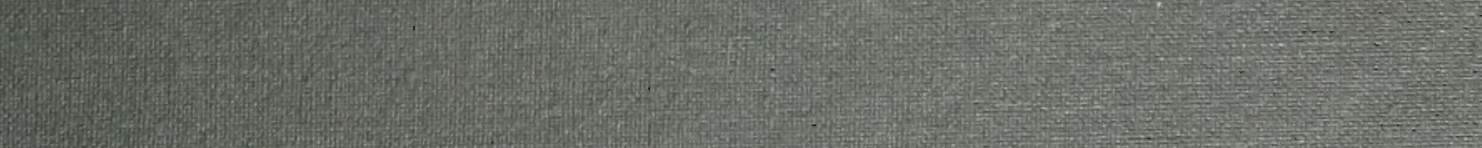

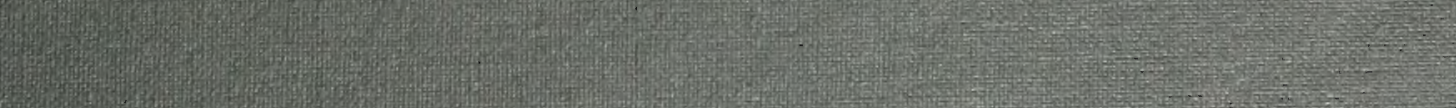

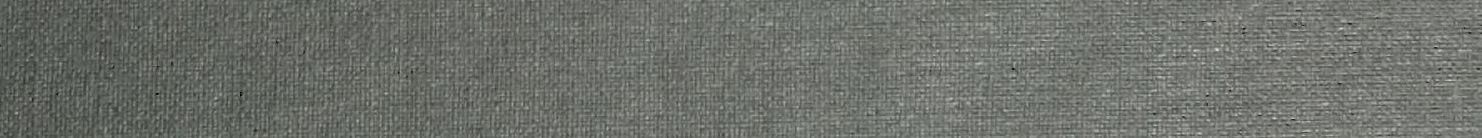




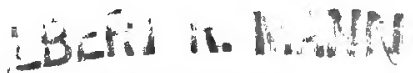 LIBRARY COFNFLL UNIVERS}


$\begin{array}{lllll}3 & 1924 & 073 & 870 & 267\end{array}$ 


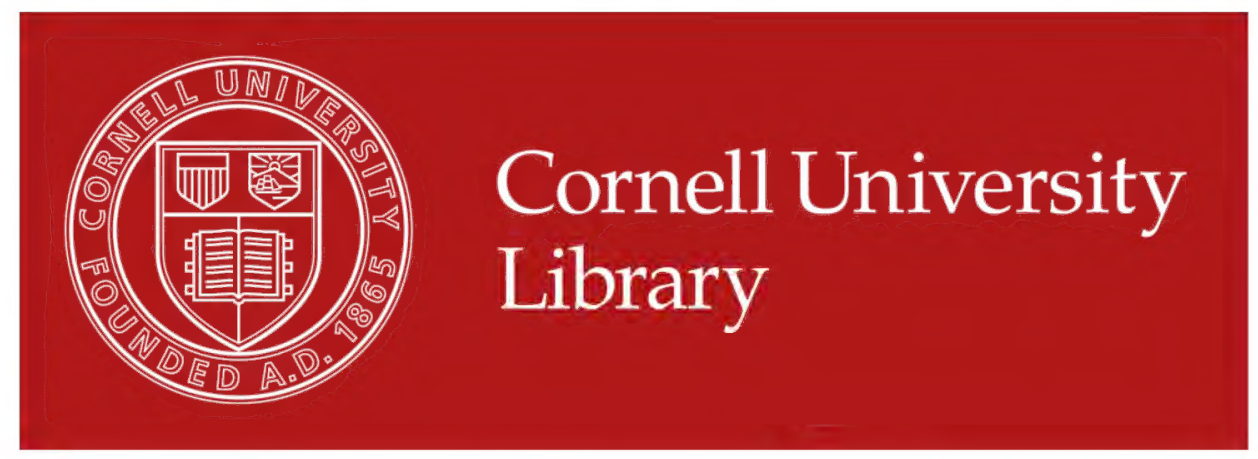

The original of this book is in the Cornell University Library.

There are no known copyright restrictions in the United States on the use of the text.

http://www.archive.org/details/cu31924073870267 




\section{Production Note}

Cornell University Library produced this volume to replace the irreparably deteriorated original. It was scanned at 600 dots per inch resolution and compressed prior to storage using CCITT/ITU Group 4 compression. The digital data were used to create Cornell's replacement volume on paper that meets the ANSI Standard Z39.48-1992. The production of this volume was supported by the United States Department of Education, Higher Education Act, Title II-C.

Scanned as part of the A. R. Mann Library project to preserve and enhance access to the Core Historical Literature of the Agricultural Sciences. Titles included in this collection are listed in the volumes published by the Cornell University Press in the series The Literature of the Agricultural Sciences, 1991-1996, Wallace C. Olsen, series editor. 




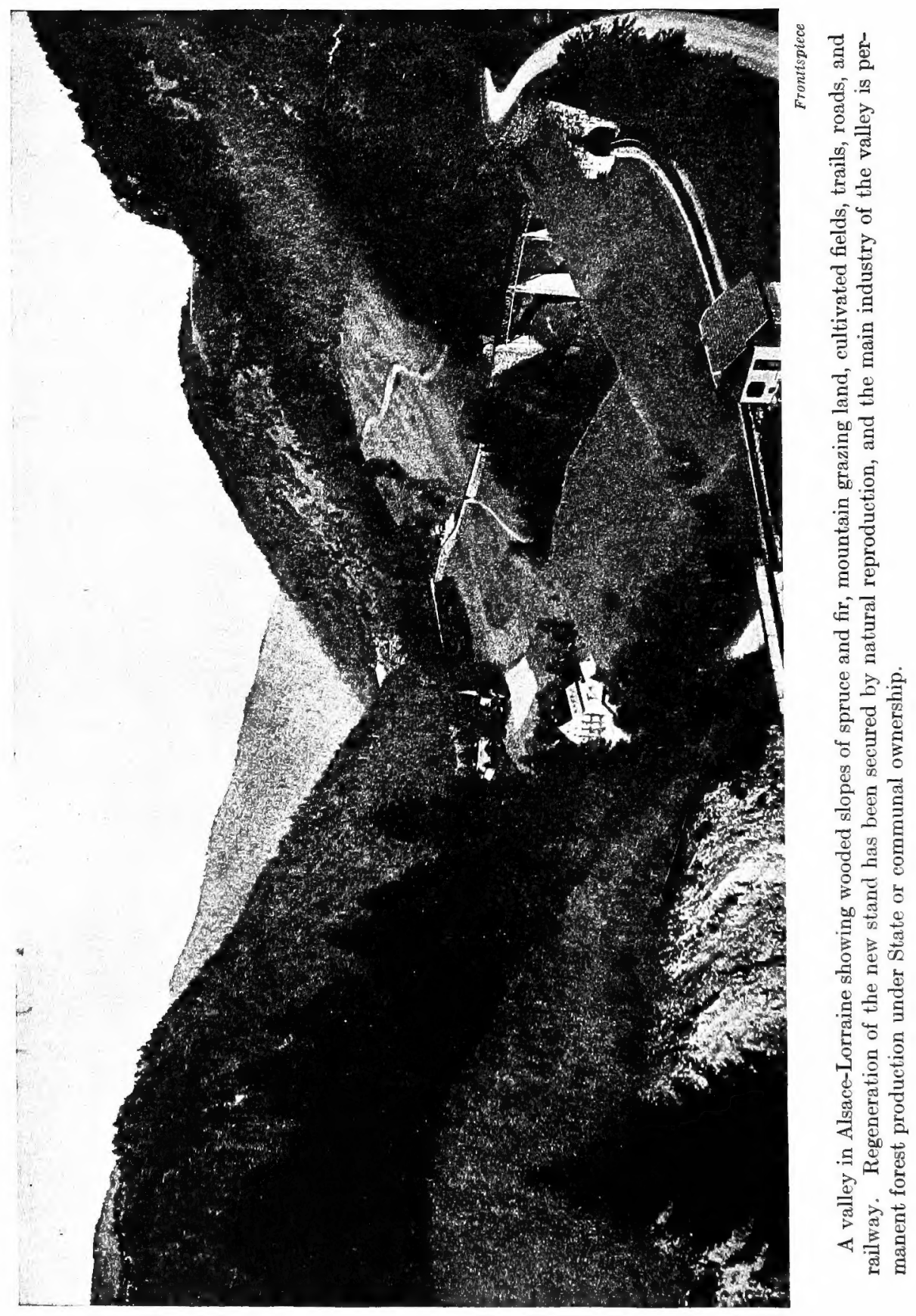




\title{
STUDIES IN FRENCH FORESTRY
}

\author{
BY \\ THEODORE S. WOOLSEY, JR. \\ Consulting Forester, Author of French Forests and Forestry (Tunisia, Algeria. \\ Corsica), and Executive Member Interallied War Timber \\ Committee, Paris, 1917-1919 \\ WITH TWO CHAPTERS BY \\ WILLIAM B. GREELEY \\ Forester, U. S. Forest Service, and formerly Chief, Forestry Section, \\ C. and F., S. O. S., American Expeditionary Forces
}

\author{
NEW YORK \\ JOHN WILEY \& SONS, INC. \\ LONDON: CHAPMAN \& HALL, LMITED


(c) $2+i$

Copyriaht, 1920,

BY

THEODORE S. WOOLSEY, JR. 




\section{PREFACE}

The maternal for this book was collected largely in 1912. Administrative work in the United States Forest Service, teaching at Yale Forest School, and service in the Corps of Engineers, U. S. A., during the war prevented an earlier completion of my task.

The success of the American Expeditionary Forces in securing its timber supply, under conditions existing in France in 1917-18, was due chiefly to the extraordinary capacity of the commanding officers at Tours and the American lumbermen and foresters who assisted them throughout France. These efforts might have failed, however, if the American E. F. had not been so ably seconded by l'Administration Générale des Eaux et Forêts under the direction of M. Dabat, Conseiller d'Etat, Directeur, and by M. Antoni, now an Inspecteur Général des Eaux et Forêts and Sous-Directeur, as well as by the French officers and officials working under or in collaboration with Général de Division Chevalier, D. S. M., Inspecteur Général du Service des Bois, notably:

Lieut.-Col. Joubaire, Armand, Conservateur des Eaux et Forêts à Saumur, Président de la Commission Forestière d'Expertises.

M. Emery, Auguste, Conservateur des Eaux et Forêts, Ministère de l'Agriculture, Paris.

Lieut.-Col. de Lapasse, Louis, Conservateur des Eaux et Forêts à Bordeaux, Gironde.

Lieut.-Col. Buffault, Pierre, Conservateur des Eaux et Forêts, à Aurillac, Cantal.

Lieut.-Col. Deroye, Nancy, Meurthe et Moselle, Chef du Service Forestier d'Armée.

Lieut.-Col. Mathey, Alphonse, Conservateur des Eaux et Forêts à Dijon, Côte d'Or.

Lieut.-Col. Schlumberger, Pierre, Conservateur des Eaux et Forêts à Colmar, Alsace.

Commandant Badré, Louis, D. S. M., Inspecteur des Eaux et Forêts, Liaison Officier Américain, G. H. Q.

Commandant Jagerschmidt, Jean, Inspecteur des Eaux et Forêts, Membre de la Commission Forestière d'Expertises.

Colonel Steiner, Directeur des Etapes, Service Forestier, à Vesoul et Valleroy.

Capitaine Sinturel, Emile, Inspecteur Adjoint des Eaux et Forêts, Chef du Secteur Forestier de Gray, Haute-Saône. 
Capitaine Fresson, Maurice, Officier de Liaison auprès du Délégué Américain au Comité Interallié des Bois de Guerre.

Capitaine Vantroys, Henri, Inspecteur Adjoint des Eaux et Forêts, Membre de la Commission Forestière d'Expertises.

Capitaine Oudin, Auguste, Inspecteur Adjoint des Eaux et Forêts, Membre de la Commission Forestière d'Expertises.

Capitaine Roux, Edgar, Inspecteur Adjoint des Eaux et Forêts, Adjoint a M. le Général Chevalier.

Capitaine Rivé, André, Garde Général des Eaux et Forêts, Membre de la Commission Forestière d'Expertises.

Capitaine Hurteau, Henri, Garde Général des Eaux et Forêts, Membre de la Commission Forestière d'Expertises.

Capitaine Coulon, Jean Pierre, Membre du Bureau de la Centre des Bois de Bordeaux.

Lieutenant Girault, Pierre, Garde Général des Eaux et Forêts, Membre de la Commission Forestière d'Expertises.

Lieutenant Sébastien, Maurice, French Délégué, C. I. B. G.

Lieutenant Detré, Léon, Adjoint au Bureau du Délégué Américain au Comité Interallié des Bois de Guerre.

Capitaine Fresson and Lieutenant Detré labored assiduously in my own office on the Executive Committee of the Interallied War Timber Committee. Lieut.-Col. Pardé and Commandant Hickel gave much personal help, and Commandant Hirsch, Director of the Bureau des Végéteaux Combustibles under the Ministre de l'Armement, assisted in the purchase of manufactured cordwood.

The local French officers in charge of forests and conservations at all American operations everywhere in France gave the utmost help.

During this allied campaign coöperation was the key to final victory. To General Lord Lovat, K. T., K. C. V. O , K. C. M. G., C. B., D. S. O.. Director of Forestry of the British Expeditionary Forces; Colonel John Sutherland, C. B. E., Assistant Director of Forestry and British Representative on the C. I. B. G.; Major Viscount de Vesci, who served on the C. I. B. G. after the armistice; General MacDougall, C. B., Chief of the Canadian Forestry Corps; General White, C. M. G., in charge of C. F. C. operations in France; Lieut.-Col. Lyle, the Canadian member of the C. I. B. G.; and to Commandant Parlongue, Belgian delegate to the C. I. B. G., thanks are due for hearty coöperation and assistance in a campaign for timber supplies which overshadowed for the time being the management and preservation of French forests. To those who worked in the World War this spirit of coöperation has left the pleasantest of memories. Many whose names are not given here gave freely to help the American E. F. As a matter of fact these very efforts, which helped to gain the victory for the allied cause, were detrimental to the forests of 
France. Many forests were clear cut with no satisfactory provision for regeneration, and in others the growing stock of sawlog material was so reduced that "normal" production cannot be secured for a century or more. Yet, it must be recognized that this destructive use of .the French forests helped to save France and her armies. It is for this reason that it seems fitting to make this acknowledgment to those who coöperated in directing and facilitating the American manufacture of French timber and the acquisition of the raw supplies.

January 1, 1920.

THEODORE S. WOOLSEY, JR. 



\section{CONTENTS}

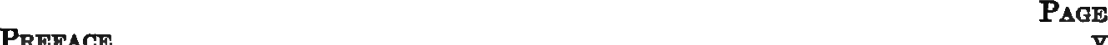

INTRODUCTION $\ldots \ldots \ldots \ldots \ldots \ldots \ldots \ldots \ldots \ldots \ldots \ldots \ldots \ldots \ldots \ldots \ldots \ldots \ldots \ldots$

\section{CHAPTER I}

IMPREgSIONS OF FRENCH FORESTRX $\ldots \ldots \ldots \ldots \ldots \ldots \ldots \ldots \ldots \ldots \ldots \ldots \ldots$

Economic needs and national traits........................ 1

Significant public phases of French forestry.................. 2

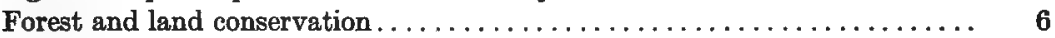

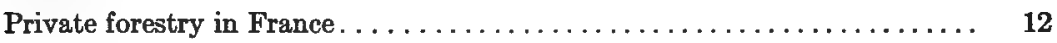

Forest problems of France and the United States.............. 15

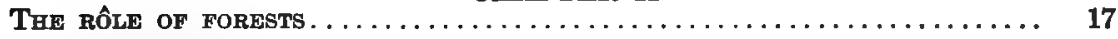

The value of forests $\ldots \ldots \ldots \ldots \ldots \ldots \ldots \ldots \ldots \ldots \ldots \ldots \ldots \ldots \ldots \ldots$

Forest influences................................... 19

CHAPTER III

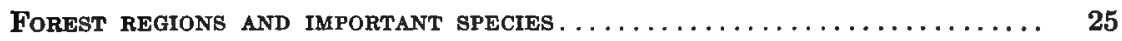

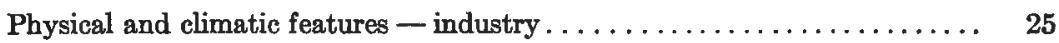

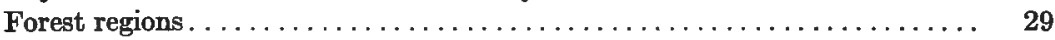

Important forest species . . . . . . . . . . $40 \ldots \ldots \ldots \ldots \ldots \ldots \ldots$

CHAPTER IV

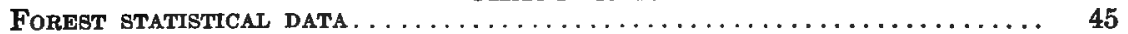

Private forest owners. . . . . .

CHAPTER V

NAtURAL REgeneration $\ldots \ldots \ldots \ldots \ldots \ldots \ldots \ldots \ldots \ldots \ldots \ldots \ldots \ldots \ldots \ldots, \quad 6 . \ldots \ldots$

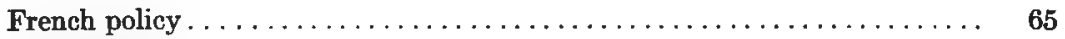

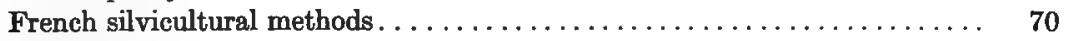

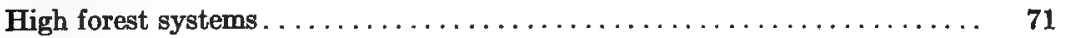

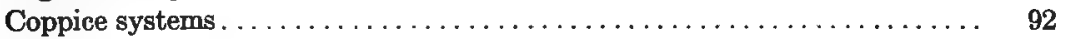

Care of the stand after regeneration $\ldots \ldots \ldots \ldots \ldots \ldots \ldots \ldots \ldots \ldots \ldots$

CHAPTER VI

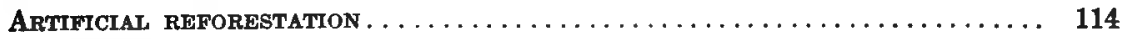

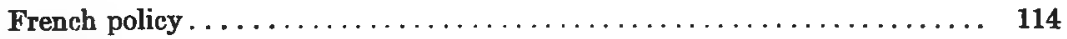

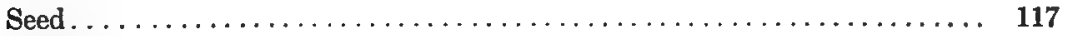

Nurseries. . . . . . . . . . . . . . . . . 122

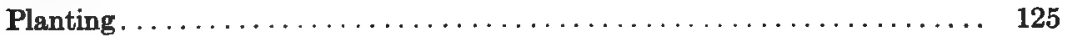

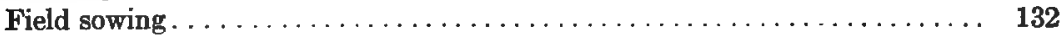




\section{CHAPTER VII}

Control of grosion in the motntains ..................... 140

French policy and summary of reforestation. . . . . . . . . . . 140

The damage. . . . . . . . . . . . . . . . . . . . . . . . . . 147

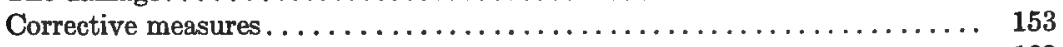

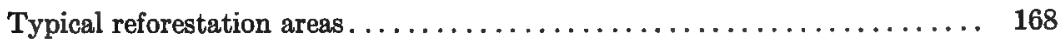

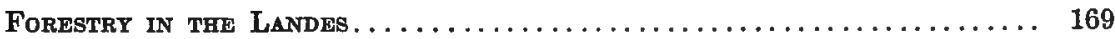

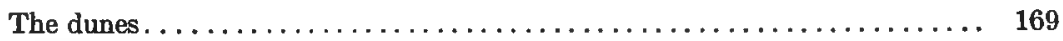

History of reclaiming the Landes. . . . . . . . . . . . . . . . 173

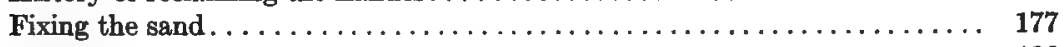

Management of maritime pine forests . . . . . . . . . 186

CHAPTER IX

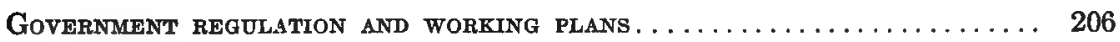

Mensuration in working plans. . . . . . . . . 206

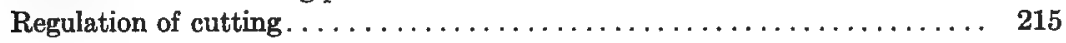

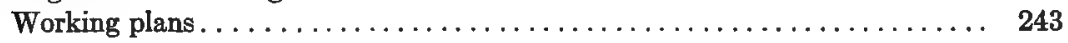

CHAPTER $\mathrm{X}$

Features of French national forest administration............ 261

Brief summary of legislation. . . . . . . . . . . . . . . . . . . 261

Administrative organization and education $\ldots \ldots \ldots \ldots \ldots \ldots \ldots \ldots \ldots . \ldots \ldots$

Protection. . . . . . . . . . . . . . . . . . . . . . . . . . . . . . . 275

Betterments. . . . . . . . . . . . . . . . . . . . . . . . . . . . . . 290

Sale of timber. . . . . . . . . . . . . . . . . . . . . . . . 293

CHAPTER XI

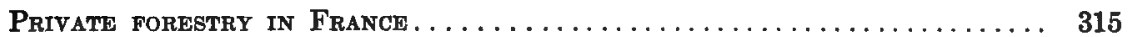

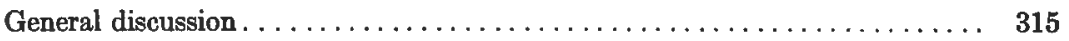

Examples of the best private forestry . . . . . . . . . . . . . 323

CHAPTER XII

The American Forest Enginemer in France................. 336

Timber in modern warfare $\ldots \ldots \ldots \ldots \ldots \ldots \ldots \ldots \ldots \ldots \ldots \ldots \ldots \ldots \ldots$

The organization of Forest Engineers. . . . . . . . . . . . . 338

The Forestry section of the Expeditionary Force. . . . . . . . . . 340

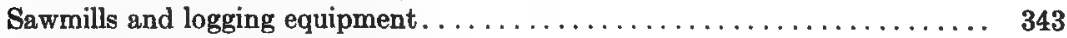

The production of fuel wood $\ldots \ldots \ldots \ldots \ldots \ldots \ldots \ldots \ldots \ldots \ldots \ldots \ldots \ldots$

What the Forest Engineers accomplished . . . . . . . . . . . . . 348

Coöperation with the forest agencies of France................ 351

Forest troops loaned to French and British armies.............. 357

What the American woodsmen learned in France............... 358

The war a vindication of French forestry . . . . . . . . . . . . . . 358

\section{APPENDIXES}

A то L 


\section{ILLUSTRATIONS}

A valley in Alsace-Lorraine.......................... Frontispiece

Fig. $\quad$ Page

1 Rainfall and summer temperatures........................ 26

2 The richest silver fir (with spruce) stands in France are found in the State forest of La Joux (Jura) .............................. 32

3 Larch and cembric pine in the Canton of Melezet, communal forest of Villaro-

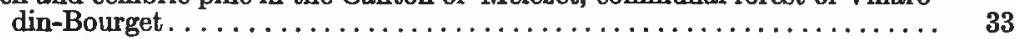

4 (a) The communal forest of Manigod (Haute-Savoie) . . . . . . . . . . . 39

4 (b) The communal forest of Gets........................... 39

5 Distribution of six important forest trees.................... 42

$6(a$ to $f)$ State forest of Hez-Froidmont.................... $58-59$

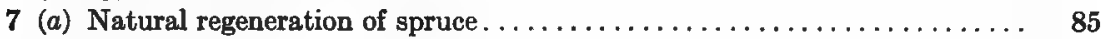

7 (b) Spruce stand in the Melezet Canton, communal forest of Villarodin-

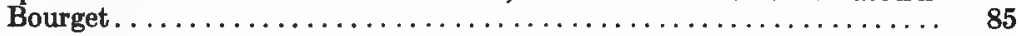

8 Pure larch in the communal forest of Tignes .................. 90

9 (a) Pole stand of spruce in the communal forest of Beaufort . . . . . . . 109

9 (b) Spruce and fir in the Canton du Mont, communal forest of Thones-Ville. . 109

10 (a) Costly system of dams to prevent erosion in the bed of a French torrent.. 154

10 (b) An expensive masonry dam, Gave de Pau (Hautes-Pyrénées) . . . . . . . 154

10 (c) Log and dry stone dams to prevent erosion at Var-Moyen (Alpes-Mari-

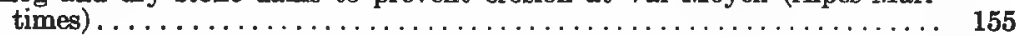

10 (d) Wattle work on small side gullies and masonry dam in main ravine in Ubaye area (Basses-Alpes) . . . . . . . . . . . . . . . . . . 155

11 (a) Retaining walls on a hillside that had been slipping down . . . . . . 159

11 (b) Walls to prevent avalanches with an inspection trail in the foreground... 159

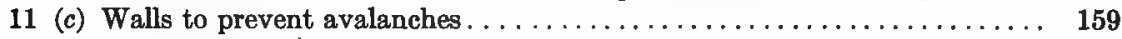

12 Paved drains at Bastan (Hautes-Pyrénées) .................... 161

13 (a) Wattle work in a ravine in the Verdon-Supérieur (Basses-Alpes) area. ... 163

13 (b) Bed of small ravine stabilized by wattle work .............. 163

14 (a) The Rata ravine at Ubaye (Basses-Alpes) after the reclamation work was

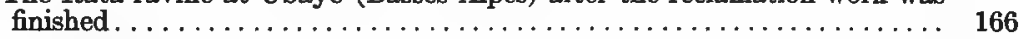

14 (b) A mountain village in the Pyrénées menaced by erosion............ 166

14 (c) Preventing further erosion by larch plantations in Ubaye area (Basses-

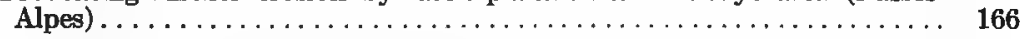

15 Protection dune at Lacanau-Océan in State forest of Lacanau (Gironde) . . . 171

16 Barrel price of turpentine at Bordeaux..................... 185

17 (a) Maritime pine 57 years old during improvement felling. . . . . . . . . 194

17 (b) Simall tree being tapped to death prior to utilization for mine props..... 194

18 French turpentine tools. . . . . . . . . . . . . . . . . . . . . . . 197

$19(a$ and $b)$ Examples of stand graphics.................... 216-217

$20(a$ and $b$ ) Growing stock compared with present stock and with the normal

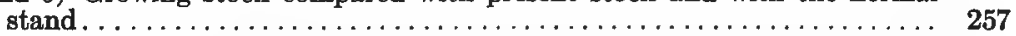

21 A graded trail, which serves as a compartment boundary, and which can be used by tourists. . . . . . . . . . . . . . . . . . . . . . . . . 



\section{INTRODUCTION}

No student can fail to see that forestry may attain its optimum development under the favorable climatic, regenerative, and vegetative conditions that exist in France. Dr. Martin, of Tharandt, remarked, after a tour of French forests, that "Natural regeneration is more successful and far more general than in Germany because of the mild climate, sufficient rainfall, and prolific seeding." Natural regeneration of sessile oak in the valley of the Adour is not only certain but easily obtained; and what could be simpler than the clear cutting of maritime pine, followed by complete seeding? Even the high forests of pedunculate oak in mixture with beech are naturally regenerated because the soil and seed may be made ready for regeneration by the application of forest science. ${ }^{1}$ The silver-fir stands in the Vosges, Jura, Savoie, Haute-Savoie, and the Pyrenees regenerate naturally. Even spruce can be reproduced with but little artificial aid./But when Martin predicted, in 1906, that artificial forestation was on the increase in France, he missed the mark. With the shortage and high cost of labor to-day, France is further away from artificial regeneration than ever before, except to repair the ravages of war and counteract the results of past improvident and excessive exploitation.

The value and necessity of maintaining a conservative forest policy is to-day recognized in France as never before. It is generally admitted that the area (18.7 per cent) already in forest is insufficient. France had to import heavily before the war and her timber needs cannot be met from local sources even with the return of Alsace-Lorraine. What countries will furnish this timber deficit is difficult to predict. The cost of importing timber from the United States has been accentuated by the increase in steamship and railway freight rates, and by the unfavorable rate of exchange, since to-day it takes 10 to 11 French francs to equal one dollar. Even with the timber France can buy from countries with depreciated currency and with the timber she should receive from Germany as reparation, every acre of waste land should be forested. France cannot afford to neglect maintaining and increasing her natural forest resources, not only for their direct returns, but also for their indirect value

1 Soil preparation is usually obligatory, and it is often difficult to maintain the proper proportion of oak in the north or west of France because good oak-seed years occur only every 10 to 12 years. 
as protection against unfavorable climatic conditions, erosion, drought, frost, and hail, as well as providing a playground for the millions that will flock to France during the reconstruction period. French statesmen have seen France saved by her forests, and the agitation in the press against overcutting during the last phases of the war was merely a reaction from the excesses made necessary by war demands. When the history of the defense of France is written the part played by French forests should be recognized. These forests gave fuel and lumber during the crisis of ocean transportation, when every available ship was required for men, munitions, food, and other necessities which could not be wholly supplied from local sources. Then, too, the large forested areas in the line of actual fighting proved a point of defense which apparently could not have been spared. It is impossible to determine what would have occurred without the forests of Compiégne and Villers-Cotterets. Had France wasted her forest resources in the past (like Spain and Italy) the war might have been a draw or a defeat, instead of a victory.

In the past French forests have suffered from abuse. Much of the damage in the Alps, Pyrenees, Central Plateau, Landes, and Gironde occurred during or before the Middle Ages, and a part of the damage at least resulted either directly or indirectly from war. The two great achievements of French forestry are the repair of this damage and the reforestation of eroded soils in the mountains as well as the reclamation of the sand dunes along the Gulf of Gascogne and Pas-de-Calais. The leaders responsible for these two achievements, Démontzey and Brémontier, will long live in the history of France. Who will successfully reforest and rehabilitate the land damaged by the war of 1914? There are more than a million acres to be restored to productivity, as well as innumerable forests whose growing stocks must be enriched by economy at a time when the economic demands for wood products will be at least double the normal consumption.

There are certain features of French forest administration and management that deserve emphasis: the State, Communal, and Institutional forests are almost invariably managed on longer rotations than are private forests of the same species and situation. It is evident from what is taught at Nancy, that, in a narrow sense, the rotations in State forests are clearly not financial: (1) In protection forests the trees should, in theory, be left standing until they decline in vigor; the product will then have but small value. (2) In a great country like France commerce requires wood of large size. To obtain this it must be cut at an advanced age. This leads to retaining a considerable unnecessary capital, and decreases the interest returns to a figure that is too small for the private owner. These two considerations justify the State ownership of a certain number of forests, which alone can logically accept this situation 
(low returns) for the general welfare. In times of emergencies, such as have just passed, the wisdom of maintaining State forests as storehouses of heavy timber cannot be questioned. On the other hand an unnecessarily long rotation means an excess growing stock, or forest capital, which must earn so much greater income to be profitable; besides there is apt to be more damage from fungi, insects, and windfall. Yet, because of the favorable climatic and soil conditions already emphasized, little silvicultural damage has resulted. The tendency in State management, where climate and species permit, is toward the high-forest systems and away from coppice and coppice-under-standards. These conversions also necessitate cutting less than the growth for many years, as well as increasing the rotation. There is always a safety valve, however, because, as Professor Jolyet puts it, "Prudence demands frequent inventories - repeated every ten years for example - establishing the oscillation of standing timber volumes." This frequent stock-taking is a safeguard against retaining overmature timber, because the working-plans officer is sure to demand its removal. But on the whole the average French State forester is perhaps overconservative. This has been inbred into him, for the French code itself prescribes that 25 per cent of the yield in communal forests shall be set aside for emergencies. This rule was due to the overcutting of two centuries ago. During the past few years some State forests have been cut to the extent of ten to cighteen annual yields and perhaps this will prove to French foresters that the growing stock in such forests as Risol and Levier (Jura) have been excessive and can be reduced without danger. Private forests, chiefly coppice and coppice-under-standards, on the contrary, are heavily cut perhaps overcut - on short rotations, which is liable to gradually impoverish the soil. The high prices prevailing since 1916 have tempted many private owners to dispose of their forests entirely or at least to make inroads on the growing stock. This was but natural when prices doubled in 1917 and trebled in 1918. Undoubtedly the private forests in France yield a higher rate of interest on the investment than do State forests, but the product is inferior and not so essential to French industry. Private owners are practically unfettered in the treatment, management, and exploitation of their forest lands, provided the clearing of timber is not intended. According to the Forest Code:

"Opposition to the clearing can only be formulated for the timber whose preservation is recognized as being necessary -

" 1 . For the maintenance of soil on mountains or slopes.

"2. As a protection against soil erosion and silting up of creeks, rivers, and torrents.

" 3 . For the preservation of springs and water courses.

"4. For the protection of dunes and coasts against crosion by the sea and encroachment by sand.

" 5 . As a protection of territory in that part of the frontier zone which shall be determined by regulation of the civil authorities.

"6. For the sake of public health." 
Exactly the same law ${ }^{2}$ applies to Algeria and Corsica and it is rigidly enforced where large areas are to be deforested and where the public interest is at stake. It does not apply to -

1. Timber sown and planted and less than 20 years old.

2. Parks or fenced gardens.

3. Isolated stands less than 10 hectares $(24.7$ acres) in extent and if not on mountains or slopes. But the private owner is exempt from his land tax for "areas sown or planted on the summits or slopes of mountains and upon the dunes or waste lands."

This law against the clearing of land is fully justified by the forest history of France. A country with only about 18.7 per cent of forested area cannot afford to allow further deforestation, even if unintentional. For this reason excessive cutting or abusive treatment which would result in complete destruction comes under the prohibition of this law. Who would advocate further deforestation of mountain land after the disasters of erosion in the French Alps and Pyrenees; or the deforestation of sand dunes after the difficulties of reparation have been driven home? The observance of this law against cutting strategic forests along frontiers has been fully justified by the war of 1914, when France was protected against German drives. Ample provision ${ }^{3}$ is made for the enforcement of the law, and for reparation in case the law is violated, but on the other hand its application is liberal when it comes to clear cutting, followed by natural or artificial regeneration, as is the practice in the maritime-pine stands in the Landes.

The art of the French forester lies in his keen perception of the true objective and in his simple methods. In thinnings he attacks the stand in its top story, to allow the development of the trees that will form the future commercial stand. He deals with stands rather than with trees the correct viewpoint. In the regulation of yield of selection forests he computes the cut with an admittedly inaccurate formula, but he gets his desired results - a reasonably equal annual cut - and he realizes that with oft-repeated inventories the inaccuracies of the formula will be corrected. His mensuration is a rough guess, many refinements (used even in the United States with its extensive conditions) being omitted as unnecessary to the objective. If he makes an error in estimating the volume of a sale this slack is taken up in the bidding, and there are stringent laws against illegal combinations in restraint of true competition. Timber sales are kept small so as to give the small local millman a chance as well as to increase competition. No logging is done by the State, as in Germany, except experimentally in Alsace-Lorraine.

2 See Part VI of the Algerian Forest Code, pp. 184-188, French Forests and Forestry, Theodore S. Woolsey, Jr., John Wiley \& Sons, Inc.

'See Chapter X on "Legislation." 
It is as a silviculturist that the French forester is at his best, and regulation statistics are rarely allowed to interfere with silviculture. One State forester was deliberately departing from his working plan because good silvics demanded a group-selection cutting instead of the shelterwood.

The success of the State Forest Administration is largely due to its splendid personnel; the Director is the only political appointee, and no doubt this position will soon be assumed by a technical forester with breadth of vision. Though woefully underpaid, even in these times, the morale of the service has not been broken and it is most unusual for a forester to retire to take a more lucrative position elsewhere. The authority is clearly decentralized and the Conservator (or "District Supervisor" as the position really is) has full authority to handle his district without undue interference. Given more money for a modern office establishment he would be able to spend more time in the forest with his inspectors - a needed improvement.

One of the perplexing problems which confronts the American student of French forests is to understand the units of measure in common use. For example, a stand of 200 cubic meters, or steres per hectare, conveys no concrete idea to the forester accustomed to speaking in terms of board feet or cords per acre. To avoid this difficulty the American units of measure have been adopted in this study and the following equivalents used in conversions:

\begin{tabular}{|c|c|}
\hline 1 pound (avoirdupois) $\ldots \ldots \ldots \ldots \ldots$ & $=0.45359$ kilogram \\
\hline 1 pound (Troy) $\ldots \ldots \ldots \ldots \ldots \ldots$ & $=0.37324$ kilogram \\
\hline 1 millimeter. & $=0.03937 \mathrm{inch}$ \\
\hline 1 centimeter... & $=0.3937$ inch \\
\hline 1 meter $\ldots \ldots \ldots \ldots \ldots \ldots \ldots \ldots$ & $=3.28083$ feet \\
\hline$(\ldots \ldots \ldots \ldots \ldots \ldots \ldots \ldots \ldots$, & $=1.093611$ yards \\
\hline 1 kilometer. & $=0.62137$ mile \\
\hline 1 square millimeter.. & $=0.00155$ square inch \\
\hline 1 square centimeter........ & $=0.1550$ square inch \\
\hline 1 square meter. & $=10.764$ square feet \\
\hline 1 square meter. & $=1.196$ square yards \\
\hline 1 square kilometer. & $=0.3861$ square mile \\
\hline$\ldots \ldots \ldots \ldots \ldots \ldots$ & $=2.471$ acres \\
\hline millimeter............. & $=0.000061$ cubic inch \\
\hline ntimeter........ & $=0.061$ cubic inch \\
\hline 1 cubic meter. & $=35.314$ cubic feet \\
\hline 1 cubic meter. & $=1.3079$ cubic yards \\
\hline 1 liter... . . . . . & $=1.05668$ quarts (liquid) \\
\hline 1 liter.. & $=0.26417$ gallon (liquid) \\
\hline 1 liter & $=0.9081$ quart (dry) \\
\hline 1 liter. & $=0.11331$ peck \\
\hline 1 hectoliter................. & $=2.83774$ bushels \\
\hline (at & - 154304 orgins \\
\hline
\end{tabular}




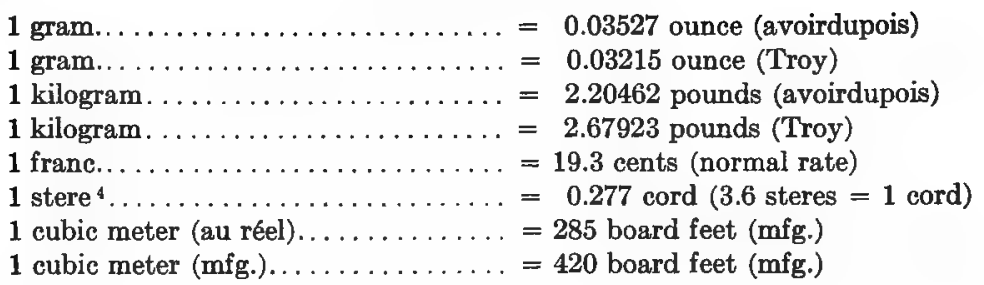

These are exact equivalents and can be changed back to the metric system without error, with the exception of the board feet equivalent which varies with the size of the timber, method of manufacture, and product. A cubic meter in large logs yields more board feet than from small logs; a mill equipped with a band saw yields more per cubic meter than does a wasteful circular saw; and if logs are cut into large dimension stuff, or ties, the yield from a cubic meter is higher than if the product is inch boards. The only authoritative data on the ratio between cubic meters (au réel) on the stump and board feet are those secured by the U. S. Army during 1917-19. In the Landes where the American mills equipped with circular saws cut 148,585 cubic meters the product was $41,437,304$ board feet, mill tally, or 278 board feet to one cubic meter. The ratio varied from a minimum of 227 board feet at Sabres to 287 at Candale. For general calculations it may be said that $3 \frac{1}{2}$ to $4 \frac{1}{2}$ cubic meters of standing maritime pine is equal to a thousand board feet. In the Jura silver-fir stands 144,203 cubic meters yielded $43,639,876$ board feet, or 303 board feet to the cubic meter. Here the timber was larger than in the Landes. At one sawmill (Morteau) a cubic meter averaged 383 board feet, at Mouthe only 311 . In round figures it takes $2 \frac{1}{2}$ to $3 \frac{1}{2}$ cubic meters of silver fir to cut a thousand board feet. For general computations it would be safe to count 4 cubic meters of maritime pine or 3 cubic meters of silver fir to the thousand board feet. In the Dijon hardwood belt it was found that 319 board feet were secured from the average cubic meter, or 3 to the thousand. As an average converting factor for all saw timber logs in France $3 \frac{1}{2}$ cubic meters to the thousand is suggested, and for different sized timber, the following:

Small timber.....................

Medium timber...................4 to 1,000 board feet

Average timber..................

Large timber...................... to 1,000 board feet

Very large timber.................. $2 \frac{1}{2}$ to 1,000 board feet fuel.

When dealing with stands, from 10 to 40 per cent must be deducted for

${ }^{4}$ In his statistical work (Notes sur les Forêts de l'Algérie) Marc took 3 steres of fuel to 2 cubic meters, 50 poles to 1.30 cubic meters, ties at their full volume less 30 per cent. He counted 1 cubic meter as 750 kilos and 12 steres to one ton of charcoal. 
Frequently it is of convenience to use rule-of-thumb methods for quick, rough calculations. With exchange at 5.18 francs to the dollar, and taking 420 board feet to the manufactured cubic meter, 285 board feet to the cubic meter of standing timber (unmanufactured) and 3.6 steres (stacked cubic meters) to the cord, we have: (a) To reduce francs per cubic meter of manufactured timber to dollars per thousand board feet, multiply by 0.46 . (b) To reduce francs per cubic meter of standing timber to dollars per board foot, multiply by 0.64. (c) To reduce francs per stere to dollars per cord take 0.7 .

For example: 100 francs a cubic meter for boards is equal to. $\$ 46$ a thousand; 50 franes a cubic meter of standing timber is equal to a stumpage rate of $\$ 37$ a thousand; and 10 francs per stere is $\$ 7$ a cord. It is obvious that these approximate ratios would vary with the rate of exchange, and in case (b) to the per cent deducted for cordwood.

Any student who has toured the forests of France must be impressed with the occasional difference between the theoretical forestry that is described in the text-books and the practical forestry one sees in the different regions. The writer has accordingly tried to combine the practice with the theory. An excellent illustration of the difference between text-book and field forestry is found in the aleppo pine forests in the Provence, already alluded to. In theory these light-demanding coniferous stands might be managed by the shelterwood system. In actual practice not more than 15 to 20 per cent of the volume is removed in gradual selection cuttings. Yet in any study it is necessary to rely on text-books. Accordingly, the writer addressed the Director of the Waters and Forests Service at Paris in regard to the foremost standard authorities. These are:

(1) Silviculture - Le Traité de Sylviculture de MM. Boppe et Jolyet (BergerLevrault, Editeur -5 Rue des Beaux-Arts, Paris).

(2) Forest Economy - (all phases of forestry) L'Économie Forestière de M. Huffel -3 Tomes. (Laveur, Éditeur - 13 Rue des St. Pères, Paris.)

(3) Forestation - Guide de Planter et Semer - D. Cannon (Laveur, Éditeur).

(4) Reboisement - Restauration et Conservation des Terrains en Montagne (Parties 1, 2, and 3, Paris, Imprimerie Nationale, 1911).

(5) Forest Law - Code de Législation Forestière, par Puton et Guyot (Laveur, Editeur).

(6) Organization-Aide-Mémoire du Forestièr (Imprimene: Jacquin, Besançon (Doubs)).

An authoritative synopsis of the original working plans of some notable forests is contained in the Appendix. The formal statistius given in Chapter IV is from "Statistique des Forêts de France" (Volumes 1 and 2).

Of necessity much of the material is borrowed from authoritative French sources, and no claim can be made for originality. This was impossible 
if a true picture of French forestry was to be drawn. One of the editorial problems was, then, to decide what should be quoted and what should be merely digested. Exact translations only are written with quotation marks. Information digested (but not in the exact words of the original source) is not quoted. To accurately depict the French viewpoint it was considered advisable in many cases to adhere quite literally to the form of expression used by the French author, and yet, because of the need for reducing the verbiage, a complete translation could not be given. Occasionally whole chapters of a French work have been condensed and given in tabular form, as for example Table 11.

One of the first questions that confronts the student is which forests to visit. There are many communal and national forests in France under formal technical management and naturally the student of French forestry should visit those which will furnish the most instructive lessons typical of French forest management. Conservateur de Lapasse, now stationed at Bordeaux, furnished the following list of forests with relative data. These he thought were most worth a visit: 
INTRODUCTION

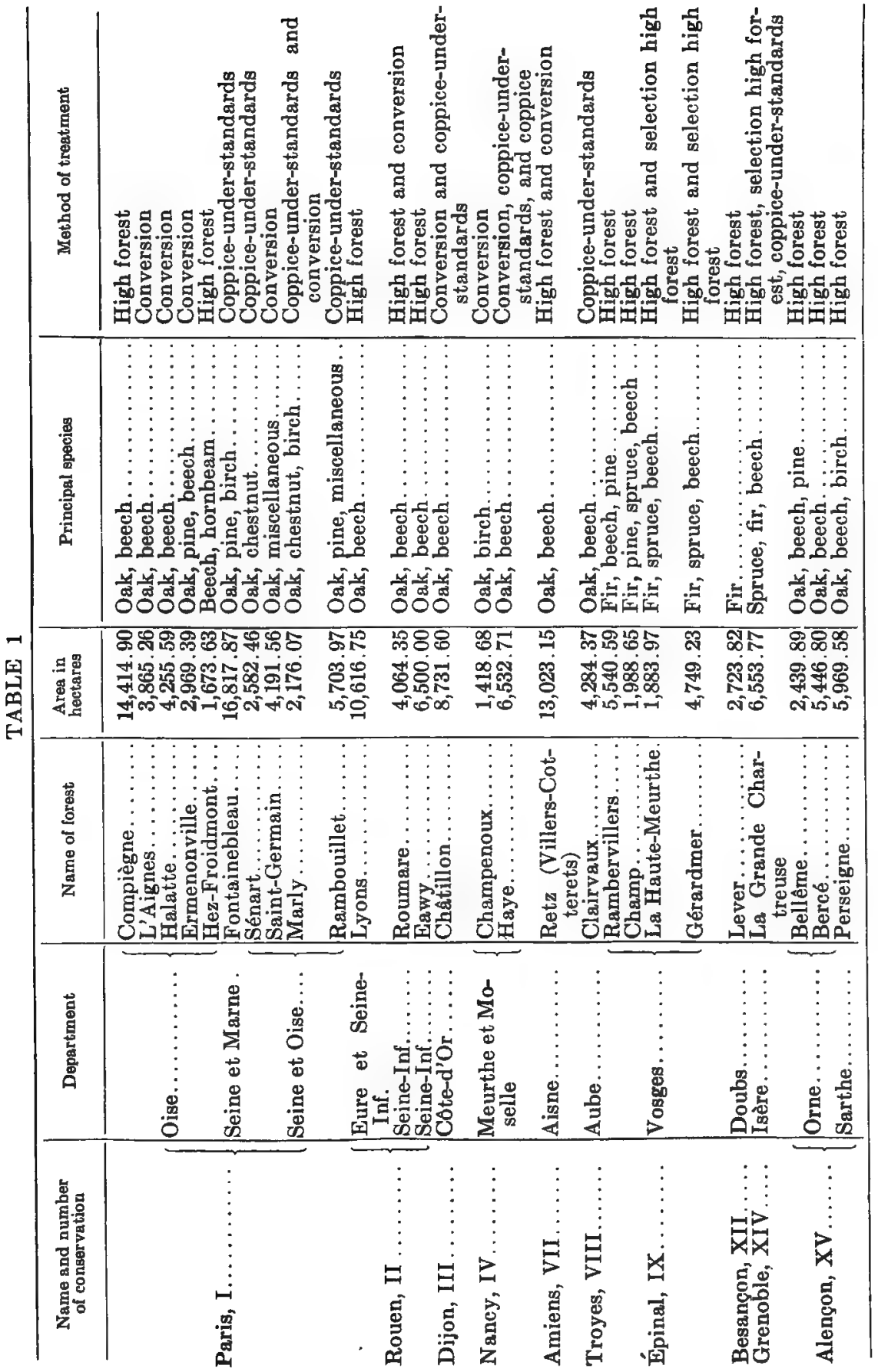




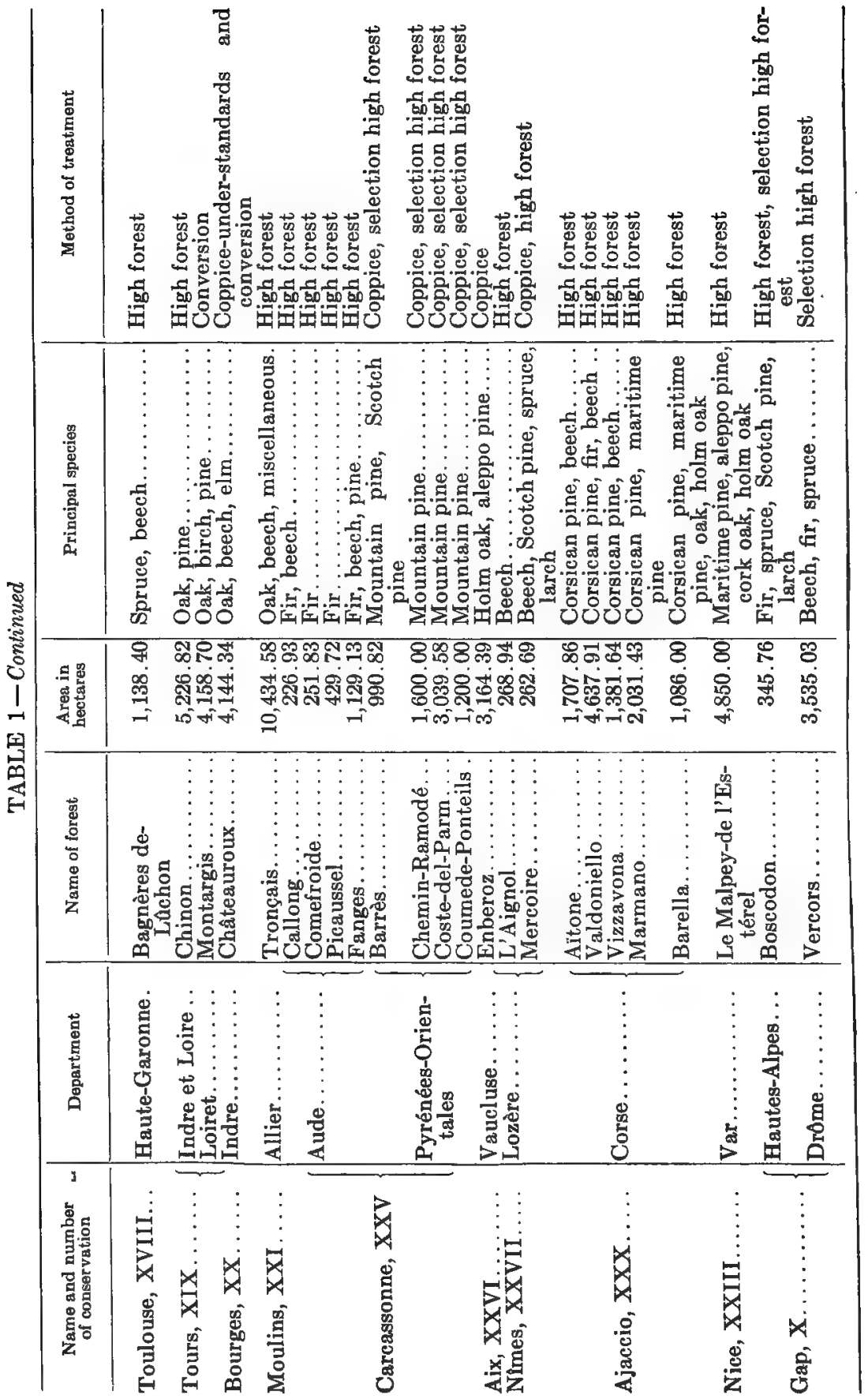


The foregoing list of forests is not necessarily conclusive, since it is a matter of individual opinion which are the most typical and instructive. It is, therefore, of interest to give, in addition, another list furnished by Henry, for years Assistant Director of the National School of Forestry at Nancy. The fact that many of the forests mentioned in the preceding table are duplicated by Henry make it all the more authoritative, especially since the list which follows was compiled in collaboration with his professional colleagues. According to Henry: "In such a vast region as the Central Plateau, one cannot cite a single characteristic forest. It is necessary to examine quite a number."

This list is classified by forest regions rather than by conservations or administrative divisions:

vosGes

1. Periégélaine Lorraine: Forest of Haye (Calcareous soil), Amance (clay).

2. La Vôge: Daruey.

3. Basses-Vosges (Grès Vosgien): Celles, Bois Sauvages, Ellieux.

4. Hautes-Vosges (Granite): Gérardmer, Rudlin.

JURA

1. First Plateau: Forest of Moidons.

2. Second Plateau: La Joux, Levier.

3. Third Plateau: Pontarlier, La Fuvelle.

4. Haute-Jura: La Risoux, Le Mont d'Or (almost wholly grazing).

1. North Alps.

ALPS

(a) Pré-Alpes (Calcaires): Forest of Grande Chartreuse, La Bauges

(b) Hautes-Alpes: La Maurienne, La Tarentaise (Briançon).

2. South Alps.

(a) Pré-Alpes (Calcaires): Le Luberon.

(b) Hautes-Alpes: Vallee de Barcellonette, Forêt des Alpes-Maritimes - Massif d'Allos.

1. North: Le Morvan.

Central platead

2. South: La Montagne Noire l'Aigonal.

1. East: Forest of Entrevals.

PYREANES

2. Central and West: Luchon, Iraty.

PROVENÇALE

Forest of Maures et de l'Estérel.

GIRONDINE

1. Oaks de l'Adour: Forest of Titieux.

2. Maritime Pine of the Landes and the Dunes: Forests near Mimizan and Arcachon.

Provided we may judge from the lessons of French forest history the following conclusions are fully warranted, and, because they are generally applicable to countries of the temperate zone, should be brought home to every citizen of the United States: 
1905, six months in 1912-13, and in part by trips through forests in 191719 in connection with the work of the Engineers (Forestry), U. S. Army. This volume supplements "French Forests and Forestry," published in 1917 by John Wiley \& Sons, Inc., which described the forests and forestry of Algeria, Tunisia, and Corsica.

Acknowledgment is made to C. M. Ballard for preparing the text for publication and seeing the book through the press, to Commandant Badré, who reviewed the technique, and to many friends who made valuable suggestions. The photographs were taken by Commandant Thiollier unless otherwise indicated. 


\title{
Studies in French Forestry
}

\author{
CHAPTER I

\section{IMPRESSIONS OF FRENCH FORESTRY}

\author{
By W. B. Greeley \\ Formerly Lieut.-Col., 20th Engineers, A. E. F.
}

Economic Needs and National Traits (p. 1). Forestry a National Art.

Significant Public Phases of French Forestry (p. 2). The Special Legal Status of Forests, A Penal Code of Their Own, Laws Dealing with Forest Fires, State Control of Forest Devastation, A Striking Infringement of Property Rights, Tax Exemptions on Forests.

Forest and Land Conservation (p. 6). Stabilization of the Gascon Sand Dunes, Forestation of Communal Lands, Flood Control in the Alps, Expropriation of the Use of Land for Forest Fnterprises, Private Forests in Conservation Projects, The Core of Publicly Owned Forests, Checkered History of the State Forests of France, The Extent of the Public Forests, Their Technical Management, The Communal Forests of France, Educational Value of the Public Forests.

Private Forestry in France (p. 12). Its Economic Basis, Forest Versus Farm Crops, The Importance of Private Forestry to France, Returns from Private Forests, Forest and Sawmill Divorced, Lumber Manufacture Adapted to Forestry Practice, Private Forestry on Its Own Feet.

Forest Problems of France and the United States (p. 15). Intensive Use of Limited Resources in France, The Handicap of Lumber Shortage, America's Problem Idle Land.

Not alone in its technical practice does the forestry of France offer much of interest and value to Americans. In the attitude of the French people toward their forests, in the historical and legislative development of their forest policy, in their public forest enterprises, and in the economic situation of France as regards the supply and use of timber, the United States may glean a deal that is suggestive and illuminating. Notwithstanding contrasts between new and old world conditions, we may learn much in seeing how a nation just as democratic and individualistic as our own has met a forest situation similar in some respects to what America herself is approaching.

Economic Needs and National Traits. - Forestry in France rests upon two main bases. The first is economic necessity; the second, national temperament. The shortage of home-grown timber compels France to 
import from 30 to 40 per cent of the wood products which she requires. Hence the timber produced in her own forests not only has a high value but is utilized far more closely than is now possible in the United States. Intensive use of forest land - particularly the maintenance of forests on large areas of mountain slopes and sand plains unfit for farm crops follows of necessity. But, to an almost equal degree, forestry in France is an expression of the thrift, the conservatism, the love of beauty, and the social inheritances of the French people. The genius of the French for making the most of small things, developed by centuries of close and frugal living, is expressed in the thrifty growing of wood on odds and ends of poor land, in hedges, in the rows of trees bordering roads, canals, and farms. The love of the chase and the social prestige conferred by the ownership of forests and hunting preserves, so highly prized by the old seigneurs, survive in modern France. Many forests have been preserved to serve as a beautiful setting for a château. We will not interpret forestry in France rightly as a purely economic development. The national traits and habits of her people have contributed largely to it and are reflected in her forest legislation and public policies.

Forestry a National Art. - By the same token, the American is impressed by the well-nigh universal understanding of forestry on the part of the French people. Forestry in France is far more than a propaganda. Like American agriculture, its practice is much older than its science. It is a rural art, ingrained in the lives and habits and modes of thinking of the people. Deputies in Parliament write newspaper articles on forest fires or forest taxation or reforestation in the Alps. The local silviculture is a part of the farm lore of the region - on the same footing as the care of vineyards or the growing of wheat. It is not to be inferred that forestry practice in France is uniformly good or that her forest policies command united support. The French are far too individualistic a race for that. Local antagonisms, as on the part of the Alpine mountaineers, have handicapped public efforts; and the commercial considerations of the moment have outweighed conservative forest management in the case of many land owners, even on occasion in the case of the State itself. But a striking difference exists between France and the United States in that forestry with us is still largely a governmental activity alone, an educational development working downward from the top, whereas in France it is an established art - a common possession of the rural population.

\section{SIGNIFICANT PUBLIC PHASES OF FRENCH FORESTRY}

The Special Legal Status of Forests. - Forest conservation has thus become almost an instinct of the French people. This makes it easier to understand certain public phases of forestry in France which are of special interest and suggestiveness to Americans. First among them is 
the legal recognition of forests as a resource standing apart from other resources in its need for extraordinary care and protection. In this principle of French law are reflected the timber and fuel-wood famines, actual or threatened, through which France has passed, and the prolonged struggles which she has waged to check sand dunes on the Gascon Coast and torrential erosion in the Alps. Because of the long period of time required to restore forests once destroyed or impaired and because of the far-reaching public interests which they serve, forest property is given a special status in French jurisprudence both as regards the police powers and duties of the State and as regards the rights of private ownership. Under the French theory, a shortage of cereals or other farm crops can be made good in a year or two, but public injury from the destruction of forests may be irreparable for a generation. Hence, the State must intervene with special measures for the protection of forests which are applicable to no other forms of property.

A Penal Code of Their Own. - Probably the most striking application of this principle is found in the protective features of the National Forest Code. The common law alone is regarded as inadequate for the protection of forests in France, which are placed under what is practically a separate penal code of their own. This code applies particularly to the forests under public administration but certain features of it are extended to private forests. Furthermore, the private forest owner may place his property under public administration and thereby obtain the full protective benefits of the forest code. Many penal provisions of the code were taken bodily from ordinances of Louis XIV. After the revolutionary upheaval had subsided, republican France extended to her forests many of the severe and restrictive forms of protection which they were accorded under the "ancien régime." There is nothing comparable in French jurisprudence concerning other classes of property.

In the maze of detailed prohibitions and penalties in the penal section of the forest code, one gains a deal of light upon French conceptions of forest conservation. A fixed schedule of fines and imprisonments is applicable for trespass and other violations of the code solely upon verification of the fact that an offense was committed. Considerations of good faith or mitigating circumstances are excluded. Aside from penalties to the State and civil damages to the owner of the forest for tangible losses which have been sustained, the code authorizes further damages for intangible injuries such as the disruption of a plan of management. These are adjudged as not less than the penal fine. Thus the trespasser who cuts green timber, however innocently, pays a fine - the commercial value of the stumpage cut - and an additional sum representing the value of the trees to the owner for further growth or seed production. If trees are cut which were planted or sown by hand and do not exceed five years in 
age, imprisonment is obligatory, together with a fine of 3 francs for every tree.

While the admission of mitigating circumstances is forbidden, the courts are compelled to impose severer penalties when a trespass is repeated within twelve months, when it is committed at night, or when illegal cutting is done with the saw. In the last two cases the purpose of the heavier punishment is to discourage trespasses under circumstances which render them difficult of detection. The difficulties of the State service in preventing unauthorized grazing on public forests and the stress placed upon the protection of forest reproduction from injury by grazing have led to exceptionally severe penalties for offenses of this character, involving obligatory imprisonment in most cases. The mere presence of sheep or cattle in a public forest is penalized and the stated fines are doubled if the animals are discovered in woods under 10 years of age.

Laws Dealing with Forest Fires. - The provisions of the forest code dealing with fire are of special interest to Americans. Fires may not be set for any purpose within 600 yards of a forest under public administration except by land owners, or in the exercise of public franchises, or with the permission of a forest officer. While the incendiary firing of cut timber is punished by imprisonment for limited periods, an incendiary fire in a forest is punishable by imprisonment at forced labor for life, a distinction which well illustrates the French viewpoint toward forest conservation. The forests of the Mediterranean provinces of France, which experience a summer drought and fire hazard comparable to our Southwest, are placed under the protection of a special fire code. Surface burning by land owners to destroy underbrush, a practice formerly common at the time of harvesting cork oak bark, is expressly forbidden. Neither the owner of the land nor anyone else may set fires within 600 yards of any area of forest or brush land from June 1 to September 13 in each year. The departmental governor alone may authorize the use of fire within forest or brush lands for charcoal burning or other industrial purposes. And any owner of forest or brush land in this region can compel his neighbors to share the cost of a fire trench, or break, at the boundaries of adjoining holdings. These breaks must be from 60 to 150 feet wide and kept clear of herbs, brush, and resinous trees.

The forest penal code, which these examples illustrate, is more terrifying on the statute books than in actual enforcement. This hardly could be otherwise in view of the tact and diplomatic skill of French forest officers and their effort to overcome local antagonisms to the forest policies of the State. Nevertheless it is a striking expression of the national instinct of forest conservation.

State Control of Forest Devastation. - The same solicitude toward forests as a resource requiring exceptional public safeguards is illustrated 
by the laws concerning the denudation of privately owned forest lands. Here again the minute restrictions of the old kings were swept aside by the great outburst of democracy and individualism in the Revolution. For a considerable period following 1791 private owners were freed from all control and many forests were destroyed. This was in part a necessary process of converting forests into wheat fields, but apparently went too far and contributed to the acute shortage of forest products which France experienced near the middle of the Nineteenth Century. In time the wave of revolutionary freedom was checked by a reawakening of the conservative instincts of the French toward their natural resources. The law against the devastation of forest land, which was enacted substantially in its present form in 1859, has often been called a striking anomaly in the jurisprudence of modern France. It restricts the rights of private ownership in one class of property alone - forest land - which is singled out for special interference and control by the State.

The French Government does not dictate how the private forest owner shall cut his timber but, with the exception of small, isolated tracts or enclosed areas adjoining dwellings, holds him responsible for not destroying his forest or converting the land to other uses without prior warrant from the State. Violations of the law are judged solely by the fact that forest land has actually been devastated. Whether this resulted from the methods of cutting, from fire, from over-grazing, or from deliberate clearing for agriculture is immaterial. So is the intent or good faith of the owner. If "défrichement" has actually resulted, without permission in advance, the owner of the land is liable to a fine of as much as $\$ 115$ per acre. He may also be ordered to reforest the denuded land within a prescribed period.

These penalties may be avoided by obtaining the consent of the State to the destruction of a forest in advance. This requires a declaration of intent by the owner of the forest eight months in advance, investigations and reviews by various forest and other administrative officials, and a final decision by the Minister of Agriculture. The request of an owner to destroy his forest can be denied on the ground that its preservation is essential to protect water sources, to protect mountain slopes from erosion, to prevent the movement of sand dunes, or to safeguard the public health or the national defense. Many attempts have been made to amend the law so that the destruction of a private forest may be forbidden on the ground that it is needed by the immediate community or by the country at large for growing timber. None of them has yet overcome the resistance to this further invasion of the rights and liberties of the property owner.

A Striking Infringement of Property Rights. - The control of private forests and forest devastation thus stands as an interesting compromise 
between the French instinct for forest conservation and their present-day spirit of personal liberty. With its limited application the value of this law exists largely as a support of the efforts of the Government to prevent deforestation on mountain slopes where torrential erosion is liable to occur. The law is of special interest to Americans, however, because it expresses a far-reaching principle - the responsibility of the private forest owner for keeping his land productive as a forest. The significance of this infringement of the rights of private ownership can be appreciated only in the light of the sacredness of property rights in France. A people fully as jealous of individual liberties as ourselves have not hesitated to curtail property rights - in the case of forests as distinct from all other classes of land - because of the special public interests which forests serve.

Tax Exemptions on Forests. - The distinctive value of forests as a national resource is also recognized by the French in their methods of taxation. All forest plantations are accorded tax exemptions in varying degrees during the first 30 years. This exemption from tax burdens is complete in the case of plantations on mountain slopes or summits or on sand dunes or other barrens. Otherwise forests in France are taxed on their current income. Under the law of 1907 land in all forms of culture is classified periodically in accordance with its productivity. There may thus be three or four classes of forest land as determined by soil, timber species, and the value of wood products. The net yearly income from each class of forest is then fixed from a study of sample areas. All forest properties are classified and assigned an income rating. This represents the average net yearly receipts for wood and timber after deducting costs of upkeep, fire protection, administration, thinnings, planting, and other cultural measures. The national and local taxes usually amount to 8 or 10 per cent of the net income.

\section{FOREST AND LAND CONSERVATION}

Stabilization of the Gascon Sand Dunes. - Another striking chapter in the economic history of France, in keeping with her national attitude toward forests, has been the recognition of forestry and related land problems as a special field for public initiative and development, together with the value of "the armor of the forest" for stopping destructive movements of soil and water. At the beginning of the Nineteenth Century, a large section of southwestern France was menaced by the sand dunes along the Gascon Coast. Various attempts to check this invasion during the preceding century had been futile. Many of the dunes were moving inland at rates varying from 30 to 100 feet a year, burying farms and villages in their path.

A successful method of combatting the dunes was finally evolved 
through stabilizing the outer waves of sand with mats of brush and hardy herbs and then sowing the ground with maritime pine, a fast-growing pitch pine native to the region. A national project for stabilizing and foresting the entire Gascon dune belt, of some 250,000 acres, was initiated in 1810 and completed during the following 60 years. In the prosecution of this work, section by section, each land owner was given the choice of doing the work himself under State supervision or of placing his land under the custody of the National Government which then proceeded with reforestation at its own cost. Once the forest was established the owner could acquire possession of his land by reimbursing the public outlay upon it with interest. Otherwise the State retained possession until its expenditures had been recouped from sales of timber and naval stores. This process, in fact, was surprisingly rapid, owing to the low cost of planting, the rapid growth of maritime pine in the humid climate of the region, and its early yields of turpentine and timber. The Government of France, which did practically all the planting itself, has retained in the whole dune belt some 150,000 acres. Most of this has been incorporated in permanent State forests which form a protective belt along the coast and are managed with special precautions to prevent fresh outbreaks of the old peril. The remaining land has been restored to its original private and communal owners.

Forestation of Communal Lands. - The successful reforestation of the dune belt led to another public forestry enterprise in this region. A law passed in 1857 ordered the planting of all the barren and unused land owned by communes throughout the great sand plain known as the Landes. Again the State stood ready to shoulder the work if the owners of the land were unwilling or unable to carry it out and to retain possession of the planted forests until the cost of their creation had been returned. This time, however, State planting was unnecessary. The communes carried out the law themselves and under its far-sighted terms 185,000 acres were added to the public forests of France.

Flood Control in the Alps. - In the control of torrential erosion in the Alps, with its destructive effects upon the farm lands in the lower valleys, France has undertaken another public forestry enterprise of a far more difficult character. The erosion was traceable directly to forest denudation and excessive grazing of the Alpine pastures. The difficulty has lain chiefly in the resistance of the mountain people to outside interference in the exercise of their ancestral rights and the pastoral pursuits upon which their livelihood largely depends.

Following the severe floods of 1859 a law "on the reforestation of the mountains" authorized the designation of restoration areas within which existing forests were placed under public control and the planting of denuded lands was decreed as necessary in the public interest. Private 
owners who declined to reforest their lands were expropriated by the State, with indemnities, but could reacquire their property within five years after planting had been finished by reimbirring the Government for all outlays expended upon it. Communal lands, under like conditions, were not condemned but were taken possession of by the State, to be planted and held until revenues from the newly created forests had wiped out the account.

Under the obstacles created by hostile local sentiment and the reluctance of the French Government to deal with it forcefully, this project has made but slow progress. The law was changed in 1882 owing to the opposition of the mountain communes to what they asserted, with some degree of justice, was the practical confiscation of their lands without indemnity; and since that time all areas where planting or other intensive measures were needed have been acquired outright by the State. The protection of mountain watersheds in France has thus taken a course almost identical with that in the United States under the terms of the Weeks law, that is, public acquisition and absolute control of important "key" areas. The French Government has thus acquired about 200,000 acres on the headwaters of important streams in the Alps, and the work is still being continued. In addition some 52,500 acres of communal lands were reforested under the earlier law and placed under public administration.

Under the law of 1882 France has also attempted to enforce a new and significant principle in watershed protection. This is the designation of large protection belts in the mountains, surrounding the limited areas in which serious erosion is actually taking place and must be combatted by intensive methods. In these protective zones, which were designed to prevent the starting of fresh torrents, the administration was empowered to forbid any use of land or forest which would destroy the vegetative cover. And to extend further the general scheme of prevention, the grazing of certain communal pasture lands was placed under public control. The administrative procedure devised for carrying out this system has been exceedingly cumbersome and has sought to conciliate local opposition at every turn with many provisions for safeguards and indemnities. Its practical value has been very small, and the effort of the French Forest Service to check mountain floods has of late years been concentrated mainly upon the acquisition of land at critical points by the State and its systematic reforestation.

The actual work done in the Alpine gorges and on their adjoining slopes is an example of intensive conservation fully as striking as the stabilization of the sand dunes. Tree planting is the primary method, but it was necessary at many points to hold the soil or stop the cutting action of streams before planting was possible or would be effective. 
Small gullies have been blocked with dams of sod or loose stones or with brush rip raps. More elaborate dams of rubble or masonry have been built in the channels of many torrents, sometimes at intervals of a few chains to check erosion and the rush of floodwater and afford soil-collecting basins which would later be planted with trees. Rubble or masonry dams or walls have been constructed at various points to stop the caving of banks or check incipient land-slips or snow-slides. Hardy shrubs have been set out in masses of glacial drift or the talus of a slope where the ground was too unstable or too sterile to support trees. But the general aim is to get the land under forest cover as soon as it can be done. French foresters and engineers are agreed that an extensive mantle of forest is the final solution to watershed protection.

Expropriation of the Use of Land for Forest Enterprises. - One of the legal principles developed in these public forest enterprises of France suggests a modus operandi for State or Federal projects in America where the reforestation of private land is deemed necessary in the public interest. It bears points of similarity to the plan already adopted by some of our States to encourage the planting of private land. This principle is not the purchase or condemnation of private property - but the expropriation of its tenure, or occupancy, for a sufficient period to establish forests, with provision for ultimately restoring the land to its owner after it has repaid the cost of the enterprise. Applied in the southwestern sand plains where planting was cheap and tree growth rapid and where returns from the new forest were realized in a relatively short time, this method succeeded. Applied in the Alps, where reforestation was much more costly and the climate much more rigorous, it amounted to practical confiscation and failed. In both instances it bears proof of the French attitude toward the conservation of forests and soil as a dominant public interest, taking precedence over the rights of private property.

Private Forests in Conservation Projects. - Another illustration of the same national viewpoint, brought out in the development of French policy in dealing with sand dunes and mountain torrents, is the provision of law placing all forests within the perimeters of control or restoration projects, whatever their ownership, under the "régime forestier." That is, such forests not merely are subject to the law preventing denudation; they can be cut only in accordance with methods approved by the State service. They are also accorded in full the special and stringent protective measures carried by the penal section of the forest code. Private forests on the critical areas embraced in public conservation projects are thus given a special status - subject both to public control and an exceptional degree of public protection.

The Core of Publicly Owned Forests. - Another interesting and suggestive fact about France is the extent to which her forestry develop- 
ments and activities have centered around and grown upon a core of publicly owned forests. These national and community holdings fittingly express the forestry sense, or instinct, of the French people. Their extension, their standards of administration, their educational influence, the technical service entrusted with their care - these have been first and last the greatest supports of forestry development in France. Yet their history has not been one of smooth, uninterrupted progress. In certain chapters it reminds us strikingly of the history of the public domain in the United States.

Checkered History of the State Forests of France. - The first effect of the French Revolution was toward the nationalization of the forests of the country. The royal domains, largely forested, were declared to be the property of the State. A law of 1789 , placing church property at the disposition of the nation, added more forests to the public holdings. In 1792 the forests owned by emigres of the old nobility were confiscated. Then a counter, individualistic movement, tending to break up national

- control, set in. In the reaction against the abuses and usurpations of the old seigneurs, and during the lax administration of the earlier revolutionary period, the rural communes were encouraged to take possession of the old royal, noble, or ecclesiastical forests under any sort of pretext based upon entailed rights or old claims. Many properties of the fugitive nobility were restored to their former owners. Large areas of State forests were sold outright under the individualistic economic theories of the times. Every subsequent revolutionary overturn was followed by fresh disposals of State timberland. Up to the beginning of the Third Republic the attitude of the French toward their public domain was similar at many points to that in the United States during the Nineteenth Century.

Under the Third Republic the policy of France has turned definitely in the opposite direction. Alienations of national forests have been restricted practically to minor adjustments of communal claims. On the other hand, the State holdings have been enlarged steadily by plantations in the sand dunes and by the purchase and reforestation of mountain lands in connection with the protection of watersheds. Most important of all, the forest code has placed public forests of every kind, including communal lands and the properties of public institutions, under a unified public administration, by an expert service of exceptionally high technical standards and practical ability.

The Extent of the Public Forests. - These public forests now comprise nearly $8,000,000$ acres, about one-third of the forested area of France. $3,000,000$ acres of this total are the property of the French nation, the community forests together aggregating considerably more than the holdings of the central government. 
Their Technical Management. - The forest code establishes the principle that all of these public forests must be handled under a precise scheme of management, the main point of which is to fix the amount of wood which may be cut yearly without reducing the growing stock, or capital, and to prescribe the methods of cutting so as to maintain the productivity of the forests. The importance attached by the French to their public forests is illustrated by the fact that the management plan for each unit must not only be approved by the high council of the Forest Service and by the Minister of Agriculture but must be authorized by a decree of the President of the Republic. The function of State and communal forests is settled to be the supplying of national industries with the classes of products which they most need, particularly large timber which may not be grown on private lands because it is less profitable. The purpose of State and other public forests is thus to supplement the materials produced in the largest quantities by other owners with choice timber whose growing is long and costly, a distinction which often disappears, however, under the scale of values fixed by supply and demand.

The Communal Forests of France. - The communal forests of France are one of the most interesting and suggestive phases of her public forestry. The French Commune may be compared with the New England township - a self-governing, rural community of exact geographical limits. In the break-up of the old order these little communities, which usually had held entailed rights to the use of wood and forage from royal or seigneurial estates, asserted their claims so vigorously as to acquire many small tracts of forest and pasture land in fee simple. Their forest huidings were increased in various ways, as through the planting of 185,000 acres in the southwestern sand plains under State supervision. To-day they form a sixth of the forests of France. Under the terms of the forest code, the great bulk of them are administered as part and parcel of the public forests. While still serving their original purpose of furnishing supplies of wood, especially fuel, for local use, they thus are important contributors to the national lumber pile.

Some communes own and operate their own small sawmills. These community forests are important sources of revenue for hundreds of French villages, reducing taxes and affording the means for constructing town halls, roads, and other local improvements. The situation in France would be paralleled if every village in New England or the Lake States owned 500 or 1,000 acres of forest, kept continuously in the highest state of production, furnishing the timber locally needed, affording a substantial income for community purposes, and providing steady employment for a number of its citizens.

Educational Value of the Public Forests. - The real value of the public forests of France, as of her whole forestry system expressed in the "régime 
forestier," can be gauged only in an appreciation of the administrative skill of the French, of their practical genius for coopperation, and of the intelligence of many rural classes. These factors have extended the technical practice in public forests far beyond their own limited areas. Public forests and their staff of trained officers are to be found in every section of the country. They set the standards and their results have demonstrated good forestry to every timber owner in France - in his own immediate neighborhood. How to cut and restock timberland has thus become a common knowledge of the people. The local forest officers of the State are recognized leaders and advisers in all forestry matters. Direct forms of coöperation with private land owners have resulted in the special recognition given to associations of forest owners and in the opportunity to place private holdings under the technical methods and legal protection of the "régime." The public forests have thus had a marked educational value and have given stimulus and direction to the whole forestry development of France.

This fact is indeed suggestive to the United States. In our first steps toward forest conservation, public forests, Federal, State, and municipal, should have a dominating part. They should be created in every section and be identified with its local problems of fire hazard, of timber growth, and of provision for future needs. They should develop the technical practice adapted to our varied forest types and make it common knowledge by concrete demonstration, the most effective of all educational measures. In democratic America, as in democratic France, a core of public forests will prove the key to progress.

\section{PRIVATE FORESTRY IN FRANCE}

Its Economic Basis. - Private forests in France obviously are on a footing totally different from that in the United States. Aside from the national conservatism of the French, their love for forests as things of beauty, and the social inheritances which put their forests in high regard, the high price and close utilization of wood afford an economic basis for the successive cropping of timberland. The prevailing stumpage values of French timber in 1917 averaged at least five times the prices for corresponding species in the United States. The American Army, for example, paid about $\$ 36$ per thousand feet on the stump for oak timber of all grades in the Loire River Valley and up to $\$ 50$ per thousand feet for silver fir and spruce in the Vosges Mountains. A crop of hardwood coppice, grown in 20 years, brought at the same time from $\$ 50$ to $\$ 60$ per acre for fuel as it stood in the woods. These were inflated war-time rates, but on a pre-war basis the disparity between timber values in France and the United States is almost equally great. This is due not alone to the shortage of timber in France and the necessity of importing 
a third of the lumber which the country uses. Low conversion costs are an important factor. The forests of France for the most part are very accessible. The simple methods of manufacture by small local mills, with almost no investment or overhead charges, are inexpensive. The wages paid to forest labor, 5 francs, or less than $\$ 1$ per day in 1917 and still less before the war, is very low. With lumber prices influenced by the importations of Baltic and other foreign stock, with keen competition for all stumpage put upon the market, the standing timber gains the benefit of the low costs of manufacture. The situation in the United States, where manufacturing charges are the chief element in the mill price of lumber, is reversed in France. The standing tree takes a third or more of the selling price of its products.

Forest Versus Farm Crops. - France contains large areas of land in her eastern and southern mountains, in the southwestern sand plains, and in the rugged hills on the headwaters of the Marne and Seine which are fit only for timber production or for grazing. The presence of such land - of relatively low value - is a further stimulus to private forestry; $1,500,000$ acres of private forests, for example, were created outright by planting maritime pine in the Landes. Her forests are not limited, however, to areas too poor for cultivation. The economic balance between forests and farm crops has shifted at various periods in French history. At the time of the Revolution the country was short of agricultural products, especially cereals, and a large acreage of forest was put in tillage. Fifty or sixty years later the pendulum swung back. Shortage of farm labor appears to have been the immediate cause. Many rural proprietors in central and northern France, finding their fields lying fallow year after year, resorted to tree planting. There has been no important change since that time with probably a slight tendency in later years to increase the farm area at the expense of the forest.

We in the United States are prone to think that the farm must always be given right of way over the forest; and doubtless that is the safest guide in our present stage of development. The economic growth of France has carried her beyond such broad assumptions. The demand for wheat and the profit in growing it compared with the demand for timber and fuel and the profit in growing these products are the considerations which govern. The area devoted to forest is fixed by the balance struck - over comparatively long periods of time - between all the economic necessities of the country; and that balance has not thus far limited her forests, either publicly or privately owned, to non-agricultural lands. This sort of readjustment is impending in some of the older parts of the United States.

The Importance of Private Forestry to France. - Two-thirds of the forests of France are privately owned. Her 16,000,000 acres of private 
forests, which for the most part are fairly well cared for and kept in continuous production, are a striking object lesson to Americans who are wont to regard forestry as possible only for the Nation or State. About 30 per cent of them are devoted to the production of hardwood fuel. Otherwise their technical management, while less regular and uniform and usually less conservative, does not differ in essential respects from that of the public forests. Upon her privately owned forests France depends for the bulk of her lumber and fuelwood.

Returns from Private Forests. - While æsthetic and social considerations and the play of national conservatism have their part in this result, forestry is a real business in France. Large areas of woodland are held as long-term investments and often are highly regarded as stable securities for the investment of family or institutional funds. Well-managed oak and beech forests yield net revenues of from $2 \frac{1}{2}$ to 4 per cent. Such forests may furnish a crop of coppice every 20 or 25 years and at the same time usually carry an over story of high-grade timber, which may require 200 or 240 years to mature but is actually harvested in small quantities at every periodic cutting. A large forest property is split into lots or compartments containing sprouts or timber of different ages. Some material is harvested every year or at least every 4 or 5 years. There is thus an actual current revenue in keeping with the size of the whole property; and the problem of accrued carrying charges, which is so burdensome to the owner of undeveloped timber in the United States, searcely exists in France.

Forestry as a commercial business is most highly developed in the pineries of the Landes where the low value of the land and the combined yields of naval stores and timber make it exceptionally profitable. Net returns of 6 per cent on investments in southern pineries are not uncommon. Here also the revenue is practically continuous. The larger properties contain blocks of timber of varying ages, and aside from a steady return from turpentine orcharding, realize every few years upon a. small cut of stumpage.

Forest and Sawmill Divorced. - The great bulk of the French forests is in separate hands from the timber-using industries. This has an important bearing upon their management. The forest is relatively independent of the sawmill. The forest owner determines the amount and location of the stumpage which he wishes to cut from year to year. Foresters or forest rangers are employed on all of the larger properties, and the cutting area is selected, marked, and estimated by them. The sawmills are uniformly small and most of them are portable. In the eastern mountains there are many little stationary mills, driven by steam or water power, which obtain their logs from the yearly cuttings on any one of a dozen or more forest properties in their vicinity. Logs are 
hauled by ox teams, in full tree lengths, for distances up to 15 or 20 miles, to these little mills. In the level pineries of the south a light steam tractor of the "locomobile" type, operating a band saw 3 or 4 inches wide, is almost universal. These little mills roam about the Landes, picking up a few hundred cubic meters of timber here and there, sawing it into boards, and then passing on, leaving neat, triangular cribs of lumber to be hauled out by the two-wheeled mule carts of the region whenever it has seasoned sufficiently.

Lumber Manufacture Adapted to Forestry Practice. - In a word, the lumber manufacturing industry has grown up on and adapted itself to a system of forest management which permits but small cuttings at any one place in any one year or series of years. Cases are rare when the wellbeing and permanence of the forest are sacrificed to the requirements of a manufacturing enterprise - an exact opposite of the situation so common in the United States where the manufacturer owns the timber and has denuded one forest region after another in order to supply his large stationary mills to their maximum capacity. While this relation is largely a result rather than a cause of the economic status of private forestry in France, it indicates the industrial adjustments which will become necessary in America as our emphasis shifts from supplying sawmills to growing timber.

Private Forestry On Its Own Feet. - Private forestry in France stands largely upon its own merits. It is mainly a free reaction to the economic requirements of the country and an expression of the thrift and habits of its people. Aside from tax exemptions on plantations under 30 years of age and assistance in technical practice, it receives no public subsidies or support. The laws against devastation have restricted the decrease of forest areas in the French mountains - but elsewhere have not had an important effect. It is probable that the greatest public leverage upon the private owner to keep his timberland productive has been the stimulus and example of the publicly owned forests, with their wide distribution throughout France and their high standards of technical practice.

\section{FOREST PROBLEMS OF FRANCE AND THE UNITED STATES}

Intensive Use of Limited Resources in France. - The forest problem of France is totally different from that of the United States. Intensive use of a limited land area to support her dense population is forced upon France. Her situation would be paralleled if a third of the people in the United States were crowded into an area somewhat smaller than the State of Texas. At the best, France must import a large volume of wood products. France has had to strike a close balance between her needs for lumber and her needs for farm crops and, notwithstanding the number of mouths to be fed, has had to devote a considerable acreage of 
agricultural land to timber production. Intensive methods of growing successive crops of timber form a necessary part of her national economy. The shortage and high cost of wood have given an impetus to the practice of forestry as a business which is scarcely approached in any part of the United States.

The Handicap of Lumber Shortage. - Lack of cheap lumber is an economic handicap in France. It is apparent, particularly in her rural districts, where a new structure of any kind is a rare sight and the ancient, moss-covered farm buildings give an impression of decadence which is only partly real but nevertheless portrays forcibly the low standards of rural improvements which not only reduce the comfort and wholesomeness of country life but inevitably lower the efficiency of agricultural industries. The manufacturing industries of France suffer from the scarcity and high cost of timber. The per-capita consumption of lumber is not more than 100 board feet per annum, less than one-third that of the United States. In other words, France illustrates the evils of a situation where lumber is a luxury, in part - an imported luxury. Her 18 per cent of forested land is not enough. Her intensive forestry can but partially offset the effects of a shortage of timber-producing land.

America's Problem - Idle Land. - It is not our problem in the United States to strike a close balance between the forest and the farm. That can be left to the economic adjustments of the future. We have an ample area of forest land beyond all requirements for agriculture. It is rather our problem to put idle land to use. The United States contains probably 500,000,000 acres of forest land. Our uncut virgin timber has been reduced to not more than $150,000,000$ acres. Of the $350,000,000$ acres of cutover land at least a third has been reduced by heavy cutting and forest fires to unproductive wastes. An area of forest land at least five times that of all the forests of France combined is producing nothing.

Timber has been cheap and plentiful in the United States as compared with other nations. Our per-capita consumption of lumber is two or three times that of any of our principal competitors. It is our problem to keep timber cheap and plentiful, to make it unnecessary to restrict the use of wood in domestic industries or export trade, to avoid reductions in the per-capita consumption of lumber toward the lowest limits of civilized existence which it has reached in France. This does not require as yet the practice of intensive European forestry. It can be accomplished by the simplest measures of protection and regeneration which will keep timberland productive. The starting point must be to stop the devastation of the forest lands now being cut and to put our millions of idle acres at work growing trees. This will require not only a large share of public coöperation but also, as in France, a recognition of the obligations carried by forest ownership. 


\section{CHAPTER II 1 \\ THE RÔLE OF FORESTS}

The Valde of Forests (p. 17). Objective, Dangers of Deforestation, Fundamental Causes, Obligation of the State.

Forest Influences (p. 19). Effect on Temperature (Air Soil), Wind, Frost, Hail, Humidity and Rainfall, Water Level, Springs, Floods, Avalanches and Erosion, Health, Recreation, and Beauty, Literature and Art.

\section{THE VALUE OF FORESTS}

Objective. - The objective of this chapter is to give the American forester an insight into French views - somewhat idealistic to be sure on the rôle that the forests play in national life and to summarize briefly the technical viewpoint on "forest influences." Huffel's exposition on forests and springs is given in full in the Appendix, p. 361, and Jacquot's statement on the physical, economic, and social rule of forests, on p. 381 .

Dangers of Deforestation. - If forests fail to yield a good revenue, should they be cut? or are they worth financial sacrifices? French policy is based on the economic fact that her forests are worth the sacrifice, and her forest history points unfalteringly to the evils of reckless deforestation. Who could view the eroded Alps, Pyrenees, or the torrents of the Lozere and think otherwise? The penalty for using up forest capital is too great.

"When the mountains are baked ${ }^{2}$ all is ruined. The rains . . . fall in torrents and rush off the denuded soil. They first carry off the vegetable cover. The mountain shows its rocky skeleton, the rocks break up, cones of erosion are formed, landslides, gullies, unstable slopes become so many running sores by which the substance of the mountain is carried down. The rocks offer more or less resistance according to their texture, but none withstand. Even granite splits up into enormous blocks which roll irresistibly down into the valleys. . . . When the highlands are ruined, what becomes of the plain? . . . The river becomes a torrent when it rains, carrying down earth, trees, and rocks. Swollen beyond measure, it flows over the plain in a sudden flood which destroys houses, flocks, villages, and people. . . . The sudden flood is characteristic of denuded countries . . . the mountain can no longer supply the valley with water. Now is the time of drought and famine. Irrigation is impossible for the rivers are dry. . . . The cultivators try to continue the struggle by means of reservoirs and costly dams."

What a picture, but how true! Look at deforested countries and they

1 G. A. Pearson kindly reviewed this chapter.

2 Déboisement et Décadence. F. Régnault. La Revue, March 1, 1904. 
all bear the same evidence: Palestine, Assyria, Arabia, Greece, Tunisia, Algeria, Italy, Spain, Persia, Sardinia, Dalmatia. To-day England is the only virile Great Power without extensive forests; what she has are in her colonies. It appears that decadence goes hand in hand with deforestation. Which is the foundation stone of a nation's decline? Is the sequence decadence-deforestation or deforestation-decadence? Or is deforestation simply a general lack of foresight coupled with poor forest management?

Fundamental Causes. - What is the fundamental cause of deforestation? According to Regnault:

"It is well to seek the causes. They are of various kinds. The most important is civilization itself. Civilization increases the sale value of wood, and provides the means of transport, without which sales would be very limited. It awakes greed in the mind of the landowner and at the same time allows him to satisfy his greed. Thus the barest countries are always the seats of the oldest civilizations. Certainly, when the landowner finds it to his interest to plant, he does not hesitate to do so. Thus the truffle industry has caused the plantation of more than 148,000 acres of oak in the Vaucluse; and recently the oil trade has caused the plantation of an immense olive forest round Sfax in Tunis. But such cases are quite exceptional.

"The cutting of trees is a source of immediate profit, but it entails later a great diminution of revenues. Hence reboisement meets with great difficulties, not only in the want of money, but in the hostility of the inhabitants. These people were originally hunters, woodsmen, petty cultivators, but especially herdsmen, enjoying rich pastures and large herds of cattle. The destruction of the forest forces them to change their livelihood. They become shepherds and goatherds, for sheep and goats are the only animals which can exist on the soil when it has become impoverished. These animals live on young shoots and buds, and prevent the forest from growing again. The shepherds themselves oppose every attempt at reboiscment, pulling up young trees, destroying seedlings, etc., for they fear to lose their living. They even burn the forest in order to obtain further areas, until the mountain disintegrates and their last resources are swept away by landslides and erosion.

"The political condition is of great importance. A strong government enforces respect for the forests."

Obligation of the State. - Speaking of the deforestation in France Regnault calls upon the State to do its duty: ${ }^{3}$

"While the State is thus so badly neglecting its duty, all the authors who have studied the subject of déboisement are agreed that the State is the only possible source of salvation. They wish to forbid all clearings by communes or by private persons, and to make the private interest yield to the public good. A despotic government can indeed enforce blind obedience on the part of its subjects, but in a republic, where every one is a judge and critic of policy, the best laws are useless unless the citizens understand their utility."

After a careful study of the Loire watershed, Benardeau, then Conservator of Forests at Moulins (Allier), concluded as follows: ${ }^{4}$

${ }^{3}$ La Forêt, A. Jacquot, 1900.

4 Correction de la Loire et de ses Affluents, F. Benardeau, deuxidme edition, 1906. 
"To summarize: forests scarcely cover 13 per cent of the surface of the valley of the Loire, while the average for France reaches 18.7 per cent. Two per cent only of the wooded area was under forestry regulations. . . . We must not, therefore, be too surprised about the damage which everybody regrets today, but for which every one is in a way responsible. All the vital interests of the country, its military force, its agriculture, its industry, its commerce, its navy, the climate, temperature, the conservation of the soil and of the waters which supply it, even the existence of a part of the population which lives by manual labor in the neighborhood of forests, or from the product of its stock in mountainous regions, have an interest in the Loire problem which is really connected with the most serious problems of economic policy. Considering the continual development of material interests that periodic inundations jeopardize, the public executive power will not hesitate to agree to the necessary sacrifices, especially if they recall that the single flood of June 4, 1856, not counting the human lives, houses, goods, manufactures, and harvests destroyed, has cost 33.4 million dollars for defence betterments and lines of communications.

"The improvements that are required, owing to the bad condition of the Loire and Allier Rivers, are just as useful as a work made for the national defense and where the budget (with the backing of public opinion) has always been on such a generous scale. For the complete suppression of erosion and of sand deposits, it appears necessary to give the Service des Eaux et Forêts sufficient resources, in order that improvements may be made in advance of the damage, which is incessant in the basins of these rivers."

It is true that the discovery of iron, cement, coal, gas, and electricity has tremendously reduced the need of wood. Yet a French writer says: "Even without modern uses of iron, cement, and coal there is an insufficiency in the world's wood production which some time will be keenly felt by the great powers of the world."

There is therefore every incentive to inculcate in the minds of all students the national need for wise forest management. This study, the French believe, should begin in primary and secondary schools. Arbor day (f̂êtes de l'Arbre) celebrations are required by law. There are French societies organized for the promulgation of forestry. The Jura has sixtyeight such societies and the Touring Club de France has a standing committee on conservation. In France the planting of trees as a celebration at births is often practiced, and in Alsace trees are often planted at both births and marriages. To celebrate the birth of the "King of Rome" in 1811 an entire forest was planted. It is felt necessary to make the love of forests and realization of the necessity for their wise use a part of French national life. ${ }^{5}$

\section{FOREST INFLUENCES}

Effect on Temperature (Air Soil). - According to investigations started by Mathieu at Nancy in 1886, the mean annual temperature is less in the forest than outside. Other investigators have confirmed these

${ }^{5}$ The French viewpoint is admirably presented by Jacquot in his summary of "The Forest, from a Physical, Economic, and Social Viewpoint." A brief and translation is given in the Appendix, p. 381. 
early French investigations. The results of an experiment (1869-1888) in a beech forest at an altitude of 1,115 feet showed the mean annual temperature inside the forest to be $0.45^{\circ} \mathrm{C}$. less than outside. In thirteen experiments at various altitudes in pine, spruce, beech, and larch forests, the forest temperature averaged $0.66^{\circ} \mathrm{C}$. less than in the open. The difference was greater in summer than in winter. The mean maximum days at Nancy averaged $24^{\circ} 0.48^{\prime} \mathrm{C} .\left(76^{\circ} \mathrm{F}\right.$.) in the open and $21^{\circ} 0.51^{\prime} \mathrm{C}$. $\left(70^{\circ} 0.7^{\prime} \mathrm{F}\right.$.) in the forest. In the cold weather the average outside the forest was $-5^{\circ} 0.12^{\prime} \mathrm{C}$. $\left(31.89^{\circ} \mathrm{F}\right.$.), inside $-4^{\circ} 0.24^{\prime} \mathrm{C}$. $\left(31.91^{\circ} \mathrm{F}\right.$.). The investigation thus showed that the temperature extremes were raised $3^{\circ}$ to $5^{\circ} \mathrm{C}$. by a forest cover, but that the temperature in the forest was warmer in winter and cooler in summer. In other words, the forest acts as an equalizer of temperature. ${ }^{6}$

The Nancy research officers established the following laws: (1) The mean annual temperature that was reached is $\frac{1}{2}^{\circ} \mathrm{C}$. less in the forest than in a nearby open area. (2) This difference in temperature, while slight during the winter months, is greater in summer. (3) The minimum temperature is raised in the forests by nearly $1^{\circ} \mathrm{C}$. and the maximum lessened about $2^{\circ} \mathrm{C}$. In other words, there is a decided difference between the minimum and maximum of $3^{\circ} \mathrm{C}$.

In addition it may be said that conifers lessen winter extremes of temperature more than do broadleaves and that the denser the summer foliage the cooler the forest in comparison with the open areas. These differences are greatest at 35 to 40 feet above the soil.

Investigations by Cuif ${ }^{7}$ show conclusively that soil is almost $4^{\circ} \mathrm{C}$. warmer during July in the open than under high forest or under coppice. $\mathrm{He}$ also proved that soil temperature variations outside and incide the forests are less extreme than the variations in the air temperature by from $2^{\circ}$ to $4^{\circ} \mathrm{C}$.

Wind. - The value of forests as shelter belts against the wind is proved for agricultural crops and for water surfaces to prevent evaporation.

Frost. - It has always been recognized that forest cover prevents frosts. They are less frequent and less severe under cover, which is the reason why the shelterwood system must be applied to beech. Without the top story the beech seedlings would be frost-killed. In 1912 Cuif ${ }^{8}$ proved that the forest cover prevented damage from late frosts and showed that in the State forest of Amance (Meurthe-et-Moselle) oak

- Huffel, Vol. I, pp. 45-67.

${ }^{7}$ Influence du Couvert de la Forêt sur la Température du sol à diverses profondeurs, par M. E. Cuif. Bulletin de la Société des Sciences, 1909.

- Action de la Forêt sur les Gelées Tardives, par M. E. Cuif. Annales de la Science Agronomique française et ctrangère. Sept., 1912. 
plantations after cutting were badly frosted two years out of three, while the plantations under scattered seed trees were not damaged.

The frost penetrates the soil about one-half as far in the forest as on the outside. According to four experiments (quoted by Huffel) the average soil depth of frost outside the forest was 17 inches, while inside the ground was frozen only to the depth of $11 \frac{1}{2}$ inches.

Hail. - Hailstorms are less frequent in the forest than outside. Huffel quotes Riniker (1881 Die Hagelschage), who says: "In general hailstorms stop at the border of well-stocked mature forests. Both on the plains and in the mountains one often sees hailstorms cut in two or divided when they pass above wooded stands . . . small coppice would not do this." France had studied the effect of hailstorms on forests and vice vers $a$, but by the decree of January 20, 1892, the work was discontinued and no decisive results were obtained. Jacquot notes the fact that of the eighteen departments where hail does the most damage fourteen are the least forested.

Humidity and Rainfall. - Huffel ${ }^{9}$ says that "the relative humidity of the air is greater under a stand than in the open, not, as one would suppose, because the atmosphere of the forest holds more vapor, but because it stands at a lower temperature and is nearer its saturation point." According to Fautrat's experiments in the Ermonville Forest in 1876 the air under the stands showed 7 per cent to 12 per cent greater moisture content than in the open.

French foresters believe that forests mean more rainfall and, as Huffel puts it, "The rain increases according to the progress of forestation," and "it rains more, all things being equal, in the center of a large stand than on its border, and more on the border than a few miles away, that the difference appears to be independent of the season of the year, but is slightly greater during rainy years and less during a drought." The French viewpoint is given more fully under "Springs" (in the Appendix, p. 361), but French statistics collected near Nancy are at least significant. If the rainfall $(a)$ in the forest is represented by 100 , the rainfall $(b)$ near the forest and (c) well outside would, on the average, be (b) 93.3 per cent and (c) 76.5 per cent. It is at least safe to assume that forest tends to increase rainfall.

Water Level. - Experiments ${ }^{10}$ show that the water level the year round is unquestionably lower in the forests than in openings, and that there are smaller fluctuations in the water level in the forests than else-

${ }_{9}$ Vol. I, pp. 67-81, especially p. 75. It should be stated here that the theory that forests increase rainfall (except under rare circumstances) is not accepted by American meteorologists.

${ }^{10}$ E. Henry and A. Tolsky. Les Forêts de Plaine et les Eaux Souterraines. Annales de la Science Agronomique française et étrangère, 1902-03. 
where. The level is lower under a mature stand than in young growth, the differences being greater in a dry than in a wet climate. Where there is a great deal of rainfall the difference may not exceed 9 or 10 inches. Henry's observations at Nancy (see Appendix, p. 379) confirmed these conclusions (about 1 foot difference) and De Lapasse now cites proof on a large scale. It was already proved that surface water in the Landes and Gironde had dried up, after extensive areas had been sown, planted, and drained, in the Nineteenth Century, but it was not until 1917 that proof was secured that if these forests were cut the water level would rise again. This has now been proved in the forests of Porge (Gironde) where 8,649 acres were clear-cut during the period from 1904 to 1911; where 5,436 acres were clear-cut in the forest of Solferino (Landes) during the period from 1905 to 1911 ; and where 1,236 acres were clear-cut in the forest of Soulac. In the latter case the timber was 65 years old; the felling began in 1912 and was finished in 1914. According to accurate data secured by Conservateur de Lapasse the former water level at Soulac was 3.3 feet below the floor of the local church. At the end of 1916 the water began to flood the chapels to the depth of 2 inches and on January 6, 1917, the water flooded the central nave and the church itself to a depth of 6 inches and the chapels to a depth of 19 inches. In the same locality (Soulac) ${ }^{11}$ the water level of the wells rose $27 \frac{1}{2}$ inches; the local hotel cellars, formerly dry, had standing water to a depth of 8 inches. According to de Lapasse this is proof positive that clear cutting these mature pine forests has materially raised the water level. Such a conclusion is of immense importance in connection with drainage problems.

Springs. ${ }^{12}$ - According to Huffel, ground in a forest is better watered from the atmosphere than are the bordering plains. This difference is greater in winter than in summer - may be 20 per cent more. In the mountains forests unquestionably diminish run-off and bring about a greater infiltration of water which may ultimately feed springs. This is due not only to the obstacles which trees, roots, and litter present to prevent run-off, but also to the greater porosity of the forest soil and to the fact that snow melts slower under forest cover. Both French and Russian experiments have proved, however, that the water level in the forest on level ground is about one foot lower than in the fields. On the other hand, the variation in water level is less in the forest; the infiltration is slower; in other words, the forest is a regulator of water levels (as with temperature). Huffel concludes that forests increase precipitation, retain a part of the rainfall on branches and return it to the air directly,

${ }^{11}$ L'Influence de la Forêt sur le Régime des Eaux à Soulac, pp. 1-8, M. de Lapasse, 1917.

${ }^{12}$ See Appendix, p. 361, for a more detailed discussion of this subject, as presented by Huffel. 
decrease evaporation, favor infiltration in the mountains and may or may not favor it on level ground in cold or temperate climates, yet he concludes that "Nevertheless, it must be observed that springs are only numerous and important in mountain regions, and that there the forests are favorable to them."

Floods, Avalanches, and Erosion. - No one can read Chapter VII "Control of Erosion in the Mountains," without becoming convinced that forests lessen the intensity of floods and avalanches and largely decrease erosion and the formation of "torrents."

Health, Recreation, and Beauty. - The French ${ }^{13}$ claim that the forests have exerted a beneficial effect on the health of mankind. Life in the forest is especially beneficial in various nervous diseases. In India there is less cholera in the forest regions than in plains. In the forest of Haguenau there was less disease in the middle of the last century while the cholera epidemic was raging in Europe proper. The leaves of trees seem to filter the air and forests are so-called "reservoirs of pure air." Forest soil is especially unfavorable to the development of microbes. In the Landes, after the sand dunes were reclaimed, the birth rate rose and the death rate fell; in 1878 Trelat reported that the fever had practically disappeared in those regions. "The forests furnish pretty places for the invalid as well as corners of recreation . . . this need of the beautiful is deep rooted in our very nature." Fontainebleau, Compiegne, Grande Chartreuse, and Rudlin are famous recreation forests in France, but there are many others. One might say that every State forest region is a recreation ground for the French people. The forests around Nice, the rosges near Gérardmer, and almost the entire Alps and Pyrenees are visited annually by thousands. One might almost say that without its forests France would not be worth living in. Broilliard ${ }^{14}$ in 1911, toward the end of a life spent in the National Forest Service, speaks of the forest as "poetry and perfume of the earth." He says that the tree gives the forest its charm, since it is found in a thousand forms on the slopes, in clumps, in battalions, on the borders, near small openings, and even around the former Roman Camp at Morey. The old trees act as protectors of the species. In his old age he still can dream of the pretty paths, openings, undergrowth of varying aspects at different seasons, summer tranquility, autumn fruits, and sombre lines. Huffel claims that "the beauty of our forests is an object of public utility."

On June 29, 1899, Daubrée ruled that since "the Federal and communal forests often contain famous trees, because of historical or legendary interest or because of their grandeur or exceptional size, such trees belong to the æsthetic wealth of France. They add to the beauty of the land-

13 Economie Forestière, Vol. I, pp. 199-206.

${ }^{14}$ Beautés de la Forêt, par Ch. Broilliard, 1911. 
scape, they bring visitors into the regions where without them they would stay away. We must love and appreciate our forests. The local people have a real attachment for these evidences of a bygone age and see them disappear with regret. I attach great importance to this and they should be constantly protected by the Forest Service. They should never, under any pretext, be included in the cut as long as they show signs of life."

Literature and Art. - Naturally the forest has stamped its mark on French literature. Russeau spent much of his time in France and did much to make the forests popular. Chatteaubriand drew wonderful pictures of American forests but they were not very real; they were more the product of his imagination. Lamertine was a great admirer of the French forests and La Fontaine was the son of a professional forester. William Shenstone, who flourished in England in 1760, was undoubtedly influenced by his knowledge of the French forests.

I $t$ is well recognized that all forms of art are founded on nature. Some persons believe that the gothic arch was suggested by the arcades of the forest. In painting, almost every landscape owes much to the color and shape of trees. Of the earlier French painters Claude shows most love of foliage, but few of his pictures look as if he had painted them in the woods. In every European forest the trees are so dense that it is difficult to paint modern forests. In the words of a Frenchman, "You foresters should think of this and not only space the trees, since then and then only may the carefully tended forests become useful to the artist as well as to the lumberman." Diaz was a man who spent most of his time in the woods. The Brabigan school painted woods more or less; iut Corot (like Claude) had no use for a "regular forest."- What he wanted was a group of trees for the purpose of composition.

While some of these French claims regarding forest influences may be questioned by the scientist, yet no one familiar with the history of forest economics can question for a moment the statement that no nation can afford to destroy its forests because their direct and indirect benefits have an increasingly important influence on national efficiency. 


\section{CHAPTER III}

\section{FOREST REGIONS AND IMPORTANT SPECIES}

Peysical and Cumatic Features - Industry (p. 25). Area and Topography, Climate, Agriculture, Other Industries, Water Power, Commerce, Government.

Forest Regions (p. 29). Broad Divisions, Plains, Parisienne Zone, Gironde Zone, Provençale Zone, Mountains, Vosges Zone, Jura Zone, Alps Zone, Central Plateau Zone, Pyrenees Zone, Some Mountain Forests in Detail, Vosges, Alps, Pyrenees.

Important Forest Species (p. 40). Acreage and Distribution, Pedunculate Oak, Sessile Oak, Beech, Hornbeam, Holm Oak, Cork Oak, Silver Fir, Scotch Pine, Maritime Pine, Norway Spruce, European Larch, Aleppo Pine, Exotics, Use of Exotics. (See Appendix, p. 387, for data on species.)

\section{PHYSICAL AND CLIMATIC FEATURES - INDUSTRY ${ }^{1}$}

Area and Topography. - France is a western country in western Europe, hexagonal in form, bounded northwest by the North Sea, Strait of Dover (Pas-de-Calais) and the English Channel (La Manche); west by the Atlantic Ocean; southwest by Spain; southeast by the Mediterranean; east by Italy, Switzerland, and Germany; northeast by Germany, Luxemburg, and Belgium. From north to south its length is about 600 miles, measuring from Dunkirk to the Col de Falgueres; its breadth from east to west is 528 miles, from the Vosges to Cape Saint Mathieu at the extremity of Brittany. The total area is estimated at 207,170 square miles, including the island of Corsica, which comprises 3,367 square miles. The coast line of France extends for 384 miles on the Mediterranean, 700 on the North Sea, the Strait of Dover, and the Channel, and 865 on the Atlantic. The country has the advantage of being separated from its neighbors by natural barriers of great strength over the greater part of its frontier, the Pyrenees forming a powerful bulwark on the southwest, the Alps on the southeast, and the Jura and the greater portion of the Vosges Mountains on the east. The frontier generally follows the crest line of these ranges. Germany possessed both slopes of the Vosges north of Mont Donon, from which point the northeast boundary is conventional and unprotected by nature. France is geographically remarkable for its possession of great natural and historical highways between the Mediterranean and the Atlantic Ocean. The one following

1 These data are furnished by the service géographique de l'armée, except where otherwise noted. See Appendix, p. 495, for data on Alsace-Lorraine, now restored to France. 
the depression between the Central Plateau and the eastern mountains by way of the valleys of the Rhône and Saône, traverses the Côte d'Or hills and so gains the valley of the Seine; the other skirting the southern base of the Cévennes, reaches the ocean by way of the Garonne Valley. Another natural highway traversing the lowlands to the west of the Central Plateau unites the Seine basin with that of the Garonne.

Climate. - The north and northwest of France bear a great resemblance, both in temperature and produce, to the south of England, rain occurring frequently and the country being consequently suited for pasture. The rains are less frequent in the interior but when they do occur are much heavier, so there is much less difference in the annual rainfall there as compared with the rest of the country than in the number of rainy days. The annual rainfall of the whole of France averages about 32 inches; the precipitation is greatest along the Atlantic seaboard and in the elevated regions of the interior. It attains over 60 inches in the basin of the Adour (71 inches at the western extremity of the Pyrenees), and nearly as much in the Vosges, Morvan, Cévennes, and parts of the Central Plateau. The zone of level country extending from Rheims and Troyes

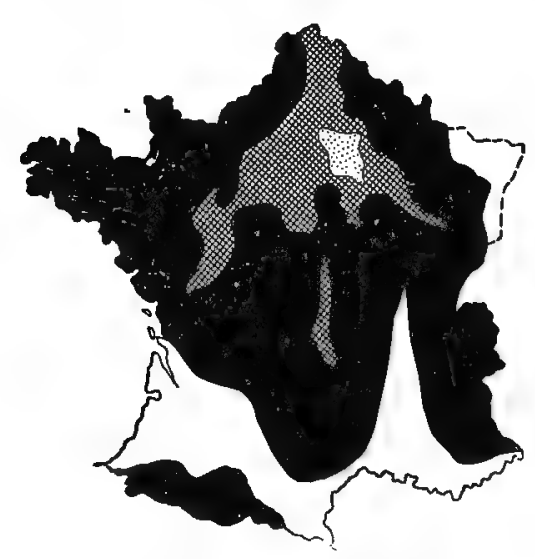

FIG. 1 (after Jolyet). — The black areas represent rainfall of over 24 inches, the hatched area 16 to 23 inches, and the dotted areas 8 to 15 inches. The portions of France left blank represent summer temperatures of over $68^{\circ} \mathrm{F}$. to Angers and Poitiers with the exception of the Loire Valley and the Brie, receives less than 24 inches of rain annually (Paris about 23 inches), as also does the Mediterranean coast west of Marseilles.

The prevailing winds, mild and humid, are west winds from the Atlantic. Continental climatic influences make themselves felt in the east wind which is frequent in winter and in the east of France, while the Mistral, a violent wind from the northwest, is characteristic of the Mediterranean region. The local climates $^{2}$ of France may be grouped under the following seven designations: (1) Sequan climate, characterizing the Seine basin and northern France, with a mean temperature of $50^{\circ} \mathrm{F}$., the winters being cold and the summers mild. (2) Breton climate, with a mean temperature of $51^{\circ} \mathrm{F}$, the winters being mild and summers temperate; it is characterized by west and southwest winds and

${ }^{2}$ Based on the six Ecological zones proposed by Dr. Mayr of Munich, the Nancy (Traite Pratique de Sylviculture, 1916, Jolyet, pp. 414-418) school recognizes the fol- 
by frequent fine rains. (3) Girondin climate, characterizing Bordeaux, Agen, $\mathrm{Pau}$, etc., having a mean temperature of $53.6^{\circ} \mathrm{F}$., with mild winters and hot summers; the prevailing wind is from the northwest; the average rainfall about 28 inches. (4) Auvergne climate, comprising the Cévennes, Central Plateau, Clermont, Limoges, and Rodez; mean temperature $51.8^{\circ} \mathrm{F}$., with cold winters and hot summers. (5) Vosges climate, including Epinal, Mézières, and Nancy, having a mean temperature of $48.2^{\circ} \mathrm{F}$., with long and severe winters and hot and rainy summers. (6) Rhône climate, experienced by Lyons, Châlon, Mâcon, and Grenoble; mean temperature $51.8^{\circ} \mathrm{F}$., with cold and wet winters and hot summers; the prevailing winds are north and south. (7) Mediterranean climate, at Valence, Nimes, Nice, and Marseilles; mean temperature $57.5^{\circ} \mathrm{F}$., with mild winters and almost rainless summers.

Agriculture. - Of the $39,000,000$ population some $17,000,000$ depend upon agriculture for a livelihood, though only about 6,500,000 are engaged in work on the land. The cultivable land occupies some 195,000 square miles, or about 94 per cent of the total area. Of this, 171,000 square miles are cultivated. There are besides 12,300 square miles of uncultivable area covered by lakes, rivers, towns, etc.; only 37,672 square miles are in forests (241.2 million acres). While wheat and wine constitute the staples of French agriculture, the distinguishing characteristic is the variety of its products. Cereals occupy about one-third of the cultivated area. For the production of wheat, in which France is self-supporting, French Flanders, the Seine basin, notably Beauce and Brie, and the regions bordering on the lower course of the Loire and the upper course of the Garonne are the chief areas. Rye is grown in the poor agricultural territories of the Central Plateau and in the Parisian region. Maize covers considerable areas in Landes, Basses-Pyrénées, and other southwestern departments.

Other Industries. - In France, as in other countries, the development of machinery, whether run by steam, water power, or other native forces,

lowing zones as occurring in France:

(1) Laurentum, with minimum temperature of $-10^{\circ} \mathrm{C}$., where "everywhere ornamental shrubs with persistent leaves can be cultivated in the gardens."

(2) Castanetum, with occasional temperatures down to $-25^{\circ} \mathrm{C}$., where the maritime pine and chestnut can be grown.

(3) Carpinetum, with temperature down to $-30^{\circ} \mathrm{C}$., where there are drought, hot summers, but dangerous frosts and extremes of cold. This includes most of the rich Normandy forests.

(4) Mountains, broadly speaking (for the same exposure) for each 3.3 feet of altitude the average temperature diminishes $1.2^{\circ} \mathrm{C}$. and the rainfall increases 10 per cent. Exceptions occur, depending on the slope of the mountain and on the latitude. Typical of the mountain climate are abrupt changes in temperature, severe frosts coupled with intense heat (radiations solaires) during the day. 
has played a great part in the promotion of industry. With the exception of Loire, Bouches-du-Rhône, and Rhône, the chief industrial departments of France are to be found in the north and northeast of the country. The department of the Seine, comprising Paris and its suburbs, which has the largest manufacturing population, is largely occupied with the manufacture of dress, millinery, and articles of luxury (perfumery, etc.), but it plays the leading part in almost every great branch of industry with the exception of spinning and weaving. The typically industrial region of France is the department of the Nord, the seat of the woolen industry, but also prominently concerned in other textile industries, in metal work, and in a variety of other manufactures, fuel for which is supplied by its coal fields.

Water Power. - France is relatively poor in coal, and even in ordinary times must import a large amount for use by its factories. Since Germany's destruction of the collieries of the north, which have supplied about three-fourths of all the coal mined in France, the situation is made difficult even with the Sarre basin. Fortunately for France, she is rich in hydraulic power. The water power is estimated at nine to ten million horse power. Of the European countries only Norway and Sweden possess a larger amount of available hydraulic power. Still more fortunate for France, most of her water power is to be found in the South, free from war damage, particularly in the Alps, the Pyrenees, the Cévennes, and the Jura, although some water power is available in the Vosges and the Central Plateau. During the war the water power development in France has received a tremendous stimulus. Many new factories have been built in which the motive power is electricity, ger.erated by hydraulic force, for the manufacture of machinery, munitions, and other supplies necessary for the army. The manufacture of products necessary for military purposes has not only absorbed all the power which at first was left unutilized because of the discontinuance of a number of factories engaged in the production of ordinary commodities, but it was soon found necessary to increase the available water power. Thus several of the Pyrenees water power companies have raised the dam of a lake which served as a reservoir by seven feet and thus increased its reserve in water by $1,300,000$ cubic meters, and obtained a proportional increase in the available water power. Several water power establishments in the Alps and in the Pyrenees have entirely changed their equipment and adapted their factories for the manufacture of products needed by the Government. The Government has rushed the completion of a number of factories in the course of construction and has taken over in the Central Plateau several waterfalls for the development of water power. During the war the Government increased the available hydraulic power by at least 60,000 horse power. The Government not only sought to develop water 
power for the manufacture of war necessities on its own initiative, but also secured the coöperation of private hydraulic companies. This development will probably decrease the use of coal and fuel wood during the next decade.

Commerce. - Being in the main a self-supporting country, France carries on most of her trade within her own borders and ranks below Great Britain, Germany, and the United States in volume of exterior trade.

Government. - The principles upon which the French constitution is based are representative government (by two chambers), manhood suffrage, responsibility of ministers, and irresponsibility of the head of the State. France is divided into 86 administrative departments (including Corsica), or 87 if the territory of Belfort, a remnant of the Haut-Rhin department, be included. These departments are subdivided into 362 arrondissements, 2,911 cantons, and 36,222 communes. (See AlsaceLorraine, p. 495.)

\section{FOREST REGIONS}

Broad Divisions. - The forest regions of France may be divided into two broad divisions - the plains and the mountains. As might be supposed, conifers predominate in the mountains and the broadleaf species in the plains. In this latter region there are ravines and hills but the maximum altitude does not exceed 1,970 feet. The winter season lasts 4 to 5 months, the vegetative season 7 to 8 months. In the mountains the rinter lasts 7 to 8 months and, at altitudes of 5,900 to 6,560 feet, the snow remains until June 15, and begins to fall shortly after the middle of September. There is no spring or fall - only winter and summer. Naturally this results in rapid growth with very regular rings, as opposed to the somewhat irregular growth in the plains forests owing to the variations of climate during the growing season. The forest divisions of France (as distinguished by Boppe) are:

1. Plains -

(a) Parisienne: (1) West, (2) Center, (3) East.

(b) Gironde: (1) Oaks of Adour, (2) Landes, Gascoyne.

(c) Provençale.

\section{Mountains -}

(a) Vosges: (1) Lorraine plains, (2) Basses-Vosges, (3) Hautes-Vosges, (4) (5) see text.

(b) Jura: (1) First plateau, (2) Second plateau, 1,640 to 1,968 feet, (3) Third plateau, 2,625 to 2,953 feet (4) Haute-Jura.

(c) Alps: (1) North, (2) South.

(d) Central Plateau: (1) North, (2) South.

(e) Pyrenees: (1) East, (2) Central, (3) West. 
Plains. - From the foregoing it is seen that the plains forests may be divided into three general zones: (1) Parisienne; (2) Gironde; (3) Provençale.

Parisienne Zone. - The Parisienne Zone includes more than half of France, and the forest wealth is composed of broadleaf trees except where conifers have been artificially introduced. Hornbeam is a characteristic species, sessile oak and pedunculate oak the most numerous. Beech abounds but it is not necessarily typical of the region because it extends into the mountain zones. The Federal administration has introduced such species as ash, maple, and elm to a considerable extent. Less valuable species typical of this zone are the willows, limes, and poplars. The annual rainfall averages 27.5 inches, most of it occurring in the summer. Droughts are rare and on the whole the climate may be termed exceedingly favorable for tree growth. It is partly for this reason that natural regeneration of such species as oak is comparatively simple in France while almost unattainable in many parts of Germany. The prevailing wind is west. The best high forests in France that produce exceedingly valuable oak logs are found in this zone. There are, of course, coppice and coppice-under-standards.

This general region can be subdivided into three parts: (1) West, which includes such forests as Fontainebleau, d'Orléans, and Montargis. This limited area is bounded by the valleys of the Perche and Bretagne. The climate is exceedingly mild and humid. (2) Center, including the Sologne, where a moist silicious soil has been partly deforested. This includes the Champagne region where the tree growth is quite ordinary. (3) East, which includes the Argonne, the Langres Plateau, the Plains of Lorraine, Franche-Comté, and Bourgogne. Here 25 per cent of the area is forested and most of it is in coppice-under-standards, although conversions are the order of the day where soil will permit.

Gironde Zone. - The second important zone - the Gironde - follows the ocean from Bayonne to the Loire, and includes two subdivisions: (1) the oaks of the Adour, and (2) the maritime pine of the LandesGascoyne. The important species are maritime pine, occidental oak, and pyrean oak. The sessile oak is almost entirely lacking, and the holm oak is found chiefly on limestone soils. The maritime pine, which now reproduces naturally but originally was established by artificial means (see pp. 182), is the species of the Landes-Gascoyne. It grows on pure sand and has increased the value of land worthless for agriculture many thousands per cent.

Provençale Zone. - The third important zone - Provençale - is dry and hot and borders the Mediterranean between Nice and Port Vendres. The region is indented by the Maritime Alps and the Pyrenees at each extremity and extends up the Rhône as far as Valence. The important 
species are the holm oak, white oak, aleppo pine. On the silicious soils of the Maures and the Estérel maritime pine and cork oak form the predominant stand with a thick undergrowth of heather. In this region trees rarely attain large size, but yield good fuel charcoal and tanbark. The secondary revenue from truffles is in places as much as $\$ 38.60$ per acre. The prevalent northeast wind, known as the "mistral," is a source of danger during the fire season. This is especially significant since in this region there is much less rain than in the Parisienne.

Mountains. - The mountains are divided into five main zones: (1) Vosges, (2) Jura, (3) Alps, (4) Central Plateau, (5) Pyrenees.

Vosges Zone. - The Vosges begins at 1,150 feet elevation. It is rich in forests; fir, beech, and spruce are the dominant species at certain points; oak and hornbeam disappear completely toward the summits. The spruce continues with the fir to the highest altitudes. Much Scotch pine has been artificially introduced. The zone extends to a maximum altitude of 4,590 feet, but the average limit of tree growth is at 4,100 feet. Between the maximum and minimum altitudes five types of stands have been distinguished: (1) the Lorraine plain; here coppices of hornbeam, oak, and poor quality birch have led to an increase in the per cent of beech in order to improve the soil. Where, however, the conditions are exceedingly bad, Scotch pine is being introduced. (2) Basses-Vosges; here silver fir is the typical species. (3) Hautes-Vosges; on account of the granitic formation it is well watered, but the forest area is much cut up by farms and grazing lands. Here are found a number of protection forests. Two less important subdivisions are: (4) where on the south slope toward the Franche-Comte plains the schists give place to syenites and porphyries and the fir is replaced by the oak. There was formerly a good deal of coppice alternating with field crops in this region and there is still much simple coppice grown for bark production. The fifth (5) (la Vosge), also relatively unimportant, is apparently an island of variegated sandstone where high forests of oak and beech predominate on the fine-grained sand.

Jura Zone. - Exceedingly rich mountain forests are found in the Jura. They are less extensive than in the Vosges but much richer. In the Vosges the soil is silicious, while in the Jura it is calcareous. The important commercial Jura species are silver fir and Norway spruce. In this region there are four subdivisions, based on altitude: (1) The first plateau really belongs more to the plain than to the mountain region, but fir has been introduced. (2) In the second region, with an altitude of 1,640 to 1,970 feet, the fir is mixed with spruce. The best fir forests of France are found on the rich soil above this first escarpment on Jurassic formation. The forests of Levier and La Joux (Fig. 2) are world famous. 
(3) In the third division ${ }^{3}$ the average elevation is 2,620 to 2,950 feet but extends to 3,940 feet. The climate is severe and the production less than in the lower zone. After windfall, provided insects can be kept out, the soil usually seeds naturally to a good stand. With fir, spruce, and beech there is some sycamore. The rainfall averages more than 39 inches a year. The forest of Risoux is typical. (4) The Haute-Jura, like the Haute-Vosges, is chiefly valuable for grazing, such as is found in the forest of La Dôle.

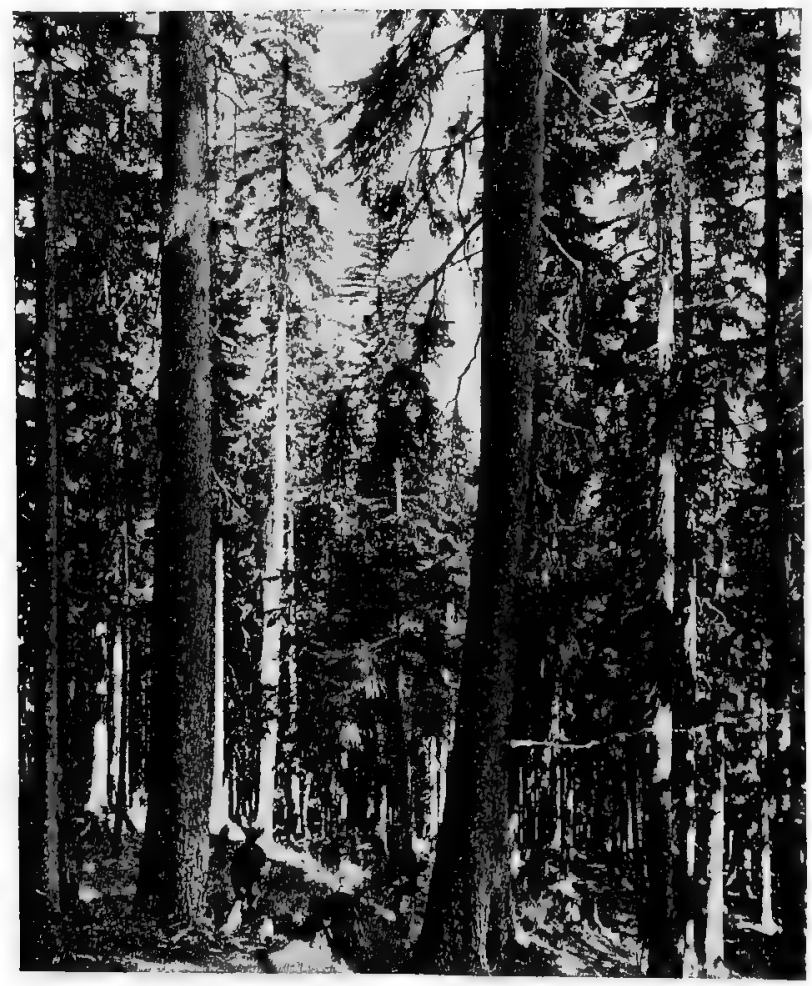

Fig. 2. - The richest silver fir (with spruce) stands in France are found in the State forest of La Joux (Jura). Note the clear boled stand from natural regeneration. During the war the Canadians cut heavily in this superb forest.

Alps Zone. - The third great mountain subdivision, the Alps, extends from the Lake of Geneva to the Mediterranean - from the limit of tree growth to the sea level. In the lower mountains, up to 1,970 to 2,130 feet, one finds such typical plains species as the white oak, holm oak,

s Jolyet claims the third Jura plateau is a myth and prefers the term "Hautes chaines du Jura" to "Haute-Jura" for the fourth subdivision. 
chestnut, and Scotch pine. At higher elevations there is mountain pine, larch, and cembric pine. (See Fig. 3.) This latter species extends to the limit of tree growth, although larch is considered the most valuable of the Alpine species. The most notable stands are the beech of Vercors, the spruce of Tarentaise, the mountain pine of Embrunais, the fir of such rich valleys as the Var, and the larch of Briançonnais, of Queyras, and of Comté de Nice. French foresters divide the Alps into two regions: (1) North Alps, which extends as far as Pelvoux. The valleys face the

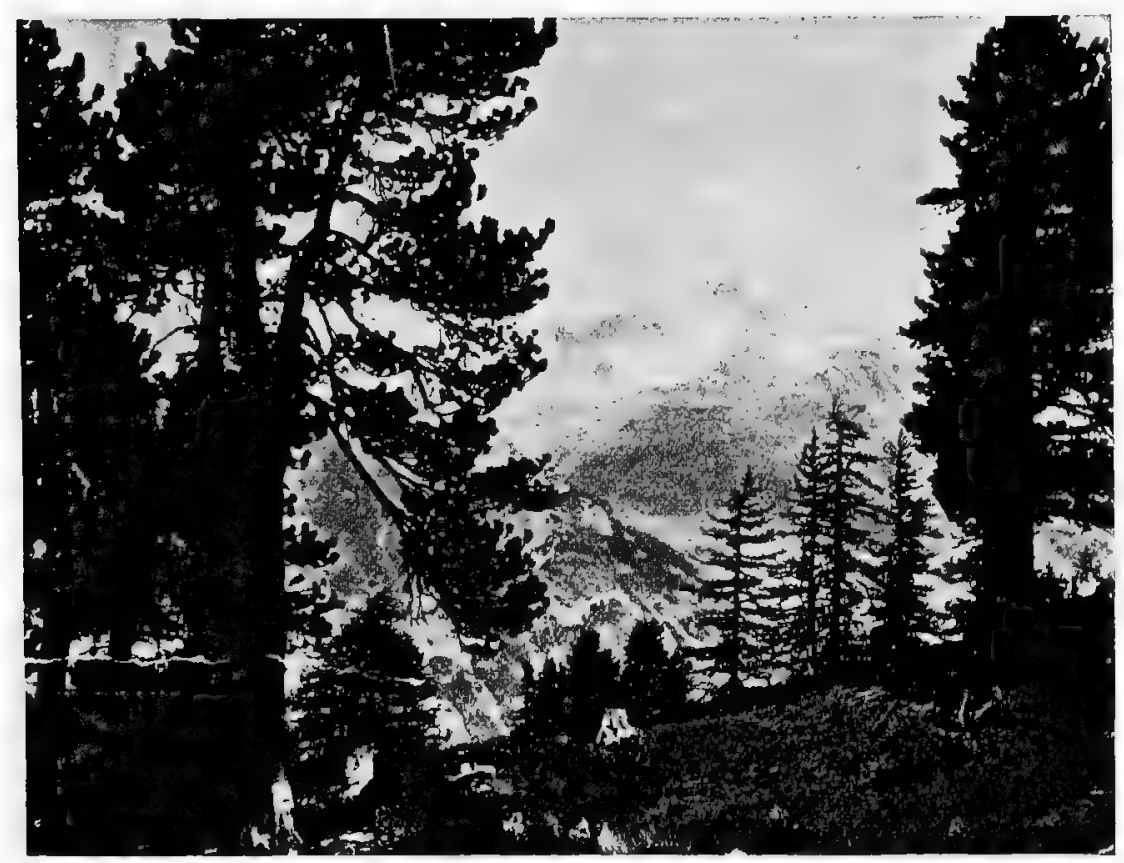

FIG. 3. - Larch and cembris pine at an altitude of 7,050 feet (north exposure) in the Canton of Melezet, communal forest of Villarodin-Bourget. The soil must be worked to facilitate regeneration.

north and the stand is fairly intact. The chief species are beech, fir, spruce, while larch is rare. (2) In the South Alps, from Pelvoux to the Mediterranean, there are southerly exposures and a variable and severe climate. Here is found the greatest damage from torrents. There are, however, good stands of fir and spruce, while the larch is exceedingly important. There are also aspen, Scotch pine, and chestnut. Considerable damage from grazing is experienced.

Central Plateau Zone. - The Central Plateau includes the mountains of Morvan, where beech is the important species, and the Cévennes, with its stands of Austrian pine. 
Pyrenees Zone. - The fifth and last mountain zone, to my mind perhaps the most attractive for the traveler, has been divided into two divisions: (1) The Eastern Pyrenees and (2) the Central and Western Pyrenees which is influenced by the Atlantic Ocean. The dividing line between this zone and the eastern zone is the basin of the Aude and the Ariège. In the eastern zone the climate is more like the Maritime Alps but moister, the rains being less torrential, however, and consequently the floods are not so dangerous. The chief species are fir, beech, and mountain pine. In the Department of the Aude the fir is almost as good as in the Vosges and Jura. Here the mountain pine does not form pure dense stands but is found in mixture with spruce and larch. There has been considerable overgrazing. A typical forest area is the Montagne Noire. In the second division (central and western) there are irregular west winds, and there is more rain and better forage. The same species are grown as in the eastern division but the stands are denser, with a larger percentage of beech mixed with the conifers. Scotch pine largely replaces the mountain pine. Typical forests are Lûchon, Barèges, and Caûterets.

Some Mountain Forests in Detail. - Of all the forest zones or regions of France, those of the four great mountain areas - Vosges, Jura, Alps, and Pyrenees - are most interesting to the American forester. For a more intimate view of local conditions in the Jura reference is made to the Appendix where the essentials of a working plan for the forest of Grande Côte is reproduced. Let us consider in greater detail some of these mountain regions.

Vosges. - Before the Vosges ${ }^{4}$ were acquired by the State they belonged to the Duc de Lorraine, to lesser nobles, and to various abbeys. Since they were largely maintained for fuel and for shooting it is not surprising that a great deal of forested area still remains -37 per cent of the total land acreage being now in forest. A total of 520,041 acres of forest is divided as follows:

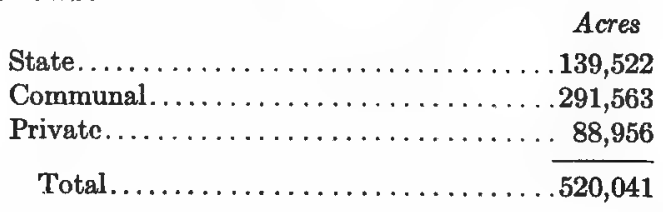

Considering the region as a whole, and separating the area of plains forests from the Vosges forests proper, the species, in order of importance, are: Beech, 60 per cent; oak, 30 per cent; miscellaneous species, 10 per cent. Of the strictly mountain area the species on the Vosges sandstone in order of importance are: Fir, 75 per cent; beech and miscellaneous

${ }^{4}$ Sommaire sur les Forêts domaniales du Département des Vosges. Mongenot. 
species, 18 per cent; Scotch pine, 6 per cent; spruce, 1 per cent; on the mountain granite formation fir comprises 51 per cent; spruce, 18 per cent; pine, 1 per cent; and beech, 30 per cent. It is clear then that in the mountains fir is the important species, and mature, fully stocked stands yield from 350 to as high as 1,000 cubic meters $(12,360$ to 35,314 cubic feet) per hectare; about 26,000 to 74,000 feet board measure per acre. In the so-called plains forests of the Vosges the product in logs is only 30 per cent, due to the larger proportion of broadleaf trees, while in the mountains sawlogs ("work wood") reach 55 per cent of the total production. On 20,000 hectares $(49,420$ acres) of coniferous forests the average volume from forested hectares was 317 cubic meters $(11,194.5$ cubic feet), about 23,000 feet board measure to the acre, and on the various forests included in this average, the average by forests varied from 196 to 390 cubic meters $(6,921.5$ to $13,772.5$ cubic feet per hectare), or about 14,000 to 30,000 feet board measure to the acre. The total average yield in cubic meters for the entire Vosges was $245,574(8,672,200.2$ cubic feet) in $1870-79 ; 231,835(8,187,021.2$ cubic feet) for $1880-89$; and 314,046 $(11,090,220.4$ cubic feet) for 1890-99, these latter yield figures being considerably above normal owing to increased windfall and the consequently forced cut. The price per cubic meter ( 35.3 cubic feet) since 1877 has been 1 to 3 francs (19 to 58 cents) higher in the mountains than in the Vosges plains, due in part to the larger proportion of logs and to the decreasing demand for hardwood fuel. The average price per cubic meter (35.3 cubic feet) taken to the nearest franc for the whole region was 8 francs $(\$ 1.54)$ in $1871,16(\$ 3.09)$ in $1876,15(\$ 2.89)$ in $1879,8(\$ 1.54)$ in 1887,13 (\$2.51) in 1898; in 1914 the price had risen to 20 francs (\$3.86) and in 1918 to 55 franes ( $\$ 10.61)$. In the mountain region it is of interest that the price for logs on the Vosges sandstone brought 1 to 6 francs (19 cents to $\$ 1.16$ ) more than for the same class of material on the granite formation; it is safe to draw the conclusion that, during 1890-99, the price was at least on an average of 5 francs (96 cents) more. The table which follows shows the money yield per forested hectare (2.5 acres) in even francs (and in dollars per acre) by 10-year periods from 1870 to 1900 , separately for the mountains and plains forests and averaged for the whole region. The figures in parentheses are dollars per acre:

\begin{tabular}{|c|c|c|c|c|}
\hline & 1870 & 1880 & 1890 & 1900 \\
\hline Mountains. . & $.55(\$ 4.24)$ & $55(\$ 4.24)$ & $65(\$ 5.02)$ & $100(\$ 7.72)$ \\
\hline Plains...... & $.30(\$ 2.32)$ & $35(\$ 2.70)$ & $30(\$ 2.32)$ & $45(\$ 3.47)$ \\
\hline Averag & $45(\$ 3.47)$ & $50(\$ 3.85)$ & $55(\$ 4.24)$ & $85(\$ 6.55)$ \\
\hline
\end{tabular}

The decreasing net values for the plains forests and the increasing values of the mountain forests is due to the decreasing price of fuel and 
the increase in the price of sawlogs. This increase and decrease is typical of almost all portions of Europe since the introduction of coal and the scarcity of logs of large dimensions. Naturally it should influence the silvicultural policy pursued. It means that high forest systems should replace coppice and coppice-under-standards whenever local conditions permit. The conversion is not always simple from the economic standpoint on account of the demand of the communes for a steady revenue. Conversions mean increasing the growing stock, an economy which communes cannot always afford, because of their local needs for wood and because of the money returns from auctions of timber which make taxation that much less.

Alps. - According to Huffel ${ }^{5}$ the Alps comprise 19,305 square miles, one-fifth of which is forested; of this forest area nearly two-thirds is in private hands and one-third communal - the remainder State forests, not including areas under reforestation. The forests tributary to Nice have typified systematic grazing devastation. The basin of the Durance is the most devastated because drought has accentuated the evils of overgrazing and overcutting, and the torrential rains have completed the damage. The Department of the Basses-Alpes is only 18 per cent actually forested (26.3 per cent classed as "forest") and on an average produces but onehalf a cubic meter ( 17.6 cubic feet) per hectare ( 2.5 acres) per year for the area under "forest"; four-fifths of this production is firewood, equal to about one-tenth cord per acre per year. It is only fair to say that most of this area belongs to the communes, the State owning only a few reforestation areas. The basin of the Drôme and the trasin of the Isère and Haute-Savoie have favorable climates and soil. 'The area is in the transition zone between the South (dry) Alps and the North (wet) Alps. Of 217,448 acres of communal forest, half the area is in high forest, a quarter in coppice, and the rest blank. During the period 1877 to 1886 it produced only 1.9 cubic meters (67.1 cubic feet) per hectare per year, or a revenue of 33 francs (\$6.37), while the coppice production was 1 cubic meter ( 35.3 cubic feet) or a revenue of 1.27 francs ( $\$ 0.245)$, since the firewood brought but little return - a combined yield of about three-fifths of a cord per acre per year. From the reforested areas of this region the revenue is as yet nothing. Of the two important Federal forests near Gap the forest of Durbon yields 1 cubic meter (35.3 cubic feet) or 10 francs (\$1.93) per hectare per year, (77 cents per acre), and the forest of Boscodon 2.5 cubic meters (88.3 cubic feet) or 30 francs (\$5.79) per year ( $\$ 2.32$ per acre). The larch forests of the Alps, Embrunais, and Briançonnais are considered the most interesting. The forest of MontGenèvre at the source of the Durance, at an altitude of 6,235 to 8,200 feet, comprises 2,281 acres of which 1,359 acres are forested. It is a high 5 Économie Forestière, Vol. MI, pp. 391-397. 
forest with a 150-year rotation and includes cembric pine, Scotch pine, and larch. In the communal forest of Puy-Saint-Pierre, below Briançon, the larch is managed on a 200-year rotation. In the aggregate the larch forests of France comprise about 121,000 acres and are treated as regular high forests, except when maintained purely for protection purposes, when light selection cuttings are made.

In the Haute-Dauphiné there are several Federal forests in good condition. The best known is the Grande Chartreuse, north of Grenoble. Of the total of 16,061 acres 13,343 acres are productive. Before the abolishment of the monastery 368 acres were reserved simply as a scenic forest. Since the separation of the church from the State this has been added to the productive area and is now being conservatively lumbered. The rotation is 162 to 225 years. For the period 1865 to 1905 the average production for the whole area of this forest was 1.8 cubic meters (53.6 cubic feet) per hectare ( 2.5 acres) per year, or 2.2 cubic meters ( 77.7 cubic feet) for the productive areas ( 120 board feet). The gross revenue for the whole forest during this same period was 17 francs (\$3.28) per hectare per year, or a net of 10.3 francs $(\$ 1.99)$ for the productive area, 20.5 francs $(\$ 3.96)$ and 12.4 francs $(\$ 2.39)$, equal to $\$ 1.58$ gross and 96 cents net per acre per year.

The Savoie comprises some 56,833 acres of forests; here the climate is considered favorable and it is the best wooded part of the French Alps. Six-tenths of the forest area is communal and the State owns but 1,483 acres - the forest of Belle Vaux above Thonon where the spruce predominates. A typical communal forest of this region is that of Vailly opposite Lausanne on the Lake of Geneva. At an average altitude of 3,600 feet spruce is 50 per cent of the stand, beech 29, and fir 21 . The average revenue, 1886-1902, was 7.17 francs $(\$ 1.38)$ per hectare per year, or but 55 cents per acre.

It is significant that the proportion between fuel and logs is as 211 is to 110 , where, as the working-plans officer says, the proportion ought to be as 60 is to 100 .

Another interesting forest in Savoie is in the valley of Fier, ${ }^{6}$ near the little village of Thônes, comprising 321 acres. It shows what recovery can be made when a forest is properly managed. The growing stock increased from 54,000 cubic meters $(1,906,956$ cubic feet) in 1895 to 60,000 cubic meters $(2,118,840$ cubic feet) in 1900 , notwithstanding the regular annual cut. While this forest is considered almost normal to-day, in 1840 the growing stock had been so reduced that the commune proposed to open it to goat grazing, something that is rarely done except in the case of brush land. The recovery which this region has made under French forest management is a lasting tribute to the foresters of the Republic.

${ }^{6}$ Une Jolie Forêt. A. Schæffer, pp. 1-4. 
This region was only ceded by Italy in 1860 , and prior to that date the forests had been overcut and damaged, the prices were low, and there was a large amount of overmature diseased timber. A. Schaeffer, for many years chief of working plans, with headquarters at Grenoble, has studied the rotation, cutting period, stand per hectare, increment, and financial yield before and after past working plan revisions, and has proved that the conservative management introduced by the French is successful. These forests, classed according to yield production, may be grouped in four classes:

1. Those forests with a yield of over 6 cubic meters (211.9 cubic feet) per hectare $(2.5$ acres $)$ per year. These are found on the sandstones, schists, warm calcareous soils, and alluvial soils near the lakes of Geneva, Annecy, and Bourget. Such yields are almost comparable with the famous Jura and Vosges.

2. The second- and third-class forests are yields between 4 and 6 meters (141.3 and 211.9 cubic feet) and between 3,4 , and 2 meters (141.3 and 70.6 cubic feet) respectively. Here, either the soil or the climatic conditions are naturally poor producers. Sometimes this intermediate yield is due to the mediocre combination of both climate and soil.

4. The fourth class of forests is where the production is less than 2 cubic meters ( 70.6 cubic feet) per hectare ( 2.5 acres) per year. These are located in the high valleys or rocky slopes where the climate is severe or relatively dry. (See Fig. 4, $a$ and $b$.)

Pyrenees. - The forests of the Pyrenees may be differentiated in two ways, by geographical location or by zones of altitude. The geographical differentiation has already been described. On account of their importance and interest to the American forester, it is well worth while to add the altitude zones in order to make the regional distribution complete.

In the first altitude zone, above 3,280 feet, fir and beech are found pure and in mixture. Fir predominates in the central and beech in the eastern and western Pyrenees. Mountain pine and Scotch pine predominate near Mont-Louis. The limit of tree growth is 7,530 feet for mountain pine, 6,890 feet for fir, 6,230 feet for beech; usually typical grazing forests begin at an altitude of from 5,580 to 5,740 feet; sessile oak reaches 5,085 feet in the eastern and pedunculate oak 4,593 feet in the western Pyrenees.

The second zone, 1,640 to 3,280 feet, has beech as the chief species with fir and oak as secondary.

In the third zone, 1,640 to 560 feet, there is oak with beech and chestnut, sessile oak in the eastern and pedunculate in the western and central Pyrenees.

The fourth zone, below 660 feet, has the same species as the third zone with the addition of holm oak and maritime pine. 


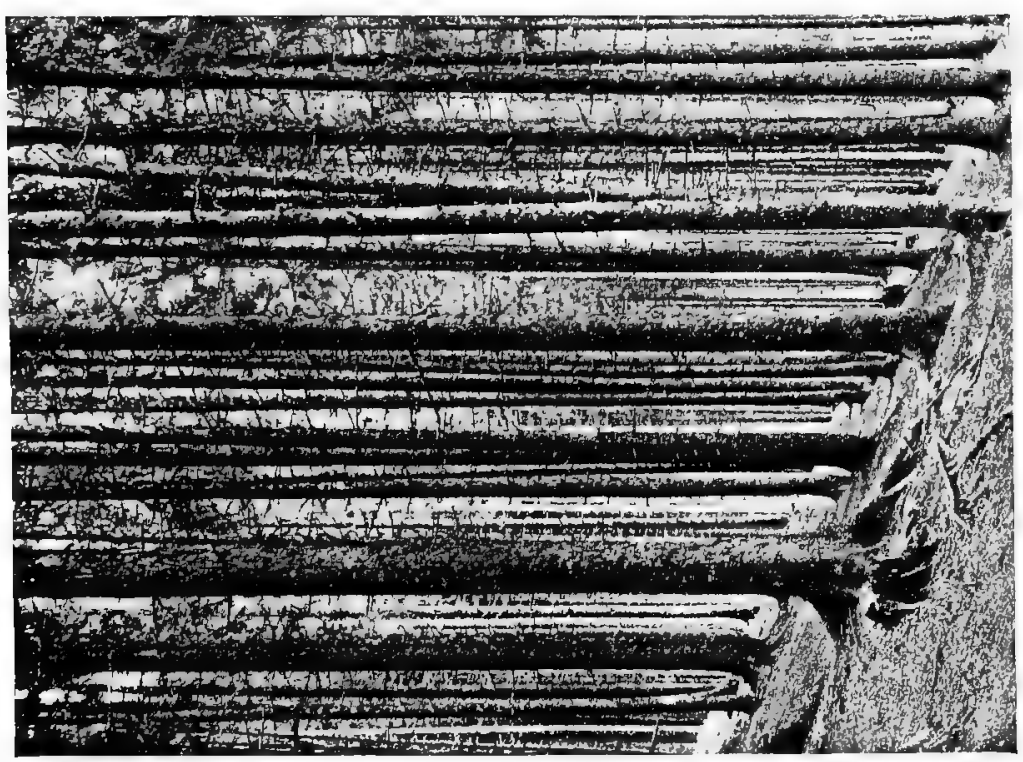

영

ज㻤

$\because, 0$

늘

.

?

$\infty$

욤 bo

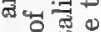

8 용

3

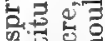

跑

व

क्ष के

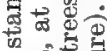

을

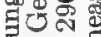

○.

证䒹

1范焉

o.

+ ज़

불

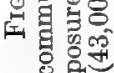

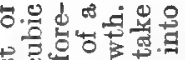

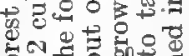

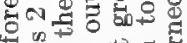

줄의을

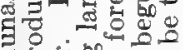

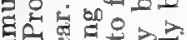

ह

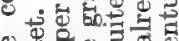

幽品

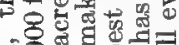

ช0

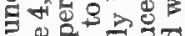

웅월

는

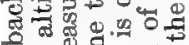

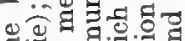

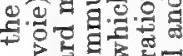

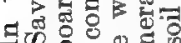

ज和 - 영

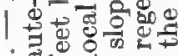

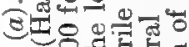

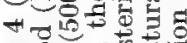

5.

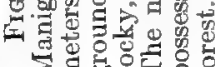




\section{IMPORTANT FOREST SPECIES}

Acreage and Distribution. - The figures that follow show the proportionate area stocked with each of the principal species in France in the forests under State supervision. These statistics are based on Huffel's figures of 1904, corrected proportionately to conform to the official statistics on total forest area published in $\mathbf{1 9 1 2}$ by the Service des Eaux et Forêts.

According to these figures, broadleaf trees occupy 77 per cent of the area as against 23 per cent for the conifers. There are no accurate figures for private forests, nor for communal and institutional forests not under State supervision, but Huffel estimates that for all of France the timber oaks occupy 35 per cent of the ground, the holm oak 4 per cent, miscellaneous broadleaf trees 41 per cent, and the conifers about 20 per cent. Table 2 follows:

TABLE 2. - AREA OCCUPIED BY BROADLEAVES AND CONIFERS

\begin{tabular}{|c|c|c|}
\hline Species & $\begin{array}{l}\text { Acres, } \\
\text { productive forest }\end{array}$ & $\begin{array}{l}\text { Per cent of total area, } \\
\text { productive forest }\end{array}$ \\
\hline 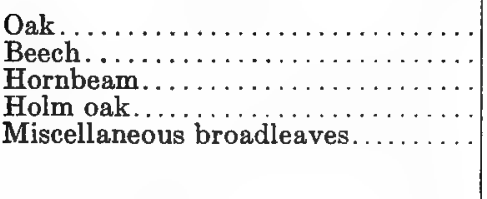 & $\begin{array}{r}1,796,000 \\
1,194,000 \\
717,000 \\
264,000 \\
1,053,000 \\
5,024,000\end{array}$ & $\begin{array}{r}27.5 \\
18.2 \\
11.0 \\
4.0 \\
16.0 \\
76.7\end{array}$ \\
\hline 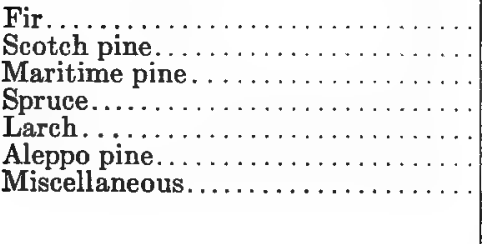 & $\begin{array}{r}455,000 \\
430,000 \\
262,000 \\
178,000 \\
116,000 \\
30,000 \\
54,000 \\
1,525,000\end{array}$ & $\begin{array}{l}7.1 \\
6.5 \\
4.0 \\
2.7 \\
1.8 \\
0.4 \\
0.8 \\
23.3\end{array}$ \\
\hline Grand total.................. & $6,549,000$ & 100.00 \\
\hline
\end{tabular}

As the foregoing table indicates, the occurrence of the various species depends chiefly on climatic conditions and the oak is unquestionably by far the most important and typical timber species. The timber oaks not only occupy 27.5 per cent of the total productive forest area under working plans but are also encouraged in regeneration in their fight against other species, and in many State forests the oak is grown to unprofitably long rotations in order to supply industry with the class of wood which it requires. Two important species are the sessile and pedunculate oak; they occur in mixture and separately. Oak is found all over France ex- 
cept in the higher mountains and in the regions bordering the Mediterranean and the Atlantic Ocean. The essential silvicultural characteristic of each of these species is given on pp. 387 .

Beech is the second important species and occupies 18.2 per cent of the productive forest area. It is found everywhere except in the highest mountains, on the Mediterranean, and plains of the southern Atlantic coast line, including the Gironde, Landes, and Dordogne. The distribution of beech is shown in Fig. 5 .

The hornbeam, although it occupies 11 per cent of the productive area, is not an important timber species notwithstanding its wide distribution. It does not grow to large size and its chief function is to supply fuel and to maintain soil conditions. The distribution of hornbeam is shown in Fig. 5.

The holm oak is confined chiefly to the regions not occupied by the timber oaks, by beech, and by hornbeam. It is often found in mixture with cork oak (whose distribution is given in Fig. 5) and with aleppo pine.

Silver fir occupies 7.1 per cent of the productive forest area and is especially adapted to the climate prevailing in northern, eastern, and central France, and is a typical species of the Vosges, Jura, Alps, and Pyrenees. It reaches its optimum development in the Jura.

Notwithstanding that Scotch pine occupies 6.5 per cent of the productive forest area, it does not grow naturally in level country, but only in the mountains of the Vosges, Central Plateau, Alps, and Pyrenees; it has not grown naturally in the Jura, since in that department it cannot maintain its struggle for existence on limestone soil. But because of its use for forestation it is found in every department in France except ten; it forms at least one-tenth the stand of technically administered forests in twenty-six departments.

The maritime pine commercially is one of the most important timber species of France, but is limited to a comparatively small region, as shown by Fig. 5 .

Norway spruce is found only in the higher mountain regions of the Jura, Vosges, and Alps, and does not grow naturally in the Pyrenees. Outside of these mountain regions it is unimportant, since the mild climatic conditions of the plains do not favor its growth.

The larch also is confined even more markedly to the higher mountain regions. Its natural habitat is the Alps.

These five broadleaved species and six conifers are the important trees of France. How they are distributed in the different forest regions has already been explained. To give a more intimate view of French silviculture, the writer has included monographs on these principal species. The data are not original; much are freely translated from authoritative 


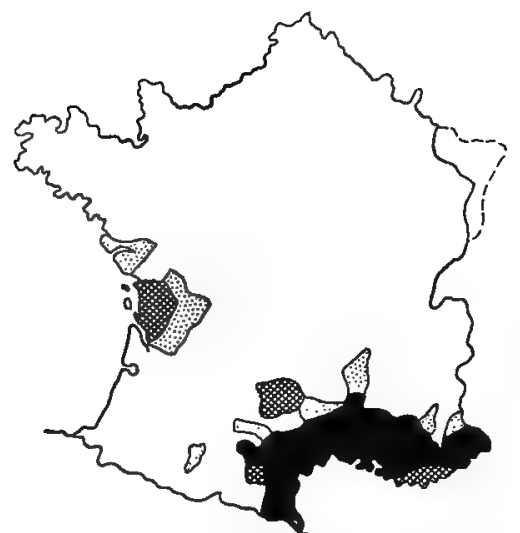

A - Cork oak (Chêne vert)

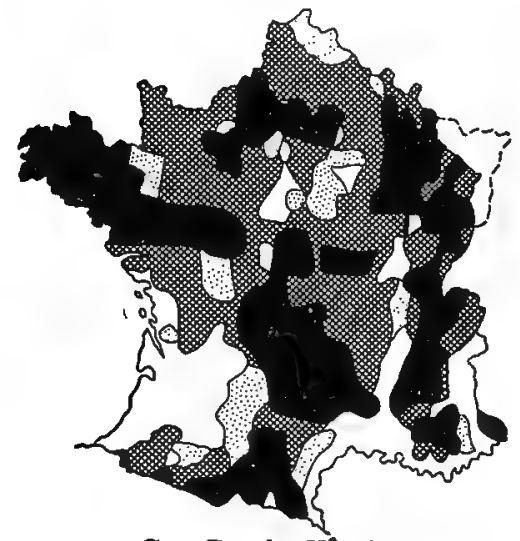

$$
\mathrm{C} \text { - Beech (Hêtre) }
$$

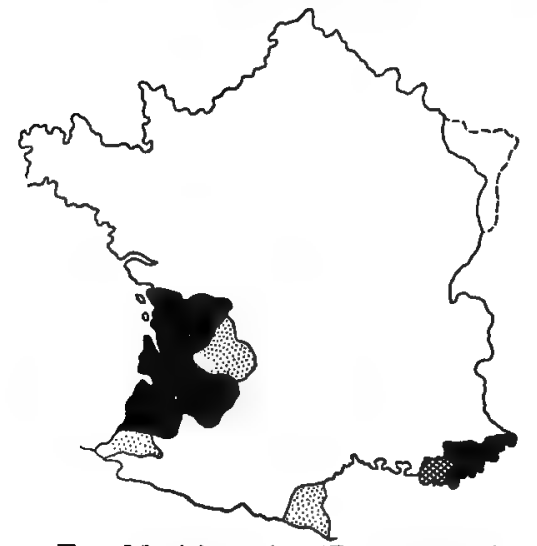

E - Maritime pine (Pin maritime)

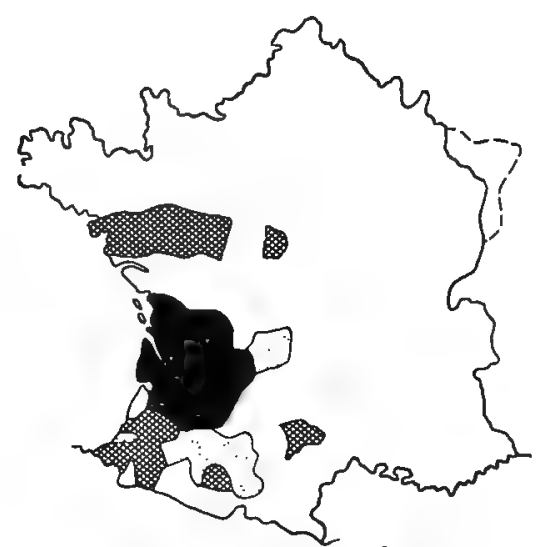

$\mathrm{B}$ - Pyreneenean oak (Chêne blanc)

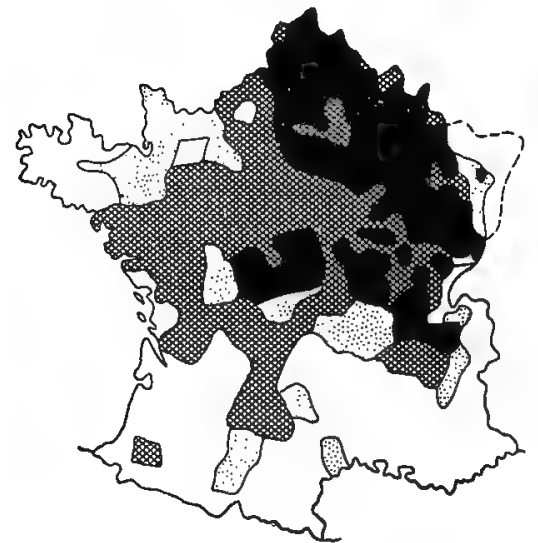

D - Hornbeam (Charme)

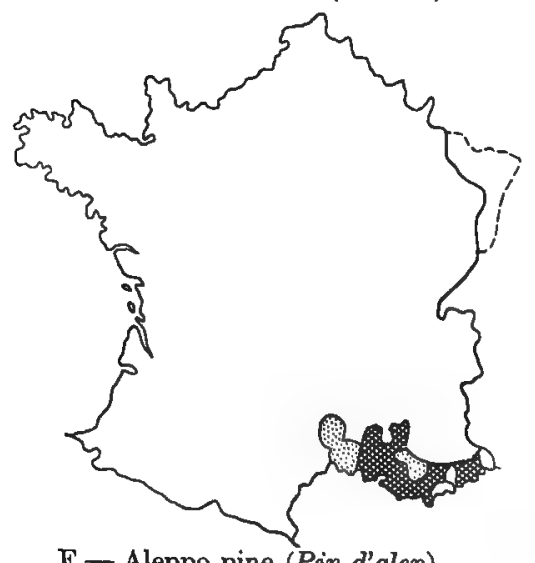

F-Aleppo pine (Pin d'alep)

FIG. 5 (after Jolyet). - Distribution of six important forest trees in France.

Key: Dominant, ; subordinate, rare, ing, 
sources, but it was considered very essential to present the data so as to give, as nearly as possible, the French viewpoint on the silvics of each important species. In order not to encumber the text these data on species are given in the Appendix.

Exotics. - Jolyet, on the authority of Belgian and French authors, eites the following exotics as of possible value in France:

Red oak (Quercus rubra L.), rapid growth; hardy.

June oak (Quercus pedunculata, var. tardissima Simonkai), hardy.

White ash (Fraxinus americana L.), hardy; rapid growth.

"Parrotia" (Parrotia persica C. A. Meyer), much like beech but can develop on dry, shallow, limestone soils; Carpinetum zone.

Common walnut (Juglans regia L.), cabinet wood; Carpinetum zone.

Black walnut (Juglans nigra L.), cabinet wood; Carpinetum zone.

Butternut; White walnut (Juglans cinerea L.), cabinet wood; a hardier tree; Carpinetum zone.

Shellbark hickory (Hicoria ovata (Mill.) Britton), cabinet wood; Carpinetum zone.

Mocker nut hickory (Hickoria alba (L.) Britton), cabinet wood; Carpinetum zone.

Yellow birch (Betula lutea Michxf.), cabinet wood.

Black cherry (Prunus serotina Ehrh.), cabinet wood; Carpinetum zone.

Aspen (Populus tremuloides Michaux), furnishes soft wood; hardy.

Yellow linden (Tilia rubra var. euchlora $\mathrm{C}$. Koch), furnishes soft wood; hardy; from Crimea.

Manchurian linden (Tilia mandschurica Ruprecht and Maximovicz), furnishes soft wood; hardy.

Honoki; Japanese magnolia (Magnolia hypoleuca Siebold and Zuccarini), furnishes soft wood; rapid growth.

Yellow poplar (Liriodendron tulipifera L.), furnishes soft wood; Carpinetum zone.

Locust (Robinia pseudacacia L.), a durable hard wood; hardy.

Tree of heaven; Ailanthus (Ailantus glandulosa Desfontaines), rapid growth and hardy; near ocean in Laurentum zone, and in Castanetum zone.

Chinese "cedar"; Cedrela (Cedrela sinensis A. Jussieu), quality of ash but hardier; near ocean in Laurentum zone, and in Castanetum zone.

Keaki (Zelkova acuminata Planchon), wood like elm; requires fresh soil; Carpinetum zone.

Douglas fir (Pseudotsuga taxifolia (Poit) Britton), rapid growth; hardy.

White fir (Abies concolor (Gord) Parry), rapid growth; hardy.

Oriental spruce (Picea orientalis Carr.), drought enduring; comes from Asia Minor between Trebizond and Erzerum.

Lodgepole pine (Pinus contorta Loudon), hardy for "Karst" soils.

White pine (Pinus strobus L.), rapid grower; hardy; liable to borers and parasites.

Norway pine; Red pine (Pinus resinosa Aiton), rapid grower; hardy; free from insect danger.

Use of Exotics. - Certain conclusions can be reached regarding the introduction of exotic species:

(1) Exotic species are almost always uncertain, even after they have reached the sapling or pole age. Local species should be favored.

(2) If exotics are used they should never be employed on a large scale 
until they have been thoroughly tested over a rotation under similar conditions.

(3) When employed there must be a definite justification for not using local trees -

(a) Quality of wood (not contained in local species) required by national wood industries.

(b) Rapid growth or hardiness under adverse soil or climatic conditions. France is poor in tree species (see p. 40) and particularly needs cabinet woods and woods easy to work, like yellow poplar. She requires trees hardy on unfavorable sites, but nevertheless, because of the high cost of foreign tree seeds the use of exotics, even though of proven worth, is rarely practicable. There are, of course, exceptions to this fundamental rule - notably Scotch pine, whose range has been increased largely by artificial means. Too often the forester may be tempted to use an exotic which has been grown successfully in botanical gardens. This is poor practice and should not be followed. Beware of exotics, because they rarely succeed and are subject to insect and fungous damage! 


\section{CHAPTER IV \\ FOREST STATISTICAL DATA}

Private Forest Owners (p. 45). Ownership, System of Cutting, and Production, Forest Areas and Per Cent of Species by Departments, Analysis of General Statistics, Management Statistics, Costs of Administration, Statistics of Fir Stands in the Jura, Statistics for Levier.

Private Forest Owners. - About one-tenth the French forest area belongs to the State, two-tenths to communes and public institutions, and seven-tenths to private owners. There is an incredible number of small owners, a fact never before noted by English or American writers. In 1912 there were 1,538,526 private forest owners ${ }^{1}$ (excluding the communes, which are really groups of small joint owners). There were fully $1,446,200$ owners with less than 25 acres, only 82,285 owners with forests of 25 to 1,253 acres, and but 742 owners of forests over 1,235 acres. Take any department at random: In the Puy-de-Dôme 101,510 acres out of the total area are in the hands of 32,684 owners, each owning less than 25 acres, and there are only 628 owners who possess more than 25 acres each. Even in the Seine-et-Marne, just west of Paris, there are 50,787 acres in the hands of 31,085 owners. Out of ten departments, taken at random, there were 97,710 owners with less than 25 acres of forest each, their average holdings being 3.2 acres. This is of the utmost importance; it is the key to the stability of France. In other countries the forests are usually in the hands of large owners; in the Republic of France the forest land, as well as the agricultural land, is divided among the people. There are few large estates remaining. Out of all the private forests in France there are only seventy-nine over 2,500 acres; in twenty-one departments there are none of this size. In the United States there are millions of farmers owning small woodlots, but according to the Society of American Foresters:

"A few men have secured vast amounts of private timber and timberlands. Already 1,802 owners control more than $79,000,000$ acres of the forest lands of the United States. In Florida 182 holders own more than 9,000,000 acres. In Michigan over 5,000,000 acres are held by 32 owners. In Louisiana 27 holders own more than 6,000,000 acres. In the Pacific Northwest three owners have more than 9,000,000 acres. And these are but typical instances."

1 The figures of the total number of owners, given in the official French Forest Atlas of 1912, do not check with the owners under the various size classes. This discrepancy cannot be explained but does not affect the conclusions. 
From a national and political standpoint France is unquestionably the gainer by having her forests in small holdings. From the standpoint of forest management and the treatment of individual stands small ownership necessarily implies that each owner will cut spasmodically to satisfy his needs in the village or farm. The large owner, on the contrary, upon competent technical advice, manages his forest as a permanent business and adheres fairly well to a sustained annual yield and to regulated fellings. Other things being equal, having forests in small holdings benefits a nation but deteriorates the stand.

Ownership, System of Cutting, and Production. - The summaries that follow (taken from the official statistics of 1912) have been somewhat modified by the cutting and destruction made necessary by a great war. But fundamentally the statistics will probably remain correct as regards forest area because of the stringent laws against deforestation. For the next hundred years the wood production will probably be at least 10 per cent less than during the past century. This means that in the next decade the production will be, say, 20 per cent less, while during the period 2010 to 2019 the loss may be only 1 per cent. In other words, the recovery will be gradual and progressive if a proper forest policy is followed. Detailed statistics (p. 50) show that 18.7 per cent of the total area of France is in forests. A summary of forest ownership, system of management, and annual production follows:

TABLE 3. - SUMMARY OF FOREST OWNERSHIP, SYSTEMS OF MANAGEMENT, AND ANNUAL PRODUCTION

\begin{tabular}{|c|c|c|c|c|c|c|c|c|}
\hline \multirow{2}{*}{ Ownership } & \multirow{2}{*}{$\begin{array}{c}\text { Total } \\
\text { area, } \\
\text { acres }\end{array}$} & \multirow{2}{*}{$\begin{array}{c}\text { Unpro- } \\
\text { ductive, } \\
\text { acres }\end{array}$} & \multirow{2}{*}{$\begin{array}{l}\text { Coppice, } \\
\text { acres }\end{array}$} & \multirow{2}{*}{$\begin{array}{l}\text { Coppice- } \\
\text { under- } \\
\text { stand- } \\
\text { ards, } \\
\text { acres }\end{array}$} & \multirow{2}{*}{$\begin{array}{c}\text { Under } \\
\text { conver- } \\
\text { sion, } \\
\text { acres }\end{array}$} & \multirow{2}{*}{$\begin{array}{c}\text { High } \\
\text { forest, } \\
\text { acres }\end{array}$} & \multicolumn{2}{|c|}{ Annual production } \\
\hline & & & & & & & $\left|\begin{array}{c}1,000 \\
\text { board feet }\end{array}\right|$ & Cords \\
\hline State............... & $2,968,861$ & 366,226 & 64,109 & 792,539 & 241,186 & $1,529,825$ & 288,745 & 496,664 \\
\hline $\begin{array}{c}\text { Communes and pub- } \\
\text { lic institutions.... }\end{array}$ & 481 & 188.632 & 302 & & & & & \\
\hline Privato.............. & $15,988,857$ & 610,901 & $\begin{array}{r}040,892 \\
4,856,214\end{array}$ & $\begin{array}{l}2,471,352 \\
5,856,947\end{array}$ & $\begin{array}{r}33,008 \\
106,314\end{array}$ & $\begin{array}{l}1,476,186 \\
4,558,481\end{array}$ & $\begin{array}{r}355,061 \\
1,205,555\end{array}$ & $\begin{array}{r}943,422 \\
3,157,516\end{array}$ \\
\hline Communes and pub- & & & & & & & & \\
\hline lic institutions.. & 662,590 & 81,357 & 202,627 & 43,735 & 3,590 & $3,311,836$ & 68,292 & 66,719 \\
\hline Totals. & $24,430,456$ & $1,247,116$ & $5,768,942$ & $9,134,553$ & 384,098 & $10,876,328$ & $1,917,756$ & $4,664,379$ \\
\hline
\end{tabular}

${ }^{a}$ A factor of 3.5 cubic meters of $\operatorname{logs}$ to 1,000 board feet and 3.6 steres of fuel to one cord was used to obtain the column "Annual production." Because of depletion during the war these statistics are probably 10 to 20 per cent too high.

Table 4 which follows shows the average annual per hectare production in cubic meters by departments.

These data are classed especially for Federal, communal, and institu- 
OWNERSHIP, ETC.

TABLE 4.-AVERAGE ANNUAL PER HECTARE PRODUCTION IN CUBIC METERS BY DEPARTMENTS

\begin{tabular}{|c|c|c|c|c|c|c|c|c|}
\hline \multirow{3}{*}{ Department } & \multicolumn{4}{|c|}{ Under technical msnagement } & \multirow{2}{*}{\multicolumn{2}{|c|}{ Private }} & \multirow{2}{*}{\multicolumn{2}{|c|}{ Communal }} \\
\hline & \multicolumn{2}{|c|}{ Federal } & \multicolumn{2}{|c|}{$\begin{array}{c}\text { Communal and } \\
\text { institution }\end{array}$} & & & & \\
\hline & $\log s$ & Fuel & Logs & Fuel & Logs & Fuel & Logs & Fuel \\
\hline Ain... & 4.0 & 1.2 & 1.3 & 1.0 & 0.2 & 1.8 & 0.1 & 1.1 \\
\hline Aisne. & 2.1 & 2.7 & 1.6 & 2.6 & 0.8 & 2.1 & 0.4 & 1.7 \\
\hline Allier.... & 1.0 & 1.4 & 0.6 & 2.6 & 0.3 & 2.7 & 3 & 2.8 \\
\hline Alpes (Basses) & & & 0.05 & 0.35 & 0.08 & 0.62 & 0.3 & 0.4 \\
\hline Alpes (Hautes). & 0.2 & 0.1 & 0.26 & 0.24 & 0.15 & 0.45 & 0.1 & 0.2 \\
\hline Alpes-Maritimes. & 0.2 & & 0.4 & 0.2 & 0.1 & 0.5 & 0.1 & 0.5 \\
\hline Ardèche. . & 0.3 & 0.55 & 0.1 & 1.3 & 0.5 & 0.8 & 0.3 & 0.2 \\
\hline Ardennes. & 0.9 & 2.6 & 0.4 & 2.4 & 1.0 & 2.2 & 0.4 & 1.0 \\
\hline Ariège. . & 0.3 & 0.8 & 1.2 & 0.8 & 0.1 & 0.9 & & 7 \\
\hline Aube.. & 0.7 & 2.5 & 0.6 & 3.1 & 0.5 & 2.0 & 0.4 & 2.3 \\
\hline Aude... & 1.1 & 0.7 & 0.2 & 0.6 & 0.5 & 1.4 & & 0.8 \\
\hline Aveyron. & $\ldots$ & 0.8 & 0.1 & 0.9 & 0.1 & 1.3 & 0.1 & 1.1 \\
\hline Belfort (Territoire de). & - & & 0.4 & 3.9 & 0.3 & 2.7 & 0.1 & 3.1 \\
\hline Bouches-du-Rhóne..... & & & 0.2 & 0.3 & 0.3 & 0.6 & 0.05 & 0.75 \\
\hline Calvados. & 1.4 & 3.4 & & & 0.1 & 2.2 & 0.02 & 1.98 \\
\hline Can & 2.0 & 1.0 & 0.6 & 1.2 & 0.4 & 0.8 & 0.1 & 1.0 \\
\hline Charente... & 0.4 & 2.1 & 0.1 & 1.8 & 0.1 & 2.3 & & \\
\hline Charente Inférieure. & 0.3 & 1.6 & 0.1 & 2.2 & 0.3 & 3.1 & 0.2 & 0.8 \\
\hline Cher..... & 0.9 & 1.5 & 0.7 & 3.2 & 0.4 & 2.7 & & 2.9 \\
\hline Cor & 1.0 & 2.0 & & 2.2 & 0.1 & 0.4 & & \\
\hline Cors & 0.2 & 0.4 & 0.1 & 0.5 & 0.4 & 0.7 & 0.4 & 0.9 \\
\hline & 0.6 & 2.7 & 0.4 & 2.5 & 0.5 & 2.5 & 0.3 & 1.4 \\
\hline $\begin{array}{l}\text { Côtes-du-No } \\
\text { Creuse..... }\end{array}$ & 0.4 & 3.3 & 02 & 22 & $\begin{array}{l}0.3 \\
0.4\end{array}$ & $\begin{array}{l}2.7 \\
2.6\end{array}$ & $\begin{array}{l}0.6 \\
0.2\end{array}$ & $\begin{array}{l}1.6 \\
2.7\end{array}$ \\
\hline Dorc & & & & & 0.6 & 1.3 & & 0.4 \\
\hline Doul & 6.8 & 1.2 & 1.7 & 2. & 1.1 & 1.8 & 0.7 & 1.4 \\
\hline Drô & 0.3 & 0.3 & 0.3 & 0.8 & 0.1 & 0.9 & & \\
\hline Ev & 1.4 & 2. & 0.2 & 2.1 & 0.3 & 1.9 & 0 . & 1. \\
\hline t-Loir & 1.1 & 1.9 & 0.05 & 1.15 & 0.2 & 1.9 & 0.1 & 1.5 \\
\hline êre... & 1.3 & 1. & & & 0.2 & 2.7 & & 2.1 \\
\hline $\mathrm{Ga}$ & & $0.2-2-10$ & & 1.0 & 0.2 & 0.8 & & 0.4 \\
\hline ine (Haut & 0.3 & 0. & 0.5 & 1.5 & 0.1 & 1.9 & & 1.3 \\
\hline Ger & & 3. & 0.6 & 2.9 & 0.2 & 1.8 & 0.2 & 1.6 \\
\hline & 1.6 & 0.2 & 1.0 & 1.2 & 1.4 & 2.0 & 1.3 & 1.0 \\
\hline $\mathrm{H}$ & & & & 0.4 & & 0.5 & & \\
\hline -Vilaine & 1.4 & & & 2.0 & 0.3 & 2.5 & 0.1 & 1.5 \\
\hline Indr & 0.5 & 2. & 0.3 & 2.4 & 0.2 & 2.7 & 0.5 & 2.5 \\
\hline Indre-et-Lo & 0.8 & 2 & & & 0.1 & 1.8 & & \\
\hline Isère. . & 1.3 & 0.2 & 0.8 & 0.8 & 0.4 & 1.7 & 0.2 & 0 . \\
\hline $\mathrm{Ju}$ & 2.1 & 3.2 & 1. & 2. & 0.7 & 1.6 & 0.3 & 1. \\
\hline La & 1.6 & 0.6 & 1.4 & 1.0 & 2.7 & 1.0 & 3.0 & 1.0 \\
\hline et-Cher & 1.2 & 2.0 & 0.8 & 2.0 & 0.4 & 1.8 & 0.1 & 1.6 \\
\hline Loir & & & 2 . & 0.8 & 2.9 & 1.1 & 3.7 & 0.8 \\
\hline Loire (Hal & 0.25 & 0.25 & $1 . \overline{1}$ & 0.4 & 2.3 & 1.2 & 1.5 & \\
\hline Loire-Inférieur & 1.1 & 1.2 & & & 0.3 & 3.2 & & \\
\hline Loiret. . & 0.3 & 2.5 & 0.1 & 4.1 & 0.1 & 2.0 & 0.1 & 1.2 \\
\hline Lot. . & $\ldots$ & $\ldots$ & & & 0.1 & 0.6 & 0.1 & 0.6 \\
\hline et-Garonne & $\ldots$ & $\ldots$ & 0.3 & 2.5 & 1.1 & 1.6 & 0.9 & 0.7 \\
\hline Lozè & & & 0.2 & 0.5 & 0.4 & 1.2 & 0.3 & 0.8 \\
\hline Mai & 1.8 & 1.5 & & & 0.1 & 3.1 & & \\
\hline Manche. & 0.08 & 6.32 & 0.4 & 2.5 & 0.2 & 2.1 & 0.2 & 2.0 \\
\hline
\end{tabular}


TABLE 4.- Continued

\begin{tabular}{|c|c|c|c|c|c|c|c|c|}
\hline \multirow{3}{*}{ Department } & \multicolumn{4}{|c|}{ Under technical manangement } & \multirow{2}{*}{\multicolumn{2}{|c|}{ Private }} & \multirow{2}{*}{\multicolumn{2}{|c|}{ Communal }} \\
\hline & \multicolumn{2}{|c|}{ Federal } & \multicolumn{2}{|c|}{$\begin{array}{c}\text { Communal and } \\
\text { institution }\end{array}$} & & & & \\
\hline & Logs & Fuel & Logg & Fuel & Logs & Fuel & Logs & Fuel \\
\hline Marne. & 1.5 & 3.4 & 0.9 & 3.1 & 0.4 & 1.9 & 0.2 & 0.8 \\
\hline Haute-Marne & 0.8 & 2.2 & 0.6 & 2.3 & 0.6 & 2.1 & 0.4 & 1.1 \\
\hline Mayenne.... & 3.7 & 1.6 & & & 0.2 & 1.5 & 0.2 & 2.0 \\
\hline Meurthe-et-Moselle & 1.0 & 2.6 & 0.5 & 2.7 & 0.8 & 1.7 & 0.3 & 1.1 \\
\hline Meuse.... & 0.8 & 2.6 & 0.5 & 2.5 & 0.5 & 2.0 & 0.3 & 1.4 \\
\hline Morbihan. & 1.9 & 2.7 & & & 1.0 & 2.0 & 1.8 & 0.3 \\
\hline Nièvre... & 0.6 & 3.8 & 0.6 & 4.6 & 0.4 & 4.0 & & 5.0 \\
\hline Nord.. & 2.5 & 1.7 & 2.3 & 2.2 & 1.4 & 2.0 & 1.0 & 1.5 \\
\hline Oise. & 1.0 & 2.0 & 0.3 & 2.0 & 0.6 & 2.4 & 0.5 & 2.1 \\
\hline Orne. & 0.7 & 1.8 & & & 0.5 & 2.6 & & 2.2 \\
\hline Pas-de-Calais & 1.9 & 2.3 & 0.6 & 2.2 & 1.2 & 2.6 & 1.0 & 2.4 \\
\hline Puy-du-Dôme & 1.3 & 0.5 & 0.5 & 1.2 & 0.8 & 1.1 & 0.3 & 0.3 \\
\hline Pyrénées (Basses). & 0.6 & 3.0 & 0.5 & 1.1 & 0.3 & 2.0 & 0.1 & 1.5 \\
\hline Pyrénées (Haute). & 0.3 & 1.2 & 0.4 & 1.0 & 0.4 & 1.7 & 0.2 & 0.6 \\
\hline Pyrénées-Orientales. & 0.1 & 0.1 & 0.3 & 0.4 & 0.8 & 1.1 & 0.1 & 0.6 \\
\hline Rhône......... & 3.6 & 1.2 & & & 1.5 & 2.0 & & 3.3 \\
\hline Saóne (Haute) & 1.9 & 2.1 & 0.9 & 3.6 & 0.5 & 3.1 & 0.1 & 2.2 \\
\hline Saône-et-Loire & 1.5 & 2.6 & 0.7 & 3.5 & 0.5 & 2.7 & 0.1 & 2.1 \\
\hline Sarthe.... & 2.0 & 1.5 & 0.2 & 2.8 & 0.2 & 1.9 & 0.2 & 2.2 \\
\hline Savoie.. & & 0.3 & $0 . \overline{7}$ & 0.7 & 0.5 & 1.3 & 0.3 & 0.4 \\
\hline Savoie (Haute) & 0.2 & 0.1 & 0.7 & 0.9 & 0.5 & 1.2 & 0.4 & 0.5 \\
\hline Seine.. & 0.2 & 3.8 & 0.2 & 3.2 & & 0.5 & & 0.6 \\
\hline Seine-et-Marn & 0.2 & 1.6 & 0.9 & 3.1 & 0.3 & 3.0 & 0.3 & 2.5 \\
\hline Seine-et-Oise & 0.3 & 2.5 & 0.3 & 2.2 & 0.2 & 2.3 & 0.1 & 2.4 \\
\hline Seine-Inférieure & 1.4 & 3.2 & 1.4 & 3.9 & 0.5 & 2.3 & 0.2 & 1.7 \\
\hline Sèvres (Deux). & 0.9 & 4.4 & & 2.6 & 0.1 & 3.0 & 0.1 & 3.6 \\
\hline Somme. & 0.6 & 3.0 & 0.7 & 2.5 & 0.9 & 2.2 & 0.8 & 2.6 \\
\hline Tarn. . & 0.7 & 1.3 & & 1.7 & 0.2 & 1.7 & ... & 1.4 \\
\hline Tarn-et-Garonne & 0.4 & 3.8 & & 3.0 & 0.1 & 0.9 & & \\
\hline Var....... & 0.3 & 0.4 & 0.4 & 0.6 & 0.3 & 0.5 & 0.3 & 0.4 \\
\hline Vaucluse. & 0.1 & 0.5 & 0.1 & 0.5 & & 0.5 & $\ldots$ & 0.1 \\
\hline Vendée. . & 0.4 & 1.6 & & & 0.2 & 2.5 & $\ldots$ & 1.5 \\
\hline Vienne.. & 0.8 & 1.4 & 0.1 & 2.4 & 0.1 & 2.0 & & \\
\hline Vienne (Haute). & 0.2 & 1.5 & & & 0.2 & 3.1 & 0.3 & 3.5 \\
\hline Vosges.... & 2.5 & 1.9 & 1.4 & 2.0 & $0 . \overline{9}$ & 1.5 & 0.5 & 1.3 \\
\hline Yonne.. & 0.6 & 3.0 & 0.3 & 2.7 & 0.3 & 2.6 & 0.2 & 2.1 \\
\hline
\end{tabular}

tional forests which are under technical State management and for private and communal forests which are ordinarily not under technical supervision. The figures for each class of owner are divided into logs and fuel, and represent the number of cubic meters which the forests produce per hectare and per year. In order to reduce these figures to American units of measure (board feet and cords) the figures in the log column should be divided by 3.5 and figures in the fuel column by 0.277 , the approximate answers being 1,000 board feet and cords. A study of these figures shows clearly that the forests under technical management produce a much higher proportion of sawlogs to fuel than do the private or 
communal forests not under management; for example, take the department of Ain: the Federal forests produce more than three times as much saw timber as fuel, while the private forests produce nine times as much fuel as saw timber.

A somewhat similar ratio holds for other departments.

Forest Areas and Per Cent of Species by Departments. - Table 5 which follows shows by departments: (a) per cent forested; (b) total forest area, areas under technical management, and areas not under State working plans; $(c)$ for the forests under technical management the per cent of the important species given to the nearest tenth. 


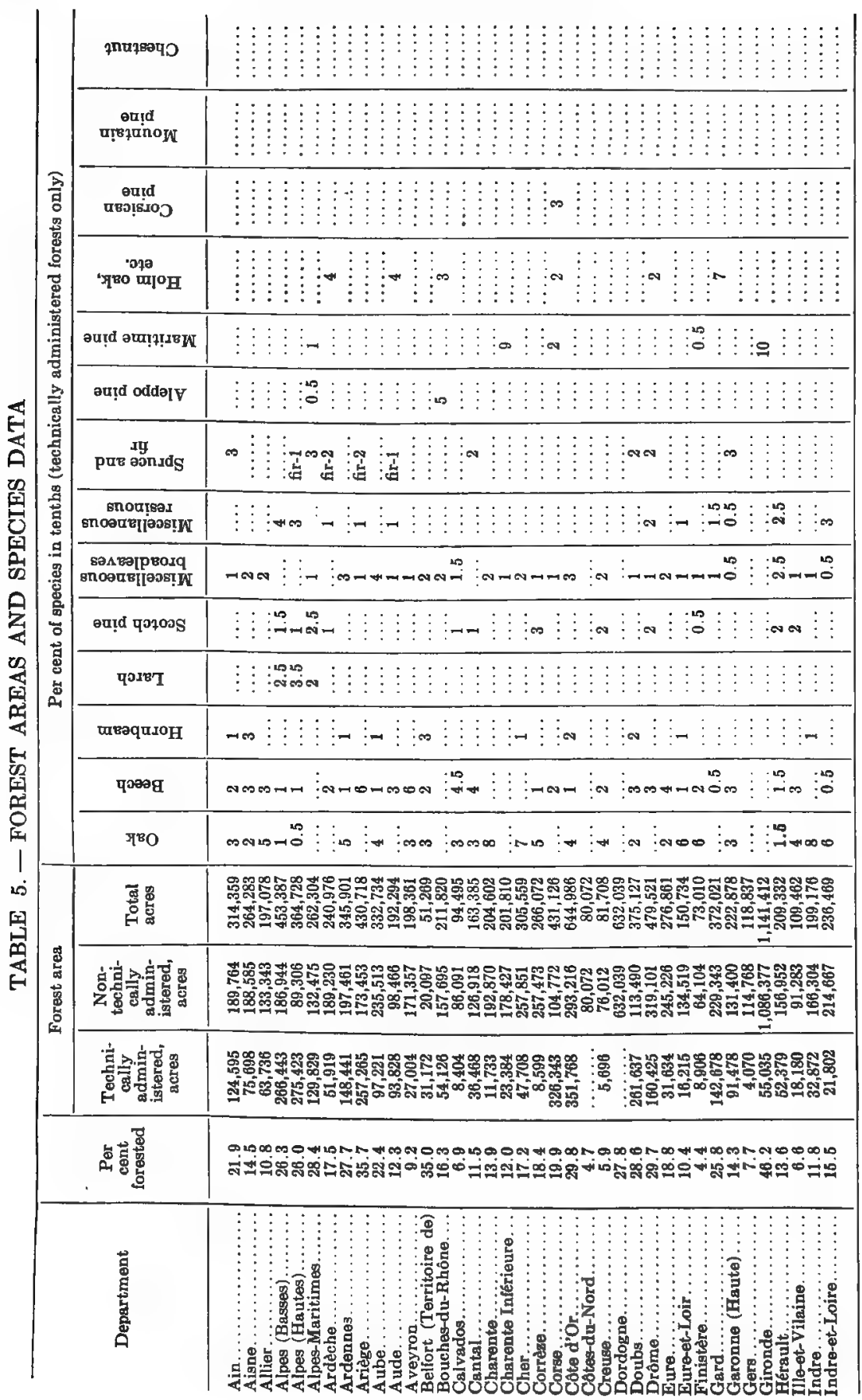




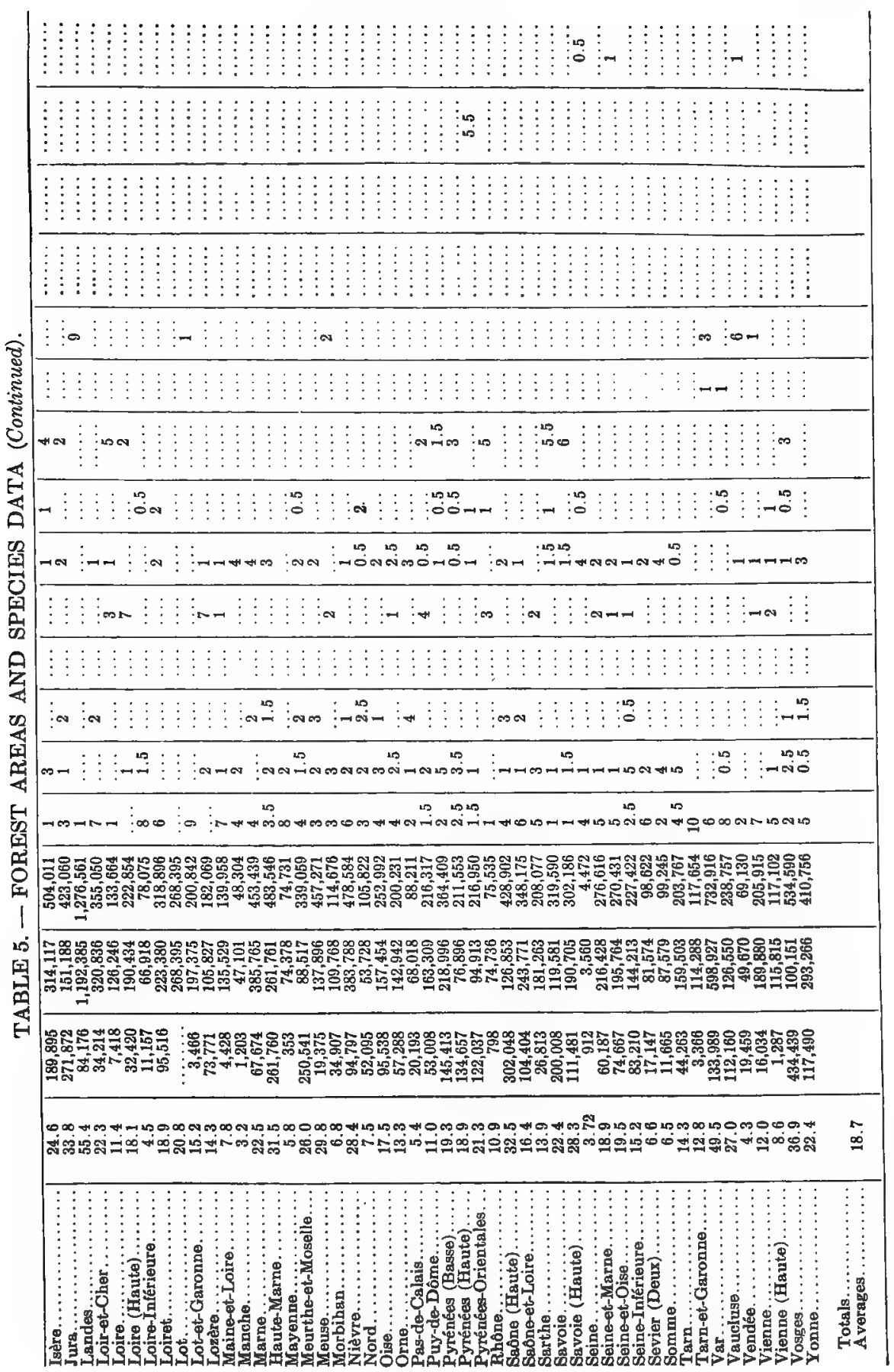


A comparison of the ten most heavily forested departments with those least timbered is given below:

TABLE 6. - MOST HEAVILY AND THE LEAST FORESTED DEPARTMENTS

\begin{tabular}{|c|c|c|c|c|}
\hline \multirow{2}{*}{$\begin{array}{l}\text { Numerical } \\
\text { order }\end{array}$} & \multicolumn{2}{|c|}{ Most hesvily forested } & \multicolumn{2}{|c|}{ Least forested } \\
\hline & Department & Per cent forested & Department & Per cent forested \\
\hline $\begin{array}{r}1 \\
2 \\
3 \\
4 \\
5 \\
6 \\
7 \\
8 \\
9 \\
10\end{array}$ & 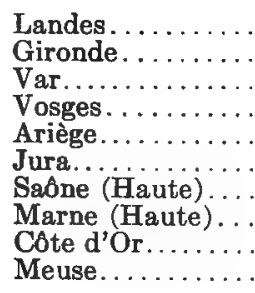 & $\begin{array}{l}55.4 \\
46.2 \\
49.5 \\
36.9 \\
35.7 \\
33.8 \\
32.5 \\
31.5 \\
29.8 \\
29.8\end{array}$ & 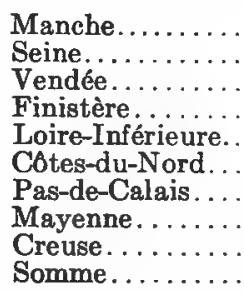 & $\begin{array}{l}3.2 \\
3.7 \\
4.3 \\
4.4 \\
4.5 \\
4.7 \\
5.4 \\
5.8 \\
5.9 \\
6.5\end{array}$ \\
\hline \multicolumn{2}{|c|}{ Averaged by departments. . } & 38.1 & & 4.8 \\
\hline
\end{tabular}

An analysis of the heavily forested departments discloses that two were sand wastes (like parts of Minnesota and Michigan) but were reforested; five are mountainous, or very hilly; and two are hilly or too wet for agriculture. The least forested departments are largely agricultural land or moors. When it is considered that the final use of this land has been evolved after centuries of settlement, the present-day use is significant, and it is especially noteworthy that there is to-day much land growing timber. which is suitable for agriculture, yet the French Forest Code recognizes that it is in the public interest to retain the land now under forest for the production of timber, even where it could grow agricultural crops.

Analysis of General Statistics. - General. - The following facts are shown by Tables 3 to 6: (a) Out of 24.5 million acres of forest land less than one-third is under technical forest management. (b) Less than 5 per cent of the entire forest area is unproductive. A larger proportion of State and communal forest land is unproductive because the State and communes own most of the mountain slopes requiring conservative cutting, and where considerable areas cannot support tree growth. (c) More than two-thirds of the private forests are treated under coppice, or coppiceunder-standards; less than one-half of one per cent of this area is being converted into high forest. Only two-fifths of French forests are under high forest. (d) The total annual production of French forests is estimated at 1,917,756,000 feet board measure and 4,664,379 cords of fuel.

State Forests. - According to the original statistics on State forests: 
(a) There are no State forests in the departments of Côtes-du-Nord, Dordogne, Lot, Lot-et-Garonne, Rhône, Vienne (Haute). (b) The six departments with the most State forest area, in the order of importance, are: Ariège, Alpes (Basses) Vosges, Côte d'Or, Loiret, Drôme. (c) The six heaviest producing (State forest) departments, in the order of their importance, are: Vosges, Seine-Inférieure, Côte d'Or, Aisne, ${ }^{2}$ Jura, Meurthe-et-Moselle. ${ }^{2}(d)$ The unproductive land in the State forests is chiefly in the mountains, notably in the departments of Ariège, Alpes (Hautes), Pyrénées-Orientales, Drôme, Isère, Alpes (Basses).

Communal and Institution Forests. - There are no communal and institution forests under State control in the following departments: (a) Calvados, Côtes-du-Nord, Finistère, Indre-et-Loire (Inférieure), Lot, Maine-et-Loire, Mayenne, Morbihan, Orne, Vendée. The largest areas are in the (b) Vosges, Saône (Haute), Côte d'Or, Doubs, Meuse, Marne (Haute), but as regards production (c) Saône (Haute) is first with Doubs, Vosges, Jura, Meuse, Côte d'Or, in the order named. (d) The unproductive land is also in the mountains, notably in the following departments: Alpes (Hautes), Var, Ardèche, Isère, Pyrénées-Orientales, Alpes (Basses).

Private Forests. - The statistical data on private forests and on communal and institution forests not under management is less trustworthy. (a) But it is certain that there is privately owned forest land in every department of France, with a minimum ownership of but 121 acres in the Seine which includes Paris (this corresponds to the District of Columbia in the United States). (b) The largest areas of privately owned forests are in the Landes, Gironde, Dordogne, Var, Nièvre, Marne. The Var mountain forests produce but little saw timber though the acreage is large. (c) The heaviest production of private forest land is found in the Landes and Gironde, together 3,008,483 cubic meters (corresponding to $445,253,000$ feet board measure and 340,963 cords of fuel), Nièvre, Dordogne, Marne, Côte d'Or, together 1,871,144 cubic meters (or about $88,928,000$ feet board measure and 481,563 cords). Certain features of production are illustrated by these figures and by the original statistics. In the Landes the fuel produced was about one-third the volume of the timber, while in the Gironde (also a maritime pine producing department) the ratio of fuel to timber was as 8 is to 6 . Moreover, in the Nièvre, Dordogne, Marne, and Côte d'Or, where private forests are largely coppice and coppice-under-standards, the total timber production was but one-fifth that of the Landes and Gironde, but the fuel produced exceeded the latter two departments by more than 140,000 cords. (d) There is less unproductive forest privately owned than publicly owned, although the total area of private forest is about double that in the hands of the State, communes, and institutions.

${ }^{2}$ Heavily devastated by the war operations of the Germans and the French. 
Management Statistics. - Unquestionably the management of French State forests is over-conservative. No systematic attempt has been made to follow financial rotations. There have been excess growing stocks, ${ }^{3}$ due in many cases to over-careful working plans that followed an era of overcutting. In communal forests, managed by the State, this excess is usually 25 per cent and often more. As contrasted with those publicly managed, the forests in private hands are managed on shorter rotations and far too great an acreage is in coppice, or coppice-understandards. As an illustration of this tendency to short rotations we find eight-tenths of the private forests in coppice or coppice-understandards, no-tenths in conversion, and only two-tenths in high forest. With State forests five-tenths in high forest, three-tenths in coppice and coppice-under-standards, and two-tenths in conversion.

This variance in the length of rotations is further illustrated by the detailed statistics for each department. Take some typical examples:

VOSGES (CONIFERS)

\begin{tabular}{|c|c|c|}
\hline \multirow{2}{*}{ System of treatment } & \multicolumn{2}{|c|}{ Length of rotation in years } \\
\hline & $\begin{array}{l}\text { Under } \\
\text { State control }\end{array}$ & $\begin{array}{l}\text { Private or uncon- } \\
\text { trolled communal }\end{array}$ \\
\hline 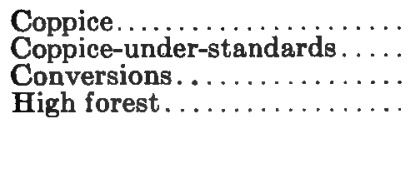 & $\begin{array}{l}25-40 \\
100-132 \\
120-150\end{array}$ & $\begin{array}{l}15-25 \text { (few 35) } \\
\text { 80-100 (few 120) } \\
\text { Some are cut for paper } \\
\text { pulp at } 30 .\end{array}$ \\
\hline
\end{tabular}

For the high forests under State control the prevalent rotation is 144 years, while notable State forests like Gérardmer, Ban d'Etival, la Bresse, Cornimont, and Champ have 150-year rotations.

SAVOIE (HAUTE) (CONIFERS)

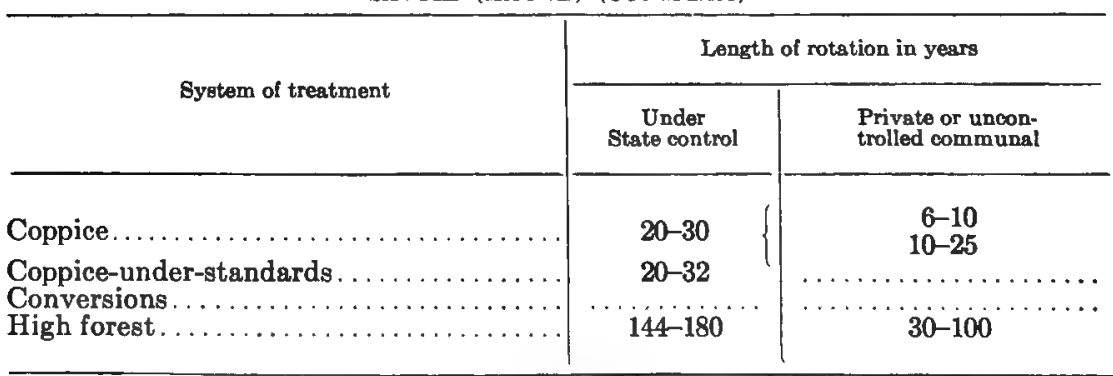

${ }^{3}$ For example, in the State forest of Berce (Sarthe) there are compartments with 700 to 800 cubic meters of oak to the hectare, worth 30,000 to 40,000 francs. In the forest of Levier silver fir runs as high as 1,000 cubic meters per hectare, or 25,000 francs, on soil worth 100 to 200 francs per hectare. 
The rotation of 180 years is chiefly for forests at high altitudes where the growth of spruce or fir is slower. Chamonix is 200 years (see p. 252), Samoëns 162 to 180, and the forest of Houches 180 to 240. These are all selection forests in a severe mountain climate.

SAVOIE (CONIFERS)

\begin{tabular}{|c|c|c|}
\hline \multirow{2}{*}{ System of treatment } & \multicolumn{2}{|c|}{ Length of rotation in years } \\
\hline & $\begin{array}{l}\text { Under } \\
\text { State control }\end{array}$ & $\begin{array}{l}\text { Private or uncon- } \\
\text { trolled communal }\end{array}$ \\
\hline Coppice........................ & $20-25$ & $\begin{array}{r}6-10 \\
10-25\end{array}$ \\
\hline $\begin{array}{l}\text { Coppice-under-standards } \ldots \ldots \ldots \ldots \ldots \ldots \\
\text { Conversions } \ldots \ldots \ldots \ldots \ldots \ldots \ldots \ldots \ldots \ldots \ldots \ldots \\
\text { High forest. } \ldots \ldots \ldots \ldots \ldots \ldots \ldots \ldots\end{array}$ & $\begin{array}{c}25-35 \\
144-180\end{array}$ & ${ }_{30}+120$ \\
\hline
\end{tabular}

These long high forest rotations are for selection forests in the mountains. A few run even higher, notably Pussy communal at 200, Tignes communal 180 to 240 , and Bramans 198 to 264 . The State forest of Bellevaux is 144 years. These communal forests with long rotations were formerly overcut and are now being improved and a suitable growing stock accumulated.

VAR (MARITIME PINE, ALEPPO PINE, HOLM OAK, COMMON OAK)

\begin{tabular}{|c|c|c|}
\hline \multirow{2}{*}{ System of treatment } & \multicolumn{2}{|c|}{ Length of rotation in years } \\
\hline & $\begin{array}{c}\text { Under } \\
\text { State control }\end{array}$ & $\begin{array}{l}\text { Private or uncon- } \\
\text { trolled communal }\end{array}$ \\
\hline $\begin{array}{l}\text { Coppice ................... } \\
\text { Coppice-under-standards. } \\
\text { Conversions . } \ldots \ldots \ldots \ldots \ldots \\
\text { High forest. . . . } \ldots \ldots \ldots\end{array}$ & $\begin{array}{c}18-25 \\
25-30 \\
60-80\end{array}$ & \begin{tabular}{l}
\multicolumn{1}{c}{$10-18$} \\
$\ldots \ldots \ldots \ldots \ldots$ \\
$50-60$ and less
\end{tabular} \\
\hline
\end{tabular}

PYRENEES-ORIENTALES (MOUNTAIN PINE, HOLM OAK, BEECH, MISCELLANEOUS)

\begin{tabular}{|c|c|c|}
\hline \multirow{2}{*}{ System of treatment } & \multicolumn{2}{|c|}{ Length of rotation in years } \\
\hline & $\begin{array}{c}\text { Under } \\
\text { State control }\end{array}$ & $\begin{array}{l}\text { Private or uncon- } \\
\text { trolled communal }\end{array}$ \\
\hline 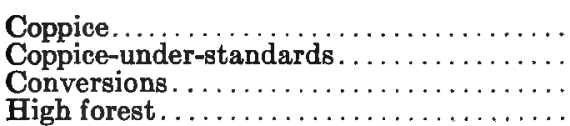 & $\begin{array}{c}18-26 \\
32-40 \\
150-180\end{array}$ & 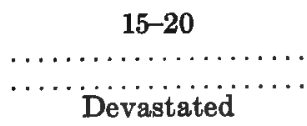 \\
\hline
\end{tabular}


The mountain pine in the regular State high forest of Barrès is handled on a 180 to 200 year rotation, and the fir and mountain pine in the communal forest of Bolquere, 240 years.

ORNE (BROADLEAVES)

\begin{tabular}{|c|c|c|}
\hline \multirow{2}{*}{ System of treatment } & \multicolumn{2}{|c|}{ Length of rotation in years } \\
\hline & $\begin{array}{c}\text { Under } \\
\text { State control }\end{array}$ & $\begin{array}{l}\text { Private or uncon- } \\
\text { trolled communal }\end{array}$ \\
\hline 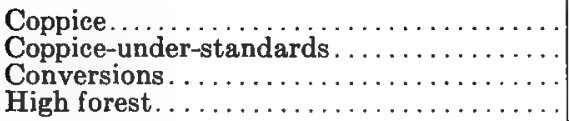 & $\begin{array}{c}20-30 \\
150-180 \\
150-180\end{array}$ & \begin{tabular}{c}
\multicolumn{2}{c}{$8-12$} \\
$\ldots \ldots \ldots \ldots \ldots \ldots \ldots$ \\
$\ldots \ldots \ldots \ldots \ldots \ldots$
\end{tabular} \\
\hline
\end{tabular}

The oak and beech in the State forest of Econnes is managed on a rotation of 180 years; State forest of Bourse 180 years; State forest of Bellème 200 years; State forest of Réno-Valdieu 180 years. The pine which has been introduced in this region is not yet mature.

OISE (BROADLEAVES)

\begin{tabular}{|c|c|c|}
\hline \multirow{2}{*}{ System of treatment } & \multicolumn{2}{|c|}{ Length of rotation in years } \\
\hline & $\begin{array}{c}\text { Under } \\
\text { State control }\end{array}$ & $\begin{array}{l}\text { Private or uncon- } \\
\text { trolled communal }\end{array}$ \\
\hline 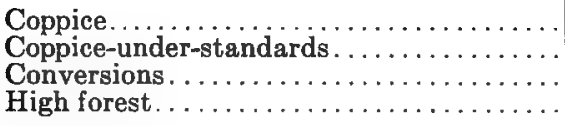 & $\begin{array}{l}\cdots \\
20-35 \\
\cdots \\
80-150\end{array}$ & 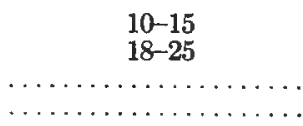 \\
\hline
\end{tabular}

The State forest of Hez-Froidmont (see Fig. 6 ( $a$ tof )), oak, beech, etc., has a rotation of 150 years. Compiegne (where the Germans were stopped) 150 for high forest and 35 for the coppice and coppice-under-standards.

HAUTE-MARNE (BROADLEAVES)

\begin{tabular}{|c|c|c|}
\hline \multirow{2}{*}{ System of treatment } & \multicolumn{2}{|c|}{ Length of rotation in years } \\
\hline & $\begin{array}{l}\text { Under } \\
\text { State control }\end{array}$ & $\begin{array}{l}\text { Private or uncon:- } \\
\text { trolled communal }\end{array}$ \\
\hline 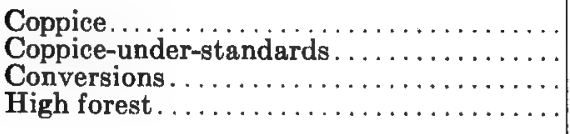 & $\begin{array}{c}25-40 \\
144-150 \\
144-150\end{array}$ & $\begin{array}{l}\text { 14-25 (few } 30-40) \\
\ldots \ldots \ldots \ldots \ldots \ldots \ldots \ldots \ldots \\
\ldots \ldots \ldots \ldots \ldots \ldots \ldots \\
\ldots \ldots \ldots \ldots \ldots \ldots \ldots\end{array}$ \\
\hline
\end{tabular}


There are no rich notable State forests in this department. The State forest of d'Auberive is managed on a 150-year rotation; Bussières 144; de la Haie-Renault 144; all of these are being converted from coppice and coppice-under-standards to high forest.

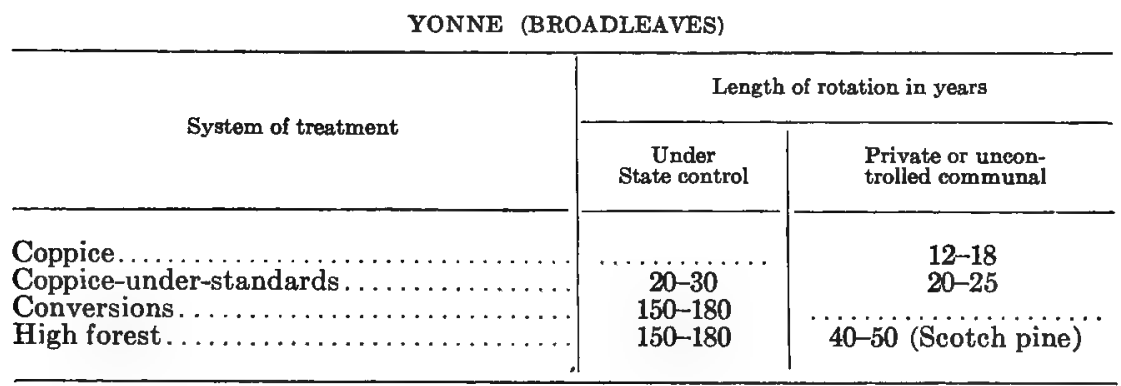

Here four-fifths the forest area is under rotations of less than 25 years. LANDES (MARITIME PINE)

\begin{tabular}{|c|c|c|}
\hline \multirow{2}{*}{ System of treatment } & \multicolumn{2}{|c|}{ Length of rotation in years } \\
\hline & $\begin{array}{l}\text { Under } \\
\text { State control }\end{array}$ & $\begin{array}{l}\text { Private or uncon- } \\
\text { trolled communal }\end{array}$ \\
\hline $\begin{array}{l}\text { Coppice } \ldots \ldots \ldots \ldots \ldots \ldots \ldots \ldots \\
\text { Coppice-under-standards } \ldots \ldots \ldots \ldots \ldots \ldots \ldots \\
\text { Conversions } \ldots \ldots \ldots \ldots \ldots \ldots \ldots \ldots \ldots \ldots\end{array}$ & $\cdots \ddot{20}-25^{\prime}$ & $\begin{array}{c}10-20 \\
\ldots \ldots \ldots \ldots \ldots \ldots \ldots \ldots \ldots \\
\ldots \ldots \ldots \ldots \ldots \ldots\end{array}$ \\
\hline High forest. . . . . . . . . . . . . & $60-120$ & $\begin{array}{l}60-80 \\
12-16\end{array}$ \\
\hline
\end{tabular}

GIRONDE (MARITIME PINE)

\begin{tabular}{|c|c|c|}
\hline \multirow{2}{*}{ System of treatment } & \multicolumn{2}{|c|}{ Length of rotation in years } \\
\hline & $\begin{array}{c}\text { Under } \\
\text { State control }\end{array}$ & $\begin{array}{l}\text { Private or uncon- } \\
\text { trolled communal }\end{array}$ \\
\hline 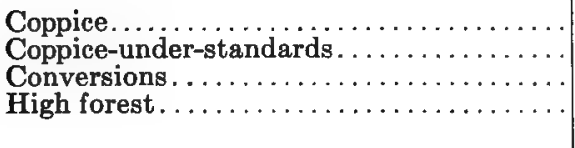 & $\begin{array}{c}15-25 \\
15-25 \\
50-72\end{array}$ & $\begin{array}{c}12-15 \\
20-25 \\
\ldots \ldots \\
15-30 \text { (mine props) }\end{array}$ \\
\hline
\end{tabular}

Costs of Administration. - As Huffel points out, it is difficult to say authoritatively just what it costs to manage the State forests because the budget provides also for the management of communal forests and public establishments, for game and fish protection, for control of deforestation, for the reforestation of eroded mountain lands, for dune protection and for 

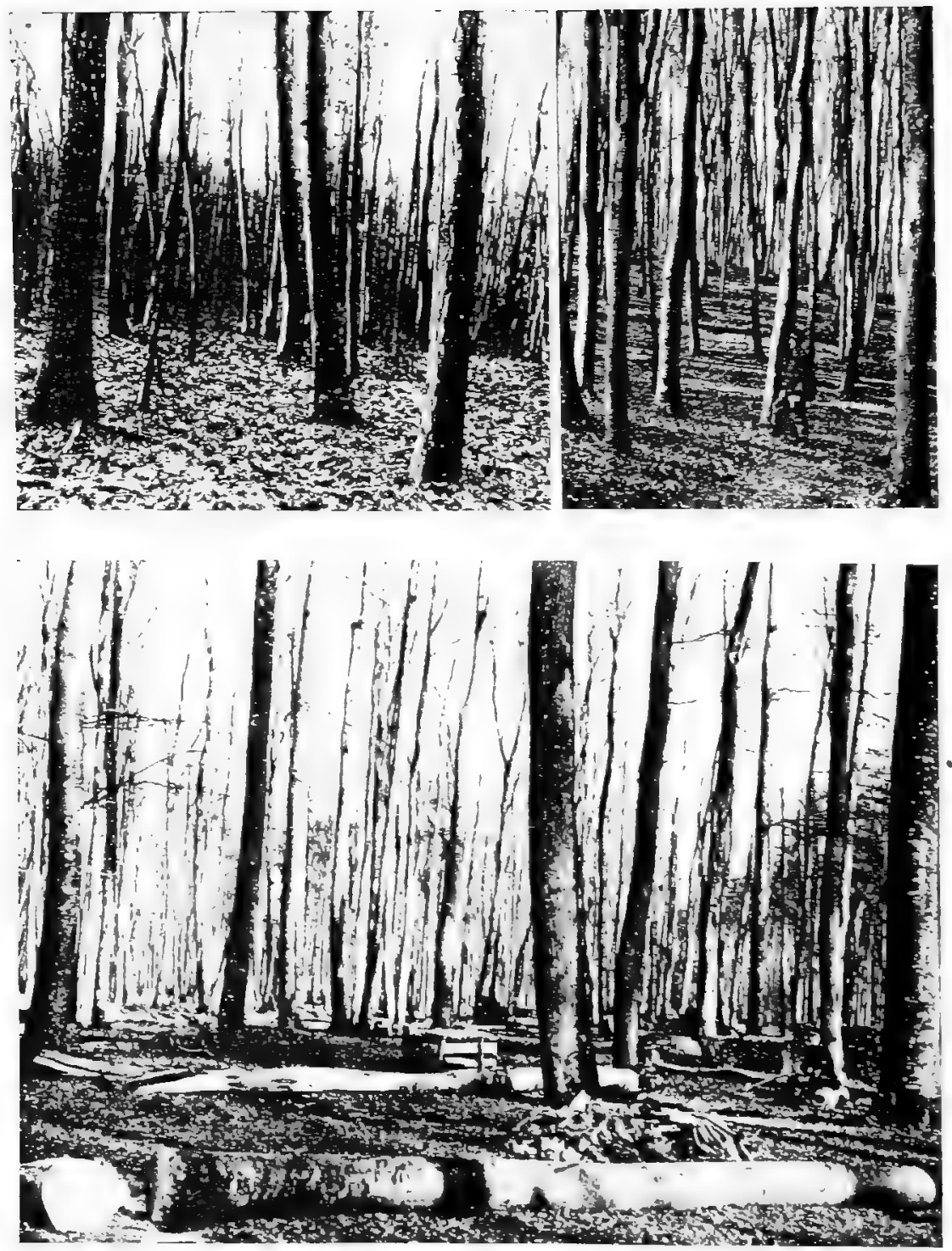

Fra. 6 ( $a$ to $c$ ). - State forest of Hez-Froidmont. First working group: ( $a-$ top left) Oak and beech saplings; ( $b$ - top right) Poles; ( $c$ - bottom) Seed felling in course of exploitation, illustrating thorough utilization and use of long, clear lengths. 


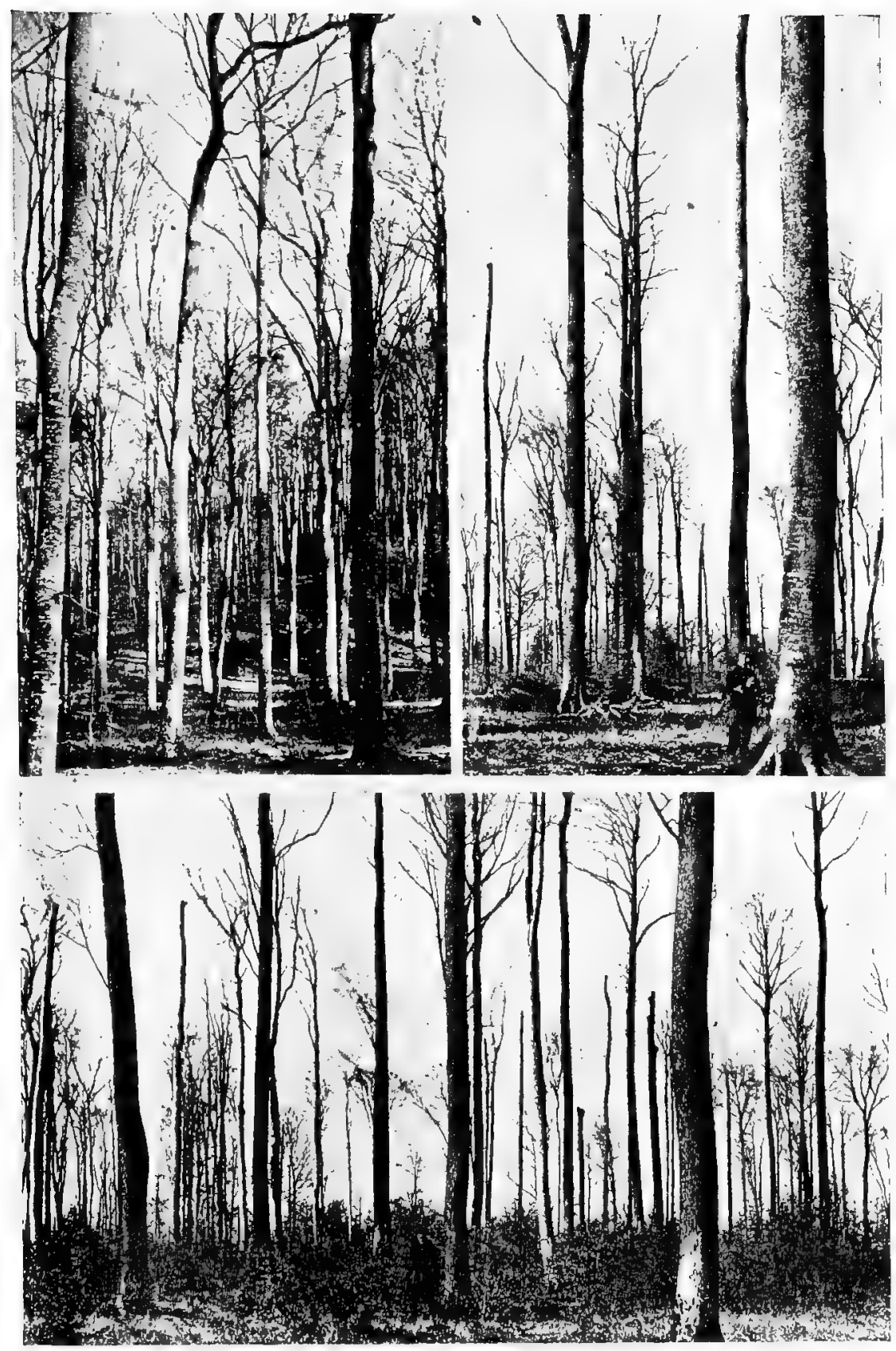

Fig. 6 ( $d$ to $f$ ). - State forest of Hez-Froidmont. ( $d$-top left) Appearance after seed felling is completed; ( $e$ - top right), ( $f$-bottom) Secondary felling showing regeneration secured by seed felling. The advance growth in the background will be cut back, so as to assure an even-aged stand. 
grazing betterments. Much the same thing is true in the United States, where the Forest Service has a lump-sum appropriation to cover all manner of scientific work and investigations as well as for the management and protection of the National Forests. Huffel ${ }^{4}$ makes the conclusion:

"Taking everything into consideration, it is estimated that $\$ 173,700$ is about the expense for the management of the State forests; this figure corresponds to 6 cents per acre. It is estimated that protection costs 16 cents per productive acre; maintenance absorbs 12 cents per acre; communal and departmental tax 16 cents per acre. We have then the following revenues and costs per productive acre in State forests for 1892 (which is considered a typical year):

\begin{tabular}{|c|c|}
\hline & $\begin{array}{l}\text { Per cent of } \\
\text { gross revenue }\end{array}$ \\
\hline$\$ 2.26$ Net yield, or. & 81.2 \\
\hline .06 Cost of management, or.... & 2.5 \\
\hline .16 Cost of protection, or........ & 5.8 \\
\hline 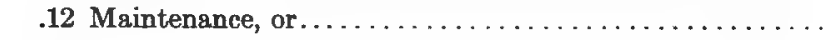 & 4.5 \\
\hline 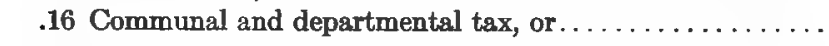 & 5.9 \\
\hline .76 Gross revenue & 99.9 \\
\hline
\end{tabular}

"The expense for the personnel in France represents only 23 cents per productive acre, or 8.3 per cent of the gross revenue."

It is of interest to note that this cost figure is less than those for Bavaria, Prussia, Saxony, or Würtemberg where the lowest (Würtemberg) absorbs 12.1 per cent of the gross revenue for personnel.

Statistics of Fir Stands in the Jura. - One of the questions asked by private forest owners and others interested in the yield of forests is: What will forests (naturally regenerated) return in lumber or money? The answers given to this question by normal yield tables, usually based on planted stands, are often so high that they cannot be applied, without much guesswork and modification, to American conditions. Actual averages of compartments or whole forests are more reliable for the purposes of judging what forestry can attain. (See also Chapter XI.) Therefore the statistics ${ }^{5}$ which follow, for fir-spruce forests in the Jura mountains of France, somewhat comparable to spruce-fir stands of northern New England, are of particular interest and value. They show what forestry can attain (as a maximum) under favorable conditions on non-agricultural mountain land over whole compartments of 15 to 30 acres.

(a) Compartment 18, fifth working group, State Forest of La Joux (second Jura Plateau), 60 per cent fir and 40 per cent spruce, fully stocked, thrifty stand planted after a windfall in 1812; 100 years old in 1912 .

${ }^{4}$ Pp. 408-409, Vol. I, Economie Forestière.

s Based on unpublished data supplied by Devarennes, Inspector, French Forest Service, in charge of Jura working plans in 1912. 


\begin{tabular}{|c|c|c|c|c|}
\hline \multirow{2}{*}{$\begin{array}{l}\text { Diameter, } \\
\text { breast-high, } \\
\text { izches }\end{array}$} & \multirow{2}{*}{$\begin{array}{c}\text { Number of } \\
\text { trees } \\
\text { per acre }\end{array}$} & \multirow{2}{*}{$\begin{array}{l}\text { Volume, cubic } \\
\text { meters } \\
\text { per acre }\end{array}$} & \multicolumn{2}{|c|}{ Approximate $a$} \\
\hline & & & $\begin{array}{c}\text { Board feet } \\
\text { per acre }\end{array}$ & $\underset{\text { per acre }}{\text { Cords }}$ \\
\hline $\begin{array}{r}10 \\
16 \\
22 \\
28 \\
\text { Totals. . }\end{array}$ & $\begin{array}{r}45.6 \\
63.6 \\
24.8 \\
3.2 \\
137.2\end{array}$ & $\begin{array}{r}32.4 \\
112.0 \\
88.0 \\
24.0 \\
256.4\end{array}$ & $\begin{array}{r}5,700 \\
32,300 \\
23,400 \\
7,200 \\
68,600\end{array}$ & $\begin{array}{r}4.8 \\
15.0 \\
11.8 \\
1.6 \\
33.2\end{array}$ \\
\hline
\end{tabular}

(b) Same forest and working group but compartment 19 and from entirely natural regeneration; 100 years old, but 90 per cent fir and 10 per cent spruce.

\begin{tabular}{|c|c|c|c|c|}
\hline \multirow{2}{*}{$\begin{array}{l}\text { Diameter, } \\
\text { breast-high, } \\
\text { inches }\end{array}$} & \multirow{2}{*}{$\begin{array}{c}\text { Number of } \\
\text { trees } \\
\text { per acre }\end{array}$} & \multirow{2}{*}{$\begin{array}{l}\text { Volume, cubic } \\
\text { meters } \\
\text { per acre }\end{array}$} & \multicolumn{2}{|c|}{ Approximate $a$} \\
\hline & & & $\begin{array}{l}\text { Board feet } \\
\text { per acre }\end{array}$ & $\begin{array}{l}\text { Cords } \\
\text { per acre }\end{array}$ \\
\hline $\begin{array}{r}10 \\
16 \\
22 \\
28 \\
\text { Totals. . }\end{array}$ & $\begin{array}{r}67.2 \\
98.0 \\
35.2 \\
4.0 \\
204.4\end{array}$ & $\begin{array}{r}47.2 \\
170.8 \\
123.6 \\
24.0 \\
365.6\end{array}$ & $\begin{array}{r}8,400 \\
45,300 \\
33,800 \\
7,200 \\
94,800\end{array}$ & $\begin{array}{r}7.2 \\
22.6 \\
16.4 \\
1.6 \\
47.8\end{array}$ \\
\hline
\end{tabular}

Such yields seem incredibly high, and the larger number of trees and the higher yield on the area naturally regenerated is especially noteworthy. The fact remains that these yields were attained, within at least 10 per cent, allowing for a possible 10 per cent error in estimate.

(c) Pure spruce, 100 years old from natural regeneration on a compartment in the forest of Ouhans (first Jura Plateau); altitude 2,300 feet.

\begin{tabular}{|c|c|c|c|c|}
\hline \multirow{2}{*}{$\begin{array}{l}\text { Diameter, } \\
\text { breast-high, } \\
\text { inches }\end{array}$} & \multirow{2}{*}{$\begin{array}{c}\text { Number of } \\
\text { trees } \\
\text { per acre }\end{array}$} & \multirow{2}{*}{$\begin{array}{l}\text { Volume, cubic } \\
\text { meters } \\
\text { per acre }\end{array}$} & \multicolumn{2}{|c|}{ Approximate $a$} \\
\hline & & & $\begin{array}{c}\text { Board feet } \\
\text { per acre }\end{array}$ & $\underset{\text { per acre }}{\text { Cords }}$ \\
\hline $\begin{array}{r}10 \\
16 \\
22 \\
\text { Totals. }\end{array}$ & $\begin{array}{r}97.2 \\
84.8 \\
13.2 \\
195.2\end{array}$ & $\begin{array}{r}60.8 \\
151.2 \\
54.4 \\
266.4\end{array}$ & $\begin{array}{l}10,600 \\
39,600 \\
14,500 \\
64,700\end{array}$ & $\begin{array}{r}9.2 \\
21.6 \\
7.2 \\
38.0\end{array}$ \\
\hline
\end{tabular}

a These conversions $(a, b, c, d)$ were made as follows: For 10-inch trees 4 cubic meters were counted to the 1,000 feet after 30 per cent subtracted for cordwood. In the other diameter classes 3 cubic meters were counted to the 1,000 feet, after subtracting 20 per cent for the cordwood in the 16 and 22 inch classes and only 10 per cent of the 28 -inch class. Two cords were considered equal to 1,000 board feet. 
(d) Ninety per cent fir, 10 per cent spruce, 100 years old from natural regeneration on a compartment in the forest of St. Point (third Jura Plateau); altitude 3,280 feet.

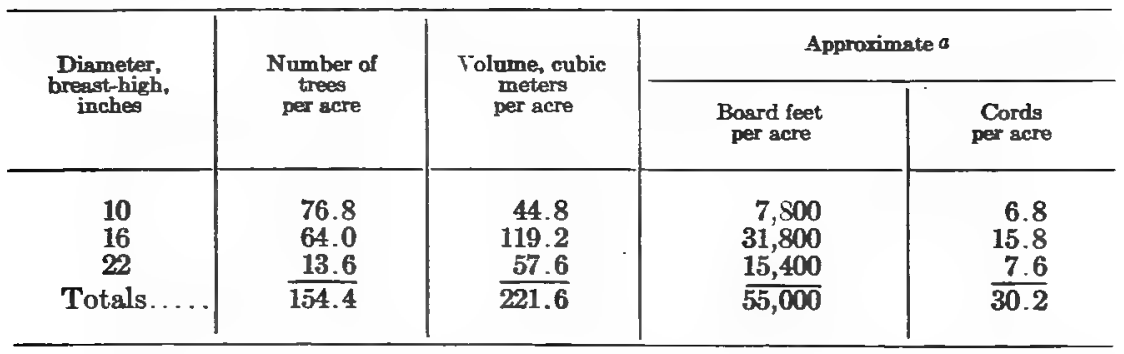

These four compartments average almost 71,000 board feet per acre and indicate what can be attained in 100 years as a maximum with thrifty, vigorous stands of silver fir under proper forest management.

Statistics for Levier. - The Federal forest of Levier ${ }^{6}$ perhaps contains, next to La Joux, the best large body of silver fir in the Jura and is one of the richest and most productive in France. It is situated near Pontarlier and rests on three plateaus cut by more or less deep valleys. With interspersed private and communal forests it makes a stand of about 24,000 acres of almost pure fir. It runs up to 800 cubic meters to the hectare ( 80,000 to 85,000 board feet to the acre). There is an excellent road system. The forest was formerly the property of the Prince de Châlon, afterwards Philip II, of Spain. It was added to the Federal domain in 1674, with the exception of the forest of Vignory which was sold to the king in 1782, and the forest of Gonailles which was not joined to the royal domain until 1725. The forests of Aro and Maublin were despoiled by the neighboring communes. One canton has the right "for timbers in case of fire or in other cases resulting in the destruction of inhabited places." The same communes have the right to remove stumps and débris, and some grazing. The grazing right, however, is not exercised. The total area of this Federal forest is 6,713 acres, of which 6,702 acres are productive. There are eight working circles with an average area of 838 acres. and 193 compartments with an average area of

${ }^{6}$ La Forêt Domaniale de Levier, par G. Mongenot, 1912, pp. 1-23, Lucienn Laveur, Editeur.

Since this forest was a notable American center during the war, considerable detail is given.

The forest of $\mathrm{La}$ Joux is the richest in the Jura, the yield amounting to 15.8 cubic meters per hectare (about 1,900 feet board measure per acre) per year. The grass revenue has averaged for a period as high as $\$ 15.12$ per acre per year. The net revenue is approximately $\$ 14.81$ per acre per year. 
35 acres. The soil is generally deep, fresh, and rich in humus, and the rainfall is 4.5 to 6.5 feet per year. The fir comprises 90 per cent of the stand and the spruce 10 per cent. The beech is, unfortunately, rare. Fir 160 years old yields timber 115 to 131 feet in length and when 210 to 260 years old it is 3 to 4 feet in diameter. Seed years occur every two years and reproduction is easy if there are no briars. In the past there has been but little insect damage, but recent windfalls which were not immediately barked occasioned some insect damage. The fungus, Aecidium elatium, when it affects trees, is removed in thinning. Under present conditions game is quite rare and the hunting is annually let for \$79.13. Before regular logging the timber is generally lopped and lightly squared with the axe and the smaller pieces barked. It is hauled in full lengths. There are 42 miles of local forest roads, 6.5 to 16.4 feet in width, which are maintained at an annual expense of about $\$ 3,474$. There are also 29 miles of rather poorly laid out old roads, and the entire forest is bounded by a rough stone wall, 39 inches in height, to prevent grazing and trespass. There are two small nurseries (one near the Ronde Ranger Station). Formerly the yield was fixed at one and a half trees of 1.33 meters (4.26 feet) diameter per hectare ( $3 \frac{3}{4}$ trees per acre) per annum. These moderate cuttings, below the real capacity of the forest, accumulated a considerable reserve. In 1818-1820 Lorentz inspected this forest and advised the cutting of all the old trees over the young growth. In 1844 the yield was 7 cubic meters per hectare $(2.8$ cubic meters per acre). In 1861 the yield was by volume coupled with improvement selection cuttings every four or five years without limitation of volume. This proved a happy innovation because it diminished the excess growing stock and saved a great many trees that were declining in vigor. From 1881 to 1894 the average yield was 10.27 cubic meters per hectare (4.1 per acre) per year, worth $\$ 32.47$ or 33.17 per cubic meter (about $\$ 10$ per acre). Of this yield, it should be mentioned, however, that 10 per cent was branch and stump wood. The compartments were made approximately equal. This was an error, since it would have been better to have them differ somewhat in size and follow natural features for boundaries. In 1894 the working plan was revised and all trees 9.5 to 60 inches in diameter were calipered, giving 231 trees per hectare (94 trees or 49,000 feet board measure per acre). The yield per cent was established at 2.35 per cent, plus a fraction of the excess volume, bringing the total cut up to 2.74 per cent. During the years 1905 to 1911 the yield was 11.93 cubic meters per hectare (4.8 per acre) per year, or a revenue of $\$ 16.12$ per acre. This amounted to 2.66 per cent of the total volume. In 1911 it is interesting to note that the windfalls amounted to 11,134 cubic meters and were sold at $\$ 42,196$. During 1916-1919 about eighteen annual yields were cut to supply the armies. 
This is the history of a forest where the results of sound management have proved increasingly beneficial. It is cited in connection with the study of forest statistics to illustrate the history of a well managed forest and to drive home the increasing benefits derived. 


\section{CHAPTER V 1}

\section{NATURAL REGENERATION}

French Policy (p. 65). General, Nancy School Policy, Assist Nature, Study Soil Conditions, Soil Preparation.

French Silvicultural Methods (p. 70). Systems of Cutting, The Market.

High Forest Systems (p. 71). Clear Cutting Oak, Clear Cutting Maritime Pine, Clear Cutting Aleppo Pine, Spruce Strip Fellings, Shelterwood Cuttings in Oak, Seed Felling, Secondary Felling, Final Felling, Shelterwood for Beech, Shelterwood for OakBeech, Shelterwood for Maritime Pine, Shelterwood for Scotch Pine, Shelterwood for Fir, Shelterwood for Spruce, Shelterwood for Fir and Spruce in Mixture, The Selection System in Broadleaf Stands (Beech), Fir Selection Fellings, Spruce Selection Fellings, Selection Fellings for Scotch and Aleppo Pine, Group Selection for Fir or Spruce, Group Selection for Larch (and other methods), Treatment for Scenic Forests.

Coppice Systems (p. 92). General, Simple Coppice, Coppice with Field Crops, Selection Coppice (Beech), Coppice-Under-Standards, A Substitute for Coppice-UnderStandards (Futaie Claire), Conversions.

Care of the Stand AfTer Regeneration (p. 105). Intermediate Cuttings, Cleaning (and Freeing) Young Stands, Thinnings, Improvement Fellings.

\section{FRENCH POLICY}

General. - The French forester has always been a close student of soil conditions, seed crops, and methods of seed germination, because his ideal has always been to obtain the natural regeneration of forests. And to-day high labor costs will make artificial forestation almost prohibitive. It has been argued that natural regeneration is the more costly in the end, because to regenerate forests naturally took 15 to 20 years or more and that even then the results were unsatisfactory. But in France, with a mild climate, plenty of rainfall, rich soil, and species that produce seed crops in abundance, natural regeneration has succeeded and will be continued, except when normal forest conditions must be restored in the devastated war zones and where the damages of past overcutting have not yet been completely repaired.

The French forester is a student of nature. For generations he has been taught "Imiter la nature, hâter son ouvre, telle est la maxime fondamentale de la sylviculture." His simplest problem is where he can clear-cut the entire stand and yet secure his second crop without planting; his difficulties increase as the cuttings must be varied in degree and in number so as to tempt the next generation of trees to gain a footing

${ }^{1}$ Professor Hawley kindly reviewed this chapter. 
in competition with grass, weeds, and undesirable species. But he recognizes that success cannot always be obtained under these difficult conditions without assisting nature. Consequently he is ready to wound the ground covered with grass so that the seed can germinate in the mineral soil, or he may have to cut back briars or heather which is crowding out the commercial stand.

In the United States there are three schools of forest sentiment: (1) The lover of primeval forests wants to spare all trees for the sake of their beauty. He does not care whether trees mature and die and go to waste. (2) The lumberman, who buys forests for profit. After stripping off the merchantable timber he lets the soil take care of itself if he cannot sell to a land speculator. (3) The State preaches a middle course - grow timber as a crop and cut the stand when it ripens. This should be the forester's Golden Rule. Let us profit by the example of a country like France and use nature to help us in our task. Natural regeneration is the aim in France and, in the United States, with our high labor costs, forestry will be a business failure for some time to come unless 95 per cent of our forest soil can be stocked without sowing or planting.

Nancy School Policy. - Jolyet argues that:

"In France silvicuiture has always aimed at securing regeneration by the play of natural forces alone, man intervening only for exploitation, so as to give more or less space to the crowns of trees selected as seed trees, and more or less light to the soil destined to receive the seed. Our silviculture teaches us, moreover, that artificial regeneration is not only onerous, but in addition gives poorer results. And this viewpoint is fully justified. In reality, if you plant or sow by day labor, you are forced for economy's sake to reduce to a minimum the quantity of seed, or the number of plants per unit of area . . . and the owner is forced to retain for as long a period as possible all these trees which have cost so much; he will do his utmost to preserve even the most decrepit specimens . . they will have, therefore, on the whole, a reduced vitality. On the contrary, if you employ natural regeneration, the seed trees sow on the soil of the cutting area without counting the seeds; the seedlings come in excess numbers and in this mass of individuals, amongst which commences an active fight for existence, the weaker and less sturdy are eliminated by the most vigorous which remain masters of the soil. The stand will then be composed of trees selected by nature herself, on whose vitality and longevity you have the right to count."

This latter argument is perhaps contrary to the reasoning of some who claim that young trees are only weakened by undue competition and that thinnings (made so as to favor the most vigorous trees) should eliminate this struggle to decide the survival of the fittest. But it remains a fact that with proper thinnings natural regeneration produces a finer forest than any feasible plantation and better than the average sown stand.

Assist Nature. - But the forester knows from bitter experience that satisfactory regeneration cannot always be secured from nature alone; adverse soil conditions may have to be bettered, suitable seed trees may 
be lacking, frost may destroy seedlings when it is too late to await natural regeneration longer. "It is rare," says Jolyet, "without question, when the conditions are such that any production of acorns or nuts is absolutely impossible; it is, on the other hand, quite common to find this production insufficient."

To await natural regeneration under these conditions is, therefore, often poor forestry; particularly with virgin stands which have not been under intensive forest management, it is often best to aid nature. In many German forests, it is argued that natural regeneration at best is difficult and uncertain and requires more time and consequently a longer rotation; so why not plant or sow at once and be done with it? In France, as already explained, the conditions are more favorable. In the Landes natural regeneration is almost certain; in the silver fir reasonably certain; in the spruce or Scotch pine quite possible of attainment; in aleppo pine attainable; with beech usually certain, as with the oak, under favorable conditions. In mixture with beech the regeneration of the oak is often more difficult because it cannot compete with the more shadeenduring species.

Study Soil Conditions. - It is, therefore, vital to thoroughly understand the properties, constitution, and influences of the forest soil upon the final results attained. Like agricultural soil the forest soil ${ }^{2}$ is mineral and organic. But the forest soil is more complex and more difficult to keep in proper condition; moreover, conditions are constantly changing so that what are normal soil conditions at the beginning of the regeneration period should gradually change as the canopy is opened up. Forest soil has (1) a dead litter of leaves, twigs, bark; (2) a humus or decayed litter; (3) a vegetable soil or mixture of humus with the mineral soil; (4) a mineral soil coming from the decomposed rock, and (5) the base rock itself. It takes years to get a normal forest soil (that may be ruined by over-exposure or fire), while the agricultural soil can be acquired artificially by introducing the necessary elements that may be lacking. Of these ingredients, in forest soils, humus is the most important. True forest humus is beneficial; on the contrary, acid humus is harmful and prevents or hinders regeneration. Acid humus, infrequent in French forests, may be due to a number of causes - insufficient heat, too much moisture, drought, or sterility. In everyday practice the forester is troubled more by the physical texture of the soil and with the litter and vegetable cover than by the chemical composition or the presence or absence of chemical ingredients. A soil baked by the sun or packed by grazing usually prevents regeneration, as does a cover of dry leaves, grass, sod, or weed growth. For example, a growth of heather under

2 Traite Pratique de Sylviculture, Antoine Jolyet, Baillière et Fils, Paris, pp. 298-358. 
Scotch pine absolutely prevents reproduction. Jolyet holds that "the depth of a soil from the rock base will be always greater in the forest than on bare ground. This is due to the greater rapidity of decomposition, owing to the effect of water infiltration which is charged with carbonic acid by percolating the litter." Forest soil is deepened not only by decomposition from the underlying rock, but also by the accumulation of humus from above.

Every forester should study the depth ${ }^{3}$ and character of soils. A deeprooting tree on a shallow soil cannot develop its root system properly and normally, but on a shallow soil with an outcropping rock such trees as aleppo, mountain, or Austrian pine possess root systems that penetrate the rock fissures and make the most of a sterile soil. A soil covered with tree growth is always more porous than the same soil denuded. It is not enough for a soil to receive the water necessary for tree growth; water must be stored or retained in such form izat it is available for use when required by the tree during the vegetative period. On a bare though porous soil the run-off is excessive.

Soil Preparation. - Soil preparation is often necessary in any kind of cutting, yet in France the sentiment is everywhere in favor of natural regeneration, preferably without the additional expense of artificial soil preparation. But the more the system departs from nature's method, the more the soil must be worked. With the shelterwood system there must be more soil preparation than with the selection method. The success of natural regeneration depends on the proper number and location of trees bearing seed, the right amount of light or shade for the development and existence of the young seedling, as well as upon proper texture of the ground free from weed cover. But it is only under the most favorable conditions that some kind of soil preparation is not necessary for the successful regeneration of a species like spruce. In theory, the forest could wait until natural regeneration came in without assistance. In practice, the regeneration would often be incomplete; it would come in slowly and seed trees valuable for timber of the highest quality would decrease in value and become firewood. Even with very full seed crops some kind of assistance may have to be given natural regeneration usually for three reasons: (1) Because of a dense vegetable cover which prevents the seed coming in contact with the mineral soil; (2) because of an excessive cover of undecomposed dead needles, or (3) because the surface of the soil itself is too compact.

The vegetable cover is often too thick because, unfortunately, as trees mature their cover is less dense - especially with species like oak or

3 Very shallow soil, less than 6 inches deep; shallow soil, less than 12 inches deep; slightly deep soil, less than 24 inches deep; deep soil, less than 3.28 feet deep; very deep soil, over 3.28 feet deep, - according to French classification. 
Scotch pine - consequently weeds and shrubs take possession of the soil. Under such conditions it is an obligatory rather than an optional expense to remove this cover. It is not always necessary to regularly cultivate the soil. On the contrary, it is usually better to keep the surface of the soil where the seed can reach it. It suffices, then, to tear up the vegetable cover. This work should be localized on those areas where there are seed trees and where there is suitable light for seedlings. The operation should be carried out only during the seed year, otherwise the vegetable cover will reinstate itself before any benefits have been received.

In oak forests, where the regeneration is prevented by grass or herbaceous growth (Jolyet, p. 362), the soil preparation must usually be carried out over the whole surface of the ground. The rake is the best implement for this purpose. The seed crop cannot usually be determined accurately before the month of August, so that the work should not begin before this date, although it may be continued during and after the crop has fallen. In certain forests, it was the practice to drive hogs over the area to be seeded; this gave very fair results. The hogs ate up a large amount of seed no doubt, but in wounding the soil they gave a thorough soil preparation which cost nothing. In mature Scotch pine forests it is usual to find a cover of heather or shrubs which practically prevents regeneration. With a mattock or hoe it is usually possible to weed the area and encourage regeneration. The work is costly, no doubt, but it can be diminished by localizing the soil preparation on parallel strips or in spots. The cultivated strips should have a width of 5 feet and should be separated by uncultivated areas of about 10 feet. This would cover about one-third of the entire ground. Spots are even more economical; they may be 5 feet square and 10 feet apart. This covers about one-ninth of the total area. In spruce stands similar methods may be of value. The choice of implements to use is usually governed by local conditions, although in Germany the so-called forest plow is favored. It has but one wheel and is light enough so that one horse can pull it. It wounds the soil without actually turning it over, and is not sharp enough to cut the roots which it may cross.

Where the leaf litter is too thick, as in certain pure stands where the dead leaves decompose very slowly, the roots of the seedling cannot become established in mineral soil before the summer drought. The top layer and humus dry out and this results in the death of the seedling. With a good, strong iron rake, dead needles can be mixed with the humus on spots about 29 inches square and 5 feet apart. In some forests in France a regular harrow is used for this work. Where the soil surface is too compact it must be wounded if the regeneration is to be a success. This is especially true on compact soils, such as clays, where there has been grazing before the seed felling. 


\section{FRENCH SILVICULTURAL METHODS}

Systems of Cutting. - French silviculture is especially simple. Where the German silviculturist may describe twenty or thirty different methods of cutting, French authors generally confine themselves to a comparatively few. Special methods of cutting, or variations from regulated systems, they leave to the individual silviculturist who uses his judgment in varying standard methods so as to meet local conditions. These variations, as well as special emphasis on the object of cutting and method of attaining the end, are usually cited in the local working plan. The systems used in France are: (1) Clear cutting, (2) shelterwood (progressive cutting), (3) selection fellings, (4) group fellings, (5) coppice, (6) coppiceunder-standards, (7) conversions. A routine description of these standard methods does not seem necessary, but instead the French method of application of silviculture to the more important species has been studied and cited. The illustrations are from original French working plans.

The Market. - According to Huffel, forests have always played an important rôle in the national life. First, for hunting and food; then, until the Nineteenth Century, the forest furnished fuel, timber for houses and ships, tools and utensils, honey and wax, dead leaves for manure, nuts, various fruits, and resin. Grazing was important, and as late as 1560 the forest of Haguenau in Alsace was described by the number of hogs it would support. Additional products were strawberries, raspberries, mushrooms, moss, plants, twigs, cones, heather, and ferns, much of which were collected by the poor, since the French have always considered that "the forest is the cloak of the poor." In the present century, although the tendency is decidedly toward the production of saw timber, three-fourths of the output is still firewood. In 1815 Paris consumed 0.50 cords per inhabitant; in $1865,0.13$, and in 1900 , but 0.05 cords per inhabitant. Not only has the use of charcoal for cooking fallen off, but factories use coal to the almost total exclusion of wood or charcoal. The early writers, prior to the discovery of coal, often predicted a wood famine, and had not coal been discovered their predictions would have come true, because to supply the equivalent of the present coal consumption of France more than ten times the total forest area would be necessary. Fortunately for the timber resources the use of wood is becoming less and less. Iron was first used for shipbuilding in 1843; iron and cement have largely replaced wood for houses. The great demand to-day is for a good quality of boards, mine props, ties, paving blocks, wood pulp, tan bark, and cork, as well as for such products as turpentine, rosin, alcohol, etc. This rough summary of the decreasing use of wood products and the change in kind of material required is merely given as an illustration to show how necessary it is for the forester to study the future needs of the country. 
He must be far-sighted, since he cannot count on present demands. Generally speaking the world's industry demands more and more high forests for timber and fewer coppice forests for fuel and minor products.

\section{HIGH FOREST SYSTEMS 4}

Clear Cutting Oak. - In the valley of the Adour [70] above Dax the pedunculate oak grows in areas subject to inundations and where agriculture is not feasible. It is practically pure, with rapid growth and a remarkable longevity. These forests are celebrated for the enormous quantity and quality of the oak wood which they produce and especially, in former years, for the ship timber which was used when wooden battleships were built. With such a warm climate the trees are prolific seed producers. Abundant crops of seed are borne every year. On the other hand, late frosts must be guarded against. These high forests are not treated by any regular system since the fertility of the soil, coupled with its depth and freshness, enables the trees to seed and the seedling to live, notwithstanding the overstory of old trees and notwithstanding the underbrush; apparently the only danger is hog grazing, which does considerable damage, but in this wet region the growth of shrubs and vines is almost tropical in character and forms such a dense thicket that the young seedlings are in part protected against such injury. It is interesting to note that the seedlings, which in other parts of the country would be suppressed by the underbrush, shoot up through the entanglements, twisting their terminal shoots in the direction where there is most light. This results in the production of rather crooked trees. [74] These pedunculate oak forests of the Adour are regenerated to-day very successfully by a simple system. Taking for granted that there are always acorns ready to germinate and that these will survive the cover of the old trees, the old trees are clear cut in one felling. At the same time all the briars, undergrowth, oak seedlings (damaged by exploitation or suppressed by the cover) are cut level with the ground. The shoots from these very young stumps have practically the same qualities as seedlings. Almost invariably this clear cutting will be followed by the development of an incalculable number of young oaks which rapidly cover the soil with a complete stand which in time develops into an oak high forest. In the valley of the Adour the growth of the young oak is sufficiently rapid so that cleanings are rarely necessary. Thinnings, on the con-

4 Since the high forest systems are of paramount importance in the United States their application to typical species has been given in detail.

NoтE. - The bracketed numbers refer to page references in La Forêt, by Boppe, the source of much of this material. 
trary, are very important in all the young stands. With clear cutting it is naturally necessary to regulate grazing. On account of the richness of the soil the grazing is quite valuable, and the communes even insist on the clearing out of the briars and underbrush which formerly protected the young oak. Under these conditions the grazing is prohibited two years before the clear cutting in order to enable the seedlings to establish themselves to the very best advantage, and in addition the area cut over is closed for 12 years after felling operations [75], making 14 years of closure.

Clear Cutting Maritime Pine. - The maritime pine is essentially a light-demanding tree, and while it can stand the average winter in the northeast of France it cannot withstand unusual cold. It furnishes an abundance of seed every year with remarkable regularity. It was formerly treated by a sort of crude selection system. The great importance of the tree is on account of its resin production. Formerly it was tapped for resin and when a tree was dying it was cut. In these openings the young seedlings came up but developed poorly because there was insufficient light. On account of the prolific seed production after clear cutting and because cones open under the effect of the sun's heat, after the trees are felled, it is essential that the species be clear cut. Scattered seed trees after felling are unnecessary. The young seedlings develop excellently in full sunlight and are neither damaged by the heat nor by the spring frosts. According to the working plan for the State forest of Carcans the following silvicultural operations are in force:

“1. Successive regeneration by clear cutting preceded by tapping to death.

"2. Thinning by tapping to death the superfluous stems of those which are of poor quality after the trees reach 26 years of age. Tapping alive trees which have reached a diameter of 13 inches.

"3. Thinnings in young stands in order to obviate the extremely slow growth of very dense stands."

It should be noted that the maritime pine immediately bordering the ocean is never clear cut but is maintained as a protection belt against the sand dunes. Only dead and dying trees are cut from this shelter belt. As a matter of fact the trees, owing to the wind, are inferior in quality and stunted in growth.

Clear Cutting Aleppo Pine. - On account of the dry soil conditions which are prevalent in aleppo pine or stone pine forests, clear cutting is rarely advisable (see pp. 88-89). The forester in charge of the important aleppo pine forests around Marseilles uses a conservative groupselection system, making it a point never to expose the soil.

Spruce Strip Fellings. - Notwithstanding the development of various forms of strip fellings in Germany and Switzerland, they have not been practiced to any extent in France. This is only another illustration of 
the simplicity of French silviculture and the absence of variations from the few standard systems of cutting which have been in use for centuries. The keynote to French practice is that the method of natural regeneration should closely approximate nature's method. "Strip cuttings," according to Jolyet, "are nothing more than a variation of clear cutting." In theory, at least, it should succeed with spruce, provided the strips are not too wide. They should be in the shape of long rectangles and should extend up and down the slope with their axis preferably at right angles to the prevailing wind. Since this method of cutting has not been developed by French silviculture, the details will not be discussed here.

Shelterwood Cuttings in Oak. - Some of the best high forests [81] of France are composed of sessile oak (with some beech in mixture) on sandy loam soil. These soils are often quite sandy in character and yet splendid forests, such as Perseigne, Bercé, Blois, Senonches, Bellême, result. Thanks to the mild climate, the acorn crop is frequent but by no means annual, as in the valley of the Adour. In this region an acorn crop can be counted on every 6 to 8 years; besides the sandy soil is particularly favorable to natural seeding. In former days hunting to hounds was extremely popular, so that it was fortunately necessary to have high forests rather than coppice. The first regular method of cutting applied to these high forests was the so-called "tire et aire" - successive clear cutting with a reservation of eight seed trees per hectare (2.5 acres). Unfortunately the acorn crop did not always correspond with the year of regeneration felling and the soil was soon covered with weeds and heather. It is ordinarily sufficient, however, to have an acorn crop the year before felling, or at least within two or three years after.

To-day these oak (beech) forests are treated by what the French call the method of progressive ${ }^{5}$ fellings (shelterwood system), or "system of natural regeneration and thinnings." This method means felling not at one time by a clear cutting, but instead by a number of cuttings succeeding one another and removing progressively all the old trees. These cuttings are called seed fellings, secondary fellings, and final fellings which together constitute the regeneration fellings.

Seed Felling. - Seed felling, as the term implies, aims at starting regeneration. In order that the seedlings may start two things are necessary: plenty of seed and a chance for development for the seedlings after they have germinated. Three steps comprise these seed fellings: (1) The crowns of a certain number of trees designated as seed trees are isolated. This gives light for the development of the seed trees as well as for the development of the existing seedlings. The isolation of these

"Also termed "regular method" for high forests. The French have never copied the German term "shelterwood." They prefer "progressive cutting" (coupes progressives). 
crowns may vary. A so-called "dark" felling, according to Bagneris, is when the lateral branches of the crowns of the reserved trees touch when the wind is blowing. In an "open" or "light" felling the space between the crowns may be 7 to 16 or 20 feet. A "dark" felling has this advantage, in that the seed trees are more numerous, the acorns are better scattered over the entire surface of the felling area, and the seedlings are better protected against the late frosts. The trees chosen for seed trees must be sound and must have well developed crowns. (2) All trees, other than seed trees, whose foliage extends to the ground and is therefore suppressing seedlings, are removed. Beech, or hornbeam, which often forms a valuable understory in order to preserve soil conditions up to the time of the seed felling, is cut. (3) If the soil is covered with weeds they are cut level with the ground, as are also oak advance growth unsuitable for future regeneration. The soil, after a seed felling, must be cleared of all low growth. If necessary, the surface of the soil is loosened by wounding it. A successful seed felling is where there are one or two seedlings per square yard. Often there is practically a carpet of young oak.

Secondary Fellings. - The next step is to gradually remove the seed trees and to gradually free the existing seedlings without causing too much damage. These secondary fellings in oak stands are usually two or three in number. Care should be taken not to expose the existing seedlings to late frosts, not to damage too many seedlings in the lumbering operations, and to retain enough seed trees in localities where seedlings have failed. It is also essential not to remove the seed trees so rapidly that the ground may run wild to weeds. The best time to mark secondary fellings is during the summer, since the state of the vegetation can be more accurately determined. The removal depends primarily on the condition of the ground. If the seed crop is poor it may be necessary to again cut back the weeds and to wound the soil. If, on the other hand, the seedling growth is very luxuriant, cutting can be much heavier. The result of the secondary felling is to increase the growth and development of the seedling crop and to enable it to maintain possession of the ground.

Final Felling. - As soon as the young crop is complete and the first seedlings have developed into saplings, it is time for the final felling, which is really a final secondary felling and which is generally termed final felling. This felling merely removes the remainder of the seed trees at one stroke, since it is rarely advisable to hold over a few seed trees even where regeneration may be lacking in a few spots. When seed trees are held over it means that very valuable timber decreases in value, since as soon as these mature oaks are isolated, epicormic [92] branches develop, the crown deteriorates, large branches die, and there is great danger of rot or damage from insects. The regular high forest (shelterwood) aims at 
the complete natural regeneration of the proper species of uniform age. It has the advantage of preserving the soil and of producing regularly formed trees, but the disadvantage of possible damage from insects, snow, wind, and weeds unless the species are mixed.

According to De Gail ${ }^{6}$ the regular shelterwood system was adopted all over France during the last half of the last century.

"The rotation was divided into a certain number of periods, generally of equal length, frequently four or five. For each one of these periods there was a corresponding periodic block on the ground. During each of the periods the corresponding block had to be regenerated while the others were run over by improvement cuttings. The volume to be removed each year in the regeneration fellings formed the chief yield and was the quotient of the existing volume in the periodic block in question, growth included, divided by the number of years forming the period. Improvement fellings were assigned by area at regular intervals, the volume to be realized remaining unfixed."

The objection to this system was that it was good in theory but did not work out on the ground. Too many sacrifices had to be made for regularity, and damage resulted from fire, wind, and insects. Very frequently the whole scheme was disarranged by unforeseen damage, and yet the working-plan scheme depended for its success on orderly arrangement. Exactly the same yield was unnecessary each year, but great differences had a bad effect on the regulation, as, for example, after an enormous cut following an unforeseen windfall. In 1878 an endeavor was made to correct the weakness by first subtracting accidental yields from the major yield before the regular annual cut was prescribed. But even this was not entirely satisfactory, chiefly on account of windfall in such regions as the Jura and Vosges.

The forest of Paridas working plan stated that during the regeneration of this oak forest it is usually necessary to fence to prevent damage from game. The old oak is growing close together and very heavy openings are made in this stand, since the luxuriant grass crop seems to assist the oak regeneration inasmuch as it freshens the soil. After regeneration cutting there are about 80 trees per acre with the openings often 100 feet across. Occasionally the cuttings are made lighter because of the danger of briars and weeds. There is very rapid growth and the rotation is 120 years. Where thickets of blackberries have come in they are removed at the first cleaning when the reproduction is 12 to 15 years old. If cut earlier they spring up again. There has been some damage to the oak from the "sidium" disease, which must be sprayed with salt as a curative and preventive, but there is danger of the salt hurting the roots. Where the oak stands are very dense there is much less seed, as is illustrated by conditions in the Paridas forest. The oak sometimes comes in even in dense heather but frequently it is necessary to cut strips in the heather to en-

${ }^{6}$ Nouvelles Tendances et Méthodes d'Aménagement, No. 2, 1907, S. F. deF. C. et B. 
courage regeneration. The regeneration period is 30 years. Light thinnings are made every 10 years, and usually after 35 years the canopy of the crowns is complete.

Shelterwood for Beech. - Beech forests are still important in France [130] on the Parisian Plateau, on the Plateaus of Lorraine, Bourgogne, Franche-Comté, on the lower mountain slopes of these regions, and on all the mountains in the fir zone. The regeneration of beech is always by the shelterwood method (progressive fellings), but regeneration by clear felling is absolutely impossible, since the beech seedlings are very susceptible to damage from late frosts and from drying out. While it is true that the mast is not more frequent than the acorn crop, yet it is easier to secure beech seedlings, since on account of its tolerant quality the advance growth is often existing at the time of the seed felling, even if the cover is considerable, whereas the oak seedling must be freed from overhead cover. This step is not so necessary with the beech since it is so tolerant. There is less danger of the beech seedlings being damaged by weeds or briars than of the oak. The seed felling with the beech is always light, since the seedlings cannot stand a rapid opening up. When there is a thick carpet of undecomposed dead leaves on the ground wounding the soil is quite necessary in order to expose the humus. This is sometimes secured by driving hogs through the area just before the seed felling, in order to let them, without expense, dig up the weeds and wound the soil. Frequently it is sufficient to let in enough light to eat up the leaf cover. The secondary fellings are also "dark," and often it is necessary to hold over trees which should be felled, on account of the danger of making too large openings. This means that instead of two or three secondary fellings, as with the oak, it may be necessary with the beech to make three or four secondary fellings. This has no drawbacks since the young beech seedlings can stand the shade of the seed trees. The final felling is made as soon as the seedlings have grown to the sapling stage and it should not be held over too long because of the damage which results to the saplings. The final felling always removes all the remaining trees.

Shelterwood for Oak=Beech. - A feature of oak and beech naturally regenerated is the maintenance of the soil in good condition and a suitable mixture of beech in the understory. The tolerant beech always has a tendency to take possession of the soil and therefore it is often necessary to favor the oak. This can be done by reserving more oak seed trees in the seed felling and by cutting the beech in the understory, by hastening the secondary felling and making it rather open wherever oak seedlings have established themselves. Otherwise, they may be crowded by the tolerant beech. The seedling of the oak may be favored by wounding the soil. When the seedlings are freed, and in the thinning, the oak also may be favored. According to Inspecteur Badré it is very difficult to 
maintain beech and oak in mixture, side by side, for the beech always dominates the oak unless it is progressively freed from the surrounding beech. The most practical solution is to grow the oak in small groups, which can often survive the struggle with similar groups of beech without assistance. The forest of Parc et St. Quentin has had working plans made in 1869,1884 , and 1905 . As a result of experience a rotation for 120 years was found too short because of the large proportion of oak. It was, therefore, increased to 150 years. Where there is difficulty in regeneration, according to the following most recent working plan, the cuttings would be regulated according to seed crops rather than to the sequence of fellings as developed:

"The density of the seed fellings will be regulated so as to allow for the requirements of the species - oak and beech - which should be forced into the proper mixture (about half and half). The existing understory must be completely removed above this size, and under no pretext whatever should it be allowed to form part of the future stand. The seed fellings will be followed by secondary and final fellings laid out exclusively according to the cultural needs. The improvement cuttings should aim at the establishment of a high forest with a suitable mixture of species and as fully stocked as possible; they will be carried out by the use of regular normal thinnings, the removals limited to trees already dead or almost wholly so. . . . In the young stands the valuable species will be carefully freed and, in accordance with their needs, the softwoods and species of secondary value will be sacrificed."

The working plan of the forest of Malmifait is as follows:

"The regeneration fellings which remain to be carried out during the second period, consist solely of secondary and final fellings. The secondary fellings will be made carefully according to the amount and vigor of the existing reproduction. Where considered advantageous, the natural seeding will be assisted by soil preparation during seed years, coupled with the dibbling of acorns and beech nuts if necessary; this will be supplemented, if need be, by plantations which will be set out in systematic lines in order to make future clearings easier and cheaper. Seedlings and plants must always be protected at the start against the briars and the grass, as well as sprouts of species of secondary value. The final felling will take place as soon as regeneration is secured, and without too much delay, in order to lessen the damage, always considerable, caused by the exploitation and removal of the trees. When the cutting area is completely cleared, all the damaged stems must be cut back. It will be carefully seen to that the game, especially the wild boar and hares, do not increase to an excessive degree. Thanks to this precaution it will be unnecessary to build wire fences, which are very expensive and which usually give only mediocre results, around the compartments recently seeded; especially since the patrol force of the Malmifait forest is composed of a single employee who, without question, would find it difficult to maintain the fences in good order and to watch continually the rabbit holes. But in the areas where the mammals are most dangerous, it may be unsafe to start reforestation by means of plants, whose stems should be protected by wire netting fastened to stakes."

An interesting example of field practice in marking ${ }^{7}$ shelterwood fellings was studied in the oak-beech forest of Parc et St. Quentin. Before

${ }^{7}$ In France the marking hammers are kept locked up by the forest assistant or inspector, and when trees are marked they are stamped both on the roots and at breast- 
beginning the inspector explained to the rangers the fine points of the marking. In the area marked he illustrated the need of favoring beech, especially trees with well-developed crowns, on account of the necessity for plenty of seed. The trees cut were calipered and every record checked by being repeated by the tallyman. All poor trees were cut, notwithstanding the need of beech in mixture on account of its being insufficient. The marking passed the long way with the cutting area, and in some places it was noticed that regeneration was protected against rabbits by wire netting. The marking was very carefully executed, and the first time the rangers went over the felling area they merely blazed the trees to be cut. As a protection they went over this same area a second time to see whether mistakes had been made. At this second trip they stamped and blazed the roots of the trees left, and in addition, because of their great value, tallied the number of large trees left standing. It was explained that seed fellings were held up in 1911 and 1912 because of poor seed years. The local inspector favored seed fellings by area as well as improvement cuttings by area, since it would obviate extensive calculations of yield.

Shelterwood for Maritime Pine. - The shelterwood system should never be applied to maritime pine. Clear cutting is, and must be, the invariable rule except in protection belts along the dunes.

Shelterwood for Scotch Pine. - The shelterwood system is sometimes applied to Scotch pine. Here the seed felling is made very open, the secondary fellings are delayed and are rarely more than one or two in number and the final felling comes early. It really takes on the aspect of clear cutting with the reservation of seed trees [160]. The forest of Ermenonville presents an interesting study in the treatment of Scotch pine in the Paris region. ${ }^{8}$ The soil in the fourth, fifth, and sixth working circles of this forest is quite sterile over some 3,672 acres and therefore unsuitable for broadleaves. The rotation is 80 years of eight periods and the regeneration is nominally by the shelterwood system, although the results thus far, without sufficient artificial assistance, are very imperfect. The forty to sixty seed trees per acre are chosen with care and distributed

height. The trees marked for any cutting are usually tallied by five-centimeter classes ( 2 inches). If any marked tree is blazed twice on the bole it means that it must be limbed and the top cut off before it is felled to prevent damage to existing reproduction. The forest guards check the cutting after it is finished and go to every stump to see if the tree was marked. If all right the stump is stamped on the top. The guards and rangers are always on the lookout for windfall and dead wood. When found the tree is numbered consecutively and the following data secured: serial number, circumference, and general location. It is a guard's special duty to look out for windfalls in spring so that they may be disposed of while they are still salable.

8 Traitement du pin sylvestre dans la région de Paris, par L. Parde, Nos. 19 and 20, March 1 and 15, 1905. Revue des Eaux et Forêts. 
as uniformly as possible over the area. The soil is cleared of brush, cones, and needles, either in strips or in spots, and there is artificial sowing where young seed trees are available. According to Parde:

"If necessary the regeneration will be completed by plantations at the time of the first improvement felling when the seed trees will be cut. For my part, I confess that I am now rather disposed to admit that, so far as the Scotch pine high forests around Paris are concerned, the regeneration by artificial means would be preferable to the shelterwood method actually followed."

Various steps have been taken to assist regeneration, such as raking strips and spots during the seed years; in addition the young seedlings are sheltered by means of branches, which is apparently very favorable to their development. If the natural seeding fails the plantations must be made promptly before waiting for the first improvement cutting. Assisting regeneration in this locality has cost as much as $\$ 8.70$ per acre, while restocking blanks costs about $\$ 12.19$ (1905 labor prices). Notwithstanding the expense of $\$ 8.70$ for soil preparation, the regeneration is in poor shape, due to local droughts. Even with a large number of seed trees retained, the cost in windfalls has been heavy.

In the forest of Fontainebleau.there are some 822 acres of Scotch pine. The regular rotation is 72 years and the same methods have been applied as in the forest of Ermenonville. Probably one-tenth of the surface has been naturally seeded, chiefly from advance growth rather than from the results of seed fellings. In the forest of Rambouillet, on 4,942 acres of Scotch pine, but 680 acres have been regenerated successfully. According to Parde:

"In practice the preparation of the soil has consisted in a light harrowing which removes the very thick mat which covers the soil; this mat is piled up at the foot of the reserved trees. The harrowing is followed with broadcast seeding, 6.2 pounds per acre, when, in order to work the seed into the soil, it is again harrowed lightly and covered with branches."

Even after soil preparation regeneration has not been successful, and it will be necessary to sow or plant artificially. Probably it will be necessary to abandon the seed trees and to cut clean and sow broadcast by the method described above. The conclusion reached, as a result of the attempt of natural regeneration of Scotch pine around Paris, is that the present shelterwood system will probably be abandoned, at least until further experiments determine upon a successful method. Apparently it is unnecessary to leave seed trees scattered over the area under regeneration, since these trees are damaged by windfall and their extraction damages seedlings, increases the area under fellings, and makes the protection against game more difficult. Experiments are recommended with the two following systems: 
1. Cut clear strips at right angles to the wind and remove the stumps. Clear the ground cover and harrow. Sow artificially with protection of branches. If seeding does not take place within a few years plant at once before the ground cover comes back. Never wait more than five years.

2. Proceed as in the case of the system described above, but with the reservation of seed trees.

Of the two methods, the one without seed trees is probably preferable. The product would sell better; there would be no windfall; insect damage would be lessened; with the surface completely cleared, temporary nurseries would be more conveniently established where planting was necessary; fencing would be less costly; there would be no damage to young stock in the final fellings.

Shelterwood for Fir. - In order to secure fir regeneration it is necessary to have a deep fresh soil and a humid climate; the chemical composition is less important. In order that fir seedlings may develop properly it is necessary to preserve the shelter of the cover stand as a protection against drying out and against spring frosts. It is also necessary to have a thick humus cover and a protection against summer drought and weeds. The seedlings establish themselves under the immediate shelter of the seed trees. In every case the young seedlings develop naturally during the first five to ten years under the cover of the mother stand. Therefore, any system of clear felling is out of the question, but the shelterwood method may be successfully used. In fir stands advance growth almost always exists, therefore the seed felling is really a light secondary felling, since its object is to allow this advance growth to develop. This first secondary felling or seed felling is made very conservative so as to remove the cover gradually and not to expose the seedlings to drying out or to permit weeds to take possession of the soil. Even if suppressed for a number of years, fir seedlings have the ability to develop into good trees after the cover has been removed. The other secondary fellings which follow should also be "dark," since a gradual removal of the cover is essential. On the other hand, the final felling should always be complete on account of the danger from windfall and because of the damage which results to the old isolated trees from drying out. De Gail has shown (see p. 75) that because of windfall and the consequent irregularity of the stand (and derangement of working plans) the shelterwood system for fir is fast proving unsuccessful. An excellent illustration of the derangement of working plan yields by windfall is in the forest of Gérardmer (Vosges). On September 1, 1908, the inspector reported that, in the first, third, fourth, sixth, seventh, and eighth working circles, which had a prescribed annual yield of 11,971 cubic meters, on account of tremendous windfalls 46,378 cubic meters, or the yield for almost four years, had already been cut. As a result of the 
windfalls of 1902 the conservator favored a return to an irregular selection instead of the shelterwood system. The selection preferred is one regulated by volume and by area. In the fir forest of Noirémont (Jura) the seed felling removes practically two-fifths of the volume, the two secondary fellings one-fifth each, and the final fellings one-fifth. After the final felling in this forest there were openings 33 feet across where the parent trees had been cut. Here the openings were being planted up. The improvement fellings in this forest, regulated by area, remove the badly suppressed trees, badly formed trees, those dry topped, and the socalled "wolf" trees. But even under the favorable conditions existing the shelterwood system may be abandoned. In the forest of Risol they have a rule of cutting not more than 100 cubic meters per hectare at one time. According to the ranger's records:

"Cultural operations should always be directed with the aim of developing as much as possible the growth of existing stands without sacrificing anything for regularization. The ripe trees should always be removed when encountered in the fellings, but on condition that their retention is not considered necessary for reproduction."

In the sapling stands the dominant beech is almost invariably cut. In the pole stands the suppressed and damaged trees are removed, and in the high pole stands quite heavy thinnings in the top story are begun. All beech not needed for reproduction is removed.

Shelterwood for Spruce. - While the spruce is not essentially a tolerant species like the fir, yet it is not exactly a light-demanding species like the oak; it does not grow while under direct cover, and while it will come in naturally on pastures, some side cover is desirable on account of its demanding fresh soil. It is deeper rooted than the fir and more difficult to secure. The seed of the fir is quite heavy, is of average size, and cannot be carried great distances. On the other hand, most of the cones are at the top of the tree; they open, not because of the heat, but because of the moisture at the end of the September rains. The spruce cones, to the contrary, are lower down on the tree and most of them are found at the ends of the branches; they open under the influence of heat, especially when the dry east wind is blowing, so that the seed may be carried some distance from the tree. Moreover, the spruce seed does not germinate well under the immediate cover of the mother tree nor do the seedlings germinate successfully on dry needles, therefore the best conditions for the germination of spruce seedlings are openings in the mature stands, exposed to the full sunlight, and where the mineral soil is at least partially bared. In theory, at least, the shelterwood method of progressive fellings is applicable to this species, but unfortunately there are difficulties. The tree is subject to windfall on account of its superficial root system and the heavy foliage. It is therefore necessary to make the 
seed fellings conservatively but, after the seedlings are once established, to cut the mature stand very rapidly [193]. As with the fir, the shelterwood system has not been wholly successful.

Shelterwood for Fir and Spruce in Mixture. - Fir and spruce are very often found in mixture. From the economic viewpoint they have about the same value. It is silviculturally advisable to have them in mixture since, when mixed, insect and fungous damage is not so dangerous and the soil is better conserved: When in mixture advance growth of fir is quite common under the old stand. It is therefore necessary to fell old trees here and there in order to enable the spruce to profit by the light and establish itself in the center of the openings. While the advance growth of the fir has the advantage of age the spruce seedlings develop more rapidly and make an excellent mixture. The more you want to favor the spruce the larger the openings should be made. It is also advisable to favor it by wounding the soil. The mixture can be regulated in the cleanings and thinnings that follow [202].

The Selection System in Broadleaf Stands (Beech). - In practice the [137] treatment by selection fellings is not systematically applied in France to broadleaves. The beech is an exception. Because of the irregularity of beech regeneration, even if treated by the method of progressive fellings, it may often assume the character of a selection forest. The beech may be treated under the selection system except in those forests where it is mixed with fir. In theory, at least, the selection system is very simple. In the working plan the exploitable or maximum size of trees is given and the amount, either in number of trees or in cubic meters, that should be cut each year. The entire forest is cut over, and trees above the stated diameter limit are removed to the amount of the estimated yield. In practice the forest is often divided into a number of compartments and, for the sake of economy in lumbering, the selection fellings are concentrated on a portion of the forest. Selection fellings avoid the crisis of regeneration which other more regular methods precipitate at the time of the seed fellings. Moreover, the classic selection felling is only suitable to shade-enduring species. Selection fellings mean irregularity as opposed to the regularity of clear cutting, shelterwood (progressive fellings), etc., [213]. Practically speaking the classic selection fellings of a few trees from the entire area under treatment is never applied in France except possibly in the sub-alpine forests where, in order to assist the forest in its struggle for existence against unfavorable climate and soil conditions, a light selection (or improvement) felling is usually employed. Clear cutting, even by strips or by the shelterwood method, is extremely dangerous in the mountains, but in the subalpine forests, where the larch is one of the most important species, the simple selection felling becomes a group selection, since the larch (see 
p. 89) is a light-demanding species and considerable openings in the stand must be made. With cembric pine, or mountain pine, the openings can be much smaller and the removal of a single tree is sufficient. Without question the tendency in France, as in other European countries, is away from the original tree selection. Instead, especially with somewhat intolerant trees, the practice is now to cut in groups so that, preferably, there are clumps of even-aged trees all over the forest which can be thinned.

Fir Selection Fellings. - In theory, at least, the fir should be treated under selection fellings except for the difficulty of lumbering all over a forest and the danger on the other hand of compressing fellings into too small an area and thereby making too great openings. Consequently, in fir forests, selection fellings run over the same area on an average of every eight years, removing about $12 \frac{1}{2}$ per cent of the stand. For this reason, even in fir stands, the selection assumes the character of a group or hole selection system. At high altitudes, in theory, the per cent removed at one time should be small, but in practice as high as 18 or 20 per cent may be cut in order to make logging feasible. For example, in the communal forest of Cette-Eygun (p. 17 of the working plan) the method of exploitation is as follows:

\footnotetext{
"These two working groups will be treated by the selection method; the high altitude, the severe elimate, the danger of avalanches, the slowness of reproduction at the higher elevations, the control of water flow, the obligation in a country habitually and essentially pastoral to keep stands open for grazing so far as possible, necessitates maintaining a dense forest on all areas and slopes, and ratifies the choice of this selection method for all regulated mountainous forests."
}

About 18 per cent of the stand is cut at one time.

Mathey argues (Société de Franche-Comté et Belfort) that to obtain the regeneration of spruce in the Alpine forests, the following are necessary:

1. Maintain shelter belts and groups of trees as a precaution.

2. Encourage the mixture of broadleaf trees and conifers so that the former comprise at least 12 per cent of the upper story and 13 per cent of the lower story, or 25 per cent in all.

3. Remove the sod in spots where it is desired to favor the development of seedlings.

4. Cut conservatively. In the lower working group cut every 6 or 8 years over the same area. In the average working group (4,000 to 5,000 feet altitude) cut every 10 to 12 years, and in the upper working group (5,000 to 6,000 feet altitude) cut only every 14 to 16 years. Areas above 6,000 feet should be considered zones of protection solely. It is absolutely essential to be conservative in the treatment of these forests.

For the best management of a selection forest it is necessary for the 
forester to have in mind the normal or average local number of trees per acre for the different diameter classes; then by a comparison of the normal with the actual stand it can be determined whether the forest has too many or too few trees of the different size classes. Such data would be a guide to determine from what diameter classes in a selection forest trees should preferably be cut. The following table, compiled by Huffel, shows average figures per acre for fir in different regions.

TABLE 7-AIERAGE FIGURES PER ACRE FOR FIR

\begin{tabular}{|c|c|c|c|c|c|c|}
\hline \multirow{3}{*}{$\begin{array}{l}\text { Diamoter, } \\
\text { breast-high, } \\
\text { inches }\end{array}$} & \multicolumn{6}{|c|}{ Number of fir trees per acre } \\
\hline & \multirow{2}{*}{$\begin{array}{l}\text { Alpes } \\
\text { (average } \\
\text { for } \\
\text { Sevoie) }\end{array}$} & \multirow{2}{*}{$\begin{array}{l}\text { Vocges } \\
\text { Lorraine } \\
\text { slope }\end{array}$} & \multicolumn{3}{|c|}{ French Jura Mountains } & \multirow{2}{*}{$\begin{array}{c}\text { Pre-Alpes } \\
\text { of Dauphine } \\
\text { toward } \\
3,200 \text { to } 3,460 \text { fees }\end{array}$} \\
\hline & & & Low & Average & High & \\
\hline $\begin{array}{r}6^{\star} \\
8 \\
10 \\
12 \\
14 \\
16 \\
18 \\
20 \\
22 \\
24 \\
26 \\
28 \\
30 \\
32 \\
34 \\
\text { Total. ... }\end{array}$ & 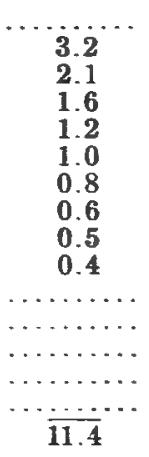 & $\begin{array}{c}12.0 \\
8.4 \\
6.0 \\
4.3 \\
3.1 \\
2.2 \\
1.6 \\
1.1 \\
0.8 \\
0.6 \\
0.4 \\
\ldots \ldots . \\
\ldots \ldots \\
\ldots \ldots \\
\ldots \ldots . . \\
\ldots \ldots\end{array}$ & $\begin{array}{r}\cdots \cdots \\
32.0 \\
26.8 \\
21.2 \\
17.8 \\
12.9 \\
9.2 \\
6.1 \\
3.4 \\
2.4 \\
1.4 \\
0.9 \\
0.5 \\
0.4 \\
135.0\end{array}$ & $\begin{array}{r}\ldots \ldots \\
\cdots .4 \\
5.6 \\
4.2 \\
3.5 \\
2.6 \\
1.8 \\
1.2 \\
0.7 \\
0.5 \\
0.4 \\
\ldots \ldots \\
\cdots \cdots \\
\cdots \ldots \\
26.9\end{array}$ & $\begin{array}{r}\ldots \ldots \\
2.3 \\
1.9 \\
1.5 \\
1.2 \\
0.9 \\
0.6 \\
0.5 \\
0.4 \\
\ldots \ldots \\
\cdots \cdots \\
\cdots \ldots \\
\cdots \cdots \\
\cdots \ldots \\
9.3\end{array}$ & 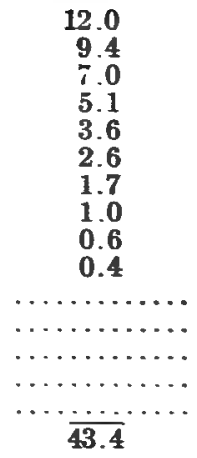 \\
\hline
\end{tabular}

- Smaller trees are not calipered.

Schaeffer ${ }^{9}$ gives the following formula for the management of a selection forest:

"1. Establish a curve of a normal high forest, as has been indicated (see p. 214) according to the existing stand.

"2. Calculate the yield by any method (if you wish, even by the number of trees), provided it is simple, taking care to adopt a figure less than the maximum yield which has been determined.

"3. First cut the over-stocked age classes.

"4. Arrange for periodic stocktaking in order to revise the yield and to make sure that it approaches the type of forest desined."

Spruce Selection Fellings. - Contrary to fir forests it is rare that advance growth is found under the parent spruce stand. Therefore, selection by groups or holes is always necessary, since it assures the regenera-

- Un Type de Futaie Jardinée, S. F. de F. C. et B., A. S. 

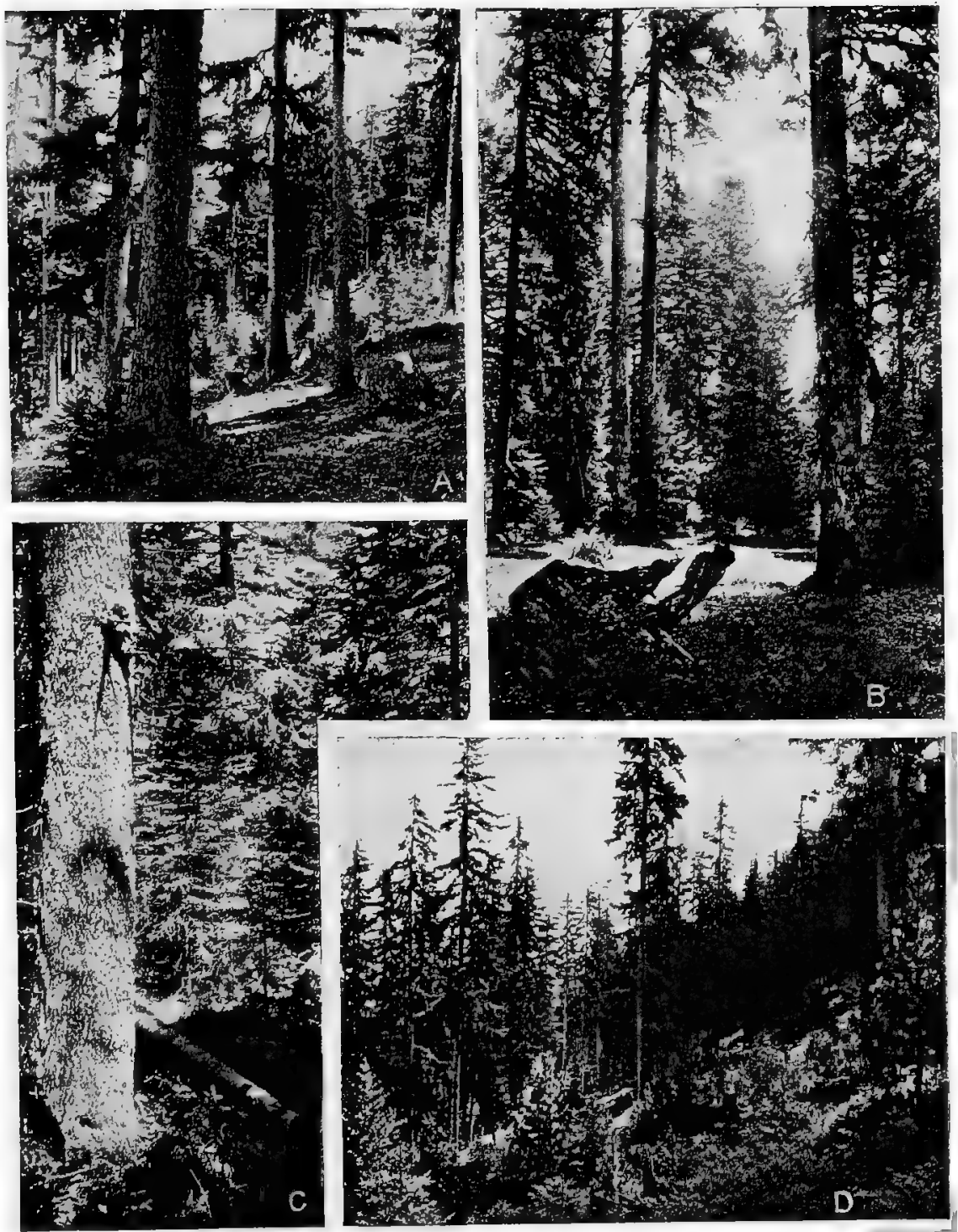

Frg. $7(a)$. - Natural regeneration of spruce in the openings where it has sufficient light. Under partial cover the seedlings have not as yet come in.

(b). - Spruce stand in the Melezet Canton, communal forest of Villarodin-Bourget, running 146 trees per acre and 109 cubic meters (36,000 feet board measure). Here selection fellings removed trees declining in vigor until openings have gradually been made. Since the soil became partially sodded and covered with spruce needles no regeneration has succeeded. Had the openings been made at once, instead of gradually, the reproduction would have been secured.

$(c)-(d)$. - Natural regeneration of spruce in the Melezet Canton, communal forest of Villarodin-Bourget, at an altitude of 6,060 feet. No regeneration of spruce came in after ordinary selection cuttings, which removed only a tree here and there. After a windfall gave sufficient light (and wounded the soil) reproduction has succeeded in the following proportions: Spruce, six-tenths; larch, three-tenths; cembric pine, one-tenth. 
tion a sufficient amount of light and at the same time it does not open up the forest enough to allow weeds to come in (see Fig. 7, $A$ to $D$ ). The openings made are not quite so large as in the Scotch pine, because the spruce does not demand the same amount of light. Frequently in spruce stands the felling of one large tree makes an opening large enough to favor the introduction of spruce seedlings, although usually two, three, four, and even five trees may be cut [199].

A study of the spruce stand in the Savoie, by Thiollier (see Fig. 7), showed that, on the whole, regeneration is difficult. In a wet, mild climate, at lower altitudes, the spruce behaves much like the silver fir, but at higher altitudes the spruce must be differently handled. To secure spruce regeneration:

(a) The seed must come in contact with fresh mineral soil, or soil covered with humus of another species. If, for example, the ground is covered with grass, or spruce litter, this must be worked and the soil bared.

(b) Isolated spruce saplings suffer from the snow, so every effort should be made to secure clumps or groups for regeneration.

(c) To secure thrifty, well-developed crowns, early and frequent thinnings are indispensable; but if too heavy the height growth is decreased, the cover is broken, and the trees become branchy; if too light, or if begun too late, the growth is slow and the trees are never really merchantable for timber.

(d) Since the spruce requires full sunlight for best development it is best grown in even-aged clumps or stands. But since it is so liable to windfall some form of selection fellings is desirable and necessary at these altitudes. This shows the vital necessity of not practicing a selection system by cutting single trees but rather groups of trees. These groups are then developed by successive cutting into fairly even-aged stands. Thiollier stated to the author personally that these three cultural rules should therefore be followed:

"1. The young stands must always be kept dense; the thinnings should only remove trees without a future and free the crowns of the best stems without ever opening up the stand.

"2. When a stand or a clump becomes of exploitable age, to regenerate it; make openings (or holes) whose size varies with the altitude, the kind of soil, exposure, to be made after an examination of existing blanks.

"3. The soil cover (grass, brush, spruce litter) should be broken up by irregular seed spots so as to form flat areas in the holes or blanks where the seeding should take place. If regeneration fails, plant in the center (of openings) with at least five trees spaced 12 inches."

In other words, Thiollier recognized the necessity of assisting natural regeneration, and that the ground must not be allowed to run wild. Since fir or beech is almost invariably mixed with spruce care must al- 
ways be taken to favor the spruce if this species is especially desired. But judging from results studied in France the practice of sacrificing a fair species like fir for spruce (which brings a little better price) is poor technique, and there is danger of windfall.

The spruce and fir regeneration in the forest of St. Martin d'Arc is favored by cleaning out the birch, aspen, and other less desirable species. In the case of pine a complete cleaning is made wherever groups require more light; with fir the cleaning is gradual and partial. In this particular forest the cutting period is 15 years with a separate rotation for each species, whereas in other parts of the Savoie the working plans officer usually establishes one rotation to cover all species. In the improvement cuttings undesirable trees are often left because if all undesirable ones were cut it would mean a too heavy felling. In the neighborhood of Thonon (Savoie), above the Drance River, the selection fellings take place every 12 to 14 years, according to the working plan, but, in practice, they cannot take place quite so often because the amount to be removed is limited and accidental fellings consume too much of the yield. On this rich soil the spruce comes in best in the openings. The protection zone covers a 30 per cent rocky slope where only windfall is removed. In the forest of Bonnevaux a selection cutting removed one tree from the center of a group of three - a diseased tree, one that was suppressed, and a stag-headed tree - as well as two trees which were suppressing fir reproduction. An opening 66 by 98 feet was made at one place because of the removal of a large tree with a bad crown. The cut probably removed 25 per cent of the stand, the amount removed being necessitated by the poor condition of the trees. In the forest of Grande Chartreuse, cut over by selection fellings, weeds have come in in the openings which were made to favor the reproduction of spruce, since fir here reproduces under cover before the spruce can gain a foothold. In the forest of Chapelle d'Huin beech and a little oak are mixed with the fir. Beech is cut rather heavily, especially in cleanings, because firewood values have decreased to such an extent. There is too much beech coming in under the old stand of fir but, curiously enough, under the beech there is a good deal of fir. In this locality, for the value of cordwood removed, the peasants will cut the beech; thus the cleaning is made free of charge.

Selection Fellings for Scotch and Aleppo Pine. - Ordinary selection felling is not suitable for Scotch pine; group selection, when applied to a light-demanding species, must produce two results - it must diminish the number of stems in the stand so as to open it up sufficiently and it must make openings large enough so that the seedlings will receive the necessary light, at least during the middle of the day. The size of these openings or holes depends on the height of the tree and distance from the seed trees. It is usually necessary to concentrate these fellings on, 
say, one-fifteenth of the forest. Under the same conditions it is possible to make the openings 2 to 4 acres in area. The diameter of the opening is usually at least one-half the height of the neighboring trees. As soon as the regeneration starts it is necessary to open up around it in order to give it sufficient light for development, always bearing in mind, however, that too wide openings, which become choked with brush, are consequently expensive to clear. This hole-selection method has been applied to aleppo pine, but until experiments in Algeria in the Oran Conservation are completed by Conservateur Laporte, no final decision can be reached as to the best method of treatment. It is very significant, however, that near Marseilles the working plan calls for the shelterwood system, that is, progressive feelings, but the local inspector preferred the method as described in the following statement furnished the author personally:

"The aleppo pine is the only coniferous species of the calcareous regions of the Mediterranean Provence. Besides this species there is only the holm oak and the pedunculate oak treated under coppice and furnishing nothing but firewood. In the Department of Bouches-du-Rhône the aleppo pine ordinarily forms almost pure stands or mixed with a small per cent of oak (.0 to 15 per cent).

"The forests of aleppo pine occupy the lower mountains where the altitude ranges from sea level to 2,600 feet. The calcareous soil is generally on steep slopes, which are usually rugged. There are numerous rock benches and stone slides with but little vegetation. The climate is characterized by hot and dry summers. The average annual rainfall is 20 inches at Marseilles to 28 inches at Aréasque (in the center of the small mountainous forest situated to the northeast of Marseilles). The average number of rainy days is 85, chiefly in autumn and spring. During 1912 there was an almost complete drought for two months - July and August.

"The aleppo pine is admirably adapted to these conditions, which any other indigenous species would not be able to stand. It is essentially light-demanding, endures drought, and is vigorous. It has a very light foliage and is easily regenerated by natural means. But while it stands heat and prolonged droughts, its growth suffers nevertheless, and its remarkable thrift when near water . . shows it can thrive on fresh soil. The young seedlings suffer from drought if the roots are not well into the soil; they are often burned by the sun in the summer if it is especially hot and dry. On certain rocky slopes where the stand is open it is difficult to get regeneration under the old trees; on the other hand, the soil should not be allowed to run wild, since it must be protected against the heat of the sun; cuttings must be light.

"The treatment by regular high forest (shelterwood) with a rotation of 60 years and with the division of the forest in three periodic blocks (each to be regenerated in turn within 20 years) has been followed in a number of forests for 50 years. But the lookedfor regularity has not been obtained on the arid and rocky soil which one finds on most of the area under management.

"Uniform stands have been obtained only on several areas where the soil was deeper and richer; these are the exception rather than the rule. In reality most areas treated by the shelterwood system have always remained in a transition stage. On the contrary the selection system is adapted to the regional conditions. Forests of more than 741 acres are divided into working groups whose area ordinarily does not exceed this. Each working group is divided into a certain number of felling areas, usually 10 to 16 , which 
are cut over each year successively (the area of each felling area usually varies from 12 to 49 acres). The number of the felling areas also fixes the periodicity of cutting over the same point, 10 to 16 years . . . and at each cut the trees which have attained exploitable size (12 to 14 inches in diameter) along with the badly shaped and overmature trees are removed; at the same time the trees, where they are too thick, are thinned, thereby freeing the promising seedlings. The yield is not fixed; the cut removes each time 15 to 20 per cent of the standing material. Seedlings ordinarily come in quickly where the stand has been opened; and if the neighboring trees shut off a portion of the sun's rays when it is low on the horizon the effect is not bad for the seedlings, but on the contrary preserves them against the dangers of excessive heat and drought, due to the intensity of the light and the lightness of the cover.

"The selection method gives in the end excellent results from the cultural viewpoint and is perfectly suited to the silvics of the aleppo pine, both as to the soil and climatic conditions. It assures the conservation of the stand, something that is essential in a region where the percentage of wooded areas is much too small (14.2). It yields shortstemmed trees, to be sure, but 36 feet of height growth is sufficient for very mediocre soil. Moreover, the length of the stem is of secondary importance, because at the sawmill the aleppo pine is cut into small boards for shipping crates. From the economic viewpoint there is the objection of giving a very great latitude to the officer who does the marking, since there is no fixed yield, but it must be remembered that because of frequent fires - it does not seem feasible to establish a precise working scheme which would have to be incessantly revised and whose provisions would be constantly reversed."

Group Selection for Fir or Spruce. - In high altitudes, or perhaps on rocky soil, the advance growth is rare and it may be impossible to wait for it to install itself. There are usually groups of advance growth, however, and these may be gradually uncovered by removing the stand surrounding them. As these groups develop other trees are removed so that they become larger and larger until the ground is completely stocked. This method has given very good results and often is the only one that can be employed. If there are no groups of advance growth an old tree may be cut here and there in order to start seedling growth. If the openings are too large there is danger of weeds taking possession of the soil [174]. Spruce reproduces better with group selection than with selection by single trees.

Group Selection for Larch (and Other Methods). - Near Briançon there are numerous interesting examples of the treatment of larch forests. (See Fig. 8.) In the communal forest of Villard St. Panerace the larch comprises an open park-like forest where cattle grazing is allowed. The cutting made is really an improvement felling, but the young growth is always freed even if a good tree has to be cut. On the other hand a good many poor trees are left rather than make large openings. According to the working plan it is a seed felling, but on the ground it was a selection felling by groups. According to the working plan no sacrifices are to be made to regularize the stand and yet the inspector is not advised systematically to make a regular stand irregular. In 
another portion of the forest the marking illustrates the freedom and flexibility of French silviculture. Here the cutting was the removal of small groups of trees and the groups left were occasionally thinned. Trees were left along roads and around a small mountain swamp. The openings were rarely more than 33 to 49 feet in diameter and the groups

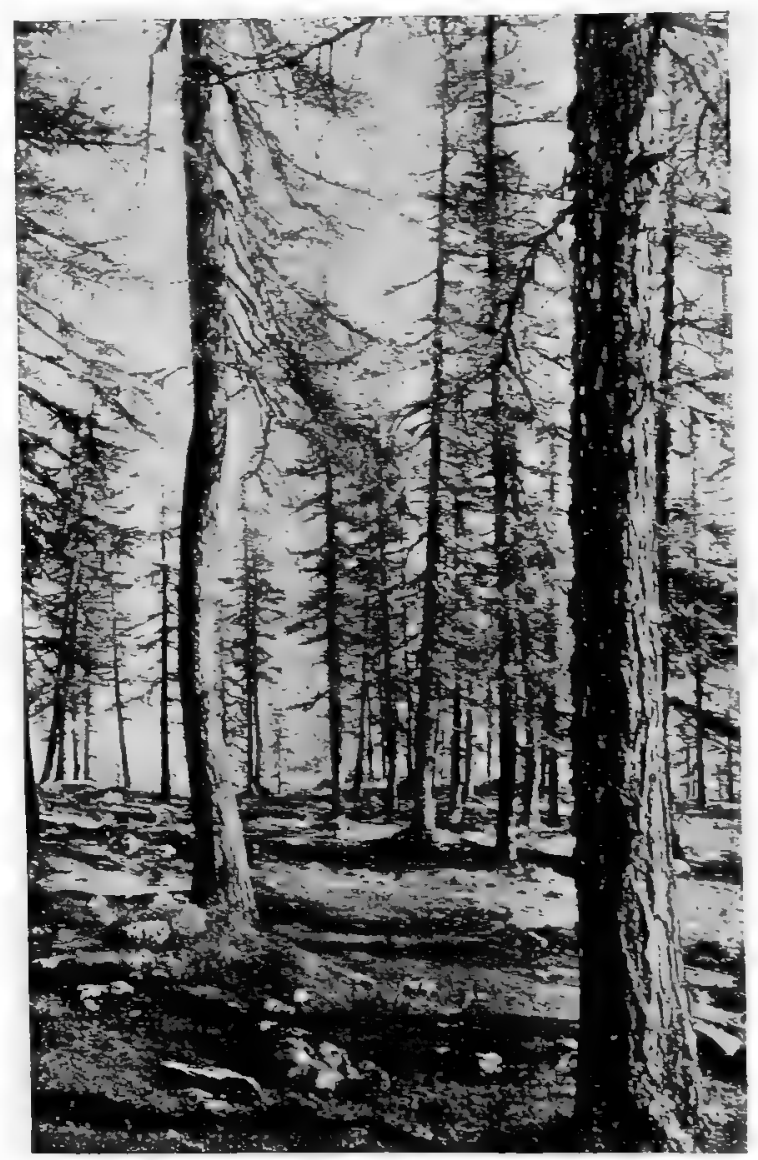

Frg. 8. - Pure larch at an altitude of 5,970 feet, in the communal forest of Tignes. The stand totals 49 trees per acre and 45 cubic meters (11,000 feet board measure). A selection felling has resulted in an open stand, because the ground (grass covered) was not worked to assist regeneration.

left were preferably on rocky ground and very steep slopes. The cutting in one locality where conservatism was indicated by the steep slopes removed, in a light selection system, about 20 per cent of the stand. An experiment was being tried out by cutting in strips running horizontally around the slopes. The strips cut were about 100 feet in width 
and the uncut strip, which was thinned, was about 65 feet wide. In the same locality in the forest of Ban de Puy-Saint Pierre the selection system was used because it did not interrupt the local grazing. The local inspector stated that if there had been no provisions in the working plan (by Broilliard, December 31, 1855), he would have used the shelterwood method on the lower gentle slopes and a conservative selection system higher up where the slopes were steep. According to page 13 of the original working plan the secondary fellings are not necessary. "The regeneration fellings fall into a seed felling and a final felling."

The trees reserved after the seed felling should be at least twenty per acre. Grazing should be forbidden in each division when it comes to be regenerated, and the extraction of underbrush should be made at the time of seed felling. When the natural reseeding is less than half completed, say 7 years after the seed felling, the ground still unstocked should be cultivated in horizontal strips 20 inches wide, spaced 3.3 feet. Moreover, any openings still remaining at the final felling should be planted. The final cutting will take place when the reseeding is completed, and the seed fellings shall not be started again until after the ground is fully stocked. The rotation is 200 years.

Treatment of Scenic Forests. - Forests retained as semi-parks for recreation are always high forests and are usually free from workingplan regulation so far as the specific amount to be cut is concerned. A selection system is usually applied but in reality it is a light improvement cutting, removing only the dead and dying trees. The young stands are often thinned. For example, in the working plan for the forest of St. Antoine in the Vosges (for the years 1908-1939), special provision is made for the scenic working group designed to protect a gorge with waterfalls and precipitous slopes. In the selection system used the fine, big trees are favored and are retained as long as possible for their natural beauty. According to the working plan:

"The aim of this scenic working group is to form and to keep a stand of beautiful trees without striving for regularity and without a necessity for economic exploitation. Each year after having marked the windfall and dead trees and having subtracted their volume, the remainder of the yield should be cut from the entire compartment . . '. by selection . . . see to it not only that the stand is not opened up, but also that it is maintained sufficiently dense. In the young stands remove only the trees wholly dominated and the stems too dense which will certainly become valueless. In the high forest . . . remove only the overmature or wholly defective trees . . . the greatest prudence will always be the maxim. The selection fellings will be extended over a large area in order to cover the working group one and one-half times during the cutting period."

In all forests under working plans famous trees are always reserved from cutting. 


\section{COPPICE SYSTEMS}

General. - Economically and silviculturally the application of any coppice system over large areas is a grave error. Tassey estimated the loss in France, due to the large areas in coppice, at more than 60 million dollars per year. In fact all the best French authorities condemn coppice and especially short rotations, yet to-day we find four-fifths of the private forests in some form of coppice. Even in the State forests more than one-third of the producing forest area is in coppice (largely coppice-under-standards). Furthermore, nine-tenths of all coppice in France is managed on too short a rotation.

In the past this type of stand was very profitable because of the high prices of tannin bark and firewood. But to-day, on account of the large decrease in these values, coppice is becoming less and less profitable, and so far as economic and silvicultural conditions permit, these stands are being transformed to high forest. One of the main objections to conversions is that it is necessary to increase the growing stock, and communes dependent on local wood supplies cannot afford this economy. In some localities where tannin bark is the chief product, coppice rotations have been as short as 12 or 15 years. In other localities the coppice of sessile oak has been continued, but with a longer rotation so as to produce mine props and stulls. With this longer rotation (which often amounts to 30 or 40 years) it is necessary to thin coppice in order to give the best chance for development to those trees which will produce mine props 16 to 33 feet in length. The management of simple coppice is popular with private owners because it has frequently given a certain fixed income, it requires little or no skill, less money is tied up in growing stock, and because there is little danger from insects or fungus. Except in very wet localities, however, it results in positive damage to the soil. According to Boppe: "There is grave danger from frost, especially to species like beech, and to have successful coppice stands for generations a mild climate is essential."

Furthermore it is necessary to study the sprouting longevity of the species in the coppice. ${ }^{10}$ For example, the sessile and pedunculate oaks in France sprout well up to 40 or 50 years of age, while other oak species, such as holm, do not sprout vigorously after 25 or 30 years. But as a matter of fact most private coppice in France should be cut on double its present rotation. Some species (oak, hornbeam, ash, maple, alder) reproduce vigorously from the stump, others (beech and birch) sprout poorly but make up for this deficiency by prolific seeding; the aspen

${ }^{10}$ See "Lre Traitement des Bois en France,"Broilliard, Nouvelle Edition, especially pp. 62-236. Since the coppice systems will not be widely used in the United States the French application to the various species has not been given in detail, 
does not sprout from the stump at all but produces root suckers in abundance. These qualities must always be considered. The chief species found in French coppice stands are locust, poplar, maple, oak, beech, ash, elm, alder, birch, and hornbeam. In a great many localities it is becoming very popular to introduce conifers into the coppice stand with the idea of converting them gradually into high forest and in order to have the conifers increase the production of timber. Maritime pine and aleppo pine are also being introduced in coppice stands in the south of France.

The following official figures give an idea of the relative yield of timber and fuel from simple coppice, coppice-under-standards, and high forest:

\begin{tabular}{|c|c|c|}
\hline & \multicolumn{2}{|c|}{ State and communal } \\
\hline & $\begin{array}{l}\text { Logs, } \\
\text { cubic meters }\end{array}$ & $\begin{array}{c}\text { Fuel, } \\
\text { cubic meters }\end{array}$ \\
\hline $\begin{array}{l}\text { Simple coppice........... } \\
\text { Coppice-under-standards. } \\
\text { High forest. . . . . . . . }\end{array}$ & $\begin{array}{l}0.015 \\
0.175 \\
0.465\end{array}$ & $\begin{array}{l}0.985 \\
0.825 \\
0.535\end{array}$ \\
\hline
\end{tabular}

Simple Coppice. - The important technique is to cut at the right season and to cut smooth, sloping stumps close to the ground. In France the season to cut oak is from March to May; for hornbeam, March to April; for birch, November to December. August is the most unfavorable month in which to cut coppice, and on fire lines it is often of value to cut in August so as to weaken and decrease the sprouting. It is of interest that there are two variations to the rule of cutting low stumps: (a) In holm-oak stands where the ground is dry and the climate hot, the stump may be cut 2 inches below the ground to increase sprouting; $(b)$ on wet ground, where there is often standing water (as in the Sologne) the stump may be cut 5 to 8 inches above the ground. This method would be followed with willow along the river beds. To maintain coppice in good condition the better species, such as oak, must be occasionally planted or sown in the blanks; these seedlings must be usually protected from suppression by the more rapidly growing sprouts. When the coppice rotation is 25 years or more one thinning, about 8 years before the end of the rotation, is necessary for the following reasons: The growth of the coppice will be increased; the first-year standards will endure isolation better; valuable species, and especially seedlings, can be assisted by cutting weed species which are competing with them; coppice suppressing the lower branches of valuable reserves, which would start rot, can be cut out; and short lived species can be removed before they die. 
Coppice with Field Crops. - "Sartage," the combination of coppice with field crops, has been largely condemned in France as poor silviculture, but Jolyet believes in it "since the potash resulting from burning the branches enriches the soil sufficiently to permit with some success the cultivation of grain." On the other hand Boppe [222] calls attention to the damage from fire, the decrease in the amount of oak, the washing away of soil foods on the slopes, and the difficulty of increasing the rotations.

Selection Coppice (Beech). - While considerable difficulty has been experienced in treating beech under the simple coppice system, it can be worked in selection coppice (taillis furete), since the selection cuttings enable the retention of part of the stand which protects the shoots against the first autumn frosts. It is usually worked on a diameterlimit basis and furnishes a great deal of charcoal for manufacturing purposes. Huffel, who likes this method, says [147] that "the treatment in selection coppice is really a methodical treatment and perfectly rational, justified by the silvics of the beech and the exceptional conditions of the coppice. . . . When employed correctly it gives good results."

Correctly applied, the selection coppice does protect the young beech from frost, but since the best sprouts are being cut continually the stand must in time deteriorate. In practice, with a 30-year rotation, one-third of the stand in each compartment would be cut every 10 years. Naturally it is difficult to cut the larger sprouts from a clump without damaging some of those that remain.

Coppice-Under-Standards. - Coppice-under-standards is composed of two distinct elements: the lower story, the coppice, which is cut clean on a short rotation, and the upper story, or reserve, ${ }^{11}$ which is usually managed on a rotation four to five times the length of the coppice. The object of this kind of management is to increase the proportion of timber. It is now generally admitted as being inferior to high forest without the advantages of coppice. The species composing the coppice in coppice-under-standards evidently should have splendid sprouting ability and should also be species that will endure some side shade. The hornbeam, the maple, and the linden are the chief species; beech and oak are less valuable. The pyrenean oak is used as coppice a good deal in the west of France, birch is useful on sandy soils, and poplar on wet soils. The chief skill in managing a coppice-under-standards forest is the choice of the upper story, which should be chosen from species of a light foliage so as not to suppress the under story, and should be selected so far as possible from seedlings or root suckers as a second choice. The pedunculate and sessile oak are of the first importance as standards, although ash, elm,

"See Jolyet, pp. 225, 250, 382, 431-439 for data on coppice-under-standards. 
and maple are good associates. Even with light foliaged oak three to six per cent of the coppice is lost through shading. The alder and linden are not so good on account of their thicker foliage, and beech can be used only in exceptional circumstances. The foliage of the hornbeam is too thin. Most stands of coppice-under-standards have been ruined through careless selection of the trees to be reserved. These reserved trees should be carefully distributed over the area so that the crowns can be isolated. According to Inspecteur Galmiche [233] the following space should be allowed for oak standards of the following ages: 50 years, 22 square yards; 100 years, 89 square yards; 150 years, 145 square yards. According to Jolyet two-thirds to one-third the growing space should be reserved for the coppice and a normal number of reserves $^{12}$ are per acre: $1 \mathrm{R}=20,2 \mathrm{R}=12,3 \mathrm{R}=8,4 \mathrm{R}=4$. Broilliard prefers not to specify any exact number of reserves as an ideal, but advises the forester to mark as many as possible if good trees can be found. He cautions against stopping the reservation of standards simply because 20 to 25 or more have been secured. If good trees can be secured it is better to go ahead and mark them. In a coppice-understandards forest near Oloron in the Pyrenees the foresters are guarding against keeping too many standards. They argue that, with too much of a reserve, the coppice does not grow well in youth and the reserves do not develop so thriftily. As explained by the local inspector the Nancy Forest School teaches the value of retaining many standards for the simple reason that they yield a larger percentage of timber, but rather than adopt this practice the local inspector favored conversion to a high forest. The normal number per acre in this section is four $3 R$, twelve $2 R$, and twenty-four $1 R$ standards. It is claimed that with many reserves they cannot grow such good trees and the oak is prevented from coming in as thriftily as it otherwise might. Major Hirsch, the owner of the famous forest of Amboise, reserves all the standards he can secure and in view of eventual conversions this seems the best policy for those who can afford it. Badré believes in greatly increasing the number of standards to secure quick conversions, especially in Normandy where up

12 The French name their reserves as follows:

\begin{tabular}{|c|c|c|}
\hline French name & $\begin{array}{l}\text { Age, } \\
\text { 30-year Goppice } \\
\text { rotation }\end{array}$ & $\begin{array}{l}\text { Key letter used } \\
\text { by author }\end{array}$ \\
\hline 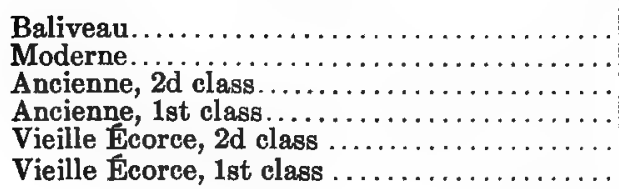 & $\begin{array}{l}30-60 \\
60-90 \\
90-120 \\
120-150 \\
150-180 \\
180-210\end{array}$ & $\begin{array}{l}1 \mathrm{R} \text { standard } \\
2 \mathrm{R} \text { standard } \\
3 \mathrm{R} \text { standard } \\
4 \mathrm{R} \text { standard } \\
5 \mathrm{R} \text { standard } \\
6 \mathrm{R} \text { standard }\end{array}$ \\
\hline
\end{tabular}


to 600 per acre are sometimes reserved. Thiollier ${ }^{13}$ gives four rules for the improvement of coppice-under-standards: (1) Lengthen coppice rotations; (2) increase the density of the reserves and thin when coppice is 20 years of age; (3) concentrate the oak on the soil best suited to it; (4) choose standards best suited to the soil. Gazin, ${ }^{14}$ one of the best foresters in France, in private employ, has called attention to the bad effect of higher labor costs on coppice exploitations and the necessity for reserving more standards and planting. He advocates using 100-foot strips through the cutting area, cutting clean the coppice on half the strips and the ripe standards on all strips so as to (1) get mine props from the coppice held over; (2) crowd out the weed trees; (3) enrich the stand; (4) improve the soil by having uncut strips. Such procedure is manifestly a compromise so as not to reduce the revenue too much during the process of increasing the growing stock.

The following rules for the choice of standards have been developed in France: ${ }^{15}$ (1) All reserved trees (standards) must be of sufficient distance apart so that the branches of their crowns cannot join before the end of the rotation which is beginning. If they do join sufficient light will not be admitted to allow the coppice understory to develop. (2) It is not absolutely essential to have the reserves evenly distributed over the cutting area because to do this means to sacrifice the choice of species. For instance, it is better to have some grouping of the reserves if by so doing some good oak standards can be secured. (3) It is advantageous to reserve a great number of standards near the forest boundaries to serve as a wind protection and to prevent the soil in the interior of the cutting areas from drying out too much. (4) It is also advantageous to have the reserves, so far as possible, situated near the logging roads and compartment lines, since it makes cutting cheaper and the product more valuable, at the same time giving the forest the appearance of richness. (5) A good, sound oak should always be favored as against other species for the reserve. (6) If two trees are oak of equal vigor the largest should be reserved if it will last until the next rotation. (7) If neither of the two trees is oak, reserve the next best species and the straightest, thriftiest tree. (8) The selection of firstyear standards should be made personally by an experienced forester. Broilliard adheres to the rule: "It is always the vigor of a tree that should determine its retention, and those are the big trees which enrich the coppice." A good coppice-under-standards is impossible with a short rotation for the coppice, because the length of clear bole of the standards is determined by the height of the coppice. With a rotation

13 Taillis et Futaie Mélangés, par E. Liouville (Thiollier cited). Besançon, 1911.

14 Coupes de Taillis sous Futaie par Bandes Alternes. Brochure, pp. 73-85.

15 Jolyet, pp. 235-239. 
of 15 to 20 years the coppice is necessarily short-boled. Broilliard therefore concludes that the rotation for a coppice-under-standards should be 30 to 40 years or more unless the soil is very rich, but unless repeatedly freed the oak shows a tendency to disappear.

It is becoming more and more popular, with the decrease in fuel values, to plant conifers in coppice-under-standards, especially on rather thin soils and where there are considerable blanks. According to Jolyet, such species, to make their introduction a success, should have the following qualities: (1) Rapid growth, especially during the initial years when there is competition with the rapidly growing coppice; (2) intolerance (or at least not tolerant); (3) light-foliaged crown; (4) hardiness (especially against late frosts); (5) must be windfirm. Notwithstanding these rules the species most frequently introduced are: (Locusts) Austrian pine, (birch) Scotch pine, white pine, alder, larch, and spruce. The spruce is clearly neither light-foliaged nor windfirm.

In the third conservation the financial yield of the coppice-understandards has been classified, ${ }^{16}$ according to the soil, into six groups:

TABLE 8. - COPPICE-UNDER-STANDARDS

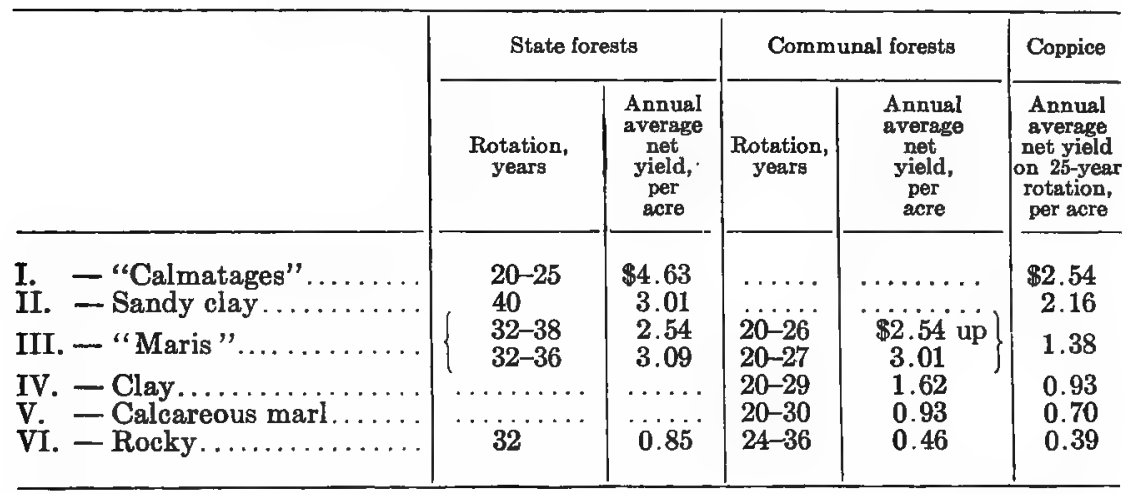

The coppice-under-standards system is typical of France but is merely a weak compromise between the high forest (the forest of the future) and the coppice (the forest of the charcoal and cordwood age which is past). French writers, like Broilliard, show clearly that it pays to hold good trees over as reserves, by citing the value of a $1 R$ standard as 20 cents, a $2 \mathrm{R}$ standard as $\$ 2$, a $3 \mathrm{R}$ standard as $\$ 8$, and a $4 R$ to $5 R$ standard as $\$ 20$, without taking into consideration the damage the standards do the coppice, for, as a rule, the better the stand-

${ }^{18}$ Traitement et Aménagement d'un Taillis sous Futaie, M. A. Mathey, 1909. S. F. 111. 
ards the poorer the coppice, except on the richest of soils. But from the American viewpoint the question must always arise: "If standards pay well, why not have high forest and be done with it?" In the majority of cases the owner of the coppice-under-standards probably prefers this system, since he has not so much capital tied up as he would have in the high forest, and because he not only gets his returns oftener but gets besides some saw timber.

A Substitute for Coppice-Under-Standards (Futaie Claire). - According to Huffel (pp. 327-333, Vol. II), a new method of treatment must be adopted for the oak-beech stands in the northeast of France:

"In a large part of France, and precisely that part where there are most public forests, the natural regeneration of broadleaf trees, where oak is the chief species, is attended by great difficulties. The seed crops are often very rare, separated by intervals of almost 25 years. (There were no complete crops in Lorraine from 1861 to 1888.) Furthermore, in this region, the oak grows on fresh (compact) clay . . . where weeds grow rapidly and prevent natural regeneration. These difficulties, and others . . - decided our predecessors to abandon the treatment of forests under regular high forest (futaie pleine) in the northeast of France. . . . They had pictured instead . . a coppice-under-standards. . . . But when fuel wood commenced to be menaced by coal . . . they looked for a substitute for the coppice-under-standards which would produce a minimum of fuel and a maximum of saw timber. Two solutions were adopted. In the State forests they generally undertook the conversion of the coppice-under-standards to regular high forest. . . . . It ended, in many forests, by their abandoning the conversions. . . . The attempts at conversion put a great many of our best stands in a state of disorder. . . Then they thought best to substitute for the coppice-under-standards what they called 'high forest over coppice,' that is to say, by multiplying as many times as possible the number of standards in the compound coppice. . . . The coppice-under-standards became gradually, under the influence of exaggerated reserves, a sort of irregular high forest over a decrepit coppice, formed mostly of weed trees in which the oak had entirely disappeared. . . Where the young standards were oak . . . the harm was not irreparable. A systematic felling of three-fourths the $2 \mathrm{R}$ standards . . would reform the coppice. . . . But where these $1 R$ standards or superabundant $2 R$ standards were beech the situation was very grave. . . . They will be forced after one or two rotations to complete the conversion to high forest. . . . The high forest over coppice, where you mark 200-300 standards from the coppice (aged 25 to 30 years) is nonsense and ends sooner or later in an 'impasse' from which it is difficult to get out.

"It seems possible to form a type of forest, more easily secured in the northeast of France than the regular high forest, and more productive in saw timber than the coppice-under-standards. It is with this aim in view that we now sketch a kind of exploitation which we call by the old term 'open high forest' (futaie claire) that our predecessors frequently used for discribing the isolated oaks which they grew above their coppice."

Huffel accordingly proposes in effect a selection high forest with oak as the principal species with fellings on a 15-year cutting cycle regulated by area. With a 120-year rotation there would be trees in the first compartment $15,30,45,60,75,90,105$, and 120 years old; 
and in the fifteenth compartment 1,16 , to 106 years, or in corresponding size classes.

"These trees are so mixed up, that at every point there would be seed trees. . . . We would thus succeed in profiting by all partial seed crops. . . . Moreover these (seed) trees are isolated, that is to say, they would not form a continuous complete stand with one story. Between the largest (oldest) trees there would be openings, whose size would be determined by the tolerance of the species, and by the need of light for the seedlings. . . . Each age class must occupy equal areas in the forest.

If we had ten, then each would cover one-tenth of an hectare (2.5 acres). In the oak forests, for which we suggest this kind of a felling, it would be advisable, as a precaution, to leave a portion of the area unoccupied . . . so as to favor the germination and maintenance of seedlings which might come in, mixed with . . . weeds and sprouts. When the time for cutting arrives the less vigorous and less desirable trees in all size classes will be felled in excess of the normal number assigned to the size class. At the same time the young seedlings, poorly formed or lacking in vigor, would be cut back and the others freed." . .

This type of forest, Huffel claims, would have the following advantages over the coppice-under-standards:

(1) Almost all seed would be used no matter where or when it is produced.

(2) The systematic and frequent cutting over the same area would insure the maintenance of the seedlings by disengagement cuttings.

(3) This frequent cutting would also make it possible to leave only small intervals between the large trees and the saw timber would therefore be increased over that obtained in coppice-under-standards.

(4) The large trees would have longer boles.

(5) The frequency of felling would allow the removal of defective trees and weed species.

(6) The felling would be lighter and hence better for the stand.

(7) The improvement felling so necessary in coppice-under-standards, though often omitted, would not be so vital because of the frequent regular fellings.

(8) "The operation of marking the fellings (without being more difficult to make them correctly in the coppice-under-standards) will be in every case clearly and precisely regulated. They could not depend on the arbitrariness of some man who changes the method of treatment of the forest by unreasonable multiplication of $1 \mathrm{R}$ standards of secondary species, or of being ruined by the excessive felling of large trees."

As empirical figures, subject to variation, Huffel gives the "normal" number of trees for each diameter class. These data would be used as a guide and for the purpose of comparison with the actual stand when the fellings are made: 


\begin{tabular}{|c|c|c|c|}
\hline $\begin{array}{c}\text { D. B. H., } \\
\text { inches }\end{array}$ & $\begin{array}{c}\text { Average number } \\
\text { of trees }\end{array}$ & $\begin{array}{c}\text { D. B. H., } \\
\text { inches }\end{array}$ & $\begin{array}{c}\text { Average number } \\
\text { of trees }\end{array}$ \\
\hline 8 & 28 & 20 & 6.1 \\
10 & 17.6 & 22 & 5.1 \\
12 & 12.8 & 24 & 4.8 \\
14 & 10 & 26 & 4.4 \\
16 & 8 & 28 & 4 \\
18 & 7 & & \\
\hline
\end{tabular}

It is too early to give the results of this suggested departure from standard methods. The greatest danger appears to be from tolerant species which may usurp more than their share of the soil. Oak demands full sunlight for its regeneration. Will this be secured? Then, too, how would Huffel's "futaie claire" differ from a group selection system with a cutting cycle of 15 years?

Conversions. - If we accept the arguments against the coppice and the coppice-under-standards systems these forests must be converted into high forest, and to-day there are 241,189 acres, one-fifth of the State forest area, in France being transformed into high forest. ${ }^{17}$ This is easy in theory but difficult to execute satisfactorily except on rich soils with good conditions for natural seeding. The procedure ${ }^{18}$ for conversions varies with the quality of the stand:

(A) With rich coppice-under-standards: (1) Increase the rotation of the coppice to reduce sprouting; (2) increase the number of standards; (3) every 10 to 12 years thin out the coppice and favor the standards; (4) at the end of the new rotation make seed fellings, secondary fellings, and a final felling as required by the silvicultural conditions; (5) fill in blanks with rapidly growing light crowned species.

(B) With a rundown coppice on poor soil rather than wait for the lengthening of the rotation or the gradual reservation of standards, it may be best to: (1) Make a heavy improvement cutting; (2) plant the blanks, and (3) protect the plantations by frequent cleanings and thinnings.

Between the extremes of (A) and (B) there may be many combinations and variations. In case (A) the coppice rotation may be increased 70 to 80 years, since aging the coppice increases the soil fertility and assists the future regeneration. The thinnings can realize the dying trees in the coppice, reduce the number of sprouts to each stump, while the cover will hinder sprouting. If the seed fellings are light, beech and

${ }^{17}$ According to Huffel (p. 328, Vol. II, footnote 2): "From 1876-1892, 348,000 acres of State forest formerly under conversion were made into coppice-under-standards. The acres of coppice under conversion were 699,000 in $1868,717,000$ in 1876, and 368,000 in 1892 ." In 1912 the area was further reduced to 241,189 acres.

18 Jolyet, pp. 149, 252, 260. 
other tolerant species will be favored against the more desirable oak. After the final felling great care should be taken to free the oak. Conversions should begin only where the conditions are favorable and not all over the forest.

Cuif, ${ }^{19}$ in charge of research at Nancy, favors conversions by group selection rather than by the shelterwood for the following reasons: (1) It is applicable to large and small forests alike; (2) forest capital is more evenly distributed; (3) the method approaches nature; (4) it profits by seed trees here and there; (5) mixtures are encouraged; (6) each species can be cut when ripe with coppice-under-standards. He favors the best stems and seedlings, cutting sprouts level with the ground to provide them with good root systems; he plants in the openings and cuts the coppice back to favor the best trees.

Probably the best-known conversion ${ }^{20}$ in France is that for the State forest of Amance undertaken by the Nancy Forest School. It was started by Lorenz in 1826 and the working plan was revised in 1856, 1877, 1888, 1901, and 1908. It offers the best chance in France for a detailed study of conversion methods as applied to hardwoods. In the original working plan Cuif says:

"The conversion of a coppice-under-standards to open high forest (futaie claire) does not seem to present very serious difficulties. It is even likely that it would automatically follow the application to a coppice-under-standards of a rotation equal to the period of an open high forest. It would suffice then, in order to accomplish this, to add to the reserve every 15 years the oak and ash seedlings which would be found mixed with the young coppice shoots and to eliminate systematically from the high forest the beech, elm, and light woods which it actually includes. This method of procedure would surely lead to the final aim. But the conversion would be long, and it would require sacrifice even greater than the coppice, destined to disappear only gradually and only because of natural forces would furnish products without commercial value. In order to alleviate this inconvenience we propose to adopt the following rules in marking the conversion fellings which follow one another at 15-year intervals:

"1. Preserve all the reserves of the oak and ash species except those which are defective or too weak to warrant the hope of seed.

"2. Complete lopping of coppice around these reserves, this lopping being extended far enough so that the circumference of the crowns may be freed completely and bathed in sunlight.

"3. Levying of a moderate yield among the trees 10 inches and above in diameter among the other species, the large beech with many by preference being eliminated.

"4. In those localities where the cover of oak and ash reserves is lacking, form with these trees (also small beech, elm, and linden, or with coppice poles) an open stand capable of serving as a nurse stand for the oak and ash. These plantations should be made in the same year as the felling; they should aim to introduce these two species in the parts where they are totally lacking.

19 Personal notes supplied the author in 1913.

${ }^{20}$ Aménagement de la Forêt domaniale d'Amance (Meurthe et Moselle), 1908. Par Cuif. 
"5. Reserve all oak or ash wherever found, but take pains to free all seedlings and saplings.

"These general principles being stated, the management of a conversion in open high forest requires: (1) Forest descriptions by divisions on the ground destined to form separate units; (2) the results of the stock-taking made in each of these divisions; (3) the regulation of felling during the first period of 15 years with an indication of the yield and the approximate amount of annual planting; (4) a critical analysis of the products to be realized before and after the conversion."

In the forest of Montargis conversion, according to the working plan, the following cultural rules are given:

"Except on several areas which are quite open, natural regeneration of the old poles can readily be obtained, but we do not pretend that the regeneration mixed in the old pole stands will thrive. The sprouts are usually not to be feared as a general rule because of their overmaturity and because of decaying stumps, but, on the other hand, there will be an insufficiency of seed coupled with a rapid deterioration of the soil and encroachment by the heather. Moreover, it is felt that it will often be advisable not to wait too long for a complete natural reproduction but, that it will be better to secure a second crop by artificial restocking. We are convinced that for these stands only resinous species are suitable."

In this forest the coppice is held over to a rotation of 70 to 80 years in order to secure complete cover, good seed bearers, soil protection, and to protect the young seedlings from the frost as well as to weaken the sprouts. It will also be necessary to free the seedlings during the first 20 years. In order to encourage seedlings to come in the ground is worked, but only where there is a probability of an acorn crop. Soil wounding here costs from $\$ 1.15$ to $\$ 1.50$ per acre. The hornbeam and beech will be cut first because they form too vigorous stands, but in one place where the beech had come in after the seed felling (because little light was admitted) it will not be sacrificed; instead it will be retained. In another working group, where the coppice had been ruined, the ground was planted to Scotch pine which was first thinned after $\mathbf{1 5}$ years and afterwards every 10 years. An interesting plantation of Scotch pine had been made on the south side of a compartment along a road in order to protect the interior stand against the sun. In some worn-out blanks single Scotch pine had been planted in November and December, separated by at least two meters from the neighboring sprouts. In this conversion the chief factors were: lengthening the coppice rotation, securing all possible seedlings and root suckers for the reserve, filling up blanks with conifers, repeated cleanings to favor the reserve so that the coppice would be gradually shaded out and the forest transformed to a high forest.

In the forest of Huit a coppice-under-standards forest is being converted into a conifer high forest. Spruce has been planted in rather a poor, open coppice-under-standards. At the age of from 10 to 15 years 
quite a proportion of the spruce was suppressed by the sprouts, and in the 1912 felling a great deal of damage was done. It is clear that the spruce should have been liberated some time ago. The 1912 cut removed all the poor material and kept all the best poles, although some of the older standards were cut in the openings; the coppice is still coming up strong, but where lots of standards have been reserved, it is fast disappearing and becoming suppressed.

The Scotch pine introduced at Baccarat (Basses-Vosges) at an altitude of from 900 to 1,900 feet, is now 70 to 80 years of age. Most of the area was in coppice-under-standards. Nine pounds of Scotch pine per acre was sown in cultivated strips 24 inches wide and 5 feet apart on the areas ruined. The broadleaves on such poor soil yield each year about four cords and 62 cents per acre. The total cost spent on conversion amounted to about $\$ 12$ per acre; this did not include the cost of cleanings at two years of age at $\$ 2.40$ per acre; at 4 to 5,6 to 8 , and 8 to 10 years at costs of $\$ 1.54, \$ 1.54$ and 38 cents, a total cost of $\$ 5.86$ per acre. Thinnings began at 10 to 15 years and paid for themselves up to 15 years; at 26 years they netted 39 cents per cubic meter; at 35 years about $\$ 1.05$ per cubic meter, and at 44 years a net yield of $\$ 1.44$ per cubic meter (about 11 cents, 29 cents, and 40 cents cord net); owing to deterioration of the soil it was found necessary to underplant with fir and beech at 25 to 30 years at an additional cost of $\$ 9.60$ per acre. This makes a total cost of $\$ 27.46$ per acre on soil preparation, seed, sowing, cleanings, and underplanting. Counting the former broadleaf forest yielding at 62 cents per acre per year, the Scotch pine at the end of 59 years has shown an annual yield of $\$ 2.01$ per acre, or $\$ 1.39$ more. Apparently this conversion will prove a sound business venture. Even with good technique it takes time to make conversions. In the communal forest of Vuillecin (near Pontailler, Doubs), the oak and beech comprise 0.6 of the stand and fir and spruce.

According to the special fellings scheme:

"In order to obtain a systematic conversion to conifer high forest and in order to accelerate the transformations with the aid of artificial restocking and local thinnings . . . the compartments have been divided into two groups. In the first group we have assigned compartments . . . where the conversion to conifers is the least advanced and where, because of the poor condition of the coppice, the large number of old beech which still remain, and because of the plantations which have been lost, improvement is needed at once. It will require about 30 years . . . to complete the restocking which is required. . . . These compartments are to undergo transformation cuttings at the start, being something like shelterwood fellings followed by plantations, then by thinnings whose renewal will depend on cultural requirements.

"The second group will include the remaining compartments under improvement cuttings.

"A. - Transformation cuttings. The compartments of the second group shall number four; two with 5-year and two with 10-year intervals. Thus it will be possible to 
give, without undue delay, all necessary care to the existing plantations, to complete them where necessary, and make sure of the transformation of the compartments of the first group during the period ( 30 years).

"B. - Improvement cuttings. The compartments of the second group shall be thinned twice during the period of 30 years, or once every 15 years.

"1. - Transformation cuttings. The first two cuttings (transformation) shall aim to give to the existing plantation what is considered a sufficient number of trees to protect the restocked areas, which shall be made after the cutting, provided that is necessary.

"The second two cuttings shall remove the overmature material that remains standing so that each compartment of the first group shall be completely converted into conifer high forest by 1939 .

"From 1910 to 1939 all the restocking shall be done exclusively in the compartments of the first group. Spruce should be used, as heretofore, for planting since it has given excellent results; on the poorer soils, however, it might be well to try out Austrian pine and Scotch pine.

"2. - Improvement cultings. These shall be carefully executed and shall consist of: (1) Extraction of fir most liable to rot and old oak or beech of poor quality that has become useless . . . general development of existing conifer poles; (2) thinnings in the poles where they are too thick, and cleanings in the thickets and saplings to assist the more valuable species, and to free them . . . removal of crooked stems and dead trees; (3) in the pole stands where the broadleaves dominate, the best beech should be resowed and, so far as possible, the conifers of all ages."

The best-known example of a conversion attempted in the United States is found under the direction of the Yale Forest School. According to a statement issued by the school:

"The general plan of management for Maltby Park may be summarized as follows: It is handled in conjunction with other forest lands owned by the New Haren Water Company, the total area being in the neighborhood of 9,000 acres. The hardwood stands will be managed on some modification of the shelterwood method, such as the polewood coppice system, on a rotation between 60 and 80 years. Several problems in connection with this method remain to be solved, such, for example, as the influence of sprouts which start after thinnings, on seedling reproduction which later on it is desired to secure.

"Where conifers have been underplanted the hardwoods will eventuslly be removed, and a coniferous or mixed stand obtained. It is believed that, on account of the relstively slow growth and low yield per acre of the hardwood species, better financial results could be obtained by converting all the hardwood stand to coniferous forest but, until approximately 2,000 acres of open land on other parts of the holdings are planted, this policy will not be adopted."

Under the condition existing at Maltby Park probably even better silvicultural results would have been secured if the hardwoods had been cut more heavily and if more money had been spent in freeing the plantations suppressed by the coppice sprouts. The value of the land as watershed would not have suffered because the area under conversion comprised only a small per cent of the drainage area. 


\section{CARE OF THE STAND AFTER REGENERATION}

Intermediate Cuttings. - Especially with natural regeneration, cleanings, thinnings, and improvement cuttings are particularly important. ${ }^{21}$ With natural regeneration there are always weed trees to be cleaned out of the stand, and valuable seedlings and saplings to be protected and favored; the over-dense stands must be thinned to prevent undue competition; and later on the stand must be continually improved by the elimination of the poorer specimens. According to Bardrillart a cleaning "is a cutting designed to clean or 'purge,' as one might say, a forest of a part of the wood, briars, brush, weed trees that damage the growth, or trees that are dead or dying, or too numerous." It is very much like weeding a garden. As a rule, private owners in France overlook the necessity of weeding or cleaning their forests because there is a definite expense involved. The French employ the term "to free a stand" as synonymous with the term "to clean," with the slight difference that they free a valuable species from crowding while they clean out a seed tree to avoid injurious competition. According to Jolyet "the chief aim of a thinning is always to favor the growth of the best trees . . . to maintain a stand in the best vegetative condition, or a mixture in the desired proportions . . . and to increase the yield." It thus appears that thinnings also free and clean the stand, but at a later period in its development, and their main objective is to increase the growth by reducing unnecessary competition for light and growing species, and at the same time realize merchantable timber.

In France the term "improvement cutting" means, as the words imply, the improvement of the stand by thinnings, or fellings which yield money returns. There appears to be no clearcut distinction as to the age of the stand when improvement fellings are applied, as may be seen by the quotation from the Malmifait working plan (p. 112).

From the standpoint of silviculture it is essential that intermediate cuttings be ordered, in current working plans, by area and not by volume. Forest valuation should never interfere, as it has in the past, with silviculture. If the forester aims at checking excessive cuts he should prescribe the area to be cut over each year with a maximum volume merely as a check. Too often in the past the French forester has marked an improvement cutting in a compartment only to find that it could not be properly executed because the working plan prescribed a maximum cut of 80 cords, whereas the marking properly executed should remove 180 cords. Happily errors due to restraining the silviculturalist from

${ }^{21}$ In France the marking, which requires real technique, is always done under the personal supervision of a forest assistant, assistant supervisor, or supervisor. Even district foresters take part in important marking conferences. 
really "purging" the stand are now well recognized in France and are avoided. Intermediate fellings should begin early, should be repeated as often as necessary, and should be governed only by good silvics.

Cleaning (and Freeing) Young Stands. ${ }^{22}$ - Jolyet describes cleanings as "the operation, which consists in retarding the development of secondary or too ambitious species, tending to improve the normal development of the future stand, consists in freeing these seedlings or 'dégagements." " Boppe says that "cleanings should aid the normal development of the best species, favor seedlings against sprouts, and should be started early, since they are only justified if in good time." They should be repeated as often as necessary to protect the more valuable species. Schaeffer, ${ }^{23}$ one of the foremost French conservators, recognized that cleanings referred especially to young stands. He wrote:

"It is admitted today that a cleaning should only include small timber, and contemporaneous authors reserve this term for the whole cultural assistance to be given young stands. However broad this definition may be, it appears to me to be still incomplete, for it lacks the ides of clearing brush from a soil under a mature stand. 'Clean' should signify: To make clean, clear; to relieve the soil of a forest of the weed growth (shrubs) means to many the very essence of cleaning; this aspect of the question should not be overlooked."

But without doubt the most important aspect of cleaning is the cutting of small immature timber to improve the stand.

Most important timber species, such as sessile oak, even when 10 to 15 years old, have a slow rate of growth as compared with the weeds or poorer species which surround them. Therefore it is necessary to free them and assist them in their competition with weeds and poorer species. It is not necessarily desired to entirely cut out interfering shrubs or species, but rather to favor only the valuable species in their fight for existence, provided the surrounding brush does not interfere with the growth of the terminal shoot. It is even an advantage to have it in mixture, since it promotes height growth and prevents snow breakage or other damage. All weeds cut in a clearance are valueless. To remove them would be expensive, to burn them often dangerous. Where they must be cut level with the ground it would be unwise to leave them, and the usual practice is to pile them around the base of the reserved trees which still occupy the felling area before the final cutting. The forest guards are the ones who should make the cleanings and it is essential that the same individual trees should always be favored in subsequent operations, since it is obviously poor policy to favor one

${ }^{22}$ See Boppe, pp. 94, 134, 162, 200, 248, 254; and Jolyet, pp. 93, 114, 134, 154, 174, $186,200,239,243,248,254,385$.

${ }^{23}$ Du Nettoiement dans les Bois. Par A. Schaeffer, Besançon. 
sapling at one clearance and a different one at another [94]. A shadeenduring species such as beech, of course, does not require freeing to the same extent as does a light-demanding species such as oak [134]. Even the maritime pine, which is a rapidly growing species and a prolific seeder, requires assistance against the genista, with which it is often in mixture [154]. Scotch pine, until it has developed above the heather, must always be assisted [162]. The young spruce does not resist shrubs even as well as the fir, and notwithstanding its rapid growth at the start it may often remain dominated by weeds unless cleanings are practiced [200]. In coppice-under-standards, it is particularly essential to protect the best species and the best seedlings or sprouts against competition with inferior species and weeds [243]. In conversion [254] cleanings are also essential.

One of the most important objects in freeing desirable species is to give them the preference over less desired species which may be more rapidly growing during youth. For example, in a mixed birch and Scotch pine stand, the birch might damage the Scotch pine, which is the more valuable, unless assistance were given it.

According to Schaeffer cleanings in regular high forest should first of all destroy the weed trees, briars, and weeds which develop on rich soils, so as to conserve light, water, and food for the future commercial stand. But he cautions all foresters against the unnecessary cleaning of light-foliaged, short-lived trees that will do no material damage to the valuable species. He favors the Bagneris method of only topping competing unmerchantable weed trees instead of cutting them off at the stump. This method, which prevents sprouting, and though cheaper, it must be recognized, means more work because it must be done oftener; it should rarely be applied in the United States. The best time to clean out weeds from young growth is in the late summer or autumn; but for cleanings in stands the spring is best because, if too heavy, the stand has time to recover before snows. In fir the period is less important, but the winter is best.

In selection forests the procedure is somewhat different. There are two schools; one believes that the ground cannot be too densely covered, while the other, led by Gurnaud, believes in periodic cleanings in the understory. Probably the theory of at least partial cleanings in selection forests is correct, but care must be taken to study the soil conditions. Some soils may need every shrub or weed as a protective cover. But since most selection forests are in the mountains, moderate cleanings are usually advisable at the time of felling the saw timber. This cleaning removes small trees damaged by exploitation, weed trees, holly, and even beech which is not required for soil cover in the mountains. 
In coppice cleanings protect the seedlings. They must be started 4 or 5 years after cutting the coppice and continue for 15 or 20 years. They act as a thinning in increasing growth and in removing the briars and weeds, weed trees, and poor stems of more valuable species. The increased growth due to a cleaning may be 40 to 50 per cent or more. Where the coppice is grown under standards the cleaning is all the more essential, because the best standards are of seedling origin, a class of tree especially protected by the cleaning. To give the best results cleanings, according to Schaeffer, must be made every 3 or 4 years. The growth of the standards is increased. Jolyet is satisfied with cleanings at 5,10 , or 15 years.

Thinnings. - Thinnings have three main objects: (1) To eliminate the least desirable specimens; (2) to increase the rate of height and diameter growth of the final stand by artificially removing a portion of it in order that the competition for existence need not weaken the best trees; (3) to improve the quality of the trees of the final stand. (See Fig. 9, $a$ and $b$ ). It is erroneous to believe that a very dense stand means rapidity of height growth. To secure proper development trees must have sufficient growing space so that their crowns can increase in vigor.

While thinnings do not always result in a greater final yield the quantity of large, good-quality timber is certainly increased and the intermediate plus the final yield of a thinned stand is always more than the final yield of an unthinned stand. Thinnings decrease insect and fungus loss as well as windfall and snow breakage. There is a general feeling among foresters that the French believe in making heavier thinnings than do the Germans. The old axiom of thinning early and often is actually practiced in the forest in France and is advocated in the text-books. The French believe in thinning the top story in order to decrease the struggle for existence among the dominant species. ${ }^{24}$ On the other hand, as in other divisions of French silviculture, the French methods are simple and direct. They have not classified the thinnings, as have the Germans, into a large number of grades.

In coppice with long rotations the French believe in moderate thinnings [111]. ${ }^{25}$ Most thinnings start in France when the stand is 20 years old and continue every 6 to 20 years. They are marked by the guards and rangers under the personal direction of the inspector, assistant inspector, or forest assistant [134]. With a species like maritime

${ }^{24}$ The bracketed page references are to Jolyet.

${ }^{25}$ This naturally is not an ironclad rule. In the forests of Mouthe and Fuvelle (Jura fir) up to 50 to 60 years the thinnings were largely in the understory; only after the stand had closed were the thinnings in the top story. This is logical. After 60 to 70 years the thinnings in fir may remove up to one-fifth the stand. 
pine it is invariably the practice to make heavy thinnings ${ }^{26}$ in order that the crowns may be fully developed when tapping for resin begins. These start at 10 years of age and continue every 5 years until tapping to death begins at about 20 years. Jolyet says [155]:

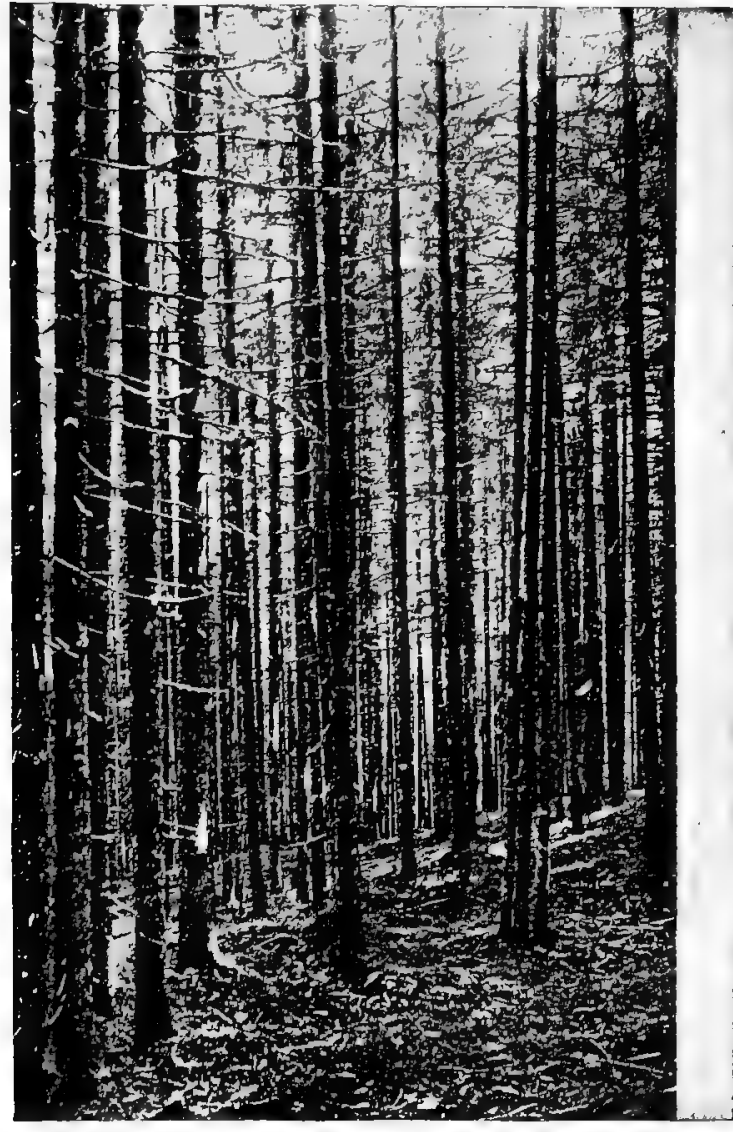

A

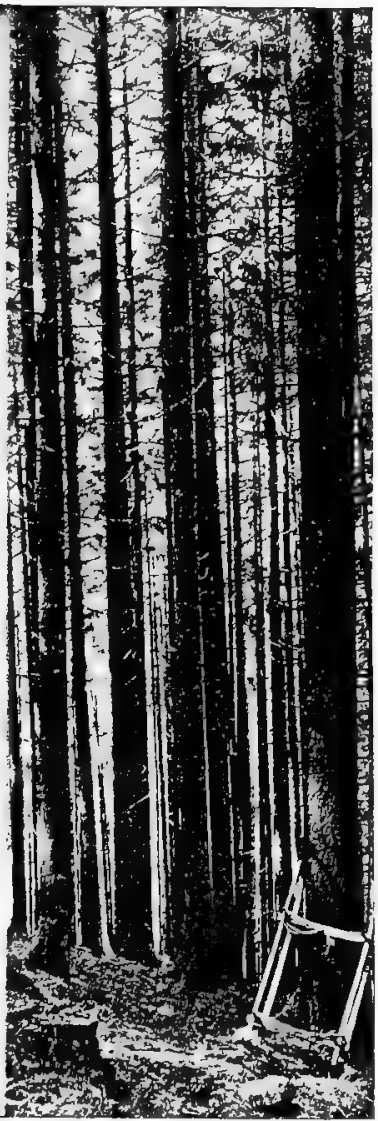

$\mathbf{B}$

Fig. 9 (a). - Pole stand of spruce at an altitude (west exposure) of 4,590 feet in the communal forest of Beaufort. There are 364 trees per acre, yielding 117 cubic meters (23,000 feet board measure). The thinnings thus far have too much light to permit crown development.

(b). - Spruce and fir running 255 trees and 283 cubic meters $(74,000$ feet board measure) to the acre, in the Canton du Mont, communal forest of Thones-Ville, at an altitude of 3,120 feet on a west exposure. Thinnings have been insufficient to free the crowns of the most promising trees.

${ }^{26}$ This is entirely proper with maritime pine but with spruce or fir, for example, care should be taken not to open up the stand too suddenly. The chief danger in the United States is of too heavy thinnings because of the need of a large cut at one time to reduce 
"At 15 years there is a second thinning (made with an axe), this coupled with a pruning of the remaining trees up to the maximum height the face will reach, that is to say up to 6.6 to 9.8 feet above the ground. At 20 years there is a third thinning, preceded by the tapping of the trees destined to be felled. There is no reason to try to maintain the vigor of these trees; the essential is to realize as quickly as possible all the resin which they can yield; they are . . . tapped to death at 25 years, and at 30 years there is a fourth and a fifth thinning, always preceded by tapping to death. After the fifth thinning is cut out the stand becomes very open; it is hardly complete. This condition is, however, favorable to the growth of maritime pine, since the crown, when well thinned or in full sunlight, produces more rapidly the substances necessary for the formation of wood and resin. The pine trees which remain are now called pins de place and are tapped alive, that is to say they are worked with a moderate number of faces so as to obtain a reasonable amount of resin without compromising the vitality of the tree. This tapping will be continued, moreover, during the entire life of the tree (with 1 or 2 years of respite). In addition the thinnings (every 5 years) are continued in the stand until the time comes for regeneration by clear cutting; it should be understood that each thinning is preceded by the tapping to death of the trees marked for felling."

In Scotch pine it is often dangerous to wait until trees are large enough to yield mine props; it is better to start thinnings earlier, say at 18 or 20 years, as purely cultural operations. After once starting they should be made every 7 to 8 years [163]. In mixed stands [182], such as beech and fir, the thinnings should favor the fir against the beech, since the latter is essentially adapted to an understory rather than to the major stand [182]. In even-aged stands it is the French practice to choose the trees which should form the future stand and then favor them in the thinnings. The mere removal of suppressed or intermediate trees is not countenanced, since the French believe very firmly in thinning the upper story [200]. The chief aim in making thinnings in the coppice of a coppice-under-standards stand 8 to 10 years before the coppice is cut is to increase the diameter growth of the most vigorous trees which will make the best standards for the upper story during the succeeding rotations [245].

Another operation, in reality a thinning or loosening (dépressage) in seedling stands, is very necessary in crowded maritime pine regeneration, and often in dense clumps of Scotch pine reproduction, to prevent damage by fungus through overcrowding. Jolyet ${ }^{27}$ says of it:

the cost of logging. Huffel says in the preface to Vol. II of Economie Forestière: "Exaggerated thinnings are fatal to the health and finally to the very existence of forests. By breaking the cover and uncovering the soil, they diminish or destroy its productiveness. The humus disappears; the soil dries out, packs and hardens. The forest is invaded by weeds, heather, and grass; the valuable species are gradually eliminated. If made too suddenly thinnings cause windfall. Too heavy thinnings are uneconomic since they increase the volume of branches and sapwood, yield short tapering boles. . . . They also decrease the quality of wood. . . ."

${ }^{27}$ Influence des Éclaircies dans les Peuplements réguliers de Sapin. E. Cuif, 1905. 
"It is necessary to break up these thickets by cutting a certain number of seedlings. The term 'dépressage' (literally loosening) explains well enough the nature of the work which is done with a bill hook or pruning iron. To sum up, the 'dépressage' is not a freeing (dégagement), but more nearly a first thinning executed in very young stands."

There can be no question but that thinnings are profitable when the trees to be cut can be sold. As a concrete example of increment the following is cited for a fir stand in France:

\begin{tabular}{|c|c|c|}
\hline & $\begin{array}{l}\text { Plot A, } \\
\text { thinned }\end{array}$ & $\begin{array}{c}\text { Plot B, } \\
\text { unthinned }\end{array}$ \\
\hline 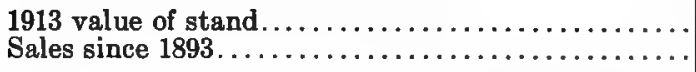 & $\begin{array}{r}\$ 889.13 \\
667.01\end{array}$ & $\begin{array}{r}\$ 1,687.78 \\
43.39\end{array}$ \\
\hline 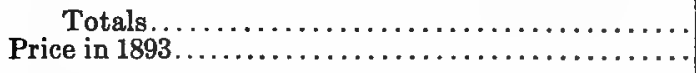 & $\begin{array}{r}\$ 1,556.14 \\
1,113.41\end{array}$ & $\begin{array}{r}\$ 1,731.17 \\
1,323.21\end{array}$ \\
\hline 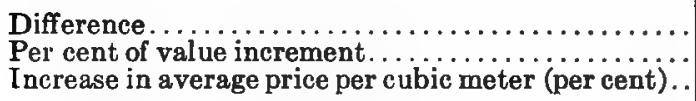 & $\begin{array}{r}\$ 442.73 \\
3.76 \\
1.37\end{array}$ & $\begin{array}{r}\$ 407.96 \\
2.80 \\
.97\end{array}$ \\
\hline
\end{tabular}

Thus thinnings, properly executed, increase average annual revenue and the unit of value of the final product. On account of the larger logs in another plot the price increment per meter was 17 cents. Cuif believes that good thinnings will enable the State to decrease the rotations.

Huffel cites some authoritative figures for the growth per cent for a spruce forest thinned and unthinned. Starting with 20 years the growth per cent is 0.7 for both stands; at 50 years the unthinned stand was growing at the rate of 4.3 per cent and the thinned at 4.5 per cent, at 100 years the growth per cent for the unthinned stand was 2.6 and for the thinned 3 per cent.

The losses througn poorly executed thinnings may be lasting. Schaeffer ${ }^{28}$ cited a case where a compartment was ruined for 30 years because the officer in charge of the marking did not study the stand curves in the working plan (see p. 216). He cited diameter limit marking as abominable. Important marking, according to French belief, should always be executed under the direction of a trained officer.

Improvement Fellings. - French text-books do not refer to "improvement fellings" as such. They describe freeings, cleanings, thinnings, and accompanying cultural operations. But in State forest and communal working plans there are always instructions under the head "Coupes d'amélioration," as distinct from regeneration fellings and freeings.

In the forest of Argon according to the original working plan, when ${ }^{28}$ Sylviculture Administrative. A. Schaeffer. Besançon, 1907. 
the stand is 50 to 60 years old there are careful thinnings in the poles and the removal of dry, suppressed trees and final fellings with light thinnings in the pole stands and the gradual elimination of the beech. According to the working plan:

"1. In the spring, one shall carefully reconnoiter the windfall, dry trees, dead trees, or those declining in vigor; the volume shall be determined from the volume table. Under the head of defective wood should be included all trees seriously defective, such as rotten, fungus infected, or very crooked trees, or those exuding resin or showing cancer."

This clean-up in the almost mature stands is in effect an improvement felling. In the forest of Malmifait, under the heading "Improvement Fellings," the working plan prescribed the following:

"The cultural rules to apply will vary according to the working group. In the third group (the first to be regenerated so far as the mature reserves are concerned, which must be zealously kept to furnish most of the future seed trees), it is necessary that only dead and dying trees be cut and everywhere on those areas where it is impossible to find suitable seed trees in the poles; on those areas all the trees are defective or hollow. In the poles the young trees of desirable species, which must furnish the future seed trees, will be freed rather energetically and prepared for seeding purposes along with the mature reserves and especially when these reserves are lacking; moreover the thinnings will be very light so as not to expose the soil; otherwise the seeding would be started (premsturely) along with briars and grass which would form, later in the third period, an obstacle to naturai reproduction. The same cultural rules will be applied in the fourth group, but with even greater moderation; it will be possible to sacrifice some of the old trees which are hollow or in mediocre condition in favor of good stems, still young, existing in the poles; but here, also, the thinning as a whole will be light. . . . In the young growth of the fifth group, where old reserves are lacking or few in number, the oak must be freed, and the good beech as required; there should be no hesitation, in the areas where the oak is the dominant species and where the beech is insufficient, in sacrificing the former of these two species to assist the latter, so as always to make sure of a proper mixture of these two species.

"Finally, in the compartments of the second group where it will be necessary to pass most often, the special cutting scheme provides for four fellings instead of two, for the other groups, during the last 26 years of the period; the improvement cutting will take the form of cleanings, liberation cuttings, or thinnings, according to the condition of the stands; besides it is necessary, wherever the regeneration does not take hold, to assist the seeding by means of wounding the soil and to complete it by plantations of oak and even beech where necessary. It is essential to continually see to it at the start that the seedlings and plants are not choked by the briars . . . and later on that the promising individuals of the good species should not be hindered in their growth by secondary species. These operations are especially delicate. So far as possible they will actually be done by the employees as betterments (improvement work). They must be carefully and progressively executed at short intervals on the same ground. Often, especially at the start, it would be better to cut out the weed trees gradually rather than to remove them all at the same time, which would uncover the seedlings too brusquely. . . . Often it will be preferable to kill the weed trees by girdling rather than to cut them level with the ground, which would favor the production of vigorous sprouts, able to very rapidly interfere with the young growth of valuable species." 
Judging from this quotation the term "improvement fellings" in France is used rather as a general term to signify any kind of intermediate felling. It has been employed by some officers in a narrower sense to denote the improvement of mature stands prior to regeneration, where dead, dying, and diseased trees are cut out systematically to realize profit on what would otherwise constitute a loss. 


\section{CHAPTER VI ${ }^{1}$}

\section{ARTIFICIAL REFORESTATION}

French Polict (p. 114). General, Choice between Sowing and Planting.

Swed (p. 117). Cultural Value of Seed, Seed Testing, Rules for Seed Control.

Nurseries (p. 122). Location of Nurseries, Nursery Practice, Two Sample Nurseries.

Planting (p. 125). Cultivation and Spacing, Age of Plants, Time to Plant, Plantation by Holes, French Planting Technique, Cover and Protection, Species and Methods to Use, Chief Dangers.

FurLd Sowing (p. 132). Prepared and Unprepared Soil, Amount to Sow, Season for Sowing, Summary of Sowing Methods as Applied to Species and Regions.

\section{FRENCH POLICY}

General. - Notwithstanding the sentiment in France in favor of regeneration by natural means it is obvious that with only 18.7 per cent of the land under forest, considerable areas must be restocked artificially if France is not to suffer for lack of wood (of the kinds needed). Thus far the Government has devoted the most time and revenue to the reclamation of the sand wastes in the Landes (see Chapter VIII) and to the reforestation of lands in the mountains (see Chapter VII), denuded through past improvident overcutting and overgrazing. Next in importance has been the planting and sowing in the Sologne and Champagne. Besides this restocking of barren areas there has been occasional sowing and planting to supplement natural regeneration when this has been a partial failure. There are always fail places in natural reproduction where nature must be assisted to maintain production and to keep the present stand from deterioration. For example, with more than three-fifths of the forest area in coppice or coppiceunder-standards these stands must be continually sown to oak or underplanted (the usual practice) to prevent blanks. In conversion from these systems to high forest more desirable species than can be secured by natural seeding must be introduced.

Too frequently, however, the private owner has allowed his forest to deteriorate because sowing or planting involved direct expenditures to-day, with returns deferred until the next generation.

To practice good forestry is to save, so it is somewhat surprising that

2 Prof. J. W. Toumey, Dean of the School of Forestry, Yale University, and Lt.-Col. A. S. Peck kindly reviewed this chapter and made many valuable suggestions. 
to-day there is not a larger per cent of French territory under wellmanaged forest. The main reasons for this deficiency can be traced to the vicissitudes of families and of the nation, coupled with the selfishness of pleasure-loving nobles, kings, and politicians. Yet, curiously enough, the search after pleasure, in the form of hunting and shooting, is responsible for some of the most famous high forests of France.

Trees are sometimes planted as shelter-belts for the fields on the right of way along the railways. This apparently is a wise use of land otherwise unproductive, but it is very hard on the eyes of travelers. Where the railroad grade passes through cuts trees have been planted to hold the earth and prevent erosion. This is a practice which American railroad engineers might well follow. At Toulouse cypress trees are planted along canals to protect them against drying winds.

Roadside tree planting is practiced very generally throughout France and results in endless rows of trees flanking the highways which is one of the characteristics of the French countryside that impresses itself most indelibly on the traveler.

French writers ${ }^{2}$ class $(a)$ the forestation of the Landes and mountains as obligatory forestation and $(b)$ the stocking of poor agricultural land or waste land, which has never been cultivated, as optional. From the standpoint of public economics no nation can afford to permit land suitable for growing crops of trees to lie idle. If the individual cannot afford the proper forestation the State must step in. There should be no waste land nor should its use for forestry be optional. It should be obligatory, but with the alternative of yielding ownership to the State under equitable conditions. With at least 300,000 acres partially or completely denuded by the recent war, France has a vital problem of reforestation to meet and must import a large portion of her seed or plants. It would certainly be a just settlement if the Germans were made to furnish much of the seed and plant material.

No attempt will be made to treat the subject of artificial stocking systematically; instead only the most interesting and instructive phases of the problems will be covered in varying detail.

Choice between Sowing and Planting. - According to such foresters as Lorentz and Parade field sowing is considered especially useful on a large scale, since it is alleged to be simpler and cheaper than plantations and because the result is more nearly like the natural forest. On the other hand, it is recognized that the plantation is surer and results in more regular stands. Therefore where the soil is dry, where it is denuded, and where it is eroding, as in the majority of cases in the Alps, planting is preferable to sowing. While no absolute rule can be formulated for the choice between sowing and planting, Demontzey, the

2 For example, see Jolyet, pp. 467-468. 
father of mountain planting, believes that planting is usually preferable and that sowing should be done only in special cases, since the sowing, while sometimes less costly than planting, is less certain and often incomplete. Sowing is best, according to the French writers, on some kinds of rocky soil where plantations are made with difficulty, where seed is very cheap, and where the soil need not be previously prepared. Otherwise it is usually more expensive.

Planting was neglected for a long time in France, but Government forestation has given it an impetus and formally established its desirability under certain conditions. Planting makes possible the control of species, mixtures, and spacing, and is generally considered better on very rich soils where weeds abound, where there is damage from rodents or squirrels, and in hot and dry regions where the young trees cannot be protected but must resist the heat. For successful direct seeding, it has been found necessary that (1) there be no dense cover that will shut out the light, (2) the young plants should have a little protection against the snow, (3) the soil should not be too exposed to heaving by frost, but that it should have a moist surface, and (4) the slopes should not be too steep. Otherwise the plants will be eroded or covered by earth transported by flood water. There are other considerations. Certain seeds take more than a year to germinate so that they remain exposed for a long time to the different agencies of destruction. For example, cembric pine seeds and some species of ash belong to this class. Therefore, planting is to be preferred to sowing for these species. Notwithstanding this, however, cembric pine is sometimes sown because of the shortness of the favorable season at the high altitudes and the diffculty of handling labor in these out-of-the-way places. Of course, species which develop a long taproot at the start are better sown, as, for example, the holm oak and the maritime pine. In the case of the cypress it is better to plant because a certain number of seeds bear plants having a pyramidal form. In Savoie and in the Basses-Alpes sowing is often employed, in connection with planting, at high altitudes and on stable ground for the cembric pine, the mountain pine, and the larch; spruce is also sown in Savoie. In the Basses-Alpes, Drôme, and Vaucluse acorns and aleppo pine seed are sown; beech nuts are also sown in the Basses-Alpes. Aleppo pine comes up well from sowing operations in the Maritime Alpes. Scotch pine, Corsican pine, and maritime pine are sown successfully in the northeastern part of the Gard department. Elsewhere in this department sowing is reserved for the summits and high altitudes where the wind is very strong. The sowing of Scotch pine on heather has been employed in the Central Plateau, in which region sowing and planting generally give about equivalent results. In the Ardèche the sowing of fir under the shelter 
of open stands of beech or pine often succeeds, as in other places where this species is suited to the climate. In the Lozère seeding is employed only for the pedunculate oak, chestnut, and Scotch pine. In the Aude and the Pyrénées-Orientales holm oak and maritime pine are sown. Pedunculate oak, chestnut, and aleppo pine in this region are both sown and planted, with a preference for sowing.

\section{SEED}

Cultural Value of Seed. - It is important for successful artificial forestation that the real cultural value of the seed to be used should be known in advance. Much attention has been given to this point. After comparing the results obtained at Paris and Barrès with those at other experiment stations, Fron concludes that the average seed value of the principal tree species, bought in the open market, is as given below. This signifies that for larch 10 pounds must be used where the sowing plans call for 4 pounds.

TABLE 9. - AVERAGE SEED VALUE

\begin{tabular}{|c|c|c|c|c|}
\hline Species & $\begin{array}{l}\text { Average } \\
\text { purity, } \\
\text { per cent }\end{array}$ & $\begin{array}{c}\text { Average } \\
\text { germination, } \\
\text { per cent }\end{array}$ & $\begin{array}{l}\text { Duration of } \\
\text { test, days }\end{array}$ & $\begin{array}{l}\text { Average } \\
\text { cultural value. } \\
\text { per cent } a\end{array}$ \\
\hline 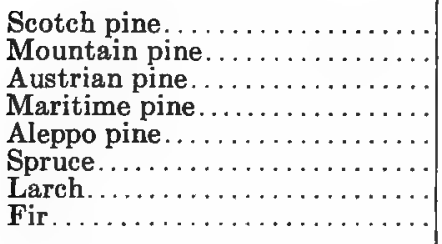 & $\begin{array}{l}95+ \\
95+ \\
95+ \\
95+ \\
95+ \\
95+ \\
80-85+ \\
88+\end{array}$ & $\begin{array}{l}75-80+ \\
70 \\
75-80+ \\
75 \\
80 \\
75-80 \\
45-50 \\
20\end{array}$ & $\begin{array}{l}10 \\
14 \\
30 \\
30 \\
42 \\
30 \\
30 \\
42\end{array}$ & $\begin{array}{l}70-75+ \\
66+ \\
70-75+ \\
70+ \\
75 \\
70-75 \\
40+ \\
16.6 \text { (Zurich) }\end{array}$ \\
\hline
\end{tabular}

a Obtained by dividing the product of germination and purity coefficients by 100 .

The experiments conducted also emphasized the fact, now so generally known, that forest tree seeds cannot be stored successfully without losing so much of their germinative per cent that storage becomes unprofitable, unless kept in air-tight retainers-not yet generally employed by seed houses. Scotch pine, with a cultural value of 74 to 79 per cent, was reduced to 49 to 58 per cent the second year, 28 to 45 per cent the third year, and less than 5 per cent the sixth year. These are maximum losses. The cultural value of mountain pine and Austrian pine decreases as rapidly, but maritime pine stands storage much better, and even after 10 years' storage has a cultural value of 40 to 60 per cent. Spruce seed values decrease rapidly with storage; if 73 to 77 per cent the first year, they are 53 to 62 per cent the second, and but 26 to 44 per cent the third year. It might almost be said that larch seed 
cannot be stored; if 39 to 44 per cent the first year, it is only 16 to 18 per cent the second, and 5 to 8 per cent the third year.

Seed Testing. - As a result of these experiments a fixed procedure was adopted for official tests on tree seeds. It must be known ${ }^{3}$ (1) whether seed can germinate and what the germination per cent will be; (2) per cent of impurities, since the germination per cent plus the purity per cent gives the cultural value of the seed, subject to practical field conditions which always modify the supposed cultural value. In addition to the above factors it is also necessary to know (3) germinative energy.

In 1872 germinative seed tests were started at the secondary school for rangers and guards at Barrès. An experimental seed-testing station at Paris was established in $1884 . .^{4}$ There were 117 analyses in 1895 and 2,201 in 1902-03. The object was to control and better the treeseed market of France. This seed-testing laboratory enabled the State to purchase seed with a guaranteed germinative per cent, and the cumulative result of germinative tests at the various stations has made it possible that no one need purchase or sow tree seeds without knowing their germinative value. The first column following gives the gross amount of seed required for a complete test, and the second column the amount usually required in the laboratory for the actual test.

TABLE 10. - SEED REQUTRED

\begin{tabular}{c|c|c|c|c}
\hline \multirow{2}{*}{ Birch and analogous species } & \multicolumn{2}{|c|}{$\begin{array}{c}\text { Seed required, } \\
\text { complete test }\end{array}$} & \multicolumn{2}{|c}{$\begin{array}{c}\text { Seed required, } \\
\text { actual test }\end{array}$} \\
\cline { 2 - 5 } & Grams & $\begin{array}{c}\text { Troy } \\
\text { ounces }\end{array}$ & Grams & $\begin{array}{c}\text { Troy } \\
\text { ounces }\end{array}$ \\
\hline Scotch pine, Corsican pine, aleppo pine ..... & 50 & 1.6 & 20 & 0.6 \\
Spruce, larch, alder, hornbeam, maple..... & 100 & 3.2 & 30 & 1.0 \\
Cembric pine, fir, cedar, oak, beech......... & 200 & 6.4 & 50 & 1.6 \\
Acacia, ash, linden, maritime pine.......... & 250 & 8 & 100 & 3.2 \\
\hline
\end{tabular}

${ }^{\Im}$ Analyse et Contrôle des Semences Forestières, par A. Fron, Paris, 1906, pp. 1-128. Those interested in seed control should study this monograph.

- So far as possible the French forest administration collects its own seed. Various local dry-kilns have been established as, for example, at Murat (Cantal), Puy-deDôme, and Gap for Scotch pine; at Modane, Briançon, and Cavanasse for mountain pine, although some Scotch pine is produced at Cavanasse. At Salzman, Corsican pine seed is produced. At Montiers (Savoie) spruce; and aleppo pine at Font-del'Orme (Vaucluse), d'Aubagne (Bouches-du-Rhône). Maritime pine is secured from Lavandee, although a part is secured from permittees who have the right to collect cones in the dunes of Gascogne. Larch and cembric pine are purchased in the HautesAlpes and Basses-Alpes and distributed from Embrun and Barcelonette. It is interesting to note that the larch seed is collected by beating the trees when they are ready to shed, between January 1 and March 1. 
For determining the weight by volume one and one-half quarts are usually required. It goes without saying that the samples from each lot must be chosen with the utmost care. First, the shipment must be thoroughly mixed, then at least ten samples, selected from different places in the pile, are mixed and a final average lot selected. When the seed comes in sacks ${ }^{5}$ samples can be extracted from each sack or from a certain proportion mixed together and sampled as given above. Where samples must be sent away for testing they must be labeled and sealed in air-tight bags, but if the water content of the sample is to be determined the shipment is made preferably in corked glass or air-tight metal boxes. It is of value to keep samples of seed known to be normal to use as a basis for comparson; with reliable samples officers that are not experts can readily check species and, occasionally, varieties. The. separation of the débris from the real seed can best be made by hand. The seeds are placed on a glass and separated from the wings, particles of cone, refuse, débris, wood, sand, and damaged or puny seed by the use of a penknife. The operation must be completed as soon as possible to guard against changes in weight due to drying. The absolute weight is determined by averaging the weight of two lots of 1,000 seeds each; with this figure the number of seeds to the pound can be decided by multiplication. When the amount of seed per quart is to be secured a number of quarts must be averaged owing to the variations usually encountered.

A reliable germination test must include four separate lots of 100 seeds each, or for acorns and nuts four of 50 seeds each; the choice of which seeds to use must be by lot to eliminate absolutely the personal element. After the tests on each lot the results ought not to vary more than 10 per cent for seed with high germination powers nor more than 15 per cent for seed germinating around 50 per cent. Before the germination tests it is customary to soak conifer seeds in sterilized lukewarm water for from 6 to 15 hours. This time counts on the total length of time allowed for germination. For germination Fron recommends a heavy sterilized blotting paper or sand with a Schribaux stove, the humidity being kept at 50 per cent to 60 per cent during the entire test. No chemicals are used. The temperature is maintained between $20^{\circ}$ C. $\left(68^{\circ}\right.$ F. $)$ and $30^{\circ}$ C. $\left(86^{\circ}\right.$ F. $)$; for conifers Fron recommends a temperature of $20^{\circ} \mathrm{C}$. to $25^{\circ} \mathrm{C}$. $\left(68^{\circ} \mathrm{F}\right.$. to $77^{\circ} \mathrm{F}$.) during 18 hours, and $25^{\circ}$ C. to $30^{\circ}$ C. $\left(77^{\circ}\right.$ F. to $86^{\circ}$ F.) during 6 hours, but Schwappach recommends $25^{\circ} \mathrm{C}$. and $30^{\circ} \mathrm{C}$. $\left(68^{\circ} \mathrm{F}\right.$. to $86^{\circ} \mathrm{F}$.), respectively. Maritime pine can stand up to $35^{\circ} \mathrm{C}$. $\left(95^{\circ} \mathrm{F}\right.$.) for short intervals. Ordinarily no light is admitted, but alder and birch appear to germinate more

${ }^{5}$ In Germany the sampler (Sonde) of Professor Noble, made by Mathes, of Tharandt, Saxony, has been used with success. 
rapidly if they are exposed to daylight. The official duration for tests has been 30 days for Scotch pine, Corsican pine, spruce, larch and most conifers, willow, alder, elm, hornbeam, maple, oak, and beech, and 42 days for maritime pine, aleppo pine, mountain pine, fir, and white pine ( $P$. strobus).

After these tests are completed note is always made as to how many of the ungerminated seeds are still fresh, but these figures do not enter into the calculation of cultural value.

To obtain the actual sowing value of any seed the product of the coefficient of purity and the germination per cent is divided by 100 . The germinative energy is measured by the number of seeds which have germinated after a fixed period, which is usually 10 days for species germinated for 30 days in all and 14 days for those requiring $\mathbf{4 2}$ days to complete the normal tests.

The following variations are allowed in deciding whether to accept purchases or not: For germination per cent, 5 per cent for species running 90 per cent and more; 8 per cent for species less than 90 per cent; purity, 2 per cent and 3 per cent; cultural or real value, 6 per cent and 9 per cent. As Fron remarks, "If the cultural value were guaranteed at 80 per cent but showed only 70 per cent or less, the seed could be accepted." For American conditions such percentages set too high a standard; they should be at least 10 to 20 per cent less.

The water content of samples is found by taking 10 to 20 grams (0.3 to 0.6 ounces T.) and maintaining it for three days at a temperature of $105^{\circ} \mathrm{C} .\left(221^{\circ} \mathrm{F}\right.$.). The loss in weight after being dried gives the desired per cent when divided by 100 .

The station record shows how the tests were made, the amount of seed received and actually used, date seed was shipped and received, how packed, and conditions after transport.

Rules for Seed Control. - French foresters have tried to have all sales of tree seeds controlled by the State so that buying, would be done on the basis of cultural value rather than on a gamble, but as yet no such regulation is in general force. The proposed rules to govern the analysis and control of forest tree seeds are as follows:

"Article I. - Name of method of analysis and of control.

A. The aim of the analysis and control of forest seeds is as follows:

1. To centralize everything touching on the study, analysis, and control of forest seed.

2. To contribute to the continuous improvement of collected forest seeds sold or utilized in France, based on the results of authentic samples of different kinds and by researches on the physiologic growth, selection. and variety with the aim of practical results.

3. To contribute to the study of exotic forest species by experiments carried out on the seeds locally and in arboretums and experimental plots. 
B. So far as the analysis and control of forest seeds is concerned the experiments will determine:

1. Correctness, so far as possible, of genus or species.

2. The purity.

3. Absolute weight.

4. The actual weight in case demand is made.

5. Germinative figure and germinative per cent.

6. Water content.

The experiments must be carried out in conformity with exact technical methods. The experiments with knife without being proved by germination may suffice for the large seeds (cembric pine, oak, beech, etc.), but give only approximate results. The results given by the experimental service are obtained by experimenting with average specimens, that is to say that the advertisements of the analysis executed by the experimental service cannot be utilized by the vendor as exact data on the value of a given purchase.

Article II. - Control of the sale of forest seeds.

1. Analysis of control. Contract houses (with the aim of controlling the sale of forest seeds) and experimental service can conclude contracts with seed merchants entitled contracts of control. The list of houses placed under the control of the experimental service can be mailed free to persons who demand it. It may be published. The conditions of these contracts are as follows:

A. The house promises to observe the rules in every particular.

B. The house engages to indicate on the bill the guarantees for the merchandise sold and delivered to the purchasers under the conditions given in the certificates of control and to furnish, at the expense of the house, an analysis of control.

C. The purchasers of seed from a controlled house acquire, if purchasing the minimum amount stipulated, without further formality and without special authorization, the right to have a free analysis by the experimental bureau of the material purchased.

D. The controlled houses must agree that the analysis made by this bureau shall be final for the purposes of fixing the amount of the bill. If the results of the analysis do not correspond with the guarantee given, they promise to make it up to the purchaser.

E. The houses controlled do not pay any annual charges to the testing bureau . . since the expenses are borne by the Maison de Commerce. . . .

F. The houses which do not guarantee to their purchasers free analysis or which do not even give a limited guarantee cannot be admitted as houses controlled by the bureau.

G. The controlled houses are forbidden to furnish several certificates of free analysis for a single sale of the same sort of seed. Each certificate is valuable only for the special sale for which it has been delivered.

$\mathrm{H}$. It is forbidden to insert in the contracts of control any stipulations concerning the probable analysis cost. The analysis of this kind must be paid for according to the tariff." 6

"Such a system of general seed control is needed in the United States. Under present conditions a private purchaser of forest tree seeds has no guarantee of the real 


\section{NURSERIES}

Location of Nurseries. - Judging from visits to a number of nurseries (1) near areas under natural regeneration and (2) at regular forestation projects, France has not much to teach us in the minutiæ of modern nursery practice. What there is to learn is chiefly along the lines of policy. For example, French foresters have demonstrated that in the forestation projects in the mountains it is important to have small local nurseries near the area to be forested, while the tendency in the United States has been to maintain large central nurseries from which stock can be shipped. On the National Forests in the United States, according to Greeley:

\footnotetext{
"The policy has been pretty generally adopted of maintaining large nurseries rather than small ones, notwithstanding the shipping cost and the danger of the stock drying out in transit. A few years ago a large number of so-called ranger nurseries were established on almost every Forest, but this proved expensive and unsatisfactory. Many of the rangers wasted time on their nursery work and it seriously interfered with their regular executive duties."
}

At Barcelonnette, in the Basses-Alpes, they have tried three kinds of nurseries: (1) Permanent or central nurseries, (2) so-called "flying" nurseries, and (3) fixed local nurseries.

Permanent or central nurseries are now rare. Small temporary or "Alying" nurseries in or near the area to be sown are extremely popular. After they have produced once or twice and the nearby planting is completed they are abandoned. The small fixed local nurseries, often two or three in each working group, are placed conveniently near planting sites where for a number of years material will be required.

Departing somewhat from this practice, Dinner, an eminent authority on forestation, had very few temporary nurseries in the Maritime Alps because he believed in thorough irrigation, and it was often diffcult to secure a certain water supply near the planting site. Dinner used 1 to 3 year old untransplanted stock and developed a formula to govern the size of his nurseries. For 100 acres of planting site his nursery covered 1 acre or $\frac{\text { planting site area }}{\text { nursery area }}=\frac{100}{1}$. He said that this worked out with remarkable accuracy, and cautioned against establishing nurseries at too high an altitude (where the climate is severe) because of the increased cost of working.

The following general principles have been developed in France to govern the establishment of nurseries:

cultural value. Other commodities, such as lumber, wool, or cotton are sold on the basis of grade or quality. If our export of tree seeds is to grow a definite scheme of seed control will be essential in order to protect foreign purchasers against fraud. 
It is advisable to locate nurseries near the land to be restocked to reduce the inconvenience and cost of transport, provided the climate is not too severe. They are usually established on a bench where the soil is sufficiently deep and fresh, near a brook or a spring, and near a forest house or camp.

The higher the altitude the more the plants may suffer from frost, from throwing, or from the snow; therefore the nursery should not be established at an altitude higher than the average elevation at which the species are to be used; in the Alps and Pyrenees it is rarely advisable to establish nurseries at a higher elevation than 5,600 feet. It must be borne in mind that the growing season at high altitudes is very short, the growth is slow, and the dangers from snow, etc., considerable. Nurseries in the Cévennes or the Central Plateau are rarely higher than 4,600 feet.

If it is necessary the plants can be transported and heeled in where they are to be used at high altitudes the autumn preceding field work; or they can be heeled in at the nursery itself in order to retard vegetation where nurseries are situated considerably below the planting area. One should not hold stock at the nursery for later shipment into higher altitudes if the nursery is much lower or on a warmer site. Ship earlier and heel in where they are to be planted.

The usual nursery practice in regions where regular reforestation work is carried on is as follows: The soil is cultivated to a depth of 16 to 20 inches, leaving the humus near the surface, and the French policy is to use plenty of fertilizer-either manure or any standard chemical type of plant food. As much vegetable mould as possible is retained in the soil. It favors the seedling, the transplant, and all other forms of vegetation, and sometimes doubles the growth. Usually sowing is in strips 2.6 to 3.9 feet in width according to the slope; the sowing on the strips is usually in drills about 1.1 inches apart. Conifers are covered with about 0.4 inch of soil. To conserve the freshness of the soil the area sown is often covered with one layer of moss or pine needles. Sometimes flat stones are placed between the drills to prevent throwing and to conserve the moisture. Before germination the seeds are protected against birds; weeding is done as required. As a protection against the sun in summer lath shade frames are used or else branches are stuck in the ground at each side of the strips and inclined toward the center. As a rule, the simplest possible methods are followed.

Nursery Practice. - One moderate watering is favored and then only when the germination is being hindered by drought or the health and vigor of the plants require moisture. But much irrigation washes the soil, decreases its fertility, and exaggerates the growth of the plants, so that later they are all the more susceptible to drought. Irrigation 
should be followed by cultivation. Yet it should be noted that Dinner departed from this policy in the Maritime Alps where the climate is especially dry.

The object is to produce nursery stock which will have: ?

"1. A complete well-developed root system, with regular and numerous rootlets.

"2. A straight regular stem, a well branched and vigorous crown with lateral branches proportionate to the age of the stock.

" 3 . Foliage or buds complete and well-formed.

"4. A healthy appearance, the stem and roots without any wound or suspicious scars."

Two Sample Nurseries. - A model nursery representing the best of French nursery practice ${ }^{8}$ is to be seen at the Barres Secondary School for Rangers. The seed here is carefully stored. It is left in sacks no longer than necessary and is frequently shifted so as to be thoroughly aërated. As a general rule, the scales and débris are kept with the seed, approximating the natural method of leaving the seed in the cones, which is recognized as the best. The nursery consists of twenty-seven plots, each 0.037 acre in extent, with two-thirds in cultivation and onethird in paths. The work is very systematically arranged. Every year one plot is sown, another transplanted, while the third furnishes the plants for shipment after a year in the transplant beds. Each plot consists of ten strips 33 feet long and 3.3 feet wide, separated by 2 -foot paths. Each strip has six lines of plants, single or double, separated by 6.3 inches from axis to axis with a margin on the edge of 3 inches. The sowing for most species ${ }^{9}$ is done as early in the spring as possible, beginning not later than March 15.

An annual is usually sown and plowed in once every three years to enrich the soil. A very simple sowing board is used, V-shaped (double or single), and about 1 inch deep. This is merely pressed in the ground in a straight line and the seed distributed along the bottom of the depression thus made.

The beds are protected against birds and rodents by small frames 4 inches high covered with 1-inch, or smaller, wire mesh. The frames are covered with a few branches for protection against the sun for six to eight weeks after the seed has germinated. Rodents have been successfully destroyed by strychnine which was mixed with flour, placed in a pan, and covered to protect it from the rain. Very little success has resulted from treating oak acorns; the general policy is to kill the rodents rather than to prepare the seed so that it will not be eaten. Stones are often placed between the transplant lines to hold the moisture in the

${ }^{7}$ See Boppe, pp. 349-392.

${ }^{8}$ From notes supplied by the director of the school.

${ }^{9}$ A species like silver fir would be sown in the fall. 
soil and prevent throwing. As a general rule, untransplanted stock is recommended in big planting operations, 2 to 3 year-old conifer seedlings being preferred. Transplanted stock, on the other hand, is used to complete natural regeneration. Here the cost is less important because only a small percentage of the total area need be planted and better success is secured, since it is less likely to be crowded out. The plants are never pulled and are not watered before shipment because of the danger of heating while en route. Baskets or open boxes are generally used for shipping.

It should be borne in mind that large nurseries, such as the one just described, are no longer numerous, many of them having been abandoned in favor of small local nurseries near the planting site. Much more typical is the small local nursery at Royat in the Central Plateau, which is situated in a narrow valley on a 6 per cent west slope. The main product here is 3-year-old spruce fir or Scotch pine seedlings. There is no transplanting, since it is considered too expensive. The fir is sown under lath frames 6.5 feet wide and placed 2.5 feet above the soil and the pine is sown in drills spaced 3 to 4 inches apart. Shade frames, 10 to 12 inches above the ground, are used for the Scotch pine also during the heat of the first year.

\section{PLANTING}

Cultivation and Spacing. - In planting, Jolyet says "cultivation should usually be considered indispensable - always advantageous." The great aim of planting is the use of the most economical local means to get the roots in touch with the humus and the soil. Complete cultivation is, of course, never necessary and would only increase the danger of erosion. Planting trees in horizontal strips is often advantageous in dry regions, but the general preference of the forester should be for holes or spots. As a rule, the French favor much wider spacing in plantations than do the Germans. Bartet even suggests spacing spruce 6.5 feet apart owing to its superficial root system and in order to give the crown a chance for development. In Germany the average distance for spacing spruce is usually 4 feet and sometimes closer. The French rule is never less than 3.3 feet and never more than 10 feet. Intolerant species like maritime pine can be spaced wider apart than a tolerant species such as fir; and as a general rule, rapidly growing species can be spaced wider than species that are slow growing during the seedling and sapling stages. Ordinarily the spacing is 5 to 6.5 feet. It is certainly apparent, without going into further detail, that the French system is more in accordance with American practice, namely, wide spacing and comparatively few trees per acre as contrasted with the close spacing in Germany. 
Age of Plants. - "In every conifer plantation aimed at restocking mountain slopes you should follow the principle of having the plants as young as possible."

The ages indicated below vary according to the nature of the species, the altitude of the nursery, and according to whether the plants are transplanted or not: Cypress, 2 to 3 years; fir, 3 to 4 ; spruce, 3 to 4 ; larch, 2 to 4; cedar, 2 to 3; Scotch pine, mountain pine, Corsican pine, Austrian pine, and Cévennes pine, 2 years (occasionally 3); aleppo pine, preferably 1 year (sometimes 2); cembric pine 3 to 5 ; ash, 2 to 6 ; beech, 1 to 5 ; chestnut, 1 to 4; sessile oak, 1 to 4 ; other broadleaves, 2 to 6 . Older plants, 4 to 5 years old, are used in certain limestone soils where the ground is badly heaved by the frost, on very steep slopes where snowslides are feared and where the plants may be torn out if they are not deep-rooted, and also on unstable shallow ground where there is dariger that the young plants may be covered with débris already eroded. The natural larch stock secured from neighboring stands is usually ball-planted at 5 to 8 years of age.

At Barcelonette (Basses-Alpes) the local rule still holds that the younger the plants the better the success. Austrian pine is ordinarily used at 2 to 3 years of age with 4 to 5 year plants on exceptionally difficult and steep talus. Larch and mountain pine are used at 2 years of age and cembric pine at 3 to 5 years, the stock rarely being transplanted. (See also p. 165.)

Time to Plant. - It has been found best to plant coniferous trees in the spring because the soil is then fresh and the plants will have one whole growing season for development before the severe autumn weather. If solidly rooted in the soil they can resist to better advantage the frost, erosion, sliding snow, and drought, as well as the wash of heavy rains. The autumn, however, is sometimes used for planting conifers at high altitudes because of the shortness of the working season.

The deciduous species, which are habitually planted at lower altitudes, may be set out in the spring before the beginning of vegetation but ordinarily this is not done until the autumn. Soil and climate have weight in deciding upon the proper season. For example, in the Ardèche the autumn plantations alone give satisfactory results on limestone soils situated at low altitudes. Planting is preferably done also in the autumn in the Aude since frosts are rare at this season and because in the spring there are often prolonged rains which may completely wash out the soil from around the plants. Dinner stated that in the Maritime Alps, in the zone where it does not freeze hard in winter, he can plant in the fall, but higher up in the mountains he must plant entirely in the spring.

At Marseilles in the forest of La Gardiole the best time for planting on 
this limestone soil is in November, December, and January so as to benefit from the late autumn rain.

At Barcelonette autumn planting, especially when done in September or in October, gives very good results in the high altitudes.

Plantations in Holes (or Spots). - While to have a complete stand from the start 4,000 spots to the acre would be required, this number is largely reduced to an extent varying with the region and on the species in order to cut down the cost of forestation and thinning. Dense plantations are reserved for land which presents very difficult conditions on account of the soil or of the climate. The depth and length of the spots is ordinarily 16 to 12 inches, the size being reduced where the plants may be badly damaged by the frost or where the slope is very steep. On difficult slopes the conifers are often planted by the French ${ }^{10}$ in clumps of two to three seedlings; the larch is usually planted single. With transplanted stock the single plants are used in the case of the broad leaves, except that beech is sometimes planted in pairs. Protection is frequently afforded by overturned sod or by stones. According to Dinner, he is obliged by the Paris office to do some sowing, but would otherwise do all his reforestation by planting. The main feature of his planting technique is the size of the holes. The Paris authorities impose a size of 10 inches square, but Dinner uses 16-inch "spots" and even larger if the ground is bad. He feels that the secret of success is in large spots which hold the moisture, whereas small spots would be dried out. On large areas he plants strips of broadleaved trees as future fire belts. Where there are 1,600 to 2,000 plants per acre the whole expense is $\$ 10$ to $\$ 12$ per acre with labor at 70 to 80 cents a day. The average loss through his inspection is 25 per cent, some seasons being almost nothing, but other years 60 to 70 per cent. At Barcelonette the planting in spots or-in bunches (that is, three or four plants to the spot) is favored. They count 2,000 spots per acre and three plants per cluster. This cost (in 1912) $\$ 3.86$ to $\$ 5.79$ per acre without the cost of the stock.

French Planting Technique. - The usual implements employed are the pick, mattock, and shovel. When digging a hole the grass is thrown to the right, the fine soil to the left, and the poor bottom soil in front. When the tree is planted the fine soil is placed immediately around the roots and the poorer bottom soil above. In this way the humus is left where it is most needed to enrich the root system. The French favor the use of stones to protect the planting spot from washing and to protect the surface from drying out; often in extensive planting operations, furrows are plowed to assist the hand work.

${ }^{10}$ See French Forests and Forestry, already cited, especially pp. 41-43, 77-87. This planting of more than one seedling in a spot is distinctly French and would rarely be advisable in the United States. 
Care is, of course, taken to keep the rootlets fresh and moist during the operation, a fundamental of successful planting. The usual method of planting is as follows: A few handsful of fine soil are placed next to the roots while the root collar is held close to the ground. With the right hand the planter fills in the loose soil after arranging the roots so as to lie naturally. The ground is pressed lightly with the hands after the soil is filled in. Soil is usually piled an inch above the root collar to allow for natural sinking. But the French are very careful not to plant too deep since this checks the roots, encourages false roots, and induces rot. On very dry ground, or sand, the planting is cheaper than on very compact moist soils where they rarely plant below the root collar. In very dry regions where rocks are not available, a mound 4 to 12 inches high is often built up on the south side of the plant for protective purposes.

For really difficult planting the French favor ball planting with the ball of earth 3 to 4 inches in diameter. This conserves the moisture, but of course costs much more. It is always necessary that the ball of earth adhere to the surrounding soil, since if this contact is not made the soil will dry out and the beneficial results of ball planting be lost. Démontzey adopted a so-called bush or clump method of planting which is sometimes used in Algeria, in which three or four plants are placed together. This was alleged to be cheaper and surer. Apparently French foresters argued that there was no danger of too many plants and that there would always be one most vigorous plant that would survive in the competition for existence. This method is only used in the mountains. The disadvantage is that, if there are contagious diseases, all plants will be affected and succumb.

In water-logged soil the French prefer ridge planting rather than mound planting. They call a stand planted by the mound method, where it is necessary to pile up 3 or 4 cubic yards of earth per thousand plants, a "plantation-de-luxe." The plowed ridges ordinarily used are much cheaper, since the work can be done on a large scale. Another special method used by the French is the so-called basket method.

"The method consists in excavating a hole (like a cone upside down) 2 to 3 feet wide at the top and 10 to 14 inches in depth; all around the sides of this hole a series of short or average-sized stems (generally broadleaf) are placed 4 to 6 inches apart and placed so that the stems form the skeleton of a basket. Then the whole is filled with loose soil, mixed with humus, if that is possible."

This results in a little green island of trees and is especially useful for planting in torrent beds or on thin soil.

Occasionally it has been found possible to plant profitably on unprepared soil by simply making a hole in the earth with a spade or stick, inserting the plant, and pressing down the soil with the foot. 
Of course this is an exceedingly cheap method. It has, however, the disadvantage of favoring a high percentage of loss. It is only desirable on exceedingly rich or fertile soil where the spade, dibble, or grub hoe can be used to advantage. With very compact clay the method is rarely successful, since the roots will not secure sufficient aerration.

In the forest of La Gardiole, on exceptionally difficult ground, the seedlings are raised in pots and set out directly without disturbing the root system. This system is very expensive. When 2-year-old aleppo pines are planted in pots the stock cost, prior to 1912 , approximately $\$ 4.82$ per thousand trees plus transport; to-day it would be at least $\$ 10$ to $\$ 12$. In the drier localities where sowing by the seed-spot method had been employed, the few surviving seedlings were under the shade of the stone which anchored the branches or under the shade of the stumps or the larger branches. Apparently even better results would have been secured if heavier protective cover had been used. The object of the reforestation project of $\mathrm{La}$ Gardiole was to serve as an example to the surrounding population and if possible to temper the hot climate of Marseilles.

Cover and Protection. - On slopes or soils that are so unstable that forest trees cannot be planted at once it is first necessary to anchor the soil with grass or shrubs. The best shrubs to use are those of rapid growth, since they must be able to take possession of the soil and fight successfully against the effects of erosion. Usually the seed of French grass and rye-grass pure or in mixture is used. The sowing is done in the spring from the top down in order that the lower lines of sowing will not be covered with débris from the higher elevations. Since the seed is so small it is covered with an extremely thin layer of soil. Strips of sod are planted in order to stop the erosion of the surface soil and in order to make possible the growth of trees. These strips or benches of sod are planted horizontally on the slope. In very easily eroded soil, such as the glacial muds, it is often necessary to protect the brush or sod by fascines in horizontal strips. No general rule can be laid down as to when to apply sod and when to use brush, but it is true that shrubs resist erosion better and are often preferable to sod in maintaining certain kinds of unstable ground. The shrubs are sown or planted, layered, or suckered. The hazel may be sown or planted, while the cherry and the alder are planted. The willows and the poplars are usually layered but the aspen and the willow may be reproduced from slips.

It is of interest to note that the seeding of some of these shrubs often takes place naturally after the bed of a stream has been fixed by means of correction works. It often happens, however, that the slopes are too steep to be stabilized by any vegetation. In such cases it is neces- 
sary to wait until the talus can be terraced when it assumes a sufficiently gentle slope to permit this work. The natural talus frequently corresponds to a slope of 67 per cent while, with the use of terraces, the ground can be stabilized up to a 100 per cent slope. (See Chapter VII.)

Species and Methods to Use. - Jolyet ${ }^{11}$ advocates the planting of coniferous stands since they furnish a larger percentage of timber. While he recognizes the force of the argument in favor of mixed forests he favors a coniferous stand with some broadleaves to assist in the preservation of soil conditions and to make natural regeneration more convenient. He recommends the introduction of a very few species of exotics. As for conifers he recommends the planting of spruce and Scotch pine, and where there is a choice as to which of these to plant he prefers Norway spruce on account of its rapid growth and high yield. If for some reason or other so-called exotics have to be introduced Jolyet especially favors the Japanese larch and the Douglas fir. He cites an ideal plantation (made at Nancy by Cuif) spaced 5 by 5 feet, which contained the following species in the ratio indicated: As major species, spruce 44 per cent; Scotch pine, 31 per cent. As secondary species, Japanese larch, 6 per cent; Douglas fir, 13 per cent; "concolor" fir, 3 per cent; beech and sycamore (each one-half), 3 per cent. Total, 100 per cent.

Dinner, head of the "Reboisement" at Nice (which includes the drier portions of the Southern Alps), uses aleppo pine on limestone soil and maritime pine on sandy soil (only) up to 2,100 feet; for altitudes of 2,100 to 4,500 feet he has found Austrian pine (see p. 167) better than Scotch pine, his 20 years of experience having shown that it grows more rapidly and has fewer enemies; above 4,500 feet he prefers larch.

For various soil conditions Jolyet recommends the following species and methods:

TABLE 11.- FORESTATION METHODS FOR TYPICAL SOIL CONDITIONS IN FRANCE $a$

\begin{tabular}{l|l|l|l}
\hline Objective & Product & Species recommended & Methods \\
\hline
\end{tabular}

(1) Areable land

\begin{tabular}{|c|c|c|c|}
\hline For profit & Saw timber & Scotch pine & $\begin{array}{l}\text { April-May. Broadcast } 7 \text { pounds per } \\
\text { sore with oats. Cultivate (plow) in } \\
\text { autumn, again in spring. Harrow, } \\
\text { sow, and harrow in }\end{array}$ \\
\hline
\end{tabular}

a Compiled and digested from Jolyet, pp. 468-520.

" Quelles essences faut-il planter? Par Jolyet. Besançon, 1911, pp. 1-15. 


\begin{tabular}{c|c|c|c}
\hline Objective & Product & Species recommended & Methods \\
\hline $\begin{array}{l}\text { Permanent har- } \\
\text { dy forest with } \\
\text { natural regen- } \\
\text { eration }\end{array}$ & (2) Light areable land \\
\hline
\end{tabular}

(3) Heavy areable land

\begin{tabular}{|c|c|c|c|}
\hline Permanent forest & Saw timber & Oak in deep soil & $\begin{array}{l}\text { Sow May } 1 \text { to } 31 \text { in plowed furrows, } 2 \text { to } \\
3 \text { inches deep and } 5 \text { feet apart, } 480 \\
\text { pounds of acorns per acre }\end{array}$ \\
\hline
\end{tabular}

(4) Brush and pasture land

\begin{tabular}{|c|c|c|c|}
\hline Permanent forest & Saw timber & Scotch pine & 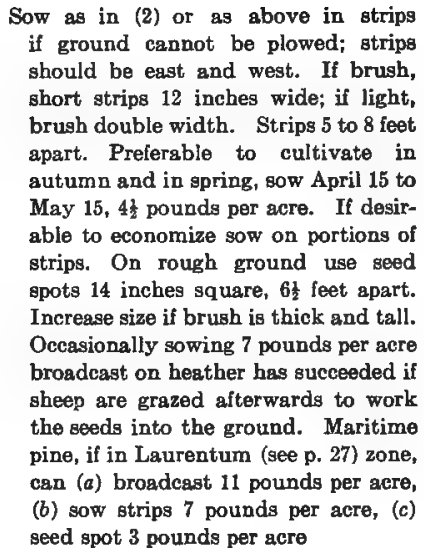 \\
\hline
\end{tabular}

(5) Barren land (dry and hilly) ${ }^{b}$

\begin{tabular}{|c|c|c|c|}
\hline $\begin{array}{l}\text { Reclamation and } \\
\text { soll cover }\end{array}$ & $\begin{array}{l}\text { Of secondary } \\
\text { importance }\end{array}$ & $\begin{array}{l}\text { Few apruce or larch or Scotch } \\
\text { pine, best sites with Aus- } \\
\text { trian pine as major species. } \\
\text { Sometimes Scotch pine can } \\
\text { be used more freely. Use } \\
\text { beech, maple, linden, horn- } \\
\text { beam, willow, alder, etc. In } \\
\text { mixture according to condi- } \\
\text { tions. }\end{array}$ & $\begin{array}{l}\text { Plant } 5 \text { by } 5 \text { feet. Take advantage of } \\
\text { favorable pockets of soil. Use grub } \\
\text { hoe and work soil well } 3 \text { to } 8 \text { woeks or a } \\
\text { season ahead of planting. Plant in } \\
\text { autumn preferably. Must be finished } \\
\text { before April 1. Holes should be at } \\
\text { least } 10 \text { inches square. Fill in with } \\
\text { humus. Dirt put under sod, then sod, } \\
\text { and lastly the dirt from bottom of } \\
\text { holes. Cover with flat stones. Plant } \\
\text { on still day }\end{array}$ \\
\hline
\end{tabular}

${ }^{b}$ For example, see Jolyet, pp. 467-468

(6) Bogs and swamp land

\begin{tabular}{c|c|c|c|c}
\hline $\begin{array}{c}\text { Reclamation and } \\
\text { drainage }\end{array}$ & $\begin{array}{c}\text { Of secondary } \\
\text { importance }\end{array}$ & $\begin{array}{c}\text { Alder, birch (white pine), } \\
\text { mountain pine, Murray pine } \\
\text { (Scoteh pine where layer of } \\
\text { alios) }\end{array}$ & $\begin{array}{c}\text { Mound planting (or perhaps plow 2 fur- } \\
\text { rows and plant on upturned ridges of } \\
\text { earth) }\end{array}$ \\
\hline
\end{tabular}




\begin{tabular}{l|c|c|c}
\hline Objective & Product & Species recommended & Methods \\
\hline Woodlots & Fuel & $\begin{array}{c}\text { Hornbeam, acacia for alder } \\
\text { on fresh soil) }\end{array}$ & $\begin{array}{c}\text { Brosdcast with easy natural } \\
\text { regeneration }\end{array}$ \\
\hline
\end{tabular}

Chief Dangers. - The dangers to sown or planted seed arise mainly from drought, mammals, insects, and birds. For rabbits, a source of much damage in France, it is considered necessary to fence with wire mesh usually 3 feet high, the barrier leaning away from area protected, and sunk 8 to 12 inches under the ground. Mice and other small rodents are killed with poisoned oats or barley. For birds poison is used, or in the case of seed spots, a cover of wire mesh. To avoid damage from drought, deep, large, well-prepared holes are used in planting, and the young trees protected with flat stones; these holes or spots must often be protected under especially unfavorable conditions by a layer of brush.

\section{FIELD SOWING}

Prepared and Unprepared Soil. - When sowing is attempted soil preparation is usually necessary to give the young seedlings a start against weeds and grass. The previous vegetation must often be removed and the soil cultivated. This cultivation enables the soil to absorb water, diminishes evaporation, and permits the rapid development of the root system and relieves the young plants of competition with weeds for water. Soil preparation, on the other hand, increases the danger of the young plants being frozen or thrown, and in light soils, especially on slopes, may result in erosion. Seed may be broadcasted, as in ordinary agricultural practice, after the surface of the ground is cleared. For broadcast sowing, cheap seed is a necessity.

Sowing in patches is merely localized broadcast sowing. This method is a convenient means of supplementing partial failures in natural regeneration, and is especially useful in introducing more valuable species into a natural stand, which varies a great deal in quality, since it permits the choice of the best spots and the adaptation of the proper soil. Seed spots are considered economical, but there is always considerable danger from mammals and from weeds. Sowing in continuous or broken strips requires less seed than broadcasting, and there is less danger from the uncleared areas. The sown strips are 20 to 40 inches in width with 3 to 10 feet of uncultivated land between the strips. On level ground or gentle slopes, it is the custom to run the lines east and west, but always horizontally on slopes above 7 or 8 per cent. Where there is danger of water collecting, the lines must be broken, even on horizontal strips. There will then be 16 to 20 feet of sown strip separated by 5 to 10 feet of unsown strip. 
Where the sowing is on unprepared soil the ground must be loose, the seed must be cheap, and the growth of the species sown rapid, so that it can protect itself against the weeds. The best example of successful broadcast sowing on unprepared soil is the sowing of maritime pine seed on the sand dunes of the Landes and Gascogne. Another well-known example is on the Central Plateau where Scotch pine has been successfully sown without any advance soil preparation. Occasionally, the sowing has been followed by sheep grazing, in order that the sheep may eat out the heather and let the seeds get to the soil. The hoofs of the sheep cover the seed sufficiently, but failures following this method are even more frequent than successes. According to my original notes,

"At Cleremont-Ferrand in the Central Plateau Scotch pine region one of my friends mentioned a former method used for the cheap artificial stocking of Scotch pine by broadcast sowing. The seed was sown plentifully in the fall and during the winter rains sheep were allowed to trample the seed into the sod. The results I saw were very good, but I found no one who had practiced it himself."

Sowing without soil preparation outside the Landes is best justified on rocky soil in the mountains, at the foot of cliffs,-in other words, where cultivation is impossible. If the soil is fresh and there is no fear of mice and grass, broadcast sowing is often successful after snowfall (see p. 136) or on the bare soil. One advantage is that it can be done when other work is impossible. When sowing on rocky ground the seed should be thrown up hill from below so that it will get some protection under the rocks. Where there is danger of erosion, broadcasting should not be attempted.

There are a number of short-cut sowing methods which find favor in France and which are well known in the United States, such as hoeing the soil and covering the seed; dibbling to complete regeneration; at high altitudes, where the ground is fresh and where regular cultivation is impossible or difficult, the dibbling or cane method of sowing (see p. 167) may be advisable.

On the whole, these special broadcasting or planting methods are justified only where made necessary by peculiar conditions and rarely are as successful as really thorough soil preparation.

Amount to Sow. - The amount of seed to use naturally varies with the soil, slope, and local climate, and also, of course, with the size of the seed, quality, method, and season of planting. The amount sown must be increased if there are droughts, frost, or mammals to allow for prospective losses.

The sowing figures used by the French foresters are shown in the following table (after Boppe): 
Season for Sowing. - The natural time to sow is when nature sows, but this is often impossible owing to the price of labor and the difficulty of seed collection. The best season for sowing seeds ripening toward the end of summer is the autumn or winter. This has the additional advantage that the seeds germinate early in the spring and get the start of the weeds. The spring gives the best results when species germinate quickly and when there is danger from rodents.

The directions for sowing which are standard in France have been summarized in the following table. It covers the more important species only:

TABLE 13.- SEASON AND METHOD OF SOWING CHIEF SPECIES

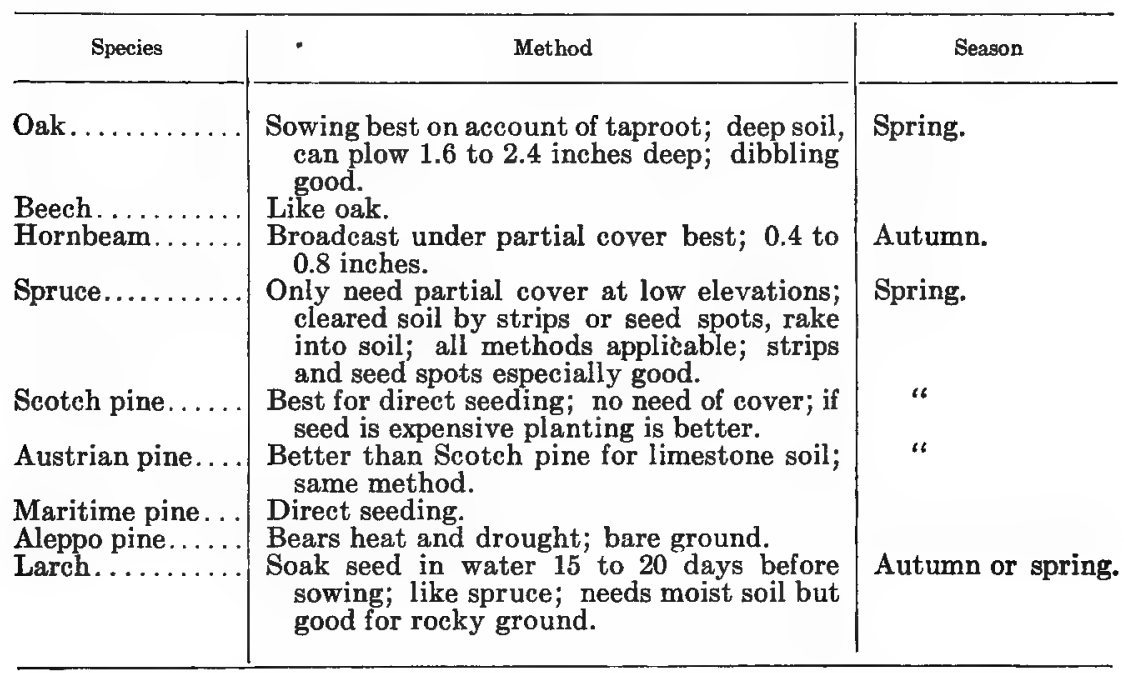

Summary of Sowing Methods as Applied to Species and Regions. In the Alps at high altitudes the sowing of larch, mountain pine, and cembric pine is usually done with seed spots or furrows of variable size. In the seed spots three to four seeds of cembric pine are planted, and eight to ten of larch or of mountain pine. They are then covered by hand. In the furrows one or two seeds per running 0.4 inch of soil are sown. In the case of the larch it is especially necessary to sow strictly according to the germinative per cent, which often varies from 40 to 70 . The amount of soil needed for covering depends on the size of the seed. Larch and mountain pine are covered with 0.4 inch of soil, while cembric pine seeds are covered with 0.8 inch. Seed bought in the autumn is sown the following spring. The spring sowing, while securing the benefit of the heat and humidity favorable for germination, does not always resist the summer drought. Autumn sowing of ten gives the best results because the seed can germinate early in the spring, thus getting a start 
over the seed sown later. Broadcast sowing in the spring on snow where the mineral soil is bared often succeeds. According to my original notes:

"Another special method of sowing was illustrated by a splendid larch stand near Barcelonette. Here European larch was sown broadcast before or during a snow storm. The moisture conditions here, however, are much better than in many parts of the western United States where we have tried this method without success. Perhaps one reason we have failed is that the French soak the seed in water for about a week (larch three weeks) before sowing so that it will germinate. We might try this out on a small scale. I am still convinced that we should not try to sow on our most difficult ground; that for the very worst soil we must use spots or a substitute (such as ball planting), but that the cost will be prohibitive for some years to come."

In the Ventoux sessile and holm oak are sown. Eight hundred to 1,600 seed spots each, 12 inches square and 12 to 16 inches deep, are sown per acre with 60 to 120 quarts of acorns. Shrubs are placed as a shelter over the seed spots and as a further protection stones are heaped up to the south side. In each seed spot the fifteen to twenty acorns are covered with 0.8 to 1.1 inches of soil; this depth is varied. The sowing is generally during November and December after the collection of the acorns and before the frost, or, if it is not done at this time, in February and March. In the Basses-Alpes seed spots are used for sessile and holm oak and aleppo pine, species of a temperate climate. These seed spots are 10 to 14 inches deep and in each spot are placed five to six acorns or eight to ten pine seeds. The sowing is generally in the autumn. In the Maritime Alpes aleppo pine and maritime pine are sown in seed spots in the spring; 2,400 seed spots per acre are prepared 16 inches square and 12 to 18 inches in depth. The same method is used for sowing chestnut and oak. In the Cévennes and Central Plateau strip sowing is sometimes employed.

In the Var (near Marseilles) the conditions are unfavorable to tree growth. There are rains from September 15 to December 15, and from February 15 to April 15 . The great drought occurs in June and it is somewhat dry during the short winter season. During a hot summer day the temperature rises to $37^{\circ} \mathrm{C}$. $\left(98.6^{\circ} \mathrm{F}\right.$.), and during the night it rarely falls below $25^{\circ} \mathrm{C}$. $\left(77^{\circ} \mathrm{F}\right.$.). The soil is limestone and once bared of tree growth is difficult to restock. Under these conditions there is but one method of artificial restocking with aleppo pine. The sowing is done in large seed spots, 3.3 feet long by 1.6 feet in width and 10 to 16 inches in depth. The whole seed spot is sown thickly, so that often as many as ten plants germinate in one spot, but because of drought few survive after a year or so. Immediately after sowing the surface of the seed spots is covered with brush held in place by rocks. This brush protects against rodents, heat, and wind. The top of the seed spot is usually left 0.8 to 1.2 inches below the rest of the ground in order to collect moisture. 
In the Puy-de-Dôme ${ }^{12}$ seed spots are often used, protected by bunches of brush or scattered in the coppice stands which are being improved. In the first case oak or pine is sown pure or in mixture; in the second, oak is sown with beech.

In the Haute-Loire stands of spruce, Scotch pine, mountain pine, and cembric pine have been obtained by means of broadcasting or by seed spots. The Scotch pine is usually broadcasted and the other species sown in seed spots 3.3 to 6.6 feet apart. These species do not give as good results as would the fir if there were the necessary protection available. In open beech stands Scotch pine or mountain pine is often sown in strips 14 inches in depth and 16 inches wide, the length depending on the size of the opening. Sometimes these strips are cut into seed spots 16 inches square. In this region sowing is done in the spring or even later, toward the middle of May. The amount of seed used is about 9 pounds per acre. It is sown generously and covered lightly with loose soil. After the sowing seed spots are covered with branches which are left until the beginning of the autumn. The seed spots are visited in the following spring or autumn in order to free the young plants of leaves or dead needles which cover them.

In the Lozère (Central), Aveyron, and the Corrèze broadcast sowing of Scotch pine generally succeeds on sandy soil partially covered with short heather, but poor results are certain on land occupied by genista and tree heather. Success is best assured by opening up seed spots only 2 inches square in the midst of the heather in order to avoid heaving by the frost. Near Nîmes maritime pine has been successfuly reproduced by broadcasting 7 pounds per acre on heather in the autumn just before the winter rains. The heather is then cut and for protection the litter left as it lies. Sowing of this kind is done very late in the spring just before hot weather. In the department of the Lozère there is also sowing of oak and chestnut. The slopes are generally not excessive and the seed spots are opened up in the spring and in the autumn are sown with acorns and chestnuts, despite the damage usually done by rodents; 3.4 bushels of acorns or chestnuts are used per acre for 1,000 seed spots.

In the Gard and Hérault, Scotch pine, Corsican pine, and maritime pine are sown in seed spots in the spring; chestnuts and acorns in the fall. The seed spots are 12 to 16 inches square and 6 inches deep. It takes 6 pounds of conifer seed or 3.4 bushels of acorns or chestnuts per

12 Digested from Démontzey. Elers Koch, of District 1, U. S. Forest Service, once wrote me: "It makes me weep to think of all the good money used in feeding pine seed to the chipmunks. . . . If there is going to be any money spent on the Lolo Forest for reforestation, it is going to be for good strong nursery stock, and we will have something to show for it." 
acre. In the Aude the sowing is done with seed spots in the autumn, the spring being generally too rainy and day laborers too difficult to secure. Sixteen hundred to 2,000 seed spots, 12 to 16 inches square and 12 inches deep, are used per acre. This takes 60 to 80 quarts of acorns or 120 quarts of chestnuts. The conifer seed, such as Scotch pine, Austrian pine, or aleppo pine, is sown at the rate of 2.2 pounds per 1,000 seed spots. Fir seed is also sown in the autumn in seed spots 4 to 5 inches square and 3 inches deep, 800 to the acre where there are open beech or pine stands.

In the Pyrenees, in the eastern part, sowing is used only for sessile and holm oak and in order to introduce fir under the shelter of other species. The seed spots, about 1,000 per acre, having the same size as those in the Aude, are sown with fifteen to twenty acorns each. The young seedlings obtained are cultivated. The stones which may cover them are removed and every 2 or 3 years trees or brush which suppress them are removed until they reach the age of 8 to 10 years, when the young stands are cut back, after which they grow very rapidly. The cost of sowing depends on the region, on the method, and on the kind of seed. As an average the cost of day labor per acre for broadcast sowing was 46 cents, $\$ 1.73$ for sowing with a very light soil cover at high altitudes, and $\$ 2.31$ to $\$ 4.62$ for sowing by seed spots. To this expense must be added the cost of the seed, 41 cents to $\$ 1.07$ per bushel for acorns or chestnuts and 44 cents to 88 cents per pound for conifer seed. To-day all these prices are double or triple - or even more.

According to one authority ${ }^{14}$ maritime pine will not grow if the soil is more than 4 per cent lime, but ordinarily the reproduction is easy on bare soil, since the seed is both winged and abundant. With 75 per cent germination and broadcast sowing it takes about 10.6 pounds of seed per acre, with strip sowing 7 pounds, and with seed spots 4.4 pounds, but these figures may be doubled or tripled under unfavorable conditions. Where sowing fails it is often customary to fill in by planting, which can be successfully done if the seedlings planted are 1 to 2 or more years old.

On the Combre dune the sowing was 9 pounds per acre of maritime pine, 8 of "genista," and 3.5 kilograms of "gourbet." (See p. 182 for additional data on sowing sand dunes. $)^{15}$

${ }^{14}$ La Forêt, par L. Boppe, pp. 47, 205, 206, 332-341.

${ }^{15}$ In 1912 a member of the U. S. Forest Service raised the following questions regarding the French forestation practice:

1. Question. - Is there any way to treat refractory seed to make it come up the first season? Answer. - See p. 119.

2. Q. - What methods and tools do they use in nursery transplanting? A.Seedling stock is usually preferred; transplanting methods have not been systematized as in Germany. See pp. 123, 124. 
SOWING METHODS AS APPIIED TO SPECIES AND REGIONS 139

3. Q. - What fertilizer do they use in seed beds? How much? A. - Ordinary commercial fertilizers in quantities determined by local soil conditions. See p. 124.

4. Q. - What sort of packages are used for shipping nursery stock? Is stock puddled? A. - See p. 125.

5. Q. - What ages of nursery stock are chiefly used? A. - See p. 126.

6. Q. - What spacing is generally adopted in planting? If we assume that we cannot thin are we justified in spacing widely? $A$. - See p. 125. The French justify wide spacing even with intensive thinnings.

7. Q. - Just what tools and methods are used for field planting? A. - See pp. $127,128$.

8. Q. - Is pine seed generally sowed broadcast or in drills in the seed beds, and why? A. - See p. 124. Cultivation is easier and it takes less seed.

9. Q. - Do they use much seedling stock or transplants in conifers? A. - Seedling stock is very much preferred because it is cheaper.

10. Q. - What spacing and arrangement of transplant rows is adopted? Do they irrigate transplants? A. - See pp. 123, 124.

Since the officer who raised these questions had the supervision of a very large and important nursery it is desired to emphasize their importance by special page references. 


\section{CHAPTER VII \\ CONTROL OF EROSION IN THE MOUNTAINS}

French Policy and Summary of Reporestation (p. 140). Introduction, Historical Summary of Legislation, Law of 1882, Statistics of Reforestation.

The Damage (p. 147). Erosion and Precipitation, Rocks and Soils Easily Eroded, Definition of a Torrent, Formation of Torrent Gorges, Causes of Torrents in Mountain Forests, Damage Caused by Torrents.

Corrective Measures (p. 153). Policy and Summary, Technique of Dams, Walls and Protection Against Avalanches, Rock Drains, Paving Channels, Tunnels and Aqueducts, Wattle Work (Garnissage), Forestation, with examples.

Typical Reforestation Areas (p. 168). Regions.

\section{FRENCH POLICY AND SUMMARY OF REFORESTATION}

\section{Introduction. - According to Daubrée, the Minister of Agriculture:}

"The Waters and Forests agents charged with the application of the laws which affect to such a high degree the national safety and property will, in the performance of their duties, continue to use the most absolute devotion and will show, as in the past, that they are worthy servants of the republic."

The Minister thus emphasized the responsibility and efficiency of the officers on reforestation work because he realized the direct bearing of forestation in the mountains of France on the future prosperity of the rich valleys many miles from the watersheds now being forested.

Moreover Huffel remarked: "The case of the forest is special because the abuse can continue a long time before the consequences become evident." According to an official report: ${ }^{1}$

"The opinion of the (local) population is profoundly modified; confidence has taken the place of enmity. Communes, of whom a large number were formerly refractory, struck with the advantages of reforestation, assured, moreover, by the moderation and by the spirit of broad conciliation of the Forest Service, ask for the execution of work (in this locality) at home. This is an omen of happy augury which cannot but encourage the administration to persevere in the way outlined in order to regenerate the mountains and assure the safety of the rich valleys."

The necessity of forested mountains has always been recognized, states an official report. Bernard Palissy (1510-1590) advocated the protection of forests; he paved the way for Surell, Cézanne, Gras, Bréton,

1 The material on reforestation is taken mainly from "Restauration et Conservation des Terrains en Montagne," Volumes I and III, 1911, and from Démontzey's
treatise on "Reboisement." 
Mathieu, Costa de Bastelica, and, finally, Démontzey, whose reforestation work for France will never be forgotten.

There is always greater rainfall in the mountains than in the plains; ${ }^{2}$ this favors erosion on the one hand, but on the other is more favorable to tree growth. This greater rainfall is due to the well-known effect of the colder air on the moisture-laden atmosphere, as it is forced to rise on meeting a mountain range. But, when an altitude of about 6,500 feet is reached, the rainfall begins to decrease again, and only scattered trees or groups of trees are found. The distribution of this rainfall has an important bearing on the problem of reforestation. Up to $45^{\circ}$ north latitude the rain is evenly distributed, whereas in the south there is little moisture in summer, the rainfall being evenly distributed between winter, spring, and autumn. But in the Alps the climate seems to have become drier, a fact due, as some authors say, "to the intervention of man" though others say it is because the air has really become drier through climatic changes. Possibly these two views can be reconciled. The Waters and Forests Service says:

"The direct intervention makes itself felt in mountain regions by felling trees along the forest limits, by unregulated grazing, and in certain places by too conservative forest fellings, as M. Thirion has indicated."

In the mountains the forester must avoid leaving too many trees which would become overmature and at the next felling could not assure the perpetuation of the forest, because, if the stand has not been opened up while the trees are vigorous, it is certain that regeneration will not be complete; and if at the same time, as happens only too often, the forest has been opened to grazing, its ruin has been completed through having too few trees and trees of very mediocre quality. To this fact can be attributed the so-called receding of the forest growth in the high mountains. The stand not having been thinned when the trees were vigorous and healthy and grazing not having been forbidden, surfaces covered with old stands have not been able to reseed and the forest has been forced to disappear. M. Flahaut says:

"In the lower mountains the passage of the plains climate to that of the heights is at first favorable to tree growth. As you rise, the pressure diminishes, the capacity of the air in water content is less, the rains are less frequent and less abundant, the heaviest winds increase the transpiration. These conditions are unfavorable to tree growth; when extreme they become fatal and completely prevent it; they are on the contrary favorable to herbaceous growth. Commencing at a certain altitude, which varies according to the geographic situation of the mountains, according to the climatic conditions, and even according to the topographic detail, the tree growth is then impossible."

${ }^{2}$ A brief summary of the campaign for forestation in its broader sense will help to an understanding of French sensibilities on the deforestation caused by the Great War. The statement by the French Government has been followed, for it gives the official viewpoint. 
Historical Summary of Legislation. - The first complete law on reforestation dates from July $28,1860 .^{3}$ Up to that time methods of preventing flood damage had been tried out locally and sporadically, "most active when the catastrophies took place, weakening as the remembrance became effaced."

The disastrous inundation of 1840 brought the problem to the front. In 1846 a proposed law "relative to the reforestation of the mountains and the conservation of forest soil" failed to pass the Chamber of Deputies. It was considered too drastic and provoked numerous objections because of economic questions, aiming especially at the grazing industry, which it aroused and antagonized. The bill was retired several months after it was presented, and for ten years a means of combatting inundation was not considered further. A veritable cataclysm was necessary to bring up the question anew. In June, 1856, terrible floods ravaged the valleys of the Rhine, the Loire, the Rhône, Garônne, and the Seine, causing the loss of a great number of lives and doing damage amounting to more than $\$ 38,600,000$. A law had been made in 1858 for the defense of towns against floods, but it was not until July 28,1860 , that the law on the reforestation of the mountains was passed. It was received with great disfavor by the grazing interests. "The reforestation," they said, "would do away with grazing; the forest would everywhere replace the pastures." Very vigorous objections were made, even to the extent of armed resistance. After the law of June 4, 1864, was passed, which authorized forestation, they learned very quickly that they were mistaken. But the law of 1864 could not produce results. Grassing alone was not in itself sufficient to fix the sliding land where it was heavily eroded, land whose preservation affected the public interest. Besides the law of 1864, which included the same principles as the law of 1860 , also contained some faults - "a collection of defects, any one of which was enough to kill it." The appropriations were too small for the work to be accomplished, but the main defect of the law was that the communal lands could be taken over without payment. The dispossession was only temporary, to be sure, but the conditions governing the return of the land were onerous and inequitable. "Since 1874 a devoted representative of the mountain population, Doctor Chévandier (of the Drôme) was asking, if not the actual repeal of the legislation on reforestation, at least a very material modification of its provisions."

In 1876 the Government proposed a law destined to replace the laws of 1860 and 1864 . The Chamber passed it in 1877, but the Senate committee opposed it with a counter project, which included the regulation of grazing. The Government withdrew the bill and sent to the Senate 3 "Restauration et Conservation des Terrains en Montagne," Première Partie, pp. 1-4. 
in 1879 a new proposed law which, after having been modified in certain of its provisions, became the law of April 4, 1882, on the "Restoration and the Conservation of Mountain Lands."

Law of I882. - The law clearly recognized reforestation as obligatory public work. Local commissions examine the plans proposed by the Forest Service and finally the law itself (Art. 2), and not merely a decree, determines the boundaries within which the work must be executedthat it only applies to land actually damaged or in "actual and present danger." Within the established boundaries the work is carried out on lands belonging to the State in fee simple, which acquires them either privately or by expropriation (Art. 4). Moreover, the private owners, the communes, or the public institutions can retain the ownership of their land if they reach an understanding with the State before the expropriation and if they engage to carry out, within the time allotted, the work of restoration under the conditions prescribed by the Waters and Forests Service administration and under its control. The State subsidizes this reforestation work because of its value to the public and in order to repay the owners for their sacrifices. The law also prescribes the "reservation" (for a period not to exceed 10 years) of grazing grounds whose degradation is not far enough advanced to justify expropriation; and the boundaries are established by decree. The deficiencies (without doubt wilful in the provisions concerning grazing) have rendered the application of the law extremely difficult. In the United States most of the additions to western National Forests can be made only by Congress, but a Presidential decree is sufficient for eliminations. The same distinction is made in France, where reforestation boundaries are made by law and grazing betterment boundaries by decree.

"From the considerations which precede, it results that parliament, guided by the dominating thought of reconciling the public interest with that of the mountain inhabitants, did not wish that the boundaries be excessively restricted. The original organic law did not foresee the inclusion of vast areas in order to regulate water courses; it only gave the administration the power to take the live sores, the lips eroded by torrents, where actual and present dangers presented themselves."

The law of 1882 ordered the revision of the former boundaries, which were found much too extended. It follows that the law did not aim to create vast forests capable of yielding large revenue in the future, but rather the concentration, over limited area, of intensive work dams, etc. - accompanied now and then by forestation.

But if these lands yield nothing in money to the State, that does not mean that they are of no value to the local community, for they protect the villages, the roads, the railways, and the crops of rich valleys against torrents or avalanches. However, in certain regions, the problem has been considered somewhat differently. It has appeared (the damage 
being small) that it was possible with the approval of the public to make the boundaries larger and to really reforest on a considerable scale. In the lower part of the Cévennes, including the departments of the Gard and Hérault, a region which has neither large lakes nor glaciers to regulate the water flow, it has seemed best to create considerable forested areas.

"The great forest which one dreams of forming in this region will act like an enormous spring; it would tend to retard the collection and then the runoff of water, by decreasing the volume and by storing most of it in order to give out released water, flowing with checked or diminished speed, to the tremendous profit of business and agriculture.

The era of hesitation and doubt in regard to the execution of the reforestation work has passed; mistakes very rarely occur. The certainty of the methods used for combating floods at their starting points, which finally consists only in a series of small, inexpensive measures, is to-day recognized. The facts established the value of French methods. The soil is stabilized, the aridity and barrenness of the slopes disappear as the forest and grass growth is re-established, and "the torrent muddy and menacing changes into a brook harmless and even beneficent"; this is what has happened in many localities through the application of the law of April 4, 1882. Everywhere the efficiency of the reforestation work is apparent.

"The provisions of the law of 1882 relative to grazing, despite the efforts of the administration, have not been able always to give the results expected, because of the opposition of the mountain people. Must one fall back on force? Nothing should oblige too rapid a march, or the attempt to do everything at once; everything, on the contrary, induces one to advance cautiously and progressively in a way which the study of the past has shown full of difficulties and possible dangers. One feels that much more would be obtained by example rather than by force. Encourage, by liberal grants, the individual initiative; stimulate everywhere good will; make an appeal very skillfully to the intelligence and interest of communities and individuals."

Such is the administration program adopted in order to bring the grazing population to a better comprehension of the value of the regulation of grazing land.

The work of grazing betterment, which is in every way the necessary counterpart of reforestation, has been greatly extended, but there are still obstacles to be met.

"Grazing betterment work has been criticised on the ground that it has only ephemeral duration; the habits of the mountaineers are in poor keeping with the betterment of a common weal, and people have proposed different remedies. Some have recently asked, in order to smooth out the deficiencies of the law, to place the communal grazing under 'a grazing régime,' similar to the régime applicable to the administration of the communal forests." 
With this brief sketch (translated and digested from official sources) of the development of reforestation legislation it must be clear what a task it has been to secure the legislative authority for the reclamation of these devastated areas.

Statistics of Reforestation. - The figures which follow show the expenditures and acreage as of January 1, 1909. The areas comprise the land within the boundaries of the projects acquired under the terms of the budget for reforestation and often include the remains of ruined forests which require improvement. Land of this nature has been included under the term "land restocked." The land impossible of forestation includes the rocky areas of shifting soils, or areas at too great an altitude. Land of the last two classes perhaps can some day be in part reforested. Discrepancies exist between the area of the land belonging to the State and the area reforested partly because the State has of its own volition decided not to expropriate land where the conditions have become more favorable, and partly because, in some places, the necessary nurseries and paths could not be constructed. Moreover where the compartments are of considerable extent the area to be forested is naturally limited by the local labor supply, for it appears to be good policy to employ the local mountaineers, so that they can receive in salaries an equivalent of the revenue which they lose through loss of grazing ground. This delay is not disadvantageous, for it gives the soil an excellent rest. The expense does not stop with the restoration work, for the maintenance cost is becoming greater from year to year, and a comparison of the results on January 1, 1893, and on January 1, 1909, sixteen years later, is of interest. During 32 years -1860 to $1891-248,863$ acres were purchased and 16,951 acres were reforested. During the period from 1893 to 1909 - 16 years - the area purchased was 263,740 acres and the area forested was 194,236 acres. These figures show that during the latter period the work progressed twice as rapidly as at the start. The Alpes contain about $65 \frac{1}{2}$ per cent of the eroded areas of France, with $23 \frac{1}{2}$ per cent in the Cévennes and Central Plateau and 11 per cent in the Pyrénées. In 1894 Démontzey reported that there were 1,462 distinct torrents in France, divided as follows: Alpes, 1,138; Cévennes and Central Plateau, 206; and Pyrénées, 118. Huffel says that "two-thirds of the torrents of Europe are in France."

For the three main forestation divisions (1) the Alpes, (2) the Cévennes and the Central Plateau, and (3) the Pyrénées - the official summary of the work undertaken is given in Table 14.

During the period from 1860 to 1909 the work executed by the communes (see Table 15) amounted to 21.6 per cent, by the departments 23.4 per cent, and by the State 54.9 per cent of the total expenditures of $\$ 1,433,994.59$ to reforest 134,064 acres. The contribution of the 


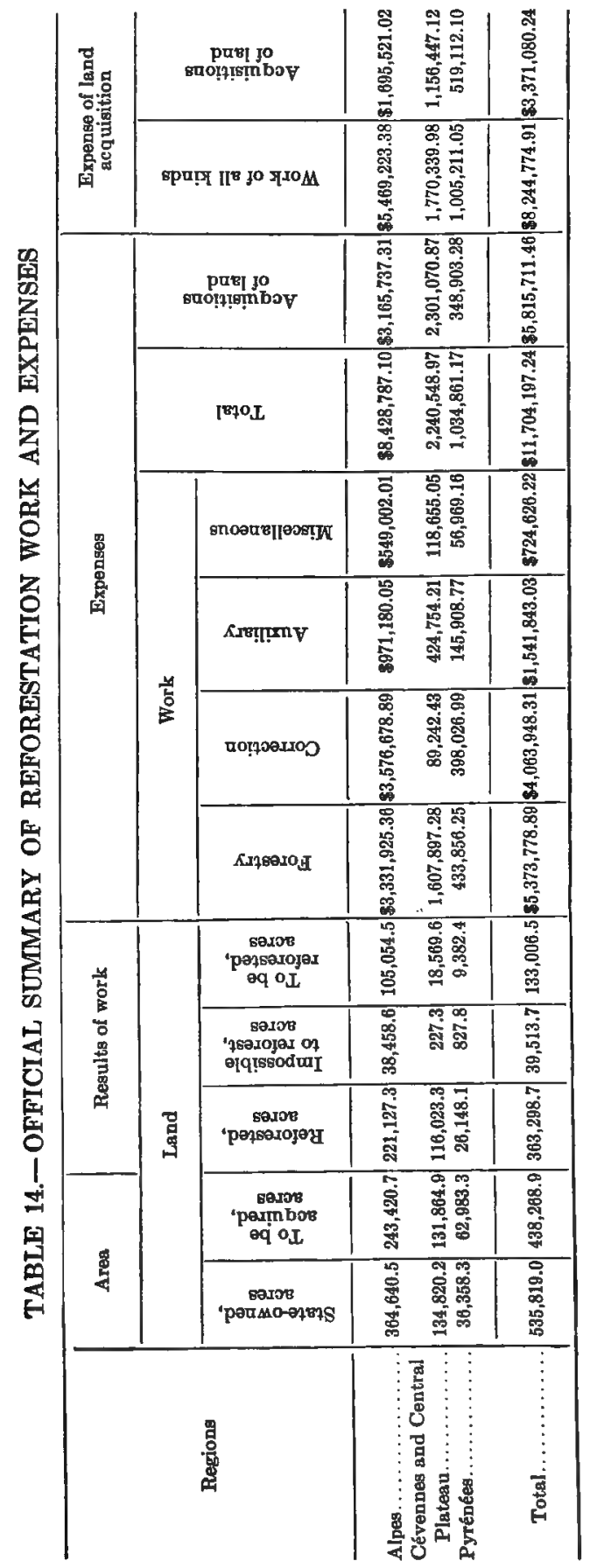


State included money or seed and plants, the plants having been estimated below their actual value.

TABLE 15.- SUMMARY OF FORESTATION BY COMMUNES, 1860-1909

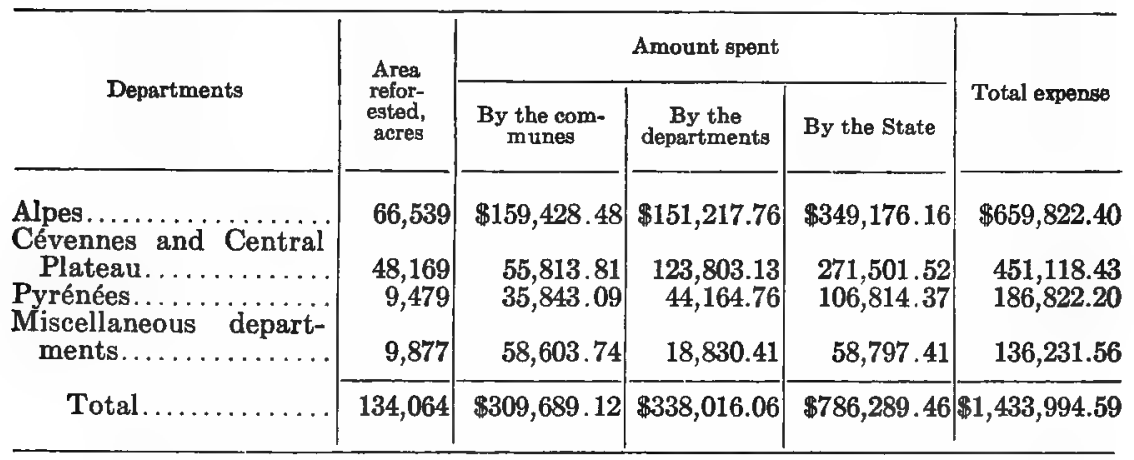

Most of the forestation work done by individuals (see Table 16) during the period from 1860 to 1909 was paid for by the individuals. The departments assisted them to the extent of 5.3 per cent of the total expense TABLE 16.-SUMMARY OF FORESTATION BY INDIVIDUALS, 1860-1909

\begin{tabular}{|c|c|c|c|c|c|}
\hline \multirow{2}{*}{ Departments } & \multirow{2}{*}{$\begin{array}{l}\text { Area } \\
\text { refor- } \\
\text { ested, } \\
\text { acres }\end{array}$} & \multicolumn{3}{|c|}{ Amount spent } & \multirow{2}{*}{ Total expense } \\
\hline & & $\begin{array}{c}\text { By in- } \\
\text { dividuals }\end{array}$ & $\begin{array}{c}\text { By the } \\
\text { departments }\end{array}$ & By the State & \\
\hline \multirow{4}{*}{ 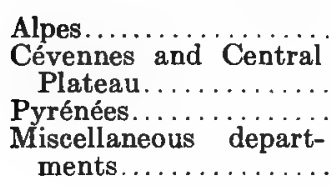 } & 13,092 & $\$ 72,862.02$ & $\$ 4,151.09$ & $\$ 27,286.33$ & $\$ 104,299.44$ \\
\hline & 107,442 & $383,435.79$ & $42,427.33$ & $270,860.93$ & $696,724.05$ \\
\hline & 7,887 & $54,011.72$ & $1,987,90$ & $24,543.67$ & $80,543.29$ \\
\hline & 3,967 & $17,051.47$ & 115.80 & $13,847.72$ & $31,015.00$ \\
\hline Total & 132,388 & $\$ 527,361.00$ & $\$ 48,682.12$ & $\$ 336,538.65$ & $\$ 912,581.78$ \\
\hline
\end{tabular}

and the State 36.9 per cent, leaving 57.8 per cent to be paid for by individuals - a total amount of $\$ 912,581.78$ spent to reforest 132,388 acres, or a cost of $\$ 6.89$ per acre. ${ }^{4}$

\section{THE DAMAGE}

Erosion and Precipitation. - It has already been pointed out (see p. 141) that the rainfall is heavier in the mountains than in the plains, and that

${ }^{4}$ In addition to expenditures for reforestation, allotments during the 10 years from 1899 to 1909 for the improvement of grazing amounted to $\$ 110,440$. These figures show the enormous damage that has resulted from deforestation (mostly due to overgrazing) in the mountains of France, which should serve as a warning to all other countries where abuse of forest or grazing lands is in its infancy. 
as a general rule the precipitation increases with the altitude. According to an official report:

"While atmospheric precipitation gives birth to torrents in the mountain regions, one must not overlook the fact that this same moisture enables the creation of forest stands to diminish the violence of floods."

It is clear, therefore, that the rains have a double effect. From one viewpoint they damage the mountains; and from the other they make forests possible and thus prevent disastrous erosion.

A part of the abundant rainfall is absorbed by the ground, a part is evaporated and a part runs off in streams. The quantity of water absorbed naturally depends on the character of the soil and on its vegetative cover. The runoff depends on the slope for its speed, and the evaporation (which is often very great) depends upon the water being available. Natural vegetation plays an important part. On impervious rocks practically all the water either runs off or is evaporated. On permeable ground, especially if it is wooded, most of the water is absorbed. The desirability, therefore, of having the slopes forested is apparent. On the other hand, one must not lose sight of the fact that on impermeable surfaces "certain ground sometimes . . . absorbs water to the saturation point and slides according to the degree of slope."

After prolonged rains or storms the water erodes the surface of the soil and forms ravines. While this form of erosion is dangerous it is not nearly so difficult to control as landslides, which occur where the permeable soil is saturated and slides over an impermeable surface. Snow frequently causes damage; it forms avalanches which erode ravines by tearing away the surface of the soil. Hail acts mechanically in detaching little particles of rock and in facilitating the movement of large rocks down steep slopes. Variations of temperature and wind all assist in erosive action. "The wind is a denuding agent which is often very active." According to my notes:

"In the Maritime Alpes on a windy day thousands of particles of rock and soil are moved by the wind; this makes a peculiar noise which struck me as being especially mournful."

Sometimes a considerable mass of water accumulates under a glacier and when it breaks out erodes a ravine with great rapidity.

Rocks and Soils Easily Eroded. - In the Alps the soils which disintegrate the more readily are the marls, the schists, the gypsums (including the so-called "terres noires"), and, finally, the detritus and the glacial and alluvial sediment. The very great abundance of land of this nature explains the intensity of the damage done by torrents in this region. Most of the slopes are steep, and the water of storms or heavy rains concentrates rapidly in the arroyos and is laden with débris of 
every kind resulting from superficial erosion. The black schists disintegrate in small fragments and form small ravines analogous to those in the granites and in the mica schists of the Cévennes and of the Central Plateau. The other "black soils" are even more easily washed and erode with very great rapidity. Soils of this kind are deeply ravined as soon as they are denuded. Glacial deposits also erode with extreme ease. These muds, often soaked to a great depth by rain or by melted snow, flow wherever they are not held in place by vegetation. The ravines that they make deepen very rapidly and become the courses of torrents which transport the detritus into the valleys below. It often happens that erodible soil rests on a steep, rocky, or compact clayey bed. Here the water filters into the top soil and great masses of earth are detached and slide to the bottoms of the ravines. Unstable ground frequently flows in a rock-mud-water lava. Fragments of all kinds of rock accumulate in the ravines and mix with the eroded earth from the black soil, forming a fluid mass which slides slowly or rapidly according to the slope of the stream bed and the amount of rain.

In the Cévennes and the Central Plateau the slopes formed by gneiss, mica schists, Paleozoic schists, and granites disintegrate the most easily. True torrent gorges are not formed on them, but instead a multitude of furrows and ravines, which transport great quantities of sandy material and fragments of rocks. It is a region of torrential rivers rather than of torrent courses such as are found in the Alps. The Pyrenees are characterized by an abundance of glacial or semi-glacial deposits. The granites disintegrate and the detritus covers considerable areas. In the Corbières the marls are especially exposed to erosion, which form short, straight torrent gorges or ravines which have numerous branches that feed and fill up the water courses with detritus.

Limestone is usually fissured, so that rain water rapidly penetrates the interior of the rock if the surface is not protected by thick grass or by well-rooted forest vegetation. Where the soil becomes denuded steady and deep erosion often forms gorges that have abrupt slopes. It is clear that excess of water is the chief danger on all easily erodible soils. From the forester's standpoint, however, too little water or drought is the greatest obstacle to the reclamation of land of this type, for the soil becomes baked and excessively arid as soon as it loses its protective vegetative cover. The soils thus suffer from the extremes of too much moisture and lack of moisture.

Definition of a Torrent. - The snow on the high mountains protects the rocks and soil against various disintegrating agencies but not against erosion due to glaciers and to subglacial water. Erosion of the soil and of the rocks accordingly takes place below the limit of perpetual snow, a limit that ranges from 8,850 to 10,800 feet in the Alps and in 
the Central and Western Pyrenees. In the Eastern Pyrenees and in the Cévennes and the Central Plateau there is not much year-long snow. Even after deducting the areas protected by snow in the Alps and Pyrenees, vast areas of erodible ground remain. The north and northeast slopes remain covered with snow for considerable periods in each year and consequently suffer less than the other slopes. On these slopes the variations in temperature are less sudden and of less extent, the rains are even less intensive, and the vegetation is habitually more vigorous than on south slopes. Therefore most of the torrent gorges are formed on south and west slopes. A French definition of a torrent gorge says it is:

"A temporary water-course in which the water concentrates after heavy rainfall and acquires, because of its mass and because of the slope of the stream bed, a considerable live force. The characteristic trait of torrent gorges is the faculty which they possess of reuniting in a single flood all the water falling within a certain time on an extensive area. This faculty is due to the configuration of the ground and the principal feature of a torrent gorge, that which gives it being is a collecting basin which favors the rapid concentration of rainfall. The basin of reception of a torrent, called also the funnel, is a more or less complete circle on whose steep slopes falls the water of heavy rains. . . . The Gavarnie 'circus' in the Pyrenees is a good example. . . . The torrents run in very short valleys, which cut the mountains at right angles to the slope just as in simple depressions. Their slope may exceed 6 per cent for their entire length but it varies a great deal and is never less than 2 per cent. They have an entirely special characteristic in that they flow in areas determined by their courses, resting upon one another and diverging because of their deposits. According to Scipiongras, a torrent is a water course whose rise is swift and violent, whose slopes are considerable and irregular and which often raises certain parts of its bed because of the deposit of material; it is this which makes the water diverge at the time of floods."

Torrent gorges may be the courses of temporary or permanent streams whose beds are not yet fixed and which perform the work of carrying away the mountain for deposit in the plain. The following definition is also of value:

"A torrent gorge is a temporary or permanent water course in which the water concentrates with extreme rapidity after heavy rains and by its energy of movement digs out its bed, which is considerable because of the mountain slope and because of the increase in density of the material transported. The soil and débris of all kinds eroded by the waters are deposited on the plain."

These different definitions support each other. Ravines have the same character as torrent gorges but are less strongly marked. "A ravine is a branch of a torrent gorge in process of formation. . . ."

Formation of Torrent Gorges. - The energy of movement or force of water that flows down a steep slope is greater at the base of the slopes than at the summit and erosion is therefore greatest at the base. It also follows that the lower part of the slope is often erodible ground 
and, moreover, it is ordinarily little protected by forest vegetation, for in France much land of this type is in fields or is devoted to agriculture.

The formation of a torrent gorge involves three distinct areas: (1) An area on which rain water falls before it runs into the "thalweg" or collecting basin; (2) an eroded area, the torrential gorge or bed; and (3) an area of deposit, the delta or torrential cone. Surell designates, under the name of the basin of reception -

". . . The region in which the water collects and floods the ground, but, when concerned with work of restoration, it is preferable to consider the entire collecting basin under the general definition of basin; . . . the space at the bottom of which runs a course of water and into which all the slopes are drained."

Torrent gorges that form on steep mountain slopes are short and usually run at right angles to the slopes. Where the slope is gentle the length of the gorge increases and the curves or bends in the gorge probably increase. These curves seem to be due to the unequal resistance of different parts of the hills. A torrential cone does not always exist at the base of the torrent gorge. Sometimes the gorge or the drainage way extends to the bottom of the valley and the material borne by the torrent is deposited in a river which carries it away.

Causes of Torrents in Mountain Forests. - Huffel says that torrential rains, easily eroded surfaces, and steep slopes promote torrents. Torrent gorges - the products of erosion - may be due immediately or directly to natural conditions or operations, but are usually directly or indirectly due to the destruction of the soil cover by the residents of the region in which they occur. It is conceivable that an exceptional storm might start erosion that would form a torrent gorge in a virgin forest. An accumulation of overmature timber or natural windfall coupled with a heavy snowfall and rapid melting may produce avalanches and denuded slopes. The area at the upper limit of tree growth is always liable to damage from the normal snowslides which are so prevalent in high mountains. Numerous other causes of "normal" damage by nature to forested areas could be cited, but under the usual conditions this change in topography - a change which is continually going on all over the world - is slow and localized. Where valley after valley that was once forested is being eroded and where there are numerous torrents nature is not alone to blame. The destruction must be due (1) to deforestation and (2) to the breaking of the soil surface. In France the once forested mountain areas that are now being repaired at so great expense were overcut, burned, and overgrazed. This might be termed collectively "abusive use." Even to-day typical examples abound (see also p. 153).

At Mont Dore (Puy-de-Dôme) there are Roman mineral springs, and around the watering places there has been partial deforestation caused 
by fire and grazing. On the west side of the valley there are belts of forest that extend from the foot of the slope almost to the top. On the east side, which faces the west or the south, the forest belt is narrower. At the head of the valley there is hardly any forest at all, because the slopes are rocky and very steep. Above and between the present forest zones grazing by sheep had started erosion and landslides. The soil, permeated with water, loosens and slides down, the slides producing great gullies. This is a good example of how small torrents begin.

At Barcelonnette it was pointed out that the beginning of ravines on bare grass-covered slopes was usually due to grazing by sheep and particularly to permanent bedding grounds at the heads of high mountain valleys. According to my field notes:

"The Ravine de Roche Noire (Basses-Alpes) 50 to 60 years ago was merely a cow trail or a path where wood was sledded down the slope. The soil, formed of a schistmarl, has now been eroded to a depth of 30 to 40 feet. As no dams were built when the slopes of this ravine were reforested the erosion has continued, and it is now necessary to build low, dry stone dams to prevent further damage. Without these dams, which are built without masonry binder, the erosion will eat in 20 inches after a single bad storm. It was explained that this erosion was not caused by grazing but was merely due to the falling of rocks, through natural causes, from the precipices above. This raises an interesting question: What would the natural erosion in the Alps have amounted to without the advent of man! The local inspector said that while sheep grazing is still doing great damage it cannot be forbidden or even summarily restricted because it is the sole industry of the mountain villages, and drastic restrictions would mean the depopulation of the countryside."

Damage Caused by Torrents. - We have already seen that "a torrential wash" is a fluid mass which carries material of all sizes and whose speed is dependent upon the slope and upon the amount of rainfall. This material comes from a number of sources. It may consist of débris from the disintegration of rocks, carried by gravity, by water, or by avalanches; (2) it may be due to simple erosion by rainwater, to slides, or to the movement of glaciers; (3) it may include trees, branches of trees, and débris from fellings, which, even if small, are dangerous elements in washes because, on account of their light weight, they do not stop until the slope becomes very gentle and they form temporary dams behind which the water accumulates only to break forth and inflict greater damage lower down. Each year torrents and ravines cause material and even great damage and, only too often, loss of human life. Such accidents direct public attention to their danger. The direct losses during 17 years are estimated in Table 17, and it is very noteworthy that the damage was always less in the areas where erosion betterments had been started: 
TABLE 17.- LOSSES FROM NOTABLE TORRENTS FROM 1890-1907

\begin{tabular}{|c|c|c|}
\hline Year & Loeality & Financial losg \\
\hline $\left.\begin{array}{l}1890 \\
1891\end{array}\right\}$ & Bassin des Gardons (Lozère)...... & $\$ 225,810$ \\
\hline 1891 & Bassin de la Beaume (Ardèche) .......... & 317,485 \\
\hline 1892 & Le glacier de Tête-Rousse (Haute-Savoie). & $337,750^{a}$ \\
\hline 1895 & Bassin du Gave Pau (Hautes-Pyrénées).. & 10,000 \\
\hline 1897 & Bassin de la Pique (Haute-Garonne). & $100,000^{a}$ \\
\hline 1897 & Bassin de la Haute-Ariège (Ariège).. & 48,250 \\
\hline 1897 & Bassin de Bastan (Hautes-Pyrénées) & $50,000^{a}$ \\
\hline 18 & Bassin de l'Allier (Ardèche). & 9,650 \\
\hline 1899 & Bassin de la Pique (Haute-Garonne). & $10,000^{a}$ \\
\hline 1899 & Bassin de l'Arve (Haute-Savoie)... & 2,000 \\
\hline 1900 & Bassin de la Beaume (Ardèche)... & $1,761,125$ \\
\hline 1901 & Bassin de la Pique (Haute-Garonne). & 10,000 \\
\hline 1901 & Bassin du Tarnon (Lozère).......... & 57,900 \\
\hline 1904 & Bassin du Doron (Savoie). & 96,500 \\
\hline 1906 & Bassin de l'Arc (Savoie).. & 115,800 \\
\hline & Bassin de Bastan (Hautes-Pyrénées). & $1,000^{a}$ \\
\hline & Bassin de Gave de Pau............. & $15,000^{a}$ \\
\hline & Bassin de la Lergue (Hérault) & $2,000^{a}$ \\
\hline & Bassins de I'Hérault et de la Dourbie (Ga) & $500^{a}$ \\
\hline 1907 & Bassin de la Céze (Gard). & $1,000^{a}$ \\
\hline 19 & des Gardons (Gard). & 200,000 \\
\hline \multirow[t]{2}{*}{1907} & Miscellaneous basins (Lozère). & $5,000^{a}$ \\
\hline & Total 1890-1907 & $3,376,770$ \\
\hline
\end{tabular}

${ }^{a}$ Amount of loss estimated.

\section{CORRECTIVE MEASURES}

Policy and Summary. - Briot, formerly a conservator in the French Forest Service, was the first to make a fight against "dead works" in reforestation as opposed to living plantations of grass, shrubs, or trees. The final judgment of the French foresters seems to be that though to permanently reclaim an eroded area vegetation is essential, yet dams, walls, and like works are also necessary. During the early work in the Alps, the operations of the French engineers might possibly be criticised on the ground that they depended too much on masonry dams (see Fig. 10, $a$ to $d$ ) and purely artificial corrective works rather than on the permanent vegetation (grass, shrubs, and trees) which is necessary if erosion is to be permanently corrected. Briot did a great deal of good in agitating for less masonry and for more vegetation. He argued that to get at the root of the evil the correction must start at the top of the slope because otherwise the dams fill up with silt and the slopes remain as bad as before. Possibly Briot went to extremes in his propaganda against the methods then current, but to-day it is unquestionable that the results of his attacks have been beneficial. The present methods are the result of having wasted public money and of having profited by the mistakes. 


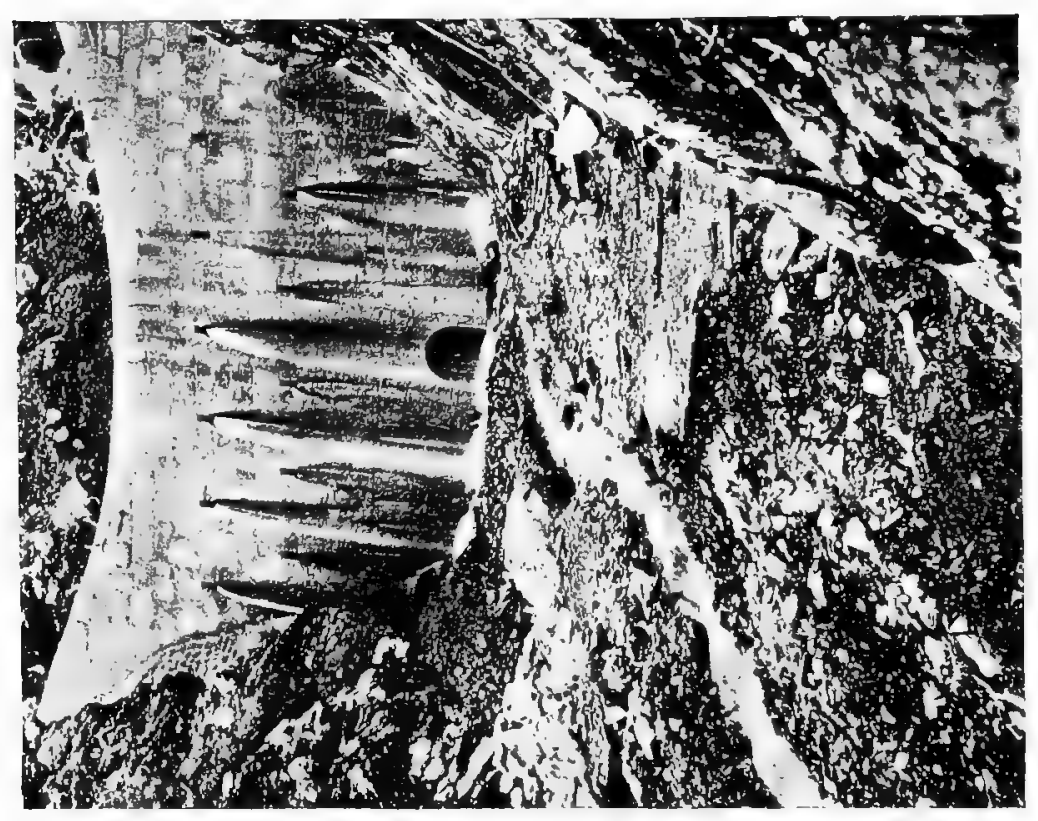

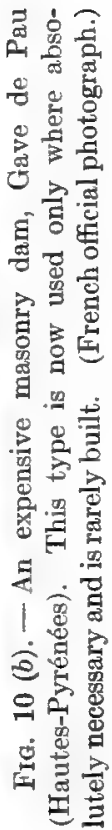

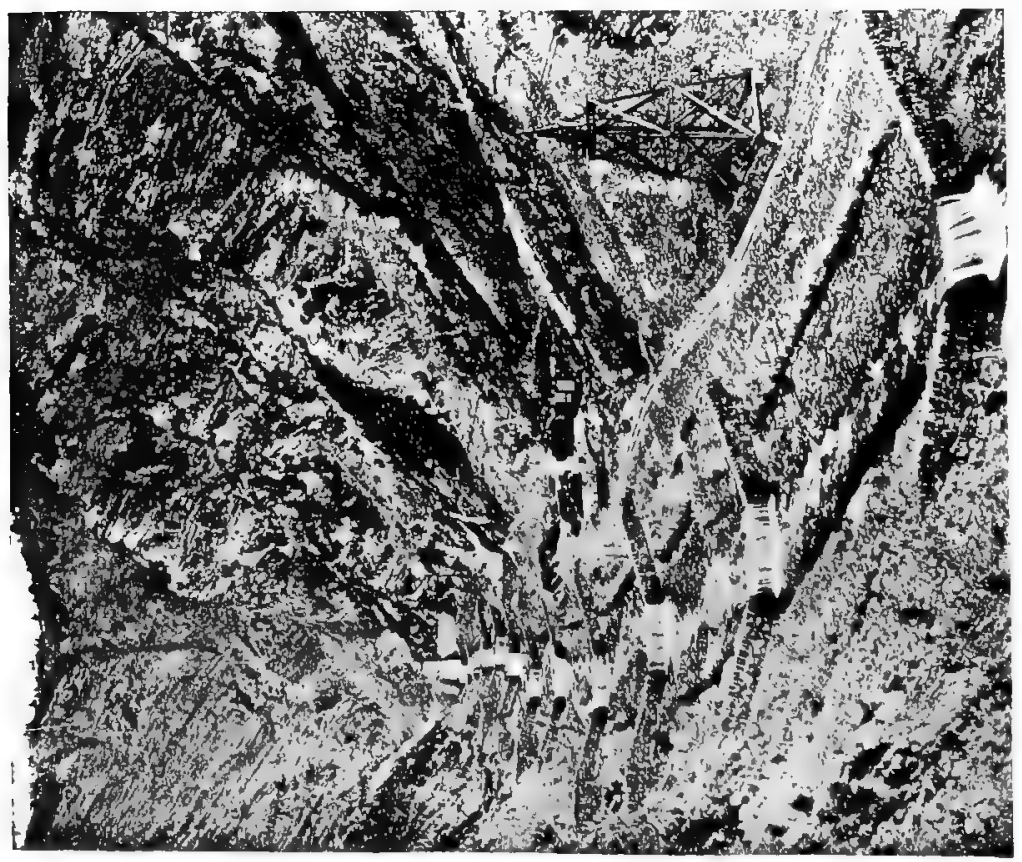

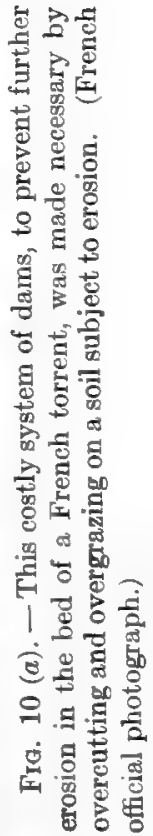




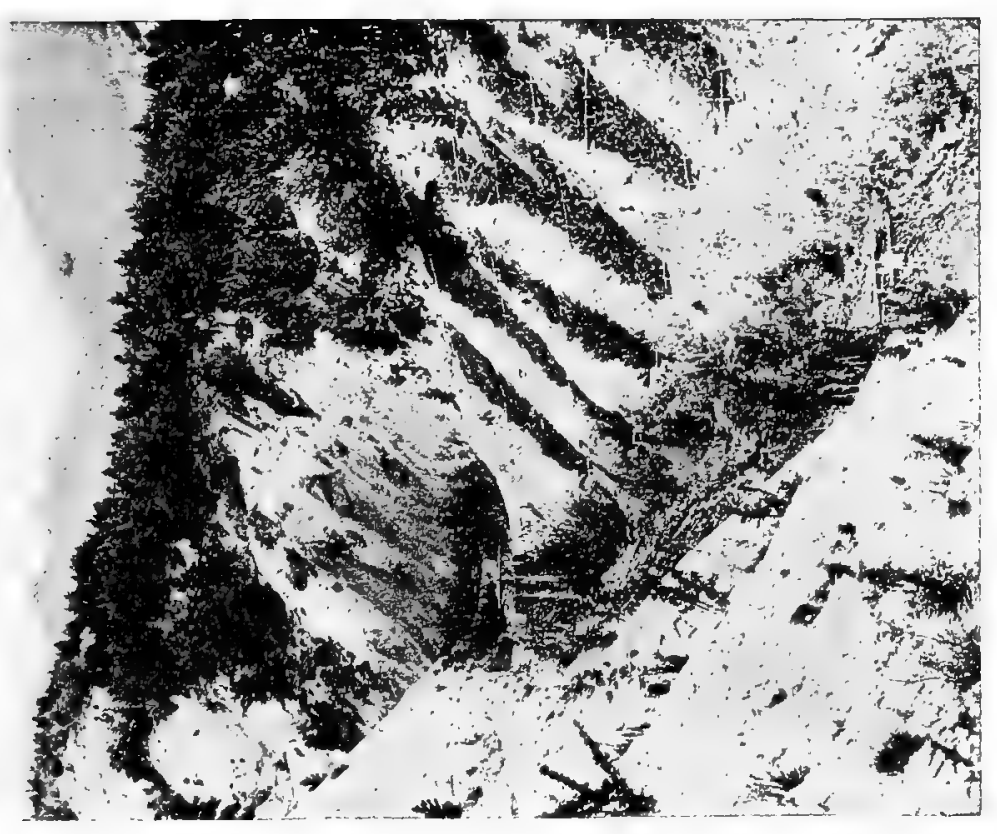

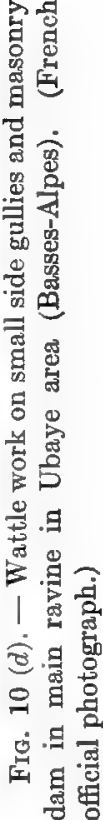
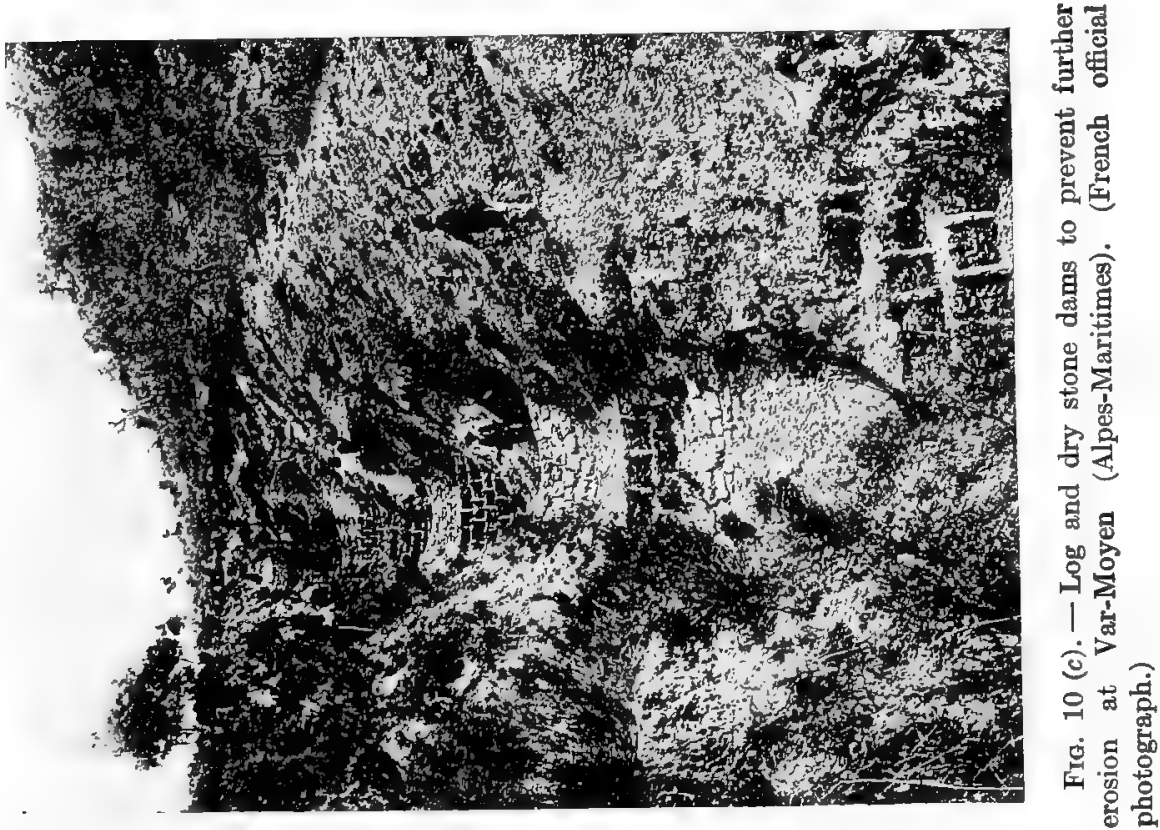
One of the first problems to arise - a problem of great importance practically - was: How much ground should the work of restoration cover? According to Surrel and his followers it is necessary to include the entire receiving basin of a torrent and the slopes of the gorge. To-day it is still felt to be best to include as large an area as possible to take in the torrent basins and their slopes. The communes usually, with their narrow self-interest, argue for withdrawing the minimum area; the Forest Service, on the other hand, realizes the technical requirements and desires to set aside the area already eroded and the area immediately threatened.

The correction of the effects of a "torrent" comprises a number of operations, all closely related to their effect upon the surface of the slopes and the bed of the stream: Dams (barrages), walls, rock drains, protection against avalanches, the paving of channels, the building of tunnels and aqueducts, wattle work (garnissage), and the introduction of grass, shrubs, or trees.

Concisely stated, a theoretical torrent above a rich village might be controlled somewhat as follows: Where a ledge of rock crosses a stream bed, and where there are good foundations, a base masonry dam is constructed; at the same time dry stone dams are built higher up the main bed to prevent deeper erosion of the stream bottom. A slope in danger of sliding into the main bed is fixed by a masonry retaining wall. Small, incipient gullies are rocked over as drains to prevent further erosion and to act as permanent drains. Small ravines are held in place by wattle work and garnissage (p. 162). Beginning at the top of slopes that are liable to erosion selected areas are first sodded; then, as soon as the soil is stable enough, shrubs are planted on the slopes and in the stream beds. After shrubs are established and the soil is held in place trees are planted. Wattle work may be necessary here and there where the soil is crumbling away, and the main bed of the torrent perhaps must be paved to prevent further washing below the base dam.

An illustration of the corrective methods employed (see also p. 168) in full swing is afforded by the torrent of St. Julien, in Savoie. Here the schist is easily eroded, for it is very friable. The torrent begins at an altitude of 9,186 feet, is 6.2 miles long, and covers some 4,942 acres of land, of which 1,866 acres belong to the State. The village of St. Julien had been damaged, parts of a railroad and wagon road had been washed away, and portions of Mont-Denis were gradually sliding and were being washed away by the torrent. The corrective measures employed were as follows:

Where there was danger that the stream might undermine a prominent ridge, and to reduce the flow of water in the main channel, it was conducted 843 feet through a 32 per cent tunnel cut through solid rock. Where the stream passed the village it was paved to prevent further 
erosion. In order to reduce the slope of the stream bed to approximately a 5 per cent grade, where the erosion was most severe, it was necessary to construct twenty-six small and three large dams. Along one stretch there was one dam every 85 feet. The catchment basin is being grassed over and planted. In addition a very complete system of rock drains has been built on the most dangerous slopes. A drain 13 feet deep and 5 feet wide cost $\$ 2.31$ per running yard; one 5 feet deep and 3.3 feet wide cost only 97 cents per yard. It was necessary to put in a holding wall at the foot of the slope, where erosion was particularly severe. The trees planted included alder, willow, Scotch pine, ash, oak, maple, and poplar. It is interesting to note that for planting Scotch pine, two-year seedlings are used in spots with two seedlings per spot. The spots are 12 to 20 inches square and number about 2,800 per acre. The cost of stopping the movement of the earth on Mont-Denis, together with the system of trails that it was necessary to build, was $\$ 30,494$, and the improvements on this one torrent alone have cost, so far (1913), over $\$ 129,310$.

This example affords an excellent illustration of the difficulty of correcting erosion after it has once started, and shows the absolute necessity of not letting it get a start. Much of the difficulty has been caused by waiting too long before beginning corrective measures.

Technique of Dams. - The principal objects of dams are (1) to stop material transported by the water, (2) to diminish the speed of the water, (3) to prevent further erosion, (4) to prevent the enlargement of the torrent bed and the erosion of the border talus, and (5) to hold up unstable slopes. Dams are constructed in torrents and ravines that are under active erosion. It is usually advisable to establish dams of about the same size, that they may be homogeneous, and to avoid the installation of secondary dams of doubtful stability. Of course, uniformity of construction cannot always be maintained. The dams must be constructed to fit local conditions, and usually the torrents have a double character. Their slopes are eroding and the material eroded is carried along in the flood. In certain places it is sufficient to construct a stone step across the bed to prevent further erosion. As the construction of these stone dams is entirely a work of engineering based on the stress which they must withstand, no details of construction are given. Above each dam it is customary to construct a rough paved area at the level of the dam, $2 \frac{1}{2}$ to 5 feet in thickness. It is constructed with stones which cannot be used in the masonry work. These paved areas are made to diminish the drop upstream so as to decrease the pressure of the water collected behind the dam. But there can be no ironclad procedure. So far as the work of correction is concerned, it is usually best to construct only absolutely necessary dams at the base of the torrent 
until the small dams at the head have been built. The base dam must be faced upstream on a part of the stream bed which is absolutely stable. It is necessary to avoid building so-called "suspended" dams, which must necessarily disappear as the stream erodes upward or downward. It often happens that a torrent is intersected by a rocky barrier. This barrier or ledge is an excellent point for the base dam.

Many of the dams in the Alps are simple, some of them consisting of a single log staked in position across the bed of a ravine. The general tendency is to avoid building expensive masonry dams and to build simple stone dams without mortar. Formerly it was often the practice to curve the face of the dam, but now they are built straight, for experience has proved that the curved dam is not necessary to withstand the average pressure.

Walls and Protection Against Avalanches. - The main protective measures against avalanches are walls, benches, or steps with wattle work or high stumps. (See Fig. 11, $a$ to $c$.) Avalanches are very frequent in the high mountains, and most of them follow the depressions or the lines of least resistance, where they do not cause a great deal of damage. But it is often necessary to prevent them, especially if they menace villages or carry great quantities of eroded material or if they damage forested areas. Walls (or benches) are usually built where the snow begins to slide. The walls are built of dry masonry and usually have a total height of $6 \frac{1}{2}$ feet and a minimum length of 50 feet. The width at the top is from 24 to 31 inches, depending on the height. The depth of the foundation varies with the ground and is sometimes as much as $\mathbf{5}$ feet. So far as possible, large stones are used, preferably of the same width as the wall. Masonry is used when dry stone of the proper size and quantity is not available. On a slope that has a practically uniform grade walls are run on the level at equal distances apart. Where the snow slides in regular runways, the walls are really dams, some with a clear height of 10 feet and a width of 31 inches at the top, with an increase of one in five inches to the base. In Savoie, where there is no resistant material at hand for such construction and where consequently it is not possible to build regular barriers, it is necessary to build benches, a bench being a flat pocket in the rock 3.3 feet wide and about 33 feet long. Where possible, this is inclosed with a small wall on the outside of the cut to collect débris. The benches constructed in the Pyrenees are of two different types: (1) Horizontal platforms about $6 \frac{1}{2}$ feet wide, slopes slightly downward toward the mountain. The talus is held by a dry stone wall with a decrease in width of 1 in 5 toward the top. Its length is 16 to 49 feet, 33 feet being the average. These platforms are 26 to 33 feet apart horizontally and about 33 feet below one another.

(2) The platform cut into the side of the mountain 


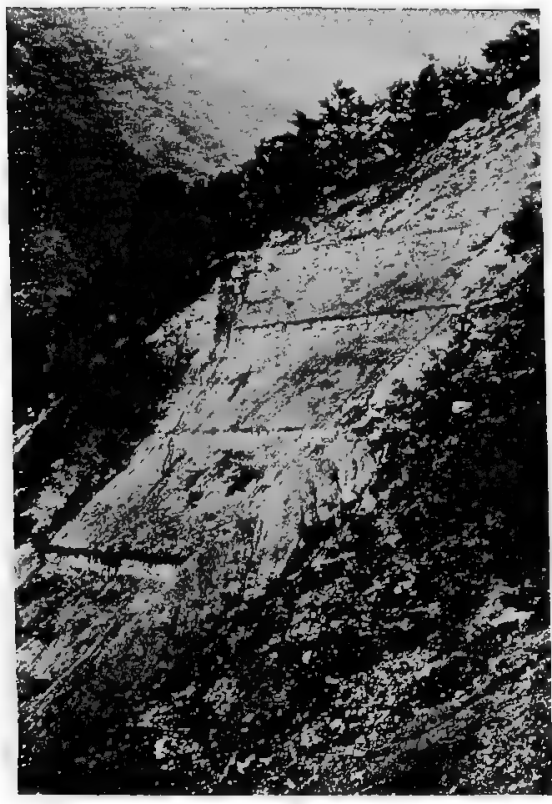

A

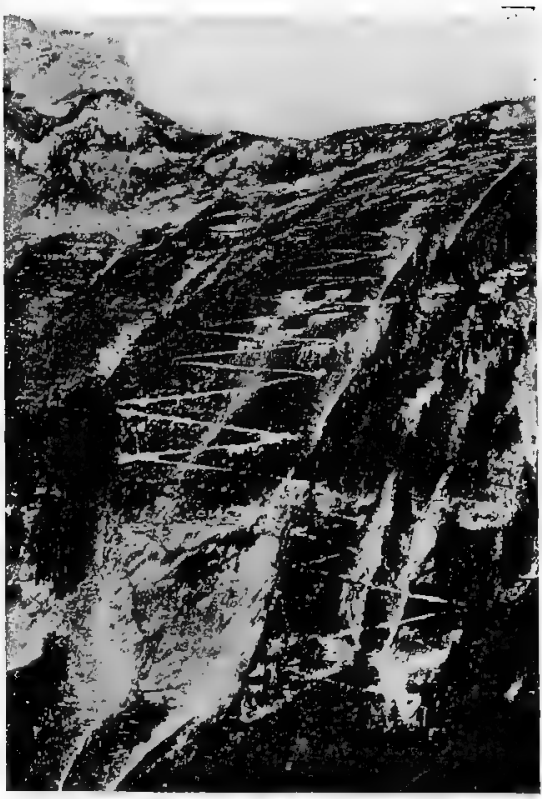

B

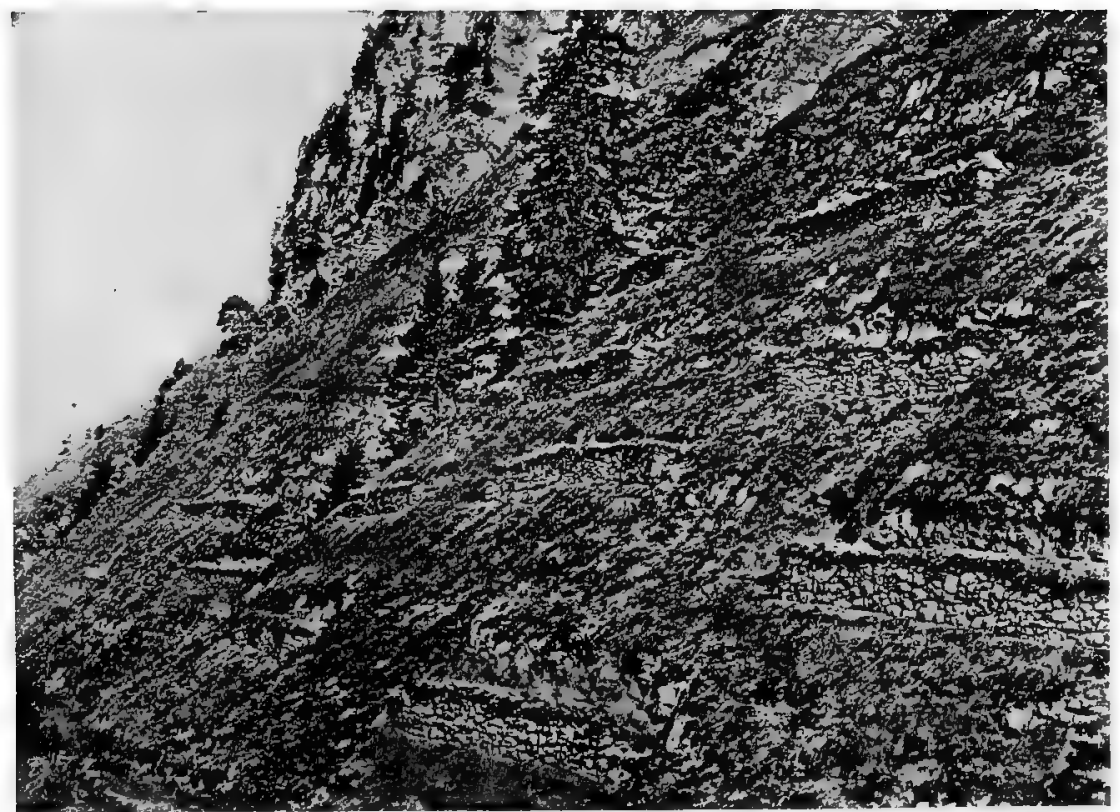

C

FIG. $11(a)$. - Retaining walls on a hillside that had been slipping down. (French official photograph.)

(b). - Walls to prevent avalanches (at top) with an inspection trail in the foreground. (French official photograph.)

(c). - Walls to prevent avalanches. (French official photograph.) 
serves as a support for dry stone barricades that jut out about $6 \frac{1}{2}$ feet. If the walls or benches are in a forested region the plantations are made under their protection; here they are considered only temporary for when the trees take hold protection is no longer necessary. Sometimes it has been found advisable to establish ordinary snow walls to turn snow slides from their course; where pockets of snow are heaped up by the wind it is often necessary to build walls 3.3 to 5 feet high back of the drifts to prevent the snow from blowing over. Wooden snow fences and wind shields, so common in the western United States, are not used in France. The tendency in France is ever toward simplification in the protection against avalanches; sometimes chunks of earth are cut out of a steep slope 13 to 16 feet in length and 3.3 feet in width at the bottom. Stakes are then set at the lower limit of the cut and are bound together with branches. With a large number of these steps cut in the slope avalanches can often be prevented, for the pits or steps act as catchment areas for loose material that slides down. These pits are often placed 7.5 to 10 feet apart vertically and 6.5 feet apart horizontally. Where there is danger from slides in partly forested areas, or where the timber has been killed by fire, dead and dying trees in improvement fellings are cut, and their stumps, 2 to 5 feet high, used to anchor the snow.

Rock Drains. - Saturated soil loses all cohesion and flows on a steep slope; it even slides on underlying strata that are less permeable. These earth movements are due to the infiltration of water coming from prolonged rains, from the melting of snows, from deep springs, and from irrigating canals that are not leak-proof. Such movements are combated by drainage, which makes the soil cohere and thus prevents slides. In order to accomplish this work canals or drains are built to conduct the water into the valley bottoms. (See Fig. 12.) Where considerable ground is in movement it is not possible to open trenches sufficiently deep for drainage, but by digging a large number of drains the soil can be dried up and a sufficiently resistant surface formed to prevent it from disintegrating. The average depth of such drains is $6.5,5$, and 3.3 feet. The deepest drains, called "collectors," ordinarily have a width at the bottom of 28 inches and an increase in width toward the top of 1 in 5 . The best drains have a concave base, built on a radius of 10 or 20 per cent, and are so constructed as to form a canal of triangular construction. Above this base the ditch is filled with stones of all sizes, the largest being placed at the bottom. Drains 6.5 feet deep for the chief drainage and 3.3 feet deep for the lateral drainage generally suffice. The triangular section is sometimes replaced by a half-circular section or by a rectangular section, which is easier to construct. Second-class or third-class drains have a depth of 3.3 to 5 feet and a width at the bottom of 16 to 24 inches. 
The drains must be large enough to insure the prompt runoff of water. Under exceptional circumstances the French have managed to dry ground to a great depth, sometimes up to 10 to 13 feet, but the expense is much greater. First-class drains are generally built where the slope is steep, in order to assure rapid runoff. They are less likely to be dislocated by soil movements. At the head of drains little walls are constructed as props.

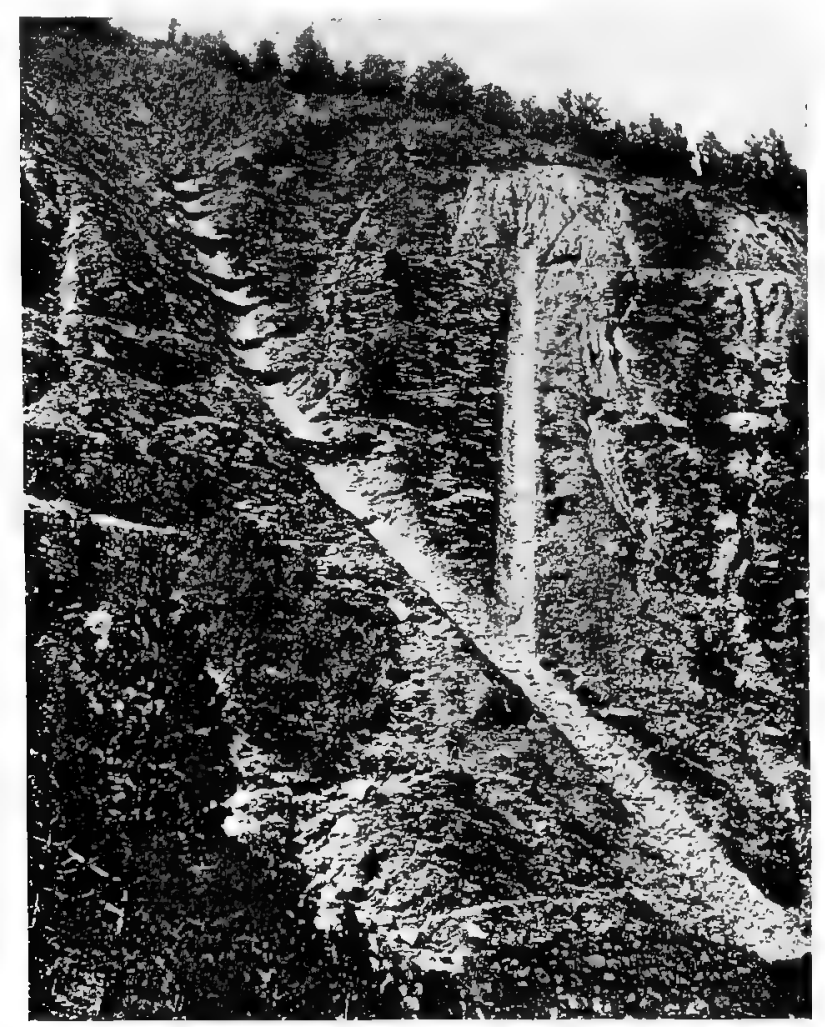

Frg. 12. - Paved drains at Bastan (Hautes-Pyrénées). (French official photograph.)

When the drainage water is abundant it is often united in a paved trench built in the valley bottom to carry the water under the dams. Where the soil movements are due to a leaky canal it is often better to stop the cause of the infiltration rather than to take up the expensive work of drainage. To prevent running water from eroding the soil it is often advisable to collect it in little canals, about 20 inches in depth, which follow the slope and which are filled with little stones or fascines. These canals can be replaced by paved drains if the earth is in movement. Trees are planted 
as soon as the drainage has made the soil sufficiently stable. Drainage has always been satisfactory where it has been used to stop superficial slides over a small area or to dry up saturated soil. Where earth is sliding over a nonpermeable surface the timber still standing is almost invariably cut so as not to retain surplus water.

Paving Channels. - The typical torrent is almost dry except during a period of storms. To prevent erosion, enlargement, and changes in the main channel bed it is necessary to pave the bed. This facilitates the passing of the detritus during floods, especially below the base dam.

Tunnels and Aqueducts. - In a few places it is necessary to use tunnels or aqueducts to conduct excess water through ridges or over artificial obstacles, such as roads or railways. For example, near Thonon (HauteSavoie), where the limestone soil is badly eroded, a road is protected by carrying the wash from a ravine over it on an aqueduct.

Wattle Work (Garnissage). - On steep slopes (more than 60 per cent) and in small ravines wattle work is often necessary. (See Fig. 13, $a$ and b.) A common method is to stick willow shoots in the ground 1 to 3 feet apart and to weave willow branches in between the shoots to hold the rocks and shifting earth. The shoots take root and when established assist in holding the sod, when forestation becomes possible. Another system of building wattle work (now largely abandoned) was to lay the brush straight up and down the stream bed and pin it in position with cross pieces every 6.5 feet. The latest method is to lay the brush as formerly but to hold it in place with two stakes driven in the soil in the shape of a $\mathrm{V}$, the head of the $\mathrm{V}$ pointing down stream. According to Démontzey:

"The 'garnissage' correction of little dry ravines and the consolidation of unstable slopes is as follows:

"In the dry ravines of the Alps 'garnissage' is often used in the bed of the stream; stems of branches are laid on the bottom so that the ends of the branches may be toward the top. By dry ravines is meant those that carry no water during normal times or those in which there is a very small trickle of water. The branches are so placed as to form a slightly concave surface, and are held in place here and there by cross pieces fixed in place by stakes. The most common form of 'garnissage' employed during the past years has been to place brush on the bottom of the ravine and then to mat it down by interwoven branches. When completed, the branches form squares on top of the débris. Winter willow or poplar branches are used, and the ends are covered with earth, commencing from the top of the ravine and extending downward, so that they can take root and form a living protection. Most 'garnissage' eventually results in vegetation that forms a permanent protection against erosion. In the Maritime Alpes where branches cannot be had at a reasonable expense, the flow of water in the ravines is controlled by a series of little dams formed of balls of sod, used alone or combined with stone. When the water falls it is stopped at each dam so that it cannot attain sufficient velocity to be dangerous. The debris backs up behind each little dam and further lessens the velocity of water. . . . The dams must become larger and larger down stream in order to resist the floods . . . until these dams reach a height of $\mathbf{3 . 3}$ 


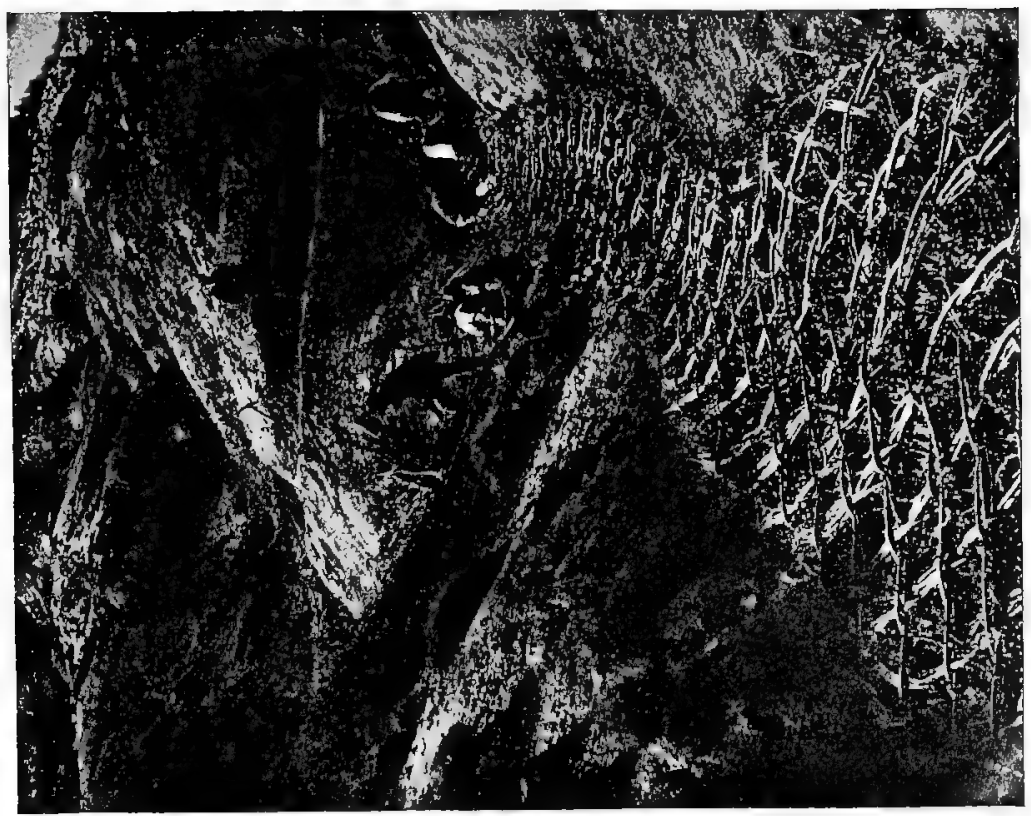

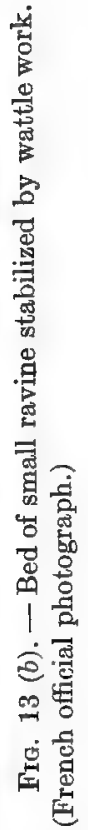

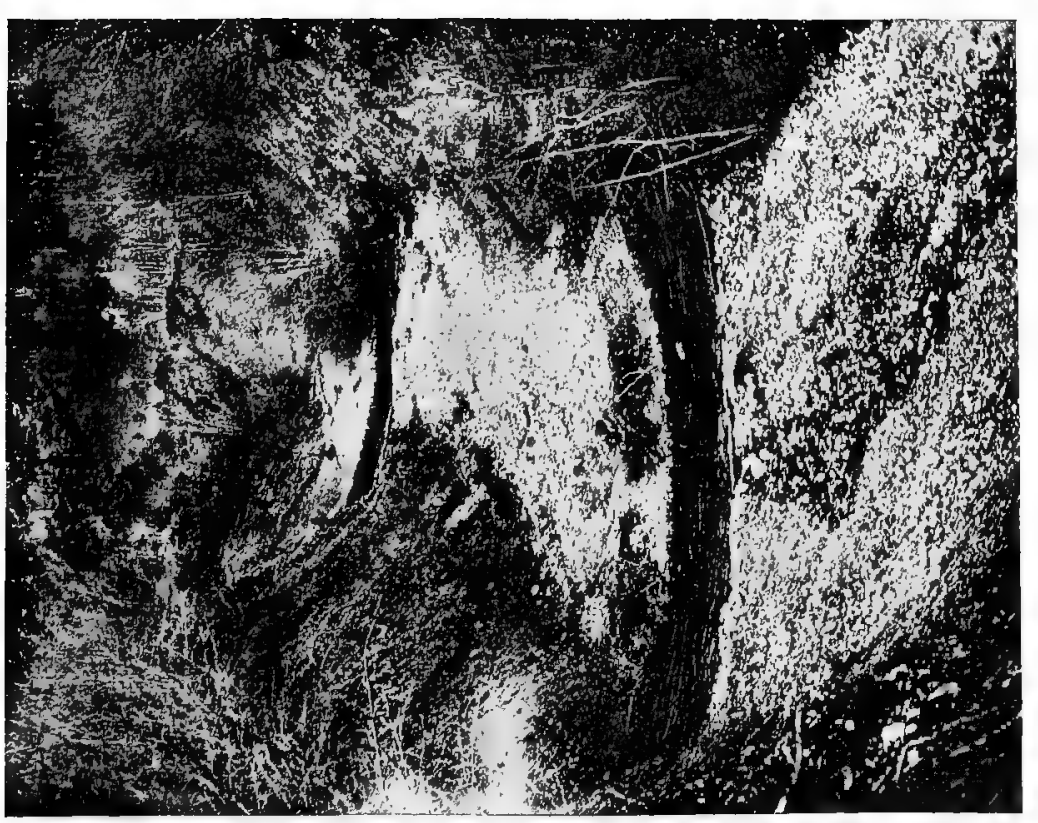

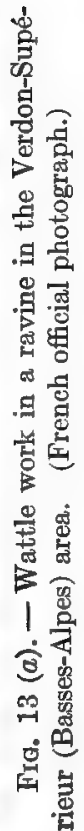


feet and a length of several yards. Where sod cannot be obtained layers of branches alternating with layers of stone are used. Sometimes also these ravines are held in place by small dry stone dams some 16 to 23 inches in height, solidly anchored. In the high mountains, in certain places, some of the ravines are filled with stones just as if they were small drainage canals. This method of cover has given good results on slopes situated at an altitude of 6,500 feet in the upper Verdon valley. In addition to fixing the ravine bottom, a necessary precaution to prevent erosion from extending farther up is to construct just below the summit a so-called consolidation wall about 20 inches in height, which if well anchored holds the ground. After this wall is built the soil around it can often be sodded over. The methods used for fixing unstable banks or slopes are extremely variable. If their instability is very pronounced they must be sustained at the bottom by transverse works very much like the wall that holds up the side of the ridge. Some slopes can be held up by a superficial cover of branches held in place by stakes or poles, such as are used in a ravine. Under the shelter of this cover natural vegetation can easily be developed. Little horizontal structures, wattle work 10 to 12 inches high, or fascines reinforced by.layers of shoots between which are sown forage plants, are used everywhere. Where stones are abundant little walls of dry stone are built, topped with sod."

Forestation, with Examples. ${ }^{5}$ - The purpose of dams, walls, drains, wattle work, and other artificial "dead works" is to stop the movement of the surface soil, because until that is anchored forestation is impossible, and before the final protective cover is planted the surface must often be held in place by grass or shrubs. It is clear from the French literature on reforestation that engineers have not always admitted or realized the importance of vegetative cover for permanent reclamation:

"Some geologists have expressed the view that a torrent is a phenomenon whose development cannot be stopped. If this opinion is accepted there is nothing to do but to let the destruction of the mountain go on and try to defend the valleys against the results of torrents. Some feel that protection against torrents can be obtained in a certain measure (when the limit of slope erosion has approached) by installing a canal to conduct the eroded material from the foot of the mountains to the river. But the danger is not overcome. The detritus is merely transported from the torrential valley to the main valley. Others believe that it is impossible to slow up the torrent by these canals and use the water for commerce. They believe that a dam can be built high enough to retain the flood waters and that these waters, once stored, can be used for commerce or for agriculture, thus making the flood a benefit rather than a damage. Quite often this method is possible, provided the ground and the economic conditions permit, but it cannot be considered a general answer to the problem. Foresters take another point of view. We have already seen that the rapidity of erosion depends on the fluid mass, on the slope, on the river bed, and on the resistance of the ground. Is it not necessary, therefore, to try to retard the flow and diminish it and to retain the rocky débris which is sliding on the slopes? This result can be obtained only by a forest cover on the soil in and between the existing ravines."

Surrel (quoted by Huffel) concluded that: "(1) Forests stop the formation of torrents; (2) deforestation delivers the soil as a prey to torrents;

5 The methods of forestation are described in Chapter $\mathrm{V}$ and the chief species used in French reforestation work are given in the Appendix, p. 407. 
(3) the development of forests tends to stop torrents; (4) the fall of forests redoubles the violence of torrents and can even start them afresh." An interesting study ${ }^{6}$ that illustrates methods of reforestation is an area in the basin of the Ubaye (see Fig. 14, $a$ ) which comprises some 46,661 acres, 18 per cent of which was natural forest, now bearing only 34 per cent of a stand. The species growing naturally include larch, fir, spruce, mountain pine, beech, oak, alder, and willow. The species introduced artificially are Austrian pine, ash, locust, birch, green alder, and aspen. Of the species growing naturally the larch is the most valuable and is found at its optimum in the forest of St. Paul. Unfortunately the growth of Austrian pine slows up and the needles turn yellow when 15 to 25 years of age. Prior to this the tree makes good growth.

In this region the limit of stable soil is a slope of 45 per cent. Where the slope is less than this the ground can be planted immediately, but where it is more the ground must be first sodded before it can be planted to tree growth. Where the slope is 60 per cent or more grassing cannot be undertaken, for the instability of the soil is an absolute obstacle. In this event it is necessary to construct artificial dams or to wait until the accumulation of talus has abated.

Two general methods have been used to grass over ground that has been eroded - sowing forage seed and planting sod. The first method was formerly used .over large areas in this region but is now limited to unstable soil. "Sainfoin" and "fenasse" (see p. 408) were used separately or mixed in the proportion of three to one. The seed was sowed in small trenches or in horizontal lines at variable distances apart. On an average 18 pounds of seed (costing $\$ 9.65$ ) was necessary to sow one acre of eroded ground. The labor amounted to $\$ 6.75$, making a total cost of $\$ 16.40$ per acre. But as a result of experience laying sod has proved to be the best method. Large tufts of Clamagrostis argentea were cut fromnear-by grass land and planted in rows $1 \frac{1}{2}$ to 3 feet apart, or in quincunx." The sod costs $\$ 3.83$ a thousand. Still another method that is often used to fix rapidly the slopes of mountains or ravines is to sow "bugrone arbrisseau" or to propagate hippophæ rhamnoide, or willows, by suckers.

Sowing was formerly employed in reforestation, but to-day the preference is for planting. Cembric pine, larch, and mountain pine are sown at high altitudes, provided the slope is not more than 30 per cent to 40 per cent and there is enough vegetation or rock to protect the young seedlings against water and sun. Otherwise planting is considered necessary. The seed is sown in the spring, at these high altitudes about the end of May. Although the spring sowing is often burned out by the sun, if the sowing is delayed too late the germination is retarded and the

${ }^{6}$ Étude sur les Forêts et les Reboisements de la Vallée de l'Ubaye, par H. Vincent, 1909. 


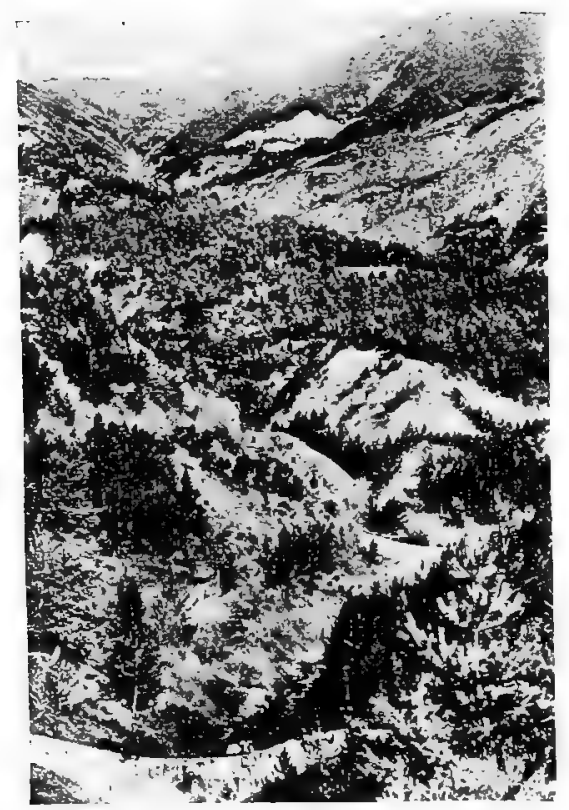

A

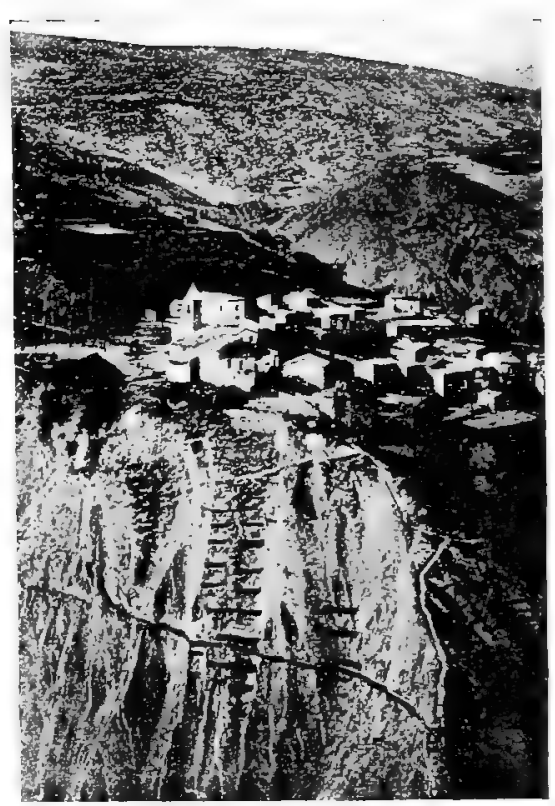

B

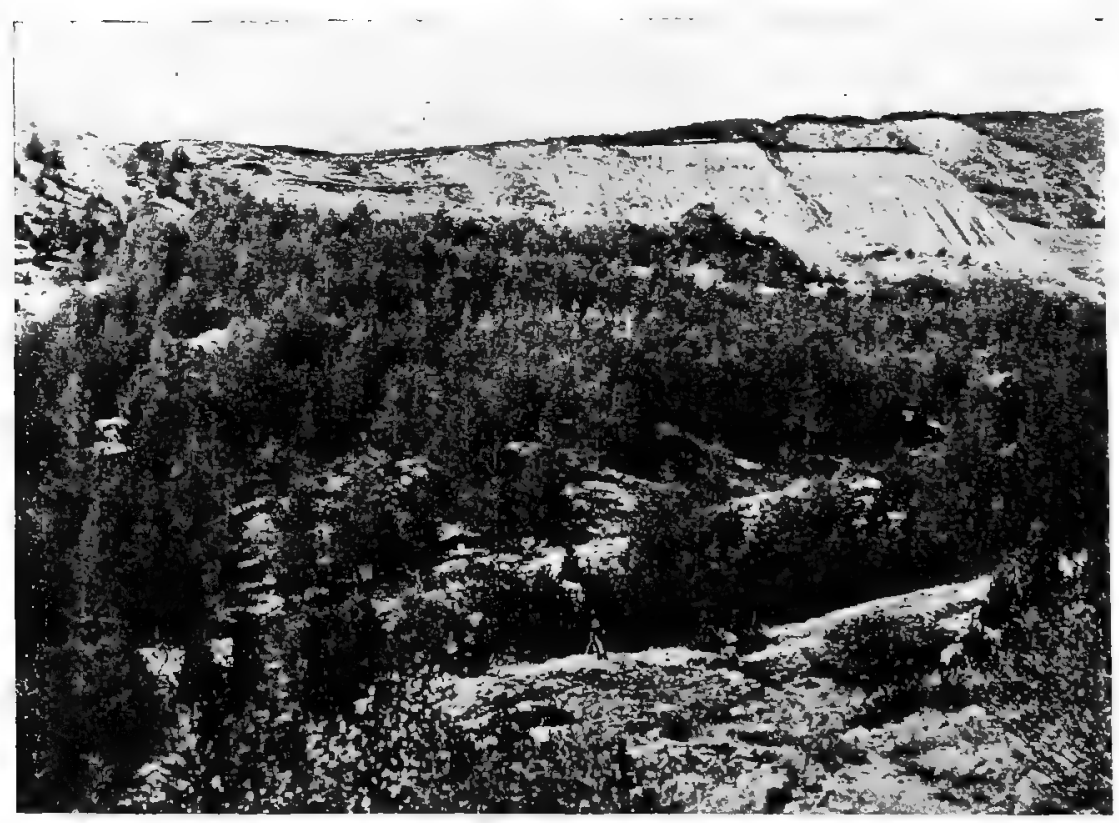

C

FIG. 14 (a), - The Rata ravine at Ubaye (Basses-Alpes) after the reclamation work was finished. (French official photograph.)

(b). - A mountain village in the Pyrenees menaced by erosion. (French official photograph.)

(c). - Preventing further erosion by larch plantations in Ubaye area (BassesAlpes). (French official photograph.) 
seed is more exposed to mice and to birds. The seed sown in the autumn is covered almost at once by snow, and in the high mountains the period from September 1 to October 30 is considered the best time. Excellent results were occasionally obtained in the past by sowing broad cast on the snow, especially by the notable sowing at Barcelonnette in the years 1842-1846. Now, however, an entirely different method is employed, known as the stick method (à la pointe du bâton) (see p. 133).

"'The workman, who wears a little apron sack belted to his waist, holding 4 to 6 pounds of seed, is given a stick 1 to $1 \frac{1}{2}$ inches in diameter and 12 to 16 inches in length. With this stick, one end of which is pointed, he makes little furrows in the soil at suitable places. The depth of these furrows should not exceed 0.8 to 1.2 inches and the length should be between 8 inches and 3.3 feet. In this diminutive trench he places pinches of seed carefully spaced; one or two seed to each 0.4 inch is amply sufficient; as a rule the workmen tend to put in too much, and the seed is thus wasted. Experience has shown that this "stick sowing" gives surer and better results than sowing by any other method. It is, moreover, quicker and cheaper. Its cost does not exceed $\$ 3.86$ to $\$ 4.82$ per acre. The amount of seed used per acre is variable, an average perhaps of 8.8 pounds for the larch and mountain pine and 22 pounds for cembric pine. Moreover, the seedlings obtained by this procedure have also the advantage of being ready for removal for fall planting if desired."

This is a local method, however, which has not received wide official sanction. At Barcelonnette (see p. 136 for further discussion) considerable success was attained by sowing larch seed on the snow in March or April, especially when it was sown on the grass immediately before snow fall. In this region the fir is both sown and planted, but apparently, according to the local inspector, the best results were obtained by sowing seed spots. Spruce is usually planted. Planting is generally employed where the soil is bare. According to French practice transplants are not necessary. Here, in accordance with French practice, good-sized rocks were placed south of seedlings on south slopes in grass where there was danger from sun and drying. It is curious to find in the Barcelonnette region a considerable use of Austrian pine, although Scotch pine grew there naturally. According to the local inspector:

"The foresters in France always like to change things. This apparently was the only reason for using an exotic when a local species would have given better results. In this locality, for planting on plateaus in grass, the hole is dug 12 by 12 by 12 inches with a grub hoe. The richest soil is placed next the roots and the sod is turned upside down and replaced around the plant. On steep slopes the method is somewhat different. The hole is dug 10 to 12 inches deep, 4.5 to 6 inches wide, and 12 to 14 inches in length, and care is taken not to cut the sod below the hole, if there is any, in order to avoid erosion. A peculiar method of planting in grazing land, where public interest demands grazing and yet some tree shelter is desired, is to plant a group of fifty trees and then another group about 160 feet away."

One of the best examples of reforestation in the Alps is in the valley of the Drôme above Valence, called the Luc working group. Corrective 
measures were begun in 1865, and on January 1, 1899, 1,547 acres had been reclaimed at a total expense of $\$ 67,656.15$, or about $\$ 42$ per acre. The species planted were chiefly Austrian pine and Scotch pine, but included various broadleaf trees. The Scotch pine is to-day doing very well. In another nearby project the cost was $\$ 40$ per acre, divided as follows:

Cost of soil purchase. $\ldots \ldots \ldots \ldots \ldots \ldots \ldots \ldots \ldots \ldots \ldots \ldots \ldots \ldots \$ \$ \ldots .10$

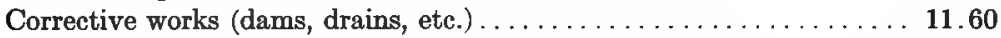

Plantations (grass, shrubs, trees) ................... 19.30

Total. .............................. $\overline{\$ 40.00}$

These costs would now be doubled or tripled, but today the difference in the present rate of exchange and the normal must be deducted to get the relative cost in dollars.

A remarkable example of the control of a torrent which did a great deal of damage from 1832 to 1847 is to be found at La Grollaz. The correction work was started in 1880 . To-day the torrent is a pretty brook with waterfalls over artificially constructed cement dams protected by an absolutely dense cover of alder, which holds the soil immediately along the brook. Further up from the stream Scotch pine has been planted, so that the result is a pretty New England trout stream bordered by trees 50 feet in height. This illustrates the two great principles in the control of erosion: first, to stop the earth from moving as a whole and, second, to cover it with shrubs, nurse trees, and forest.

\section{TYPICAL REFORESTATION AREAS}

Regions. - To give a picture of the conditions in the principal regions, important reforestation areas (see Fig. 14, c) in the Alpes, sub-Alpes, Central Plateau, Cévennes, and Pyrénées are described in considerable detail, the material being furnished in the official report, "Restauration et Conservation des Terrains en Montagne." The routine and systematic descriptions (given in the Appendix, p. 422) of the conditions following erosion, and the tedious difficulty (see Fig. 14,c) of stopping the damage, emphasize the dangers and costs of overgrazing and deforestation. 


\section{CHAPTER VIII}

\section{FORESTRY IN THE LANDES}

The Dunes (p. 169). Introduction, Kinds of Dunes (Causes), Rate of Advance, Local Conditions.

History of Reclaiming the Landes (p. 173). Periods of Work, Before Brémontier, The Brémontier Period, The Dune Commission, The Bridge and Road Service, Waters and Forests Service, Statistics.

Fixing The Sand (p. 177). Construction of Coast Dunes, Forestation, Special Betterments in the Landes, Cost and Price Data.

Management of Maritime Pine Forests (p. 186). Objects of Management (Protection Forests), Silvicultural Systems, Intermediate Fellings, Rotations, Felling Cycles, Working Groups, New Tapping Scheme, Tapping Other Species, Resin Sales, French Tools for Tapping and Their Use, French and American Methods Contrasted, Technique of Tapping, Effect of Tapping, Utilization, Logging and Local Specifications, Yield of Maritime Pine, Protection.

\section{THE DUNES}

Introduction. - The reclamation and forestation of the sand wastes of the Landes and Gironde between Bayonne and the Garonne River (north of Bordeaux) is perhaps the best possible illustration of the benefits of forestry to the individual, to the community, and to the nation. The individual who pioneered in sowing these sands made a handsome profit, the communities were saved from obliteration by the encroachment of the sand dunes and, after being bankrupt, became rich, and lastly France found itself sovereign of departments producing handsome revenues instead of having to furnish them assistance. Before forestation the Landes was populated with a shiftless class of "poor whites" eking out a livelihood. To-day it is one of the most progressive and perhaps the most prosperous region in.France, with good schools, splendid churches, and up-to-date communal buildings. Nor should the indirect benefits of this work be overlooked; a region formerly fever-stricken became healthy, and to-day places like Arcachon and Mimizan are health resorts both in summer and winter. Much of this land was sand, worthless for agriculture and mediocre for grazing, but nevertheless an ideal soil for the rapidly growing, resin producing maritime pine. Brémontier, a great engineer and believer in forestry, was able to put the work of stabilizing the dunes and forestation on a sound basis during the years 1787 to 1817 and the problem was solved during his administration. $\mathrm{He}$ proved to the canny French that the work was sound financially. The 
parallel between the so-called sand wastes of the southern United States and the great Landes region in southern France is most striking. What has been accomplished in the Landes? In place of virtually worthless fever-stricken land the French have a balance sheet of: (1) Revenue producing forests, protected from fire; (2) a protection for such important industries as agriculture; (3) a needed supply of timber, ${ }^{1}$ mine props, and resin products; (4) a healthy land to live in and largely increased population.

Is it to be wondered at that the French Chamber of Deputies has declared that producing forests are of paramount necessity to the nation and insist on their perpetuation, or that reforested land of this class should be exempted from taxation for thirty years? But it should be noted that the French Government itself took the initiative financially and technically in the reclamation and sowing of the Landes; it blazed the trail for the private owner.

The Landes is a triangular area of some $1,977,000$ acres ${ }^{2}$ bounded by the Atlantic Ocean and the three rivers, Garonne, Midouze, and Adour. Three-quarters of a century ago this was mostly an unhealthy sand waste of swamp land, ponds, brush, and limited scrubby stands of maritime pine and a scattering of oak with other broadleaves. There was no system of roads and the chief industry was sheep and goat grazing. As early as 1737 the reclamation of this waste land was under consideration, but only after Chambrélent and Brémontier had shown that drainage and forestation was practicable did the State secure the law of 1857 which provided for the $(a)$ drainage of communal land and (b) the construction of a system of roads to feed the areas drained and forested. Without these betterments the continued forestation on a large scale would have been well-nigh impossible.

The drainage was finished in 1865 and cost only $\$ 172,484$ to drain 468,767 acres (which had been purchased from the communes), and by $1860 \$ 1,238,095$ had been spent on roads. The communes had forested 183,000 acres by 1891 (or three-fourths the waste area they owned) and the forestation of private land had not lagged behind. It should be emphasized that to-day the State and communal forests under working plans occupy the poorer sands on the dunes almost entirely on a strip within four miles of the ocean. They form protection belts for the richer private forests and agricultural land which is found on the better soils inland. The system of management described later in this chapter

${ }^{1}$ The principal exploitations of the American Forest Engineers, A. E. F., were in the Landes south of Bordeaux. They cut 41.4 million board feet. Major Swift Berry, who was stationed in the Landes for two years, kindly reviewed this chapter and made many valuable suggestions which were incorporated in the text.

${ }^{2}$ Huffel, Vol. I, pp. 177-184. 
applies to public forests under working plans. The distinction between public and private management is described on page 186. The State and communal forests thus lie mostly in the dunes and the private forests in the level Landes behind the dune region.

Kinds of Dunes (Causes). - The maritime dunes of France are formed of sand usually drifted from the ocean or occasionally from the beds of rivers near the sea. The sand dries out on the beach or river bed at low tide and is blown inland. The normal dune is entirely a natural phenomenon, but its movement far inland is usually caused and accentuated by the destruction of bordering forests and soil cover. Huffel ${ }^{3}$ says:

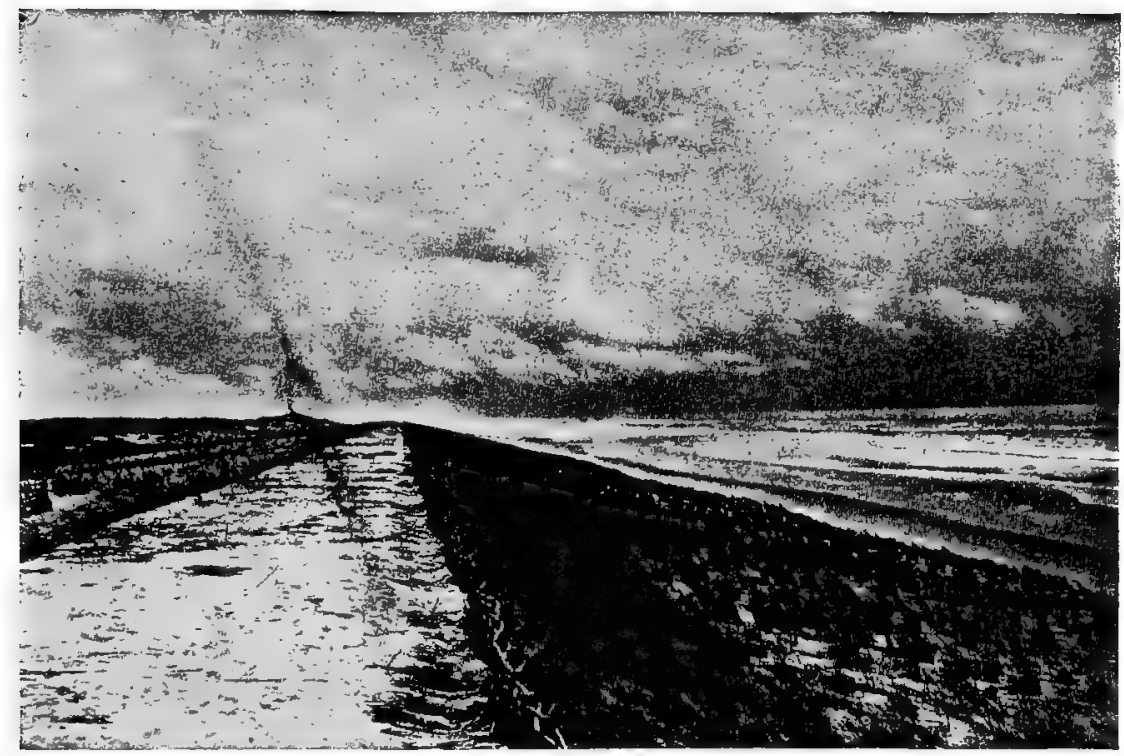

Fig. 15. - Protection dune at Lacanau-Océan in State forest of Lacanau (Gironde). The sand is held in place by planting maram grass on the wind-swept dunes.

"Two kinds of dunes are found on the shores of Gascony: (1) Recent new dunes which were fixed during the last century; (2) very old (prehistoric) ones, known locally by the name of mountains, which are still covered to-day with very old forests of pine, live oak and cork oak. These mountains do not form (as the recent dunes do) chains of ridges separated by little ravines parallel to the shore; their confused grouping tends to show that they formed at a period when the shore line was not so remarkably straight, as it became in recent times, under the action of the north-south currents."

These recent dunes ${ }^{4}$ may be of three kinds: (1) High dunes; (2) flat

${ }^{3}$ Huffel, Vol. I, p. 152.

${ }^{4}$ Notes sur les Dunes de Gascogne, par J. Bert, 1900, which has been largely followed in tracing the history and development of the dune reclamation work. River sand in the dunes probably comes down into the Bay of Biscay from the streams of the Pyrenees and is then, according to Major Berry's conclusions, thrown up on the beaches. 
dunes; and (3) scattered dunes. Types (1) and (2) require no further elaboration. Type (3) are dunes where the sand had formed irregular banks or mounds on adjacent level areas. Near the ocean the western slope (facing the sea) is 4 to 25 per cent and the eastern slope 7 to 75 per cent. Dunes are rarely more than 200 feet high, the maximum height being 292 feet in the forest of Biscarrosse. See figure 15.

Rate of Advance. - The ends of a dune usually advance more rapidly than the center, but the ridges are about parallel to the beach and at right angles to the wind. They are irregular and form mounds of various shapes. The rate of advance inland has been estimated at from 33 to 164 feet per year, depending unquestionably on the wind and on the local topography. The average is probably 65 to 80 feet per year. There is another phenomenon connected with the dunes - the erosion of the shore line by the sea. According to my field notes:

"At La Teste, during the period 1886 to 1912, the sea has eaten away 2,231 feet of shore dunes opposite the ranger house at Gaillouneys, and at the ranger station of La Sallie 623 feet has been eroded between 1886 and 1912 (85 and 24 feet per year)."

It appears reasonably certain that the forest of Biscarrosse (partly logged by the American E. F. in 1918) extended to the ocean in the 13th century. Huffel ${ }^{5}$ finds no reference to moving sand prior to 1580 when Montaigne wrote: "Along the ocean in Médoc my brother, le sieur d'Arzac, saw his land covered with sand that the sea vomited over it . . . the inhabitants say that for some time . . . they have lost four leagues of land." " A "liève" of land was about 4.4 kilometers or 2.7 miles. If this is correct it might be argued that the destructive action of moving sand in France dates from about the year 1200 if the land was covered for 4 leagues inland (17.7 kilometers or 11 miles) at the rate of 50 meters (164 feet) a year. But this is only conjecture.

Local Conditions. - There are fresh water ponds between the dunes from the Gironde to the Adour. Only one of these (Arcachon) is connected with the sea so as to form a bay. The average elevation of these ponds varies from 39 to 59 feet (Hourtin and Lacanau) and from 6 to 19 feet (Soustons). These ponds are typical of the dune region and are responsible to a large extent for the unhealthy climate of the region prior to the systematic drainage undertaken by the State. The water

${ }^{5}$ Huffel, Vol. I, p. 153.

6 That the area from Biscarrosse north to the Etang of Cazeau has been forested for a long period is evidenced by ancient vested rights which permit residents of the community to cut trees for fuel and construction. It was originally one estate, but has since been divided through heirs into a multitude of holdings. The owners can take the resin but have no right to cut the trees. The portion logged by the A. E. F. was on the newer dunes planted by the French Government, and possibly a little farther south than the old forest. 
hollows (lettes) between the dunes were also a source of fever. In former days there was considerable cattle, sheep, and goat grazing which did a great deal of damage. According to Bert:

"After the execution of the first work, the water holes between the dunes furnished quite good drainage ground for some time. But because of the drying action of the pine, the grass production disappeared little by little; the grazing in the region of the dunes became practically of no value."

This has had an important bearing on the attitude of the communes, since the restocking of the sand areas often meant the physical obliteration of their grazing, and because grazing was often disastrous to the artificial forestation and had to be curtailed or forbidden altogether. Bert says:

"One of the most important problems confronting the Dune Comamission was the ownership of the land. The dunes were evidently regarded as belonging to the State and the forestation was certainly alluded to at that time as belonging to the Nation, to the republic, to the Government, and as royal property. If this private property, whether belonging to individuals or to communes, had been left to shift for itself it certainly would have been lost to the Nation. But possibly a great deal of trouble would have been avoided if the land, then worthless, had been exappropriated at its actual sale value instead of being merely sown or planted by the State after having been abandoned by its original owners. It is significant that one or two owners in after years had their lands returned to them upon payment, with interest, of the cost of forestation. On account of the damage done by grazing these private rights were gradually extinguished by purchase by the State."

This is similar to the policy now followed in the Alps (see p. 143).

The climatic conditions are favorable to the growth of maritime pine since the extremes of temperature are $3^{\circ}$ and $23^{\circ} \mathrm{C}$. $\left(37.4^{\circ}\right.$ and $73.4^{\circ} \mathrm{F}$.) for cold and heat, the average rainfall 31 inches, and the average number of rainy days 200. An unfavorable climatic factor, which is often disastrous but which can be alleviated by shelter belts, is the violent west winds so typical of the region (see p. 204, "Fire Protection"). According to my field notes:

"In the vicinity of the Lacanau Ocean (forest of Lacanau) the average temperature throughout the year is $13^{\circ} 54^{\prime} \mathrm{C}$. $\left(56.3^{\circ} \mathrm{F}\right.$.); in summer the average is $20^{\circ} 48^{\prime} \mathrm{C}$. $\left(68.9^{\circ} \mathrm{F}\right.$.), and in autumn $13^{\circ} 32^{\prime} \mathrm{C}$. $\left(56.3^{\circ} \mathrm{F}\right.$.). There are 102 clear days annually, with a rainfall of 32 inches, coupled with frequent fogs. Violent west and southwest winds are very frequent."

These violent winds made the fixation of the sand all the more difficult.

The main dune area (see p. 177 for statistics) is between the Gironde and Adour rivers in a strip 3 to 4 miles wide and 145 miles in length.

\section{HISTORY OF RECLAIMING THE LANDES}

Periods of Work. - Five periods ${ }^{7}$ are distinguished in the development and reclamation of the dunes:

${ }^{7}$ Bert, id. (see p. 171). 
1. The groping of those who preceded Brémontier, 1734-1786.

2. Brémontier himself, 1787-1793 (with interim).

3. The Dune Commission, 1801-1817.

4. Administration of the Bridge and Road Service, 1817-1862.

5. The Waters and Forest Service, 1862 on.

(1) Before Brémontier. - Before Brémontier's time, a number of persons had suggested the possibility of reclaiming the dunes and preventing the disasters caused by the advancing sand. Following a disastrous fire in the forest of Teste in 1716 the forest was resown by its communal owners in 1717 , although there is a possibility that the records are inaccurate and that the sowing was natural rather than artificial. De Ruat, a member of the Bordeaux Parliament, argued in 1776 that it was perfectly practicable to sow the dunes, and on March 23, 1779, a decree in council accorded him perpetual ownership of a concession in the Teste region if he would reforest the area and prevent the sand from further encroachment. He had to pay, as purchase price, two pounds of wheat for each acre. Desbiey, former receiver at Teste, on the 25th of August, 1774, presented a statement to the Academy of Sciences at Bordeaux arguing that the sowing of the dunes was entirely practicable. In 1779 , De Villers wrote a special report on the possibility of fixing the Gascogne dunes. In 1778-1779 a commission studying the dune problem proposed interior plantations of trees, with plantations of genista and little bundles of straw held in place by stakes to hold the genista in place. According to Bert:

"It therefore appears certain that the methods of sowing and fixing dunes were known before the first experiments of Brémontier. They had been applied to a certain extent by Peychan, taken account of by De Ruat, and described by De Villers."

Tassin made some claims of originating the dune protective work but, apparently, in the words of Brémontier:

"He told me positively that my sowing and plantation of the dunes would never have been considered except as a brilliant theory which it is impossible to make practical use of."

Brémontier's ${ }^{8}$ credit for this great reclamation work rests on his devotion, activity, persistence, and clearness of vision rather than on an origination of ideas or methods. He was the man "to put it across."

${ }^{8}$ According to the Indian Forester, p. 415, Vol. 21, 1895, July 10, history has given Bremontier the credit for being the father of dune reclamation in France, but it is certain that there was considerable sowing on the dunes before Bremontier's time. In 1734 Alaire de Rust planted or sowed pine and oak on the dunes. In 1779 this work was continued by De Rust's grandson, but owing to fires the experiment was not successful. In 1773 the Comte de Mont Ausier presented a petition to the King to undertake dune reclamation, but at that time it was declared illegal. In 1777 Desbiey 
(2) The Bremontier Period. - Following the study of drainage in the Landes, completed in 1773, the Controller General, by letter dated September 20, 1786, put at the disposition of the proper authorities "the sum of 50,000 livres (about $\$ 9,650$ ) to be employed in works aimed at assuring the execution of a canal in the Landes and of finding efficacious means of fixing the dunes."

This work was assigned to Brémontier who, in turn, appointed Peychan, of Teste, who had taken charge of the sowing of the water hollows between the dunes for De Ruat. The earliest important document signed "Brémontier" is dated September 28, 1781, wherein he calls attention to the necessity of having 90,000 livres (about $\$ 17,370$ ) to assure the maintenance of local roads. According to the Memoir of De Villers dated 1779:

"Work was commenced near the sea at a point above the high tides in order to stop the sand in the areas planted, protect these parts by layers of wattle work or fascines, scattering the pine seed evenly over the ground with acorns here and there and a quantity of bush and plant seeds in order to fix the sand in place. The furze, genista and maram grass appear especially suitable to accomplish this object."

On the 21st of April, 1797, Brémontier sent Peychan, who was in charge of the experimental work at Teste, specific directions which did not mention the use of genista, furze, or maram grass seed recommended by De Villers, but, nevertheless, Peychan mixed the genista seed with that of the pine, and since then it has been recognized that the mixture was indispensable. The work began March 12, 1787, and in 1793 practically the whole amount appropriated had been spent. Peychan was succeeded by Déjean as Inspector of Works.

(3) The Dune Commission. - The Dune Commission, 1801-1817, on the recommendation of Brémontier, was appointed August 5, 1801, after a lapse of some years following Brémontier's first experimental work. The commission was composed of the Prefect of the Gironde; Du Bois; Brémontier, Engineer-in-Chief; Guyet-Laparde, Conservator of Forests; and three scientists from a Bordeaux society. Brémontier was the

wrote a paper on the sowing of pine seed. In 1778 the engineer Baron de Villers was sent by Louis XVI to study the question of dune reclamation with special reference to the harbor at Arcachon. He recommended in his report the sowing of pine seed and that the seed must be prevented from being blown away, and he solicited a trial of the system. In 1784 Brémontier was set to carry on this experiment, being aided by a private landowner named Peychan. This gentleman had previously made several successful attempts and he had covered the seed with branches to prevent it from being blown away. In 1787 Bremontier began the work of dune forestation, but the first experiments were failures, since he refused to use the Peychan method of covering the soil with branches to prevent damage by wind. In 1802 Brémontier's enterprise can really be said to have been successfully started and to be inaugurated as a successful project. 
ruling genius of the commission until he was appointed Inspector General of Roads and Bridges at Paris. He claimed that the cost would not be more than 4,000,000 livres (about $\$ 772,000$ ).

In 1804 the new Inspector of Dune Work, Déjean, covered the sowing with branches with the ends stuck about 4 inches in the sand, using heather, genista, and furze, as well as tamerisk and pine branches. In the same year he was able to report that the trees sown in 1788 and 1789 at Teste (Gironde) produced 2,196 pounds of resin and that many trees had reached 12 inches in diameter at the end of 14 or 15 years, while in the Landes 30 years is necessary to reach the same size. On September 17, 1808, the first public auction was held by the Forest Service agents to sell resin and turpentine secured from reforested areas. The cost in 1807 was about $\$ 9.26$ per acre but varied considerably (see p. 183). In 1810 locust, chestnut, poplar, and oak were planted with some success.

(4) Bridge and Road Service. - The administration by the Bridge and Road Service, 1817-1862, followed the commission form of administration which had established the methods of sowing, regulated the productions of the sown areas, and had practically solved the question of ownership. The principle of an artificial dune was described by Bremontier as early as 1787 , but the first work of this kind was undertaken some years later by the Forest Service which was able to successfully stop the sand. The permanent administration of these areas and the continuance of the work, however, required a stable organization, and the commission was therefore terminated in 1817, the work being turned over to the Bridge and Road Service. At that time the Forest Service was in bad odor and could not count on the liberality of appropriations which the Bridge and Road Service could secure.

(5) Waters and Forest Service. - As the stands began to mature it was increasingly difficult to keep distinct the work of the Forest Service and that of the Bridge and Road Service which, until 1862, had charge of the reclaimed areas. The engineering details of barrier dunes and drainage had been solved so the main problem was to protect and manage the forests. It was therefore entirely logical to turn the entire forestry work over to trained foresters, which was done in 1862. This organization is still in charge.

Statistics. - Huffel ${ }^{9}$ says there are the following maritime dunes in France:

$$
\text { Huffel, Vol. I, pp. 149-150. }
$$


TABLE 18.- AREA OF FRENCH DUNES

\begin{tabular}{|c|c|c|}
\hline Departments & Area in acres & Main ownership \\
\hline 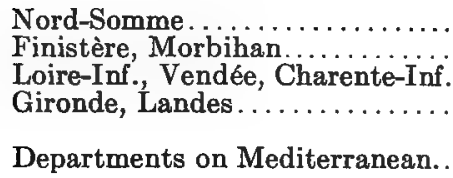 & $\begin{array}{r}30,147 \\
3,954 \\
33,606 \\
10252,046 \\
2,422\end{array}$ & $\begin{array}{l}\text { Private } \\
\text { Two-thirds private, one-third State } \\
\text { State } \\
\text { One-half State, one-half private or } \\
\text { communal } \\
\text { Private }\end{array}$ \\
\hline Totals for France. & 322,175 & One-half private, one-half State \\
\hline
\end{tabular}

The dune areas in the Gironde and Landes are about equal. The maritime pine covers a large area outside the dunes. There is a total forest of 1,656,630 acres in the Lot-et-Garonne, Landes, and Gironde divided as follows:

Ownership

Private and communal forest.

Communal forest under State control

State forest.
Acres

$1,510,549$

17,411

128,670

$\overline{1,656,630}$

By 1899 there were 140 miles of artificial barrier dunes in the Landes and Gironde Departments alone, the first barrier dune having been constructed in 1833 (see p. 178).

\section{FIXING THE SAND}

Construction of Coast Dunes. - It has already been seen that the ocean sand, if unchecked, drifts inland and submerges everything of value in its path. The theory of fixing or stabilizing the sand is to secure and maintain the following conditions.

Desired conditions

Objective

Gradual shelving beach. . . To allow the waves to break their force without eroding or washing the dry sand.

Barrier dune.......... To dam the drifting sand.

Grass or vegetable cover. . To maintain the sand in place on and around the barrier dune. (See Fig. 15.)

Forest protection belt.... To help maintain the sand in place and to protect the merchantable stands from the effects of the wind.

The underlying principle is as follows: ${ }^{11}$

"Every fixation system is founded on the following principle: In the mass of bare sand susceptible of being eroded by the wind, the transport takes place grain by grain. . . .

${ }^{10}$ This is substantially the same area as was reported in 1822; in 1800 Brémontier had estimated it at 271,815 acres and at over 281,420 acres in 1803 , while Villers had grossly overestimated the area in 1779 at 878,913 acres.

11 Boppe, pp. 478-481. 
Therefore, if the displacement of the surface particles can be stopped there is nothing to fear regarding those underneath, and the entire mass is fixed.

"The method consists in sowing the maritime pine under cover. It is to a landowner at Teste, Pierre Peychan - often known as Maitre Pierre - that we owe this method, both simple and practical, about which he advised Brémontier, and which we still use almost without modification.

"To keep the seed from being buried by the sand a cover of brush is laid over the entire surface seeded. This precaution is necessary not only for holding the seed but also for protecting the young plants against the action of the moving sand; for the moving crest of particles, projected without and against the growing stems, wears them out to a point when they fall over; being no longer able to hold up their heads, most of them would thus die. In practice, bundles of fagots up to 1,000 per acre are scattered over the area to be forested. These fagots are 3.3 feet in circumference measured on the withe and 4.3 in length. For their manufacture the gorze (ajouc) is the species preferred; then comes the genista (genêt), then the heather, tree heathers, the ronches (reed of fresh water marshes), and pine branches; but these latter have the disadvantage that too often under cover, cryptogamic diseases break out. The thorns, briars, ferns, and light woods do not protect the soil sufficiently.

"Immediately after the sowing of the seed the areas sown are covered over, or better still, the two operations are carried out at the same time. The brush is placed as you proceed toward the sea, the large ends facing (the sea) and the branches of each tier covering the base of those which proceed them. Then in order to keep this cover in place, the workmen put good sized (pelletées) sand on the portions where no seed has been sown and spread it on the outstretched branches, about 12 inches apart, measuring from the centers. The sole improvement made on the system of Pierre Peychan and Brémontier is that of fixing the cover in place by means of small poles placed across and held down by notched stakes driven into the sand."

At the end of the day's work the last row is securely fixed so any wind storm will not wreck the work already done.

"To sum up, it is really a dead cover which has been placed on the soil. But it would not last indefinitely, it is but the beginning to be followed by a living cover which will carry on its rôle."

Otherwise the sand coming from the ocean would be blown landward and would continue to cover the areas which had been reforested. Therefore to start with:

". . . There ${ }^{12}$ was established above high tide at a distance of 100 to 165 feet a wattle work fence or palisade. As the new sand drifted in front of this obstacle a part passed through the spaces between the planks or the wattle work holes and banked up behind. Little by little the sand rose and covered the palisade which was then gradually raised until the dune was 33 or 49 feet above the the level of the sea."

When the proper height was attained, the sand was planted to maram grass in order that it might be held in place. Once it was fixed in this manner it had to be maintained, since with every storm there were areas to be repaired. (See Fig. 15.)

"In $1858{ }^{13}$ there were 17 consecutive days of storm; the littoral line was broken at several points and it was impossible to repair it with sufficient rapidity. More than $\$ 9,650$ damage to sown areas was done in the Department of the Landes alone."

12 Les Landes et les Dunes de Gascogne, par. ch. Grandjean, Paris, 1897.

${ }^{13}$ Boppe, pp. 471-481. 


\section{According to Grandjean:}

"In the Gironde the palisade was established quite close to high tides . . . but in the Landes on the contrary it was 490 feet from high tide. This palisade having been successively raised until the dune attained an elevation of 20 to 26 feet and the talus becoming too steep they established ( 5 feet to the west) a cordon of fagots at the foot of the talus."

This lessened the steepness of the slope and was an excellent modification. The tendency has been to build the artificial dunes farther from the sea, up to 820 to 980 feet. In 1851 the artificial barrier or coast dune was constructed as follows:

"At 165 to 260 feet from the high tide mark, parallel to the shore that is to-day perpendicular to the direction of the wind, a palisade is built of joists 4.7 inches wide and 1.2 inches thick; these joists are deeply imbedded in the sand with a projection of 3.3 feet above the soil; they are spaced 0.8 to 1.2 inches from each other. After each storm the sand, driven by the wind, accumulates in front of the palisade and piles up on the other side through the spaces left between the joists; according to the size of the particles the equilibrium between the piles on the two sides is more or less readily established. This operation is repeated until the artificial dune is 33 to 39 feet high above high tide. The theory of this method is that the wind is harnessed by man to do his work. The slope is quite rapid on the talus facing the sea and the best grade or relief is always an important problem which must be studied locally. The surface is fixed with maram grass (gourbet, calam agrastis arenacea) secured by sowing or by root suckers. The maintenance work consists chiefly of repairing the breeches made by the sea or wind."

To-day the profile of these artificial dunes is being reversed, and the slopes are gently inclining toward the sea and abrupt on the land side, since it has been found by experiment that this gives better results.

"This new profile is secured by placing (parallel to the shore) successive lines of little hedges about 24 inches in height built of pine branches at the foot of which the sand accumulates. The skill consists, according to the form of the shore line and the progress of the sand, in placing these obstacles at the desired point to assist the dune to form its ridge line at such a distance from the shore that the slope can extend on the most practical incline. These very cordons, coupled with the maram grass sowing without a branch cover, can stop and hold in check the 'whistle-wind' and the ravines that the wind bores in the dune. . . .

"Moreover, it is marvelous to see how experienced foresters know how to use the growth to model the dune sand, something so mobile and capricious; where the (desired) profile has been secured they use the maram grass to fix these points, or on the contrary, pull out or thin the plant when they wish the wind to remove the piles of sand or mounds which have become useless or troublesome. Frequently hedges parallel to the coast are flanked with dikes whose direction is perpendicular to them, when these can be further subdivided into crow's feet or reverse dikes.

"When winding shores with sharp points are exposed to very violent wind, a careful study of the situation only can determine the places where defense work must be established, and what direction to give them. . . Finally, on points where the sea in eroding its shores and breaks into waves without depositing sand the material becomes scarce . . . the force of the waves is reduced by the erection of a forest of solid stakes driven into the sand and called break-water (brise-lame). The tamerisk, with its long flexible branches, renders the greatest service in consolidating all these dead 
works by a live growth. At the same time they try to replace the former profile outlined by the caprice of the waves by a suitable artificial beach with a grade as low as 5 or 6 per cent, so that the wave can roll in, losing its power of erosion. Moreover, each point demands a special solution. . . . In fact the final dune profile is not yet discovered; perhaps it will never be."

At Lacanau they began the artificial slope of the protective dune at 33 feet from high tide and extended it 148 feet to where the palisade originally stood. The protective dune was 52 feet high and 13 feet wide (across the top) with sand barriers at each side of the top. The dune then sloped gradually to a bench 164 feet farther back; perhaps about 65 feet farther on the lowest point was reached and the sand rose again to another dune where the protective pine zone began.

At Lacanau there were four kinds of barriers against sand erosion: (1) To prevent the erosion of the tops of barrier dunes upright stakes were placed 1.6 feet apart, 1.3 feet in height, with interwoven branches and genista to prevent the sand from sifting through. Here the ordinary palisades had been abandoned because the natural method just described is considered cheaper to maintain when once the protective dune is raised to the proper height by use of the palisade method. Here the artificial dunes were 52 feet in height. (2) To protect the rear of the protective dune rows of genista 2.3 feet high were sunk 1.1 to 1.3 feet in the soil. This resulted in keeping the rear of the protective dune to the proper height. (3) To hold the sand branches were laid on the sand to prevent wind erosion. (4) To hold and build up areas where the sand had been excavated by the wind near the ocean clumps of genista 1.6 feet in circumference were planted in quincunx. The French specifications for the "Fixation and Maintenance of Dunes" is given on page 429 of the Appendix. This gives a very minute and accurate account of the methods now in use. According to Lafond: ${ }^{14}$

"The littoral dune is the best defense in the dune region. If it is abandoned or if its maintenance is not kept up, new natural dunes invariably form and, blown by the wind, cover successively not only the forests created at great expense but afterwards additional country."

North of Bordeaux the protective dune seems to have assumed special importance. Parallel to the ocean and at a distance of about 656 feet from high tide a plank ${ }^{15}$ palisade, formed of planks 8 inches wide and spaced 1.2 inches is sunk in the sand. As soon as the sand accumulates, as in other dune regions, the palisade is raised about 31 inches. After the dune has once been formed it is of course planted to maram grass.

${ }^{14}$ Fixation des Dunes, par M. A. Lafond, Paris, Imprimerie Nationale, 1900.

${ }^{15}$ Frequently ordinary wattle work made of sticks 6.5 feet long and 2.5 inches in diameter sunk 1.6 feet in the sand and 1.6 feet apart is used. These pieces are then woven with branches and shrubs to a point 1.6 feet above the sand level. 
The height of the artificial dunes in this region is usually 33 feet. Lafond says:

"If higher, they cost much more to establish and are more difficult to maintain, and they give more of a lever to the winds, moreover, if they are built too high. Usually a lower height is sufficient."

From Point Arvert to Point Coubre (Charente Inférieure Department) the height of the artificial dune is usually 23 feet. At Requin it is extremely variable, being from 6.5 to 65 feet, and at Volcan 43 feet. From the Tournegand Canal to Palmyre it is $\mathbf{1 6}$ feet in height and from there on to the Grande-Côte it is but 13 feet. This shows how the height of the artificial dune must vary with the local conditions.

The destruction of these littoral dunes comes either from the wind or from the sea. The wind is the commonest danger but the sea the most difficult to combat. According to Lafond:

"A littoral dune not too high and bordering a permanent beach is on the whole easy to maintain. It is sufficient to keep the maram grass plantation (executed at the time of construction) in good condition and to maintain its original density on the different parts of the dune surface; the beach sand blown by the wind slides along the dune where it is scattered as nourishment for the clumps of maram grass. The excess amount passes behind the dune and is scattered in the littoral hollows (ledes). It does not cause any damage, however, because it is only a small amount and covers the soil so slowly that the brush or shrubs can grow as fast as the sand covers the soil and also keeps it fixed."

It is not nearly so easy to maintain a high protective dune at Coubre. Here the sand accumulates at certain points and forms hummocks which must be fixed immediately. "The formation of hummocks is avoided by not allowing the maram grass bunches to grow too thick and by removing every obstacle on the dune."

If hummocks of sand are formed their summit has to be broken so as to make the sand mobile and allow the winds to blow it away. If these irregularities can be avoided then, so far as the wind is concerned, the artificial dune can maintain itself.

Lafond says a dune can always be kept in good condition by means of maram grass plantations judiciously placed so as to hold the sand in the depressions and let it blow over the humps so as to have nothing but regular slopes or long undulations.

When the littoral dune is washed by the waves during storms it usually suffices to build barriers to retain the sand in place and permit it to resume its original shape.

"If the breech is quite considerable, to smooth it over the sand is topped by means of fagots planted in quincunx; often these quincunx are placed in two barrier lines, the one completing the action of the other. Where the erosion by the water is caused by dangerous currents then it is a very serious undertaking and masonry or expensive cement work is often necessary." 
Lafond describes in great detail special problems caused by the action of the ocean currents.

Forestation. ${ }^{16}$ - It has been seen that the first step is to make sure that the protection dunes are stable, and that the first essential is to sow or plant maram grass on the slopes toward the sea about 60 to 70 feet from high tide. It is usually planted in November to February since, if planted later after the rains have ceased, it is apt to die. It is dug up from maram bunches (which are too thick) and usually six to eight shoots are planted at one place. It is cut 8 inches below the soil when collected and is dibbled 12 inches deep in the sand; it is spaced 31 inches apart near the sea and farther back 20 inches. This wider spacing near the ocean is because it needs plenty of fresh sand in order to thrive, yet inversely if it is covered with too much sand it dies out and must be replanted.

The next step is to sow the maritime pine coming back to the barrier dune.

According to a report published in 1834 the method of sowing was as follows:

"Pine seed, mixed with genista, furze, or maram grass was used for sowing in the littoral zone. It was covered with branches of genista, furze, or pine according to the locality. . . . These branches were laid flat and placed as if they were ferns. . . They were held in place on the soil with a little sand (thrown broadcast)."

The methods have remained about the same. According to the instructions of May 16, 1888, 9 pounds of pine per acre with 8 pounds of genista or 9 pounds of maram grass pure were used; in either case it took 400 fagots of 44 pounds each for the covering.

The present method of sowing takes about 18 pounds of seed ${ }^{17}$ per acre of maritime pine, 1.8 of genista, and 1.8 of maram grass. The tendency is to sow too densely. The correct method of sowing means scattering the seed, theoretically about 1 to 2 inches apart. The seed is then covered with branches held down by sand. The cover is absolutely essential so that the sand will not burn the seed and so that the surface will not blow. A second method is by holes 4 inches deep and 20 inches apart, covered with genista and held down with sand. A third method now used is sowing in ditches 8 inches deep and 8 inches wide. These are then covered with sand and with a light brush cover. For dry localities the best time to sow is in October but for wet localities in March. When maritime pine is occasionally planted wild stock is used. According to Boppe (already cited):

16 The land tax on forested land on mountains, dunes, or waste land is exempt for thirty years; three-fourths the land tax is remitted on any cleared soil that is afterwards planted.

${ }^{17}$ Maritime cones are collected from January 1 to March 1 . Genista seed is collected in June and July and thrashed the end of July; maram grass is collected in August. 
"For this purpose, instead of using pure maritime pine seed, the following mixture is sown per acre: Maritime pine, 26 pounds; furze, 2.6 pounds; genista, 2.6 pounds; maram grass, 2.6 pounds; miscellaneous seed to attract birds, 2.6 pounds. This formula is used in the Coubre Dune. In the Landes practice the maritime pine is reduced to 9 pounds per acre, while the genista is increased to 8 and the maram grass to 3.5 pounds.

"The pine, the genista, and the furze come up simultaneously, and it is usually noted that the pines are better if the necessary seedlings are more numerous, moreover the cover rots where it lies and gives the soil its first supply of organic material. When the forestation is commenced at the very base of the dune the first stands established for a distance of 660 to 980 feet damaged by the ocean winds usually remain stunted and crooked; but under cover of this protective zone the stands which follow it develop normally; it is even stated that the pines on a dune yield more resin than those growing on (ordinary) ground."

Special Betterments in the Landes. - Next to the fixation of the sand and the drainage work one of the greatest problems in the Landes has been road construction, since paved roads have proved extremely expensive. It is for this reason that narrow-gauge railroads are so popular when a large area is to be worked. A special kind of wagon road is built of wood blocks 14 by 4 inches laid vertically. The usual dune road is the so-called "paillage." Such roads are 8.8 to 6.5 feet in width and the sand is dug out to a depth of $4 \frac{1}{2}$ inches and thrown to one side. Then twigs and branches are placed in the bottom and a cover of pine needles and moss placed on top. Roads of this type are confined largely to the dunes or pure sand areas. All main roads in the flat Landes are macadamized and the others are dirt roads, sometimes covered with needles.

Cost and Price Data. - Brémontier's original estimate for the dune control and forestation was about $\$ 772,000$ (see p. 170). The final cost ${ }^{18}$ of reclaiming 195,212 acres totaled $\$ 1,854,344$ or $\$ 9.50$ per acre. In addition $\$ 656,200$ was spent on maintenance of roads, forest houses, fire lines, and barrier dunes, making a grand total of $2 \frac{1}{2}$ million dollars. But just as Brémontier predicted, the annual revenue from this land, which would otherwise have been worthless, is more than the original amount spent. According to Huffel ${ }^{19}$ the total Dune and Landes pine forest (including State, communal, and private) comprised 1,611,121 acres which represents an investment of $\$ 10,331,290$ on the following basis:

${ }^{18}$ Huffel, Vol. I, p. 159.

${ }^{19}$ Huffel, Vol. I, pp. 182-183. The average costs are low because of the partial use of natural regeneration after the original dune forestation had been completed; this explains the difference between $\$ 9.50, \$ 10.75$ and $\$ 4.25$ per acre. 


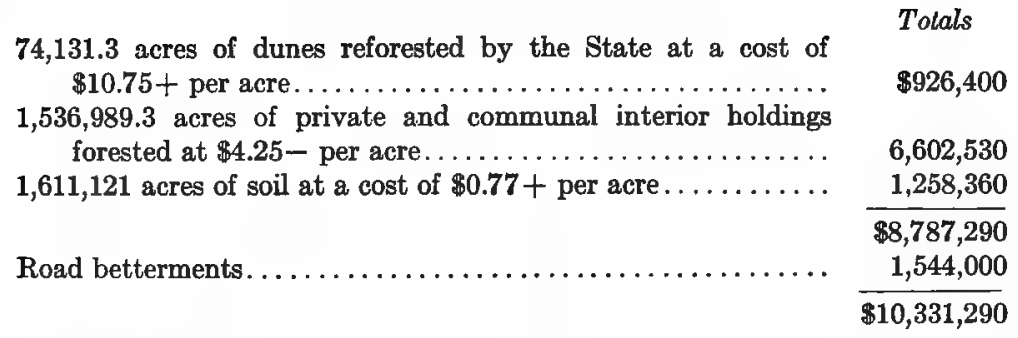

This is equal to an average investment of only $\$ 6.41$ per acre. A conservative estimate of yield, before the war, was $\$ 2.22$ per acre per year. Thus if taxation is eliminated the original investment yields over 30 per cent as a national "speculation," but it must be noted that the real soil value was almost nothing at the time the investment was made. It is at least significant that prior to 1914 timber appraisals of young stands used an interest rate of 7 per cent for the calculations, which is unique in forest technique and is due to the high returns and to the risk from fire.

Huffel estimates the average forest revenue in the Landes at $\$ 2,702,000$ net per year, representing a new capitalization including timber of at least $\$ 86,850,000$, or about $\$ 54$ per acre. As a matter of fact State forests with growing stock have been sold for around $\$ 60$ per acre and to-day average more than $\$ 93$ per acre for land purchased at less than a dollar! The bare soil sold for $\$ 16$ to $\$ 32$ an acre prior to 1914 - in other words, it was capitalized on the basis of what it could produce in resin and timber. ${ }^{20}$

The artificial barrier dunes cost about $\$ 96$ per mile. The forestation cost has been as high as $\$ 38.60$ per acre in the Landes and in the Coubre dunes only $\$ 14.20$. In 1817 a large area was sown at a cost of $\$ 15.05$ per acre. In 1827 Déjean reported ${ }^{21}$ the cost per acre had been reduced

${ }^{20} \mathrm{~J}$. H. Ricard says that unpeeled mine props sold for 15 francs per English ton in 1903, and up to 18 francs in 1908; ties of various specifications 2 to 3.40 francs; squared timber 22 to 25 francs per ton. Regarding land values Ricard says that the bare land sold in 1835 at 8 to 15 francs per hectare as a minimum, with 30 to 40 francs as an average. In 1910 the values were 40 francs minimum, 100 francs $(\$ 7.72$ per acre) average, and up to 300 francs maximum $(\$ 23.16)$.

${ }^{21}$ The details were as follows:

Cutting 1,400 fagots at 0.80 francs per $100 \ldots \ldots \ldots \ldots$

Working them up at 0.80 franes per $100 \ldots \ldots \ldots \ldots \ldots$

Transport 1,500 to 2,000 meters at 4 francs per $100 \ldots \ldots$.

Drying at 1 franc per $100 . \ldots \ldots \ldots \ldots \ldots \ldots \ldots$.

Miscellaneous fagot expense at 0.75 francs per $100 \ldots \ldots$.

One-half hectoliter maritime pine seed..............

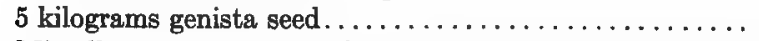

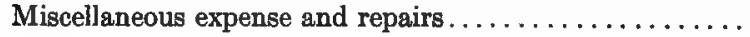

Francs per hectare

11.20

11.20

56.00

14.00

10.50

10.00

2.50

Total

4.60

$\overline{120.00}$ (or $\$ 9.26$ per acre). 


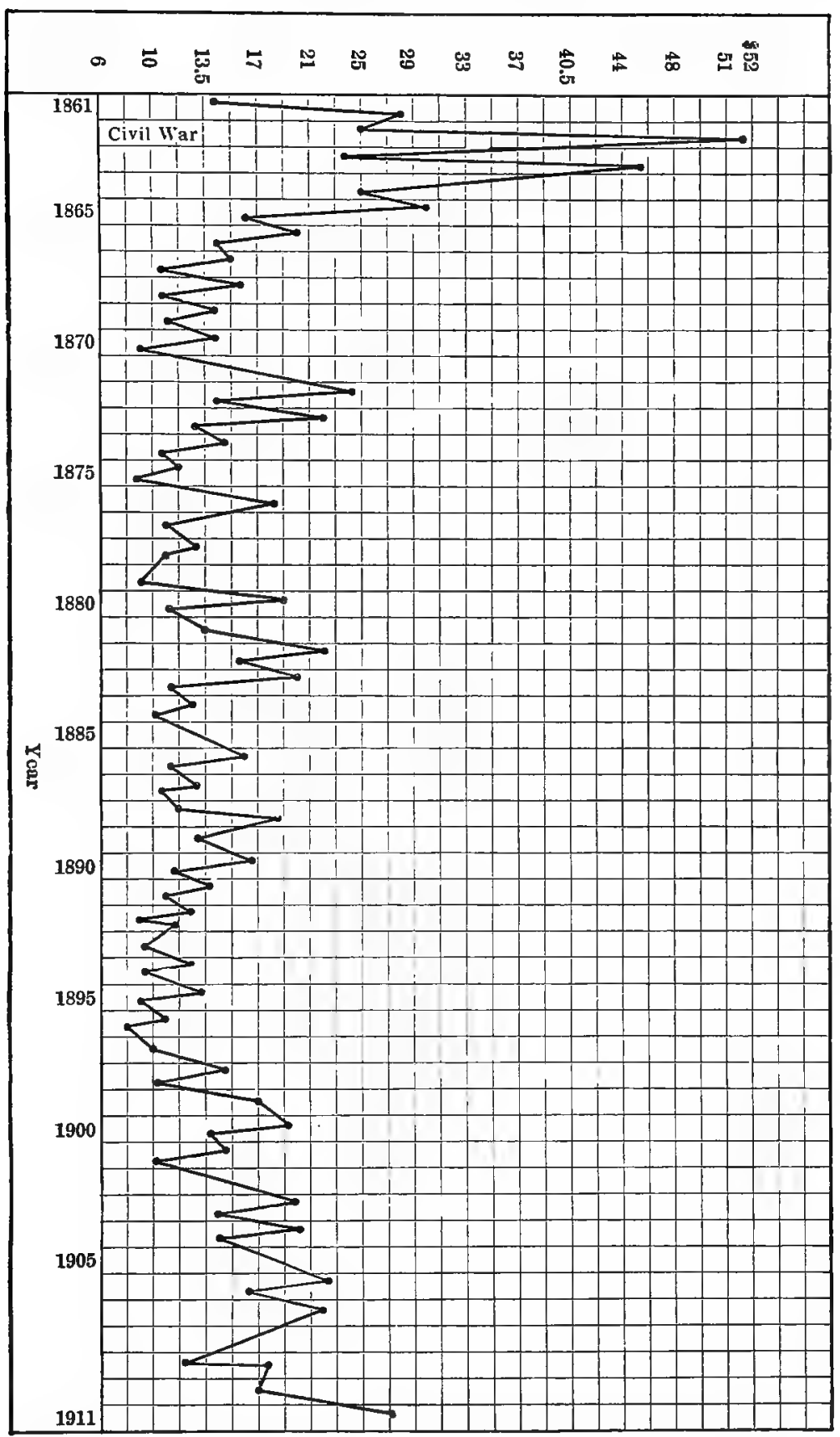

Fig. 16. - Barrel price, in dollars, of turpentine at Bordeaux. 
to $\$ 9.26$. To-day there would be natural regeneration. The cost per acre for hoeing (to 8 inches deep) and clearing fire lines has been, according to Bert, about $\$ 6.50$, or for a fire line 33 feet wide $\$ 26$ per mile.

The price of turpentine at Bordeaux from 1861 to 1911 is shown in Fig. 16. The extremely high price per barrel (340 liters or exactly 359 liquid quarts) in 1862 was because of the American civil war.

According to Conservateur de Lapasse, writing from Bordeaux December 16,1919 , the average prices per liter (1.05671 liquid quarts) of resin (résines ou gemmes) for the past 14 years were as follows:

TABLE 19.- PRICE OF CRUDE RESIN

\begin{tabular}{c|c|c|c}
\hline Year & $\begin{array}{c}\text { Price per liter, } \\
\text { dollars }\end{array}$ & Year & $\begin{array}{c}\text { Price per liter, } \\
\text { dollars }\end{array}$ \\
\hline 1906 & 0.050 & 1913 & 0.048 \\
1907 & 0.052 & $1914^{a}$ & 0.054 \\
1908 & 0.052 & $1914^{b}$ & 0.025 \\
1909 & 0.058 & 1915 & 0.046 \\
1910 & 0.071 & 1916 & 0.093 \\
1911 & 0.079 & $1917^{a}$ & 0.125 \\
1912 & 0.071 & 1918 & 0.135 \\
& & 1919 & 0.208 \\
\hline
\end{tabular}

a Price up to the war.

${ }^{b}$ Price August 1 to October 1, 1914.

- In 1917 the franc ran $5 \frac{1}{2}$ to the dollar, in 1918 about $5 \frac{1}{2}$ to $5 \frac{3}{4}$, and in $1919,5 \frac{3}{4}$ to $11 \frac{1}{2}$. The normal rate $\$ 0.193$ to the franc has been used in conversions.

\section{MANAGEMENT OF MARITIME PINE FORESTS}

Objects of Management (Protection Forests). - The objects of State management are to protect the soil from drifting sand and to produce resin, lumber (short length), ties, mine props, paving blocks, and other special wood products. The aim of the Government has apparently been greater volume production, disregarding consideration of the sizes in which it is produced, while private owners look to resin production and to higher stumpage values involved in larger timber. This is natural, because the poorer soils where State timber grows could not produce tall, large saw timber. The State is now looking more to receipts from resin. But according to Barrington Moore:

"The essential difference between Government and private management is that the former aims to produce a maximum volume of wood, whereas the latter aims to produce as much turpentine as possible and considers the wood as secondary. As might be expected, the Government must care for the needs of the community as well as for revenue. The Government foresters themselves admit that turpentine is more profitable than wood. . . . The silvicultural difference is, briefly, that the Government thins its forests lightly in such a way as to keep a complete canopy in order to grow 
the trees tall and straight and keep a maximum number per acre, whereas private owners choose the best trees to leave and thin heavily around them to give each tree full sunlight and encourage a large crown development."

Yet, as a matter of fact, the best timber is in private hands because the private forests usually occupy the richest soils, while the State forests are along the coast. In the Landes and Gironde most of the dune forests are in public hands and they are primarily held as a zone of defence against drifting sand. Of necessity they are heavily thinned relatively to allow the crown development so necessary to a light-demanding species. Moreover, so far as my own investigations show, even State forests outside protection working groups are now managed for resin rather than for lumber. Private forests are in less exposed situations and are managed solely for profit, and resin yields more than two-thirds the income.

According to an unpublished official note it appears that protection working groups must be handled with great conservatism:

“. . . The protection ${ }^{22}$ working group will then be treated with cuttings having a selection character; a physical exploitability will be applied, taking count, however, in a certain measure, of the special vegetative conditions of the maritime pine. Tapping without killing will be practiced, but with prudence, the yield in resin being first sacrificed in the interest of keeping the stand as fully stocked as possible in the essential rôle of protection. Experience has shown that the faculty given executive agents by the special decisions governing exploitation of the coast working groups, of commencing the application of tapping without killing pine measuring 12 inches and over in diameter (instead of 14 inches in the other working groups), has had unfortunate results on the increment and longevity of the trees faced. In the last marking we have really been obliged to let a considerable number of pine clearly over-worked remain idle in order to allow them to heal their scars which were too numerous and too wide.

"Being selected for protection working groups the production in wood is only secondary; on the other hand the production in resin can return an important revenue from these stands. But this production will not continue sustained unless it is not overwhelmed by a premature chipping of the trees exposed to the ocean winds, and consequently growing under less favorable conditions than the stands in the interior. Accordingly we believe that the reverse of this has been carried out and under penalty of making mistakes it is essential that the pine of the coast working groups be treated conservatively and only tapped without killing when they reach a size which will enable them to stand this operation. We are of the opinion that, as in the case of the exploitation working groups, the tapping without killing cannot be applied until the trees measure at least 14 inches in diameter. In the seventh working group the fellings will take place on the basis of special recommendations; the work done will follow the principles which have just been explained."

22 Cultural rules for protection working groups, unpublished note by De Lapasse, dated December 21, 1908: The general forest conditions of the Landes and Gironde have already been described (see p. 169) and also the silvical characteristics of the maritime pine (see p. 401). Mature stands 60 to 70 years old average 10,000 to 20,000 board feet to the acre; this high yjeld from small timber is because the soil is fully stocked. On private land mature timber runs 60 to 70 trees per acre and in State forests 100 or more. 
On the Lacanau (Gironde) State Forest the dune protection strip, according to the current working plan, is 2,625 feet wide where only the dead and dying trees are cut. In the State Forest of Carcans (Gironde) the protective zone is classified into three distinct parts and the growth of the dune forests as you approach the ocean (east to west) is similar to the decrease in growth as you near the limit of tree growth in the mountains: (1) The littoral zone of mere shrubs which is 535 to 1,322 feet wide. (2) A zone of badly formed trees of no commercial value, of slow growth and open formation. (3) A third zone where the stand is sufficiently dense to be tapped but which is maintained without tapping as a protective barrier. It is very significant that these trees which are exposed in part to the rigors of the ocean winds are not tapped at all but are maintained exclusively as a protective zone.

Silvicultural Systems. - Next to the protection working group (which is in the shape of a long strip five-eighths of a mile parallel to the ocean) additional working groups (in strips) are laid out from west to east. These are treated as high forests by the shelterwood compartment system with the usual seed fellings and secondary fellings omitted, since regeneration is easy by clear cutting without the necessity of seed trees or the shelter of a portion of the mature stand. The seed is furnished by the tops of the felled trees. The normal compartment is 247 acres which may be leased for tapping or sold for cutting as a unit or in as many as four sub-units, especially if because of dunes or previous fires the character of the timber differs. Final cutting is clear for the unit. All tops are lopped out and left or scattered to lie flat on the ground to assist reseeding. Before felling all underbrush and seedlings are felled flat for the same purpose. The cover of moss, needles, limbs, and brush prevents any movement of the sand before the pine seed has a chance to sprout. Under this procedure natural reseeding nearly always occurs. On areas in which it fails sowing is done. Because of sod, highwater table, etc., natural seeding is frequently not so successful in the private forests. Sowing there may be broadcast or in plowed strips. Planting is also done extensively, largely with seedlings collected from nearby stands. Grazing is not permitted for about four years after sowing or planting on private areas. Immediately around Arcachon the maritime pine is under the selection system and is kept entirely cleared of undergrowth, since it is maintained as a sort of pleasure park for tourists. In the nearby forest of La Teste some clear cutting was practiced entirely too near the sea and after two years the regeneration had only partially succeeded. It would have been much better to have left a protective zone of virgin timber for seed, since clear cutting close to the sea is always dangerous, especially with the current fire danger. 
Intermediate Fellings. - After the stand has been regenerated the sapling thickets are thinned by the so-called "dépressage" (see p. 110), before they reach merchantable size, to avoid fungous damage, and cleanings are sometimes necessary to protect the pine against the heather.

Under "Improvement Cutting" the Biscarrosse working plan provides:

"Cleanings and thinnings without tapping. Commence the cleanings in the regenerated 'periodic blocks' 5 years old; at the same time lop the lower whorls of the vigorous shoots and cut the weeds which suppress the pine. These (cultural) operations should be made periodically every 5 years and will become thinnings at 10 to 15 years; thus the stand will be systematically thinned and when about 20 to 25 years old there should be about 200 stems per acre. Do not hesitate to cut back the weeds at each period, both broom and furze, with the double object of doing away with thickets which promote conflagrations and to give the pine the air and light so necessary for good growth. It is, in effect, absolutely proven in the Landes that the pineries on cleared soil grow much better than those with thick understory (of weeds). In the older stands the thinnings (without tapping or with the axe) have almost entirely the character of weedings; the advance seedlings of no value at the time of regeneration will then disappear under the cover of the dominant story."

Pruning usually starts at 10 years of age. The typical 3 -inch tree is naturally pruned up to 2 feet above the ground, while the typical tree of 6 inches is pruned artificially up to 10 to 12 feet above the ground. The branches, which are left as they fall, take about 5 years to rot. This pruning is done every 5 years. In order to protect stands from fire at the time of cleaning the genista is now cut. Stands artificially sown are usually mixed with a dense stand of genista 10 feet high; consequently the pine has to be freed. The first thinning or cleaning is quite heavy and one stand was noted where there were 800 trees per acre before the thinning that showed only 480 per acre after the thinning.

Regular thinnings "with the axe" without tapping (see p. 110) are thus usually necessary before the trees are large enough to stand a face. At about 25 years, depending on the growth, the regular thinnings by tapping to death begin, often preceded by tapping to exhaustion (see quotation below). This merely means that instead of at once felling a tree, which is superfluous or of poor quality, it is first heavily tapped for a period and then tapped to death and cut after four or more years of very intensive tapping. This type of thinning is continued every 5 to 10 years until the stand is mature and rather open (see p. 192).

In the forest of Biscarrosse (Landes) thinnings by tapping alive are conducted as follows: ${ }^{23}$

${ }^{23}$ Extract from the revised working plan for Biscarrosse (Landes) forest containing an inspection note from De Lapasse of December 21, 1908. Reference is made to page 193 where the new 4-year cycle (for thinnings and tapping) is fully explained. 
"The thinnings made every 5 years will aim to open up the forest. This favors both the production of wood and resin in maritime pine. The thinnings will aim to maintain the timber in a good state of growth by placing it under the best conditions for increment; owing to the fact that the maritime pine is a light demanding species one should not forget that in the case of this species the underwood as well as the suppressed trees are valueless and that the upper story alone is of interest. This cultural rule seems much surer than that given in the working-plan report.

"In the regenerated stands the thinnings with tapping will commence at about 25 years of age, or as soon as the timber shall have attained a sufficient size to enable it to stand a face. Except when the removal of a pine is more or less urgent tapping to death or 'tapping to exhaustion' will be followed. The 'tapping to exhaustion' will precede the application of tapping to death by at least the length of a period ( 5 years); it can then be accomplished by one or by two faces according to the size of the trees. This method of tapping will be applied to the entire stand of each periodic block during the period which precedes regeneration. The tapping without killing (gemmage a vie) will continue to be applied to the pine 14 inches and over at breast height. Very vigorous trees measuring at least 16 inches in diameter can be intensively tapped without killing and receive two faces. This method of extracting the resin can be made general and will be justified chiefly during the three or four periods preceding regeneration.

"The application of 'exhaustive tapping' and of intensive tapping without killing (without injury to the stands) has been rendered possible by the decision of the Director General, dated March 23, 1908, who has authorized the Mont-de-Marsan inspection to reduce the sizes of the faces in height and in diameter."

It should be particularly noted that. so-called exhaustive tappings which precede the usual thinnings by tapping to death is a new feature of French practice aimed at the increase of resin production in State forests. This means that there is a good deal of marking expense. In 1905, in the inspection of Mont-de-Marsan, 15,180 acres had to be marked; the work lasted practically continuously from February, 1915, to July 8 , and the marking removed on an average of almost exactly 40 trees per acre, or 612,455 trees. This illustrates the heavy thinnings followed in State forests - so necessary for maritime pine to develop good crowns. The first cleaning in private forests takes place at 4 years, and the first tapping to death for thinning at 15 years. By 30 years the stand is pretty well reduced to its final number and tapping of all trees alive begins. The "Landes" rule is that no permanent tree should be tapped until it is at least 13 inches in diameter. All private tapping is now being done 4 years to a face.

Rotations. - The State forest rotations adopted in the past have been 70 years with fourteen periods of 5 years each, 72 years with twelve periods of 6 years each, 75 years with fifteen periods of 5 years each, and 80 years with sixteen periods of 5 years each. When the length of the period is six years the consecutive tapping is separated by one year of rest. In a large number of forests, however, the final rotation is preceded by a transitory rotation which usually differs for each working 
group. Rotations in private forests are usually shorter. The average is between 55 and 65 years and, where the production of mine props is the chief objective, the rotations can be reduced to about 40 to 50 years. With the new 4-year thinning cycle the present rotations may be slightly reduced.

According to the working plan for the forest of Biscarrosse, revised January 7, 1910, the maritime pine has a 75-year rotation. The forest is divided into fifteen periodic blocks. The growth data available show that the maximum growth of the maritime pine is between 40 and 50 years; therefore a transitional rotation of 60 years has been recommended. It is almost certain that as the humus in the different maritime forests fertilizes the soil the growth will become more rapid, so that the proverbial 70 to 75 year rotations may be generally reduced to 55 to 65 years.

According to this working plan "The yield is established by area; the surface of each periodic block is run over by a clear-cut regeneration felling, exploited during the period having the same numerical order as the periodic block."

Felling Cycles. - In the past the felling cycle was almost invariably 5 years, but sometimes 4 to 6 years. In the future it will usually be 4 years (see p. 193). In the past the trees were resined for 4 years and felled the fifth year. But in the forest of Carcans a 6-year period allowed 5 years for tapping and the usual 1 year for felling.

Working Groups. - According to De Lapasse the past method of management was as follows:

"These forests are divided into working groups whose number varies from two to six, according to their importance and size; working groups are established in long strips parallel to the ocean, bounded by parallel fire lines, the first working group being placed on the east side of the forest. In each working group the periodic blocks are numbered in the order in which regeneration is fixed, from the north to the south. In each forest the working plans have established a group without predetermined treatment, to include the dune and littoral zone, designed to form a shelter belt which protects the remainder of the stand against wind action and sand coming from the west.

"The scheme is very simple. During each 5 -year period each periodic block (except those to be regenerated and those including young growth) is run over by a thinning with turpentine operations. The trees which are to be removed are, before they are cut, tapped to death during a period of 4 years; simultaneously, the pines which have reached 14 inches in diameter and above are tapped alive for 5 years. The oldest periodic block in turn is regenerated by clear cuttings preceded by tapping to death all the trees. These are felled during the fifth (see 'New Tapping Scheme,' p. 193) and last year of the period. The periodic blocks of young growth are run over by ordinary thinnings without tapping. At the beginning of each period (every 5 years) each working group is completely marked (and valued) to compute the material of the clearcut regeneration fellings (to be sold standing) and the trees to be tapped alive where the contractor receives only the resin." 
With the new 4-year tapping cycle a working plan for a maritime pine forest having a 68-year rotation and 17 periods would normally be worked as follows:

TABLE 20.- WORKING PLAN FOR A MARITIME PINE FOREST

\begin{tabular}{|c|c|c|c|c|c|c|c|c|c|c|c|c|c|c|c|c|c|c|c|}
\hline \multirow{2}{*}{ 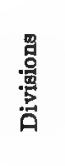 } & \multirow{2}{*}{ 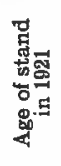 } & \multicolumn{17}{|c|}{ Tapping periods } & \multirow{2}{*}{ 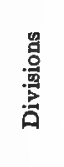 } \\
\hline & & $\begin{array}{c}1 \\
1921 \\
\text { to } \\
1924\end{array}$ & $\begin{array}{c}2 \\
1925 \\
\text { to } \\
1928\end{array}$ & $\begin{array}{c}3 \\
1929 \\
\text { to } \\
1932\end{array}$ & $\begin{array}{c}4 \\
1933 \\
\text { to } \\
1936\end{array}$ & $\begin{array}{c}5 \\
1937 \\
\text { to } \\
1940\end{array}$ & $\begin{array}{c}6 \\
1941 \\
\text { to } \\
1944\end{array}$ & $\begin{array}{c}7 \\
1945 \\
\text { to } \\
1948\end{array}$ & $\begin{array}{c}8 \\
1949 \\
\text { to } \\
1952\end{array}$ & $\begin{array}{c}9 \\
1953 \\
\text { to } \\
1956\end{array}$ & $\begin{array}{c}10 \\
1957 \\
\text { to } \\
1960\end{array}$ & $\begin{array}{c}11 \\
1961 \\
\text { to } \\
1964\end{array}$ & $\begin{array}{c}12 \\
1965 \\
\text { to } \\
1968\end{array}$ & $\begin{array}{c}13 \\
1969 \\
\text { to } \\
1972\end{array}$ & $\begin{array}{c}14 \\
1973 \\
\text { to } \\
1976\end{array}$ & $\begin{array}{c}15 \\
1977 \\
\text { to } \\
1980\end{array}$ & $\begin{array}{c}16 \\
1981 \\
\text { to } \\
1984\end{array}$ & $\begin{array}{c}17 \\
1985 \\
\text { to } \\
1988\end{array}$ & \\
\hline I & 64 & $\mathbf{R}$ & n & e & e & e & e & ge & ge & ge & ge & ge & ge & ge & ge & G3 & G2 & $\mathrm{Gg}$ & $I$ \\
\hline II & 60 & $\mathrm{Gg}$ & $\mathbf{R}$ & $\pi$ & e & e & $\theta$ & e & ge & ge & ge & ge & ge & ge & ge & ge & G3 & G2 & II \\
\hline III & 56 & G2 & $\mathrm{Gg}$ & $\mathbf{R}$ & ก & $\theta$ & $e$ & e & $\theta$ & ge & ge & ge & ge & $\mathrm{ge}$ & ge & ge & ge & G3 & III \\
\hline IV & 52 & G3 & G2 & $\mathrm{Gg}$ & $\mathbf{R}$ & $\pi$ & e & 0 & $\theta$ & e & ge & ge & ge & ge & ge & ge & ge & ge & IV \\
\hline $\mathbf{V}$ & 48 & ge & G3 & $\mathrm{G} 2$ & $\mathrm{Gg}$ & $\mathbf{R}$ & n & e & $\theta$ & e & e & ge & ge & ge & ge & ge & ge & ge & $\mathbf{V}$ \\
\hline VI & 44 & ge & ge & G3 & G2 & $\mathrm{Gg}$ & $\mathbf{R}$ & $\pi$ & e & e & $\theta$ & e & ge & ge & ge & ge & ge & ge & VI \\
\hline VII & 40 & $g \theta$ & ge & ge & G3 & G2 & $\mathrm{Gg}$ & $\mathbf{R}$ & 11 & e & e & e & $\mathrm{e}$ & ge & ge & ge & ge & ge & VII \\
\hline VIII & 36 & ge & ge & ge & ge & G3 & G2 & Gg & $\mathbf{R}$ & n & $\theta$ & e & $\mathbf{e}$ & e & ge & ge & ge & ge & VIII \\
\hline IX & 32 & ge & ge & ge & ge & ge & G3 & G2 & $\mathrm{Gg}$ & $\mathbf{R}$ & n & e & e & e & e & ge & ge & ge & $\mathbf{I X}$ \\
\hline$X$ & 28 & ge & ge & ge & ge & ge & ge & G3 & G2 & Gg & $\mathbf{R}$ & " & e & $\theta$ & e & e & ge & ge & $\mathbf{X}$ \\
\hline XI & 24 & ge & ge & ge & ge & ge & ge & ge & G3 & G2 & $\mathrm{Gg}$ & $\mathbf{R}$ & n & e & $\theta$ & e & e & ge & $\mathbf{X I}$ \\
\hline XII & 20 & ge & ge & ge & ge & ge & ge & ge & ge & G3 & G2 & $\mathbf{G g}$ & $\mathbf{R}$ & " & e & $e$ & e & $\theta$ & XII \\
\hline XIII & 16 & e & ge & ge & ge & $g e$ & ge & ge & ge & ge & G3 & G2 & $\mathbf{G g}$ & $\mathbf{R}$ & $\pi$ & $\theta$ & e & $\theta$ & XIII \\
\hline XIV & 12 & e & e & ge & ge & ge & $g e$ & ge & ge & ge & ge & G3 & G2 & Gg & $\mathbf{R}$ & $n$ & e & e & XIV \\
\hline XV & 8 & e & e & $\theta$ & ge & ge & ge & ge & ge & ge & ge & ge & G3 & $\mathrm{G} 2$ & $\mathrm{Gg}$ & $\mathbf{R}$ & " & e & $\mathrm{XV}$ \\
\hline XVI & 4 & $\theta$ & e & e & e & ge & ge & ge & ge & ge & ge & ge & ge & G3 & G2 & Gg & $\mathbf{R}$ & $\pi$ & XVI \\
\hline XVII & 0 & " & e & e & e & $\theta$ & ge & ge & ge & ge & ge & ge & ge & ge & G3 & $\mathrm{G} 2$ & $\mathrm{Gg}_{\mathrm{g}}$ & $\mathbf{R}$ & XVII \\
\hline
\end{tabular}

Data furnished by Conservateur de Lapasse, April 7, 1920. Key to abbreviations used in above table:

R - Regeneration fellings, by clear cutting after tapping to death during 4 years. The felling takes place at the end of the fourth year (winter up to January) of the period and during the first year (winter after January) of the next period.

Gg - 1. Exhaustive general tapping (gemmage-épuisement général) during the period that precedes regeneration. All trees receive at least one face. 2. Continued tapping alive.

G2-1. Exhaustive tapping during the period which precedes Gg. All trees 10 inches and over in diameter are given one face. 2. Continued tapping alive.

G3 - 1. Moderate exhaustive tapping during the period which precedes G2. All trees 11 inches and over in diameter are given one face. 2. Continued tapping alive.

ge - 1. Rapid exhaustive tapping or tapping to death of all excess trees which must be quickly removed by thinnings. 2. Slow exhaustive tapping of trees which will be gradually removed in thinnings. 3. Tapping alive with one face of all trees at least 12 inches in diameter. Also the felling of damaged trees at the end of the fourth year of the period and during the first part of the first year of the next period.

" - No cultural operations.

e-Cultural operations without tapping. 1. In the young stands beginning with about 5 years: freeing of seedlings and clearing of brush heather. 2. In stands 10 to 20 years old: "dépressages," and thinnings with gradual pruning of lower branches up to a height of 11.5 feet on the bole. The foregoing system (which slightly modifies the past procedure in state forests as can be seen from the text) is now (1920) to be standard for all forests under public forest management. 
New Tapping Scheme. - The French have abandoned the fifth year of tapping (see Fig. 17, $a$ and $b$ ) because of the following objections: (1) Difficulty of chipping the face when it is over 9.8 feet in height; (2) this high face, which is often too deep because of the difficulty of accurate chipping, heals poorly or at least very slowly; (3) an important part of the bole is damaged by a high face. For these reasons the tapping period has been changed from 5 to 4 years. The dimensions for the faces now are:

TABLE 21.- WIDTH AND BEIGHT OF FACES

\begin{tabular}{|c|c|c|c|c|}
\hline \multirow{2}{*}{ Year } & \multicolumn{2}{|c|}{ Width } & \multicolumn{2}{|c|}{ Height } \\
\hline & Centimeters & Inches & Centimeters & Inches \\
\hline $\begin{array}{l}1 \\
2 \\
3 \\
4 \\
\text { Total. }\end{array}$ & $\begin{array}{l}9 \\
9 \\
8 \\
7 \text { to } 6 \\
\end{array}$ & $\begin{array}{c}3.5 \\
3.5 \\
3.1 \\
2.75 \text { to } 2.36 \\
\ldots \ldots \ldots \ldots\end{array}$ & $\begin{array}{r}60 \\
60 \\
75 \\
95 \\
2.90 \text { meters }\end{array}$ & $\begin{array}{l}23.6 \\
23.6 \\
29.5 \\
\frac{37.4}{9.5} \text { feet }\end{array}$ \\
\hline
\end{tabular}

With the former fifth year system in vogue the total height was 3.70 meters (12.1 feet) before 1904; 3.40 meters (11.1 feet) from 1904 to 1909 ; and 3.20 meters (10.4 feet) since 1910. A translation of the official tapping rules is given in the Appendix, p. 429.

According to Cattin and Saint-Jours a period of rest of 1 or 2 years is not always necessary with strong, thrifty trees, although the annual growth is unquestionably increased if the rest is given. On the Florida National Forest in the United States there are 6 years of tapping followed by 3 years of rest; with the French system of tapping such a period of rest is generally considered unnecessary.

In the forest of La Teste trees but 7, 10, and 12 inches in diameter each (being tapped to death) had three faces the first year and later four to five. The trees tapped alive had one face only. Formerly, the faces began on the south side and went to the north, then to the west, and then to the east. Now the first face is placed on the east side of the tree (away from the ocean) where the growth is best, then to the west; the third and fourth faces being regulated by the contour of the tree. The best growth in this locality is always opposite the ocean and the prevailing winds.

This reduction in the length of the tapping period, when applied to forests being worked on 5-year cycles, will mean the revision of working plans. The regeneration by clear cutting will be every 4 years instead of 5 years as formerly, and the cycle for thinnings will also be reduced from 5 to 4 years. In the future the cleanings will be made earlier after re- 
generation, since experience has shown the inconvenience of waiting for 5,6 , or 7 years as was formerly done.

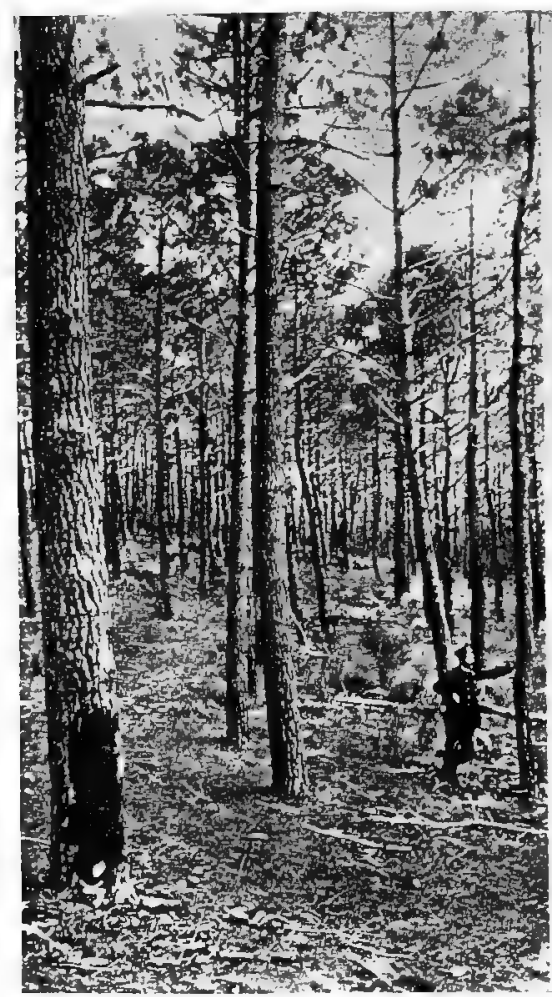

A

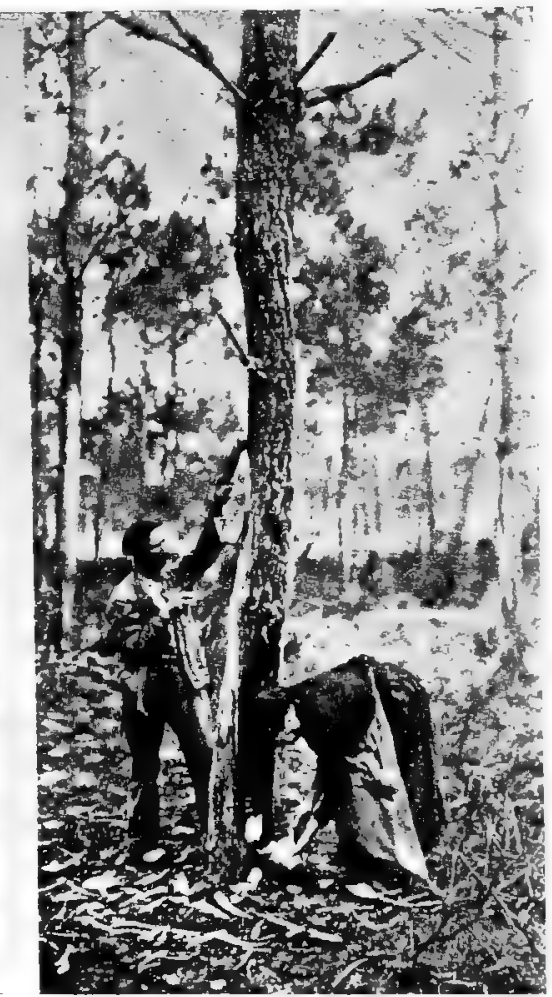

$\mathbf{B}$

FIG. 17 (a). - Maritime pine 57 years old during improvement felling. The face on the first tree, which is being tapped alive, has been worked only one week.

(b). - Small tree being tapped to death prior to utilization for mine props.

Tapping Other Species. - According to unpublished notes loaned the writer by Cuif in 1912, he has concluded finally that the tapping of Austrian or Seotch pine will never be commercially practicable without a decided increase in present turpentine and rosin prices. ${ }^{24}$ This agrees with the results in other forests which are not usually tapped for resin. For example, in Corsica, during the extremely high prices caused by the American Civil War, Corsican pine had been tapped for awhile and then abandoned; the same was true of California yellow pine.

${ }^{24}$ Le Gemmage du pin noir d'Autriche et du pin sylvestre en Meurthe-et-Moselle, par Cuif, 1912 (unpublished notes). 
Resin Sales. - According to a digest of resin sales made at Mont-deMarsan, October 5, 1909, for the period 1910 to 1914, inclusive, the policy of favoring the small operator is just as much in evidence as with ordinary timber sales in other parts of France. The payments which are made annually vary between $\$ 400$ and $\$ 2,000$ and, ordinarily are less than $\$ 1,500$. If a large company, for example, desired to secure a considerable area for resin operations, it would be necessary for it to bid in a number of contiguous or nearly contiguous resin sales, some of which might be advantageously located for a small local operator. This clearly results in a better price and gives the small operator an excellent chance to secure areas convenient to his home. Each bidder is supplied with detailed data as to the stand and estimated products, boundaries, methods of removal, and charges, as in the case of ordinary timber sales. An example follows:

"Article 1. - Forest of Biscarrosse - Fifth series. - Affectation 1 (p) Canton dune de Jaongue-Soule. First lot, area 91 acres.

Clear-cut regeneration felling, with privileges of tapping to death for 4 years from 1910 to 1913 , comprising the exploitation of 15,379 pines, to wit:

$\begin{array}{lllllllllllll}\text { D. B. H. inches }=\text { Poles } & 8 & 9 & 10 & 11 & 12 & 13 & 14 & 15 & 16 & 17 & 18 & 19\end{array}$

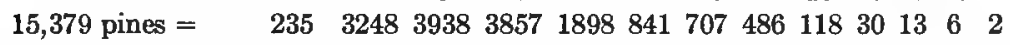

Estimated products: Lumber 3,164 cubic meters; firewood, 1,186 steres; resin 1,762 hectoliters.

Boundaries: N. fire line boundary of the Gironde; E. fire line parallel No. 2; S. second lot; W. communal water hollow of Jaongue-Soule.

Removal: By the Cugnes and Brofond roads.

Accessory exploitation: Lopping understory. Products may be left as they lie.

Charges: Repair of roads, $\$ 173.70$.

Fire tool box: The contractor shall install, either in a tapper's cabin or in a special locked box, in a place to be designated by the local forest officer, the following tools 2 axes, 2 sickles, 2 shovels, and 2 rakes. The kind of tools will be selected by the head ranger; they will remain the property of the contractor who will keep them intact and in good condition; the depot will be ready by January 31 following the sale."

The following special clauses were specified:

"The extracting of resin will take place in the following manner instead of as specified in Art. 19 of the specifications (see Appendix, p. 429):

Of the trees to be tapped alive those so designated by the Forest Service may receive two faces.

If the period of tapping is 5 years, the face may be raised 23.6 inches during the first two years; 25.6 inches during the third and fourth years, and 27.5 inches during the fifth, provided the total height of the face does not exceed 10.5 feet. If this period is four years, the face may be raised 25.6 inches the first year, 27.5 inches during the second and third years, and 29.5 inches during the fourth, provided the total height of the face does not exceed 9.2 feet. In all cases the width of the face must not exceed the following dimensions: During the first year 3.5 inches, during the second 3.1 inches, during the third 2.8 inches, during the fourth 2.4 inches, during the fifth 2 inches. 
The decrease in the width will be made gradually in such manner that the width at the end of each year will equal that of the next year.

The faces will be made . . . so as to divide the circumference of the tree in three practically equal parts, the second face to be opened at the right (facing it) of the first. The faces shall be raised by following the grain of the wood. The other non-conflieting stipulation of Article 19 shall remain in force."

The regular French specifications covering resin operations are given in full, as are those for the United States and for British India, in the Appendix.

Each operator is informed that payment must be made annually for a period of five years, that in the thinnings the pines to be tapped to death are marked with two imprints of the State marking hatchets, one on the bole and one on the roots, while trees to be tapped permanently (gemmage à vie) with one face are stamped once on the bole; if two faces, two stamps on the bole, one below the other. Contractors who do not furnish the fire fighting tools (prescribed under "charges") must understand that they will be bought by the Waters and Forests Service and charged to their account. Foreign workmen can be hired only up to 10 per cent of the total number employed. A fixed price for the transportation of products from Federal forests is agreed upon with the local railways and the rates furnished the contractor. In some instances the Forest Service has built both narrow and broad gauge railways on State forests which are leased to the operator or to connecting lines.

French Tools for Tapping and Their Use. - Fig. $18^{25}$ shows the principal French tools used in tapping maritime pine to secure the resin for the manufacture of turpentine. The letters following correspond to those in the figure.

(a) Barrasquit d'Espourga. - This tool is used to shave off the bark of trees to be tapped. This is a preliminary operation made at the beginning of each year; the workman shaves the bark vertically from top to bottom to remove the dry and hard superficial bark, so as to make the tapping easier. The area cleaned is 11.8 to 13.7 inches wider and 3.9 to 5.9 inches higher than the dimensions of the proposed face. It should be noted, however, that the shaving is usually done with an ordinary axe for the first year of tapping, because the face is low and easily reached; for the second year of tapping it is sometimes done with an axe or with the short-handled barrasquit. Before the third or fourth year, the cleaning is always done with the instrument shown in the figure. The "barrasquit de barrasque," a similar tool, is used to scrape the dry, solidified resin from the face at the end of the season. This

${ }^{25}$ Adapted from Plate IX, Bulletin 229, U. S. Dept. of Agriculture. The names of the instruments have been added in the legend under the figure and the description of use materially changed and corrected. 

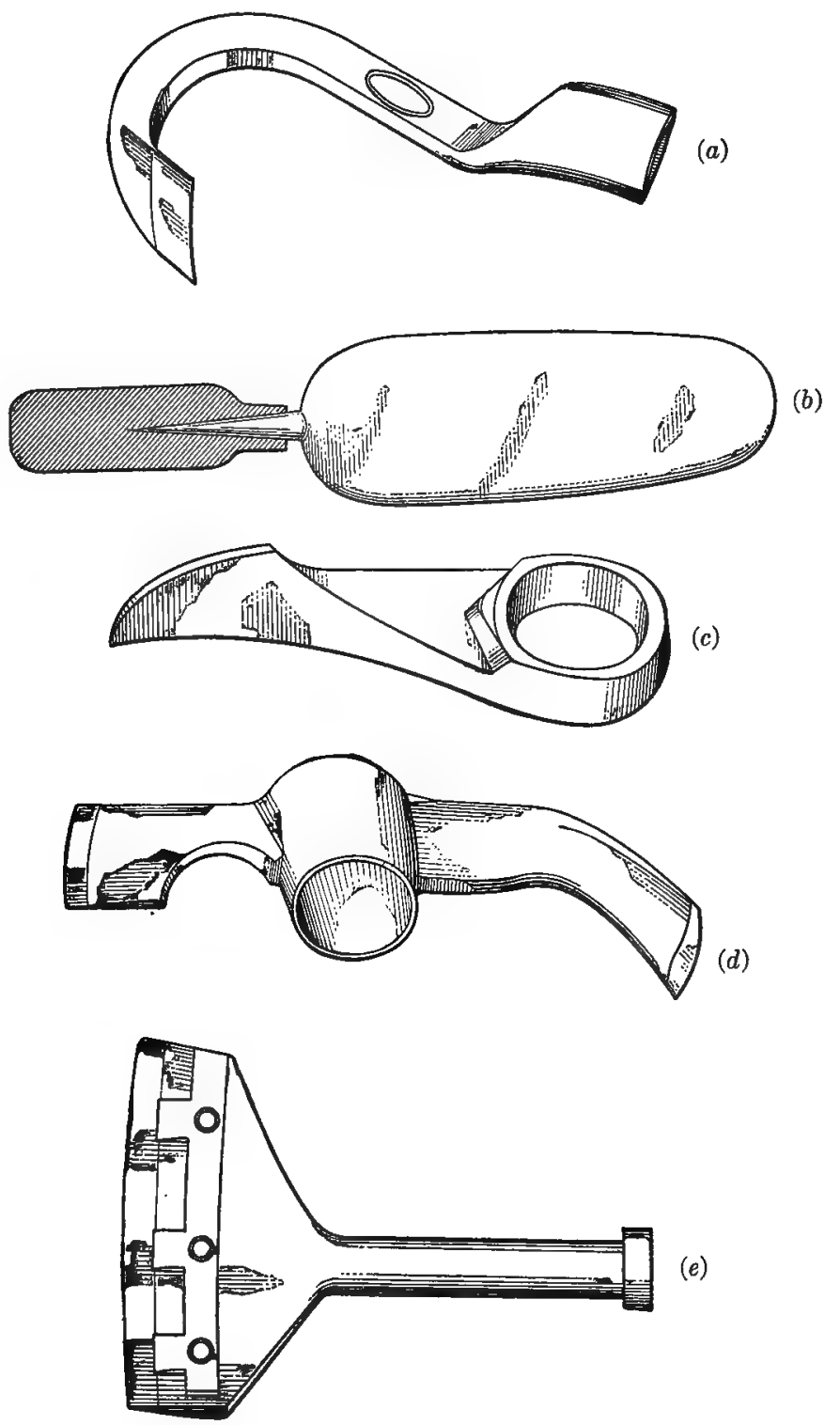

$(e)$

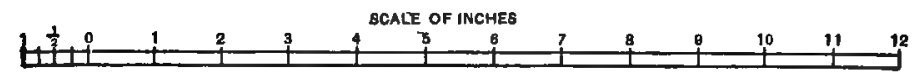

Fra. 18. - French Turpentine Tools. (a) Barrasquit d'espourga; (b) Palette (or palinette); (c) Hapchot (new model is called bridon); (d) Rasclet; (e) Place-crampon (or pousse-crampon). 
so-called scrape is collected in a bucket at each tree, or is allowed to fall on a piece of cloth spread around the base of the tree.

(b) Palette (or Palinette). - A flat trowel, or scrape, for transferring the soft resin from the pots (attached to the trees) to the collection bucket. The short handle shown in the figure $(b)$ is of wood, usually reinforced with an iron band. The wooden bucket, or "l'escouarte," usually holds 5.2 gallons. When the bucket is full the resin is transferred to a barrel, used for transport to the turpentine still, or is stored temporarily in a "barc," a wooden tank sunk in the sand and protected with a wooden cover. A barc holds 60.7 to 92.4 gallons.

(c) Hapchot (new model is called Bridon). - This is the special axe for clipping the face. The successive shavings are made from right to left, or from the top downward; the left hand is placed on top, resting against the iron of the axe; the right hand underneath grips the wooden handle (see Fig. 17b). Each shaving is cut clean and thin and starts the resin canals flowing again after they have become clogged up. The length of handle depends on the height of the incision above the ground; it is used for clipping faces of the first, second, and third year periods. If used for the fourth and fifth years (fifth year now generally abandoned) the workman must use a ladder, usually simply a notched pole.

(d) Rasclet. - The curved cutting edge (at the right) is used for clipping the high faces of the fourth or fifth years of tapping. The tool has a long handle and is used like the hapchot, described above. The straight cutting edge (at the left) is used for making incisions to hold thin, flat pieces of wood which prevent the gum from dripping on the ground and guide it into the pot.

(e) Place-Crampon (or Pousse-Crampon). - The place-crampon is used for inserting at the base of the face the zinc blade, or crampon, which finally guides the resin into the pot without any waste. The workman holds the place-crampon in his left hand with convex face (shown in Fig. 18) toward the soil, the edge on the lower part of the face where he wishes to insert the gutter. It is then tapped with a wooden mallet, held in the right hand, and an incision made about one-fifth of an inch into the wood of the tree. The place-crampon is then pulled out, the gutter tapped into place, and the pot is then hung below the gutter. The tin trays which hold the resin (in use at La Teste) were 2.3 by 6 inches; but usually earthenware pots are used of the same capacity. ${ }^{26}$

${ }^{26}$ In 1836 (according to J. H. Ricard) H. Serres suggested terra cotta troughs instead of the wasteful "box" cut in the base of the tree. Hughes, in 1841, suggested a small earthenware pot but the improved methods were not adopted until about 1855 or later. Galvanized sheet-iron "cups" have been tried because they are lighter than the earthenware pots. The nail to hold the cup is a bad feature, since it might be left in the butt log and cause damage to saws at the mill. Probably the ideal "cup" 
French and American Methods Contrasted. - The main difference between tapping methods in France and the United States on National Forests seems to be in the width of the face and the annual rate of increase in its height, and the number of faces per tree. In the United States the first streak cannot begin higher than 10 inches above the ground. In France it can be anywhere above the root swelling. In the United States the maximum depth of streak is 0.5 inch; in France it is approximately 0.4 inch. In the United States in Federal tapping operations ${ }^{27}$ no tree less than 10 inches can be tapped, and trees 16 inches and over can have two faces, while trees 10 to 16 inches can have but one face. In France the minimum diameter of trees tapped alive on State forests (trees to be removed in thinnings can be tapped to death no matter how small) is 13 inches and the number of faces is specially designated by the local forest officer. In the United States the face can be 12 to 14 inches wide with no specified decrease in width as the face proceeds up the tree. In France it is 3.5 to 2.4 inches, decreasing each year as the distance above the ground increases. The maximum height increase per year in the United States is 16 inches, while in France the face can be lengthened 24 to 26 inches, and even up to 39 inches in case of 4-year tappings. Without exhaustive experiments the best methods to follow cannot be stated, but tentative results from the Florida Forest in the United States show the French method is not applicable to mature, large timber and that the yield in resin per square inch of face is slightly greater with the American (Government) method of wide faces.

Technique of Tapping. - The trees (on State forests) for tapping alive are blazed on the bark and stamped "AF" at the base and at breast height.

It is necessary ${ }^{28}$ for a good worker to be able to cut a thin, even slice of wood to increase face and to continue the face vertically following the grain of the wood. The sliver is about 3 inches wide, 5 to 7 inches long, and usually less than 0.4 inch deep. The first step is always to smooth the outer bark with the axe. The tendency is to bark too large rather than too small an area. In placing the gutters care should be taken not to cut into the tree with the place-crampon more than 0.2 inch; this is a sufficient depth, inasmuch as the gutter is glued by the sap as soon as it flows, and besides if the gutters are set too deep it is very difficult to remove them in the autumn. The gutter should, of course, be slightly inclined toward the ground so that the sap will run off into the cup.

has not yet been invented. It must be easy to place, secure, easy to remove, and must not damage the tree.

Ricard states that the yield of resin is greatest near the ocean, with thrifty, rapidly growing trees, with thin chipping at frequent intervals, and with hot weather.

${ }^{27}$ It would be unwise to attempt to pass legislation limiting the size of trees that should be tapped. This is a technical problem to be solved for each forest.

${ }^{28}$ Le Pin Maritime (Manuel Pratique) par R. Cattin et J. J. Saint-Jours. 
There seems to be a good deal of variation in the frequency of tapping. Some chip once a week during the entire season, others every 5 days, while still others will only chip once every 12 to 15 days; this latter method decreases the resin flow. On the whole, it is better to chip at regular intervals, with the rule that the chipping would be more frequent during the hot weather in the summer than during the spring or autumn. A common rule followed in the Landes is to "chip once every 5 days from May 15 to September 15 and once a week during the remainder of the period."

The cups are usually cleaned seven times a year and the rain is poured out after chipping. The trees are scraped once sometime between October and December. It is usually recommended to begin the first of March and continue until the end of October. ${ }^{29}$

It is not only necessary to secure a quantity ${ }^{30}$ of gum but also to secure a good quality. Therefore, it should not be allowed to deteriorate in the cups. Yet to collect too frequently means unnecessary expense. To dip ten times per season is hardly necessary, while seven or eight times is a good average. Five jcollections a year, on the other hand, is not often enough. The difference between good, clean resin and that which is full of chips and other débris may be as much as a dollar per barrel.

Effect of Tapping. - There is no question but that the turpentine operation decreases the rate of growth of maritime pine, but, on the other hand, it makes the wood harder and more durable and the impregnation even extends to the heartwood. The general opinion is that tapped trees are better for flooring, boards, ties, and planks, while untapped pine is better for telegraph poles, mine props, and box boards. Unquestionably the quality of the wood diminishes after 25 to 30 years of tapping alive, and is inferior to wood cut from trees tapped to death for only 3 to 4 years.

${ }^{29}$ J. H. Ricard, writing in 1910, made the following conclusions: Tapping operations are from March to October. The face should be chipped every 8 days in spring and fall and every 4 to 5 days in summer. The pot should be emptied every 2 to 3 weeks and there should be one barrel for storage per 1,000 trees tapped. There are about 40 chippings per season and the cut should be less rather than more than 0.3 inch; wide faces are unnecessary because the resin comes from the sides of the cut and "the return in resin has not been proportional to the surface of the face." After 4 years of tapping trees should be given a rest of 2 to 3 years. Trees under 8 inches in diameter are rarely tapped unless they are to be removed in thinnings. A workman can chip 1,000 to 2,000 pine per day, according to the ground, and often tends about 4,000 trees.

${ }^{30}$ The workmen received, before the war, one-half the resin for their pay and the operator or owner furnished the cups and gutters. The smoothing off of the bark begins the last of February and the scraping off of dried pitch is usually finished in early December. In the interim the resin tappers work at clearing underbrush and pruning young stands. 
Utilization, Logging, and Local Specifications. - The trees from early thinnings which range from about 6.5 to 12 feet in length and from 3 to 4 inches in diameter up are utilized for mine props. They are peeled when intended for use in the coal mines of France, and left with bark on for export to England. Props are also taken from the tops of mature trees cut for lumber.

Later thinnings are utilized for props or sawlogs and so far as possible for telegraph poles. These poles range from 26 to 49 feet in length; firstclass poles must have a diameter inside bark of 6 inches at 3.3 feet from the butt and 4.5 inches at the top; and the second-class poles, 10.5 inches 3.3 feet from the butt and 4.5 inches at the tops. All poles are peeled in the woods.

In cutting saw timber the felling is done with saws, and the logs are immediately bucked into lengths of 6.5 to 13 feet; 9 feet is the usual length. These short lengths are to eliminate crooks and to make handling easier. The logs are then peeled, since after seasoning they are far easier to handle. The bark left on the ground also serves to build up the soil. Logging is done with two-wheeled mule carts, the logs being lifted by hand into the carts, the tires of the wheels are wide enough to permit their use on sandy roads.

Many of the sawmills are stationary and are located on the railroads. Logs are hauled to these sawmills for considerable distances on the metalled roads with the same conveyances. However, because the coupes are usually small, the bulk of the lumber cut in the Landes is produced by small portable band mills that are set in the middle of the tract to be cut. The lumber is then hauled to the station in mule carts. These small band mills are quickly moved from one site to another, and their adaptation for use under similar conditions in America seems desirable. A large part of the production of such mills consists of sawed railroad ties.

The following is a summary of the specifications of wood products cut from maritime pine:

Telegraph poles. -23 to 39 feet in length and up to 39 inches in diameter inside bark, 4 inches.

Piling. - All lengths minimum diameter at the small end, 13 inches.

Box boards. -6.5 to 7.7 feet in length and 8 to 12 inches in width, 0.4 to 0.8 of an inch thick.

Flooring. - Length variable, width 3.1 to 5.9 inches, and thickness 1.1 inches.

Beams (Grosse Charpente). - Length from 13 feet up by 9.8 to 12.6 by 7.1 to 7.8 inches.

Joists. - Length from 9.8 feet up and 7.1 to 7.8 inches by 3.9 to 4.3 square.

Charcoal. - Usually sold in 10-barrel lots (barrel of 300 quarts).

Ordinary fire wood. - Length $\mathbf{3 . 3}$ feet with sale unit a stack 3.3 feet long on the base by 4.4 high.

Lath, etc. - Miscellaneous dimensions. 


\section{Bert is authority for the following data:}

"Two cubic meters (about 550 board feet) of maritime pine will furnish 1 ton of boards. For rough calculations the average volume of mine props is . . . 20 mine props to the ton. A cubic meter of fuel wood weighs 0.7 ton, expanding to $1 \frac{1}{2}$ steres. The weight of a stere ( 0.227 cord) is 0.467 of a ton. A barrel of resin (Gironde) of 235 quarts weighs 0.2415 of a ton with a density of 1.05. A barrel of resin (Landes) of 340 quarts weighs 0.357 of a ton."

A 235-quart barrel produces 110 pounds of turpentine and 352 pounds of dry material, chiefly resin.

Yield of Maritime Pine. - In 1892 there were 105,763 acres of conifer State high forests in the Landes, and in addition, 22,625 acres, or between one-fourth and one-fifth as much as the productive area, had to be given up to protection. The production amounted to 30,072 cubic meters of timber (about 8,360,000 feet board measure or 80 feet per acre) and 4,161,960 pounds of resin.

The yield of maritime pine stands ${ }^{31}$ in the Mont-de-Marsan Inspection for the year 1905 showed a total of 47.6 cubic meters per acre (on an area of 22.2 acres) for pine 40 to 50 years old. According to Lapasse:

"The resinous products represent approximately one-fifteenth the total weight or 7 per cent of the yield in weight of a maritime pine felling; the proportion of the product realized then, in weight, is wood product fourteen-fifteenths or 93 per cent, resinous products one-fifteenth or 7 per cent. The production of resin is variable; it depends on the density of the stand, on the underwood, on the state of growth, the size of the trees, the age of the face, the distance from the ocean, and on the skill of the workman. The yield attains its maximum in open stands completely cleared of undergrowth, situated near the sea and during the second or third year of tapping. A humid and hot atmosphere favors the secretion of gum. The yield in resin is, on an average for 1,000 trees tapped alive, 640 quarts . . . per year, and in 5 years, the duration of the tapping alive, 10,200 quarts. One might say that . . . 166 pines can yield annually a barrel of resin, but in order to collect 100 quarts it is necessary to have 50 pines tapped alive, each tree producing an average of two quarts. In the thinnings 1,000 trees tapped to death may yield (according to the size of the trees) from four to six barrels of 340 quarts each or an average of five barrels or 1,700 quarts per year and in the 4 years' duration of the tapping to death, 6,800 quarts. In this case, 200 pines . . . produce annually a barrel or 59 pines tapped to death are necessary to obtain 100 quarts of resin. In the regeneration fellings with pine 65 to 70 years old with four faces each, each face can produce $1 \frac{1}{2}$ quarts or 6 quarts per tree per year. One thousand pines tapped to death should produce 6,000 quarts or about 18 barrels per year, and 24,000 quarts in 4 years. An acre stocked on an average with 80 trees will yield about 480 quarts of resin per year and 1,920 in 4 years. To collect 100 quarts of resin it is necessary to have seventeen pines tapped to death per year."

These figures are below rather than above the average. In the thinnings marked during 1900 to 1905 on a total area of 57,847 acres in the

al Rendement des Forêts Domaniales de pin maritime dans les dunes landaises, Revue des Eaux et Forêts, June 1906. To simplify the calculations the author has taken a liter as equal to 1 liquid quart, whereas a liter is really 1.05671 quarts (liquid). 
Inspection of Mont-de-Marsan, with the trees averaging 40 years in age, the average yields per acre were as follows:- (1) Timber products, 22 pines removed, with a volume excluding branches of 3.6 cubic meters, about $1 \frac{1}{2}$ cords (or roughly 750 board feet). (2) Resin products, total yield for the 5 years of tapping, including the pine tapped alive, 340 quarts.

The average return per acre from the timber was $\$ 3.42$ (average price 95 cents per cubic meter on the stump). During this period the value of resin varied from $\$ 10.61$ to $\$ 17.37$ a barrel (of 340 quarts). Excluding 50 per cent of the value of the resin as the labor cost the net value of resin rights was $\$ 1.98$ per 100 quarts, and the total average yield from thinnings was $\$ 10.15$ per acre $(\$ 2.03$ per year). Thus the yield from resin is twice that of timber.

During the same period the clear-cut regeneration fellings yielded an average of 131 trees per acre ( 80 to 84 trees per acre is a fairer average), and the yield per acre was 48 cubic meters - 6,500 quarts of resin (about 10.9 thousand feet board measure) at a total net price of $\$ 116.76$ per acre ${ }^{32}$ for land which, had it not been forested, would not only have been worthless to-day but would even have constituted a menace.

For the year 1905 the gross receipts from all the State forests in the Landes Department amounted to $\$ 111,788$, with an expense for administration of $\$ 15,976$, making a net revenue of $\$ 91,941$ for 56,762 acres, or a net yield per acre per year of $\$ 1.67$. In 1889 there was a deficit of $\$ 7,008$ in the Landes. Eight years later, 1897, there was a net surplus of $\$ 5,793$ while, after eight years more, the revenue had increased to almost $\$ 96,500$. This increase in revenue was partly in producing capacity and partly in the increased value of the product.

It is interesting to compare the yield in cubic meters, steres, and hectoliters (100 quarts) with the annual charge. ${ }^{33}$ According to data furnished by De Lapasse in one locality 62,840 trees furnished a total of 14,640 cubic meters, 5,489 steres, and 7,900 hectoliters at a total annual charge of $\$ 9,090$.

On a unit basis per tree the yield is 0.28 cubic meter, 0.08 stere, 0.12 hectoliter at an annual cost to the operator of 13 cents. The relative yield from thinnings is naturally very much less, since the trees are that much smaller.

Protection. - When the dune reclamation work began, the commission (see p. 173) found it very necessary to have a permanent local force to prevent grazing trespass. This trespass was considered forest trespass and therefore forest guards were placed in charge, and as early as 1809 the Prefect of the Gironde decreed that "burning can under no circum-

${ }^{32}$ Huffel cites the average net yield as $\$ 2.22$ per acre per year, which agrees closely with Bert's estimate of $\$ 2.16$.

${ }^{33}$ Huffel, Vol. I, p. 183. 
stances extend over more than one-sixth the land owned by each commune," and the local forest officer must be consulted. It is interesting that, dating from 1741, there was a law that there could be no grazing for 5 years following the burning of forest land. A similar law is now in force in Tunisia and Algeria to punish the natives for burning over grazing ground.

Even when the tendency to set fire decreased, accidents tended to increase the fire danger in a region where the hazard was already very great. Notwithstanding the strict rules and fines against setting fire within 328 feet of forest, heather, or wood, fires have always done considerable damage in the maritime pine belt due to inflammable underbrush and regeneration, high winds, and drought. During the 10-year period, 1883-1892, only 254 acres were burned or 0.0002 of the area (protected by the State service) per year and 0.002 per year of the communal forest area. In the area not under Federal control the relationship between the area burned each year and the area not burned was as 0.78 is to 100 . In other words, 11,621 acres were burned over each year out of a total area of about 1,482,626 acres.

In the Landes the regulations are extremely strict against trespass and against the use of fire by contractors. The following is an example:

"It is strictly forbidden:

"1. To smoke, to light matches, or to carry a fire of any kind whatsoever in the forest or on forest soil.

"2. To damage, move, or tear up any stakes, signs, poles, boundary notices, or notices of any kind whatsoever erected by administrative authority.

" 3 . To remove sand, dry pine needles, sod, or any other product of the forest soil. Violations will be followed by prosecution."

\section{According to Bert:}

"The protection measures include; (1) Installation of tool caches in forest houses and in the cutting areas; (2) the establishment of telephone lines connecting certain forest houses with the nearest telegraph office; (3) the construction of watch towers in the Inspection of Mont-de-Marsan."

Additional protective measures are: The establishment of charcoal pits is not allowed in the interior of pine forests (except in cleared openings at least 33 feet from the nearest tree); charcoal burning cannot be done before the first of October or after the first of April of each year (that is, during the fire season), and the charcoal could not be removed until nine days after the burning was finished; stacks of sawmills had to be covered with spark arresters and the ground cleared. The conclusion was finally reached that fire lines were indispensable. Accordingly main fire lines at right angles to the direction of the wind, about 3,280 feet apart and 33 feet wide, were constructed; in addition 
each forest was divided into compartments of 247 acres, separated by fire lines of 33 feet in width. The weeds, grass, and vegetable débris were all removed from the lines. As a rule these lines were used to backfire from, since they alone would not stop the average fire. ${ }^{34}$

Another important item of protection in the State forests is against a root fungus, which greatly decreases growth and ultimately kills the trees. It is transmitted through the roots and is controlled by digging a trench about $2 \frac{1}{2}$ feet deep around infected areas. Such areas are detected by the fact that the reproduction within them starts to die. Owners claim that this disease usually appears where the roots of living trees are injured by fire. That is one reason for not permitting burning of charcoal among standing timber. A preventive measure is to thin the timber before it reaches the sapling stage. ${ }^{35}$ There is some damage from caterpillars, and there was some good-sized areas in the State forests (near Lacanau) that appeared materially damaged in 1918.

${ }^{34}$ See p. 275 for additional data on intensive fire protection.

${ }^{25}$ See p. 110 for the details of early thinnings (dépressage). 


\section{CHAPTER IX}

\section{GOVERNMENT REGULATION AND WORKING PLANS}

Mensuration in Working Plans (p. 206). Summary, Units of Measure, Volume Tables, Rule-of-Thumb Methods, Ocular Estimating, Calipering Stands, Stand Graphics.

Reguratton of Cutring (p. 215). Broad Aims of French Regulation Policy, Application to United States, Abuses Led to Legislation, The Policy of "Reserves," Summary of Principles and Methods, Management Subdivisions, Rotations and Cutting Cycles, The Normal Forest, Regulation of Cut, Pure Area, Diameter Limit by Single Trees, Area and Age, Method of 1883, Area (Volume) Allotment by Periods, The Gurnaud Method.

Working Plans (p. 243). General, The Working Plan Report, Chamonix Working Plan.

\section{MENSURATION IN WORKING PLANS}

Summary. - The greatest achievements of French mensuration are: (1) The recognition that mathematics and formulæ are distinctly secondary to silviculture and that exactness in forest mensuration, especially in yield data, is relatively unimportant if there is frequent stocktaking and good silviculture. (2) The use of graphics in depicting the stand instead of cumbrous, unintelligible tables. (3) The development of empirical data for selection forests. (4) Simple and workable methods unfettered by the application of theory. ". . . it heads straight for the desired goal."

Broilliard, a leader in French silviculture, said, in the preface to the second edition of his "Le Traitment des Bois en France"

" . . fearing to give too many figures to readers, persuaded, as I still an to-day, that mathematics leads silviculture into errors and that equations . . . never disclose the secret of the living forest. The increasing weight of matbematics in forest studies is full of dangers, notably in Germany (where the experiment stations engage in calculations without end). Too of ten mathematics works on a false base; it leads to the idea of absolute conclusions, always different with the phenomena of nature; mathematios does not give, moreover, the solution of this simple problem: What is the future of a tree, of a stand? . . ."

On the other hand there are weaknesses: (1) Confusion and variation in the use of the cubic meter and in squared log content formulæ, and in the use of diameters or circumferences. There is a distinct lack of standardization. (2) The excessive use of short-cut methods. (3) The

${ }^{1}$ Mensuration in France, by Donald Bruce, pp. 686-690, Journal of Forestry, No. 6, Vol. XVII. Donald Bruce and H. H. Chapman kindly reviewed Chapter IX. 
lack of more accurate local volume tables which could have been easily and cheaply obtained. (4) Failure, through lack of funds, to keep abreast of scientific investigations and to contribute more to forest science.

But the French viewpoint is of great value to the American forester even if the details of mensuration practice can rarely be used without modification.

Units of Measure. - The unit of measure for logs, piling, poles, and props is the solid cubic meter ${ }^{2}$ which contains 35.3 cubic feet or approximately 285 board feet log scale.

Contrary to the general belief in the United States it is agreed in France that there is much confusion because the cubic meter is not used in a uniform manner, and one writer said: ${ }^{3}$

"I defy two Frenchmen, living 125 miles apart, to understand each other when they speak of cubic meters according to the usage of their locality even if they use the same tariff."

This confusion, due largely to different methods of measurement and calculation, has led to the demand for a "legal cubic meter" which a committee defined as follows:

"The volume of a log shall be equal to the volume of a cylinder having the circumference of the $\log$ measured at its middle point to the nearest 2 centimeters $(0.8$ inch) and its length measured to the nearest 20 centimeters ( 8 inches). The measurement of the circumference shall be made with a melastic tape at right angles to the axes of the log. . . . The volume (thus obtained) shall be called a legal 4 cubic meter."

But to be complete there must be standard rules for reductions on account of defect or irregularities. The following were proposed: (1) Measure between knots or swellings. (2) Where a log becomes irregular the purchaser can cut it off and remeasure. (3) Defect deductions to be made by joint scale. (4) Logs with checks or lightning marks clear to the heart can be rejected. (5) Logs must be at least 6.5 feet in length.

Cordwood $^{5}$ is measured by the stere, a stacked cubic meter, and is usually cut in 1 meter (3.3 foot) lengths, and in statistical work it is sufficiently accurate to count 1 solid cubic meter as yielding $1 \frac{1}{2}$ steres of

${ }^{2}$ For a discussion of converting factors see the Introduction. Those who have much converting to do should draw a converting-graph based on the best data obtainable for the conversion problem in hand.

Solide et Métre Cube, B., S . F . de F-- C. et B., Sept. 7, 1908, J. Banchereau.

* An interesting comparison between the new and old French measures is given on pages 14-19 of Carnet - Agenda du Forestier. Besancon, 1902. Paul Jacquin, Imprimeur. It should be noted that in France logs are measured outside bark, while in the United States log scaling is always inside bark.

"See also classes of cordwood and saw timber given under "Sale of Timber," page 307. 
piled fuel. Cordwood is frequently sold by the ton; this is an excellent system. It compensates at once for species and for seasoning. For the measurements of log lengths the French prefer a melastic tape, and for diameter ${ }^{6}$ an accurate adjustable caliper to take maximum and minimum diameters, or a diameter tape if only one measurement can be taken. The French policy is clearly to avoid unnecessary and costly accuracy when something less exact will serve just as well.

Volume Tables. - Volume tables for estimating the cubic (metric) contents of standing timber are simpler and more standardized in France than in the United States. There are no volume tables in use which give the contents of trees in terms of the manufactured product. The following classes of volume tables are used:

(1) A "universal" table, based on diameter, total height, and taper of a tree (there are also tables giving contents of cylinders of given diameter and length which must be reduced by a form factor).

(2) Merchantable log length table, especially designed for standards or for high forest trees, based on diameter and the merchantable length of the bole (to a top limit of 9.8 inches) classified by 2 or 4 meter lengths (6.5 to 13.1 feet).

(3) Cordwood tables, based on the diameter of standards and whether (a) very branchy, (b) average, (c) mediocre, or $(d)$ few branches.

(4) Local volume tables for (a) total or $(b)$ merchantable contents in cubic meters based on diameter alone are common and are usually based on the type (1) table and on local diameter and height measurements. It is customary to give the name of forest, working group, year table was made, author, soil, part of tree included, silvicultural system, species, altitude, and general quality.

Cordwood from the top or from branches is estimated by using a ratio of the bole; this varies with the species, height of the tree, age, top cutting limit for saw timber, and silvicultural system. The results are naturally subject to wide variations. An average figure for oak high forest is 60 per cent to 75 per cent saw timber with 25 per cent to 40 per cent fuel (of this fuel one-third is fagots); for beech the figures for saw timber would be 10 per cent to 20 per cent less; for fir or spruce 80 per cent to 90 per cent saw timber and 20 per cent to 10 per cent fuel. But in statistical computations the French usually figure that 100 cubic meters gross yield of standing timber will give in (a) hardwoods, 80 cubic meters of timber and 20 cubic meters (equal to 30 stacked steres) of fuel; in (b) softwood, 90 cubic meters of timber and 10 cubic meters (15 steres) of fuel.

- Huffel thinks there may be a 5 to 10 per cent difference between the measurements and volume computation of a lot of large irregular logs even if great care is taken. Much of the data which follows is from Huffel, Vol. II. 
It is clearly established that trees of the same $(a)$ species, $(b)$ diameter, (c) silvicultural system, and (d) height yield a greater volume as they increase in age but the variation is usually disregarded in ordinary valuation surveys, except so far as it is represented in local volume tables. The wide variation between local volume tables for the same species and diameter is merely a repetition of experience in all countries. But another complication arises in working plan revisions. It is desired to estimate the present stand accurately yet to-day's stand must be compared with the stand at the last revision because the original stand plus the cut, minus or plus the difference between the original stand and the present stand, gives an accurate line on growth. It is, therefore, necessary to compute the volumes to be compared by the same volume tables. In fact, with hundred per cent estimates, each compartment or working group is in reality a permanent sample plot which at each working plan revision gives fairly exact data on growth and yield.

The sample volume table which follows is for spruce and fir in the Jura. To the figures given 10 per cent must be added if branches are included. The volume tables supplied the local officers also give the volume by circumference and heights for one to nineteen trees (omitting the volumes for ten and twenty trees) to facilitate multiplication when figuring results of valuation surveys: 


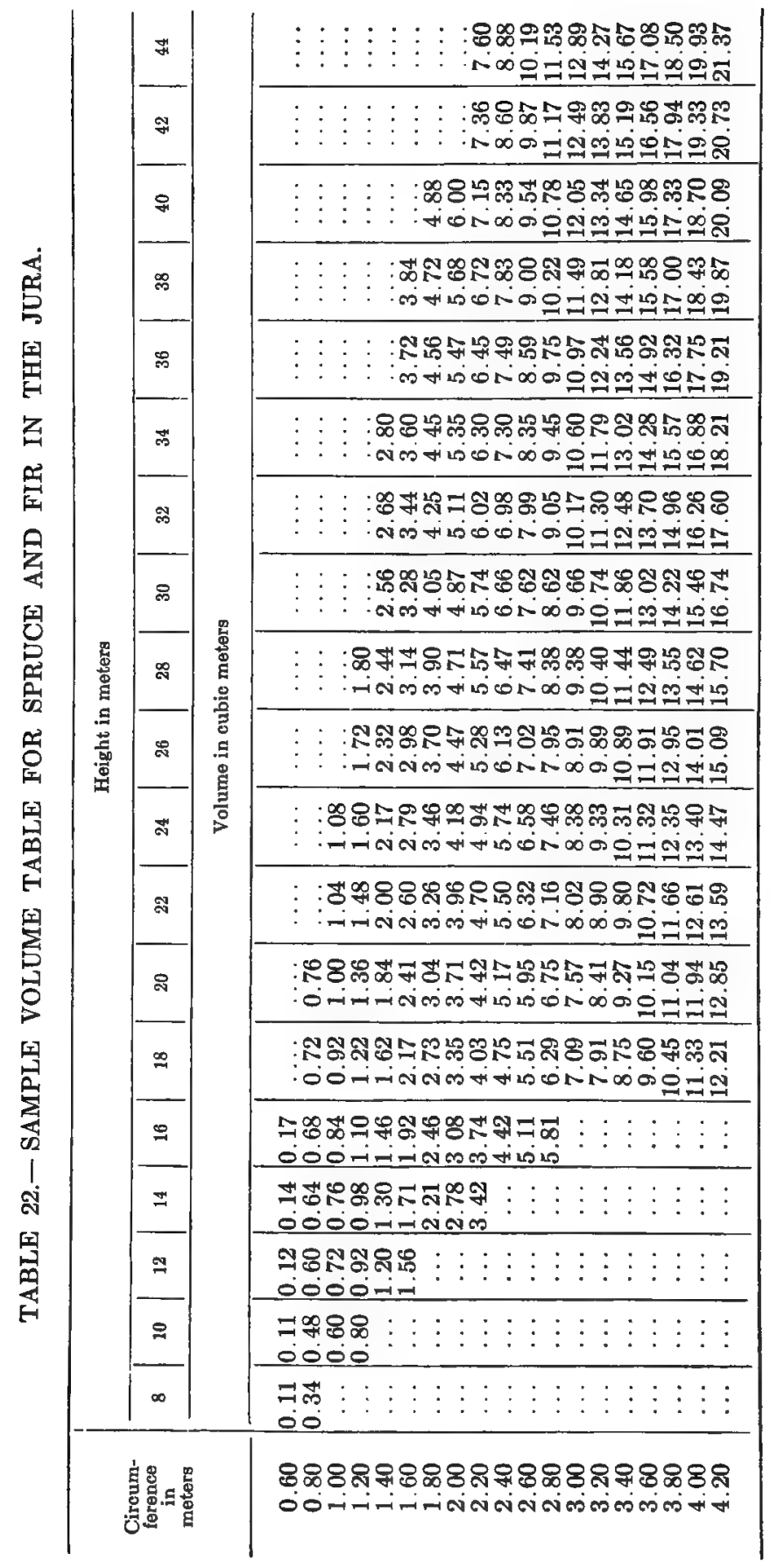


Rule-of-Thumb Methods. - There are various rule-of-thumb methods ${ }^{7}$ all based on the metric system. They are chiefly of value in stimulating local forest officers to study the laws of diameter, height, and volume.

(1) Bouvard formula: $V=\frac{1}{2} D^{2} H$ which is somewhat conservative, though used for coppice-under-standards.

(2) d'Auverne formula: $V=7 / 10$ volume of cylinder of size of middle girth, for oak cut to top limit of 11.8 inches.

(3) Villers-Cotterets formula: $V$ in steres = circumference in centimeters minus one meter (i.e., $1.70-1.0$ or 0.7 steres) used for beech locally.

(4) Algan formula: $V=0.33 D^{2} H$. Used for spruce 5.9 in diameter at small end; or $V=0.42 D^{2} H$.

(5) Plank formula: $P=\frac{1}{2} N D^{2}$.

In the Vosges it is customary to estimate in "board feet" or planks $4 \mathrm{M}$ long $\times 0.25$ wide $\times 0.025$ thick or $1 / 40$ plus or minus of a cubic meter.

Ocular Estimating. - In regular fully stocked stands of coppice or young high forest ocular ${ }^{8}$ estimating is exceedingly accurate, and coppice is rarely estimated by any other method since the number of steres per hectare can be gauged if the age and soil quality are known. Then too it must be remembered that each compartment has been cut over for generations and where the rotation or treatment has not been modified there are usually the records of past cuts to base estimates upon. Such ocular estimates for coppice can be made within 90 per cent of the actual cut or even closer so that they answer for sale purposes and the price is usually a lump sum per hectare. High forest timber, except when in the sapling stage, is never estimated ocularly.

Calipering Stands. - The French measure the diameter or circumference of standing timber at 1.50 meters (4.92 feet) or 1.30 (4.26 feet) above the ground and on hillsides they measure the breast-height point from the uphill side of the tree. They often take into account the fact that the largest diameters are parallel with the wind or the crown or root development; this would apply especially to an intolerant species like the maritime pine in the Landes where there are strong winds from the ocean. But generally these points are waived since the errors in calculating volumes are even greater. In accurate estimating the merchantable sawlog length is almost invariably measured or approximated in the field; this is especially important with standards. In growth studies in coppice-under-standards the length of the merchantable bole

${ }^{7} V=$ Volume in cu. m.; $D=$ d. b. h.; $L=$ length of merchantable bole; $H=$ total height, $\mathrm{d}=$ middle diameter of standing tree; $P=$ plank; $N=$ number of trees.

${ }^{8}$ A rule-of-thumb method given by Huffel (p. 120, Vol. II) for estimating mature (a) fir or (b) oak stands is to multiply the average merchantable length by from (a) 25 to $(b) 30$ the answer being cubic meters per hectare. This illustrates the bearing of height on volume in fully stocked stands. 
is often periodically measured by hand, through the use of ladders or by climbing the tree.

When stands must be calipered, the following principles govern the valuation survey:

(1) Diameter classes are 5 centimeters (or 1.97 inches) ${ }^{9}$

(2) It is not customary to note the height classes of all trees calipered except in very large valuable timber; instead, the merchantable height of a few normal trees of varying size is secured from felled trees or by measurement. The results are averaged graphically and a local volume table made for the compartment, cutting area, or working group. The height classes are usually 2 to 4 meters ( 6.5 to 13.1 feet).

(3) In merchantable stands 100 per cent estimates are almost uniform; with cheap labor this is fully warranted.

(4) In timber sales estimating is always done when trees are marked for cutting. The usual and necessary errors in estimating are considered 6 per cent of the true volume even under favorable conditions; in virgin or mature stands they count for possible errors up to 10 per cent to 13 per cent. But the French defend the volume table method of obtaining volume, even in experimental work, against the German and Swiss sample tree methods. In other words, they prefer volumes based on a local table of 40 to 50 trees rather than on 5 to 10 sample trees chosen by mathematical averages ${ }^{10}$ but selected on the basis of judgment.

${ }^{9}$ The 1-inch diameter classes used by the U. S. Forest Service for its early working plans was an absurdity. The writer used 3-inch diameter classes for estimates in western yellow pine in Arizona and New Mexico. Captain Kittredge reported that $20 \mathrm{~cm}$. circumference classes ( $2 \frac{1}{2}$ inch $d . b . h$. classes) were used in the Côte d'Or. In practice the French usually measure regular trees once; and irregular trees twice in order to secure the average diameter.

${ }^{10}$ The valuation surveys in private forests bought by the A. F. F. were made as follows, according to a report by Dunning:

Estimators are equipped with calipers and scribes or marking hammers. They proceed through the timber in parallel strips, mark each tree to be cut, taking the circumference at $1 \mathrm{~m} 30$ from the ground, or in the fir of the Jura at $1 \mathrm{~m} 50$. The tallyman repeats each circumference announced to avoid mistakes. Trees from 20 to 30 $\mathrm{cm}$. in circumference are recorded as poles. In hardwoods trees below $50 \mathrm{~cm}$. are not usually marked.

The estimators rate the height of each hardwood tree in meters usually to a top circumference of $60 \mathrm{~cm}$.; if serious crooks, forks, or large limbs occur the height is taken as far as a reasonably straight log can be obtained.

In uniform stands of pine the chief of detachment or tally-man estimates the average height for each circumference class, the trees being tallied by 10 or $20 \mathrm{~cm}$. classes, and the estimators announce only the circumferences. In open stands of old pine the height of each tree is taken.

In the fir of the Vosges the circumference only is taken, heights being given by circumference classes in volume tables, to a top diameter of $20 \mathrm{~cm}$.

When the average height method is used allowance is made for exceptionally short 
border trees or broken trees by diminishing the circumference.

Average heights are obtained by eye estimates, by measuring sample felled trees, or by some simple method such as the use of two sticks of equal length.

The chief of detachment or tally-man also determines for each stand the average middle circumference for each breast-height circumference class. This is usually done by eye or by determining the average taper per meter of length by measuring sample felled trees. In the large fir of the Jura it is impracticable to estimate the middle circumference, and volume is taken from tables based on circumference at $1 \mathrm{m50}$ and curved heights.

For felled trees the length and middle circumference outside bark is taken.

Maritime, Scotch, and Austrian pine are tallied separately. In hardwoods, where occasional individuals of several species occur, these are tallied with the more numerous species which they most closely resemble, for example, poplars as birch, locust as oak, and hornbeam as beech. Sometimes larch is thus tallied as Scotch pine.

Small trees which would be broken during felling operations are sometimes marked.

Standing dead trees are tallied if sound.

Cordwood. - In stands of pine the amount of fire-wood in steres is roughly taken as one-fifth of the number of cubic meters of saw timber, unless the chief of detachment considers the conditions unusual, when he estimates the variation accordingly. In the silver fir forest of Levier, Doubs, the number of steres of fire-wood was taken as one-tenth of the number of cubic meters of saw timber.

For hardwoods the chief of detachment estimates for each stand according to conditions whether the number of steres of fire-wood is $1,1 \frac{1}{2}$, or 2 steres to the cubic meter of saw timber.

Estimates of coppice are made in steres per hectare, according to species, age, density, etc., and depend much on the experience of the estimator.

Reports on private forests consist of the tally (kept much the same as in America), the estimates of fire-wood and other products, and a description of the various factors of location which affect the value of the timber.

Computation. - Using the middle circumference and height to a top circumference of $60 \mathrm{~cm}$., the volume is taken from a table of contents of cylinders. The same method is used for all species, except in the large fir timber of Doubs State Forests where the tally-man records the cubic contents of each tree directly in the field from a volume table. Although volume tables exist for the pines of the Landes, men of the C. F. E. say that no tree tables are used in that office.

Accuracy. - The methods used are probably as nearly accurate as any in common use. For saw timber the principal factor affecting the estimate is height. Pine stands are usually uniform and the average beight by circumference classes can be estinuated closely.

In the large fir timber in the selection forests of Doubs and Jura, separate volume tables are used for distinct site classes where the height growth varies greatly.

For hardwoods the height of each tree is estimated and French foresters vary greatly in their height estimates. One chief of detachment may instruct the men to take heights only to the first large branch, fork, or serious crook, while another may insist that beights be taken to the top circumference limit as long as the trunk can be divided into straight log lengths to eliminate the effect of crook, etc. In hardwoods the height factor greatly affects the accuracy of the estimate.

Cordwood estimates depend much on the experience of the estimator, and can be only approximate. Wherever possible measurement of the piled wood after cutting should be made.

For saw timber under American methods of exploitation, check scales of logs after 
Stand Graphics.- Under the leadership of Schaeffer, ${ }^{11}$ now conservator at Vesoul, the routine descriptions of selection forest stands (which "had to be done, were a great bore, and were never looked at") have been largely replaced by graphics based on the stock sheet for each compartment and for the forest. The objective is to picture the size classes of the stand so the marking will be guided accordingly. This, perhaps, is the feature of French mensuration and can be applied in the United States under intensive conditions. This method and its interpretation is illustrated by Figs. $19(a)$ and $19(b)$ (after Schaeffer) which depict the number of trees per hectare per ( 5 centimeter) two-inch diameter class at breast height in fir-spruce selection forests. Certainly these graphics would disclose inaccurate and untrustworthy valuation surveys.

No. 1 represents a pure high forest of ten acres, where there is not a single tree less than 35 centimeters in diameter. It shows at once past regeneration has been a failure.

No. 2 is for a younger stand, similar in character and where no trees less than 20 centimeters in diameter, breast-high, have been calipered.

No. 3 represents a selection high forest, where the number of trees is approximately inversely proportional to the squares of the diameters. Consequently the curve approaches an hyperbola and the stand is more satisfactory to the forester.

No. 4 shows at once that the stocktaking was carelessly done, for evidently those who were supposed to caliper did not scrupulously measure all trees, but estimated a good many with the eye. This accounts for the evident error in classifying more trees 20,30 , and 40 centimeters in diameter than trees 25 or 35 . In any compartment, of course, certain diameter classes may predominate, but there would be no such irregularity like the teeth of a saw as is shown in No. 4 .

No. 5 represents a forest of 10,000 acres and consequently unevennesses have been eliminated but it is clear there are too few trees per acre, especially in the larger age-size classes.

No. 6 is a young pole stand where the large number of stems less than 20 centimeters in diameter are coming into the merchantable class. The

removal from the woods will nearly always fall short of the French estimates, especially in the large fir timber of the Jura, owing to defect and a certain amount of unavoidable breakage.

Conclusions. - Methods used are as nearly accurate as practicable, when properly applied, for standing saw timber, felled trees, and counted material. Cordwood estimates are only approximate, depending on the experience of the estimator.

The men are usually capable and experienced enough to apply the methods to advantage.

u Interprétation des Graphiques de Peuplements. A. Schaeffer, B. S. F. de F.-C. et N., No. 6, 1912. Since the figures are merely to illustrate methods, no conversions to American units were made. 
evolution of a regular stand from the pole stage to maturity is shown in graphic No. 10.

No. 7 shows the progress of a forest toward the normal state. It is a forest which was formerly poor but which is becoming more valuable, owing to the conservative fellings. The curves show that presently it will be more nearly normal. At the first stocktaking the stand was open; trees of all diameters developed freely, but now the stand is well stocked and the young trees have ceased to increase in number, either $(a)$ being eliminated or $(b)$ after a successful struggle for existence have reached higher diameter classes. The curve of the third stocktaking is approaching the normal by a sort of wave movement very characteristic in a forest conservatively managed.

No. 8 represents a forest in poor condition and where the yield is low. The old trees continue to accumulate and the density of this old excess growing stock is damaging the young growth, which is very deficient.

No. 9 shows a compartment where, despite the conservative treatment and contrary to all prearranged plans, the volume has decreased from A to $B$.

\section{REGULATION OF CUTTING}

Broad Aims of French Regulation Policy. - The aim and objective of practically all forest legislation during two or three centuries culminating in the revised forest code of 1827 was to prevent the destruction, diminution, and impoverishment of French public forests in quantity and in quality. The success of this legislation depended largely on the pressure for timber or for the capital it represented. The demand was naturally greatest (1) near the large towns, like Paris, which were the commercial timber centers, and (2) during times of stress, when families and governments needed the raw product or money.

Working plans, ${ }^{12}$ or management plans as they are sometimes called, to enforce a wise use of forests, were finally required by law simply because it was found that systematic forest production with a sustained yield could not be obtained without them. Forest history has proved that even the trained forester cannot be trusted not to overcut unless he is systematically guided and controlled by a working plan that prescribes the maximum amount to be cut. And after centuries of practice the French consider a sustained yield for each forest and working group essential for the following reasons:

${ }^{12}$ Huffel says (in a footnote, p. 15, Vol. III): "Out of 504 forests or working groups

. . in Meurthe-et-Moselle, there are 230 . . . antedating the forest code of 1827,187 . . . prior to 1789 , and 15 . . prior to 1860 , the oldest dating from 1726." 

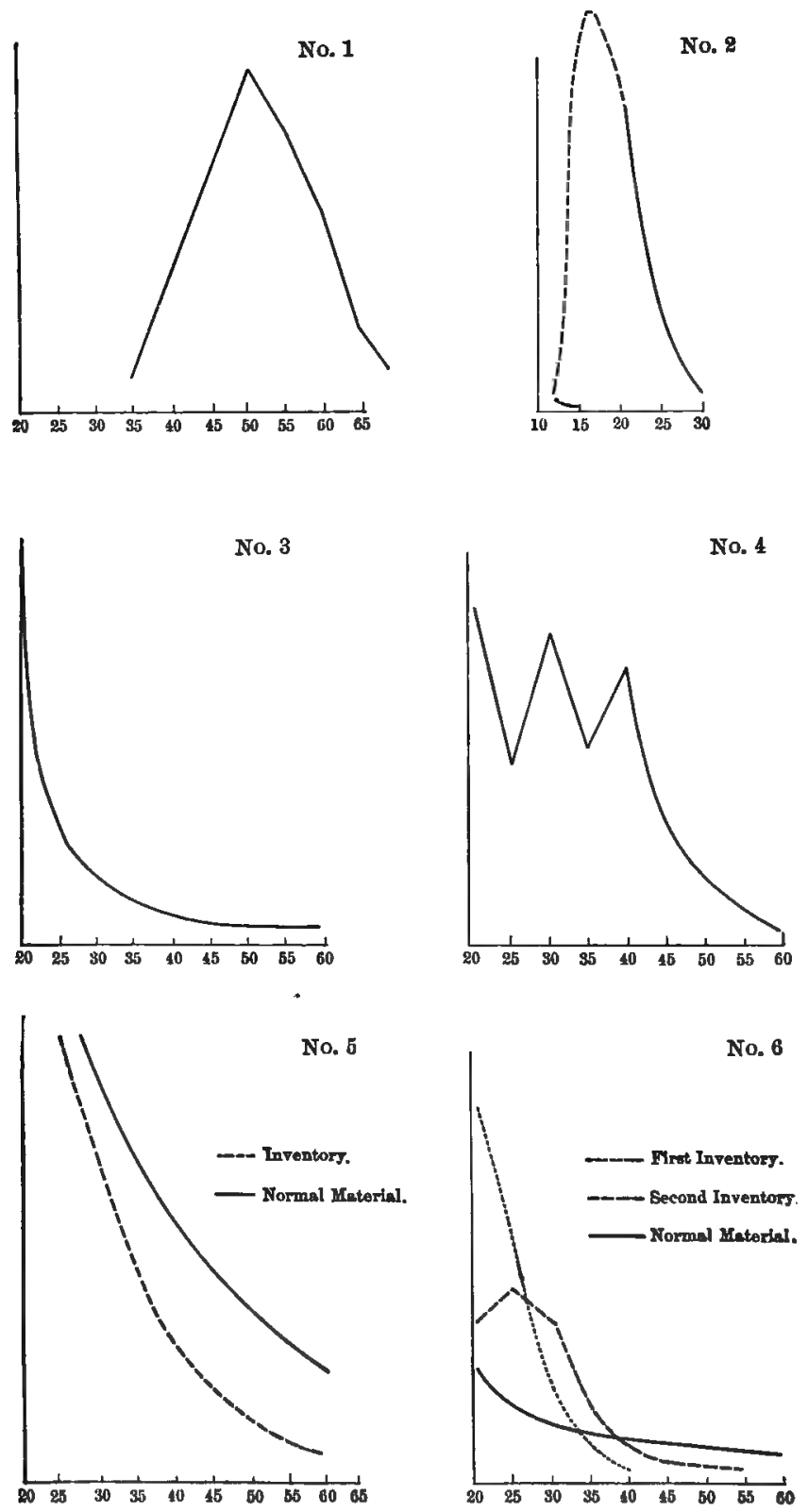

Fig. 19 (a). - Examples of Stand Graphics. 
BROAD AIMS OF FRENCH REGULATION POLICY

217
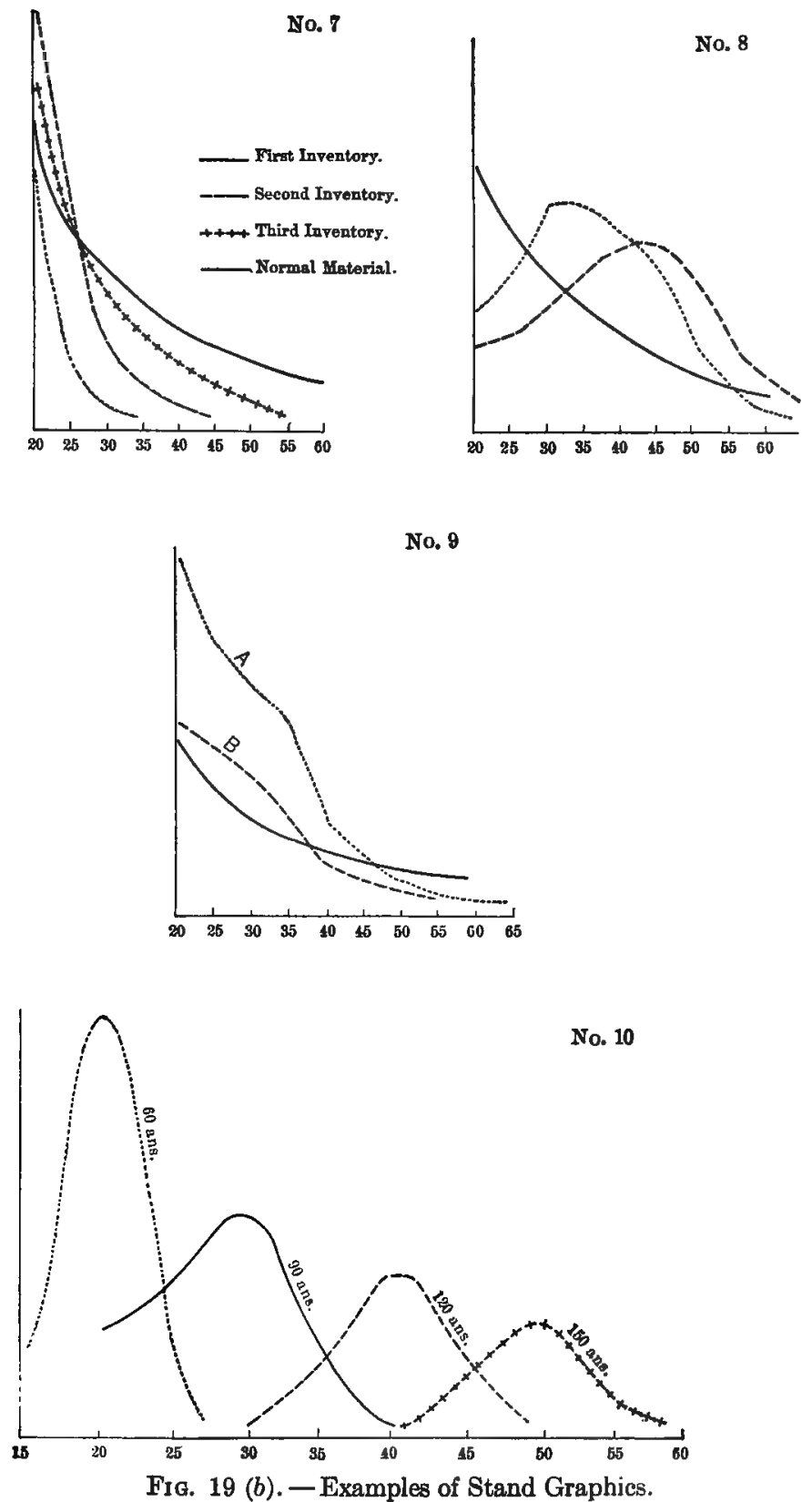

Fig. 19 (b). - Examples of Stand Graphics. 
1. Local wood markets must be stabilized; and local needs, which can only be supplied from certain forests, must be met.

2. Lumberjacks, and other forest workmen who live in local villages, must be supplied with work.

3. An annual revenue is necessary for the communes since it takes the place of income from taxes; it is not so necessary for the State owning forests all over France, but is considered a convenience.

Working plans are necessary because it is difficult to distinguish between the capital or growing stock, which is "property held in trust"13 and the annual income or growth which constitutes the owner's returns.

The main trouble with forest crops is that they become merchantable only after a long time. The yield is essentially periodic. There is a final yield at the end of the rotation, and only if thinnings are profitable or practicable is there in addition an intermediate yield. After a forest is once established, this disadvantage of deferred yield is obviated by having part of the crop mature every year and thus give a sustained annual yield, which, if necessary, may be periodic instead of annual.

The longer the rotation the larger the growing stock and usually with long rotations the per cent earned by the capital invested is less than with short rotations. For example, a coppice on a rotation of 20 years, in theory at least, has less than one-fifth the growing stock when ripe of a high forest with a 100-year rotation. In practice, since the high forest soil yields more heavily, this disparity is even more marked. Due to the small interest returns from long rotations private owners frequently favor coppice with a short rotation, notwithstanding the consequent damage to the soil. On the other hand, the French State policy has been to grow the kind of wood most needed rather than that which would be most profitable.

The beginnings of forest regulation in France make interesting reading because often we see conditions depicted which bear some resemblance to the conditions during the past decade in the western United States. The beginning of systematic cutting in the great Vosges ${ }^{14}$ fir-spruce forests is of particular interest:

"At the commencement of our era the Sylva Vosagus belonged to the imperial treasury. Later the great abbeys such as Remiremont, Senones, and Moyenmoutier divided the ownership of this immense domain with the Lorraine dukes, who inherited from the emperors. The Vosges fir stands thus belonged to a few very rich and powerful owners who began a systematic improvement (of the stands) at an early date, an improvement not only of grazing and of wood usage but also of fellings for the supply of the trade. The method adopted by the Vosges foresters for this objective was the construction of sawmills. Set up on small streams which supplied the power . .

13 d'Aménagement. Puton, pp. 1-18.

${ }^{14}$ Huffel, Vol. III, pp. 108-110. 
they were pretty well over the whole region at the end of the 15 th century. . . . The sawmills, which belonged to the dukes and abbeys who had built them, were leased with the stipulation that the number of trees that could be sawed would be furnished each year. These trees were cut in the watershed where the sawmill was located . . . or here and there. Thus there was a real selection felling, with the yield in number of trees, fixed not by the productive capacity of the forest, but according to the output of the sawmill . . . about 200 fir of average size per year. When the country tributary to a sawmill was exhausted the forest was closed and the felling was transferred to another area. Thus the Lorraine foresters obtained an exact idea of the relation between the area of the forest and the number of trees which it could annually yield without being depleted."

Application to United States. - The theoretical need of working plans has been recognized by the U. S. Forest Service for the last ten years but no systematic recording of management plans has yet been done except on a very few Forests. As a result, a number of National Forest divisions or working groups have possibly been overcut; later on this may mean hardship to the local interests. Obligatory working plans are needed to-day for all National Forest areas which are being intensively logged. It is not enough to refuse to make sales because of fear of overcutting - there must be a definite scheme planned in advance. Otherwise the Forests will unquestionably suffer. Such is the lesson from France. And it is equally important to provide transportation to tap virgin timber where literally millions of dollars of raw product is going to waste every year, notwithstanding the timber famine which has been predicted.

We must, of course, recognize that we are in a transition period, and when regulating virgin stands the excess growing stock must be reduced. Moreover the practical conditions often make it appear advisable to make very large sales so as to compete with offerings of private owners. There are forests, like the Plumas, where some over-cutting is probably necessary because the Forest Service owns but a small proportion of the timber, the bulk being in private hands. In such case the choice may be between $(a)$ leaving islands of inaccessible uncut timber or (b) overcutting. In such case (b) may be the lesser evil. But even admitting that our present rotations, cutting cycles (and even our silvicultural practice) are transitory, yet, even then, obligatory regulation is necessary for our public forests, for even the forester cannot be trusted to cut by rule-of-thumb. This is doubly true where many of our officers are not technically trained. Broad-gauge regulation does not signify at once tying to a mean annual growth nor a strict academic sustained annual yield - concessions must often be made to meet practical demands - but let us have our regulation down in "black and white," in orderly and systematic working plans. Such detailed plans are generally nonexistant, and yet are needed. It is open to argument whether even large 
virgin areas of timber, distant from transportation, should be heavily cut (as they may be) without first having a working plan to show how the removal of the over-mature timber will merge into the desired forest management.

There is a striking analogy between the early crude regulation in the Vosges and the 1905-1918 "regulation" on some of our National Forests where the yield area unit or working group may correspond to the area required to supply one or more sawmills. In the Vosges "however numerous were the sawmills, they touched only a small portion of the immense stand." The excess of supply over demand unquestionably saved these Vosges forests just as our early logging of only a small portion of the stand on private forests, because the rest was unmerchantable, saved large areas from total destruction. But with a more intensive market these conditions have changed; everything - even small trees - are merchantable, so we must look to the future. Until 1919 on our National Forests the great danger was that real mandatory (obligatory) regulation ${ }^{15}$ was not generally in effect. From 1905 until about 1918 the administrator has been more powerful than the working plan expert, because the expert has not formulated a practical plan something exceedingly difficult because of changing conditions, unstabilized and unforeseen local demands, and economic factors which dictate the export of all good grades of lumber to far distant regions. Even with obligatory regulation recognized as a necessity there is danger in making sales for 8 to 10 years. With long-term sales and sales for enormous amounts to one company, as have been planned and made in a few instances, the tendency is to sell immense tracts and thus to bind the local forester to an economic lumberman's policy for years to come. Because of the frailty of human foresight, these contracts which bind the Forest Service to a long continued economic exploitation are probably unwise. This means that an administration in 1910 may blindly bind the administration in 1930 to a policy of overcutting a locality in the West. The administrator of 1925 may want to build a privatelyowned railroad as a separate enterprise and sell in small amounts. This he could not do because perhaps ten or fifteen townships in question had been sold to a great lumber corporation on a 20 -year sale; once the investment is made can further sales be refused without hardship on the operator even if his plant has been amortised in the meantime? Shall a local forest industry be wiped out? I believe such a situation is almost unique in the history of our Government. These big sales are justified by the necessity of selling overmature timber which

\footnotetext{
${ }^{15}$ Since this was written it is understood that the Forest Service has begun the study of regulation in earnest and that long-term sales are to be largely confined to Alaska. It is hoped that the change in policy will be effective - but the lesson holds good.
} 
is wasting - something commendable in itself - but they bind the future administrations of our Government to a policy which may not be wise at that time. Suppose the timber were required for local use by small isolated communities whose development was not foreseen when the long-term sale was made. The lumber company could not store the timber until needed. It must be exported where the demand for a large output is keen. It would be better to develop Government or private transportation as a separate business and then sell to small mills for short periods. The details of long-term sales have been wisely worked out but the broad-gauge policy is at fault. Would the present Forest Service administrator willingly sell the Kaibab Forest to one company to secure development? I believe not, because the sentiment has changed within the past year. How do large sales affect regulation? It means that to justify the very large cut, required for big sales, which removes one-half to two-thirds or more of the stand, the working groups are extended to take in as much growing stock as is needed to yield the annual cut of the large sale. Under such conditions the real regulation for the benefit of the future local community may be impossible. There must be smaller working groups, smaller sales, and permanent road and railroad transportation, because the long-term sales such as have been sanctioned by the Secretary of Agriculture are merely compromises between destructive lumbering and forestry. There is no need to make such compromises, and these sales should be abandoned. The intensive, energetic, and serious campaign for real regulation, which began in the fall of 1919 on all National Forests, based on silviculture, local economic requirements, and yield should result in excellent management plans - needed but not yet in effect.

Abuses Led to Legislation. - Anyone who doubts the folly of the present forest destruction in the United States, by the private owner who treats his forest as a mine instead of an annual crop, should read and study the forest history of overcutting in France. The campaigns against the use of forest capital for income did not always succeed; it took a national need for timber to make regulation possible and to stop abuse and overcutting. It was a succession of ups and downs for forest conservation, and much of the overcutting was in royal forests under trained foresters. The great conservationist Colbert showed clearly by his appointment of a special forest commission that he did not trust the foresters in charge because he had found that the tendency had been to overcut. Let us examine a few instances of the early vicissitudes of forest control. In 1596 an attempt was made to prescribe the amount of timber to be sold annually in royal forests. The plan was never followed and in 1612 was formally suppressed. In 1614 new restrictive rules were made especially for the Normandy forests but abuse and 
overcutting continued. In 1661 royal forests were closed to cutting as a "reformation against forest abuse" and in 1662 Colbert started a reconnaissance and stocktaking. Colbert's $\mathrm{s}^{16}$ code of 1669 , which above all was "an organic law and one of policing," was the first step that really counted because it became part of the recognized law of the country, and though it was evaded and was modified from time to time, it remained a bulwark against forest profligacy. In 1668 definite arrangements were made for working plans, which included a check and a map of the boundaries, estimates of timber, descriptions of the soil, species, merchantable sizes, local needs, rotations, and special data on timber suitable for ships. But certain abuses continued even after 1669; poor location of sales, high stumps, waste and failure to reserve sufficient standards.

The Policy of "Reserves". - In French forest management the "reserve" refers to the growing stock or timber capital held in excess of the stock which would normally be provided by the working plan. The need of reserving a nest egg of timber in communal forests (in excess of the normal growing stock), a policy continued to the present day, is clear when we look back at past improvidence. It was natural to "lean over backwards" and to retain excess growing stocks. And during the war it was fortunate for the allies that these reserves existed, for without them the war shortage would have been more acute.

Huffel ${ }^{17}$ thus summarizes the history of "reserves": "Commenced in the 16th century they then aimed solely at the general welfare," at the expense of the clergy and communes and were therefore ineffective. Reëstablished in the 17 th century, they aimed at the private and public interest. But during the 18th century, because of poor execution, the so-called reserves impoverished more forests than they enriched. In the 19th century the reserves were maintained for the communes and especially for their finances. They were more effective as the administrative

${ }^{16}$ As a matter of fact the wood famine predicted by Colbert never arrived because he based his prediction on an increased demand for cord-wood whereas fuel wood has been replaced by coal, oil and electricity. It is not unlikely that a real world timber famine will never arrive because an acute shortage will bring pressure and lead to substitutes. But from the viewpoint of national efficiency and health forests will become more necessary as our civilization and settlement intensifies. It is interesting to compare the gross and net revenue (cited by Huffel, p. 256, Vol. III) before and after the Colbert reforms. In 1682 the area of the royal forests was 1,303,834 arpents (about 1.3 million acres). In the years $1660-69$, the average gross revenue was 447,623 livres, the average net revenue was 325,699 livres; $1680-89$ the average gross revenue was $1,557,363$ livres, the average net revenue was $1,110,773$ livres.

${ }^{17}$ Vol. III, pp. 84-85. The history of "fonds de réserve" is from Huffel who is the best author on French forest economics. The French reserve to-day is usually separate from the working group being systematically cut over; it is held for emergencies and cut when required. 
control became firmer. The next development in the objective of the reserves was to stabilize revenue in case of an act of Providence or errors in management. Contrary to ordinary German usage, the French insist on carrying more than a "normal" growing stock. This, they argue, will stand them in good stead if there are windfalls, insect attacks, or wars. This question of a reserve in publicly owned forests is important, because we are about to begin the regulation of our National Forests. It is therefore of interest to examine how and why the policy of reserves was established in France. As early as 1549 it was ordered "that a third of the forests belonging to the communal citizens shall be reserved for growth in high forest." In 1561 this was extended to include royal forests but the reserve was reduced from one-third to one-fourth. In 1580 the order was cancelled by Henry III, but 17 years later, because of continued forest destruction, the order of 1561 was reëstablished and Colbert's code of 1669 provided that one-fourth the communal and clerical ${ }^{18}$ forests over 25 acres in area, conifers excepted, should be thrown into a reserve. From 1706 to 1730 the policy of reserves was suppressed in portions of France, but the principle was firmly established and was embodied in the working plans for communal broadleaf forests which were almost all completed by 1750 . It was found best to have this "quarter in reserve" separated from the rest of the forest so that an inspector could determine on the ground whether a bona fide reserve had actually been made. And to-day these reserves are still considered advisable in communal forests, as provided by the revised code of 1827 , because if the cutting in the regular working groups, for example, is stopped by having to clean up heavy windfall, then the reserved portion can be worked during the crisis. This furnishes employment for local laborers and safeguards the continuance of a revenue from special fellings in the reserve. Where, as in some instances, the reserve was not separated out on the ground but merely banked by having an excess growing stock through cutting only three-fourths the estimated yield called "fonds de réserve à assiette mobile," the silvicultural results were less satisfactory, but the reserve supply of fine, large timber strengthened the special industries which depended on a local supply of high-class logs. Before the war the long rotations so prevalent in State forests constituted a strong reserve which war requirements largely reduced. As much as 15 to 18 annual yields were cut in 1917-1918 in some fir (Jura) forests. Judging by the experience of France, our public forests in the United States should not be cut up to their full capacity unless it is locally essential from the viewpoint of sound silvics. Under American conditions perhaps the best

18 The A. E. F. bought a part of the forest of Citeaux (Loire-et-Cher) so it is interesting to know that the Citeaux monks protested for over 50 years against the reserve required by the law of 1669 . 
way to obtain a reserve is to use rotations somewhat longer than is indicated by the culmination of mean annual growth, or frankly to adopt a physical rotation and grow the large timber that the private owner can never afford to produce because of the lower financial returns.

Summary of Principles and Methods. - French Government regulation ${ }^{19}$ of cutting shows "for a given period ${ }^{20}$ when, how, where, and how much should be cut in the forest."

With more complicated silviculture, where the number of fellings must be increased to secure natural regulation, or with windfall or other accidents, regulation is naturally more difficult and requires modification oftener than with clear cutting. With simple coppice, regulation, once wisely established, will last indefinitely, provided the rotation remains unchanged.

The management of a forest includes the $(a)$ preliminary work upon which the working plan is based and $(b)$ the regulation of felling which is based on the fundamental statistics collected under $(a)$. French writers recognize only four essential kinds of yield regulation:

(1) By area, which is simple but entails sacrifices if parts of the forest are irregular and if too rigidly applied to secure an orderly sequence of age classes.

(2) By number of trees, usually with a diameter limit system.21 This gives a variable volume yield and has been abandoned, except for experimental purposes, with the exception of selection beech coppice (tallis furete). In India this method, really a crude volume method, is still extensively used possibly partly because of the fact that coolie labor is used to collect working plan valuation survey data.

${ }^{19}$ The following management terms (French terms and American equivalents) are used by French writers: Règlement d'exploitation (cutting plan). Procès-verbal d'aménagement (working plan report). Possibilite (yield; amount forests can furnish without diminishing revenue). Série (working group which forms a distinct economic unit). Rotation (cutting cycle). Révolution (rotation). Affectation périodique (periodic block, cut over during the period). Produits normaux (product or yield prescribed by permanent working plan). Produits normaux prévus (abnormal regeneration fellings). Produits extraordinaires (cutting of reserve, in communal forest). Produits principeaux (yield of mature timber, final regeneration fellings). Produits intermédiares (thinnings).

${ }^{20}$ Huffel, already cited.

${ }^{21}$ Where all trees over a fixed diameter are cut by the so-called diameter limit method brought to the United States by Gifford Pinchot and first described by Lorenz in France in 1867, there is great danger of irregular yields and of overcutting virgin stands where age class normality is rarely found. Huffel says, "such a system can evidently be applied only to forests very nearly normal. In a fir stand rich in large trees, seedlings, and saplings, but poor in average sized trees, it would result in a rapid and ill-considered cutting of all the old timber in a short period of superabundance, which would be followed by a period of largely reduced fellings or even by a complete suspension of income." 
(3) By volume, which is supple, difficult to calculate, requires short periods between working plan revisions and frequent inventories and is somewhat dangerous, since it is apt to lead to overcutting if the growth is largely overestimated.

(4) By area and volume, a combination of (1) and (3). This is the modern method of regulation except for coppice stands which can usually be regulated correctly by area after making suitable allowances for soil quality (see page 232).

Management Subdivisions. - The great lesson in a study of the details of European forest management is that in dealing with nature perfection is impossible. Regeneration is usually not complete; there are windfall and insect attacks to throw out yield calculations and create disorder silvically and financially. Until the forester learns this lesson he cannot create proper pictures of the future forest, especially if he follows the ideal of natural regeneration, which will usually be the rule in the United States for some years to come.

In systematizing the cut or in regulating a forest there are two kinds of management work: (1) "Preliminary work . . . the study of physical conditions, growth, and the economics of exploitation. Essential work . . . the regulation of felling."

After deciding on the classes of product desired, based on the local or general industrial requirements (see "Rotation," page 226), and the system ${ }^{22}$ of silviculture necessary to the objects of the State (see Chapter V) the first important step in the systematic management of a forest is to form so-called management ${ }^{23}$ subdivisions, for without these no yield regulation is possible. Management divisions rest fundamentally on two bases: (a) silvicultural systems and (b) economic units. A priori, simple coppice is not mixed with high forest but forms separate sections; these sections are then formed into working groups "destined to form distinct economic units with distinct cutting cycles and a sustained yield." Whether a section is divided into one or more working groups or whether the working group may comprise one or more sections depends on the size of the section and the economic conditions. Usually in France the section of high forest in State forests forms more than one working group and the section of coppice only one. This is immaterial to our consideration of the subject of French public forest regulation.

${ }^{22}$ In France there is always a presumption in favor of the former method of treatment which is the result of centuries of evolution. A change in treatment involves financial sacrifices and has usually been brought about by a change in market, which would justify a conversion from coppice to high forest, or an error in the original choice of treatment through failure to secure natural regeneration.

${ }^{23}$ French administrative subdivisions built up from the beat, the forest, the canton, the inspection and the conservation are not treated in detail (see Chapter $X, p .273$ ). 
From the American viewpoint it is interesting to note that the areas covered by each working group in France are usually small - 1,000 to 1,300 acres - but it should be emphasized that this is due to the intensive economic conditions. In France a small valley may supply a lumber-jack village in the mountains with its sale of logs essential to the continuance of its waterpower sawmill. If this valley is $\mathbf{1 5}$ to 20 miles from a railroad, up a steep grade, the cost of obtaining the necessary local supply of lumber from a large producing center would be prohibitive. Without steady work during the winter months, when farming is impossible, the laborers would have to migrate or give up their home life. These conditions often explain the small working groups, which cost more trouble and money to establish, but which hold the local population. For parts of New England it is the ideal which public forests should strive to imitate, but it must be admitted that the more working groups there are, the more difficult and complicated is the logging, since the sales must be smaller.

According to the teaching at Nancy "the solid base of the whole management structure, the indispensable criterion of its precision, the incessant guide of administration, the necessary means of the control of operations and of the results obtained" is the compartment sub-division. Under intensive conditions this is usually between 15 and 40 acres in area and, unless soil quality varies greatly, the compartments in one forest do not vary greatly in area. An important exception is where the regulation is by area and where to obtain a nearly equal annual cut it is necessary to increase the size of compartments, where the poorer soil gives a smaller yield per acre. The main criticism of compartment boundaries, as found in French State forests, is that they are sometimes too artificial. The soil, exposure, logging roads, ridges, valleys, canals, and railroads should all govern the shape and boundary of the compartment, but usually the boundaries in hilly country should be perpendicular to the logging road to facilitate logging. The so-called "étoile," so common in level forest subdivisions, is more important from the scenic or shooting viewpoint than from the standpoint of logging.

Rotations and Cutting Cycles. - The rotations are based on the object of the owner and are determined by technical, silvicultural, economic, or financial considerations as limited by silvicultural possibilities. According to Fernow a rotation is "the time through which the crop is allowed to grow normally until cut and reproduced."

The viewpoint in India as expressed by D'Arcy ${ }^{24}$ is contrary to the European conception of rotation, except in selection forests in France: "the exploitable age of a forest crop is the age at which the individual ${ }^{24}$ D'Arcy, W. E. Preparation of Forest Plans in India. Calcutta, 1898, 3d edition. 
trees furnish the kind of produce most wanted." Endres says ${ }^{25}$ that "by rotation period or rotation is meant that time which elapses under normal conditions between the planting and the utilization of a stand. In the case of the working group the rotation is the average time of growing merchantable material which is the fundamental consideration in working plan calculations." Variations from the normal may be due to unusual silvicultural, financial, or economic conditions. Rotation is not to be confused with cutting-cycles ${ }^{26}$ in selection forests, which is the period elapsing between cuts on the same area. Obviously in selection forests the length of the cutting cycle has an important influence on the amount removed, and the frequency of cut also has a

${ }^{25}$ Endres, pp. 220-221.

${ }^{26}$ There are strong arguments in favor of a long cutting period. The longer the time between cuts the more time will be allowed for eradicating damage caused by logging. When it is necessary to cut a amall amount per acre over a large area it necessarily increases the cost of logging. Some argue that the cutting cycle should not be less than the time which it will take the tree to pass from one diameter class to the following. On the other hand well-known writers, like M. Gazin, argue that the cutting cycle should be very short -5 or 6 years - in order to secure the yield without opening up the stand too much and without the necessity for heavy cuttings. If, for example, the growth per cent is 4 , a cutting cycle of 5 years means removing an amount equal to 20 per cent of the original volume; with a 10-year cutting cycle 40 per cent must be removed; and with 15 years, 60 per cent, which is certainly too much from a cultural point of view. A short cutting cycle, moreover, enables the removal of dead and dying trees which otherwise would lose a great deal in value. As a general rule, the more intensive the treatment the shorter the cutting cycle. With the recognized tendency to coniferous forests, intensive treatment becomes more and more necessary if the spruce, fir, or pine is to be favored in the cutting. Moreover, recent yield investigations show that the growth of coniferous stands is much more than had been supposed. Schaeffer, a specialist in fir forests, advocates neither the very short nor the very long cutting cycle, but has called attention to the possibility of cutting over the same ground twice during one cycle. This double cut idea is only advocated, however, for the rich compartments, since one cut per cycle would be sufficient for the areas where conditions of growth are less favorable. He says: "The cutting cycle of 16 years, usually followed under average conditions in the Savoie Alps, can be continued with 8 years between the cut. In calculating the yield with conservatism it will result in certain compartments realizing every 16 years 30 per cent or more of the stand. This volume cannot be secured at one time without endangering the future of the stand." Two cuts, therefore, would be justified during the course of the formal felling cycle. However, it should be recognized that in exceptionally rich forests it would be possible to reduce the cutting cycle to 12 years and the interval between the two cuts to 6 years. On the other hand, in certain stands where the time necessary for trees to pass from one diameter class to another is 40 years, 20 years would be a better felling cycle, but instead of fixing the length of the cutting cycle arbitrarily Schaeffer advocates the determination of the number of years which it takes a tree to pass from one diameter class to another, and adopts this figure, provided during this cutting cycle each compartment will be cut over twice, but after the first cutting no new stocktaking need be made. (De la Durée de la Rotation dans les Futaies Jardinées. A. Schaeffer, 1907. B. de S. F. de F. - C. et B.) 
direct bearing on the amount that is lost through decay; consequently there is a tendency with intensive management to short cutting cycles of from 5 to 10 years. With extensive management longer cutting cycles are unavoidable. In Oregon (western yellow pine) a cutting cycle of 50 to 60 years has been tentatively adopted, obviously far too long when the market is established. In France, under most intensive conditions, the cutting cycle is 5 to 8 years; under less intensive conditions 9 to 18 years, and rarely more than this. The cutting cycle is usually a submultiple of the rotation; with a cutting cycle of 5 years it is presumed that 5 per cent of the stand will be cut every 5 years, with a cutting cycle of 10 years 10 per cent would be cut every 10 years, and with a cutting cycle of 20 years 20 per cent must be cut every 20 years. This has an important effect on practical logging, especially in the United States where a considerable cut is usually essential to justify logging investments. Short cutting cycles which are best for the cultural needs of the stand are only possible under intensive conditions.

The tendency is to have too narrow an idea of what length of rotation means. For example, if 5-year-old transplants are used in a plantation, after clear cutting, which is allowed to grow 100 years, the rotation in this case would be 100 years rather than 105 years, since the age of the transplants at the time used would be omitted in the calculation. On the other hand it is recognized that the length of the rotation is shortened by the use of well-formed transplants simply because the stand matures sooner. Frequent and early thinnings are of the utmost importance in affecting the length of a rotation. With thinnings the stand will become mature earlier than if left unthinned. It must be borne in mind that while the forest as a whole may be managed according to specified rotations yet individual stands may be cut before or after the age fixed by the rotation because of accidents, market conditions, or numerous other considerations. Still another point worthy of emphasis is that it is usually sufficient if the rotation can be established to the nearest decade; it is splitting hairs to figure to the exact year when computing the rotation.

According to one writer: ${ }^{27}$ "It has often not been appreciated that the rotation actually employed is not that corresponding to the age of the smallest trees felled, but of the number of years in the felling cycles in excess of this." In India economic conditions necessitate an annual felling area, an average tree best suited to the objects of the management, sufficiently heavy fellings to insure regeneration, and, of less importance, a felling cycle which shall be a sub-multiple of the rotation.

${ }^{27}$ Blascheck, A. D. "The True Selection System." Indian Forester, 1913, pp. $427-430$. 
One of the chief difficulties in computing rotations, and especially financial rotations, is that the forester must use present statistics or the trend of present statistics for calculations which pretend to answer management problems on the basis of unknown or roughly approximated conditions a half century or a century hence - obviously impossible to fathom. But the proper regulation viewpoint is that the problem should be solved for the present on the basis of the best available data on the assumption that when the working plan is systematically revised these calculations will be recomputed and brought up to date. The fact that a revised and altered answer to the rotation problem will be certain is no reason for not doing our best with available statistics. As a matter of policy it is safe to estimate future conditions based on the trend of economic conditions, rather than to follow blindly present stumpage prices, present cost values, present current interest rates, and market requirements for forest products. The best regulation implies some attempt to fathom the future. We know from past history that forest conditions change; therefore to follow blindly present conditions we arrive at the least accurate predictions. There is a middle ground between following to-day's data on the one hand and on the other of making unwarranted guesses at the future. Moreover, we must realize that our calculations are at best approximations and therefore the minutia may often be omitted with profit and propriety.

Efficient thinnings not only enable the forest to grow timber of a specified size in fewer years, but they increase seed production and promote earlier seed crops, they decrease the date of the culmination of mean annual growth, and, as Endres puts it, "The greatest benefit is felt where the highest soil rent is maintained. It is recalled that large, early yields produce large soil rent and vice versa . . . a stand that has been thinned up to the $n$th year will have higher value than one that has not been thinned."

In intensive regulation, as for example in parts of New England, the forester must, in theory, distinguish between the rotation for a particular stand and the rotation for a working group which is composed of a number of stands of varying quality, but in the West, in northern Arizona for example, a rough general average rotation for even an entire region will usually be a sufficiently close approximation for conditions prevalent while National Forests are being organized. Even in a selection forest such as Chamonix (see p. 252) the French prescribe one technical rotation for Ncrway spruce and larch based on a rough proportion of the length of time it takes to grow the two species weighted according to the aggregate volume present. This rightly emphasized the futility of minute mathematical calculations for the solution of a problem which demands only an approximate answer. 
No strictly financial rotations ${ }^{28}$ have been established on public forests in France. The nearest approach to a high forest financial rotation is with maritime pine and Scotch pine, but even here the usual public forest rotations are 10 to 30 years more than would probably be indicated by soil rent calculations. Even coppice rotations are usually 10 to 20 years longer than soil rent rotation, but are sometimes calculated on the best gross money returns.

Technical rotations in the United States are of more than mere historical interest. Here a technical rotation, especially under conditions existing in the West, might be the final rotation chosen. Take the case of a watershed which is most suitable for producing railroad ties, because railroad ties alone could be floated down a drivable stream as on the Carson National Forest, Arizona. Here a technical rotation based on the length of time it took to grow ties of given dimensions is clearly indicated. The exact length, in this instance, would depend on the most suitable period for growing the quality of tie which yielded the largest net return on the investment, not taking into consideration compound interest charges (according to C. F. Korstian) unless the data for financial calculations were available.

In French Government selection forests technical rotations are usually chosen which will produce the kind of material most in demand by the public, so as to support local industries of value to the economic life of the locality. This kind of rotation, under the economic conditions existing in the Vosges, Jura, or Alps has been severely criticized by German foresters because of the financial losses usually involved. The German viewpoint as expressed by Endres ${ }^{29}$ is:

"Were we to apply the technical rotations to even aged high forests, producing mainly large timber, great financial losses would take place. However, the policy of bringing about a mixture of species in order to meet market requirements or demands is apparently correct . . . it is in keeping with sound forestry because it also maintains soil fertility. . . The technical rotation may also be used by the State for social and political reasons . . . but the technical rotation can only be recognized when production costs . . . are of no consequence to the owner."

Undoubtedly there are some economic rotations on French State coppice forests where the objective is to get the maximum quantity of wood. The silvicultural rotation idea, based on the limitation of the species to reproduce or to resist decay, is always present but is never the chief factor - which is always physical - namely, the product most necessary for local or general French industry. ${ }^{30}$ Rotations may

${ }^{28}$ No references have been found in French working plans based on maximum soil rent or maximum forest rent. For statistical data on rotations see page 54 .

${ }^{2}$ Endres, pp. 243-244.

${ }^{30}$ The rotation in France is ordinarily based on the length of time it takes a tree to grow to exploitable size; or, in other words, it is purely a technical rotation. For 
be temporary where it is clearly recognized that the rotation adopted is a temporary expedient (see p. 191).

The Normal Forest. - The normal forest with its normal distribution of age classes, normal increment, and normal growing stock is not used by the French Government in its regulation. Where the normal forest is used in working plans it is the empirically normal stand based on selected average local stand tables which show the volume in cubic meters and the number of trees by age classes. Schaeffer, in his development of working plans for selection fir stands in Savoie and HauteSavoie, used this empirical normal stand as a basis of comparison, especially for marking the fellings prescribed by the working plan (see p. 256).

Regulation of Cut. - The regulation of the cut comprises two distinct operations: (1) The final fellings, regulated by area or volume or both, which naturally constitute the chief return. These are regulated by the working plan in general terms while much depends on the progress of regulation and accidents: "A more complete regulation is necessary for administration; year by year there must be prescribed the place, the kind, and the quantity of the fellings to make." (2) Intermediate fellings or thinnings, which are not regulated by volume but by area. This form of regulation is also applied to the cork-oak bark collections and to the resin crops from maritime pine.

The essential regulation of French public forests may be classified as follows: ${ }^{31}$

example, in a slow growing forest, like Risoul, the rotation is 180 years, while in $\mathrm{La}$ Grande Côte, where the growth is much hetter, the rotation is reduced 30 years to 150 years. In the forest of La Joux, notwithstanding the rapid growth, the rotation is 150 years, because in this State forest very large wood was desired (Bois de Marines). The low returns from long technical rotations may be somewhat increased by the higher prices secured from large-sized timber.

${ }^{31}$ Masson's method, like Von Mantel's, which consists in dividing the total growing stock of the forest by half the length of the rotation, is well known. In applying this method there is realized each year a fraction of the stand represented by $2 / R$. This per cent of realization is not a function of the rotation. It will be 2 per cent for a rotation of 100 years, 1.43 per cent for 140 years, 1.12 per cent for 180 years, and 1 per cent for 200 years. It is necessary to have a normal stand or the cut is too high for an impoverished forest and too low for a rich, well-stocked forest. In order to obviate this error Schaeffer worked out a correction figure based on a knowledge of the stand per acre. (No. 3, 1905, B. de S. F. de F. - C. et B.)

The Masson formula was used extensively in the Vosges in the niddle of the last century and gave fairly accurate results, simply because the fir rotation was usually 140 years, and by the formula the yield was thus 1.4 per cent which happened to agree exactly with the average site of the Baden yield tables for silver fir. This method is no longer in use (see Appendix $K$ (2)), because the fundamental assumptions, on which the formula is based, are in error. 


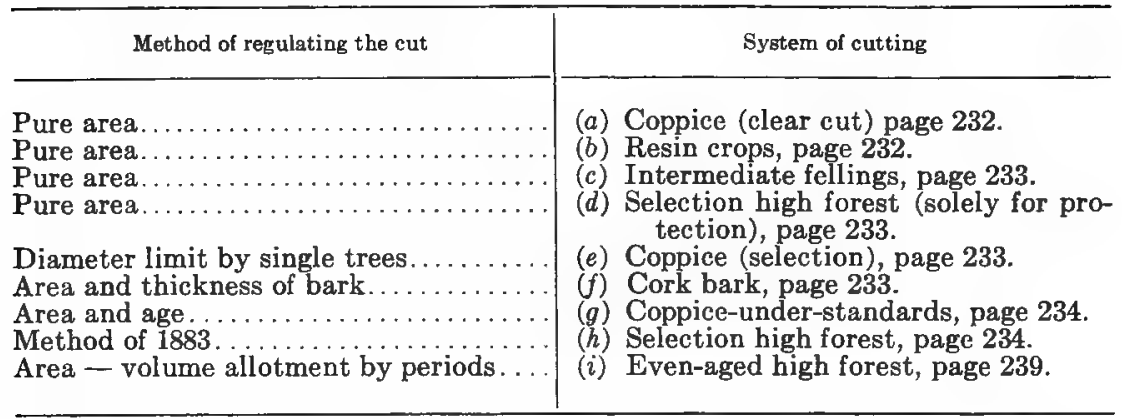

Pure Area. - The underlying principle is to divide the area to be cut over into a number of equal cutting areas corresponding to the number of years in the rotation.

(a) Coppice (clear cut). - If there are wide variations in soil quality, which would necessarily mean a variation in yield per acre, then the fixed area to be cut over each year can be increased or decreased so as to equalize the cut.

Illustration. - If a coppice forest of 250 acres had a 20-year rotation with three-fifths the area producing 10 cords at the end of 20 years and two-fifths the area only producing 5 cords, then the area cut over would be 10 acres per year for 15 years, and 20 acres per year for 5 years when the poorer soil came to be logged. Certain principles govern the designation of the cutting areas on the ground. If the forest is small, say 30 acres, it is better with a 30-year rotation to divide into fifteen or ten cutting areas, making a cut of 2 acres every other year, or 3 acres every three years. If possible similar types should be grouped into one cutting unit unless this interferes with the logging plan. Obviously it is poor policy to divide the coppice without seeing to its practicability as a logging unit. Broilliard favors rectangular cutting areas, say 1,500 by 600 feet. It is better to follow contours or logging roads in establishing coupe boundaries on hilly ground than to adhere rigidly to rectangles. The coppice cutting order should be against the prevailing storm direction and it should be numbered in the order of cutting. When coppice rotations are lengthened or shortened the redivision of the cutting areas is usually an interesting puzzle which can be solved only after careful study on the ground.

(b) Resin crops. - Both the final and intermediate yields are regulated by working over equal areas each year. No attempt is made to get a more exact yield by taking into account the soil productivity. For a detailed description of the system of working and an illustration of yield regulation see pages 191 and 192, Chapter VIII. The final yield of these maritime pine forests is also regulated by cutting equal 
areas each year. This is simple and works well, because regeneration immediately after clear cutting is practically certain.

(c) Intermediate fellings. - These are regulated by cleaning, freeing, or thinning an equal area each year. It was found that where the volume to be removed by intermediate fellings, especially thinnings, was limited the forest suffered silviculturally, consequently no limitation of volume is considered advisable.

(d) Selection high forests, usually maintained in the high mountains solely for protection purposes, are, however, cut over periodically on a cutting cycle of 12 to 20 years so as to remove the dead and dying trees which would otherwise be lost. With a protection working group of 120 years and a 12-year cutting cycle 10 acres would be cut over each year. At high altitudes where logging is difficult and expensive it is often considered more practicable to combine several years' operations, so under the conditions enumerated it would probably be better to cut 30 to 50 acres every 3 to 5 years rather than to $\log 10$ acres, for the few trees it would yield, each year. There is no limitation of volume since the restriction of cut is secured by the silvicultural rule of cutting only dead, dying, and deteriorating trees.

Diameter Limit by Single Trees. - The basis for this method is to cut all trees which have attained a certain diameter. This system, now largely abandoned, was first used in the Vosges in the middle ages where there was an excess of raw material and where only trees of a certain size and number were wanted at the local sawmills.

(e) Coppice (selection). - The selection coppice forests of beech are found chiefly in the Pyrenees. When applied to high forest virgin stands where age class normality is rarely found, there would be grave danger of overcutting, for as Huffel says, "Such a system can evidently only be applied to forests very nearly normal." No illustration of the method is necessary.

( $f$ ) Cork bark. - The cork-oak bark yield ${ }^{32}$ is regulated by computing the number of trees which bear bark thick enough to be merchantable. In other words, there is the diameter limit idea applied to single trees but it is gauged by the thickness of the bark (not by the total diameter of the tree), and by the area to be harvested. (See also page 396.)

Illustration. - The forest of l'Esterel is divided into two divisions each with three working groups. It takes 12 years for the cork to reach a thickness of 0.9 inch, the merchantable size, and it is collected on a cutting cycle of 2 years. The yield is obtained by dividing the number of trees (with salable bark on a working group) by 2 and multiplying by the average yield per tree.

${ }^{32}$ For further details see Chapter III, French Forests and Forestry, by T. S. Woolsey, Jr. John Wiley \& Sons, Inc., 1917. 
Area and Age. - The regulation of $(g)$ coppice-under-standards is based on clear cutting the coppice and felling the ripe or deteriorating standards (and thinning the $1 R$ standards where necessary) each time the coppice is clear cut. Therefore the cutting cycle is equal to the coppice rotation. The coppice cut is regulated by felling an equal area each year (see (a) page 232); the standards are cut when they reach maturity - say four coppice rotations - and sooner if they show signs of disease. In addition some of the immature standards are also removed at the time of the coppice felling. An approximately equal annual cut in standards is obtained, since an approximately equal number of fresh standards are reserved when the coppice is cut. The natural loss of standards while they are growing to maturity is fairly uniform. Great freedom is allowed in leaving thrifty trees for added growth and in removing those at a standstill. Occasionally the amount of the cut in standards is gauged by applying an empirical growth per cent to the growing stock represented by the overwood or standards and then cutting just the amount of the growth. Since the standards are selected and reserved from the coppice stand the number secured is in theory fairly uniform and there is no danger in cutting on a growth per cent basis unless the new supply of $1 R$ standards falls short (see pp. 94-98).

Method of 1883. - This method originated in France and will therefore be discussed in considerable detail, especially as Schaeffer has developed several refinements which have never been understood in the United States, and since this method could be applied to selection forests of spruce and fir in New England and elsewhere. This so-called method ${ }^{33}$ of 1883 as applied to $(h)$ selection forests of tolerant species is as follows:

After the inventory, by diameter classes, determine the rotation and the corresponding size of tree, then classify the stock in three classes: (1) Old wood, trees more than two-thirds the exploitable diameter; (2) average wood, less than two-thirds and more than one-third; (3) young wood, less than one-third (usually not calipered). Where there is a normal, or nearly normal, proportion of old and average wood the cut ${ }^{34}$ equals the volume of the old wood divided by a third of the rotation

s Based on the original official instructions issued by the Secretary of Agriculture and on the Chamonix Working Plan, by A. S. Schaeffer.

${ }^{34}$ The student should compare this method with the Hufnagl "diameter class method" described by Recknagle, pp. 100-105. The Hufnagl method (Variation 1) is: "Annual cut $=$ Volume of trees or of diameter classes $\frac{r}{2}$ years and over, plus increment thereof in $\frac{r}{4}$ years. . . ."

Recknagle gives an interesting example of (Variation 2) where the trees have been grouped by 3 -inch classes with the basis data (for each class) of volume per tree, average number of trees per acre, and years required to grow from one class to the next (and 
plus the growth on the old wood class while it is being cut. But in many former working plans the growth of the old wood class was not computed; the result was therefore a slightly more conservative yield.

The method was designated for selection high forests of tolerant species, where the regeneration could be secured in at least one-third the rotation, and where a sustained yield was important. It is based on the conception that a selection forest, normally constituted, is just like an even-aged forest (where, on equal areas, stands of all ages, up to the rotation age, are found), except that the various aged trees are intermingled. In the latter case an equal cut is secured by cutting each year areas of the same size and productivity. But in the selection forest the cutting must remove only ripe trees here and there over the 'entire area without any comparison of surface. Therefore in this case volume must be substituted for surface.

The method is based on the assumption that the volume of the old wood is five-eighths and the volume of the average wood three-eighths the total merchantable volume, presuming that the young wood is unmerchantable. According to the French Secretary of Agriculture the data furnished by research on the mean annual rate of growth of high forests shows that this relationship is approximately as 5 is to 3 . Therefore, whenever in a selection forest the volume of the old wood and the average wood is as 5 is to 3 it can be taken for granted that these two groups are similar to the first two periodic blocks of a high forest. To demonstrate that the volume covering the first two periodic blocks of a regular high forest (divided into three periodic blocks) is about as 5 is to 3 , which represents their average age respectively, it suffices to note that the trees of the second periodic block are the average wood, which has arrived at a state where the annual growth is very uniform and just about equal to the average of the stand and at a period when it is safe to figure the future growth as equal to the past average. Suppose a high forest with a 150-year rotation were divided into three periods of 50 years each. The average age of the first (old wood) and second (average wood) periodic blocks will be 125 and 75 years and will be separated by a length of time equal to a period of 50 years. In admitting that the future growth will be equal to the average growth, the volume of the 125-year wood will be equal to that of the 75-year old wood increased by an amount equal to 50 times the annual growth. "average age of the average tree in each diameter class"). For each class the cut is $=$ Volume of class $\times \frac{\text { Number of trees per acre }}{\text { Years to grow to next class }}$. The summation of the yield for all classes is the cut per acre which can then be increased or decreased according to the surplus or deficit in the growing stock.. According to Recknagle's example the surplus is reduced in one cutting cycle (which is made equal to the number of years to grow to the highest diameter class for the preceding class). 
Then if we designate the volume of the 75-year-old wood as 3 the 125year-old volume will be

$3+\frac{3}{75} \times 50=3+2$ or 5 . This assumption of an equal mean annual growth of course is not exact, but according to French reasoning it is sufficiently accurate for an approximate formula which is being continually revised at working plan revisions, when the standing timber is recalipered. According to the original circular:

"One can object to this method of classification (see definition, page 234) because the diameters are not exactly proportional to the ages, that they are not equal for the same species, or same age, inasmuch as the trees of a selection forest are very far from growing under the same conditions. But it is to be supposed that with a large number of trees . . . a sufficient compensation will take place in order to even off the inaccuracies and render them negligible. Moreover, it is not essential, nor possible, to arrive at exact mathematical results. . . ."

The language and the argument of the original French instructions are instructive in considering the method and in applying it. As originally promulgated, so as to be conservative, no increase was made in the cut for the growth which took place on the old wood while it was being harvested. But within recent years it is customary to figure growth.

The method is simple when the proportion of the old wood to the young wood is as 5 to 3 or nearly so (see definition of method, page 234) but this normal ratio is not usually found. Instead there is (1) an excess of old wood, (2) an excess of average wood. In either (1) or (2) an approximately normal ratio is secured by transferring diameter classes from the old wood to the average wood or vice versa if it is safe silviculturally to hold over some of the older trees or if, where the average wood is too great, the large average wood sizes can be cut without too great a sacrifice.

An important feature of the application of this method by the best French working plan officers is that they compare the actual growing stock, on the basis of number of trees per acre of different sizes, with an empirical "normal" stand (an adjusted average for the region). This is an essential and important part of the method as best applied but is not mentioned in the official instructions. Fig. 19 illustrates the method used, where the actual forest is progressing toward an empirically normal state. At the first stocktaking the stand was open; there was an improvement of the stand at the second measurement, and the curve of the third stocktaking is approaching the normal by a wave movement already referred to on page 215 .

A rough area check can be applied, if desired, by considering that the area cut over should be proportional to the volume removed. The original instructions stipulated that (1) the length of the felling period 
be a submultiple of a third of the rotation; (2) the number of compartments be about equal to the years in the period; (3) the local forester be free to allot the amount of the cut in each compartment according to local requirements at the time of cutting; (4) the yield be revised at the end of each felling period.

Disadvantages. - (1) To be exact the number of years in each class should be varied in accordance with the number of years of growth actually consumed. (2) Unless there is some other check on the normality of the old wood and average wood besides the proportion of 5 to 3 it is insufficient because an acre might contain 5 board feet of old wood and 3 board feet of average wood without being normally constituted. There must be some conception of total volume. (3) Trees must be tallied down to one-third the rotation (exploitable size).

The advantages are: (1) The yield is in accordance with the condition of the stand. (2) The tendency is to work toward normal diameter classes. (3) A sustained yield is secured and the growing stock is being continually built up. (4) The method has worked fairly well in practice.

Illustration. ${ }^{35}$ - The merchantable size is 24 inches corresponding to a rotation of 180 years. The old wood is 17 inches and over, the average wood 9 to 16 inches inclusive, and the young wood 1 to 8 inches.

A sample inventory is shown on the following page.

(A) According to the inventory the normal proportion exists, the average wood totaling $3,000 \mathrm{M}$ and the old wood 5,000 $\mathrm{M}$ - therefore the cut is $\frac{5,000}{60}=83 \mathrm{M}$ per year or if the old wood were growing at the rate of 2 per cent per year $\frac{5,000 \times 0.02 \times 60}{2}$ or $3 \mathrm{M}$ would be added making the cut $86 \mathrm{M}$.

(B) Suppose the volume of the old wood $=6,200 \mathrm{M}$ and the volume of the average wood $=1,800 \mathrm{M}$. Here the old wood exceeds the normal proportion so the old wood diameter classes should be examined to see if they can be transferred to the average wood group and held over a period equal to 60 years - one-third the rotation. If there is no objection to this transfer the trees in the 17 and 18-inch diameter classes,

${ }^{35}$ An exact adaptation of an official French illustration of the method and as illustrated by the Chamonix Working Plan, by A. Schaeffer. American units have been substituted. The art of French regulation under such an expert as Schaeffer rests chiefly on a thorough, intimate knowledge of the local conditions rather than on the organization of methods that differ fundamentally from what has already been accepted. Schaeffer knew the selection conifer forests of the Savoie region so well that he could probably estimate ocularly the growth per cent on any forest within one-half of 1 per cent by simply making a reconnaissance on foot. Such insight into the growth of a forest is similar to the knowledge of stands per section obtained in the West by seeing what the timber on sections of land ( 640 acres) looks like, and then learning what they cut out under given methods of logging. 
which we will presume totals $800 \mathrm{M}$, will be deducted from the old wood. Thus $6,200 \mathrm{M}-800 \mathrm{M}=5,400 \mathrm{M}, \frac{5,400}{60}=90 \mathrm{M}$ per year, plus growth.

(C) Suppose the volume of the old wood equals 3,300 $\mathrm{M}$ and the volume of the average wood equals $4,700 \mathrm{M}$. Here the average wood is in excess of the normal ratio, so it is determined where one or more of the largest average wood diameter classes can be transferred to the old wood for immediate cutting. If it were found that the 16-inch diameter class, which we will presume totals $600 \mathrm{M}$, can be added to the old wood, the volume will be $3,300 \mathrm{M}$ plus $600 \mathrm{M}$ which equals 3,900 $M$ and the cut $\frac{3,900}{60}$ equals $65 \mathrm{M}$, plus growth.

\begin{tabular}{|c|c|c|c|c|c|c|c|c|}
\hline \multicolumn{3}{|c|}{ Young wood } & \multicolumn{3}{|c|}{ Average wood } & \multicolumn{3}{|c|}{ Old wood } \\
\hline$\underset{\text { inches }}{\text { D. B. H. }}$ & $\begin{array}{c}\text { Number } \\
\text { trees }\end{array}$ & $\begin{array}{c}\text { Total } \\
\text { volume, } \\
\text { board } \\
\text { feet }\end{array}$ & $\underset{\text { inches }}{\text { D. B. }}$ & $\underset{\text { trees }}{\text { Number }}$ & $\begin{array}{c}\text { Total } \\
\text { volume, } \\
\text { board } \\
\text { feet }\end{array}$ & D. B. H., & $\underset{\text { trees }}{\text { Number }}$ & $\begin{array}{c}\text { Total } \\
\text { volume, } \\
\text { board } \\
\text { feet }\end{array}$ \\
\hline $\begin{array}{l}1 \\
2 \\
8 \\
4 \\
5 \\
6 \\
7 \\
8\end{array}$ & $\begin{array}{l}\text { Not cali } \\
\text { compu }\end{array}$ & Totals... & $\begin{array}{r}9 \\
10 \\
11 \\
12 \\
13 \\
14 \\
15 \\
16\end{array}$ & \multicolumn{2}{|c|}{$\begin{array}{l}\text { Completely } \\
\text { calipered } \\
\text { and } \\
\text { computed }\end{array}$} & $\begin{array}{l}17 \\
18 \\
19 \\
20 \\
21 \\
22 \\
23\end{array}$ & $\begin{array}{c}\text { Comple } \\
\text { calip } \\
\text { and } \\
\text { comp }\end{array}$ & ely \\
\hline
\end{tabular}

After studying the application of this method of 1883 for 25 years, Schaeffer ${ }^{36}$ decided that the results were very satisfactory; it has

${ }^{36}$ Possibilité des Futaies Jardinées, A. Schaeffer, pp. 321-326. Revue des E. et F., 1908. 
enriched poor stands and in some cases has resulted in an excessive growing stock. But the excess of the timber capital is in accordance with the government policy of conservation. From the viewpoint of good silviculture, Schaeffer has formulated a rule for selection fir-spruce stands of always cutting at least two-thirds the actual increment each year. Otherwise the stand cannot be maintained in good condition because if less than two-thirds the increment is removed it means that some diseased or decrepit trees must be held over a cutting cycle. Such a rule has wide application to similar stands in the United States when a wave of forest saving shall finally lead us away from the current forest destruction. To practice too intensive economy in a stand means an increase in defective timber.

Area (Volume) Allotment by Periods. - This method, called by French writers the ${ }^{37}$ "combined method," is as follows when applied to an (see $i$ page 232) even aged high forest: The method is applied throughout France to the rich oak-beech high forests which are so noteworthy in the so-called Parisian zone of the Plains (see p. 30) where the regeneration is by the shelterwood system over a regeneration period of 20 to 30 years. Formerly great stress was laid on the necessity for an orderly sequence of fellings. Lately the tendency is to break away from any preconceived order of felling and instead to base the order and sequence of fellings on the conditions actually existing in the various compartments. ${ }^{38}$ But protection against dangerous winds and the maintenance of protection belts of old timber is always sought after. In the sprucefir forests great difficulty has been experienced in regularizing fellings (see p. 75).

"After having fixed the length of the rotation, it is divided into equal periods, which should be long enough to permit the regeneration of a complete forest canton (during a period)."

The period adopted is usually 20 to 30 years and rarely 40 years. The next step is to determine what compartments are to be cut during each period.

${ }^{37}$ See Huffel, Vol. III, "Méthode combinée." To give an accurate picture of how the French apply this method, the text has been followed as closely as possible.

${ }^{38}$ Where the shelterwood system was applied to fir-spruce stands it had been customary to divide the forests into four fixed periodic blocks corresponding to four periods, equal to one-fourth the rotation. This led, according to Huffel, to "excessive cutting of large timber on half the area (blocks I, IV, and sometimes III), absolutely deplorable felling of average-sized timber on most of the forest (blocks I, IV, and often II), and during (the operations) the maintenance of overmature timber in the second periodic block no less deplorable. . . . In the first period the revenue was too much, in the second about correct, in the third a deficiency, and in the fourth very deficient. . . . The "précomtages" invented in the last case to correct this deficiency rendered the yield calculation incoherent and illogical, without remedying the evil very much." 
"Each periodic block must be formed of a single contiguous area, naturally delimited, separated and distinguished in a permanent way from the bordering blocks so as to form a topographic mass in the forest. . . . The yield of chief fellings is calculated by volume, as in Cottas method. The immediate fellings (thinnings) have no fixed yield; it is enough to indicate the annual area they run over during the period. . . The (exact) location of the principal fellings is not determined (in advance); they take place according to the needs of regeneration, at any point within the periodic block to be realized in turn."

At the end of each period the yield is recalculated for the periodic block which will then be cut over. In theory the areas of periodic blocks should be equal, but owing to varying soil quality they may vary considerably.

As already stated the period must be long enough so that regeneration can be secured, because "during a period of fixed length an entire periodic block of determined area will be cut." It is considered better to prescribe the cutting of 125 acres in 20 years rather than 250 acres in 40 years, because in the latter case it leads to irregularity and confusion. For example, with a rotation of 144 years, there would be a choice of (a) eight periods of 18 years, and with oak and a mild climate $(a)$ would be preferred to the $(b)$ or $(c)$ alternatives which follow; $(b)$ six periods of 24 years; (c) four periods of 36 years. The compartments are arranged in the order in which they require cutting, and they put in the first period all compartments most in need of cutting, in the order of urgency.

If there is a lot of old overmature timber declining in vigor the French use the "précomptage, where they then subtract their volume from the yield of the normal maximum fellings . . . and by the same amount decrease the cut of the block when its turn comes to be cut."

This is too artificial and often results in confusion. It is really borrowing from the future cuts to make a heavy present cut so as to get rid of overmature stands in need of regeneration.

The main disadvantages of this method if applied too rigidly is that it is impossible to fix the order of cutting in advance even for one period, because the schemes are soon disarranged by nature, and contiguous blocks are impossible. If an ironclad order of cutting is maintained heavy sacrifices must be made, because stands are cut before or after they should be cut silvically. If there are subtractions and transfers, i.e., "précomptage," then the whole scheme of future management becomes disarranged (see p. 75). Variations in the commonly accepted periodic block method have been suggested by Huffel and others. Changeable periodic blocks which are not formed of contiguous compartments are advocated in preference to the fixed periodic block of the older working plans. This means that there is only one periodic block the first - which at the end of each period is always being revised. 
similar scheme is where the forest is divided into a number of compartments equal to the number of years of the rotation. Then the period is based on the time it takes to get regeneration with a margin of a few years for safety. The compartments, equal in number to the years of the period, and most in need of cutting, are grouped into the periodic block to be cut during the period, and the yield is the total volume in this compartment divided by the years of the period.

The Gurnaud Method. ${ }^{39}$ - The Gurnaud method of yield regulation bases the cut upon the actual growth of the different size classes subject (a) to the condition of the stand and (b) to the judgment of the forester since, according to Jobez, "the interpretation of these figures (the growth) is entirely a personal matter and according to each individual case."

The growth is secured by adding the present growing stock to the cut for the last cutting cycle; this total is subtracted from the original stand to give the apparent growth. To obtain the real growth the volume of the trees under the minimum size calipered, which grew into the merchantable size classes, is subtracted from the apparent growth. This last step is a new idea in American forest technique; it may be going to an extreme of refinement, and might be questioned. The growth per cent is then figured by dividing the original volume into the real growth. The method demands great technical skill and sound judgment in its application; any method can be made to serve under such circumstances but the Gurnaud formula is especially exacting in this respect. The method was designed for selection forests and where a forest had the normal growing stock it could be readily applied as could any other formula method.

The advantages of the method are: (1) It necessitates a frequent and detailed study of the stand by size classes, and allows the forester to use his judgment. (2) The growth is based on the increment of the whole stand and allows for the volume of trees which were too small to be calipered but which grew into merchantable size classes during the cutting period. This avoids the calculations of growth based on the increase in size of individual trees. (3) The trained forester realizes that growth and yield figures are, at best, an approximation. ${ }^{40}$ Therefore, the best way to avoid errors is to have frequent stocktaking.

The disadvantages are: (1) It is not a real method of regulating the yield because correct results depend on the art of forestry rather than on definite clear-cut principles. (2) Instead of dividing the real growth by the original volume to get the growth per cent Gurnaud should have taken the mean of the first and second inventories. This error,

${ }^{39}$ Based on the discussion by Huffel, Vol. III, Economic Forestière.

${ }^{40}$ Accroissement d'un Massif Jardiné, S. F. de F. C. et B., No. 5, March, 1908, A. S. 
which could easily be corrected, tends to make the growth per cent appear too high. (3) The method as originally designed requires frequent and accurate stocktaking and therefore is expensive and tedious. (4) The accuracy of the growth calculations depends on accurate inventories which might easily be in error by 5 to 10 per cent. Therefore if both the (a) first and (b) second inventories were (a) 10 per cent too much and (b) 10 per cent too little an error of 20 per cent would result in the yield. (5) Too much is left to the opinion and judgment of the forester. (6) Huffel advances another objection with which the writer is not wholly in sympathy, namely, that it is dangerous to examine too minutely the growth of trees of different sizes and ages because the stand should be regarded as a whole. The tendency to-day in the opinion of the writer is to use more judgment in treating selection stands and if possible to get rid of tree classes which show they are declining in vigor or annual growth. On the other hand the method would not work well with abnormal stands.

Illustration. - Suppose a selection fir forest of 1,000 acres were divided into ten equal cutting areas, and that every 10 years, beginning in 1910, all trees over 12 inches in diameter were calipered and estimated by 2 -inch diameter classes. Gurnaud would first calculate the growth for each cutting area as follows:

\begin{tabular}{|c|c|c|}
\hline Ares of cutting 100 acres & Trees & Feet, board measure \\
\hline $\begin{array}{l}\text { Stand in } 1920 \ldots \ldots \ldots \ldots \ldots \ldots \ldots \ldots \ldots \ldots \ldots \ldots \ldots \ldots \\
\text { Cut } 1910-1920 \ldots \ldots \ldots \ldots \ldots\end{array}$ & $\begin{array}{r}2,000 \\
100\end{array}$ & $\begin{array}{r}1,000,000 \\
50,000\end{array}$ \\
\hline $\begin{array}{l}\text { Total } \\
\text { Stand in } 1910\end{array}$ & $\begin{array}{l}2,100 \\
1,960\end{array}$ & $\begin{array}{r}1,050,000 \\
980,000\end{array}$ \\
\hline Apparent growth. & $\overline{140}$ & 70,000 \\
\hline
\end{tabular}

To arrive at the true growth a deduction must be made for the $\mathbf{1 4 0}$ trees which grew into the merchantable size class: 140,11-inch trees $\times 100$ board feet, or 14,000 feet board measure; true growth for 10 years, 56,000 feet board measure; true growth for 1 year, 5,600 board feet. $\frac{5,600}{980,000}=.57+$ per cent or better if the mean of the two inventories 5,600

were to be taken $\frac{1,000,000+980,000}{2}=.56+$ per cent. The stand per acre would be 10,000 feet and the growth per acre per year 56 board feet. When it comes to an analysis of the stand separately for each size class the process is somewhat more complicated; those interested in a further study of the method should study La Méthode du 
Contrôle, P. Jacquin, Besançon, 1886, or La Méthode du Contrôle, published in 1890 by the Exposition Universelle of $1889 .{ }^{41}$

\section{WORKING PLANS}

General. - The working plan, or management plan, is merely the means of enforcing systematic, obligatory, mandatory regulation. It is "The plan or plans under which a given forest property is to be continuously managed." In France the government working plans in use to-day are the revised plans, good for only 15 to 30 years. In theory the working plan revisions have to be made at the end of each period, but in Savoie, where the yield will be greatly increased after 20 years, it may be necessary to make revisions oftener. They are simple, concise, and must be followed by the local officer in charge. There is no differentiation into planting, protection, grazing, improvement, administration, or felling plans, such as have been attempted in the United States on our National Forests. The French working plan is essentially a timber felling plan for one or more small economic units (or working groups) of a distinct local forest.

The ideal working plan should control and order the fellings; but in addition there is a certain suppleness necessary owing to unforeseen accidents which may occur even in well-managed forests. To be successful, any working plan should be adaptable to local changes, for, without suppleness, a working plan is a failure and the tendency of any working plans officer without experience is to be too narrow and to insist on rigid methods applicable to all forests.

An excellent illustration of the derangement of working plan yields by windfall is in the forest of Gerardmer. On September 1, 1903, the inspector reported that in the first, third, fourth, sixth, seventh, and eighth working groups, which had a prescribed annual yield of 11,971 cubic meters, on account of tremendous windfalls, 46,378 cubic meters, or the yield for almost four years, had already been cut. In the United States fire will be the greatest cause of overturning working plans for years to come.

The main difference between the working plans ${ }^{42}$ of State and com-

${ }^{41}$ Before leaving the subject of regulation the writer should acknowledge that some of the ideas - and very fundamental and sound ones - have been absorbed from the regulation lecture notes of Professor H. H. Chapman of Yale University. Those who had the privilege of hearing Professor Chapman lecture may judge to what extent his technique has been followed.

4 The stocktaking of an average forest now costs aoout 1.5 francs per hectare, but on account of the increased cost of labor this will soon increase to 2 francs per hectare. No detailed system of cost keeping is kept for different phases of a working plan, but the total cost per hectare, including office work, boundaries, and compartment boundaries, is about 3 francs per hectare (23 cents per acre). (1912 cost data.) 
munal forests is that in communal forests the cut has to be divided up so that each village will not have too far to go. In other words, this is a potent reason for small sales. For example, in the forest of Dingy St. Clair, the annual cut has to be divided up so that there will be one sale near each village. The forest is on each side of a valley and it would be too costly to have one or two central sales, since the transport of the wood would have to be across the valley. This is an inconvenience to the working plans officer since it complicates the sales problem.

Before attempting a new working plan it has been the French custom to have a frank discussion of the essential problems with the local force before the working plans officer makes his final decision. At this conference it is entirely feasible for the local officers in charge to emphasize exceptions from the general rule. Once formulated the plan must be accepted by a commune.

Each ranger in charge of a district is furnished with a digest of the working plan. ${ }^{43}$ The main points covered in this digest are the order, location and area of fellings during the period. The exact data included are rotation, yield and what should be charged against the annual felling budget; volume fellings with the canton, compartment, area, total volume, and estimated amount to be cut designated for each separate felling; area fellings with year, canton, compartment, and area of felling classified by compartment. Under remarks is included the method of treatment, such as selection fellings, special instructions regarding the fellings, cultural rules given separately for volume and area cuttings. The data are precisely presented, and cover rather more than a double page.

In past years the inventory frequently included only trees of considerable size. To-day it usually includes trees down as small as 0.20 meter (7.9 inches) in diameter by 5 -centimeter (2-inch) classes. In other words, all trees were measured in the valuation survey down to the estimated diameter which would be reached in one-third the years of the rotation. The general feeling is that this very complete inventory is exceedingly valuable for the sake of future comparisons.

Schaeffer ${ }^{44}$ has originated new methods of working plan description. In describing the fertility of the soil he argues that "figures are better than epithets." Recognizing the inaccuracy of describing soil quality, Schaeffer has established this simple rule:

4s The working plans in France are rarely typewritten but are copied by hand. Copying costs 75 centimes per double foolscap page and one franc for tables, an ordinary map 5 francs per copy. Four copies must be made of each working plan - one copy for Paris, one for the conservator, one for the inspector, and one for the local ranger.

* A. Schaeffer, S. F. de F. C. et B., No. 5. March. 1910, "Coefficients de Fertilité des Sols." 
"To obtain the coefficient of fertility of any stand in a selection (fir) forest, normally stocked (that is to say, complete and carrying trees of all ages properly spaced), divide the figure 40 by the average number of rings in the last centimeter of growth."

This rule is explained by the following table:

\begin{tabular}{c|c|c|l}
\hline $\begin{array}{c}\text { Number of rings in the } \\
\text { last centimeter (average) }\end{array}$ & Growth per cent & Soil fertility (key) & Equivalent \\
\hline 2.0 & 5.64 & 20 & \\
2.1 & 5.64 & 19 & Excellent \\
2.2 & 5.64 & 18 & Excellent \\
2.4 & 5.64 & 17 & Very good \\
2.5 & 5.64 & 16 & Very good \\
2.6 & 5.64 & 15 & Good good \\
2.8 & 5.64 & 14 & Good \\
3.0 & 3.76 & 13 & Good \\
3.3 & 3.76 & 12 & Quite good \\
3.6 & 3.76 & 11 & Quite good \\
4.0 & 2.83 & 10 & Quite good \\
4.5 & 2.83 & 9 & Passable \\
5.0 & 2.26 & 8 & Passable \\
6.0 & 1.88 & 7 & Passable \\
7.0 & 1.61 & 6 & Mediocre \\
8.0 & 1.41 & 5 & Mediocre \\
10.0 & 1.13 & 4 & Poor \\
13.0 & 0.87 & 3 & Poor \\
20.0 & 0.57 & 2 & Very poor \\
40.0 & 0.28 & 1 & Very poor \\
\hline
\end{tabular}

Another innovation in working plan description is the wide use of graphics which allow a comparison between the forest at different stages of its development and with average or normal conditions. An example of the latest forest description follows (see also p. 532): 
246 GOVERNMENT REGULATION AND WORKING PLANS

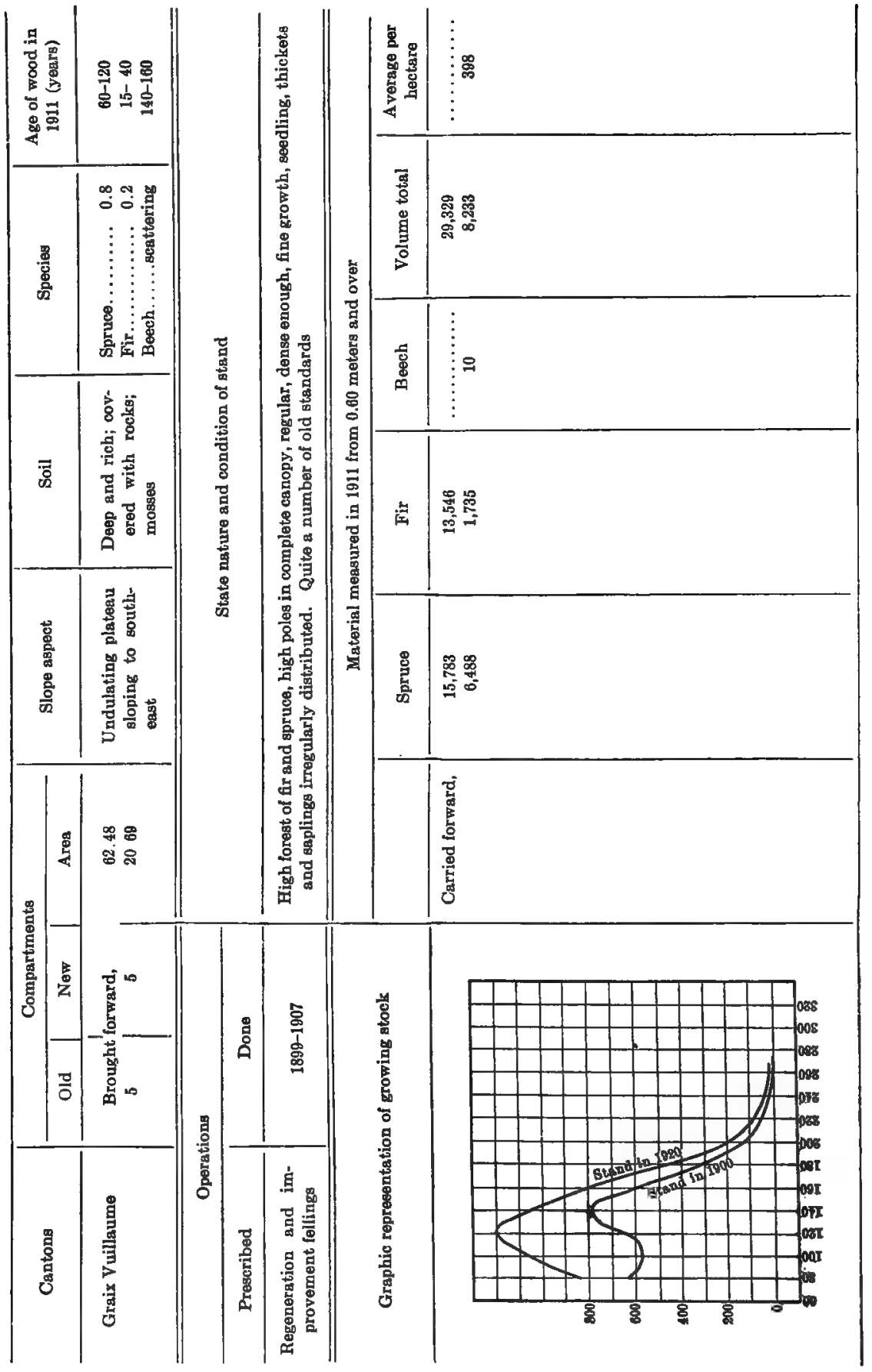


The Working Plan Report. - According to the Dictionnaire des Forêts, by Rousset et Boner, page 68, the working plan report follows the outline given below:

Part I. - General data. - 1, Name. 2, Total area, area wooded, openings and clearings. 3, Boundaries. 4, Rights and servitudes. 5, Topography and drainage. 6, Soil. 7, Climate. 8, Nature and condition of stand. 9, Kind of treatment. 10, Wood products, principal and secondary; their volume and value in money during the next ten years. 11, Routes, roads and method of logging. 12, Nurseries. 13, Market. 14, Grazing, pasturage, agriculture.

Part II. - Chapter 1. - Digest and critical review of treatment and, if there has been any, of the working plan in force.

Chapter 2. - Basis of the proposed management. 1, Division of the forest into sections and justification of this division. 2, Division of each section into working groups and justification. 3, Choice and justification of the method of cutting to apply to each working group. 4, Table (A) of the working groups by sections.

Part III. - Special studies of each working group. 1, High forest section. (1) Division into compartments with description of compartments in table (B). (2) $\mathrm{De}$ termination of the normal age for cutting and consequently normal rotation; division of this rotation into periods; division of the working groups into periodic blocks; general system of normal cutting with table (C). (3) Preparatory rotation. (4) Chief transition rotation. (5) General scheme of felling with table (E). (7) Yield with table (F). (8) Allotting the cut with table (G). (9) Application of the yield; cultural rules.

2. Coppice section. (1) Division into compartments with description of compartments. (2) Determination of the exploitable age for the coppice, decision as to the length of rotation; division of this rotation into periods, where (furete) coppice is concerned. (3) Establishment of the general scheme of cutting; quarter in reserve in the public (institution) and communal wood with table (H). (4) Standards. (5) Improvement cuttings; gleanings; freeing of seedlings.

Part IV. - Works and betterments. (1) Preparation of the general map and the compartment map. (2) Subdivisions of management; the boundaries. (3) Survey and marking of the boundary. (4) Artificial reforestation and nurseries. (5) Drainage.

(6) Roads.

Part V. - Comparative examination of the annual production and accessory products in material and money, now and after management.

Maps. - Part of the working plan is a general map on tracing cloth, showing gradient, water courses, routes, roads, ranger stations, sawmills or nurseries, boundaries of working groups, cantons, periodic blocks, compartments, and coupes. If the scale of the map will not allow all the necessary details, there should also be a map by working groups.

Appendix. ${ }^{45}$ - Should include tables, stand tables, and stem analyses used in fixing the yield. The outline for the revision follows:

Part I. - Preliminary data. - (1) Name. (2) Area. (3) Department and district. (4) Conservation, inspection, canton. (5) Altitudes. (6) Species by per cent.

Part II. - Management in force. - (1) Digest of the management in force; system and method of felling applied to the forest; division in sections and working groups. (2) Digest of the general and special scheme of felling. (3) Aim of management and

${ }^{45}$ The outline for the revision of a working plan should be compared with the above and with the outline actually followed in the revised working plan (1910) for the communal forest of Thiez given in the Appendix, page 517. 
results obtained by the reproduction cuttings, selection, preparatory in coppice, improvement.

Part III. - Revisions. - Chapter 1. - General considerations. Modifications to make in the general fundamentals of management, to the division in sections and working groups, to the rotation, etc. Table (A) of new sections and working groups.

Chapter 2. - Special studies in each new working group.

High Forest Section. - (1) Composition of the working group compared with the former working plan. (2) Compartments. (3) General scheme of felling, normal and provisionary. (4) Special scheme of felling. (5) Determination of the yield. (6) Location of fellings for the period. (7) Allotment of the yield; cultural rules.

Coppice Section. - (1) Composition of the working groups compared with the former working plan. (2) Description of stands. (3) Determination of the exploitable age for coppice; fixing the rotation; division of the rotation into periods; selection coppice. (4) General scheme of felling; quarter in reserve; yield. (5) Special scheme of felling with table (H). (6) Standards. (7) Improvement cuttings; cleanings; freeing of seedlings.

Part IV. - Betterments. - Betterments prescribed by the working plan. Betterments accomplished (remarks on the methods employed, results obtained). Betterments remaining to be done. Estimate of the expense.

Part V. - Comparative review by working groups of the annual products, principal and secondary, in material and money realized before and after the revision.

Federal Forests (Digest). - Complete data replanting, etc. (1) Species seeded, amount per hectare, methods. (2) Species planted, kind and number per hectare, methods. (3) Results. (4) Care and expense of upkeep, weeding and replacements. (5) Total cost. (6) Necessary data to get better results in future.

Sample Plots in all Federal forests when natural seeding with thinnings close onehalf hectare area in young stand, chosen by chief ranger, checked by inspector, marked and boundary stones laid, take inventory after each cutting to determine exploitability and revenue.

Communal. - One-fourth in reserve when area more than 10 hectares, "and not entirely stocked with conifers on one-fourth area."

Chamonix Working Plan. - The best picture of a modern French working plan revision is obtained by the study of a working plan in actual use; the Chamonix working plan ${ }^{46}$ has therefore been studied at length. It is for a communal forest where there is need for a sustained annual yield, and where, because of its importance as a tourist center, the forest cover must be maintained. A selection system is considered imperative on account of steep slopes, the danger from windfall and avalanches, as well as the necessity of taking every precaution to guard against erosion.

There follows a complete résumé of the plan with an explanation of the methods employed. It is divided into five parts with an appendix following Part V. By way of introduction the author, M. Schaeffer, states that the original working plan contains complete statisties, but that a number of points require modification and correction. Part $I$,

4 Procès verbal de revision d'Aménagement, par A. Schaeffer, 1910. This plan costs about 20 cents per acre excluding office work. 
preliminary data, includes a very detailed review of area changes (Art. 2), ${ }^{47}$ the present area being 4,733 acres; brief allusions to, (Art. 3) boundaries; (Art. 4) rights and servitudes; (Art. 5) topography; (Art. 6) soil; (Art. 7) climate; (Art. 8) composition and condition of stand; the per cent of each species is calculated on the basis of the volume of all trees calipered, namely, 5 inches and over; the per cent given in even hundreds was found to be: spruce 78 per cent; larch 20 per cent; fir, Scoteh pine, and cembric pine (with alder, birch, and service tree) 2 per cent; (Art. 11) roads, paths, means of logging; besides some 22.5 miles of new trails many of the old paths which had faulty alignment had been reconstructed; (Art. 14) pasturage, gathering needles. The practice of gathering the dry needles, the moss, and even the humus, has led in some cases to the impoverishment of the stand and the commune is, therefore, urged to put a stop to it at once in view of the æsthetic value of the stands bordering this great tourist center.

Part II. - Management in Force. - The fourteen working groups are listed in numerical order and by name with the area of each as for example: first working group, "Argentiére-Nord," 508 acres. The working groups vary in size considerably, one with 23 acres, six with from 99 to 247 acres, three with 249 to 494 , and four with from 496 to 581 ; M. Schaeffer believes a working group in the mountains should not be more than 1,000 acres. Then follows the felling scheme for the period dating from March 9, 1892. This table is headed as follows:

\begin{tabular}{c|c|c|c}
\hline Working group & Order of fellings & $\begin{array}{c}\text { Method of calculating } \\
\text { the yield }\end{array}$ & Remarks \\
\hline $\begin{array}{c}\text { First working group } \\
\text { of Argentiére-Nord. }\end{array}$ & $\begin{array}{c}\text { First lot: } \\
\text { A, B, C, etc. }\end{array}$ & $\begin{array}{c}\text { Transfer of trees } \\
\text { from 5 inches up } \\
\text { in the "average } \\
\text { wood." }\end{array}$ & \\
\hline
\end{tabular}

${ }^{47}$ Art. I is "name" (see official outline for working plans given on page 247 for the list of other project headings not included in the revision). According to W. B. Greeley: “. . . it is probable that the greatest public encouragement to the private owner to keep his timberland productive has been the stimulus and example of the publicly owned forests. These are scattered through practically every section of the country. In every forest region, the private owner has seen good forestry practice demonstrated for scores of years on State or communal holdings. He knows the forest officers in his locality and consults them on the methods applicable to his own woodland. The widely distributed public forests have not only set the standards of good management but have made the local silviculture a part of farm lore of the region. The rural population of France knows how to grow trees just as it knows how to grow potatoes or care for its vineyards. . . . And, by a law passed in 1913, the expert services of the State are offered at cost to owners of timberland who wish to cut their holdings on a conservative basis corresponding to the requirements of the "régime forestier" and to obtain the special forms of protection against trespass now accorded to public holdings by the forest code. This law is of too recent origin to have yet demonstrated its value." 
Under the topic, "Application of the working plan," there are given by working groups the data below:

\begin{tabular}{|c|c|c|c|c|c|c|c|c|c|}
\hline \multirow{3}{*}{$\begin{array}{c}\text { No. of } \\
\text { working } \\
\text { group }\end{array}$} & \multirow{3}{*}{$\begin{array}{c}\text { Compartments } \\
\text { eut over }\end{array}$} & \multirow{3}{*}{$\begin{array}{c}\text { Material } \\
\text { to be } \\
\text { cut. } \\
\text { cu. m. }\end{array}$} & \multicolumn{6}{|c|}{ Material cut } & \multirow[b]{3}{*}{ Remarks } \\
\hline & & & \multicolumn{4}{|c|}{ Subtracted from yield } & \multirow{2}{*}{$\begin{array}{c}\text { Not } \\
\text { sub- } \\
\text { tracted, } \\
\text { cu. m. }\end{array}$} & \multirow{2}{*}{$\begin{array}{l}\text { Grand } \\
\text { total, } \\
\text { cu. m. }\end{array}$} & \\
\hline & & & $\begin{array}{l}\text { Main } \\
\text { cut, } \\
\text { cu. m. }\end{array}$ & $\begin{array}{l}\text { Emer- } \\
\text { gency, } \\
\text { cu. m. }\end{array}$ & $\begin{array}{l}\text { Wind- } \\
\text { fall } \\
\text { dead- } \\
\text { wood, } \\
\text { cu. m. }\end{array}$ & $\begin{array}{l}\text { Total, } \\
\text { cu. m. }\end{array}$ & & & \\
\hline 1 & A, B, C, D, & 1,720 & 1,509 & 13 & 307 & 1,829 & $\ldots$ & 1,829 & \\
\hline Totals. & $\ldots \ldots$ & 26,100 & 20,215 & 579 & 8,363 & 29,157 & 1,061 & 30,218 & \\
\hline
\end{tabular}

Results obtained. - While admitting that an exact comparison for the whole forest is not possible, yet notwithstanding the overcut M. Schaeffer feels that the forest has been enriched by the management during the past period. For those areas which can be compared be gives the results in tabular form:

\begin{tabular}{|c|c|c|c|c|c|c|}
\hline \multirow[b]{2}{*}{ Working group } & \multirow{2}{*}{$\begin{array}{l}\text { Former } \\
\text { volume } \\
\text { by new } \\
\text { volume } \\
\text { tables, } \\
\text { cu. m. }\end{array}$} & \multirow{2}{*}{$\begin{array}{l}\text { Present } \\
\text { volume, } \\
\text { cu. m. }\end{array}$} & \multirow{2}{*}{$\begin{array}{l}\text { Volume } \\
\text { cut, } \\
\text { cu. m. }\end{array}$} & \multicolumn{2}{|c|}{ Growth } & \multirow[b]{2}{*}{ Remarks } \\
\hline & & & & $\begin{array}{l}\text { Total, } \\
\text { cu. } \mathrm{m} \text {. }\end{array}$ & $\begin{array}{c}\text { Per } \\
\text { hectare, } \\
\text { cu. } \mathbf{m} .\end{array}$ & \\
\hline $\begin{array}{c}1 \\
\text { etc. }\end{array}$ & 21,648 & 26,547 & 1,609 & 6,508 & 1.84 & \\
\hline Totals... & 114,509 & 230,778 & 19,230 & 75,499 & 2.92 & \\
\hline
\end{tabular}

This comparison, systematized as it is, cannot help but be an accurate guide in determining the yield and consequently it is all the more surprising that the calculation is omitted from so many plans. Changes in lines between working groups often make an exact comparison by groups impossible, but the figure for the whole forest is well worth the cost of the calculation. M. Schaeffer makes it a rule to multiply the former growing stock figures by the volumes of the latest volume table if the original table is not still in use.

The systematic comparison of financial results is equally interesting; it is by years, and has been given in full so as to illustrate the fluctuations which must be looked for owing to windfalls and unforeseen damage to growing stock or to unusual communal demands: 


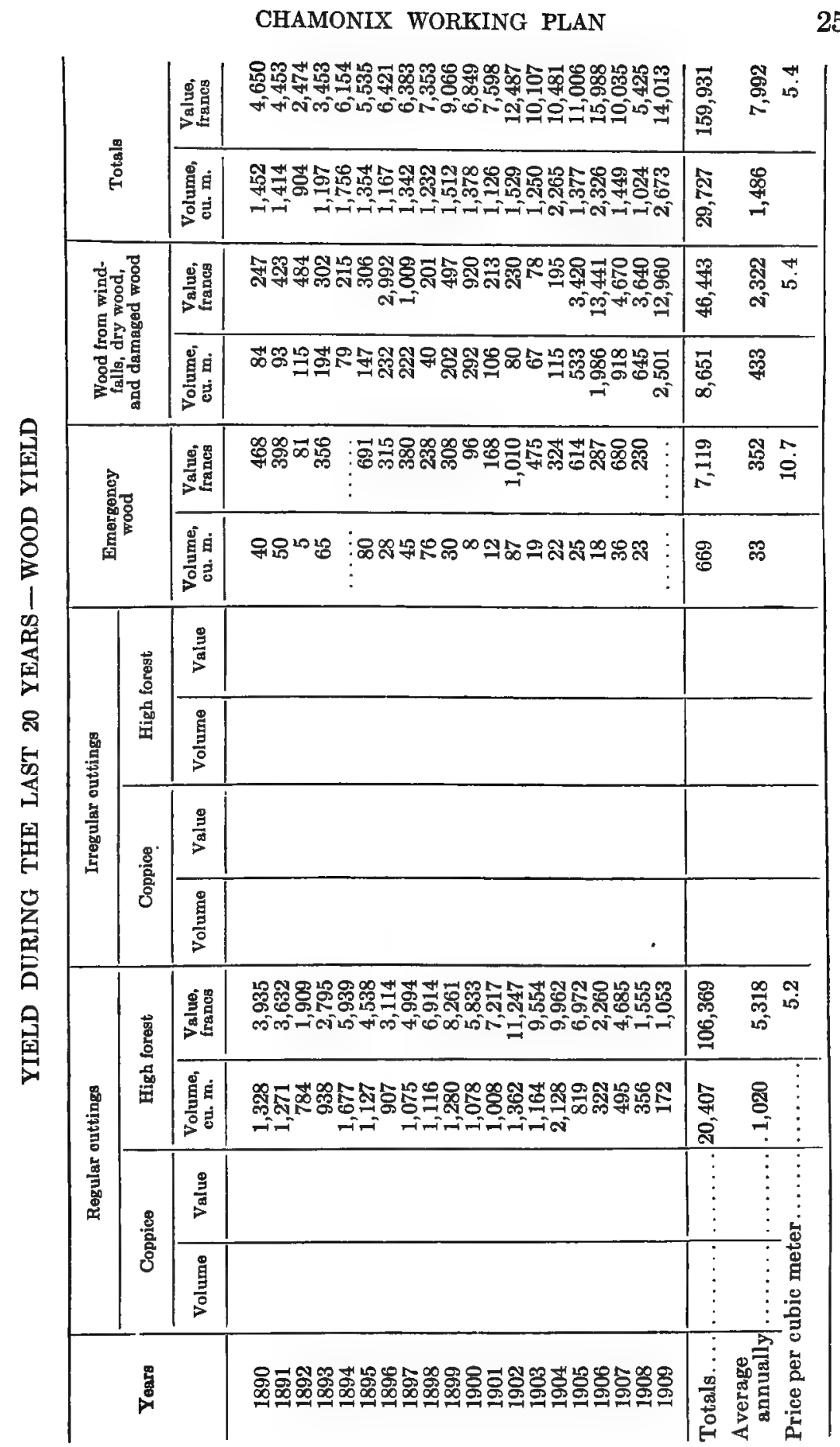


ACCESSORY YIELD (non ligneux) in Francs

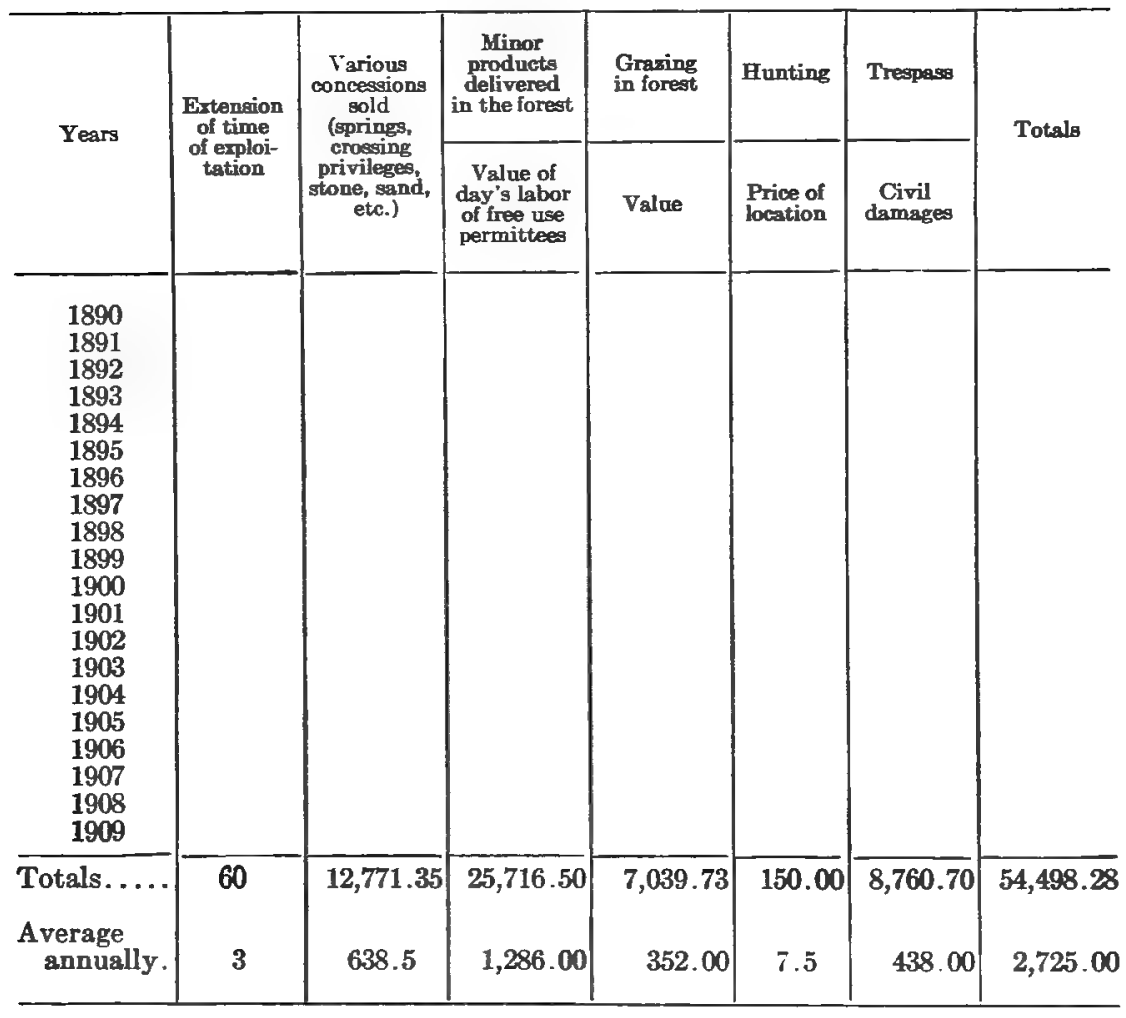

It is rather surprising to see the price per cubic meter for the windfall (5.4) greater than the price for the regular cut (5.2); this is explained by the cost of logging scattered timber as contrasted with the clean cutting of a considerable windfall even though it were thrown on the market quite unexpectedly.

Part III. - Revision. Chapter 1, General Considerations. - The necessity for varying the management boundaries is here taken up; these are, of course, merely working plan lines.

Rotation. - In the words of M. Schaeffer, "The rotations are actually fixed at 180 years for the spruce and pines and at 240 years for the larch. The notion of a distinct rotation for each species is a theoretical consideration which does not possess much weight practically . . . as a simplification we propose to adopt a single average rotation of 200 years." This policy seems to be so well adapted to practical conditions in the United States that it has been quoted in part verbatim.

Chapter II. - Special Study of Each Working Group. - (Art. 1) 
Composition of the working groups as compared with former plan. (Art. 2) "Compartments."

The feature of the working plan is the conciseness with which statistical data are presented. Those who are familiar with the detailed compartment descriptions given in German working plans will be particularly interested in the graphic representation of the growing stock. This is of great importance because in reality it is the key to the marking. The weak link is the determination of the normal growing stock which is taken to be the same for all situations and stands, but to be exact would be practically impossible without undue expense.

The stand descriptions are exact and are not by any means perfunctory: For example, "Despite the avalanche of February 17, 1904, which knocked down 3,116 trees and poles in the middle of the growing compartment, the stand has recovered and is approaching a normal growing stock." As one glances through the pages care for exact details is evident: "Avalanche area 3.91 hectares; numerous defective stands; opening of 3.00 hectares; a number of trees dead topped; reproduction sufficiently abundant" ; these are partial examples of the detail. Possibly more care could have been taken in describing the reproduction, but I rather surmise it is often lacking, so no mention is made.

(Art. 3) Regulation of felling. Exact order left to local officers.

(Art. 4) Determination of the yield. The yield is calculated under the so-called method of 1883 where in the selection forest the volume of the "old wood" is supposed to be five-eighths and the volume of the "average wood" three-eighths of the total. If the minimum tree measured is 8 inches in diameter then the "average wood" includes trees 8 to 14 inches inclusive, the "old wood" all above 14 inches, and the "young wood" the trees below 8 inches.

In this case the actual total of the "average wood" amounted to $165,797.7$ cubic meters and the "old wood" $126,979.3$, a total of 292,777 cubic meters. The working plan says:

"The normal proportion should be: old wood, $\frac{292,777 \times 5}{8}=182,986$; average wood, $\frac{292,777 \times 3}{8}=109,791$. It is far from being attained, but experience has shown that it is necessary to convert it artificially. The principal yield would otherwise be lowered by the normal volume of 'old wood.' It appears on the other hand from the descriptive summary that a careful thinning is necessary in a large number of compartments; there the average wood forms regular even-aged stands. It is then necessary to add to the yield of the principal products an accessory yield comprising the loss which is unavoidable because of the volume which does not enter into the calculation of the yield, namely 109,791 cubic meters. We put this loss with great conservation at 0.25 per cent per year, and we will then have for the actual yield $(P), P=\frac{182,986}{\frac{200}{3}}+$ 
$\frac{0.25}{100} \times 109,791=2,744+274=3,018$ cubic meters, this result corresponding to 1.03 per cent of the total growing stock and to 1.68 cubic meters per hectare figuring on the basis of 1,800 hectares actually wooded. This yield is considered so conservative that it is expected the actual growing stock will be increased."

Reference should be made to the growth figures, pages 256 to 260 .

(Art. 5) Allotting the yield. The annual cut is allotted by convenient districts, 10 in number, so that the wood will be convenient to the different hamlets or small sawmills. In other words, it would impose a hardship on some of the villagers if the cut were made in one locality alone. This complicates the management, but much the same problem may be looked for in the United States on National Forests where a number of small local mills must be supplied with stumpage or else they will have to shut down and move elsewhere.

(Art. 6) Marking the cutting areas during the second period (19101929). The order of cutting is often disarranged by windfalls, etc., but it is carefully worked out by the working plans officer by working groups. The form used is:

\begin{tabular}{c|c|c|c|c|c|c}
\hline Canton & Compartment & Area & $\begin{array}{c}\text { Volume } \\
\text { inven- } \\
\text { toried }\end{array}$ & $\begin{array}{c}\text { Per cent } \\
\text { to be } \\
\text { realized }\end{array}$ & $\begin{array}{c}\text { Estimated } \\
\text { yield }\end{array}$ & Remarks \\
\hline L. E. Grand Chantey... & 70 & 12.69 & 1,549 & 25 & 388 & \\
\hline
\end{tabular}

In the first working group the per cent to be cut varies from 10 to 25 per cent of the standing timber. The total amount inventoried was 43,360 cubic meters, and the cut estimated at 872 .

(Art. 7) Cultural Rules. (A) Fellings by volume.

"A large number of compartments have not been cut over for quite a long time, therefore, the overmature and rotting trees, and those crooked or dry topped, are abundant. In certain divisions they even form most of the stand. We estimate that their removal would almost equal the yield during a period at the very least . . . on the steep slopes so frequent in the forest, every day there are trees damaged by falling stones or by the logging. But it must be observed that while on the one hand one must often remove disessed trees, yet on the other there are compartments where poles and young high forest need immediate thinnings. It will then be the thinning of these young stands which will complete the yield and we believe it necessary to insist on this point. One can but admit that to get a considerable volume by marking stands of small size on steep slopes is hard work. The officer in charge of marking must guard against the tendency of the markers to designate large trees . . . he will also have to fight against the difficulties of the ground. This rule should be applied specially in the compartments (enumerated) on areas where the regeneration is difficult (compartments - especially) continue the existing thinnings and in the little openings caused by the removal of several overmature trees at once start reforestation by groups.

In the old compartments (unmanaged) the stand should be kept as fully stocked as 
possible. Be careful to take the necessary steps to get rid of all stems which might start an insect attack. There is another group of divisions which require attention; there are those which are situated in the valley near the group of hotels and really form a park. (Compartments . . .) usually stocked with an old spruce stand on the decline and for the most part in a critical condition. The soil packed by the walkers, free to grazing and litter gathering they are in a terrible condition for reproduction and the future of the stands is absolutely compromised. . . One can without great inconvenience let the old oaks stand until the last stages of decay, but not so with the spruce which when they decline . . . collect insects. . . . These stands must be closely watched and not allowed to wait until the last phase of decay. Several measures seem necessary; closure to common entry and litter gathering, successive fencing areas to start the regeneration."

In the park behind the Casino the existing reproduction should be opened up so as to form little patches of advance growth.

$(B)$ Felling by area. It will consist in topping the broadleaved trees to favor the conifers, but birch in good condition should be preserved where it is of æsthetic value.

(Art. 8) Deduction. All trees 8 inches and over are counted against the yield.

Part IV. - Betterments. - The following improvements are taken up. Map, compartment numbers; boundary pillars; restocking; regeneration has been retarded by grass and weeds so $M$. Schaeffer recommends the grubbing out of horizontal seed spots 3 by $3 \frac{1}{2}$ feet in size, since they have given excellent results. They should be not only in the openings but also in the sodded ravines.

"When the slope is steep the sod which is removed should be placed on the lower side to form a bench. On the bare soil sow broadeast several larch seed. We have not seen any failures, and the experiment thus far may be considered as decisive. It should be seen, however, that the seeding is not too thick because usually the natural regeneration will complete it . . . and an excess density is to be feared since with the larch it is a cause of damping off."

The little benches have also proved of value in stopping small snowslides.

Works to prevent avalanches. The plan of campaign recommended is: (1) Don't bother with those areas which are almost impossible to correct. (2) Where work will avail the Reforestation Branch will build dry masonry walls on a small scale, and plant denuded areas to larch and cembric pine. (3) The small ravines which are eroding should be handled by the local force by building small benches. The finances are then discussed and the commune assured of State assistance.

Part V. - Financial Summary and Forecast. - From 1890 to 1909 the average annual revenue is given as $\$ 2,078$ and the cost of administration $\$ 768$, leaving $\$ 1,310$ net. For the next 10 years the gross revenue is estimated at $\$ 5,196$, the expenses at $\$ 725$, and the net revenue at $\$ 4,471$ 
or more than triple that of the past period. The rise is due chiefly to increases in stumpage. Counting 4,450 acres of forest this is $\$ 1$ net per acre per year for a mountain forest. It will be double or triple this figure owing to the increase in stumpage since the war. ${ }^{48}$

The Appendix. - The Appendix is especially interesting and instructive. To start with there is a tabular and graphic comparison of the old and new volume tables. These are based on diameter alone and the same volume table figures are used for spruce and larch, but a separate table for the pine. Next comes a list of all trees calipered by compartments. The species are listed separately as follows:

COMPARTMENT 14

\begin{tabular}{|c|c|c|c|c|}
\hline \multirow{2}{*}{ D. B. H. } & \multicolumn{3}{|c|}{ Number of trees } & \multirow{2}{*}{$\begin{array}{l}\text { Volumes } \\
\text { cubic meters }\end{array}$} \\
\hline & Spruce & Larch & Total & \\
\hline $\begin{array}{r}20 \\
25 \\
\text { etc. }\end{array}$ & $\begin{array}{l}5,948 \\
2,986\end{array}$ & $\begin{array}{r}121 \\
88\end{array}$ & $\begin{array}{c}6,069 \\
3,074 \\
\ldots \ldots \ldots\end{array}$ & $\begin{array}{r}1,213.8 \\
1,229.6 \\
\ldots \ldots \ldots .\end{array}$ \\
\hline
\end{tabular}

On each page in the first column before the d. $b$. $h$. figures is given the volume in cubic meters (to the nearest tenth only) for each diameter classified. Separate records are given for each of the 137 compartments, for each working group total, and for the entire forest. After giving his theoretical normal hectare of selection forest, 400 trees 8 to 24 inches in diameter, totaling 343 cubic feet, the growing stock (for the entire forest) for 1889 is graphically compared with the present stock and with the normal stand. These curves show at a glance that the forest is still understocked especially in the larger diameters. But it also illustrates the progress made during the past ten years in conserving a depleted stand. A point in policy which $M$. Schaeffer has established is that it is not safe to hold over more than one-third the annual increment because of the continual need of cleaning out overmature material in a selection forest and of making thinnings. The curves are reproduced below; in the original working plan, they are supplemented by a table giving for the normal hectare the number and volume of trees by 2 -inch diameter classes 8 inches to 24 inches.

The Pressler borings are given in full, tabulated by 2 -inch diameter classes. There are not many, but they are carefully selected under average conditions. For 8 -inch trees there are 39; for 10, 48; for 12, 46; for 20 , but 22 . The readings are the number of years it takes the tree in each class to grow 2 inches. These are then averaged for each diam-

48 During the war 700 cubic meters sold for 70,000 francs! 
eter class and the growth per cent calculated for the corresponding classes by the growth per cent formula. The results were then evened off as

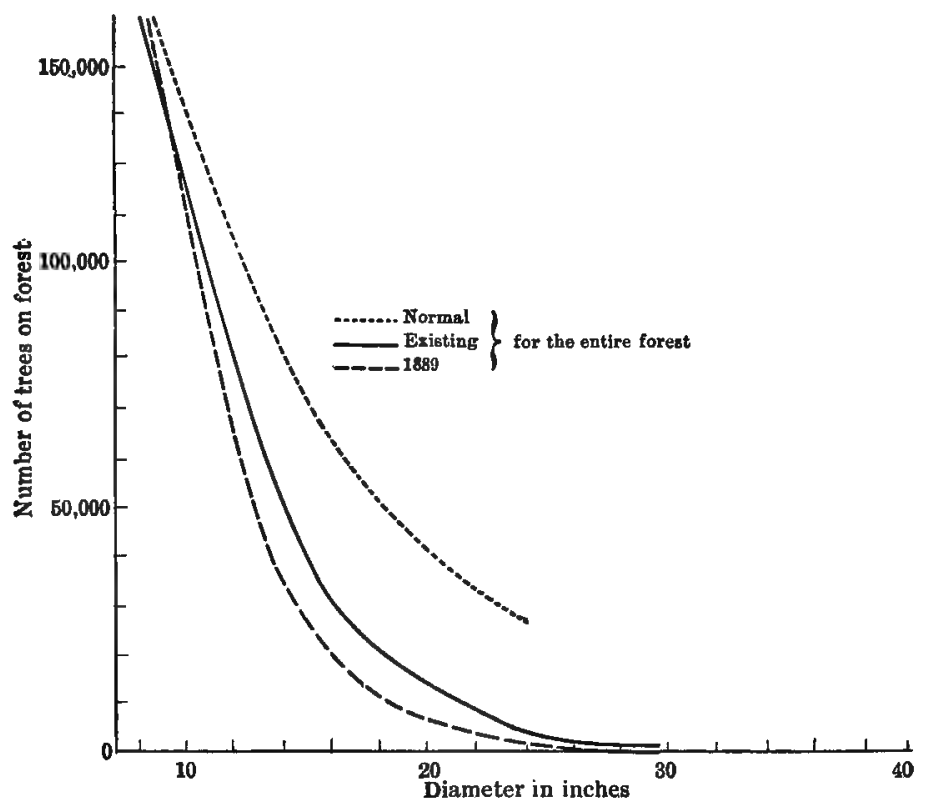

Frg. $20(a)$.

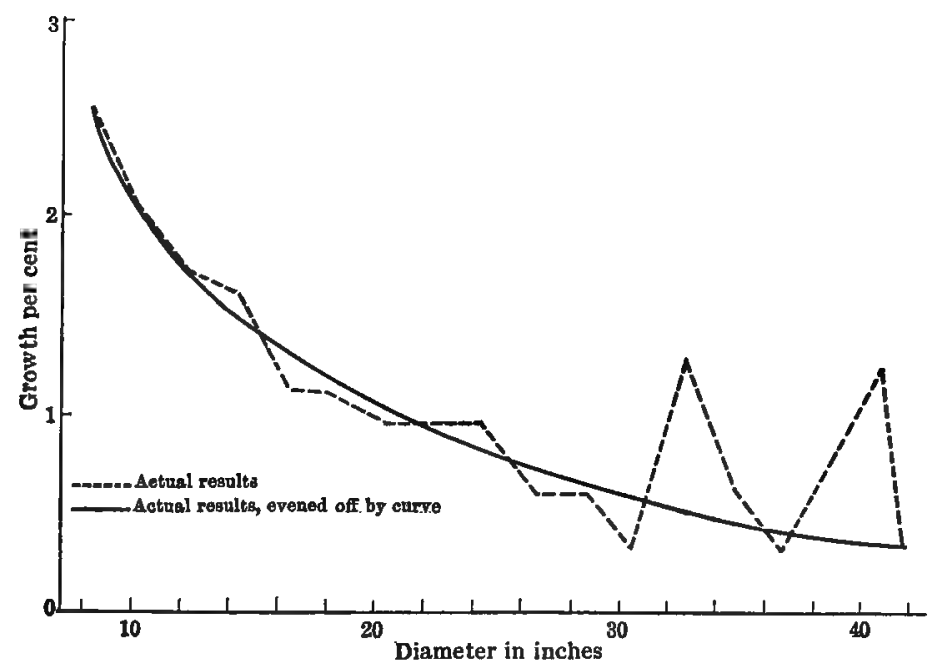

Fia. $20(b)$.

follows, the irregularity in the larger diameters being due to insufficient data: 


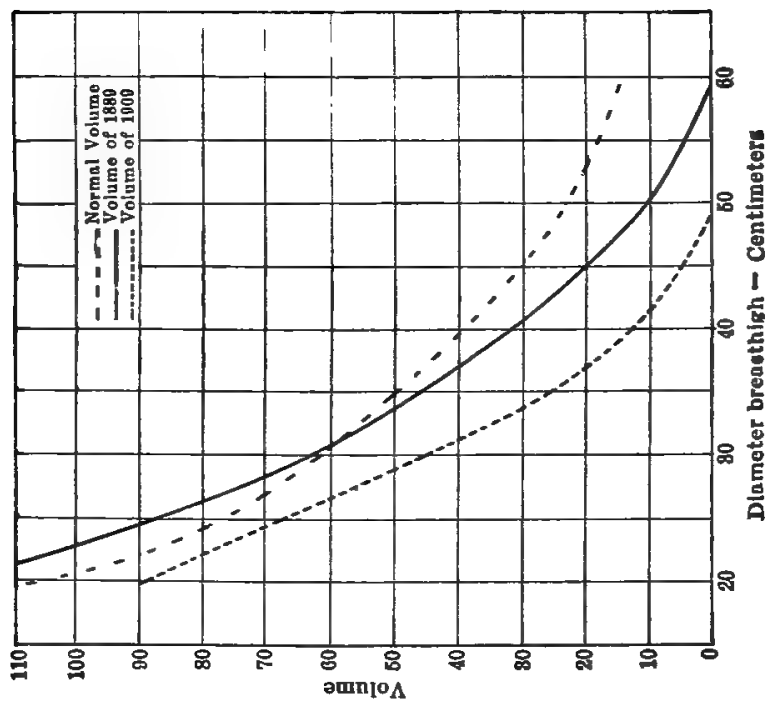

\begin{tabular}{|c|c|c|c|c|c|}
\hline 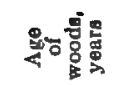 & & 38 & 語 & $=$ & $\mathbf{q}$ \\
\hline$\frac{8}{8}$ & & 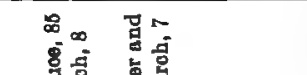 & 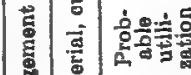 & $=$ & 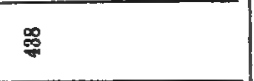 \\
\hline & & $\frac{1}{3}$ & 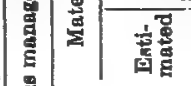 & $\because$ & 衰 \\
\hline$\overline{\bar{B}}$ & $\infty$ & 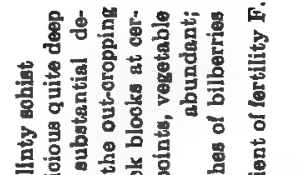 & 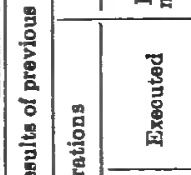 & $=$ & 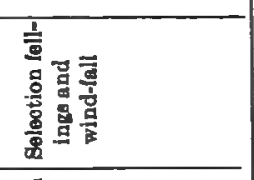 \\
\hline & & 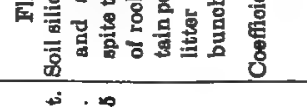 & 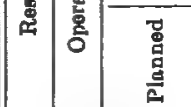 & $=$ & 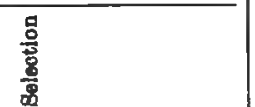 \\
\hline 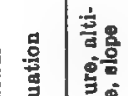 & - & 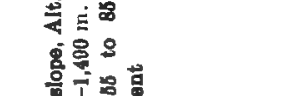 & 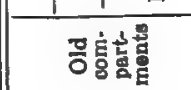 & $\approx$ & $0 \frac{3}{5}$ \\
\hline 焉 & & 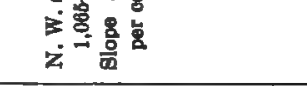 & sis & $=$ & 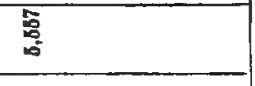 \\
\hline 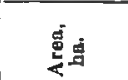 & $\infty$ & 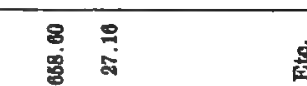 & 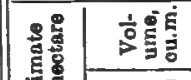 & 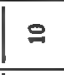 & है \\
\hline & & & 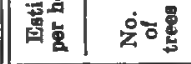 & 1. & हू \\
\hline \begin{tabular}{|l|l} 
\\
\end{tabular} & ^ & $\cong$ & $\bar{a}$ & 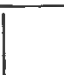 & 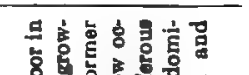 \\
\hline$\frac{\mathrm{g}}{\mathrm{s}}$ & - & 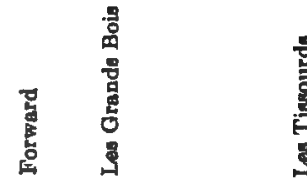 & 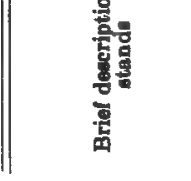 & $\infty$ & 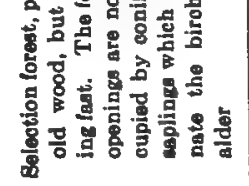 \\
\hline
\end{tabular}


M. Schaeffer's argument based on these figures is given in full since it illustrates the judgment - or, if you like, guesswork — which enters into the final yield analysis and answer.

“'The 312 trees (bored) together take 6,742 years to pass from one (2-inch) diameter class to another or an average of $\frac{6,742}{312}=21.6$. If one glances at the preceding table (see curve) it is evident that for the diameter classes between 8 and 28 inches the time it takes to pass is about constant. . . . One can conclude also that the length of the period fixed at 20 years by the working plan of 1890 should be considered as a minimum and that the rotation of 200 years adopted in the present study is not too high when it takes the average seedling 194 years to pass from a diameter of 6 inches to $24(21.6 \times 9=194)$. This conception of the average length of time (to pass from one class to another) establishes, in a way, an index of the forest. For the forest of Houches, where situated in a valley . . . the average time was 19.4 (Chamonix 21.6). This difference of two years shows that the forest of Chamonix is less favorably situated than its neighbor, and it might be said this inferiority amounts to 10 per cent. The rotation of the forest of Houches has been fixed at 180 years; that of Chamonix, therefore, ought to be normally 200 (as it is).

"In evening off this growth per cent graphically (see curve) . . . several interesting deductions can be made. To start with it is noticeable that in the lower classes where the measurements were numerous, the evened off curve follows the actual curve. It might be stated also that beginning with 24 -inch diameters the growth per cent falls normally below 1 per cent. This merits the conclusion that the reservation of trees of higher diameters should be the exception. If the evened off growth per cent is multiplied by the total volume (on the entire forest) as given in the recent stocktaking, the probable production of the forest as it stands is obtained: $2.54 \times 30,437$ $+2 . \times 43,951$, etc. (for each class), with the following total $=\frac{451,162.6}{100}=4,511$ cubic meters. The average per cent would then be $\frac{4,511}{292,777}=1.54$ per cent. If it is possible to conclude that 1.54 is the maximum growth per cent under actual conditions, and given the yield reduced to 1.03 per cent then 0.51 per cent (of the growth) or about one-third will be saved each year.

"There are other methods of valuing the probable production of the Chamonix forest. Taking for granted that the figure of 1,800 hectares represents the area actually forested, it might be argued that the average stand is $\frac{292,777}{1,800}=160$ cubic meters roughly. By referring to the table (of average production for Savoie) . . . it appears that when it takes 22 years (to pass from one diameter class to another) and the stand per hectare is 160 cubic meters then the growth is 2.5 cubic meters per hectare; the total growth then is $1,800 \times 2.5=4,500 \mathrm{cu} . \mathrm{m}$., a figure which exactly agrees with that obtained (by multiplying the volume by the growth per cent). It is, moreover, confirmed by the comparison of the compartments calipered twice; those 20 years ago had a volume of 218,980 cubic meters (calculated by the present volume table) and to-day 278,360 . Since about 26,000 cubic meters (by same volume table) was cut, the production has been $278,360+26,000-218,980=85,380$ or 4,269 per year, a figure which is also in accord with the preceding when it is considered it applies to only about 1,700 hectares (i.e., $\frac{4,269 \times 18}{17}=4,519$ ).

"Finally if we use the formula of the whole yield, that is to say, if we take count of the growth of 'old wood' and a third of that of the 'average wood' (remembering that 
in view of the transfer the rate of growth of the 'old wood' is about 1 per cent, and that of the 'average wood' 2.1 per cent) we will have

$$
P(\text { yield })=\frac{182,986+\frac{182,986 \times 200}{6} \times \frac{1}{100}}{\frac{200}{3}}+\frac{0.7}{100} \times 109,791=4,428,
$$

a figure which is also near the others (already given above). This similarity, it is interesting to note, allows one to conclude that the production of the forest of Chamonix is in the neighborhood of 4,500 cubic meters and that in fixing the yield at 3,018 cubic meters there will be an annual saving of about 1,500 meters. This economy, which is really an enrichment of the stand, is fully justified and is in perfect accord with the wishes of the officials."

The American professor of management could easily pick flaws in this working plan. To start with, he might argue that the same normal stand should not hold for all soils, species, mixtures, and altitudes; that Pressler's method is not exact; that the decrease in the number of trees is not fully known, and so on. But what impresses me most is the simplicity of the plan, its evident practicability, its freedom from ponderous descriptions which are replaced by tables and curves showing at a glance what the administrator must know. No two plans are exactly alike. Where there is a "Chief of Management" stationed in a district, they have no cut-and-dried air. Some of the methods are far too intensive for the United States, but it is believed the review contains suggestions which may be of value to the profession. There is practically no difference in the important details between an original plan and a careful revision. As a matter of fact, the methods could be followed very closely in a forest where intensive management had to be applied such as on a small estate. It is no wonder that M. Schaeffer is recognized as the foremost working plan expert in France. 


\section{CHAPTER $\mathrm{x}$}

\section{FEATURES OF FRENCH NATIONAL FOREST ADMINISTRATION 1}

Brief Stumary of Legislation (p. 261). General, Corsica, Maures and l'Estérel, Frontier Forests, Fishing and Shooting, Dunes and Landes, Mountain Landes, Clearing of Private Timber, References to Legislation.

Administrative Organization aNd Eddcation (p. 268). Early Organization, Reorganization of 1882, Salaries, Modern Organization, Military Rank, Education.

Protection (p. 275). Introduction, Damage from Logging, Servitudes and Use of Minor Products, Excessive Pruning, Damage by Birds, Insect Damage, Damage by Game, Damage from Grazing, Fungous Damage, Windfall Damage, Damage by Frost, Damage by Sunscald and Drought, Snow Damage, Intensive Fire Damage, The Fire Problem in the Forest of l'Estérel (Var), Fire Insurance in France.

Betrerments (p. 290). Forest Houses, Roads and Trails, Boundaries, Maps.

Sare of Trmber (p. 293). General Sales Procedure, Estimate and Appraisal, Cutting and Logging Rules, Example of a Long-term Sale, Stumpage Prices.

\section{BRIEF SUMMARY OF LEGISLATION}

General. - It is rather surprising to find a forest code and ordinance still in force, except for minor modifications, that was passed in 1827. Since that time there have been numerous special laws for Corsica ${ }^{2}$ on account of the less intensive conditions and long-term logging contracts; for the Maures and l'Estérel, between Toulon and Cannes, on account of the dangerous fires; for frontier forests; for Algeria, ${ }^{2}$ IndoChina, Tunisia, ${ }^{2}$ and other colonies. There are also special laws for fishing and shooting, dunes and Landes, eroded slopes in the mountains, military organization of the Forest Service, pensions, taxes, public works, water (including log driving), and rural police.

There are many who believe that the Forest Code of 1827 is out of date and therefore should be replaced by a new law more suited to changed conditions. On the other hand it is strict, it is well understood, and a change would be strongly opposed by many foresters because of the disastrous effects of too lenient forest laws and the impossibility of passing a law as drawn up by the Forest Service owing to the probability of amendments by the legislative assembly. Those who wish to obtain an idea of the essential details covered by the code are referred to the translation of the Algerian Code of 1908 which follows

1 Major R. Y. Stuart kindly reviewed this chapter.

2 See Appendix of French Forests and Forestry (Tunisia, Algeria, and Corsica). John Wiley \& Sons, Inc. 
closely, in part word for word, the French Code of 1827. The main difference is that the Algerian Code is more supple and less repressive.

Corsica. - Since 1840 the Waters and Forest Service was given the right to make sales for periods up to 20 years after suitable public auction. This law provided that the transport improvements should revert to the State when the sale expired; that the State should have an option to purchase sawmills within 1.2 miles of the forest. The object of this law was to develop forests hitherto inaccessible under ordinary sales. The law of 1854 abolished grazing servitudes in Corsica but as a matter of fact even to-day grazing is practicaliy unrestricted.

Maures and l'Estérel. - Owing to the excessive fire damage a special fire-protective scheme was legislated in 1870 and revised in 1893. The provisions of this law are discussed in this chapter under "Protection."

Frontier Forests. ${ }^{3}$ - Trespass committed on a bordering State can be judged in France under French law if the State in question has passed a reciprocity law to the same effect.

Fishing and Shooting. - Important and detailed laws have been enacted to govern the administration of fishing and shooting. It is interesting to note that the law of 1908 contains a list of the useful and harmful birds.

Dunes and Landes. - The decree of April 29, 1862, placed the fixation, maintenance, conservation, and exploitation of the dunes under the Ministry of Finance (Director of Forests), but the Ministers of State, Finances, Agriculture, Commerce, and Public Works were all charged with the execution of the decree. The decree of December 14, 1810, provided for the fixation and forestation of the dunes. In the first place a map was required showing State, communal and private lands with a plan as to the best methods to follow. Where owners were unable to carry out the measures prescribed it was arranged that the work should be undertaken by the State and managed until the cost of the work was completely paid for with interest (since April 7, 1900, calculated at 4 per cent). The measures included: Forbidding the removal of weeds or plants from dune areas without special authorization, patrol and police force, and the State was given the right to remove brush from private land. The ordinance of February 5, 1817, provided that the work should be directed by the "Ponts et Chaussees" under the Ministry of the Interior, with the provision that when the trees reached a certain age, to be determined later, they would be under the Waters and Forests Service. The ordinance of January 31, 1839, sanctioned the auction of resine on 18,632 acres of wooded dunes; both thinnings and final cuttings were mentioned and natural regeneration was to be

The basis for these data and what follows is: Code de la Législation Forestière, A. Puton et Ch. Guyot, Paris. 
provided for. The ordinances of July 15, 1810, and May 2, 1810, provided protective measures for the dunes in the Department of the Pas-de-Calais, no ditches or removal of sand within 200 fathoms of high water, no removal of grass or weeds, no grazing without special authorization.

The law of June 10,1857, provided for the drainage and sowing of communal lands at the expense of the communes, or if they were unable at the expense of the State, with reimbursement from the proceeds with principal and interest.

Mountain Lands. - The law of July 28, 1860, which provided for the restoration of the eroded mountains, was superseded by the law of April 4,1882 . Before a reforestation area boundary is decided upon there is an open hearing in each of the communes interested, a meeting of the municipal councils, a recommendation of the Arrondissement Council, General Council, and Special Commission. The period of inquiry is 30 days and if a decision is made to set aside the area for reforestation then a law is passed setting aside the land required as shown by the approved reports, maps, and plans of forest officers. The work is carried out by the Waters and Forest Service at the expense of the State. The ownership of this land is governed as follows:

Where institution, communal, or private land is being damaged by grazing it can be reserved from use after inquiry and consideration similar to that required before reforestation, but if, after 10 years, it is still necessary to reserve it, public expropriation is necessary. The annual loss during the first 10 years of reservation is paid for from the municipal treasury. Work can be undertaken at the expense of the State to hasten restoration, and trespass will be prosecuted as if on a forest.

Clearing of Private Timber. - The restrictions against clearing private forest land, even if for purposes of cultivation, are so stringent that the analysis of the law by Guyot is given in full. It is generally referred to as the law of June 18,1859, put into effect December 19, of the same year. ${ }^{4}$

Art 219 (Law of June 18, 1859). - No private owner has a right to grub up or to clear his timber without notifying the sous-prefecture at least 4 months in advance, during which time the administration may inform the owner of its opposition to the clearing. The declaration of the owner states choice of residence in the canton in which the timber is located.

Before signifying opposition, and at least 8 days after advice is given to the party concerned, the inspecteur or the "sous-inspecteur," or one of the "gardes géneraux" of the circonscription, proceeds with the examination of the condition and location of the timber and makes out a detailed "procès-verbal" of which the party is given notice with the request that any objections be submitted.

4 Translated by R. C. Hall. 


\section{FEATURES OF FRENCH NATIONAL FOREST ADMINISTRATION}

The prefet, "en conseil de préfecture," gives his opinion on this opposition.

The forest agent of the department is notified of this opinion as well as the owner, and it is transmitted to the Minister of Finances who makes an administrative decision, after having consulted the financial section of the "conseil d'etat."

If, within six months following the notification of opposition, the decision of the minister is not given and transmitted to the owner of the timber, the clearing may take place.

Original Art. 219. - For 20 years from the date of promulgation of the present law, private owners have no right to grub up or to clear their timber, unless they notify the sous-prefet at least 6 months in advance, during which time the administration may inform the owner of its opposition to the clearing. Within the 6 months from this notification, the prefet has to decide the case subject to approval of the Minister of Finances. If within the 6 months following the notification of the opposition, the decision of the minister has not been given and transmitted the owner, then the clearing of timber may take place.

Ordonnance of August 1, 1827, for the execution of the "Code Forestier."

\section{REgULATIONS REgARDING THE CLEARING OF TMMER}

Art. 192. (Decree Nov. 22, 1859.) - The declarations prescribed in Art. 219 of the "Code Forestier" must indicate the name, the location, and the area of the timber which private owners desire to clear; furthermore they must mention the choice of a residence in the canton in which the timber is located; these declarations will be made in duplicate and deposited at the prefecture where they will be put on record. They will be signed by the sous-prefet who will give back one of the copies to the owner making out the declaration, and will immediately transmit the other to the "agent forestier supérieur de l'arrondissement."

Art. 193. (Decree of Nov. 22, 1859.) - Before proceeding with the investigation of the conditions and location of timber, and at least 8 months in advance, one of the agents designated by Article 219 of the "Code Forestier" will have to send the party concerned, at the residence selected by this party, a notice stating the day on which the said investigation will take place and inviting the party to assist or to be represented.

Art. 194. (Decree of Nov. 22, 1859.) - The procès-verbal established by the forestry agent will mention all data and information which may be of such a nature as to cause objection to the clearing on account of one of the reasons enumerated in Article 220 of the "Code Forestier"; furthermore, if the timber in question is located in part of the frontier zone, where the clearing cannot take place without authorization, this fact will simply be mentioned in the procès-verbal.

Art. 195. (Decree of Nov. 22, 1859.) - The procès-verbal will be transmitted with all papers to the conservateur who, before reporting his opposition, will have a copy of it sent to the party concerned, inviting him to present his objections.

Art. 196. (Decree of Nov. 22, 1859.) - If the conservateur thinks that the timber must not be cleared, he will transmit his opposition to the owner and he will immediately refer the case to the preffet, transmitting him all his papers with his objections. In a contrary case, the conservateur will refer without delay to the directeur général des forêts, who will report on the matter to the Minister of Finances.

Art. 197. (Decree of Nov. 22, 1859.) - Within a month's time, the preffet, at the prefecture meeting, will give his opinion regarding the opposition with full details.

Within 8 days following this opinion, the prefet will have it transmitted to the owner of the timber and to the conservateur and, if there is no conservateur in the 
department, to the "agent forestier superieur" who will decide the case after having consulted the financial section of the "conseil d'etat." The ministerial decision will be transmitted to the owner within 6 months from the date of notification of the opposition.

Art. 220. (Law of June 18, 1859.) - Opposition to the clearing can only be formulated for the timber preservation of which is recognized as being necessary:

(1) For the maintenance of soil on mountains or slopes.

(2) As a protection against soil erosion and silting up of creeks, rivers and torrents.

(3) For the existence of springs and water courses.

(4) For the protection of dunes and coasts against erosion by the sea and invasion of sand.

(5) As a protection of territory in that part of the frontier zone which shall be determined by regulation of public administration.

(6) For public health.

The previous Article 220 is now the new Article 221.

Art. 221. (Law of June 18, 1859.) - In case of violation of Art. 219 the owner is

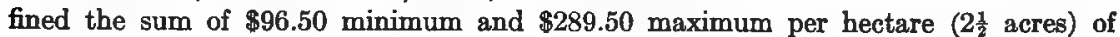
cleared timber. Furthermore, he is compelled, if so ordered by the Minister of Finances, to replant places cleared with timber trees within a period which cannot exceed three years. "Code Forestier," 91, 159, 160, 165, 198, 199, 219, 223.

Original Art. 221. - In case of failure of the owner to do the planting or the sowing within the time prescribed by the judgment, the work will be done at his expense by the forestry administration upon authorization previously given by the prefet who will settle the voucher covering this work and will have it executed against the owner.

Ordonnance of August 1, 1827. Art. 198. (Decree of Nov, 22, 1859.) - When mayors and adjoints shall have made out procès-verbaux stating that clearing work has been effectuated in violation of Title 15 of the Forestry Code, they will be obliged, independently of the delivery they must make of them to our "procureurs," to send a certified copy to the local forestry agent.

Art. 199. (Decree of Nov. 22, 1859.) - The conservateur will report to the directeur général des forêts on the condemnations pronounced in the case provided for in Par. 1 of Article 221 of the Forestry Code, and will give his advice on the necessity of replanting the places with timber trees. The ministerial decision which will order replantins will be transmitted to the party concerned through administrative channels.

Art. 222. (Law of June 18, 1859.) - In case of failure of the owner to do the planting or sowing within the time prescribed by the ministerial decision, the work will be done at his expense by the forestry administration upon authorization previously given by the prefet who will settle the voucher covering this work and will have it executed against the owner. "Code Forestier," 15, 41, 140, 221.

New Article 222 (Forestry Code) is only a reproduction of Article 221 of the same code, except for the substitution of the words "ministerial decision" for the word "judgment," as a consequence of the change brought by the law of June 18, 1859, to the wording of former Article 220.

Art. 223. (Law of June 18, 1859.) - The disposition contained in the preceding four articles may be applied to the sowing and planting made for replacement of cleared timber pursuant to the ministerial decision. "Code Forestier," 219 s., 224.

Article 223 (Forestry Code) modified by the Law of June 18, 1859, reads like the old Article 222 of the same code, in which the word "judgment" has been replaced by the expression "ministerial decision" in order that this disposition may agree with the new wording of Article 221. 
Art. 224. (Law of June 18, 1859.) - There are excepted from the regulations of Art. 219:

(1) Young timber during the 20 years following its sowing or planting, except in case provided for in the preceding article.

(2) Parks or fenced gardens, or gardens adjoining houses.

(3) Open timber of less than 10 hectares area (24.7 acres) when not part of another forest, the whole of which aggregates an area of 10 hectares, or when not located on the top or on the slopes of a mountain. Forestry Code 219, 223.

New Article 224 (Forestry Code) corresponds to the old Article 223. It only modifies it by: (1) Substituting the figure of 10 hectares for 4 hectares for the area of timber which may be cleared without fulfilling formalities determined by Article 219 (Forestry Code). (2) Substituting the expression "fenced gardens or gardens adjoining houses" for the words "fenced gardens and gardens adjoining houses," concerning trees forming part of parks or gardens exempted by the application of Article 219.

Art. 225. (Law of June 18, 1859.) - Court actions concerning clearings made in violation with Article 219 are outlawed after lapse of two years from the date when the clearing took place. - Forestry Code 185, 187, 221.

New Article 225 is the reproduction of previous Article 224.

Art. 226. (ILaw of June 18, 1859.) - The sowings and plantings of timber on the top or on the slopes of mountains, on dunes, or in the waste lands will be exempted from taxes for 30 years. - Forestry Code 194, 195, $219 \mathrm{~s}$.

New Article 226 reproduces the terms of Article 225, except two changes.

Law of March 29, 1897. - Fixing the general budget of expenses and receipts of exercise, 1897 (Renueil Périodique Dallez, 97.4.33).

Art. 3. Article 116 of the Law of the 3 Frimaire, an VII, regarding the repartition and the situation of the land-tax is modified as follows: "The revenue taxable on any cleared soil which shall be afterwards planted or sown with timber will be reduced by three-fourths during the first 30 years after planting or sowing, whatever may have been the state of cultivation of the soil prior to the clearing.

1. The ministerial decision which refuses an owner of timber the authorization of clearing is not limited in its duration; it is final and lasts with all its effects so long as unmodified or not recalled by the minister who rendered it. - Cr. c., March 15, 1884. D. P., 84.5.281.

2. The prohibition of clearing pronounced under these conditions has the character of a true legal servitude burdening directly the timber itself, and as long as this interdict has not been recalled, it keeps all its force in regard to the owner who has made the declaration requesting clearing as well as toward his assigns "a titre gratuit" or "a titre oncreux." Then, if the said owner or his assigns thinks proper to provoke a new investigation in order to be authorized to clear all or part of the timber on which the ministerial decision has been made, he should not proceed in accordance with the terms prescribed in Art. 219 (Forestry Code), but should address directly the minister who has made the decision in order to obtain from him the modification or cancellation of his decision. - Same decree.

3. Par. 2 of Article 214 (Forestry Code) which excepts from the probibition of clearing "the parks or fenced gardens adjoining houses," must be understood in this sense, that the exception exists only in favor of parks or gardens which are actually both fenced and adjoining habitations. Riom, June 11, 1883, D. P., 84.5.283.

4. Especially one cannot consider as a park in the meaning of Article 224 (Forestry Code) a body of timber around a chateau but not fenced; it makes little difference if this timber combines certain conditions of management for the satisfaction and interest of the owner. - Same decree. 
5. And the appellate judge cannot admit the proof of the enclosure of the timber when the lack of enclosure has not been established by a court which has had authority to deal with the subject. - Same decree.

6. The Par. 3 of Art. 224 (Forestry Code) freeing from the interdiction of clearing, timber not fenced, of less than 10 hectares (24.7 acres) area, provided it is not part of another forest which would make up an area of 10 hectares, does not establish any distinction between timber belonging to the same owners or to different owners. Riom, June 11, 1883, D. P., 84.5.282.

7. The accused party has to prove that the timber cleared was of an area less than 10 hectares, and that it was not part of a body of timber of more than 10 hectares area. - Same decree.

8. And this proof cannot be accepted when the contrary is formally stated by a "procès-verbal" which must be trusted until shown false. - Same decree.

9. The exemption from all taxes during 30 years, established by Art. 226 (Forestry Code) in favor of sowings and plantings of timber on the tops or slopes of mountains is only applicable to the "land-tax" and not to the registration taxes, especially to taxes for transfers due to death. - Req. July 7, 1885. D. P., 85.1.453.5

Certain features of land control (or acquisition) for combating drifting sand or erosion deserve emphasis if only to illustrate how democratic the governmental methods are in France when the interests of the local inhabitants are concerned:

(1) Where private owners are unwilling to repair damage injurious to the public interests the use of the land can be taken over by the State, the work done and the land only returned to the original owners when they pay the bill with legal interest, or when the costs are earned by the land itself; or in the mountains the land may be condemned, the necessary work done by the State when the owner could secure his

- Speaking of French forest taxation, W. B. Greeley concludes:

". . When land is planted which has lain fallow for a considerable time, the law provides that there shall be no increase in the assessed value, or rated income, of the ground for a like period. Aside from these exemptions, private forests in France are taxed on their current income, a method which dates back to the Revolutionary period. Under the law of 1907 a valuation commission periodically classifies the lands in all forms of culture, commune by commune, in accordance with their relative productivity. There may thus be three or four types of forest, as determined by their soil and timber species and the value of their products. A net yearly income is then obtained for average areas within each type. All forest properties shown on the official survey and plats of the commune are thus classified and a net income based upon the sample tracts studied is assigned to each. The periodic revenues custonary in French forests, where nearly all properties harvest some products every few years, are, under this system, reduced to an annual basis which represents the net returns for stumpage after deducting costs of upkeep, fire protection, forest guards, thinnings, planting blanks, and other cultural measures. The tax is levied upon this net income and usually amounts to 8 or 10 per cent, about half of which goes to the central government. The rest comprises the departmental and conmunal taxes and levies for local roads. It is of interest to note that French forest owners are demanding a straight-out yield tax levied upon forest products when actually cut, the same principle which is generally regarded as the basis for forest tax reforms in the United States. . . ." 
land by repaying the State with interest; as an alternative the private owner could secure half his land by trading the other half to the State to cancel the costs of reparation. Similar methods were applied to communal lands which were really private lands owned in fee simple but with the various interests undivided.

(2) Before mountain land can be reserved from use the scheme advocated by Government technical representatives had to be passed upon by the village, by the commune, by the arrondissement, by the department, by a technical and political commission, and by the Secretary of Agriculture who also had to have a decree by the House of Deputies before the actual work could be begun.

These details are recited to illustrate the difficulty of securing legislation in France, even if it aims at benefiting the public, if private interests are on the defensive. Even during the Great War the requisition of private timber finally had to be passed upon by a local and a central commission before the requisition could be placed. And in France the adverse interests are always represented on the commissions. Moreover these interests have representatives in the House of Deputies who can embarrass the ruling party if injustice is done.

References to Legislation. - Special features of French forest legislation are treated in the various studies of this volume; the references are given in the Index under "Legislation."

\section{ADMINISTRATIVE ORGANIZATION AND EDUCATION}

Early Organization. - The quality and efficiency of the French Waters and Forests Service has varied with the history of France. It is not surprising that, in the early days, there was a great deal of graft and incompetency. It was the order of the day. At a period when even the bishops and clergy lent themselves to corrupt methods of administration it was no wonder that the Forest Service suffered likewise. Beginning in 1554 positions in the Forest Service were sold by the King and from the 17th century employment in the royal forests was hereditary. The first mention of regular "conservations" was in 1791, when France was divided ${ }^{6}$ into 28 conservatorships with inspectors, assistant inspectors, guards, surveyors, and rangers as assistants. In 1817 the Forest Service was suppressed, but in 1820 it was reëstablished. Real forestry might be said to have started in France December 1, 1824, with the founding of the Nancy Forest School, the first director being Bernard Lorentz, who had studied under Hartig in Germany. Such foresters as Parade, Nanquette, Bagneris, and Broilliard were the result of teaching by Lorentz.

- See Huffel, Vol. I, pp. 308, 325. 
Reorganization of $1882 .-$ On August $1,1882,{ }^{7}$ the forest department was reorganized. On that date the departmental establishment was simplified and was reorganized to include general inspectors, conservators,

7 "You will find below the text of a Government order, dated August 1, 1882, which confirms the new organization of the Forest Department of which the foundations had been laid by the Minister of Agriculture on the 28th of April preceding. The publications of M. Tassy, late Conservator of Forests, have made known to you the spirit and object of this much needed reform.

"It was in fact necessary to put an end to the confusion of functions everywhere existing in our department; it was necessary to suppress divers grades corresponding to identical duties as superfluous; and lastly, it was necessary to stop the frequent transfers of forest officers, and to accelerate their chances of promotion to responsible posts.

"Such are the results that we may be permitted to expect from these reforms. The departmental establishment is simplified. It is composed of general inspectors, of conservators, of inspectors, of general guards. It would seem useful to define summarily the attributes attaching to these several grades.

"General Inspectors. - They represent the superior administration in their tours of inspection in the provinces.

"V'isiting the different forest regions every year, in frequent contact with the officers of all grades, and thus becoming acquainted with their capabilities, it is the mission of the general inspectors to secure unity of action in conformity with plans previously agreed upon.

"In the intervals between their tours, as members of the administrative council under the presidency of the director general, they are enabled, from a complete local knowledge, to offer their opinions on the proposals made by forest officers.

"Conservators. - The conservator's role is to transmit orders and to explain their spirit and object to the officers placed under his orders. His attributes are not altered, but the control of operations and works, which he used to exercise in concurrence with inspectors, now falls on him alone and will necessitate a greater activity on his part.

"The efficacy of this control will besides be facilitated by the early formation of new forest circles.

"Inspectors. - The inspector of forests has now become the chief executive officer of the department, and has the initiative and responsibility in all principal forest operations. He prepares and executes plans and estimates of works. He directs fellings, whether principal or secondary, and remains responsible for those, the execution of which is intrusted in certain cases to his subordinates. He issues all executive orders and conducts all the correspondence. Under the new system he combines the former duties of an inspector with most of those which hitherto devolved on range officers (chefs de cantonment), that is, sub-inspector, general guard, or general guard 'adjoint.'

"The execution of all these duties has been rendcred possible by the Government order of August 1, last, which increases the number of inspectors from 160 to 240, and at the same time reduces the areas of their charges to about 30,000 acres.

"The inspector will be assisted in his office work by a clerk, and in his other duties by a number of subordinates from the secondary forest schools. The latter will serve under his orders in charge of ranges with the title of general guard, and will be responsible to him.

"General Guards. - The general guard is an officer whose duties are essentially active, who should be as often as possible lodged in a house belonging to the department, and should keep neither an office nor records. . . . In the same spirit it is intended that in order to reward capable and zealous foresters, promotion to certain posts of 
inspectors, and forest assistants. ${ }^{8}$ The general inspectors represented the administration at Paris and inspected the work throughout France. In the office they passed upon proposals submitted by forest officers. The conservator transmitted orders sent him from Paris and explained their spirit and object to the officers under his charge. The inspectors were made the chief executive officers and had the initiative and responsibility for all important forest operations, such as executing plans and making estimates, supervision of fellings, correspondence, and such work as is now performed by forest supervisors in the United States. Under the inspectors the forest assistants performed field work, but were not responsible for administration. They assisted and supervised rangers and guards. The organization of 1882 did not last long, for in 1883 they returned to the system of "cantonments" managed by forest assistants and assistant inspectors. The general inspectors" positions which had been done away with in 1887 and replaced by administrators under the director at Paris were reëstablished at the end of 1911, but the number was reduced to two. A résumé of the successive organizations is shown in the table which follows:

TABLE 23-- NUMBER OF OFFICERS IN EACH GRADE

\begin{tabular}{|c|c|c|c|c|c|}
\hline & 1882 & 1887 & 1902 & 1911 & 1912 \\
\hline 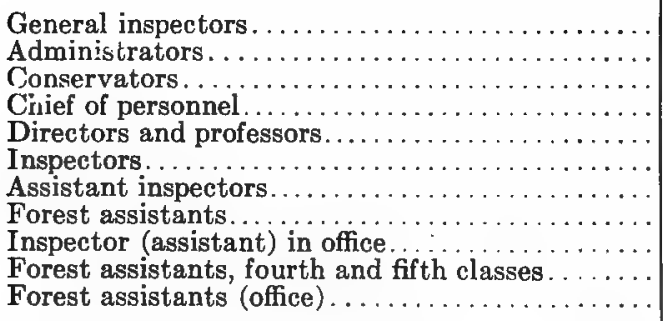 & $\begin{array}{c}39 \\
\ldots \\
139 \\
300 \\
213 \\
\cdots \\
\cdots \\
71\end{array}$ & $\begin{array}{r}8 \\
41 \\
1 \\
3 \\
244 \\
234 \\
243 \\
\cdots \\
\cdots \\
65\end{array}$ & $\begin{array}{r}3 \\
36 \\
\cdots \\
5 \\
237 \\
228 \\
179 \\
\cdots \\
\cdots\end{array}$ & $\begin{array}{r}3 \\
37 \\
3 \\
5 \\
235 \\
223 \\
202 \\
\cdots \\
46\end{array}$ & $\begin{array}{l}2 \\
\text { etc. } \\
\cdots \cdots \\
\cdots \\
\cdots \\
\cdots \\
\cdots \\
\cdots \\
\cdots\end{array}$ \\
\hline $\begin{array}{l}\text { Total supervisory force..... } \\
\text { Total subalterns ......... }\end{array}$ & $\begin{array}{l}234 \\
584\end{array}$ & $\begin{array}{l}287 \\
554\end{array}$ & $\begin{array}{l}281 \\
463\end{array}$ & $\begin{array}{l}280 \\
471\end{array}$ & $\cdots$ \\
\hline Totals.. & 818 & 851 & 744 & 751 & $\cdots$ \\
\hline
\end{tabular}

general guard may be open to them, although they may not have undergone the tests of passing out from the secondary schools.

"For the success of the reform, I rely on the zeal and good will of officers of all grades. They will find in the new organization better chances of promotion, and will be able to devote a part of the time hitherto spent in the office to out-door work. To these advantages I hope that increased pay may soon be added, and in this expectation I am encouraged by the benevolent intentions of which the Minister of Agriculture has already given us so many proofs. In any case I can announce that traveling allowances will shortly be better proportioned to the actual expenses incurred by oflicers."

${ }^{8}$ For detailed data and names of officers see the Annuaire des Eaux et Forets, published annually by the Revue des Eaux et Forêts. 
No change in 1912 in other grades.9 Reorganization under consideration.

Salaries. - The yearly salary of a French forest officer is low ${ }^{10}$ and has

' L'Administration Forestière et des Transformations. By "P. F.," "R. E. and F.," pp. 618-620. 1911. These data on organization were checked by Lt. Col. Pardé, Director of the Barrès Ranger School.

${ }^{10}$ During the war they have received per diem allowances to compensate for the high cost of living. As a matter of fact these were entirely inadequate and were only $\$ 1$ to $\$ 2$ a day. The amount depended on rank.

On account of the increased cost of living, the following new salary schedule (retroactive to July 1, 1919) was approved by Deschanel on March 13, 1920. The salaries are in dollars at the normal rate of exchange:

\begin{tabular}{|c|c|c|c|c|c|c|c|}
\hline Class & $\begin{array}{c}\text { General } \\
\text { inspectors }\end{array}$ & Conservators & Inspectors & $\begin{array}{l}\text { Assistant } \\
\text { inspectors }\end{array}$ & $\begin{array}{c}\text { Forest } \\
\text { assistants }\end{array}$ & $\begin{array}{l}\text { Professors } \\
\text { at sehool } \\
\text { of Nancy }\end{array}$ & $\begin{array}{l}\text { "Agents } \\
\text { compatable" } \\
\text { at school }\end{array}$ \\
\hline 1 & 4,250 & 3,470 & 2,700 & 2,120 & 1,330 & 3,090 & 1,740 \\
\hline \multirow[t]{2}{*}{2} & 3,860 & 3,090 & 2,500 & 1,930 & 1,230 & 2,900 & 1,560 \\
\hline & & & & \multicolumn{3}{|c|}{ on clerical duty } & \\
\hline 3 & 3,470 & 2,700 & 2,310 & 1,740 & $\begin{array}{c}1,140 \\
\text { students }\end{array}$ & 2,700 & 1,380 \\
\hline 4 & & $\ldots \ldots \ldots$ & 2,120 & 1,530 & 770 & 2,500 & 1,200 \\
\hline 5 & & $\cdots$ & . & .. & . & 2,310 & 1,020 \\
\hline 6 & . & & $\ldots \ldots$ & $\ldots \ldots$ & $\ldots \ldots$ & 2,120 & 880 \\
\hline
\end{tabular}

As a matter of fact these salaries at the current rate of exchange are about one-third the amounts listed in dollars because to-day (May 15, 1920) it takes 15 francs to equal a dollar.

It is interesting to compare the French salaries with those paid in British India in 1916, which are more than double those paid officers in the U. S. F. S.: Inspector general, $\$ 10,600$ per year. Chief conservators, $\$ 8,600$ per year. Conservators in three grades, $\$ 7,600, \$ 6,800$, and $\$ 6,000$ per year. Deputy conservators and assistant conservators, $\$ 1,520$ per year, rising by annual increments of $\$ 160$ to a maximum salary of $\$ 2,800$, when the annual increment becomes $\$ 200$, until a maximum of $\$ 5,000$ is reached in the twentieth year of service. (While drawing pay up to and including $\$ 2,160$, officers are styled assistant conservators, and after this deputy conservators.)

The provincial Forest Service, recruited from the native population, includes: Extra assistant conservators, $\$ 1,000$ per year, and rising by annual increases of $\$ 80$ to $\$ 2,200$ in the sixteenth year of service. Extra deputy conservators, $\$ 2,300$ per year, and rising by annual increments of $\$ 100$ to a maximum of $\$ 2,600$. By special orders in each case an extra deputy conservator's pay may be raised to $\$ 2,800, \$ 3,200$, or $\$ 3,400$, respectively.

The subordinate force is paid as follows: Rangers, $\$ 200$ to $\$ 800$ per year. Deputy rangers and foresters, $\$ 60$ to $\$ 160$ per year. In Burma the pay ranges from $\$ 80$ to $\$ 200$ per year.

For guards and other subordinates the pay varies, according to the standard of wages in the various provinces, from $\$ 28$ to $\$ 60$ per year. 
always been considered too low when the nature of his work is compared with other branches where higher pay is received. The allowances for travel are on a per diem basis and increase with the higher rank.

\begin{tabular}{|c|c|c|c|c|}
\hline \multirow{2}{*}{ Position } & \multicolumn{4}{|c|}{ Classes } \\
\hline & 1 & 2 & 3 & 4 \\
\hline 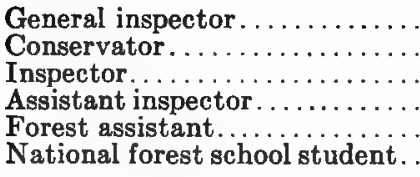 & $\begin{array}{r}\$ 2,509.00 \\
2,316.00 \\
1,302.75 \\
916.75 \\
636.90 \\
\text { a } 231.60\end{array}$ & $\begin{array}{r}\$ 2,123.00 \\
1,930.00 \\
1,206.95 \\
820.25 \\
550.05 \\
\cdots\end{array}$ & $\begin{array}{r}\$ 1,737.00 \\
1,090.45 \\
723.75 \\
\ldots \ldots \ldots \ldots \\
\ldots \ldots \ldots \ldots\end{array}$ & $\begin{array}{r}\$ 1, \mathbf{5 4 4 . 0 0} \\
\mathbf{9 9 3 . 9 5} \\
\ldots \ldots \ldots \ldots \\
\ldots \ldots \ldots \\
\ldots \ldots \ldots\end{array}$ \\
\hline
\end{tabular}

If an agent, such as an inspector or assistant inspector, is attached solely for office duty he receives the regular pay of his rank. Frequently a forest assistant or an assistant inspector who is poor at field work may be given a position similar to that of chief clerk.

The rate of pay per year for the subordinate force (préposès) was (1918):

1. Detailed as clerks:
Special (office assistant)
Rangers.............. $\$ 328.10 \quad \$ 308.80$
Guards.... One class of $\$ 250.90$ with free lodging.
$\begin{array}{llll}1 & 2 & 3\end{array}$
$\$ 289.50 \$ 270.20$

2. In the forest with free lodging:

\begin{tabular}{|c|c|c|c|c|}
\hline & Special & 1 & 2 & 3 \\
\hline Gua & $\begin{array}{r}2508.80 \\
250.90\end{array}$ & $\begin{array}{r}\$ 289.50 \\
231.60\end{array}$ & $\begin{array}{r}\$ 270.20 \\
212.30\end{array}$ & $\begin{array}{r}\$ 250.90 \\
193.00\end{array}$ \\
\hline
\end{tabular}

In addition to this schedule of pay every employee entitled to the forest honor medal for exceptionally meritorious work receives $\$ 9.65$ a year extra. While a ranger is at the Barrès Secondary School he receives the full salary attached to his rank. All officers and subordinates receive a pension.

Modern Organization. - The modern organization of the French Forest Service (the result of the 1888 decree) is as follows:

It is under the Department of Agriculture and is managed by a Director General who is a Conseiller d'Etat. The different bureaus at Paris are under three conservators (corresponding to branch chiefs in the U. S. F. S.). These bureaus are divided into sections as follows: Personnel and organization, areas, forest instruction, grazing and game, management, exploitation, reforestation, betterments, and fish culture. The two general inspectors are charged with the inspection of the work in all departments outside Paris. 
France proper is divided into thirty-two conservations. This includes Corsica ${ }^{11}$ which is listed as the thirtieth conservation. These thirty-two conservations are located at the following points:

(1) Paris (Oise, Seine, Seine-et-Marne, Seine-et-Oise).

(2) Rouen (Calvados, Eure, Eure-et-Loire, Manche, and Seine-Infér.).

(3) Dijon (Côte-d'Or).

(4) Nancy (Meurthe-et-M. Meuse p., Vosges p.).

(5) Chambery (Mayenne, Savoie, Haute-Savoie).

(6) Charleville (Ardènnes, Aube p., Marne).

(7) Amiens (Aisne, Nord, Oise p., Pas-de-Calais, Somme).

(8) Troyes (Aube, Côte-d'Or p., Marne (Haute) p., Yonne).

(9) Epinal (Meur-et-M. p., Vosges).

(10) Gap, Alpes (Hautes).

(11) Valence (Ardèche, Drôme, Vaucluse).

(12) Besançon (Doubs, Terr. de Belf.).

(13) Lons-le-Saunier (Jura).

(14) Grenoble (Isère, Loire, Rhône).

(15) Alençon (Côtes-du-Nord, Finistère, Ille-et-Vilaine, Morbihan, Orne, Sarthe).

(16) Bar-le-Duc (Ardènnes p., Meuse).

(17) Maçon (Ain, Saône-et-Loire).

(18) Toulouse (Ariège, Haute-Garonne, Gers p., Tarn-et-Gar).

(19) Tours (Indre-et-Loire, Loir-et-Cher, Loire-Infér., Loiret, Maine-et-Loire).

(20) Bourges (Cher, Indre, Nièvre).

(21) Moulins (Ailier, Creuse, Puy-de-Dôme, Haute-Vienne).

(22) Pau (Gers, Basses-Pyrénées, Haute-Pyrénées).

(23) Nice (Alpes-Marit, Var).

(24) Niort (Charente, Charente-Infér., Vendée, Vienne).

(25) Carcassonne (Aude, Pyrénées-Or., Tarn).

(26) Aix (Basses-Alpes, Bouches-d.-Rh.).

(27) Nimes (Gard, Herault, Lozère).

(28) Aurillac (Haute-Loire, Aveyron, Cantal, Corrèze, Lot).

(29) Bordeaux (Dordogne, Gironde, Landes, Lot-et-Gar).

(30) Ajaccio (Corse).

(31) Chaumont (Haute-Marne).

(32) Vesoul (Haute-Saône).

At the head of each conservation there is a conservator. Each conservation is divided into "inspections," comprising a number of forests, administered by an inspector; each inspection includes two or three "cantonments" under assistant inspectors or forest assistants (gardes géneraux). The protective force includes rangers and guards; these employees are usually housed by the State. As compared with the United States the Forest Service administration in Washington corresponds to the central administration in Paris, but in France there is less centralization. The districts of the United States Forest Service

11 See Chapter IV, French Forests and Forestry. There are now three new conservations in the restored provinces (a) Metz (Moselle), (b) Strasbourg (Bas-Rhin), (c) Colmar (Haut-Rhin). See appendix, page 495. 
correspond to the conservations in France except that the conservations are really one-man positions and are consequently very much smaller than the seven large centralized districts in the United States. On the forests, the inspector corresponds to the supervisor, and the assistant inspector to the deputy supervisor or forest examiner, except that the assistant inspector may be in sole charge of a forest. The garde général corresponds to the forest assistant in the United States; the ranger and guard positions are the same except that in France these officers are in charge of definite areas rather than on special projects, such as large timber sales, as is often the case in the Western United States. In the central bureau at Paris the rank does not differ from the rank on the forests themselves. For example, a conservator or inspector may be in charge of a bureau or section, respectively, whereas in the United States a new position has been created, namely, that of assistant forester or forest inspector, when an officer is given special administrative work at the central bureau at Washington. In the Service des Eaux et Forêts the responsibility is essentially personal for all lines of work; in the U. S. Forest Service there is a tendency to divide the work among a staff of specialists. In France forest operations are largely controlled by the working plan; at the time of writing there are no real working plans in operation on U. S. National Forests (see p. 219). There is no position in France corresponding to that of State Forester in the United States.

Military Rank. - The corresponding military rank held by forest officers in time of war is as follows:

\begin{tabular}{|c|c|}
\hline Forest rank & Military rank \\
\hline Guard. & $\left\{\begin{array}{l}\text { Private (first class) } \\
\text { Corporal }\end{array}\right.$ \\
\hline 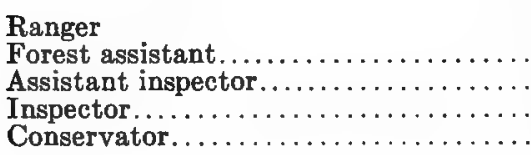 & $\begin{array}{l}\text { Non-commissioned officer } \\
\text { Lieutenant } \\
\text { Captain } \\
\text { Commandant (battalion chief) } \\
\text { Lieutenant colonel }\end{array}$ \\
\hline
\end{tabular}

The Forest Service uniform is theoretically retained in time of war, subject to changes made necessary by general changes in color or material to conform with the Regular Army standard. It is customary to assign the younger forest officers to line regiments (usually, if not always, to the infantry) and the older men to executive and administrative work of various kinds. ${ }^{12}$

Education. - The officers of the French Forest Service are recruited chiefly from Nancy, the official State forest school established Decem-

12 For a further discussion of administrative organization see French Forests and Forestry, especially pp. 18-21, 53, 101-105, 123-128. 
ber $1,1824 .^{13}$ It is a 2-year course with extensive field work in local forests followed by a tour of all important regions. The ranger force is educated at Barrès (Loiret) where there is an extensive botanical garden of exotic species. An excellent forestry course is given at (a) the Institut Agronomique and at (b) the Ecole Polytechnique; students enter Nancy after two years' study at $(a)$ or (b). Guards are trained at Nogent-sur-Vernisson (Loire et Cher).

As part of the forestry education and propaganda system there are a number of important societies ${ }^{14}$ and associations which aim at protecting and popularizing French forests. These have been arranged in alphabetical order:

(1) Académie d'Agriculture de France, of Paris, is interested in all branches of agriculture and has a silviculture section which specializes in all general forestry questions, such as physiology, development of trees and stands, wood utilization, management, reforestation, etc. It is interesting to see forestry made an integral part of agriculture.

(2) Association Centrale Pour l'Aménagement des Montagnes, of Bordeaux, specializes in restoring mountain areas by improving grazing lands, in creating woodland on poor ground, and in reforesting mediocre grass land.

(3) Club Alpin Français, of Paris, furthers the reforesting of denuded mountains.

(4) Comite des Forêts, of Paris, a syndicate of forest owners, has to do with the improvement of private forest property, and especially its administration and exploitation.

(5) Societe des Agriculteurs de France, of Paris, entirely independent of the Government, is active in all branches of the theory or practice of agriculture and silviculture.

(6) Société Forestière Français des Amis des Arbres, which has a section at Paris and affiliated sections in the departments, conducts propaganda for the improvement and the creation of forests, planting of fruit trees, and betterment of grazing lands. It also supplies seed and planting stock to its members.

(7) The Societé Forestière de Franche-Comte et Belfort, of Besançon, aims to improve technical methods and furthers reforestation on uneultivated land and grass land.

(8) Societé Gay-Lussac, of Limoges, organizes a congress each year on "Trees and Water."

(9) The Touring-Club de France, of Paris, has a section of "Land and Forests" which conducts an active campaign for preserving beautiful forests, reforestation, reclamation of eroded mountains, and general forest betterments.

\section{PROTECTION}

Introduction. - The prevention of damage of all kinds must depend on the practicability and cost of prevention. Logging operations result in unavoidable damage and in war-time logging much of the finesse of European methods had to be waived. But even in France most of the damage is by fire, although only in the Provençe (chiefly from the Italian border to Marseilles) and in the Landes and Gascogne is inten-

18 See Huffel, Vol. III, for further data.

14 This list was obtained for the writer by Captain Fresson. 


\section{FEATURES OF FRENCH NATIONAL FOREST ADMINISTRATION}

sive fire protection necessary. In these localities the danger of fire is so great that even costly protection has frequently failed and large areas have been burned. Owing to the excessive fire damage in the Maures and l'Estérel (Var) a special fire protective scheme was first legislated in 1870 and revised in 1893. The main provisions of the law are: The use of fire in any form is forbidden during July, August, and September within 656 feet of forest or brush land, except upon special authorization; at other times charcoal kilns, and other dangerous use of fire, can only be located at the risk of the owner or contractor. Special police powers are accorded both private and public forest officers. Owners of forest or brush land which is not entirely cleared of undergrowth may be required by neighbors to open cleared fire lines 65 to 164 feet in width to be built half on each owner's land. Railroads are also required to clear and maintain fire lines 65 feet from the track; if not completed the work can be done under the direction of forest officers at the expense of the railroads. To encourage road building a subsidy of $\$ 932$ per mile was granted for suitable roads built within the Maures and l'Estérel area. (See p. 285 for additional details.)

In 1918 and 1919, however, there were disastrous fires in the Landes and in the Maures and l'Estérel regions because, owing to the war, the undergrowth could not be systematically cleared. The Engineer (forestry) troops salvaged more than 120,000 cubic meters (about $30,000,000$ feet board measure) of fire-killed timber in the Landes alone. The chief fire preventive measures in France ${ }^{15}$ have been fire notices, lookout posts connected with telephones, tool depots, fire lines (to fight from, since the French hold that "one should never count on a fire line to stop a fire by itself") 33 to 66 feet wide, and secondary lines 3.3 to 6.6 feet wide, and, finally, cutting of inflammable undergrowth (an efficient means of fire prevention, but expensive). But unquestionably the fire prevention and fighting practice in the United States is on a greater scale and is farther advanced than in Furope; consequently the opportunity for developing forest-fire technique has been larger. Perhaps the greatest lesson to be derived from the intensive protection in France is that with dense and inflammable brush under a pine high forest no measures are reasonably certain unless the underbrush is kept cleared. ${ }^{16}$ Even intensive fire lines will not prevent or stop dangerous fires if there is underbrush and high winds during a drought. In France the protective measures against birds, mammals, fungous diseases, dangers following windfall, or snow damage have not been so intensively developed as in other European countries. There are three main reasons for this.

${ }^{16}$ Jolyet, pp. 581-586.

${ }^{18}$ See also French Forests and Forestry, T. S. Woolsey, Jr., John Wiley \& Sons, Inc., for conclusions in Algerian and Tunisian fre protection. 
(1) The appropriations for experiments of all kinds have always been meagre; (2) under the favorable climatic conditions usually prevailing in the rich forest regions there is not the same danger and damage as in countries like Germany; (3) with natural regeneration on such an extensive scale, ordinary damage is usually discounted by having such a bountiful oversupply of seedlings or saplings. The protection of forests against trespass is discussed in this chapter under "Legislation." Forest trespass in such an old established forest region as France is naturally well controlled, but the general principle has been evolved that the good will of the neighboring population is much better than repressive measures and very complex inspection control. French measures for protecting forests from damage have most value to the American forester practicing under intensive market conditions.

Damage from Logging..$^{17}$ - The best time for logging broadleaves is in the late winter and operations in coppice are suspended in France pending the two months following the rising of the sap, since at that time young trees are easily injured. It is current practice to cut the branches off large trees when they must be felled into reproduction, but this practice may be abandoned because of expense and lack of skilled labor. It has been found better to cut the lower branches first. In a fir forest it is considered better to cut the stem into fairly short lengths, since the dragging of long logs is the cause of most of the damage in the Vosges and the Jura. Thinnings in hardwood forests are made in the summer so far as practicable in order to discourage sprouting. Sliding and dragging logs on erodable ground should be kept at a minimum. As a rule, hardwood high forests suffer less damage from lumbering operations than do resinous ones, but the damage is almost always proportional to the length and weight of the stems removed.

Servitudes and the Use of Minor Products. - A necessary evil in many forests (see p. 261, "Legislation") is the free use or sale of dead wood, dead stumps, brush, litter, leaves, grass seed, mushrooms, plants of various kinds, stone, sand, heather, or peat. Such material is often given for a few days' work or sold, or the local peasants may have certain rights (or servitudes). While there is real need for certain of these minor products, the use is often abused and frequently results in damage to the forest. The dead wood and leaves make valuable humus and even the removal of dead branches is often deleterious. Even grass is sometimes needed to protect reproduction (see p. 68), and the removal of moss often means the trampling and damage of seedlings. Seed collection obviously reduces the seed supply if not properly restricted, and if it is not carefully supervised results in damage. Such an innocent pastime as gathering wild strawberries has often resulted in damage ${ }^{17}$ See La Forêt, pp. 260-305. 


\section{FEATURES OF FRENCH NATIONAL FOREST ADMINISTRATION}

to young stands. Often the undergrowth may be required to preserve forest conditions and the removal of the soil itself sometimes means uncovering the roots and later results in local erosion. To sum up: As a result of experience in France regarding the removal of minor products the concensus of opinion is that it often results in damage to the forest and should be restricted ${ }^{18}$ so far as practicable.

Excessive Pruning. - The removal of "epicormic" branches from the boles of standards (in coppice-under-standards) is often practiced, but French foresters agree that it is rarely advisable to remove branches over 0.4 of an inch in diameter. ${ }^{19}$ If practiced at all it should be done in the middle of the summer or in the autumn. Ordinary pruning of green branches to improve the appearance of the bole is generally forbidden. When pruning must be done the wounds should preferably be covered with pitch, except in the case of maritime pine or trees which heal cuts by resin flow. Sometimes the removal of branches from trees soon to be cut is advisable in order to increase seed bearing. Conifers generally should not be pruned, and even dead branches should not be removed from light-demanding trees since the wind will break them off at the proper time. Dead branches on shade-enduring trees are a sign of bad health.

Damage by Birds. - Owls and other mice-eating birds are encouraged since they destroy rodents; but sparrows and other birds which destroy immense quantities of seed must be combated. Poisoned seed and shooting are the usual combative methods. While it is recognized that all birds destroy insects and should consequently be encouraged, yet French foresters have found in practice that they do not destroy insects in sufficient numbers to actually prevent insect infestations.

Insect Damage. - It is proverbial that coniferous trees suffer more from insects than do broadleaves and a pure conifer stand is most liable to damage. It is often necessary to fell or burn whole forests when once an insect attack gains headway.

The methods of insect control in France are to first secure the life history of the insect doing the damage and then to be on the lookout for local damage and to at once fell and burn trees attacked so as to

18 There is always a balance between the forest and the local climate which must not be disturbed. The writer recalls the disastrous results following the drainage of a stagnant lake or marsh near the top of a mountain in the Black Forest (Baden). After the drainage was carried out (a work which aimed at the improvement of the forest) a great many fir trees on the slopes below suffered severely from lack of moisture which they had evidently secured by seepage.

19 An exception is where the lower branches in the crowns of standards are removed up to a diameter of 2 to $3 \frac{1}{2}$ inches. 
destroy the larvæ. This principle is simple and is in universal use. In the words of Conservateur de Gail: ${ }^{20}$

"Local officers are instructed to carefully reconnoitre the trees attacked; fell, bark, and limb them at once, make a fire with the branches and throw the bark with its larvæ into it."

If the weather is dry and hot there is all the more danger and it is difficult to distinguish the trees attacked from trees damaged by drought. According to de Gail the value of the trees damaged by insects in the Vosges region was in a few years more than $\$ 67,550$. It is obvious that large insect attacks demand special study by experts, but the forester's rule-of-thumb in France is to fell and burn at once all trees attacked by dangerous insects and to restock blanks with species which are resistant. A typical contract clause from the 12th conservation (Besançon) reads:

"Art. 18. Those trees sold which are found to be attacked by insects shall be felled and peeled as soon as they have been designated by the local agents; the bark, crowns, and branches unpeeled shall be immediately burned up 'sur place.' If the highest bidder or the contractor refuses to do this work within five days of the extra judicial summons which shall be made, there shall be official proceedings for these costs in conformity with the provisions of Art. 41 of the Forest Code."

Damage by Game. - Wolves and foxes are considered desirable in forests since they destroy quantities of field mice which are so destructive of seed; foxes also eat considerable numbers of injurious insects. Wild boar are favored under some conditions since they destroy insects and mice and wound the soil, ${ }^{21}$ thus favoring natural regeneration. On the other hand they eat seed and damage seedlings. Deer and stags are on the whole harmful to forests in nibbling tender shoots and barking saplings (especially hornbeam) in spring, and for this reason fencing is often necessary (see p. 77). Hare nibble the bark of young trees in winter and damage nurseries, and rabbits are especially dangerous in coppice and open pine plantations, both in destroying the bark of young shoots and damaging root systems. But, on the whole, if we except rabbit damage, game causes such insignificant loss that ordinarily it is considered advisable to stock forests so that hunting or shooting privileges can be leased. (See p. 326 for returns from shooting.) Squirrels eat seeds and shoots, especially the tender young bark of the spruce, fir, and beech. Mice destroy enormous quantities of seed, especially in artificial reforestation, and store a great deal which is never touched, even eating the tender bark of hornbeam and hazel. Apparently the

${ }^{20}$ Une Invasion de Bostriches dans les Vosges, Revue des Eaux et Forêts, April 1, 1905.

${ }^{21}$ In the fir-spruce forests of British India the wild boar wound the soil and help regeneration. 
French consider that the best preventive for mice is the encouragement and protection of owls, buzzards, vultures, foxes, and cats.

Damage from Grazing. - The French policy is to exclude goats and sheep from all forests without exception and only to allow other classes of stock, such as eattle and horses, when unavoidable, but never in broadleaf stands, where even logging teams must be muzzled when not at work. As explained in Chapter V (p. 69), hogs are sometimes driven through beech forests to wound the soil and assist regeneration, but this is rare, and hogs are never allowed to graze freely. In the United States the grazing of stock, so generally allowed on National Forests in the West, was an inheritance from the public lands administration. Admittedly much damage results, but at the present stage of our economic development in the West it is a necessary evil in the extensive conifer stands, but graxing of all kinds should certainly be rigidly excluded from our broadleaf stands if serious damage to young growth is to be avoided. Grazing is tolerated in the United States to a far greater extent than in France, and the damage will become more and more serious as the silvics of our species are studied and systematized.

Fungous Damage. - The actual loss from fungus in well-managed forests is small. In the fir stands there is some damage from the socalled canker, and one of the most important objects of frequent thinnings is to remove trees infected with this disease in order to gradually stamp it out and prevent it from spreading to neighboring stands. The good results of this simple operation are evidenced by the small amount of rot in the final fellings. In a trip of more than a month's duration in the Jura the writer saw only two cases where timber cut was badly damaged by rot, and in one place the amount left in the woods did not amount to more than 10 per cent of the entire tree. In the remote inaccessible stands of the Pyrenees and Alps there is considerable defect because periodic thinnings cannot be made. In the Landes there is some damage from fungus in the maritime pine stands. This has been controlled by isolating with a ditch the groups of trees attacked so that the mycelium of the fungus cannot spread to the roots of other trees. This method, while still used, is not satisfactory; it is best to prevent the damage by "dépressage" or thinnings in seedlings or sapling clumps, since the damage is usually due to overcrowding.

Windfall Damage. - The material loss from windfall is not great, since usually as soon as discovered and before it becomes worthless the down timber can be sold at approximately five-sixths of the full stumpage price. The damage is mostly in the mountains, but occasionally occurs

A windfall in the Jura sold in May, 1919, at about five times the normal stumpage price of 1913. This was due to the abnormal shortage of softwood lumber and inability to import. 
also in the plains. Especially with shallow-rooted species, such as spruce, the cut should be managed so as to proceed toward the wind. Usually in the mountain regions, where the damage from the windfall is greater because of heavier fellings, the selection felling must be used rather than the shelterwood compartment system. In the high forests under regeneration the windfall has been estimated to be twentythree times as great as in uncut stands or in coppice-under-standards. Often belts of shelter trees managed under the selection system must be maintained around a forest where windfall is dangerous and zones of defense against wind in the mountains may often be maintained. According to De Gail, ${ }^{23}$ on January 30, 1902, a hurricane came from the northeast and resulted in windfall (in the Vosges) amounting to $1,206,755$ cubic meters (about 302,000 thousand feet board measure) on a total area of 215,757 acres, and amounting to 5.64 cubic meters (about 1.4 thousand feet board measure), per acre where the average stand was originally about 120 cubic meters ( 30,000 feet board measure) per acre. Equalling almost two and one-half years' growth it interrupted the sustained yield and resulted in increased labor prices and consequently diminished profits. It is interesting to note that the measures taken by the local conservator were: (1) The suspension of all regular fellings for the year 1902; (2) extension of time for the timber sales of the past year; (3) payment for windfalls in four installments instead of wholly in advance; and (4) more than the usual time allowed for felling and removal. The average price received for this windfall, including branchwood, was nine-sixteenths the regular price, or a diminution of 44 per cent below normal because of the wholly unusual amount of timber thrown on the market. De Gail says the irregular stand stood the hurricane best, especially where there was a tremendous disparity in the height of the trees comprising the stand. The total estimated loss was as follows:

Reduction in price.

Breakage.

Loss through felling immature timber.................

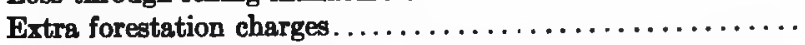

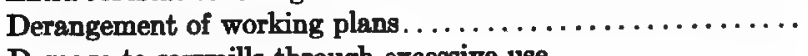

Damage to sawmills through excessive use...............
$\$ 1,068,932.82$

$68,411.75$

$595,059.14$

$17,885.31$

$11,580.00$

$4,168.80$

$\$ 1,766,037.82$

Damage by Frost. - The damage from hail, frosts, or ice (on trees) is considerable, and apparently there is no known preventive. In January, 1879, 41,666 cords of fuel wood were broken by an ice storm of unusual severity. Late and early frosts can be guarded against by using species which are not easily damaged and by maintaining a pro-

${ }^{23}$ L'Ourage de 1902 dans les Vosges, Revue des Eaux et Forêts, July 15, 1903. 


\section{FEATURES OF FRENCH NATIONAL FOREST ADMINISTRATION}

tective cover for such species as beech so as to prevent damage. Frost cracks, frequent in hardwood forests, let in rot and result in eventual damage. Quick changes of cold are most dangerous and apparently are more so on a sandy soil than on clay, clayey limestone, or peat. The damage is accentuated with thin barked trees.

Damage by Sunscald and Drought. - Thin barked trees, especially when young, suffer from exposure to the fall rays of the sun. It is for this reason that severance cuttings are sometimes necessary; these are merely "the clearing of a narrow strip on the border of a young stand" to accustom the bark to the full intensity of the sun.

In the forest of Saint Antoine (Vosges), there were at least eighty redtopped fir trees in one working group killed by the unusual drought of 1911. It is of rather frequent occurrence to see spruce which has been rocked by the wind die from drought because the root systems have been weakened by having the rootlets lose contact with the soil. The damage was less with the selection system than with the shelterwood.

Snow Damage. - Snow damage can best be controlled by early, frequent, and correctly executed thinnings. The most resistant French species against snow damage in the high mountains is the cembric pine. A recent (1911) snowslide ${ }^{21}$ below Mont Blanc overturned 23,000 trees which brought only 12 francs per cubic meter for logs and 3 francs per cubic meter for cordwood. This avalanche was started by a block of ice ${ }^{25}$ and, had not immediate removal of the timber been planned, it would have resulted in the starting of insect damage on the area destroyed. The actual physical damage by the avalanche itself was 650 feet wide but the wind pressure on each side of the snow extended it 325 feet on one side and 650 feet on the other; in places the total damaged area was more than 1,640 feet wide.

Intensive Fire Damage. - In most sections of France there is comparatively little danger from fire, the most dangerous portions, as might be expected, being in the conifer ${ }^{26}$ and brush forests of the South where the summers are hot and dry. French fire protection is most intensive in the Maures and l'Esterel because of the resulting damage and because the locality is an important tourist center where it is very essential that forest conditions be maintained in order not to damage the important pleasure grounds of the Côte d'Azur between Toulon ${ }^{27}$ and Monte

${ }^{24} \mathrm{~A}$ method used by French foresters to prevent avalanches on steep slopes is to cut stumps 3 to 5 feet high above the soil in order that the stumps may hold the snow and prevent the starting of snowslides.

${ }^{25}$ Most of the damage was due to the wind caused by the avalanche and not by the snowslide itself.

${ }^{26}$ For lightning damage there is, apparently, no prevention.

${ }^{27}$ The best center for studying intensive protection is from St. Raphael. In the maritime pine forests of the Landes the student should go from Bordeaux to some center like Arcachon or Mimizan. 
Carlo. The damage from fires in the Landes is not so great because of the ease of regenerating the maritime pine after fires; the problem of reforestation is far less serious than in the Maures and l'Estérel country. The law of August 19, 1893, already referred to on p. 262, covered State, communal, and private forests. After establishing the nominal area of fire danger the law provided that from June to September open fire was forbidden within 656 feet of all forests or brush land without special authorization. The préfet or the conservator could grant permits for charcoal making, but it was provided that in case of damage the party burning charcoal would be liable. The law also provided that fire may be authorized on forests cut by fire lines, but the responsibility for damage would not be waived. The penalty for building fires illegally was five days in jail or a fine of $\$ 3.86$ to $\$ 9.65$, and the responsibility of children or workmen was fixed on parents or contractors. Forest officers were given police powers, as were private guards after being duly authorized by the conservator or the prefet. According to Article 9 of this law:

"Every owner of wooded land, forest or ground, covered with brush, which has not been entirely cleared may be compelled by the owner of similar adjoining land to open and maintain on his part along the boundaries of the two contiguous areas a fire line cleared of all brush or conifers and maintained in a thoroughly cleared state; the width of this fire line, to be established half on each property, shall be from 66 to 164 feet. Its location shall be fixed by agreement between the interested owners and in case of disagreement, by the prefet, with the approval of the conservator of forests."

Railroads operating in this region are required to open fire lines and keep them cleared 66 feet from each rail within 6 months from the enactment of the law and entirely at the expense of the railroad. The débris must be suitably disposed of and if not it can be done by the Service of Waters and Forests and the cost assessed against the railroad company. By special agreement in exceptional cases trees on fire lines need not be felled.28 The local mayor of the commune, or his deputy, or the highest official may alone start back fires without danger of civil suit in case of resulting damage. A subsidy of $\$ 932$ per mile for the network of main line defense roads for this region was provided by the law.

The Fire Problem in the Forest of l'Estérel (Var). - According to the local working plan, by Inspector Salvador in 1906, and subsequent official reports the following areas have been burned over:

28 For a discussion of the problem of entire or partial clearance of fire lines see French Forests and Forestry already cited. 


\begin{tabular}{|c|c|}
\hline Period & Acreage burned \\
\hline 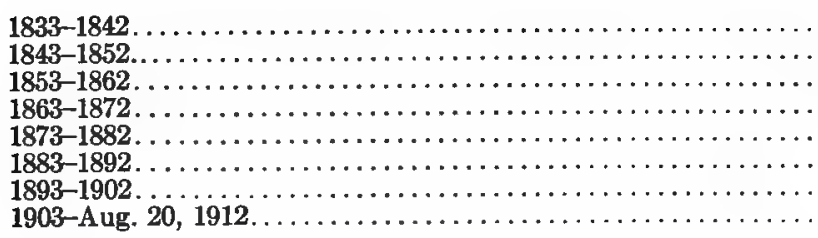 & $\begin{array}{c}11,120 \\
1,169 \\
4,989 \\
35.8 \\
4,381 \\
30 \\
86 \\
435\end{array}$ \\
\hline
\end{tabular}

Up to 1862 apparently the chief cause of fire was incendiarism, but since that time it has been carelessness, railroads, and the execution of improvement work. During the last period given in the above table fires on 297 of the 435 acres burned over were caused by lumbering operations. It is quite significant that out of a total of 21,999 acres burned over during the years 1838 to 1857 the amount was $17,310.16$ acres, and during 1858 to 1877 the area burned over was reduced to $4,459.65$ acres, and from 1878 to 1905 it was only 229.66 acres. Unquestionably the largest conflagrations have been due to the extreme droughts when even fire lines failed to stop the damage. The disastrous fires of 1918 were due largely to the lack of labor with which to clear out underbrush which is cleared out by day labor. Light burning is never permitted.

Much the best example of intensive Federal fire protection is in the State forest of l'Estérel which is in the Nice Conservation (Toulon Inspection), with a forest assistant residing at Frejus near St. Raphael, Agay, and Le Trayas on the main line of the P. L. M. Railroad between Toulon and Nice. The total area of this forest is 14,226 acres, of which 10,915 is forested. The boundary ( 34.7 miles) is marked by boundary pillars, and fire lines, half on the forest and half on bordering land, have been maintained since 1894 for the entire boundary in accordance with the law of 1893 . There are no free-use rights other than right of passage for grazers and this is restricted to forest roads. The topography is hilly, two small mountains reaching an altitude of 2,020 and 1,788 feet, respectively, but the general relief is rugged. The soil is formed from volcanic rocks (porphyries), with some projecting ledges of schists. Red porphyry occupies alone more than two-thirds of the surface of the forest. It produces on decomposition a sandy soil which is arid, easily dried up and very permeable. The climate is typical of the French Mediterranean border, with extreme temperatures, hot summers, and mild and humid winters. The annual temperature is $14.5^{\circ} \mathrm{C} .\left(58.1^{\circ} \mathrm{F}.\right)$, minima of $6^{\circ} \mathrm{C}$. to $8^{\circ} \mathrm{C}$. $\left(42.8^{\circ} \mathrm{F}\right.$. to $46.4^{\circ} \mathrm{F}$.) are exceptional. The winds are frequent and very violent, the so-called "mistral" blowing 
from the northwest and northeast, but when from the northeast it is often accompanied by rain. Of an average annual rainfall of 35.7 inches, half falls in the autumn and the remainder in the winter or in the spring. There is practically no rain during the summer months. Maritime pine (64 per cent of the stand) is the dominant species. The trees are characteristically distributed in groups with openings caused by past fires and stocked with heather. The cork oak is next in importance ( 26 per cent of the stand) but is not distributed over the whole forest. It is usually found in clumps generally localized at the foot of the porphyry slopes or below cliffs. The holm oak (6 per cent of the stand) is found on the rocky slopes and on steep escarpments along ravines. The aleppo pine is found chiefly along the ocean on a narrow zone of schists and on red sands, with some limestone soil in mixture. The chestnuts, the sessile oak, the maple and the nettle trees comprise 1 per cent of the stand.

In the first, second, third and sixth working groups, which alone are cut over by regular fellings during the first cutting cycle of 16 years (1903-1918), pines 10 inches in diameter and above, estimated at 204,343 small trees, amounting to 75,909 cubic meters (about 10,000,000 feet board measure), were removed. The forest is divided into six working groups, treated by the selection system, both for the felling of conifers and for the collection of cork oak. During the years 1902-1911, 20,059 cubic meters (about $2 \frac{1}{2}$ million feet board measure) of wood netted $\$ 26,986.03$; while 121,695 pounds of bark netted $\$ 41,457.56$; and accessory products, including the hunting privileges, yielded $\$ 10,921.87$; a total of $\$ 79,365.46$ or an average annual yield in money of $\$ 7,936.55$ for the forested area under management. This amounts to 61 cents per acre per year at 0.450 cubic meters ( 60 feet board measure) of wood and 94 cents for 27 pounds of bark. It is unfortunately true that fuel has practically no value, and consequently the yield from this source is insignificant. The average value of the soil without the timber is estimated at $\$ 15.44$ per acre. The road and trail system is admirably developed as follows: Thirty-five miles of roads 11.48 feet in width, eightyeight miles of roads 8.20 to 9.84 feet in width, and 129 miles of trails. This road system is cut by two branches of the National Highway between Toulon and Nice, one inside the forest and one along the ocean front, often outside the forest, called "La Corniche." There are no nurseries. Artificial restocking has been suspended since 1895, since it would obviously be poor business to plant or sow until the fire danger is better controlled. The products are sold locally and at Marseilles. There is no grazing nor is litter collection allowed. The lower limit of exploitability for the conifers is 13 to 15 inches in diameter depending on the working group. These sizes correspond to an age of 90 to 110 years. 
The cutting cycle is 16 years and the yield is based on number of trees. It takes 12 years for the cork to reach a thickness of 0.9 inch, the exploitable size; it is worked on a cycle of two years. The forest is divided for cork oak extraction in two divisions, each comprising three working groups. The yield for each working group is calculated by dividing the number of trees of salable size in the working group by 16 . In each of the six working groups there are also intermediate cuttings by area which aim at thinning young stands which are too dense, removal of damaged or dead timber and the freeing of promising clumps of cork oak. In reality the selection system practiced in this forest is not a theoretical selection of single trees but selection by groups.

In addition to the maintenance of the forest houses, roads, trails, etc. (the communications cost about $\$ 1,544$ a year to maintain), the protection work takes first importance. This comprises a system of fire lines 33 to 98 feet in width along the boundaries, on the main ridges, and along the main roads and trails. This system of fire lines covers 1,332 acres. The fire protection also includes complete brushing, with root extraction, in the compartments where the trees are most susceptible to fire. The fire lines are cleared every 4 years and the brush every 8 years. The fire lines cost $\$ 1.69$ per acre to clear, and to grub the brush costs $\$ 5.02$ per acre. In addition there is a complete telephone system connecting all the ranger stations with the lookout station on Mont-Vinaigre and with the forest assistant's office at Frejus. The expenses for improvement work during the period from 1902 to 1911 were $\$ 10,586.44$ per year, or an excess of more than $\$ 2,509$ over the revenue. The personnel for this complete fire system includes two rangers without any assigned district and seven guards. Besides, during 8 months of the year, there are ten special guards for fire protection and for supervising betterment work. During the four summer months these special guards comprise a floating force to see that the law of 1893 is carried out. Of the nineteen employees cited, eighteen are lodged within the forest in eleven forest houses. The clearing of underbrush over large areas is the feature of this intensive fire protection. It means that even expensive and numerous fire lines cannot alone control fire under these dangerous conditions. Otherwise it is certain that the French would never have gone to this unusual expense which has resulted in a deficit.

\footnotetext{
"According to the rules for contractors issued for the twenty-third conservation governing the work in the Toulon Inspection, there can be no subcontract. The contractor cannot work intermittently, he must begin within 15 days of the contract award, and the details must be in accordance with instructions and orders and must proceed in logical sequence.

"In addition, during the dry season from the first of June to the first of October, he cannot stop for more than a month the work which is in the course of execution
} 
under forfeiture without a specific reason. The workmen employed must be sufficient for the work in hand. All the weeds, shrubs, and plants of all kinds must be taken out by the roots. However the arbute and phyllaria will be only cut level with the ground upon designation by the local guard. The contractor will cut level with the ground all pines which are designated around cork oak and lop others to one-third their height.

"Poorly shaped cork oak will be cut back level with the ground and all wood felled or extracted will be stacked. The products which cannot be utilized will be piled and burned in openings. Any fire, except charcoal pits, is forbidden from the first of May to the first of October and the location of charcoal will be designated by the local ranger and can be visited by employees or officers during the day or night for inspection purposes. Before the contract work is accepted there will be a general cleanup of the area cleared and weeds, etc., which have grown up will be burned. Then a month after the permit for work is issued the contractor must open a brush line 6.5 feet wide around the contract area in order to facilitate survey. On fire lines, however, this line will be opened up in the center. In case the contractor refuses to abide by the calculated area a re-survey may be ordered but it will be at the expense of the contractor in case the original survey is found to be correct. All loss to the contractor on account of fire or other natural causes will be at his expense, but in case the area which is being cleared is burned over, a re-estimate of the work may be made and the contract relet."

The fire lines are usually 132 feet in width on the boundaries (that is, 66 feet on the State forest and 66 feet on private land), 66 feet on the ridges but with an increased width of 98 feet where the danger is particularly great. The fire lines dividing the compartments are usually but 33 feet in width. According to past practice thrifty oak or pine on the lines are usually left uncut, but the tendency now is to clear the lines of all cover, since the needles and leaves falling from the trees on these fire lines often partly destroy their value. An ideal system would be to plant the lines with non-combustible hardwoods. ${ }^{29}$ The second clearing of fire lines cost $\$ 1.31$ to $\$ 2.32$ per acre, and the average cost per acre during the years $1906-1908$ was $\$ 1.70$.

Ridge lines are almost invariably favored, since they (1) are better for fire fighting, (2) contain less timber, (3) are easier to clear, and (4) facilitate the direction of fire fighting operations. Side-hill lines are never constructed except where absolutely necessary along boundaries. The lines which are cleared every 4 years become covered with rough grass, ferns, and weeds after 2 years, so that they would not stop fire without artificial aid. It is only by the clearance of brush and débris throughout the forest that crown fires are prevented.

"The complete brushing aims to entirely remove and burn the weeds. . . . This will materially improve the growth, assure a positive protection against fire for 3 to 4 years, according to the soil. . . . One need not hesitate to profit at the time of brushing . . . by making a first thinning in the maritime pine saplings . . . increases growth . . . and reduces the danger period."

${ }_{29}$ The American Consulate at Rouen, France, reported that the enclosure of coniferous forests with non-inflammable hedgerows of opuntia had been tried out. It is not known by the writer whether the experiment was successful or of practical value. 
The paths are cleared of pine needles twice a year - in October and May - and at the same time the trails are repaired. In the Toulon Inspection the needles fall in July and August during the danger season, and in May a path was noticed which was covered with needles.

When fighting fire in this locality, even with fire lines, it is usually necessary to back-fire, although occasionally it is possible to station men along the paths or fire lines and beat out the fires with boughs. The night is invariably considered the best time for fire fighting, since there is less wind. ${ }^{30}$

Fire Insurance in France. - In theory there is more need for fire insurance of forests than there is of city dwellings. In practice there is but little forest-fire insurance even in European countries where the fire danger is much less than in America because the rates are so high that private owners cannot afford it, while it is the policy of governments not to insure. A number of companies pretend to insure forests but most of them refuse when it comes to the point; they will only insure forests where the danger is so small that there is no object in insuring. Where the risk is great the rates are prohibitive.

Ordinarily companies only insure broadleaf high forests, coppice, or coppice-under-standards which do not contain more than 10 per cent of conifers in mixture. The insurance of forests which contain a larger proportion of conifers than broadleaves or where the conifers are less than 10 years old is rarely agreed to, and then only in the north or center of France where the fire danger is much less than in the south. Insurance companies do not ordinarily insure the theoretical damage ${ }^{31}$ to management following fire or the loss of sprouting capacity. They refuse to insure cover, regeneration, felled timber and bark, and débris of every kind which has fallen on the ground. ${ }^{32}$

Typical rules concerning the insurance of forests are:

"Based on the average price at the day of exploitation and based upon half of this average price if the forest is under management or on half the usual age at the time of felling if the forest is not run under formal working plan.

"1. For the coppice. To value the capital insured by calculating the value of the cutting at different ages according to the amount grown at the time the fire takes place with policies fixed for 10 years and a re-valuation at the end of each decennial period.

"2. For the reserves. To value the capital to be insured by classes by determining for each diameter class the value of the average tree and the average number of trees

${ }^{20}$ For Landes methods see pp. 203-205.

"1 For a detailed discussion of French damage appraisal methods see "Incendies en Forêt," by Jacquot. This has been translated and published in English. A critique of (company) forest fire insurance is given by Jacquot in "Assurance des Forêts Contre Incendie." Le Mans, 1909.

82 "Assurance des Forêts Contre l'Incendie," par M. Deroye, Besançon, 1911. 
to the acre. These classes would be established according to the size of the trees either by circumference or diameter.

"3. For the establishment of stands. To value the capital to be insured by the amount necessary to restock the area forested, supposedly entirely destroyed, by means of plantations. This would include the purchase, transport and planting of the stock as well as the necessary accessory costs.

"4. For the humus and dead cover. To value the capital to be insured by the sum necessary to replace the quantity of fertilizing material lost by means of manure appropriate to the nature of the soil. In this amount would be included the purchase, transport and spreading of the manure as well as all supplementary expense."

The companies demand, for coppice and coppice-under-standards, a rate of 70 cents per $\$ 100$ applicable to all the insured risks. They require besides a special tax of 10 cents per $\$ 100$ for the risk of lightning. The French forester would prefer a variable scale of charges according to the risks and local conditions, depending on the vicinity of railroads or public roads, absence or presence of fire lines or brooks, existence of green vegetation, as well as danger from local industries such as charcoal burning. They hold that the risk should start at 50 cents per $\$ 100$ with increases of 5,10 , or 15 cents according to the supplementary risk of fire. They would also take into account the fire statistics based on the percentage of fires in the neighboring forests managed or not managed by the Federal foresters. Companies should charge, as they do not, the same rates for various risks. A special lightning risk should be eliminated in order to simplify the calculations.

According to present practice the companies value the fire damage in the case of coppice by a simple proportion based on the actual age as compared with the usual age at the time of felling. Moreover they diminish the amount arrived at by 4 per cent for each year remaining up to the usual age of felling. Finally they subtract the amount of wood salvaged after the fire; for the reserves according to their value at their average age at time of felling, diminished by depreciation from this age at the time of the fire, and further diminished by 4 per cent remaining before the usual age of exploitation; for forestation by the amount necessary to plant two plants per tree destroyed without the cost of removing the stumps. French foresters hold that: $(a)$ The coppice burned should be estimated at its actual age calculated according to the amount grown without any deduction made for salvage. (b) The reserves burned should be valued individually according to their value by classes with deductions for salvage. (c) The damage caused to growth should be calculated by the acre according to the amount insured. (d) The damage caused to the litter and humus should be calculated by the acre according to the amount agreed upon. (e) It is absolutely essential to establish in advance the rate of interest to be used in calculations, and the exploita- 
tion should also be insured except for the timber actually felled, which should be insured separately. ${ }^{33}$

The rates prevailing in 1912 were as follows:

\begin{tabular}{|c|c|}
\hline Type of forest & Rate per $\$ 100$ \\
\hline 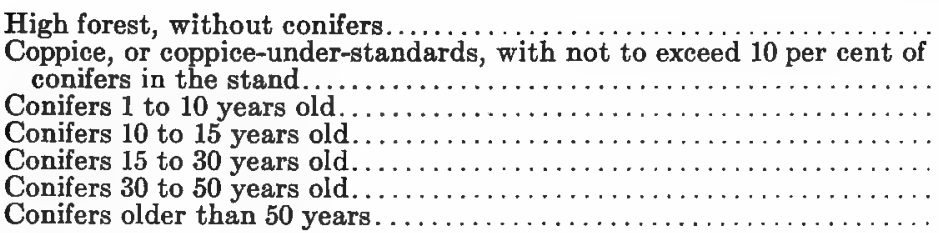 & $\begin{array}{l}\$ 0.40 \\
0.70 \\
7.70 \\
3.85 \\
2.70 \\
1.95 \\
0.40\end{array}$ \\
\hline
\end{tabular}

It is curious to note that the rate for conifers older than 50 years is the same as the rate for a broadleaf high forest without conifers. This hardly seems fair, but according to French writers there is but little danger in old conifer stands, since insurance is limited to portions of France where the fire damage is at a minimum. There is not a company in France that would assume the risk of insuring aleppo pine stands along the Mediterranean - the risk is considered too excessive. Nor would they insure maritime pine stands in the Landes. The company, La Providence of Paris, charges approximately 20 per cent higher rates than those cited. Judging from the results thus far there will never be practicable fire insurance in France for stands where the fire risk is really great. But it is hoped that the day will come in the United States when forest-fire insurance will be possible for the majority of stands.

\section{BETTERMENTS}

Forest Houses. - Very substantial houses are constructed for the use of French rangers. They are of fire-proof construction, with cement floors, tile roofs, and stone or cement walls. On the large forests the ranger house is sometimes in the center of the ranger district even if it is some distance from local villages. In such cases the problem of transportation is a simple one, since all the roads are suitable for bicycles. Where practicable the tendency is to locate the ranger station on the outskirts of or near local villages. In one or two instances double houses for two guards and their families have been tried, especially in out-of-theway places, but this arrangement is rarely successful.

Roads and Trails. - The roads are generally of two main classes -

${ }^{33}$ A translation of a French forest fire damage calculation is given in the Appendix, p. 534 .

${ }^{3}$ See French Forests and Forestry already cited. 
paved and unpaved. Paved roads are first-class in every respect and are usually maintained by the State, being macadamized and each length of road being in charge of a separate laborer outside the employ of the Forest Service. A great many forests are traversed by first-class main route national highways which are always kept in perfect condition. The dirt forest road is maintained by a charge on the purchaser of timber, a certain tax being added for road maintenance, usually amounting

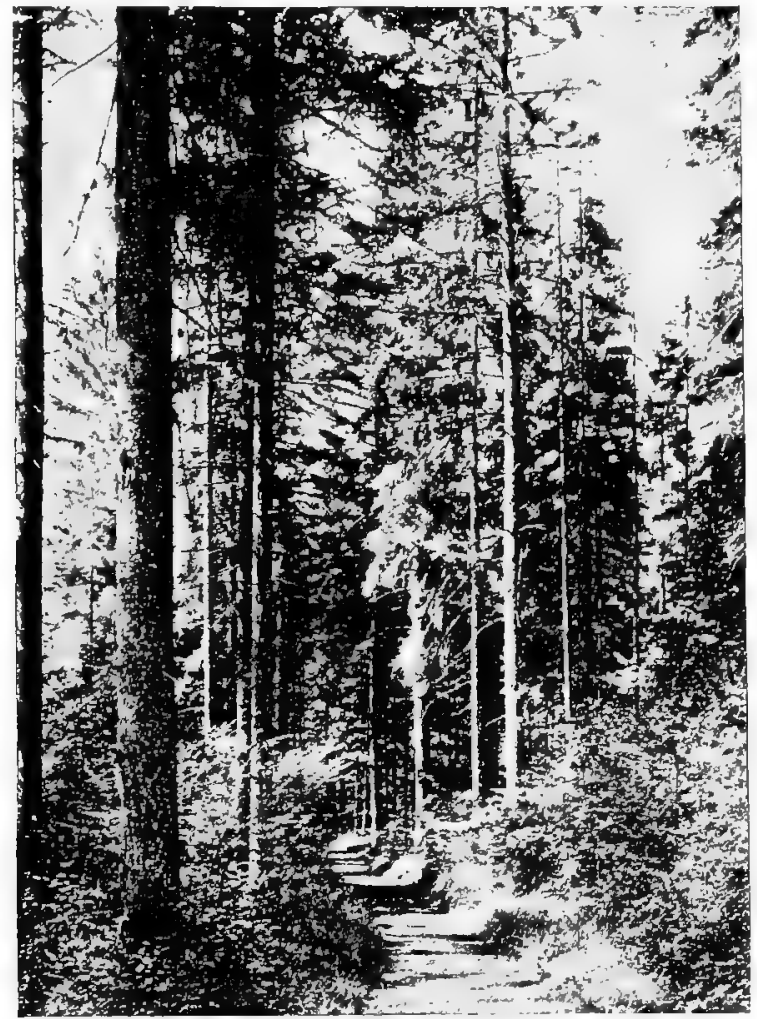

Fia. 21. - A graded trail, which serves as a compartment boundary, and which can be used by tourists.

to about 4 per cent of the purchase price. In the Landes the sand makes cheap dirt forest roads impossible and the roads are merely lanes cut through the forest, covered with branches and pine needles so that the wheels can get traction. Near the frontiers special permission must be secured before building forest roads on account of their strategic value to the enemy in case of an attack. One unfortunate feature of French State forest roads is illustrated by the roads in the forest of Levier in the Jura; here the forest roads were laid out at right angles 
along compartment boundaries whereas they should have followed the contour. This mistake in alignment is often encountered. Trails rarely have a grade of more than 12 per cent and are kept in excellent repair. One feature is the provision for adequate drainage and up-keep. The drainage is often secured by placing a cross-piece of wood, 6 or 7 inches in diameter, so that when the water runs down the path it is deflected as soon as it reaches the wooden barrier; it is raised 1 to 2 inches above the level of the path. Trails that are used largely by tourists (see Fig. 21) are marked with distinctive paint that corresponds with guide maps used by the Touring Club de France.

Boundaries. - The boundaries of all French forests are accurately marked and some of the former royal forests are surrounded by stone walls. There are usually at least stone boundary pillars properly chiseled and marked in red, giving the number of the compartment working group and the serial number of the boundary post. For example, $54 \mathrm{E} 1$ would mean boundary post No. 54, compartment $\mathrm{E}$ of working group No. 1. In the forest of Risol in the High Jura, the compartment boundaries usually follow roads and trails, but a few had to be blazed and marked through the forest. On each side of the road along compartment boundaries there is a letter every 50 yards or so giving the number of the compartment. Where two boundaries join both sides are marked in order to avoid confusion. When it is considered that the area of a compartment is usually as small as 35 to 50 acres the intricacy of boundary up-keep may well be realized. A favorite method of marking is to paint the border tree with a white square with the letter in red in the center.

In the thirty-second conservation (Vesoul) the following specific directions were issued regarding boundary ditches:

"Ditches. - New ditches or those repaired will be designated on the ground by the local agent. . . . They will have the full dimensions."

\begin{tabular}{|c|c|c|c|}
\hline & \multirow{2}{*}{$\begin{array}{l}\text { Vertical depth. } \\
\text { inches }\end{array}$} & \multicolumn{2}{|c|}{ Width } \\
\hline & & $\begin{array}{l}\text { At top, } \\
\text { inches }\end{array}$ & $\begin{array}{c}\text { At bottom. } \\
\text { inches }\end{array}$ \\
\hline 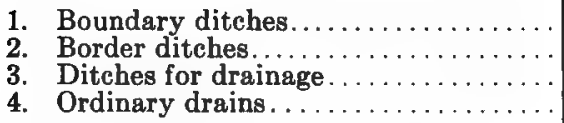 & $\begin{array}{l}39 \\
24 \\
20 \\
16\end{array}$ & $\begin{array}{l}79 \\
59 \\
47 \\
26\end{array}$ & $\begin{array}{l}8 \\
8 \\
8 \\
4\end{array}$ \\
\hline
\end{tabular}

As an alternative:

"And if it is recognized by the local agent that the nature of the soil prevents the construction of boundary ditches a stone wall may be substituted, solidly constructed, with a height of 39 inches, a width at the base of 31 inches and at the top of 20 inches. If there is no stone the wall may be replaced by an earth embankment 79 inches at the base and 39 inches high." 
According to Article 19, forest boundary stones must be of good quality and for the outside boundary of the forest must be 31 inches high and 8.7 by 7.1 inches square. They extend 14 inches above the ground and are engraved with letters 3.1 inches high. Boundary pillars of felling areas are 24 inches high by 7.9 by 5.9 inches square. They extend 7.9 to 9.9 inches above the ground, and have numbers painted in black 2 to 2.4 inches high.

Maps. - Separate maps, issued for each State forest, rarely give contours but include roads, trails, towns, villages, houses, telephone lines, ranger stations, fire lines, boundaries of forest, working groups and compartments, names of border forests, areas of compartments, alienations, ponds and streams. The usual scale is $1 / 20,000$ or even larger. ${ }^{35}$

\section{SALE OF TIMBER}

General Sales Procedure. - There are five main steps necessary before French timber under forest management can be cut:

(1) The working plan prescribes the area to be cut over in final fellings. Frequently the working plan also indicates, in the order of importance, when stands of timber should be cut, but considerable leeway is left to the local officer in charge, since a good deal depends upon seed years, the reproduction, weed growth, windfall, and other unforeseen accidents.

(2) The trees on the area where the cutting is to be made are carefully marked, usually under the supervision of an officer of the rank of deputy supervisor (assistant inspector) or forest supervisor (inspector). After the marking in any forest is completed the local inspector makes a formal report showing the number, size, and volume of the different species marked, and the approximate value. A minimum price is always established.

(3) Announcement is made when an auction will be held and a detailed description of the timber to be sold is printed for general distribution. The data furnished include the location, the estimated products, boundaries, method of removal, and assessed road charges, if any.

(4) At the time appointed for the auction the bidders assemble and each lot or sale is auctioned off by calling the maximum possible price for the lot first and gradually reducing the price until a bidder calls "I take it."

(5) After the sale is made and all charges paid in advance, cutting is allowed after certain formalities (see contract clauses) have been completed.

The French sale on the stump is in reality a sale for a lump sum on the basis of the scale of the standing timber.

The French consider that their method of selling timber standing is

${ }^{35}$ For grazing, dune, and reforestation betterments see Chapters VI, VII, and VIII. 
more economical and suits the timber purchaser better than the German method of selling in the log, since he can get the lengths that he prefers and, as he is in close touch with his local market, his judgment is likely to be correct. (See Appendix, page 498.) Selling the timber standing after the marking is completed is certainly cheaper, simpler, and better than to have the exploitation by day labor under State control. The only disadvantage appears to be the danger of having somewhat more damage done in the woods, since it is often difficult to supervise a large number of small operations going on at the same time. For this reason the contract clauses are very specific, particularly where they provide for damages in case sales methods are departed from (see also Chapter X, "Protection"). Upon the day and hour announced for the auction the proper officials assemble and the presiding officer explains the conditions of the sale. If the price bid goes below the estimated value then the bidding is stopped and the lot auctioned at a later sale. In the auction at Pontarlier (held July 4, 1912), the prices for State timber were 2.45 per cent above their estimated value and the communal sales 12 per cent above. If the value of the timber is estimated at 7,000 franes the bidding will be started at, say 13,000 franes, the price being gradually decreased until one of the bidders exclaims "I take it." Where there is competition for timber the shouting often begins before the price is actually read, and where there is a tie the bidding is started over again, or the successful bidder may be chosen by drawing lots. Immediately after the public auction each bidder signs an agreement to purchase. The sureties are usually looked up and examined as to solvency prior to the auction. This sale of $\$ 115,800$ worth of timber in 102 lots at Pontarlier was conducted in less than an hour's time. Practically and theoretically this method of sale seems to possess a great many advantages where the amounts sold are small, where there is keen competition, and where the utilization is intensive.

Individual contracts, such as are used for large timber sales by the United States Forest Service, reciting in great detail the special felling rules for each individual sale, are unnecessary for the small French sales. The expense of repeating the rules and regulations would prove too great. Instead there are certain general rules which apply to the whole of France, with special clauses to cover necessary departures in each conservation. This is a simple and economical method which could be well copied to some extent in the United States after our sales methods are standardized for each locality. For small sales the French Forest Service has a printed form of contract which only requires the addition of routine data.

Estimate and Appraisal. - In estimating a fair price for timber the government allows a 10 per cent contractor's profit under ordinary 
conditions and up to 20 per cent where the risk is greatly increased. Although the sale is made by estimate and it is considered essential that very accurate estimates be made of the timber marked for cutting, based on a tree-to-tree count, yet, as a matter of fact, errors in estimating occur. This does not necessarily mean a loss to the State, since bidders usually re-estimate lots they intend to bid on; a low estimate by the State merely means that the bid is that much higher per cubic meter or stere and the error in calculating the presumed products is thus discounted. All the State guarantees is that the number of trees in the size classes is accurate. Since the demand for timber is greater than the supply the competition for State and communal sales is sufficient to make the price depend upon competitive bid rather than on the minimum estimated price based on the costs of logging, transport, and allowed profits subtracted from the estimate sales price of the product. ${ }^{36}$ With the exception of a few large sales in the Pyrenees, timber sales are in small lots usually with intensive market conditions. The location of sales has nothing to do with the demands of the purchaser but is planned in the working plan according to the needs of intermediate cuttings and regeneration. If the boundaries of sales do not correspond to compartments the lines are clearly marked with paint. When there are extensive windfalls or where there are insect attacks special fellings are authorized. In communal forests special sales are often allowed to provide mainly for special improvements, such as a school house or town hall. It is as if the forest were a communal bank, safe-guarding the reserve capital of the inhabitants.

There are three main methods of selling timber: (1) By the lot on the stump; such sales are the rule in France for saw timber sales and for coppice. (2) By unit of product; intermediate fellings are sometimes sold

${ }^{36}$ A sample appraisal follows: Francs

Building material: 60 cubic meters at 45 francs............ 2,700

13 cubic meters at 35 francs.............. 455

Building material (small size): 300 cubic meters at 25 francs........ 7,500

119 cubic meters at 17 francs.......... 2,023

Fire wood: 45 steres at 7 francs........................ 315

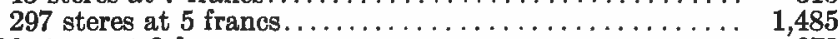

Charcoal: 126 steres at 3 francs........................ 378

Total............................. $\overline{14,856}$

From which must be deducted the following:

Contrantors' 15 per cent.............................. 2,228.40

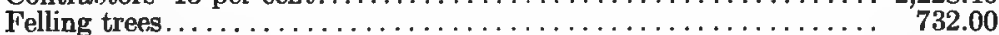

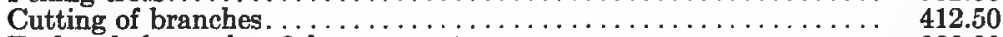

Fuel and charcoal at 2 francs per stere.................. 936.00

Special work ...................................... 450.00

Fiuel for local officers............................... 108.00

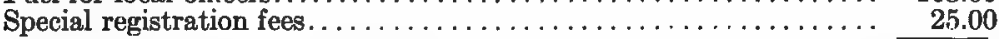

Total. . . . . . . . . . . . . . . . . . . . . . . $\overline{4,891.90}$

Net value of timber $(14,856.00-4,891.90) \ldots \ldots \ldots \ldots \ldots \ldots \ldots, 9,964.10$

Less 5 per cent for special costs. . . . . . . . . . . . . . . . . 4999.00

Net total value . . . . . . . . . . . . . . 


\section{FEATURES OF FRENCH NATIONAL FOREST ADMINISTRATION}

on the basis of the material cut and stacked, since it is often difficult to estimate the product accurately in advance. (3) By unit of product after the timber has been exploited by the State; this method is rarely used.

Before any timber sale is made it is customary to advertise the lots very widely, and there are strict laws against combinations or agreements to eliminate competition. The method of describing the lot to be sold differs somewhat in the different conservations, and according to the material to be disposed of, but as a rule the purchaser is given an exact and complete description of the product, the conditions he must work under, and his obligations for road repair or other charges. ${ }^{37}$

Orders have been issued to make small sales, because if large only a few of the larger manufacturing companies can compete. The writer attended the sale of 102 lots (each a separate small timber sale) at

${ }^{37}$ Two examples of the data furnished purchasers are given below:

(1) In the Oloron inspection a sale of timber to be removed in thinning was described as follows:

Thinning on 4.94 hectares, including the felling of stems designated or to be designated.

Estimated product -1 cubic meter of building material, 8 cubic meters of small building material, 80 steres of cordwood, 150 fagots.

Boundaries - Correspond to the compartment.

Logging - Existing roads.

Estimated prices - 12 francs per cubic meter of building material, 6 francs per cubic meter of small building material, 1.50 franes per stere of firewood, 2 francs per 100 fagots.

(2) In the Saint Die inspection even more data were given in the booklet describing a regeneration felling.

Art. 49-Forest of Moyenmoutier (first working group), Balthazard Canton, Compartment 13 (Lot No. 1), Beat of, etc.

Regeneration felling, 98 trees and 16 poles, to wit:

Diameters: $20,25,30,35,40,45,50,55,60,65,70,75,80,85,90$

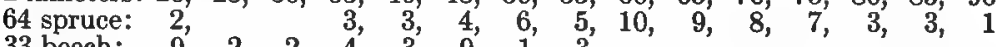
33 beech: $9,2, \quad 2,4,3,9,1,3$,

1 oak:

Estimated product - Fir, 261 meters of sawlogs, 39 steres of fuel; beech, 61 steres; oak and miscellaneous, 3 steres.

Boundaries - North Compartment 12, east, same, south, second lot, west, communal forest of Raon-l'Etape.

Sawmill - Use of the Federal sawmill Briségenoux commencing with the day after the sale of December 31, 1910.

Charges 1 . Francs

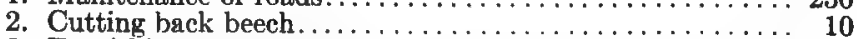

3. Furnishing 16 steres of beech fuel for the forest house at Balthazard, making and transport being estimated at a value of ............................ 45

Total charges....................... $\overline{305}$

Cleaning - Estimated at 5 steres of first-class fuel.

Number of trees to limb before felling, 23.

Etival railroad station, 6 kilometers. 
Pontarlier (Jura) July 4, 1912, composed of dry, diseased, and windfallen trees. At this auction the lot estimates averaged 253 cubic meters (about 60,000 feet board measure and 30 cords) and $\$ 1,099.33$, with average charges for road upkeep, etc., of $\$ 41.69$. In this case it is noted that the "charges" amounted to about one-twenty-sixth of the sale value; in other words, a tax of about 4 per cent to be added to the sale price; but the bid is, in theory, 4 per cent lower. This method of making a charge on the purchaser for the upkeep of roads, for the delivery of fuel, etc., is somewhat similar to the requirements made on the U. S. Forest Service purchasers for piling, scattering, or pulling brush on timber-sale areas; the difference is that in France the "charge" is on the purchaser, so he bids that much less, while in the United States the charge is figured in the appraisal. Out of 65 lots on other forests in the inspection of Pontarlier regular fellings the largest sale made was for 747 cubic meters - the minimum 89 cubic meters and the average 289 cubic meters. In the inspection of Saint Die the first 50 sales made on October 2, 1910, averaged 221 cubic meters, with the maximum at 370 and the minimum at 116. The material sold both at Pontarlier and at Saint Die was almost entirely fir. In the inspection of Oloron, with oak and beech as the chief species, in sales made in 1911 the average number of cubic meters in any one sale (there were 11 sales that only included cordwood) amounted to 157 cubic meters, with a maximum of 732 cubic meters and a minimum of 6 assigned from those sales where there was nothing but fuel cordwood. This shows clearly how the policy of small sales is encouraged in France where conditions make this method possible.

Cutting and Logging Rules. - With the sale of timber on the stump it is essential that the purchaser be given very minute directions how the exploitation should be conducted. The central office at Paris accordingly issues, from time to time, a printed circular giving clauses and conditions that govern sales procedure and exploitation. The last revision was made May 11, 1912, following closely the issue of June 22, 1903, and May 27, 1909. Part III, "Exploitations," of this circular is of interest, and cutting on any timber sale must conform to these general conditions unless the local conservation in which the sale is made has issued ${ }^{38}$ modifications (see p. 298) to the general rules; the essentials are as follows:

Payments must be made in advance of cutting; partial payments are only allowed on long-term sales. Before cutting begins the ranger must be shown the payment receipt.

Estimates. - If the purchaser can show an error in the number of trees advertised he is given a pro-rata reduction.

General conditions. - Timber cannot be piled outside the sales boundaries without special permission, nor is grazing allowed within the felling area. Sawdust and bark must be disposed of as directed.

See also the different methods in long-term sales, p. 301. 


\section{FEATURES OF FRENCH NATIONAL FOREST ADMINISTRATION}

Stumps must be cut with an axe in coppice fellings so that water cannot gather on the stump to cause rot, and in high forests the stumps must be sawed or chopped level with the ground. Where the stumps are removed the holes must be filled up.

Surface of the ground. - Débris must be removed or burned as directed and cordwood stacked as the cutting proceeds. Areas occupied by buildings must be leveled and reforested.

Damage to regeneration and to the stand. - Trees so designated must be topped and limbed before felling and must be thrown up hill so as to cause the least possible damage. In coppice stands old sturnps and weed growth must be cut level with the ground. Peeling of timber while standing is not allowed nor can débris or wood be left or piled on regeneration or against standing timber, nor can standing timber be damaged in any way.

Penalties. - If reserved trees are damaged or destroyed by the exploitation they can be replaced by similar trees marked for cutting, or the purchaser may be required to pay cash at the rate of 3 cents to 9 cents per inch of circumference for standards, or 3 cents to 11 cents for high forest trees, but the timber so paid for remains the property of the State or commune.

Seasons of cutting. - Cutting must be completed by April 1 and corded by June 1; logging by April 15, except for trees peeled, which must be cut by July 1 and corded by July 15. Necessary extensions of time may, for a nominal charge, be granted.

Protection of forest betterments. -- Roads must be maintained and kept free from débris and manufactured products, and all damage to any forest betterment must be repaired or paid for.

Protection of cutting area. - Buildings or betterments made necessary by the sale must be built only on approval of the forest officers, and spark arresters are always required on smokestacks, the purchasers being held responsible for damage.

Logging restrictions. - Hauling must be over designated roads and timber cannot be skidded on roads, rolled or slid down slopes, nor should logs or squared timbers be skidded on the felling areas.

Miscellaneous provisions. - Three days before the check of the felling area purchasers must place stakes near all trees felled to facilitate inspection, the "A. F.," imprint must show upon all stumps or roots.

Foreign labor. - Only a specified percentage of foreign labor can be employed on government sales.

In unit of product sales the same rules apply and in addition the product must be piled by the price classes agreed upon when a joint scale is made; removal is only after specific authorization. In case wood is removed illegally, double the stumpage price can be levied and in addition punitive damages assessed. Extensions of time for logging costs 1.6 per cent the purchase price of the material not logged for each ten days.

Supplemental to these general rules each conservation issues special clauses or modifies general rules which cannot be applied locally. For example, in the ninth conservation, which includes the fir and spruce forests of the Vosges, the use of the saw is authorized for cutting coppice when the stump measures more than 59 inches in circumference. Contractors are not obliged to top and cut the branches from designated trees before felling if they are willing to pay all damage for trees injured in any way. Felling of cordwood may take place at any time during the year and for any species in the inspection of Saint Die, Fraize, Senones, and Remiremont, and in these districts the time for the removal 
of the wood is extended to May 10, of the second year following the sale. The right to bark trees is granted in all fellings, but peeling trees standing is tolerated only under special conditions. Firewood coming from felled trees must be made up within 48 hours after felling. Sliding logs can be authorized by the conservator under exceptional circumstances when it is necessary, but special care must be taken to protect the public and to assume responsibility in case of accident. The contractor is held responsible for all damage to unmarked timber. The fuel to be delivered to forest employees or to communes must be stacked by June 1 following the sale. Foreign laborers can be employed only up to a proportion of 20 per cent. When government saw mills are used special permit is necessary and the contractor must be responsible for the maintenance of the houses and for all equipment. Payments for the use of sawmills are made monthly and the contractor cannot claim any reduction in price because of fire or any other act of Providence. The contractor who, without special authorization, permits manufactured material to remain more than 10 days around the sawmill will be fined 58 cents a day for each day thereafter.

There is a good deal of similarity in the special clauses issued by each conservation, so these will not be repeated unless the wording is of special interest. In the twenty-second ( $\mathrm{Pau}$ ) conservation, which includes the western Pyrenees, the right to add windfalls or damaged trees to current sales is reserved, provided the total windfall does not exceed one-tenth the total original sale. If it does exceed 10 per cent the contractor can refuse to accept the windfall wholly or in part. In the high forest fellings it is provided that the trees marked for cutting can be barked standing. The sliding of the logs is permitted only in the felling areas designated as "mountain felling." Proper precautions to avoid accidents or damage must be taken by the contractor. In the coppice fellings the beech shoots (see p. 94) shall be cut above the stump of the last felling. Contractors may bark coppice trees standing provided they make a circular incision at the foot of each stem at least 4 inches above the root collar. Special provisions are also made for delaying the clean-up on the felling areas to suit local conditions. When sales are made by unit of product the contractor must have the material ready for scaling within 2 months after the felling is completed. The fire wood for forest employees, mayors, schools, etc., will be piled by steres and by bunches of 50 fagots for scaling by the local ranger not later than June 1 of the year following the auction. The reforestation of areas occupied by huts, workshops, and charcoal pits need not be carried out unless specially provided for in the auction announcement. This work will be done according to the methods suggested and at the time fixed by the local ranger and in the presence of the local 


\section{FEATURES OF FRENCH NATIONAL FOREST ADMINISTRATION}

guard. Not more than 60 per cent of foreign workmen can be used in the mountain felling (see p. 302) and not more than 10 per cent for the other fellings.

In the thirty-second conservation, at Vesoul, the special clauses are even more minute.

According to Article 2:

"Peeling oak. - Permission tw peel is granted in all oak fellings. Peeling standing is only permitted if a cireular incision is first made around each stump 5 inches above the soil and provided that the felling keeps pace with the peeling. . . ."

According to Article 3:

"Method of felling. - Fellings shall be made level with the ground except for clumps of beech stool shoots which must be cut in accordance with the direction of the local agent. The use of the saw is authorized in high forest fellings for all trees and in coppice fellings for trees measuring more than 59 inches in circumference at breast high. The local agent can authorize stump extraction in the reserve fellings on condition that the resulting excavations shall be carefully filled and leveled, that these areas shall be planted before the first of April . . . with the species suitable for the soil, at the rate of two per square yard, in accordance with the directions of the forest agents "

According to Article 4:

"Cleaning, extraction of weeds, arrangement of brush. - In the high forest fellings, the contractor must cut level with the ground not later than the first of November of the year following the sale . . . in accordance with the demand of the local ranger all trees damaged, bent, or injured by felling. . . . The branches from peeled oak may be scattered over the felling area between the stumps in accordance with the instructions from the local agents. In all the felling areas, the heather and weeds (if there are any designated in the marking record) shall be hoed up before the fifteenth of April of the year following the auction, except in the selection fellings and thinnings."

Special provision is made for the pruning of branches on the trunks of coppice standards, which must be done before May 15 of each year. Logs or trees can be dragged only in the interior of felling areas and not on roads paved or unpaved except with the express permission of the local ranger. Areas covered with huts or workshops must be leveled and planted at the expense of the contractor before April 1 of the year in which the sale is terminated. Not more than 20 per cent of foreign labor can be employed in the felling areas. Withes will be paid for at the rate of 58 cents per thousand.

Very detailed directions are given for the classification of fuel to be delivered to the Federal and communal employees.

"The fagots must be 4.36 feet in length and 32.5 inches in circumference. . . . Each fagot must be composed of 10 billets having a minimum diameter of 2 inches; fagots may be substituted by stacked billets having at least 8 inches circumference at the small end of beech, or hornbeam at the rate of 3 steres ( 3.6 steres -1 cord) per 100 fagots.

In the twelfth conservation (Besançon), which includes part of the valuable Jura region, trees can be peeled standing and the contractor 
"may leave standing parts of the felling area difficult to log" after designation by a forest officer. Unmerchantable débris is burned if in regeneration fellings, elsewhere it is scattered. In coppice stands "oak, beech, ash, and maple seedlings over 2.5 inches in diameter must be protected." Here, bordering Switzerland, one-third foreign labor is allowed. Cleanings are limited as follows:

"Art. 15. - The cleanings specified by Art. 52 (see Appendix) of the general exploitation rules only pertains to stems at least 8 inches in diameter on the stump; the products of these operations shall be removed, corded, and stacked without delay at the designated places; they shall be delivered to the highest bidders at the price fixed by the contract, and in the absence of special stipulations at the price of 39 cents per stere and 58 cents per 100 fagots."

Such minute and specific directions for all details of forest exploitation can of course be worked out only after years of experience. Specifications are so well known by local contractors and lumber-jacks that it is hardly necessary for them to refer to written specifications which are part of their trade education.

The utilization of timber sales naturally varies with the difficulty of transportation and with the local demand for by-products. In the Pyrenees, on ground difficult to $\log$ and with an expensive haul, defective trees (such as would be logged in a government timber sale in the western United States) are merely girdled to make room for new growth, but may be left standing. Logs half or one-third merchantable are often left to rot. Even in the Landes where, during the war, saw timber stumpage prices rose to $\$ 16$ to $\$ 30$ per thousand feet board measure, the tops were usually left in the woods, since there was no local cordwood market and transport was impracticable; the same conditions prevailed during peace times. In most parts of France every portion of the tree has a market. For example (according to Captain Kittredge) in the Côte d'Or the market is intensive:

"The trees over about 10 inches in diameter are cut into shingle logs, full length to a top diameter of 4 to 6 inches. The stems are hauled off the forest in this form. The material in the coppice and in the tops from 3 to 6 or 8 inches in diameter is cut usually into 52-inch lengths and piled for cordwood. The smaller stems and branches from three-fourths inch to 3 inches in diameter are cut into 26 -inch length sand piled. Later this wood is usually converted into charcoal right on the ground or hauled to a nearby hardwood distillation plant. The twigs below three-fourths-inch diameter are bound into bundles with limber twigs and hauled away for local use as kindling."

Example of a Long-term Sale. - The sale of 236,000 cubic meters (about 66,000,000 feet board measure) extending over a period of 14 years, made by the Inspection at Oloron in 1908, called for deviations from the regular sales methods of France. It is typical of methods used in Corsica in similar sales. Even before the timber was marked and more than two years before the bidding was called for, the local inspector ad- 
dressed circular letters to possible purchasers in order to interest them in the details of the proposed sale. He called attention to the necessity for a personal study of the timber and explained that after the marking a detailed synopsis of the estimated volume would be furnished them, showing the proportion between sawlogs and cordwood. ${ }^{39}$ After the estimate was made the material to be sold was divided into "lots" and the amount of beech and fir in cubic meters was listed separately. The stand in each lot was carefully analyzed as follows:

Situation, altitude, area.- These forests occupy slopes and are on fairly level ground. The slope facilitates logging. The total area is estimated at 14,209 acres at an altitude between 1,640 and 4,921 feet.

Sizes of the trees. - Ninety per cent of the trees included in this sale are more than 21.5 inches in diameter and 10 per cent from 12 to 21 inches. In the forest of Laune, there are very few fir that measure less than 25.5 inches in diameter and there are some as large as 63 inches. The height of the saw timber varies from 30 to 60 feet.

Ounership. - All of the forests are communal.

Rights of v:ay. - There are no rights of way which must be bought. The roads belong to the forests and all the bordering ground belongs to the communes.

Logging. - The purchasers can establish such roads as they deem necessary under the direction and with the approval of the Forest Service. This approval will not be refused. The alignment of the roads will be indicated by the Forest Service. Moreover, the successful bidder can install necessary railroads but must negotiate with the communes for the right of way outside the forest.

The sale. - The sale will be made by public auction.

Contract conditions. - The contract will follow the general rules (see p. 297) of the Forest Administration subject to certain modifications; special clauses will be drawn up to cover the sale.

Price. - The estimated value of the timber is as follows: Lot No. 1, a maximum of 1.15 francs per cubic meter (about 78 cents per thousand board feet). I ot No. 2, a maximum of 1.50 franes per cubie meter (about $\$ 1.01$ per thousand board feet). Lot No. 3, a maximum of 1.25 francs per cubic meter (about 83 cents per thousand board feet).

Cost of logging. - Unfortunately lumber-jacks will have to be imported since there is no local labor available. It is estimated that the cost of felling will be about 19 cents per tree with an addition of 19 cents per stere for cordwood. Unfortunately fire wood is not in demand locally, but perhaps small quantities can be sold at 6.50 francs per stere delivered (about $\$ 4.50$ per cord). Therefore the balance of the wood will have to be made into charcoal. Probably sufficient labor can be imported from Spain or from the Vosges.

Cost of transportation. - Much of the transport in the forest can be by mules, oxen, and cattle. The ox is better for road work and the cattle better for work in the forest itself. The exact cost of transportation will vary according to the distances, the roads, difficulties of ground, etc., so no further exact data can be given. A good cow suitable for logging purposes costs locally from $\$ 58$ to $\$ 68$, while a mule costs $\$ 77$ to $\$ 87$.

Merchantable material. - Fir is in great demand and brings good prices, since Bayonne is only 87 miles from Oloron by railroad. At Oloron the local price is 50 francs

${ }^{39}$ In this locality it was estimated that 100 cubic meters of fir would equal 86 cubic meters of building material and 21 steres of fuel; 100 cubic meters of beech would equal 82 cubic meters of building material and 27 steres of fuel. To reduce round timber to square timber purchasers were advised to multiply by 0.7854 . It is likely that the policy of making large long-term sales will be abandoned by the French government. 
per cubic meter au carrèe ( $\$ 23$ per thousand board feet). The beech, which is generally used for ties, sells at Oloron or at Mauleon at 48 cents each or 25 franes per cubic meter for squared timber ( $\$ 11.50$ per thousand feet). There is a good export demand in Spain where the beech is usually sent to Barcelona, the center of the industry. Detailed data can be secured at this point.

Profits. - As already explained, the maximum price will probably be 1.15, 1.50, and 1.25 francs for the three lots, or an average of 1.28 francs per cubic meter ( 85 cents a thousand feet). The material being about two-fifths fir and three-fifths beech. Considering 86 per cent of the fir and 82 per cent of the beech as building material, this means a net cost of 30 cents per cubic meter of saw timber or 38 cents for squared lumber which would bring at Oloron or Mauléon an average of about $\$ 6.76$.

These calculations upon which the estimated profit and stumpage price is based seem simple and primitive compared with the minute calculations in the United States National Forest appraisals. Nothing is said of the cost of equipment, interest on the capital used, depreciation of equipment, nor cost of supervision. Rule-of-thumb methods are followed, and in the appraisal the contractor's profit was figured at 20 per cent.

This sale was finally made in 1908 , and it is interesting to note that the sale price was 19 cents per cubic meter (about 67 cents per thousand board feet) instead of the 25 cents ( 85 cents per thousand) estimated in the appraisal. According to the special contract conditions the sale, as finally made, covered 10,089 acres, comprising first-class merchantable material, but in part defective, damaged, diseased, or dying trees which were marked for removal for the improvement of the stand. These defective trees were partly girdled and partly felled in the actual operations, the choice being left to the purchaser. As in small sales in France, all the marking was completed prior to the formal auction. The sale was made in one lot, with provision for the division of the proceeds between the various communes interested, based on the volume of merchantable material marked in the forests owned by each, prorated according to the average rate received in each forest. At the auction the minimum purchase price was placed at $\$ 37,635$ and was decreased by jumps of $\$ 193$ until a bidder took it. The payment was made as follows:

Within 10 days of the auction the successful bidder had to pay 10 per cent of the total purchase price and the remainder in twenty-four equal installments payable quarterly on March 31, June 30, September 30, and December 30 of each year, beginning with September 30,1908, and ending June 30, 1914, inclusive. A discount of $1 \frac{1}{2}$ per cent per year was provided for if payments were made in advance of their being called for. The final date for removal of the timber was fixed at December 31, 1922. The compartments could be cut over in the order desired by the contractor, and more than one compartment could be cut at one time. Three years were allowed for felling each compartment after cutting once began. If the imprint of the official marking hatchet shows a tendency to disappear toward the end of the sale the trees already marked will be 


\section{FEATURES OF FRENCH NATIONAL FOREST ADMINISTRATION}

re-marked by the Forest Service in collaboration with the contractor or his representative. Special timber not included in the sale and used for logging was to be charged for at the sale rate of 19 cents per cubic meter ( 67 cents per thousand feet). No claim can be allowed for ground which proves impracticable to log. Wood used for improvement of the roads or any other logging purpose must be purchased at the regular price. The contractor must within 6 months after the expiration of the sale remove all machinery and furnishings; but houses, workshops, or permanent betterments will become the property of the communes upon whose ground they are situated. No allowances were to be made for windfalls or other damages which may occur during the duration of the sale. Special charges aggregating $\$ 6,214.60$ were made for improvements and roads used by the contractor and he had to deliver about 18 cords of fuel per year to the local commune. There are certain features of this sale which should be emphasized:

(1) The stumpage price of 67 cents per thousand is far less than the stumpage for similar timber in the western United States.

(2) The methods of logging were wasteful; the French policy was that the timber had been sold and the purchaser could use it or waste it as he desired. Marked unmerchantable trees could be merely girdled.

(3) Permanent improvements, after the sale is completed, become the property of the commune.

(4) No attempt was made to adjust the stumpage price during the sale period of 14 years; the price of 67 cents held during the entire period. The French felt that rise in timber values would mean proportionately higher operating costs.

(5) The contractor's profit allowed was 20 per cent as contrasted with 10 per cent in ordinary sales.

Stumpage Prices. ${ }^{40}$ - The stumpage values in France under the intensive management that exists are of interest to the American forester because they give a rough indication of the prices that may be secured in this country after the supply of cheap virgin timber is exhausted. But

${ }^{40}$ The prices paid for manufactured lumber by the French Woods Service during 1918-19 were approximately as follows:

\begin{tabular}{|c|c|c|c|}
\hline Species & Class of product & $\begin{array}{l}\text { Franos per } \\
\text { cubic meter }\end{array}$ & $\begin{array}{c}\text { Dollars a per } \\
\text { thoussnd } \\
\text { board feet }\end{array}$ \\
\hline $\begin{array}{l}\text { Hardwoods. } \\
\text { Spruce-fir... } \\
\text { Pine........ }\end{array}$ & $\begin{array}{l}\text { Boards, etc. } \\
\text { Boards, etc. } \\
\text { Boards, etc. }\end{array}$ & $\begin{array}{l}180 \pm \\
160 \pm \\
140 \pm\end{array}$ & $\begin{array}{l}79 \\
70 \frac{1}{2} \\
61 \frac{1}{2}\end{array}$ \\
\hline
\end{tabular}

${ }^{a}$ Exchange at 5.45 francs to $\$ 1$.

But to secure offerings at these low prices the product had to be requisitioned for 
in making the comparison it must be borne in mind that no one can predict what the future conditions will be, and whether changes in building methods will materially modify the demand for lumber, wood products, and timber. Then, too, what will be our cost of production and carrying charges? It is most surprising to find French communes prior to 1912 selling good saw timber in the Pyrenees at 67 cents per thousand board feet,

Army use. According to the French Forest Service the correct commercial prices in March, 1919, were as follows:

\begin{tabular}{|c|c|c|c|}
\hline Species & Class of product & $\begin{array}{c}\text { Francs per cubic } \\
\text { meter }\end{array}$ & $\begin{array}{l}\text { Current dollars a } \\
\text { per thousand } \\
\text { board feet }\end{array}$ \\
\hline $\begin{array}{l}\text { Fir-spruce. } \\
\text { Poplar..... } \\
\text { Oak....... } \\
\text { Beech ...... } \\
\text { Ash....... } \\
\text { Elm ....... }\end{array}$ & $\begin{array}{l}\text { Boards and dimension } \\
\text { Boards and dimension } \\
\text { Boards and dimension } \\
\text { Boards and dimension } \\
\text { Boards and dimension } \\
\text { Boards and dimension }\end{array}$ & $\begin{array}{c}250-300 \\
225 \\
300-350 \\
250 \\
350-400 \\
200-220\end{array}$ & $\begin{array}{c}100-132 \\
99 \\
132-154 \\
110 \\
154-176 \\
88-97\end{array}$ \\
\hline
\end{tabular}

${ }^{a}$ Exchange at 5.45 francs to $\$ 1$.

These prices are excessive and are due to an acute shortage and to speculation, but in 1920 were still higher.

The approximate prices asked by the American E. F. on the liquidation of its stocks in France are as given in the table below. The main reasons for these comparative low prices, in the face of a large demand and acute shortage, were because of (1) need for quick sale, (2) difficulty of transportation, and (3) faulty manufacture as judged by French standards.

\begin{tabular}{|c|c|c|c|}
\hline Product & Unit & $\begin{array}{l}\text { Price at } \\
\text { railroad, } \\
\text { francs per } \\
\text { unit }\end{array}$ & $\begin{array}{l}\text { Approximate equivalent } \\
\text { dollars }{ }^{a} \text { per thousand } \\
\text { board feet }\end{array}$ \\
\hline 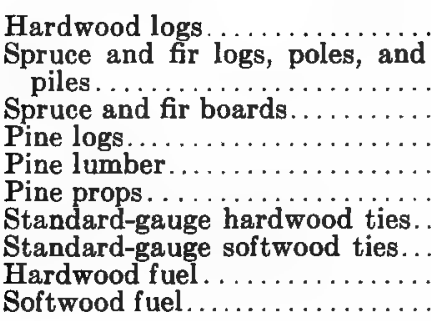 & 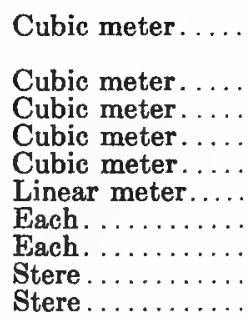 & $\begin{array}{r}82 \\
75 \\
160 \\
55 \\
130 \\
0.90 \\
10.40 \\
6.50 \\
25 \\
15\end{array}$ & \begin{tabular}{|l}
$52 \frac{1}{2}$ \\
48 \\
70 \\
35 \\
57 \\
0.049 per linear foot \\
57 \\
36 \\
16 per cord \\
10 per cord
\end{tabular} \\
\hline
\end{tabular}

a Exchange at $\mathbf{5 . 4 5}$ franes to $\$ 1$.

In the final settlement these prices were reduced 10 to 20 per cent (or more for fuel), but even as they stand they are low even for very large wholesale operations. Until the market becomes stabilized by steady imports the prices will vary, owing to shortage of supply and to speculation. In France the stumpage price represents a larger proportion (often one-third to one-half) of the final market price than it does in the United States.

See also "Private Forestry in France," page 320, for additional data on stumpage prices. 


\section{FEATURES OF FRENCH NATIONAL FOREST ADMINISTRATION}

simply because the logging and transportation was difficult, when similar timber in the Vosges and Jura on accessible forests was, in 1912, worth $\$ 9$ to $\$ 12$ and more. Such a divergence in price seems extraordinary when one compares this price of 67 cents in the Pyrenees near a good market with the $\$ 2$ to $\$ 3$ received for accessible timber difficult to $\log$ in our western National Forests. Perhaps the American has solved the problem of cheap large-scale railroad logging better than the French.

As already emphasized in other chapters, cordwood values of two centuries ago have decreased and saw timber, especially softwoods and oak, has increased. During the war there was much speculation in timberlands, labor was abnormally high, the value of the franc ${ }^{41}$ had depreciated, and transportation was extremely difficult, there was no real competition with import timber from foreign markets because it could not be transported; all tonnage was requisitioned by the Allies solely for war needs. Then, too, many French merchants wanted to have their capital in timberlands rather than in currency or loans.

Before reviewing average local prices it is well to emphasize some of the shortcomings and difficulties of giving average price figures. As in other countries there are "variables" which affect the price of all classes of timber - distance from market, cost and difficulty of logging, kind of cutting (clear cutting or light thinnings), cultural and betterments costs, other economic difficulties and expenses, species, size, quality, local and general demand as compared with the local and general supply, and cost of imported timber. Then, too, abnormal or unusual sales, such as occur after heavy windfall, bring less than regular sales. Quite frequently a local shortage, as in Haute-Savoie during the war, leads to unusual values ${ }^{42}$ because in France there are distinct local markets. This is surprising considering the small size of the country and the comparatively short hauls necessary to enter the general market. It is partly due to the effect of permanent forest production which protects and maintains small local industries and prevents the local market from being exhausted. Under normal conditions the price of French stumpage is the market price for the manufactured product less the cost of cutting, logging, transportation, manufacture, and contractor's profit. In most sales the auction price must be increased by so-called charges for road repair and damage to other forest betterments and growing stock, which in the aggregate averages 5 per cent of the stumpage cost. The French usually distinguish three classes of product: (1) Fuel, (2) saw timber, and (3) miscellaneous products (such as bark). The price of cordwood depends on its size; the

a With a gold reserve of only 16 per cent the French paper currency is really promissory notes issued by the French Government with no date set for liquidation.

${ }^{2}$ Spruce and fir timber on steep rocky slopes, difficult to log sold in 1918 for over 100 francs per cubic meter or over $\$ 63$ per thousand feet board measure for the stumpage secured. 
standard length is now 1 meter (3.4 feet). While diameter classes may differ in various parts of France the following is the usual classification:

\begin{tabular}{|c|c|c|}
\hline Class & Size and specification & $\begin{array}{l}\text { Usual price } \\
\text { ratio } C_{\text {on }} \\
\text { bagis of } \\
\text { ntere }\end{array}$ \\
\hline Quartier... & $\begin{array}{l}\text { Over } 4.7 \text { inches in diameter outside bark at small end. } \\
\text { Split wood } \ldots \ldots \ldots\end{array}$ & 100 \\
\hline $\begin{array}{l}\text { Rondin }{ }^{b} \ldots \ldots \ldots \\
\text { Charbonnette...... } \\
\text { Fagots........... } \\
\text { Bourrées........ } \\
\text { Charcoal ........ }\end{array}$ & 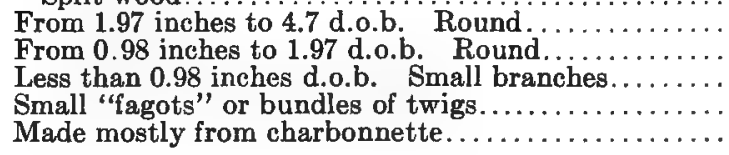 & $\begin{array}{c}\quad 66 \\
33 \\
\cdots \cdots \cdots \\
\cdots \cdots \\
\cdots \cdots\end{array}$ \\
\hline
\end{tabular}

a Subject to wide variation.

b Sometimes two classes of rondin are distinguished (a) small rondin and (b) large rondin.

The price of saw timber (bois d'œuvre) also varies according to the classification of the product:

\begin{tabular}{|c|c|c|}
\hline Class & Size and specification & $\begin{array}{l}\text { Usual price } \\
\text { ratio on basis } \\
\text { cu. m. }\end{array}$ \\
\hline $\begin{array}{l}\text { Bois de Service or construction. } \\
\text { Bois d'Industrie or travail ..... } \\
\text { Bois chauffage................. }\end{array}$ & $\begin{array}{l}\text { (See footnote } 45) \ldots \ldots \\
\text { (See footnote 45) ......... } \\
\text { (See preceding table).... }\end{array}$ & $\begin{array}{r}100 \\
50 \\
15\end{array}$ \\
\hline
\end{tabular}

The minimum diameter of saw timber varies considerably. Oak and beech is used to 9.8 inches for ties, softwoods to 5.9 for saw timber, and 2.7 to 3.1 inches for mine props.

In the "log" and lumber market prices are usually for round logs (grume or au réel) but may also be for:

Squared timber with some wane (au carrée) equal cubic volume of round ${ }^{\text {s }} \log$ $\times 0.7854$.

Squared timber normally without wane or sap (au $t$ e déduit) equal cubic volume of round $\log \times 0.5026$.

Squared timber without wane but with some sap (au $\frac{1}{8}$ e déduit) equal cubic volume of round $\log \times 0.5454$.

Squared timber without wane but with all sap (a vive arète) equal cubic volume of round $\log \times 0.6366$.

The ratios between the different methods of commercial sales are as follows: ${ }^{44}$

43 "Volume grume" is the cubic volume of a round log based on a cylinder with the diameter equal to the middle circumference of the log; it is also called "au réel" when referring to standing timber or stumpage. For further details see Cubage des Bois. R. Roullean., Paris, 1905.

${ }^{4}$ Carnet - Agenda du Forestier, Besançon, 1902, p. 92. 


\begin{tabular}{|c|c|c|c|c|c|}
\hline From & $\begin{array}{l}\text { Au sans } \\
\text { déduction }\end{array}$ & $\begin{array}{c}\text { Au ș sans } \\
\text { déduit }\end{array}$ & $\begin{array}{c}\text { Au z } \\
\text { déduit }\end{array}$ & $\begin{array}{c}\text { Grume } \\
\text { (logs) }\end{array}$ & $\boldsymbol{\Lambda}_{\text {arete }}$ \\
\hline $\begin{array}{l}\text { Meter cube grume (round logs)... } \\
\text { Meter cube grume au } \frac{1}{4} \text { sans déduit } \\
\text { Meter cube grume au } \frac{1}{6} \text { déduit..... } \\
\text { Meter cube grume au } \frac{1}{8} \text { déduit..... } \\
\text { Meter cube grume au } \frac{1}{10} \ldots . . . . . .\end{array}$ & $\begin{array}{l}0.7854 \\
1.3400 \\
1.5625 \\
1.2337\end{array}$ & $\begin{array}{l}0.5454 \\
0.6944 \\
0.0851 \\
0.8567\end{array}$ & $\begin{array}{r}0.5027 \\
0.6400 \\
0.9216 \\
0.7896\end{array}$ & $\begin{array}{l}1.2732 \\
1.8335 \\
1.9895 \\
1.5708\end{array}$ & $\begin{array}{l}0.6366 \\
0.8106 \\
1.1672 \\
1.2665 \\
\cdots\end{array}$ \\
\hline
\end{tabular}

In other words 100 cubic meters of logs are equal to 78 cubic meters of logs squared according to the $\frac{1}{4}$ rule, or 54 cubic meters by the $\frac{1}{6}$ rule. Inspector Montrichard has invented a slide rule by which can be read the contents of a $\log \left(a_{b}\right)$ grume, $(b)$ au $\frac{1}{4},(c)$ au $\frac{1}{5}$, or $(d)$ au $\frac{1}{6}$ of known diameter or circumference and length. The principle of a comparison of log rules by the use of a slide rule has wide application in the United States.

There are frequent misunderstandings, however, because in one locality logs are sold round (or "au réel") while elsewhere the prices quoted are for squared timber "au carrée," and because of different methods of measurements (see p. 207). Thus to speak of French stumpage rates in exact terms it would be necessary to give at least the data enumerated below; obviously in general averages such minute data are out of the question: (1) Region (and forest), (2) haul, (3) species, (4) kind of felling (and area to be cut over), (5) charges, (6) size of trees, (7) per cent $(a)$ saw timber and (b) cordwood.

The forests of the Vosges, Jura, and Savoie are comparable to the coniferous forests of Vermont and northern New Hampshire except that (1) the road system in French forests is already constructed and logging is therefore that much cheaper, (2) the cutting removes a smaller percentage of the stand, and (3) there is a better market and therefore more competition for the stumpage. To secure an exact line on French stumpage rates on timber in these fir-spruce forests logs were scaled on timber sales in 1912, resulting as follows:

(a) In a good stand of silver fir (final felling) 1.1 miles haul to tramway and $\mathbf{1 0 . 5}$ miles from Pontarlier, ten logs averaging 16 inches d. i. b. and $13 \frac{1}{2}$ feet in length sold for 28 francs per cubic meter; 6.6 cubic meters sold for $\$ 36$; the scale of these logs by the Scribner Decimal C rule amounted to 1,350 board feet or $\$ 26$ per thousand feet board measure on the stump. Adding 5 per cent for all charges the rate is $\$ 27.30$ per thousand feet board measure.

(b) In the forest of Gerardmer with a wagon haul of 3 to 4 miles to a broad-gauge station three-fourths spruce and one-fourth fir (intermediate fellings) brought only 18 francs per cubic meter. The sale of a representative number of logs (averaging 6 to 11 inches d. i. b.) by the Scribner Decimal C rule netted $\$ 21.40$ per thousand; which increased 5 per cent for charges is $\$ 22.47$ per thousand feet board measure. In other 
sales in the same forest the rates (based on an actual scale of the logs) were (1) (average d. i. b. 4.4 to 15.6 inches) $\$ 22.17$ per thousand feet board measure or $\$ 23.27$ with 5 per cent added for charges; (2) (average d. i. b. 6.4 to 11.5 inches) $\$ 19.73$ and with 5 per cent added $\$ 20.72$.

(c) In the rich fir forest of Noirémont secondary fellings brought $\$ 21.62$ per thousand feet, or $\$ 22.70$ with the 5 per cent added. Here the haul was longer than in Gérardmer.

(d) In the Jura (forest of Frivelle) small pulpwood on the stump from thinnings was $\$ 3.47$ per cord.

(e) In the forest of Risol (Jura) stumpage was about $\$ 19.30$, or with 5 per cent added $\$ 20.26$.

(f) In the forest of Mouthe (Jura) fine timber near the road cut in final fellings brought $\$ 27.50$ per thousand feet board measure, or with 5 per cent added $\$ 28.87$.

(g) In the forest of Chotel (with a 26-mile downhill haul for the lumber) the price for fir was $\$ 24$ to $\$ 25.20$ a thousand. This high price was due to competition between local mills.

From the foregoing figures it is safe to say that in 1912 the best fir-spruce stumpage, easy to log, sold for $\$ 20$ to $\$ 25$ a thousand feet board measure or four to five times the then current price in northern New England which was between $\$ 4$ and $\$ 8$ per thousand feet board measure. Since the war stumpage prices in France have increased to a greater degree than in the United States.

A comparison of stumpage rates ${ }^{45}$ in the various regions, on the basis of average sales gives a lower price and is less exact but nevertheless of interest. In the table which follows the ratio between thousand feet board measure and cubic meters has been varied according to the estimated size of the timber; this explains why 60 francs per cubic meter of fir is less than 60 francs per cubic meter of oak and why 55 francs per cubic meter in the Cévennes is more than 55 francs in the war zone. Maritime pine which takes 4 cubic meters to the thousand board feet is relatively more expensive (per cubic meter) than fir which takes 3 cubic meters to the thousand. The same applies to small Scotch pine.

${ }^{45}$ For statistical purposes it is presumed that in mature conifer stands cordwood will comprise 10 per cent of the yield (under French logging conditions) and in mature hardwood forests 20 per cent; the amount of cordwood varies, but to simplify the calculations the average saw timber rates have been merely increased 10 per cent and 20 per cent; this provides for the loss in saw timber but allows nothing for the 10 per cent to 20 per cent of cordwood stumpage received by the purchaser in lieu of that much saw timber. The normal rate of exchange has been used.

"Boise d'Oeuvre" or timber included: (1) "Bois de service or de construction" includes (a) "Charpente" or construction timber of considerable size, the exact dimensions varying with the different markets; (b) ties; (c) telegraph poles; mine props. (2) "Boise d'Industrie ou de Travail" may be (a) "sciages," boards, and scantlings of 
310 FEATURES OF FRENCH NATIONAL FOREST ADMINISTRATION TABLE 24. - COMPARISON OF PRE-WAR AND WAR STUMPAGE
PRICES $\odot$ FOR SAW TIMBER PAID BY THE A. E. F.

\begin{tabular}{|c|c|c|c|c|c|}
\hline \multirow{2}{*}{ Region } & \multirow{2}{*}{ Chief of species } & \multirow{2}{*}{$\begin{array}{c}\text { Average } \\
\text { pre-war } \\
\text { prices, } \\
\text { francs } \\
\text { per cubic } \\
\text { meter }\end{array}$} & \multirow{2}{*}{$\begin{array}{l}\text { Approrimate } \\
\text { dollars per } \\
\text { thousand }\end{array}$} & \multicolumn{2}{|c|}{$\begin{array}{c}\text { A verage war prices } \\
1918-19\end{array}$} \\
\hline & & & & $\begin{array}{l}\text { Franes } \\
\text { per cubie } \\
\text { meter }\end{array}$ & $\begin{array}{l}\text { Approximate } \\
\text { dollars per } \\
\text { thousand }\end{array}$ \\
\hline 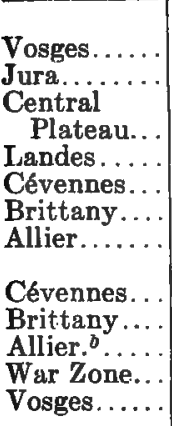 & 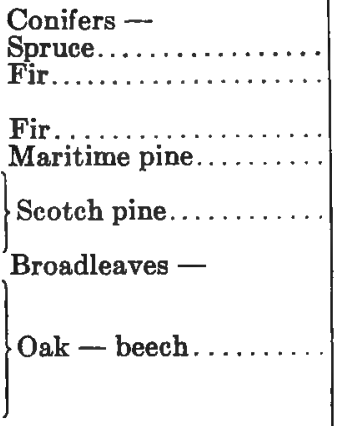 & $\begin{array}{l}18 \\
11 \\
15\end{array}$ & $\begin{array}{r}14.00 \\
12.75 \\
11.45 \\
9.30 \\
12.70\end{array}$ & $\begin{array}{l}55 \\
58 \\
\\
37 \\
28 \\
33 \\
35 \\
30 \\
\\
70 \\
55 \\
60 \\
55 \\
41\end{array}$ & $\begin{array}{l}34.75 \\
37.00 \\
\\
23.50 \\
24.00 \\
28.00 \\
28.70 \\
25.50\end{array}$ \\
\hline
\end{tabular}

a Based on data collected by the American Delegate, Interallied Timber Executive Committee, Paris, France.

${ }^{b}$ Chiefly Haute-Marne, Meuse. In this connection see the stumpage rates given on p. 320, Chapter XI.

It is especially with hardwood logs that the price per cubic meter varying length, width, and thickness according to local species and market; (b) "Bois de fente" cooperage stock, etc.

As an illustration of French lumber grades the following "Sciages du Jura" is given:

\begin{tabular}{|c|c|c|}
\hline French term & Width, inches & Thickness, inches \\
\hline 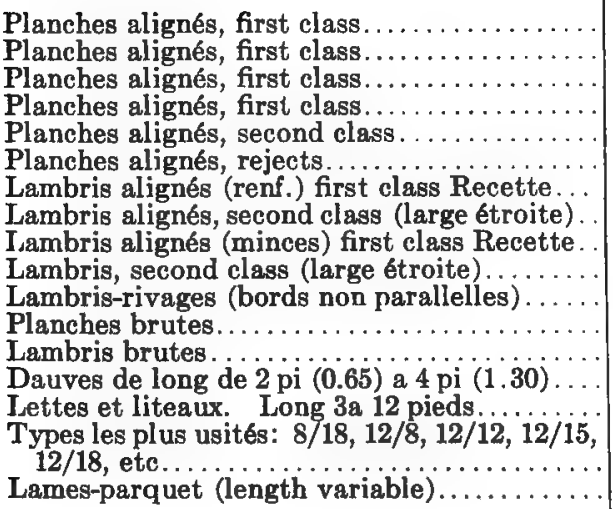 & $\begin{array}{r}12.80 \\
11.71 \\
10.65 \\
4.26-7.48 \\
4.26-12.80 \\
4.26-12.80 \\
8.74-12.80 \\
4.26-7.48 \\
8.74-12.80 \\
4.26-7.48 \\
\ldots \ldots \ldots \ldots \\
3.19-5.32 \\
0.71-1.60 \\
\\
0.04-0.07\end{array}$ & $\begin{array}{r}0.98-1.08 \\
0.98-1.08 \\
0.98-1.08 \\
0.98-1.08 \\
0.98-1.08 \\
0.98-1.08 \\
0.71 \\
0.71 \\
0.52 \\
0.52 \\
0.42-0.71 \\
1.08-1.60 \\
0.52-0.71 \\
0.71-0.98 \\
0.71-1.08 \\
\\
0.71-1.08\end{array}$ \\
\hline
\end{tabular}


varies widely with the size. For example the official price for oak in the Meuse department in October, 1918, was as follows:

\begin{tabular}{|c|c|c|}
\hline Diameter, breast height, inches & France per cubic meter & $\begin{array}{l}\text { Approximate dollars } \\
\text { per thousand }\end{array}$ \\
\hline $\begin{array}{r}7-11 \ldots \ldots \\
11-17 \ldots \ldots \\
17-24 \ldots \ldots \\
\text { Over } 24 \ldots\end{array}$ & $\begin{array}{l}24 \\
36 \\
54 \\
72\end{array}$ & $\begin{array}{l}21 \\
26 \\
36 \\
42\end{array}$ \\
\hline
\end{tabular}

These prices are about 30 per cent to 50 per cent over the pre-war rate. The price of beech is usually about two-thirds that of oak and the larger the size the more marked is the difference in price.

Before the war cordwood was difficult to dispose of and all the small material (charbonnette) was made into charcoal before it could be moved from the forest. During the war the coal shortage doubled and tripled prices. In the Haute-Marne the averages for all State hardwood-fuel sales on the stump were as follows:

\begin{tabular}{|c|c|c|c|c|c|c|}
\hline \multirow{2}{*}{ Class of product } & \multicolumn{2}{|c|}{1914} & \multicolumn{2}{|c|}{1917} & \multicolumn{2}{|c|}{1918} \\
\hline & $\begin{array}{c}\text { Francs } \\
\text { per } \\
\text { stere }\end{array}$ & $\begin{array}{l}\text { Approx. } \\
\text { dollars } \\
\text { per cord }\end{array}$ & $\begin{array}{c}\text { Franes } \\
\text { per } \\
\text { stere }\end{array}$ & $\begin{array}{l}\text { Approx. } \\
\text { dollars } \\
\text { per cord }\end{array}$ & $\begin{array}{c}\text { Francs } \\
\text { per } \\
\text { stere }\end{array}$ & $\begin{array}{l}\text { Approx. } \\
\text { dollars } \\
\text { per cord }\end{array}$ \\
\hline $\begin{array}{l}\text { Quartier........ } \\
\text { Rondin....... } \\
\text { Charbonnette.. }\end{array}$ & $\begin{array}{l}5.30 \\
3.10 \\
0.35\end{array}$ & $\begin{array}{l}3.70 \\
2.10 \\
0.24\end{array}$ & $\begin{array}{l}7.80 \\
5.70 \\
1.20\end{array}$ & $\begin{array}{l}5.40 \\
4.00 \\
0.83\end{array}$ & $\begin{array}{r}15.00 \\
11.00 \\
5.00\end{array}$ & $\begin{array}{r}10.40 \\
7.60 \\
3.50\end{array}$ \\
\hline
\end{tabular}

These prices are typical of average conditions in France; most of the salable fuel comes from the tops of hardwood trees or from coppice. Softwood cordwood has but little value in the Landes or in the mountains. Near the large towns the prices in the above table may be largely exceeded. The American E. F. settled most of its cordwood purchases from State or communal forests at 9 francs per stere for quartier, 6 francs for rondin, and 3 francs for charbonnette. A large purchase in the Côte d'Or was recommended for settlement at a flat rate of 5.50 francs per stere ( $\$ 3.80$ per cord). This was about double the 1914 rates. ${ }^{46}$

There has been much speculation regarding future French prices. Unquestionably in the general market prices will fall to the level established by the cost of imports and will be below war rates, but much

16 It should be noted that the early 1919 exchange rate was 5.80 francs to one dollar; toward the end of 1919 it was 10 to $11 \frac{1}{2}$ francs to the dollar, but all conversions have been made on the normal value of the franc, 19.3 cents. 


\section{FEATURES OF FRENCH NATIONAL FOREST ADMINISTRATION}

higher ${ }^{47}$ than the 1912 price level because the demand for timber will exceed the supply for years to come. For the next few years the prices may go even higher because of the depreciation of the franc and because of unrestrained speculation.

Additional original data on stumpage prices during the past century has been supplied (March 27, 1920) by the Directeur Général des Eaux et Forêts, from the official archives at Paris, but $\mathbf{M}$. Dabat states in his letter of transmittal:

“. . . . I must call your attention to the fact that since the price of timber is not under official control, the figures below have only a relative value . . . they only indicate . . . . and are not exact data on the price variations during the long period examined."

${ }^{47}$ According to data furnished by Colonel Sutherland, C.B.E., the average market price of pitwood, "ex ship Cardiff" has been as follows:

\begin{tabular}{c|c||c|c}
\hline Year & Dollars per ton & Year & Dollars per ton \\
\hline 1910 & 4.70 & 1915 & 8.76 \\
1911 & 5.31 & 1916 & 11.22 \\
1912 & 5.39 & 1917 & 16.79 \\
1913 & 5.49 & 1918 & 15.86 \\
1914 & 5.56 & 1919 & 15.86 to 13.42 \\
\hline
\end{tabular}

The dollar has been figured at the normal rate of $\$ 4.87$ to 20 shillings. It is significant that the English coal mines are withholding their orders and are now refusing to pay the high war rates, and on January 1, 1920, report the market "glutted." A ton is equal to about one cubic meter; it takes 3.6 stacked cubic meters to make one cord. The relative imports (chiefly from France) from the "board of trade returns of imports of pitprops and pitwood" in million carloads are as follows:

\begin{tabular}{c|c|c|c}
\hline Year & Million loads & Year & Million loads \\
\cline { 2 - 3 } 1902 & 2.0 & 1911 & 2.9 \\
1903 & 2.3 & 1912 & 2.9 \\
1904 & 2.3 & 1913 & 3.45 \\
1905 & 2.1 & 1914 & 2.5 \\
1906 & 2.4 & 1915 & 2.1 \\
1907 & 3.0 & 1916 & 2.0 \\
1908 & 2.6 & 1917 & 1.0 \\
1909 & 2.8 & 1918 & 0.7 \\
1910 & & 1919 & 1.5 \\
\hline
\end{tabular}


(a) State Forest of Tronçais (Allier), oak saw-timber stumpage prices:

\begin{tabular}{c|c|c}
\hline Year & $\begin{array}{c}\text { Franes per cubic } \\
\text { meter }\end{array}$ & $\begin{array}{c}\text { Approx dollars per } \\
\text { 1,000 board feet }\end{array}$ \\
\cline { 2 - 3 } 1820 & 34.00 & \\
1830 & 36.50 & 26.00 \\
1840 & 43.00 & 28.00 \\
1850 & 30.00 & 33.00 \\
1860 & 51.00 & 23.00 \\
1870 & 53.00 & 39.00 \\
1880 & 32.00 & 40.75 \\
1890 & 42.00 & 24.50 \\
1900 & 60.00 & 32.25 \\
1910 & 70.00 & 46.00 \\
1920 & 170.00 & 53.75 \\
& & 130.50 \\
\hline
\end{tabular}

a Estimated.

(b) State Forest of Ban d'Etival (Vosges) fir saw-timber stumpage prices:

\begin{tabular}{l|c|c}
\hline Year & $\begin{array}{c}\text { Francs per eubic } \\
\text { meter }\end{array}$ & $\begin{array}{c}\text { Approx dollars per } \\
1,000 \text { board feet }\end{array}$ \\
\hline $1835-1870$ & 10.00 & 7.00 \\
$1871-1889$ & 13.50 & 9.50 \\
$1890-1899$ & 15.00 & 10.50 \\
$1900-1909$ & 20.00 & 14.00 \\
$1910-1913$ & 22.00 & 15.50 \\
1918 & 60.00 & 42.25 \\
\hline
\end{tabular}

(c) State Forest of Gérardmer (Vosges), fir saw-timber stumpage prices:

\begin{tabular}{c|c|c}
\hline Year & $\begin{array}{c}\text { Francs per cubic } \\
\text { meter }\end{array}$ & $\begin{array}{c}\text { Approx. dollars per } \\
1,000 \text { board feet }\end{array}$ \\
\cline { 2 - 3 } $1870-1879$ & 9.50 & 6.75 \\
$1880-1889$ & 11.00 & 7.75 \\
$1890-1899$ & 11.50 & 8.00 \\
$1900-1909$ & 14.00 & 9.75 \\
$1910-1913$ & 20.00 & 14.00 \\
1918 & 60.00 & 42.25 \\
\hline
\end{tabular}




\section{FEATURES OF FRENCH NATIONAL FOREST ADMINISTRATION}

(d) Gérardmer Region (Vosges), hardwood cordwood stumpage prices:

\begin{tabular}{c|c|c}
\hline Year & Francs per stere & $\begin{array}{c}\text { Approx. dollars per } \\
\text { cord }\end{array}$ \\
\hline $1830-1839$ & 5.00 & 3.50 \\
$1840-1849$ & 6.00 & 4.20 \\
$1850-1859$ & 5.50 & 3.85 \\
$1860-1869$ & 5.50 & 3.85 \\
$1870-1889$ & 6.00 & 4.20 \\
$1890-1899$ & 6.00 & 4.20 \\
$1900-1909$ & 5.60 & 3.92 \\
1918 & 16.00 & 11.20 \\
\hline
\end{tabular}

(e) Port of Clamecy (Yonne), coppice cordwood ready to load on canal boats:

\begin{tabular}{c|c|c}
\hline Year & Francs per stere & $\begin{array}{c}\text { Approx. dollars per } \\
\text { cord }\end{array}$ \\
\hline & $10.30-14.50$ & $7.21-10.15$ \\
$1817-1827$ & $11.00-8.00$ & $7.70-5.60$ \\
$1837-1847$ & $10.00-9.00$ & $7.00-6.30$ \\
$1857-1867$ & $12.00-11.00$ & $8.40-7.70$ \\
$1877-1887$ & $10.00-12.50$ & $7.00-8.75$ \\
$1897-1907$ & $9.50-25.00$ & $6.65-17.50$ \\
$1913-1918$ & & \\
\hline
\end{tabular}

A study of these figures shows:

(1) There have always been higher saw-timber stumpage prices during and after great wars; and that investors who placed their money in forests in 1914 would have been spared the losses due to the depreciation of French currency.

(2) Stumpage values for saw timber during the past century have about doubled and since the war have been almost three times the pre-war value.

(3) Stumpage values for cordwood have remained about the same for the past 100 years, but during the war they almost tripled owing to the shortage of coal throughout France.

(4) The prices charged the American E. F. by the French Government (see p. 310) were much less than the current commercial average rates. Some of the difference in price is due to the fact that the timber cut by the American E. F. took fewer cubic meters to the thousand board feet than that sold the average customer. 


\section{CHAPTER XI \\ PRIVATE FORESTRY IN FRANCE}

General Discussion (p. 315). Trend of Private Ownership, Areas and Systems of Management, Legislation Against Deforestation, Forestry as an Investment, Money Yields from Public Fir Forests (Jura-Doubs), Drawbacks and Advantages to Forest Investments, Indirect Benefits.

Examples of tie Best Private Forestry (p. 323). Three Notable Forests, The Grand Domaine of Arc-et-Chateauvillain (Haute-Marne), Forest of Amboise (Indreet-Loire), A Fir Forest (Vosges), Conclusions.

\section{GENERAL DISCUSSION}

Trend of Private Ownership. - In 1912, when the last statistics were compiled, seven-tenths of the forest area in France was privately owned and with the possible exception of the Landes and Gironde this forest area was largely in small holdings. Out of ten departments, taken at random, there were 97,710 owners, each with less than 25 acres of forest, the average holding being 3.2 acres. In the Puy-de-Dome department 101,510 acres were in the hands of 32,684 persons, and around Paris 31,085 owners divided 50,787 acres. In all France it is safe to say that there are less than 100 families that own more than 5,000 acres each. From the national and political standpoint this era of small forest holdings is beneficial. It has been stated that social upheavals will be prevented by this division of forest and agricultural land. But other things being equal forests divided into small ownerships benefit a nation but deteriorate the stand. The reason is that the peasant cuts spasmodically to satisfy his needs in the village or farm, to realize on his capital, or to allow an estate to be settled. The large owner on the contrary can afford to employ a competent forester and can manage his forest as a permanent producing business, based on a sustained annual yield. Or, better than this, the rich landlord may increase his growing stock and improve a deteriorated stand. 1 The kings and nobles formerly owned the best high forests in France and to-day the best of the private forests are unquestionably in the hands of the old nobility and the new industrial millionaire.

1 The Count de Grancey, the largest private owner in the Côte d'Or, had increased his coppice rotations and was increasing the number of standards. It was unfortunate that some of his best stands had to be requisitioned and cut for the A. E. F. fuel supply. 
But nevertheless many of the great forest properties are disappearing ${ }^{2}$ because the higher cost of operation usually reduces the return to less than 3 per cent.

Areas and Systems of Management. - No less than 15,988,857 acres of forest (out of a total of 24.4 million acres) are in private ownership. Of this 610,901 acres are unproductive; 4,856,214 acres in coppice; $5,856,947$ acres in coppice-under-standards; 106,314 in conversion; and less than one-third, or 4,558,481 acres, in high forest. In other words more than two-thirds of the private forests are in coppice or coppice-under-standards, and in 1912 less than 1 acre in 100,000 was being converted to high forest. The individual clearly wants his forest to yield returns frequently and he desires but a small amount of capital tied up in growing stock. Therefore it is only when local conditions almost force the high forest on the private owner that he holds this class of stand. In the Landes and Gironde, in parts of the Sologne, in mining districts where there is a great demand for props, and in the mountains where coppice will not thrive, he must fall back on the high forest. In order to still further reduce the capital tied up in growing stock the private owner invariably chooses shorter rotations than does the technically trained State forester. It is not infrequent that private coppice is managed under a 6 - to 18-year rotation, whereas the State forest coppice would be at least 25 to 40 years. For spruce or fir the public forest rotation would be 120 to 180 years and the private forest 30 to 120 . A similar difference exists in pine stands, although this difference is less marked with maritime pine than with Scotch pine.

Legislation Against Deforestation. - All through the later forest history of France the Government has always tried to restrain the private owner and force him to conserve his property. "The files of the Chamber of Deputies are full of projects that menace forest property," wrote Bonnevoy, the Rhône deputy, in commenting on proposed conservation laws. Yet from 1815 to 1870 the State itself sold no less than 871,401 acres $^{3}$ of public forest for $\$ 59,251,000$ !

With the necessity for restraining the private owner it is not surprising that there should be a stringent law against the "clearing of private timber" revised and reënacted in 1859 (see p. 263).

The owner is given an opportunity to present his argument at a public hearing. It is my impression that the law is leniently applied but in notable instances large properties have been held to be essential forest land and could not be clear cut. Most French laws benefit and protect the private owner, especially against theft, trespass, and fire.

${ }^{2}$ The great forest of Eu-et-Aumale was sold in 1912 for $\$ 1,883,500$ to a company which was preparing to clear cut. This the Government was unwilling to allow and was, therefore, planning to purchase it as a State forest.

${ }^{8} \mathrm{Du}$ Rétablissement de Nos Forets, par Ch. Broilliard. Besançon, 1910. 
Where the owner of land has mismanaged it and allowed erosion or drifting sand to destroy its value, even then the State must buy the land before reclaiming it, notwithstanding the resulting common good for the community. If land is being damaged by overgrazing it can be reserved from further use, but during a 10-year period the value of the rental must be paid the owner, and if after that period forestation is deemed necessary, exappropriation, with payment, is obligatory.

The dunes, as well as the mountain reforestation areas which have been restocked, are exempt from taxation for a period of 30 years. Other plantations are exempt for 20 years only and this applies also to the restocking of blanks which have existed for at least 10 years before the passage of the law. ${ }^{4}$ Even during the war, where the power of Army requisition had been extended to cover standing timber needed by the Allies as well as by the French people, the rights of the individual were fully protected. In fact an individual with political power could sometimes evade the requisition. The conclusion is that the property rights of the individual are practically free from obnoxious State control, and that in fact every encouragement is given the private owner to practice forestry.

Forestry as an Investment. - Many writers (even such an eminent authority as Broilliard) have argued that money in savings banks paying only $2 \frac{1}{2}$ to 3 per cent interest ${ }^{5}$ had better be invested in producing forests. In forest valuation it is customary to use low interest rates for calculations. Certainly one reason why this is done is because usually if rates of 4 per cent or more are adopted for the basic interest rate the forest investment shows a decided loss. Yet even here there are notable exceptions as in the Landes where it was estimated that by sowing sand wastes, soil formerly worth an average of 77 cents per acre is now selling at $\$ 54$ to $\$ 93$ per acre. We know that it cost some 10.3 million dollars

${ }^{4}$ L'Impôt sur le revenu des Forêts, S. F., XI, 5, pp. 372-375.

5 The interest rates paid by the French Government have varied from a maximum of 8.6 per cent (in 1816) to a minimum of 3 per cent, the prevailing rate in 1901 . Notable variations in these rates, due to wars and revolutions, are shown in the following table (after Huffel) for 100 years:

\begin{tabular}{|c|c|c|c|c|c|c|c|}
\hline Year & Per cent & Year & Per cent & Year & Per cent & Year & Per cent \\
\hline $\begin{array}{l}1816 \\
1818 \\
1821 \\
1823 \\
1828 \\
1830\end{array}$ & $\begin{array}{l}8.60 \\
7.52^{a} \\
5.79 \\
5.58 \\
3.87 \\
3.92\end{array}$ & $\begin{array}{c}1832 \\
1841 \\
1845 \\
1847 \\
1848 \\
\ldots \ldots \ldots\end{array}$ & $\begin{array}{l}5.06 \\
3.13^{b} \\
3.95 \\
3.88 \\
5.00^{c} \\
\ldots \ldots \ldots\end{array}$ & $\begin{array}{l}1854 \\
1855 \\
1859 \\
1861 \\
1863 \\
1868\end{array}$ & $\begin{array}{l}7.81^{d} \\
4.61 \\
4.83 \\
4.32 \\
4.50 \\
4.32\end{array}$ & $\begin{array}{l}1870^{\circ} \\
1870^{\circ} \\
1871 \\
1886 \\
1901 \\
1918\end{array}$ & $\begin{array}{l}4.95 \\
7.42 \\
6.23 \\
3.75 \\
3.00 \\
6.83\end{array}$ \\
\hline
\end{tabular}

$a$ and $7.45,{ }^{b}$ and $3.50, c$ and $6.64,{ }^{d}$ and $4.69,^{e}$ and $4.00,{ }^{f}$ Aug., $o$ Oct. 
to reforest 1.6 million acres, or about $\$ 6.41$ per acre. As a national investment this has certainly paid. It has created enormous wealth in a region formerly poverty stricken and unhealthy. But from the standpoint of the individual to-day the investment is not so attractive, because, if the sale value is compared with the revenue it is seen that land worth (with its growing stock) perhaps $\$ 54$ per acre nets year in and year out about $\$ 2.22$, or about 4.1 per cent. According to $\mathrm{Huffel}^{6}$ the average returns from private forests were, in 1892, 1.16 cubic meters (about twothirds to three-fourths of this is fuel) worth 67 cents per acre per year ( 2.90 cubic meters and 16.80 francs per hectare). If we place a soil and growing stock value of only $\$ 30.88$ per acre (400 francs per hectare) the net return is about 4 per cent. The return is probably less than this. According to French data the lower the soil values the better the forest investment but the higher the risk from fire, fungus, insects, and acts of Divine Providence. This seems logical because the risk in the management of maritime pine on Landes sand is unquestionably greater than in the thrifty coppice of the Côte d'Or on rich well watered soil.

According to Huffel's definition the soil or "fonds" includes everything that remains in a forest after it is completely clear cut: the unmerchantable part of the stumps, roots, seed, humus, dead leaves, boundaries, roads, management divisions, drainage ditches, fire lines, forest houses, and all other betterments. Any study of soil values shows the advantage of reforesting cheap, so-called waste land; proof is abundant in French forest history - the Landes Sands (where values increased from 77 cents to as many dollars per acre), the uncultivated land in Champagne (which sold at $\$ 1.50$ to $\$ 4.50$ until planted to Austrian pine, when soil values increased to $\$ 10$ or more, because it could produce $\$ 60$ per acre from timber crops on a short rotation); similar advantages occurred to foresting cheap waste soils in the Central Plateau, Sologne, and elsewhere. But the State had to prove the way. Values are created; for before the forestation the value of the soil is the local sale value, while after the pioneer has created the forest the value is based on what the soil can produce. It has been made revenue-producing, and the pioneer reaps the profit.

A good illustration may be taken from the sale of stock. Let us assume that a wire company sells its stock at par, or $\$ 100$ a share, and pays 8 per cent (in accordance with 1920 rates). The concern prospers, earns and pays 12 per cent. Capital values have been created by its earning capacity and the stock sells at $\$ 150$ a share instead of $\$ 100$. The same increase in values occurs when barren soil is made to produce salable forests.

- Economie Forestière, Vol. I, p. 407. G. Huffel, 1904. Some writers claim a return of 6 to 7 per cent on timber investments in the Landes. See also Chapter VIII. 
French writers are apt to make excessive claims for forest investment returns, Risler, ${ }^{7}$ director of the Institut Agronomique, claiming 5 to 10 per cent for conifer plantations. For a pine plantation near Selongey (Côte d'Or) a return of 5.7 per cent was claimed ${ }^{8}$ for a 30 -year rotation on soil worth $\$ 7.72$ an acre (100 francs per hectare). For a larch stand at Boisy near Geneva, Barbey claimed a return of 6.30 per cent. And it was said that "a private owner in the Pyrenees spent 10,000 francs on reforesting uncultivatible slopes worth 20,000; forty-five years later he left to his children a property worth 270,000 francs." Cases such as this are numerous where the owner reaped good returns by reforesting ground which he would have held anyway.

The following returns are cited for plantations of broadleaf species, such as chestnut:

\begin{tabular}{|c|c|c|c|c|c|}
\hline Soil & $\begin{array}{l}\text { Soil cost } \\
\text { per acre }\end{array}$ & $\begin{array}{c}\text { Cost of } \\
\text { plantation } \\
\text { per acre }\end{array}$ & $\begin{array}{c}\text { Return } \\
\text { at end } \\
\text { of rotation }\end{array}$ & Rotation & $\begin{array}{l}\text { Rate of } \\
\text { return, } \\
\text { per cent }\end{array}$ \\
\hline $\begin{array}{l}\text { Mediocre........ } \\
\text { Quite good..... } \\
\text { Very favorable. }\end{array}$ & $\begin{array}{r}\$ 3.86 \\
9.65 \\
19.30\end{array}$ & $\begin{array}{r}\$ 7.72 \\
9.65 \\
11.58\end{array}$ & $\begin{array}{r}93 \\
193 \\
386\end{array}$ & $\begin{array}{l}35 \\
40 \\
50\end{array}$ & $\begin{array}{l}6.25 \\
6.00 \\
5.12\end{array}$ \\
\hline
\end{tabular}

For a fir stand in the Doubs on poor soil an average annual revenue of $\$ 8.96$ per acre was secured (116 francs per hectare) but there are no exact data on the soil and growing stock values. Extraordinary yields are often cited for this region. Mangenot owned 9.1 acres which in 1868 were estimated to have 1,510 trees or 667 cubic meters worth 9,265 francs. From 1868 to 1890 he cut 498 trees or 604 cubic meters and sold at 9,650 francs; in 1890 he still had 1,600 trees estimated at 660 cubic meters and worth 9,165 francs. These exact data cited by Schaeffer ${ }^{9}$ were equal to a net annual yield of about $\$ 9$ per acre per year. The growing stock per acre was worth in round figures $\$ 199$ and the soil at least $\$ 10$, so this return of $\$ 9$ per acre was only 4.3 per cent on the invested capital in a favorable forest region and with rapidly growing fir, spruce, and beech. But it should be noted that if this property had been held until 1918 and then clear cut down to a low diameter limit he would have doubled his money because of the high prices prevailing during 1918 and because the French currency had depreciated. But this introduces a new feature - a speculative one - which is present in all forest investments, namely, the sporadic increase in stumpage values with occasional very high levels.

7 Placements Financiers en Bois. A. Jacquot.

${ }^{8}$ In the State forest of Levier the gross returns have been as high as $\$ 15.90$ per acre, according to an engineer officer writing in American Forestry (p. 1537), 1919.

- Quelques Conseils aux Sylviculteurs du Chablais. A. Schaeffer, Annecy, 1894. 
Much of this increase may be due to the decrease in the purchasing power of money in addition to an increasing shortage of supply. In the.State and communal forests under the inspector at Lorient (Morbihan) the average price per cubic meter for commercial sales ${ }^{10}$ was as follows:

\begin{tabular}{c|c|c|c}
\hline Year & $\begin{array}{c}\text { Total sales, } \\
\text { cubic meters }\end{array}$ & $\begin{array}{c}\text { Average price, francs } \\
\text { per cubic meter }\end{array}$ & $\begin{array}{c}\text { Price } \\
\text { per thousand feet } \\
\text { board measure }\end{array}$ \\
\hline 1890 & 12,749 & 10.99 & $\$ 11.31$ \\
1900 & 16,932 & 13.34 & 13.73 \\
1910 & 21,211 & 14.78 & 15.22 \\
1912 & 41,338 & 8.58 & 8.83 \\
1913 & 25,365 & 11.90 & 12.25 \\
1914 & 18,586 & 10.70 & 11.02 \\
1915 & 23,560 & 14.28 & 14.70 \\
1916 & 25,822 & 14.69 & 14.86 \\
1917 & 23,353 & 23.16 & 23.84 \\
1918 & 25,032 & 29.54 & 30.41 \\
\hline
\end{tabular}

a This is only approximate since these prices were averages including cordwood. To reduce to dollars per thousand, the average price figure has been increased $33 \frac{1}{3}$ per cent and four cubic meters counted to the thousand board feet.

These original data show how the private owner could have taken advantage of the prevailing high prices in 1917 and 1918 and could have profitably reduced his growing stock. They also show a steady increase in price since 1890, with the probability of much higher prices even after the abnormal war conditions are passed. Under such conditions the new owner, who has bought at the higher price level, may be influenced to cut and sell at the new price level.

The forest investment, even after stumpage values increase, is much the same because the capital values of the land and growing stocks have increased in the same proportion; but it is during such times that the incentive to liquidate the investment is greatest.

Money Yield from Public Fir Forests (Jura-Doubs). - It is interesting to compare the returns from the private forests just reviewed with those from public forests which are perhaps more conservatively managed. Table 25 which follows ${ }^{11}$ shows the basic data:

Much can be learned from a study of the following table, for the past history of four important State and communal fir and spruce forests in the Jura Mountains can be accurately analyzed. (a) The average rotation is 150 years; in other words it takes 150 years to grow (Jura) fir and spruce 22.8 inches in diameter breast-high. (b) The average stand (mean

${ }^{10}$ The low price in 1912 was due to windfall; the low price in 1914 was due to the unsettled conditions prevalent during the initial period of the war.

${ }^{11}$ From original data prepared by Inspecteur Dévarennes. Such detailed data on managed French forests have never before been made public in the United States. 


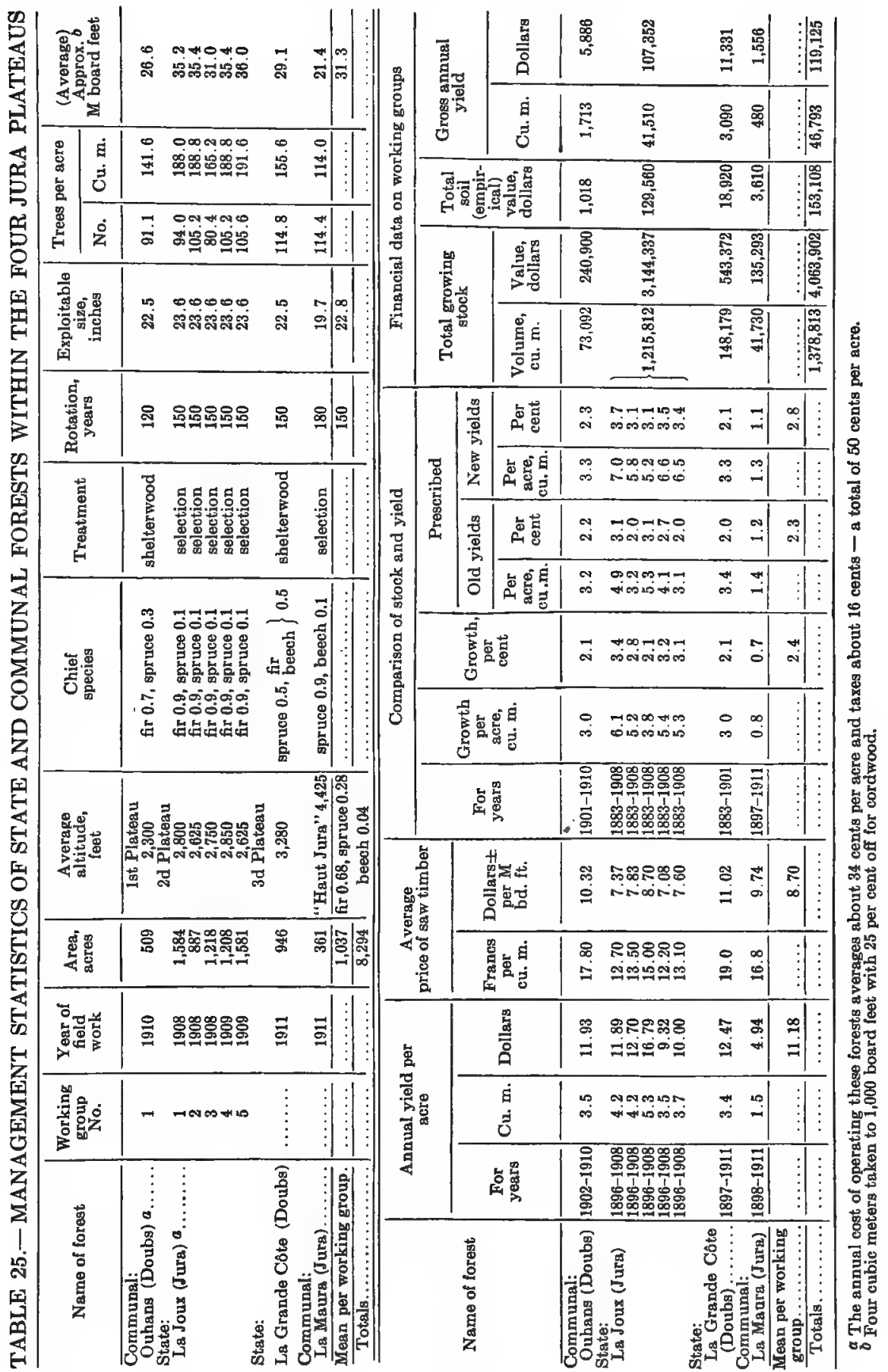


per working group) over the whole area of 8,294 acres is over 31,000 board feet per acre. This was secured by natural regeneration. (c) The average working group is 1,037 acres (see p. 226). (d) The gross yield per acre is $\$ 11.18$ and the net yield about $\$ 10.68$; this $=$ for mountain land unquestionably unsuited to agriculture. The average price for saw timber prior to 1911 was $\$ 8.70$ per thousand feet board measure on the stump. The local stumpage prices are now three to five times that figure. (e) These fir-spruce forests averaged 2.4 per cent in growth and the prescribed yield was 2.8 per cent of the growing stock - a little more than the growth so as to reduce the quantity of overmature timber. (f) In $1908-1911$ the capital invested was: Timber growing stock $\$ 4,063,902$; empirical soil value (estimated), $\$ 153,108$; total, $\$ 4,217,010$.

The gross annual revenue ${ }^{12}$ from timber sales was: $\$ 119,125$; annual cost of administration and taxes, $\$ 4,147$; annual net return, $\$ 114,978$.

This is about 2.7 per cent net on the invested capital ${ }^{13}$ for the period prior to $1908-1911$, or perhaps $2 \frac{1}{2}$ per cent on a conservative basis. It should be noted that this is less than secured by private owners who use shorter rotations and do not allow excess growing stock to accumulate.

Drawbacks and Advantages to Forest Investments. - Many forest owners were almost ruined when the demand for charcoal and cordwood was largely reduced by coal production. It is only too common that much of the growing stock (conifers) is wiped out by fire, by disease or by insects. Considerable losses are frequent from windfall and even in France with a good market 20 to 50 per cent drops in stumpage values are common when considerable areas of windfall are suddenly placed on the market. Like farming land forest property is apt to deteriorate unless the owner gives it his personal attention and exercises good technique.

Some advantages of owning forest property as a long-term business investment in part compensate for its low financial returns as an investment in permanent forest production are: (1) Stumpage prices are increasing, especially in countries where the virgin timber is being exhausted. After the virgin timber is cut then stumpage must be based on the cost of production or import, but even then prices will increase as the intensity of population increases. (2) With inflated or depreciated currency forest values increase and forest property can be sold at a profit. (3) In countries like the United States, where the essential techñique of forest valuation is not widely known, the values placed on unmerchantable young timber are usually below the market - hence private owners

${ }^{12}$ Compare with the figures for La Joux (2 per cent) given in the Appendix, p. 514.

${ }^{13}$ According to Huffel, Vol. II, Page VII of preface: "Exploitations . . . which are organized with a view to producing saw timber of large size always yield small returns; they hardly yield 1 or 2 per cent on the invested capital in the case of oak high forest with long rotations." 
can often acquire cut-over land at very reasonable rates. (4) Where land values are generally low forest property often acquires, as the country develops, a greatly enhanced sales price for other uses.

Indirect Benefits. - In France it is especially true that the individual owns forests for indirect benefits as well as for an investment. The ownership of forests gives the landowner a certain prestige. The average country estate or château loses half its value, or more, unless there is surrounding forest. For the rich, the management of a forest property in France is an occupation which has advantages difficult to find elsewhere. Shooting, a rich man's pastime, requires a forest. To-day every great family in France has its country estate with some forest, but within the past 30 years, it should be again emphasized, there has been a decided tendency to dispose of large estates. The same is true in England. To-day M. Hirsch and his near relations own more forest and better-managed forest than any other family in France - notably the forests of Amboise (Indre-et-Loire) and Dreux (Eure-et-Loire). The forests of the Duc de Penthièvre in the Haute-Marne are being improved by A. Gazin, a notable private forester. But these are exceptions.

\section{EXAMPLES OF THE BEST PRIVATE FORESTRY}

Three Notable Forests. - It was found exceedingly difficult to secure authoritative data on the management of private forest properties. Many owners did not possess accurate and complete records while others hesitated to give freely to a stranger more or less private information on costs, revenues, and methods of management. But French foresters were in accord that (a) the Arc-et-Châteauvillain Forest (Haute-Marne) (b) Amboise Forest (Indre-et-Loire) and (c) the Forest of X (Vosges) were three examples of the best private forestry in France and representative of entirely different problems; $(a)$ is chiefly a poor coppice-understandards and mediocre high forest, $(b)$ is a rich coppice-under-standards, and $(c)$ is a rich stand of silver fir. Some day the writer hopes to secure private forest data on mountain forests, on Scotch pine, and on the Landes maritime pine.

The Grand Domaine of Arc-et-Châteauvillain (Haute-Marne). - This forest property is being conservatively administered and the rotations lengthened ${ }^{14}$ notwithstanding the small investment returns. The forest contains some 28,000 acres intact, and the Duc de Penthièvre is improving his property, under the able direction of $\mathrm{M}$. Gazin ${ }^{15}$ by (1) reforesting, (2) by increasing the rotations, (3) by increasing the age

14 Un Grand Domaine Forestier, par A. Gazin. Besançon, 1910.

15 The total receipts and expenses for 1911 for the property managed by Gazin were as follows: 
of the reserves in coppice-under-standards, (4) by developing a road system, (5) by securing a better range force through increasing their pay.

The property was bought in 1693 by Louis-Alexandre de Bourbon, Count of Toulouse; his son Louis de Bourbon, Duke of Penthièvre, inherited it. It was sequestered during the revolution but was restored to

\begin{tabular}{|c|c|c|c|}
\hline RECEIPTS & Francs & EXPENGES & Francs \\
\hline Wood. & $119,900.00$ & Salaries. . & $29,199.64$ \\
\hline Windfall... & $1,647.10$ & Clothing. & $1,140.90$ \\
\hline ock, etc........... & $1,161.01$ & Office... & 246.48 \\
\hline Grazing. . & 76.00 & Cost of making sales. & $4,920.90$ \\
\hline demnities. . . . . . . . . . . . & 273.80 & Road maintenance. . . . . . . & $2,008,185$ \\
\hline$\ldots \ldots \ldots \ldots \ldots$ & 10.00 & Plantations. & $1,049.585$ \\
\hline$\ldots \ldots \ldots$ & 700.00 & Pruning reserves. & 870.50 \\
\hline Hunting... & $\begin{array}{r}32,000.00 \\
152.20\end{array}$ & Private logging.$\ldots \ldots \ldots$ & 168.19 \\
\hline & $155,920.11$ & Stamp (tax) ................. & 6.20 \\
\hline \multirow{7}{*}{$\operatorname{arms}(n e t) \ldots \ldots \ldots \ldots$} & (1) & $\begin{array}{l}\text { Lawsuits...................... } \\
\text { Policing game rights. }\end{array}$ & 200.00 \\
\hline & $\pm 8, \pm 00.00$ & $\begin{array}{l}\text { Advertising, etc.......... } \\
\text { Horses and stable }\end{array}$ & 707.592 \\
\hline & & $(19 / 20$ to "forests") . . . . . & $1,799.22$ \\
\hline & & Insurance. . . . . . . . . . . & 22.60 \\
\hline & & 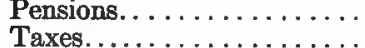 & $\begin{array}{r}928.75 \\
24.263 .86\end{array}$ \\
\hline & & Stamps for pensions. . . . . . & 33.75 \\
\hline & 320.11 & Totak & $\overline{69,804.952}$ \\
\hline
\end{tabular}

These figures simply serve to illustrate the low net returns for large forest estates in France. The percentage return on the investment cannot be computed but it is certainly less than 2 per cent. The taxes eat up more than 10 per cent of the gross receipts.

Gazin's budget is divided into six chapters followed by a general summary: (1) Forests; (2) houses and farms; (3) sawmills; (4) châteaux and parks; (5) hunting and fishing; (6) pensions; (7) recapitulation. The estimate signed December 18, 1912, and approved by the Duc de Penthièvre, is as follows:

\begin{tabular}{|c|c|c|c|}
\hline & $\begin{array}{c}\text { Receipts, } \\
\text { francs }\end{array}$ & $\begin{array}{c}\text { Expenses, } \\
\text { francs }\end{array}$ & $\begin{array}{l}\text { Taxes, } \\
\text { francs }\end{array}$ \\
\hline 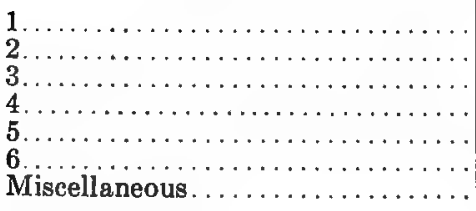 & $\begin{array}{r}188,320 \\
3,753 \\
5,913 \\
1,500 \\
32,100 \\
\ldots \ldots \ldots \ldots \\
\ldots \ldots \ldots\end{array}$ & $\begin{array}{r}67,405.40 \\
13,348.00 \\
55,500.00 \\
13,815.96 \\
1,000.00 \\
5,245.05 \\
3,051.09\end{array}$ & $\begin{array}{r}23,826.25 \\
1,018.00 \\
\cdots \\
1,756.00 \\
\cdots \cdots \\
\cdots\end{array}$ \\
\hline & 231,586 & $\begin{array}{c}159,365.50 \\
\text { Net, } 72,220.50\end{array}$ & $26,600.25$ \\
\hline
\end{tabular}

The cost of administration totaled 3.40 francs per hectare per year; maintenance 0.98 ; cost of making sales, 0.60 ; total of 4.98 francs, excluding taxes ( 34 cents per acre). The coppice in 1865 sold for 95,000 francs; in 1866, 152,000; in 1870, 120,000; and in $1913,16,000$ francs, or only about 10 per cent gross receipts. This illustrates the loss to forest owners in France through the discovery and use of coal. 
the daughter of the duke in 1814 who had married the Duke of Orléans. It was finally left to a nephew of King Louis Philippe, the Prince of Joinville. In 1852 it was again confiscated and sold to the Sociéte Passy but in 1873 the Prince of Joinville bought it back. At the death of this Prince on June 16, 1900, his son Pierre d'Orleans, the present Duke of Penthièvre, inherited it. After such changes of ownership it is not surprising that the forest needed betterments.

The total area of the property amounts to 27,866 acres divided as follows: Forest (including 212 acres reforested), 26,309 acres; deer park around château, 608 acres; small park, 77 acres; château park, 178 acres; saw mill, etc., 15 acres; farms and meadows, 679 acres. It is situated in the department of the Haute-Marne almost at the center of the triangle formed by the towns Chaumont, Langres, and Chatillon-sur-Seine. The mean altitude is 1,148 feet, the lowest elevation 722 and the highest 1,312 feet. The climate is severe and grapes cannot be cultivated except on the south exposure of walls. In certain parts of the forest frost occurs almost every month of the year. The variations in the climate and the permeability of the limestone soil, coupled with spring and fall frosts, makes the climate unfavorable for good. growth. Considerable damage is also done by game with which the forest is stocked. The soil is generally dry and of mediocre quality. The species are principally oak, beech, and hornbeam. Hornbeam forms 63 per cent of the coppice stands, while in the coppice-under-standards there is almost twice as much oak among the standards as there is beech or hornbeam. There are some 33.5 miles of paved roads on the property maintained in good condition. An administrator (Gazin) has charge of the property and is resident at Arc-en-Barrois. The force includes seventeen men divided into three ranger districts, each guard's beat averaging about 1,850 acres. It is interesting that all employees are housed and furnished free heat, a uniform, pension, and medical care. The salary paid rangers and guards in 1912 was as follows: Rangers, first class, $\$ 270$; second class, $\$ 232$; guards, exceptional class, $\$ 193$; first class, $\$ 174$; second class, $\$ 154$; besides they are paid a bonus of 24 cents per day when they are engaged in manual labor. The pension begins when they are 55 years old and is one-sixtieth of the salary of each year of service. For example, if a man has worked 30 years with an average yearly salary of $\$ 200$ he would retire when he was 55 with an annual pension of $\$ 100$. It is now planned to regulate the salary of the guards according to the size of their families - the more children the larger salary. In addition the guards and rangers receive supplementary pay for killing destructive animals and a bonus for each head of game killed. The forest is well stocked with game and during a 10-year period the average annual kill was 10 stags, 30 deer, 87 roebuck, 50 wild boar, and 14 hare. During 1908 the right to hunt 
was leased to a club at 23 cents per acre per year. This club charged its members the following premiums: Club members who shoot on this forest pay in addition ( 35 per cent of which goes to the rangers and beaters and 65 per cent to the guards): Roe-buck 48 cents per head for the first 50 killed; $\$ 1.93$ for the following $150 ; \$ 2.89$ for the rest. Stags, $\$ 3.86$ per head for the first $10 ; \$ 5.79$ for the 10 following; $\$ 7.72$ for the third 10 ; $\$ 9.65$ for the fourth $10 ; \$ 11.58$ for the fifth $10 ; \$ 13.51$ for the rest. Deer, $\$ 3.86$ per head. In addition the club paid the following rewards for killing beasts of prey: Fox, $\$ 1.16$; badgers, $\$ 1.35$; wild cats, $\$ 2.90$; martins and pole cats, $\$ 1.16$; domestic cats caught in the forest, 58 cents; martins, fur species, $\$ 3.86$; weasels, 58 cents; ermine, 97 cents; buzzards, 19 cents. The pelts were reserved for the use of the club. For the discovery of poachers the club paid $\$ 7.72$ for those caught during the day; $\$ 15.44$ for poachers caught during the night, and $\$ 1.93$ for dogs caught in the forest.

The forest yields truffles in considerable quantity. Practically all sawlog material is exported and firewood in small amounts is used locally. Mine props are exported to the northern part of France and Belgium, the wood and charcoal to Paris. The average prices secured are as follows: Oak, first quality (20 inches in diameter and better), $\$ 6.76$ per cubic meter in the $\log$; second quality (12 inches to 19 inches in diameter), $\$ 4.83$; third quality ( 8 to 11 inches in diameter), $\$ 2.32$. Beech logs bring about $\$ 2.90$ per cubic meter on the average; mine props, 53 cents per stere $(0.277$ cord); firewood, 48 cents per stere; and charcoal made of branch wood, 5 cents. ${ }^{16}$

Management. - The system of coppice-under-standards is applied to the nineteen working groups of the forest and the rotation averages from 25 to 30 years. The rotation has been lengthened, however, and owing to the small value of fuel and the increasing value of sawlogs, is now 27 to 32 years. In the past, with the rotation 25 to 30 years and because the reserves were insufficient, the yield averaged 0.32 cubic meters of sawlogs per acre and 1 cubic meter of firewood. The price of charcoal has dropped from 58 cents to 5 cents per stere on the stump ( 3.6 steres to a cord). The objection to converting this coppice-under-standards to high forest is that it would take too long and cost the owner too much. There is so much game in this forest that the conversion would be difficult, especially if fir were planted. The number of reserves is to be increased to such an extent, however, that the coppice-under-standards will resemble an open high forest. There are also objections to lengthening the rotation: (1) The necessary decrease in the proportion of oak; (2) the impossibility of securing the full value of the reserves which become ripe, decayed, or overmature; (3) the decrease in the growth of the reserves, since the 
greatest development comes during the 10 years following the cutting of the coppice. This last may be in part compensated for by the increase in value of the coppice felling because of the increasing price for large mine props.

Growth. - It is the policy to keep an accurate record of the growth of the reserves in the coppice-under-standards. All these reserves (firstclass standards) are numbered and measured at the time of the coppice fellings and at all subsequent stocktakings. According to data secured the oak takes 20 years to grow from one 2 -inch class into another and 15 years for the beech; on an average the growth for the oak is 2.5 per cent and for the beech 3.5 per cent. According to the marking made on about 1.977 acres in 1907-1908, 23.6 cubic meters were left and 18.4 cubic meters of reserves cut.

Yield. - For the years 1907-1908 (976 acres were cut over each year) the final yield from the reserves was 5.2 cubic meters of sawlogs per acre and 6.8 cubic meters of fuel -12 in all, while the coppice yielded a cut of 22 cubic meters of fuel, charcoal, and mine props. For the 2 years the final yield was $\$ 22.13$ per acre for the high forest and $\$ 7.34$ for the coppice, an average of $\$ 1.91$ per cubic meter for the high forest systems, branches included, and but 33 cents per cubic meter for the coppice. This illustrates very vividly the great advantage of growing saw timber instead of cordwood. The net yield on the investment is probably 1.5 to 2.0 per cent.

Forestation. - The first plantations date from 1838 to 1848 , when the Vendue and Essarts farms were forested with Scotch pine and oak, with avenues of spruce and pine along the boundaries. This planting has been very profitable. Some of the spruce is now more than 27 inches in diameter and is growing rapidly. Planting in the blanks has, on the whole, given excellent results. The popular species used lately, planted in groups of about $2 \frac{1}{2}$ acres according to the nature of the soil, are spruce, Scotch pine, Corsican pine, Austrian pine, larch, and beech. Some fir, as well as white pine, Douglas fir, and Japanese larch has been planted. Since the soil is limestone it is likely that this last species will give mediocre results.

The House of Orléans deserves a great deal of credit for its conservative treatment of this forest, and, as Broilliard has said, "The owner who conserves his forest is continually working for the country; he is essentially a benefactor."

Forest of Amboise (Indre-et-Loire). - The forest of Amboise was bought from the Emperor of Bulgaria by M. Hirsch, ${ }^{17}$ then an inspector in

${ }^{17}$ Through the courtesy of M. Hirsch the writer obtained access to his private forest records and was enabled to visit the forest with the owner. Unfortunately much of the best saw timber and cordwood was requisitioned and cut by the A. E. F. during the Great War. 
the Waters and Forests Service, stationed at Paris. The domain formed part of the royal forests until 1761, when it was given to the Duke of Choiseul by Louis XV; in 1784 it was purchased by the Duke of Penthièvre. After suffering confiscation at the French Revolution it became the property of Louis XVIII, who gave it to the Duchess of Orléans, who later became Queen Marie Amélie. When Louis Philippe divided his possessions the forest of Amboise fell to Princess Louise, the Queen of Belgium. After the revolution of 1848 some 4,942 acres were confiscated and sold so that at the restoration in 1872 but 10,378 acres remained. In 1874 the remnant was ceded to the Princess Clementine and the Duke of Wartenberg; it finally was acquired by the Prince of Bulgaria and the Duke of Saxe-Cobourg-Gotha.

The forest is situated 15 miles east of Tours, between the Cher and the Loire rivers. The historic town of Amboise is directly north and Bleré is to the south. The forest contains 10,691 acres and varies from 0.62 to 3 miles in width and is 10 miles long. The soil is a deep clay, often sandy in character, quite compact, and yet the roots penetrate quite easily. Usually there is a good humus. The climate is mild in winter and quite hot in summer; the snow remains only a few days at a time. The annual rainfall varies from 20 to 24 inches. The stand is almost pure oak, half sessile and half pedunculate, with scattering beech, hornbeam, birch, chestnut, acacia, and aspen, with Scotch pine and maritime pine which have been introduced artificially. The regeneration of the oak is very easy because of its abundant seed crops; its quality is first class. The conifers have not as yet proved especially successful. There are no rights or servitudes, the boundaries are well established, and a fairly complete system of main and secondary roads already exists. The local force in 1912 comprised a ranger (\$232), two head guards (\$174), and six guards and one road guard ( $\$ 135$ each). The force is lodged and has the privilege of a $2 \frac{1}{2}$-acre garden, $2 \frac{1}{2}$ cords of fuel, and 100 fagot bundles per year.

Treatment. - The forest is divided into seventeen working groups varying in size from 376 to 791 acres, with the exception of the section, "Les Bertherelles" which has only 113 acres. Two working groups, 903 acres, have not been regularly cut since 1883, but 153 acres (Scotch pine) were burned over in 1893; with the exception of 113 acres under high forest the remainder is under compound coppice. There are no blanks of any size and the whole forest is in good condition. The Waters and Forests Service, which administered the forest from 1851 to 1873, began a conversion to high forest and this accounts for the high forest on 113 acres. The present owner has accordingly changed three working groups with 20 -year rotations to two working groups with 30 -year rotations. In addition he has an extra working group for remnants. $\mathrm{He}$ 
will gradually realize on the bit of high forest and turn it into coppiceunder-standards. ${ }^{18}$

Products. - The products are logs and firewood. The coppice yields charcoal, fagots, fagot bundles, and bark; the high forests yield sawlogs and additional fuel.

The shooting rents for $\$ 1,737$ per year and includes deer, wild boar, hare, and pheasants. The fishing is worth $\$ 193$ a year with an additional $\$ 135$ average from special sales of fish.

The average revenue for the years 1897 to 1908 was: Wood, $\$ 24,358$; shooting, fishing, etc., $\$ 2,818$, or a total of $\$ 27,175$; but from this must be deducted $\$ 9,540$ for taxes, administration, and patrol, leaving a net revenue of ony \$1, $\$ 0 \$ 5$.

An average year (1906) showed the following detailed receipts and expenses:

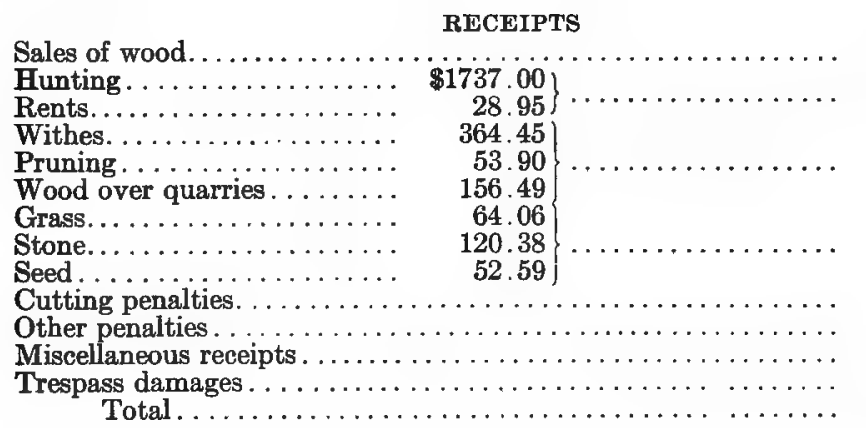

$\$ 25,057.19$

$1,765.95$

$\mathbf{5 7 4 . 8 4}$

237.03

22.58

89.17

6.72

0.60

$\overline{\$ 27,754.08}$

EXPENSES

Taxes of all kinds

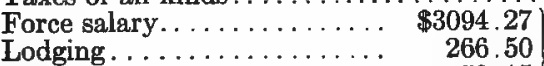

Bureau................. 52.15

Doctor, ete........... 106.97

$\$ 3,779.53$

Maintenance roads. .............. 1020.76

Houses. . . . . . . . . . . . 295.14

Pruning reserves. . . . . . 145.21

Park and Château......... $\quad 54.29$

Trimming along roads...... 20.99

965.48

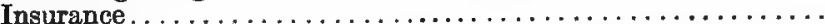

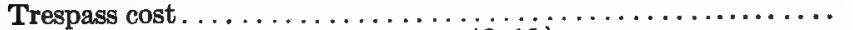

Reforestation... 12.16

Construction of three stalls... 25.52

Special construction........ 9.65

Extra guard............. 161.73)

Unforeseen expenses. .

Total

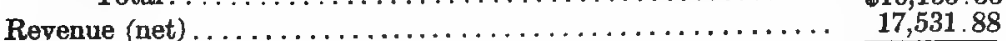

Gross revenue. . . . . . . . . . . . . .

a These totals did not balance with the gross receipts in the original tables.

18 Hirsch believes in accurate valuation. He marks three rotation standards with three red circles and with serial number at d. b. h., $2 \mathrm{R}$ standards with two red circles and serial number, while $1 R$ standard (baliveau) with red circle but no number at all. This work costs only $\$ 80$ a year. 
Growth. - From the measurement of selected plots over a period of 14 years it appears "that the average annual growth on the circumference is 0.0153 per tree and that the volume increases each year by $0.0233 . "$ These figures apply to the trees 15 inches and over in diameter. There are no figures for trees less than this but the growth is estimated at 3 per cent. For the conifers the growth per cent was fixed at 0.025 . The amount to cut each year is therefore obtained by multiplying the volume in each diameter class (above or below 15 inches in diameter) by the per cents given above. The coppice is worked by area.

For each of the seventeen groups is given a digest of the growing stock divided into coppice cuttings. For example: for the third working group Chanteloup, 754 acres, 24 coupes; Coupe No. 1, area 47 acres; age of coppice end of 1907, 19 years; volume of oak (reserves), under 15 inches, 96.47; over 15 inches, 181.62 cubic meters; volume of conifers, 274.30. The total volumes are then footed and the following calculations made: growth of the oak, below 15 inches, 5,546 cubic meters $\times 0.03=166.38$; above 15 inches, 2,439 cubic meters $\times 0.023=56.97$; total, 223.35. Growth of the pine, below 15 inches, 2,300 cubic meters $\times 0.025=57.5$.

This growth would sell as follows: 223 cubic meters at $\$ 6, \$ 1,291$; branches, 223 steres at 77 cents, $\$ 172$; pine, 86 steres at 97 cents, $\$ 93$; total $\$ 1,546$. $\$ 1,546$ capitalized at 4 per cent equals $\$ 38,600$.

"The product of the (coppice) felling area when ripe is estimated at $\$ 45$ per acre. The net value per acre of the soil and of the coppice amounts then to $\$ 30$. This amount capitalized at 4 per cent represents a value of $\$ 23,558$ for the whole working group." A résume of all the working groups is shown in Table 26 on opposite page.

The "Domain of Rouillardière," added to the forest of Amboise in 1885, comprises 126 acres. It consists of a magnificent coppice and compound coppice. As a final valuation the forest is put at:

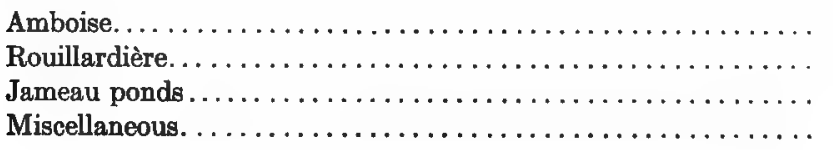

$\$ 893,937.40$

$7,720.00$

$3,377.50$

285.64

$\$ 905,320.54$

The following deductions can be drawn from the foregoing data:

(1) The net income for 1906 was $\$ 10,135.34$ on a capitalization of $\$ 905,320.54$. This shows a net yield of only 1.9 per cent, but it should be recalled that the forest is being built up by the reservation of large numbers of standards. Hence the real profit is 1.9 per cent plus the 
FOREST OF AMBOISE

TABLE 26. - VOLUME OF OAK IN 1907

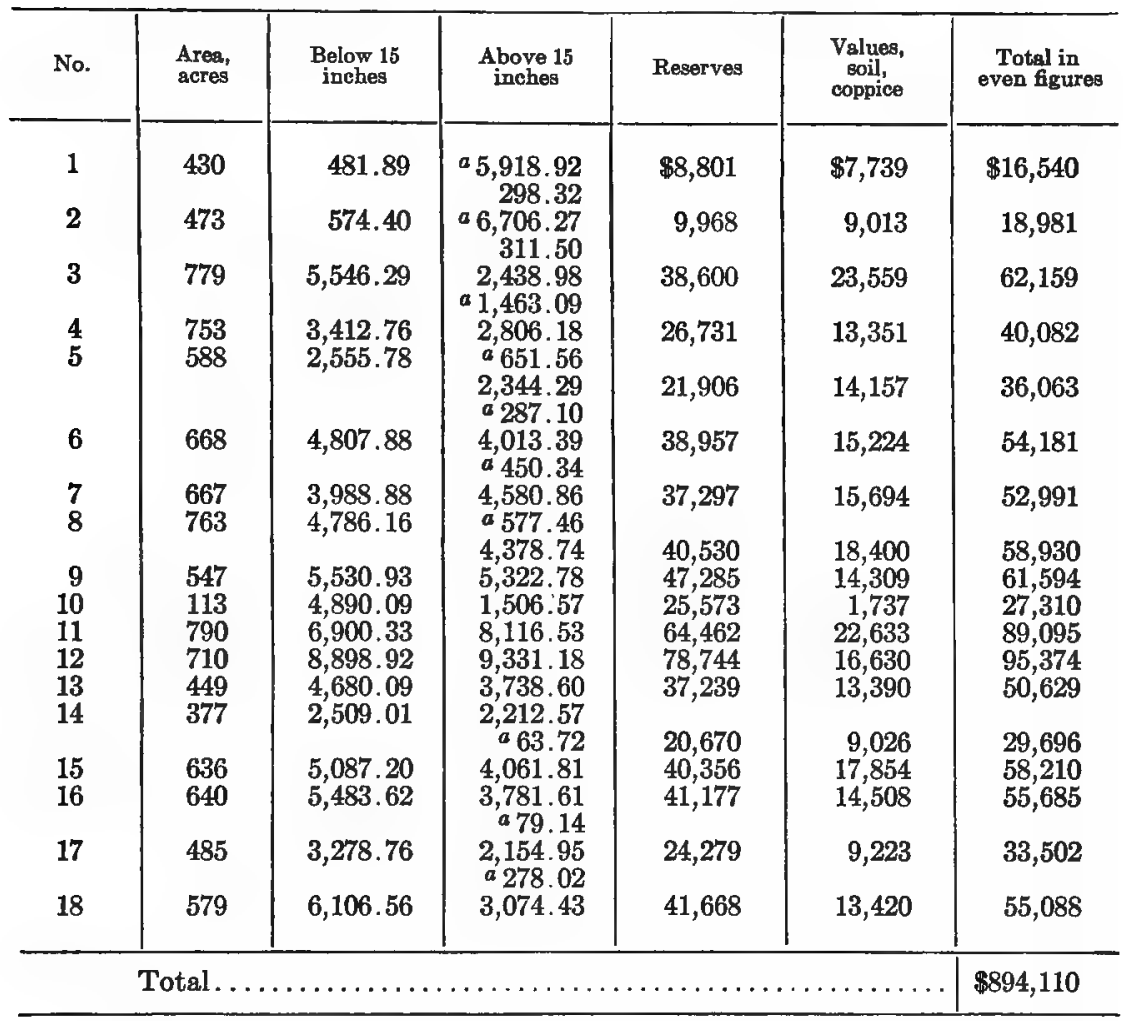

${ }^{a}$ Conifers.

average yearly value of the increase in growing stock. ${ }^{19}$ The owner estimated his real return at 4 per cent.

(2) In 1906 the expenses (cost of operation) were 37 per cent and the taxes 13 per cent of the gross revenue; the taxes were 0.14 of 1 per cent of the appraised book value.

(3) It is of interest to note the receipts for hunting, rents, withes, pruning, wood cleared at quarries, grass, stone, seed cutting penalties, miscellaneous receipts, and trespass were about one-ninth the receipts from timber and coppice sales.

${ }^{19}$ The A. E. F. purchased $\$ 231,600(1,200,000$ francs) worth of coppice and timber (18,760 cubic meters and 26,094 steres) from this forest during 1918-1919; the damages for faulty cutting were $\$ 1,930$. In addition these high sales values will be partly balanced by largely increased working costs for a number of years. The cut in 1909 was 4,489 cubic meters and 3,321 steres; 1910, 4,204 cubic meters and 2,697 steres; 1911, 2,224 cubic meters and 2,887 steres. Thus the A. E. F. cut about 5 years of timber crops and 9 years of cordwood. This unquestionably damaged the forest from the standpoint of permanent management. 
(4) To calculate the yield, rule-of-thumb growth per cent figures were multiplied by the growing stock to obtain the yield of timber; for the coppice an average per acre yield figure is simply estimated as a result of past averages.

A Fir Forest (Vosges). - Perhaps the most interesting private fir forest in France, and certainly the best managed, is the Forest of $\mathbf{X}$, jointly owned by ten distinguished French foresters. Suffice it to say that Gazin, manager for the Duc de Penthièvre forest properties, and Schaeffer, conservateur des Eaux et Forêts, are two of the ten owners.

The forest comprises 155 acres and is situated at an altitude of from 1,540 to 2,100 feet in the lower Vosges Mountains on rather rocky sandy loam (grès vosien). The principal stand is silver fir, with some Scotch pine in mixture, and perhaps 1 per cent of beech. The property was purchased in 1906 for $\$ 31,845$, but really cost net only $\$ 19,300$ because the overmature timber was at once sold for $\$ 12,545$. The appraised book value is, however, $\$ 23,160$ instead of $\$ 19,300$ because the purchase price was less than the full value. The stumpage values were 15 francs per cubic meter (about $\$ 10.50$ per thousand feet board measure) in 1906 , and 17 to 18 francs, or 15 to 20 per cent more, in 1913.

The stand is cut over every 5 years and is completely calipered. The marking is under the personal supervision of one of the ten owners who receives an allowance of $\$ 9.65$ for his work as director of marking, but each owner manages his one-tenth of the forest. Thus far the dividends have been 3 per cent per year. They are now limited to 4 per cent until the original growing stock, as it stood after the removal of the overmatured timber, has been increased 33 per cent by saving some of the growth each year. Then and then only it is proposed to increase the dividends to 6 per cent. The cost of the original working plan was $\$ 86.85$ and the annual expenses for marking, taxes, etc., have been $\$ 185.63$. The annual taxes were $\$ 12.74$ or 8 cents per acre. The average annual cut was 833 cubic meters (about 222,000 feet board measure or 1.4 thousand feet per acre per year).

The aim of management is to get the best financial returns, and the group selection system is applied with cleanings, freeings, and thinnings every 5 years. The yield is regulated by the Gurnaud method. With stocktaking every 5 years as exact data are secured on growth as if the forest were a sample plot. Thus far the forest has netted 3.25 per cent on the investment ( 3 per cent dividend and 0.14 of 1 per cent as surplus bank balance) but in addition the volume on the ground has increased 2,390 cubic meters, ${ }^{20}$ worth in $1912 \$ 8,072$ (41,825 francs). Thus the actual revenue has been $3 \frac{1}{4}$ per cent plus an annual increase in capital of $\$ 807$, or 3.9 per cent on the book value without compound interest or

${ }^{20}$ The figures in proof of this are as follows: 
deducting any share of annual expense which the marketing of this excess reserve might have entailed.

It is safe to say that thus far the real annual revenue has been close to 7 per cent. But the forester must realize that there may be setbacks due to windfall, disease, and unforeseen acts of Providence, so the board of control set 6 per cent as their maximum interest goal. Anything above this will at present be held as a reserve.

Conclusions. - Writing in 1910, Broilliard, perhaps the most eminent French forester of our times, said: "Bad at business and poor at manufacturing, the State is, nevertheless, the best forest owner, able to assure good treatment to timber of all species . . . " "and he argued for more State forest acquisition and especially the purchase of forests in being rather than land that requires forestation. This is certainly a good policy for the United States to follow, because a study of the private forests of France leads us to the following conclusions, which, at least, have a bearing on what the United States should do:

(1) Private forests, purely as permanent investments, would be largely

\begin{tabular}{|c|c|c|c|c|c|}
\hline \multirow[b]{2}{*}{ Serial number } & \multirow[b]{2}{*}{ Acres } & \multicolumn{2}{|c|}{ October, 1892} & \multicolumn{2}{|c|}{ October 31,1912} \\
\hline & & $\begin{array}{c}\text { Cubic meters, } \\
\text { total }\end{array}$ & $\begin{array}{c}\text { Cubic } \\
\text { meters } \\
\text { per acre }\end{array}$ & $\begin{array}{c}\text { Cubic meters, } \\
\text { total }\end{array}$ & $\begin{array}{c}\text { Cubic } \\
\text { meters } \\
\text { per acre }\end{array}$ \\
\hline $\begin{array}{r}1 \\
2 \\
3 \\
4 \\
5 \\
6 \\
7 \\
8 \\
9 \\
10\end{array}$ & $\begin{array}{r}24.4 \\
7.8 \\
21.6 \\
7.2 \\
15.0 \\
12.9 \\
18.0 \\
19.8 \\
17.1 \\
10.9\end{array}$ & $\begin{array}{r}1,673 \\
735 \\
1,529 \\
606 \\
1,175 \\
1,063 \\
1,606 \\
2,166 \\
1,293 \\
631\end{array}$ & $\begin{array}{r}68.0 \\
92.4 \\
70.0 \\
83.6 \\
77.2 \\
81.6 \\
88.4 \\
108.0 \\
74.8 \\
57.4\end{array}$ & $\begin{array}{r}2,695 \\
926 \\
2,214 \\
556 \\
826 \\
535 \\
1,819 \\
2,473 \\
1,864 \\
959\end{array}$ & $\begin{array}{r}109.4 \\
115.4 \\
100.1 \\
76.4 \\
53.6 \\
40.8 \\
100.0 \\
122.8 \\
106.4 \\
88.0 \\
\end{array}$ \\
\hline Totals.......... & 154.7 & 12,477 & $\ldots \ldots$ & 14,867 & $\ldots \ldots$ \\
\hline Averages.. & $\ldots \ldots \ldots$ & & 80.0 & & 94.8 \\
\hline
\end{tabular}

Thus the stand has increased 38 cubic meters per hectare or 15 per cent plus per acre. The average growth per cent for this thrifty fir stand has been 6 . In marking the following rule has been adopted: "In each age class it seems necessary to cut at least 10 per cent of the stand and imprudent to cut more than 25 per cent. The amount to be maarked from the (a) small (b) average, and (c) large diameter classes is always decided before the marking begins. Nothing has ever been published on this forest of $\mathbf{X}$ because the owners prefer to keep the French tax assessors ignorant of the exact returns, since they feel that taxation should not be increased simply because of their good management. For the forest student this is perhaps the most valuable demonstration forest in France. 
done away with unless there were laws against deforestation, or unless the State subsidized forest property.

(2) The kind of forestry on private land that is forced by mandatory legislation will not result in real timber production; ${ }^{21}$ it will entail a waste in the use of forest soils.

(3) Private forests maintained solely for revenue cannot afford to produce the high-grade timber always required by certain industries.

(4) The private forests of France rarely yield over 4 per cent as a permanent investment in timber production on the capitalized value of the soil and growing stock. Exceptions occur when cheap soil, such as sand wastes, can be cheaply stocked and where in addition taxes may be reduced by State laws and the owner subsidized. But the risk is apt to be correspondingly greater.

(5) The risk from windfall, insects, fungus, fire, and changes in the wood market is considerable. An investment in a private forest cannot be considered as safe as many bonds that now yield 7 per cent or more semi-annually.

(6) During eras of high prices the private forest capital or growing stock is usually greatly reduced because of the opportunities to realize at a profit. This puts a premium on public ownership because the State can then supply the demand for raw material from its reserves.

(7) The best managed private forests are usually owned by the rich or by the nobles and are not maintained alone for the money they return, but for the dignity, pleasure, or indirect benefits which they yield. The farm woodlot is an indispensable part of a nation's economic forest wealth, and in France has been wretchedly managed through lack of free technical advice and propaganda. The small owner is apt to use too short rotations and to allow his forest to depreciate in value and quality.

(8) The ownership by the public should be increased by purchase from owners who are no longer able to maintain their forests properly, and in addition the private owner should be assisted financially and technically and should be given adequate protection from trespass and fire.

(9) Most of the high-investment returns from forest properties are really due to speculative increases in local values; the advantage of these high prices largely disappears when the property is held as a permanent investment because the soil values and growing stock values increase proportionately. The high profits from buying and then selling at higher prices should not be confused with the business of permanent forest production.

${ }^{21}$ The timber-culture act in the United States certainly never resulted in forests. 
It must therefore be concluded that forestry is a poor investment for an individual, but an exceedingly good one for the nation, because the nation can take part of its revenue in indirect benefits. ${ }^{22}$ Under a democracy it seems better for the State to acquire cut-over or virgin forest soils rather than to try to force the private owner to practice the unprofitable business of permanent forest production if he holds his forest property solely for its financial returns. But while the temporary owner is realizing on his investment it is certainly incumbent upon the State to require that the forest be maintained in a condition that will not menace the lives and property of others. But professional foresters should avoid vague generalities; the time has come for details about the forest and about the forest as an investment. Be frank with the private owner and tell him what to expect.

${ }^{22}$ A water company in the United States that owns its watersheds would be foolhardy if it did not practice forestry. Paper companies and other permanent corporations, with heavy investments in machinery, must do all they can to perpetuate their timber supply. But it is yet to be proved whether they would not be better off buying stumpage from the State rather than owning all their own timber supply. Recent increases in pulp stumpage may tend to confuse the issue, namely, permanent forest production, as an investment. 


\title{
CHAPTER XII
}

\section{THE AMERICAN FOREST ENGINEERS IN FRANCE}

\author{
By W. B. Greeley \\ Formerly Lieut.-Col. 20th Engineers, A. E. F.
}

Timber in Modern Warfare (p. 336). The Wood Used by Two Million American Soldiers, A War of Transportation, Forest Preparedness in France.

The Organization of Forest Engineers (p. 338). American Woodsmen Called to the Colors, The Man Behind the Sawmills, A Division of Forestry Troops.

The Forestry Section of the Expeditionary Force (p. 340). Its Military Organization, Geographical Distribution of Forestry Operations, District Managers, The Headquarters Staff - Equipping the Sawmills, Strategy in Military Lumbering, Sales and Traffic Department, The Timberland Department.

Sawmilis and Logaing Equipment (p. 343). Early Makeshifts, The Heavy Sawmill, The Light Sawmill, The Flying Sawmill, Heavy and Light Artillery in Timber Warfare, The Transport Problem, Value of French Highways, Motor Trucks and Caterpillars, Logging Railways.

The Production of Fuei Wood (p. 347). An Enormous Problem in Itself, Fuel Wood Cut by the Forest Engineers, The Special Fuel Supply Service.

What the Forest Fingineers Accomplished (p. 348). The Beginning and the End, The Spirit of the Forestry Troops, Winning the War with Lumber.

Coöperation with the Forest Agencies of France (p. 351). French Organization of Timber Supplies for the War, Early Negotiations with the French Government, The Interallied Timber Committee, Forest Acquisition in the War Zone, Scouting France for Timber, Cutting Requirements Imposed by the French, Restrictions Upon the Amount of Timber Cut, Meeting French Foresters on Their Own Ground, The French View of American Operations, French Difficulties in Supplying American Requirements, Effectiveness of French Coöperation.

Formst Troops Loaned to French and British Armies (p. 357).

What the American Woodsmen Learned in France (p. 358).

The War a Vindication of French Forestry (p. 358).

Timber in Modern Warfare. - That timber is an essential munition of war is demonstrated forcibly by the enormous quantities of wood which were required by the allied armies in almost every phase of military operations in France. The great military bases behind the lines consumed lumber in vast amounts for camps, hospitals, shops, and warehouses. No advance could be undertaken without large supplies of railroad ties for extending railheads into conquered territory, of bridge timbers and road plank for throwing forward quickly built roads over streams and shell-torn ground, and of lumber, logs, and pickets for constructing fortifications. 
The Wood Used by Two Million American Soldiers. - To establish the American Army as a fighting unit in France and carry its operations to the end of the war required $450,000,000$ board feet of round or manufactured timber and 650,000 cords of fuel wood. This represented a ton and a half of wood for every American soldier sent overseas. Much of this material was, of course, used in the construction of depot and supply facilities and at base camps behind the fighting zone. But even after such structures had been largely completed, the two million American troops in France, fighting under the conditions which existed from the beginning of the St. Mihiel offensive, required some 70,000,000 board feet monthly of all classes of timber except fuel wood.

Thirty-eight and one-half per cent of this vast quantity of timber was required in the form of lumber in small dimensions for the construction of barracks, hospitals, and warehouses and of rough field shelters and fortifications; 27 per cent was fuel wood; railroad ties came third, with $13 \frac{1}{2}$ per cent; about 9 per cent had to be furnished in large timbers for building docks, barges, trestles, and bridges. The most difficult requirement to fill was the need for 39,000 piles, in lengths up to 100 feet, used chiefly in the docks built by American engineers at various French ports. Six per cent of the total covered the demands for telephone and telegraph poles, wire entanglement stakes, and pickets for supporting camouflage nets.

A War of Transportation. - In the last analysis, the war of 1917 was a war of transportation. Nothing illustrates this fact better than the means which had to be employed to obtain the enormous quantities of wood required by the armies in the field and get them to the points of use. Owing to the scarcity of ships, less than 1 per cent of the timber used by the American forces in France was forwarded from the United States. The difficulties in transporting such bulky material from neutral countries like Norway and Switzerland were only slightly less serious. France herself was short of manufactured products. Hence over 75 per cent of the timber required by the American Army had to be cut from French forests by our own engineer troops.

Forest Preparedness in France. - That France was able to supply these vast demands was a factor in national preparedness of the utmost importance to the allied forces, particularly to the American Army, which was compelled to operate far from home. If France had set about deliberately, 60 years ago, to supply the armies of the allied nations with timber during the great war, she could hardly have built up her forest resources more effectively than her thrift and foresight had actually done. France contained probably 150 billion board feet of merchantable timber at the outbreak of the war. The character and distribution of her forests were almost ideal for the military requirements 
which actually developed. The region immediately behind and adjoining the American sector of the front was well forested. The fir and spruce forests of the Vosges and Jura Mountains furnished ideal timber for the manufacture of construction lumber as well as the large timbers and long piling which proved to be a vital necessity. Even lumbermen from northwestern America took off their hats to some of these upland stands of silver fir. In the Besançon District, the American Engineers cut as much as 65,000 board feet of saw timber to the acre. The largest tree felled, a silver fir, had a diameter of 56 inches and contained 5,530 board feet. The logs cut in these softwood forests of the Eastern Mountains averaged $6 \frac{1}{2}$ per thousand feet. The Vosges afforded operations of special military value because they were within a stone's throw of the American First and Second Armies and of the supply facilities just behind them.

A second important forest belt was traversed by the main line of communications of the American Army, through the Loire River Valley and across the headwaters of the Seine and Marne. This is chiefly an agricultural region, but, as in most of France, one is seldom out of sight of patches of woods. Its oak forests were an unfailing supply of railroad ties, road plank, and large timbers for the construction of docks and bridges. Some of its 200 or 240 year old oak timber attains fine dimensions. A 60 inch log, the largest found in France, was cut from an oak tree near Dijon. At the large operations near Eclaron the oak logs averaged ten to the thousand board feet. At other hardwood camps the average was fifteen or seventeen. This region also, with its extensive areas of hardwood coppice, seemed almost to have been designed in advance as the principal source of fuel for the American troops. In its many plantations of Scotch pine it also furnished ready to hand material suitable for the millions of wire entanglement stakes and small poles required in modern warfare. A third important forest region, the pineries of southwestern France, afforded another large supply of railroad ties, lumber, and piling which proved to be well located for our great cargo ports at Bordeaux and other large American-installations. The pitch pine of this region resembles the shortleaf pine of the Southern States. At the better sets it averaged seventeen and one-half logs per thousand board feet and yielded a fair proportion of 50 and 60 foot piles. For a war in which timber played such a striking part, France was indeed well prepared.

\section{THE ORGANIZATION OF FOREST ENGINEERS}

American Woodsmen Called to the Colors. - Soon after the advance guard of the American Expeditionary Force landed in France it was 
foreseen that to supply our troops with timber from French forests would require a special organization of engineers experienced and equipped for this work. In fact one of the first requests for help from the United States by both our French and British Allies was for regiments of trained lumbermen. The organization of lumberjack units had actually been begun in May, 1917, and was continued until March, 1918. By May, 1918, forty-eight companies of forest and road engineers, each 250 men strong, had been sent to France. The core of a 49th Company was obtained subsequently from the New England Sawmill Units, a private organization which was sent to Old England in the early summer of 1917 to cut lumber for the British Government. These troops represented every State in the Union. Practically every forestry agency in the country, together with many lumber companies and associations, helped in obtaining the right type of men. The road engineers of the United States took hold of the organization of the twelve companies of troops designed for road construction in a similar spirit. The lumber units were officered largely by picked men of experience in the forest industries of America, and the road units by road and construction engineers of exceptional technical ability.

The Men Behind the Sawmills. - The earlier units were made up entirely from volunteer enlistments. The later units contained a large proportion of men from the draft, selected for forestry work mainly on the basis of their former occupations, together with many volunteers beyond the draft age from among the experienced loggers and sawmill mechanics of the country. But there was no distinction between volunteer or drafted soldiers among the American forest engineers in France. These men represented the best of their hardy and resourceful profession in the United States. They came from her forests and sawmills, trained in her woodcraft, with all of the physical vigor, the adaptability to life in the open, and the rough and ready mechanical skill of the American woodsman.

Special credit is due to the officers and men of the three battalions, the 41st, 42d, and 43d Engineers, which were organized and equipped for road construction work in connection with forestry operations. They came to France keen to take up this task for which they too had been especially fitted by training and experience. But the necessities of war dictated otherwise. They landed in France to find the undermanned Forestry Section struggling to keep up with the timber needs of an army already twice the size of that originally intended. It was necessary for these road builders to turn lumberjacks themselves, cutting fuel wood, piling, or entanglement stakes as occasion demanded and manning the new sawmills which were installed as fast as they arrived from the United States. The road companies took hold of this work, 
to which most of them were unaccustomed, with splendid spirit and in the end some of their mill crews made off with the laurels of certain pure lumberjack units, in the records of the operations for production.

To meet the growing requirements of the American Army, Engineer Service battalions were rapidly added to the forestry and road troops during the summer and fall of 1918. At the end of hostilities, thirty-six Service Companies were working with the 20th Engineers. The first four of them were white troops, organized as the 503d Engineers. They contained a large proportion of railroad men and other skilled workers and were soon in the mills and woods and on railroad jobs, on all fours with the forestry troops. Upon the other Service Companies, composed of colored troops, fell the brunt of cutting the fuel wood which the quartermaster was calling for by the hundreds of thousands of cords. But several sawmill crews composed largely or entirely of black soldiers made exceedingly creditable records.

A Division of Forestry Troops. - By the date of the armistice the Forestry Section numbered 12,000 engineer troops, organized in the fourteen Battalions of the 20th Engineers, and 9,000 service troops. The Section operated from eighty to ninety sawmills during the last two months of the war and employed some 3,600 draft horses and mules. In addition to this vast organization about 10,000 service troops from the Quartermaster Corps were engaged in cutting fuel wood under the direction of forest engineer officers.

\section{THE FORESTRY SECTION OF THE EXPEDITIONARY FORCE}

Its Military Organization. - The Forestry Section grew with the size of its task through a flexible development of the regimental organization of the Army. Its engineer troops and attached service companies constituted a single regiment, which functioned as a distinct Supply Service under the Chief Engineer of the Army. Its duty was to keep all branches of the American Expeditionary Force, from the base ports to the front, supplied with timber. It was thus one of the far-flung Services of Supply, "the Army behind the Army," the vast military-industrial organization of ships, docks, railroads, factories, bakeries, repair shops, distributing depots, and training camps in France, which did not fight battles but without which no battles could have been won.

Geographical Distribution of Forestry Operations. - The Forestry Section resembled a large lumber corporation. As each battalion of troops arrived in France it was assigned to operations at points where the best forests were available and where the production of lumber, railroad ties, or piling was most needed to supply the growing requirements of the Army. The first districts to be operated were the soft- 
wood forests of the Jura, directly behind the American Advance Section and near the great distributing station at Is-sur-Tille, and the pineries of the Landes, whose timber was rushed to Bordeaux to build the first American docks in France. New forestry operations followed in the Loire River Valley, along the main line of communications, furnishing materials for the large depot at Gièvres, for the Air Service Shops at Romorantin and the Replacement Depot at St. Aignan. A little later forestry troops were assigned to the fir forests of the Vosges and the oak forests of the upper Marne, their operations ultimately extending right up to the American front.

As the war progressed more and more sawmills were installed in the advance zone, near Nancy, Toul, and the Alsatian frontier, where their products could be shipped to the advance railheads with a minimum of time and of vital transport equipment. During the last two months of the war a flying squadron of small mills was organized to take to the field with the First Army. This operated under the engineer officers in charge of preparations for the St. Mihiel and Argonne offensives, supplying the advance engineer dumps from day to day with bridge timbers, railroad ties, bomb-proofing, fortification lumber - whatever was needed most urgently at the moment and could not be forwarded in time from the rear. Thirteen of these advance camps were operated, at times actually under shell-fire.

The quest for timber also necessitated extending forestry operations into the northern French Alps and the Central Plateau and many new sawmills were set up in the Landes and at fresh locations along the main artery of American traffic through central and northeastern France.

District Managers. - The operating districts were readjusted from time to time as new battalions and sawmills arrived and were fitted into the general plan. Each battalion commander was a district manager, running from two or three up to ten or twelve mills, with his own personnel and supply officers, his own shipping organization, his own experts on mill and logging equipment and his own overhead staff of millwrights and mechanics. The battalion office received its cutting orders from the regimental headquarters at Tours and distributed them among its operations to fit their timber, the other work on hand, and the all-important problem of obtaining the quickest and shortest transportation of the material to the points where it was needed. These battalion commanders, or district managers, represented the stable geographical units in the forestry organization. Their task was not only to keep their mills producing the last possible foot of lumber but also to steadily develop the resources of their territory, to locate more timber, and to master the intricacies of getting the best possible service from their local French railroads. 
The Headquarters Staff - Equipping the Sawmills. - These fourteen district managers were directed from the central headquarters of the Forestry Section, which had a staff, or departmental organization, patterned on industrial lines. One lieutenant-colonel with the regimental adjutant had charge of military administration and personnel, with their innumerable records. A second group of officers, headed by one of the most experienced lumbermen from the Northwest, handled the supply and upkeep of technical equipment - sawmills, logging tools, horses, motor trucks, steel and rolling stock for logging railroads, etc. This department supervised the going logging and manufacturing operations and directed the installation of sawmills and railroads at new locations. In less than 15 months it equipped and put through ninetyfive sawmill installations, many of which required logging railroads as well as sidings to connect with existing French lines.

Strategy in Military Lumbering. - High strategy was called for in the location of the forestry operations. It was not only necessary to scout for suitable timber and mill sets over practically all France; we had to keep posted, literally, from one day to the next, on the kind of products needed by the Army and at what points in its vast field of operations. Changes in the materials which were needed most critically and in the points whose requirements were most urgent were innumerable and necessitated not only an incessant revision of cutting and shipping orders but also frequent modifications of the plans for locating operations.

Sales and Traffic Department. - A third department at the headquarters of the Forestry Section, under another seasoned lumberman, had charge of the products manufactured and their shipment. In its hands rested the important duty of receiving and correlating requisitions for timber from every branch of the Army, and of determining, under general instructions from the Chief Engineer or the General Staff, the order in which they should be supplied. This was a task of no small difficulty and responsibility during the summer of 1918 when orders were flying in for three times what the Forestry Section was able to produce. This department also worked over and standardized the specifications for the innumerable forms of timber demanded and fitted them to what our mills and loggers could cut from French timber under pressure for the utmost speed in production. It issued the cutting and shipping orders to the district commanders and put all its energy and resourcefulness into providing cars or boats and getting the shipments through in time.

Let it be said in passing, that transportation was the neck-a very small neck - of the bottle. Lack of transport equipment was by all odds the greatest difficulty which the entire Services of Supply had to overcome. Every conceivable scheme was employed to keep lumber and railroad ties moving steadily to the front and other points of use, including 
fleets of motor trucks, barges, and shuttle trains of American cars on fixed runs whenever they could be obtained. By indefatigable efforts and the use of many expedients, the Department of Product and Shipment kept the movement of lumber on current orders within 86 per cent of production and the shipment of railroad ties within 72 per cent of the cut. One officer who handled deliveries from a group of mills in the Landes moved about 100,000,000 feet of lumber over a single railroad system in a year's time, a record which would rank high in American lumber traffic during normal times.

The Timberland Department. - A fourth staff department at forestry headquarters was responsible for obtaining the standing timber for exploitation. It organized and conducted a reconnaissance to locate suitable forests in practically all parts of France, including the Pyrenees and the southern Alps; passed upon all proposed acquisitions; put desirable purchases or condemnations through the established French agencies; and threshed out the terms as to price and cutting requirements. Officers of this branch represented the American Army on the interallied committee which correlated and controlled all purchases of forests for military requirements in the French Zone of the Rear. Through other officers it also had access to the French Army organization which controlled the disposal of forests in the Zone of the Advance. Between September 1, 1917, and the signing of the armistice this department acquired some $630,000,000$ feet of saw, pole, and tie timber and 700,000 cords of fuel wood. Half as much more had been located and cruised and was in process of acquisition.

\section{SAWMILIS AND LOGGING EQUIPMENT}

Early Makeshifts. - At the outset the forest engineers were sadly handicapped by the delay in the arrival of their sawmills and logging equipment. Many were the expedients resorted to to make good this deficiency. The first piles cut in the Landes were hauled to the railroad by man power, on the running gear of army escort wagons. At another camp ties were hewn with the most heterogeneous collection of axes ever assembled and logged out by mule teams outfitted with bridles of sacking - with 20-penny spikes for bits - and with harness of rope and wire. Eight stationary French mills were taken over and operated. These were little, under-powered affairs with very light saws. For a carriage there was usually a little platform on miniature wheels on which logs were fed to the saw with the bare hands or by a hand-turned crank. Bolstered up and made over by the resourceful American mechanics, five or six thousand feet a day was still all that most of these little plants could turn out; and they were discarded as rapidly as American equipment arrived. 
The Heavy Sawmill. - Three types of American sawmills were employed in France and they proved to be well adapted to the varying size of her forests and the different grades of timber. The first was a well-powered permanent steam plant, rated to cut 20,000 feet of lumber in 10 hours. It carried a circular head-saw with a 3-saw edger and two cut-offs. It required a substantial installation, with a dutch oven for the best steaming and cement mounting for the engine, but could be set up so as to begin cutting lumber, under the pressure of war-time urgency, in 12 or 14 days. Its ample power and weight and the substantial character of its parts permitted continuous hard driving at high speed, the key to production. Operated for two shifts daily, these mills turned out from $1,000,000$ to $1,200,000$ board feet per month. Some of them exceeded 2,000,000 feet in their best months' runs. These sawmills were utilized for all of the larger timber purchases, which in France meant areas of from 10 to 30 million feet. They were also much more satisfactory for the larger and heavier timber. In fact, for military requirements, in which dollars and cents cut no figure, the "large" mill was regarded generally as the most effective for compact sets containing $4,000,000$ feet or more of timber.

The Light Sawmill. - The second type was a much more portable mill, adapted to the innumerable small woodlots and château forests of France. It carried a 30-horsepower over-mounted engine and was rated to cut 10,000 board feet of lumber in 10 hours. It could be put up on timber foundations in 4 days. One of these mills, in fact, was moved 35 kilometers in the Landes, was reset, and began cutting its first log 47 hours after sawing the last $\log$ at the old site. These plants manufactured the same class and variety of products as the larger mill but could not withstand the same degree of driving. Many of them, however, cut steadily 600,000 board feet per month; and one of them made a month's record of a million feet of hardwood lumber and ties.

The Flying Sawmill. - The third plant was the last word in portable sawmills - a little bolter rig running a single 36 -inch saw and weighing but 3 tons with all of its equipment. It was rated to cut 5,000 board feet in 10 hours but could turn out much more than that. Its best work was done on logs 16 feet and under in diameter and 10 feet or less in length. It proved an excellent little machine for slabbing railroad ties or sawing unedged plank such as were used extensively in field fortifications. This diminutive sawmill could be operated by a 25 -horsepower steam or gas engine of any type but was most effective in combination with a 10-ton caterpillar tractor, both for operation and for its own transportation. The rig can be taken down in 4 or 5 hours, loaded on a couple of log wagons, moved by its own power to a new site, and reset in a similar length of time. The bolter mill and caterpillar made ideal 
equipment for the flying squadron of forestry troops working in the combat zone and for short sets in small timber at any point. It was often combined with larger plants, for slabbing small logs into ties, or moved into the woods after the large timber had been logged - to work up small material.

Heavy and Light Artillery in Timber Warfare. - All told, the Forestry Section marshalled a battery of 27 large mills, 62 light mills, and 61 of the little portables. These different types of sawmills proved to be well adapted to operating requirements in the French forests, with their wide variety in extent and in the size and quality of their timber. They also afforded well-balanced equipment for the numerous and varied demands of military operations. Sawmills, like artillery, must be adapted to work at different ranges from the trenches. The heavy, or comparatively permanent, mills were well fitted for long-time operations near permanent depots and base ports where continuous hard driving to produce the maximum quantity of lumber was of the first importance. The other types proved well adapted to the more temporary operations in which mobility and speed in setting up were the principal factors. With this complement of sawmills the Forestry Section kept from 80 to 90 milling operations going continuously, several of which employed two or more machines. A 30 per cent excess of sawmills is none too great for keeping an army supplied with timber under the strenuous conditions which existed in France. New mills were being installed constantly up to the day of the armistice and it was essential that this be done without stopping production at the established plants.

The Transport Problem. - First and last, the toughest problem in practical lumbering which the forest engineers had to overcome was the transportation of logs from woods to sawmill and of piling, poles, etc., from woods to railroad shipping point. Its difficulty was increased by the many different kinds of ground and topography which were encountered. In southern France it was a succession of flat sand plains, with occasional stretches of sand so loose as to make wheel traction very difficult. In the hardwood forests on the plains and hills of central and eastern France, the great obstacle was bottomless clay mud which, in its frequent state of saturation from weeks of continuous rain, defied almost any kind of traction put upon it.

In the fir forests of eastern France the logging conditions were more like those of the Adirondacks or the White Mountains. There was much good logging ground, some steep grades, bad patches of rock and moss, and occasional "sled snows" in wintertime. To find the right equipment for each job was not easy. The rough and ready mechanical skill of the American lumberjack was never displayed to better advantage. Spool skidders and 4 and 8 wheel $\log$ wagons were the mainstays, the 
former for short-distance skidding, up to 300 yards; the latter for hauls, up to 6 or 8 miles. Big wheels were used successfully on several jobs for skidding distances intermediate between those adapted to the spool skidders and hauls requiring a $\log$ wagon. They were employed in moving out piling at a number of operations. Drays, or "go-devils," were constructed for short-distance work in mud or snow or on rough ground at many operations; and in several instances the old-fashioned bob-sled - for long hauls on snow roads - came into its own.

Value of French Highways. - Much of the $\log$ transportation was facilitated greatly by the splendid system of French forest roads and surfaced highways. The maintenance of this wonderful network of rural communication all over France is a phase not only of preparedness for war but of national efficiency at all times which the United States would do well to emulate. Logs could often be handled by motor truck to a central mill site from several small forests within a radius of 10 or 12 miles. Enormous quantities of poles, piles, hewn ties, lumber, and fuel wood were moved to rail by the same means. Much normal railway traffic was, under the exigencies of the general transport situation, handled by fleets of motor trucks and trailers.

Motor Trucks and Caterpillars. - With the motor trucks and irontired tractors, which were used both in the woods and on hard roads, it was found necessary to have two types of trailers, each of about 5-ton capacity. The first was a high-speed trailer, with rubber tires and roller bearings, adapted to fast work on good roads. The second was a slowspeed trailer, with high wheels and 6-inch iron tires. This machine was designed for work in the woods primarily, although it was often advantageous to send a string of trailers from the landings through to the mill or railroad, without rehandling their loads but perhaps changing the type of power when hard roads were reached. One of the most difficult transportation jobs required in France was the moving of 90 and 100 foot piling out of the Vosges Mountains. This was done with gas tractors and iron-tired trailers, the latter fitted with special built-up bunks for the purpose.

Caterpillar tractors did wonderful work in hauling trailers or log wagons over ground which was impassable to horses and to any other type of motor equipment. These powerful machines with 8-wheeled log wagons were the last resort in keeping logs moving through sodden clay mud when everything else had failed.

Logging Railways. - The forestry operations in France had to resort to logging railroads or horse trams in many cases because of lack of horses, the lack of suitable motor traction, difficulties arising from mud, swamps, or loose sand, and in several cases because of the large quantities of timber to be moved over distances of 2 to 6 miles. In many operations, 
in fact, the logging railroad demonstrated its superiority, where topography was favorable, even for sets as small as $6,000,000$ feet. A difficult area in the Vosges Mountains was logged by means of a 4,000-foot meter gauge incline, with an average grade of 35 per cent, down which carloads of logs were lowered by donkey engine and cable.

The light railway sectional track, of various gauges 2 feet and under, used by the Army at the front, was employed in many forestry operations. It rendered good service in handling light products, like poles and fuel wood, and was used successfully at several operations for transporting logs. It was often preferable for small jobs because laying and removal were so fast. For extended operations, however, the forestry officers found that 3-foot gauge track laid with 25 or 40 pound steel saved time and cost in the long run. When our real 3 -foot gauge rolling stock arrived and steel rails were available in sufficient quantities the difficulties of the forestry operations were materially reduced.

\section{THE PRODUCTION OF FUEL WOOD}

An Enormous Problem in Itself. - Supplying the American Army with fuel wood was a special problem in itself, whose proportions increased from month to month practically in a fixed ratio to the increase in the number of American soldiers in France. Considerable supplies of fuel wood were obtained from French stocks. Cutting the added amounts needed was not a serious matter during the first winter of American operations, but became an enormous task during the fall and winter of 1918-19. The monthly production necessary to keep the Army warm and fed reached the figure of 287,000 cubic meters in December, 1918.

Fuel Wood Cut by the Forest Engineers. - The forest engineers themselves cut large quantities of fuel as a by-product in all their operations. It was obtained not only from mill slabs and edgings and from treetops, but also from the dense stands of sprouts which covered the ground in most of the hardwood forests which were operated and which had to be swamped out in logging the large timber. By April 1, 1919, the Forestry Section produced 1,195,000 cubic meters of fuel wood. Owing to the shortage of transport, however, but 50 per cent of this amount could be moved to the points where it was needed. The supplemental production of fuel wood was essential and it had to be localized, particularly in the Advance Section, in the immediate vicinity of the larger bodies of troops.

The Special Fuel Supply Service. - During the first winter this was done under the direction of the Quartermaster Corps by employing civilian labor, by details from combat organizations, and by the assignment of a few companies of infantry to this particular duty. The use of combat troops for this work proved unsatisfactory and led invariably 
to large damage claims for injuries to the carefully regulated French forests. The enormous demands in prospect during the summer of 1918 made it necessary, in any event, to organize a special fuel wood service on a much larger scale. The Quartermaster Corps thereupon assigned 10,600 of its service troops to this duty in the Advance Section. This project was placed under the direction of a lieutenant-colonel of the Forestry Section with a supply officer from the Q. M. C. Thirty-three officers and non-commissioned officers were furnished by the Forestry Section to locate and acquire the timber needed and supervise its cutting. The Quartermaster troops included fifteen pack trains, two wagon trains, and a motor truck company.

This hastily assembled organization conducted thirty-eight fuel wood camps, all told, in the hardwood coppice forests of northeastern France. Its operations were distributed through practically all of the divisional training areas in the Advance Section and six companies were employed during September and October, 1918, to supply the troops constituting the First Army. It was a task of no small difficulty to organize and equip this enormous force of woodcutters. As usual, the question of transport was the kernel of the problem. Every sort of available equipment which could move fuel wood was utilized - tractors, motor trucks, 40 and 60 centimeter sectional track, lumber wagons, escort wagons, two-wheeled French carts, and sleds. Chutes made of corrugated iron were employed at several operations; and a deal of fuel wood was dragged or carried out to hard roads by sheer man power. Forty-centimeter sectional track with light cars, moved by mule or man power, proved to be very serviceable equipment. The fuel wood camps were placed, as far as possible, right in the troop areas, and much of the wood, once placed on hard roads, was distributed by the transport equipment of the division which used the fuel.

In spite of the difficulties encountered, the special fuel supply unit was thoroughly successful and tided the Army over the shortage of fuel wood which would otherwise have been acute during the cold months of 1918-19. A total of 930,000 cubic meters was cut, giving the Army a comfortable surplus over its requirements and indeed permitting the turning over of considerable quantities of fuel to the French when the Advance Section was evacuated.

\section{WHAT THE FOREST ENGINEERS ACCOMPLISHED}

The Beginning and the End. - The first log was sawed by American forestry troops at a little French mill in the Jura Mountains on November 26, 1917. Three days later the first American sawmill in France began operating in a forest of Scotch pine on the Loire River. Prior to these dates another camp of forestry troops in the southwestern 
pineries had begun cutting 50-foot piles which were urgently needed for the American docks at Bordeaux. Less than one year later, when the armistice was signed with Germany, the forestry troops were operating eighty-one American sawmills and cutting 2,000,000 board feet of lumber, ties, piles, and poles every working day, aside from vast quantities of fuelwood. Within this year's time over 90 per cent of the personnel of the Forestry Section had landed in France, taken their stations, put up their sawmills, constructed their railroad connections, and cut 300,000,000 board feet of lumber and railroad ties, 38,000 piles, and 2,878,000 polés and entanglement stakes. The cut of fuel wood during the same period was some 317,000 cords.

The Spirit of the Forestry Troops. - A deal of labor, of Yankee ingenuity, and of determination to back up the fighting troops of the American force with the timber which they needed were required in producing these results. Nor is it possible to describe the pressure upon all of us during the summer and fall of 1918 when every lumberjack in the regiment felt the tenseness of the final grapple and put everything he had into it. I will never forget the big mill at Eclaron as I saw it one October night - sparks streaming from its stacks, its two carriages flashing back and forth, loads of oak logs creaking up to the mill deck, cars being shunted about, ties loaded into them hot from the saws, and the sober, earnest faces of the men as they worked under the electric lights. They were shipping 5,000 ties daily to the Argonne offensive. That scene was typical of the eighty or more forestry operations in France during the great drive.

Winning the War with Lumber. - The daily and monthly mill cuts afford an excellent index of the spirit which the lumberjack engineers put into their work. Rated capacities quickly disappeared in the sawdust. The 27th Company, at Mouthe, holds the record for the largest day's cut at any forestry operation. This company produced 177,486 board feet of fir lumber and timbers on a " 20,000 " mill in 23 hours and 25 minutes. The 37th Company, formerly Company F of the Tenth Engineers, made the largest 20-hour cut, 163,376 feet, with the same type of mill and product. The camp of the 26th Company, at la Cluse, carried off the pennant for a 20 -hour run with a " 10,000 " mill, knocking out 78,881 feet of fir lumber and timbers. Three other companies, operating in softwood timber, made daily records with 10,000 -foot mills of from 63,000 to 68,650 feet. Several of the 10,000 -foot mills made daily records, in two shifts, of from 40,000 to 55,539 feet of hardwood lumber, ties, and timbers.

One of the most remarkable achievements was that of the 19th Company in the 7th Battalion, which in $10 \frac{1}{2}$ hours cut 64,000 board feet of oak ties with a bolter mill rated to produce 5,000 feet per shift. 
In the face of the enormous quantities of timber required to carry forward the work of the American Army in almost all of its branches, every possible effort was made to speed up production at the forestry operations. Practically all of the sawmills were operated day and night, some of them on three 8-hour shifts. More than double the rated capacity of the plants was obtained currently at many of the forestry operations - by continuous hard driving. The following figures, covering 7 months in 1918, illustrate the rate at which mill capacity was increased during the critical period of the war and also the actual output of sawed products as compared with the rated capacity of the plants.

\begin{tabular}{|c|c|c|c|}
\hline $\begin{array}{l}\text { Month } \\
(1918)\end{array}$ & Number of mills & $\begin{array}{l}\text { Average rated } \\
\text { capacity per } \\
10 \text { hours, } \\
\text { M ft. b.m. }\end{array}$ & $\begin{array}{l}\text { Average } \\
\text { cut per day, } \\
\text { M ft. b.m. }\end{array}$ \\
\hline 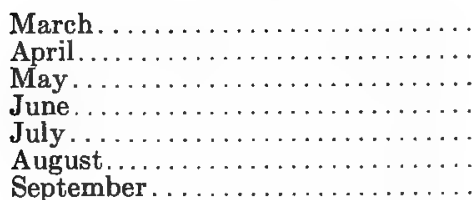 & $\begin{array}{l}33 \\
41 \\
48 \\
54 \\
64 \\
68 \\
77\end{array}$ & $\begin{array}{l}255 \\
303 \\
402 \\
542 \\
757 \\
797 \\
850\end{array}$ & $\begin{array}{r}302 \\
560 \\
665 \\
835 \\
1,215 \\
1,550 \\
1,700\end{array}$ \\
\hline
\end{tabular}

The last column contains the actual daily output, including time lost from breakdowns, shifts in location, and delays incident to the operating of new mills.

The principal thing which made such a showing possible was the experience and skill of the men comprising the forestry companies and the esprit de corps which actuated their work. These qualities in its personnel were by far the greatest asset of the Forestry Section. The actual accomplishment of the Forest Engineers as a distinctive unit in the American Army was summed up in these words from their commanding officer, shortly after the armistice was signed:

"Recent reports from the various depots and construction projects of the American E. F. show that the Army was at the time of concluding the armistice well supplied with lumber. When ties were called for in large quantities to support the advances of our troops at St. Mihiel and in the Argonne they were ready. At practically every dock project deliveries of piling and lumber were well ahead of the construction. In other words, the Forestry troops have made good on the work for which they were brought to France. Notwithstanding the difficulties in obtaining equipment and transportation, notwithstanding the enormous increase in the size of the American E. F., and the work which it undertook over the original estimates, the Army has been given the lumber 
which it needed, and the suspension of hostilities finds us with a substantial surplus which will be used for the restoration of France."

\section{COÖPERATION WITH THE FOREST AGENCIES OF FRANCE}

French Organization of Timber Supplies for the War. - When the advance guard of Forest Engineers reached Paris in 1917, they found the French Government and Army highly organized for the procurement of timber for military requirements. Each of the French Army groups carried a Forestry Service on its staff, with an elaborate organization extending throughout its entire section of the Army Zone. This service requisitioned existing stocks of lumber or wood, bought or requisitioned forests, ran sawmills with German prisoners or French engineer troops, and operated its own transport system for distributing forest products to all units in the Army group. This was a purely military organization which exercised practically absolute control over all forests and forestgrown materials in the territory designated as the Army Zone.

A distinct organization functioned in the Zone of the Rear, under the Minister of Munitions. It centered in the Inspector General of Timber who directed the activities of some twenty "timber centers" embracing all parts of France outside of the Army Zone. Each timber center consisted of a group of French engineer or forest officers who purchased or requisitioned forests, operated sawmills with prisoners of war or military labor, and largely controlled the disposal of timber products cut by private agencies. They were authorized by a war-time decree to requisition 75 per cent of the output of any sawmill at a scale of prices fixed by the Inspector General and also made contracts for railroad ties, piling, barracks, and other special products needed by the armies. This was a civilian organization, although made up largely of militarized personnel, responsible to the French Cabinet and obtaining and distributing its timber in accordance with the programs formulated by the Minister of War and Minister of Munitions.

The Service of Waters and Forests under the Department of Agriculture maintained its customary organization and functions during the war, although with ranks sadly depleted by the call to arms. It administered all of the State forests and the great bulk of the communal forests and forests owned by public institutions. Its guards and rangers were to be found in practically every forested canton of France; and its inspectors and conservators represented an exceptionally intelligent and expert corps of foresters who rendered assistance of the utmost value to the allied armies in locating suitable supplies of wood. They determined the maximum quantities of timber that could be cut from State and communal forests without doing serious violence to their plans of 
management and placed most of these cuttings at the disposal of the war-time supply services as preferred purchasers.

Early Negotiations with the French Government. - Rather extended negotiations were necessary before the work of supplying the American Army with timber was adjusted effectively to these existing forestry organizations in France. Not alone were the means of obtaining forests for American operations involved; other questions, such as the advance of lumber and railroad ties from French stocks for the most immediate and urgent needs of our Army, the control of American wood purchases by the French Government, and the loan of American troops and equipment to the Inspector General of Timber, had to be settled. A satisfactory adjustment of these matters was reached in the latter part of August, 1917, and reasonably effective coöperation with the various French agencies then developed.

The Interallied Timber Committee. - A committee which had existed previously for correlating the forest purchases of the French and British supply services was expanded into the Interallied Committee on War Timber, with French, British, Canadian, Belgian, and American representatives. This committee functioned under the French Inspector General of Timber and served as a clearing house for the consideration of all requests from the various armies for the purchase of forests in the Zone of the Rear and for adjusting conflicting demands. The purchase of any forest for a particular army had to be passed upon by this committee before action was taken through the competent French agencies.

Once the purchase of a particular tract of timber was approved by the committee and sanctioned by the Inspector General, a direct cession was obtained from the Waters and Forests Service in the case of State or communal holdings, the cession specifying the quantity, price, and cutting requirements. If the tract was privately owned a commission of French forest experts undertook the estimate and appraisal of the stumpage and the negotiations for its purchase. If a friendly purchase could not be effected a request for the requisition of the property was made to a still different war-time organization, called the Standing Committee on War Timber. This board was composed of the Inspector General, representatives of the Department of Agriculture, members of Parliament, and prominent French lumber manufacturers. It had been created in the course of the war as a means of developing and controlling the general policy of the French Government for meeting military demands for forest products, and was the final court on the condemnation of private forests.

Forest Acquisitions in the War Zone. - At the same time that officers of the Forestry Section took their places in this somewhat complicated 
administrative machinery for the purchase of forests in the Zone of the Rear, other American officers were stationed at the headquarters of our Army at Chaumont and established direct connections with the French Army organizations which controlled timber supplies in the War Zone. Their procedure for acquiring forests, based upon martial law, was much more direct and expeditious.

Scouting France for Timber. - Thereafter the acquisition of forests for operation by our troops, which began to arrive in October, 1917, moved forward rapidly. The advance guard of foresters and lumbermen who preceded the troops were employed largely on reconnaissance to locate suitable operating units. As each battalion of forest engineers arrived, one or more of its officers took up the same work in their immediate operating region. Reports on desirable areas came in thick and fast and their acquisition was pushed through the various stages as rapidly as possible. Notwithstanding many delays and difficulties and the inability to carry through requisitions of private forests in some instances, the Forestry Section was able to locate all of its incoming troops at operating points without loss of time and to keep them continuously supplied with timber.

Cutting Requirements Imposed by the French. - The French agencies retained control of the technical requirements to be observed in all forestry operations and frequently inspected the American cuttings. The methods of cutting State and communal forests were drafted by the conservator of the district and fixed in the terms of cession. Officers of the Forest Service inspected these operations very closely. Cutting regulations applicable to private forests were usually outlined in the report of the expert commission in connection with the appraisal of the timber. These were later embodied and sometimes changed in the formal contracts made with the owners of the forests by the local timber centers. Such contracts were almost uniformly delayed until long after cutting had begun; but a liaison officer, representing the Inspector General in each region, directed the methods to be followed in cutting private forests and settled complaints from owners. In the Army Zone these duties were discharged by an engineer officer representing the Timber Supply Service of the Army staff.

The requirements of French forestry were rather strictly enforced in operations on State or communal holdings. In a few instances even, large, full-crowned fir or spruce trees had to be limbed before felling in order to reduce the injury to young growth when they were brought to the ground. In a few cases the terms of cession required cutting out patches of briars to facilitate the regeneration of the forest or pulling up the stumps of species like beech, which the French foresters wished to get rid of for silvicultural reasons. The piling of slash was required 
in the pine and fir forests of central and eastern France, but not as a rule in the hardwood forests where the close utilization of fuel wood left practically nothing but small twigs. In cutting hardwood coppice special precautions had to be taken to leave smooth, rounded stumps which would shed water and prevent decay injurious to the new crop of sprouts.

Restrictions upon the Amount of Timber Cut. - The most serious restriction from the standpoint of effective logging was the limitation on the quantity of timber which could be removed from many forests. In the southern pineries, following the forestry system of the region, the timber was cut clean and the requirements imposed were comparatively simple. In the hardwood forests and the softwood forests of the eastern mountains only trees selected and marked by the French foresters could be cut. These usually comprised from 15 to 40 per cent of the actual volume of merchantable timber. In the State and communal forests of the Vosges and Jura, containing many fine areas of fir and spruce timber, cutting was restricted to a limited number of "coupes" which were ready for felling under the exact methods of management applied by the Waters and Forests Service. Blocks of mature timber would be withheld, for example, because the regeneration of young trees was not sufficiently advanced.

As the result of constant pressure by the American representatives in the interally organization, the markings in these forests were often extended to include from five to ten "annual possibilities," that is, from five to ten times the quantity permitted to be cut in one year under the plan prescribed for the management of the forest in question. All the timber marked, however, was restricted to trees which could be removed properly from the standpoint of maturity and the generation of the next crop. As a matter of fact French forestry practice is so conservative that many of these forests carried an excessive amount of old timber, and cuttings of this character and extent were not injurious from a purely technical standpoint. The most extreme illustration of the strict application of French forestry requirements occurred in a few large, rich forests where the cutting of but a small fraction of the merchantable timber was allowed, this being restricted mainly to windfalls or thinnings.

The usual forestry rules were departed from in the case of many private forests which had been requisitioned or whose owners were favorable to a heavier cut than would ordinarily be permitted. On a few large hardwood areas such special concessions allowed the removal of as much as 80 per cent of the merchantable material.

Meeting French Foresters on Their Own Ground. - The officers who represented the American Army in the negotiations with the French 
foresters were quick to appreciate how little their conceptions of sound forestry practice had yielded to the urgent demands of the war. We could but respect this vigorous assertion of the national instinct for forest conservation in the face of a world-wide emergency, although at times it appeared to be carried farther than a vigorous and effective prosecution of the war should permit. The American officers endeavored consistently to meet the French foresters on their own ground, and to understand and work in harmony with their technical requirements. This was indeed the attitude of the operation commanders and of the rank and file of the forestry troops to a remarkable degree, considering how foreign the French forestry viewpoint was to their past experience and habits of thought as lumbermen. The French foresters thus acquired a large measure of confidence in the American engineers at work in their woods, a fact which proved to be of great benefit to the Forestry Section in the long run.

The French View of American Operations. - As a matter of fact the French made practically no serious criticisms of the American cuttings as far as compliance with forestry requirements was concerned. The common sense and practical understanding of the situation on the part of the average French forester made many requirements less burdensome in practice than they threatened to be in the formal contract. The criticism of the French was directed chiefly against the American methods of utilizing timber, particularly the 7 and 9 gauge circular saws with which our mills were equipped. Accustomed for centuries to the closest possible utilization of valuable timber, with human labor and rate of production wholly secondary considerations, and to the use of narrow bandsaws of a thinness approached only in light work in planing-mills or wood-working factories in the United States, the wide kerf eaten out of the logs by the heavy American circular saws was anathema to the thrifty French. Nor were they convinced by the American argument that heavy equipment was necessary to stand up under the continuous hard driving required to get the maximum production from our mills and that the war would be won by volume of output rather than a minimum of waste.

A related question was that of the class of products cut from large, high-grade timber. The State foresters could not forget how they had sought from time immemorial to make the public forests of France supply the clear, high-grade timbers, in large sizes, needed by her industries. When an American captain under the pressure of "rush" orders cut such logs into ties or scantling, as occasionally happened, the incident was apt to become a subject for grave discussion by the Inspector General at his monthly meeting with all the Allied forestry chiefs. The upkeep of their wonderful system of forest roads and surfaced highways was 
another thing which the French forester kept close at heart and which the impatient American was apt to put aside. Thoroughgoing repairs on all of the roads used in our operations, however, were made by the forest engineers before they left France.

French Difficulties in Supplying American Requirements. - In judging the effectiveness of the coopperation of the French with the American Forestry Section, it must not be forgotten that the war brought many difficulties and problems to the forest agencies of the country, and that these were vastly increased by the presence of the American Army. Not only did France have to supply her own vast military requirements from her limited forest resources as well as the bulk of the lumber needed by the British, Belgian, and American forces; she had also to meet the urgent needs of her civilian population and she had to foresee and provide for the restoration of the sixth of her territory which the Germans occupied. Moreover, the French are an exceedingly democratic and individualistic nation. Forest conservation and the sacredness of property rights are two of their most cherished and deeply rooted characteristics. The war administration had to hold the political support of these people during four and a half years of stress and sacrifice. Any source of dissatisfaction or unrest strengthened the "defaitists," who sought an early peace at any terms.

Discontent over the inroads upon French forests was already rife during the winter of 1917 . During 1918 it assumed the proportions of an organized movement. It became the subject of interpellations on the floor of Parliament. The opposition of the turpentine workers in the Landes against what was regarded as a depletion of the forests upon which their livelihood depended necessitated a change in the spring of 1918 in the methods of purchasing timber in that region. Thereafter all forest acquisitions in southwestern France had to be passed upon and approved by a local commission on which the "résiniers" were represented. During the summer of 1918 , when the Germans were at the very gates of Paris, the whole system of acquiring forests for military requirements in the Zone of the Rear had to be reorganized, with new officials representing the "opposition" in Parliament in positions of control.

Effectiveness of French Coöperation. - In consideration of these difficulties with which the French Government was confronted, its coöperation in supplying the American Army with timber must, in all fairness, be regarded not only as a vital factor in the success of our military operations but also as effective as the circumstances permitted. It was inevitable that the French should view the cutting of their forests for war purposes differently from the Americans; and that their inborn attitude toward forests and their training in forest conservation should 
find expression in a degree of caution and control which the impatient Yankee could not understand. The whole French attitude toward the war was different from our own. Wars come and pass, in every generation, but forests remain as a vital element in national economy.

Notwithstanding procedure that was often cumbersome and delays that were often vexatious, notwithstanding restrictions that at times seemed petty and unnecessary, the American Army, first and last, was amply supplied with timber from the French forests. At no time were the operations of the forest engineers seriously handicapped either by lack of timber or by the requirements which governed its removal. The slowness and conservatism of the French administrative machinery was offset largely by the extraordinary ability and personal force of individual French forest officers. It is to these men who quickly grasped the requirements of the American Army and the American manner of doing things and who found a way through nearly every difficulty that the success in obtaining the standing timber needed for our operations in France was largely due.

\section{FOREST TROOPS LOANED TO FRENCH AND BRITISH ARMIES}

One of the first acts of the American Government after entering the war was to promise a regiment of lumbermen to the British Army: Shortly after another regiment was assured tentatively to the French Army, a promise later confirmed and enlarged by the Commander-inChief of the Expeditionary Force. The enormous increase in the size of the American forces in France subsequently determined upon, with their corresponding demands for timber, made it impossible to fulfill these agreements until after a fair start had been made toward supplying our own troops with the material essential to their initial operations in France.

In February, 1918, however, it was possible to assign a battalion of forest troops to each of the French and British forces. The battalion loaned to the French arrived and was established at operations selected by the Inspector General of the French Timber Service in March, 1918. It functioned as an American unit in all respects except that its forests were provided by the French Government and its products were furnished directly to the French Army. This battalion operated for French requirements until February 1, 1919, cutting over 13,000,000 feet of sawed material, 125,000 pieces of round products, and 46,000 cubic meters of fuel wood. Its work elicited the warmest praise from the French Government.

The battalion assigned to the British Army was torpedoed on the transport Tuscania and was unable to begin lumber manufacture in 
France until May, 1918. It worked for the British forces until October of the same year, cutting over 14,000,000 board feet of lumber and railroad ties and beating all of the Canadian and English units under the British Director of Forestry in its record of production. With these operations under its direction, the Forestry Section of the American Army assumed a truly allied character and was able to render valuable assistance to our comrades in arms on the far-flung battle line.

\section{WHAT THE AMERICAN WOODSMEN LEARNED IN FRANCE}

The American woodsmen in the forest regiments have learned much from their experience in French forests. The change from new world to old world methods of cutting and from new to old world viewpoints toward the forest was very sharp. The average lumberjack arriving in France was scornful of the restrictions imposed by the French foresters - of the smooth hardwood stumps which he was required to cut, of the limited felling which he was permitted to do in many fine stands of timber, of the sawing of big trees level with the ground, and of the watchfulness to prevent injury to seedlings and saplings. But as the months in the French forests passed by most of the American soldiers appreciated the fundamental common sense behind these forestry rules. Particularly as they came to know the French country people and to appreciate the scarcity of wood on their farms and in their fireplaces, they began to understand the whole thing as a natural outgrowth of French economic life, on a par with their intensive agriculture. They sensed forestry as simply another expression of French thrift, of the national genius for making the most out of their limited resources.

The average American lumberjack left France with a far different attitude toward her forestry practice than he had upon arrival. How lasting the effects of this first-hand experience in old world methods will be is problematical. But certainly many of these thousands of woodsmen have brought back to our own forests a totally new conception of their economic value and of practical means for conserving it.

\section{THE WAR A VINDICATION OF FRENCH FORESTRY}

Let it be emphasized in closing that probably never in the history of the world has the forest policy of a nation been so clearly vindicated as was that of France by the war of 1914 . Wood was one of the most vital military necessities, and the allied armies drew the great bulk of their supplies from the forests of France. More than that, her forests had a strategic value for defense of the highest importance. For the forest barriers in northern France and for the abundant supplies of timber available to the battle lines, the allied world must thank the patience 
and foresight with which the French nation has built up its forest resources. France could have kept on supplying the vast armies on her soil for one or two years more, if need be, without cutting seriously into her forest capital. Without these ample reservoirs of timber, the transport difficulties being what they were, the handicap which the allied armies would have suffered would have been almost insurmountable. Apart from its value to her peace-time life and industries, the forest policy of France has been vindicated as a capital element of national strength in the greatest crisis of her history. 


\section{APPENDIXES}

(A) The Forest and Springs (p. 361).

(B) The Forest, From a Physical, Fconomic, and Social Viewpoint (p. 381).

(C) Silvics of Important Forest Species. Lists of Trees, Shrubs, and Plants Used in Reforestation in the Mountains (p. 387).

(D) Statistics on Public and Private Forests over Five Thousand Acres in Area (p. 409)

(E) Typical Reforestation Areas in the Mountains (p. 422).

(F) Specifications for Tapping Maritime Pine and for Fixing Shifting Sand Dunes (p. 429).

(G) State and Communal Timber Sale Regulations (p. 438).

(H) French Forest Literature (in Library, Nancy Forest School) published 18701912, classified as follows: (a) Forestry Proper, etc., (b) Forest Law, (c) Forest Education, $(d)$ Engineering (Reboisement), (e) Forest Administration, $(f)$ Miscellaneous, $(g)$ Botanical and Silvical (p. 448).

(I) German Comment on French Forestry with a Comparison with German Methods, by Dr. Martin, of Tharandt (p. 469).

(J) The Forests of Alsace-Lorraine (p. 495).

(K) Original Working Plan Data (p. 500). (1) State Forest of Grande-Côte (Jura) (p. 500); (2) State Forest of Ban d'Etival (Vosges) (p. 508); (3) Communal Forest of Mont Gloire (Savoie) (p. 511); (4) Communal Forest of Lardies (Basses-Pyrénées) (p. 512); (5) State Forest of La Joux (Jura) (p. 512); (6) Communal Forest of Fillinges (Haute-Savoie) (p. 515); (7) Communal Forest of Burdignin (Haute-Savoie) (p. 516); (8) State Forest of Parc-et-St. Quentin (Oise) (p. 517); (9) Communal Forest of Thiez (Haute-Savoie) (p. 517).

(L) Model Insurance Calculations of Damage by Fire (p. 534). 


\section{APPENDIX A}

\section{THE FOREST AND SPRINGS}

(BY HUFFEL)

Springs and Their Origin. - Before approaching the diffeult and controversial question of the influence of forests on the maintenance of springs, ${ }^{1}$ it is necessary to define exactly what is meant by a "spring," and what is the origin of springs.

"A spring," says Littre" "is the water which issues from the ground at the origin of a stream."

Nowadays everyone admits that springs are fed by the percolation of water into the earth derived from the atmosphere. It has been calculated ${ }^{2}$ that the total flow of water into the ocean of the principal rivers of the globe represents only about threesevenths of the water which falis into their basins, derived from atmospheric sources. There is therefore sufficient rainwater alone to feed the water courses, without its being necessary to seek for other sources of supply, as Descartes has done.

Percolation, or infiltration, is the slow penetration through fissures and through interstices in the soil, of water derived from rain, from the melting of snows, from the condensation of atmospheric vapors on the surface of vegetation, and on the superficial parts of the soil.

These waters, after penetrating into the soil, accumulate in certain parts and form what is called subterranean sheets of water.

In fact the deeper the water penetrates the less subject does it become to evaporation, and finally it reaches a point where it has passed beyond the region of drainage, and that tapped by the roots of plants. It is thus, generally speaking, that subterranean sheets of water are formed below this region, which, at any point where there is a depression in the soil at their level, come out as springs. ${ }^{3}$

The level of the subterranean sheet of water in permeable soils is more or less deep, according to whether there have been recent rainfalls or not and whether these have been abundant or scanty. Evaporation prevents it from establishing itself babitually at the surface of the soil; the effect of drainage, and the suction of plant roots will equally prevent the entire saturation of a more or less substantial stratum of soil, or one more or less deeply situated, according to the nature of the flora. Thus it will be found that under a forest, the stratum of soil dried by roots is appreciably deeper than that below a piece of ground under cultivation.

Other things being equal, the level of "phreatic" " waters will be all the lower: if the soil is more permeable; if the rains have been less abundant or less recent; if evaporation has been greater; if the stratum drained by the roots of plants is deeper.

1 Translated (literally) from Economie Forestière, G. Huffel, Vol. I, pp. 83-124, Chapter III, "The Forest and Springs."

2 Elisée Réclus, "La Terre."

"See the "Traité de Géologie" of M. de Lapparent, 4th edition 1900, Vol. I, p. 195 and following pages.

"Daubrée ("Les Eaux Souterraines." Vol. I, p. 19) has introduced this term to designate the sheet of subterranean water the nearest to the surface, because this is the one which feeds the wells. 
In order to understand precisely the nature of springs, it is necessary to distinguish three different types: those in permeable soils, which are called "thalwegs"; those in stratified soils; and those in soils where fissures abound.

Let us take the case of a surface composed of permeable ground which is perfectly horizontal; under this the water which filters through will form a sheet of which the surface will be level, and will approach more nearly to the surface of the soil, according to whether the precipitations have been more abundant or more recent.

This point established, then if the plain happens to be approached by a valley the latter will produce upon it an effect of drainage so that its level will become lower the nearer it approaches the valley. If, at the base of this valley there is a stream of water running, this stream will be fed by the sheet; thus it is that in all valleys composed of permeable soils, to the right and left of the river bed, similar sheets of water are to be found, and these will feed it, and do not always originate from the infiltration of its waters, as has been said. ${ }^{5}$

If the surface of the soil is uneven the subterranean sheet will have an undulated surface, reproducing in an attenuated form the unevenness of the ground. One sees that in such soil the depth of wells will attain its maximum in the ridges, its minimum in the thalwegs.

It is this fact that has been perfectly verified in the sands of the Sahara, for instance, and in the plains of permeable soil in the basin of the Seine.

So long as the depressions in the soil do not reach as far down as the sheet of water formed by infiltrations the latter has no possible outlet. But as soon as it comes in contact with the bottom of a "thalweg" it overflows in springs of a kind which are only found in "thalwegs." These springs, which are called "sommes" in Champagne, are rarely perennial; they go up and down the valleys to the length of many kilometers according to the oscillations of the subterranean sheet of water. In Picardy, a province of notably perneable soil, the springs formerly came to light at a very considerable distance up the river from their present point of emergence, a circumstance which is generally attributed to the influence of deforestation.

Let us now consider the case of a stratified soil formed of strata of varying degrees of permeability. This is a case of most frequent and most simple occurrence. After having passed through the permeable soil the water will be arrested by strata that are impermeable, or are so in a lesser degree; if the surface of contact of the two soils arrives at a point intersected by a valley there will be along the whole line of intersection a "spring level," as it is called. If the strata of the soil are inclined in a certain direction the springs will be more numerous on the slope of the mountain corresponding to that direction. They will rise at points where the line separating the strata of the soil takes a turn, or else at points where this line is cut by a "thalweg" or ravine. It is easy to see that there may be several spring levels along the slopes of the same hill; it is only necessary for this that the strata become less and less permeable. Faults, or a thousand other geological accidents, can alter the regular course of springs.

Nothing is more variable than the hydrological course of formations which owe their permeability entirely to fissures. ${ }^{7}$ It generally happens that limestone and sandstone formations which are most cracked at the surface, are quite compact at their bases. Water cannot form continuous sheets in these; it concentrates therefore in pockets and fissures; the overflow no longer takes place in regular lines, as in other soils, but at veritable points of selection. Springs have often a very considerable underground course; they flow from the waters which have filtered through from vast plateaus; they

${ }^{5}$ The usual direction in the movement of subterranean waters towards a river can be reversed, when the latter is in flood. Daubrée has shown this very clearly in the case of the subterranean sheet of water extending along the course of the Rhine in Alsace.

6 De Lapparent.

${ }^{7}$ De Lapparent, op. cit., p. 199. 
are generally fed by a series of intercommunicating reservoirs. Sometimes also they have a considerable and remarkably regular flow. This type of spring is very common in the Jura; the springs of Cuisance, Luzon, and a great number of others furnish good examples. The famous fountain of Vaucluse belongs to the same type.

Space will not permit us to concern ourselves here with this last category of springs, which do not, properly speaking, come under the definition given above, because they are only waste weirs of a lake or a series of subterranean lakes.

Special Remaris on the Action of Forests on Springs. - Do forests favor the feeding of springs? Formerly there was no doubt on this subject. Our fathers always considered forests and springs as co-partners and Buffon wrote," "The more a country is cleared the poorer it becomes in water." The Forest Code of 1827 only sanctions the general belief of the period when it authorizes the forest officials to oppose the clearing of forests with a view to protecting the existence of the springs.9 One must allow that such an ancient, prevalent, and persistent belief constitutes a strong presumption in favor of the utilitarian purpose of a forest; common opinion can only be the result of proved facts.

It is only recently that doubts have been expressed on this point. Cases have been quoted where reafforestation has reduced the output of the springs. On the other hand, marshy grounds have been known to lose their superficial water in consequence of reafforestation, and it was concluded from this fact that the forest acted as a kind of pump to inhale in bulk, by means of its roots, the free water of the soil and return it to the air by means of the evaporation of its leaves. It might, however, be objected to in this last case that it is equally admissible that forests have caused superficial stagnant water to disappear by favoring their infiltration.

It is an extremely difficult and delicate matter to ascertain by direct observation the influence of the afforestation or deforestation of a soil on the output of a spring. It is in fact only by chance in many cases that we are able to recogaize exactly the place whence the waters filter which we find oozing forth at a given point; the natural reservoirs may be very far removed ${ }^{10}$ from the place where they appear above ground and be separated from them by valleys, heights, etc. The exact defining of the feeding basin of a spring is sometimes a very complicated problem, enough to embarrass the most experienced of geological specialists. The direction of the springs, too, is often altered by works such as the cuttings made for roads or railways, for galleries in mines, etc., undertaken very far away from the place where these waters become visible. Certain springs are so superficial that shallow ditches or simple farm drainage can deflect them. Finally the actual output of a spring depends especially on the rainfall of the current year, a factor which is always in the preponderance. A certainty could only exist in the case where reafforestation or clearings practiced on a large scale would have affected to a permanent and notable degree the output of all the springs of a given region. It has often been asserted that this was the case, and was taken to prove that the general level of the waterflow had diminished in many parts, in proportion to the degree of clearing practiced locally; but it is well to recognize that published observations are far from being entirely reliable or irrefutable."1 Whatever may be the diffi-

"Histoire de l'Académie Royale de France," 1739, "Mémoire sur le Rétablissement et la Conservation des Forêts."

- Art. 220.

${ }_{10}$ To quote only one instance: The waters which have filtered through into the green sand of the basin of the Meuse are found again at Paris at a depth of 1,798 feet (artesian wells of Grénelle), or at 1,903 feet (wells of Passy), and this may well appear at the surface of other extremely remote points.

11 We should be led away too far if we reproduced here even a small part of the mass of observations more or less precise on this subject. A great number will be found 
culties of experimenting and even of making direct observations on the action of forests bearing upon the feeding of springs, some light has necessarily been thrown on this question from several directions.

The different attempts which have been made have not all proved equally successful; too great a number, especially those directed toward measuring directly the quantity of water which passes through soil covered with varied vegetation, seem practically of very little value. It does not concern us to discuss them here; we would only say that all measurements and weighing performed in a laboratory can do nothing toward solving the problem.

It can only be solved by practical experiments on a large scale, and in the forests themselves. To the "Station des recherches suisse" must be given the honor of having inaugurated such an experiment, thanks to the initiative of its zealous director, Professor Bourgeois. ${ }^{12}$

M. Bourgeois has chosen in the Emmenthal a fresh green valley in the hollow of the northern buttresses of the Alps two little streams, the Rappengräbli and the Sperbelgraben, ${ }^{13}$ secondary affluents of the Emme, whose upper reservoirs could not be better adapted to the researches he proposed to undertake. With an area of about 198 to 247 acres each they have the appearance of almost entire circles, very clearly defined by a ridge in the form of a horseshoe. The general aspect of the thalweg (toward the southeast) is identical as well as the nature of the soil and the altitude (which varies from 3,215 to 4,035 feet in the case of the Rappengräbli, and from 2,953 to 3,937 feet for the Sperbelgraben). The first is almost entirely composed of pasture land and has only 18 per cent of forest disposed in a thin ribbon along the stream, in the thalweg; the second (Sperbelgraben) is covered for 91 per cent of its extent with a splendid irregular growth of fir.

With the concurrence of the Federal hydrographical office, a depositary has been installed upon the two little streams, at the point where they issue from the almost enclosed basins which constitute their upper valleys, permitting their outflow to be measured with the utmost exactness. On the other hand rain gauges have been placed

reported among the periodicals on forestry, especially in the "Revue des Eaux et Forêts" (see particularly the volumes for the years 1866, 1867, 1868). A Swiss engineer, R. Lauterburg, quoted by $\mathbf{M}$. Weber in the "Encyclopedie Forestière de Lorey," asserts that the destruction of forests carried out in the canton of Tessin, principally during the first half of the 19th century, must have reduced by a quarter the minimum outflow of the Adige at the period of low water. A similar phenomenon has been reported of the Po. Observations undertaken with the greatest care in Prussia by M. G. Hagen (quoted by M. Lehr in the "Handbuch der Forstwissenschaft") seem to prove conclusively that there has been a reduction in the total flow of nearly all the rivers which have been observed (for instance the Elbe, Moselle, Vistula, Pregel, Memel) in the course of the second half of the last century, but nothing proves that this phenomenon is connected with the deforestation which was taking place at the same time. M. Henry, a professor at the "Ecole National des Eaux et Forets," has also collected a number of interesting and well-proved facts in a communication made in 1901 to the "Société des Sciences de Nancy" under the title "Le Rôle des Forêts dans les Circulations des Eaux." "Le Journal Suisse d'Economie Forestière" (1898) reports some observations of $M$. de Rothenbach which prove, in a manner which appears to be conclusive, the influence of forests on the abundance of water in the springs which supply the city of Berne, etc.

12 The premature death of M. Bourgeois on the 8th September, 1901, has removed one from whom the science of forestry had much to hope. He was under 46 years of age. His work in the Emmenthal is being carried on by his worthy successor, Professor Egler; up till the present (July, 1903) no result of it has been published.

${ }_{13}^{13}$ See Sheet No. 197 of the map of the "Etat-Major Suisse" at 1/25,000. The experiments took place about 21.1 miles east (airline) of Beme in the canton of the same name, $47^{\circ} 1^{\prime}$ north latitude and $5^{\circ} 32$ (about) east longitude (of Paris). 
at various altitudes, indicating in an exact manner the quantity of rain which falls into the two basins. ${ }^{14}$

The observations are made daily, and were begun in 1900 .

There will, in the future, perhaps be occasion to simplify the depositary employed for the gauging of the outflow by substituting, for example, self-registering apparatuses for the intermittent measurements now being effected.16

It is also doubtful whether these two little streams exactly give off (in the visible part of their course) all the water which filters into their basins. It is probable that it is so; but no one can positively assert that there does not exist some fissure of the subsoil where masses of water accumulate, by means of which they are lost, and escape observation. The installation of rain-gauges in a wooded region would also be very difficult if one wished to collect all the water drawn from the atmosphere by condensation on the branches, water of which only a part reaches the soil by rolling down the trunks, etc. This does not prevent the experiences gained in the Emmenthal from constituting an essay of the greatest interest, in view of the solution of a question as controverted as it is important. The installation of these instruments will be epoch making in the science of forestry, and one cannot but be grateful to Professor Bourgeois for taking the initiative in an experiment which we hope will not remain isolated. It is with impatient curiosity that we await the result of the measurement in the two little basins of the Bernese Eimmenthal.

In view of the difficulty which the direct study of the influence of forests on the feeding of springs presents, an attempt has been made to simplify the question by exanining how the presence of woodlands modifies the different factors uponjwhich the abundance of springs depends.

This abundance is evidently the result (1) of the quantity of water which comes from the soil; (2) of the proportion of this water which, having filtered through the ground, has reached the subterranean sheet, of which the springs are apparently the overflow. Our study therefore divides itself naturally into two parts. The first concerns that which is known of the influence of forests on the quantity of water which reaches the soil. The second is devoted to the influence of forests on the proportion of that water which filters through to the subterranean sheet. 'These two elements of the question will form the subject of the following paragraphs.

Influence of Forests on the Quality of Atmospheric Water which Reaches the Soil. Water which reaches the ground is derived from three principal sources:

1. From rains, snows, hail, etc., which, forming on the upper strata of the atmosphere, are precipitated on the ground.

2. From the condensation of vapor upon the surface of vegetation, when this is colder than the air itself; water thus condensed reaches the ground in a solid or in a liquid condition, in the latter case either in falling through the air or in rolling down stalks.

14 The gauging apparatuses were installed under the direction of " $M$. l'mgennieur en chief de Morlot," according to the plans of "M. l'ingénieur Epper," employed in the Federal service. When the outflow is weak it is directly measured by diverting the waters into a gauged basin and noting the mass of water collected in a given time; when the water is plentiful it is made to run through one or two or three channels, terminating in orifices with rectangular sections where the outflow is calculated according to the formula indirated by the French engineer, M. Bazin ("Annales des Ponts et Chaussées, Vol. XVI, 1888, and XIX, 1890), by estimating the bulk of the sheet of water passing on to the waste weir.

16 Since our first visit to the Emmenthal in 1900 the wish expressed above has been gratified. In April, 1903, self-registering apparatuses have been installed on the two streams; at the same time the apparatuses for gauging the snow and rainfall in their basins have been improved. 
3. From condensation taking place on the superficial parts of the soil itself, upon its covering of dead leaves, where the ground is wooded.

We will begin by discussing this last source of the feeding of the soil by water, not because it is without importance, but because its relative importance has not yet been discovered. ${ }^{18}$

- In the previous chapter it has been shown in detail, that the presence of forests increases the rainfall in a very marked degree.

This result has been incontestably obtained, at least in the case (unique it is true) ${ }^{17}$ noted at the Research Station of Nancy. During 33 consecutive years, without any divergences, it has been proved by observation that, while in the center of the forest of Haye $(17,297$ acres of beech, hornbeam, and oak) there is a rainfall of 33.4 inches annually in the open, on a piece of ground cleared for about 5 acres, while on the other hand only 31.4 inches fall on the borders of the forest, and 25.6 on a similar piece of ground some distance off; and it is to be remembered that this difference in the rainfall occurs in the same ratio, each year at every season, whatever may be the direction of the winds, and is only slightly altered without being reversed by the total amount of rainfall during the year.

The measurements of $\mathbf{M}$. Fautrat, also given above; those of $\mathbf{M}$. de Pons in the forest of 'Tronçais (Allier) although less reliable because they extend over a smaller period of years; as well as many others carried out in Germany, Austria, and Russia, in AngloIndia, etc., lead one to believe that this phenomenon is common to all countries.

If the summits of wooded masses are more bedewed than the neighboring fields, does the same hold good for the soil in a forest?

Here, incontrovertible observations are much more rare.

It is not enough in fact, to place a rain gauge under the trees in order to arrive at even an approximate idea of the quantity of water which reaches the soil of the forest. As Mathieu already observed 30 years ago, the quantity of water collected will vary in a singular degree, according as one puts the rain gauge near the trunk sheltered under the network of big branches, or under a gap in the leafage of the summits, or under the center of a branch, or at the extremity of this same branch which will drain into it like a gutter, in emptying into it all the water or all the snow fallen on its surface, and upon that of the upper branches. M. Boppe ${ }^{18}$ has shown that rain gauges placed under the same tree, at very short distances from one another collect quantities of water varying to an unbelievable degree.

Finally a procedure such as this does not take into account the quantity of water which reaches the soil by running down stalks, and whose proportion may be 15 to 20 per cent, perhaps even more of the annual rainfall, even if this water is derived from rain, or is directly drawn from the atmosphere by means of condensation on leaves or on stalks.

It is for this reason that no mention will be made here of the results obtained in France or abroad by means of ordinary rain-gauges placed under trees. The only

16 Giseler, quoted by M. Ney ("Der Wald und die Quellbildung," Metz, 1901), has proved by experiment that in a tube of glass maintained at $0^{\circ} \mathrm{c}$,, and placed in a room where the temperature remained uniformly equal to $-4,5 \mathrm{c}$. a quantity of water was condensed in one year equal to a rainfall of 13.8 inches. It is superfluous to remark that this experiment as well as many others effected in laboratories in the cause of agronomy have no real value. Things happen entirely differently in nature, than in the conditions rendered obligatory for the purposes of experiment.

${ }_{17}$ Since January 1, 1903, new experiments have been undertaken upon our initiative at different points of the French Vosges, with a view to verifying the generality of the facts observed in the neighborhood of Nancy.

18 "Regenmessungen unter Baumkronen," 11th number of the "Mitteilungen aus dem forstlichen Versuchewesen Oesterreichs," Vienna, 1896. 
really reliable data are those obtained by means of the simple and reliable depositary invented by Mathieu in 1867, which has been retained at the Research Station of Nancy, during 32 years of observations. Here is the description of it, taken from the inventor himself : 19

"La Station des Cinq-Tranchées, situated about 5 miles to the west of the town of Nancy, at a height of 1,247 feet, is situated in the midst of a large wooded plateau, 'La Haye,' which the limestone strata form of the lower oolith. Two rain-gauges are placed there; one in the middle of the wood, under a polewood of beeches and hornbeams, moderately compact, of about 40 years of age in 1866 . The other, at a short distance from the preceding, is in the middle of an open space of about 5 acres, adjoining the 'Maison Forestière des Cinq-Tranchées.'

"The quantity of rain water which a gauge receives, when placed in a forest, varies with the position of the instrument in dense foliage or in openings. The forest raingauge is especially constructed to avoid this source of possible mismeasurement; it is provided with a receptacle of large dimensions, of which the circular surface is exactly equal to the projection of the top of one of the poles of the clump. ${ }^{20}$ The stem of one of these passes through the center, and is surrounded by a kind of collar; thanks to this arrangement, the water which runs down the trunk can be collected, be it the result of prolonged rainfall, or of a dense mist, or the effect of a thaw in producing the melting of snow, or of hoar frost on the branches."

These observations began in 1867 and were continued until 1898 when an accident happening to one of the instruments prevented them from being carried on longer. They embrace, however, a period of 32 years.

The following table gives a résumé of the results obtained: 21

\section{SUMMARY OF MONTHLY AVERAGES OF RAINFALL OUTSIDE AND} INSIDE THE FOREST

\begin{tabular}{|c|c|c|c|c|c|c|c|c|c|}
\hline \multirow{2}{*}{ Months } & \multicolumn{4}{|c|}{$\begin{array}{c}\text { Average rainfall in inches outside } \\
\text { the forest }\end{array}$} & \multicolumn{4}{|c|}{$\begin{array}{l}\text { Average rainfall in inches inside } \\
\text { the forest }\end{array}$} & \multirow{2}{*}{$\begin{array}{l}\text { Per cent o } \\
\text { rainfall } \\
\text { actually } \\
\text { received } \\
\text { by forest } \\
\text { soil }\end{array}$} \\
\hline & $1867-77$ & 1878-88 & $1889-98$ & $1867-98$ & $1867-77$ & $1878-88$ & $1889-98$ & $1867-98$ & \\
\hline May-October*... & 16.7 & 20.2 & 19.2 & 18.7 & 14.8 & 17.8 & 17.2 & 16.6 & 88.8 \\
\hline November-April. & 14.9 & 15.2 & 13.8 & 14.6 & 14.0 & 14.8 & 13.5 & 14.2 & 96.9 \\
\hline Totals for year.. & 31.6 & 35.4 & 33.0 & 33.3 & 28.8 & 32.7 & 30.7 & 30.8 & 02.4 \\
\hline
\end{tabular}

* The figures for the individual months have been omitted and the data rearranged.

A comparison of the foregoing figures will show us that, for a certain number of months, especially in winter, the rain-gauge placed under cover collects the greatest

10 "Metéorologie Comparée Agricole et Forestière; rapport a M. le sous-secrétaire d'Etat, etc.," of 25 February, 1878, p. 4. In this report, published by the "Imprimeri, National," Mathieu gives an account of the results of the first eleven years of observations.

${ }_{20}$ This pole was a young hornbeam of about 41 years of age at the beginning of the experiments, of a regular shape and with well crested top.

21 This table is borrowed from the work by M. de Bouville already quoted: "Observations de météorologie . . de la Station de Recherches de l'Ecole National des Eaux et Forets," Paris, 1901. 
quantity of water. A similar fact had already been observed in 1878 and 1890 in the reports published by Mathieu and M. Bartet ${ }^{22}$ on the results obtained in those years by the "Station de recherches" of Nancy.

This is the more instructive, inasmuch as it is the winter rains which are the most important from the point of view of the feeding of springs.

The fact is very naturally explained by the condensation of aqueous vapor on the considerable surface presented by the crests of forest trees. ${ }^{23}$

At all seasons of the year and all hours of the day the trees are, in fact, colder than the surrounding atmosphere. Nevertheless the difference is greater in summer than in winter, and during the day rather than at night. It is also greater at the base of the trunk than among the branches.

Here are some figures on the subject. The Swiss observations give results recorded on an average of 12 years; those in Bavaria were undertaken during two years only:

\section{DIFFERENCES (IN CENTIGRADE DEGREES) BETWEEN THE TEM- PERATURE OF THE TREES * AND SURROUNDING AIR}

\begin{tabular}{|c|c|c|c|c|}
\hline & Spring & Summer & Autumn & Winter \\
\hline 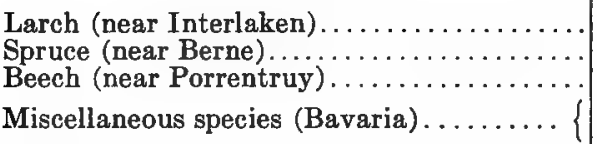 & $\begin{array}{l}2.1 \\
3.4 \\
1.5 \\
1.3 \\
0.8\end{array}$ & $\begin{array}{l}3.3 \\
4.1 \\
3.2 \\
1.7 \\
1.2\end{array}$ & $\begin{array}{l}1.0 \\
2.2 \\
1.5 \\
0.7 \\
0.4\end{array}$ & $\begin{array}{l}0.4 \\
0.9 \\
0.3 \\
1.3 \\
1.4\end{array}$ \\
\hline
\end{tabular}

* In the Swiss experiments the temperature of the tree was taken at breast-height, while in Bavaria it was in the branches of the crown.

These reports suffice to give us the key to the important phenomenon noted above. Trees with considerably spreading crowns form very excellent condensers of vapor from atmospheric water which they conduct to the soil in a liquid condition; this process is naturally more marked at the beginning and end of winter, periods when the atmosphere of our latitudes, especially in forests, is very near the point of saturation. The slightest lowering of the temperature is then sufficient to produce condensation.

In conclusion, the results obtained by the observations conducted at Cinq-Tranchées can be summed up in the following manner: Of a hundred millimeters ( 3.94 inches) of atmospheric water, the instrument placed under shelter of the crest of a young hornbeam only received in an average year $92 \mathrm{~m} . \mathrm{m} .4$ ( 3.64 inches); therefore $7 \mathrm{~m} . \mathrm{m} .6$ ( 0.299 inch) were retained by the crown a balance produced by the amount of condensation from branches and the top of the trunk.

22 "Météorologie Comparée, Agricole et Forestière. . . . Observations faites a la Station de Recherches de l'tcole National Forestière," published by M. E. Bartet, Paris, 1890 ("Bulletin du Ministere de l'Agriculture").

${ }^{23}$ It happens sometimes that a considerable quantity of water is supplied to the forest soil in a very short period of time. This occurred in January, 1882. The east wind accompanied by fog had deposited such a quantity of hoar frost on the trees that a great number of branches were broken by the weight of it. This first took the form of icicles ten centimeters in length. A twig covered with them, cut off with great care, weighed 550 grams; relieved of its burden, it only weighed 70 grams ("Bulletin de la Cornmission Météorologique de Meurthe-et-Moselle"). This frost in melting on January 17 was equal to a rainfall of $7 . \mathrm{m} . \mathrm{m} .4$ according to the rain-gauge under the trees at Cinq-Tranchées. In January, 1879, a branch of birch from the forest of Fontainebleau, weighed by $M$. Croizette-Desnoyers, covered with a thick crust of rime, turned the scales at 700 grams. Weighed again after the frost had melted, the result given was only 50 grams. 
The action of the forest besides differs appreciably at different seasons of the year.

In winter the trees are denuded, although at that period they are more than ever favorable to the condensation of atmospheric vapors. Also once in every three times almost the gauge under the trees is the fullest, and this one contains on an average 96.9 per cent of the water fallen during the months from November to April - almost all of it.

The condensation by the tree crests suffices therefore to compensate almost entirely for the loss due to the adherence of a part of the water fallen upon the trees.

During the summer, on the contrary, the branches covered with foliage intercept the rain more efficaciously. If one compares the maximum rainfall occurring in the months from May to October on the open ground, and under the trees, respectively, one finds that they are equal to the numbers 100 and 88.8 .

If the proportions in which the forest soil is watered vary according to the season, they ought therefore to be somewhat different according to the age and density of the plantations. In fact, calculating by averages of three successive periods approximately equal, and no longer by the total period during which observations have been made, it has been ascertained that under the trees in summer 89.1 per cent, 88 per cent, and 89.4 per cent of the quantity of water precipitated by atmospheric water have been collected. The portion retained by the crowns of trees increases from 1867 to 1888 at the same time as does that under cover, owing to the growth of the tree under observation from 40 to 62 years old. It then diminishes as a result of the gradual lightening of the foliage coinciding with the decline of the vegetation, which shows itself in the hornbeam sprouts in the forest of Haye about every 60 to 70 years under ordinary conditions.

Let us quote a few figures taken from abroad relative to the proportion of rain intercepted by the tree tops.

The absolute quantity of water that adheres to the trees and returns to the atmosphere by evaporation is regular for the same tree, whatever may be the duration of the rainfall, but evaporation is sufficient to absorb the rainfall entirely, especially in summer, if the rain is of short duration, while it will only absorb a steadily decreasing quantity in proportion to the increase in the duration of the rainfall.

The loss of water owing to shelter is therefore very variable according to the local distribution of rains.

The same applies to different species of trees. By placing a great number of rain gauges under the crown of the same tree at varying distances from the trunk, M. Boppe has tried to obtain an average of the quantity of water which passes directly through the trec tops. He has then measured separately the water running down the trunks. Combining these results with those obtained by himself, M. Ney ${ }^{24}$ has arrived at the conclusion that the loss due to adherence to the crowns is: 15 per cent of the annual rainfall for the beech tree; 20 per cent for Scotch pine; 33 per cent for spruce.

If one considers the water rainfall separately, the only important one for the feeding of springs, one ascertains according to the same author:

That the crowns of beech trees retain 7 per cent, those of pines 15 per cent, and those of lower spruce pines 20 per cent. This last figure should be still in relation to the surplus of rain acquired by the presence of forests, according to French experiments.

The figures given by $M$. Ney do not take into account the water supplied by the tree crowns through the process of condensation, and moreover are only based on a small number of measurements.

It remains now to draw conclusions from all the preceding data, relative to the feeding of springs. ${ }^{25}$ The question to be resolved is as follows: Is the ground under cover of

$$
{ }^{24} \text { Op. cit., p. } 10 . \quad{ }^{25} \text { De Bouville, op. cit. }
$$


the forest better watered than cultivated ground? To understand the matter rightly it is sufficient to compare the records of the rain gauges installed under the trees at Cinq-Tranchées with those of the instrument established at Amance-la-Bouzule.

The following table has that object in view by giving the records for the whole period during which they were kept, and also separately for summer and winter and the entire year.

A comparison between the quantity of rain water which reaches the ground in an open agricultural region on the one hand, and on the other that which reaches the ground in a forest under shelter of the trees. (Summary only is given for the years 1867-1898.)

\begin{tabular}{c|c|c|c|c|c|c}
\hline & \multicolumn{2}{|c|}{ May-Ootober } & \multicolumn{2}{c|}{ November-April } & \multicolumn{2}{c}{ Entire year } \\
\cline { 2 - 6 } & Forested & Open & Forested & Open & Forested & Open \\
\hline $\begin{array}{c}\text { Yearly averages } \\
\text { inches of rainfall*... }\end{array}$ & 16.6 & 14.3 & 14.2 & 11.2 & 30.8 & 25.5 \\
\hline
\end{tabular}

* The forest measurements were at Les Cinq-Tranchées and those on agricultural land at Amance-la-Bouzule.

An examination of the figures demonstrates that the ground of the forest of Haye, at the center, and under cover of its trees, is always better watered than the neighboring plains. The difference is particularly marked in winter; it diminishes in summer by reason of the foliage. In an average year only 82 per cent was collected at Amance-laBouzule of the quantity of rain water collected under the trees at Cinq-Tranchées, the proportion being 86.4 per cent for the months from May to October, and 78.7 per cent only for those from September to April.

The conclusions drawn from the French reports, however, call for a few remarlss.

The forest rain-gauge indicates the loss resulting to the soil, from the adherence of a part of the atmospheric waters to the foliage; all that it receives arrives at the soil intact. It is not the same with the rain gauge installed on a cultivated field. The surface of this field is covered with a thick carpet of grasses or vegetables which retain a considerable portion of the fallen rain water, and allow it to evaporate in the air exactly as do the leaves of trees. ${ }^{26}$

On the other hand the water condensed by contact with the carpet of vegetation has not been measured either; it is true it must be a very small quantity comparatively, because the carpet of vegetation often fails in cultivated fields during autumn and winter. One may infer that this quantity of water is comparable (somewhat less as far as one can judge) to that which is condensed by contact with dead leaves on the forest soil.

It appears, therefore, that these remarks will further strengthen the conclusions favorable to the forest, will become, in fact, valuable a fortiori. Taking into consideration the actual knowledge to hand, it must be admitted the ground covered by forests in leaf receives more water from the atmosphere than ground under cultivation; the difference can be considerable and reach to 20 to 25 per cent of the rainfall in winter, a season which alone supplies infiltrated waters.

It would appear that the same holds good in the case of pine forests, especially in

${ }^{26}$ It has been calculated (M. Ney, "der Wald und die Quellen," Tübingen, 1894, p. 30) that the crop of a field of wheat would have a growing surface of 32,370 square yards to the acre, that of an uncultivated field would have 22,006 square yards, that of a field of clover 27,190 , of a field of potatoes 24,876 . The surface of a well developed forest of beech trees of average age would be 39,707 square yards. 
winter. The fact may be accepted as almost certain in the case of Scotch pine and larch, and it is probable even of the spruce, the trec of our country whose foliage is the thickest.

Influence of Forests on the Infiltration of Water. - In the preceding paragraph the influence of conditions on the quantity of water which reaches the soil has been shown. It remains for us now to examine how forests modify the conditions of the feeding of springs, in working on the deep infiltration of the water as far as the subterranean sheet, of which springs constitute the overflow.

Of the water reaching the ground, one part runs along the surface and arrives directly at the water courses in the form of streams. Those waters which run along the surface without penetrating into the soil are called "wild waters" - and "coefficient in surface flow," is the term (le nombre) which expresses their relative importance.

A second part returns directly to the atmosphere, in a gaseous condition, as a result of the phenomenon of physical evaporation.

A third part, after having penetrated the superficial strata of the soil, is extracted from it by suction of roots which carry it into the body of the plants. This water is partially utilized in forming vegetable tissues, but the greater part returns to the atmosphere in gaseous form by the stomata of leaves, after having brought into the latter the mineral elements necessary to the growth of the plant. This important phenomenon is called physiological evaporation; it carries away from the soil considerable quantities of water which have already penetrated to greater or lesser depths according to the dimensions of the vegetation. One understands in fact that the zone thus drained is quite near to the surface in the case of grass or cereals with superficial roots, while it can be fairly deep in the case of forests whose roots penetrate very far down in permeable soils.

Lastly, a fourth part having penetrated, thanks to the permeability of the soil, manages to pass through the entire depth of the region where roots can inhale, or from which, by means of capillary action, it can raise itself into the region where the roots are active. It penetrates deeper and deeper into the soil until, encountering the obstacle of an impermeable stratum, it accumulates and founds a subterranean sheet of free water. It is this sheet which dispenses itself outwards when the conditions stated in Paragraph I of this chapter have been fulfilled. If the lie of the ground is such that the water cannot reach the open air, the subterranean sheet is then exploited by means of wells, and it has been proposed ${ }^{27}$ to call the sheet nearest to the surface a "phreatic sheet," because it is this one that feeds the wells, their depth being naturally limited to the level of the upper part of the highest subterranean sheet, and not generally getting beyond it even when this level sinks.

Before proceeding further, it is necessary to establish an essential distinction between springs in mountainous regions and those in a country of plains.

In the mountains the surface flow plays such an important part in the question we are about to consider that we need only concern ourselves with this phenomenon, after setting aside those of evaporation and permeability. The influence of the loss due to superficial running waters ("wild waters") surpasses all others. This special and most simple case is the only one upon which one can formulate absolutely certain conclusions. It is, moreover, much the most important; springs are infinitely more numerous, abundant, and useful in the mountains than in the plains. Springs in the plains are either fed by waters which have filtered down from the mountains or else they have virtually no influence on the regular course of waters on account of their feeble outflow. The rainfall in low regions is, in fact, too feeble, after the levy made on it by agricultural vegetation generally speaking, to allow remaining a sufficient proportion to feed the springs. Often indeed the soil of the plains bears crops, $\mid$ which, in order to develop,

${ }^{27}$ Daubrée "Les Eaux Souterraines," Vol. I, p. 19 (Paris, Dunod, pub., 1887). 
absorb more water than the local fall produces, the balance being provided by natural or artificial irrigation by means of the surplus of higher regions.

In the plains, on the contrary, surface flow does not exist, and the feeding of the subterranean sheet depends upon the permeability of the soil and upon evaporation.

The Influence of Forests on the Infiltration of Water in Mountains. - The proportion of the surface flow increases according to the declivity, and according to the greater or less rapidity with which rain falls or snow melts on the slopes. It can become very great. M. Imbeaux, ${ }^{28}$ in a study on the course of the Danube, has discovered "during the three exceptional floods of Oct. 27, 1882; Oct., 1886, and Nov., 1886 , that the proportion of surface flow at Mirabeau was from 0.33 to 0.39 and 0.42 , that is to say, more than a third of the rainfall; it fell to 0.27 during lesser floods, and even to 0.23 and 0.18 for average and small floods, thus demonstrating that the law of its decrease is parallel with that of the intensity of the rainfall." Of the Danube at Vienna the Central Hydrographic Office of Vienna has discovered, in applying the same method, 42.1 per cent for the period from July 28 to Aug. 14, 1897.29

Other authors (Démontzey and M. Ney) have proved that the proportion of surface flow can reach 40 to 50 per cent of the rainfall on wooded slopes. Démontzey even quotes a case where it has reached three-quarters of the water brought by a storm of rain into the bed of a torrent, extending over more than 1,977 acres.

The action of forests on the reduction of "wild waters" is so well known, so universally recognized, that to insist upon it has become commonplace. We will only recall that it results principally from: $(a)$ the fact that, thanks to the obstacle caused by mountain tops, water reaches the soil with hardly any celerity; (b) that the rainfall, other things being equal, is more frequent and less violent in forests, and above all the melting of snows is much less rapid, as this process often lasts a fortnight or even a month longer in the forest than in open ground; $(c)$ that the obstacle offered to the course of the water by stalks and the roots of trees, and lastly the absorption of a considerable quantity of water by mosses or dead leaves covering the soil. It has been calculated that such coverings of dead leaves or moss retain by their hygroscopicity a rainfall of 2.91 inches of depth falling in one day before allowing anything to run off by surface flow. ${ }^{30}$

Even when the covering is saturated, it only allows the water to escape drop by drop, so that the soil is able to imbibe the whole of it, to the great benefit of the subterranean sheet. One may say that the process of surface flow is almost entirely suppressed on wooded slopes in good conditions where the covering of the soil is left alone.

We could not better sum up the subject of the action of forests on the feeding of springs in mountainous districts than by quoting so great an authority as Professor Henry: "Wooded mountains attract rain; it is there that precipitations from the atmosphere attain their maximum; it is there that great reservoirs of water are found;

${ }^{28}$ Essai-Programme d'Hydrologie, by Dr. Imbeaux, ingénieur des Ponts et Chaussées. Published in the Zeitschrift für Gewasserkunde, 1898 and 1899. (Quotation borrowed from M. Henry.)

${ }^{29}$ Die Hochwasser - Katastrophe des Jahres, 1897, in Oesterreich. . . . Beiträge zur Hydrographie Oesterreichs. Published by the $K$. K. Hydrographischer Central Bureau of Vienna, II bulletin, 1898.

${ }_{30}$ Ebermayer ("Die gesammte Lehre der Walstreu," Berlin, 1876, pp. 177 to 181) shows that moss can retain in suspension 2.8 times its weight in water. The sphagnums and species of hypnums such as $\mathrm{N}$. loreum can absorb up to 4.5 kilograms of water by the square meter of ground where it grows. Dead beech leaves retain about 2.3 times that of pine or spruce, 1.2 times their weight in water. See also M. Ney's work, "Der Wald und die Quellen," p. 70 (Tübingen, 1894).

${ }^{31}$ Communication made to the "Congrès International de Sylviculture a Paris en $1900, "$ p. 327 of the "Compte-rendu Official." 
it is there that nearly all springs are concentrated. Forests existing on mountains, notably on those whose aspect is perpendicular to those of moist winds, cause the precipitation of the greatest quantity of aqueous vapor which they contain. It is enough to cast a glance at a hydrographic map to be convinced of this fact. Bare, denuded mountains have only a very feeble action in this respect; the countries bordering on the Adriatic as well as on a part of the Mediterranean, which are renowned for their dryness, show this in a very striking manner. Deprived of forests, these mountains lack the means of cooling the air and drawing to themselves in consequence the vaporous precipitations it contains. The denuded soil, which the sun penetrates with intense heat on those parts exposed to the west and the southwest, does not certainly possess this property."

"A second distinction consists in the enormous diminution in the proportion of surface flow on wooded mountains, compared with the same slopes when they are denuded. . . . The water, instead of precipitating itself into the thalweg and causing thereby sudden and dangerous inundations, penetrates slowly through the covering and into the soil which it soaks to a great depth. Therefore it is unquestionable, and we believe an uncontested fact, that mountain forests are favorable generally to the production of springs."

There is a stronger reason still for this being the case when mountain forests grow in a hot climate where physical evaporation is considerable.

The Influence of Forests on the Infiltration of Waters in the Plains. - The influence of the surface flow is complete in the case of forests in the plains. There the feeding of the subterranean sheet will depend only on physiological evaporation and on the permeability of the soil. Let us first examine the action of forests on this permeability of the soil.

Forest soil in good condition is naturally light. The roots of trees penetrate deeply into it, sometimes to a depth of 10 and 13 feet and more; in swelling out they produce the effect of wedges which divide the soil mechanically. When the trees have been felled the roots decompose and their place is taken by a network of channels filled with hygroscopic matter, which directly conducts the water to considerable depth. Along the roots of trees under foot, especially near the stem between the soil and the bark, there exist empty spaces which are caused by the swaying of the tree when shaken by the wind; rain water, which has run along the stem, arrives directly, one might say instantaneously, by means of these at the soil. Lastly, forest vegetation is favorable to the division of the soil through the action of earthworms.

In winter, the temperature of the forest soil is appreciably higher than that of the open ground. It often results from this that during the cold season the rainfall or melting snow acts upon a frozen surface, which has become impenetrable at the surface, in such a manner that all the water disappears in surface flow. In the forest, the soil which is less cold need not necessarily be frozen, and can therefore absorb the fallen water.

According to all the evidence collected, physical evaporation of the water of the soil is less under trees than on an agricultural soil. The forest covers the ground with a double protective screen; first the covering of dead leaves, an eminently hygroscopic substance, and in consequence always cool, which, superimposed immediately on the ground, opposes evaporation with great energy. Higher up, the crown, often very dense, offers its maximum density in summer, at a period when evaporation is greatest. The temperature of the air is also lower under the trees than outside, especially in summer. This forms a powerful impediment to evaporation. The lowest temperature of the forest soil in summer acts again in the same way.

Finally, evaporation is much favored in a flat country by the wind, which is continually renewing the strata of the air, saturated by direct contact with the soil. 
An attempt has been made to measure the comparative importance of evaporation beneath the trees and outside of them by ascertaining the quantity of liquid lost from receptacles full of water placed under cover and in the open fields. Under these conditions two to five times, in certain cases eight times, but on an average three times, more water is evaporated in the open country than under the trees. But these experiments are of little value even when the receptacles of water are replaced by impenetrable chests full of earth; the conditions under which the experiments are made being too far removed from natural conditions. ${ }^{32}$

It remains for us now to compare the forest with land under cultivation from the point of view of the quantity of water drawn off from the soil by the vegetation.

To tell the truth, we are absolutely ignorant of the quantity of water necessary to the production of agricultural or forest crops. One observer, Wollny, ${ }^{33}$ undertook in 1879 and 1880 direct measurements of the quantities of water consumed by various plants (barley, oats, red clover, grass, rye, etc.) which he had sown in especially prepared boxes without drainage. At the beginning of the experiment he had ascertained the quantity of water contained in the soil of the boxes; by adding to this the same quantity of water as would be furnished under natural conditions lasting over a similar period of time, either by rain or by dew, and by removing from the bottom of the boxes all that filtered through the earth, and which he carefully collected, the amount of water consumed was obtained. In reality the quantities measured are superior to this consumption for they include, in addition, that which has been lost by evaporation from the soil, or by evaporation of the water remaining adherent to leaves and stalks. The experiments of Wollny were extended over 105 to 155 days of the season of growth.

The consumption of water was on an average 38 million pounds to the acre, the maximum figure being furnished by the clover which reached 47 million. These figures represent an average consumption per acre per day during the growing season of about 18 to 19 cubic yards.

In 1870 and 1871 an older writer, Risler, ${ }^{34}$ discovered that the average daily consumption per acre during the season of growth was 27 cubic yards for Luzern and fields generally, 23 for oats, 12 for rye, etc., and on an average 17 for cultivated vegetables, while it would only be 4.2 cubic yards for the fir tree and 3.1 lfor the oak. It is much to be regretted that we have no means of judging of the value of these figures, as we do not know how they were obtained.

M. Ney, by combining the figures of Wollny and of Risler, calculates ${ }^{35}$ that field vegetables in general consume 2,093 cubic yards of water per acre during the growing season.

An Austrian experimenter, V. Höhnel, has directly measured the quantity of aqueous vapor emitted by the leaves of different trees from June 1 to October 1 . During that period he found that the leaves of the several species emitted the following percentages of their own weight in aqueous vapor: Birch, 68 per cent; ash, 57 ; hornbeam, 56 ; beech, 47; oak, 28; spruce pine, 6; Scotch pine, 6 ; fir tree, 3.

With these data for basis, M. Ney ${ }^{36}$ calculates that the consumption of water per

${ }^{32}$ For the French experiments see M. de Bouville, op. cit., pp. 25 et seq. For those carried out in Switzerland consult the "Mitteilungen" of the Research Station of Zürich. For the German observations see the official accounts published by M. Müttrich on the work of the Research Stations; a résumé of the results is to be found reproduced by M. Weber in the "Encyclopedie Forestière de Lorey."

3s "Forschungen auf dem Gebiete der Agricultur - Physik, Vol. XII, p. 27.

${ }^{34}$ The experiments of Risler are only known by the quotations made by Wollny in the work mentioned previously, and we are ignorant of the methods pursued by this
experimenter.

${ }_{35}$ "Der Wald und die Quellen," p. 74.

${ }^{36}$ Op. cit., p. 75 . 
acre during the season of growth would be $24,112,000$ pounds for beech (5.6 yards per diem); $18,568,000$ pounds for spruce pine (47 yards per diem); $6,424,000$ pounds for Scotch pine (1.6 yards per diem).

It is to be remarked that these quantities do not include the water incorporated in the tissues of the trees for the purposes of their growth, but only that emitted by evaporation from leaves. ${ }^{37}$

Other figures have been published by Th. Hartig, V. Höhnel and Wollny; they differ sometimes so much from those quoted above that one is necessarily very sceptical as to the value of the results obtained. As $M$. Henry remarks very justly: ${ }^{88}$ "If it is easy to determine, by means of weighing, the evaporation on a sapling in a pot, or of a square of young forest trees, of grass or corn; if one can calculate, strictly speaking, according to those results, without fear of too great discrepancies the evaporation on an acre covered with grass, with corn, or young forest trees of equal height, ${ }^{39}$ it is far too rash to apply the results obtained by experiments on an isolated sapling grown in a pot to a forest comprising many tangled and superimposed stages of growth, whose leaves giving more or less shade are doing their work with different degrees of intensity."

In the present condition of science it is not therefore possible to determine by contrast in a sufficiently precise manner the difference between the volume of water under the trees and in the open which goes to feed the subterranean sheets.

In view of the great interest this question presents, and of the diversity of opinions on the subject, the greatest efforts have been made in an indirect manner to arrive at a clear idea of the action of clumps of trees on the feeding of the subterranean sheet.

A primary series of researches has been undertaken with a view to determine comparatively the quantity of water which filters through a stratum of earth enclosed in a box without drainage, its surface being covered with different kinds of plants.

It has proved that the bare earth allows more water to pass than that which is covered with vegetation, dead leaves, moss, etc. This is almost the only definite result obtained, and even this is controvertible. We do not lay much stress on these experiments which, it would seem, can give us no definite information as to what occurs under natural conditions. ${ }^{40}$

An attempt has been made to measure directly the quantity of water contained in the soil under the trees and in the open at different depths.

Experiments undertaken in Germany ${ }^{41}$ and in Russia have brought to light the following facts which appear to be properly established:

The humidity of forest soil is very great at the surface, but diminishes rapidly to a depth varying in degree which does not go beyond 31.5 inches under plantations of spruce pine, according to Ebermayer, and which reaches a depth of 10 or 13 feet, according to Russian experiments. Below this level the amount of water keeps on increasing with the depth. There exists in the ground, therefore, a dry zone more or

${ }^{37}$ The quantity of water remaining annually in the tissues of trees may be estimated at 2,640 pounds per acre.

${ }_{38}$ "Annales de la Science Agronomique," 2nd Series, 4th year, 1898, pp. 20 et seq. ${ }^{39}$ It is doubtful if even this is admissible.

${ }^{40}$ For the measurements made in Switzerland see Bulletin IV of the "Mitteilungen" of the Research Station of Zürich; for the Bavarian works, see the various publications of M. Ebermayer, etc.

41 "Einfluss des Waldes," etc., an article by M. Ebermayer which appeared in the January 1888 number of the "Allgemeine Forst und Jagd Zeitung." A good translation has been published by $M$. Reuss in the first volume of the "Annales de la Science Agronomique," 1889. A complete résumé of all the works published up till then is inserted in the account of the "Congrès International de Sylviculture à Paris en 1900," pp. 328 et seq. (Communication bylM. Henry to this Congress). 
less thick and more or less deep, lying between the humid region of the surface and the humid region below.

One sees there, in a very clear fashion, the influence of the absorption of water by roots of plants in the region where they are active, or in that immediately below where the water can raise itself by capillary action after drying up the superior stratum. ${ }^{22}$ This is a general fact for all ground covered with living plants; they present a dry stratum more or less removed from the surface, according to the depth of the root system of vegetation above. This depth being greater in the case of forest vegetation than in others, it is clearly to be seen that at a similar level, within certain limits, the soil of the forest will be poorer in water than an agricultural soil. ${ }^{43}$ It has been concluded from this that the forest absorbed more water by its vegetation than other species of culture, and thus was harmful to the feeding of phreatic sheets of water.

It must be admitted that there is no evident and necessary connection between the humidity of the soil in its superficial parts and the alimentation of the subterranean sheet. Other things being equal, the latter depends not so much on the degree of dampness of the soil as upon its permeability. A stratum of coarse sand will allow rain water to filter through rapidly, while a fine clay will keep it stagnant at the surface and give it over to evaporation. And, nevertheless, the sand will be dry, while the clay will always contain a quantity of hygroscopic water.

An extremely interesting fact, which will perhaps throw some light on the relation of the wooded condition of the surface with the feeding of phreatic waters, has been quite recently brought forward. We think we ought to dwell on this with some detail, borrowing what follows from the last publications of our learned colleague, M. Henry.44

The Imperial Free Economic Society of St. Petersburg undertook a series of researches into subterranean hydrology in the forests of the steppes of Russia, the directorship of which was confided to M. Ototzky, curator of the Mineralogical Museum at St. Petersburg.

From borings effected in the forest of Chipoff (province of Voronez) and in the Black

42 The depth of the system of our large tree species is much greater than has been generally supposed. The tempest of February 1, 1902, having torn up by their roots a multitude of fir trees of all ages in the Vosges, we took advantage of this opportunity to ascertain the depth to which the roots, thus rendered visible, had penetrated the Vosges sandstone formation. It varied from 5 to 11.5 feet. If one takes into account that the extremities of the roots were still remaining in the soil, one can realize that these trees were deriving nourishment from a stratum which must extend to a depth of 13 and perhaps of 16 feet.

${ }_{43}$ These researches of a very delicate nature only meet with reliable results when they are conducted simultaneously for a very long period of time under the trees and in the open. If one observes the soil after heavy rain one sees it saturated at the surface to a greater or lesser depth. The rain having ceased, the free surface water sinks down gradually into the soil under the action of its weight, saturating always a deeper and deeper zone, above which the ground has become dry, until it comes in contact with the phreatic sheet of water of which it raises the level. It is conceivable that very varying amounts of water in the soil, at one particular season and depth, have to be accounted for, according to the proximity and abundance of the latest rainfall, that is to say, according to fortuitous circumstances which, up till now, observers do not seem to have taken into account.

${ }^{44}$ M. E. Henry, professor of the "Ecole Nationale des Eaux et Forêts," was the first to draw attention to the Russian borings, the results of which, up till then, had been unnoticed both in France and Germany. He gave an account of these in a series of articles, one after the other, from 1897 and February, 1898 (Annales de la Science Agronomique), until 1903. In his article of $1903 \mathrm{M}$. Henry narrates for the first time the complete result of his own researches undertaken in the forest of Moudon. The few pages which M. Ebermayer devotes to the subject in his publication dated 1900 (Einfluss der Walder auf das Gumdwasser) only reproduce, almost word for word, M. Henry's report of 1898. 
Forest (province of Cherson), M. Ototzky was led, since 1897, to formulate this theory, that, all physico-geographical conditions being equal, the level of phreatic waters in the forests of the region of the steppes is lower than in neighboring open spaces. In support of these unexpected conclusions M. Ototzky published the results of a series of soundings, of which some it is true are open to objection as proof positive of his theories. ${ }^{45}$

In $1897 \mathrm{M}$. Ototzky was directed by the Imperial Society to undertake some new researches, but this time in the Province of St. Petersburg at $60^{\circ}$ north latitude in a region whose rainfall is much greater than that of the steppes, where he had worked in 1895 (23.6 inches annual rainfall instead of 11.8).

He proved again that, under the forests where observations were made, the phreatic sheet is depressed compared with what it is n neighboring cultivated regions. The difference of levels is rather slight, and varied from 19.7 to 44.5 inches.

On July 1, 1899, M. Henry, professor at the "Ecole Nationale des Eaux et Forêts," at his own request, was authorized to undertake at the expense of the "Administration des Eaux et Forêts" some soundings, with a view to verifying and completing the data furnished by the Russian experimenter.

The forest of Moudon near Luneville (Meurthe-et-Moselle) was chosen for these researches. It forms a large mass of woodland about 4,942 acres in extent (the altitude varies from 807 to 873 feet). The soil is composed of strata of sand, gravel, and flint, originating from the ancient alluvial beds of the Meurthe and the Vezouse, at the confluence of which rivers the forest is situated. The water-bearing strata are met at a slight depth, their upper level being given at depth of about 6.5 to 16.4 feet. A little lower, about 23 feet or more, one finds an impermeable clay against which the infiltrations are arrested. These different strata, and especially the last named, appear to be horizontal.

The rainfall in the forest was 28 inches in 1900 and 35 in 1901 . The mean annual temperature is $9^{\circ} 4 \mathrm{C}$. $\left(49^{\circ} \mathrm{F}\right.$.) with an average of $+1^{\circ} 43 \mathrm{C}$. $\left(345 \mathrm{~F}\right.$.) in winter and $17^{\circ}$ $70 \mathrm{C} .\left(64^{\circ} \mathrm{F}\right.$.) in summer.

The forest is composed of oak, beech, and hornbeam; it has been planted with storied coppice in a rotation of 35 years in the greater part of its extent. Some small parts are to be found covered with Scotch pine, the result of the replanting of ancient gaps in the forest.

In the spring of 1900 ten holes of 2 inches in diameter were drilled by the aid of the Belgian geological borer, and these holes were lined with zinc tubes which had been pierced with small apertures and furnished at their lower end with a similarly perforated cone. Thus the earth was prevented from falling in and filling up the bottom of the well. The numerous small apertures in the metal allowed the water easily to find its own level.

Five holes were bored in bare ground in parcels of ground which had been cleared for the use of the forest guardians, in the nursery gardens, and in the communal pasturage, but always on the borders of the forest, the farthest removed being about a hundred meters. Five others, destined to be compared with the preceding five, were made under the neighboring woodlands, as nearly approaching the same conditions as it was possible to give.

${ }^{45}$ Evidently it is well to operate only in ground which lies horizontally at the surface, and which is of a homogeneous character to a great depth, so as to avoid the influence of an uneven surface, and that of the undulations of the upper levels of deep impermeable strata, whose projection may be very different from that of the surface. In stratified ground, with strata alternately more or less permeable, the course of the subterranean waters depends solely on the way these strata run, and can give us no notion of the influence of the superficial vegetation. Unfortunately the ground in which M. Ototzky first undertook his experiments appears to have been far from homogeneous, since he found there in less than 16 feet of depth, three different well-defined spring levels. Moreover the projection of the soil seems to have been taken very little into account, notably in No. 3 boring in the forest of Chipoff. 
There were, therefore, five pairs of borings.

Observations were made once a month from May 4, 1900, to August 24, 1902.

The leveling was done by the pupils of the "Êcole Forestière" in May, 1900, and May, 1901 , in taking for the initial point the altitude of the Station of Marainvilliers which is about 790.1 feet.

One will find in the following table (page 379 ) all the measurements taken at Moudon; none have been omitted (abridged in translation).

We have been obliged, however, to omit the report of one of the five pairs, of which one bore was made in the fields of the farm of St. George and the other in the neighboring coppice (third cutting in the third series of coppices) because the bore made in the field was destroyed by the plow in March, 1901.

The figures of the table (page 379) give the immediate results of the measurements effected, without taking into account the difference in the altitude of the orifices of the borings.

If all the measurements are reduced to the same horizontal level, one finds that the level of the water under the forest at all seasons is lower than that under bare ground: By 11.8 inches for the first couple, 7.9 for the second couple, 16.5 for the third couple, 12.2 for the fourth couple.

It is certain that the difference of level is more accentuated than these figures would indicate, since one knows that in permeable soils the phreatic sheet follows the variations of the outline relief of the stratum, although with far less pronounced undulations.

But let us accept the preceding figures as unquestionable minima whose average is 11.8 inches.

We can affirm that, according to the measurements effected each month from May 4, 1900 , to August 24, 1902, in eight borings made at random, sometimes under the woodlands, sometimes under the bare ground near the forest of Moudon (Meurthe-et-Moselle) the level of subterranean waters at all seasons is at least 11.8 inches deeper under the woods than it is outside.

The experiments of M. Henry, carried out regularly for a period of 28 months have further brought to light the following facts, which are absolutely new.

The oscillations in the level of phreatic waters is less under the woods than in the open. The infiltration, too, is slower in the forest. The maxima and minima occur about a month later than those observed outside of the woods.

One sees here that the forest plays the same rôle of regulator and stabilizer which one recognizes it to do with regard to the temperature.

Some experiments made quite recently by M. Ototzky, an account of which has been published in Russian in the fourth number of 1902 of the Magazine "La Pédologie," and of which a French translation by $\mathbf{M}$. A. de Lebedef, attache of the "Ministère de L'Intérieur" at St. Petersburg, is in the press has still further confirmed these facts.

M. Ototzky's experiments were made at the "Ecole forestière" of Staraia Rossa (province of Novgorod) at $58^{\circ} \mathrm{N}$. latitude, near to the Lake of Ihnen. "One is obliged to conclude," says M. Ototzky at the end of his article, "that the level of subterranean water is lower in the forest than in the stratum exploited, in summer as well as in winter, and also that the oscillations are less. ${ }^{46}$

To sum up, we seem to have gained the information that in the forests of the plains in temperate or cold climates, ${ }^{47}$ whose soil is formed of homogeneous

${ }^{46}$ Quotation borrowed from M. Henry (Revue des Eaux et Forêts, 1903, p. 197).

47 In the tropical region of the globe where the heat is torrid, it is physical evaporation from the soil which plays the preponderating part, while physiological evaporation does not increase with the temperature. It may be, therefore, that in this case the level of the subterranean waters is even higher in the forest. M. Ribbentrop has vouched for this fact near Madras (Revue des Eaux et Forets, 1901). 
DEPTH OF THE SUBSOIL WATER (IN FEET) IN THE FOUR COUPLES OF BORINGS IN THE STATE FOREST OF MOUDON.*

\begin{tabular}{|c|c|c|c|c|c|c|c|c|}
\hline & $\begin{array}{c}\text { Bare } \\
\text { ground }\end{array}$ & $\begin{array}{l}\text { Old } \\
\text { coppice }\end{array}$ & $\begin{array}{c}\text { Bare } \\
\text { nursery } \\
\text { site }\end{array}$ & $\begin{array}{c}\text { Old } \\
\text { coppice }\end{array}$ & $\underset{\text { ground }}{\text { Bare }}$ & $\begin{array}{l}\text { Old } \\
\text { coppice }\end{array}$ & $\begin{array}{c}\text { Bare } \\
\text { pasture }\end{array}$ & $\begin{array}{c}\text { Scotch } \\
\text { pine }\end{array}$ \\
\hline Altitude of station, in feet..... & 799.77 & 802.42 & 802.26 & 803.8 & 845.37 & 849.31 & 811.87 & 807.08 \\
\hline $\begin{array}{l}\text { Average depth of water level, } \\
\text { in feet...................... }\end{array}$ & 8.50 & 12.11 & 13.32 & 15.39 & 9.25 & 14.57 & 7.09 & 3.31 \\
\hline $\begin{array}{l}\text { Average depth of water level } \\
\text { corrected for altifude, in } \\
\text { feet.................... }\end{array}$ & 11.12 & 12.11 & 14.73 & 15.39 & 13.19 & 14.57 & 7.09 & 8.10 \\
\hline Difference, in feet........... & $\ldots \ldots$. & +.99 & n...... & +.66 & & +1.38 & & +1.01 \\
\hline $\begin{array}{c}\text { Maximum monthly varia } \\
\text { tions, in feet................. }\end{array}$ & 4.43 & 3.44 & 5.68 & 3.84 & 6.66 & 6.56 & 10.73 & 5.12 \\
\hline
\end{tabular}

* Totals and averages only are given in translation, condensed and rearranged from results of field work extending over 28 months, May 4, 1900, to August 24, 1902 . See page 22 for a confirmation of these conclusions.

strata lying horizontally and in which in consequence the subterranean sheet is motionless:

(1) The level of phreatic waters is lower under the forest at all seasons, than outside of it.

(2) The depression appears greater in regions where the rainfall is less, than where it rains a great deal.

(3) The oscillations in the level are considerably reduced and lessened by the presence of the forest.

Returning now to our subject, can we conclude from the foregoing that forests are injurious to the feeding of the subterranean sheet of water on level ground in temperate climates?

This certainly seems probable. The intensity of physiological evaporation may be the explanation of this curious lowering of the subterranean sheet under the woods. This will be the lower, that is to say, the less thick (admitting that the impermeable stratum by which the infiltrated waters are arrested, is horizontal), because the forest abstracts more water from infiltration in its growth than does the neighboring ground.

Nevertheless, there is one thing which may cause us to doubt the truth of these conclusions. A careful examination of Table 6 shows us that the depression of the sheet beneath the forest is more marked during the season of repose in vegetation than during the summer. This fact is verified in the case of all the couples of borings, and for the whole length of time during which observations were made. One might conclude from this that it is not the vegetation of the trees that causes the lowering of level.

Are we here perhaps in the presence of a fresh consequence of this fact that, under the forest, the region drained of water by roots, the dry zone in fact reaches to a lower level than under cultivated ground?

However this may be, if the fact of the lowering of the level of subterranean waters under the woods appears certain, its interpretation is less so, and we are left in doubt as to the definite influence, all things taken into consideration of the woods upon the feeding of springs in level ground.

This first study was in the press when we received notice (March, 1904) of the official 
account of the fourth congress of the International Association of the "Stations de Recherches Forestières," which assembled in Austria in September, 1903.48

At this congress, M. Hartmann, an engineer of the Bavarian State, gave an account of the results of researches undertaken in collaboration with the Forest Service by the Royal Hydrotechnical Service with a view to the comparative study of the oscillations of the level of the subterranean water in wooded ground or in the open.

Observations were taken at two points. The first, Mindelheim, at a height of 2,014 feet, is situated on almost perfectly horizontal ground at the surface (inclination six per thousand) composed of the alluvial deposits of the Mindel, a direct tributary of the right bank of the Danube.

The forest is situated in a small piece of isolated ground composed of about 988 acres in the midst of landed estates, and is composed of oak, Scotch, and spruce pines, of about 9 years of age. The other station, Wendelstein, is in the neighborhood of Nürnberg.

M. Hartmann thinks it can be concluded from his statements ${ }^{49}$ that the forest exerts no influence on the level of the subterranean sheet. The latter is generally not stagnant (as has been known for a long time) but takes a more or less rapid course according to the inclination of the surface of the subsoil, the thickness of the subterranean sheet in motion, and the degree of permeability of the soil in which it moves. The considerable differences in the level of subterranean waters observed in Bavaria at points contiguous to a horizontal and homogeneous soil at the surface, can only be explained by the variation in the projection of the subsoil stratum, and by the very variable depth and celerity of the subterranean sheet.

At Mindelheim, in fact, the subterranean sheet is nearer the surface under the woods than in the open. M. Hartmann thinks that the forest counts for nothing, and that the reverse might just as equally hold good.

Conclusions. - In the course of this long study on the influence of forests on the feeding of springs, we have particularly insisted on certain points which, recently brought to light, have hitherto only been dealt with in original memoranda, and are therefore inaccessible to the greater number of readers.

This chapter, now that its end has been reached, leads to one conclusion.

(1) We have seen that the forest has the effect of increasing the abundance and the frequency of atmospheric precipitations.

This action of the forest, proved by many experiments in France and abroad during 30 years, must be regarded as a well established fact, although certain authors, without absolutely denying it, have declared it negligible, or else of so slight a nature as not to be ascertained by ordinary rain gauges, since these instruments are lacking in absolute accuracy.

The increase of water which the forest obtains, amounts to 23 per cent in an average of 33 years of observations taken at the "Station de Recherches" of Nancy. It seems however to increase with the altitude of the place where the forests are situated.

(2) The forest retains a part of the fallen water by its adherence to the crowns and branches and this returns to the atmosphere by direct evaporation. On the other hand these same crowns and branches are always colder, and often to a very considerable

68 Vierte Versammlung des internationalen Verbandes forstlicher Versuchsanstaten, 1903. Mariabrun, 1904 (published by the "Station de recherches autrichienne").

"It seems to us that the conclusions of the Bavarian engineer are somewhat lacking in precision, at least in the text we have before our eyes. One might conclude, it would seem, especially from the accounts given by himself, that the two points chosen for the experiments were not at all suitable for the purpose, the subterranean sheet being far from immovable, and the subsoil not horizontal. In any case, we find nothing here of a nature to invalidate the very clear and well balanced results of the measurements taken at Moudon, as given us by M. Henry. 
degree colder, than the surrounding air, and sometimes are the means of condensing enormous quantities of aqueous vapor, which they introduce to the soil in a liquid state. Moreover, it is not uncommon, especially in winter time, to see the soil which is immediately shaded by a tree, receive more water than a neighboring point in the forest where there is a gap in the shade. For the rest it would seem that the loss of water arising from its retention by the crowns is inferior to the increase of water obtained by the presence of the forest itself. This fact has assuredly been established in the case of the broadleaved plantations in the neighborhood of Nancy; it would seem also certain in the case of the plantations of Scotch pines and larches, and it is probable even for those of spruce pine. One can therefore affirm that, in spite of the screen afforded by the treetops, generally speaking, the forest soil receives more water than does the neighboring soil under cultivation.

(3) The forest causes an enormous diminution in physical evaporation, and prevents surface flow almost entirely. Moreover in numerous cases where one of these phenomena - and a fortiori when both simultaneously - play a preponderating part, as often happens in hot countries and on sloping ground, it is unreservedly admitted that the forest is favorable to the feeding of the subterranean sheet, and in consequence to that of springs.

(4) So far as our researches have actually progressed, we cannot be sure that the forest is favorable or unfavorable to the feeding of subterranean waters in level ground or in cold or temperate climates.

As a matter of fact we are ignorant as to whether its vegetation does not abstract more water from the soil than do agricultural vegetables, as the lowering in the level of the phreatic waters observed under the woodlands would seem to indicate. It may be that such an increase in the communication is compensated by the increase in the watering of the soil, and the reduction in physical evaporation when these two last factors are unimportant (as for example at low altitudes and in cold climates). For the rest, the facts noted are contradictory; cases of springs are quoted which have dried up in consequence of clearings as, on the other hand, superficial dryings up of the soil have been observed, where replanting has taken place. Doubt is therefore forced upon us in this special case; the action of the forest on the feeding of the springs remains uncertain, and it is probably variable according to circumstances which, as yet, remain unelucidated.

(5) Nevertheless it must be observed that springs are only numerous and important in mountain regions, and there certainly the forests are favorable to them.

In the plains the springs are infrequent, and have a feeble output. We are therefore justified in repeating, as our fathers declared, that the forest is the mother of the rivers; the labors of modern science have served only to establish the parentage, universally and at all times recognized, which connects the spring with the tree which shades it.

\section{APPENDIX B}

\section{THE FOREST, FROM A PHYSICAL, ECONOMIC, AND SOCIAL VIEWPOINT 1}

\section{(BY JACQDOT)}

To-day there is strong sentiment in favor of forests. Newspapers defend, Congress discusses and prepares laws for them, associations organize for the protection of existing

1 La Forêt, A. Jacquot, pp. 287-305. Digest and part translation made with a view to preserving Jacquot's picturesque language. According to scientific research Jacquot exaggerates, but it must be borne in mind that he is presenting the subject of forest influences from a popular viewpoint. 
stands as well as for the forestation of uncultivated lands. The Touring Club of France should be cited as a special example. Numerous governments are instituting Arbor Days. In solemnly planting trees with their own hands, the kings of Spain, Italy and England, and high government officials in the United States are merely imitating an example given by our societies or by the ancestral custom, observed in certain communes of Alsace, of planting at least one tree at the birth of each child. There also, newly married couples plant two fir trees on the day of their marriage. . . . The tree which grows in humanity which is increasing. The instinctive cultivation and religious admiration of primitive peoples for the trees is based on science and reason.

Physical Rôle of Forests. - Humidity. - Forests increase the degree of humidity in the air. Not only are the arid zones sheltered by forests . . . but furthermore, in the majority of cases, the presence of a vegetative mantle on the mountains is of importance in the yield of crops and favors life and populations. Here the forestation, true talisman of life, becomes a work of safety, and a question to be or not to be. All floods have their rise on the bare ground created by the destructive felling of timber which protects it. In these regions the forest disappears even though it is indispensable to agricultural crops, the foundation of human life. It is on account of aridity alone, and not for any other reason, that there have been terrible famines in Russia, in India, and in China. Deforestation dries up a country. Without water there can be no life, without humidity the ground will become as dead as the moon, and forests are necessary in order to have water. Since their deforestation . . . Columbia, the Islands of Maurice, of Reunion, and of Ascension, Sicily, Asia Minor and all other denuded regions have experienced terrible droughts. These droughts immediately stopped in localities where tree growth has been reëstablished. In Porto Rico and in Jamaica, the phenomenon is doubly verified in recent times. The rains disappear with the trees but return with them. Above the forests there are light clouds, and after the shower the branches drip onto the soil. . . . During the night the trees water the heather as if the urns of the sky were thinking of the earth in order to fill up the divine springs. We have seen all that and have concluded that the forest is the mother of the waters. But figures will suffice to give an idea of the strength of the forest: an acre of high forest pumps every day into the soil 10,000 to 12,000 quarts of reserve water; its evaporation can be placed at 2,616 cubic yards per year representing a stream 20 inches high or almost threefourths the total rainfall falling in France. The quantity of liquid emitted by the same area of water, mineral substance or vegetable substance are in the proportion of 1,3 , and 60 . The forest is certainly a reservoir of humidity. It is also a regulator.

While running water is often dangerous, its infiltration is desirable for the life of springs. This infiltration attains its maximum under forest stands. The cover of trees (doubled by a brush under story) largely reduces evaporation. Under the forest the soil is better irrigated than on bare soil. On the other hand, the snow falls more slowly, consequently the absorption of the forested land is perfect. The forest tends to make the temperature more uniform by reducing the extremes of heat or cold. It exercises the same action as does the sea at the seashore. On limestone soil, which forms the major part of our planet, the running water digs out the soil and is then hidden by these very fissures. Drought is accentuated, increasing the intensity of burning sands, the bare steppes, and the arid deserts. It is a war of thirst, which menaces the twentieth century. The forest alone by the shelter of its thick layer of humus is capable of making a successful fight against the bankruptcy of the waters.

Hail. - The trees diminish the storms, lessening electric discharges and rendering less frequent and less dangerous the fall of hail, which in the deforested regions cuts and damages the crops. Numerous examples have been established. In eighteen departments, where the hail is usually the most damaging, fourteen are the least forested in France. 
Frost. - Around the forest, but not in it, one finds the white frosts which are so common in dry climates. The upper story protects the lower vegetation like a tender blanket. It replaces, after a fashion, artificial shelter.

Wind. - Without the trees in numberless countries, the violence of the wind lays low the plants or dries them up. . . . The smallest shrub or the simple hedge of cypress of the Provence exercises a beneficial protective cover. In Russia, when the June vegetation of the steppes is in full bloom, the squares enclosed with planted hedges remain green, and furnish half again as much revenue. In Algeria, they say that nothing can resist the sirocco. Nevertheless, it has been conquered by the trees. Look at the delicate plants in the experimental gardens at Algiers and the rich plantations of the Mitidja.

Springs, Avalanches. - All the world to-day bears witness to the benefit of the vegetable cover for the maintenance and conservation of springs (see Appendix, $p$. 361 ). This is also true of the value of forests in protecting against avalanches.

Floods. - The forest is the sovereign regulator of waterflow. On the denuded slope, the rain rushes along carrying the material eroded from the loose soil. This mass, increased by the mixture of débris, and with its increasing speed, communicates a tremendous live force to these thousands of little streams. It becomes a furious torrent which carries off the slopes, bears rocks along and even fields and houses. Gravel fills the bed of the rivers and hinders shipping. It covers the plain with blocks of stone and sterile sand. What would happen, on the other hand, with a wooded slope? A large proportion of the rain will have been stopped by the foliage and branches to be given back to the atmosphere. The remainder, broken up by the foliage, strikes the soil as if it had passed through a sieve. The layer of dead leaves and humus which carpets the forest floor is a soft sponge with an extraordinary capacity for absorption. It absorbs five, six, and even nine times its liquid weight before saturation, when it lets the water seep, drop by drop, to the surface and to the interior of the soil to feed subterranean streams which result in springs. The small surplus water, which is not retained, encounters in its flow innumerable obstacles, trunks, roots, moss, herbaceous flora, dead branches, dead leaves, and the inextricable lacework of roots. The flow is divided slowly up and does not erode the soil. It arrives at the foot of the slope slowly and in small quantities. . . . Against the heat of the sun and the drying winds of the south the branches serve as a screen. In the spring they diminish the damaging effect of warm rains on the snow and prevent too rapid melting. The regularity of the run-off is determined by the state and extent of the forests which cover the basin. Numerous experiments in valleys, some forested and others bare, have proved this. These comparisons have given rise to the adage: "He who wishes to master the waters, must first master the forests." Thus to the trees crowning the mountains the soil is held in place. The slopes are maintained and erosion ceases. Its action can thus be summarized:

"The presence of forest stops the formation of torrents. Its development extinguishes it. Its destruction delivers the soil as a prey to erosion. All the fundamental laws recognize the absolute necessity of reforestation. In the denuded countries, what ravages! The torrents attack the mountainsides like a 'pieuvre,' eat them out, disintegrate and carry them piecemeal to the plain. High up the rock is bared, lower down they cause the fields to become barren and covered with débris. The roads are interrupted. The railway lines cut and the bridges demolished. One sees the opening up of abysses, the cut of railroad lines, and the engulfment of entire villages. Each year, in France, the floods cause an average damage of $\$ 5,790,000$. With the expense, which has been caused by such floods during the 19th century, all Europe could have been reforested. These catastrophes have been the result of excessive deforesta- 
tion - a veritable social crime. It is the ruination of the mountaineer. . . . Moreover, the man that deforests assassinates the plain. The damage is far reaching. . . . The waterfall which directs our turbines and produces the power for heat and light may be done away with and rendered useless by deforestation. If you kill the forest, you kill the brook which is the friend of mechanics. Thanks to electricity. . . . water has become (as the ancients said) the most precious of gifts. . . . By enormous dams, engineers have hoped to avoid the terrible results of deforestation. . . . How much inferior is this inert masonry, limited to a single valley, in comparison with the strength and value of forests, living, supple, growing forever, which cover the valleys as they do the plain. Free accumulator of water, ideal, green, cool, which man removes and cuts like grain! In every deforested basin, the difference between the low-water mark and the flood waters is formidable. For example, in the Loire, the Cheliff, the Seybouze, the Vidourle, the Verdon, it is $900,1,500,6,600,1,500$, and 2,000,000 times the ordinary flow. The flow of the Ardèche is usually reduced to 6.5 cubic yards, whereas it sometimes amounts to 10,500 , when it has the size of a Mississippi, or an Orinoco, or a Danube. The flood that comes with the rapidity of a galloping horse and throws into the Rhone such a volume of water that the flood level rises 16.4 feet. If there is no stand of trees to stop the erosion of storm floods, every deluge ravages slopes all the way to the plain. . . . The damage done by the Garonne means an annual loss of $\$ 1,544,000$. This same amount spent only once, but properly applied, that is to say for reforestation in the Pyrenees, would permit the suppression of every cause of the damage. . . . One now commences to realize that the forest is a twofaced army to fight for or against water. The same water which is not stored by the forest may be transformed to mechanical energy or . . . may suddenly precipitate itself in a formidable, devastating mass. The impoverishment of the world, erosion, the transport from the mountain to the sea, the frightful loss of water . . . the forest alone can stop it. . . . Deprived of their cover of wood or of grass, the slopes erode, waste away, and fall in ruins. On the forested slopes, on the contrary, everything remains. The roots fix the humus to the rocks. Everywhere the forested mountain changes a foolish water into a wise one. It renders the typhoon inoffensive by dividing up its floods and distributing its monstrous mass in millions of drops which flow slowly over the old surface of the earth. We must then recognize that the water being everything and life being impossible without it, the tree which holds the water is everything itself. If the forest was held sacred by religion, it should be held still more sacred by reason of its social necessity. To plant a tree is to accomplish a good deed, to create a forest is to enrich the country by a conquest which does not cause a tear or shed a drop of blood.

"Economic Rôle - Utility of Wood. - From the beginning of the world wood has been a prime necessity. The prehistoric people lived in the forest and on the forest. Coal, gas, and electricity have modified the use of wood but without abolishing or diminishing the demand. Imagine the enormous volume used by the thousands of trades which must have wood products for the innumerable objects manufactured, from the great steamship to the little doll. Alone, paper mills could devour all the forests of the world and only to assure the printing of 70,000 newspapers of 200 volumes which are published daily. For France alone it represents the annual production of $1,235,000$ acres of high forest. The coal mines use each year $24,000,000$ cubic meters (about 5 million thousand feet board measure) in their galleries, about nine and a half times the volume of the greatest pyramid in Egypt. Finally the world uses more wood than it produces. The excess of use over normal increase is about $2,620,000$ tons per year. The deficit is momentarily made up by the destruction of forests. It is an expedient of which the fallacy is clear. A dearth of timber menaces us. Our country 
imports annually from 39.5 to 42.5 million dollars worth. Plant new stands with the utmost ardor, since the operation is profitable. ${ }^{2}$ The pineries, for example, yield 5 to 10 per cent. There does not exist any other more advantageous investment. Forestation enriches the planter and makes our country stronger.

"Social Ro8le - Climate. - Following excessive deforestation, the local climate becomes worse. The prosperity of agriculture, the health of inhabitants, the public fortune itself, depends upon normal proportion of forest. This per cent is itself an element to regulate the world's circulation of cloud, rain, snow, flood, and even the ocean. The denuded zones in the mountains must be restocked in order to re-ëstablish order in nature, without which all economics are profoundly upset; it is partly due to the absence of forests that one must attribute the burning climate of the interior of Asia, Africa, and Australia. The destruction of stands has produced disastrous climatic changes in Greece, in Russia, . . . in Asia Minor, and in certain regions of India. All history agrees on this point. It shows clearly the disastrous effects of great deforestation on climate. Aristotle, Pliny, and Strabon predicted to their contemporaries the sterility which would follow deforestation . . . which, in lowering the humidity necessary for vegetation, . . . has brought on something more terrible than any war, namely, the decadence of the most powerful empires, . . . those great countries which were the founders of the human race - Mesopotamia, Turkestan, Bactres, the splendor of the Greek civilization under Alexander the Great, Palestine, Syria, deprived of forests made the water, the vegetation, and the inhabitants disappear. Desert and sterile, the jaded country once so populous, deforestation has driven away life itself. Deforestation has even permitted the sea to recover land once cultivated the Pomeranian shore, the Zuyder Zee. At the middle of the seventeenth century, the Chinese had transformed Tartary into a desert by removing the trees which protected it. Because of deforestation, the temperature of the winter season is even lower than it was in Norway. On the plateau of Iran, the temperature passes in several hours from $60^{\circ} \mathrm{C}$. to $7^{\circ} \mathrm{C}$. $\left(140^{\circ}\right.$ to $44.6^{\circ} \mathrm{F}$.). The air is so dry that nothing can withstand it. We must go back to the old tradition and realize that it is a scientific fact that the ancient veneration for trees shown by our fathers is because the forest is completely indispensable to creation.

"Hygiene. - Under the majority of cases, hygiene is intimately linked with forests. From the Roman times it has been recognized that the exccssive felling of forests exerts an unfortunate effect upon the physical condition of the country and compromises the health of the inhabitants. Swamp fevers follow deforestation everywhere in the subtropical zones. On the other hand, forestation accompanied by drainage dries up the marshes and diminishes sickness in fever regions such as the Roman Campagna certain steppes of Russia, Tuscan Maremme, in the Landes, in Poitou, and in other places less known. The difference between sickness and health, between prosperity and extreme misery, coincides with the appearance or disappearance of the arborescent mantle. Such are the contemporary facts. The Belgians celebrate by an official fiesta the social rôle of silviculture, proclaiming that the forests exercise the most healthy influence on climate and public hygiene. It is not necessary to have great areas of forest to manifest its curative strength. A single eucalyptus tree may drain the excess water from one-quarter of an acre. In Algeria, a hedge several yards in length . . . may guarantee all the occupants of a house against swamp wet soils so conducive to malaria. Thousands of examples prove it. The marsh of Bonfarick, one of the unhealthiest localities in Algeria, has been transformed by planting into one of the healthiest colonies in France. In 30 years the pineries have made healthy, fertile, and rich

2 This, of course, is an exceptional instance of profitable private forestry. Here worthless sand wastes were made to yield a handsome revenue (see p. 183). 
the Sologne which exaggerated deforestation had reduced to a state of pestilential fever. Formerly unsalable, the Landes of Gascogne are now worth 193 million dollars or more. A region formerly unhealthy because of fever has to-day the name which is doubly merited of Côte d'Argent; formerly devastated by sickness, the population now lives in perfect health in what is actually a health resort. Forests are a potent obstacle to the spread of certain diseases. Not only is the air free from deleterious gas, but there is no dust or nocturnal dampness, but the acid of forest soil kills the germs of cholera, typhus, the bacilli of tetanus. . . . The forestation of watersheds gives a guarantee of purity. Often a sequence of deforestation is a decrease in population. It is something that has happened in most of the Mediterranean islands, as well as in the Azores and in the Canaries. When the Venetians ruined the forests of Dalmatia, three-quarters of the inhabitants were compelled to leave. In France, the thirty departments where there is the most deforestation have a depopulation seven times as rapid as the fiftyseven departments where the forests are maintained. Not only does the birth rate diminish and the mortality increase in the deforested departments, but the inhabitants still emigrate. They go in search of a living. . . . Forests precede people, deserts succeed them. . . . Deforestation has transformed Turkestan into a desert, where it was formerly fertile. Deforestation has destroyed its equable climate, its former ferility, and, in consequence, its population. . . . Since the planting near Sologne, the local population has increased 2,250 per cent. The examples are too numerous to enumerate. A Servian proverb summarizes the problem: 'He who kills a tree kills a man.'

" Asthetic. - That is, the material side of the forest; but that is not the only question to consider. . . . In the spring the forest is an enchantment for the eyes. One sees the bare forest clothe itself from branch to branch. . . . Nature is irresistible. Artists feel the seduction of the forest and found colonies in it as at Barbizon. . . . The first homage of man was addressed to the great forests, eternal and immovable, which cover all parts. . . . The forests, according to Chateaubriand, were the early temples. This religion was that of all the peoples of antiquity: The forest is sacred. . . It was worshipped by numberless tribes. . . . The disappearance of the forests on the plateau of Central Asia made it so uninhabitable that whole tribes and races who occupied it were forced to emigrate. . . . Manon had in his laws (the most ancient of the world): 'Defend the forest against destruction. One finds in any of the old religions, the myth of the sacred tree, the gods assembled under its shade. . . . The imagination of the Greeks and of the Romans was peopled with sylvan deities. . . . Almost always the temples were surrounded by sacred forests. It was often in the forests that the gods spoke through oracles. . . . In Ceylon, in Spain and Persia, and in Manila, the trees are still worshipped. Saint Valery, fighting against paganism, turned his anger against the nymphs of the forest and the fountains. . . . We know now that the disappearance of the forest destroys the equilibrium of natural forces and makes for disastrous climatic changes, substituting sterility for richness, the desert for abundance, death for life. As though crazy, mountaineers often say: 'After us the deluge,' without realizing that the forest means water and freshness so necessary for pasturage. . . . The existence of man is coupled with the existence of the forest, moreover the forest is the index of public welfare and the richness of a people. It is necessary, then, that each man become a friend of the trees and that our laws and our hearts protect this arborescent vegetation without which our civilization would perish. Against the savage violence of the torrent or the deadly menace of the avalanche we must oppose the serene strength of our great benefactress - the forest. Child of Nature itself, it shields, with its protective cover, children of humanity. The present children need it with its living force 
which maintains the activity of the entire world under the beneficence and splendor of its shade.

"As the centuries roll by, let us unite in reflecting on the instinctive sentiment of the ancients for inviolable forests and the cultivation of the tree."

\title{
APPENDIX C \\ SILVICS OF IMPORTANT FOREST SPECIES. LISTS OF TREES, SHRUBS, AND PLANTS USED IN REFORESTATION IN THE MOUNTAINS \\ FRENCH SILVICS OF PEDUNCULATE OAK
}

\author{
(Quercus pedunculata) ${ }^{1}$
}

Size. - Quercus robur. ${ }^{2}$ Under this name Hooker, De Candolle, and other eminent authorities include Quercus pedunculata (peduncled oak) and Quercus sessiliflora (English oak), the British representative of the species.

Pedunculate oak is a species which reaches considerable dimensions. During youth, and up to 40 to 50 years of age, it has an irregular bole but later on the shaft becomes straight, cylindrical, sometimes with a clear length of 65 feet. This tree may reach a height of from 131 to 147 feet and even 190 feet in a few instances; thanks to its very great longevity it reaches large diameters. The Montravail oak, near Saintes (Charente Inférieure Department), is between 6.6 and 7.6 feet in diameter at breast height; its main branches have a diameter of 3.3 feet at their base; the total height is 65.6 feet, the crown width 131.7 feet, and it is estimated to be some 2,000 years old.

Habit. - The crown of pedunculate oak is formed of a few irregularly bent and twisted main branches; the foliage is very unevenly distributed in tufts with wide and numerous openings. . . . The foliage is incomplete and less thick than that of sessile oak.

Leaves. - Pedunculate oak leaves (more so than those of Quercus sessiliflora) dry up at the end of autumn and drop off immediately, except those of coppice shoots and suckers which are semi-persistent. Of a light green color, sometimes reddish or yellowish at the beginning of summer, the leaf is moderately shiny or quite dull; it is of a somewhat sea green (glaucous) hue; frequently it is undulated, more seldom flat. . . . If green and gathered during September, it has an average weight as compared to sessile oak leaves as 34 is to 40 . (A. Mathieu.) When used dry as agricultural manure 300 to 350 pounds is equal to 100 pounds of straw. Pedunculate oak is . . . much less suitable than sessile oak for pure plantations, since it has a lighter foliage and yields less litter. This is why coppice-under-standards composed of pure sessile oak yields a fair stand while the same cannot be said to be true of pure pedunculate oak.

This species seems eminently suitable for coppice-under-standards on clayey, moist soils and for high forests when mixed with tolerant species; sessile oak, however, should be preferred to it whenever . . . pure forestation is attempted.

Seed Capacity. - Pedunculate oak bears acorns from 60 to 100 years of age, according to whether grown single or in close stand. Sprouts bear acorns as early as 20 years, and even before; but plentiful seed crops occur only 3 to 4 years and even 8 to 10 years according to whether the climate is more or less favorable. An absolute failure of acorns, such as happens with beech between crops, is rare; some few are always to be found on isolated or border trees.

${ }^{1}$ Based on a free translation from French authors.

${ }^{2}$ See also Chapter V. 
Germination. - The germination of acorns is quick and takes place at a low temperature, from 3 to 4 degrees C. ( 37 degrees to 39 degrees F.) above zero; they are difficult to preserve even till spring. A bushel weighs about 40 pounds on an average and contains approximately from 8,000 to 9,300 seeds.

Rooting. - The tap root of pedunculate oak is developed first; at one year of age it is often 12 inches in length. Only when about 6 to 8 years old does it produce a few laterals; but at 60 to $\mathbf{7 0}$ years the laterals are dominant and the tap root becomes of secondary importance and seldom reaches below 3 to 5 feet. Stump and root wood, with 12-inch stumps, represents 14 per cent to 17 per cent of the total cubic volume.

Shoots and Suckers. - Dormant buds keep alive a long time and retain great reproductive power to an advanced age; per contra, it means that standards are liable to have numerous root suckers after the coppice has been felled. Pedunculate oak is therefore more liable to have epicormic branches than its associate sessile oak.

Adventitious buds are but rarely formed and only in very fertile soils; they produce poorly attached shoots which wind, snow, and hoarfrost easily cause to break. Stump shoots root but superficially and do not require deep soil.

Bark. - The bark is smooth, shiny, and silver-gray up to 20 to 30 years . . . after that age, a brown bark with longitudinal flakes which becomes thicker and thicker.

Geographical Distribution. - The habitat of pedunculate oak is very extensive. It is found between east and west longitude 65 degrees, from the Ural Mountains and the coast of the Caspian Sea to the Atlantic Ocean. Its southern limit is from southern Spain, at a point in the Sierra Morena, south of Sicily, Italy, Greece, thence through Minor Asia as far as the Eastern Caucasus. The northern limit starts from Scotland, goes to 63d latitude in Norway and thence southeastward through St. Petersburg to Orenburg, in the Ural. It thus extends through about 26 degrees of latitude.

Location. -- The pedunculate oak prefers the plains and the valley bottoms, but it is found in the hills and even reaches as high as 3,280 feet in the Eastern Pyrenees.

Soil. - Pedunculate oak does not show any particular preference as regards the mineral nature of the soil provided it is sufficiently moist, and deep. Sandy-clay soils, even if occasionally flooded, suit it especially well; it is a serious error to drain them.

Tolerance. - Pedunculate oak is a light demanding species. In order to grow, it requires at least four months of uninterrupted vegetative activity with a mean temperature of $12.25^{\circ} \mathrm{C}$. $\left(54^{\circ} \mathrm{F}\right.$.), provided no protracted drought intervenes; in order that acorns may mature a total temperature varying (south to north) from $28.75^{\circ}$ to $20.20^{\circ} \mathrm{C}$. $\left(83.75^{\circ}\right.$ to $68.50^{\circ} \mathrm{F}$.) is necessary. The maximum temperatures that it can stand are, in the south, $44^{\circ} \mathrm{C}$. $\left(111^{\circ} \mathrm{F}\right.$.); in the north, $37^{\circ} \mathrm{C}$. $\left(98^{\circ} \mathrm{F}\right.$.). When in vegetative activity, it is easily affected by cold; young shoots, leaves and flowers will usually die if, during spring, the thermometer falls below $0^{\circ} \mathrm{C} .\left(32^{\circ} \mathrm{F}\right.$.).

Timber. - It yields primarily building timber. The sapwood is white and clearly defined; the more active the vegetation the wider is the sapwood. According to the Nancy Forest School collection the total thickness of sapwood is from 0.63 to 3.0 inches; the total number of annual rings 36 to 7 . The density for timber completely air dried is from 0.647 (Forest of Haye, Nancy) to 0.906 (Adour oak), with average yearly increments of 0.186 of an inch.

Uses. - . . . The wood is especially prized for ship building.

Fuel Value. - Its fuel value (based on calorific power) averages, as compared with beech, $91 / 100$, according to G. L. Hartig; 85/100, according to Worneck.

The market value of firewood is below this because pedunculate oak crackles while burning, requires a strong draught, and the coals do not hold the fire well. There is a great difference as to quality in this respect. Bark from mature trees, on the other 
hand, has a very high calorific power; as compared with beech wood, the ratio is 108 to 100 and it burns slowly, with a short flame to be sure, but producing live embers that last till entirely burnt out.

Oak charcoal is valued as compared with beech as 91 is to 100 .

By-Products. - The bark yields tannin of good quality, inferior, however, to that of the other species of the same genus. Young pole stands (coppice) between 20 to 30 years of age yield the best tannin.

Silvicultural Characteristics. - (See sessile oak.)

\section{SESSILE OAK}

(Quercus sessiliflora)

Climate and Soil. - The sessile oak, as well as the pedunculate oak, is dependent upon the texture, depth, and fertility of the soil rather than on its mineral composition. It prefers loose clay. For some time foresters considered that the sessile oak could be substituted for the pedunculate oak, or vice versa. Now, they realize that the pedunculate oak requires a moister, or, at least, fresher soil; sandy loam, even inundated at certain seasons of the year, is considered very favorable since it is a species of the plains or valleys. On the other hand, low wet clays are less favorable to the sessile oak.

It is distributed almost all over France, except in the high mountains and in the hotter regions bordering the Mediterranean. The pedunculate oak is very abundant in the southwest where it forms almost pure stands in the Landes and the Adour Basin. The sessile oak is the dominant species in the center of France and in the hilly country, where it extends to 3,281 feet of altitude and slightly above. Both the species attain their maximum development in the temperate zone where they are of characteristic abundance in the region which corresponds to that cultivated for grapes. Above the oak comes the fir.

Tolerance. - Both species are hardy when young. They have a light foliage, often incomplete, as in the case of the pedunculate oak. They resist heat as well as the cold of winter, but their leaves are very liable to spring frost. The pedunculate oak, which begins growing later than the sessile oak, is less liable to frost damage. They are both gond sprouters.

Root System and Seeding. - Both species have long tap roots. The fruit is a heavy acorn and the seed years are usually frequent in the southwest where it is possible to collect seed almost every year; as one advances toward the north, seed are less frequent. In northern France they come every 10 to 15 years.

Growth Longevity. - The growth of these oaks, slow at the start, soon becomes quite rapid on good soil and continues to an advanced age, for their longevity is very considerable and exceeds 200 years. The growth in height in a dense stand, as well as isolated individuals, slows up towards 100 years.

Utilization. - Oak wood must take the first rank for its general quality but its strength depends more or less on whether the growth is rapid or slow. Generally speaking, the wood of the pedunculate oak is denser than that of sessile oak and is better for construction purposes. Sessile oak is more highly valued for wood working and for cabinet work; but the pedunculate oak of Hungary is highly esteemed for that purpose.

By-Products. - The bark is used for tanning purposes. The bark of sessile oak is generally richer in tannin than is pedunculate oak when it grows in warm situations and in the open.

Silvicultural Characteristics. - " The chief value of oak for the private owner," says Broilliard, "is because it is abundant, because it grows on almost cvery kind of soil, because it flourishes whether growing alone or in dense stands, whether in high forest 
or as coppice and grows to such an old age that almost every tree can reach large dimensions."

The oak is well adapted to treatment as simple coppice and furnishes excellent fuel, besides tannin bark, but its chief value is in dimension timber of large size. Treated as high forest it flourishes in the plains, but does not reach its maximum value before 200 to 300 years of age. It requires early thinning and, since it impoverishes the soil, it should not be grown pure, but in mixture with the bcech or hornbeam. If these accessory species are lacking, it is indispensable to preserve undergrowth to protect the soil from drying out. From this standpoint, grazing in an old high forest does a good deal of damage. On the whole, the thicker crown of the sessile oak enables its treatment as a pure stand easier than does the pedunculate. . . . Especially the pedunculate oak is adaptable to standards in a coppice-under-standards forest. It yields, however, a smaller proportion of timber when grown as coppice-under-standards than it does as high forest. When grown in an open stand, it formerly furnished ribs highly valuable for ship construction. These two oaks, and especially the sessile oak, possess the faculty of adapting themselves to divers conditions which different methods of treatment propose. On the driest and thinnest soils, the sessile oak will merely grow into a bush and, while both species prefer rich soil, they often give satisfactory results on soil of moderate quality.

\section{BEECH}

\section{(Fagus sylvatica)}

Size. - Beech is one of the most widely distributed and important of forest trees; it attains great size but is smaller than oak or fir, owing to much shorter longevity. It rarely lives more than from 300 to 400 years and only occasionally grows to 131 feet in height with a maximum diameter of 6.5 feet.

Habit. - The straight stem is remarkably cylindrical up to a great height and the bole remains clear to the crown. . . . The clear length is often 66 feet. When grown in the open or under other species it branches at from 33 to 49 feet. . . . Up to 10 years of age, the shoots are a dark olive-green; beyond this age, stems and branches are ashy gray.

Bark. - . . The white coloring of beech bark is not natural, but results from numerous lichens (Verrucaris Beformis et Epidermis; graphis scripta; Opegraphia varia, etc.) which coat its surface as early as the 10 th year with their very thin thalli.

Buds. - . . Beech buds are longer, more tapering, and more angular than those of any other species; they are covered with a large number of stipulate scales that are brown, dry, hairless, and shiny.

The strongest buds produce normal shoots, the internodes of which are well developed; but there are many less vigorous ones . . . which only give rise to shortened shoots, the leaves of which are not numerous, almost fasciculated, lack buds at the apex, and produce a single terminal bud. Resulting boughs . . . do not ramify, lengthen with extreme slowness, and contribute, on account of their great number, to increase the beech's foliage and cover. After 15 to 20 years boughs of this kind attain at most $4 \frac{1}{2}$ to 6 inches in length with a diameter of from 0.16 to 0.2 inches.

A few of the weakest produce neither shoots nor leaves.

Tolerance. - Beech requires shelter during youth and cannot endure protracted exposure to the sun; it is very sensitive to spring frosts on account of its tendency to early growth.

Foliage. - The consequence is that its crown is dense and foliage heavy.

Aspect. - It prefers north and northwest exposures.

Reproduction. - . . . Sprouts come more frequently from adventitious buds 
. . beech, especially if mixed with other species, is unsuitable for coppice; it rarely grows suckers.

Leaves. - Leaves are alternate . . . they vary ${ }^{-}$in size according to altitude; the higher the altitude, the smaller the leaves. At 3,900 feet the leaves are one-half the size they attain at sea level. An acre of high forest, fully stocked, produces as early as the 30th year practically equal quantities of litter until the end of the rotation - a yearly average of 3,664 pounds of air-dried leaves (to be reduced 20 per cent if oven dried). (Ebermayer.) This weight in litter is a good deal greater than that of the kilndried timber grown on an acre in the same time and under identical conditions. The above quantity of leaves would cover ten times the area they are grown on; decomposition is fairly slow and the accumulated leaves would form a thick layer on the ground.

Seeding. - Beech produces seeds only at an advanced age, about 60 to 80 years in closed stands, 40 to 50 when in the open; it bears abundant masts only every 5 to 6 years under the most favorable circumstances, but sometimes only every 15 to 20 years. In the latter case, between full seed crops partial ones take place. A remarkable fact about seeding is that, in certain years, there is such a scarcity of beech nuts that one could not gather a liter full even on a considerable area. Full seed crops are more common in the plains and on moderately sloping ground than in mountainous districts.

Flower buds are formed as early as August and are easily distinguished from foliage buds by their more plump shape. The abundance, scarcity, or lack of flower buds indicates almost to a certainty what the next mast crop will be. Consequently, the effect of spring frosts is not a satisfactory explanation of the irregular seed crops observed for this species. Obviously, the temperatures during the year when the buds start have a preponderating influence on bearing capacity.

Beech nuts are very difficult to preserve even until the next spring; therefore it is better, as a rule, to sow them in the autumn; they keep perfectly in pits, however, if they are properly established. A kilogram contains about 1,600 seeds.

Germination. - When sown in autumn, beech nuts germinate very early in the spring, toward the end of April. The tigella extends immediately under the cotyledon, pushing the latter about 4 inches above the ground. The two cotyledons, folded irregularly one over the other, develop into two wide, opposite, pulpy, reniform, full leaves (the upper side of these leaves is green and the under side silky white). This early germination, coupled with a rapid development of the tigella and cotyledon, and the tenderness of these rapidly grown tissues, render the young plant very liable to be affected by temperature variations, especially by spring frosts.

Growth. - During the first years after sowing the plant grows slowly (about 4 inches in height a year) but after 5 years it shoots up. At 40 to 45 years it reaches its maximum annual growth; but when 100 years old the tree does not increase appreciably in height.

Each annual ring is from two to three times thicker near the top of the bole and at the beginning of the main branches than at the base; this fact, which is true to a lesser degree for all the other speeies, enables beech to keep its cylindrical shape to a considerable height.

Root System. - During the first few years of growth the tap root grows below the ground to about the same extent as the stem grows above it. At about 3 years from two to three oblique laterals, well provided with root hairs, are developed; at about 12 to 15 years they grow rapidly (at the expense of the tap root, which remains inactive); at 30 years of age the laterals cease growing and are gradually replaced by superficial, shelving roots, which sometimes protrude out of the ground for some distance from the base of the tree. In rocky soil these roots frequently interlace with 
one another. To sum up, the whole root system is of no considerable depth (from 1 to 1.6 feet) but widely extended; the volume of the root wood equals one-fifth the total contents of the bole and branches.

Geographical Distribution. - The beech extends south and north from Mt. Etna in Sicily to the sixtieth degree, beyond Christiana in Norway, over a length of about $24^{\circ}$ of latitude; east and west; from the Caspian Sea to the Atlantic Coast, over about $65^{\circ}$ of longitude. France is included in this area, but the greater part of Spain and the whole of Algeria is excluded.

Beech becomes a lowland tree only in the northern latitudes, on the North and Baltic seacoasts. Its limit of altitudinal distribution naturally increases the farther south you go; its maximum is not over 850 feet in Norway, but as high as 7,087 feet on the slopes of Mt. Etna. In France the limit of growth is 4,541 feet in the Vosges, 5,223 feet in the Jura, 5,381 feet on Mont Cenis, 5,462 feet on Mont Ventous, and 5,577 feet in the Pyrenees.

The lower limits of the beech zone are less accurately known; it extends into the vine region but does not reach the valley bottoms where the soil as a rule precludes beech forests.

Climate. - Toward the north and in the higher altitudes, cold limits the extension of beech, which ceases growing when the January mean temperature falls below $5^{\circ}$ to $6^{\circ} \mathrm{C}$. $\left(41^{\circ} \mathrm{F}\right.$. to $42.8^{\circ} \mathrm{F}$.) in the plains and $6^{\circ}$ to $7^{\circ} \mathrm{C}$. $\left(42.8^{\circ}\right.$ to $44.6^{\circ} \mathrm{F}$. $)$ on slopes.

The southern limits are fixed by an excess of heat and consequent drying out due to an insufficient rainfall. Thus beech ceases to grow when a maximum of $44^{\circ} \mathrm{C}$. $\left(111.2^{\circ}\right.$ F.) or when the sum of the temperatures during the vegetative season exceeds $5,750^{\circ} \mathrm{C}$. And yet, in order that beech may reach the above extreme limits, it requires from seven to eight rainy days during the summer months - June to August.

Soil. - Porous, light, and even rocky ground is suitable for beech provided rains keep the soil fresh; compact, moist and marshy soils are absolutely harmful; this is why it does not generally grow in the rich alluvial soil of the broad valleys.

The mineral character of the soil seems of no great consequence, since fine forests are found in sand, sand and rock, granite, porphyry, and pure clay; they seem to thrive best in the latter.

Yet beech is one of the most exacting species in respect of mineral nutrition; according to the averages arrived at by Ebermayer after numerous experiments, a high forest takes from the soil $\mathbf{4 7 6}$ pounds of mineral elements, 70 of these only for timber and 406 for leaves in order to produce 14,400 pounds of completely air-dried matter (timber and leaves); under the same conditions and to produce an equal solid volume, a forest would absorb only 139 pounds, in all about 37 for timber and 102 for leaves. The requirements of beech as regards mineral elements are, therefore, as compared with those of pine, in the ratio of 3.4 to 1 . No doubt, as compared with some other species, the ratio would not be so great.

Competition with Other Species. - Favored by its thick foliage and its ability to endure shade, beech . . . has taken the place of such light demanding trees as oak, pine and birch. This was the case in Denmark, Holland, and other countries where (as proven by the numerous charcoal pits found there) this tree did not formerly grow, while pine, judging from the amount of the pine débris, was plentiful. Beech is nowadays the dominant species of the forests of those countries, while pine has disappeared from them. Julius Caesar found no beech in England where to-day it is plentiful.

Timber. - Despite morphological analogies, beech yields a timber very different from that of oak or chestnut. It is white when cut; it becomes reddish through exposure to air, and after seasoning becomes a uniform light red, without any well-marked 
distinction between the sapwood and heartwood. The heart of the old trees . . . colors a brownish red . . . with rather prominent but moderately close medullary rays. It lacks pliancy and easily becomes twisted and cracked; it is liable to rot and does not polish; when subjected to alternate drying and wetting it does not last long but is fairly durable under water and when constantly wet.

Beech is not therefore a building timber; but, being easily worked, it is frequently used by a number of trades, such as wheelrights for felloes, by basket makers, shoemakers, joiners, mechanics, turners, etc. It is one of the easiest woods to be thoroughly treated with preservatives; when so treated it makes good railway ties. Density, one of the most important properties of beech, depends on several circumstances such as altitude, latitude, aspect, soil, and whether grown in open or dense stands. It is in no way proportional to the thickness of the rings which vary from 0.27 to 0.36 of an inch.

Fuel Value. - The most important use of beech is for fuel. The calorific power has been taken as a unit by the best authorities (G. L. Hartig, Werneck, I. Hartig) not on account of its having the highest fuel value, for some other species (yoke elm and sorb tree) exceed it, but because it is the best known and the most frequently used. As a matter of fact, the fuel value is proportional to and as variable as the density of the wood. Beech wood burns with a bright clear flame and gives embers which remain incandescent until completely burnt out. . . Beech charcoal is highly prized for domestic purposes and for treating ores.

By-Products. - The kernel of the beech nut contains from 15 to 17 per cent of its weight in a fat (non-siccative) oil which is edible raw, when extracted, and is quite suitable for lighting purposes.

A heavy mast is for this reason an important source of profit both for the owners of the beech plantations and for those who buy the right to gather the fruit. An acre of 150-year-old beech high forest yields, in years when there is a mast, up to 57 bushels of beech nuts (Retz forest, according to Fortier) from which 409 pounds of oil may be extracted.

Silvicultural Characteristics. - The beech is best grown in high forest, and because of its dense crown and abundant litter it fertilizes the soil. . . . It is usually regenerated from seed and the tolerance of the seedlings makes complete natural regeneration all the easier. While it can be grown pure, it is advantageous to mix it with species of more rapid growth, since beech exerts a most favorable influence on their good development. On the other hand, it is necessary to guard against the tendency of the beech to again become dominant instead of remaining in the understory. - . Beech can be managed under the selection system and then the trees furnish less wood than in the high forest. It does not retain its sprouting capacity long enough to permit advantageous management as simple coppice. Under this form of treatment the stand does not remain fully stocked except on open slopes and provided it is cut very young. Of all the forest species it is almost the only one which accommodates itself to treatment as selection coppice (furete). Retained as standards in the coppiceunder-standards system, the beech has such a thick, full crown that it shades out all vegetation underneath; only short-bole trees are obtained which yield a small amount of sawlogs of mediocre quality. To sum up: The beech is a species that is especially valuable in shallow soil and where the ground has been impoverished by grazing or by destructive treatment. - • HORNBEAM

(Carpinus betulus)

Climate and Soil. - The hornbeam is a tree of the plains and valleys. In the mountains, such as the Vosges, Jura of the Central Plateau, it disappears abruptly and hardly becomes more than a bush. It is found throughout the entire part of France 
situated north of a line drawn between Grenoble and the mouth of the Gironde. It is very common in the northern and eastern departments. While it will grow on all kinds of soil, it shows a marked preference for fresh and deep ground.

Tolerance. - The hornbeam, although it becomes quite hardy, has need of a nurse tree during its youth, because of its shallow rooting and the consequent danger if the soil dries out. It demands considerable light but not too much. On dry rocky soil, it usually succumbs to exceptional drought. On the other hand, in all regards it shows remarkable resistance to spring frosts. Its root system is weak and shallow. It is composed of numerous lateral roots, but the tap root soon disappears and the root system, as a whole, rarely extends deeper than 20 inches. Despite the shallow root system suckers are rare, but it sprouts from the stump with great facility. In the forest of Champenoux thickets of this species are so abundant that it is a serious obstacle to the natural regeneration of oak. The hornbeam begins to bear seed at an early age, at 20 years or before. . . . The fruit of the hornbeam is a small nut which, on account of its lightness, is easily distributed. It only germinates the second spring after it matures.

Growth Longevity. - Its growth is always slow, being much less than that of the oak or the beech. Sprouts, on the other hand, are quite rapid in growth for the first 20 or 30 years, when it slows down quite materially. Whatever its origin, whether from seeds or sprouts, the hornbeam is always a secondary tree. It can live to 100 or 120 years and even exceed 150 years under favorable conditions, and when it is silviculturally desirable to retain it in the stand.

Wood Uses. - It furnishes firewood of the first quality, but it is not used for construction purposes. . . . Notwithstanding its hardness . . . it is useful for the manufacture of miscellaneous utensils.

Silvicultural Characteristics. - Hornbeam is only found pure in high forest because of silvicultural errors. Due to its slow growth it is always dominated by species in mixtures; as a secondary tree it is quite valuable as soil cover. Treated as coppice it produces up to quite an advanced age (50 to 60 years) very abundant sprouts which give good results. In proper situations it sprouts well, even under unfavorable conditions, and it is thus owing to its presence that certain coppice on almost sterile soil yields a considerable return. Its growth is too slow and its crown too low to enable it to form with profit a standard in coppice-under-standards. . . . It has the same value as the beech as ground cover, but, of course, does not produce the same bole in high forest.

\section{HOLM OAK}

(Quercus ilex)

Climate and Soil. - This southern species is rare on the Pacific Ocean but very common on the shores of the Mediterranean from Menton to Ceret, from the sea, as far inland as Digne, Sisteron, and Montelimart. It even extends as far north as Valina. It seems to prefer, in France at least, calcareous soils and is abundant along the Mediterranean, except in the granite areas on the Maures and Estérel. . . . It is found in the Alps and in Provence up to an altitude of 2,460 to 2,600 feet, and in the Pyrenees up to 2,000 feet.

Tolerance. - Holm oak is quite hardy and thrives on the hottest south slopes. Its evergreen foliage is quite light and it sprouts up to an advanced age.

Root System and Seeding. - It is anchored solidly in the soil and has strong lateral roots. Is an early seeder; seed years occurring every 8 to 10 years; production continues abundantly and regularly up to an advanced age.

Growth Longevity. - Its growth is very rapid during youth, but it never reaches beyond the size of a third-class tree. It lives to be 300 years and more. 
Wood Uses. - The wood of holm oak is very hard, heavy, and extremely compact. It is difficult to work and its heavy wood and small size limits its use as construction wood. It makes excellent fuel.

By-Products. - The bark yields excellent tannin; better than that of oaks that shed their leaves. The acorns, when they are fresh, have an agreeable taste and make excellent food when they are properly cooked. In several departments they are collected as an edible food.

Silvicultural Characteristics. - Since it does not reach a large size, it is only suitable for simple coppice. It is often found in mixture with aleppo pine and with this species it forms an excellent understory, since it is fire-resistant.

\section{CORK OAK ${ }^{3}$}

\section{(Quercus suber L.)}

The cork oak is an oak with persistent leaves like the holm oak. . . . Both belong to the southern part of France where the first forms high forests, the second coppice. The economic importance of cork oak is considerable in the south of France, in Corsica, and especially in Algeria. Spain and Portugal also furnish cork which competes with our own in the markets. The botanists distinguish cork oak, properly called Quercus suber, and the western cork oak, Quercus suber var. occidentalis; the former being found in the Mediterranean (Algeria, Corsica, Provence, Pyrénées-Orientales), and the second belonging to the Atlantic flora (Gascogne, where towards the north it is of especial importance, beginning with the point of Léon). From our point of view it does not appear to be necessary to make this distinction, the two forms having the same requirements, furnishing the same product - cork - and being treated the same way. Both of them avoid calcareous soils and are confined to sandy soil. The length of their tap roots makes it necessary to have deep soils if they are to develop properly. The cork oak, although an xerophytic species, without doubt requires more moisture than does the holm oak. In Algeria it is infinitely more common in the province of Constantine, where the climate is quite rainy, than in Oran where it is very dry; in France it is found at the Maures and Estérel hills, which have a sufficient altitude to produce enough rainfall, and in Gascogne where the climate is very hot but also quite humid.

Regeneration. - When the cork oak forms pure stands they are always very open and usually even incomplete. (These pure stands, while common in Algeria, are rarely met with in the Maures and Estérel and do not exist at all, naturally at least, in the Gascogne.) On the other hand, the foliage of the tree is quite light. It therefore results that everywhere in the forest the soil is sufficiently open to permit the seed to germinate and develop, since the species is light demanding first of all. When cork oak is found in mixture with another species the stand becomes denser, but, since this other species, in France at least, is almost always maritime pine, whose cover is extremely light, the situation remains about the same from the point of view of regeneration. While this species exists in every part of the forest, without regeneration fellings it has to be favored and assisted. Systematic fellings are not made in cork-oak stands, but the fellings tend to realize old cork oak whose production of cork has ceased to be remunerative.

Freeing the Young. - One cannot say that the regeneration of cork oak can be left to itself. On the contrary it is necessary to give it cultural aid. In those forests in reality where the soil is sandy and quite open, there exist thickets of evergreen shrubs in which tree heather often dominates and which is called maquis (similar to the term chaparral). Numerous species of small heather increase the density still more near the soil and make it so thick that it is not easy to penetrate. The acorns fall here and there

`Traité Pratique de Sylviculture, par A. Jolyet. Paris, J. B. Baillere et Fils, 1916. 
in this brush and the young oak, overwhelmed by such a thicket, does not receive the quantity of light which one would expect in such open stands. Seeds are of ten scattered by the birds, chiefly by the doves; in mixed forests of oak and pine often the oak seedlings are found in the neighborhood of the pine trees because the doves love to perch on the branches of the pine, which are the largest trees of the stand, and from there let fall the acorns which they have transported. Often seedlings are so suppressed by the heather that they cannot develop, remaining poor and stunted and fually often disappearing altogether. It is therefore necessary to take care to search out the oak seedlings in the midst of the brush and free them.

Cutting Back the Young Poorly Formed. - The seedling which appears to have suffered from the heather cover to such an extent that its vitality is injured should be cut level with the ground, and after this operation the heather should be cut for a distance of 1 to 2 feet around the shoot. The sprouts which develop on this little stump will have even more vigor than do seedlings. Moreover, if in a stand of cork oak which has already attained a height of $4 \frac{1}{2}$ to 6 feet, but whose growth appears slow, it is much better to cut them back in order to obtain good sturdy shoots in their place. These shoots have just about the same value as seedlings. This cutting back, it is true, has the objection of encouraging the formation of sprouts; the collection of cork oak being difficult on sprouts, it is better to choose between them when they have attained the height of about 6 feet and leave the best sprouts and cut the others.

Division of a Forest of Cork Oak into Compartments. - Work such as this enables the improvement of cork-oak stands to favor whose regeneration there is no other method applicable. To execute the freeing and cutting back of seedlings systematically the forest should be divided into some fifteen compartments so that each one can be gone over every year to free the seedlings, cut back the poor sprouts, and thin the sprouts when they are too numerous. It would be a good plan to have this work coincide in each compartment with the removal of the mature oak. The cost of this work is small in comparison with the benefits received and the owner should pay for it without doubting its advisability.

Precautions to Take against Fire. - The existence of brush is a perpetual danger of fire. . . . It should be remarked, however, that the cork is an excellent insulation and that the violence of the fire is rarely enough, in France at least, to kill the cambium of the oak when they are protected by a sufficient thickness of tissue. The oak recently peeled, however, is very susceptible to the slightest fire. . . . To avoid fires in any part of the forest becoming veritable disasters, it is therefore necessary to make sure that the trees recently peeled should not all be grouped in the same range.

In order that the cork of a tree should attain the thickness demanded by commerce (27 to 29 millimeters), the period varies according to the climate: 12 years in Algeria, and 15 to 28 years in France. Taking for granted that the period of 15 years should be the one indicated by investigation, the forest should be treated as follows:

Divide it into fifteen compartments and the first year bark all the oak in Compartment No. 1, the second year all those in Compartment No. 2, etc., and the fifteenth year all those in Compartment No. 15. In the sixteenth year the oak in Compartment No. 1 will have had 15 years of growth and reached the proper thickness. One can then proceed with new felling operations on trees of this compartment and continue indefinitely. But if, by misfortune, fire has broken out in a compartment where the bark has been removed from all the trees, every one will be destroyed and the compartment will be ruined without hope even of natural regeneration. Under such circumstances it would have been better to adopt another combination. The number of years necessary for the growth of the bark is divided by 3 . For example $15 / 3=5$; if the forest is divided then into the number of parts given in this quotient, each compartment would be 
divided into 5 parts. This being done, one-third of the oak of the first compartment is barked the first year, choosing the trees here and there over the whole extent of the compartment. The second and third years the work is continued similarly in Compartments Nos. 2 and 3. The sixteenth and seventeenth to the thirtieth years the second third of the trees is barked in Compartments Nos. 1 to 15 . The thirty-first and thirtysecond to the forty-fifth years the third third is barked in each compartment. In the forty-sixth year the bark has reached the proper thickness on the trees in Compartment No. 1 which was peeled the first time. . . . This method appears to be more conservative than peeling the trees in the entire compartment at one time. It is nearly the same idea that is expressed in the treatment of the Corsican pine when the selection system was adopted because of the fire danger in young even-aged stands which follow the use of the shelterwood compartment method of regeneration.

\section{SILVER FIR}

\section{(Abies pectinata)}

Size. - Silver fir is a tree of first-class size; it may, when from 180 to 200 years of age, reach 131 feet in height and 6.5 feet in diameter breast-high. Its longevity is very great, and some trees 800 years old have been observed in the Pyrenees.

A silver fir 207 feet high and 10 feet in diameter has been discovered in a Bohemian virgin forest (Hochstetter). In France itself . . . on the best soils, 131 feet in height is often exceeded. A silver fir in the Gérardmer State Forest is $\mathbf{1 6 4}$ feet high.

Habit. - The straight, slender bole branches regularly. . . . At an advanced age . . . the crown becomes more and more flattened; this is the period when full seed crops are produced. . . . The loss of the leader or main shoot is more serious with fir than with any other species. Often this leader cannot grow out again, particularly if the tree is a veteran.

Root System. - The tree is well rooted. There is a tap root, 3 or more feet deep, which divides into long, stout laterals. When cut flush with the ground the stump and root wood is about 16 per cent of the total volume.

Crown. - The foliage of fir is abundant and leaves may be persistent for 8 to 10 years. . . These leaves and young shoots are readily browsed by cattle and game.

Bark. - Silver fir bark . . . is in most cases a characteristic silvery gray color . . the thickness increases with age but rarely exceeds 1.18 to 1.57 inches. . . .

Natural Grafting. - Silver fir has a growing bark up to an advanced age. This allows the bole, branch, or roots to easily grow together when the parts happen to remain in contact for some time. From this numerous vegetative phenomena arise. One of the most frequent and interesting phases is when the stump (after the tree has been felled) . . continues to increase in diameter, and produces an excrescence which gradually covers the surface. . . . This growth . . . is due to the extensive adhesion of one or more roots of the tree that has been cut down with those of a neighboring unfelled fir. The latter . . . acts as a wet nurse for the stump and causes a continuation of growth.

Seeding. - Seeding is fairly regular and constant, having none of the irregularities that are so common with certain other species, such as pine, oak, and beech.

The seed is easily distinguished by its irregular, truncated shape, its shiny brownishyellow color, and its size which is larger than most other firs. It contains a great deal of turpentine which gives it a pungent, hot taste; it is covered by a brownish opaque husk, some remnants of which always remain, even when cleaned. There are 10,450 
fresh seeds, and 14,090 clean seeds to the pound, or 8,063 to the quart. It will not stand packing nor shipment and keeps only from autumn until the following spring.

Germination. - The germination of seed sown in the spring takes place in 3 to 4 weeks. After the young plant sprouts . . . it has from 4 to 8 cotyledons (generally 5). They are twice as long as and broader than ordinary cotyledons.

Seedling. - During the first 2 to 3 years all the vegetative activity concentrates in the deep-reaching tap root and in stem diameter increase. From about 3 to 4 years the seedling begins to ramify by producing annually from 1 to 2 lateral branches, first in one and then in the other direction . . . after the tenth year ramification becomes normally verticillate, and from that time vegetation is rapid if there is sufficient light.

Tolerance. - Silver fir will bear protracted shade better than any other species. Under dense cover, saplings, 3 feet high and 0.79 to 1.18 inches in diameter, are of ten found which are no less than 60 to 70 years of age and which, if given space and light, will develop vigorously . . . and become splendid trees. Early vegetative activity makes young fir liable to suffer acutely from spring frosts; they often lose their lateral shoots (the first to be developed).

Timber. - Fir timber is formed only of tracheids and medullary rays and is almost entirely devoid of resiniferous channels . . . consequently it has no pronounced odor, and the resin is well disseminated. . . .

The timber is white, though often tinted a very light reddish-brown. . . . There is no very appreciable difference, especially when dry, between the sapwood and the heartwood. The sapwood does not possess the quality of the heartwood and is more subject to rot. On the other hand, the sapwood is easily injected with preservatives, while the heartwood is very difficult to impregnate, as is the case with other similar resinous timbers, such as spruce, larch, cedar, and pine.

The annual rings are very clearly defined on account of the great difference in color and in hardness between the spring and autumn tissues. The lack of homogeneity in fir timber (formed of cylindrical zones of alternately soft and hard wood) is evident when it is being cut into firewood. It has a distinct tendency to split in a circular direction. . . . In fir timber, as in all those of non-homogeneous structure . . . breaks will occur in the direction of the less resisting tissues, which . . . correspond to the soft spring rings . . . (ring shake). . . . Its shade-enduring quality means that rings close together may be followed by wide rings of annual growth obviously a defect.

Specific Gravity. - The density of fir wood is extremely variable and seems to increase with southern latitudes, or as the trees have more space in which to develop their crowns; on the whole it is superior to that of spruce and varies from 0.381 to 0.640 .

The horizontal strength and resiliency of fir timber are considerable and have been ascertained by numerous tests. . . . It was found that fir from the Aude Department was superior to any indigenous and exotic timber except the longleaf pine (of the United States). . . . Fir timber will not last very long if exposed to moisture.

Uses. - The large size, good quality, and abundance of fir timber make it one of the commonest building materials for planks, boards, beams, laths, etc.; it is even used for masts. It splits easily and is good for basket making, shingles, and roofing.

Fuel Value. - According to G. L. Hartig the average fuel value of fir as compared with beech is as 69 is to 100 , and is inferior to spruce. It is poor fuel, burning with a bright flame but crackling a great deal and smoking badly.

It should be pointed out, however, that the branch-wood (Vosges) which is formed of very thin rings (the density is therefore higher) makes far superior cordwood than the stump or bole. 
Habitat. - Silver fir does not extend beyond the limits of Europe except to the East, where it penetrates for some distance (beyond the Sea of Marmora) into Anatolia. Its somewhat restricted area is in the shape of an irregular ellipse, whose main axis rests east and west, reaching from the western Pyrenees, in the neighborhood of the Gulf of Gascony, to beyond Constantinople, over a length of about $32^{\circ}$ of longitude; the smaller north and south axis, from Cologne to Mt. Etna, extends over $14^{\circ}$ of latitude. Ireland, England, Belgium, Holland, Northern Germany, Sweden, and Norway, and the whole of Russia are beyond the northern and eastern natural limits of this species . . . also Spain, exclusive of the Pyrenean slopes, Sardinia, southern Sicily, and Greece. There is a possibility that silver fir may be found in the Caucasus. In France, it is found only east and south of a zigzag line, which starts from Epinal, and passes by Bourg, Clermont, Aurillac, Carcassone (to reach along the Pyrenees) and down to Bayonne.

The distribution of fir within its habitat area is most irregular; eastwards it is scattered amongst beech and spruce, but, as one goes westward, it becomes more plentiful so that it reaches its maximum development about the western limits of the area and forms pure stands or is the most important species. It may be seen pure (in France) in the Pyrenees, Upper Corsières, Cévennes, the Auvergne, Forez and Loire Mountains, the Dauphine Alps, and principally the Jura and Vosges; (Germany) in the Schwarzwald (Black Forest) and the Franconian Hills.

Situation. - Silver fir (Frigoris comes et causa, as Linnæus put it) is essentially a species of the mountains... above the vine and oak but below the spruce. Coming almost into the plains at northern latitudes . . . it reaches between 1,300 and 4,250 feet altitude in the Vosges; 1,500 to 1,960 feet in the Jura; up to 4,900 feet in the Monts-Dore, 5,590 feet in Corsica, 6,390 feet on Mt. Etna group, and 6,397 feet in the French Pyrenees on northern exposures.

Soil. - It seeks deep, cool, fertile soils, avoiding compact, marshy or peaty ground. The mineral nature of the soil is of minor importance, provided its physical requirements are met. In the Jura, on limestone soil, the fir forests are equal if not superior to the best grown in the Vosges on silica or granite.

Conditions of Vegetation. - There must be a mean August temperature of at least $15^{\circ} \mathrm{C}$. $\left(59^{\circ} \mathrm{F}\right.$.), with a maximum of not over $39^{\circ} \mathrm{C}$. $\left(102.2^{\circ} \mathrm{F}\right.$.); mean January temperature not below $5^{\circ} \mathrm{C}$. $\left(41^{\circ} \mathrm{F}\right.$.), nor above $27^{\circ} \mathrm{C}$. $\left(80.6^{\circ} \mathrm{F}\right.$.), with a vegetative rest of at least 3 months, and plenty of moisture.

Silvicultural Characteristics. - The fir, like other indigenous conifers, should be treated as high forest. It forms very dense stands. A fir forest, left to itself, is always many-storied. . . . A thick cover results in retaining the fertility of the soil, as well as its freshness. . . . In addition the fir can be treated in selection stands. Moreover, in all forests which have been injured by grazing or by excessive exploitation, the natural regeneration is never lacking, even under a complete canopy. Unless local climatic conditions prevent it, the fir forms a regular high forest. . . . When it has stopped its height growth its crown becomes open, exposed, and thin, so the soil, insufficiently protected by the cover . . . runs wild. . . . This makes natural regeneration often difficult and sometimes even impossible. . . . The fir forms excellent pure stands, but it is preferable to mix it with other species, notably beech or spruce. The mixture depends on the conditions of the altitude. . . . The fir makes an excellent mixture with broadleaved trees or shrubs which protect the ground. 


\section{SCOTCH PINE}

\section{(Pinus sylvestris)}

Climate and Soil. - Scotch pine is the tree of the plains and sandy hills. In France it is found growing naturally in the Vosges up to an altitude of 3,600 feet, in the Central Plateau up to 4,900 feet, in the Alps up to 5,600 feet, and in the Pyrenees up to 6,560 feet. It ordinarily prefers southern exposures. Except in the aleppo and maritime pine areas, Scotch pine has been extensively used in reforestation; both in the plains and in the mountains its range has been widely extended by artificial means. While it will grow on compact soils, it much prefers those which are loose and porous.

Tolerance. - Scotch pine has a light, open crown, even up to advanced age; seedlings are light demanding and will not develop in very dense stands. It requires plenty of space to develop its crown. . . . While this species withstands winter and spring frosts, more than any other tree, it is liable to damage by insects and fungus, especially when growing outside its natural habitat. The tree also avoids the summits that are exposed to violent winds; nevertheless it appears to resist the rigour of winter, but after its crown exceeds the usual depth of snow it may suffer damage.

Root System and Seeding. - The root system varies according to the ground. In a light, deep soil the tap root develops and is the essential part of the root system up to 30 or 40 years. After this period the laterals increase in vigor and have a tendency to replace the tap root. On other soils the tap root stops growth quite early and the laterals soon replace it.

Scotch pine begins early to bear seed, and isolated trees produce cones with good seed as early as 15 years. Ordinarily, in stands, it does not bear until about 50 years and even after. On the whole, some cones are borne every year, but seed is abundant only every 3 to 5 years.

Growth Longevity. - When adapted to the situation, the Scotch pine is a tree of large size, which reaches 98 to 131 feet in height, but rarely exceeds 3.2 to 6.5 feet in diameter breast-high. . . . Its growth, quite slow in the North, is infinitely more rapid in the southern zone. Its longevity is very great. In the plains, where it has been introduced, it lives a much shorter life.

Wood and Its Uses. - The wood is of first quality in the northern climate and in the mountains, but becomes of secondary value, as the growth increases, in the milder zones. In the latter case the proportion of sapwood is considerable as compared with heartwood. This heartwood, while of good quality, is far less valuable for lumber . . . than the Scotch pine of Norway and Finland. As fuel it is better than the fir and spruce and is much sought after by bakers. . . . It is much used for paper pulp.

By-Products. - Scotch pine is not tapped for turpentine, but the stumps, when distilled, yield tar and charcoal of good quality.

Silvicultural Characteristics. - The Scotch pine should be treated as regular high forest. In pure stands, in suitable localities, the young stand maintains the soil up to 25 or 30 years; afterwards, when the stand becomes more open, natural regeneration becomes quite difficult under the pure veterans. This explains why, in run-down forests, one is often obliged to resort to artificial regeneration which, however, is quite easy, either by plantations or by seeding. Scotch pine grows well with beech, fir, or spruce, and, thanks to its rapid growth, remains dominant and furnishes an excellent yield. These mixtures are unfortunately much too rare in France, and, under the circumstances, it would be valuable to create mixed stands artificially. In the high mountains it is possible to treat it under the selection system. . . . On low-grade soil . . . it is indispensable to retain every kind of vegetation (as a soil cover). Whether it is pure 
or mixed, Scotch pine is easy to manage. All that is necessary is to give the best trees plenty of light in order that they may develop their crown with freedom. . . . It is a valuable species for valleys and low mountains.

\section{MARITIME PINE}

\section{(Pinus maritima)}

Root System. - Maritime pine develops a strong tap root and laterals; this makes it absolutely wind-firm and suitable for forestation on the so-called "moving sand" of the Landes. As with silver fir, sometimes roots of felled trees graft with those left standing, thus furnishing nourishment to stumps.

Seed Capacity. - Seed crops begin early (sometimes at 15 years of age), yield abundantly, and are almost continuous through middle age. . . . The seed is usually of good quality and retains its germinating power for 3 to 4 years. It sprouts 15 days after spring sowing and produces hardy plants with eight cotyledons which grow rapidly when fully exposed to the direct rays of the sun. There are 10,000 seeds to the pound and 12,080 to the quart.

Habitat. - Maritime pine occupies an area somewhat similar to that covered by aleppo pine, but is somewhat more restricted and extends farther to the west. It is found west and east from Portugal to Greece, over $30^{\circ}$ of longitude; north and south from Dalmatia and the Maures and l'Esterel (at Cannes) to Sicily and Algeria, a distance of some $10^{\circ}$ of latitude. Within this area it occupies essentially shore and insular sites, never reaching far from the sea. In Corsica, however, it ascends to 3,280 feet on hills facing the sea and to 4,265 feet in Grenada. Its maximum yield is in the west, where, in Gascony, it forms extensive pure forests. As you proceed eastward the tree becomes smaller and is more scattered. Its optimum region is the opposite of that of aleppo pine. There is but little maritime pine in Algeria, it is common in Corsica, on the shore of the Mediterranean, especially in the Maures and l'Estérel, in the Almeres hills, and along the foot of the Pyrenees. It is especially dominant from Bayonne to the Sables d'Olonne. Its habitat has been considerably increased by artificial means. It has been used successfully in central France in mixture with the Scotch pine in reclamation work in the Sologne marshes.

Soil. - Its optimum growth is on sandy soils; it does not thrive on clay. . . . Its failure to grow on clay soils is explained by the fact that it absorbs too much lime and does not get enough potash and iron. If this mineral requirement is met it will grow on almost any soil, except clay, but prefers light, deep, fresh soils; it will, however, grow on rock soils, such as granite, porphyry, and schist.

Tolerance. - While it will stand cold (even the climate of Lorraine), in central and western France, it is seriously damaged by severe winters. In 1879 to 1880 whole forests in the Sologne were frost-killed. North of Paris its growth is slow, since it demands a mean annual temperature of at least $12^{\circ} \mathrm{C}$. $\left(54^{\circ} \mathrm{F}\right.$.) with a winter average never below $6^{\circ} \mathrm{C}$. $\left(43^{\circ} \mathrm{F}\right.$.), but, given suitable climatic conditions, its growth is remarkably active; it often forms two whorls of branches a year.

Timber. - The sapwood is white; the heartwood varies from light red to more or less dark red-brown. The grain is coarse and the annual rings wide and very conspicuous. It is quite hard, heavy, and pliant, and yields more resin than any other conifer. The numerous and large resin ducts, which radiate longitudinally, appear in the heartwood a brownish-red on account of being impregnated with resin. Its specific gravity, when air dried, is from 0.524 to 0.769 . It is employed somewhat for ship building, construction purposes, railway ties, telegraph poles, piling, and mine props. It is sawed into boards, planks, staves, lath, and boxboards. When used as fuel it gives a 
bright, clear flame, but does not hold the fire. It crackles a great deal when burned and throws out innumerable sparks. Trees that have been tapped last longer in the ground than untapped timber. The tapping, however, slows up the increment. . . . Tapped trees have less sapwood than those which have not been tapped, and the wood is heavier, harder, richer in resin, more durable, and of greater fuel value. The method of tapping maritime pine is described in detail in Chapter VII.

By-Products. - It yields turpentine paste, spirits of turpentine, colophony, rosin, pitch, grease used for machine and axle lubricant, lamp black, fire lighters, basket material, etc.; the needles are sometimes woven into a sort of cotton wool. A great many mine props are exported annually.

\section{NORWAY SPRUCE}

\section{(Picea excelsa)}

The Norway spruce is a tree of very large size, with a straight, cylindrical bole that may reach up to 131 feet and more in height. Wessely asserts that in the Carpathian Mountains some trees of this species are 223 feet high and 3.5 feet in diameter at breast height. Its longevity is from 400 to 500 years.

Habit. - Spruce . . . has slender persistent branches . . . that form a bushy, pyramidal, narrow, elongated, pointed non-truncated top up to the most advanced age. . . . Of all (European) forest species, spruce probably forms the densest stands and yields the largest amount of wood. . . . Spruce can be readily pruned and makes close and impenetrable hedges.

Root System. - Its root system is shallow, without a tap root, but with somewhat slender laterals; consequently this tree cannot withstand wind pressure. The stump yields on an average of 16.5 per cent of the total volume when cut flush with the ground; 14.7 per cent for the stump itself, and 1.8 per cent only for roots. (T. Hartig.)

Seed. - Seed crops are more intermittent and irregular than with pine, and, according to the locality, are abundant only every 2 or 6 or even 8 years; normally seeding begins at 30 years of age. If cones are sometimes seen on trees which have not reached this age (chiefly in plantations), care should be taken not to gather them, for, almost always, they only yield sterile seeds. The least heat is sufficient to cause the cones to open and release the seed. . . . The abundance of seeds and the ease with which they are extracted account for the low price. When fresh, with the wings on, they run $\mathbf{5 6 , 3 6 0}$ to the pound and 62,660 to the quart. Spruce seeds retain their germinating vigor for from 3 to 4 years. If sown in the spring they will germinate after 4 or 5 weeks; they contain a non-siccative oil fat (instead of turpentine) and consequently have a pleasant taste.

The Seedling. - The seedling . . . usually has nine cotyledons; within a year it elongates its plumule into a young shoot with one to three very small laterals . . . by the end of the first year the cotyledons have already dried up and the plant is from 2 to 3 inches in height. . . . At 5 years of age it is, under good conditions, from 10 to 12 inches tall.

Tolerance. - With its shallow root system the spruce requires shelter during youth, so that the surface of the ground, where it is planted, should not become dry; but it requires light and has not the same vigor that pine has under partial cover; it dies out rapidly under complete shade. If, in mixed spruce and pine forests, the soil often reproduces to pine under spruce stands, no other reason need be given, other than the ability of the pine to endure heavy shade where spruce could not exist. . . . The tap root stops growing after the furst year and produces numerous very slim laterals that spread in all directions. . . . Spruce bark is reddish-brown in color. . . . 
Distribution. - Spruce does not extend as far south as does pine, but it reaches much farther north, and its range is far more extensive. It is irregularly distributed; its narrowest zone is southwestward. The region occupied by spruce broadens as you go through Central Europe in a northeasterly direction, from the Maritime Alps, a little below $44^{\circ}$, on the one side, to near the Iceland Sea, not far from Cape North $\left(69^{\circ}\right)$. In France, there is little spruce west of a line drawn from the Alps to the Vosges; nor in Belgium, Holland, lower North Germany (up to the Vistula River), Denmark, and the British Isles. To the south, Spain, Corsica, Sardinia, Italy (except the Lombard Alps and Venetia), Greece, and the greater part of Turkey are all outside the spruce zone. So it is with southern and eastern Russia where Norway spruce does not extend beyond Moscow and Archangel (39 longitude). . . . (The Siberian Picea, which goes farther north, is, as yet, inaccurately delimited).

Habitat. - In the north (in Norway for example), spruce comes to sea level, but, as regards its upper limit, scarcely reaches higher than 655 feet. . . . In the Tyrol (at $46^{\circ} 45^{\prime}$ north latitude), spruce grows up to 6,807 feet; in the Engadine (at $44^{\circ} 40^{\prime}$ ), up to 6,926 feet; at Mont Ventoux $\left(44^{\circ}\right)$, up to 5,643 feet. As the upper limit extends, the tree leaves the plains and valley bottoms. . . . The lower limit is about 2,000 feet in the Vosges and Jura Mountains, and 2,600 feet in the Maritime Alps. In France, therefore, spruce is distinctly a mountain species which reaches up to the Alpine region and is characteristic of a higher vegetative zone than is the silver fir. . . .

Soil. - Any moist soil, no matter what its geological and mineralogical formation, is suitable for spruce, provided it is neither too compact nor too porous. A peaty soil, while not favorable, is not absolutely objectionable. In dry and arid soil spruce can sometimes live, but it does not prosper. Under such conditions the foliage is yellow rather than a dark green color (so generally characteristic), the needles short, the cones plentiful but half grown (one-third or one-fourth the usual size).

Vegetation. - Spruce requires a mean July temperature of at least $10^{\circ} \mathrm{C} .\left(50^{\circ} \mathrm{F}.\right)$, but not more than $18^{\circ} 75^{\prime} \mathrm{C}$. $\left(66^{\circ} \mathrm{F}\right.$.); a mean January temperature not below $12^{\circ} 5^{\prime} \mathrm{C}$. $\left(54^{\circ} 5^{\prime} \mathrm{F}\right.$.) (Willkomm). It requires, above all, a moist atmosphere, frequent rainfalls, and heavy dews so that the surface soil may be kept fresh - absolutely necessary for such a shallow-rooted species.

Timber. - Spruce wood is generally whiter than pine; some spruce from northern Europe, however, is very light red (like Scotch pine) and is indicative of inferior quality. This reddish spruce timber comes from trees grown in marshy soils, chiefly of the Siberian variety. . . . The sapwood has the same value as the heartwood; as a matter of fact, it is scarcely distinguishable. . . . Spruce boards generally have smaller but more numerous knots than pine. In most cases, these branch knots are loose. . . . Density varies according to the growth conditions; for air dried timber the specific gravity varies from 0.337 to 0.597 .

Uses. - Spruce timber is lighter and weaker than pine but serves the same uses. . . It is soft, spongy, and of inferior quality at lower elevations because of too rapid growth. Near the upper limits of habitat, however, it . . . may be worth from one-quarter to one-fifth more than pine timber. To sum up: it is a first-rate building and manufacturing timber. . . . The straight, clear boles make excellent masts. . . . The regular fiber makes splitting very easy . . . it is prepared for baskets and for shingles . . . and almost exclusively (under the name of "sounding wood"), for sounding boards of musical instruments - pianos, violins, etc. . . Match factories also use considerable quantities of spruce wood. Reduced by machinery to a soft paste or pulp it supplies, besides, the raw material for high quality papers and pasteboards.

Fuel Value. - The fuel value of spruce, as compared with beech, is as 70 is to 100 . 
- . According to T. Hartig the fuel value of spruce, as compared with other species under identical vegetative conditions, is as follows:

\begin{tabular}{|c|c|c|}
\hline & $\begin{array}{c}\text { Rotation, } \\
\text { years }\end{array}$ & Fuel value \\
\hline 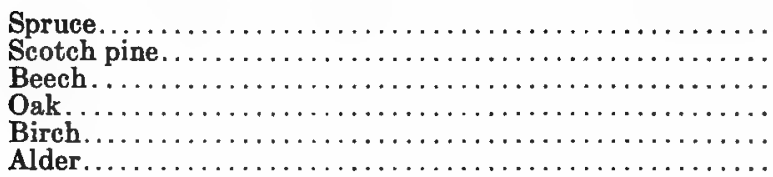 & $\begin{array}{r}120 \\
120 \\
120 \\
120 \\
60 \\
60\end{array}$ & $\begin{array}{l}5,110 \\
3,600 \\
3,500 \\
3,150 \\
2,890 \\
2,200\end{array}$ \\
\hline
\end{tabular}

By-Products. - Spruce is tapped for rosin by . . . means of long, narrow, longitudinal incisions or slashes clean through the bark; the large radiating channels in the liber allow the turpentine to ooze out abundantly. Those slashes need only be widened from time to time, through the new liber layers, in order to secure the gum product up to a very old age. This operation is quite profitable and is practiced on an extensive scale in the North; but it weakens the trees and decreases their size. In France it is all the more objectionable since in most cases . . . instead of just gashing the bark, deep cuts are needlessly made into the wood. . . . Turpentine, colophony, "Burgundian" tar, and lamp black are manufactured. The bark contains some tannin and is used (in higher Jura, for instance) for curing leather; for this purpose the bark of trees from 60 to 80 years of age is preferred. In some countries the natives pulverize the inner liber (freed from its rhytidome) and obtain a kind of flour which, either pure or mixed with barley flour, is used to make bread. The seed contains from 20 to 25 per cent of fat, non-siccative oil.

Silvicultural Characteristics. - Like the fir, the spruce should be maintained in a dense stand. . . . More than any other conifer it can survive in very dense stands which enable it to return very large yields. It is advantageously managed as high forest, but when it is very exposed or liable to wind-fall it is better to mix it with beech, fir, or larch. . . . On account of its hardiness it is a good species for natural regeneration by clear cutting. No other species is so easily transplanted. It is adaptable to most any soil.

\section{EUROPEAN LARCH \\ (Larix europea)}

Larch is a large-sized tree, with a slender, straight bole 98 to 115 feet in height and up to 27 inches in diameter. . . . In Silesia, a larch has been measured which is 178 feet high and 3.3 feet in diameter, breast-high.

Habit. - The crown is shaped like a narrow, long acute pyramid. . . . The branches are numerous, tapering, thin and generally pendant; the branches of forestgrown trees form only one-sixth the total volume (stump wood included).

Root System. - There are several main roots. These penetrate to a considerable depth at oblique angles, and from these spring a large number of rootlets; the tap root is obliterated within the first few years. The actual stump and root timber comprises about 10 per cent or 11 per cent of the total volume.

Leaves. - The first spring leaves of the larch are almost exclusively in bundles; one month later solitary leaves appear and also the young shoots. . . . The leaves form a somewhat thin crown that is light demanding.

Seeding. - When grown in temperate regions the larch may seed early; but seeds are then sterile and it is only in middle age that fructification is regular. The cones 
sometimes open in autumn, but usually during the following spring. They are persistent and, when empty, are brownish-black in color; they are readily distinguishable from the new reddish-gray cones.

Seed. - Larch seed falls in March; if the ground is then covered with erusted snow seeds in the hollows where they have been carried by the wind are easily gathered with a broom. Another way of gathering seed in March is by beating the branches with a pole and collecting them in sheets at the foot of the tree. Seeds so gathered are better in quality than those obtained by artificially opening the cones by heat. The successful extraction of seeds is difficult if the heat is at all above the normal $15^{\circ} \mathrm{C}$. to $17^{\circ} \mathrm{C}$. $\left(59^{\circ} \mathrm{F}\right.$. to $62.6^{\circ} \mathrm{F}$.). The rosin contained in the cones becomes fluid and seals the scales. Seeds purchased in the market are rarely more than 34 per cent to 45 per cent good; sometimes much less. An easy test may be made by putting the seeds into water; those that float are usually sterile. . . . When seeds are fresh they average 58,000 to the pound, 56,300 to a quart. If fresh, germination is rapid - within 3 to 4 weeks. They may be preserved for 3 to 4 years, but in the latter case the germination is proportionately slower. Seedlings may not sprout until the second or even the third year. In the lowlands a good plan is to soak the seeds in water for 10 to 15 days before spring sowing; the softening greatly facilitates and hastens germination.

Seedlings. - Seedlings have five to seven cotyledons (generally six) and immediately produce a shoot with solitary unindented leaves (leaves of silver fir and pine are indented at the edges). At first small and slender, the seedling reaches, under favorable conditions, some 4 to 5 inches in height at the end of the first year; its tap root is then from 6 to 10 inches according to the soil. The seedling grows to 2 to 3 feet in height at the end of 2 or 3 years.

Bark. - The bark is somewhat similar to that of the pines, both on account of its creviced, scaly surface and because of its structure and method of growth. There are, however, some differences.

Distribution. - Its habitat coincides with the high mountains of Central Europe forming a narrow strip westerly and southwesterly, from the Maritime and Dauphine Alps to the North and South Carpathians, about 20 degrees, from the third to the twenty-third degree of longitude. Its southern limit is beyond Nice; its northern limit does not reach in the Carpathians beyond the fiftieth degree of latitude. This species thus is confined to the high mountain areas of middle latitudes and does not extend (like the spruce or silver fir) to the northern plains. Perhaps it would not find there the sum of the temperature, that is $1,672^{\circ} \mathrm{C}$., that it requires during the vegetative period. Spruce is less exacting, being satisfied with $1,450^{\circ} \mathrm{C}$.

Larch grows naturally in France only in the Savoy, Dauphiné, and Provence Alps, where it begins at an altitude of 3,281 feet in the North, 3,940 feet in the South, and reaches up to 8,200 feet (and with cembric pine, the extreme limits of vegetation, in the Alpine pastures).

The vegetative requirements are: At least $1^{\circ} \mathrm{C} .\left(33.8^{\circ} \mathrm{F}\right.$.) and at most $8^{\circ} \mathrm{C} .\left(46.4^{\circ} \mathrm{F}\right.$.) annual temperature with a rest of at least 4 months. Larch prefers well-sheltered coves at high altitudes but does well on calcary, dolomite, schist, or sandy soils, if they are sufficiently light, fresh, and deep. Larch will not stand crowding; the forests are therefore always open, with fine grass which can be regularly cut or grazed. It even helps to restore the range where impoverished by overgrazing.

Endeavors have been made to grow larch outside its natural habitat. . . . It will often grow with remarkable vigor during youth, but shows early signs of premature decline. In these cases its timber is of poor quality (but very useful . . . for hop poles).

Timber. - Larch timber has a very conspicuous and well defined light yellow sapwood, containing six to twenty annual rings which form as a rule a very thin layer. 
This is especially so with slow-growing veterans. The heartwood is reddish-brown, veined with rings of darker colored fallwood. . . . When completely air dried wood from mountain-grown trees has a specific gravity of 0.557 to $0.686-0.456$ to 0.531 if grown at lower elevations.

Uses. - Larch is the "mountain oak." Its timber is one of the most valuable to be found in French forests; its complete lignification and its great richness in rosin make it very durable and the regularity and thinness of the annual rings, as well as their arrangement in alternate soft and hard zones, give it remarkable strength and resiliency. It does not crack; it is not attacked by insects, and is suitable for . . . mast and ship building. In Russia it is even used for ship-ribs . . . shingles, staves, and barrels made of this wood have the advantage of allowing very little evaporation; vine props and water pipes made of larch will last almost indefinitely.

Fuel Value. - As firewood larch crackles and throws sparks, even more so than other resinous woods. On the other hand it has a fairly high fuel value. Charcoal obtained from larch, as compared with beech, is of good quality and better than that from pine or spruce.

Tapping for Resin. - Turpentine is fairly abundant in larch. . . . There are various methods of tapping for resin; the following is practiced in the Valais by the Lombardians:

With an auger 1.2 inches in diameter holes are bored 2 feet from the ground. These holes are inclined upward a little . . . point to the center of the tree but do not reach it. . . . The openings are fitted with wooden or bar gutters and a trough placed underneath. A tree may yield on an average 85 to 100 grams of turpentine a year for 40 to 60 consecutive years if care is taken to plug thoroughly the holes during winter; the total quantity may reach $5.5+$ pounds (Varchland). . . . It seems that larch trees so tapped . . . are fit only for firewood.

In the southern Tyrol another method is used. In the spring a horizontal (1.1 inches in diameter) hole is bored at the base of thrifty trees right to the centre; if the tree stands on a slope the hole is bored into the upper side. The aperture is securely plugged with a wooden stopper. Turpentine gathers in the hole during the summer and in the autumn it is scooped out with a specially shaped spoon; then the plug is put back. At the end of a year another quantity of turpentine is scooped out and so on from year to year (Hugo Vohl). This method, though infinitely less productive, does not injure the trees and there is no deterioration in the quality of the timber (Wessely).

Larch turpentine is known as "Venetian Turpentine" . . . it is purer and better quality than that distilled from pine.

By-Products. - Larch leaves secrete a peculiar resinous substance, which solidifies in the shape of small whitish grains, and which is prescribed by doctors as an aperient under the name of "Briançon Manna." Young bark is used for tanning, and in some German States larch is extensively cultivated on account of the excellent quality of its bark; it is used also for brown dyeing.

Silvicultural Characteristics. - In the high mountains where the larch is found the stands must combat the rigorous climate, the rough soil, steep slopes, and grazing. Moreover, the management of any forest is always a delicate matter because the least error may possibly occasion irreparable disasters. Because of its extreme intolerance the larch does not grow well in more than one story. Rather open stands composed of trees of the same height is preferable to any other method. To continue such a condition it is necessary to favor it in every way, not only when young, but even toward the end of the rotation when regeneration is necessary. If there is sufficient light the natural seeding is possible in the grass which usually covers the ground in larch forests. At its lower limits of growth the larch can be advantageously mixed with spruce, mountain 
pine, and Scotch pine. It can even be treated under the selection system adapted to these other species. In pastures at high elevations, when retained in groups, it protects the cattle and at the same time furnishes excellent products.

\section{ALEPPO PINE \\ (Pinus halepensis)}

Soil and Climate. - This Mediterranean species is very liable to damage from winter frosts. . . . It is confined to the limestone soils of the temperate Provence. It grows satisfactorily on rocky slopes stripped of vegetation and scorched by the sun.

Tolerance. - The seedling is very hardy but intolerant. On account of its droughtresisting qualities it is a very valuable tree.

Root System and Seeding. - The tap root is the dominant root, but the laterals are well developed and, unfortunately, remain shallow. Aleppo pine bears abundant seed at an early period and it is characterized by the persistence of the open cones, which remain attached to the branch for an indefinite period.

Growth Longevity. - The aleppo pine has quite a rapid growth, nevertheless it does not exceed the size of a secondary species. Toward 20 years it forms a tree with a slender, sweeping bole; when the growth slows up at an advanced age the crown increases in size and becomes umbrella-shaped like the stone pine (Pinus pinea).

Wood and Its Uses. - The wood, of mediocre quality, is, nevertheless, used considerably by carpenters, and furnishes quite a good deal of saw timber for packing boxes and crates. As a fire wood it is valuable for certain kinds of factories.

Silvicultural Characteristics. - Aleppo pine is usually not found pure. Ordinarily it forms forests where grazing is allowed, in mixture with holm oak and other broadleaf trees. These are managed as coppice, with the aleppo pine reserved until it reaches merchantable dimensions. Under these conditions the tree regenerates very early.

\section{TREES, SHRUBS, AND PLANTS USED IN REFORESTATION IN THE MOUNTAINS}

TREES 4

Large-leaved linden (Tilia platyphyllos). Sycamore maple (Acer pseudo-platanus). Tree of heaven (Ailanthus glandulosa). Locust (Robinia pserdacacia):

Scotch laburnum (Laburnum vulgare). Sweet cherry (Cerasus avium). Mahaleb cherry (Cerasus mahaleb). Whitebeam (Sorbus aria).

Mountain ash (Sorbus aucuparia).

Common ash (Fraxinus excelsior).

Scotch elm (Ulmus montana).

Beech (Fagus sylvatica).

Chestnut (Castanea sativa).

Sessile oak (Quercus robur sessiliflora).

Holm oak (Quercus ilex).

Hop-hornbeam (Ostrya carpinfolia).

Silver birch (Betula verrucosa).

Black alder (Alnus glutinosa).

Grey alder (Alnus incana).
Green alder (Alnus viridis).

Willow (Salix).

White poplar (Populus alba).

Aspen poplar (Populus tremula).

Black poplar (Populus nigra).

Upright cypress (Cupressus sempervirens). Silver fir (Abies pectinata).

Norway spruce (Picea excelsa).

European larch (Larix europea).

Mount Atlas cedar (Cedrus atlantica).

Scotch pine (Pinus sylvestris).

Corsican pine (Pinus laricio).

Austrian pine (Pinus austriaca).

Pyrenees black pine (Pinus laricio monspeliensis). ${ }^{5}$

Aleppo pine (Pinus halepensis).

Maritime pine (Pinus pinaster).

Swiss stone pine (Pinus cembra).

- See page 68, Vol. I, Restauration et Conservation des Terrain en Montagnes.

5 Salzmann first published this form as Pinus monspeliensis. Later Dunal published it as Pinus salzmannii, probably not knowing that Salzmann had previously described and published it as $P$. monspeliensis. Salzmann's name must, of course, have precedence over Dunal's $P$. salzmannii, and this fact would prevent the use of the common name "Salzmann pine." 
Common clematis (Clematis vitalba).

"Tanners' sumac" (Coriaria myrtifolia).

Rest-harrow (Ononis fruticosa).

Kidney vetch (the species used was probably A. vulneraria, "sand clover," or "woundwort").

Smooth-fruited apricot (Prunus brigantiaca).

Sea buckthorn (Hippophe rhamnoides).

Filbert (Corylus avellana).

Common juniper (Juniperus communis).

PERENNIAL HeRbaceodg PLaNTS

Alpine poppy (Papaver alpinum).

Yellow pansy (Viola lutea).

Alpine flax (Linum alpinum).

Alpine clover (Trifolium alpinum).

Sainfoin; Holly clover (Onobrychis sativa). (Now known as O. viciafolia).

Creeping avens (Geum reptans).

Laserwort (Laserpitium gallicum).

Pyrenean valerian (Valeriana pyrenaica).

Alpine plantain (Plantago alpina).

Feather-grass (Stipa calamagrostis). ( $L$. is antedated by stipa, which is now very generally recognized.)

Perennial oats (Avena sempervirens).

Common false-oat (Arrhenatherum avenaceum).

Sheep's fescue (Fetuca ovina).

"Fenasse brun" (probably a species of heather). 


\section{APPENDIX D}

\section{STATISTICS ON PUBLIC AND PRIVATE FORESTS OVER FIVE THOUSAND ACRES IN AREA}

The following is a summary of State and communal forests over 5,000 acres in extent. It has been arranged by departments and shows for each forest the arrondissement, the area in acres, chief species, treatment, and the rotation.

\begin{tabular}{|c|c|c|c|c|c|c|}
\hline Department & Arrondissement & Name of forest & \begin{tabular}{|c|} 
Area \\
(acres)
\end{tabular} & Chief apecies * & $\begin{array}{l}\text { Treat- } \\
\text { ment }+\end{array}$ & Rotation \\
\hline Ain. & None..... & & & & & \\
\hline L'Aisne. & Soissons.. & Retz........... & 31,128 & $\begin{array}{l}\text { Oak, beech, hornbeam, } \\
\text { mis. bd. Ivs. }\end{array}$ & C. & $\begin{array}{l}150 \\
\text { Unknown }\end{array}$ \\
\hline L'Aisne. & Laon. & St.-Gobain-Coucy.. & 10,376 & $\begin{array}{l}\text { Oak, beech, hornbeam, } \\
\text { mis, bd. lvs. }\end{array}$ & $\begin{array}{l}\text { H.F. } \\
\text { C.U.S. }\end{array}$ & $\begin{array}{r}160 \\
35\end{array}$ \\
\hline L'Aisne. & Laon. & Coucy-Basse. & 5,323 & $\begin{array}{l}\text { Oak, beech, hornbeam, } \\
\text { mis. bd. lvs. }\end{array}$ & C.U.S. & 35 \\
\hline L'Aisne. & Vervins. & St. Michel.. & 7,569 & $\begin{array}{l}\text { Oak, beech, hornbeam, } \\
\text { mis. bd. Ivs. }\end{array}$ & C.U.S. & $30-33$ \\
\hline L'Allièr. & Montluçon. & Tronçais. . & 25,785 & $\begin{array}{l}\text { Oak, beech, Scotch pine, } \\
\text { mis. bd. lvs. }\end{array}$ & H.F. & 180 \\
\hline Basseg-Alpes.. & Barcelonnette. & Méolans, Revel... & 8,481 & $\begin{array}{l}\text { Fir, spruce, larch, } \\
\text { Scotch pine, } \\
\text { pine }\end{array}$ & H.F. & Unknown \\
\hline Hautes-Alpes. & Briançon. & Nevache.......... & 6,580 & $\begin{array}{c}\text { Larch, Scotch pine, } \\
\text { mountain pine }\end{array}$ & $\begin{array}{l}\text { H.F. } \\
\text { H.F. }\end{array}$ & $\begin{array}{l}180-200 \\
180\end{array}$ \\
\hline Hautes-Alpes.. & Embrun & Coillac. . & 5,723 & $\begin{array}{c}\text { Larch, Scotch pine, } \\
\text { mountain pine }\end{array}$ & H.F. & 180 \\
\hline Hautes-A lpes. . & Embr & Guillestre. & 6,521 & $\begin{array}{l}\text { Larch, Scotch pine, } \\
\text { mountain pine }\end{array}$ & $\begin{array}{l}\text { H.F. } \\
\text { H.F. }\end{array}$ & $\begin{array}{l}180 \\
180\end{array}$ \\
\hline Alpes-Maritimes. & None & $\ldots \ldots$ & $\cdots \cdots$ & 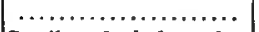 & $\ldots \ldots$ & $\ldots \ldots \ldots$ \\
\hline L'Ardèche. & Priv & Bourg-Saint-Andéol & 4,972 & Sessile oak, holm oak & C. & $20-25$ \\
\hline Ardennes. & Mézieres. & Signy-l'Abbaye.... & 7,860 & $\begin{array}{l}\text { Oak, beech, hornbeam, } \\
\text { mis. bd. lvs. }\end{array}$ & C.U.S. & $30-32-36$ \\
\hline Arder & Rocro & Revin. & 8,463 & Oak, birch, mis. bd. Ivs. & $\begin{array}{l}\text { C.U.S. } \\
\text { C.U.S. }\end{array}$ & 25 \\
\hline Arde & Seda & Sedan & 10,497 & $\begin{array}{c}\text { Oak, beech, hornbeam, } \\
\text { mis. bd. lvs. }\end{array}$ & C.U.S. & $25-30$ \\
\hline L'Ariège. & Foir. & $\begin{array}{l}\text { I'Ancien Consulat } \\
\text { de Foix }\end{array}$ & 7,631 & Beech, mis. bd. Iva. & $\begin{array}{l}\text { Conv. } \\
\text { C.U.S. }\end{array}$ & $\begin{array}{l}\text { Unknown } \\
30\end{array}$ \\
\hline L'Ariège. & Foix. & Hares............... & 7,173 & $\begin{array}{c}\text { Beech, fir, mountain } \\
\text { pine }\end{array}$ & $\begin{array}{l}\text { C.U.S. } \\
\text { H.F. }\end{array}$ & $\begin{array}{l}30 \\
120-144\end{array}$ \\
\hline L'Ari & Saint-Giro & Seix...... & 5,733 & Beech & $\begin{array}{l}\text { C.U.S. } \\
\text { H.F. } \\
\text { H.F. }\end{array}$ & $\begin{array}{c}40 \\
140 \\
\text { Unknown }\end{array}$ \\
\hline L'Ariège. & Saint-Girons... & d'Ustou.... & 6,563 & Beech, fir & $\begin{array}{l}\text { C.U.S. } \\
\text { Conv. } \\
\text { H.F. }\end{array}$ & $\begin{array}{l}20 \\
\text { Unknown } \\
144\end{array}$ \\
\hline $\begin{array}{l}\text { L'Aube. } \\
\text { L'Aube. }\end{array}$ & $\begin{array}{l}\text { Bar-sur-Aube... } \\
\text { Bar-sur-Seine... }\end{array}$ & 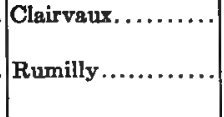 & $\begin{array}{l}10,502 \\
5,656\end{array}$ & $\begin{array}{l}\text { Oak, beech, hornbeam, } \\
\text { mis. bd. Ivs. } \\
\text { Oak, hornbeam, mis. } \\
\text { bd. Ivg. }\end{array}$ & $\begin{array}{l}\text { C.U.8. } \\
\text { Conv. } \\
\text { C.U.S } \\
\text { Conv. }\end{array}$ & $\begin{array}{l}36 \\
\text { Unknown } \\
30 \\
175\end{array}$ \\
\hline $\begin{array}{l}\text { L'Aude...... } \\
\text { L'Aveyron. }\end{array}$ & $\begin{array}{l}\text { None....... } \\
\text { Espalion... }\end{array}$ & 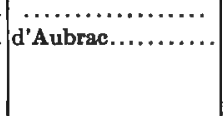 & $\ddot{5,859}$ & Beech, mis. bd. lve. & $\begin{array}{l}\text { H.F. } \\
\text { C.U.S. } \\
\text { C.U.S. }\end{array}$ & $\begin{array}{l}162 \\
30 \\
15-18\end{array}$ \\
\hline
\end{tabular}

- Mis. bd. lvs. = Mircellaneous brondleaves.

† C. = coppice; Conv. = conversion; H.F. = high lorest; C.U.S. = coppice-under-standards. 


\begin{tabular}{|c|c|c|c|c|c|c|}
\hline Department & Arrondissement & Name of forest & $\left|\begin{array}{c}\text { Area } \\
\text { (acres) }\end{array}\right|$ & Chief species * & $\begin{array}{l}\text { Treat- } \\
\text { ment } \dagger\end{array}$ & Rotation \\
\hline Belfort. & None. & & 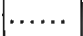 & & & \\
\hline $\begin{array}{l}\text { Bouches-du- } \\
\text { Rhône }\end{array}$ & None... & $\ldots \ldots \ldots \ldots \ldots \ldots$ & $\ldots \ldots$ & $\ldots \ldots \ldots \ldots, \ldots \ldots \ldots$ & $\ldots \ldots$ & ........ \\
\hline Calvados..... & None... & .......... & $\ldots \ldots$ & & ....... & ........ \\
\hline Cantal. & None.. & & $\ldots \ldots$ & & ....... & $\ldots \ldots \ldots$ \\
\hline Chare & Angouleme..... & Braçonne............ & 9,803 & Oak, mis. bd. Ivs. & $\begin{array}{l}\text { H.F. } \\
\text { C.U.S. }\end{array}$ & $\begin{array}{l}120 \\
25-30\end{array}$ \\
\hline $\begin{array}{l}\text { Charente- } \\
\text { Inférieure }\end{array}$ & Marennes. & Coubre............. & 9,808 & Maritime pine & H.F. & Unknown \\
\hline Cher.... & Bourges.... & Vierzon. & 13,099 & $\begin{array}{c}\text { Oak, beech, hornbeam, } \\
\text { birch, Scotch pine }\end{array}$ & $\begin{array}{l}\text { H.F. } \\
\text { C.U.S. } \\
\text { C. }\end{array}$ & $\begin{array}{r}160 \\
35 \\
12\end{array}$ \\
\hline Cher. & Boürges. & d'Allogny.......... & 5,459 & Oak, beech, hornbeam & H.F. & 180 \\
\hline Corrère & None..... & n................ & $\ldots \ldots$ & $\ldots \ldots \ldots \ldots \ldots \ldots \ldots$ & $\ldots \ldots$ & $\ldots \ldots$ \\
\hline Corse. & Ajaccio. & Bastelica.... & 8,555 & $\begin{array}{l}\text { Holm oak, mis, conif. } \\
\text { and bd. lvs. }\end{array}$ & $\begin{array}{l}\text { C.U.S. } \\
\text { H.F. }\end{array}$ & $\begin{array}{c}30 \\
\text { Unknown }\end{array}$ \\
\hline Corse. & Ajaccio & Bocognano. & 5,743 & Mis, beech & $\begin{array}{l}\text { C.U.S. } \\
\text { H.F. }\end{array}$ & $\begin{array}{l}\text { Unknown } \\
\text { Unknown }\end{array}$ \\
\hline Corse. & Ajaccio & d'Évisa. . & 5,424 & $\begin{array}{l}\text { Corsican pine, maritime } \\
\text { pine, holm oak }\end{array}$ & C. & $\begin{array}{l}\text { Unknown } \\
\text { Unknown }\end{array}$ \\
\hline Corse. & Ajaccio & Zicavo.. & 9,780 & Beech, corsican pine & $\begin{array}{l}\text { C.U.S. } \\
\text { H.F. }\end{array}$ & $\begin{array}{l}\text { Unknown } \\
\text { Unknown }\end{array}$ \\
\hline Corse. & Cort & Corte. & 11,048 & $\begin{array}{c}\text { Beech, Corsican pine, } \\
\text { Maritime pine }\end{array}$ & $\begin{array}{l}\text { H.F. } \\
\text { H.F. }\end{array}$ & $\begin{array}{r}70 \\
280\end{array}$ \\
\hline Corse & Cort & Marmano... & 5,439 & Beech, Corsican pine & H.F. & 360 \\
\hline Corse & Calvi... & na.......... & 7,445 & $\begin{array}{l}\text { Maritime pine, Corsican } \\
\text { pine, hoim oak }\end{array}$ & H.F. & $120-360$ \\
\hline Corse. & Calvi. & $\begin{array}{l}\text { d'Albertacce, Cala- } \\
\text { cuccia, } \\
\text { cioli, Casamac- } \\
\text { Lozzi (dite dursica, } \\
\text { Fango) }\end{array}$ & 15,839 & $\begin{array}{c}\text { Holm oak, maritime } \\
\text { pine, Corsican pine }\end{array}$ & H.F. & Unknown \\
\hline Cors & Calvi. & Fango ............. & 9,862 & $\begin{array}{c}\text { Holm oak, maritime } \\
\text { pine, Corsican pine }\end{array}$ & C.U.S. & 46 \\
\hline Cors & Calvi & Tartagine-Melaja... & 6,877 & $\begin{array}{c}\text { Holm oak, maritime } \\
\text { pine, Corsican pine }\end{array}$ & H.F. & $120-360$ \\
\hline Cors & Cal & Vald & 10,854 & Corsican pine, fir, beech & H.F. & 360 \\
\hline Cors & Cor & d'Alber & 5,555 & Corsican pine & H.F. & Unknown \\
\hline Corse & Corte. & soumise d'Asco..... & 6,299 & $\begin{array}{l}\text { Corsican pine, maritime } \\
\text { pine }\end{array}$ & H.F. & Unknown \\
\hline Corse. & Corte.. & Ghisoni. & 10,052 & $\begin{array}{c}\text { Holm oak, Corsican } \\
\text { pine, maritime pine }\end{array}$ & $\begin{array}{l}\text { H.F. } \\
\text { H.F. }\end{array}$ & $\begin{array}{l}160 \\
\text { Unknown }\end{array}$ \\
\hline Cors & Cort & Tova... & 6,808 & $\begin{array}{c}\text { Maritime pine, Corsican } \\
\text { pine, mis. bd. lvs. }\end{array}$ & H.F. & $\begin{array}{l}100,140 \\
300\end{array}$ \\
\hline Corse & Corte. & Vivario... & 6,012 & $\begin{array}{c}\text { Beech, Corsican pine, } \\
\text { maritime pine }\end{array}$ & H.F. & $120-300$ \\
\hline Corse. & Corte. & $\begin{array}{l}\text { Carbini, Figari, Le- } \\
\text { vie (magsif de } \\
\text { Cagna) }\end{array}$ & 5,221 & $\begin{array}{c}\text { Holm oak, maritime } \\
\text { pine, mis. bd. lvs. }\end{array}$ & $\begin{array}{l}\text { H.F. } \\
\text { C.U.S. }\end{array}$ & Unknow \\
\hline Corse & Sartene. & Zonza.. & 10,129 & $\begin{array}{l}\text { Maritime pine, Corsican } \\
\text { pine }\end{array}$ & H.F. & 80,150 \\
\hline Cor & & $\begin{array}{r}\text { Barocaggio- } \\
\text { Marghese }\end{array}$ & 6,768 & $\begin{array}{l}\text { Maritime pine, Corsican } \\
\text { pine }\end{array}$ & $\begin{array}{l}\text { H.F. } \\
\text { H.F. }\end{array}$ & $\begin{array}{r}125 \\
90\end{array}$ \\
\hline Côte-d'Or & Beaun & Citeaux... & 8,626 & $\begin{array}{l}\text { Oak, beech, hornbeam, } \\
\text { mis. bd. Ivs. }\end{array}$ & $\begin{array}{l}\text { Conv. } \\
\text { C.U.S. }\end{array}$ & $\begin{array}{l}\text { Unknown } \\
36\end{array}$ \\
\hline Côte-d'Or. & $\begin{array}{l}\text { Châtillon-sur- } \\
\text { Seine }\end{array}$ & Chatillon. & 21,550 & $\begin{array}{r}\text { Oak, beech, hornbeam, } \\
\text { mis. conif, and bd.lvs. }\end{array}$ & $\begin{array}{l}\text { Conv. } \\
\text { C.U.S. }\end{array}$ & $\begin{array}{l}140 \\
30,35\end{array}$ \\
\hline Côte-d'Or. & $\begin{array}{l}\text { Chattillon-sur- } \\
\text { Seine }\end{array}$ & Choume.. & 6,368 & $\begin{array}{l}\text { Oak, beech, hornbeam, } \\
\text { mis. bd. Ivs. }\end{array}$ & C.U.S. & 32 \\
\hline
\end{tabular}




\begin{tabular}{|c|c|c|c|c|c|c|}
\hline Department & Arrondissement & Name of forest & $\begin{array}{c}\text { Area } \\
\text { (acres) }\end{array}$ & Chief species * & $\begin{array}{l}\text { Treat- } \\
\text { ment } \dagger\end{array}$ & Rotation \\
\hline Côte-d'Or. & Dijon. & Val-Suzon. & 5,199 & $\begin{array}{l}\text { Oak, beech, hornbeam, } \\
\text { mis. bd. lvs. }\end{array}$ & C.U.S. & $\begin{array}{l}28,30 \\
32\end{array}$ \\
\hline Côte-d'Or. & Dijon. & d'Is-sur-Tille. & 7,527 & $\begin{array}{l}\text { Oak, beech, hornbeam, } \\
\text { mis. bd. lva. }\end{array}$ & C.U.S. & 30 \\
\hline Côtes-du-Nord. & None. & $\because \ldots$ & $\ldots \ldots$ & 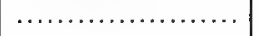 & ....... & ........ \\
\hline Creuse. . & None. & ............. & $\ldots \ldots$ & n................ & ....... & n..... \\
\hline Dordogn & Non & $\ldots \ldots \ldots \ldots \ldots \ldots$ & $\ldots \ldots$ & $\ldots \ldots \ldots \ldots \ldots \ldots \ldots$ & $\ldots \ldots$ & $\ldots \ldots \cdots$ \\
\hline Doubs. & Besar & Besançon.. & 5,078 & Oak, beech, mis. bd. lvs. & C.U.S. & 30 \\
\hline Doubs. . & Pontarlier. & Levier..... & 6,714 & Fir, spruce & H.F. & 160 \\
\hline Drôme. & Dié.. & Vercors... & 8,691 & $\begin{array}{l}\text { Beech, fir, spruce, mis. } \\
\text { bd. Ivs. }\end{array}$ & H.F & 180 \\
\hline Drôme & Dié. & Lus-ia-Cros-Haute. . & 6,576 & Beech, fir, Scotch pine & $\begin{array}{l}\text { C. } \\
\text { H.F. }\end{array}$ & $\begin{array}{r}36 \\
180\end{array}$ \\
\hline Drôme. & Dié. & Lente. & 8,135 & Beech, fir & $\begin{array}{l}\text { H.F. } \\
\text { H.F. }\end{array}$ & $\begin{array}{l}160 \\
160\end{array}$ \\
\hline L'Ev & Les $A$ & Lyons & 14,920 & Oak, beech, hornbeam & H.F. & 150,180 \\
\hline $\mathbf{L} \mathbf{E}$ & Lou & Bord. & 8,649 & $\begin{array}{l}\text { Ork, beech, hornbeam, } \\
\text { Seotch pine, mis. bd. } \\
\text { lvs. }\end{array}$ & $\begin{array}{l}\text { H.F. } \\
\text { Conv. }\end{array}$ & $\begin{array}{c}90,150 \\
\text { Unknown }\end{array}$ \\
\hline D'Eure & Dreur & Senonches & 10,554 & $\begin{array}{r}\text { Oak, beech, hornbeam, } \\
\text { mis. conif. and bd. lvs. }\end{array}$ & $\begin{array}{l}\text { H.F. } \\
\text { Conv. } \\
\text { C.U.S. }\end{array}$ & $\begin{array}{r}180 \\
150 \\
25\end{array}$ \\
\hline $\begin{array}{l}\text { Finistère....... } \\
\text { Gard......... }\end{array}$ & $\begin{array}{l}\text { None..... } \\
\text { None.... }\end{array}$ & ${ }^{\ldots} \ldots \ldots \ldots \ldots$ & $\ldots \ldots$ & $\cdots \cdots$ & …. & $\begin{array}{l}\ldots \ldots \ldots \\
\ldots \ldots \ldots\end{array}$ \\
\hline Haute-Garonne & None.. & $\ldots$ & $\ldots \ldots$ & $\cdots$ & $\ldots \ldots$ & $\ldots \ldots$ \\
\hline Gers. & None... & $\ldots$ & $\ldots \ldots$ & $\ldots$. & $\ldots \ldots$ & $\ldots \ldots \ldots$ \\
\hline Gironde. & Bordesux. & Teste... & 5,817 & Maritime pine & H.F. & 60 \\
\hline Giro & Bor & Lege, Garonne... & 10,230 & Marit & H.F. & 60 \\
\hline Girc & 8 & Lacanau.... & 12,353 & Maritim & H.F. & 70 \\
\hline Girond & Lespe & $\begin{array}{l}\text { Soulac-Flamand- } \\
\text { Hourtin }\end{array}$ & 12,835 & Maritime pine & H.F. & 66,67 \\
\hline Girond & $\mathrm{L}$ & Carcans... & 7,537 & Marit & H.F. & 60 \\
\hline L'H & Mon & Puechabon... & 5,019 & Holm & C. & 20 \\
\hline D'Ille- & Renn & Rennes...... & 7,360 & $\begin{array}{l}\text { Oak, beech, hornbeam, } \\
\text { mis. bd. lve. }\end{array}$ & Conv. & 120 \\
\hline L'In & Chat & Chateaur & 12,704 & Oak, mis. bd. lvs. & Conv. & 180 \\
\hline L'In & Issou & Bommiers & 11,021 & $\begin{array}{l}\text { Oak, hornbeam, mis. } \\
\text { bd. lve. }\end{array}$ & $\begin{array}{l}\text { C.U.S. } \\
\text { Conv. }\end{array}$ & $\begin{array}{c}25-30 \\
\text { Unknown }\end{array}$ \\
\hline D'Indre-t-Loire & Chinon & Chinon... & 12,936 & $\begin{array}{l}\text { Oak, Scotch pine, mari- } \\
\text { time pine, mis. bd. } \\
\text { lvs. }\end{array}$ & H.F. & Unknown \\
\hline D'Ind & Loche & Loches & 8,866 & $\begin{array}{l}\text { Oak, beech, hornbeam, } \\
\text { mis. bd. lve. }\end{array}$ & H.F. & 150,180 \\
\hline L'Isè & Gren & Grande-Chartreuse & 16,306 & $\begin{array}{l}\text { Beech, fir, spruce, mis. } \\
\text { bd. Ivs. }\end{array}$ & $\begin{array}{l}\text { H.F. } \\
\text { C.U.S. }\end{array}$ & $150-180$ \\
\hline L'İèr & Grenobl & Grese & 5,550 & Beech, fir, mis. bd. lvs. & $\begin{array}{l}\text { H.F. } \\
\text { C. }\end{array}$ & $\begin{array}{r}162 \\
30\end{array}$ \\
\hline L'Isèr & Grenobl & d'Au & 5,550 & Beech & H.F. & 117 \\
\hline Jura & Dole... & Chaux..... & 31,998 & $\begin{array}{l}\text { Oak, beech, hornbeam, } \\
\text { mis. bd. lvs. }\end{array}$ & $\begin{array}{l}\text { C.U.S. } \\
\text { H.F. }\end{array}$ & $\begin{array}{l}30 \\
\text { Unknown }\end{array}$ \\
\hline Jura & Poligny & Moidons.... & 7,705 & $\begin{array}{l}\text { Oak, beech, hornbeam, } \\
\text { mis. bd. lvs. }\end{array}$ & C.U.S. & $30-33$ \\
\hline Jura & Poli & Joux. & 6,534 & Fir, spruce & H.F. & Unknown \\
\hline Jura & Poligny & Poligny. & $\mathbf{7 , 3 4 4}$ & $\begin{array}{l}\text { Oak, beech, hornbeam, } \\
\text { mis. bd. lvs. }\end{array}$ & C.U.S. & 30 \\
\hline Lan & D & $\mathrm{Li}$ & 8,058 & Maritime pine & H.F. & Unknown \\
\hline Land & Da: & Vielle-Saint-Girons. & 6,395 & Mariti & H.F. & 75 \\
\hline Landes. & Marsan & Mimizan... & 8,175 & Maritime pine & H.F. & Unknown \\
\hline Landes.. & Mont-de-Marsan & Sainte-Eulalie..... & 18,123 & Maritime pine & H,F. & 70,75 \\
\hline Landes. & Mont-de-Maraan & Biscarrosse.. & 16,131 & Maritime pine & H.F. & 60 \\
\hline
\end{tabular}




\begin{tabular}{|c|c|c|c|c|c|c|}
\hline Department & Arrondissement & Name of forest & $\begin{array}{c}\text { Area } \\
\text { (acres) }\end{array}$ & Chief species & Treat- & Rotation \\
\hline Loir-et-Cher. & Blois. & Russy.. & 7,855 & $\begin{array}{l}\text { Oak, beech, hornbeam, } \\
\text { Seotch pine, mis. bd. } \\
\text { lvs. }\end{array}$ & H.F. & 150 \\
\hline Loir-et-Cher. . & Blois. & Blois. & 6,798 & Oak, mis. bd. Ivs. & H.F. & $150-180$ \\
\hline Loir-et-Cher.... & Blois. & Boulogne. & 9,884 & $\begin{array}{l}\text { Oak, beech, hornbeam, } \\
\text { Scotch pine, mis. bd. } \\
\text { lvs. }\end{array}$ & H.F. & 150 \\
\hline Loire & None...... & $\cdots$ & 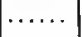 & $\ldots \ldots \ldots \ldots \ldots \ldots \ldots \ldots$ & $\ldots \ldots$ & n....... \\
\hline Haut & Non & & $\ldots \ldots$ & n.m. & $\ldots \ldots$ & $\ldots \ldots \ldots$ \\
\hline Loire-] & Paim & Gavre... & 11,033 & $\begin{array}{l}\text { Osk, beech, birch, mari- } \\
\text { time pine }\end{array}$ & H.F. & 180 \\
\hline Loiret & Orléans. & d'Orléans. & 84,618 & $\begin{array}{l}\text { Oak, hornbeam, birch, } \\
\text { Scotch pine }\end{array}$ & $\begin{array}{l}\text { C.U.S. } \\
\text { H.F. }\end{array}$ & $\begin{array}{l}30 \\
80,90\end{array}$ \\
\hline Loiret & Montargis. & Montargis. & 10,262 & $\begin{array}{l}\text { Oak, beech, horrbeam, } \\
\text { Scoteh pine }\end{array}$ & Conv. & 120 \\
\hline Lot. & Non & $\cdots \cdots$ & $\cdots \cdots$ & $\ldots \ldots \ldots$ & ….... & ….... \\
\hline Lot-et-Gar & None & $\cdots \cdots \cdots$ & $\cdots \cdots$ & $\ldots \ldots \ldots \ldots \ldots+\cdots \cdots \cdots$ & $\cdots \cdots$ & $\cdots \cdots+$ \\
\hline Lozè & None & & $\cdots \cdots$ & $\cdots \cdots \cdots \cdots \cdots \cdots$ & $\cdots \cdots$ & $\cdots \cdots \cdots$ \\
\hline Maine- & None. & $\cdots \cdots \cdot$ & $\cdots \cdots$ & 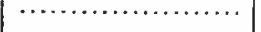 & ....... & $\cdots \cdots \cdots$ \\
\hline La Manche & None & $\cdots$ & $\cdots \cdots$ & $\cdots \ldots \ldots \ldots \cdots$ & $\ldots \ldots$ & $\cdots \ldots \cdots$ \\
\hline Marne. & Éper & Traçonne..... & 6,051 & $\begin{array}{l}\text { Oak, beech, hornbeam, } \\
\text { mis. bd. lvs. }\end{array}$ & C.U.S. & 30 \\
\hline Marr & Vitre-le-François & Trois-Fontaines. & 12,384 & $\begin{array}{l}\text { Oak, beech, hornbeam, } \\
\text { mis. bd. lvg. }\end{array}$ & C.U.S. & 36 \\
\hline Haute-Marne.. & Langres & Auberive. & 13,386 & $\begin{array}{l}\text { Oak, beech, hornbeam, } \\
\text { mis. bd. lvs. }\end{array}$ & Conv. & 150 \\
\hline Haute-Marne... & Wassy. & $\begin{array}{c}\text { Roches and Bet- } \\
\text { taincourt }\end{array}$ & 5,577 & $\begin{array}{l}\text { Oak, beech, hornbeam, } \\
\text { mis. bd. Ivs. }\end{array}$ & C.U.S. & 25 \\
\hline Haute-Marne. & Wassy & Doulaincourt....... & $\mathbf{5 , 3 5 2}$ & $\begin{array}{l}\text { Oak, beech, hornbeam, } \\
\text { mis. bd. lvs. }\end{array}$ & C.U.S. & 30 \\
\hline May & Non & & & & $\ldots \ldots$ & $\cdots$ \\
\hline $\begin{array}{l}\text { Meurthe-et- } \\
\text { Moselle }\end{array}$ & Briey & Moyeuvre. & 5,216 & $\begin{array}{l}\text { Oak, beech, hornbeam, } \\
\text { mis. bd. Ivs. }\end{array}$ & Conv. & 160 \\
\hline $\begin{array}{l}\text { Meurthe-et- } \\
\text { Moselle }\end{array}$ & Lun & Élieux. & 5,145 & $\begin{array}{c}\text { Oak, beech, fir, Scotch } \\
\text { pine, mis, bd. Ivs. }\end{array}$ & H.F. & 144 \\
\hline $\begin{array}{l}\text { Meurthe-et- } \\
\text { Moselle }\end{array}$ & Lune & Parr & 6,435 & $\begin{array}{l}\text { Oak, beech, mis. bd. } \\
\text { lvs. }\end{array}$ & C.U.S. & 40 \\
\hline $\begin{array}{l}\text { Meurthe-et- } \\
\text { Moselle }\end{array}$ & Nan & de Haye. & 15,913 & $\begin{array}{l}\text { Oak, beech, hornbeam, } \\
\text { mis. bd. lvs. }\end{array}$ & & $\begin{array}{l}120,144 \\
150\end{array}$ \\
\hline Meuse..... & Bar-le-Duc. & Beaulieu. . & 6,467 & $\begin{array}{l}\text { Oak, beech, mis. bd. } \\
\text { lvs, and conifers }\end{array}$ & Conv. & 140 \\
\hline $\begin{array}{l}\text { Meuse... } \\
\text { Morbihar }\end{array}$ & $\begin{array}{l}\text { Bar- } \\
\text { Non }\end{array}$ & $\begin{array}{r}\text { Lisle. . . } \\
\ldots \ldots\end{array}$ & $\begin{array}{c}6,674 \\
\ldots \ldots\end{array}$ & $\begin{array}{c}\text { Oak, beech, mis. bd. lvs. } \\
\ldots \ldots \ldots \ldots \ldots \ldots \ldots\end{array}$ & $\begin{array}{l}\text { C.U.S. } \\
\ldots \ldots\end{array}$ & $\begin{array}{l}40 \\
\ldots\end{array}$ \\
\hline Nièvre. & Cosne.. & Bertranges. & 8,795 & $\begin{array}{l}\text { Oak, beech, hornbeam, } \\
\text { mis. bd. Ivs. }\end{array}$ & $\begin{array}{l}\text { C.U.S. } \\
\text { Conv. }\end{array}$ & $\begin{array}{r}35 \\
180\end{array}$ \\
\hline Nievre. & Neve & de Guerigny. . & 5,644 & $\begin{array}{l}\text { Oak, beech, hornbeam, } \\
\text { mis. bd. Ivs. }\end{array}$ & $\begin{array}{l}\text { C.U.S. } \\
\text { H.F. }\end{array}$ & $\begin{array}{l}30 \\
\text { Unknown }\end{array}$ \\
\hline Nor & Avesne: & Mormal. & 22,650 & $\begin{array}{l}\text { Oak, beech, hornbeam, } \\
\text { mis. bd. lvs. }\end{array}$ & $\begin{array}{l}\text { H.F. } \\
\text { C.U.S. }\end{array}$ & $\begin{array}{r}150 \\
30\end{array}$ \\
\hline $\mathbf{N}$ & & Nier & 6,215 & Oak, beech, mis, bd. lvs. & C.U.S. & 30 \\
\hline Nor & Valencienne & St. Amand. & 8,192 & $\begin{array}{l}\text { Oak, beech, Scotch pine, } \\
\text { mis. bd. lvs. }\end{array}$ & C.U.S. & 25 \\
\hline L'Oise. & Compiègne & Laigue. . & 9,439 & $\begin{array}{l}\text { Oak, beech, hornbeam, } \\
\text { mis. bd. lvs. }\end{array}$ & Conv. & 144 \\
\hline L'Oise. & & & 35,650 & $\begin{array}{l}\text { Oak, beech, mis. bd. Ivs. } \\
\text { and conifers }\end{array}$ & $\begin{array}{l}\text { H.F. } \\
\text { C.U.S. }\end{array}$ & $\begin{array}{r}150 \\
35\end{array}$ \\
\hline L'Oise. & Senlis. & Chantilly. & 13,289 & $\begin{array}{l}\text { Oak, beech, hornbeam, } \\
\text { mis. conifers and bd. } \\
\text { lvs. }\end{array}$ & $\begin{array}{l}\text { C.V.F. } \\
\text { H.F. } \\
\text { H.F. }\end{array}$ & $\begin{array}{l}30 \\
\text { Unknown } \\
72\end{array}$ \\
\hline
\end{tabular}




\begin{tabular}{|c|c|c|c|c|c|c|}
\hline Department & Arrondissement & Name of forest & $\left|\begin{array}{c}\text { Area } \\
\text { (acres) }\end{array}\right|$ & Chief species * & $\begin{array}{l}\text { Treat- } \\
\text { ment } \dagger\end{array}$ & Rotation \\
\hline L'Oise.. & Senlis. & d'Ermenonville. & 7,337 & $\begin{array}{l}\text { Oak, hornbeam, Scotch } \\
\text { pine, mis. bd. Ive. }\end{array}$ & $\begin{array}{l}\text { H.F. } \\
\text { C.V.F. }\end{array}$ & $\begin{array}{l}80 \\
30\end{array}$ \\
\hline L'Oise. & Senlis. & d'Halatte & 10,605 & $\begin{array}{l}\text { Oak, beech, hornbeam, } \\
\text { mis. bd. Ivs. }\end{array}$ & Conv. & 125,130 \\
\hline L'Orne. & Alengon.. & Écouves. & 18.610 & $\begin{array}{l}\text { Oak, beech, mis. bd.lvs. } \\
\text { and conifers }\end{array}$ & $\begin{array}{l}\text { C.U.S. } \\
\text { H.F. }\end{array}$ & $\begin{array}{r}20-30 \\
180\end{array}$ \\
\hline L'Orne.. & Domfront. & Andaines. & 13,460 & $\begin{array}{c}\text { Oak, beech, birch, } \\
\text { Scotch pine }\end{array}$ & $\begin{array}{l}\text { C.U.S. } \\
\text { Conv. }\end{array}$ & $\begin{array}{c}30 \\
\text { Unknown }\end{array}$ \\
\hline L'Orne... & Mortagne. . & Belleme. . & 6,000 & $\begin{array}{l}\text { Oak, beech, Scotch pine, } \\
\text { mis. bd. lvs. }\end{array}$ & H.F. & 200 \\
\hline L'Orne & Mortagne. & Perche. & 5,258 & $\begin{array}{l}\text { Oak, beech, birch. } \\
\text { Scotch pine }\end{array}$ & H.F. & 150 \\
\hline $\begin{array}{l}\text { Pas-de-Calais.... } \\
\text { Puy-de-Dôme.. }\end{array}$ & $\begin{array}{l}\text { Boulogne... } \\
\text { None...... }\end{array}$ & Boulogne. & 5,019 & Oak, beech, mis. bd. Ivs. & $\begin{array}{l}\text { C.U.S. } \\
\ldots \text {... }\end{array}$ & $\begin{array}{l}30 \\
\ldots \ldots \ldots\end{array}$ \\
\hline Basses-Pyrénées. & Bayonne. . & $\begin{array}{l}\text { Saint-Peo-sur- } \\
\text { Nivelle }\end{array}$ & 5,834 & Ped. oak, pyr. oak & $\begin{array}{l}\text { P. } \\
\text { C. }\end{array}$ & $\begin{array}{l}15 \\
18\end{array}$ \\
\hline Basses-Pyrénées. & Mauléon. & Cize............ & 7,794 & Beech & H.F. & $132-144$ \\
\hline Basses- & Mauléon & Soule... & 10,091 & Beech, fir & H.F. & 135 \\
\hline Basses-Pyrénées. & Oloron. & Arette.... & 5,609 & Beech, fir, mis. bd. Ivs. & H.F. & 153 \\
\hline Busses-Pyrénées. & Oloron. & Laruns.... . . & 14,621 & Beech, fir & H.F. & 144 \\
\hline Basses-Pyrénées. & Oloron. & Sainte-Marie. . & 5,612 & Oak, beech, mis. bd. lvs. & $\begin{array}{l}\text { Conv. } \\
\text { H.F. } \\
\text { H.F. }\end{array}$ & $\begin{array}{l}120 \\
120 \\
\text { Unknown }\end{array}$ \\
\hline Hautes-Pyrénées & Argeles-Gazost. & Saint-Savin & 9,133 & Beech, fir & $\ldots \ldots$ & $\ldots \ldots \ldots$ \\
\hline Hautes-Pyrénées & Argèles-Gazost. & Saint-Pie. .. & 6,407 & Beech, fir, mis. bd. Ivs. & $\begin{array}{l}\text { C.U.S. } \\
\text { H.F. }\end{array}$ & $\begin{array}{l}20 \\
\text { Unknown }\end{array}$ \\
\hline Hautes-Pyrénées & $\begin{array}{l}\text { Bagneres-de- } \\
\text { Bigorre }\end{array}$ & Vallé de Barousse. & 5,123 & Oak, beech, fir & H.F. & Unknown \\
\hline $\begin{array}{l}\text { Pyrénés-Orien- } \\
\text { tales }\end{array}$ & Prades....... & Casteil. & 5,683 & $\begin{array}{l}\text { Fir, mountrin pine, } \\
\text { mis. bd. lve. }\end{array}$ & $\begin{array}{c}\text { Un- } \\
\text { known }\end{array}$ & Unknown \\
\hline Du Rhône..... & None & & $\cdots \cdots$ & n.wn & $\ldots \ldots$ & $\ldots \ldots \ldots$ \\
\hline Haute-Sæône... & Lure & St. Antoine. . & 6,630 & $\begin{array}{l}\text { Beech, fir, spruce, mis. } \\
\text { bd. lvg. }\end{array}$ & $\begin{array}{l}\text { H.F } \\
\text { H.F. }\end{array}$ & $\begin{array}{l}128 \\
128\end{array}$ \\
\hline Sâ̂ne-et-Loire. . & Autun & Planoise. & 6,356 & $\begin{array}{l}\text { Oak, beech, hornbeam, } \\
\text { mis. bd. Ivs. }\end{array}$ & $\begin{array}{l}\text { H.F. } \\
\text { C.V.F. }\end{array}$ & $\begin{array}{l}144-150 \\
40\end{array}$ \\
\hline Sarthe & Saint Cala & Berce. & 13,403 & $\begin{array}{l}\text { Oak, beech, Scotch pine } \\
\text { maritime pine }\end{array}$ & H.F. & $\begin{array}{l}216,150, \\
60\end{array}$ \\
\hline Sarthe. & Mamers. & Persiègne. & 12,513 & $\begin{array}{l}\text { Osk, beech, Scotch pine, } \\
\text { mis. bd. lvs. }\end{array}$ & H.F. & 180 \\
\hline Savoie.. & Albertville. & Beaufort..... & 5,172 & Fir, spruce & H.F. & $\begin{array}{l}162-180 \\
801\end{array}$ \\
\hline $\begin{array}{l}\text { Haute-Savoie... } \\
\text { Seine........... }\end{array}$ & $\begin{array}{l}\text { None............. } \\
\text { None........... }\end{array}$ & & $\begin{array}{l}\cdots \cdots \\
\cdots \cdots\end{array}$ & 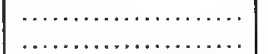 & $\begin{array}{l}\cdots \cdots \\
\ldots \cdots\end{array}$ & an. \\
\hline Seine-t-Marne. & Fontainebleau. . & Fontainobleau. . & 41,659 & $\begin{array}{l}\text { Oak, beech, hornbeam, } \\
\text { birch, Scotch pine }\end{array}$ & $\begin{array}{l}\text { H.F. } \\
\text { H.F. } \\
\text { C.V.F. }\end{array}$ & $\begin{array}{l}\text { Unknown } \\
56 \\
30\end{array}$ \\
\hline Seine-ot-Marne. & Melun.. & Villefermoy. & 5,506 & $\begin{array}{l}\text { Oak, hornbeam, mis. } \\
\text { bd. Ive. }\end{array}$ & C.V.F. & 32 \\
\hline Seine-t-Oise.. & Corbeil.. & Sénart... & 6,177 & $\begin{array}{l}\text { Oak, birch, Scotch pine, } \\
\text { mis, bd. lvs. }\end{array}$ & C.V.F. & 30 \\
\hline Seine-t-Oise. . & Rambouillet. . & Rambouillet. & 32,316 & $\begin{array}{l}\text { Oak, beech, hornbeam, } \\
\text { Scotch pine, mis. bd. } \\
\text { lvs. }\end{array}$ & $\begin{array}{l}\text { C. } \\
\text { H.F. }\end{array}$ & $\begin{array}{l}30 \\
90\end{array}$ \\
\hline Seine-et-Oise.. & Versailles. & Marley.. & 5,088 & $\begin{array}{l}\text { Oak, hornbeam, chest- } \\
\text { nut, mis. conifers and } \\
\text { bd. lvs. }\end{array}$ & $\begin{array}{l}\text { H.F. } \\
\text { C.V.F. }\end{array}$ & $\begin{array}{r}150 \\
25\end{array}$ \\
\hline Seine-et-Oise.... & Versailles. & Saint-Germain. . & 9,187 & $\begin{array}{l}\text { Oak, hornbeam, Scoteh } \\
\text { pine, Austrian pine, } \\
\text { mis, bd. lvs. }\end{array}$ & $\begin{array}{l}\text { H.F. } \\
\text { H.F. } \\
\text { C.V.F. }\end{array}$ & $\begin{array}{l}120 \\
\text { Unknown } \\
30\end{array}$ \\
\hline Seine-Inférieure. & Dieppe & d'Eawy. & 16,455 & Beoch, mia. bd. lvs. & H.F. & 150 \\
\hline
\end{tabular}




\begin{tabular}{|c|c|c|c|c|c|c|}
\hline Department & Arrondissement & Name of forest & $\begin{array}{c}\text { Area } \\
\text { (acres) }\end{array}$ & Chief species * & $\begin{array}{l}\text { Treat- } \\
\text { ment } \dagger\end{array}$ & Rotation \\
\hline eine-Inférieure. & leufchatel & Lyons..... & 11,293 & Beech, oak, hornbeam & 9. & 180 \\
\hline eine-Inférieure. & Rouen... & Roumare.. & 10,025 & $\begin{array}{l}\text { Oak, beech, hornbeam, } \\
\text { Scotch pine, mis. bd. } \\
\text { lvs. }\end{array}$ & $\begin{array}{l}\text { C.V.F. } \\
\text { C. Conv. } \\
\text { H.F. }\end{array}$ & $\begin{array}{r}30 \\
150 \\
75\end{array}$ \\
\hline Seine-Inférieure. & Rouen.. & Londe.. & 5,318 & $\begin{array}{l}\text { Oak, beech, hornbeam, } \\
\text { mis. bd. lva., Scotch } \\
\text { pine }\end{array}$ & H.F. & 120 \\
\hline Seine-Inférieure. & Rouen. & Couronne... & 8,011 & $\begin{array}{l}\text { Oak, beech, hornbeam, } \\
\text { Scotch pine, mis. bd. } \\
\text { lvs. }\end{array}$ & $\begin{array}{l}\text { H.F. } \\
\text { C. Conv. }\end{array}$ & $\begin{array}{r}90 \\
150\end{array}$ \\
\hline Seine-Inférieure. & Yvetot.. & $\begin{array}{l}\text { Trait-Saint-Wan- } \\
\text { drille }\end{array}$ & 16,697 & $\begin{array}{l}\text { Oak, beech, hornbearn, } \\
\text { Scotch pine, mis. bd. } \\
\text { lvs. }\end{array}$ & C.V.F. & $150-90$ \\
\hline Deux-S & Niort & Chize. & 11,406 & $\begin{array}{l}\text { Oak, beech, hornbeam, } \\
\text { Scotch pine, mis. bd. } \\
\text { lvs. }\end{array}$ & $\begin{array}{l}\text { C.V.F. } \\
\text { H.F. }\end{array}$ & $\begin{array}{c}30 \\
120\end{array}$ \\
\hline Somme & Abbeville. & $\begin{array}{l}\text { Crécy.... } \\
\text { Saint-Am }\end{array}$ & 10,406 & $\begin{array}{l}\text { Oak, beech, hornbeam, } \\
\text { mis. bd. Ivs. } \\
\text { Oak, beech }\end{array}$ & $\begin{array}{l}\text { C.V.F. } \\
\text { H.F. } \\
\text { C. }\end{array}$ & $\begin{array}{l}30 \\
\text { Unknown } \\
30\end{array}$ \\
\hline $\mathbf{T}$ & Gaill & Grés & 8,053 & $\begin{array}{l}\text { Oak, hornbeam, mis. } \\
\text { bd. lvs. }\end{array}$ & $\begin{array}{l}\text { H.F. } \\
\text { C. }\end{array}$ & $150-156$ \\
\hline ar & & & & & & \\
\hline II & Brig & Ria & 5,943 & White oak, holm oak & C. & 20 \\
\hline Var & Drag & Bag. & 6,630 & $\begin{array}{l}\text { Cork oak, maritime } \\
\text { pine }\end{array}$ & H.F. & Unknown \\
\hline Var & Dragui & l'Estérel. & 14,226 & $\begin{array}{l}\text { Holm oak, cork oak, } \\
\text { aleppo pine, maritime } \\
\text { pine }\end{array}$ & H.F. & Unknown \\
\hline Var & Toulo & Pierrefeu. & 6,968 & $\underset{\text { pine }}{\text { Cork oak, maritime }}$ & H.F. & Unknown \\
\hline Vauclus & Avignon. & Luberon. & 7,967 & Holm oak, aleppo pine & $\begin{array}{l}\text { C. } \\
\text { H.F. }\end{array}$ & $\begin{array}{c}25-30 \\
\text { Unknown }\end{array}$ \\
\hline Var & Car & Be & 15,568 & $\begin{array}{l}\text { White oak, beech, } \\
\text { mountain pine }\end{array}$ & $\begin{array}{l}\text { C. } \\
\text { H.F. } \\
\text { H.F. }\end{array}$ & $\begin{array}{l}25-30 \\
\text { Unknown } \\
\text { Unknown }\end{array}$ \\
\hline & Font & Vou & 5,721 & $\begin{array}{l}\text { Oak, chestnut, mis. bd. } \\
\text { lvs. }\end{array}$ & $\begin{array}{l}\text { C.V.F. } \\
\text { H.F. }\end{array}$ & $\begin{array}{l}25-30 \\
144\end{array}$ \\
\hline Venc & Sables & Barre & 6,395 & $\begin{array}{l}\text { Maritime pine, mis. bd. } \\
\text { lvs. }\end{array}$ & H.F. & Unknown \\
\hline Vien & Poitie & Moul & 8,320 & $\begin{array}{l}\text { Oak, beech, hornbeam, } \\
\text { maritime pine, mis. } \\
\text { bd. Ive. }\end{array}$ & Conv. & 180 \\
\hline & & & $\cdots$ & n.......... & & \\
\hline Vo & 10 & $d^{\prime} \mathrm{Ep}$ & 5,602 & $\begin{array}{l}\text { Oak, beech, fir, spruce, } \\
\text { Scotch pine }\end{array}$ & $\begin{array}{l}\text { H.F. } \\
\text { C.V.F. }\end{array}$ & $\begin{array}{r}144 \\
30\end{array}$ \\
\hline Vos & Épin & Rsmber-ville & 13,679 & $\begin{array}{l}\text { Oak, beech, fir, Scotch } \\
\text { pine }\end{array}$ & $\begin{array}{l}\text { H.F. } \\
\text { H.F. }\end{array}$ & $\begin{array}{l}144 \\
144\end{array}$ \\
\hline Vo & Mires & Marti & 13,064 & $\begin{array}{l}\text { Oak, beech, hornbeam, } \\
\text { Scotch pine }\end{array}$ & H.F. & 160 \\
\hline & & & 7,101 & Oak, f & H. & 150 \\
\hline Vosg & Rémi & Buss & 6,874 & Oak, fir, & $\begin{array}{l}\text { H.F. } \\
\text { H.F. }\end{array}$ & $\begin{array}{l}138 \\
\text { Unkn }\end{array}$ \\
\hline Vos & & & 11,809 & & H.F. & 150 \\
\hline & & & 5,310 & & H.F. & 150 \\
\hline Vosges & Saint-Dié. & Sénones.. & 10,332 & Fir, mis, bd. Ivs, & $\begin{array}{l}\text { H.F. } \\
\text { H.F. } \\
\text {..... }\end{array}$ & $\begin{array}{l}150 \\
\text { Unknown } \\
\ldots \ldots \ldots\end{array}$ \\
\hline
\end{tabular}




\section{IMPORTANT PRIVATE FORESTS}

As of 1912 (statistique des Forêts de France) the important private forests of France (over 5,000 acres or 2,024 hectares in area) are listed below, with statistical data for each unit:

\begin{tabular}{|c|c|c|c|c|c|c|}
\hline Department & Arrondissement & Name of forest & $\begin{array}{c}\text { Area } \\
\text { (acres) }\end{array}$ & Chief species * & $\begin{array}{l}\text { Treat- } \\
\text { ment }\end{array}$ & Rotation \\
\hline L'Ain. & Bourge. & $\begin{array}{c}\text { Couvandières, Prince, } \\
\text { Genou, Priay }\end{array}$ & 7,883 & $\begin{array}{c}\text { Oak, hornbeam, } \\
\text { mis. bd. lve. }\end{array}$ & $\begin{array}{l}\text { C. } \\
\text { c.U.S. }\end{array}$ & $12-25$ \\
\hline Aisne. & Vervins. & Nouvion............... & 9,234 & $\begin{array}{l}\text { Oak, beech, mis. } \\
\text { bd. lve. }\end{array}$ & C.U.S. & 30,35 \\
\hline Aillier. & Gannat. & $\begin{array}{l}\text { Montpensier, Charmeil, } \\
\text { Vendat }\end{array}$ & 6,311 & Beech, oak, spruce & C.U.S. & 25 \\
\hline Aillier.. & Moulins. . & Chapeau, Leyde........ & 5,585 & $\begin{array}{l}\text { Oak, beech, horn- } \\
\text { beam, mil. bd. } \\
\text { lvs. }\end{array}$ & C.U.S. & 20 \\
\hline Basses-Alpes..... . & None.......... & $\cdots$ & .... & n.............. & & \\
\hline Haute & None.. & n.w. & $\ldots$. & n.w. & $\ldots \ldots$ & $\ldots \ldots$ \\
\hline Alpes-Maritimes. & Grasse. & Particulière.......... & 6,919 & $\begin{array}{l}\text { Holm osk, aleppo } \\
\text { pine, maritime } \\
\text { pine }\end{array}$ & $\begin{array}{l}\text { H.F. } \\
\text { C. }\end{array}$ & $\begin{array}{l}10-50 \\
18-20\end{array}$ \\
\hline Ardèche. . & Largentière. & $\begin{array}{l}\text { Lagorce (ou bois } \\
\text { d'Ajude) }\end{array}$ & 5,251 & $\begin{array}{l}\text { Sessile oak, holm } \\
\text { oak }\end{array}$ & C. & $10-20$ \\
\hline Arder & Mezière & Mazarin, d'Énelle. & 7,030 & $\begin{array}{c}\text { Oak, hornbeam, } \\
\text { mis. bd. lvs. }\end{array}$ & C.U.S. & 25 \\
\hline Ardennes.. & Sedan.. & Sauton, etc. & 5,169 & $\begin{array}{l}\text { Oak, beech, horn- } \\
\text { beam, mis. co- } \\
\text { nifers and bd. } \\
\text { lvs. }\end{array}$ & $\begin{array}{l}\text { C. } \\
\text { C.U.S. } \\
\text { H.F. }\end{array}$ & $\begin{array}{c}16,17 \\
20-25 \\
\text { Unknown }\end{array}$ \\
\hline Ardennes. & Vouzièrs. & $\begin{array}{l}\text { Boux, Bas, Bourgogne, } \\
\text { Chesne, Voncq. }\end{array}$ & 17,223 & $\begin{array}{c}\text { Oak, hornbeam, } \\
\text { mis. bd. lve. }\end{array}$ & $\begin{array}{l}\text { C. } \\
\text { C.U.S. }\end{array}$ & $20-30$ \\
\hline L'Ari & Foir & Montségur.............. & 5,879 & $\begin{array}{l}\text { Beech, fir, mis. } \\
\text { bd. lvs. }\end{array}$ & $\begin{array}{l}\text { C.U.S. } \\
\text { H.F. }\end{array}$ & $\begin{array}{l}30 \\
70\end{array}$ \\
\hline L'Aub & Bar-sur-Aube... & $\begin{array}{c}\text { d'Hugemenil, Soulaines, } \\
\text { Chantecoq, Fulvy, } \\
\text { Ferrières, Pute-Bête, } \\
\text { Bouron, Arrêt, Rothi- } \\
\text { ère, Beaulieu }\end{array}$ & 6,049 & $\begin{array}{c}\text { Oak, hornbeam, } \\
\text { mis. bd. Ivs. }\end{array}$ & C.U.S. & $20-25$ \\
\hline L'Aube. & $\begin{array}{r}\text { Bar-sur-Aube } \\
\text { and Troyes }\end{array}$ & Grand-Orient, Larivour & 13,191 & $\begin{array}{c}\text { Oak, hornbeam, } \\
\text { mis. bd. lvs. }\end{array}$ & C.U.S. & $20-25$ \\
\hline L'Aub & $\begin{array}{r}\text { Bar-sur-Aube } \\
\text { and Troyes }\end{array}$ & $\begin{array}{l}\text { Rumilly, Aumont, Cha- } \\
\text { ource, Praslin, Cus- } \\
\text { sangy, Perchois, Cha- } \\
\text { moin }\end{array}$ & 13,640 & $\begin{array}{c}\text { Oak, hornbeam, } \\
\text { mis. bd. lvs. }\end{array}$ & C.U.S. & 25 \\
\hline L'Aube. & Troyes. . & d'Othe................. & 24,214 & $\mid \begin{array}{c}\text { Oak, hornbeam. } \\
\text { scotch pine, } \\
\text { mis. bd. Ivs. }\end{array}$ & $\begin{array}{l}\text { H.F. } \\
\text { C.U.S. }\end{array}$ & $\begin{array}{l}50-60 \\
20-25\end{array}$ \\
\hline $\begin{array}{l}\text { L'Aude............. } \\
\text { L'Aveyron......... }\end{array}$ & $\mid \begin{array}{l}\text { None........................... } \\
\text { None.... }\end{array}$ & 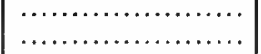 & $\begin{array}{l}\ldots \ldots \\
\ldots \cdots\end{array}$ & $\ldots \ldots \ldots \ldots \ldots \cdots$ & $\ldots+\ldots$ & \\
\hline Belfort............ & None........ & 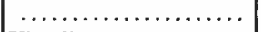 & $\cdots \cdots$ & $\ldots \ldots \ldots \ldots \ldots \ldots$ & ....... & $\ldots \ldots$ \\
\hline Bouches-du-Rhône & Air. & Vitrolles......... & 6,110 & $\begin{array}{l}\text { Aleppo pine, holm } \\
\text { oak }\end{array}$ & H.F. & $50-60$ \\
\hline Bouches-du-Rhône & Aix. & Sainte-Victoire. & 24,587 & $\begin{array}{l}\text { Sessile oak, holm } \\
\text { oak, mis. bd. } \\
\text { lvs. }\end{array}$ & C. & 20 \\
\hline Bouc & $\mathrm{Aix}$. & l'Eataque. . & 8,154 & Aleppo pine & H.F. & $50-60$ \\
\hline Bouches-du-Rhône & Aix.. & Saint-Paul. & 5,498 & $\begin{array}{l}\text { Sessile oak, holm } \\
\text { oak }\end{array}$ & C. & 20 \\
\hline
\end{tabular}

- Mis, bd. lvg = Miscollaneous broadleaves.

† C. = coppice; Conv. = conversion; H.F. = high forest; C.U.S. = coppice-under-standards, 


\begin{tabular}{|c|c|c|c|c|c|c|}
\hline Department & Arrondissement & Name of forest & $\begin{array}{c}\text { Area } \\
\text { (acres) }\end{array}$ & Chief species * & $\begin{array}{l}\text { Treat- } \\
\text { ment } \dagger\end{array}$ & Rotation \\
\hline Bouches-du-Rhône & Marseille. & l'Etoile. & 10,625 & Aleppo pine & H.F. & $50-60$ \\
\hline Bouche & Aix and Mar- & Regagnas..... & 8,525 & $\begin{array}{r}\text { Seasile oak, bolm } \\
\text { oak, aleppo pine }\end{array}$ & $\begin{array}{l}\text { H.F. } \\
\text { C. }\end{array}$ & $\begin{array}{c}50-60 \\
18\end{array}$ \\
\hline Bouches-du-Rhóne & Arles. & Alpilles............... & 5,189 & Holm oak & C. & 18 \\
\hline Bouches-du-Rhône & Marseille. & Roussargues.......... & 22,832 & $\begin{array}{c}\text { Aleppo pine, holm } \\
\text { oak }\end{array}$ & H.F. & $50-60$ \\
\hline Calvados. & Pont-l'Évêque. & $\begin{array}{c}\text { Touques (ou de St. } \\
\text { Gatien) }\end{array}$ & 8,108 & $\begin{array}{l}\text { Oak, beech, fir, } \\
\text { mis. conifers } \\
\text { and bd. lvs. }\end{array}$ & $\begin{array}{l}\text { C.U.S. } \\
\text { H.F. }\end{array}$ & $\begin{array}{c}12-30 \\
\text { Unknown }\end{array}$ \\
\hline Cants & None & & 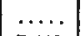 & .............. & & ....... \\
\hline Chare & Angoulềmo. & Rochechourart... & 7,413 & Oak, chestnut & C. & $15-20$ \\
\hline $\begin{array}{l}\text { Charente-Inféri- } \\
\text { eure }\end{array}$ & Rochefort. & Benon................. & 5,931 & Oak, mis. bd. lvs. & $\begin{array}{l}\text { C. } \\
\text { C.U.S. }\end{array}$ & $\begin{array}{l}10 \\
20\end{array}$ \\
\hline Cher. & Bourges. & Castelnau, Civray, etc. & 6,178 & $\begin{array}{c}\text { Oak, hornbeam, } \\
\text { mis. bd. Ivs. }\end{array}$ & C.U.S. & $18-20$ \\
\hline Cher. & Saint-Amand. . & $\begin{array}{c}\text { l'Ecoron, Primelles, Lu- } \\
\text { nerette,Thoux, Balay, } \\
\text { Effe, Chateauneuf }\end{array}$ & 22,239 & $\begin{array}{l}\text { Oak, hornbeam, } \\
\text { mis. bd. lvs. }\end{array}$ & C.U.S. & 20 \\
\hline Cher. & Saint-Amand.. & $\begin{array}{l}\text { Parnay, Meillant, Grail- } \\
\text { ly, Flouret, Poudy, } \\
\text { Chailloux, Contres }\end{array}$ & 17,792 & $\begin{array}{c}\text { Oak, hornbeam, } \\
\text { mis. bd. lvs. }\end{array}$ & C.U.S. & 20 \\
\hline Cher. & Saint-Amand. . & $\begin{array}{l}\text { d'Apremont, Boucard, } \\
\text { Les Bouranis }\end{array}$ & 17,297 & $\begin{array}{c}\text { Oak, hornbeam, } \\
\text { mis, bd. lvs. }\end{array}$ & C.U.S. & 20 \\
\hline Cher. & Saint-Amand. & d'Aubigny, Fournay... & 8,402 & $\begin{array}{c}\text { Oak, hornbeam, } \\
\text { mis. bd. lvs. }\end{array}$ & C.U.S. & $16-20$ \\
\hline Cher & Sancer: & d'Ivoy-le-Pré.. & 6,445 & $\begin{array}{l}\text { Oak, beech, mis. } \\
\text { bd. lvs. }\end{array}$ & C.U.S. & $15-20$ \\
\hline Cher. & Sancerre & $\begin{array}{l}\text { Boucard, Seng-Beaujeju, } \\
\text { Villegenon }\end{array}$ & 5,881 & Oak, mis. bd. Ivs. & C.U.S. & $15-20$ \\
\hline Corrèz & None. . & ….......... & $\cdots$ & .. & & \\
\hline Corse. & Sartene. & Toga... & 6,301 & $\begin{array}{l}\text { Holm oak, mari- } \\
\text { time pine }\end{array}$ & Unknown & Unknown \\
\hline Cóte-d'Or. & $\begin{array}{l}\text { Chatillon-sur } \\
\text { Seine }\end{array}$ & Rochefort, Thoureau... & 6,425 & $\begin{array}{l}\text { Oak, beech, horn- } \\
\text { beam, mais. bd. } \\
\text { lvs. }\end{array}$ & C.U.S. & $\begin{array}{l}20-25 \\
30\end{array}$ \\
\hline Côte d & Dijon. & $\begin{array}{l}\text { Marey, Cugsey, Mau- } \\
\text { champs, et Brun }\end{array}$ & 5,046 & $\begin{array}{l}\text { Oak, beech, horn- } \\
\text { beam, mis. bd. } \\
\text { lvs. }\end{array}$ & C.U.S. & $24-25$ \\
\hline Cóte & Semu & Lacour-d'Arcenay. & 9,390 & $\begin{array}{l}\text { Oak, beech, horn- } \\
\text { beam, mis. co- } \\
\text { nif. and bd. Ivs. }\end{array}$ & C.U.S. & $20-30$ \\
\hline Cótes-du-1 & Loudéac. & Loudéac. . & 6,585 & $\begin{array}{l}\text { Oak, beech, mis. } \\
\text { conifers and bd. } \\
\text { Ivs. }\end{array}$ & C.U.S. & 18 \\
\hline Cótes-du-Nord. & Baint-Brieuc. . & Lorge. . & 6,425 & $\begin{array}{l}\text { Oak, beech, mis. } \\
\text { bd. lvs., Scotch } \\
\text { pine }\end{array}$ & $\begin{array}{l}\text { C.U.S. } \\
\text { H.F. }\end{array}$ & $\begin{array}{c}15 \\
\text { Unknown }\end{array}$ \\
\hline & Non & & & …........... & & \\
\hline Dorgn & Bergera & Montclar... & 5,189 & $\begin{array}{l}\text { Oak, chestnut, } \\
\text { maritime pine }\end{array}$ & $\begin{array}{l}\text { C. } \\
\text { C.U.S. } \\
\text { H.F. }\end{array}$ & $\begin{array}{l}15 \\
25\end{array}$ \\
\hline Dordogne & Bergerac. & Lajudal . & 5,436 & $\begin{array}{l}\text { Oak, chestnut, } \\
\text { maritime pine }\end{array}$ & $\begin{array}{l}\text { C. and } \\
\text { C.U.S. } \\
\text { H.F. }\end{array}$ & $\begin{array}{l}15 \\
25\end{array}$ \\
\hline Dorgne. & & & 11,614 & Oak, ohestnut & $\begin{array}{l}\text { C. } \\
\text { C.U.S. }\end{array}$ & 15 \\
\hline Dorgne. & Sarlat. & Barade.. & 7,660 & $\begin{array}{c}\text { Oak, chestnut, } \\
\text { maritime pine }\end{array}$ & $\begin{array}{l}\text { C. } \\
\text { C.U.S. } \\
\text { H.F. } \\
\quad \ldots \text {.... }\end{array}$ & $\begin{array}{r}15 \\
25 \\
\ldots \ldots\end{array}$ \\
\hline
\end{tabular}




\begin{tabular}{|c|c|c|c|c|c|c|}
\hline Department & Arrondissement & Name of forest & $\mid \begin{array}{c}\text { Area } \\
\text { (acres) }\end{array}$ & Chief species" & $\begin{array}{l}\text { Treat- } \\
\text { ment }\end{array}$ & Rotation \\
\hline Drôme. . & Dié.. & Rochecourbe............ & 6,079 & Oak, beech, & $\begin{array}{l}\text { C. and } \\
\text { C.U.S. } \\
\text { H. F }\end{array}$ & $5-40$ \\
\hline Drốme. & Dié.. & Condamines............. & 6,146 & $\begin{array}{l}\text { Oak, } \\
\text { Seotch peech, } \\
\text { mis. bd. lvg. }\end{array}$ & $\begin{array}{l}\text { C. } \\
\text { C.U.S. } \\
\text { H.F. }\end{array}$ & $\begin{array}{l}10-20 \\
60 \\
60\end{array}$ \\
\hline Drômo. & Dié. & $\begin{array}{l}\text { l'Echarasson, Larps, } \\
\text { Goulets et l'Allier }\end{array}$ & 8,350 & $\begin{array}{l}\text { Oak, beech, fir, } \\
\text { spruce, mis. bd. } \\
\text { lvs. }\end{array}$ & $\begin{array}{l}\text { C. and } \\
\text { C.U.S. } \\
\text { H.F. }\end{array}$ & $\begin{array}{l}10-30 \\
80-120\end{array}$ \\
\hline Drôme. & Valence. . & Raye.. & 6,835 & $\begin{array}{ll}\text { Oak, } & \text { beech, } \\
\text { Scotch } & \text { pine, } \\
\text { mis. bd. lvs. }\end{array}$ & C. & $\begin{array}{l}15-25 \\
60-80\end{array}$ \\
\hline Drốme. & Montelimar. & Rochas, l'Ufernet..... & 5,090 & $\begin{array}{l}\text { Sessile oak, holm } \\
\text { oak, beech, mis. } \\
\text { bd. lvs. }\end{array}$ & C. & $10-25$ \\
\hline Drôme. . & Valence. & $\begin{array}{l}\text { Grands, Rigauds, Mont- } \\
\text { pourchier }\end{array}$ & 5,078 & $\begin{array}{c}\text { Sessile oak, beech, } \\
\text { mis. bd. lvs. }\end{array}$ & C. & $10-25$ \\
\hline Drôme. & Valence. & 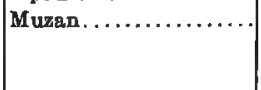 & 11,271 & $\begin{array}{l}\text { Oak, beech, } \\
\text { Scotch pine, } \\
\text { mis, bd. lvs. }\end{array}$ & $\begin{array}{l}\text { C. } \\
\text { H.F. }\end{array}$ & $\begin{array}{l}12-30 \\
60-80\end{array}$ \\
\hline L'Eure. & Bernay. & Beaumont-le-Roger.... & 5,782 & $\begin{array}{l}\text { Oak, beech, horn- } \\
\text { bearn, mis. bd. } \\
\text { lvs. }\end{array}$ & C.U.S. & $20-25$ \\
\hline L'Eure. & Evreux. & Conches. & 18,194 & $\begin{array}{l}\text { Oak, beech, horn- } \\
\text { beam, mis. coni- } \\
\text { fers and bd. lvs. }\end{array}$ & C.U.S. & $22-28$ \\
\hline L'Eure. & Evreux. & Bréteuil. & 15,528 & $\begin{array}{r}\text { Oak, beech, horn- } \\
\text { beam, mis. coni- } \\
\text { fers and bd. Ivs. }\end{array}$ & C.U.S. & $18-28$ \\
\hline L'Eure. . & Evreux... & d'Évteux.................. & 7,883 & $\begin{array}{l}\text { Oak, beech, horn- } \\
\text { beam, mis. coni- } \\
\text { fers and bd. Ivs. }\end{array}$ & C.U.S. & $18-25$ \\
\hline L'Eure & Évreux. & d'Ivry, Roseux.......... & 6,981 & $\begin{array}{l}\text { Oak, beech, horn- } \\
\text { beam, mis. coni- } \\
\text { fers and bd. Ivs. }\end{array}$ & $\begin{array}{l}\text { C. and } \\
\text { C.U.S. }\end{array}$ & $15,20-25$ \\
\hline L'Eure. & Louviers. & $\begin{array}{l}\text { d'Acquigny, Mesnil- } \\
\text { Jourdain, Canappe- } \\
\text { ville, Feuguerolles }\end{array}$ & 7,932 & $\begin{array}{r}\text { Oak, beech, horn- } \\
\text { beam, mis, coni- } \\
\text { fers and bd. lvs. }\end{array}$ & $\begin{array}{l}\text { C.U.S. } \\
\text { H.F. }\end{array}$ & $\begin{array}{c}15-18 \\
\text { Unknown }\end{array}$ \\
\hline D'Euroet-Loir. & $\begin{array}{l}\text { Nogent-le-Ro- } \\
\text { trou }\end{array}$ & Champrond ............ & 5,436 & $\begin{array}{l}\text { Oak, beech, horn- } \\
\text { beam, mis. bd. } \\
\text { lvs. }\end{array}$ & $\begin{array}{l}\text { C. and } \\
\text { C.U.S. }\end{array}$ & $15-20$ \\
\hline D'Eure-t-Loir. . & Dreux. & Dreux....... & 8,031 & $\begin{array}{l}\text { Oak, beech, horn- } \\
\text { beam, mis. coni- } \\
\text { fers, bd. lvs. }\end{array}$ & C.U.S. & $20,25-30$ \\
\hline D'Eure- & Dreux. & Ferte-Vidame, Saucelle. & 9,857 & $\begin{array}{l}\text { Oak, beech, horn- } \\
\text { beam, mis. bd. } \\
\text { lvs. }\end{array}$ & C.U.S. & $15-30$ \\
\hline Finis & Non & ………… & $\ldots .$. & $\ldots \ldots \ldots \ldots \ldots$ & $\ddot{a}$ & $\ldots \ldots$ \\
\hline Gard & Alais & Méjannes.. & 6,351 & $\begin{array}{l}\text { Holm oak, sessile } \\
\text { oak }\end{array}$ & C. & $20-25$ \\
\hline Gard. & Nimes. & Lens........ & 5,931 & $\begin{array}{l}\text { Holm o a k, } \\
\text { Kerme-bear- } \\
\text { ing oak, mis. } \\
\text { pine }\end{array}$ & C. & $16-20$ \\
\hline Haut & Non & & ..... & n.............. & $\cdots$ & $\cdots \cdots \cdots$ \\
\hline D & Non & & $\cdots \cdot$ & n........... & $\ldots \ldots \ldots$ & $\ldots \ldots \ldots$ \\
\hline & None.. & & ... & n............ & $\cdots$ & ......... \\
\hline L'Hérault. . & None.. & & $\ldots$ & n........... & & $\ldots \ldots \ldots$ \\
\hline D'Ille-t-Vilaine. & Montiort. & 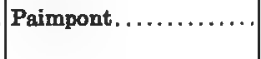 & 16,593 & $\begin{array}{l}\text { Oak, mis. conifers } \\
\text { and bd. Ivs. }\end{array}$ & $\begin{array}{l}\text { C.U.S. } \\
\text { H.F. }\end{array}$ & $\begin{array}{c}18 \\
\text { Unknown }\end{array}$ \\
\hline
\end{tabular}




\begin{tabular}{|c|c|c|c|c|c|c|}
\hline Department & Arrondissement & Name of forest & $\underset{\text { (acres) }}{\text { Area }}$ & Chief species * & $\begin{array}{l}\text { Treat } \\
\text { ment } \dagger\end{array}$ & Rotation \\
\hline D'Ille-et-Vilaine.. . & Rennes.... & Chèvre (ou de la Vallée) & 5,634 & $\begin{array}{l}\text { Oak, beech, horn- } \\
\text { beam, mis. bd. } \\
\text { lvs. }\end{array}$ & C.U.s. & $18-20$ \\
\hline D'Illo-t-Vilaine... & Vitre.......... & Guerche..... & 7,250 & $\begin{array}{l}\text { Oak, beech, chest- } \\
\text { nut, mis. bd. } \\
\text { Ivs. }\end{array}$ & C.U.S. & 18 \\
\hline L'Indre. & ChAtesuroux .. & Lauçonne... & 9,390 & Oak, mis. bd. Ivs. & C.U.s. & 20 \\
\hline L'Indre. & ChAteauroux.. & Gatines.... & 5,357 & Oak, mis. bd. lvs. & C.U.S. & 25 \\
\hline D'Indreet-Loire... & Tours. . & d'Amboise. . & 10,327 & $\begin{array}{c}\text { Oak, mis. bd. lvs. } \\
\text { and conifers }\end{array}$ & $\begin{array}{l}\text { C.U.S. } \\
\text { H.F. }\end{array}$ & $\begin{array}{l}25 \\
\text { Unknown }\end{array}$ \\
\hline D'Indre-et-Loire. & Tours.. & Château-la-Vallière. & 6,178 & Oak, mis. bd. lvs. & & 18 \\
\hline L'Isère. & Grenoble....... & Vercors........... & 10,013 & $\begin{array}{l}\text { Fir, spruce, Scoteh } \\
\text { pixe }\end{array}$ & H.F. & 60-150 \\
\hline L'Isère. . & Saint-Marcellin. & Coulmes. & 21,004 & $\begin{array}{l}\text { Oak, beech, chest- } \\
\text { nut, mis. coni- } \\
\text { fers and bd. Ivs. }\end{array}$ & $\begin{array}{l}\text { C. } \\
\text { Conv. } \\
\text { H.F. }\end{array}$ & $\begin{array}{l}15-30 \\
60-100 \\
60-100\end{array}$ \\
\hline L'Isère. & Saint-Marcellin & Chambarands.. & 14,826 & $\begin{array}{l}\text { Oak, beech, chest- } \\
\text { nut, mis. bd. } \\
\text { lvs. }\end{array}$ & $\begin{array}{l}\text { C. } \\
\text { C.S.S. }\end{array}$ & $\begin{array}{l}15 \\
15-25\end{array}$ \\
\hline L'Isère. & Vienne... & Bonnevaux.. & 7,907 & $\begin{array}{l}\text { Osk, beech, chest- } \\
\text { nut, mis. bd. } \\
\text { lve. }\end{array}$ & $\begin{array}{l}\text { C. } \\
\text { C.U.S. }\end{array}$ & $\begin{array}{l}12-18 \\
18-30\end{array}$ \\
\hline ura. & None & $\cdots$ & $\cdots \cdots$ & 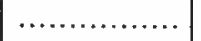 & $\cdots \ldots$ & n........ \\
\hline Landes..... & None..... & $\ldots \ldots \ldots \ldots$ & $\ldots \ldots$ & $\ldots \ldots \ldots \ldots \ldots$ & $\ldots \ldots$ & $\ldots \ldots$ \\
\hline Loir-e & Blois..... & Chambord. & 11,275 & $\begin{array}{l}\text { Oak, Scotch } \\
\text { pine, mis. bd. } \\
\text { lvs. }\end{array}$ & C.U.S. & 20 \\
\hline Loir-et-Cher. & Blois.. & Marchenoir.. & 8,669 & $\begin{array}{c}\text { Oak, hornbeam, } \\
\text { mis. bd. lvs. }\end{array}$ & $\begin{array}{l}\text { C.U.S. } \\
\text { H.F. }\end{array}$ & $\begin{array}{c}18-30 \\
130-140\end{array}$ \\
\hline Loir-et-Che & Romorantin.... & Bruadan. . & 5,140 & $\begin{array}{cr}\text { Oak, } & \text { mis. bd. } \\
\text { lvs., } & \text { Scotch } \\
\text { pine, } & \text { maritime } \\
\text { pine } & \end{array}$ & C.U.S. & $15-20$ \\
\hline Loir-et-Cher.. & Vendôme.. & $\begin{array}{c}\text { Greteval (la Gaudi- } \\
\text { nière) }\end{array}$ & 6,771 & $\begin{array}{c}\text { Oak, hornbeam, } \\
\text { mis, bd. Ivs. }\end{array}$ & $\begin{array}{l}\text { C.U.S. } \\
\text { H.F. }\end{array}$ & $\begin{array}{l}15-25 \\
120\end{array}$ \\
\hline Loire. & Roanne. & Bois Noirs.... & 5,981 & $\begin{array}{l}\text { Beech, fir, Scoteh } \\
\text { pioe }\end{array}$ & H.F. & $60-120$ \\
\hline Loire. & Roanne. & Madeleine.. & 5,683 & $\begin{array}{l}\text { Oalk, beech, mis. } \\
\text { bd. lvs. }\end{array}$ & C.U.S. & $15-25$ \\
\hline Loire. & Saint-ftienne. . & Mont Pilat. & 11,120 & Fir, Scotch pine & H.F. & $60-120$ \\
\hline $\begin{array}{l}\text { Haute-Loire } \\
\text { Loire-Inférie }\end{array}$ & $\begin{array}{l}\text { None........... } \\
\text { None......... }\end{array}$ & $\ldots \ldots \ldots \ldots \ldots \ldots \ldots$, & $\cdots \cdots$ & …… & $\cdots \cdots \cdots$ & $\cdots \cdots \cdots$ \\
\hline Loire-1niex & Orléans. & $\begin{array}{|cr|}\text { Folleville, Donjon, Qua- } \\
\text { tre-Vents, } & \text { Concyr, } \\
\text { Maison-Fort, } & \text { Bois- } \\
\text { Gibault, } & \text { Meaières, } \\
\text { Bois-le-Roi, } & \text { Bouri, } \\
\text { Villefallier, d'Aunay, } \\
\text { Gachetières, Cendray } \\
\text { Pully, Francs-Bois }\end{array}$ & 18,854 & $\begin{array}{c}\text { Oak, Scotch pine, } \\
\text { mis. conifers } \\
\text { and bd. Ivs. }\end{array}$ & $\begin{array}{l}\text { C. and } \\
\text { C.U.S. } \\
\text { H.F. }\end{array}$ & $\begin{array}{r}9-18 \\
50-60\end{array}$ \\
\hline Lot. & None. & $\ldots \ldots \ldots \ldots$ & $\cdots$ & & & \\
\hline $\begin{array}{l}\text { Lot-e } \\
\text { Lozè }\end{array}$ & $\begin{array}{l}\text { None.. } \\
\text { None.. }\end{array}$ & $\ldots \ldots \ldots$ & $\cdots$ & $\ldots \ldots$ & $\cdots \cdots \cdots$ & $\cdots \cdots$ \\
\hline Marche. & Mortain... & Lande-Pourrie.... & $\begin{array}{l}\cdots \\
5,436\end{array}$ & Oak, beech, mis. & C. & is \\
\hline Marn & $\begin{array}{l}\text { Sainte-Mene- } \\
\text { hould }\end{array}$ & & 7,858 & $\begin{array}{l}\text { Oak, beech, horn- } \\
\text { beam }\end{array}$ & C.U.S. & $20-25$ \\
\hline Marn & $\begin{array}{l}\text { Sainte-Mene- } \\
\text { hould }\end{array}$ & Princes.. & 5,683 & $\begin{array}{l}\text { Oak, hornbeam, } \\
\text { beech }\end{array}$ & C.U.S. & 25 \\
\hline
\end{tabular}




\begin{tabular}{|c|c|c|c|c|c|c|}
\hline Departmeat & Arrondissement & Name of forest & $\begin{array}{c}\text { Area } \\
\text { (acres) }\end{array}$ & Chief species * & $\begin{array}{l}\text { Treat- } \\
\text { ment } \dagger \text {, }\end{array}$ & Rotation \\
\hline Marne.... & $\begin{array}{l}\text { Sainte-Mene- } \\
\text { hould }\end{array}$ & LaGruerie.............. & 7,117 & Oak, beech & C.U.S. & $20-25$ \\
\hline Haute-Marne.. & Chaumont. & $\begin{array}{l}\text { Ecot, Champ-Briot, } \\
\text { Grendes-Bois, Flo- } \\
\text { rainville, Bosse, Jard, } \\
\text { Charmoy }\end{array}$ & 5,718 & $\begin{array}{l}\text { Oak, beech, horn- } \\
\text { beam mis. bd. } \\
\text { lvs. }\end{array}$ & $\begin{array}{l}\text { C.U.S. } \\
\text { H.F. }\end{array}$ & $\begin{array}{c}25-30 \\
\text { Unknown }\end{array}$ \\
\hline Haute-Marne.. & Chaumont. . & $\begin{array}{c}\text { Etoile, Marchat, Relau- } \\
\text { vaux, Bois Charrue }\end{array}$ & 8,436 & $\begin{array}{l}\text { Beech, oak, horn- } \\
\text { beam,mis.bd.Ivs. }\end{array}$ & C.U.S. & $20-25$ \\
\hline Haute-Marne. & Chaumont. & $\begin{array}{l}\text { d'Are et de Chateauvil- } 2 \\
\text { lian }\end{array}$ & 21,181 & $\begin{array}{l}\text { Uak, beech, horn- } \\
\text { beam, mis. bd. } \\
\text { Ivs. and conifers }\end{array}$ & C.U.S. & $25-30$ \\
\hline Haute-Marne... & Wassy... & du Val................... & 8,550 & $\begin{array}{l}\text { Oak, beech, horn- } \\
\text { beam, mis. bd. } \\
\text { lvs. }\end{array}$ & C.U.S. & $25-30$ \\
\hline Haute-Marne. & Wassy.. & $\begin{array}{l}\text { Cirey l'Aillemont, } \\
\text { Bellevaume, Com- } \\
\text { manderie, Grande- } \\
\text { Ordons }\end{array}$ & 6,220 & $\begin{array}{l}\text { Oak, beech, horn- } \\
\text { beam, mis. bd. } \\
\text { Ivs. }\end{array}$ & C.U.S. & $25-30$ \\
\hline Haute-Marne. & Wasgy... & Der.................. & 12,101 & $\begin{array}{l}\text { Oak, beech, horn- } \\
\text { beam, mis. bd. } \\
\text { lvs. }\end{array}$ & C.U.S. & 25 \\
\hline Mayenne. & Laval. & Charnie. & 13,097 & $\begin{array}{l}\text { Oak, beech, chest- } \\
\text { nut, mis. bd. } \\
\text { lvs. }\end{array}$ & C.U.S. & 18 \\
\hline Mayenne & Mayenne. & Mayenne. & 9,316 & $\begin{array}{l}\text { Oak, beech, chest- } \\
\text { nut, mis. bd. } \\
\text { lvs. and conifers }\end{array}$ & C.U.S. & 18 \\
\hline Mayenne.. & Mayenne. & Pail ................... & 6,573 & $\begin{array}{l}\text { Oak, beech, mais. } \\
\text { bd. lvs. }\end{array}$ & C.U.S. & 24 \\
\hline Meurthe-et-Moselie & Luneville. & \begin{tabular}{|} 
Ban-Lemoine, Grand- \\
Bréheux, Vala, Alem- \\
combe, Herbaville, \\
Charaille, Bagse-Scie, \\
Taurupt, Ton, Moyen- \\
Sapinot, - Fontaine \\
Voirhage, Pôt-de-Vin, \\
Folie, Gagere, Trou \\
Marmod, Grandes et \\
Petites Moises, Grand \\
Retour, Voincheres, \\
Chatillon, Zoinique, \\
Rupt-de-Laro, Petit et \\
Grand Rougimont, \\
Martimont, Guindri- \\
mont
\end{tabular} & 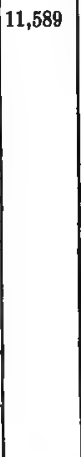 & $\begin{array}{l}\text { Oak, beech, fir, } \\
\text { mis. bd. lvs. }\end{array}$ & H.F. & $80-100$ \\
\hline Morbihan & Ploermel & Lanouée............... & 9,192 & Oak, mis. bd. lvs. & C. & 20 \\
\hline Morbihan. . & Pontivy. & Quenecan............. & 6,178 & Oak, mis. bd. lvs. & C. & 18 \\
\hline Nièvre. . & 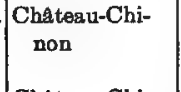 & $\begin{array}{c}\text { Remiches Fromage, } \\
\text { Breugnet, Sanclerges, } \\
\text { Jacob et Pierre }\end{array}$ & 5,931 & $\begin{array}{l}\text { Osk, beech, mis. } \\
\text { bd. lvs. }\end{array}$ & $\begin{array}{l}\text { C. } \\
\text { C.U.8. }\end{array}$ & $\stackrel{9}{18-20}$ \\
\hline Nièvre. & $\begin{array}{l}\text { Chateau-Chi- } \\
\text { non }\end{array}$ & $\begin{array}{c}\text { Vandenesse Deffend, } \\
\text { Morillon }\end{array}$ & 6,425 & $\begin{array}{l}\text { Oak, beech, horn- } \\
\text { beam, mis. bd. } \\
\text { lvs. }\end{array}$ & C.U.S. & 18 \\
\hline Nièvre. & $\begin{array}{l}\text { Chateau-Chi- } \\
\text { non }\end{array}$ & $\begin{array}{r}\text { Oursières, Montsauche, } \\
\text { Gouloux, Beauvernois }\end{array}$ & 5,060 & Beech & C. & $8-10$ \\
\hline $\mathrm{Nie}$ & $\begin{array}{l}\text { Chateau - C h i } \\
\text { non and Cla- } \\
\text { mecy }\end{array}$ & $\begin{array}{l}\text { Montreuillon, Boule, } \\
\text { Cuy, Baume, d'Oussy, } \\
\text { Montraute }\end{array}$ & 11,144 & $\begin{array}{l}\text { Oak, beech, horn- } \\
\text { beam, mis. bd. } \\
\text { lvs. }\end{array}$ & C.U.S. & $18-23$ \\
\hline
\end{tabular}




\begin{tabular}{|c|c|c|c|c|c|c|}
\hline Department & Arrondissement & Name of forest & $\mid \begin{array}{c}\text { Area } \\
\text { (acres) }\end{array}$ & Chiel species * & $\begin{array}{l}\text { Treat- } \\
\text { ment } f\end{array}$ & Rotation \\
\hline Nièvre. & $\begin{array}{l}\text { Chateau - Chi- } \\
\text { non and Cla- } \\
\text { mecy }\end{array}$ & $\begin{array}{l}\text { Blin, Dame, Crots, } \\
\text { Mouches, Vaur, } \\
\text { Mouilles-Verrées }\end{array}$ & 5,100 & $\begin{array}{l}\text { Oak, beech, horn- } \\
\text { beam, mis. bd. } \\
\text { lvs. }\end{array}$ & C.U.S. & $18-20$ \\
\hline Nièvre. & $\begin{array}{l}\text { Chateau - Chi- } \\
\text { non and Nev- } \\
\text { ers }\end{array}$ & Fours............ & 7,413 & $\begin{array}{l}\text { Oak, beech, horn- } \\
\text { beam, mis. bd. } \\
\text { lvs. }\end{array}$ & C.U.S. & 18 \\
\hline Nièvre. & $\begin{array}{l}\text { Chateau - Chi- } \\
\text { non and Nev- } \\
\text { ers }\end{array}$ & Buremont, Maxilles. . & 3,212 & $\begin{array}{l}\text { Oak, beech, horn- } \\
\text { beam, mis. bd. } \\
\text { lvs. }\end{array}$ & C.U.S. & 18 \\
\hline Niêvre. & Clamecy.... & $\begin{array}{l}\text { Bazoches, Graviers, Ra- } \\
\text { pières, Ferlées, Chev- } \\
\text { rière }\end{array}$ & 8,673 & $\begin{array}{l}\text { Oak, beech, horn- } \\
\text { beam, mis. bd. } \\
\text { lvs. }\end{array}$ & C.U.S. & 20 \\
\hline Nièvre. & Clamecy. . & $\begin{array}{l}\text { Dames, Tremblée, } \\
\text { Grand-Piece, Carré- } \\
\text { des-Courgéonneries, } \\
\text { Minerai, Parc }\end{array}$ & 3,707 & $\begin{array}{c}\text { Oak, hornbeam, } \\
\text { mis. bd. lvs. }\end{array}$ & C.U.S. & 20 \\
\hline Nièvre. & $\begin{array}{l}\text { Nevers and } \\
\text { Cosne }\end{array}$ & Tronsay, Saint-Franchy & 6,845 & $\begin{array}{l}\text { Oak, beech, horn- } \\
\text { beam, mis. bd. } \\
\text { lvs. }\end{array}$ & C.U.S. & $18-25$ \\
\hline Nièvre. & $\begin{array}{l}\text { Nevers and } \\
\text { Cosne }\end{array}$ & $\begin{array}{l}\text { Beaumont-la-Ferrière, } \\
\text { Reaux, Soueilles, } \\
\text { Tremone }\end{array}$ & 3,195 & $\begin{array}{c}\text { Oak, hornbeam, } \\
\text { mis. bd. lvs. }\end{array}$ & C.U.S. & $18-20$ \\
\hline Nièvre. & $\begin{array}{l}\text { Nevers and } \\
\text { Cosne }\end{array}$ & $\begin{array}{l}\text { Vaux, Donne, Gros- } \\
\text { Buissons, Côteauz }\end{array}$ & 3,605 & $\begin{array}{c}\text { Oak, hornbeam, } \\
\text { mis, bd. lvs. }\end{array}$ & C.U.S. & 18 \\
\hline Nièvre. & Cosne. . & $\begin{array}{l}\text { Donzy, vallée de } \\
\text { l'Epeau, Forts, Vaulu- } \\
\text { rins }\end{array}$ & 6,548 & $\begin{array}{l}\text { Oak, beech, horn- } \\
\text { beam, mis. bd. } \\
\text { lvs. }\end{array}$ & C.U.S. & $20-22-15$ \\
\hline Nièr & Nevers... & $\begin{array}{l}\text { Perray, Chabet, Mussy, } \\
\text { d'Ye, Loges-Fraillous, } \\
\text { Cordes, Fonds, Nor- } \\
\text { mand }\end{array}$ & 17,792 & $\begin{array}{l}\text { Oak, hornbeam, } \\
\text { mis. bd. lvs. }\end{array}$ & C.U.S. & $20-25$ \\
\hline Nievre & Nevers.. & $\begin{array}{c}\text { Nolay, Mauboux, Saint- } \\
\text { Bénin Folies, Lichy }\end{array}$ & 8,649 & $\begin{array}{l}\text { Oak, beech, horn- } \\
\text { beam, mis. bd. } \\
\text { Ivs. }\end{array}$ & C.U.S. & 18 \\
\hline L'Orn & Alengon. & $\begin{array}{l}\text { Ballu, Goult, Montgom- } \\
\text { meries }\end{array}$ & 5,510 & $\begin{array}{l}\text { Oak, beech, Scotch } \\
\text { pine }\end{array}$ & C.U.S. & $15-20$ \\
\hline L'Or & Arge: & Silli-on Gouffern. ...... & 8,248 & $\begin{array}{l}\text { Oak, beech, mis. } \\
\text { bd. lvg. and } \\
\text { conifers }\end{array}$ & C.U.S. & $15-20$ \\
\hline L'Or & $\begin{array}{l}\text { Argentan and } \\
\text { Mortagne }\end{array}$ & Saint-Evroult. . . & 7,447 & $\begin{array}{l}\text { Oak, beech, fir, } \\
\text { Scotch pine, } \\
\text { mis. bd. lve. }\end{array}$ & $\begin{array}{l}\text { C. } \\
\text { C.U.S. } \\
\text { H.F. }\end{array}$ & $\begin{array}{l}8-12 \\
16-25 \\
55\end{array}$ \\
\hline OOrne & Mórtagne... & de Longny ............. & 5,622 & $\begin{array}{l}\text { Oak, beech, mis. } \\
\text { bd. lvs. }\end{array}$ & C.U.S. & $15-20$ \\
\hline uy- & Rion & Ran & 6,425 & Oak, mis. bd. Ivs. & C.U.S. & 15 and 20 \\
\hline & Thie & $\begin{array}{l}\text { Bois Noirs (ou de Mon- } \\
\text { toncel) }\end{array}$ & 6,771 & $\mid \begin{array}{l}\text { Oak, beech, fir, } \\
\text { Scotch pine }\end{array}$ & $\begin{array}{l}\text { H.F. } \\
\text { C. }\end{array}$ & $\begin{array}{c}80-120 \\
\text { Unknown }\end{array}$ \\
\hline Pyrénées (Houtes-) & $\begin{array}{l}\text { Bagneres-de- } \\
\text { Bigorre }\end{array}$ & Baronnies..... & 5,896 & Oak, beoch, fir & $\begin{array}{l}\text { C. } \\
\text { H.F. }\end{array}$ & $\begin{array}{l}10-40 \\
50-150\end{array}$ \\
\hline Pyrénées (Hautes-) & $\begin{array}{l}\text { Bagneres-de- } \\
\text { Bigorre }\end{array}$ & Noston & 6,410 & Beech, fir & $\begin{array}{l}\text { C. } \\
\text { H.F. }\end{array}$ & $\begin{array}{l}10-40 \\
50-150\end{array}$ \\
\hline Sab́neot-Loi & $\begin{array}{l}\text { Chalon-sur- } \\
\text { Saóne }\end{array}$ & Chagny, Lessart. & 11,713 & $\begin{array}{c}\text { Oak, hornbeam, } \\
\text { mis. bd. lvs. }\end{array}$ & C.U.S. & $16-22$ \\
\hline Saóne- & $\begin{array}{l}\text { Chalon-aur- } \\
\text { Sab́ne }\end{array}$ & Rombois & 8,649 & $\begin{array}{l}\text { Oak, hornbeam, } \\
\text { mis. bd. lvs. }\end{array}$ & C.U.S. & $15-20$ \\
\hline & $\begin{array}{l}\text { Mamers and } \\
\text { Mans }\end{array}$ & Le Sille. . & 5,313 & $\begin{array}{l}\text { Oak, mis. bd. Ivs. } \\
\text { and conifers }\end{array}$ & C.U.S. & $16-18$ \\
\hline Savoi & Chambery. & $\begin{array}{l}\text { Montagne d'Hauterens, } \\
\text { Joigny }\end{array}$ & 6,672 & $\begin{array}{l}\text { Oak, beech, mis. } \\
\text { bd. Ivs. }\end{array}$ & C. & $10-20$ \\
\hline
\end{tabular}




\begin{tabular}{|c|c|c|c|c|c|c|}
\hline Department & Arrondissement & Name of forest & $\left|\begin{array}{c}\text { Ares } \\
\text { (acres) }\end{array}\right|$ & Chief species * & $\begin{array}{l}\text { Treat- } \\
\text { ment } \dagger\end{array}$ & Rotation \\
\hline Seine-t-Marne. & $\begin{array}{l}\text { Coulommiers, } \\
\text { Méaux, and } \\
\text { Melun }\end{array}$ & $\begin{array}{l}\text { Grange, Lochelles Beau- } \\
\text { rose, d'Attilly, d'Ar- } \\
\text { mainvilliers, d'Her- } \\
\text { mieres, Motte, Fqu- } \\
\text { vins, Crécy, Croissy, } \\
\text { Guette }\end{array}$ & 28,417 & $\begin{array}{c}\text { Oak, hornbeam, } \\
\text { mis. bd. Ivs. }\end{array}$ & C.U.S. & $18-25$ \\
\hline Seine-et-Marne. & Fontainebleau & Commanderie, Bourron & 9,360 & $\begin{array}{c}\text { Oak, Scotch pine, } \\
\text { mis. bd. Ivs. }\end{array}$ & $\begin{array}{l}\text { C. } \\
\text { C.U.S. }\end{array}$ & $15-20$ \\
\hline Seine-t-Marne. & $\begin{array}{l}\text { Fontainebleau } \\
\text { and Melun }\end{array}$ & $\begin{array}{l}\text { Charme, Sucrement } \\
\text { Croir-Saint-Jerome, } \\
\text { Fourche, Bois-Rond }\end{array}$ & 9,143 & $\begin{array}{c}\text { Oak, Scotch pine, } \\
\text { mis. bd. Ivs. }\end{array}$ & $\begin{array}{l}\text { C.U.S. } \\
\text { H.F. }\end{array}$ & $\begin{array}{l}15-20 \\
20-40\end{array}$ \\
\hline Seine-et-Marne. & $\begin{array}{c}\text { Fontainebleau } \\
\text { and Melun }\end{array}$ & $\begin{array}{l}\text { Valence, Saint-Martin, } \\
\text { Fresnay, Graville, } \\
\text { l'Argentèrie, Garenne, } \\
\text { Champigny }\end{array}$ & 11,367 & $\begin{array}{l}\text { Oak, hornbeam, } \\
\text { mis. bd. lvs. }\end{array}$ & C.U.S. & $20-25$ \\
\hline Seine-ot-Oise. & Corbeil... & $\begin{array}{l}\text { Mont-Griffon, Grange, } \\
\text { Camaldules, Pare, } \\
\text { Gros-Bois, Nôtre- } \\
\text { Dame, Pontillaut }\end{array}$ & 6,425 & $\begin{array}{l}\text { Oak, hornbeam, } \\
\text { mis. bd. lvs. }\end{array}$ & C.U.S. & $16-25$ \\
\hline Seine-t-Oise. & Pontoise. & Montmorency.......... & 5,436 & $\begin{array}{l}\text { Oak, chestnut, } \\
\text { mis. bd. lvs. }\end{array}$ & $\begin{array}{l}\text { C. } \\
\text { C.U.S. } \\
\text { H.F. }\end{array}$ & $\begin{array}{l}12 \\
15 \\
\text { Unknown }\end{array}$ \\
\hline Seine Inférieure. & $\begin{array}{r}\text { Dieppe and } \\
\text { Neufchatel }\end{array}$ & d'Eu. & 22,711 & $\begin{array}{l}\text { Oak, beech, horn- } \\
\text { - beam, mis, bd. } \\
\text { lvs. }\end{array}$ & $\begin{array}{l}\text { C.U.S. } \\
\text { Conv. } \\
\text { H.F. }\end{array}$ & $\begin{array}{r}30 \\
120 \\
120\end{array}$ \\
\hline Var. & $\begin{array}{l}\text { Brignoles } \\
\text { guignan } \\
\text { lon }\end{array}$ & $\begin{array}{l}\text { Nine private forests of } \\
\text { little value }\end{array}$ & $\begin{array}{c}\text { Total } \\
\text { ing } \\
499,151\end{array}$ & $\begin{array}{|cr|}\text { Cork oak, holm } \\
\text { oak, sessile oak, } \\
\text { white } & \text { oak } \\
\text { (chene } & \text { blane), } \\
\text { aleppo } & \text { pine, } \\
\text { maritime } & \text { pine, } \\
\text { chestnut } & \end{array}$ & $\begin{array}{l}\text { C. } \\
\text { C.U.S. } \\
\text { H.F. }\end{array}$ & $\begin{array}{l}15-20 \\
18 \\
40-60\end{array}$ \\
\hline L'Yonne. & Auxerre.. & $\begin{array}{l}\text { Pomard, Chateau, Char- } \\
\text { bonnais, Grand-Val- } \\
\text { lée, d'Arnus }\end{array}$ & 6,299 & $\begin{array}{l}\text { Oak, beech, mis. } \\
\text { bd. lvs. }\end{array}$ & C.U.S. & 20-25 \\
\hline L'Yonne & $\begin{array}{l}\text { Auxerre and } \\
\text { Joigny }\end{array}$ & $\begin{array}{l}\text { Merry, Vaux, Bois-Bon- } \\
\text { tin }\end{array}$ & 6,054 & $\begin{array}{l}\text { Oak, beech, mis. } \\
\text { bd. lvs. }\end{array}$ & C.U.S. & $17-25$ \\
\hline L'Yonne & Avallon... & $\begin{array}{l}\text { Souche-Noire, Vaux- } \\
\text { lanes, Garenne, Fon- } \\
\text { teaux, Poruches }\end{array}$ & 10,554 & $\begin{array}{l}\text { Oak, beech, horn- } \\
\text { beam, mis. bd. } \\
\text { lvs. }\end{array}$ & C.U.S. & $20-25$ \\
\hline L'Yo & Joigny & Saint-Fargeau..... & 6,919 & Oak, mis. bd. Ivs. & C.U.S. & 17 and 25 \\
\hline & Joigny & & 16,714 & $\begin{array}{l}\text { Oak, beech, mia. } \\
\text { bd, lvs. }\end{array}$ & C.U.S. & $20-25$ \\
\hline L'Yonne. & Tonnerre. & $\begin{array}{l}\text { Maulnes, Villon, Bour- } \\
\text { cière, Commissey }\end{array}$ & 9,266 & $\begin{array}{l}\text { Oak, beech, horn- } \\
\text { beam, mis. bd. } \\
\text { lvs. }\end{array}$ & C.U.S. & 20-25 \\
\hline
\end{tabular}




\section{APPENDIX E \\ TYPICAL REFORESTATION AREAS IN THE MOUNTAINS}

Alps Region (Department of Haute-Savoie, Arc Supérieur Forestation Area.) - The valley of the Arc (which corresponds to the ancient province of Maurienne) has a length of 79 miles from the Girard Pass to the Royal Bridge. It divides into two parts: the High Maurienne from the source of the Arc to St. Jean de Maurienne, and from the Lower Maurienne to the St. Jean at Isère. The average slope is 2.7 per cent . . . the higher part of the valley of the Arc extends to Modane on the Italian frontier, from the summit of Oin, 11,529 feet, to Thabon, 10,517 feet. . . . The Arc is fed by the waters of vast and numerous glaciers which occupy an area of more than 9,884 acres. Important secondary valleys bring to it the waters of other glacial groups. These are, on the left, the valleys of Avarole and of Ribon, and, on the right, the valley of Doron de Termignon.

Geological Conditions. - The high Maurienne is almost entirely included in the Briançonnais and Preniont zones. The axis of the zone of Briançonnais is formed by carboniferous soil which extends from Modane to Saint-Michel. . . . The glacial deposits and drifts are of common occurrence on the slopes and help feed the torrents with material.

Climate. - The climate of the Arc Valley is very much like that of the Haute-Alpes. It is the continental climate rendered severe by the enclosure of the valleys and by the high altitudes. The rainfall, however, is less frequent and less abundant than in the rest of the department. . . . During the winter of 1903-1904 the average snowfall recorded was from 3.6 feet at St. Jean de Maurienne, 2,195 feet altitude, to a maximum of 12.6 feet at St. Jean d'Arves, 4,908 feet altitude. The number of days of rainfall and the amount of rainfall diminishes as you proceed from the Isère toward Modane which has quite a dry climate. This dry climate is due to the absence of mists and fogs. In the autumn fog rarely passes Chamberg. Moreover, the intensity of the light is more considerable in the Maurienne than in the rest of Savoie.

Production. - Vineyards extend to an altitude of about 3,280 feet in the western part of the region. . . From Modane to Belleval the dominant crop is almost exclusively rye. At Modane rye fields are found between 3,280 to 4,590 feet and at Bramnas they reach 4,920 to 5,250 feet. . . . In the valley of the Averole certain fields extend up to 6,560 feet. . . . The high pasturage is grazed by sheep. . . . The forests under State control in the Haute-Maurienne have an area of 27,230 acres. The larch, the cembric pine, and the spruce occupy the best soils, the mountain pine and Scotch pine being found on the gypsums and the hot slopes. The fir, the beech, and the elm are in mixture with the other species on the better soils.

Administrative Situation, Area, Population. - The basin of the Arc Superieur includes 26 communes of the District of St. Jean de Maurienne and a portion of the communes of Albiez-le-Jeune and Saint-Jean. The total area is 308,216 acres, some of the communes being the biggest in the department. The population includes 23,980 inhabitants.

State of Soil Erosion. - Little or no grass, arid, steep slopes, burned by the sun, cut by ravines and torrents - such is the aspect of the Haute-Maurienne entirely on the right side of the Arc. The erosion, once started in the mountains, increases from day to day and includes bordering surface soil in good condition. This erosion is due to the nature of the ground, to the steepness of the slopes, and to the small area of the forest cover (10 per cent of the basin area), to the excessive grazing and to too abundant irrigation. Because of this situation avalanches slide without hinderance and continue 
to work deforestation, removing little villages, farms, herds, and too often menace life itself. In four winters avalanches have destroyed 700,000 board feet of timber, cut sixty-seven roads and trails of all kinds, destroyed fourteen houses, killed seventy sheep, and injured sixty-seven people, of whom eight died. Dangerous torrents, such as Envers, St. Martin, and St. Julien have eroded the mountains, covered the cultivated fields with débris and overturned houses. . . . The Arc Supérieur area was established by the law of July 26, 1892, and includes 7,801 acres, of which 6,422 acres belong to the State.

Work. - The work of restoration is about finished in nine of the thirteen working groups. The torrent of Envers . ... rises in the mountains of Petie-Mont-Denis $(10,269$ feet). After leaving the schists of this higher basin it flows into a deep gorge hedged in by gypsum. The ravines have been corrected, embankments have stopped the avalanches from destroying the forestation, and drainage canals (by drying the soil) have been effective in holding the snow and assuring the stability of the slopes. Cembric pine has been sown at an altitude of 6,560 to 8,200 feet and spruce, larch, and mountain pine planted between 5,900 to 7,200 feet. The torrent of Saint-Antoine, communes of Villarodin-Bourget and Modane, flows from the little glacier of Bellefenier $(10,140$ feet). Its upper basin is a vast funnel with very steep slopes formed of schists. . . . The torrent passes through a steep gorge of eroded gypsum and, cut by a bank of compact limestone, its floods are very dangerous. The correction has been effected by means of dams or drainage canals and avalanche walls. Moreover, at an altitude between 5,900 and 7,550 feet, cembric pine has been sown and there have been plantations of spruce, larch, and mountain pine. In the working group of Orelle and of Thyl, the Pousset runs through sand and carboniferous schist. The deforestation of its basin, the very steep slopes of its bed, the erosion and soaking of the soil, make its floods frequent and violent between an altitude of 4,920 and 7,870 feet; here an area of 395 acres has been reforested with spruce, larch, and mountain pine. When the young forest is sufficiently developed the various branches of the torrent will be improved and it will be possible to gradually take up the other work of necessary correction. In the working groups of Beaumé, Saint-Michel, Saint Martin la Porte, the Grollaz (see page 168) is bounded entirely by schists and carboniferous sand. The correction work took place from 1880 to 1892 and from 1895 to 1905 , and the forestation has extended over most of the basin. A complete stand of 124 acres of mountain pine, spruce, and larch has modified the aspect of the mountain. Lower down in the gorge, Scotch pine and alder are growing well. During the past few years the pine in favorable localities has grown more than 2.3 feet per year. The forest already established finishes the final working plan. The torrent of St. Martin in the commune of the same name runs from the little pass of Encombres. Two branches eroded in the gypsum have been corrected by means of dams and drainage canals. The left slope of the torrent (for the most part carboniferous in character) is an entire area of moving earth of about 3,700 acres. It is hoped to stop this important slide by drainage work which so far has given excellent results. Between 3,280 and 4,260 feet of altitude very complete forestation has been finished. The Scotch pine looks well but the instability of the soil makes the results as yet uncertain. The material eroded by the torrent is sluiced to the river in a masonry canal. This important work has not as yet been finished and is not maintained by the Waters and Forests administration. The Rieu-Sec torrent, communes of St. Martin and St. Julien, flows from the rock of Beaume to the south extremity of the Encombres, through compact limestones and from the badly eroded black schists. The characteristic of this torrent is the very steep slopes of its basin. . . The dams of enormous blocks of stone constructed from 1897 to 1900 constitute the absolute correction of the torrent and have suppressed the lava floods (of stone, mud, water, etc.), which might have formed in its basin. 
The forestation of the two slopes and part of the cone have very much improved matters, but, with such a topography, it is certain that it will always produce dangerous and sudden floods. The Daret, commune of St. Julien, flows from north to south to a point southwest of the Rieu-Sec. On the left it is joined by three ravines which originate in the Croix des Têtes. Its basin is formed by gypsums, limestone, and schists. As in the case of the Rieu-Sec, the dams have been constructed of blocks of stone each about 1 cubic yard in volume. Several drainage canals and forestation of spruce, larch, and mountain pine complete the control work started by the dams. The St. Julien torrent (see page 156), communes of St. Julien and Mont Denis, is a vast and complex torrent. Its basin comprises some 4,940 acres and is cut by ravines eroded in the schists, glacial muds, and marls. All this kind of soil is easily eroded. The floods and lava flows of St. Julien have been very numerous and have caused tremendous damage. The diversion canal, cut in the rock, has stopped a vast landslide which threatened the village of Mont Denis. Dams below and above the source of the damage have fixed the bed of the torrent and its waters are now conducted to the Arc by a drainage canal. Forestation of Scotch pine, oak, and ash has been completed in the slide area and plantations of poplar, willow, and alder have been made in the gorge. It appears that considerable damage has been reduced to the minimum. The torrent of Rieu-Bel, communes of Albiez-le-Jeune and Villergondran, rises in the commune of Albiez-leJeune at an altitude of 5,085 feet. It runs north for a length of more than 2 miles. Its circular upper basin is cut by little ravines which reunite in one big torrent below 3,600 feet altitude. The soil comes from the disintegration of schists, usually saturated with water and shows a tendency to slide. By its floods and rockfall the torrent of Rieu-Bel menaces the village of Villergondran. Rough dams have been constructed to fix the bed of the torrent and drainage canals have been established with a view to draining the soil. Plantations of spruce and larch, not yet thrifty, completed the work, which, however, must be continued.

The torrent of Roches Noires, communes of Villergondran and St. Jean de Maurienne, is cut in the black schists and in the glacial drifts. The steep slopes and the sterility of the soil have rendered the forestation difficult and uncertain. Everywhere the bed had to be fixed with wattle work but even then vegetation could not be introduced. Forestation is more important in this perimeter than in those which have already been described. The area forested includes some 1,599 acres. The corrective work, which remains to be finished as soon as possible, is limited to the construction of dams at the base, and the establishment of little accessory dams.

Forestation Area of la Blanche. - The torrent of the Blanche is a tributary of the left branch of the Durance which rises in the southeast of Seyne at the summit of Roche Close. It runs from the east to the west to the hamlet of Chardavox, when it turns to the northwest and follows into the Durance after a course of 19 miles. From the hamlet of Viérard (commune of Saint-Martin-les-Seyne), or until it joins the Durance, this stream follows through narrow rocky gorges and is called the torrent of Rabious. Its drainage area belongs to the sub-Alpine region; it is bounded on the east by a very high chain of mountains, called la Blanche, whose altitude varies from 7,220 to 8,860 feet. - . Taking the basin as a whole, the Blanche has no important tributaries, but several of them, because of the tremendous slopes, are dangerous torrents. The greatest altitude is that of the Pic de la Blanche $(9,075$ feet) and the lowest is at the confluence with the Durance and Rabious (2,149 feet).

Geological Conditions. - The bottom of the Blanche basin is occupied by glacial deposits from which emerge black marls. . . . At the extreme southeast of the valley there is a great deal of limestone soil. . . . On account of the predominance of the glacial deposits under the black marls which form soil very susceptible to erosion, this basin is, on all sides, composed of deep ravines and sharp hills. 
Climate. - The climate is very cold in the upper valley and cold in the lower parts. On the summits the snow begins toward the end of October and persists until June. In the bottom of the valley it generally lies from December to April. Because of its exposure and its altitude the Blanche valley receives more rain than the south part of the department of Basses-Alpes. Long droughts are rare. Storms are frequent in summer on account of the nearness to the very high mountains. They have even the character of veritable waterspouts and are very disastrous to the crops which occupy the lower slopes and the bottoms of the valleys.

Basins. - The mountains are covered with grazing ground and in many localities are damaged on account of overgrazing. Every summer the ground is overstocked by sheep and the easily erodable soil is bared and forms deep ravines. Coniferous stands cover large areas and have a tendency to seed the neighboring bare ground. The Scotch pine forms pure stands on south exposures and is associated with fir and spruce on the moister slopes. On cold exposures these two species are frequently pure or in mixture with beech. The mountain pine is also found. Beginning with 3,280 feet altitude, there are stands of larch on the drier ground on north slopes. At very high altitudes the cembric pine appears. The forests which are not subject to Federal control are exposed to destructive cutting and to intensive grazing, so that the soil becomes impoverished and the stands become more and more open. The lower slopes and the bottoms of the valleys are used for agriculture. Fruit trees are not over-abundant. The cultivated land yields cereals and potatoes; the natural prairies occupy large areas and produce a very valuable forage grass.

Administrative Situation, Area, Population. - The Blanche basin extends over one commune (la Bréole) in the district of Barcelonnette and five communes in the district of Digne.

State of Soil Damage. - On all sides, but especially on south and west slopes, the Blanche basin is cut by ravines of a torrential character, all more or less dangerous. This damage has been caused by excessive grazing by cattle which has been too intensive on all the uncultivated land. On account of its geologic constitution, the sub-soil, formed either by black schists or by glacial deposits, is easily eroded after the cover has been removed by sheep grazing. Besides, because of the very long and steep slopes and on account of the abundance and frequence of snowfall and the rigor of the climate, it often happens in spring that in the higher areas avalanches contribute to the destruction of the slopes. On certain areas the water filters into the soil and produces dangerous landslides.

Composition and Area. - The Blanche forestation area includes five working groups according to the law of August 7, 1910. The total area amounts to 6,835 acres, of which 3,623 actually belong to the State.

Work. - The Seyne working group is composed, for the most part, by the old Seyne area and some of the Colle, the reforestation of which aimed at preventing the recurrence of floods (produced by the overflow of the Blanche river) and at the extinguishment of the torrents of Faut, Château, Allevar, Combannière, and "Terre rouge." They extend over the west slopes of a high chain of mountains which separate the Blanche basin from that of Ubaye and are situated at altitudes varying from 4,590 to 8,200 feet. The work of control and reforestation was begun in 1862 and is still in progress. At the beginning they proceeded simultaneously with sowing and plantations of conifers and broadleaf trees, but it was not long before they found out that the sowing generally gave poor results. . . . Accordingly plantations became the rule except in special cases. The species used for the most part were larch, spruce, cembric pine, mountain pine, Scotch pine, and Austrian pine. The larch was used in mixture with the cembric pine in the highest zone, at an altitude between 6,560 and 8,200 feet, on very steep slopes, covered with snow for the greater part of the year, and often 
subject to slides; in the zone immediately below, between 5,580 and 6,500 feet, mountain pine, pure or in mixture with Scotch pine; below 5,580 feet, there were Scotch pine and Austrian pine, sometimes mixed with mountain pine. Spruce has been introduced on south slopes as an understory for the pine. The plans provide for little nurseries established all over the area in order to avoid the cost of transport. These plantations have produced quite variable results. The lower parts of the working group are generally covered with a good sapling or low pole-stand of larch and pine, but the higher areas, because of the rigor of the climate, the nature of the soil, and short growing seasons, have resulted in general failure. Willows, poplars, alders, etc., have been planted and layered at the bottoms and on the slopes of ravines in order to fix the soil and decrease the violence of the water wherever it has been possible. Beginning with the year 1862 the sodding of the soil has also been started either by sowing the seed of "fenasse," "luzerne," or "sainfoin," indigenous to the locality, or by planting tufts of "fettique." Results have been very satisfactory. The corrective work undertaken simultaneously with the reforestation and sodding is very important. It consists in the construction of a large number of dams and of sills in dry stone in the bottoms of the ravines, in order to help maintain the mountain sides, in order to diminish the steepness of the valley bottom, and to decrease the speed of the running water. Between these dams fascines and wattle work barriers have been established. Since 1876, wherever possible, the ravines and the bottoms of the brooks have been thinned where the stands were too dense. This work, which aims at stopping the action of the water on the erodable soil, has given excellent results. The work as a whole has succeeded in almost entirely stopping the action of the torrents in eroding the Seyne working group, with the exception of the torrents of Allevar, Chateau, and Faut, which rise in very steep ground and at high altitudes, and where the growth is very slow, and which do not seem susceptible of correction for some time yet. The working group of Montclar is formed for the most part by the old area of Lachaux, the reforestation of which aimed at preserving the grazing plateau of Lachaux from the danger of floods and avalanches. It extends to the extreme north of the slope, where the Seyne working group is at an altitude which varies from 6,400 to 8,200 feet. The reforestation work, which began in 1864, has consisted in sowing and planting larch and cembric pine in the higher areas, and larch, mountain pine, Scotch and Austrian pine lower down. After sowing forage seed and planting willow (as nurse trees) the area has been completely restocked to conifers. Quite a number of sills of dry stone were established in the chief ravines at the same time the work of covering the slopes began. The restoration of this working group is just about completed. The total area reforested is approximately 3,539 acres.

According to my original notes: "At Barcelonnette, there had been a veritable depopulation on account of the damage from erosion. The work of forestation and erosion prevention was started shortly after 1862, and began in the so-called "terre noir," where the damage was the worst. After six years of practice the local inspector re ported that a large number of small dams were preferred to a few large expensive dams, as was formerly the practice. Below 5,900 feet of altitude white alder was generally preferred along stream beds and green alder at higher altitudes. In this region the annual rainfall is about 43 inches, but during July, August, and September there are very few storms. The torrents seem to have started on slopes 30 degrees or steeper. On slopes up to 20 degrees bad erosion rarely starts in. The main damage at Barcelonnette seems to have been caused by grazing an average of 2.4 to 3 sheep per acre whereas the grazing ground.would only support 0.8 to 1.6."

Central Plateau Region (Puy-de-Dôme Department, La Sioule Forestation Area). - La Sioule, which flows into the Allier, rises in the forests of Mont Dore at the Servières Lake, which occupies an old crater, at an altitude of 3,937 feet. It flows with a rapid slope for $7 \frac{1}{2}$ miles through narrow and deep gorges with an average descent of 3.5 per cent. . . . The basin occupies a vast undulating plateau slightly inclined 
to sthe north and formed, for the most part, by gneiss and mica schists with granite on about half its drainage area. . . . The upper basin of la Sioule occupies about 25 miles of circumference. . . . The highest altitudes are those of the Puy-deDôme, 4,806 feet. The lowest altitude is where the Sioule leaves the department, 1,037 feet.

Climate. - The climate of the region is severe, despite the moderate altitude of the plateau, and is characterized by rapid changes in temperature. The spring rains are very abundant and result in sudden floods. During the summer violent storms are succeeded by prolonged droughts. The winter is long and vigorous and is marked by heavy falls of snow in the mountain forests.

Basins. - The basin of the Sioule is divided into two regions (the grazing area extends over about one-fourth of the total area). The natural mountain zone, which bounds the basin on the southeast and comprises all the volcanic soil from the Dômes chain to Mont Dore. The agricultural area occupies the plains. It extends into the plateau region and produces fruit, rye, barley, grain, oats, and potatoes. A considerable proportion (about 20 per cent) of the uncultivated land belongs to the State and is covered by heather, which is open to sheep grazing. The forest occupies about 10 per cent of the area and comprises simple oak coppice and pole stands of conifers.

Administrative Situation. - The part of the basin included in the department of the Puy-de-Dôme extends over twenty-one communes of the Clairmont district and fifty-six communes of the Riom district. The area is about 339,769 acres and the population about 72,600 .

State of Soil Erosion. - The soil erosion as yet is not very important. Because of the solid nature of the rock the surface water flows from the gentle slopes without cutting in. Once in the bottom of the thalweg, it . . . is almost unerodable. The solidity of the rock facilitates the different correction work; forestation aims almost entirely at forming a cover.

Composition and Area. - The Sioule area was laid out by Art. 16 of the law of April 4, 1882. It includes eight working groups, but a total of only 1,453 acres.

Work. - The forestation undertaken under the law of July 18, 1860, had as its first objective the creation of important forests capable of retaining the soil on the slopes and of regularizing the general waterflow . . . the work has been both by means of sowing and of plantations. In the case of the Scotch pine the seed has been sown broadcast on land covered with a short growth of heather (see page 133). The pedunculate oak has been sown in seed spots. The species used in plantations have been the following: Scotch pine, spruce, pedunculate oak, beech, and birch. Usually the two methods of forestation - sowing and planting - have been employed together. The work has been finished for some time and the stands obtained are now making excellent growth.

Cévennes Region (Lozère, Ardèche Departments Chassezac Forestation Area). - The Chassezac is much the most important tributary of the Ardèche. With a total length of about 47 miles it rises in the Lozère and extends to Alfigère, but it flows in to the Ardèche River at the Sampzon rock, not far from the confluence with the Beaumé. It flows, to start with, in very narrow but extremely deep gorges, then in a valley of increasing width. It has a length of 27 miles in the Ardèche department with an average slope of 2 per cent, and an average width of 148 feet. Its flow per second in the lower parts of its course is 1.5 cubic yards at low water, 8 cubic yards under average conditions, and 2,500 cubic yards during floods. Bounded on the north by the Cévennes (which separates it from the Allier basin) and by Mt. Tanargue (which separates it from the upper Ardèche), this basin reaches at the hamlet of Bez an altitude of 4,072 feet; in the State forest of Tanargue, 4,462 feet; and on the plateau of the Borne working group (near Tanargue), 4,951 feet. 
Administrative Situation. - Entirely in the Largentière district, it includes a total area of 100,633 acres with a population of 16,791 inhabitants scattered through twenty-eight communes.

Destruction of the Soil. - The Chassezac was established by the law of July 18, 1906. It includes 4,774 acres, of which, 1,315 actually belongs to the State.

Work. - There is only one working group, that of Laubresse, exappropriated in 1886. Others are now being acquired. This working group, situated on the mica schists at an altitude varying from 3,280 to 4,167 feet, forms (on the Laubresse plateau) several isolated cantons covered with superb stands of pine from 18 to 20 years old. In the purchases in the working circles of Borned, Saint Laurent les Bains, Mont Selgues, there is also at the same altitude on the same plateau and on the same kind of ground a very complete thrifty stand of pine from 24 to 28 years old. The total area actually reforested is 1,594 acres.

Pyrénées Region (Department of Haute-Pyrénêes, Gave de Pau Forestation Areas). - The Gave de Pau is the most important water course in the Hautes-Pyrénées. When it flows into the Adour at Peyrehorade, after a length of 109 miles, its volume has increased fourfold. . . . The highest altitudes vary from 7,487 to 10,673 feet.

Geologic Conditions. - The high basin of the Gave de Pau only includes stable ground, with the exception of the watershed of Gararie, formed of white limestone, and the Blane and Gavieton, which are formed of gravel, marls, and limy marl. The granite occupies the higher basin of the Gave de Cauterets. . . . The glacial deposits and detritus are frequently mixed with the original soil on the slopes.

Climate. - The climate of the valley of the Gave de Pau is similar to the general Pyrenees climate, that is to say it is temperate and humid. In the high areas there are considerable changes in temperature. The northwest winds, which always bring rain, give rise to erosion on the slopes. The aspect is without influence on the formation of avalanches, since they are produced on both north and south slopes of the Cauterets valley. Fogs and mists are frequent. The snow and the rain are very abundant, but the river is chiefly dangerous in spring when the winter snow is not yet melted, or sometimes in autumn after the first snowfall. Hail storms are quite frequent but their effect is very localized.

Production. - The basin of the Gave de Pau was formerly more heavily forested than it is to-day. . . The forests have been cut so as to give place to pasturage, which is often mediocre in character. Outside the forests and the grazing ground the cultivated fields are very limited and only occupy the bottom of the valleys and the foot of the slopes. They consist of meadows for fattening beef, or are in grain and potatoes used by the agricultural or pastoral population of the region.

Administrative Situation. - The upper basin of the Gave de Pau is situated in the District of the Argeles. Its area is 244,633 acres and its population about 31,000 .

State of Soil Erosion. - The causes of erosion are: The steepness of the slopes, the abundance of erodable deposits, the climate, and the occupation. Too often the forests are destroyed and the sod broken. Occasionally, in the more inaccessible areas, the forest cover has been perfectly maintained and there are no avalanches. Overgrazing results in landslides or erosion.

Composition and Area. - The area includes five working groups, comprising 2,832 acres, of which 917 belong to the State.

Work. - This area included the Péguere slide and the torrent of Lizey. The fixation of the Péguere slide is worth a special visit. The Lizey torrent, which used to be an apparently inoffensive brook, quickly changed its character in 1895 . From the $22 \mathrm{~d}$ to the 27th of April a flood cut the national highway for a distance of 1,970 feet and to an average depth of 5 feet. . . . The volume of the material deposited has been estimated at 40,000 cubic yards. All this débris came from slopes covered with glacial 
deposits. This danger has now been corrected. The State lands of the Péguere and lizey are partly forested. The stands have been fully stocked and the openings filled in by means of local species, beech, pine, and fir, and to a lesser extent, the larch, spruce, birch, and alder. The total area forested amounts to 734 acres.

\section{APPENDIX F}

\section{SPECIFICATIONS FOR TAPPING MARITIME PINE AND FOR FIXING SHIFTING SAND DUNES}

The rules and specifications governing the tapping in (a) France, (b) British India, and $(c)$ the United States are given in full.

According to the conditions for sales for the extraction of resin (cahier des charges), approved May 17, 1912, by the Secretary of Agriculture, the work will be ordered as follows:

Arts. 1-17 cover the method of sale, terms of payment, and various technical costs. Beginning with Part III, Exploitation, the instructions are:

Art. 17. - The permit to cut will be delivered by the Waters and Forests agents, chief of service, on the presentation $(a)$ of certificates showing that the contractor has furnished his sureties or his security and fulfilled payments called for by Art. 12 of the current cahier des charges; $(b)$ for State woods . . . as provided by the law of July 18, 1907. The Waters and Forests agent will sign these papers. He will also deliver to the contractor if demanded: (a) A copy of the record of sale which will be certified to by the secretary at the place of sale; (b) a copy of the advertisement data with the articles, clauses, and conditions which concern it when this advertisement is a part of the record of sale. All these papers will be stamped.

Art. 18. - The contractor will deliver the permit to the head ranger and inform him of the day when he expects to commence exploitation. In any case this cannot be before January 1 of the first year of the cutting period.

Art. 19. - Unless otherwise indicated (see p. 190) or contrary to the special contract clauses, the extraction of resin must conform to the following provisions:

(A) Tapping without Killing (Gemmage a vie). - The tapping will have either one or two faces, according to the directions of the Waters and Forests Service. Trees to be tapped with two faces are only those which have been so designated and indicated in the record of sale. The faces will be begun above the root collar, but will be raised vertically, following the grain of the wood. If the period of tapping is for 5 years the face may be raised 23.6 inches during the first year and 25.6 inches during the following years, in such a manner that the total height will not exceed 10.5 feet. If the tapping period is 4 years (now the current practice, but see p. 193 for latest sizes) the face may be raised 23.6 inches during the first year, 25.6 inches during the second year, 33.5 inches during the third, and 39.4 inches during the fourth, so that the total height of the face shall not exceed 10.2 feet. In any case the width of the faces must not exceed 3.5 inches the first year, 3.1 inches the second, 2.7 inches the third, and 2.4 inches beginning with the fourth. The decrease in width must take place gradually so that the width of the face at the end of a year will equal the width of the face (prescribed) for the beginning of the next year. Their depth must not exceed 0.4 inches measured with a string stretched from one side of the gash to the other, beginning at the red part of the bark. The tapping will take place in accordance with the directions from the Waters and Forests Service; either on four faces (au quart), all faces being made as far as possible two by two on opposite diameters; or by three faces of 
three made by dividing the circumference of the tree into three practically equal parts, the second having been cut at the right of the first when facing it. Unless specially provided for in the sale contract, the tapping will be done on four faces. The former faces will be abandoned no matter what their height. The contractor may, on his demand, be authorized by the conservator to replace a 5-year tapping period by a 4-year period, adopting for the faces the sizes prescribed for the 4-year period. This request may be made during the course of exploitation but must be before the face exceeds the dimensions prescribed for the year corresponding to the chosen period.

(B) Tapping to Death (Gemmage a mort). - If the trees to be tapped to death form part of the sale or are marked for the contractors, the latter can work them as they think best. On the other hand, contractors cannot tap trees so as to diminish their value as sawlogs or firewood. The size of the faces should be such that their whole area never exceeds the limits of a regular face.

Art. 20. - Any tree worked contrary to the principles described in the preceding article or the special clauses will be considered as having been mutilated, thus falling under the penalty of Arts. 192 and 196 of the Forest Code. The contractor will be liable to the same penalties, if at any time, in order to lead the resin into the cup, he shall have made at the foot of the trees tapped alive circular incisions sufficiently deep to damage the wood.

Art. 21. - Tapping operations shall be limited to between March 1 and October 31 of each year, but the contractor may commence to bark the pine to be tapped and to place the cutters after February 1. He may also collect the scrape up to December 1 of each year of the tapping period, except that the last year (of the period) must be terminated by November 15 . If, by any reason of local conditions, other periods must be adopted for the aforesaid collection, mention will be made of it in the special sales clauses.

Art. 2\%. - The contractor may prune the trees to be tapped alive up to a height of 13.1 feet. Unless stipulations have been made to the contrary, he may dispose of the products of this operation.

Art. 29. - The felling of trees sold to be tapped to death cannot commence before July 1 of the year before the final year of the felling period. The contractors who wish to anticipate the felling of all or a part of these trees shall ask authorization for it from the Director-General of Waters and Forests, whe will fix the new conditions of exploitation and, if there are any, for the payment of annuities. In any case this authorization will not be necessary for trees unfit for tapping that measure less than 6 inches in diameter at breast height; the contractors will have the privilege of varying them at any time during the exploitation period on condition that they notify the local agent when they commence felling. Dead standing trees designated at the time of the marking shall be felled either in the first month of the period of exploitation or within one month from the day of the auction, if this took place after the beginning of the exploitation period.

Art. 24. - Trees sold shall be cut with the axe or with the saw as near as possible to the stamp on the stump without injuring it. In no case and under no pretext may the imprint of the State marking hatchet be erased from trees tapped alive or, with equal force, those which are to be tapped to death; these marks must remain intact through the entire period of exploitation and to this end all necessary precautions shall be taken from the first cutting of the faces; it shall even be carefully seen to that these marks are not covered by the resin. Every tree on which the aforesaid marks shall have disappeared will be considered as not forming a part of the sale and will render the contractor liable to the application of Arts. 34 and 196 of the Forest Code. The method of marking will be indicated in the advertisement and in the sale record.

Art. 25. - If, because of unforeseen circumstances, such as patrol paths, fire lines, 
working-plan improvements, work for the protection of the coast line, alienation, and resale, or for any other cause of this sort, trees tapped alive, felled, or diverted from felling an indemnity equal to the average new revenue produced by each tree alive shall be allowed to the contractor for each year remaining. When, under the same conditions, trees to be tapped to death should be felled or included in compartments outside the felling area, a like indemnity shall be credited him for these trees if the privation of tapping oceurs before the third year of the exploitation period. Under such conditions the contractor shall be bound to exploit them and remove them within the period which shall be allotted; in default of which the owner of the forest may dispose of the trees as he likes. These indemnities shall be arranged between the head ranger and the contractor or his representative after a hearing and approval by the conservator.

Art. 26. - When the plan of sale authorizes or requires felling by extraction of stumps, the contractors shall fill up and level the holes made by the uprooted trees as the cutting proceeds.

Art. 2\%. - The contractors shall only be required to brand and top trees (before felling) marked for exploitation which shall be so designated by the Waters and Forests Service; the number of such trees and how they are marked shall be indicated in the advertisements and sale data. The wood resulting from these operations as well as that from the removal of branches and tops (done at the contractor's option) shall be immediately removed, and especially before felling, when they cover either young growth or seedlings.

Art. 28. - Trees shall be cut in such a way as not to damage those reserved and felled so far as possible upon areas where there is no reproduction.

Art. 29. - The twigs and branches shall be removed and piled as the cutting proceeds so as not to hinder access to the felling areas.

Art. 30. - Unless otherwise stipulated in the special clauses of sale, the felling of all wood shall be terminated by April 15 of the last year of the period, whether the wood has been tapped or not.

Art. 31. - Every contractor who cannot finish felling or cording according to the prescribed periods and requires an extension of time shall be bound to make the demand of the conservator on "stamped" paper at least 20 days before the expiration of the cutting period. This request shall include information as to the amount of wood remaining to be cut or the amount and quality of the wood remaining to be corded, the causes of the delay in felling, and the extension which it is necessary to grant. It will be judged on its merits by the conservator. The contractor, simply by making such a request for an extension of time for felling, obligates himself to pay the costs fixed by the administration. The extension runs from the day of the expiration of the periods fixed in the preceding article. When the contractors have not profited by the extensions which they have been granted, they cannot obtain any refund of the indemnity fixed except by a report of the Waters and Forests agent or head ranger, dated at the latest on the day of the expiration of the term of exploitation, and showing clearly they have profited by the benefits of the decision. This report is exempt from stamp and registry fees. (Law of May 15, 1818, Art. 30.)

Art. 32. - The contractor is forbidden: (a) To pile or allow branches, chips, sawdust, bark, etc., to remain (on the ground) except on areas designated by the local Waters and Forests agent or his representative The contractor may be required to scatter these remnants if it is considered necessary; $(b)$ to place or pile wood on young growth or against reserved trees; $(c)$ to place the material of exploitation outside the limits of the felling except at depots specially designated by the local Waters and Forests agent or his representative.

Art. 33. - As cutting proceeds the contractor must remove wood which falls in the paths separating the felling areas. 
Art. 34. - The roads must be continually kept free in the felling areas so that wagons can pass at any time.

Art. 35. - The contractor must not injure any reserved trees, whatever their quality or number. Under no circumstances, except as specified in these rules, can the contractor have reserve trees marked, even when he finds the number of trees sold less than those recorded in the auction estimate sheet. This difference cannot give the contractor any right to an indemnity. When, during the course of felling, the trees to be tapped alive or reserved trees are burned, die, are overturned or damaged by the wind or by any other cause over which the administration has no control, the contractor will notify the local Waters and Forests agent, so that reconnaissance of these trees can be made without delay. The contractor must, upon demand, fell such trees within 15 days, except those burned. He will have the right to receive the stocktaking sheet and estimate, which shall be drawn up by the local agent and which, signed by the contractor, and approved by the contractor, shall be executed without further formality under the conditions prescribed in Art. 59. The contractor shall be considered as having renounced his preëmption right, if within $\mathbf{1 5}$ days of the time he was formally notified he has not returned this paper to the local agent showing his acceptance. Said notification shall be made in the discretion of this agent either by the intermediary of an employee or by registered letter but no indemnity, restitution, nor decrease in price shall be granted the contractor for any loss which he may occasion from trees destined to be tapped alive.

Art. 36. - Trees to be tapped to death and sold, which die during the course of the felling period, must be immediately felled by the contractor and at the latest within 15 days after notification of their death has been made by the local agent. If the trees tapped to death are not sold, the same procedure shall be followed during the course of the felling period as has already been described for the trees to be tapped alive and for the reserves. The contractor cannot claim any indemnity for loss of resin.

Art. 3\%. - When any tree marked for felling shall lodge on a reserve, the contractor cannot fell this reserved tree until after the local Waters and Forests agent or his representative acknowledge the necessity for the felling.

Arts. 38-39. - When, despite the observations of the rules relative to the fellings, reserves are knocked down or damaged by felling, or knocked down under the conditions described in the preceding article, the local Waters and Forests agent or his representative shall proceed in company with the contractor for a reconnaissance of this wood, and, after an estimate of the damage caused, the contractor shall pay to the owner of the forest an indemnity equal to the total damage. When reserves are knocked over or felled the indemnity will not be less than the following minimum:

Stumps less than 7 inches in diameter at -

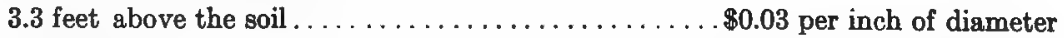
7 to 14 inches................................ 14 to 24 inches................................. 24 to 35 inches............................ diameter Over 35 inches........................... 0.12 per inch of diameter

This minimum will be equally applicable to reserves damaged, which the local agent believes cannot thrive or remain standing, and the contractor will be bound to fell these trees within 8 days after notification by the aforesaid agent. . . . Until the payment of said indemnities the reserves overturned, damaged, or felled will continue to belong to the owner of the forest; but the contractor will have the right to acquire the trees overturned or felled according to the method and conditions indicated in Art. 36 .

Art. 40. - The Waters and Forests Service will have the right to sell, without waiting for the final inspection of the cutting area, the windfall, wind damaged, burned or 
dead trees, as well as reserves overturned, felled, or broken, which the contractor refuses to take under the conditions specified in Arts. 46 and 39 . Under these circumstances the contractor will be bound to allow the lumberman to bring his workmen and tools into the felling area. . . .

Art. 41. - All collection or removal of cones, where the trees are standing or felled, is strictly forbidden. These products are not part of the sale and their removal will be prosecuted in accordance with the provisions of Art. 44 of the Forest Code.

Art. 42. - The contractors may establish in the interior of the felling areas workshops for the manufacture of wood, huts, charcoal pits, forges, distillation outfits, and steam sawmills only after making a demand (free from stamp rights) of the local Waters and Forests agent who shall designate in writing the location and areas where leaves, moss, stones, brush, and sod considered necessary (for construction purposes) shall be removed. This material shall be granted free of charge, but the holes caused by the trees' removal shall be immediately filled up and leveled. Charcoal pits shall be surrounded at 4.4 yards from their base by a ditch 4.9 inches wide at the bottom. The ground between the base of the charcoal pit and the ditch surrounding it shall be entirely cleared. Fire cannot be lighted before October 1 and will be put out before March 1 of each year. The chimneys of steam engines and other similar apparatus must be covered with metal screens, fine enough to prevent the ejection of sparks. The contractors must, besides, take all precautions prescribed by the Waters and Forests agent and shall be bound to conform to the laws and rules in force. Under any circumstances they shall be held responsible for damage resulting from the use of these machines and apparatus and from fire which occurs in consequence.

Art. 43. - The contractor shall have the privilege of constructing, in the cutting area, on areas indicated by the local Waters and Forests agent or his representative, huts for the lodgement of the resin workers. These huts shall be required to be demolished and the material removed within two months after the period fixed for the completion of the removal of the timber or of the tapping. In default, or beyond this period, the houses will become the property of the owner of the forest.

Art. 44. - Existing houses which can be put at the disposal of the contractor will be suitably maintained during the period of exploitation and rendered in perfect state of habitation. . . .

Other special rules which bind the contractor are as follows:

He can build new roads where necessary.

He is forbidden to drag wood on carriage roads, to slide or roll wood down steep slopes or to graze work animals in the forest. The removal of all products must be finished by November 15 for improvement cuttings and by April 15 for regeneration fellings.

The other rules are similar to those given under timber-sales clauses, p. 438 of the Appendix.

\section{RULES FOR TAPPING IN THE NAINI TAL DIVISION AS AT PRESENT IN FORCE}

The following revised tapping rules are circulated for guidance:

2. Attached is a statement showing the areas so far set aside for tapping. Early in the year the trees in the areas set aside for tapping will be numbered with a serial number as the numerator and the numbers of the channels as the denominator, e.g., 2674/2 which means that 2,674 is the serial number and 2 the number of pots the tree is to earry. Each compartment will have a series of its own. The forester or a trusty forest guard can number the compartments to be light tapped and the range officer those 
compartments to be heavy tapped. Heavy tapping will be only carried out in those areas to be felled for firewood within the next 5 years and only those trees in them will be heavy tapped that are to come out at the felling, the remaining trees in the coupe being light tapped.

\section{NOMBER OF POTS PER TREE}

3. Light tapping. - One pot for trees between $3 \frac{1}{2}$ feet and $4 \frac{1}{2}$ feet in girth. Two pots for trees between $4 \frac{1}{2}$ feet and 7 feet in girth. Three pots for trees over 7 feet in girth.

Heavy tapping. - One pot for every foot in girth of bark. METHOD OF TAPPING: HANGING OF THE POTS

4. Having arranged for pots, tools and lips, the pots will be hung on the trees as follows: Choose places for the pots at the base of the tree, taking care that when two or more pots are prescribed that they are equidistant from each other, then cut a channel 4 inches wide by 1 inch deep and about 6 inches long at the base, so as to allow a free hang to the top, place the lip (a piece of thin iron sheet 5 inches by $1 \frac{1}{2}$ inches) in a curved incision (made by a special chisel with that curve), care being taken that the lip slopes downward from the tree and underneath toward a side drive in a nail on to which the pot will be hung.

The channel when first cut should be 4 inches to 6 inches long above the lip. For the cutting of a channel an ordinary sharp adze is required. When commencing work for the year on trees already tapped, the old lip will be extracted and inserted at the head of the previous year's channel, the pot being hung below it as before.

\section{FRESHENING}

5. For this a very sharp adze (Basula) is required. As the flow ceases, which, according to the time of year, may be after one, two or three weeks, a point on which the range officer and beat guards must be particularly careful, the channel will require freshening at the top. This is done by the removal of a thin shaving not more than $2 \frac{1}{2}$ inches of the vertical length of the tree. The flow has ceased because of the clogging of the outlet of the resin ducts, and all that is necessary is to remove those clogged and to open out other ducts - the ducts more or less ramifying through some 2 inches or so of outer wood in a vigorous first-class tree.

No hard-and-fast rule can be fixed as to the length of the channel to be cut each year, as this depends on the extent of the freshening necessary and on the tree itself as a resin-producer. A maximum of 15 inches, however, is fixed; but the less the better, as the longer the use of the ladder is postponed the more quickly can work be done.

The cutting of the bark on the sides of the channel is not allowed; simply remove the old pieces of loose bark by hand and put a piece of bark over the pot itself to prevent foreign matter falling into the resin.

\section{COLLECTION}

6. As the pots become full they must be emptied of their resin. Here again no fixed period ean be fixed, but during the season of greatest flow once every fifteen days is necessary, but otherwise not less than once a month. As a rule, the resin should not be allowed to reach within $\frac{3}{2}$ inch of the nail hole or the top of the pot, whichever is lowest.

The collection will be made by means of wooden spoons, the resin being put into kerosene oil tins fixed up with a handle, which will be emptied into other tins at convenient centers for transport to Bhowali.

7. Tapping will go on for five successive years between about March 15 and November 15 , according to season and then a rest of 10 years, so that during 14 years the 4-inch channel should be closed over by callous formed on the sides. 


\section{United States Forest Service - Florida Nationat Forest}

\section{SAMPLE TURPENTINE PERMIT}

December 11, 1911.

In consideration of the granting to us of this permit to work for turpentine certain longleaf and slash pine timber on an area to be definitely designated by a forest officer before cupping begins, located in Sections 14, 24, and 26, T. 2 N., R. 21 W., Tallahassee Meridian, within the Florida National Forest, estimated to contain 19,000 cups more or less, we do hereby promise to pay to the First National Bank of Albuquerque, New Mexico (U.S. Depository), for said permit at the rate of $\$ 86$ per thousand cups in two payments of at least one-half of the total amount due, credit being given for the sums, if any, hitherto deposited with the said First National Bank of Albuquerque in connection with this permit; and we further promise and agree, should this permit be granted to us, to work said timber in strict accordance with the following and all other related regulations governing the National Forests and prescribed by the Department of Agriculture:

1. Timber on valid claims and timber under other contract is exempt from this permit.

2. No tree will be cupped, chipped, raked, or worked in any manner until the first payment has been made.

3. No gum or other product of the timber will be removed before the cups on the area have been counted and recorded. Title to the product of the timber included in this permit will not pass to the permittee until it has been paid for as herein prescribed.

4. No timber will be cupped except that on the area designated by a forest officer; and no marked trees or trees under the diameter limits will be cupped or chipped under any consideration.

5. No tree 10 inches or less in diameter will be cupped; not more than one cup will be placed on trees from 11 to 15 inches inclusive in diameter; not more than two cups will be placed on trees from 16 inches to 25 inches inclusive in diameter, and not more than three cups will be placed on any tree. All diameter measurements are to be taken at a point $2 \frac{1}{2}$ feet above the ground.

6. So far as possible, the depth of all streaks will average one-half inch or less, and in no case will the depth of streaks exceed three-quarters of an inch not including bark. The width of the streaks will be so regulated that no more than one-half inch of new wood will be taken from the upper side with each streak and so that the total height of the faces shall not exceed fifty inches during the life of this permit. Bars or strips of bark no less than 4 inches wide in the narrowest place will be left between faces, and the edges of faces will be parallel with each other and be placed vertically up the tree. So far as possible, where more than one face is placed on a tree, one bar between them will not exceed 6 inches in width. No more than one streak will be placed on any face during any one week. The chipping will be uniform in depth from shoulder to peak. Faces not chipped in accordance with these specifications may be marked out and the cups removed by the forest officer.

7. One of the modern cupping systems will be used, and the cups and aprons or gutters will be so placed that the shoulders of the first streak will not be more than 12 inches distant from the bottom of the cup and the cups will be placed as near the ground as possible. No wood will be exposed on any tree by removing the bark below the gutter or aprons.

8. No unnecessary damage will be done to cupped trees, marked trees, or to trees below the diameter limit. Trees that are badly damaged during the life of this permit, when such damage is due to carelessness or negligence on the part of the permittee, 
shall be paid for at the rate of $\$ 5$ per 1,000 feet b. m., full scale, and the forest supervisor shall decide as to the presence and extent of damage.

9. No cups will be placed later than March 1, 1912, without written permission from the forest supervisor, and all timber embraced in this permit will be cupped before said date.

10. Unless extension of time is granted, all timber will be cupped, chipped, dipped, scraped; the product and all cups, aprons, gutters and nails removed and each cupped tree thoroughly raked to the satisfaction of the forest officer, on or before and not later than January 1, 1915.

11. No fires shall be set to the timber, underbrush or grass on the area included in this permit without the written permission of the forest supervisor, and every effort will be made by us, our employees, sub-contractors and employees of sub-contractors, to prevent the burning over of said area from any unauthorized cause; and during the time that this permit remains in force and effect we and all our employees, sub-contractors and employees of sub-contractors, without any charge whatsoever to the Forest Service, will do all in our power both independently and on request of forest officers to prevent and suppress unauthorized forest fires.

12. All cupped trees will be raked in a workmanlike manner for the space of $2 \frac{1}{2}$ feet around each tree before January 1 of each year of the life of this permit; and a fire line not less than 3 feet wide in the narrowest place shall be hoed or plowed around the area covered by this permit in such a manner as to completely isolate it from adjoining lands. Natural fire brakes, such as creeks, swamps, roads, etc., may be utilized with the consent of the forest officer. These fire lines must be made and receive the approval of the forest officer before any cups are placed the first year or new streaks made at the beginning of the second and third years.

13. Special-use permits will be obtained for such cabins, shelters, camps, telephone lines, etc., as may be required on Government land in carrying out the terms of this permit.

14. The first payment shall be made before the cups are placed the first year and the second payment shall be made on or before December 31, 1912 .

The decision of the district forester shall be final in the interpretation of the regulations governing this permit.

Work may be suspended by the forest supervisor if the regulations contained in this permit are disregarded, and the violation of any one of said regulations, if persisted in, shall be sufficient cause for the district forester to revoke this permit and to cancel all other permits for other privileges.

"No member of or delegate to Congress, or resident commissioner, after his election or appointment, and either before or after he has qualified and during his continuance in office, and no officer, agent, or employee of the Government shall be admitted to any share or part of this contract or agreement, or to any benefit to arise thereupon. Nothing, however, herein contained shall be construed to extend to any incorporated company, where such permit or agreement is made for the general benefit of such incorporation or company. (Section 3741 R. S. and Sections 114-116, Act of March 4, 1909.)"

No person undergoing a sentence of imprisonment at hard labor can be employed in carrying out the terms of this permit. (See Executive Order of May 18, 1905.)

Refund of deposits under this permit will be made only at the discretion of the district forester, except when the amount of such deposits is more than the total amount required under this permit.

This permit is non-assignable. (See Section 3737, Revised Statutes of the United States.)

The conditions of this permit are completely set forth herein, and none of its terms can be varied or modified except with the written consent of the forest supervisor. 
No subordinate forest officer has, or will be given authority for this purpose. If required as a guarantee of a faithful performance of the conditions of this permit we will submit a bond in the sum of $\$ 500$, which bond, together with all moneys paid or promised under this contract, upon failure on our part to fulfill all and singular the conditions and requirements herein set forth, or made a part thereof, shall become the property of the United States as liquidated damages and not as penalty.

\section{CONTRACT STIPULATIONS}

In the dunes of the Gironde and the Landes, the following contract stipulations must be followed by contractors:

\section{Chapter I. - General Rules. - Fixation and Maintenance of Dunes.}

Art 1. - The dunes are fixed according to plans by the director of works, $(a)$ by sowing with ground cover or (b) by the plantation of maram grass (Psamma arenaria), and $(c)$ by broadcast sowing or transplanting in the waterholes between the dunes.

\section{BOWING WITH COVER AND TRANSPLANTING}

Art. 2. - Contractors shall use per acre of dune: (a) The amounts of maritime pine seed, genista or gorse, and maram specified in the plans; $(b)$ the number of brush fagots properly called "bourées" likewise to be determined by the plan (80 to 400 per acre) and according to the conditions detailed in Art. 9 which follows. The transplanting of the water-hollows between the dunes shall be at the rate of (except upon contrary stipulation) 3.5 pounds of pine seed and 1.7 pounds of genista or gorse seed per acre.

\section{PLANTATION OF MARAM (GOURBET)}

Art 3. - When maram is planted the tufts are placed in quincunx, spaced 1.6 feet apart; the spacing of the clumps may be, however, on order of the director of works, reduced to 8 inches or increased to 3.3 feet. The maram shall be planted in conformity with the rules in Art. 10.

$$
\text { PALISADES, BARRIERS }
$$

Art. 4. - Contractors shall use for each 328 linear feet (109 yards) of palisades an average of 500, 5.2 feet in length, 1.2 inches thick, and between 6.7 and 8.6 inches in width. The stakes for the woven barriers shall, according to the orders of the local agents, have a length between 8.2 feet and 29 inches. For each 328 linear feet of barrier the following stakes and fagots shall be set: 200 stakes 8.2 to 4.9 feet in length. 80 fagots; 200 stakes 4.1 feet in length, 60 fagots; 200 stakes 3.3 feet in length, 40 fagots; 200 stakes 29 inches in length, 20 fagots; per 328 linear feet of simple barrier (cordon), 70 fagots.

\section{EXCAVATIONS}

Art. 5. - The fagots for excavations shall be set in holes 16 to 20 inches in circumference with a depth of 16 inches, and separated 12 to 16 inches from circumference to circumference, according to the instructions of the director of works. The height shall vary from 8 to 24 inches above the soil according to the locality.

\section{LEVELING}

Art.6. - The places to be leveled shall be worked to a depth of 14 inches and the ground shall be cleared of all vegetation and débris whatsoever which could stop the movement of the sand. The green maram susceptible of being replanted will be carefully taken out, made into bundles, and heeled in; the maram which cannot be used and débris of all kinds will be placed in the nearest excavations. 
Art. 7. - The maram, where it is too thick, will be thinned in conformity to the prescriptions of the director of works. The stumps which are removed will be dug out and deposited where specified by the foreman.

Chapter II. - Places of Extraction. - Nature and Quality of the Material. - Fagots and Stakes.

Art. 8. - The fagots and stakes will come from the places indicated by the agents in the State forest and situated at the average distance specified in the plans. Without special authorization from the supervisor (chef de service) they cannot be removed from the so-called protection zone. The thinnings will be under the direction of a forest employee and conducted without interruption, as the work proceeds. When the work is stopped at any point the boundary of the area thinned shall be regularized so far as possible by straight lines. If the brush and the stakes cannot be secured in sufficient quantities, or are completely lacking in the Federal forest, the contractor must procure them at his expense in private forests, provided, however, that the average distance of transport shall not exceed the average distance specified in the plans.

Art. 9. - The brush and the stakes shall be used green. The fagots shall not include cones or branches with a diameter of more than 1.2 inches. Maritime pine, genista or gorse, shall be used for their manufacture instead of heather, unless specially stipulated in the plans. The brush fagots must weigh at least 44 pounds from September 1 to May 31 and 33 pounds from June 1 to August 31; those which do not come up to the proper weight shall be rejected and immediately rebundled. No account shall be made for the contractor for the fagots which exceed the stated weight. The stakes . . . 4.9 to 8.2 feet shall have a minimum diameter of 2.4 inches at the small end. Those 4.1 feet and less shall not be less than 2 inches in diameter at the small end.

\section{MARAM}

Art. 10. - The maram to be transplanted shall be secured in the areas designated by the director of works at the average distance indicated in the plans and extraction shall be made by . . .

\section{APPENDIX G}

\section{STATE AND COMMUNAL TMMBER SALE REGULATIONS}

The regular contract conditions and clauses were issued by the administration at Paris, June 22, 1903, and revised May 27, 1909, and again May 11, 1912. The following translation of Part III - Exploitation, is given in full since it is basic for all timber sales throughout France unless exceptions are made in the special clauses issued by the local conservators.

\section{PART III. - EXPLOITATION 1}

Art. 17. - Every successful bidder who, before the delivery of the cutting permit, shall demand a recount because of an alleged deficit in the number of trees indicated in the record of the trees reserved and marked for cutting binds himself, merely by his request, to pay at the depository of the collector for the local Canton an indemnity of 10 francs per day's work for each agent and 3 francs per day's work for each guard, if there is found to be no deficit.

1 Part I describes the routine of the auction; Part II explains payments, charges, stamp rights, and registry. See page 292. 
Art. 18. - The permit to cut will be delivered by the agent of Waters and Forests service, chief of service, on the presentation of certificates showing that the purchaser has put up his securities or security, furnished his remittances, promissory notes, or cash and made the payments required under Art. 12 of this circular.

The Waters and Forests agent will sign these papers. He will besides give to the purchaser if he asks for them: (a) A copy of the minutes of his auction, as soon as they have been verified at the Secretary's office at the place of sale; (b) a copy of the sales circular and of the special clauses; $(c)$ a copy of the special circular for the articles, clauses, and conditions which concern him when this bill of sale is added to the auction circular; (d) a copy of the survey notes and, if there is one, a map of the felling area. All these papers shall be vised for stamps.

Art. 19. - The contractor shall send the permit to the ranger in charge and inform him in advance of the day he plans to start cutting.

Art. 20. - Unless otherwise indicated or supplementary to the special auction clauses the wood shall be cut:

In the coppice fellings: "a tire et aire" with the axe as close to the ground as possible, and so that the water cannot remain on the stumps. The roots must remain intact.

In the high forest fellings: level with the ground, with the axe or saw.

Conifers marked for cutting in coppice felling areas may also be sawed down.

Art. 21. - When the sales circular authorizes or prescribes felling with stump extraction, the purchasers must fill up and level the holes made by the uprooted trees as the cutting proceeds.

Art. 22. - The purchasers shall be bound to limb and top before felling only those trees marked for cutting which have been previously designated by the Waters and Forests Service. The number of these trees and how they have been designated shall be given in the sales circular. The wood resulting from the operations including that from the preliminary work of limbing and topping undertaken voluntarily by the successful bidders shall be immediately removed, and especially before further felling, when it covers young growth or seedlings.

Art. 23. - The trees shall be felled, so far as possible, so as not to damage those reserved and cut areas where there is no young growth. In felling areas on a rapid slope the trees shall be felled, unless otherwise authorized, in the direction of the slope, with the crown up hill.

Art. 24. - As cutting proceeds, the purchasers in coppice fellings shall be bound, unless waived in the sales circular, to remove old stumps and to cut level with the ground the boles bent or broken, the brush, brambles, weeds, shrubs, and injurious undergrowth.

This cleaning is not obligatory in high forest fellings unless prescribed in the contract.

Art. 25. - The small branches and limbs shall be removed and piled, as the cutting proceeds, so as not to obstruct hauling in the felling areas.

Art. 26. - The material resulting from cording the small branches and limbs shall be stacked or placed in piles as eutting proceeds.

Art. 27. - The cutting of wood shall be finished by April 15 after award.

The wood peeled by virtue of the contract shall be cut before July 1 .

The cording of small branches and limbs, including piling or stacking the material resulting from this cording, shall be finished by June 1 following the award.

As regards the small branches and limbs resulting from wood peeled by virtue of the contract, this period is extended to July 15 following.

If local conditions necessitate other terms they will be given in the special clauses of the contract.

Art. 28. - Every purchaser who cannot finish felling or cording during the prescribed period and who requires an extension shall be bound to make the request of 
the conservator, on stamped paper at least 20 days before the expiration of the aforesaid period. This request shall explain the area or the amount of timber remaining to be cut, or else the amount and kind of wood remaining to be corded, the causes of the delay in the logging, and the extension that it is necessary to have. It will be judged on its merits by the conservator. The purchaser, solely by his request for an extension of time for logging, obligates himself to pay the indemnities fixed by the administration. The extension will run from the day of the expiration in the periods fixed in the preceding article. In case the purchasers do not make use of the extensions which they have been granted, they cannot obtain a refund of the charge made, except after a report from the agent of Waters and Forests local officer in charge, dated at the latest on the day of the expiration of the felling period, stamped and registered at their expense and showing unmistakably that they could not profit by the extension.

Art. 29. - The purchaser is forbidden, at least unless the sales circular contains an explicit authorization, to peel or bark standing any wood in his sale, under the penalties prescribed by Art. 36 of the Forest Code.

Art. 30. - It is also forbidden: (a) To leave branches, twigs, chips or bark on areas stocked with seedlings; (b) To place or pile wood on seedlings, live stumps, or against reserved trees; (c) To notch these trees on the bole or roots or to drive nails; $(d)$ To pile the products of logging outside the boundaries of the felling area, except on landings specially designated by the local Waters and Forests agent or his representative.

Art. 31. - The purchasers must remove, as the cutting proceeds, the wood which falls into the lanes separating felling areas.

Art. 32. - They must always keep the roads open in the felling areas, so that wagons can pass at any time.

Arl. 39. - The purchaser will protect all the reserved trees, whatever their quality and number. In no case, nor under any pretext whatever, can any reserved tree be marked for the purchaser, even when it may be found that there are more than recorded in the marking and sales report. He will protect (coppice) standards of every age class and other reserved trees, even if they may be broken, or overturned by the wind, or damaged by an act of Providence independent of the logging. He will be bound to preserve them, as well as their crowns and branches.

Art. 34. - When a tree marked for cutting shall lodge in its fall on a reserved tree, the purchaser cannot fell this reserve until after the local Waters and Forests agent or his representative shall have recognized the necessity for felling.

Art. 35. - Whenever, despite the observance of the felling rules applicable to the cutting areas, the reserves shall have been overturned by logging, or when the reserves shall have been knocked down under the conditions anticipated in the preceding article, the purchaser shall be bound, if the Waters and Forests agent considers it necessary, to replace these reserves by trees taken from those marked for felling. These trees shall be chosen by the aforesaid agent and marked with his special marking hatchet. Under no circumstances can the value of the tree thus designated exceed that of the trees replaced. If the restitution is not required or if it is effected by trees less valuable than those reserves overturned or knocked down, the purchaser will pay as damages the value of these reserves or the difference between their value and that of the trees marked to replace them, after a check valuation has been made. The valuation of the reserves can never be less than the following established minimum:

\section{COMPOUND COPPICE FELLING AREAS}

Standard of the first rotation, $\$ 0.03$ per 3.9 inches of circumference.*

Standard of the second rotation, 0.06 per 3.9 inches of circumference.

Standard of the third rotation, 0.09 per 3.9 inches of circumference.

* These figures are for circumferences made 3.3 feet above the ground. 


\section{HIGH FOREST FELIING AREAS}

Saplings 20 inches in circumference $-\$ 0.03$ per 3.9 inches of circumference.*

Trees 24- 43 inches in circumference -0.06 per 3.9 inches of circumference.

Trees $\quad 47-75$ inches in circumference -0.08 per 3.9 inches of circumference.

Trees 79-114 inches in circumference - 0.09 per 3.9 inches of circumference.

Trees 118 inches in circumference and over, 0.11 per 3.9 inches of circumference.

* These figures are for circumferences made 3.3 feet above the ground.

When reserves are damaged the same procedure shall be followed as for reserves overturned or knocked down, if the local agent decides that they cannot thrive if left standing. If, on the contrary, the local Waters and Forests agent believes that the damaged reserves may conveniently be left standing the purchaser will pay the amount of damage caused the reserve in accordance with the estimate which shall be made by the aforesaid agent.

A record of these estimates and charges shall be prepared, which shall be signed by the contractor or his agent, and addressed to the conservator, who, after having checked and approved it, will see to the collection of the amounts due. This certificate is exempt from stamp rights and registry. (Art. 80 of the law of May 15, 1818.)

Notwithstanding all replacements or payments made by the purchaser in accordance with the provisions of this article, the reserves overturned, knocked down, or damaged, will continue to belong to the owner of the forest.

Art. 36. - After violation of the clauses and conditions of the sale, relative to the method of felling and cleaning of the cutting areas, shall be punished in conformity with Art. 37 of the Forest Code.

Art. 37. - The purchaser can establish within the cutting area, huts, charcoal pits, or pitch and tar pits, temporary lime kilns, and yards for the sawing and sale of wood provided the request is made to the local Waters and Forests agent who will designate in writing the areas to be occupied and these where the leaves, moss, stones, cinders, and necessary grass be removed. These products will be granted free, but the holes resulting from their removal must be immediately filled and leveled.

Art. 38. - The purchasers will have the right to install portable sawmills in their felling areas, for the manufacture of the wood, on areas designated by the local Waters and Forests agent. They must cover the furnace smokestacks with a metallic screen, fine enough to prevent any cinders from coming out, and must take every precaution which is prescribed by the Waters and Forests agent. They are besides bound to conform to the relating laws and regulations. They will in any event be held responsible for damages which may result from the use of these machines.

Art. 39. - If it is recognized that the purchasers cannot find a sufficient quantity of withes among the products which they have purchased, and provided the stand allows it, they can be granted free on the authorization of the local Waters and Forests agent in charge. They will be cut on places designated by the local agent or his representative by workmen agreed upon by him, and cannot be removed until after having been counted by the aforesaid agent or his delegate.

\section{PART IV. - LOGGING}

Art. 40. - The hauling shall take place along roads designated in the sales report or sales circular. Nevertheless on the purchaser's request the conservator may, while the logging is in progress, designate, other logging roads or authorize the establishment of new ones. Merely by his request the purchaser will be bound to pay the indemnity or to complete the work at his own expense, unless he gives up the privilege.

Art. 41. - Unless otherwise stipulated it is forbidden: (a) To skid timber on wagon 
roads; (b) to slide or roll wood down the slopes; $(c)$ to graze work or pack animals or allow them to pasture in the forests and even to lead them unmuzzled into felling areas stocked with seedlings or young growth. Logs or squared timbers cannot be skidded on the surface of felling areas except under unusual circumstances, which the local Waters and Forests agent will decide upon.

Art. 42. - When the purchaser wishes to dispense with the removal of small branches and other logging débris, he must burn them on areas which will be designated by the local Waters and Forests agent or his representative unless the sales circular contains an explicit authorization to scatter them on the felling area.

He must take every necessary precaution that this (brush) burning does not damage either the new growth or reserved trees, and he will be held responsible for any damage which may result even when carried out in the presence of and under the supervision of Waters and Forests officers and employees.

Art. 43. - The sawdust and bark from manufactured wood will be removed, spread on forest roads, or burned under the conditions specified in the preceding article.

Art. 44. - Unless the special sales clauses specify other periods, the logging must be completed within one year dating from April 15 following the auction.

Art. 45. - The provisions of Art. 28, relative to felling delays, are (also) applicable to logging delays.

Art. 46. - The provisions of Art. 35 are applicable to the reserves which, despite the observance of the rules governing the removal of the wood, shall be overturned or damaged by logging.

Art. 47. - The purchasers on Federal sales must pay to the communes the special subsidies, to which they must be entitled, under Art. 14 of the law of May 21, 1836, and under Art. 11 of the law of August 20, 1881, for extraordinary (exceptional) damage caused by hauling sales products on roads, classed as parish or rural.

Art. 48. - Unless waived by the Waters and Forests officer in charge the purchasers must, three days before the date fixed for the check (of the sales area): Surround with a conspicuous band all standing trees in the felling areas where reserved trees have been marked; place visible stakes near the stumps of trees felled in the felling areas where the trees were marked for cutting. They will see to it that these stakes are protected up to the date for the check. If the purchasers fail to fulfil the above requirements, it can be done at their expense in accordance with the provisions of Art. 41 of the Forest Code.

\section{PART V. - CHECK (OF SALES AREA)}

Art. 49. - Under penalty of the law the purchasers must show the imprint of the Federal marking hatchet on all wood and trees reserved, and in the felling areas marked for cutting, on the stumps of trees cut, at the time the felling area is checked over.

Art. 50. - In the felling areas, where the trees were marked for cutting, and when the stumps are removed in logging, the root bearing the imprint of the marking hatchet must remain intact in the ground.

Art. 51. - The purchaser who wishes to obtain, after the stump check, the certificate mentioned in paragraph 4 of Art. 8, must present to the Waters and Forests agent in charge receipts showing that he has made the payments required under Arts. 59 and 61 .

He must besides prove payment for the products sold on the unit of product basis when his felling area requires it.

\section{PART VI. - ACCESSORY SALE ON THE UNIT BASIS}

Art. 52. - When the sale contract binds the purchaser to make within the boundary of his felling area, in addition to the main logging, accessory fellings with the obligation 
of taking the products of these operations at a fixed price, the purchaser must complete this logging within the period fixed by the special sales clauses or as shall be indicated by the local Waters and Forests agent.

Art. 53. - The purchasers cannot, under the penalties given in Arts. 33 and 34 of the Forest Code, fell or cord wood other than that which has been designated by the local agent or his representative.

Art. 54. - He must manufacture the wood into material corresponding to the specifications established in making the (unit) price and must pile this material by classes.

Art. 55. - The scaling of the products will first be made in a preliminary report which will be checked jointly by the local Waters and Forests agent and the purchaser and approved by the conservator.

Art. 56. - The purchaser cannot remove the wood, or dispose of it, until he has obtained a permit, which will be delivered to him by the local Waters and Forests agent in charge, after the approval of the inventory by the conservator.

In case this rule is violated the purchaser must pay as damages double the value of the products unduly removed, besides the cost of stamping and registering the record of proof, and without prejudicing the punitive fines which may be levied. If the amount and grade of the wood removed have not been established, the value then shall be fixed by the officiating conservator.

Art. 57. - The purchasers of national fellings shall pay at the depository of the federal collector: (a) For an extension of three months the total amount inventoried; $(b)$ for an extension of 10 days 1 franc, 60 per cent of the total amount inventoried (not yet logged), the proportional registry charges, and, if there are any, the proportional surety charges.

The purchasers of communal or public institution felling areas shall pay for extensions the amounts indicated above: (a) At the depository of the collector for the commune or public institution, the total amount inventoried; $(b)$ at the depository of the registry collector, the proportional registry charges, and, if there are any, the proportional surety charges.

The extension shall run from the date of the approval of the inventory by the conservator.

Art. 58. - All the conditions of the present circular which are not modified by the provisions of this section are applicable to the accessory sales which form a part of it.

\section{PART VII. - LABOR AND MATERIAL}

Art. 59. - The purchasers must deduct the amount of wood given in the sale circular from the material felled and furnish it to the Waters and Forests employees, communes, public institutions, and right holders. The employees' wood and, unless otherwise stipulated, that due the communes, public institutions, and right holders, must be of good merchantable quality and put up in accordance with local usage. It must be ready for receipt on the cutting area by the dates given in the sales circular and handed to the places designated in the advertisement within 15 days counting from the time it is received. The local Waters and Forests agent's report accompanied by the acquittance of the receivers will suffice as a release for the purchasers.

Art. 60. - In fellings comprising a sale on the unit basis, when the wood to be delivered, in accordance with the preceding article, cannot be wholly secured from the material sold on this basis, they can complete it from an additional sale on the unit basis, but the wood thus levied will be included when the material is scaled, and will be paid for by the purchaser.

Art.61. - The labor and materials levied on the felling areas shall be completed up to the values given in the sales circular, under the direction of the local Waters and For- 
ests officer in charge by contractors and workmen agreed upon and when he chooses. The purchasers will pay the contractors and laborers on sight of the certificates which will be issued by this agent, and which, duly receipted by the assignees, will form a release. The payment must be made by the purchaser within 15 days counting from the delivery of the reported receipt of the labor and materials.

Art.62. - Nevertheless, so far as communal felling areas are concerned, the sales circulars can require the immediate payment for all material and labor at the depository of the communal collector, and the receipts for these payments must then be presented to the Waters and Forests officer in charge along with the papers enumerated in Art. 18. The municipal collector will pay the assignees directly upon sight of any order issued by the mayor upon the production of a receipt showing the material or labor has been received, signed by the local Waters and Forests agent, and countersigned by the officer in charge.

Art.63. - The purchasers are also obliged: (a) To dig, level, replant or sow areas occupied by their huts or workshops; $(b)$ to repair the lanes or ditches crossing or bounding the felling areas; (c) to reëstablish boundary pillars, enclosures, posts, walls, fences, etc., damaged or destroyed because of logging or hauling wood.

Art. 64. - If the purchasers fail to live up to the obligations enumerated in Arts. 59, 61, and 63 of Part VII it will be done at their cost under the direction of the Waters and Forests Service, in conformity with the provisions of Art. 41 of the Forest Code.

\section{PART VIII. - MISCELLANEOUS PROVISIONS}

Art. 65. - The sales agent which the purchaser may have, in conformity with Art. 31 of the Forest Code, cannot be the kinsman or related by marriage to the guard of the beat, nor to the local agents. He must be agreed upon by the Waters and Forests officer in charge and sworn before the justice of the peace.

Art.66. - The purchasers must: (a) Refrain from working laborers, lumberjacks, and teamsters Sundays or holidays; this rule may be waived in virtue of an authorization given by the Waters and Forests officer in charge. (b) Not employ foreign workmen except in the proportion which shall be fixed by the special sales clauses.

Each (original) purchaser must besides when working Federal forests, place or cause to be placed under the régime of the law of April 9,1898, all lumberjacks working in the felling areas either when they are doing the logging themselves, or when it is being done through contractors or when the felling areas may have been resold before exploitation began.

When repeated violations of the provisions of this article may have been proven against any purchaser, the Waters and Forests director general may decree his temporary or permanent exclusion from the auctions of felling areas of State wood, without prejudicing suits which may be brought against him.

Art.6\%. - The purchasers as well as their foremen, employees, lumberjacks, workmen, and teamsters cannot let their dogs run loose in the forests. Dogs guarding huts, workshops, or yards must always be tied or shut up.

Art.68. - The purchaser will conform, besides, to the special provisions of the Forest Code and to the ordinance of August 1, 1827, which concerns him.

Art.69. - Every violation of the conditions of the sale, for which an exemption is not given by the present "circular" or the Forest Code, will require the payment of 10 franes by right of civil damage, besides the stamp costs and the cost of registering the brief of proof, without prejudicing civil punitive suits which may be entered.

Approved May 29, 1909, by the Secretary of Agriculture. 


\title{
SALE OF FELLING AREAS ON THE STUMP BY UNIT OF PRODUCT
}

\section{Part 1. - Auction. -}

\author{
CONTRACT CLAUSES
}

Art. 1. - Sales by unit of product take place under the clauses and conditions of the general sales circular, except as modified by the provisions which follow.

Art. 2. - The sale includes, without guarantee as to area, number of trees or amount, all the timber designated in the felling area at any time during exploitation by Waters and Forests officers and employees, on condition that the purchaser fells it and works it up and pays the price based on the valuation survey approved by the Waters and Forests conservator, in accordance with the rate established by the auction record.

Art. 3. - The ownership of the wood will be conveyed to the purchaser from the date of approval by the conservator of the valuation survey. Commencing with this date, the wood counted will be at the risk and danger of the purchaser, without prejudicing the right of reservation in case of bankruptcy or of delayed payment and of the right of claiming by means of seizure in case of removal or resale.

Art. 4. - The auction will take place either by decreasing or raising the prices. It will be on all the various units of product of which the basis and method of appraisal shall be indicated in the advertisement.

The lowering or raising of the prices will be regulated at so much per cent in accordance with the basis or method of appraisal. Fractions in hundreds will not be permitted.

Art. 5. - The auction by lowering the price will take place in the following manner: The figure announced by the crier will be successively lowered, in accordance with a tariff established in advance and advertised in the auction room, until someone announces the words: "I take it." If several people are bidders simultaneously, the felling area is drawn by lot, at least unless one of them does not bid a higher price; the competition is then open between them as indicated in the following article.

Art. 6. - The auction by raising the price will be decided after the extinction of three tapers lighted in succession. If the duration of the last of the three tapers outlasts the increases in price, the auction will not be judged until after the extinction of a final fire without increase in price.

Art. 7. - In conformity with the provisions of the first paragraph of Art. 8 of the general sales circular, the purchaser will be bound to furnish security and a surety.

These securities will be received subject to the approval of the federal collector in the case of felling areas of federal wood, and subject to the approval of the mayors and municipal collectors, administrators, and public institution collectors for the felling areas of communal and public institution wood.

In case of the insolvency of securities, proven by bankruptcy or otherwise, all the amounts due shall become immediately demandable, unless the purchaser produces a new security acceptable by the collector interested. (Code Civil, Art. 2020.)

\section{Part II. - Exploitation. -}

Art. 8. - The cutting permit will be delivered to the purchaser by the local Waters and Forests officer in charge, on presentation of the certificate showing he has furnished his securities.

Art. 9. - Under penalties carried by Arts. 33 and 34 of the Civil Code, the purchaser cannot fell trees other than those which shall have been designated by the local agent or his representatives.

Art. 10. - All the wood, which shall be considered suitable for building timber or industrial manufacture by the Waters and Forests officers, shall be left in the log and cannot be cut off below the point where the local agent or his representative shall have placed his hammer mark for regulating the cutting into logs. 
The advertisement will show the minimum sizes for this wood, if there are any.

Art. 11. - Wood which has not been classed as fit for building timber or manufacture by the Waters and Forests agents shall be worked into minor construction material (small logs, split wood, poles, mine props, etc.) or into firewood (fuel, charcoal, fagots, fagot bundles, etc.) so that the commodities manufactured can enter the classes given in the sales circular used for the establishment of the price.

Art. 12. - The minor construction material will be left separate in the log, or laid out in lines of ten each, or piled between stakes according as they are regularly placed by the purchaser in a class sold by the cubic meter, by the piece, or by the stere.

Art. 13. - Unless otherwise stipulated in the special sales clauses, the firewood and charcoal will be stacked according to local usage. The piles must always contain even steres unless there is insufficient material.

Art. 14. - The fagots, bundles of fagots, etc., will be stacked in piles of 10,20 , or 25 or multiples thereof.

Art. 15. - When the bark is sold separately it will be bound in bundles; it will then be stacked as fagots or bundles of fagots.

Art. 16. - The roots and chips from chopping will be stacked in round piles.

Art. 17. - All the piles will be made according to the commodity class and in each class by lengths.

Art. 18. - If during the logging the purchaser desires to make a class of commodity other than those recited in the sales circular, he will make the request in writing of the conservator, who will fix the bases of price for the new product units and will give notice to the aforesaid purchaser in writing.

In case this rule is broken the price of the new commodity classes will be fixed officially by the conservator, without prejudicing the application of Art. 69 of the general circular.

Art. 19. - At any time during logging the agents can check the wood to make sure of its quantity and class; the piles which shall have been broken will be at once restacked by the purchaser.

Art. 20. - The purchaser will convert and arrange for inclusion in the scaling: (a) The wood resulting from windfall, windbreak, and from surveying lines, situated within the felling area. However, he will not be held to this obligation if the value of the aforesaid wood exceeds by 10 per cent the total amount of the felling area. (b) The wood from lopping if there is any.

Art. 21. - As the conversion proceeds, wood of all kind, except the trees in the log, will be (if there is any) collected at the areas indicated by the special sales clauses. In any case it will be arranged for scaling as directed by the Waters and Forests agents or their representatives.

Art. 22. - The purchasers can have the special clauses waived for the conversion of branches having at the large end a maximum circumference, determined according to local usages and indicated in the advertisement, on condition that they conform to the prescriptions of the aforesaid clauses governing the destination for these products.

Art. 28. - The time for felling and converting (including the grouping, piling, or stacking) will be established by the special sales clauses.

Art. 24. - The withes for the fagot bundles, fagots and bark, resulting from the sale, will be given to the purchaser free of charge, who will gather them at his expense under the superintendence of the local guard in the places designated by the range officer. If the Waters and Forests agents judge that this removal cannot take place, or that it should be limited to certain species, mention will be made in the sales circular.

Art. 25. - Before the permit for removal is given the workmen cannot help themselves, for their own use, to anything except brambles, parasitic plants, or remnants designated by the local guard. The removal of this wood and the use of any other kind 
of product will be treated as trespass, and prosecuted in conformity with the provisions of the Forest Code.

Part III. - Scaling. --

Art. 26. - As soon as the felling area shall have been made ready for receival under the conditions above determined, a scale report will be drawn up and checked with the purchaser, who will be duly notified. The report will be signed by the officers and employees present and by the purchaser or his representative; if he does not want to sign or if he is absent this will be noted. This certificate will be submitted for the approval of the conservator. Thus approved it will govern the amount due from the purchaser. Partial scaling can be authorized by the conservator under exceptional circumstances of which he will be the sole judge and under the official conditions of policy which he shall determine.

Art. 27. - Eight days before the date fixed for the scaling by the local Waters and Forests officer the purchaser must furnish this agent an inventory of the products to scale.

Art. 28. - The wood classed by the Waters and Forests agents as building material and for manufacture shall be cubed as cylinders having a height equal to the length of the $\log$ and a base equal to the circumference (or diameter of the circumference) or average diameter at the middle of the log. The allowances on the length, circumference, and diameter shall conform to the methods of measurement and volumetric tables used locally and indicated in the advertisement. Circumferences and diameters will be measured outside the bark for broadleaves and inside the bark for conifers. When the butt (culeé) of the tree is not cut (level with the grass) the point to measure the length (of the butt $\log$ ) from will include two-thirds the stump height.

Art. 29. - The minor construction wood kept in the log, as stated in Art. 12, shall be scaled as wood for building or manufacture.

Art. 30. - All the other products shall be counted in the class to which they naturally belong according to method of conversion, grouping, and piling.

Art. 31. - The stacks of wood piled between stacks shall be treated as rectangular prisms having the same length as the wood, and the width and height of the pile.

Art. 32. - The minor construction material designed for the mines can be partially peeled according to custom without any increase in value on account of the loss in volume.

Part IV. - Removal of the Wood. -

Art. 33. - The purchaser cannot remove any wood until he has obtained a permit which will be delivered to him by the local Waters and Forests officer in charge, after the approval of the scale report by the conservator. In case of violation the purchaser will be bound to pay as damages twice the value of the wood removed, in accordance with the price fixed by the auction record. If the amount and quality of this wood cannot be regularly proven, its value will be fixed officially by the conservator. The removal of the wood before the approval of the scale report by the conservator will besides involve the application of Art. 388 of the Penal Code.

Art. 34. - Unless otherwise stipulated in the special sales clauses, the removal must be completed within a period of one year counting from April 15 following the sale.

Part V. - Price of Sale."- Cost of Auction. - Registry and Stamp Rights. -

Art. 35. - The purchasers of felling areas of Federal wood will pay at the Federal collector's depositories: (a) Within a term fixed by the special clauses, which cannot exceed six months, the main price of the sale regulated by the scale report duly approved; (b) within a period of 10 days, 1 franc, 60 per cent of the amount of the sale so far as the fixed stamp rights and registry of the certificates relating to the sale as for 
all other costs, and the proportional rights of registry and of surety on the amount of the sale increased by the tax of 1 franc, 60 per cent. (Decision of the Minister of Finance, April 7, 1883.)

The fixed right of the surety certificate will be paid besides within the same period after the first scaling. The terms will run from the date of the approval by the conservator of the scale report.

Art. 36. - The purchasers of felling areas of communal and public institution wood, will pay within the terms indicated in the foregoing article. (a) At the communal collector's depository or that of the public institution owner, the principal price regulated by the scale report duly approved. (b) At the registry collector's depository, the fixed stamp rights and for the registry of the deeds relating to the sale and for the surety certificate, the proportional rights of registry and surety on the total sale, and, if there are any, also the fixed stamp rights and registry of the deeds before or after the sale, that is to say, for the marking standards report and survey notes.

Art. 37. - The total of the charges of all kinds, for work or materials to be furnished by the purchaser, and whose valuation in money is given in the advertisement, will be deducted as a whole from the total of the sale on the scale report; the amount remaining will form the chief price of the sale.

In case of partial scaling this deduction will be made from the first scale report.

June 18, 1903.

\section{APPENDIX H}

\section{FRENCH FOREST LITERATURE (1870-1912)}

(a) FORESTRY PROPER, ETC.

Title

Etude sur la production du chêne et son emploi en France

Etude sur la carbonisation des bois (système Dromart)

Etude sur les forêts du Risoux

Cri d'alarme sur les hais d'industrie, de Chauffage et le charbon de terte

Mise en Valeur des sols pauvres au moyen de la culture de Résineux

Le Mont - Boron

Les bois employés dans l'industrie

De l'influence des forêts sur le climat

Etudes sur l'aménagement des forêts

Service forestier de l'Algérie (Rapport)

Notice sur les bois de la Nouvelle-Calédonie

Notes sur le róle économique des associations pastorales (Pyténées)

Histoire du chêne dans l'antiquité et dans la nature

Histoire de la forêt de Fontainebleau

Petit manuel du garde particulier des bois et forêts

La greffe à la portée des classes populaires

Manuel de sylviculture

Enquête sur les incendies dans les landes de Gascogne

Des rapports entre les racines et les branches des arbres

Ecorcement des bois par la chaleur

Carbonisation des bois en vases clos

Exposition collective des produita d'économie rurale et forestière du royaume de Bohême

Observations sommaires sur le progrèa rural (région des Pyrénées)

Expériences forestières 1871-1874

La aylviculture au Conseil $\mathrm{g}^{\mathrm{al}} \mathrm{d}^{\text {'Auxerre (Reboisement) }}$

\begin{tabular}{lll}
\multicolumn{1}{c}{ Author } & \multicolumn{1}{c}{ Place } & Date \\
Bagneris & Paris & 1870 \\
Desnoyers Roux & Fontainebleau & 1870 \\
Gurnaud & Besancon & 1870 \\
Boutroux & Gien & 1870 \\
& & \\
Fillon & Paris & 1870 \\
& & \\
Guiot & Nice & 1871 \\
Noerdlinger & Paris & 1872 \\
Roussegu & Carcassonne & 1872 \\
Tassy & Paris & 1872 \\
Tassy & Paris & 1872 \\
Sebert & Paris & 1872 \\
Calvert & Tarbes & 1872 \\
& & \\
Coutsce & Paris & 1873 \\
Domet & Paris & 1873 \\
Dommanget & Paris & 1873 \\
Fandrin & Marseille & 1873 \\
Bagnéris & Nancy & 1873 \\
Fare & Paris & 1873 \\
Regimbeau & Nimes & 1873 \\
du Roscoät & Paris & 1873 \\
Vincent & Paris & 1873 \\
de Dombrowski & Prague & 1873 \\
& & 1873 \\
Calvet & Pau & 1874 \\
Le Chauf & Moulins & 1874 \\
de Kirwan & Auxerre & \\
& & \\
& &
\end{tabular}


L'amënagement des forêts (2d Edit.)

Calepin d'aménag ${ }^{t}$ de la forêt domanle des Reelas

Les forêts à l'Exposition de Vienne 1873

Notice forestière aur les landes de Gascogne

Notes sur les associations pastorales dans les Pyrénées

Les bois indigènes et étrangers

Dictionnaire des forêts ( $2^{\mathrm{d}}$ tirage)

Le reboisement et le regazonnement des Alpes (2d Edit.)

Des arbres resineux et de leur utilité particulière pour le boisement des frickes

L'Administration des forêts au concours régional de Troyes

Les forêts et les pâturages du Comté de Nice

Les forêts du Charollais sous les ducs de Bourgogne

Souvenir d'une excursion forestière dans l'inspection de Loris

Nouvelle méthode d'exploitation des futaies

Le déboisement et le reboisement dans les Alpes (Montagne d'Aurouse)

Forêt domaniale de Chinon, Repeuplements (de 1846-1875)

Considérations et recherches sur l'élagage dez essences forestières

Mémoire sur la carbonisation des bois en forêt

Examen des noveaux appareile pour l'écorcement des bois sous l'action de la chaleur

De l'écorcage du chêne-les écorces à tan

Les torrents des Alpes et le pâturage ( $2^{d}$ Edit.)

Herbier des fermes plants provenante de la pépinicré d'Arpajon (Caubal)

Le reboisement dans l'Ardèche

Rapport sur l'écorçage à la vapeur prégenté au Congrếs des tanneurs

Les forêts communales en 1877

De l'asséchement du sol par les essences forestières

Du déboisement des campagnes dans les rapports avec disparition des oiseaur utiles à l'agriculture

Considérations générales sur l'aménag ${ }^{t}$ des bois

Calepin d'aménagt de la foret communale Urbacke

Compte de la gruerie des baillages d'Autun et de Mont Cenis pour l'année 1419

Détermination du revenu annuel des forêts taillis sous futaie

Manuel de l'économie alpestre (trad. de l'allemand)

Mélanges forestiers (Expos. universelle de 1878)

La forêt

Manuel de sylviculture (2d Edit.)

Note sur deux procédés pour activer le développement des racines latérales du chêne en pépinière

Rapport sur le reboisement des terrains en pente de l'arrondissement de Chaumont

Outils pour semis et plantations

Notice sur l'elagage des arbres

Ecimage des fennes peupliere de la vallé l'Ourcq

Notice sur le débit et les emplois du chêne romre et du chêne pédoneulé

Notice sur les divers emplois du hêtre

Notice sur le débit et les emplois du sapin de l'épicéa et du mélèze

Notice sur le débit et les emplois des principales essences de Pins
Bouguinat

Puton

Crouvizier

Mathieu

Croizette-

Desnoyers

Calvet

Dupont

Rousset

Mathieu

Renault

Croizette-

Desnoyers

Guiot

Picard

Le Grix

Vaulot

Cardot

Thomas

Martimet

Dromart

Tissot

Perrault

Marchand

Blackere

Blackere

Negociants

tanneurs

Jacquot

Burger

Burger

Houba

Crouvizier

Picard

Puton

Schatzmann

Divers

Muller

Bagneris

Leveret

Arbeltier do

les Boullage

Prouré

Martinet

Burger

Gallat et Gast

Croizette-

Desnoyers

Gallot

Chalons

S. Saône

Paris

1874

1874

Epinal

Paria

Clermont

1874

1874

1874

Paris

1874

Paris

Paris

1875

1875

1875

Mirecourt $\quad 1875$

Troyes

1875

Paris

Autun

1875

1876

1876

$\begin{array}{ll}\text { Langres } & 1876 \\ \text { Paris } & 1876\end{array}$

Paris

1876

1876

1876

Paris

Paris

1876

Paris

1876

Paris

Arpajon

1876

1877

Paris $\quad 1877$

Tours

1877

Pithiviers $\quad 1877$

Paris $\quad 1877$

Paris

1877

Arlon

1877

Epinal

1877

Autun

1877

Paris

1877

Lausanne

1877

Paris

Paris

Nancy

1878

1878

1878

1878

Chaumont

1878

Dieppe

1878

Paris $\quad 1878$

Meaun $\quad 1878$

Paris 1878

Croizette-

Desnoyers

Paris

Paris

Paris

1878 
Title

Notice sur les étais de mines en France

Notice sur l'induatrie du Sabotage dans le départ te la Lozère

Notice sur le débit des bois de fen, lux mode vente et les procédés de carbonisation employé en France

Recherces expérimentales sur les écorces à tan du chếne Yeuse

Notice sur l'industrie des feorces à tan

Notice sur l'emploi du bois dans la fabrication de la pate à papier

Notice sur le gemmage du Pin maritime

Notice sur le contrôle et les comptabilité relatif a les gestion des forêts

Métérologie comparée agricole et foreatière

Notice sur les dunes de la Coubre

Cours d'aménsgement des forêts

Du partage des affectations en un même nombre de divisions dans les aménagements de futaie

Cahier d'aménsgt. - Méthode par contenance exposé sur la forét des Epérons

Un péril d'ęu l'Algérie - le déboisement

Catalogue des produits et exploitations forestres de la Hongrie (Exposition universelle de 1878)

Catalogue des collections exposées par le service des forêts de l'Algérie à l'Exposition de 1878

Catalogue des collections exposées par l'Administration des forêts

Notice sur le débit et les emplois du châtaignier des érables, du frêne, etc.

Le paturage our les terrains gazonnés et boisés

L'art forestier frangais à l'Exposition de 1878

L'art forestier a l'Exposition de 1878

La culture des osiers

Easai pratique du reboisement des montagnes

Le chêne-liège en Algérie

Aménagem ${ }^{t}$ des foréts-Estimation

Calepin d'aménagt de la forêt domanle de Montagne

Statistique forestière (texte et atlas)

Bibliographic de l'Exposition forestière de 1878

Determination du revenu des futaies jardinées

Aménagement des forêts - Estimation en fonds et Superficié

Restauration des forêts et pAturages du sud de la province d'Algérie

Traité sur les différents Cubages des bois en grume

Procèg-verbal d'aménagt de la forét domanle de Darney Martinvelle

Rapport sur le matériel et les procédés des industries agrioules et forestières

Une exposition forestière improvise en Auvergne

Restauration des forête et des paturages du sud de l'Algérie

Vingt années d'économie alpestre Suisse

Traité pratique de la culture des Pins a grandes dimensions ( $3^{\text {d }}$ Edit.)

Le traitement des bois en France à l'usage des particuliers

Traité de sylviculture pratiqué en Sologne

Conférence sur le reboisemt des terrains Vagues

Drainage des foréts

Essai des engrais chimiques sur la végetation forestière

Culture du chene-liège - (Rapport)

\begin{tabular}{|c|c|c|}
\hline Author & Place & Date \\
\hline $\begin{array}{l}\text { Thélu } \\
\text { Groojean }\end{array}$ & $\begin{array}{l}\text { Paris } \\
\text { Paris }\end{array}$ & $\begin{array}{l}1878 \\
1878\end{array}$ \\
\hline Larzillière & Paris & 1878 \\
\hline Rougset & Paris & 1878 \\
\hline de Kirwan & Paris & 1878 \\
\hline Jolivet & Paris & 1878 \\
\hline $\begin{array}{l}\text { Croizette- } \\
\text { Deenoyers }\end{array}$ & Paris & 1878 \\
\hline Boppe & Paris & 1878 \\
\hline Mathieu & Nancy & 1878 \\
\hline $\begin{array}{l}\text { Vasaelot de } \\
\text { Régné }\end{array}$ & Paris & 1878 \\
\hline $\begin{array}{l}\text { Broilliard } \\
\text { de Schwartz }\end{array}$ & $\begin{array}{l}\text { Nancy } \\
\text { Paris }\end{array}$ & $\begin{array}{l}1878 \\
1878\end{array}$ \\
\hline Gurnaud & Parig & 1878 \\
\hline de Metz-Noblat & Paris & 1878 \\
\hline Guiot & Paris & 1878 \\
\hline $\begin{array}{l}\text { Exposit. univer- } \\
\text { selle }\end{array}$ & Alger & 1878 \\
\hline $\begin{array}{l}\text { Exposit. univer- } \\
\text { Belle }\end{array}$ & Paris & 1878 \\
\hline $\begin{array}{l}\text { Bruant, } \\
\text { Lazillière }\end{array}$ & Paris & 1878 \\
\hline Rousset & Nice & 1878 \\
\hline de Kirwan & Bruselles & 1879 \\
\hline $\begin{array}{l}\text { Bouquet de } \\
\text { la Grye }\end{array}$ & Paris & 1879 \\
\hline $\operatorname{Cos} 2$ & Berne & 1879 \\
\hline Tanoriou & Beaune & 1879 \\
\hline Zamey & Alger & 1879 \\
\hline Fallotte & Carcassonne & 1879 \\
\hline Colnenne & Epinal & 1879 \\
\hline $\begin{array}{l}\text { Adminis on des } \\
\text { forêts }\end{array}$ & Paris & 1879 \\
\hline de Kirwan & St. Quentin & 1879 \\
\hline Puton & Paris & 1879 \\
\hline Tallotte & Carcassonne & 1879 \\
\hline Reynard & Alger & 1880 \\
\hline Zemee & Angers & $1880^{\circ}$ \\
\hline Bocquentin & Mircesnt & 1880 \\
\hline Durand-Claye & Paris & 1880 \\
\hline de Kirwan & Bruxelles & 1880 \\
\hline Reynard & Alger & 1880 \\
\hline Schwartzmann & Lausanne & 1880 \\
\hline Delamarre & Paris & 1881 \\
\hline Broilliard & Nancy & 1881 \\
\hline Girard & Romorantin & 1881 \\
\hline Muel & Epinal & 1881 \\
\hline Houba & Besançon & 1881 \\
\hline Muel & Epinal & 1881 \\
\hline Chasin & Paris & 1881 \\
\hline
\end{tabular}


Title

De l'influence des forêts sur le climat et l'origine des sources Projet d'aménagt des bois de Rochefort

Forêt commule de St. Martin Lautasque. - Projet de réglemt d'exploitation

Calepin d'aménagt de la forêt Commule de Gemaingoutte

A travers la Grande - Bretagne

L'Exposition forestière au concours régional d'Amiens

Une exposition forestière en Tourraine

Calepin d'aménagt de la forêt du Valse Senones

Etude sur l'économie pastorale des $\mathrm{H}^{\text {les-Alpes }}$

Culture et exploitation des Arbres

Essais de reboists dans la Montagne Noire

Note sur le aartage dans l'arrondt de Rocroi

Traité pratique du boisement et reboisement des montagnes, landes, etc.

Eseai sur les repeuplements artificiels et la restauration des vides et clairières des forêts

Rapport sur me nouveau procédé de culture du Chêne-liège

Petit manuel forestier

Manuel d'économie forestière (Notions d'aménagement)

De l'influence des forets sur les pluies, l'alimentation des sources

Mémoire sur l'aménagt de la Conmune de Syam

Calepin d'aménagt de la forêt Commule de Fraize

Etude sur les causes du déboisement en Algérie et les moyens d'y remédier

L'impôt foncier des forêts-détermination du revenu imposable

Note sur l'éstimation des saillis en cruissance

Vadé-mécum du forestier

Des plantations qui bordent les Loudes

Exposé des faits général relatifs à la production forestière sous le climat de la France

Notions de sylviculture enseignées a l'Ecole normale desVosges

Cours élémentaire de la culture des bois $\left(6^{\mathrm{e}} \mathrm{Ed}\right.$.)

Création de peuplements artificiels et boisement deg terrains nus

Reboisement et aménagement des eaux dans l'Aude

L'art de planter (Arond. de l'allemand)

Etude sur les vices du bois

La question des reboisements et le rôle des Eucalyptus en Algérie

Calepin d'aménag ${ }^{t}$ de la forét de Raon l'Etape

Catalogue des collections exposées a l'Expositon internatle d'Amsterdan en 1883. Service des forêts de l'Algérie

Les forêts

Bois et Forête

Philosophie sur la sylviculture

Sur la régénération naturelle des futaies

Etude aur l'éxpérimentation forestière en Allemagne et en Autriche

Manuel du cultivateur de Pins en Sologne

Achat, analyse et préparation des graines résineuses employées par l'Administration des forêts

Les repeuplts artificiels dans les forêts d'Arques et d'Eaux

Considérations sur la production et le traitement des plantes sur la créstion et l'entretien des forêts

Recherches expérimentales sur la dessiccation artificielle des bois

Notes sur les boisements artificiels des Vosges. Acclimatation du chêne rouge d'Amérique

\begin{tabular}{|c|c|c|}
\hline Author & Place & Date \\
\hline Maistre & Montpellier & 1881 \\
\hline Houba & Liege & 1881 \\
\hline Burel & Nice & 1881 \\
\hline Crouvizier & Epinal & 1881 \\
\hline Boppe & Nancy & 1881 \\
\hline Vion & Amiens & 1881 \\
\hline Martines & Paris & 1881 \\
\hline Crouvizier & Epinal & 1881 \\
\hline Briot & Paria & 1881 \\
\hline Rousset & Valence & 1882 \\
\hline $\begin{array}{c}\text { Cormouls- } \\
\text { Hautes }\end{array}$ & Mazamet & 1882 \\
\hline Cornebois & Parie & 1882 \\
\hline Levavasseur & Talaise & 1882 \\
\hline Noël & Paris & 1882 \\
\hline Chasin & Paris & 1882 \\
\hline Vaulot & Langres & 1882 \\
\hline Galmiche & Grenoble & 1882 \\
\hline Dicky & Itrasbourg & 1882 \\
\hline Gurnaud & Besançon & 1882 \\
\hline Gurnaud & Epinal & 1882 \\
\hline Chitier & Miliana & 1882 \\
\hline Puton & Paris & 1882 \\
\hline Devarenne & Andelot & 1882 \\
\hline Caquet & Paris & 1883 \\
\hline Houba & Berne & 1883 \\
\hline Boppe & Nancy & 1883 \\
\hline Muel & Nancy & 1883 \\
\hline $\begin{array}{c}\text { Lorentz et } \\
\text { Parade }\end{array}$ & Paris & 1883 \\
\hline Boppe & Nancy & 1883 \\
\hline Cautegril & Nancy & 1883 \\
\hline de Manteuffel & Paris & 1883 \\
\hline Marchal & Paris & 1883 \\
\hline Naudin & Paris & 1883 \\
\hline Crouvizier & Epinal & 1883 \\
\hline Crouvizier & Alger & 1883 \\
\hline Lesbazeilles & Paris & 1884 \\
\hline Robinson & Paris & 1884 \\
\hline Guinier & Toulouse & 1884 \\
\hline Guinier & Paris & 1884 \\
\hline $\begin{array}{c}\text { Rensset et } \\
\text { Bartet }\end{array}$ & Paris & 1884 \\
\hline Cannon & Orleans & 1884 \\
\hline Thil. & Paris & 1884 \\
\hline Prouvé & Paris & 1884 \\
\hline Parisel & Bruxelles & 1884 \\
\hline Marcus & Metz & 1884 \\
\hline Gazin & Besançon & \\
\hline
\end{tabular}


Title

\begin{tabular}{llr}
\multicolumn{1}{c}{ Author } & \multicolumn{1}{c}{ Place } & Date \\
Brenot & Arlon & 1884 \\
Gurnaud & Paris & 1884 \\
Crouvizier & Epinal & 1884 \\
Bagneris & Nancy & 1884 \\
Noẹl & Paris & 1884 \\
Direction des & Dóle & 1884 \\
$\quad$ forêts & & \\
Briot & Paris & 1884 \\
Guiot & Nice & 1884 \\
Caquet & Paris & 1885 \\
Bouquet de la & Paris & 1885 \\
$\quad$ Grye & & \\
Puton & Nancy & 1885 \\
Bertrand & Mouling & 1885 \\
Bertrand & Mouling & 1885 \\
Tirman et & Alger & 1885 \\
$\quad$ Mathin
\end{tabular}

De l'aménagement des futaies

La sylviculture française

Calepin d'amenagt de la forêt de Danipaire

Procès-verbal d'aménag ${ }^{t}$ de la forêt domaniale de Haye

Notes sur la statistique forestière de l'ouest de la France

Catalogue raisonné des collections exposées au Concours rẻgional de Dôle 1884

Questions alpestres

Les droits de bandite dans le Comté de Nice

Vadé mécum forestier

Guide du forestier - Eléments de sylviculture ( $8^{\circ} \mathrm{Ed}$.)

Le furetage en Chalais

Notice sur la pépinière de Royat

Notice sur les reboisements du Puy-de-Dôme

Programme général du reboisement du gouvernt général de l'Algérie

Du reboisement des propriétés particulières

Etude sur le résinage

La méthode française et la question forestière

Etude sur les taillis composés

La méthode du contrôle de Gurnaud

30, Mémoire sur l'aménagt des bois de la commune de Sysm

Notice sur la carte forestière de la région de Nancy

Statistique forestière du dép ${ }^{t}$ de l'Allier

Considérations générales sur les forêts l'Algérie

Concours régional de Nancy - Catalogue de l'Exposition forestière

Convention internationsle de reboisement

A propos des défrichemente et inondations

Forêt domaniale de Haye - Procès-verbal de reviaion de la possibilité au début de 1885

Les forêt's de la France

Les forets lorraines jusqu, en 1789

La sylviculture a l'Ecole primaire

Etude sur les plantations

Les reboisements par l'acacia

La restauration des montagnes

Guide pratique du reboist a l'ugage des particuliers

Reboisements et repeuplements

Situation au 31 décembre 1886 des travt de reboisement des environs de Barcelonnette

Etudes calorimétriques sur la combustion de bois

Notice sur l'emploi de la sciure de bois et l'usage de ls tourbe comme litère dang les écuries

La sylviculture française et la méthode de Controle (Réponse a M. Grandjesn)

Lee plans d'exploitation de courte durée

Missions forestières en Grande Bretagne, Autriche et Bavière

Les produits forestièra a l'Exposition de Budapest 1885

L'Exposition internat ${ }^{\text {le }}$ de 1884 a Edinbourg (Forêts)

Estimations concernant la propriété forestière

Les forêts de l'Abbaye de Citeaux

Les parcs forestiers

Notes sur les orangeries et les irrigations de Blida

La forét à traver le monde

Extraits du rapport sur le reboisement de la côte de Mslzeville près Nancy

Le propriétaire planteur. Manuel pratique des reboisements

Du boisement des sols pauvres

Cours de Technologie forestière (Nouv. Edit.)

Moureton

Blanc

Gurnaud

Burel

Grandjean

Gurnsud

Henry

de Guiny

de Guiny

Direction des forêts

Burger

Pissot

Bartet

Depelchun

Guyot

Caquet

Bert

Caquet

Benardeau

Rousseau

de Kirwan

Service du

reboisement

Petit

Jolivet

Gurnsud

Gurnsud

Boppe et Reuss

Boppe

Reuss

Puton

Picard

Caquet

Joly

Caquet

Munich et

Bremeau

Cannon

Pruvost

Boppe
Paris

1885

Paris

Besançon

1885

Paris

Paris

Besançon

1885

1885

1885

1885

Nancy

1885

Moulins $\quad 1885$

Alger $\quad 1885$

Nancy 1885

Meaux

1885

Paris

1885

Nancy

1885-86

Tours

1886

Nancy $\quad 1886$

Nevers $\quad 1886$

Alger $\quad 1886$

Nevers $\quad 1886$

Paris 1886

Carcassonne $\quad 1886$

Bruxelles $\quad 1886$

Barcelonnette $\quad 1886$

Lyon

1886

Vitry le François 1886

Besançon

1886

Bessnçon

1886

Paris

Paris

Paris

Parig

1886

1886

1886

1886

Autun

1887

Nevers $\quad 1887$

Paris $\quad 1887$

Nevers $\quad 1887$

Nancy $\quad 1887$

Orleans

1887

Troyes

1887

Paris

1887 
Title

Résistance des bois à la flexion et a la complexion

Des formations du bois rouge et du bois gras dans le aapin et l'épicéa

Les Landes de Gascogne

L'art forestier et le contrôle

Economie forestière - Principes généraux - le jardinage Estimation

Variations et équilibre de l'secroisst en forêt

De l'exploitabilité de la possibilité et de leurs differents modes

L'aménagement des forêts (V. Edit.)

Les forkts de la Meuse et leurs produits

A travers la Tunisie

Le Tarif des dousnes et les produits forestiers

Exposition internatle de Toulouse (Forets catalogue)

La culture forestière dans la région du Chablais

Etat des forêts de la France - Travaux à faire - Mesures a prendre

Le Sapin des Vosges - Etude d'estimation

Statistique forestière de Meurthe-et-Moselle

Etude sur la constitution normale des futais jardinées

Recherches sur la production ligneuse pendant la phase des coupes de régenération St. Memoire

De l'influence des éclaircies sur l'accroissement diamétral des aspins

La restauration des montagnes

Destruction de la larve du hanneton par le pal ot la Ceuzine

Dea emplois chimiques du bois dans les arts et l'industrie

L'Industrie de la carbonisation dea bois en France et la dénaturation des alcools

Traité d'économie forestière

La dune littorale

Cours d'aménagement professé a l'Ecole forestière (18851886) 2 cahiers

Les forêts de l'arrondt d'Embrun

La sylviculture dans les Vosges

Buffon et la forêt communale de Montbard

Les Alpes-Maritimes - Considérations au point de vue forestier pastoral et agricole

Concours régional d'Autun - Espositon forestière

De la situation des forêts d'essences mélangées dans d'le de Is Réunion

Influence des éclaircies ( $\mathrm{p}^{\mathrm{T}}$ st $\mathbf{2}^{\mathrm{d}}$ Mémoires)

Trajté de sylviculture

Considérations diverses à propos de taillis

Première étude sur les peuplements réguliers Sapin

Recherches sur le traitement des sapinières vosgiennes

Etude sur la place de production No $^{\circ}$ forét domaniale de Haye (St. Mémoire)

Causerie sur les bois de la Guyane

Diagrammes et calculs d'accroissement

Influence de la forêt et la consistance des peuplements

Influence du déboisem ${ }^{t}$ au point de vue de l'action torrentielle dang la $\mathrm{H}^{\text {te }}$-Ariège

Economie résumée de la foret

Procès-verbal de révision de la possibilité et de l'sménagt

St. Seire - St. Jean - Fontaine pre période 1887

Atlas forestier de la France par départements

Statistique forestière du départ ${ }^{t}$ du Cautal

Les forêts de l'Algérie

\begin{tabular}{|c|c|c|}
\hline Author & Place & Date \\
\hline Sergent & Paris & 1887 \\
\hline Mer & Paris & 1887 \\
\hline Chambreleut & Paris & 1887 \\
\hline Gurnaud & Besançon & 1887 \\
\hline Vaulot & Paria & 1887 \\
\hline Gurnaud & Paris & 1887 \\
\hline de Kirwan & Bruxelles & 1887 \\
\hline Tasgy & Paris & 1887 \\
\hline Larzillière & St. Mihiel & 1887 \\
\hline Baraban & Paris & 1887 \\
\hline Puton & Nancy & 1887 \\
\hline $\begin{array}{l}\text { Ministère de } \\
\text { l'agriculture }\end{array}$ & Foire & 1887 \\
\hline Gazin & Paris & 1887 \\
\hline Tassy & Paris & 1887 \\
\hline Puton & Epinal & 1887 \\
\hline Huffel & Nancy & $1887-88$ \\
\hline Burel & Paris & 1888 \\
\hline Bartet & Nancy & 1888 \\
\hline Mer & Paris & 1888 \\
\hline de Courson & Paris & 1888 \\
\hline $\begin{array}{l}\text { Croisette- } \\
\text { Desnoyers }\end{array}$ & Paris & 1888 \\
\hline Petit & Lyon & 1888 \\
\hline Petit & Lyon & 1888 \\
\hline Puton & Paris & 1888 \\
\hline Grandjean & Poitiers & 1888 \\
\hline Reuss & Nancy & 1888 \\
\hline Gouget & Paris & 1888 \\
\hline Claudot & Epinal & 1888 \\
\hline Perdrizet & Dijon & 1888 \\
\hline Boye & Lille & 1888 \\
\hline Adon des forets & Autun & 1888 \\
\hline Goizet & St. Denis & 1888 \\
\hline Bartet & Nancy & $1888-89$ \\
\hline Boppe & Paris & 1889 \\
\hline Suckaux & Paris & 1889 \\
\hline Bartet & Paris & 1889 \\
\hline Mer & Paris & 1889 \\
\hline Bartet & Nancy & 1889 \\
\hline Dupre & Melun & 1889 \\
\hline Bartet & Nancy & 1889 \\
\hline Ebermayer & Nancy & 1889 \\
\hline Vautrin & Foixe & 1889 \\
\hline Vaulat & Paris & 1889 \\
\hline Bartet & Nancy & 1889 \\
\hline $\begin{array}{l}\text { Benardeau et } \\
\text { Cuny }\end{array}$ & Paris & 1889 \\
\hline Gebhart & Aurillae & 1889 \\
\hline Combee & Alger & 1889 \\
\hline
\end{tabular}


Title

Statistique des forêta de la province d'Oran (Algérie)

Les forêts du départ't de l'Yonne

Statistique forestière du départ $\mathrm{t}^{\mathrm{t}} \mathrm{du}$ Loiret

Notice sur les foréts de la Tunigie

Le Var - Considérations au point de vue forestier

Quelques considérations sur les forêts vosgiennes

Mission forestière en Roumanie

Exposition universelle - Algérie, - Catalogue des collections de bois exposées

Le Pavillon forestier au Trocadéro. Exposition universelle de 1889

L'inventaire des massifs forestiers (tradt de l'allemand)

Traité forestier pratique

L'art de planter avec succès et économie

Les boisements productifs en toute situation

Guide pratique du reboisement

Moyen d'activer l'allongement des jeunes sapins

Trente jours à la Réunion.- Notes et impressions forestières

Guide théorique et pratique de cubage des bois

Compte Rendu des observations metéorologiques concernant les onze années 1878-1888

Les dunes de Belgique

Les dunes mourantes d'Ain Sebue (Algérie)

Mise en valeur des terres incultes du massif central de lo France

La méthode du contrôle à l'Exposition de 1889

Note sur une nouvelle méthode forestière dite du contrôle de Gurnaud

L'aménagt des forêts communales et du cantonnement forestier de Montbard

Notice forestière sur le départ ${ }^{t}$ de l'Aude

Le bois de Saône et Loire

Les forets de la Roumanie

Congrès international forestier de Vienne

Les Forêts

Notice sur les plantations de bois régineux dans la forêt de Culonusay (Jura)

De l'influence exercée par l'époque de l'abatage sur la production et le développement des rejets de souches

Exposition universelle de 1889 - Matériel et procédés des exploitations rurales \& forestières

Notice historique sur la forêt Communle d'Epinal

Une excursion fòrestière dans l'Eat

Les hauts plateaux oranais

Les forêts et le commerce des bois en France

Un reboisement dans les Indes anglaises

Les forêts du Japon

Forestiers et Bacherons

A travers le Japon

Les forêts et le commerce des bois en France

Traité d'économie forestière. Aménagment

Décadence de la propriêté boisée et souffrances des populations forestières

Sur les causes de variation de la densité des boia

Note sur l'accroissement et le rendement en matière et en argent d'une parcelle peuplée de bois resineux

Recherches sur le couvert des arbres de tailles sous futaie

Traitement des bois tailles

Sur quelques expériences effectuées a la pépinière des Bellefontaines

De l'infuence des sols boisés gur les climats

Notice sur les inondations de 1888 \& 1891 et sur le déboisement dans le Roussillon

\begin{tabular}{|c|c|c|}
\hline Author & Place & Date \\
\hline Mathieu & Alger & 1889 \\
\hline Picard & Auxerre & 1889 \\
\hline Domet & Orléans & 1889 \\
\hline Lefébore & Tunis & 1889 \\
\hline Boyé & Lille & 1889 \\
\hline Gazin & Epinal & 1889 \\
\hline Buffel & Nancy & 1889 \\
\hline Goizet & Alger & 1889 \\
\hline de Kirwan & Bruxelles & 1889 \\
\hline Fankanser & Neufchstel & 1889 \\
\hline Gurnaud & Paris & 1890 \\
\hline Bouquinst & Laignes & 1890 \\
\hline Fillon & Paris & 1890 \\
\hline Rousseau & Paris & 1890 \\
\hline Mer & Paris & 1890 \\
\hline Girod-Genêt & Alger & 1890 \\
\hline Frockst & Paris & 1890 \\
\hline Bartet & Parig & 1890 \\
\hline Baraban & Paris & 1890 \\
\hline Riston & Paris & 1890 \\
\hline Gebhart & Paris & 1890 \\
\hline Gurnaud & Paris & 1890 \\
\hline de Blonay & Lausanne & 1890 \\
\hline Jerdrizet & Troyes & 1890 \\
\hline Rousseau & Carcassonne & 1890 \\
\hline Gaudet & Paris & 1890 \\
\hline Huffel & Paris & 1890 \\
\hline Boppe & Paris & 1890 \\
\hline de Venel & Paris & 1891 \\
\hline Gurnaud & Pario & 1891 \\
\hline Bartet & Nancy & 1891 \\
\hline Divers & Paris & 1891 \\
\hline Claudot & Epinal & 1891 \\
\hline Cannon & Paria & 1891 \\
\hline Mathieu & Alger & 1891 \\
\hline Mélard & Paris & 1891 \\
\hline Ussēle & Paris & 1891 \\
\hline de Kirwan & Bruxelles & 1891 \\
\hline Heiner & Chatelles & 1891 \\
\hline Usiete & Paris & 1891 \\
\hline Mélard & Paria & 1891 \\
\hline Puton & Paris & 1891 \\
\hline Boneard & Paris & 1891 \\
\hline Mer & Paria & 1892 \\
\hline Mongenst & Grenoble & 1892 \\
\hline Bartet & Paris & 1892 \\
\hline Bertrand & $\begin{array}{l}\text { Clermont- } \\
\text { Ferrand }\end{array}$ & 1892 \\
\hline Bartet & Nancy & 1892 \\
\hline $\begin{array}{l}\text { Loze } \\
\text { de Boixo }\end{array}$ & $\begin{array}{l}\text { Toulouse } \\
\text { Perpignay }\end{array}$ & 1892 \\
\hline & Perpignay & 1892 \\
\hline
\end{tabular}


Title

Influence des forêts sur la production de la plaine

Histoire de la forÁt d'Orléans

Guide du forestier ( $g^{e} \mathrm{Edit}$ )

La Sxpinière idéale

Les forêts de chêne vert

Etude sur la place de production No 1. (Forêt de Cham-, penoux)

Bréviaire du ligueur

Etude sur la sylviculture

Notes sur la durée des traverses en bois (Comple des chem. de fer. P. L. M.)

Le chêne-liège, sa culture, son exploitation

Plantations résineuses de la Champagne

Nature et utilisation des produits forestiers des Pyrénées-Orientales

Les arbres et les peuplements forestiers

La forêt et la digette du fourrage

Du calcul de la possibilité dans les futaies jardinées

Une question de méthode

La question forestière algérienne devant le Sénat

Le Haut-Perche et des forêts domaniales

Note sur les forêts et le reboist dans les Pyrénées-Orien ${ }^{\text {les }}$

Le chêne liège, Sa culture, Son exploitation

$3^{\text {e }}$ Mémoíre sur l'influence des éclaircies

Le traitement des bois en France

Déboisement et reboist dans les Basses-Pyrénées

Etude économique sur le reboist ${ }^{t}$ des montagnes

Semer et planter ( $2^{\mathrm{e}}$ Edit.)

Les forêts \& le reboisem ${ }^{t}$ dans les Pyrénées-Orientles

L'extinction des torrents en France par le reboisement

La méthode du contrôle, son application à une partie de la forêt de Champenoux ( $p^{r} p^{l e}$ )

Estimations et exploitabilités forestières

Insuffisance de la production du chéne en France

Les forêts des Pyrénées

Statistique des forêts soumises au régime forestier

Quelques conseils aux sylviculteurs du Chablais

Petit manuel du proprićtaire sylviculteur

Chênes-lièges - Notice sur les forêts de l'Algérie

Les forêts de Cêdre

Les foréts et le reboist dans les Pyrénées-Orientles

Union landaise des propriétaires et fabricants de produits résineux

Exposition internat $t^{l e}$ de Chicago - Commissariat Spécial de l'Agriculture

L'art d'être propriétaire de bois

Culture intensive des forêts

Recherches sur la production ligneuse pendant la phase des coupes de régénération (Forêt domaniale de Haye) (place d'expces No 1)

Du prix du bois résineux dans le Doules

Influence des forets sur le climat

Le double du Périgord

L'Algérie et la commisaion aénatoriale

De la dépréciation des bois de feu

Le commerce des bois en Europe

Traité des plantations d'alignement et d'ornement

Traitement de l'epicéa dans les Alpes

Les taillis sous futaie des Vosges

\begin{tabular}{|c|c|c|}
\hline Author & Place & Date \\
\hline Jesnnel & Nice & 1892 \\
\hline Domet & Orléans & 1892 \\
\hline $\begin{array}{l}\text { Bouquet } \\
\text { de la Grye }\end{array}$ & Paris & 1893 \\
\hline Schoeffer & Besançon & 1893 \\
\hline de Larminat & Troyes & 1893 \\
\hline Claudot & Paris & 1893 \\
\hline Trolard & Alger & 1893 \\
\hline de l'Estrange & Chateaumont & 1893 \\
\hline Conard & Paris & 1893 \\
\hline Lamey & Paris & 1893 \\
\hline de Faillasson & Seus & 1893 \\
\hline Calas & Perpignan & 1893 \\
\hline Huffel & Nancy & 1893 \\
\hline Grandeau & Paris & 1893 \\
\hline de Liocourt & Nancy & 1893 \\
\hline Biolley & Besançon & 1893 \\
\hline Trolard & Alger & 1893 \\
\hline de Tregomain & Nancy & 1893 \\
\hline de Boixo & Perpignan & 1893 \\
\hline Lamez & Paris & 1893 \\
\hline Claudot & Paris & 1894 \\
\hline Broilliard & Paris & 1894 \\
\hline Benevent & Pau & 1894 \\
\hline Démontzey & Lyon & 1894 \\
\hline Cannon & Paris & 1894 \\
\hline de Boixo & Paris & 1894 \\
\hline Démontzey & Paris & 1894 \\
\hline Claudot & Beanęon & 1894 \\
\hline Bizot de Jontenz & Gray & 1894 \\
\hline Mélard & Bruxelles & 1894 \\
\hline de Gorse & Paris & 1894 \\
\hline de Gorsae & Paris & 1894 \\
\hline Schaeffer & Annecy & 1894 \\
\hline Sarcé & Le Mans & 1894 \\
\hline Charlemagne & Alger & 1894 \\
\hline Level & Alger & 1894 \\
\hline de Boiro & Paria & 1894 \\
\hline Puton & $\begin{array}{l}\text { Mont de- } \\
\text { Marsay }\end{array}$ & 1894 \\
\hline $\begin{array}{l}\text { Lezé, Tetet } \\
\text { Ringelmann }\end{array}$ & Paris & 1894 \\
\hline de Kirwan & Bruxelles & 1895 \\
\hline $\begin{array}{l}\text { Scarsez de } \\
\text { Locqueneuille }\end{array}$ & Bruxelles & 1805 \\
\hline Claudot & Paris & 1895 \\
\hline Brenot & Besançon & 1895 \\
\hline Huffel & Besançon & 1895 \\
\hline Gurnaud & Bearançon & 1895 \\
\hline Mathieu & Paris & 1895 \\
\hline Claudot & Poitiers & 1895 \\
\hline Matkey & Poitiers & 1895 \\
\hline Charguerand & Paris & 1896 \\
\hline Guinier & $\begin{array}{l}\text { St. Jean de } \\
\text { Maurienne }\end{array}$ & 1896 \\
\hline Watie & Paris & 1896 \\
\hline
\end{tabular}


Title

Rapport de la Commission chargée de faire des expériences sur la résistance des bois réaineux

Exploitation technique des forêts

Exploitation commerciale des levis

Influence des forêts sur les chutes de grèle

Influence des forêts sur l'humidité du sol

Les retenues d'eau et le reboisement dans le bassin de la Durance

Les arbres géants du Portugal

Projet d'aménagement et de mise en valeur des forêts de Chênes-liège

Notice sommaire sur les forêta de gastes Ste Eulalie mimi$\operatorname{zan} \mathrm{H}$.

La forêt de la Grande Chartreuse

Notes sur le développement et la gestion des forêts Communales dans le départt ${ }^{t}$ du Gard 1800-1895

Statistique forestière de l'arrondt de Pontarlier

Le foret des Ardennes

Description forestière du royaume de Prusse

L'évolution forestière dans le Canton de Neufchatel (Suisse)

Description économique et commerciale des forêts de l'Etat hongrois ( $2^{d}$ Edit.)

Etudes sur l'économie alpestre

Etude d'archéologie forestière

Du reboisement et de la fertilisation des forêts

Contre les incendies des forêts en Algérie

De l'élagage des arbres forestiers

Les merrains et la fabrication des tourmeaux

Influence des forêts sur les eaux souterraines

Les Landes et les dunes de Gaseogne

Etudes sur la côte et les dunes du Médoc

Méthode nouvelle d'exploitation forestière

Sapinières

Etudes sur les forêts résineuses de la Champagne

Etat des forêts résineures du Poups

Les forêts du Canada

Forêts, chasse et péche (Exposit. de Bruxelles)

Forêts, chasse et pêche - Exposit. intern ${ }^{l e}$ de Bruxelles

Notes pour la vente et l'achat des forêts

L'art de greffer

La surveillance des forêts (10 Edit.)

Les végetaux producteurs de Caoutchouc a Madagascar

Sur l'abatage des bois en Sologne

Notice sur le quarrimètre

Les forêts et les eaux souterraines dans les régions des plaines

Les vieux arbres de la Normandie

Etude sur l'aménagement des bois de chêne dans le canton de Geneve

Etude sur les landes de Gascogne

Etude sommaire des taillis sous futaie dans le bassin de la Saône

La foret des brocheres a la ville d'Auxonne

Des funestes effets du déboisement dans les Pyrénées

Les meilleures plantes fourragères alpestres

Plantation et culture des sols contre les inondations

Notes forestieres - Cubage, estimation, etc.

Utilitê de l'introduction du Sapin et le l'épicéa dans les saillis médiocres du Jura

\begin{tabular}{|c|c|}
\hline Author & Place \\
\hline $\begin{array}{l}\text { Thiery et } \\
\text { Pebibcollot }\end{array}$ & Paris \\
\hline Vanutbergke & Paris \\
\hline Vanutbergke & Paris \\
\hline Claudot & Nancy \\
\hline de Kirwan & Paris \\
\hline Démontzey & $\operatorname{Aix}$ \\
\hline Gebhart & Blois \\
\hline Lafond & Alger \\
\hline Demorlaine & Paris \\
\hline
\end{tabular}

Margin Grenoble $\quad 1896$

Rouis Avignon 1896

Cardot Besançon 1896

Meyrae Charleville 1896

Huffel Paris 1896

Service forestier Neuchatel 1896

Suisse

de Bedö

Budapest

1896

Briot

Paris 1896

Weyd

Thézard

Marchand

Crakay

Mouillefert

Poitiers

1897

Compiène $\quad 1897$

Dijon 1897

Bruxelles $\quad 1897$

Paris 1897

$\begin{array}{lll}\text { Ototzky } & \text { Nancy } & 1897\end{array}$

Grandjean Paris 1897

Buffaut Servigny $\quad 1897$

de Blonay Gray $\quad 1897$

de Liscourt Gray 1897

Lafond Reims 1897

Brenot Besançon 1897

$\begin{array}{lll}\text { Melard } & \text { Paris } & 1897\end{array}$

Ministère de Bruxelles 1897

l'agriculture

Lezé, Tetet

Ringelmann

Galmiche

Ch. Baltet

Bouquet de la

Grue

Girod-Genet

Croizette-

Desnoyers

Demorlaine

Henry

de Kerville

Borel

Bruxelles

1897

Besançon $\quad 1897$

Troyes 1898

Parì 1898

Alger $\quad 1898$

Fontainebleau 1898

Compeigne $\quad 1898$

Nancy 1898

Paris 1898

Geneve $\quad 1898$

Dromart Charleville $\quad 1898$

Mathey Besançon 1898

Picard

Dijon

1898

Guénot

Briot

Vadas

Paris

1898

Chambéry $\quad 1898$

Troyes 1899

Devarenne Chaumont 1899

Rumacher Besançon 1899 
Title

Coupes d'amélioration coupes intermédiaires dans les futaies et les taillis

De l'utilité des reboisements dans le midi de l'Europe et en Algérie

Influence de l'espacement des plantes sur la végétation de quelques essences résineuses

Régénération pas plantation des coupes de futaie

Les forets à Madagascar

Nouveau moyen de préserver les bois de la vermoulure

Mise en valeur des sols pauvres par le reboisemt

De la possibilitê par contenance superficielle substituée a

la possibilité par volume dans les forêts traitées en futaie

- Les forête de l'Aube

La question des forêts en Afrique

Société moscovite d'économie forestière

Histoire de la société forestière nationale hongrôise

Rapport sur les bois du Canton de Genêve

Le régime pastoral

Congrès international de sylviculture

Forêts, chasse, Péche (Exposit. de 1900)

La prochaine disette des bois d'cuvre dans l'univers

Les arbres de la Suisse

Du progrès en Sylviculture et dans l'utilisation des produits forestiers

Ls défense des forêts contre l'incendie (dunee et landes de Gascogne)

La processionnaire du Pin

Un reboisement à bon marché

Influence désavantageuse produite sur l'avenir des peuplements principalement sur ceux de l'epicéa

De quelques essences exotiques intéressantes pour les reboisements

Les essences et les travaux de boisemt (Ariège et $\mathbf{H}^{\text {te-Gar- }}$ onne)

Les essences et les travaux de boisem ${ }^{t}$ (Ariège et $\mathrm{H}^{\text {te-Gar- }}$ onne)

Etude sur les fractures des bois dans les essais de résistance

Senilisation rapide des bois et des matières fibreuses par l'électricité

Gemmage du Pin maritime (Landes et Gascogne)

Gommes, résines d'origine exotique

Observations de phénomènes consécutifs a la plantation de conifères

Fixation des dunes

Fixation des dunes (Charente et Vendée)

Notes sur les dunes de Gascogne

Forêt domaniale de Blois. Procès-verbal d'aménagement

Insuffisance de la production des bois d'œuvre dans le monde

Notice sommaire sur la forêt de Fontainebleau

Les forêts de l'Algérie

Nomenclature des échantillons de bois de la Cochin chine du

Tonkin a l'Exposition universelle de 1900

Notice sommaire sur les forêts domaniales du départment des Vosges

La production agricole et forestière dans les colonies francaises

\begin{tabular}{|c|c|c|}
\hline Author & Place & Date \\
\hline Guinier & Annecy & 1899 \\
\hline Maistre & Clermont & 1899 \\
\hline Jolyet & Paris & 1899 \\
\hline Irouve & Paris & 1899 \\
\hline Girod-Genêt & Alger & 1899 \\
\hline Mer & Paris & 1899 \\
\hline Henry & Nancy & 1899 \\
\hline de Kirwan & Bruxelles & 1899 \\
\hline $\begin{array}{l}\text { Arbeltier de la } \\
\text { Boullage }\end{array}$ & Troyes & 1899 \\
\hline Wachi & Tunis & 1899 \\
\hline $\begin{array}{l}\text { Ministère de } \\
\text { l'agriculture }\end{array}$ & Moscow & 1899 \\
\hline $\begin{array}{l}\text { Ministère hon- } \\
\text { grois de l'agri- } \\
\text { culture }\end{array}$ & Budapest & 1899 \\
\hline Borel & Genève & 1899 \\
\hline Guyot & Poitiers & 1899 \\
\hline Teissier & Paris & 1900 \\
\hline de Kirwan & Paris & 1900 \\
\hline de Kirwan & Paris & 1900 \\
\hline $\begin{array}{l}\text { Inspection féd- } \\
\text { érale }\end{array}$ & Berne & 1900 \\
\hline Claudot & Epinal & 1900 \\
\hline Delagsasseigne & Paris & 1900 \\
\hline Calas & Paris & 1900 \\
\hline Henry & Paris & 1900 \\
\hline Reuss & Vienne & 1900 \\
\hline Henry & Nancy & 1900 \\
\hline Watier & Paris & 1900 \\
\hline Banby & Paris & 1900 \\
\hline Chil & Paris & 1900 \\
\hline Montpellier & Paris & 1900 \\
\hline Violette & Paris & 1900 \\
\hline de Cordemoy & Paris & 1900 \\
\hline Servier & Paris & 1900 \\
\hline Demorlaine & Paris & 1900 \\
\hline Lafond & Paris & 1900 \\
\hline Bert & Paris & 1900 \\
\hline $\begin{array}{l}\text { Croizette- } \\
\text { Desnoyers }\end{array}$ & Blois & 1900 \\
\hline Mélard & Paris & 1900 \\
\hline Reuss & Paris & 1900 \\
\hline Lefèbre & Alger & 1900 \\
\hline Boude & Alger & 1900 \\
\hline Mongeno & Paris & 1900 \\
\hline omte & Pario & \\
\hline
\end{tabular}


Title

Description générale de la forết de Krasnostauskaia. (Traduit du Russe)

Les forêts domaniales en Autriche

Notice sur les forêta de la Roumanie

Les forêts de la Russie (trad. du Russe)

Le développement de la sylviculture en Bosnie-Herzégovine

Catalogue des objets exposés par la direction des forêts de Russie a l'Exposition univerelle de 1900

Catalogue special, Forêts de la Hongrie a l'Exposition univerelle de 1900

Congrès international de Sylviculture. C. Rendu.

Catalogue des collections exposées par l'administon des eaux et forêts (Exposition de 1900)

Catalogue raisonné, section forestière russe

Les améliorations pastorales dans l'Ariège, la Haute-Garontue

Les fruiteres de la $H^{\text {te }}$ Garonne

Des paturages de montagne

Le páturage en forêt

Traité pratique de sylviculture

Traité de Sylviculture (Gayer, traducteur)

Traitement du Sapin

Traitement des Sapinières

Introduction dans les cultures forestières d'essences étrangères à la région

Essais de reboisement en Meurthe et Moselle

Introduction des résineux dans les taillis

Restauration des peuplements d'épicéas ayant souffert d'un état trop serré

Le domaine forestier colonial de la France sa décadence

Le bois

Le champignon des maisons en Lorraine

Des divers moyens propres à préserver de l'attaque des insectes les écorces et les bois

Observations sur les arbres a caoutchouc dans le zône amazonienne

L'Industrie des résines

Le Liège

Influence de l'éclaircie des cépées sur le rendement en matière et argent dans le traitement des taillis

Sur le rôle de la forét dans la circulation de l'eau à la surface des continents

De l'influence des forêts sur le régime des eaux

Observations météorologiques 1867-1899

Calepin d'aménag ${ }^{t}$ de la forêt des Hospices de Nancy

Du réglement des exploitations dans une petite sapinière

Excursion forestière en Morvan

La forát d'Oloron-ste Mario

Les forêts et le régime forestier en Provence

Rapport sur la $3^{e}$ reunion de l'association internationale des stations de recherches forestières à Zurich

Le défrichement et la culture des terrains en pente

Quelques notions forestières a l'usage des écoles

Petit manuel à l'usage des socictés scolaires pastorales, forestièrea de Franche-Comté

L'Idée forestière sur le veraant septentrional des Pyrénées

Le Traitement des sapinières basé sur la notion d'espacement des tiges
Author

Jachnoff

Ministere de

l'agriculture

Service des

forêts

Ministere de

l'agriculture

Petraschels

Ministère de

l'agriculture

Gouvt. Kongrois

Daubrée

Vaney

Jachnoff

Campardon

Bruisson

Cardot

Matkey

Boppe et Jolyet

de Bocarme

Huffel

Mer

Jolyet

Claude
Garzin
Mer

Girod-Genet

Frochot

Henry

Mer

Huber

Rabate

Martignat

Mer

Henry

Guinier

de Drouin et de Bouville

\section{Bazaille}

Broilliard

Roy

Duchesne

Allard

Huffel

Rousget

Rabutte

Cardot

Fabre

Gaxin
Place

Dato

St. Pétersbourg

Vienne

Bucharest

1900

Paria

Vienne

1900

Vienne

Paris

Budapest

1900

1900

1900

1900

1900

Paris

St. Pétersbourg $\quad 1900$

Paris

1900

Paris

Paris

Besançon

1900

1900

1900

1901

1901

1901

1901

1901

1901

1901

1901

1901

1901

1901

1901

1901

1901

1901

1901

1901

Besançon $\quad 1901$

Paris

Epinal

1901

Besançon $\quad 1901$

Nevers $\quad 1901$

Oloron $\quad 1901$

Paris 1901

Paris 1901

Paris 1901

Vouziers 1902

Besançon 1902

Bagneres de 1902

Paris 
Title

La régénération naturelle des coupes de futaie

La mise en valeur des terres communales incultes

Amélioration a introduire dans le traitement des taillia

Le bois, le liège

Etude sur la pénétrabilité des arbres forestiers par les projectiles des armes à feu

La lutte contre le champignon des maisons

Séchage rapide, imputrescibilité et inflammabilité des bois

Influence de la couverture morte sur l'humidité du sol forestier

Forêts et navigabilité en Gascogne

Les forêts de plsines et les esux souterrsines (Expériences faites dans la forêt de Moudon 1900-02)

L'architecture forestière

Rapport sur le concours forestier entre les instituteurs organisé par la Socté francose des Amis des Arbres

La sylviculture à l'Exposition de 1900

La disparition du chêne et l'introduction des résineux dans les taillis sous futaie - Le Bouleau

Principales essences forestières

La méthode expérimentale en sylviculture

Le forestier - Expériences et Conseils

Sylviculture

Propagation du chêne, Sa substitution dans les futaies de hêtre

T.es plantes a caoutchouc et à gutta

Dégats causés aux forêts par les balles des fusils de l'armée

La vrillette

Incendies des forêts - Évaluation des dommages

Les arbres et les bois

La richesse forestière, son déclin, son relèvement

Forêts et industrie des boik

Des divers moyens propres à préserver de l'attaque des insectes les écorces et les bois par résorption de leur reserve amylacée

La liberté du travail et le droit de propriété

Prolongation du délai de vidange et d'exploitation

Exploitation et aménagement des bois

Causerie forestière

Coupes jardinatoires

De l'éclaircie chez les particuliers

Lianes caoutchoutifères de l'Etat du Congo

L'arbre (res Série)

La houille blanche et l'armature végétale du sol

Gisements de houille blanche et protection du sol

Les débuts de la fixation des dunes

Promenades, parcs jardins paysages

L'aménagement des résineux en montagne

De la possibilité par contenance dans les sapinières

Forêt domaniale des Elieux - $3^{e}$ Serie Révision de l'Aménagement

Les taillis de l'inspection de Dijon - Bud

A Madagascar, Apercu sur les forêts et leurs produits

Commission d'études forestières - Compte rendu

La gréve des bacherons de la Nièvre a la chambre

\begin{tabular}{|c|c|c|}
\hline Author & Place & Date \\
\hline Prouvé & Poitiers & 1902 \\
\hline Cardot & Poitiers & 1902 \\
\hline Mer & Paris & 1902 \\
\hline d'Hubert & Paris & 1902 \\
\hline Demorlaine & Paris & 1902 \\
\hline Henry & Nancy & 1902 \\
\hline Dumesny & Paris & 1902 \\
\hline Henry & Nancy & 1902 \\
\hline Fabre & Bordesux & 1902 \\
\hline Henry & Nancy & 1902 \\
\hline de Liocourt & Nancy & 1902 \\
\hline Cardot & Orléans & 1902 \\
\hline $\begin{array}{l}\text { Bouquet de la } \\
\text { Grye }\end{array}$ & Paris & 1902 \\
\hline Rosemont & Paris & 1902 \\
\hline Mouillefert & Paris & 1903 \\
\hline Mer & Paris & 1903 \\
\hline Morange & Genêve & 1903 \\
\hline Fron & Paris & 1903 \\
\hline Prouvê & Paris & 1903 \\
\hline Jumelle & Paris & 1903 \\
\hline Georges & Paris & 1903 \\
\hline de Fonvert & Paris & 1903 \\
\hline Jacquot & Paris & 1903 \\
\hline de Kirwan & Nancy & 1903 \\
\hline Carimintrand & Paris & 1903 \\
\hline Flahault & Paris & 1903 \\
\hline Mer & Paris & 1903 \\
\hline $\begin{array}{l}\text { Journal de la } \\
\text { Niévre }\end{array}$ & Nevers & 1903 \\
\hline $\begin{array}{l}\text { Journal de la } \\
\text { Ní́vre }\end{array}$ & Nevers & 1903 \\
\hline Mouillefert & Paris & 1904 \\
\hline Desjobert & Besançon & 1904 \\
\hline Schaeffer & Besançon & 1904 \\
\hline Broilliard & Bruxelles & 1904 \\
\hline de Vildemann & Bruxelles & 1904 \\
\hline Reynard & $\begin{array}{l}\text { Clermont- } \\
\text { Terrand }\end{array}$ & 1904 \\
\hline Fabre & $\begin{array}{c}\text { Bagnereg de } \\
\text { Bigorre }\end{array}$ & 1904 \\
\hline Fabre & Paris & 1904 \\
\hline Buffaut & Bordeaux & 1904 \\
\hline Guinier & Auncey & 1904 \\
\hline d'Alverny & Besançon & 1904 \\
\hline Broilliard & Besançon & 1904 \\
\hline Cuif & Nancy & 1904 \\
\hline Galmiche & Besançon & 1904 \\
\hline Girod-Genet & Paris & 1904 \\
\hline $\begin{array}{c}\text { Gouvt Général } \\
\text { d l'Algérie }\end{array}$ & Alger & 1904 \\
\hline Journal de la & Nevers & 1904 \\
\hline
\end{tabular}


Title

Les incendies pastoraux et les associations dites "forestières" dsns les Pyrénées-Orientles

Economie forestière

L'idée forestière dans l'histoirie

Projet d'association forestière

Lettre à un propriétaire de futaie jardinée

Influence des éclaircies dans les peuplements réguliers de sapin

Les friches de la $\mathrm{H}^{\text {te }}-\mathrm{Marne}$

Les essences forestières du Soudan propres a la construction

Le bois

Le régime des cours d'eau du depart ${ }^{t}$ de l'Aveyron et la question du reboigement

La végétation spontanée et la salubrité des eaux

Coup d'oeil d'ensemble sur les forêts coloniales de la France

Prix des bois dans le Maine en 1904

La question forestière en Soudan

La question forestière en Algerie

Notice sur les forets de la Kroumirie (Tunisie)

La richesae forestière du Canada confédéré

La question forestière en Espagne

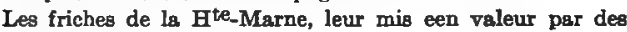
travaux forestiers

Nos arbres

Restauration d'une sapinière

Mathématiques et Nature

Aide à la gestion des bois particuliers

Les insectes dans les forêts résineuses des Vosges

Essai sur le pâturage dans les bois

Les reboisements facultatifs dans la région sous-pyrénienne

Le reboisement des terres en friche dans l'arrondissement de Neufchâteau

Anslyse et contrôle des semences forestières

Les garrigues communales des environs de Carcassonne et de Narbonne

Etude sur la question du reboisement dans le Sud-est Pyrénéen

De l'élagage des sapins et épicéas

Guide pratique du fonctionnaire se rendant en Indo-Chine

La question forestière en France

La déforestation - Peril mondial

Mémoire relatif à un projet de loi sur les forets d'utilité publique

Déboisement et décadence

La Dordogne déboisée

Les forêts et les pluies

Gironde et Pyrénées

La marche envahissante des dunes de Gascogne avant leur fixation

La forêt de Laroque des Albères

Rendement des forets domaniales de pin maritime dans les dunes landaises

Soumission volontaire au régime forestier

Exposition coloniale de Marseille - Catalogue des collections du Service forestier algérien

Répertoire des arbres, arbustes, etc., composant la collection d'ensemble des ressources forestieres de Madagascar a l'Exposit. Coloniale de Marseille

Projet d'associstion forestière ( $2^{\circ}$ article)

Traité d'exploitation commerciale des bois

Sylviculture (diverses questions)

Manuel de sylviculture à l'usage des instituteurs

Forêts, pAturages, prés-bois

\section{Author}

Fabre

Huffel

Teissier

de Liscourt

Galmiche

Cuif

Cardot

Constancia

Beauverie

Buffault

Fabre

Girod-Genêt

Roulleau

Jolyet

Demontes

Desgréaux

Leymarie

Cavaillèв

Cardot

Correvon

Broilliard

Broilliard

Desjobert

de Gail

Desjobert

Bauby

Pardé

Fron

Rouis

de Boiro

Mer

Lambert

Pardé

Duffart

Reynard

Regnault

Broilliard

Henry

Broilliard

Buffant

Buffault

de Lapasse

Broilliard

Gouvernt ${ }^{\mathrm{G}}{ }^{\mathrm{a}}$ de l'Algérie

Gouvern ${ }^{t} \mathrm{Gal}^{\mathrm{al}}$ de l'Algérie

de Liscour:

Mathey

de Kirwan

Cardot

Fron

\section{Place}

Besançon

Date

1904

Paria

Paris

Besançon

Beeançon

Paris

Paris

Pario

Paris

Rodey

Paris

Nice

Paris

Paris

Paris

Tunis

Paris

Paris

Paris

Paris

Besançon

Besançon

Besançon

Besançon

Besançon

Bordeaux

Besançon

Besançon

Carcassonne

Toulouse

1906

Besançon

Paris

Poitiera

Paris

Besancon

Paris

Bergerac

Bergerac

Bordeaux

Paris

1906

1906

1906

1906

1906

1906

1906

1906

1906

1906

Bordeaux

Poitiers

1906

1906

Besançon

Alger

1906

1906

Marseille

1906

Bessnçon

Paris

Paris

Paris

Paris
1906

1906-08

1907

1907

1907 
Autho

Place

Date

Aide mémoire du forestier - Sylviculture

Quelques mots relstifs a l'assurance des forêts en cas d'incendie

Du reboisement dans l'arrond ${ }^{t}$ de Mirecourt

Le reboisement et les conditions économiques en montagne

L'obstacle au reboisement

Déboisement et reboirement

Le reboisement dans la région des Cévennes

La question de l'élagage

Les resources agricoles et forestières des colonies frangaises

Préservation des bois contre la pourriture par le sol, les champignons les insectes

L'Industrie de la résine en Sologne

La culture des arbres et les idées des anciens sur le rôle des forête

La restauration des montagnes et la navigation intérieure

Action de la forêt sur le sol et le régime des eaux

Embellissons nos bois

Vingt-cinq années dans le service des aménagements

Forêt domaniale d'Amance - Révision de l'Aménagement

Aménagement et amélioration des forêts particuliers

Evolution des méthodes d'aménagt appliquées en France aux forets d'essences feuillues

Conférences forestières $1^{\text {s }}$ Forêts et friches particulières $2^{0}$ - aménagement

La ville d'Oloron et ag Forêt du Bager

La défense des montagnes

Les richesses forestieres de la Rusgie

L'Australie, ses ressources forestière日

Exposition internatle de St. Louis - Rapports des groupes $112,113,114$. Forête

Nouvelles études sur l'économie alpestre

L'utilité de l'anánagt des montagnes, etc.

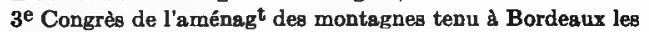
19-20-21 Juillet 1907

Etude sur la condition forestière de l'Orléanais

Etude sur les deux places de production des forêts domaniales de Haye et d'Amance

Accroissement d'un massif jardiné

Conservation des taillis en futaie

Livre vert du syndicat forestier de France

Le reboisement par l'initiative privé

De l'mpôt foncier appliqué aux forêts

La forêt, son rôle dans la nature et la société

Manuel de l'eau

Le déboirement et les inondations

Le problême de l'influence de la forêt sur l'inondation

Les plantations de pins dans la Champagne crayeuse

Des essences pour les reboisements

Forets particulières

La Sologne en 1850 - Souvenirs

Le Haut-Beaujolais

La déforestation de la France

Live vert du syndicat forestier de France (Notice)

La feuille au le revenu foncier

Le revenu imposable aux forêts

L'évaluation du revenu imposable aux forêta

Le revenu imposable aux forêta

A propos des améliorations pastorales

Le probleme pastoral et forestier

\begin{tabular}{|c|c|c|}
\hline Demorlaine & Besançon & 1907 \\
\hline Decoppet & Besançon & 1907 \\
\hline de Rozières & Mirecourt & 1907 \\
\hline Bauby & Bordeaux & 1907 \\
\hline Buffault & Bordeaux & 1907 \\
\hline de Kirwan & Paris & 1907 \\
\hline Buffault & Rodey & 1907 \\
\hline Mer & Besançon & 1907 \\
\hline Jumelle & Marseille & 1907 \\
\hline Henry & Nancy & 1907 \\
\hline de Larnage & Orléans & 1907 \\
\hline Buffault & Rodey & 1907 \\
\hline Fabre & Dijon & 1907 \\
\hline Fron & Paris & 1907 \\
\hline Broilliard & Bruxelles & 1907 \\
\hline Brenot & Morteau & 1907 \\
\hline Cuif & Nancy & 1907 \\
\hline Viardin & Neufchiteau & 1907 \\
\hline Kuffel & Neufchateau & 1907 \\
\hline $\begin{array}{l}\text { de Liocourt et } \\
\text { Viardin }\end{array}$ & Neufcháteau & 1907 \\
\hline Buffault & Toulouse & 1907 \\
\hline Descombes & Bordeaux & 1907 \\
\hline $\begin{array}{l}\text { Direct de l'agri- } \\
\text { culture }\end{array}$ & Bordenux & 1907 \\
\hline Buffault & Bourges & 1907 \\
\hline Hugo & Paris & 1907 \\
\hline Briot & Paris & 1907 \\
\hline Descombes & Bordesux & 1907 \\
\hline Descombes & Bordesux & 1907 \\
\hline de Maulde & Orléans & 1908 \\
\hline Cuif & Poitiers & 1908 \\
\hline Schaeffer & Besançon & 1908 \\
\hline $\begin{array}{l}\text { Société Forestre } \\
\text { de Franche- } \\
\text { Comté }\end{array}$ & Besançon & 1908 \\
\hline de Rozieres & Paris & 1908 \\
\hline Degcombes & Bordeaux & 1908 \\
\hline Schaefier & Besançon & 1908 \\
\hline Jacquot & Besançon & 1908 \\
\hline Reclus & Paris & 1908 \\
\hline Teissier & Lyon & 1908 \\
\hline Teissier & Poitiers & 1908 \\
\hline Lapic & Reims & 1908 \\
\hline Broilliard & Besançon & 1908 \\
\hline Deffert & Paris & 1908 \\
\hline Martin & Paris & 1908 \\
\hline Hulin & Besançon & 1908 \\
\hline de Bailly & Besançon & 1908 \\
\hline de Liocourt & Paris & 1908 \\
\hline Broilliard & Besançon & 1908 \\
\hline Roulleau & Besançon & 1908 \\
\hline Arnoult & Paris & 1908 \\
\hline Jacquot & Besançon & 1908 \\
\hline Seurre & Besançon & 1908 \\
\hline Descombes & Bordeaux & 1908 \\
\hline
\end{tabular}


Guide pour la création de Soctes forestres Scolaires

Futaie régulière d'âges gradués et jardinage cultural contrôlé

Le martelage an début de l'ére Mérovingienne

Ls Conservation en futaies des forêts traitées en taillis sous futaie

Du traitement des bois feuilles

Du traitement des bois feuilles

Considérations sur le traitement des forêts en taillis ou futaie

Les immeubles forestiers et les Cles d'assurances

Fsaai en grand du Carbolineum avenarius

Préservation des bois par des procédés simples

Le gemmage du Pin noir dans le N-E de la France

Influence du couvert de la forêt sur la température du Sol

Aménagement d'une forêt coloniale

Les eaux et forêts en Lorrsine au XVIIIe Siécle

Choses forestières colonisles françaises

Les bois et les forêta du Périgord

Les atteintes législatives a la propriété forestière - La coupe rase et la loi des cinq possibilités

Compte-rendu des excursions faites a l'occasion du Congrés de Nancy, dans les forêts d'Amance, de Haye, des Elieux

Association centrale pour l'aménagt des montagnea

La lre étape de l'association pour l'aménagement des montagnes

De l'exploitation des futaies

A propos du Pin sylvestre - Valeur des graines et plantes françirses

Le choix des semences en culture forestière

Guide pour la création de sociétés forestières acolairea

Pullulation du lapin en Allemagne Invasion du Taret dans le port de Marseille

Statuts du syndicat forestier d'Eure \& Loire

Guide pratique pour les propriétaires de bois

(b) FOREST LAW

Des forets et le projet de code rural

Dictionnaire Général des Foréts

Cours d'appel de Nancy - Conclusions pour M. M. Mohr et Haas, contre M. Haldy

Cours d'appel de Nancy-Conclusions pour M. Haldy, contre M. M. Mohr et Haas (6 Nov. 1873)

Lachasse et la louveterie

Note presentee au CriCunal de Mirecourt pour Mémvire su Consel de Préfecture ${ }^{d} T^{l \theta}$ et Vilsine

La Section des Chanoines de Dombasle, contre La Commune du dit

Questions de droit forestièr

Dictionnaire Général des forêts

Nouveau code du Chasseur

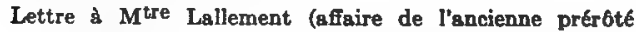
d'Hugier)

De l'Administration et do la Jouissance des forêts communales

Manuel de législation forestière

De la prescription de la peine en matière de délita forestiers

Etude sur le projet de loi sur la restauration des montagnes

Code de la Chasse et de la louveterie

Contre les Commns de Laimpont et de sr Péran

Conclusions motivées pour Monseig. le Duo d'Aumale contre ls Commune de Rigniowez (Ardennes)

Petitbien

Puton

\section{Author}

Descombes

Ducsmp

Huffel

Huffel

Vaulot

Algan

Gurnaud

Descombes

Henry

Henry

Cuif

Cuif

Jolyet

Boye

Ducamp

Buffault

Roullesu

Cuif

Descombes

Descombes

Broilliard

Hickel

Guinier

de Boixo

Henry

Mathey

Roullesu

\section{Place}

Date

Bordeaux

Bessnçon

1908

1909

1909

Poitiers

1909

Besançon

Besançon

1909

1909

1909

Bordeaux

1909

1909

1909

1909

1909

1909

1909

1909

1909

1909

Bordesux

1909

Bessunçon

1909

Bordeaux

Bordesux

1909

Bruxelles $\quad 1910$

Paris 1910

Nancy

1910

Bordesux 1910

Nancy 1910

Chartres

1910

Paris

1910

Puton

Paris

1870

Rousset

Nice

Nancy

1871-72

Hisserant

Nancy

1873

Lombard

1873

Nancy

1874

1874

Puton

Nancy

1875

Rousset

Yiel

Paris

1875

1875

$\begin{array}{ll}\text { Paris } & 1875 \\ \text { Nancy } & 1876\end{array}$

Mesume

Nancy

1876

Larsillière

Paris

1876

Puton

Puton

Paris

Paris

1876

1877

1878

Leblond

Paris

Paris

1878

Nicolière et

Puton

Mesume

Nancy

1880 


\section{Title}

Contrainte pour Corps en matière forestière

Le droit pénal forestier

Du jugement des infractions en matière forestière

La Chasse

Loi du Harril 1882-Restauration et Conservation terrains en montagne

Commentaire de la loi du Harril 1882 sur la Conservation des terrains en montagnes

Le régime forestier appliqué au bois des communes et établissements publics

Code de legislation forestière

Etude sur la revision du code forestier

Code Forestier (codes annotés)

La Question des forêts en Algérie

Du droit de Chasse dans ses rapports avec la propriété

Notice sur le projet de périmètre de l'Arc Supérieur

Essai de Commentaire Pratique de la loi du 4 Avril 1882, Conservation et Restauration des terrains en montagne

Projet de loi sur le code forestier

Les cours d'eau - Hydrologie, législation

Projet de loi sur la chasse

Des délits et des peines en matière forestière au moyen-age dans le Duché de Bourgogne

Essai sur le régime des Canaux

La réforme du code forestier

Code des cours d'eau non flottables ni navigables

De l'usufruit des prêts en droit romain et français

Manuel judiciaire de la chasse

La réforme du code forestier

Du poutage de l'affouage dans les bois communaux

Loi sur la pêche fluviale

Code Nouveau de la pêche fluviale

Les confiscations des forêts d'émigrés dans les Droit de pêche des propriétaires d'étangs

Departements de Vaucluse, du Gard et de l'Ardéche

Cours de droit forestier enseigné à l'Ecole Secondaire des Barrès

Etude sur l'application de la loi du 4 Avril 1882

Du droit de chasse et du droit de chasser le gibier

Usagers de Dabo

Principes de légialation forestière

Loi du 19 Avril 1901 sur l'affouage communal

Conservation des forêts et des Paturages dans les PyrénéesLe régime pastoral

L'espoir des cours d'eaux non navigables ni ftottables

La Péche dans les cours d'eaux

Code de législation forestière (2e Edit.)

Commentaire de la Loi forestière Algérienne

Une question de droit d'usage en forêt

Etude historique sur la propriété des dunes de Gascogne

Deux Questions forestières-La nationalisation du sol forestier - les forêts de protection

Le projet du code forestier de l'an IV

Législation et réglementation de la pêche fluviale

Observations sur la nécessité de réformer nos lois forestières

Guide du forestier - Surveillance des forêts (11 ${ }^{\mathrm{e}}$ Edit.)

Nouveau régime forestier résultant des lois du 18 juillet et 31 decre 1906

Aide mémoire du forestier - Sciences juridiques

\begin{tabular}{|c|c|c|}
\hline Author & Place & Date \\
\hline Guyot et Puton & Paris & 1880 \\
\hline des Chênes & Paria & 1882 \\
\hline Meaume & Paris & 1882 \\
\hline $\begin{array}{c}\text { Girandeau et } \\
\text { Lelièvre }\end{array}$ & Paris & 1882 \\
\hline Tassy & Paris & 1883 \\
\hline Tétreau & Paris & 1883 \\
\hline $\begin{array}{c}\text { Bouquet de } \\
\text { la Grue }\end{array}$ & Paris & 1883 \\
\hline Puton & Paris & 1883 \\
\hline Doumenjou & Paris & 1883 \\
\hline Palloa & Paris & 1884 \\
\hline Wachi & Oran & 1885 \\
\hline Barthelémy & Nancy & 1885 \\
\hline Chapelain & Chambéry & 1886 \\
\hline des Chênes & Paris & 1886 \\
\hline Viette & Paris & 1888 \\
\hline Lechalas & Paris & 1890 \\
\hline Clavé & Paris & 1891 \\
\hline Picard & Autun & 1891 \\
\hline Carpentier & Paris & 1892 \\
\hline Prudhomme & Paris & 1892 \\
\hline Boulé & Paris & 1893 \\
\hline Chancerel & Paris & 1893 \\
\hline Dumont & Paris & 1894 \\
\hline Guyot & Nancy & 1894 \\
\hline Germain & Salins & 1895 \\
\hline Bertrand & Paria & 1896 \\
\hline Martin & Paris & 1897 \\
\hline Rouis & Autun & 1898 \\
\hline Pardé & Les Barrès & 1900 \\
\hline Moujin & Poitiers & 1901 \\
\hline Barthélemy & Nancy & 1901 \\
\hline Pfister & Metz & 1901 \\
\hline $\begin{array}{l}\text { Michel et } \\
\text { Lelong }\end{array}$ & Paris & 1901 \\
\hline Germain & Paris & 1901 \\
\hline Guyot & Toulouse & 1904 \\
\hline Tisserand & Paris & 1904 \\
\hline $\begin{array}{l}\text { Del Péré de } \\
\text { Cardaillac }\end{array}$ & Toulouse & 1904 \\
\hline Puton et Guyot & Paris & 1904 \\
\hline Guyot & Paris & 1904 \\
\hline de Kirwan & Paris & 1905 \\
\hline Buffault & Bordeaux & 1905 \\
\hline Guyot & Besançon & 1905 \\
\hline Weyd & Poitiers & 1905 \\
\hline Mersey & Paris & 1906 \\
\hline Buffault & Toulouse & 1906 \\
\hline $\begin{array}{l}\text { Bouquet de la } \\
\text { Grue }\end{array}$ & Paris & 1906 \\
\hline Guibourg & Paris & 1907 \\
\hline Deroye & Besançon & 1907 \\
\hline
\end{tabular}


Title

La soumission volontsire au régime forestier

Sur les soumissions facultatives su régime forestier

Code forestier suivi des lois sur la pêche la chasse et le code rural

Notes sur les propositions des lois libérales pour le reboisement

La régime administratif et juridique de la peche fluviale

\section{Author}

Desjobert

de Kirwan

Palloz

Descombes

Raux
Place
Besançon
Besançon

Paris

Bordesux

Paris
Date

1908

1908

1908

1908

1909

\section{(c) FOREST EDUCATION}

Programme de l'enseigement, de l'Ecole forestière

Programme des études d'aménagt defutaies á faire par les élèves de l'Ecole foreatière dans la forêt des St. GobainCoucy

Programmes de l'enseignement

Ordre Général pour l'exécution du réglement de police et de discipline du 15 Nov. 1876; (l'Ecole Nat ${ }^{l e}$ des Esux et Forêts)

Réglements et programmes d'enseignement de l'Ecole forestière

La sylviculture á l'Ecole primaire

Ecole pratique des Barrès, -Programmes et conditions d'admissions pour les préposés à l'Ecole secondaire

Notices sur l'Ecole forestière et la station de Recherches

Réglements de l'Ecole forestière (12 Octob. 1889) PersonnelAdministration - Surveillance

Arret du Ministre de l'Agriculture concernant l'Ecole forestière-Personnelle

Ordre général - Organisation de l'Êngeignement

Notice sur l'installation de l'Ecole forestre de Nancy

L'Enseignement forestier en France (Ecole de Nancy)

L'Ecole forestière de Nancy

Ecole des Barrè-Régime, Digcipline, etc.

Rapport sur la visite des collections et du fardin de l'Ecole natles des Eaux et Forêts

Arrêtés et réglements concernant l'Ecole Nle des Eaux et Forets

Arrétés et réglements de l'Ecole N $\mathrm{N}^{l e}$

Paris

1876

Boppe

Nancy

1876

Ecole forestière Paris

Puton Nancy

1876-82

1883

Direction des Paris 1887

forets

Caquet

Nevers

1887

Ministère de

l'agriculture
inistere de

l'agriculture

Direction des

forêts

Paris

Paris

1888

1889

Ecole Forestière

Paris

1890

1893

Boppe

Paris

1894

Guyot

Nancy

Nancy

Guyot

Nancy

Nesmy

Paris

Direction Gle Paris

Guimer

Paris

Ministère de Paris l'agriculture

Ecole Forestière Paris

1896

1898

1904

1904

1909

1910

1910

\section{(d) ENGINEERING (REBOISEMENT)}

Les torrente des Alpes et le pAturage

Etude sur les torrente des Htes.Alpes

Les torrents, leurs lois, leurs csuses

Notes sur l'extinction des torrents

Etude d'un Systeme général de défense contre les torrents

Les torrents des Alpes et le paturage ( $2^{d}$ Edit.)

Notice sur les cartes, dessing, modeles, etc. relatifs aux travaux de reboisement dans le bassin de la Durance

Etude sur les travaux de reboisement et gazonnement des montagnes

Monographies de travaux exécutés dans les Alpes, les Cévennes, et les Pyrénées

Le reboisement des Alpes

Traité pratique du reboist, et du grzonnement des montagnes ( $2^{\circ}$ Edit.)

Etude our la construction des barrages

De l'aménagement des Eaux en Suisee

$\begin{array}{lll}\text { Marchand } & \text { Arbois } & 1872 \\ \text { Surell } & \text { Paris } & 1872 \\ \begin{array}{l}\text { Costa de } \\ \text { Bastellica }\end{array} & \text { Paris } & 1874 \\ \begin{array}{l}\text { Tassy } \\ \text { Breton }\end{array} & \text { Toulouse } & 1874 \\ \begin{array}{l}\text { Marchsnd } \\ \text { Démontzey }\end{array} & \begin{array}{l}\text { Paris } \\ \text { Paris }\end{array} & 1875 \\ \text { Pémontsey } & \text { Paris } & 1876 \\ & & 1878 \\ \text { Administration } & \text { Paris } & 1878 \\ \text { des forets } & & 1878 \\ \begin{array}{l}\text { Clave } \\ \text { Démontzey }\end{array} & \text { Paris } & 1881 \\ & \text { Paris } & 1882 \\ \text { Vaultrin } & \text { Paris } & 1884 \\ \text { de Salis } & \text { Berne } & 1884\end{array}$

* Réglement et conditions d'admission. 
Title

Charlemagne

Travaux des défensea contre les avalanches dans la vallée de Barèges

Correction des ruines de Pellafol (Isère)

Les torrents glaciaires

Les terrains et les paysages torrentiels (Pyrénées)

Restauration et conservation des terrains en montagne.

C. Reude Sommaire des trav. (1860-1900)

Notice historique sur G. G. inondations dans la Savoie

La vallée de Barèges et le Reboisement

La correction des torrents en Savoie

Les débâcles glaciaires

Les effete de l'érosion

Une excursion dans la vallée du Venéon (Isère)
Author

Thiéry

Carrière

Vaultrin

Démontzey

Démontzey

Thiéry

Démontzey

Nicollet

de Selis

Heurteloupe

Démontzey

Thiéry et

Petiscollot

Pellon

Kuss

Champsaur

Moujin

Campagne

Place

Grenoble

Date

1887

Paris

1888

Barcelonnette 1888

Toixe

Paris

1889

1889

$\begin{array}{ll}\text { Paris } & 1891 \\ \text { Paris } & 1891\end{array}$

Paris 1892

Grenoble $\quad 1892$

Berne 1892

Grenoble $\quad 1892$

Paris 1894

Paris 1896

Paris $\quad 1900$

Paris $\quad 1900$

Paris 1900

Paris 1900

Paris 1900

Bernard $\quad$ Paris 1900

Kuss Paris 1900

de Gorsee Paris 1900

Ministère de Paris 1900

l'agriculture

Durandard

Campagne

Mougin

Rabot

Pinner

Hulin
Paris

Pau

Besançon

Paris

Marseille

Besanģon
1900

1902

1904

1905

1908

1908

\section{(e) FOREST ADMINISTRATION}

De l'utilité d'une réorganisation de l'Administration des forets

La question des forêts devant l'asgemblée Nationale (Lettre a M. M. les Députés)

Réponse au rapport de $M$. Faré contre la translation de l'Administration des forêts au Ministère de l'Agriculture

Réorganisation du Service forestier, réformes de la loi du 9 Juin 1853 sur les pengions civiles

Dousniers, forestiers, etc., organisation en armes

Esagi sur la réorganisation du Service forestier en France

Etude sur la réorganisation de l'Administration forestière

Les réformes forestières

Etude sur la réorganisation de l'Administration des forêts Etudes forestières

Annexe á l'étude sur la rérganisation de l'Administration des forêts

Réorganisation du Service forestier (4 facs.)

Le Corps des forestiers et le projet de M. M. Tasay et Lorentz

De vis d'une maison de Garde (Type No. 1)

Réorganisation du Service forestier (M. de Mahyer Méline)

Notes sur le recrutement du corps forestier

La geation de forêta au Ministère des Finances

Le Dernier Directeur Général de forêts

Mer

Turot

Turot

Wisst

Caise

Caige

Meaume

Bouquet de la Grue

Bertin

Bertin

Bertin

Tassy

Deupion

Administration Forestier

Tassy

Méline

de Venel

de Venel
Provine

1871

Bars aube

1872

Bars aube

Paris

$1879-80$

1882

1882

1884

1884

1884

1884 
Title

Author

Taillis

Tsillis

Quelques considérations aur l'organisation de l'Administration des forets

Rapport sur les modifications introduites dans l'Administration forestière

Une page d'histoire forestière

L'Oeuvre de M. Viette au ministère de l'Agriculture

Discussion du budget de 1891 - discours prononcé par $\mathbf{M}$. le Comte de Youffroy d'Abbans

Le Service forestier dans le Dept. d'Oran (Aglérie)

Calendrier forestier (Tabl. des pieces a fournir)

Dictionnaire Gal des forêts (2d Edit.)

Guide du chasseur forestier ál l'usage des agents et préposés Historique administratif du Cant ${ }^{t}$ de Cirey-Vevouse

Les anciennes circulaires de l'Administon des eaux et forêts

Tournée de Vente d'un Grand Maitre des eaux et forêts

Etat des Services des Elèves de l'Ecole forestière (1825 a 1888)

Les sceaux des forestiers au Moyenage

Société de Secours mutuels des préposís forestiers du Doubs

Les gardes communaux-domanialisation

Mémoire aur les réformes à spéro dans le Service Forestier

Notice historique sur le recrutement de l'Administration des forêts et aur l'enseignt, forestier en France

\begin{tabular}{|c|c|c|}
\hline Welche & Poitiers & 1888 \\
\hline Suchsux & Vesoul & 1888 \\
\hline Suchaux & Vesoul & 1889 \\
\hline $\begin{array}{r}\text { de Youffroy } \\
\text { d'Abbans }\end{array}$ & Paris & 1891 \\
\hline Mathieu & Alger & 1892 \\
\hline Démaret & Alger & 1892 \\
\hline $\begin{array}{c}\text { Rousset et } \\
\text { Bawēr }\end{array}$ & Digne & 1894 \\
\hline Bauër & Paris & 1894 \\
\hline Weyd & Nancy & 1899 \\
\hline Weyd & Poitiers & 1904 \\
\hline Desjobert & Besançon & 1905 \\
\hline Weyd & Poitiers & 1905 \\
\hline Roman & Paris & 1906 \\
\hline Roman & Besangen & 1907 \\
\hline Chsmbeau & & 1907 \\
\hline Volmerange & Commercy & 1896 \\
\hline Guyot & Nancy & 1898 \\
\hline
\end{tabular}

Place Date

Paris $\quad 1885$

Paris 1886

1888

888

891

1892

894

1894

1904

1905

905

1906

1907

1898

\section{(f) MISCELLANEOUS}

Is République orientale de I'Uraguay à l'Exposition de Vienne

République de Salvador - Notice historique et statiatique. (Exposit. Universelle, 1878)

République de Salvador - Catalogue des objets exposés a l'Exposition universelle 1878

Notice sur les objets exposés de la République de Guatemala

Catalogue dc la collection exposée par la Chine à l'Exposition universelle

Catalogue de la section anglais

Queensland Australie - Guide de la Colonie

Le Japon a l'Exposition

Catalogue des produits des colonies françaises

Catalogue officiel - Liste des récompenses

Catalogue d'échantillons de bois du jardin botanique de St. Petersbourg envoyés a l'Exposition universelle de 1878

Notices sur les modeles, desseins, etc., rélstifo aux Travaux des Ponts et Chsursées et Mines

Exposition universelle de 1889 - Comités d'admisaion Membres du Jury - Récompenses

Les Expositions de l'Etat au Champ de Mars et aux Invalides

L'Exposition universelle de 1889

Conférences de l'Exposition universelle de 1889

Catalogue de la section française à l'Exposition de Vienne 1890

Rapport général - Rapport du Jury (Expoeition universelle de 1889) 27 volumes

Exposition Univerelle de 1889 - Produits de lo chasse, peche, etc.
Vaillant

Montevideo

1873

Vaillant

Paris

1878

Gueman

Paris

Boucard

Paris

1878

Boucard

Shsnghai

1878

Exposit. Univelle Lourre 1878 de 1878

Id.

Id.

Id.

Id.

de Loverdo

Lourre

1878

1878

1878

1878

1879

$\begin{array}{lll}\text { Ministère des } & \text { Paris } & 1889\end{array}$

Id.

Trav't Publice

Paris

1889

de Parville

Paris

1890

de Parville

Paris

Ministeres des Paria

Commerces, de

l'Industrie, etc.

de Loverdo

Vienne

1890

Picard

Paris

$1891-96$

de Clermont

Paris

1892 
Title

Exposition Universelle - Groupe de l'Economie sociale Exposition Universelle Agriculture, viticulture, pisciculture, horticulture

L'horticulture française à Chicago et aux Etats-Unie

Vie Congrès internatal d'Agriculture

Congrè internat al de l'Enseignement agricole

Congrès internat ${ }^{\text {al }}$ de Sylviculture (C. rendu sommaire)

Exposition univelle de 1900 - Sénégal et Soudan

Exposition univelle de 1900 - Notice sur le Congo françair

Exposition univelle de 1900 - Notice sur la Nouvelle Calédonie

Exposition univelle de 1900 - Les établissts français de l'Etude

Exposition univelle de 1900 - St. Pierre et Miquelon

Exposition univelle de 1900 - La Réunion

Exposition univelle de 1900 - La Côte d'Ivoire

Exposition univelle de 1900 - La Côte des Somalis

Exposition univelle de 1900 - La Guinée française

Exposition univelle de 1900 - La Guadeloupe et dépendances

Exposition univelle de 1900 - l'Indo-Chine

Exposition nouvelle de 1900 - Etablisgts français de l'Océanie

Exposition univelle de 1900 - Notice sur la Guyane

Exposition univelle de 1900 - La Martinique

Exposition univelle de 1900 - Notice sur Mayotte et les Comores

Exposition univelle de 1900 - Madagascar

Exposition univelle de 1900 - Le Dahomey

Congres internat ${ }^{\mathrm{al}}$ de viticulture (C. Rendu)

Actes de Congrès international de botanique

Congrè international d'Horticulture

Compte-rendu du Congrès international de l'Alimentation du bétail (Juin 1900)

IIme Congrès apicole (Pces Verlet des Séances)

Congrès internatal de surveillance \& de sécurité en matière d'appareils a vapeur

Exposition universelle de 1900 - Congrès international de Sylviculture (compte-rendu)

Apercée sommaire des objets exposés par l'Administration générale des apanages impériaux de Rusie à l'Exposition universelle de 1900

Les produits du sol des Colonies françaisea a l'Exposition Pan-Américaine de Buffalo

L'Alimentation en eaux et l'assainissement des villes à l'exposition universelle de 1900

Ier Congrès du Sud-Oweat navigable tenu a Bordeaux 12-14 Juin 1902 (C.-rendu des travaux)

IVe Congrès internatal de Chimie appliqué

Congrès international de l'Alpinisme

Rapports divers - (Exposition universelle de 1900) 66 volumes

Le second congrès du Bud-Quest navigable tenu a Toulouse en 1903

Exposition universelle de 1900 - Rapport Général administratif et technique 9 volumes - Preliminaires - Plan définitif

Palais et édifices - Admission Catalogues - Récompenses Congres - Concours, Services divers, etc.

Concours internationaux d'Exercices physiques et des sports

Le Bilau d'un Siecle (Exposit. Universelle)

\begin{tabular}{|c|c|}
\hline Author & Place \\
\hline Say, Lavallée & Paris \\
\hline $\begin{array}{l}\text { Ministères } \\
\text { divers }\end{array}$ & Parig \\
\hline de Vilmorin & Paris \\
\hline $\begin{array}{l}\text { Ministère de } \\
\text { l'agriculture }\end{array}$ & Paris \\
\hline de Lagorse & Parig \\
\hline Daubrée & Paris \\
\hline Exposit. Univelle & Paris \\
\hline Guillemot & Paris \\
\hline Exposit. Univelle & Paris \\
\hline Guy & Paris \\
\hline
\end{tabular}

Caperon Paris 1900

Garsault $\quad$ Paris $\quad 1900$

Mille Paris $\quad 1900$

Vignéras $\quad$ Paris $\quad 1900$

Famechon Paris $\quad 1900$

Guesde Paris 1900

Nocolas Paris 1900

Exposit. Univelle Paris $\quad 1900$

Bassières $\quad$ Paris 1900

Exposit. Univelle Paris 1900

Vienne $\quad$ Paris 1900

Exposit. Univelle Paris 1900

Exposit. Univelle Paris 1900

Exposit. de Paris 1900

$\begin{array}{ccc}1000 & & \\ \text { Perrot } & \text { Paria } & 1900\end{array}$

Bergmann Paris 1900

Exposit. Univelle Paris 1900

Caillas $\quad$ Paris 1900

Exposit. Univelle Paris 1900

Exposit. Univelle Paris $\quad 1900$

Administration Paris $\quad 1900$

Générale des

apanages im-

périaux

Méderlin

Paris

1901

Imbeaux

Paris

1902

Moisagn

Paria

1902

Moisan

Paris 1902

Moissan Clermont (Oise) 1902

Picard Paris 1902-07

$\begin{array}{lll}\text { Moigsan } & \text { Poitiers } & 1903\end{array}$

Exposit. Univelle Paris 1903

$\begin{array}{lll}\text { Picard } & \text { Paris } & 1903\end{array}$

Exposit. Univelle Paris 1903

Picard Paris 1903-07 
Title

Le ve Congrè du S. Quest nsvigable tenu a Bergerac du 6 gu 9 Juillet 1906

Premier et $2^{d}$ Congrès de l'aménagement des montagnes (Compte-rendu 1905-06)

Premier Congres internstional du froid

$\begin{array}{ccr}\text { Author } & \text { Place } & \text { Date } \\ \text { Exposit. Univelle } & \text { Bergerae } & 1906 \\ \text { Exposit. Univelle } & \begin{array}{c}\text { Bordesux, } \\ \text { Psu }\end{array} & 1906-07 \\ \text { de Loverdo } & \text { Paris } & 1908\end{array}$

(g) BOTANICAL AND SIIVCAL

Herbier forestier de la France

Pin Sylvestre

Notes gur le pin Cembro

Manuel de botanique forestière

Etude des différents sols du départ't de la Gironde

Les cendres des essences principales de la forêt de la Haye

Notes sur le sorbus Iatifolia

L'Eucalyptus et les applicstions industrielles

Flore forestière ( $3^{d}$ Edit.)

Remarques sur deux Variétés d'épicéa

Catalogue des végétaux ligneux indigènes et exotiques existant sur le domaine des Barrèa

Le Chêne vert ou le chêne yeuse dans le Gard

L'Eucslyptus, sa culture

Les essences forestières du Japon

Mérnoire sur les eucalyptus introduits dans la region Méditerranéenne

Les bois industriels, indigènes et exotiques

Notes sur les Eucalyptus géants de l'Australie

Observations sur la monographie des Pins sylvestres

Les reboisements par l'Acscia

Notes sur les arbres géants du Portugal

Etude sur le pin pinier

Les chênes de l'Amérique Septen le en Belgique

Ls végétation des Causses

Les Hybrides du Quercus suber

Causerie sur les bois de la Guyane

Arboretum de l'Ecole d'Agriculture de Grignon

Le Pin maritime des Lander et de Gascogne

Le Sapin de Douglas

Revue des travaux de botanique foreatière

Le pin \& Suere

Recherches sur la décomposition des matières organiques

Traité des arbres et des arbrisgesux

Illustrations des chênes de l'Europe et d'Orient

Arboretum National des Barres

Nature et utilisation des produits forestiers des Pyrénées-

Orientalea

Sur les formes accidentales du pinus laricio

Sols foreatiers et sols agricoles

Le Chêne de Juin

Les Sapins sans branches de Chaumont

Poids et composition de la converture morte des forets, etc.

Du reboisement et de la fertilisation des forêta

Flore forestière ( $4^{\mathrm{e}} \mathrm{Edit}$.)

Remarques sur le Juniperus Thuriferes et especes voisines du basain de la Méditérranće

Nomenclature des principales essences forestières de ls $\mathrm{Co}$ chin Chine

Le Chêne de Juin

Le Pin Laricio de Balsmann

Note sur le Pirus Cordata

Le chene de Juin (notes complimentaires)

\begin{tabular}{|c|c|c|}
\hline De Gayffier & Paris & $\begin{array}{r}1868-73 \\
1873\end{array}$ \\
\hline de Morogues & Orléans & 1873 \\
\hline Tassy & Digne & 1873 \\
\hline Flicke & Nancy & 1873 \\
\hline Baudrimont & Bordeaux & 1874 \\
\hline Heary & Paris & 1876 \\
\hline Godron & Montpellier & 1876 \\
\hline Martin & Paria & 1877 \\
\hline Mathieu & Nancy & 1877 \\
\hline Brenot & Paris & 1878 \\
\hline Adon des forêta & Paris & 1878 \\
\hline Begimbesu & Nimes & 1879 \\
\hline Pelsgand & Lyon & 1880 \\
\hline Dupont & Paris & 1880 \\
\hline Naudin & Paris & 1883 \\
\hline Grisard & Paria & 1883 \\
\hline Joly & Paris & 1885 \\
\hline de Morogues & Orléans & 1885 \\
\hline Caquet & Nevers & 1886 \\
\hline Joly & Paris & 1886 \\
\hline Flicke & Nancy & 1886 \\
\hline Houbs & Hasselt & 1887 \\
\hline Ivolas & Montpellier & 1889 \\
\hline Frabut & Paria & 1889 \\
\hline Dupré & Melun & 1889 \\
\hline Mouillefert & Paris & 1889 \\
\hline Dupré & Melun & 1889 \\
\hline Zeiller & Paris & 1890 \\
\hline Henry & Paris & 1890 \\
\hline Hickel & Rennes & 1890 \\
\hline $\begin{array}{l}\text { Wollny Trad } \\
\text { Henry }\end{array}$ & Nancy & 1892 \\
\hline Mouillefert & Paris & $1892-98$ \\
\hline Kotechy & Vienne & $1892-98$ \\
\hline Pardé & Paris & $1892-98$ \\
\hline Calas & Perpignan & 1893 \\
\hline de Vilmoris & Paris & 1894 \\
\hline Huffel & Nancy & 1894 \\
\hline Gilardoni & Nancy & 1895 \\
\hline Moreillon & Neufchatel & 1896 \\
\hline Eenry & Nancy & 1896 \\
\hline Thezard & Compiegne & 1897 \\
\hline Msthieu & Paris & 1897 \\
\hline de Coincy & Paris & 1898 \\
\hline Richa: & Salgon & 1898 \\
\hline
\end{tabular}

$\begin{array}{lll}\text { Jolyet } & \text { Nancy } & 1899 \\ \text { Calas } & \text { Perpignan } & 1899 \\ \text { Flicke } & \text { Paris } & 1900 \\ \text { Gilardoni } & \text { Nancy } & 1900\end{array}$


Author

Arbres forestiers étrangers (notes)

Notes sur les végétaux ligneux exotiques

Les principaux végétaux ligneux exotiques au point de vue forestier

La décomposition de matières organiques et les formes d'humus

Notes sur les hybrides du geare "sorbus" dans le Jura français

Influence de la converture morte sur l'humidité du sol forestier

L'Epicéa de St. Eustache

Acclimatation du chêne rouge aux environs de Rouen

Les arbres étrangers du Domaine d'Harcourt

Les cyprés chauves Condal (Saône et Loire)

Etude sur l'épicéa comparé au Sapin

Les saules, détermination, description, etc.

Lianes caoutchoutifères de l'Etat du Congo

Descriptions de Sections transversales de 12 espèces des bois indigènes et exotiques

Classification et monographie des Saules de France et d'Europe (Texte et Atlas)

Quelques vieux arbres de la contrée (Aisne, Marne, Ardennes)

Les peupliers au point de vue cultural pratique

Emploi des essences forestières indigènes et exotiques pour

le boisement des différents sols

Les vieux arbres intéressants des environs d'Autun

Les arbres du parc de Baleine

Remarques sur quelques abies méditérranéens

Les sols forestiers

Essai de Geologie forestière

La forết accumulatrice d'azote

Note pour servir à la détermination des Arbietinées de Vilmoriz

Pardé

Pardé

Wollny Trad. Henry

Flicke

Henry

Guinier

Hickel

Hickel

Gillot

Guinier

Guinier

Vildermann

Thil

Camus

Jadart

de Kirwan

Pardé

Gillot

Pardé

Guinier

Henry

Schaeffer

Heary

Hickel
Place

Date

Paris

Paris

1900

1900

Besançon $\quad 1900$

1901

1901

Paris

1902

1902

1902

1902

1903

1903

1904

1904 1904

Paris 1904

Paris

1904-5

1904

1904

1905

1907

1908

1908

1908

1908

1908

1009

\section{APPENDIX I}

\section{GERMAN COMMENT ON FRENCH FORESTRY}

Dr. Martin, of Tharandt, with a party of German foresters, made a critical study of French forest conditions in 1900 and reported upon them in 1906 . This technical critique and appreciation of French methods is of unique value to a student of forestry in France. It is, therefore, reproduced as a reference, to represent the best German views on French methods. The 1878 statistics, now out of date, cited by Martin, have been omitted, as have his generalities on French forest trees.

\section{MANAGEMENT OF THE OAK UNDER THE HIGH FOREST SYSTEM 1}

Occurrence and Growth. - In order that we might obtain an idea of the oak high forest we were shown several large forests in the catchment area of the Loire, the forests of Bellême, Bercé, and Blois which serve as representative examples of the French system of oak culture. The first-mentioned ranges (Reviere) have the character of a pure oak forest with only here and there a greater or lesser intermixture of beech; while in the forests of Blois entire stands occur which have been converted from coppice with standards and coppice stands.

${ }^{1}$ Translated for the writer by F. W. Haasis in 1913. 
That a proper value may be placed on the following information, which may, in part, seem remarkable to the German forest owners, it is not out of place to remark that in the forests mentioned we perhaps did not see mean conditions as would appear in an average of the whole country. By far the best conditions ${ }^{2}$ of site and stand of the French government forests are there represented. If we would avoid an utter misconception we must be careful not to regard foreign conditions too favorably, and not to undervalue our own system of management. Ranges (Reviere) with good conditions of site and stand are, indeed, as a rule, the best adapted to studying critically principles of management and their application. Parts of ranges which, as far as the minor resources of the soil and stand are concerned, are to be managed differently from the predominating stands were also found, so that an idea can be gained from these of other conditions where the poorer stands occur in greater numbers.

The site factors of the forests visited are very favorable for the oak. The soil is a deep loamy sand, for the most part sufficiently fresh. From analyses conducted in various stands of the Bercé forest the soil contains 0.23 per cent nitrogen, 0.12 per cent potash, 0.04 per cent lime, 0.045 per cent phosphorus. In the pole forests and mature stands there is very frequently found a cover of holly (Ilex, L.) which, in connection with the beech which occurs normally as an understory, improves the soil and prevents the growth of other cover. The elevation above the sea reaches 328 to 656 feet. The topography is mainly level or gently sloping. The climate, in accordance with the geographical location and the altitude, is mild and suitable for the oak. The mean rainfall is given as 27.6 inches. The greatest part occurs in summer so that extreme drought is not to be feared. Late and early frosts, which have so disastrous an influence upon the height growth of the oak and the character of its wood, oceur very infrequently. All these circumstances work together to produce favorable conditions for the growth of the oak. Optimum site conditions for the oak are here presented. "Everything concurs to render the climate humid and essentially favorable for tree growth," says Boppe, referring to this forest region.

Of the two species of oak the sessile-flowered is of the more common occurrence in the forest under discussion. Its growth and form are very good. The stands are characterized in a general view by straight form, clear bole, and high (according to our estimate); averages 65 feet from the ground, often higher. The crowns are very narrow; the boles have a form like that of our softwoods (Gymnosperms). If an accurate representation could be made of the proportions of crown and stem diameters a result would be attained entirely different from that found in the case of the German oaks. It is corollary to this that the basal area per hectare is very high. In certain stands, running 180 to 220 years old, which were examined in this connection, a basal area was determined of 474 to 485 square feet per acre, which is 50 per cent greater than given for corresponding stands on first-quality sites in the new German yield tables. $^{3}$ The number of trees per hectare in mature stands 180 to 200 years old amounts to about 200 ( 80 per acre) which is double the corresponding count in the tables cited; the mean diameter 20 to 22 inches, the volume of a trunk 125 to 160 cubic feet. The height of the older stands is mainly between 100 and 120 feet, individusl trees being even higher. It follows from this that the volume, also, of the stands must be very high. Stands of more than 11,430,12,860, and 14,290 cubic feet per acre, or about 67,500 feet board measure per acre, with 50 cords per acre in addition, such as can almost never occur in Germany because of the natural conditions of growth, are here met with over large, continous areas.

2 Dr. Martin was shown exceptionally favorable conditions. - T. S. W., Jr.

'Schwappach, Untersuchungen über die Zuwachsleistungen von Eichen-Hochwaldbeslanden in Preussen, 1905, S. 66. (Studies on the growth of stands of oak high forest in Prussia, 1905, p. 56.) 
The root habit of the oak, which could be very readily and very thoroughly studied on fresh blowdowns, seemed to us remarkably superficial. The observations which were made do not warrant the suggestion of an adequate explanation for this. Owing to the shallow root system, the remarkable height, the growth in fully stocked, dense, compact stands, the oak in those localities is more resistant to atmospheric influences, especially to wind, than is the case under other circumstances. A storm which had occurred the winter before our visit had wrought heavy destruction in the compartments under regeneration. This is no unusual sight. To anticipate, we were often to see the same thing in the future. The conditions here found are similar to those presented by the fir in the Vosges. The causes of breakage and damage by storms are far more often to be found in the conditions of growth than in the species. Under the conditions described, it is necessary, therefore, in the management of the oak, to employ methods which elsewhere are considered necessary only for shallow-rooted species. The ultimate strength of the crown and the distance from the ground of a crown which begins too high are of especial significance in their effects.

Establishment of Stands. - Natural regeneration is the general practice in establishing oak stands. The conditions for this are exceptionally favorable. The soil, after the removal of the encumbering growth of beech and holly, which is incumbent upon the buyer, is rich in humus, loose, and well adapted to the germination of the acorn. Yet more favorable is the second factor which is necessary for natural reproduction, namely seed production. Full seed crops are frequent, at intervals of about 4 to 5 years, with extraordinarily rich production. Between these, on the other hand, half crops occur, which, however, under the circumstances, are likewise sufficient for a complete seeding up of the reproduction area. Nowhere can the influence of climate conditions upon the possibility of reproduction be more definitely recognized than here. The chief advantage of the full mast is to be found in the ease of supplementing the preceding seeding. In the 2 to 3 year intervals between seed years the mast (following the major reproduction) falls, indeed, upon favorable soil. In the remaining gaps the young growth first established seeds in a new advance growth of its own. Since they are but little different in age and seldom suffer from frost, the trees so established close with the reproduction previously established to form a uniform stand, while with longer intervals between two mast years the soil becomes overgrown with grass. The seedlings following this are retarded a greater and greater extent, while at the same time they suffer continually from frost and suppression. From the management standpoint the frequency of seed years and the favorable climate have the important effect that there is great freedom allowable as regards the time and manner of forming the seeding stage.

Natural reproduction is generally effected through three cuttings in a manner similar to that usual in Germany under G. L. Hartig's system. The first aims to bring about seeding, the second to strengthen the young growth established, the third the isolation of the young stand. A preparatory cutting for the benefit of the soil is unnecessary. The cutting of standards (Hieb aus dem Vollen), which has given such good results in Hesse, has proved satisfactory in France also. It would seem that a preparatory cutting would be of value only for stimulating crown development and for effecting a better distribution of income. This object is better attained, however, by repeated, vigorous thinnings applied at the proper time, which would in addition result in a lessening of the long rotation period.

The first of the cuttings mentioned (seed cutting) is as a rule made when a mast has occurred. However, this first cutting furnishes an example of the fact that, as we have seen, under the favorable conditions prevailing, it is not necessary to confine operations too strictly to seed years. A seed cutting had been made in a part of the 
stand the year before our visit which was not a seed year, another part was to be so treated the coming year which gave promise of a rich mast. The marking was of that type where the trees which are to be left standing are marked at breast height and at the base with a marking hammer. This had been done some time before, and at the time of our visit the marking had been completed. Since the number and diameters of the trees which were to be felled were recorded in printed directions, which served as a basis for the sale, the marking and measuring had to be done very accurately. Subsequent variations in the formation of the seeding stage, such as sometimes seem desirable, are not permitted.

In making the seed cutting about one-third of the volume of the stand is removed. In good 200-year-old stands this amounts to 10,000 to 11,430 cubic feet per acre. The cuttings following this one are yet more severe. The seed cuttings which we saw had $\mathbf{7 , 1 5 0}$ to 8,575 cubic feet per acre of standing timber. In mixed stands the first trees to be marked for cutting are the beech which are overtopping the oak to a considerable extent and whose reproduction is at the same time undesirable; next those oaks which have poorly-formed, one-sided, faulty crowns.

As contrasted with the light-seeded conifers especial value is placed upon uniform reproduction. A dense reproduction is given preference over a uniform crop of seed. Any incidental disadvantages to the natural advance growth are not considered. Observations made on the light requirements of young oak in most German forest regions prove entirely inapplicable to the sites under consideration. It is astonishing to what degree they are able, under favorable conditions, to endure a complete cover during the seeding stage. Reproduction, which for a considerable time continues to thrive under an almost complete cover, can be seen in stands in which no reproduction cuttings have been made. Later, when such advance growth has reached a height of 3.3 feet the thickly crowded young stems begin to die off. But they are still abundant even after that, so that they are depended upon for the stocking of the stand.

The second cutting, la coupe secondaire, is ordinarily made about 3 to 5 years after the seed cutting. The young growth is given first consideration in deciding upon the exact time for this. This requires as vigorous and heavy an opening up as the first cutting was light. After that attention is given to distributing the income. There is taken out at this cutting about half the volume of the stand. In mixed stands, whatever beech are still present, they are the first to be removed. The last cutting, la coupe definitive ("the final cutting"), is made when it would be detrimental to the growth to leave the stand any longer.

The period for natural reproduction (on such soils) is 10 years. However, when it is necessary to do so, reproduction can be secured in an even shorter time. Great freedom of management is allowable in this regard because of the favorable conditions for growth. The causes which under other conditions indicate a delayed reproduction cutting are here absent. Damage from late and early frosts is not to be feared; and competition with weed reproduction, which is one of the most universal and important factors considered in locating cutting operations, can be endured safely by the oak even from an age of 3,4 , or 5 years and up. The second cutting is not absolutely essential; it can be made earlier or later, or entirely omitted. The cuttings afforded abundant evidence that the young growth shows the best development in those places where the stand had been opened up quickly. In other forest regions also experience indicates a hastening of the final cut. As a general proposition a gradual reduction of the protection afforded by the stand through a number of cuttings (in the marking of which due regard is given to the development of the seedling oaks, the distribution of income, and the damage caused in felling) is to be preferred to a single felling. In view of the damage done in felling and bringing out the heavy logs, a longer wait than 10 years is, 
however, not to be recommended. It can be justified only by circumstances which lie within the realm of practical management and which in a discussion of general technical and economic principles can be left out of consideration.

Under the favorable conditions of site in the forests which we are discussing artificial regeneration of oak stands is not even considered. Cultural operations are undertaken only to a very limited extent. Under the favorable conditions of site and stand found in central France the oak behaves just as the beech does in the best German localities where its reproduction likewise occurs to a sufficient degree without artificial aid. Wounding the ground is necessary where it has become hardened as is especially liable on the edges of reproduction (areas). Replanting, likewise, is only occasionally necessary. It will, however, be necessary in small patches, especially where loggers' huts and skid yards have been located. For that purpose 2-year-old nursery-grown seedlings are used. When the weak stems show poor growth they are fastened to sticks.

Under certain conditions - but as far as we saw, not very frequently - the beech also is used for the artificial completion of the stand. It is planted as 2-year seedlings.

Such plantings are the rule when cuttings of old oaks are made in pole stands such as is especially necessary in stands which are in process of conversion from a former coppice with standards or selection stand. Such cuttings can be very profitable financially. In one oak pole forest which we were shown there were cut out thirty-nine old oaks with 675 cubic feet which gave a money return of $\$ 2,641$. The marking of such a cutting is facilitated by the general custom of a preliminary marking of the trees to be felled. Everywhere in France there are differences of opinion as to the value of the oak or beech of the same age. That this mixture has both advantages and disadvantages is a matter of common knowledge. This idea is definitely substantiated by the French forests. Oaks are seen which continue to grow faster in height but which, because of the influence exerted upon them by the beech, are retarded in the lateral development of their crowns, and exhibit a much weaker growth than would be the case otherwise. On the other hand the condition of mixed stands leaves no room for doubt that the beech, in moderate mixture exercises a very favorable influence upon the condition of the stand as a whole. The boles grow very clear of knots and the ground is rich in humus and free of weeds. Under the conditions described, therefore, where the oak is readily kept in the lead the plan of even-aged mixed stands is highly to be recommended. The German forest officers who formed part of our party were of the opinion that in France, where the conditions for the oak are very favorable, the system deserves more extensive application.

Of other planting in general, the completing of oak stands upon poor soil with planted or seeded pine is effected in a manner similar to that? practiced on many German operations. Following the development of the two species the pine either persists, reduced to the rôle of an auxiliary species and is removed early, or it changes over into the dominant portion of the forest.

The most important question of what kind of a comparison can be made between the French method of managing oak and the corresponding practice customary in Germany reduces itself to a question of, in how far, relatively, natural reproduction, which is there used with such excellent results, can find application under German conditions. In France natural reproduction is usually regarded as universal. The handbook of the Paris Exposition begins with the words: "In France forest silvics . . . has as a fundamental principle that the forest ought to reproduce itself indefinitely through its natural resources." Artificial establishing of stands is undertaken only in exceptional cases, notably when the object of the management is the reforestation of mountains, the afforesting of waste lands, to increase the timber for the agriculturist, the afforestation of clearings, the introduction of species which do not occur 
in the stand, "the introduction of valuable species into the stands whose mixture is unsatisfactory." Hence, the French forest management is seen to be in that position to which it is assigned in the newer German literature, especially by Borggreve. ${ }^{4}$

In the French forests which we visited, natural reproduction was doubtless the best method of establishing the stand. It demanded a minimum expenditure of money; the young growth grew in a good close stand; the maintenance of that species best suited to the site is assured. Even in German practice natural reproduction has, under corresponding conditions, been looked upon as by far the preferable method since the time of G. L. Hartig. But the conditions necessary for natural reproduction of the oak very frequently do not occur in Germany. In the first place its profitable application is impossible because of the fact that stands do not occur which are adapted to the establishing of seeding compartments. Near young stands the oak occurs chiefly as isolated veterans in pure beech. Stands of middle age suitable for reproduction are rare in most of the larger forest regions. These are mostly beech stands into which the oak has been artificially introduced. Next it is to be noted that in Germany the climatic conditions are far less favorable than in France, where optimum sites are found. The system of management applicable, therefore, would seem to be artificial regeneration of the stand if the oak is to be grown in sufficient quantities. As having a direct bearing upon the status of the question under consideration there may be mentioned the excellent stands of oak reproduction on the Oberföresterei (forest) of Eichelsdorf which were described before the Meeting of German Foresters in Darmstadt (1905) by Forstmeister (Supervisor) Trautivein, who has for many years been manager of that forest. Sowing in strips not too far apart under the protection of the succeeding beech-mast is the method used in establishing the stands. In most of the other southern and central German forest regions also, especially in Spessart, in Nassau, etc., sowing is the prevailing method of reproduction. ${ }^{5}$ On the other hand, in North Germany natural reproduction can hardly be considered the common method. Satisfactory reproduction over large areas, instead of merely in groups, is not really practicable because of the scarcity of mast.

The foregoing discussions apply, in so far as they are of general application, to other species as well as to the oak. For all, natural reproduction is to be recommended where suitable conditions of site and stand occur, and where it is desired to grow the species which occurs on the site. With all, however, a greater or lesser relation exists to the existent chemico-physical and ecological conditions. In the case of beech G. L. Hartig's amount of reproduction was diminished by the requirements of the conversion of the beech or the invasion of intolerant species. In the case of spruce it is impracticable on many sites because of the danger from storms (windfall). In the case of pine the trials which have been made of natural reproduction have been very unsatisfactory in their results. Judging by our observations, it seems that, contrary to the principles set forth in the Handbook of the Paris Exposition the artificial regeneration of stands under French management is increasing ${ }^{6}$ in amount and importance. It

"Die Forstreinertragslehre, 1878, close of the book "Die principaliter-man versteherecht - als Regel verlaugte naturliche Verjungung (which chiefly - it can readily be understood - as a rule requires natural reproduction," etc.); Die Holzzucht, 2d edition, p. 117, Die Naturbesamung (Natural seeding).

${ }^{5}$ Of course, where suitable conditions of stand and site occur (oak seed trees abundant over large areas) natural reproduction with simple artificial aid (Nachhilfe) is still a very satisfactory method of establishing oak. It is therefore practiced by preference and with good results by forest owners with broader experience, as the author has had opportunity of seeing on a trip made some months ago (August, 1906) through the Forstamt (Forest office) of Rohrbrunn and the Oberförsterei (forest) of Salmünster.

${ }^{6}$ This prediction is certainly erroneous now that labor is so scarce and so costly. T. S. W., Jr. 
is never safe, however, to formulate universal rules for the establishing of stands on the contrary account must always be taken of the site factors.

Care of the Stand, and Thinning. - In France due emphasis is laid upon the retention of the oak. The necessity for their regular and continued examination becomes more insistent the more. beech takes part in the composition of the stand. In general, this is true to a greater extent in the northern and eastern parts of the country than in the southern and western. In mixed stands the cleaning axe should be applied every 4 to 5 years. The disastrous effects of too long an interval are strongly emphasized in the literature: "In fact a few years of neglect or oversight in this work, so expensive and tiresome to the force, is sufficient for irrevocably losing all the oak" (Boppe, Sylviculture). The hornbeam gives little trouble in mixture with the oak because of its slower growth; the oak is always the faster grower. Wherever this thrives, however, other faster-growing species come in, namely, birch (Betula, L.), aspen (Populus, L.), alder (Alnus, Ehrb.), round-leaved willow (Salix caprea, L.), etc. At first valuable as nurse-trees and auxiliary species in effecting the closing of the stand, they soon become harmful. With the removal of softwoods (Weichhölzer) poorly grown oaks are likewise disposed of. Because of the dense stands and the favorable site factors there is less of this work necessary here than in many German forests where the conditions for the growth of the oak as compared with those for its associates are less favorable.

As far as thinnings are concerned we are not aware of anything which would indicate that the methods are in any way different from those at present practiced in most of the German forest regions. The éclaircie par le haut (thinning in the upper story), which is considered typical of French management, was seen in pure stands far less than had been anticipated. As in Germany, it is practiced everywhere in mixed stands. As to the age for beginning the thinnings, the appearance of epicormic branches (branches gourmandes), not only upon the suppressed but also on the dominant trees, is regarded as an indication of crowding ("the upper story is, on the whole, too crowded"), and therefore enlargement of the crown space of standing trees which are too much suppressed is indicated. In general the thinnings are repeated less frequently than is considered necessary in Germany. In the juvenile stage it is considered usual to return in 8 to 10 years at the most; later, the intervals are longer. "Thinnings are repeated at intervals of 6 to 12 years during the stages from sapling (gaulis) to large pole (haut perchis), that is from 12 to 20 years of age up to the size of standards. . . . As far as we have been able to determine the actual practice corresponds to these theories in the literature (Boppe). In the forests of Bellême and Bercé which we visited the working plans provided for two thinnings within a period of 24 years. This plan was strictly carried out. Any variation requires the approval of the conservator.

The grade of the thinnings made in the forests under consideration can, in general, be designated as "moderate." The young stands of oak which we had opportunity of going through or of looking at were denser than we would consider desirable for the oak. Later on, the object will be the strengthening of the trees with good crown development which have been overlooked. "The thinnings should be conducted with the sole object hardiment (unhesitatingly) of favoring those trees which are judged to be the best, gradually giving them sufficient room for a free crown development. They begin as soon as the trees to be preserved have been definitely decided upon" (Boppe). In accordance with this direction in French silvicultural literature the best trees in the 60-year or older pole-wood stands shown to us, which were to be favored in the thinning, were marked by white streaks of paint (Färbstriche). Even in the older stands the cover is not to be appreciably interrupted. Therefore the increase in the growing space most desirable for the individual tree is often considerably too small. ("Care must always 
be taken not to break the leaf canopy.") The oaks in the understory should, for the most part, be widely spaced; there is no particular need of keeping them in the stand either for their sale value or for the benefit of the soil. "The oak cannot be expected to constitute both upper and lower stories at the same time." Just that much more pains is taken to preserve that part of the understory which is suitable for soil protection. The retaining of such species will, of course, be considered all the more necessary the milder the climate and the better the soil. For this reason it has been emphatically directed "to take particular pains to leave all woody undergrowth (suppressed trees, shrubs, etc.) which is capable of persisting in place of a lower story. This lower story must never be touched in making cuttings." Only when preparing for reproduction is the understory to be removed.

In stands where beech occurs in the mixture the thinnings retain the character of cleanings from the sapling age well up into the higher pole-wood and standard classes. ("During this long period the thinnings must always take the form of liberation cuttings if the successive crowding out of all the oaks is to be avoided.") In general, however, the raising of mixed stands of beech and oak of approximately the same age presents no difficulty if at the time of the regeneration the faster growth of the oak is encouraged. Owing to the climatic conditions this proposition is entirely feasible. In the northern part of the country the conditions are different. It has been established that here the beech is a faster grower than the oak at all ages. For such stands, therefore, the mixing of the two species by distinct groups, is directed. ("These difficulties are overcome by practicing regeneration in compartments in which each species, maintained in a pure stand . . . receives proper care throughout its entire life.") In France an intentional underwood, through which the needs and requirements of both species can best be met, is seldom formed. The special cases mentioned of the underplanting of open spaces in the stand are not, in our estimation, to be looked upon as examples of forming an underwood. This also is denounced in the literature. At least Boppe refers to the Bavarian (Spessart and the Palatinate) system of forming an underwood as a local peculiarity.

The earlier operations of thinnings can best be understood from the present condition of neighboring older stands. An examination of these leaves no room for doubt that in France as in most German States thinnings have not been conducted in strict accordance with the needs of the management. The formation of stands as described above with a volume of 11,430 to 14,290 cubic feet per acre, a clear length of 65 feet and a diameter of 20 inches - was effected by moderate thinnings.

\section{HIGH FOREST REGULATION ?}

As admirably as the management of the French State and administered forests is exhibited in everything which relates to the technical side of the subject (establishment and care of stands, thinnings, felling operations, etc.) the conditions of the forest organization and the regulation of revenue will meet with but little favor in the eyes of the German visitor. We did not, on the present trip, see any operations from which the methods of regulating income and the form it should take could be judged. But the principles of the forest regulation were so evident in the condition of the stands and from the economic maps that we could get an idea of them even without the working plans of the general form of those which may be seen for the State forests. The most important consideration characteristic of the French forest regulation has to do with the local establishment of the working groups and the choosing of the places where cuttings are to be made, with which there must at the same time be combined an establishment of the rotation period.

' Forstwissenschaftliches Centralblatt, 1908, pp. 530-47. 
Local Establishment of Working Groups. - The French State and State-administered forests are divided into "series" (working groups). These are adjacent areas with like markets and requirements for continued management, which frequently correspond to Schutzbezirken (triages) (protection forests). They are somewhat similar to the Prussian Bloken. "By series or working group is understood a portion of the forest which is designated to be placed under a special working plan ${ }^{8}$ in accordance with the provisions of which it will form a series of annual cuttings." There is a further division into sections which correspond somewhat to the German Betriebsklassen (working units). "By section is understood a portion of the forest which is distinguished from the rest of the forest (surplus) by the method of management (taillis, futaie regulière, futaie jardinée, etc., coppice, even-aged high forest, selection high forest, etc.)." The working units are subdivided into "affectations" which are the same as our Periodenflächen (periodic blocks). In the forest of Bellême which we visited there had been established eight periodic blocks of 25 years.

In locating the working units the French aim has been, as far as practicable, to so place the affectations that they will form an uninterrupted whole, and not be separated from one another by bodies of other periodic blocks. The idea of consolidating the areas of periodic blocks has been developed in France probably to a greater extent than in any other country. That there are efforts to effect this is indicated by L. Tassy, conservateur de forêts (conservator of forests). It is very characteristic of the French system of management, and we will therefore translate verbatim. The location of age-classes and felling series is given by Tassy ${ }^{2}$ as follows:

"1. From the viewpoint of the progress of the cuttings in that periodic block.

"2. From the viewpoint of the relative position of the periodic blocks.

"While the progress of the cuttings in each periodic block should be in accordance with the principles of cutting series, it is at the same time desirable that the felling areas have a regular form so that they shall present the narrower side to the most violent winds, so that they may be traversed and bounded by rides but especially that they may form separate and distinct blocks. I especially recommend that a periodic block never be broken up unless there are very especial reasons (motifs majeurs) for it. The continuity (contaquité) of the several compartments constituting a periodic block is expedient, not alone for the orderly regulation of cutting series, but also from the standpoint of the economic results of the working plan."

The regulation of the French State forests is conducted in accordance with the principles here set down. The periodic blocks are systematically grouped on the maps and in the field. It is evident, however, that it is frequently utterly impossible to adhere strictly to the system of such continuous periodic block without a great sacrifice of growth and a decided variation from the time of maturity. To avoid serious loss in this latter regard the management often seems to leave unused younger stands within the periodic block in the several periodic blocks. On the other hand, however, stands of a later periodic block will, under certain conditions, be brought to reproduction. In the high oak forests which we saw there were seed and removal cuttings in periodic blocks 1 and 2.

The importance to the management in all the larger adjacent forests as to whether and how far the age classes shall be considered in making divisions for the regulation of income is not to be minimized. Such a grouping of periodic blocks as described by Tassy and actually practiced in France results in too extensive reproduction cuttings and too great areas of the same age class. Its practice will result in conditions similar to those formerly frequent in most of the German forests. In virgin forests similar stands are

${ }^{8}$ L. Tassy, Etudes sur l'aménagement des forêts (Studies on the Organization of Forests), p. 385.

Tassy is rather out of date. Dr. Martin should have consulted Huffel. 
aiways formed under like conditions of site. G. L. Hartig ${ }^{10}$ himself noted this tendency. The areas of natural reproduction which he established have, because of the infrequency of seed years combined with a lack of systematic distribution, often resulted in extensive even-aged stands. The first result of increasing artificial regeneration has been a clearcut systematic arrangement of stands according to species and age classes.

As is well known, the opposite system to the French plan with its establishing of age classes, is practiced in the kingdom of Saxony. The formation of short cutting series has for a long time been a characteristic feature of the Saxon management. Judeich, in his writings, emphasized its superiority; the establishment of Saxon forest organization put it into practice. To promote the systematic arrangement of the working groups there were deliberately made severance cuttings and fellings which were intended to make possible the independent management of areas located near one another. In the boundaries of surveying, and regulating the Austrian State and institution (Fond-) forests, also the establishing of short cutting series is emphasized.

Which, then, of the two opposed systems is right, or, since both have weaknesses, the better? In Germany the French system has rarely been developed to such an extent as the visitor to the French forests finds it. In the main the degree of maturity is given first consideration in the location of the cutting areas. The strict regard for the maturity leads to the maintenance of the existing form of the stand. The beginning of maturity, however, and, to a yet greater extent, the actual time of overmaturity of individual stands allow of more or less extension. Many stands could, without seriously interfering with the economic results, be changed one or two periods one side or the other. A fixed policy, therefore, of separating or combining stands at the time of regeneration is inapplieable even in German practice.

If we investigate the rules for establishing stands which must, in the direction proposed, be considered the most weighty the French system does not give a very favorable impression. There are always certain dangers connected with the grouping of even-aged stands, in coniferous forests at least. Many insects, the Maybug (Maikäfer) in particular, appear in greater numbers. The increased fire danger is yet more prominent. The relation of the stands to storms must, however, be regarded as the fundamental and general basis for deciding the proposed question of retaining the stands. And even in this respect we can concede no superiority to the French system, at least not when natural reproduction is relied upon, which, as the Handbook of the Exposition emphasizes, is regarded as the rule in France. No other form of silvicultural management is so destructively visited by storms as large symmetrically arranged reproduction cuttings. The danger from storms is especially great in the case of old stands, as in the oak and fir stands of the French State forests in which it is no longer possible to strengthen the trees through reproduction cuttings, and to accustom them to a subsequent open position. As a matter of fact damage by storm has recently occurred to a very considerable extent in forests managed in accordance with the French method of regulating forest organization. The wind-breakage in oak reproduction cuttings under the mild conditions of the Loire plains has already been mentioned. In the fir stands in the Vosges such severe storm damage has occurred of late that many forest owners are no longer willing to concede the fir any superiority over the spruce as far as resistance to wind throw is concerned.

When we come to consider the employment of clear cutting there is rather more to be said in favor of the French system. If the principal face presented to the prevailing

${ }^{10}$ In the Instruktion of 1819, in which (p. 20) we find: "Since the plan for the artificial regulation of forests must be so arranged so that the compartments decided upon for every periodic block shall close on one another as fast as possible, it is necessary - (Da der Plan zur kunfigen Bewirtschaftung des Forstes so eingerichtet werden musz, dasz die für jede Periode zum abtrieb bestimmten Jagen soviel wie möglich sich einander schlieszen, so musz . . . )." 
storms were equally well protected in the case of large and small cuttings, differences in the conduct of the storm which are due to other causes would be apparent. In the case of a large number of small cuttings there are formed more openings in the stand in which a storm can attack. However, there are many other serious results of larger cuttings which become evident by trial. Many insects appear in destructive numbers. The damage from weeds, frost, and heat is greater the larger the cuttings. For tender species which grow slowly in the juvenile stage it is an acknowledged principle of management to avoid large clear cuttings.

The method of managing the Saxon State forests seems much better in this regard. It has the great advantage that the cuttings are kept small and gradually arranged together in rows. The young growth has the benefit of the protection from the standing trees. In relation to market conditions, also, and other factors which must be taken into consideration in practical management, the method of small cuttings with the possibility of a change in the manner of utilization is a desideratum. As far as storms are concerned the superiority claimed for the Saxon method by its advocates is not to be accepted without qualification. If the direction is known from which destructive storms are to be expected in the future it is possible to protect the stand by means of the methods of felling and making severance cuttings which are peculiar to the Saxon system. But this cannot be determined. Storm statisties" recently published show that even easterly storms have frequently done considerable damage. If, in spite of this fact, future efforts in forest management shall still be directed to protecting against westerly storms as far as possible, the chance of damage by storms coming from the opposite direction must also be reckoned with. Openings made in the stand by severance cuttings and fellings for the strengthening of borders exposed to western winds would, however, appear hazardous. The undesirable consequences which may be bound up with a system of severance cuttings are truly pointed out by the advocates of the Saxon method of managing State forests. Oberforster (Supervisor) August a few years ago wrote an article on the effect of southeast storms in the Olbernhau Revier (range) (Erzgebirge). He made the comment that: "The damage (which the southeast storms have caused) would not be so great if it were not for the fact that on the Olbernhau Revier one of the chief objects of the Saxon method of forest management, the creation of a large number of short cutting series, had been practically attained. Over large areas cuttings have been made in every division (Abteilung) within a decade; and as desirable as these are for establishing regeneration areas, for replanting, etc., yet in this case many reproduction cuttings begun at the eastern side have proved disastrous." The relation that tearing the stand to pieces bears to damage by storms cannot be more strikingly presented. It is to be added, however, that the damage caused by storm under the Saxon management will never have such great dimensions as is the case under the French method of making cuttings. Any careful investigation will substantiate this. Communications from Saxony have of ten confessed to damage from storms. But their effects are on a smaller scale than in the Vosges and other forest regions with extensive homogeneous areas of veteran forest. The favorable results of Saxon management are not to be accounted for by the physiological characteristics of the species - in Saxony the non-storm-resisting spruce predominates - but by the conditions of growth secured by the forest organization.

If the foregoing arguments are, in the main, susceptible of proof, yet it must not be forgotten that in this, as in most other forest regions, the extremes are necessarily the best methods. The proper economic management is often to be found nearer the mean. The French method of grouping must be unconditionally discarded. But even in regard to too strict a separation of age classes it is worth while making the observations men-

${ }^{11}$ Bargmann, Allgem. Forst- und Jagdzeitung, 1904, p. 84. 
tioned. The most essential definite problems of practice have to do with establishing the universal fundamentals through the application of which there will be effected a greater safety of the system from damage by storms. These rest, first of all, upon the way in which the forest is divided up for management. In mountainous regions, with spruce predominating, where the sequence of the cuttings is of the greatest importance, divisions must be based on the topography. Natural features - not only main ridges and valleys, but also the secondary ridges where the slopes change their direction afford the best boundaries for the fixed working divisior (Wirtschaftsfiguren), and for the cutting series. In many cases cuttings have to progress away from them in both directions. In broken (kupiert) topography the extension of uniform working groups will often be definitely prescribed by the relations of the topographic features. In level country a good network of rides with their principal direction northeast - southwest or eastwest has the same effect. A good distribution not only facilitates the breaking up of larger areas but also constitutes the best framework for similar grouping into manageable working areas. The second method of reducing the danger consists of the establishing of sufficiently broad division lines. Only rides of sufficient width are suitable for forming belts which shall be sufficient for protecting the stands against storm. It should be noted in this connection that the extension of these increases the area of unproductive soil. However, it must be remembered that many of these will be changed to the character of roads, and some, at least, of the rest used for dragging up and piling the wood. Broad rides serve, also, as a means of protection, especially for the prevention and fighting of fires. For feeding grounds for game, also, and for the raising of grass and straw for the use of those who work in the woods, rides are valuable only when of sufficient breadth.

Silvicultural measures are another instrument of forest organization or regulation which can be used for placing the stand upon a firm basis. All injuries due to the manifestations of inanimate nature will be aggravated by unsymmetrically developed roots and twigs, as well as by long clear length. Everything which works for a symmetrical development of the roots and against a long clear length renders the stands more capable of resisting storms and their consequences. Among these may be mentioned the selection of good individuals for planting, the restoring of regular spacing, timely decision upon severer thinnings, and careful closing of the borders of the stand. By the employment of such measures there will be a far greater certainty of the stands surviving than there can ever be under the French system of grouping age classes together.

Determination of the Cut, and the Rotation Period. - The most general and important problem of working plans is the determination of the yield. The basis for this has an intimate connection with studies of maturity which are always of significance in choosing the type of management and the direction it shall take. Dependent upon it, also, is the amount of forest capital which is regarded as normal and which it is desired to establish. No other subject is of more importance for the condition of the French State forest policy and the directions it will take.

In the forests of Bellême and Bercé the rotation period has been fixed at 200 years. Eight periodic blocks of 25 years each have been formed. The actual utilization amounts in the 6,000-acre forest of Bellême to 173,050 to 282,525 cubic feet in all, an average of 28.6 and 46.0 cubic feet, respectively, per acre. This on good soil and with the good condition of the stands, which were about 120 feet high, is a very conservative cut, far short of the annual increment. The effects of this exceedingly conservative management applied for long periods are clearly evidenced in the condition of the stands. The trees are full-boled and of great cubic contents. The thinnings, however, are far more moderate than is necessary with the conditions of growth which have been described (good soil and mild climate with a long vegetative period). 
No basis for the rotation period in the forest under discussion has been described by the advocates of the French State forest policy, at least not definitely enough to be repeated here. We can get an idea of it only from the condition of the stand and the information given in the literature. Tassy, ${ }^{12}$ discusses the determination of the cutting age (exploitabilité) in the following words: "The volume of the wood which has been produced, its economic value (utilité), its sale value (valeur vénale), and the ratio between its value and that of the capital from which it comes are the various factors which, individually or collectively, must be borne in mind if it is desired to make the greatest profit from the management of the forest. These several factors correspond to four objects of management: First, management for the greatest volume production; second, that for the bighest technical value; third, that for the greatest money revenue; fourth, that for the largest interest on the investment." As is everywhere the case, the rotation periods in the French forest management, as well, are dependent upon the progress of volume and value increment and the interest paid on the forest capital. The question of rotation periods in France cannot be understood and discussed further without entering into discussion of the peculiar conditions whose influence upon the condition of the forest is nowhere more pronounced than here (a fact which is not brought out in the foregoing quotation).

\section{(a) VOLUME INCREMENT}

This is everywhere a fundamental determining factor of the length of the rotation period. G. L. Hartig's teaching, that upon given areas there is always a maximum increment which should be produced, may always be accepted as essentially correet. Even if the value of the product and the interest paid on the capital be taken into consideration yet the volume increment is still an essential determining factor. If it be redueed the volume and value of the product from which revenue is obtained will likewise both suffer a diminution.

The mean increment (accroissement moyen) is looked upon as that which shall decide the age of maturity under the French system of forest management. "The rotation period giving the greatest volume production (exploitabilité absolué) is indicated by the age at which the greatest mean increment is produced." According to that the proper rotation age occurs in that period when the current increment is falling off. It corresponds to that age when the current increment is equal to the mean increment.

We have but little definite information which bears upon the problem of current increment or upon the principles of mean increment. In the forest region of Bellême and Bercé exact studies were available chiefly for a 200-year-old oak stand with an admixture of a few beeches and a ground cover of young beech, giving its increment and previous utilization. The number of trees per hectare amounted to 198 ( 80 per acre), the volume of wood larger than 28 inches at the small end (Derbholz) 13,875 cubic feet per acre. The actual utilization is given as 6,200 cubic feet per acre, the total possible as 20,080 cubic feet per acre. According to this the mean increment amounts to 96 cubic feet per acre. As a matter of fact the actual volume production was greater because during the 200-year period it is very likely that wood was utilized of which partial or no accounts were kept.

The current increment in stands more than 200 years old has doubtless heretofore not been determined because of the falling off in growth occurring at this time. The principal cause of this falling off is evidently the abundant flower- and seed-production. Otherwise the plant foods of the soil are completely utilized by the roots, and the air space by the crowns; hence any very great reduction in that increment which corresponds to the site is not to be expected. This supposition is substantiated by studies

12 l. c. Deuxième étude: de l'exploitabilité (Second article: on the age of maturity). 
made on test trees from time to time during the course of our trip. These indicate that for a dominant tree with annual rings 0.04 inch in breadth there is an annual increment of 0.9. According to this the current annual increment at present amounts to 130 cubic feet per acre and if that proportion holds true for only three-quarters the volume of the stand - the dominant trees - to (in round numbers) 100 cubic feet per acre.

This is almost the same as that which is determined from complete volume tables and yield statistics as the mean annual increment. The two kinds of increment are seen - contrary to the commonly accepted belief - at the age of 200 years to be at the point of crossing and agreement.

If the foregoing propositions_cannot, because of the lack of sufficient data, be definitely proven, yet enough observations have been made to justify the conclusion that the current annual increment of the oak under the existing conditions of the site and the indicated character of the stands exhibits a uniform decline. The falling off in current annual increment has taken place very gradually; far more gradually than most yield tables indicate for German forests, where the oak is much less crowded in the older age classes. ${ }^{13}$

To a yet greater extent is this evident in the case of mean annual increment. This, in the case above cited, has not changed appreciably for a full century. That sort of maturity known as exploitabilité absolué gives entirely too indefinite results, in that account; it may be placed at as early an age as 80 years or as late as 200 .

\section{(b) QUALITY INCREMENT}

Of greater importance than the volume increment as a determining factor of the age of maturity is the value increment. The French management shows conclusively that in their own forests especial importance is attached to the production of good quality of product. The less private individuals are inclined to grow heavy timber, the more does the State find itself confronted with the necessity of producing this economically indispensable product. The best way to get an idea of the progressive increase in value is to study the average prices paid for wood where the trees of varying size are valued separately. The approximate selling price of trees of various girths are as follows:

Trees of $200 \mathrm{~cm}$. circumference $(65 \mathrm{~cm}$. diameter $), 65$ francs per cu. $\mathrm{m}$. ${ }^{\text {19 }}$

Trees of 100-200 cm. circumference (33-36 cm. diameter), 45 francs per cu. m.

Trees under $100 \mathrm{~cm}$. circumference (under $33 \mathrm{~cm}$. diameter), 30 francs per cu. $\mathrm{m}$.

These classes are too indefinite to afford any precise idea of the value increment. They show, however, that the increase in value bears a direct relation to the increase in size. Trees whose diameter increases from 20 to 24 inches increase in value about 40 per cent. With annual rings 0.05 inch in width about 35 years are required to produce a diameter increment of 3.9 inches. Hence the yearly increase in value can be placed at a good 1 per cent.

\section{(c) THE INTEREST PAID ON THE GROWING STOCE}

It is not really possible to fix the length of the rotation period intelligently without a study of the economic principles upon which the practice is based. The kernel of ${ }^{13}$ According to Schwappach's yield tables:

On first quality site at

the age of ...........

The current annual in$\begin{array}{llllllllllll}\text { crement amounts to . } & 10.2 & 9.2 & 6.8 & 5.2 & 4.6 & 3.8 & 3.4 & 2.8 & \mathrm{~m}^{3} \text {. }\end{array}$

The mean annual increment ............... $\begin{array}{llllllll}60 & 80 & 100 & 120 & 140 & 160 & 180 & 200\end{array}$ ${ }_{14} 26$-inch trees, $\$ 12.55 ; 13-26$-inch trees, $\$ 8.70$; under 13 -inch trees, $\$ 5.80$.

Wood more than $7 \mathrm{~cm}$. in diameter at the small end 
this in its practical bearing is expressed in the questions of whether and how high a rate of interest should be expected on the forest capital invested. This question is, indeed, thoroughly discussed in the French literature. Its.treatment is of particular interest to the German forest owner, who is occupied with the theory of net income. A very clear discussion of the theoretical and practical problems and objects of the same is given by Tassy, l. c. He lays special emphasis on the nature of forest capital, offers explanations of the differences which exist in the relation of revenue to value of the wood in comparison with other branches of domestic economy, and advances the following propositions: "The rotation period which gives the greatest interest on the investment is almost always shorter than that which corresponds to the greatest mean annual increment. The less valuable the species concerned and the less likelihood there is of its increasing in technical value and in price as it grows older, the earlier does this age occur. The lower the rate of interest the more closely does the rotation yielding the greatest interest correspond to the rotation which produces the most valuable product." As opposed to this idea, however, it should be noted that not the greatest, but a suitable interest on the forest working capital is demanded by the German advocates of the theory of net returns.

From these three propositions are drawn definite policies for economic management $(l . c$.). Among these it is of special interest to note that by proper thinning the age of maturity is advanced while at the same time the production of the stands is increased, and that the capital, upon which the income is dependent, is diminished by the same. The increasing value of timbers justifies more intensive utilization. The question of underwood and the increased length of rotation are justified by that fact. The influence of the rate of interest is exhibited in the fact that a reduction of it results in a longer financial rotation in such a way, however, that the rotation period corresponding to the highest mean value increment, and that corresponding to the greatest net revenue are equal only when the rate of interest is equal to zero.

In spite of the simplicity and clarity of the arguments whose chief points have been rehearsed, no adequate basis can be derived from the literature cited, for the rotation period which can be considered correct for a given forest region and given species. The examples cited rest mainly upon hypothetical suppositions; they give very indefinite results. The first of these three propositions, namely, that the rotation corresponding to the maximum yield culminates just before the culmination of the mean annual increment, allows very wide variation. For the maximum mean annual increment occurs, as has been mentioned under (a) not at any one definite age, but somewhere within a long period comprising or exceeding an entire century.

More definite inferences as to the rotation period for the French State forests can be drawn from the actual condition of the forests themselves than from the literature. The oak stands under consideration, in the forests of Bellême and Bercé as well as the stands of fir in the Vosges, can serve as admirable examples from which to deduce more definite economic principles. Both are typical of the kind of stand to which a consistent observance of the principles of the greatest net forest revenue or of the greatest mean value increment will lead; moderate degree of thinning, dense stocking, long rotation period. The volume and value resulting from this system are of a definite amount. Restricted to the revenue at maturity the mean value increment of the stands mentioned, which consists of 34,255 cubic feet valued at 40 francs $(\$ 7.70)$, amounts to $39,000 \div 210=$ (in round numbers) 180 francs per hectare ( $\$ 14$ per acre); this is one of the highest which has hitherto resulted under management anywhere, or been extensively described. The figures given above, however, indicate that, in spite of this, the mean value increment has not yet attained its maximum. Even when the annual volume increment amounts to only 0.5 per cent, and the annual increase in value like- 
wise to only 0.5 per cent the stands, if they remain uncut, increase in value in a larger ratio than is indicated by the increase in age. The numerator of the fraction $\frac{39,000}{210}$, which represents the mean annual value increment, at that per cent increases in the ratio of 100 to 101, while the denomination becomes larger only in the ratio of 210 to 211 . From the standpoint of the greatest net forest revenue the stands under consideration have been properly managed; if the standard for their management, however, is to be the greatest mean value increment, they should not be cut yet but should be retained as capital until the per cent of volume and value increments correspond approximately to the ratio between the annual increase in age and the present age.

Of course, as soon as it is demanded in forestry that the remaining growing stock shall yield interest, even at only a moderate per cent, the factors concerned in the economical production of stands are entirely changed. From the standpoint of the theory of net profits on the land which this suggestion is equivalent to, it would have been impossible to grow such stands as the mature oak we are discussing, or even the French fir stands in the Vosges. Accurate citations as to the time and severity of thinnings, the amount of growing stock, and the length of the rotation cannot be made without detailed computations and voluminous material. The opinion presented can, however, readily be proved as one of general acceptance.

In connection with the determination of the results of applying the theory of net income to oak high forest with long rotation period it should be mentioned that for this only moderate rates of interest ( 2.5 to 3 per cent) are to be used. It should be borne in mind, in addition, that under permanent management, the forest and its contained growing stock constitute a uniform entity. A part of the growing stock is also embraced within the younger and the middle-aged stands; hence the rate of interest on the growing stock may be sufficient even though that of the oldest age classes of a given working unit have fallen below that required on the entire capital. But even by applying this conservative supposition the stands under discussion would be unable to satisfy the demands for payment of interest. In contrast to management for the greatest mean value increment which would leave those stands to grow for a yet longer period, the theory of net income from the land requires that they be thinned and opened up earlier and more heavily. The number of trees per hectare must be reduced to a greater extent in the course of gradual thinnings so that at the age of 200 years only about half (40 instead of 80 per acre) shall be present. As a result of such management the working capital will be diminished, the increment of individual trees is increased, and the interest influenced favorably by both. Under such conditions and with the favorable site factors present the miscellaneous stock, upon the production of which such importance is rightly attached in administering the French State forests, could be raised with rotation periods of 160 to 180 years.

\section{(d) OWNERSHIP OF THE LAND}

The conditions of property ownership have hitherto had a great influence in France in deciding upon the age of maturity and the characteristic form of forest which shall be regarded as normal and whose establishment shall be sought. Nowhere are the differences in the character of the forest, according to the ownership of the land, more clearly emphasized than in France. Even in the literature this is stated definitely, though not without exaggeration. Tassy says in reference to this: "It is not to be hoped that private owners will ever find it to their interests to manage their forests as high forest. For in such a case not only will the rate of interest on the money fall off considerably, but which are conditions far more difficult of attainment, the impossibility of predicting future conditions, immediate needs, the uncertainty of the immediate future, would all 
have to cease to play a rôle in human activities." This general conception was discussed more in detail in the Handbook of the Paris Exposition where it is said: "The private owner seldom manages broadleaves (Angiosperms) as high forest. They prefer coppice and coppice with standards with short rotation periods. The conifers (Gymnosperms) they use as soon as they seem available, without letting them reach that size which qualifies them as valuable economic species." The actual condition of the forests confirms these descriptions in the literature. It is also granted that as a rule the State is different in the matter of management, that other working systems are chosen, and that other rotation periods are employed, than is true for the private individuals. In addition to the Government's high forests, characterized by large capital and long rotation periods, there are the communal coppice with standards stands, characterized by a small stock of overwood, and the extensive sprout lands of private owners.

The question as to what influence the conditions of ownership exercise upon the condition and management of forests is of considerable general importance. While perhaps to a lesser extent than in France, similar differences are found in all countries, even in the German forest regions. Adjoining the great areas of most of the German State forests in mountainous regions (Harz Mountains, Thuringian forests, Spessart, etc.), and on the plains, there are often found poor forests, owned by peasants, upon essentially similar soil. The causes of these differences are to be found partly in poor management. By the removal of too much of the forest litter, irregular cutting, deficient superintendence, the demands for a good condition of the forest are by no means met. The destruction of forests in nearly all countries is directly traceable to private ownership. But even under good management (which must be assumed if questions of principles are to be discussed) there are notable differences dependent upon the conditions of ownership. Government forests are always more conservatively managed than those belonging to private owners.

The recognition that there are differences depending upon the conditions of ownership, which make themselves felt in the condition of forests and their management, has led to the assumption that there are in forestry - just as in business in general - two different systems of management dependent upon the ownership of property, a system for private owners which leads to short rotation periods and extensive management, and a system for public owners which is characterized by long rotation periods and large forest capital. Not merely the advocates of extreme socialism have inscribed upon their banners the contrast between private and coöperative management, but champions, also, of a more moderate economic course have had recourse to the double system mentioned, in explaining the differences in the condition of forests which we are discussing, and in characterizing the resulting problems of future management.

Diverse, however, as are the forest conditions and the objects of organization in the State and private forests that is no reason for trying to establish different systems of management. The causes of this diversity must be sought in other conditions. They are to be found in forest history than which the history of no other branch of economics has more far-reaching results. The distance of the forest from the consumer is another guiding factor. The forests which are in the possession of the State are preferably the more remote forests, the forests located at the interior of large wooded areas of mountain and plain. The greater the distance from the market, the longer does the rotation period become. The financial conditions, also, have an influence upon the rotation period. Those owners, alone, are in a position to manage their forests on a long rotation (ignoring the interest), who have sufficient means, who are independent of the immediate realization of income from the capital, and who have a permanent interest in the condition of the forest. No other owners fulfill these requirements to so great an extent as the State. Finally, it must be taken into consideration that the State has, 
besides its efficiency as a manager, also to take into consideration problems of political economy, not only in regard to production, but also economic relations. It is desirable that it should exert a favorable influence in that direction upon all the forests of the country. But it stands to reason, and is in accord with the status of legislation in all countries, that this shall be most emphatically done in its own forests.

Even in time to come there will still be differences of the kind mentioned — not merely in forest management but also in economic life in general. Even in future times the State forests will, as a rule, be more conservatively managed than most private forests. It is not an inevitable result of this, however, that under State or communal management a portion of the cost of production cannot be taken into account - which is the present point of difference in economic principles. Forest owners (State, community, etc.), even if they favor communal interests, need not, as the champions of all socialistic tendencies demanded, renounce the interest on a portion of the capital invested (Produktionsgrundlagen). On the contrary, the most general rule applicable to all kinds of forest ownership demands that in regulating management all costs of production in labor, capital, and land must be reckoned at their full value. But there could well be differences in the cost of production depending on the character of the forest ownership, resulting from variations in the size of the growing stock and the rate of interest charged. An analogous condition exists in agriculture. Indeed, the inter-relationships of labor, capital, and land vary according to the character of the ownership even if the objects of management be identical. The greater conservatism which characterizes State forest management cannot, however, be regarded as an indication of self-sacrifice on the part of the treasury department or of a readiness to give up claim to a part of the investment. The State does not need to give up all claims to the interest on the capital and on the value of the land in the interests of either present or future generations. The advocates of management for financial returns may expect, rather, that the woods which the coming political economy needs most urgently will best be paid for on the basis of their cost of production with which must be included the discounted value of the cost of cultivation, and the interest on the investment. In that case it is demanded of State management, however, that the rotation period shall not be longer than is required, in accordance with silvicultural principles, for the production of that particular kind of product which constitutes the object of the management. The French forest management which, because of its moderate thinnings and long rotation period, is characterized by very small interest on the investment, is susceptible of radical improvement along just these lines.

As opposed to the demand for an acceleration of production and a shortening of the rotation period which must be demanded of the French management of State forests, intelligent private owners have of late seen fit to change their hitherto extensive management to a more intensive system, and to lengthen their rotation periods. This is the direct result of the market conditions for the various grades of product.

The prices of the smaller products (twigs, bark) have declined because of the competition by charcoal and other substitutes, while those of the higher grade lumber have risen not only actually, but relatively, in comparison with other commodities. Furthermore, as was evident from the great number of the cross sections exhibited at the Paris Exposition, it has become a matter of common knowledge in France that properly conducted thinnings and openings exercise a very favorable influence upon the progress of diameter increment, upon which the rotation period is dependent. Mention is made, also, in the Handbook of the Paris Exposition of the changes wrought by this in the viewpoint of private owners, in the following words: "A change is imminent in the conditions which have hitherto existed (profitableness of the coppice system, and of short rotations). The rise in wages and the absence of a market for charcoal have reduced the value of coppice 
stands. Private owners are finding themselves forced to lengthen the rotation periods in the same. . . . At the same time the declining rate of interest and the increase in the price of wood are leading forest owners, to a greater and greater extent, to increase the amount of capital invested in forests and to defer the utilization of the stands until a more advanced age."

As in France, so in many German forest regions, we find factors which determine the sort of management which shall be practiced by the Government and by others. Even here many private owners may, in view of the present conditions and future possibilities, well increase the length of their rotations. Even for private management the rule holds good that those products must be grown which best meet the requirements of economic conditions. That this demand frequently is not met, that many private forests are left unutilized and reverted to waste lands - evident from the poor, careless management and unsuitable working units ("dwarf management" (Zwergbetriebe)) - is the cause of the financial position of many forest estates. Very often private owners are not in a position to maintain their resources in the unavailable form of standing forest capital, because they need them for very definite purposes; they have to have it in a more readily available form and for that reason often clean-cut the stands even when the increment in volume and value would be greater than the interest on the readily available capital. For leading the way toward better conditions in this regard it is desirable that renting of forests be facilitated in a manner similar to the measures of the German Forestry Association (Deutscher Forstverein).

From what has been said it can be seen that it is desirable at present in France, and in other countries as well, that the systems of management in private and in State forests be brought into closer accord. The economic laws and principles upon which management depends are restricted neither to State nor to private forests, but are of universal application. For this reason, also, the claim that there are opposed principles of management - a private and a social - is not to be accepted absolutely, in spite of the great influence upon management of consideration for the community and for the future. As a matter of fact they are not sustained under the economic conditions which, hypothetically, they favor.

\section{COPPICE WITH STANDARDS, AND SIMPLE COPPICE 16}

Coppice with Standards. - Coppice with standards is a system of management found in almost every part of France. It is most strongly advocated for the communal forests. According to the statistics cited ${ }^{16}$ the State forests comprise 269,707 hectares (666,465 acres) of coppice with standards which equals 26 per cent of the entire forest area; the communal forests 936,305 hectares (2,313,694 acres), 49 per cent. Since the French forests of coppice with standards comprise only a little overwood, and the sprout lands are stocked mainly with reserved standards, it is not always possible to draw a sharp distinction between the two. Both systems belong to the regime du taillis which is characterized by sprout reproduction as distinct from the régime de la futaie where reproduction is secured from seeds. Within the same regime further distinctions are made according to the method of handling (mode de traitment). In the case of coppice with standards the group system (mode de éclaircies) is looked upon as different from the selection system (mode de jardinage). Similar distinctions are made within the régime du taillis:

Le taillis simple, "exploite entièrement d̀ blanc étoc ou sans autres réserves que des baliv-

15 "Forstwissenschaftliches Centralblatt," 1908, pp. 655-65.

${ }^{16}$ In the Handbook of the Exposition of 1900. The figures in the statistique forestiere of 1870 differ considerably because in the interval extensive changes have occurred. 
eaux de l'age qui seront abbattus à la révolution suivante" (coppice "cut entirely, or without other reserves than of an age which will be felled at the next cutting").

Le taillis composè ou taillis sous futaie "dans lequel les baliveaux réservés sont destines à rester sur pied pendant au moins trois revolutions" (coppice with standards, in which the reserved trees are intended to remain standing for at least three rotations). (Definitions from the official Statistique forestiere, Forest Statistics.)

Since, however, no binding definitions can be applied to the question of reserving standards in private forests, essential variations occur in practice.

The peculiarity of the coppice with standards system, consisting of the juxtaposition of isolated uneven-aged seedlings and even-aged sprouts, has persisted much longer and more definitely in France than in most German forests. Their management has been extraordinarily conservative for centuries. Even now the visitor to the forests comes across the old monuments and bounded areas reserved in determining upon the management and working limits, which were established in accordance with the ordinances of Colbert. The communal forests, likewise, have been under management for more than two centuries. In Germany, coppice with standards, which was formerly extensively employed in well settled regions of hardwood forest, has undergone far greater changes. In many cases it had already developed into irregular transition forms by the 17th and 18th centuries. In the 19th century it lost its original character, even in the case of well-regulated management, because of the fact that systematic efforts were being made in the direction of establishing a generous forest capital of overwood. With such a stand of overwood as most of the German advocates of coppice stands with standards recommended ${ }^{17}$ - doubtless rightly, considering the increased revenue - the advanced reproduction of the underwood could not maintain itself vigorous over the entire area; it was partly destroyed. This is true to a yet greater extent when the overwood is held over in the form of groups as is frequently looked upon as the rule. Similar conditions exist respecting regeneration, which likewise is conducted mainly in the form of groups. In a group the growth of the young stuff is in accordance with the laws of growth characteristic of the high forest.

The following notes on the French system of managing coppice with standards (apart from stands which were observed from time to time in the course of the railroad ride) apply, chiefly, only to a small forest of 193 hectares ( 476 acres), belonging to the hospital at Blois which we were permitted to inspect very minutely at the point where it adjoined a high forest on a similar range under the management of a forest manager. In spite of its small acreage it was, nevertheless, very well suited for giving a person an idea of the features which characterize the French system of managing coppice with standards. The condition of this forest affords excellent data on the history of the standards, the political measures of the French administration, and the technical principles of management. Moreover, the revenues from the management for a decade, which were told us, afford a very good basis for forming an estimate of the economic value of the system of coppice with standards.

The organization under consideration is of general interest, first with regard to the technical management, and, secondly, with regard to a review of the system of coppice with standards from the economic standpoint.

(a) Technical aspects of the treatment OF THE COPPICE With standaRd

The standard in accordance with which the management of coppice with standards is regulated is in France, on the whole, very uniformly maintained. The unforeseen

${ }^{17}$ E. G. Schuberg. Zur Betriebsstatistik im Mittelwald (Statistics of management for coppice with standards) (city forest of Durlach, with 250-350 m.3 $(8,830-12,360$ cubic feet)); Lauprecht, Aus dem Mühlhaüser Mittelwald (250 m..$^{3}$ (8,830 cubic feet). (From the coppice with standards forest of Mühlhaus.) 
difficulties in determining the yield which have led, in Germany, to the proposing of special formulas have not been prominent in France. The regulation of income and the extent of the cuttings conformable to condition of the system of management being employed are upon the area basis. In the forest region under consideration the greater part (three-quarters) of the forested area was divided into 25 regeneration compartments of 5.75 hectares (14.2 acres) each. A quarter of the entire area was excluded from this classification and constituted a reserve to be included in the utilization only in case of unusual demand. Such exceptional demands always occur, however, some time within the course of the 25-year periods so that the establishment of such a reserve does not involve a permanent change of the rotation period.

The establishing of such reserves is a peculiarity of the French communal forests, which are under the strict supervision of the State. Even Colbert ordered their formation: "The celebrated ordinance of 1669 commands that a fourth of all woodlands belonging to the clergy, to ecclesiastical corporations, to the public, etc., be constituted a reserve. The rest of the area had to be included in the regular cuttings." The reserves are either permanently located in some definite place, "réserves d assiette fixe, délimilée et marquée sur le terrain"; or they are shifting reserves, "réserves à assiette mobile," "of such a sort that instead of cutting each year the area or volume which expresses the annual yield only three-fourths of this yield is left over for the meeting of unforeseen necessities."

In the hospital forest at Blois the method of fixed reserves was used; and this seems, also, to be the general practice. Of $8,775.13$ hectares $(21,684.10$ acres) of communal forest which were seen here, the arrangement of permanently located reserves was applied over $7,550.68$ hectares $(18,658.40$ acres).

The 25-year rotation practiced in the hospital forest of Blois is somewhat below the average for forests under Government administration. According to the department of agriculture's statistics the figures for the coppice with standards for the entire country are as follows: they are managed under a rotation period of -

\begin{tabular}{|c|c|c|c|}
\hline & $10-19$ & $20-29$ & 30 years and up \\
\hline $\begin{array}{r}\text { In Government } \\
\text { forests......... } \\
\text { In communal } \\
\text { forests......... }\end{array}$ & $\begin{aligned} 7,071 \text { hectares } & =4.1 \% \\
24,605 \text { hectares } & =2.7 \%\end{aligned}$ & $\begin{aligned} 81,557 \text { hectares } & =49.9 \% \\
707,803 \text { hectares } & =77.5 \%\end{aligned}$ & $\left.\begin{array}{r}75,521 \text { hectares }=46 \% \\
181,949 \text { hectares }=19.8\end{array}\right\}$ of the ares \\
\hline
\end{tabular}

The rotation period for the underwood is, according to this, even longer than is customary in Germany. Its choice is the result of economic considerations. The aim of the management, espesially in the communal forests, is directed constantly to the production of better firewood (fagots).

The most important problem of forest adjustment in the coppice with standards is the regulation of the overwood which constitutes the peculiar characteristic of this system of management. The overwood is classified by age classes determined on the basis of the rotation periods in the underwood. They are distinguished: (1) Baliveaux de l'age (reserves), which are a rotation period older than the sprouts of the underwood; (2) Modernes (standards of two rotations), which have been twice reserved; and (3) Anciens (veterans), which are in the fourth rotation of the underwood.

Eventually there is added to these yet a fourth class, la vieille écorce (old standards). According to this the age of maturity for the overwood under a 25-year rotation period for the underwood would be 100 years; in the case of a 30-year rotation for the under- 
wood, 120 years. The system is not followed mechanically, but vigorous trees are, rather, left standing longer without, however, practicing this to so great an extent as is customary in many German forests.

As to the number of trees per hectare in the several age classes, tolerably definite rules were given. The closeness of the stands is astonishing. In the forest at Blois the numbers in the various age classes, for the annual cut, amounted to: Baliveaux - total, 287; per hectare, 50 (20 per acre). Modernes - total, 81; per hectare, 14 (6 per acre). Anciens - total, 34; per hectare, 6 (2 per acre).

According to this, very light cuttings are made. The 25 - to 30 -year-old baliveaux contain only a very small volume; even the modernes are mainly trees with a content of less than 35 cubic feet. And the few anciens with about 35 to 70 cubic feet could have no great influence upon the total volume of wood taken from the entire cutting area. In the cutting areas which we saw, in which final cuttings had been made not long since, the entire overwood was estimated at 1,410 to 1,765 cubic feet. It is true that many advocates of the French system of forest management recommend a larger amount of overwood capital. But actually the maximum amount retained at the beginning of the rotation amounts to only 1,145 cubic feet per acre. This is far less than correspondents testify is the practice in the German management of coppice with standards.

The hospital forest of B lois does not vary much, in its composition and in the proportion of overwood, from the figures which are cited for the entire country. According to the department of agriculture's statistics the following relative figures per hectare were obtained for the fiscal year (Wirtschaftsjahr) 1876:

\begin{tabular}{l|c|c|c}
\hline & Baliveaux & Modernes & Anciens \\
\cline { 2 - 4 } $\begin{array}{l}\text { Government forest......... } \\
\text { Communal forest........ }\end{array}$ & $\begin{array}{l}39(16 \text { per acre }) \\
64(26 \text { per acre })\end{array}$ & $\begin{array}{c}11 \text { (4 per acre) } \\
18 \text { (7 per acre) }\end{array}$ & $\begin{array}{l}2 \text { (1 per acre }) \\
5 \text { (2 per acre })\end{array}$ \\
\hline
\end{tabular}

In individual parts of the country there are, of course, great differences. Individual conservations (districts) (Dijon, Rouen, Nancy, Amiens, etc.), contain over 100 baliveaux and over 30 modernes per hectare (40 and 12 , respectively, per acre).

The details of the management of the coppice with standards belonging to the State and administered by the State are worked out in accordance with the fundamental principles of the system far more systematically than in Germany. Here it is always looked upon as a difficult sort of management which makes special demands on the tact and activity of the organizing and executive officers. "Im Mittelwalde der $Z u$ kunft," is observed in the papers of the convention of German foresters at Dresden in 1889 " musz die intensivste Bewirtschaftung, reine Baumwirtschaft Anwendung findem, wenn derselbe den an seine Produkticität, an seine Gelderträge und Nachhaltigkeit zu stellenden Aufforderungen entsprechen soll" ("In the coppice with standards of the future the most intensive management, pure forestry, must find application if the same is to meet the demands placed upon it, in its productivity, its money revenues, and its permanence"). Nevertheless, it will only be very seldom that such a goal will be sought and attained in the future. It leads to a very large capital of overwood and to the death or degeneration of the underwood. Such a tendency results in a gradual changing of the coppice with standards to a regulated selection forest which is a yet better system of management for attaining the objects proposed. In most German forest regions this change has already commenced; in Prussia the coppice with standards is scarcely represented at present. Its distinguishing characteristic, the reserving of 
vigorous sprouts, demands an extensive management for the overwood, and hence it is thus that it is managed in the French State and communal forests.

The predominating species in the French coppice with standards stands is the oak. It, alone, is recorded in the statistics. In Blois it occupied 95 per cent of the forest area. The oak, under the favorable conditions of site in central France, is characterized by good sprouting capacity and abundant seed production. The renovation of overwood and underwood is effected, therefore, chiefly by natural regeneration and sprouting in a very satisfactory manner. In most instances, artificial regeneration is to be considered when large oaks, of which there are only a few per hectare, are rooted out. The rooting out of trees of a specified size is required of the buyer. When such rooting out has taken place the buyer is required to plant such places with oak or deposit the amount required for this planting. The places on which the wood has been worked must also be planted up by the buyer. He, moreover, is required to prune the reserved trees and this must be done to a height of 20 feet from the ground. These regulations are not mere matters of pen and ink; they are skilfully, carefully, and thoroughly carried out so that the visitor to the cutting areas receives the most favorable impression of the system. The impression one receives of the care of the underwood is not so favorable. Thinnings are not made in the underwood in the Blois forest - and the conditions at Blois are not exceptional - although, with the long rotation period, 'they would be just as much in order as in the coppice stands for which their importance is demonstrated by the numerous tree sections at the Paris Exposition. The maintenance, also, of voluntary seedlings and the preparation of the poles of the overwood for isolation indicate timely application of cleanings and thinnings in the underwood. The form of the purchase, however, makes for difficulties in this respect. The buyer, who has to get out the timber itself, has no interest in the small wood resulting from thinnings.

\section{(b) ECONOMIC IMPORTANCE OF COPPICE WITH STANDARDS}

Of most importance for the future of coppice with standards in France is not a welldeveloped technique, but its relations to economic conditions. The question as to whether coppice with standards, which comprises some $3,000,000$ hectares $(7,413,270$ acres) in France, yields profits commensurate with the best utilization of the land is of great influence upon its future management and the methods of regulation. The answer is dependent, on the one hand, upon the volume and value of the material which it furnishes, and on the other, upon the cost and working methods which are existent or which would have to be introduced in order to produce this volume and value.

The production of volume in the French coppice with standards stands can be very well indicated. On the basis of economic results a much more trustworthy judgment can be found for it than is possible in the case of the high forest. Utilization in the coppice with standards stands has long been much more uniform. In the forest at Blois which we visited the income corresponding to the increment amounts annually to large cuts on the 5.74 hectare (15-acre) cutting areas: In the year 1891,$548 ; 1892$, $554 ; 1893-1894,931 ; 1895,540 ; 1896,547 ; 1897,501 ; 1898,517 ; 1899,547 \mathrm{~m}^{3}$. According to this, the average volume of the annual cut on the 5.74 hectare (15-acre) amounts to $91 \mathrm{~m} .^{3}$ per hectare $(1,300$ cubic feet per acre). This is equivalent to a yearly utilization of $3.6 \mathrm{~m} \cdot{ }^{3}$ (127 cubic feet) for a 25 -year rotation. In the adjacent high forest, occupying a smiliar site, the annual yield amounts to $3.3 \mathrm{~m}^{8}$ (117 cubic feet). The volume actually used in the two systems, therefore, differs but slightly; but the coppice with standards system is in the lead. If the conditions throughout the country are compared this difference is seen to be even more favorable to the system of coppice with standards. According to the statistics of the department of soils and commerce (Ackerund Handelsministerium) there were used per hectare of forest area in the year 1876: 
In the State high forest, $2.91 \mathrm{~m} .^{3}$ (41.6 cubic feet per acre); communal, $1.73 \mathrm{~m} .{ }^{3}(24.7$ cubic feet per acre). In the coppice with standards, $4.26 \mathrm{~m}^{3}{ }^{3}$ ( 61.0 cubic feet per acre); communal, $4.00 \mathrm{~m}^{3}$ ( 57.2 cubic feet per acre). If that kind of figures were to be regarded as decisive the coppice with standards would obviously be the more profitable type of management. But such a conclusion is probably unjustified. Statistics must not be perverted to overthrow accepted existing facts. In view of the fundamental principles of increment the production of wood, other things being equal, cannot be greater in coppice with standards stands than in high forest, but really must be less. In the large amount of brushwood itself, constituting almost half the entire cutting, in which is contained much more of the soil nutrients than in the wood more than 2.8 inches in diameter at the small end (Derbholz) or in an abundant seed crop of isolated trees of the overwood, there are two fundamental impulses which, as far as sustained annual increment is concerned, act on the negative side of the balance. Moreover, stocking is seldom as complete in the stands of coppice with standards as in the regulated high forest. To understand the conflict of the French statistics of income with the actual inevitable conditions, it must be remembered that in coppice with standards stands, which are conducted very uniformly as far as rotation period and growing stock are concerned, the entire increment is used and is used earlier, so that income and increment are, at least approximately, equal. In the high forest this is not true. In the case of these, especially in the State forests, utilization has remained very much lower than increment. Moreover, in France as in other countries, coppice with standards stands are located preferably on the more favorable sites. High mountains, rugged sites, stony soils, are no sites for the coppice with standards. In many German States there have likewise been evident results similar to those in France. The grand duchy of Baden's statistics show the revenue from stands of coppice with standards as earlier and greater than that from the high forests. But more recent statistics demonstrate that the results obtained from the management of the high forest there are really superior to those from coppice with standards, under similar treatment especially when thinnings are properly conducted, and in spite of the unfavorable sites it occupies. This view is, indeed, shared even by the exponents of the French system of forest management, who have at their disposal a comprehensive knowledge of conditions throughout the country. In Chapter 4, Part 2, of his work, "De l'exploitabilite dans ses rapports avec l'interêt public" (The age of maturity in its bearing upon the public interests), Tassy summarizes the results obtained with high forest and with coppice with standards. He arrives at the conclusion that under average conditions of growth the high forest under good management could yield $6 \mathrm{~m} .{ }^{3}$ per hectare ( 86 cubic feet per acre) - "chiffre très moderé (a very conservative figure)." The average yield from stands of coppice with standards is, on the contrary, estimated at $4.30 \mathrm{~m}$. (63 cubic feet per acre).

This unfavorable showing of the absolute production of the coppice with standards cannot be compensated for even by the ratio of increment to capital, or the growth per cent. Compared with the high forest managed on a very long rotation period with a proportionately large number of trees per hectare, the system of coppice with standards does, it is true, present a very favorable appearance in the connection. But it is easy to deceive one's self in that regard by measurements of single trees. The comparative annual increments of the coppice with standards are very unequal. Especially, after the felling of the underwood and openings in the overwood, the growth per cents, of the younger age classes in particular, are very high, far higher than is necessary for meeting the demands made on the production by the stands. Later, these conditions are changed. They result more unfavorably than is the case in the high forest where the decline in increment in the pole and standard ages can be far better met by means of vigorous thinnings and openings. 
The work prepared by certain French forest owners for the Paris Exposition affords information on the increase of volume which occurs in the course of a rotation period. It deals fundamentally with stands of coppice with standards with moderately large growing stock of overwood and four age classes the numbers of whose trees per hectare stand in the ratio of 8 (baliveaux) to 4 (modernes) to 2 (anciens) to 1 (vieille écorce). The effect of the increased volume is that with a 25-year rotation period the volume of the stands increases in the ratio of 1 to 2 ; with a 30-year rotation in the ratio of 1 to 2.5 .

The system of coppice with standards seems the poorer form of management as compared with the high forest, more because of the poor quality of the wood produced than because of its small volume. It does not satisfy the demands which have been made for the most important technical properties (clean full boles). The reduction in the number of trees per hectare to about 50 (20 per acre), which occurs at the age of 25 years, has the natural result that the twigs which are present at a height of about 3 to $5 \mathrm{~m}$. (10 to 15 feet) remain and develop. Corresponding to the formation of large, deep-rooted twigs is the formation of broad annual rings which are laid on for a longer time until decreased under the influence of the underwood growing up about them and of the increasing seed production. Branchy tapering trees of unequal height are the natural result in coppice with standards stands under the conditions of growth described.

The influence of the type of management on the quality of the wood is clearly shown by presenting yield statistics. In the forests of Blois the volume and financial returns in the past decade were as follows:

\begin{tabular}{l|c|c|c}
\hline & Yield & \multicolumn{2}{|c}{ Auction prices } \\
\cline { 2 - 4 } & $\mathrm{m}^{\mathrm{3}}$ & Total francs & Per m.s, francs \\
\hline & 543 & 8,500 & 15.65 \\
1891 & 554 & 8,100 & 14.62 \\
1892 & 931 & 12,200 & 13.10 \\
1893 & 540 & 6,300 & 11.67 \\
1895 & 547 & 7,350 & 13.44 \\
1896 & 501 & 6,150 & 12.28 \\
1897 & 517 & 6,275 & 12.14 \\
1899 & $4,680 *$ & 6,500 & 13.71 \\
\hline Total ......... & & $62,375 \dagger$ & $13.33 \ddagger$ \\
\hline & & & \\
\hline
\end{tabular}

The average cubic meter is thus seen to be valued at 13.33 francs, while the adjacent Government high forest has yielded almost double this price for the average cubic meter.

Relative figures similar to those given us for the forest region which we visited at Blois exist likewise for the cntire country. According to the department of agriculture's statistics, in the fiscal year 1876: The value of the average cubic meter amounted in the Government forest to 16.26 francs ( 9 cents per cubic foot); in the communal forest to 8.42 francs ( 5 cents per cubic foot); the yield per year and hectare in the Government forest to 38.59 francs ( $\$ 3$ per acre); in the communal forest to 22.70 francs $(\$ 1.82$ per acre).

The chief cause for the difference per cubic meter and in the annual revenue is to be found in the preponderance of coppice with standards in the communal forests. In 
individual parts of the country figures on the conditions of site stand, and market will be found very different. For the conservation of Tours, which forms part of the forests visited, the yield per hectare was: in the State forest, 40.59 francs (\$3.17 per acre) for coppice with standards; 44.83 francs ( $\$ 3.50$ per acre) for conversion stands; 64.35 francs (\$5.13 per acre) for broad leaf (Angiosperms) high forest; in the communal forest, 44.21 francs ( $\$ 3.45$ per acre) for coppice with standards, 63.68 francs $(\$ 4.98$ per acre) for high forest.

How little timber the French coppice with standards produces as a whole is evident from Tassy's summary, where he says of it: "In a normal coppice with standards stand the overwood constitutes not more than a third of the volume of the annual cut; and if we grant that in the overwood a half yields timber we are giving it just as much as possible. So if I place the timber at one-sixth the volume cut I need not be accused of trying to reduce the ratio." The following estimate, based on this, shows that of 13 million cubic meters $(460,000,000$ cubic feet) produced by French coppice with standards stands, only $2 \frac{1}{4}$ million cubic meters $(88,000,000$ cubic feet) can be sold as timber. In the department of agriculture's statistics the per cents of timber for the fiscal year 1876 are given as follows: For State coppice with standards, 23 per cent; for communal, 12 per cent; for State high forest, 51 per cent; for communal, 42 per cent.

From what has been said there can be no question that the system of coppice with standards does not meet the economic demands which must be made of forest management in France. It was, as in Germany, of importance in the past. As long as firewood was a prime necessity for the entire population wood was needed in proportionately small sizes, and since in most forest regions there were insurmountable difficulties in the way of timber traffic it formed a very good system of management for those woodlands located near the consumers. Hence we find the following note to the department's statistics, concerning communal forests: "It must be appreciated that for this kind of forest ownership, it is a very suitable system. Furnishing the inhabitants, as it does, with a variety of species and kinds of wood it meets their requirements better than does the high forest." But the character of the demands made upon the woodlands has suffered a radical change in the course of the 19th century. In all essential respects coppice with standards is inferior to the high forest; in its relations to the soil as well as in its bearings on yield. For maintaining soil fertility coppice with standards is not an especially commendable silvicultural system. The mere fact that those species which form the best soil cover do not occur in it is a factor of unfavorable influence. Likewise the difficulty of amalgamating overwood and underwood into a uniform canopy. More important yet are its economic shortcomings. It stands in opposition to the general economic principle that with progressive development of the cultivation of the land, all management must be more intensively conducted, and at a greater outlay of labor and capital. The kinds most demanded by the French economic conditions, loppings and wood for splitting (Schneide- und Spaltholz), are produced only in very small quantities. It is, therefore, to the general economic interests of the country that the stands of coppice with standards be changed over into high forest as quickly as the financial condition of the owners permits. This is recognized as the right principle even in France. As far as the State forests are concerned the change has already been effected over large areas, and is to a great extent in progress elsewhere. The $\mathbf{1 8 7 6}$ statistics give the stands in process of conversion in the State forests as 290,227 hectares (717,170 acres), the Handbook of 1900 as 124,374 hectares $(307,340$ acres). For the communal forests this change can proceed only very gradually because of the financial sacrifice involved. 


\section{APPENDIX J \\ THE FORESTS OF ALSACE-LORRAINE '}

Area. - The forests of Alsace-Lorraine cover 1,085,520 acres; this is 30.3 per cent of the total land area, and 47 per cent of the area in agriculture, and corresponds to 0.6 of an acre of forest per inhabitant. Therefore Alsace-Lorraine with 30.3 per cent has almost twice the proportional forest area that France proper possesses - 18.7 per cent; and it is even above the average for Europe which is 28.8 per cent, but below that of the Vosges Department - 36.9 per cent. Since 1871 the average in acres under forests, divided according to ownership, has been as follows:

\begin{tabular}{|c|c|c|c|c|c|}
\hline Year & State & Undivided & Communal & $\underset{\text { institution }}{\text { Public }}$ & Private \\
\hline 1871 & 330,652 & 44,469 & 487,574 & & \\
\hline 1881 & 330,930 & 42,472 & 490,295 & . & $\ldots$. \\
\hline 1891 & 337,016 & 40,273 & 491,958 & & $\ldots \ldots \ldots$ \\
\hline 1901 & 337,112 & 40,162 & 494,184 & & \\
\hline 1913 & 343,119 & 40,053 & 491,342 & 5,966 & 208,069 \\
\hline
\end{tabular}

This makes a grand total of $1,088,549$ acres in 1913 but (to check with the correct total area) from this total must be subtracted 3,029 acres, probably due to incomplete statistics on private forests, which gives a net total of $1,085,520$ acres. From these statistics it is evident that the area of State forests was increased 12,467 acres and the communal forests 3,768 acres under German management. About half the increase in State forest area was due to purchases and half to transfers from forests formerly in undivided ownership. It is of interest that there were no less than 1,123 communes owning communal forests, or about 438 acres average per commune in 1913 . A very much larger proportion of the forest area is in public ownership than in France proper as may be seen from the following table:

\begin{tabular}{|c|c|c|c|}
\hline \multirow{2}{*}{ Class of ownership } & \multicolumn{3}{|c|}{ Per cent owned by classea of owners } \\
\hline & Haute-AIsace & Basse-Alsace & Lorraine \\
\hline 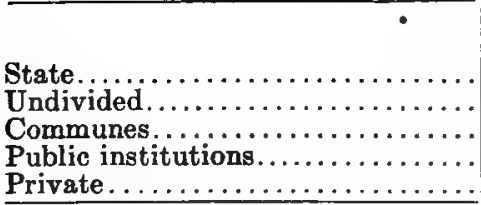 & $\begin{array}{c}\text { Per cent } \\
17.85 \\
65.38 \\
0.18 \\
16.59 \\
\end{array}$ & $\begin{array}{l}\text { Per cent } \\
25.73 \\
10.14 \\
45.85 \\
0.77 \\
17.51\end{array}$ & $\begin{array}{c}\text { Per cent } \\
47.62 \\
27.57 \\
0.61 \\
24.20\end{array}$ \\
\hline Totals.................... & 100 & 100 & 100 \\
\hline
\end{tabular}

* The most important forest in undivided ownership is Haguenau, with 35,313 acres. This is one of the most interesting forests in Alsace-Lorraine.

${ }^{1}$ Digested from Les Forêts d'Alsace et de Lorraine, par H. Lafosse, Vol. II, Traveaux et Notices publiés par l'Académie d'Agriculture de France, 1919. Based on 1913 statistics collected by the German Forest Service. A literal translation of the subject headings of the above monograph is as follows: "Area of forests, Methods of treatment and distribution of species, Free use, Forest administrative organization, Management 
Only one-fifth the forest area is in private hands and in Haute-Alsace two-thirds the forests are in the hands of the communes.

Deforestation is rare; from 1871 to 1912 only 2,923 acres of State forest, 6,642 acres of communal, and 9,768 acres of private forest (total of 19,333 acres) has been cleared - a negligible per cent for a period of over 40 years. Since Alsace-Lorraine was annexed by Germany a total of 13,919 acres has been reforested, or about 331 acres per year. There is only about 74,000 acres of barren land, of which at least 49,000 is excellently adapted for grazing, leaving perhaps 25,000 acres to be restocked. This compares most favorably with France proper, where there is perhaps 15 million acres of unused soil, at least two-thirds of which could be forested.

Important Species. - " Besides, in the forests of the recovered territory there are found the best species (fir, pine, oak, beech) and the production of timber, favored by a climate suitable for growth, reaches the average figure of 4.1 cubic meters per hectare per year" (perhaps 250 to 300 board feet per acre per year). According to Lafosse: "The forests are located for the most part in the Vosges Mountains and on their lower slopes; the Lorraine plateau is also stocked with forests and they are found in the valley of the Rhine as islands (of forest), some very important stands, notably Haguenau and Hardt (Mülhausen)." The fir and beech (high forests) are found chiefly on the Vosges sands (gres vosgien) and the granites, while the oak-beech (coppice and coppice-understandards) is on the marls and limestone. The area, by species, in the high forests is as follows: Beech $34 \frac{1}{2}$ per cent, fir $32 \frac{1}{2}$ per cent, pine 18 per cent, oak $12 \frac{1}{2}$ per cent, and birch-alder $2 \frac{1}{2}$ per cent. There are only 586 acres of larch and_about one-eighth as much spruce as fir. Counting all species the broadleaves comprise seven-tenths of the stand and the conifers three-tenths.

Silvicultural Systems. - The method of treatment for $(a)$ the broadleaves and (b) the conifers is as follows:

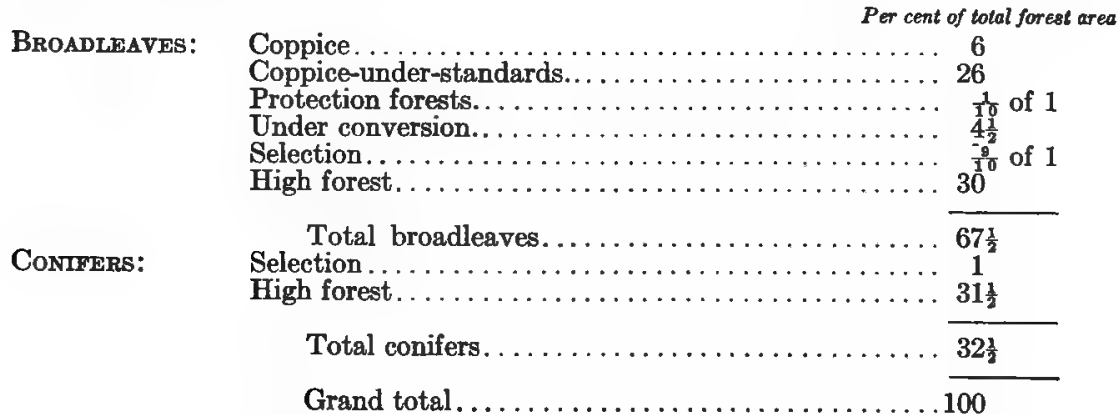

For all species the high forest systems occupy 64 per cent of the area but comprise 73 per cent in the State forests and 60 per cent in the communal and public institution forests.

The age classes, both for conifers and broadleaves, are well distributed, but Lafosse (in keeping with French conservatism) argues that the older stands (over 100 years of age)

of the forests, Exploitation of the timber, Material cut, Money yield of the forests, Wood prices, Money value of the State forests of Alsace-Lorraine, Expenditures of the Forest Service, Wood industries, Movement of the exchange of forest products, Shooting in Alsace-Lorraine, Policy of shooting, Damage caused by game." These data have been summarized and rearranged.

Lafosse is one of the most distinguished French foresters and holds the rank of Inspecteur Général des Eaux et Forêts, and after the armistice was appointed Directeur Général des Eaux et Forêts et de l'Agriculture d'Alsace et de Lorraine. 
are deficient, occupying only 14 per cent of the area. The 47,007 acres under conversion are a most noteworthy achievement in economy and are really the feature of the German forest administration, but, according to Lafosse, "The method used was not scientific and was often brutal," there having been according to French technique, too abrupt changes.

Administrative Organization. - In 1871 the Germans placed oberforsters (corresponding to supervisors) in charge of definite units instead of continuing the French system of forest organization which provided for inspectors supervising a considerable area, subdivided and under the immediate charge of assistant inspectors. In addition to the usual duties the oberforster had charge of logging because the product was sold in the $\log$ instead of as standing timber as in France. In addition all road improvements were directly under the oberforster as well as the building of ranger stations, and game control. Under the oberforster were the rangers and guards. Over the oberforster was the forstmeister, but in 1881 this position was abolished for political reasons. ${ }^{2}$ Instead, two or three advisors (or general inspectors) were attached to the office of the oberforstmeister, who corresponded to the French conservateur or American district forester. The entire service was under a director or landforstmeister. There were about 817 officers in the entire organization of whom 740 were local and 77 overhead. The oberforster and subordinate force were lodged or given an allowance for quarters. Just how this organization will be modified by the new French administration it is too early to predict but it is fairly certain that the number of officers and employees will be largely reduced (and French officers entirely substituted); if sales of timber are again made on the stumpage basis instead of as manufactured products the present organization will be totally changed.

Working Plans. - Working plans during the German administration were prepared by a commission composed of the oberforstmeister (conservateur) and the oberforster of the forest concerned and were approved by the landforstmeister (the ranking forester of Alsace-Lorraine), on the advice of the technical working plan bureau. The forests were divided into working groups, sub-working groups, sections, and compartments. The timber was divided into age classes and the soil into quality classes, and the periods were usually 20 years or less. The yield was given in cubic meters - never by area or by number of trees. The local officer in charge was bound to the prescribed yield with a leeway of 10 per cent for overrun or underrun. It is of interest to read the critique of these plans by Lafosse:

"The working plans were very rich in many columned tables; the work was quite complicated. At first glance, the French methods, because of their suppleness and simplicity - where the last word has not yet been said - seem much better. However there is one point in the former working plans which shows real progress over the French system. It is the program of logging roads. The price of timber is closely linked with logging facilities - an elementary truism which need not be further emphasized. The working plan should not only preseribe the best rules for cultural treatment, but it must also disclose the means of assuring a handy and economical removal of the products. This principle was applied by the foresters of the former organization."

Even the detailed plan of road work was incorporated in the working plan, the details being drawn by specialists, so that when the working plan was finally approved the supervisor could go ahead with his program. Automatically the necessary credits were included in the budget.

${ }^{2}$ It is of historical interest to note that the difficult and troublesome questions of freeuse rights in the old "Comté de Dabo (Lorraine)" were not settled by the Germans. From 1882 to 1908 the value of the free-use privileges nearly doubled. They attempted settlements but for political reasons "withdrew the projects." No wonder they had difficulties when it is recalled that there was a "veritable revolt" in 1848 when French records were burned and foresters shot. 
The rotations were much shorter than in France. For oak the rotation was rarely over 160 years, beech and fir 120, pine 70 to 80 , spruce plantations 80 years - "As we have said before there are no old trees in Alsace-Lorraine." The former method of clear cutting followed by planting, so generally followed, has "during the last ten years . . . shown a tendency toward the natural regeneration methods of the French." With French control unquestionably natural regeneration will largely replace clear cutting and planting.

Logging. - The German administration did its own logging. "The felled timber was transported near the roads. The oberforsters hired the lumberjacks and based their wages on price schedules issued by the conservators. The workmen were supervised by the guards and especially by the lumberjack foremen. The latter were really the ones to direct the logging." The manufactured product was classified according to species and class of product and was auctioned in small lots so as to fill the small local requirements; and with small sales there was better competition and hence higher prices. Sales could not be made by mutual agreement unless the product in question had first been offered at public auction; nor could timber or cordwood be sold at less than 10 per cent of the minimum rate (established by the landforstmeister) nor could more than $\$ 25$ worth be sold, without an auction, to the same purchaser in one fiscal year. No money could be received by forest officers or employees - it was paid to the "forstkrass" or "caisses forestières" corresponding to the American fiscal agent's office.

Yield Data. - It is of interest to compare the total yield per hectare in AlsaceLorraine with border departments:

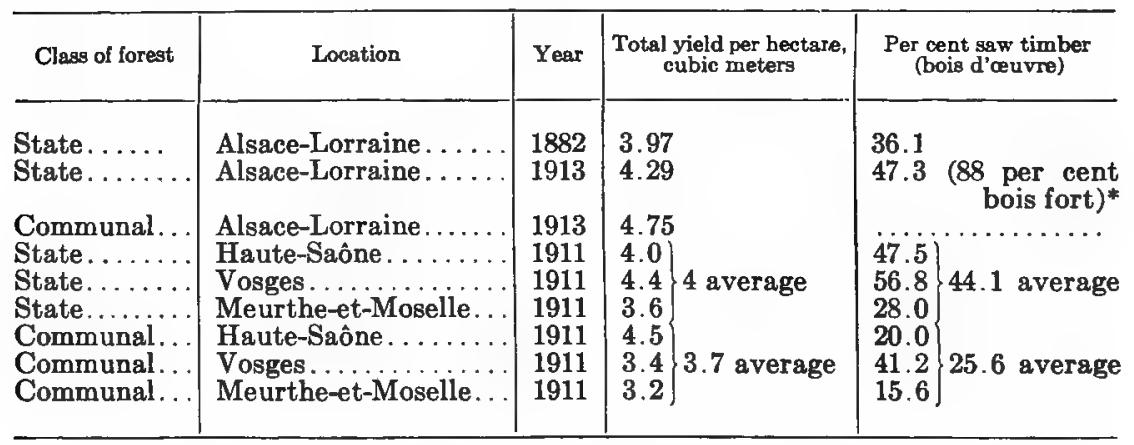

*It should be noted that according to German usage Derbholz or "bois fort" includes some wood which the French statistics do not class as saw timber, namely, "quartiers" and "rondins" of the French fuel classes (that is, everything over 2.7 inches at small end).

From the above table it appears that the communal forests in Alsace-Lorraine have a lighter yield than the State forests and that the French State forests in three border departments in 1911 averaged 4 cubic meters per hectare per year as compared with 4.29 for the State forests in Alsace-Lorraine; the relative production of saw timber was 44.1 per cent as against 47.3 per cent for Alsace-Lorraine. The French communal forests in these departments were very inferior as regards saw timber because of the high proportion of coppice and coppice-under-standards. Extremely interesting figures on the cost of logging and gross receipts are given for the communal forests. In 1913 there were 487,967 acres cut over (chiefly thinnings of varying degree) removing 862,352 cubic meters (about $107,785,000$ board feet and 44,910 cords). In addition, 45,759 cubic meters of dead leaves were removed for local use as bedding, etc. The 
cost ${ }^{3}$ of logging to point of sale was $\$ 591,738$ and the gross receipts $\$ 2,232,480$. This signifies that stumpage secured almost three-fourths the value of the delivered log or cord excluding overhead.

The total net receipts from State forests (and State forests held in undivided ownership) was $\$ 1,175,764$ or $\$ 7.78$ per acre forested; in 1913 the net total was $\$ 1,186,626$, and the net per acre $\$ 7.65$ or 13 cents less than in 1873 . In 1918 the receipts had almost doubled owing to war inflation. The revenue has been constant except in 1892 and 1902 when there were losses from windfall due to an overstocked market and consequent low prices. There are no reliable data on the returns from private forests.

Stumpage Prices. - Stumpage prices have fluctuated with the economic conditions, since forestry is a key industry in Alsace-Lorraine. The prices in 1913 and 1919 for the different classes of product are of interest:

\begin{tabular}{|c|c|c|c|c|}
\hline \multirow{2}{*}{ Class of Product } & \multirow{2}{*}{$\underset{\text { feet }}{\text { Minimum length, }}$} & \multirow{2}{*}{ 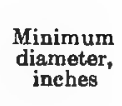 } & \multicolumn{2}{|c|}{ Dollars per cubic meter } \\
\hline & & & 1913 & 1919, February \\
\hline 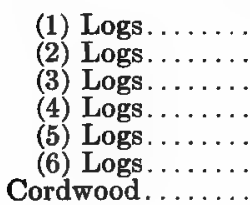 & $\begin{array}{l}59.0 \\
59.0 \\
52.5 \\
45.9 \\
32.8 \\
\text { under } 32.8 \\
\text { "Rondins" }\end{array}$ & $\begin{array}{r}11.8 \\
8.7 \\
6.7 \\
5.5 \\
4.7 \\
5.5\end{array}$ & $\begin{array}{l}6.31 \\
5.71 \\
4.76 \\
3.81 \\
3.57 \\
3.10 \\
1.67 \text { (stere) }\end{array}$ & $\begin{array}{r}11.90 \\
9.52 \\
8.33 \\
4.76 \\
4.76 \\
4.29 \\
4.76 \text { (stere) }\end{array}$ \\
\hline
\end{tabular}

For 52.5-foot trees, 6.7 inches at small end outside bark, these prices (for class 3 ) are equivalent to about $\$ 19$ a thousand board feet in the log along the roads and $\$ 33$ in early 1919 . This means about $\$ 14$ and $\$ 24$ on the stump for medium-sized trees in 1913 and 1919. It should be noted that the inflation was much greater in France, for just across the border at St. Dié the last auctions of 1918 yielded about $\$ 47$ per thousand board feet for good fir on the stump, or almost double the price in Alsacc-Lorraine.

Miscellaneous Data. - From 1907 to 1917, 304,895 acres of the State forests (about five-sixths of the total) were valued by the German service and totaled with the actual growing stock, $\$ 78,735,237$, or about $\$ 254.37$ per acre. Taking five-sixths of the net revenue of $\$ 7.65$ per acre this means a return of $2 \frac{1}{2}$ per cent on the assessed capital invested. But Lafosse estimates that France secures State forests with a round total sale value of 154 million dollars and that the return on this higher valuation has been only 1.26 per cent - "a low return." For all public forests the "coefficient of exploitation . . . was about 50 per cent" . . . but almost \$96,500 was spent annually on road and railroad development. The building of Government forest railroads has proven especially profitable. For example, the Abreschwiller paid for itself in 6 years through higher prices for the timber and cordwood. The Germans put 4.7 per cent of the total money spent each year into planting and sowing; this amounted (for the State forest area) to $\$ 4.87$ per acre for sowing labor and $\$ 7.65$ per acre for planting labor. The planting stock averaged $\$ 3.17$ per thousand transplants, which is certainly not a high cost compared with the costs on National Forests in the United States.

Wood Industries. - The chief wood industries are: Sawmills, furniture, flooring, wooden shoes, implement handles, shoe trees, vehicle bodies, billiard tables, etc.

In 1907 Alsace-Lorraine imported 50,000 tons (a deficit of about one-twentieth the total production) of wood products mostly from Austria, Sweden, and the Rhine "Pala-

The normal value of the mark 23.8 cents was used in converting marks to dollars. 
tinat," so the return of the "lost provinces" to France will not help her timber shortage. Considering that 30 per cent of the country is forested it is especially surprising to find that 70,000 steres (about 20,000 cords) of fuel are imported and in addition $7 \frac{1}{2}$ million tons of coal. Granting that Alsace-Lorraine cannot export wood to France, France must reforest with rapidly growing species her 15 million acres of land which is not now producing, and the low production of French private forests must be increased. "The owners must be persuaded to give up their short rotations (in coppice and coppiceunder-standards) and must be shown the necessity of producing saw timber" - for the benefit of the public.

Judging from the data now available the German administration of Alsace-Lorraine public forests has been honest, efficient, and along correct lines. France receives back a valuable property which has been wisely developed during the 41 years of alienation.

\section{APPENDIX $\mathrm{K}$ \\ ORIGINAL WORKING PLAN DATA}

Translations from original French Government working plans give a further insight into management methods and policy. The original French metric system has been retained. The following extracts are given:

(1) Digest of Grande Côte (Jura) working plan revision illustrating a working plan by Devarennes.

(2) Extract from working plan revision of State forest of Ban d'Etival, by Cuif, showing error in stocktaking in 1898. Masson method of yield calculation used experimentally as a comparison with the method of 1883 and regulation by number of trees. This is one of the most interesting forests in France for detailed study by those interested in forest management.

(3) Forest of Mont Glore. An example of errors in early yield calculation which resulted in an overcut.

(4) Forest of Hardies (near Oloron, Basses-Pyrénées). Forestry on alluvial land subject to flooding, and therefore unsuited to agriculture.

(5) Forest of La Joux (Haute-Jura). Yield calculation where there is an excess growing stock. Graphic of growing stock compared with an empirical normal stand.

(6) Forest of Fillinges (Haute-Savoie). Recovery of a forest after forest management.

(7) Forest of Burdignin (Haute-Savoie). Example of yield regulation by the method of 1883.

(8) Forest of Pare et St. Quentin (Oise). Example of yield regulation by periods, with the provision that the silvical needs of the regeneration fellings (which will be dependent on the seed crops secured) should be subordinate to the sequence of fellings laid out by the working plan.

(9) Forest of Thiez (Haute-Savoie). Example of a complete working plan by Schaeffer, the foremost working plans officer in France.

\section{(1) STATE FOREST OF GRANDE CÔTE (JURA)}

\section{PART I}

"All the available statistics concerning the state forest of Grande Cóte are given in detail in the management plan of February 26, 1858, and in the revisions of March 31, 1884, and April 27, 1897. Since this latter date there have been no actual changes in area. This area given in the revision of 1897 was 381.61 hectares." . . . Minor additions and substitutions have been made because of roads. 


\section{PART II. - MANAGEMENT IN FORCE \\ FORMER MANAGEMENT PLANS}

Art. 1. - Digest of the bases of management. - The State forest of Grande Cote before it became State property belonged to the order of Citeaux, Abbey St. Marie.

It was originally cut under the selection system, while the yield was regulated by the number of trees in accordance with the former usage. The decree of August 23, 1858, substituted the shelterwood system. The rotation was placed at 150 years and divided into 5 periods of 30 years each, corresponding to 5 periodic blocks on the ground.

During the first period 1858-1887, the principal felling areas had to be laid out in the first periodic block and in certain compartments of the fourth and fifth periodic blocks with a yield of 2,919 steres or $1,883 \mathrm{~m}$. c.

All the compartments not subjected to the main fellings were run over by biennial selection fellings to commence with and controlled by volume ( 310 steres or $200 \mathrm{~m}$. c.), but dating from 1864 (decree of June 25) by area and every four years.

The improvement cuttings were unlimited in volume and the local executive officers were free to propose them as they saw fit.

At the time of the 1884 revision (approved by decree of June 6, 1885) the rotation was 160 years dating from 1858 and divided into 4 periods of 40 years each, corresponding to the same number of periodic blocks.

During the last 14 years of the period (1884-1897), the yield of $1,668 \mathrm{~m}$. c. was secured in the first and fourth periodic blocks.

Timber of $0.60 \mathrm{~m}$. in circumference ( 7 inches d. b. h.) cut in the first, second, or fourth periodic blocks (except c. ${ }^{4}$ ) was subtracted from the prescribed yield.

Improvement cuttings in places selection in character, elsewhere thinnings and cleanings were carried out on a cutting cycle of 14 years in the fourth periodic block.

\section{MANAGEMENT ACTUALLY IN FORCE}

In 1897 (decree of September 3, 1897) the permanent periodic blocks were suppressed and the compartments readjusted in two groups.

The first group including the compartments to be cut over under regeneration fellings by volume, the second comprising the remaining compartments and the object of the fellings both for improvement and mere extraction by area. These latter fellings extended also to the first group, but they must not be confounded with the main fellings.

The yield recruited on the entire area of the forest was fixed at $3,200 \mathrm{~m}$. c. The volume of all conifers $0.80 \mathrm{~m}$. in circumference ( 10 inches $\mathrm{d} . \mathrm{b} . \mathrm{h}$.) and above, no matter how realized, on the entire forested area was subtracted from the yield.

During a period of 16 years, from 1897 to 1912, they carried out: (1) Regeneration fellings in the compartments $1,2,3,4,5,7,8,9,12,13$, and 23 ; (2) improvement cuttings and extraction on a cycle of 8 years on the entire surface of the forest.

Art. 2. - Results obtained. - The various fellings have left the forest in the following condition:

(1) Compartments of the first group, subjected to regeneration fellings (188.69 hectares).

The compartments 1 and 23 may be considered as entirely regenerated; they comprise poles and young standards over a complete young growth with which there is some old timber which should be cut without delay. On the other hand regeneration must be continued or secured later on in: compartments $2,3,4$, and 7 which comprise full crowned veterans, regular and dense, over advance growth and saplings in groups usually well started: $500 \mathrm{~m}$. c. per hectare on the average of which 41 per cent is timber $1.8 \mathrm{~m}$. or more in circumference. Also compartments 8, 12,13 which comprise rather 
open veterans over quite dense seedlings: $340 \mathrm{~m}$. c. per hectare on the average of which 35 per cent is ripe timber. Compartments 5 and 9 comprise standards and large poles, dense, regular, and in very fine condition, over seedling growth.

(2) Remaining compartments cut over by improvement fellings (192.92 hectares). The compartments $6,11,16,17,18$ which are in the sapling and pole stage, with several veteran stands regular and dense.

Compartments 10, 14, 15, 19, 22 are mature, in fully stocked stands; dense with a promising growth of a certain number of poles.

The compartments $20,21,23,24$ comprise irregular poles and veterans with a certain amount of scattering large timber over thick seedling growth and saplings. Generally speaking the stands are growing well. While continuing to cut the mature timber there should be no hesitation in thinning the poles so as to increase their growth.

Art. 3. - Application of the yield. - The following table gives (in accordance with the records at Pontarlier) the volume and the value of wood products realized in the State forest of Grande Côte during the 15 years from 1897 to 1911 .

\begin{tabular}{|c|c|c|c|c|c|}
\hline \multirow{2}{*}{ Years } & \multicolumn{2}{|c|}{ Fellings } & \multirow{2}{*}{$\begin{array}{l}\text { Accidental } \\
\text { products * }\end{array}$} & \multirow{2}{*}{$\begin{array}{l}\text { Total volume } \\
\text { per year }\end{array}$} & \multirow{2}{*}{$\begin{array}{l}\text { Value of the } \\
\text { products }\end{array}$} \\
\hline & Regeneration & Improvement & & & \\
\hline & $m=$ & $\mathrm{m}^{3}$ & m..$^{3}$ & $\mathrm{~m}^{3}$ & Franea \\
\hline 1897 & . & & 3,461 & 3,461 & 51,600 \\
\hline 1898 & $\ldots \ldots$ & 1,792 & 1,148 & 2,940 & 51,150 \\
\hline 1899 & ......... & 2,272 & 904 & 3,176 & 57,950 \\
\hline 1900 & $\ldots \ldots, \ldots$ & 2,246 & 978 & 3,224 & 66,600 \\
\hline 1901 & & 2,436 & 764 & 3,200 & 65,150 \\
\hline 1902 & $\therefore$ & 2,186 & 1,133 & 3,319 & 52,700 \\
\hline 1903 & & 1,983 & 1,097 & 3,080 & 59,970 \\
\hline 1904 & 1,016 & 1,025 & 1,159 & 3,200 & 70,250 \\
\hline 1905 & & 1,985 & 1,215 & 3,200 & 57,400 \\
\hline 1906 & & 2,162 & 1,040 & 3,202 & 53,070 \\
\hline 1907 & 231 & 2,022 & 966 & 3,219 & 60,840 \\
\hline 1908 & & 1,986 & 1,316 & 3,302 & 71,730 \\
\hline 1909 & & 2,353 & 765 & 3,118 & 64,120 \\
\hline 1910 & & & 3,063 & 3,063 & 57,670 \\
\hline 1911 & 1,992 & 757 & 1,337 & 4,086 & 84,760 \\
\hline Total. . & 3,239 & 25,205 & 20,346 & 48,790 & 924,960 \\
\hline Áverag & 216 & 1,680 & 7,356 & 3,252 & 61,664 \\
\hline
\end{tabular}

* Note large and varying amounts of "accidental products" - chiefly windfall. The loss in timber, where a large area is cut over and then left for 40 or 50 years, as in the western United States, must be very great. m. c. and also $\mathrm{m}^{3}=$ cubic meters.

From the preceding figures it seems that during the 15 years, the average annual yield per hectare has been:

$$
\begin{aligned}
& \text { In material } \frac{3,252}{38,161}=8.52 \text { cubic meters. } \\
& \text { In money } \frac{61,664}{38,161}=161.58 \text { francs ( } \$ 12.47 \text { per acre). }
\end{aligned}
$$

Exploitation Balance Sheet. - In the 15 years 1897 to 1911 there should have been cut $3,200 \times 15$ or $48,000 \mathrm{~m}$. c.; there was actually realized 48,790 or an excess of 790. This excess provided for the windfall of 1911 .

In order to include a period sufficiently long, we have compared the inventory of 1883 and the results of stocktaking of 1911, excluding the old compartment, 25 (now 27), which was not enumerated in 1883. 
The results obtained are shown in the following table:

\begin{tabular}{|c|c|c|c|c|c|c|c|c|c|c|c|c|c|c|c|c|}
\hline \multirow{3}{*}{$\begin{array}{l}\text { Date } \\
\text { of In- } \\
\text { ven- } \\
\text { tory }\end{array}$} & & & \multicolumn{4}{|c|}{ Number of trees } & \multirow[b]{2}{*}{ Total } & \multirow{2}{*}{$\begin{array}{l}\text { Per } \\
\text { hee- } \\
\text { tare }\end{array}$} & \multirow{2}{*}{\multicolumn{2}{|c|}{$\begin{array}{c}\text { Average } \\
\text { timber } \\
0.80 \text { to } 1.20\end{array}$}} & \multicolumn{4}{|c|}{ Volumes } & \multirow[b]{2}{*}{ Total } & \multirow{2}{*}{$\begin{array}{l}\text { Per } \\
\text { hec } \\
\text { tare }\end{array}$} \\
\hline & \multicolumn{2}{|c|}{$\begin{array}{c}\text { Average } \\
\text { timber } \\
0.80 \text { to } 1.20\end{array}$} & \multicolumn{2}{|c|}{$\begin{array}{c}\text { Interme } \\
\text { diate } \\
\text { timber } \\
1.40 \text { to } 1.60\end{array}$} & \multicolumn{2}{|c|}{$\begin{array}{c}\text { Exploit } \\
\text { able } \\
\text { timber } \\
1.80 \text { and }+\end{array}$} & & & & & \multicolumn{2}{|c|}{$\begin{array}{c}\text { Interme- } \\
\text { diate } \\
\text { timber } \\
1.40 \text { to } 1.60\end{array}$} & \multicolumn{2}{|c|}{$\begin{array}{c}\text { Exploit- } \\
\text { able } \\
\text { timber } \\
1.80 \text { and }+\end{array}$} & & \\
\hline & & $\begin{array}{l}P e r \\
\text { cent }\end{array}$ & & $\begin{array}{l}\text { Per } \\
\text { cent }\end{array}$ & & $\begin{array}{l}\text { Per } \\
\text { cent }\end{array}$ & & & $m .^{3}$ & $\begin{array}{l}P e r \\
\text { cent }\end{array} \mid$ & m..$^{8}$ & $\begin{array}{l}\text { Per } \\
\text { cent }\end{array}$ & $\mathrm{m}^{\mathbf{3}}$ & $\begin{array}{l}P \text { er } \\
\text { cent }\end{array}$ & $\mathrm{m}^{\mathrm{a}}$ & $\mathrm{m} .{ }^{8}$ \\
\hline 1883 & 50,184 & 65 & 20,613 & 26 & 7,159 & 9 & 77,956 & 214 & 47,387 & 36 & 50,241 & 28 & 33,466 & 26 & 131,094 & 343 \\
\hline 1911 & 47,851 & 62 & 21,168 & 27 & 8,303 & 11 & 77,322 & 203 & 42,866 & 32 & 53,695 & 39 & 38,633 & 29 & 135,194 & 353 \\
\hline & $-2,333$ & & +555 & & $\overline{+1,144}$ & & -634 & & $-4,521$ & & $\overrightarrow{+3,454}$ & & $\overline{+5,167}$ & & $\overrightarrow{+4,100}$ & \\
\hline
\end{tabular}

Composition of the Stands (Number of trees and volume). - The number of trees $0.80 \mathrm{~m}$. and over in circumference has passed from an average of 214 per hectare to 203 and the volume from $343 \mathrm{~m}$. c. per hectare to $353 \mathrm{~m}$. c.

The stands have not sensibly changed during the period 1883-1911; they are moreover very nearly in the condition which is considered normal in the Jura except for a slight shortage in volume of old timber.

Growth in Volume. - The comparison of the inventories of 1883 and 1911 gives an excess in 1911 of $4,100 \mathrm{~m}$. c. From 1883 to $189625,099 \mathrm{~m}$. c. has been realized making a total of 73,053 m. c. From 1897 to 1911 47,954 m. c. has been cut. The total growth for the 28 years would be 77,153 or annually $\frac{77,153}{28}=2,753 \mathrm{~m}$. c.; per hectare and per year $\frac{2,753 \mathrm{~m} . \mathrm{c} .}{364.86 \mathrm{ha} .}=7.55 \mathrm{~m}$. c.

Growth Per Cent. - Average capital $\frac{131,094+135,194}{2}=133,144$ m. c. making an average stand volume per hectare of $\frac{133,144}{36,486}=365 \mathrm{~m}$. c.

Growth per cent $\frac{7.55 \times 100}{365}$ or 2.1 per cent.

We have not thought it possible to take account of the stock estimates of 1896 because in comparing it with the inventories of 1883 and on the other hand with the inventory of 1911 we arrive at results which do not appear to be admissible.

\begin{tabular}{|c|c|c|}
\hline & $\begin{array}{l}\text { Comparison of the inventories } \\
\text { of } 1896 \text { and } 1883\end{array}$ & $\begin{array}{l}\text { Comparison of the inventories } \\
\text { of } 1896 \text { and } 1911\end{array}$ \\
\hline $\begin{array}{l}\text { Volume of the timber } \\
0.80 \mathrm{~m} \text {. in circum- } \\
\text { ference and over in- }\end{array}$ & $\begin{array}{c}1883=131,094 \text { m. c. } \\
1896=153,793 \text { m. c. } \\
\text { i.e. } 22,699 \text { m. c. more }\end{array}$ & $\begin{array}{l}1896=160,534 \mathrm{~m} . \text { c. } \\
1911=143,062 \mathrm{~m} . \text { c. } \\
\text { i.e. } 17,472 \mathrm{~m} . \text { c. less }\end{array}$ \\
\hline & $\begin{array}{c}\text { From } 1884 \text { to } 1896=25,377 \\
\text { Total growth in } 13 \text { years }= \\
48,076 \text { or per year } 3,698\end{array}$ & $\begin{array}{l}\text { From } 1897 \text { to } 1911=48,790 \\
\text { Total growth in } 15 \text { years }= \\
48,790-17,472=31,318 \mathrm{~m} . \mathrm{c} .\end{array}$ \\
\hline $\begin{array}{l}\text { Volume of the timber } \\
0.80 \mathrm{~m} \text {. in circum- } \\
\text { ference and over } \\
\text { realized.......... }\end{array}$ & $\begin{array}{l}\text { Per hectare and per year } \\
\frac{3,698}{36,486}=10.13 \mathrm{~m} . \mathrm{c} . \\
\text { Growth per cent } \\
\frac{10.13 \times 100}{390}=2.6 \text { per cent }\end{array}$ & $\begin{array}{l}\text { Per hectare and per year } \\
\frac{2,088}{8,161}=5.47 \\
\text { Growth per cent } \\
\frac{5.47 \times 100}{398}=1.4 \text { per cent }\end{array}$ \\
\hline
\end{tabular}

* Not including the compartment 25 which had not been inventoried in 1883 . 
We cannot satisfactorily explain how, in a period of 28 years, while the average volume per hectare remains sensibly the same, the annual growth per hectare could reach $10.13 \mathrm{~m}$. c. during the first 13 years considered, while it is put at $5.47 \mathrm{~m}$. c. during the last 15 years, the per cent falling similarly from 2.6 to 1.4 ; the vegatative conditions having remained the same and the yield adopted having always been very moderate (from 1.5 to 2 per cent of the growing stock enumerated). It seems that differences so marked and so abnormal must be attributed to inaccuracies in the enumerations of 1896 taken as a basis for discussion. Moreover in a forest at quite a high altitude, such as that we are discussing (average of 1,000 meters), where the climate is severe, it seems difficult to admit, as the author of the 1897 working plan has done, that the average annual increment per hectare could be $10 \mathrm{~m}$. c. and continue thus indefinitely. Such a growth is found actually at Levier and at La Joux but these two forests, situated at a lower altitude (average of $380 \mathrm{~m}$.) and in a materially milder climate, show stands which are not comparable to those of the Grande Côte. On the plea of maintaining the timber capital at as high a rate of production as possible, it does not do to merely cut the mature timber and to believe, as written in the working plan of 1897 (p. 35), that a forest, such as Levier, only depreciates its per cent of production by making sacrifices to mature timber and that the production of the Grande Côte is raised because it contains average sized trees. It is very laudable to try to obtain the maximum yield and usually it is absolutely necessary to realize the mature timber, but is it not most important to make sure the forests are perpetuated?

The factors which have an influence on the production of wood are extremely numerous; even if they are more or less known to us, yet we are still in doubt about many of them, as to what is the actual action and effective part of each in a phenomenon so complicated as that of the growth of wood and of the life history of a forest stand.

Therefore, putting aside the systematic theories which often may hide the forest as it is, we feel we will have fulfilled our task, if, adopting the main provisions of the working plan in force (in order to avoid those disorders which may compromise the benefits of a revision) and without any preconceived idea, we will succeed in placing the stands of the Grande Côte in the best possible condition to assure their vigor and to favor their growth.

\section{PART III. - REVISION}

Art. 1. - Discussion of the management in force and the method of treatment proposed. - The working plan on the whole is good; however, it appears to us to be defective in the following points:

(1) The area allotted for regeneration is too large; it occupies more than two-fifths of the forest and consequently it has been impossible to cut it over with real regeneration fellings.

Furthermore this group must be absolutely distinct and cannot be linked, without serious drawbacks, to the compartments to be cut over by area; in such a case one is compelled to practice bastard fellings, clearly without any definite character, after which the seeding does not take place.

(2) To guide the executive officers in the natural operations, it is indispensable to indicate the compartments which must be regenerated after those of the first group.

(3) It is necessary to prescribe for the beech in a definite manner; this associate species is very essential for the regeneration and good growth of fir stands. Its substitution for the conifers however should be prevented.

(4) For the reasons already explained, the actual yield, which corresponds to a production of $8.6 \mathrm{~m}$. c. must be reduced. 
It will be calculated anew with the 1911 valuations as a basis, and after taking account of the state of the stands; the annual growth of $7.3 \mathrm{~m}$. c. (which) is a growth per cent of 2 for the period 1883-1911. Under these conditions the State forest of Grande Côte will be treated as regular high forest in a single working group with a rotation of 150 years.

The shelterwood system will continue in force, but with the following modification (see "Regulation," p. 239):

The permanent periodic blocks will remain void but the compartments will be divided into three groups: $(a)$ Compartments to be regenerated; $(b)$ those compartments which according to all probability will be ready for regeneration after those of the first group; (c) the remaining compartments of the forest.

The compartments will continue to be designated from the N.E. to the S. W.; in the course of time by Arabic numerals. On the map the compartments of the first group will be shown by blue; those of the second group by yellow; while those of the third group will not be colored at all.

Art. 2. - Dividing the forest into compartments. - The former division into compartments has been preserved when it is suitable on the ground: it has only been modified as to the former compartments 23 and 24, each of which have been cut in two to form the new compartments $23,24,25,26$. In order to establish the special felling plan the compartments have been divided into three groups. In the first have been placed compartments $2,3,4,7,8,12,13$ which contain the most mature timber, whose regeneration should be carried out during the period for exploitation and which therefore will be cut for regeneration. The second group includes compartments 4, 9, 10, $14,15,19,22$ which apparently will come in turn to be regenerated after those of the first group. The third group will be formed of the remaining compartments $1,6,11$, $16,17,18,20,21,23,25,26,27$; these last two groups will be run over by improvement and extraction fellings. Consequently the following general felling schedule is proposed:

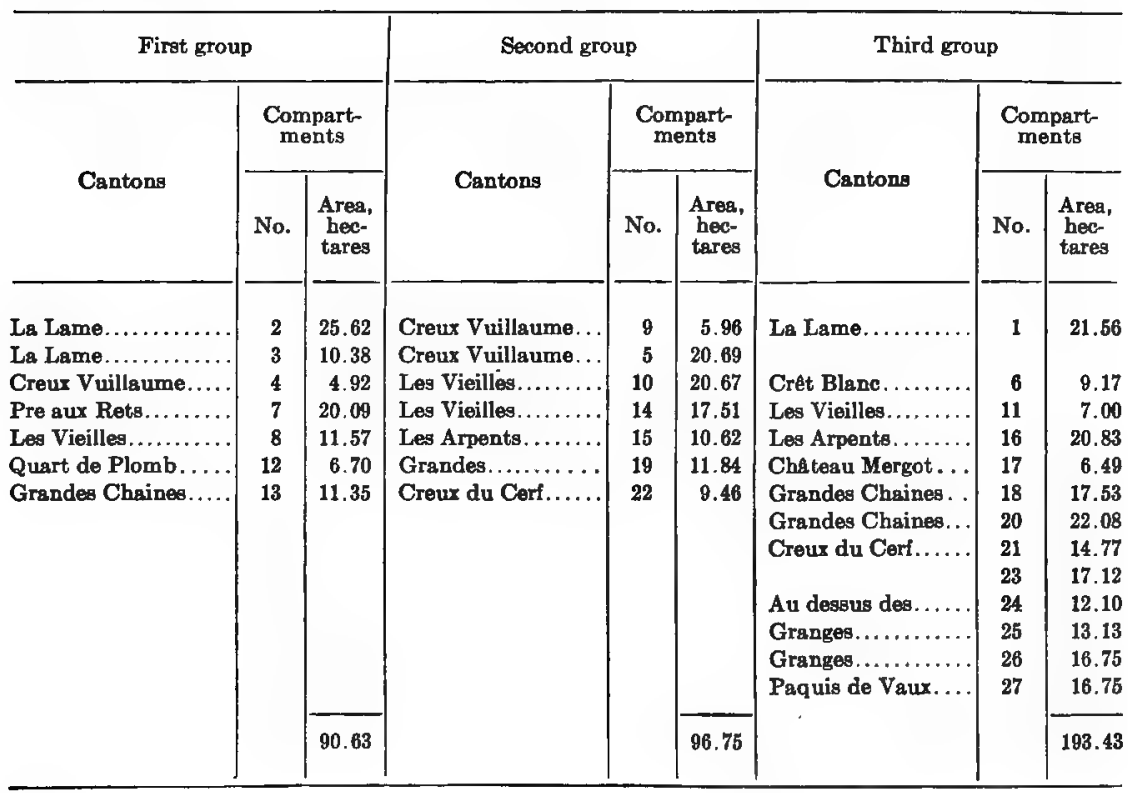


On the other hand, because of the construction of the Frasne-Vallorbe railroad, the areas of the compartments enumerated below are reduced as follows:

$\begin{array}{ll} & \text { Hectares Hectares Hectares } \\ \text { Compartment } 1=21.82-0.26=21.56 \\ \text { Compartment } 12=6.93-0.23=6.70 \\ \text { Compartment } 17=6.66-0.17=6.49 \\ \text { Compartment 23= } 17.26-0.14=17.12\end{array}$

REGENERATION FELLINGS

Art. 6. - Special fellings schedule for a period of 32 years, 1913-1944. - The essential aim of the shelterwood method is to replace a mature stand by young growth and the cultural difficulties which accompany this realization consist in its creation rather than its development until the merchantable age. In order to attain this result it is necessary to mark in the first place the regeneration felling; in order to assure its regular and methodical execution, there have been set aside each year for this operation a quota of the pre-determined yield. This share is fixed at 1,290 m. c.

The compartments of the first group include $41,068 \mathrm{~m}$. c.; this growth is not counted in order to make allowance for the polewood which can be conserved.

To realize on this volume there will be needed $\frac{41,068}{1,290}=32$ or 32 years for the annual felling; the exploitation plan will then be 32 years (years 1913-1944).

The regeneration fellings will be carried out:

(a) As final fellings in compartments 12,13 and 8; (b) as secondary fellings, then as final fellings in compartments $2,3,4$, and 7 . They will be laid out gradually in the order indicated above conforming to the rules; they will not pass from one compartment to the next one until after it has been entirely cut over.

\section{IMPROVEMENT CUTTINGS}

They will take place in the compartments of the second and third groups which will be cut over so far as possible within 10 or 12 years and in the following order: 20, 21, 1,22 to $27,5,6,11,9,10,14$, to 19 . The yield will be recruited after deducting the regeneration fellings and the chance cuttings; the area of the annual felling area will depend on the volume remaining to be marked.

Art. 6. - Application of the yield. - In order to realize the yield the local officers should at the start mark the regeneration felling. The volume of the timber $0.60 \mathrm{~m}$. ( 7 inches d. b. h.) and above in circumference cut under this head being known and at most equal to $1,290 \mathrm{~m}$. c. they will add to it (if there is any) the volume of windfall and overmature timber sold or marked during the current fiscal year. The total will be deducted from the ordinary yield and the result of this subtraction will show the amount to be cut under improvement fellings. All these volumes will be calculated by the volume table used for the valuation of the forest.

Revision of the Yield. - The yield will be revised for the year 1944 or (if there is any) for half the period assigned to the felling schedule in 1930 .

Cultural Rules. - Generally the regeneration and improvement fellings will be laid out in accordance with ordinary cultural rules. It seems necessary, however, to call local officers' attention to the following points:

Regeneration fellings - first group. - These fellings must aim to form a young stand: seeding of the soil and the substitution within a given period of seedlings, thickets, saplings, and young polewood for the existing high forest. 
Where there is not any young growth, the seed felling should be made at once and in opening up the stand carefully avoid giving any hold to the dangerous winds. For this purpose it will be best to start with quite large openings, the areas chosen being so far as possible amidst vigorous stems with well-developed crowns and long boles, leaving groups of 4 to 5 trees so as to best resist the wind. The cover should be opened up by taking short branchy trees, poles (growing) on stumps and those which are without a future. The beech and the weeds which form the bushy under story should be cut back.

Wherever the soil is covered with grass which prevents the germination of the seed, the scraping or raking (by strips) of the living cover and the thick layer of needles as yet undecomposed will assist the growth of seedlings.

In order to so far as possible decrease the considerable damage to existing young growth caused by too frequent fellings of mature timber and to decrease the windfall, the secondary fellings will be reduced to one or two at most; then the final felling will take place. These, once commenced, should extend over the entire compartment even in the parts not regenerated, for, if after the secondary felling and the freeing of the branches, the seeding has not yet taken place it will not come in naturally. Then it would be preferable to plant after the removal of the mature timber, selecting the most appropriate species either to improve the soil or to establish a mixture which is always desirable. Each time the forest is cut over care should be taken to remove ripe timber because of its size or poor condition. The medium-sized timber and the poles which are damaged, which cannot develop or which hinder reproduction, must be always marked in addition to the mature timber. Only reserve the poles and standards in groups; every tree, which after growing in a crowded stand becomes isolated, is sure to decrease in value and vigor. These regeneration fellings will always be laid out, one after the other, and should not pass from a compartment to the next one until it has been entirely cut over. At the same time, all the necessary cultural operations must be carried out: thinnings in the poles, cleanings in the thickets and saplings.

Improvement Cuttings. - (1) Compartments of the second group, 5, 9, 10, 14, $15,19,22$. The second group includes the compartments which come up for regeneration after those of the first group. After 30 years there should be a stand ready with as many merchantable trees as possible. In these compartments the thinnings will be very light, for the stands must be kept dense and the only trees which should be really logged are those above the merchantable diameter limit. Thus the promising trees whatever their diameter will get a start, and only the trees which are declining in vigor and those fully mature, which would diminish in value if left standing longer, will be removed. While avoiding an abnormal reproduction it will be possible to give a little light to existing young growth.

(2) Compartments of the third group. In these compartments the trees which have reached an exploitable size can be gradually felled and the future stock will be opened up so that they can develop with free crowns, but taking good care to keep the stand as fully stocked as possible. Everything which covers the soil, even the weeds, should be carefully preserved. No effort will be made to start reproduction; if it comes in accidentally in any case the poles and young stands will not be sacrificed. On the other hand there will be no hesitation in cutting out the overmature timber wherever it may be found, where it is suppressing the advance growth (especially in compartments $1,20,21,23,24$ ). In the pole stands regular thinnings will be carried out by freeing the crowns of the best boles. The beech, being valuable from all viewpoints, must not be eliminated. Only the excess beech stems will be cut, but it must be kept from taking the place of the conifers. 


\section{PART IV. - BETTERMENTS}

Only the absolutely essential betterments to be accomplished between 1913 and 1944 are listed:

Management Lettering. - The compartments will be marked by painting letters on a white background on boundary trees, work which may be estimated at 100 francs.

Logging Roads. - The existing roads are generally in good condition and are suffcient for logging purposes. Their maintenance requires an average yearly expense of 2,000 francs or for 32 years, 64,000 francs.

Cultural Betterments. - First for restocking the blanks which may oceur, and for completing the natural reproduction if that should be necessary, it will suffice to estimate the annual planting of 2,000 trees which will mean a labor expense of 15 francs per thousand, or 30 francs and for 32 years, 960 francs.

Secondly, these plants will be furnished by the nursery already established in the forest. It has an area of 0.23 of a hectare and its annual maintenance amounts to 120 franes or for 32 years, 3,840 franes.

Total, 68,900 francs, or an estimated annual cost of $\frac{68,900}{32}=2,153$ francs $(\$ 416)$.

\section{PART V. - COMPARATIVE REVIEW OF THE PRODUCTS TO BE REALIZED BEFORE AND AFTER THE REVISION OF MANAGEMENT}

The Federal forest of Grande Côte has produced:

From 1858-1883, 78,343 m. c., valued at 1,327,441 francs; 7.9 m. c. per hectare and per year, or 134 francs.

From 1884-1896, 25,377 m. c., valued at 395,033 franes; 5.1 m. c. per hectare and per year or 82.2 francs.

From 1897-1911, 48,790 m. c., valued at 924,960 francs; $8.5 \mathrm{~m}$. c. per hectare and per year, or 161.6 francs.

Or for the 54 years, $152,510 \mathrm{~m}$. c., valued at 2,647,434 francs; $7.6 \mathrm{~m}$. c. per hectare and per year, or 128.7 francs.

This puts the average annual yield at $2,888 \mathrm{~m}$. c., valued at 49,026 francs. In the future, up to the time the working plan may be revised, the yearly cut will be $3,090 \mathrm{~m}$. c. which should yield about 58,710 francs; in giving an average value of 19 francs per $\mathrm{m}$. $\mathrm{c}$. which has been the average during the past 15 years, the yield will be a little higher than for the period 1858-1911, but 5 per cent less than that for the period 1897-1911. This reduction is actually essential as has been explained in detail in this report; but there is every reason to hope that because of the generally very satisfactory growth in the forest of Grande Côte, and due to the good results of the management proposed, the yield will increase during future periods.

Besançon, May 8th, 1912.

Devarennes, Inspector of Waters and Forests, Chief of Management.

\section{(2) STATE FOREST OF BAN D'ETIVAL}

Near'St. Die, Vosges, 34.01 hectares, 410-540 meters altitude, 9/10 fir, 1/10 beech. (A) Working group, Corne de Lisse, Masson's Method of Yield Calculation.

During the first cutting period, 1890-1899, the yield was calculated in accordance with the formula $P=\frac{2 V}{N}$, where $P=$ yield; $V=$ growing stock; and $N=$ rotation in years.

This resulted in a yield of $\frac{2 \times 12,196}{150}$ or 163 cubic meters, equal to 4.8 cubic meters per 
hectare per year. At the second cutting period, 1900-1909, the stocktaking showed a total stand of 11,881 cubic meters, demonstrating an annual growth of $\frac{(11,881+1,902)-12,196}{34.01 \times 10}$ $=4.6$ cubic meters per hectare per year. In the words of the author ( $M$. Cuif): "There is no reason for modifying the exploitable size: that of 0.60 of a meter is still acknowledged to-day, as giving the maximum utility. . . . It is still best to fix at 150 years the time necessary for the fir to reach this size. Consequently the total growing stock taken at the end of 1908 , in the Corne de Lisse working group, being 13,560.8 cubic meters, the yield in main products determined by Masson's method is 13,560.8 $\times$ $\frac{2}{150}=180.8$ which corresponds to an average annual yield per hectare of 5.3 cubic meters."

The plan approved November 23, 1889, provided that in applying the selection system the oldest timber should be chosen as well as the trees declining in vigor, rotting or dry, and others still in good condition but needed by the owner. Care was taken to preserve the selection type of forest, but the entire working group, divided into ten parts, had to be completely cut over by the end of each 10-year period. The volume of all wood from 0.15 meters up in diameter was subtracted from the prescribed yield, whether from ordinary fellings or from windfall. Actually during the 10-year period 1890 to 1899 on the 34.01 hectares, 1,902 cubic meters was cut as against 1630 prescribed, an average per year of 190 as against 160 , or 5.6 cubic meters per hectare as against 4.8 cubic meters.

It is quite likely that the stocktaking made in 1898 was in error for some reason unknown because the measurements carefully made under the personal direction of $\mathbf{M}$. Cuif showed, as follows:

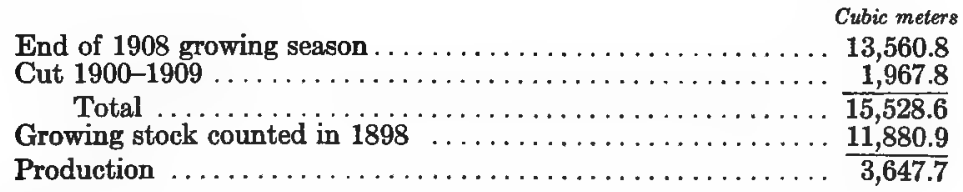

or $\frac{3,647.7}{34.01 \times 10}=10.7$ cubic meters, an inadmissably high rate of growth.

To make doubly sure of accuracy in 1908, M. Cuif adopted the plan, which he recommends for all future stocktaking in this working group, of having each tree measured, blazed at 1.30 meters above the ground, and at the point measured the guard made a vertical scratch so at the next measurement the same point could be calipered. In reality the area is a sample plot to determine the value or errors in the Masson method of regulating the growth.

A comparison between the stocktaking of 1888 and 1908 shows that in 1888 the average was 358.8 cubic meters per hectare as against 398.7 cubic meters in 1908 and that during the 20 years 3,870 cubic meters were realized as against 3,220 cubic meters prescribed by the working plan. This enrichment to the extent of 40 cubic meters per hectare for the 20 years is welcomed because there was insufficient growing stock on a number of areas. M. Cuif remarks: "Must one think, after what we have seen, that the calculation of the yield by the Masson method always leads to too small a figure? No, because such a conclusion would be contrary to a strongly entrenched theory which admits that the use of the Masson per cent certainly brings a forest to the normal, provided that the entire stand is promising. To what, then, can be attributed the results which fail to corroborate this principle? Simply to the special clause in the recruitment of the yield which prescribes the calculation of the volume of all the wood cut inclusive of 0.15 in diameter." 
During the 20-year period the total production was 7.7 cubic meters per hectare per year and of this total amount 5.8 was in wood 0.45 and above in diameter and only 1.9 in wood 0.15 to 0.40 inclusive. During this same period the wood cut totaled 5.7 per hectare per year of which 4.3 was from trees above 0.45 in diameter and 1.4 from trees 0.15 to 0.40 inclusive.

M. Cuif decided to allow the yield to be taken from sound trees 0.45 in diameter if necessary to supplement the volume of those over 0.60 to make up the yield. The calculation of the yield for 1909-1910 which by the way varies with each compartment, gives 5.3 per hectare per year as against (a) 5.8 and (b) 7.7, the figures of the amount produced $(a)$ in 0.45 meters and over, and (b) total for the last 20 years.

The improvement fellings in the wood 0.15 to 0.40 in diameter are estimated to yield about 1.4 per hectare per year. It is interesting to note that the average prices for the period 1889-1898 were 18.34 francs per cubic meter as compared with 23.14 for the years 1899-1908.

The new regulation of felling then prescribes the year of felling 1910-1919 inclusive the number of the cutting area, the area in hectares, and the total amount in cubic meters. Only wood from trees 0.45 and over are to be counted against the yield.

(B) Naufrogutte working group, Forest of Ban d'Etival. Same as Corne de Lisse but volume of fir is $19 / 20$ and beech only $1 / 20$. The area is 34.48 hectares. Method of 1883 Yield Regulation.

The old wood here includes trees 0.45 and over; the average wood 0.25 to 0.40 and the small wood below 0.25 . A comparison of the stocktakings in 1888 and in 1908 (that of 1899 appeared inaccurate) shows that: Total volume in m. c. (1888), 10,794.1; (1908), 12,363.6; total volume in $\mathrm{m}$. c. cut (1888-1909), 3,404.6. This signifies a production of 7.2 per hectare per year as against 4.9 actual cut. This production was 4.7 cubic meters in wood 45 and over, and 2.5 in wood 0.15 to 0.40 . The actual cut was 3.6 and over 0.45 and 1.3 in wood 0.15 to 0.40 .

The new cut for 1910 to 1919 is put at 1,822 for the 34.48 hectares and windfalls and dead wood 0.20 and over will be deducted from the yield. The selection felling is accompanied by an improvement felling to increase the growth of promising trees and to clean or free young stands.

In the calculation of the yield it is explained that the volume of the large wood (over 0.45 ) in 1909 was 7,917 c. $\mathrm{m}$. and the average wood $(0.25-0.40) 3,984$ c. m. making a total of 11,900 of which five-eighths is 7,438 and three-eighths 4,463 c. m. To counteract this excess of large wood Cuif subtracts 479 from the large wood and adds it to the average wood and proceeds with the calculation of the yield as given below after obtaining a growth per cent for the large wood based on the differences in volume of this class of wood in 1888 and 1909 (allowing however for the passage of trees from 0.40 to the 0.45 class) equal to 0.9 per cent.

$\frac{7,438 \times 0.009 \times 50}{2}=1,673$ c. m. or for the 50 years (one-third the rotation) 7,438 plus 1,673 or 9,111 equal to $\frac{9,111}{50}=182.2$ cubic meters per year or 5.2 per hectare.

No allowance is made for the growth of the average wood since that will merely fill the place left by the removal of the large wood.

It is interesting to note that the cut for 1888-1899 was calculated at $4.5 \mathrm{c} . \mathrm{m}$. and for 1899 to 1908 at $4.4 \mathrm{c}$. m. per hectare and per year. Figures which are clearly below the growth as is also the current figure of 5.2 but a comparison of the curve showing the estimated normal number of trees per hectare for each diameter class (based on averages of a number of (empirically) normally stocked selection stands) shows that the forest is poor in trees 0.15 to 0.35 in diameter and that consequently the economy will be welcome. 
(C) Working group Rein des Boules, Forest of Ban d'Etival altitude of 510 meters, 37.04 forested. Species by volume, fir 69 per cent, beech 31 per cent; selection. Yield by number of trees.

By the decree of October 15, 1885, approved November 27, 1886, the working group was divided into ten approximately equal felling areas and an annual yield of 41 trees at least 0.30 in diameter at $1.30 \mathrm{c.} \mathrm{m}$. (about $16 \mathrm{fir}$ and 25 beech) was established including the provision that windfalls 0.30 and over would count as part of the yield. The 41 trees to be cut were based on the estimate that the growth was $4.5 \mathrm{c}$. $\mathrm{m}$. per hectare and per year and that the fir of 0.60 meters in diameter contained $3.7 \mathrm{cr}$. and the beech of the same size 4.4. On the basis that four fir would be cut to every six beech the average volume per tree was taken at 4.12. Owing to windfalls, etc., they cut $38 \mathrm{fir}$ and 12 beech or 50 trees per year during the years 1886 to 1895, but as a matter of fact the average volume was only 2.8 per tree. During the second cutting cycle the cut was actually 54.9 trees and over per year ( 8.9 accidental) with an average volume of $4 \mathrm{c} . \mathrm{m}$. per tree. Actually during the first 29 years the production was 9.4 cubic meters per hectare and per year or 8 in wood 0.45 and above and 1.4 in wood 0.15 to 0.40. The working plans officer quotes what is considered an average selection hectare for the locality, namely, a total of $\mathbf{4 3 4 . 5}$ trees cubing 388.2 cubic meters.

In the calculation of the new yield the author, M. Cuif, proceeded as follows: During the 20 years 1885-1905 the average production was 58 trees -31 fir and 27 beech. "The 31 fir and 27 beech have been furnished actually by the trees 0.40 in diameter whose average number may be valued as follows, taking 771 as existing in 1885 (429 fir and 342 beech), 1,004 in 1896 (392 fir and 612 beech) an average of 412 fir and 463 beech; 412 fir 0.40 in diameter have given each year, 31 fir to be counted against the yield or 7.5 per cent and 463 beech, 27 beech or 5.8 per cent." Similarly the per cent passing to the next diameter class is figured, and the following results obtained:

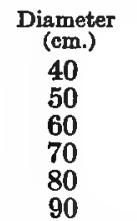

Finally the writer calculates for each compartment or cutting area the normal number of trees to cut, and in addition one-quarter the excess over the normal stand also to be cut, in order to reduce the growing stock, namely, 540 normal cut plus 160 trees as one-quarter the excess or 700 in all on 37.04 hectares. This is then divided between beech and fir on the basis of their per cent in each compartment.

One cannot but ask the question: "Why regulate the yield by number of trees if it has to be checked by a volume computation?" But it must be recalled that these three working groups are really large scale experiments on yield regulation; the conclusions will probably be available by 1921 or 1931 .

\section{(3) COMMUNAL FOREST OF MONT GLORE (SAVOIE)}

The working plan of 1885 quotes from a report dated 1842 which alludes to this forest as "Abused, impoverished in 1835 by a cut every three years of 150 fir trees." In other words, the yield was by number of trees (and probably the best were unfortunately selected) instead of by volume. This report spoke of this forest as having 90 hectares stocked with fir, 90 with beech with a fir under-story, and 145 pure beech coppice, making a total of 335 hectares of forest. The management prescribed thinnings on one-fifteenth 
of the area each year. There were, in addition, regular fellings and cleanings. In 1885, selection fellings were prescribed because of "the altitude, the rigorous climate, and the slowness of regeneration of the important species." The cut was placed at 202 cubic meters per year, but 5 per cent was reserved for betterments. The diameter limit for the exploitable tree was 0.6 meter (23.6 inches d. b. h.) on a rotation of 140 years. According to the working plan now in force, the selection method will be continued and the yield prescribed at 144 cubic meters. In other words the results of past cuttings show an overcut and it is now necessary to economize in order to bring the forest to a better producing capacity. Before the yearly cut is marked, the forest is reconnoitred in the spring for windfall and the total amount of windfall is subtracted from the total yield which is then secured, first, from dry and dying trees and from trees which must be felled to free fir seedlings or to establish or start reproduction when it does not exist. The best trees are favored. Fir over $\mathbf{0 . 6}$ meter in diameter are cut, taking the best first. The cutting is especially conservative along very steep slopes, and where too heavy cutting might encourage the formation of torrents and thus destroy agricultural land lying below.

The following improvement work is planned: A scenic road, a house for a guard, numerous plantations, and, according to the working plan, "there is much left to be done - there is a considerable danger from floods."

\section{(4) COMMUNAL FOREST OF LARDIES (NEAR OLORON, BASSES-PYRÉNEES)}

This communal forest comprises 88.35 hectares at an average altitude of 130 meters. There is pedunculate oak growing on an alluvial soil with a mild climate. From 1883 to 1905 , inclusive, 215 cubic meters were cut, valued at 1,381.10 francs. From 1886 to 1905 , inclusive, the improvement cuttings covered 1.8 hectares annually and netted 249.40 francs. The sales from windfall, aggregating 133 cubic meters, netted 530.90 francs and the secondary products 702.2 francs. This gave a total revenue of 348 cubic meters or 2,865.6 francs. The normal yield was estimated at 309 cubic meters or $2,614.7$ francs. In this forest the soil value is very small because it is often flooded; it is estimated at about 50 franes per acre. The local market is for firewood and the timber is sold at Pau. There is communal grazing by 300 head of cattle, 50 horses, and 200 hogs, yielding 100 francs per year.

According to the inspector: "The up-keep of a nursery in a small forest is relatively dear."

This points to the advisability of district nurseries where transport is possible and where the planting is on a small scale. Here the exploitability is based on economic factors rather than physical. At 20 years of age, trees are about 5 meters apart. Shortly after 70 years of age, there is a heavy thinning so as to keep the trees about 10 meters apart until the final cutting.

The yield of this regular high forest of oak is calculated by volume for the regular fellings, by dividing the total volume of the area to be cut over by the number of years in the period and subtracting 25 per cent for reserve. The yield of thinnings is fixed by area. There were cleanings in 1912,1920 , and 1922 . The revenue for the next period is estimated at 2,805 francs.

\section{(5) STATE FOREST OF LA JOUX (JURA)}

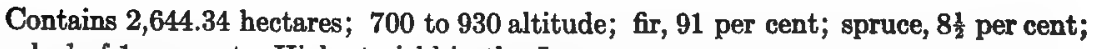
beech, $\frac{1}{2}$ of 1 per cent. Highest yield in the Jura.

The following figures on the first working group are quoted from the working plan for the State forest of La Joux, by Inspecteur Brenot, which is dated April 29, 1896. 
From 1884 to 1895 the increment per hectare and per year has been 11.97; the volume for the average hectare, 385. The increment per cent, 3.11 .

In 1883 the volume analysis of trees 0.30 in diameter and above was: Logs, 206,058 cubic meters; branches, 18 per cent, 37,090 cubic meters; total, 243,148 cubic meters.

This being true it is possible to make the following conclusions from a comparison of the stocktaking of 1883 and 1908: Volume of trees 0.30 in diameter and above, inventories in $1883,243,148$ cubic meters; in $1908,325,675$ cubic meters; increase, 82,527 cubic meters.

Volume of trees cut from 1884 to 1908 : 1884 to $1885,60,280$; 1896 to $1908,100,731$; total of 161,011 cubic meters.

Total growth from 1883 to $1908=82,527+161,011=243,538$ cubic meters or average per year of 9,741 cubic meters.

Average growing stock $\frac{243,148+325,675}{2}=284,406$ cubic meters.

Average volume per hectare $\frac{284,406}{640.89}=443$ cubic meters.

Growth per hectare and per year $\frac{243,538}{640.89 \times 25}=15.2$ cubic meters.

Increment per cent $\frac{15.2 \times 100}{443}=3.4$ per cent.

It results from the analysis of the preceding stocktakings (the volume per hectare was 380 cubic meters in 1883 and 500 cubic meters in 1908 (wood 0.30 and over)) that the growth per hectare and per year estimated at 11.97 cubic meters for the first 12 years of growth is between 3.11 and 3.40 per cent.

These figures prove . . . that we have a working group overstocked with old wood, where for the past 25 years the material has been increasing in spite of the annual cut (yield).

In view of this rather abnormal situation, it is felt that in order to prevent a further accumulation of excess growing stock it is best to base the yield upon the growth per cent of the working group during the last period of 25 years by multiplying the estimated growing stock by the mean annual growth per cent.

Material enumerated in $1908=301,260$; growth per cent from 1883 to $1908=3.4$; yield $=\frac{301,260 \times 3.4}{100}=10,242$.

Note.-For the comparison the same volume table was used to obtain both volumes, i.e., in 1883 and 1908.

If we should only cut as in the past, the average annual growth of the working group, it would be impossible to realize with sufficient rapidity the overmature material and it is feared the present state of affairs would continue indefinitely. It is therefore felt to be absolutely necessary . . . during two periods . . . to add 10 per cent of the volume to the yield obtained and to fix (the cut) at $10,242+1,024=11,266$ cubic meters, or, roughly, 11,270 cubic meters equal to 17.585 per hectare and per year and 3.7 per cent of the total growing stock.

According to Inspecteur Devarennes "the State forest of La Joux ${ }^{1}$ is one of the richest and most productive fir stands in France, and perhaps even of all Europe." The stocktaking made in 1908-1909 gave the following figures: 642,138 trees from 7.9 to 55.1 inches in diameter (245 trees or 463 cubic meters per hectare or about 42,400 feet board measure per acre, average on 6,531 acres). This is equal to 15.8 cubic meters per hectare per year (a yield per cent of 5.3) or about 1,200 board feet and 1.6 cords per acre

1 This forest was logged by the Canadians for the French; the cutting started in 1917 before the A. E. F. arrived in France. 
per year, worth $\$ 12$ per acre. The total annual revenue from timber is 406,730 francs $(\$ 84,500)$ and the soil and growing stock are estimated to be worth 20 million francs $(\$ 3,860,000)$. Deducting 50 cents an acre for taxes and administration, this gives a net of $\$ 81,235$ or about 2 per cent on the invested capital (see p. 322). A comparison of the normal (empirical) number of trees and stand per hectare with the actual stock is given in the graph which follows:
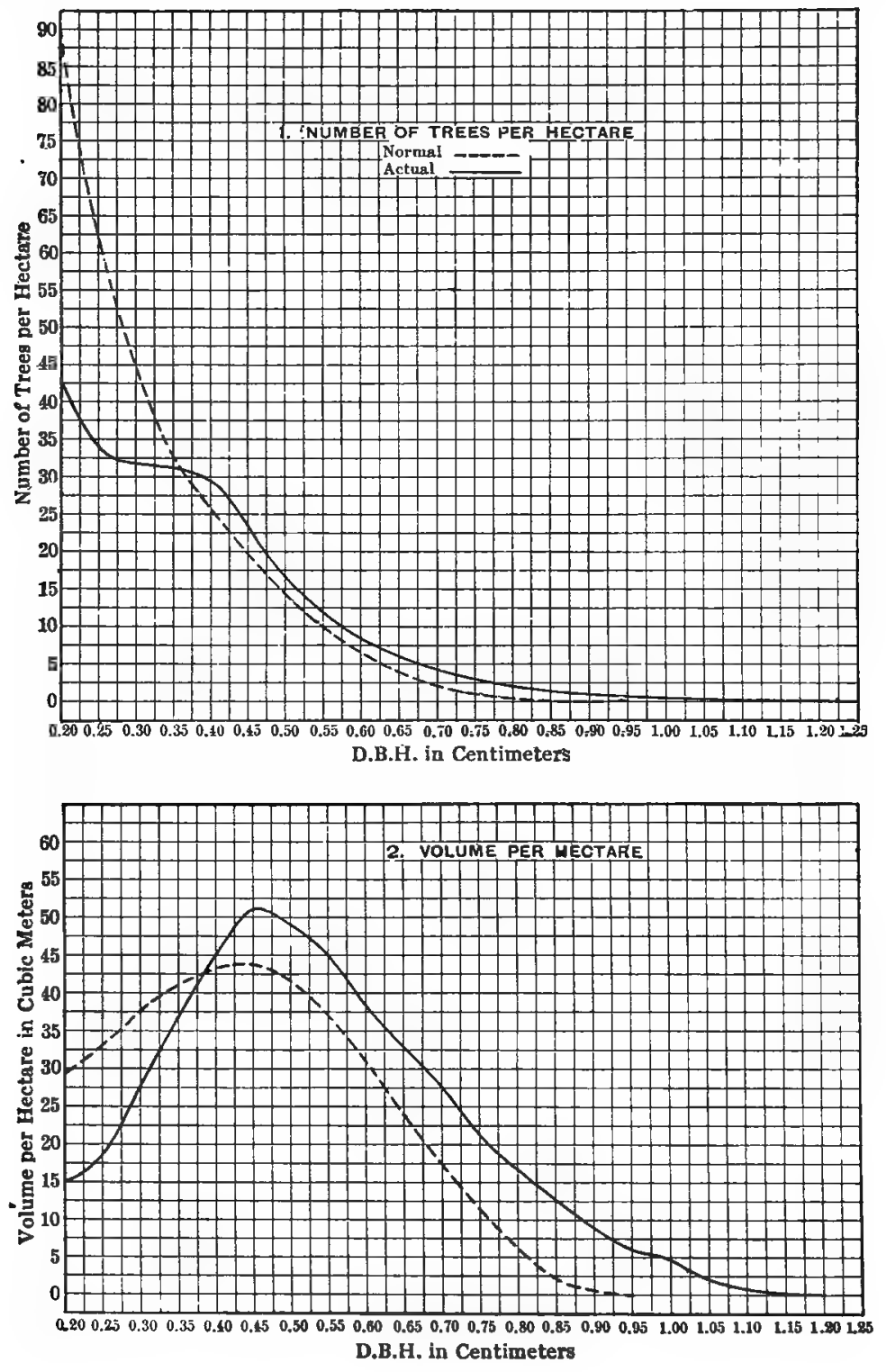


\section{(6) COMMUNAL FOREST OF FILLINGES (HAUTE-SAVOIE)}

In the revision of the working plan for the communal forest of Fillinges, there is presented an excellent example of what recovery a forest can make during a period of 19 years. The inventory in 1891 and 1910 follows:

\begin{tabular}{|c|c|c|c|c|c|}
\hline \multicolumn{3}{|l|}{1891} & \multicolumn{3}{|c|}{1910} \\
\hline Age classeg & $\begin{array}{l}\text { Number } \\
\text { of trees }\end{array}$ & $\begin{array}{l}\text { Volume, } \\
\text { cu. in. }\end{array}$ & Age classeg & $\begin{array}{l}\text { Number } \\
\text { of trees }\end{array}$ & $\begin{array}{l}\text { Volume, } \\
\text { cu. in. }\end{array}$ \\
\hline $\begin{array}{l}\text { Average wood } \ldots \ldots \ldots \\
\text { Old wood. . . . . . . . }\end{array}$ & $\begin{array}{r}5,337 \\
694\end{array}$ & $\begin{array}{l}2,117 \\
1,386\end{array}$ & $\begin{array}{l}\text { Average wood ....... } \\
\text { Old wood.......... }\end{array}$ & $\begin{array}{l}8,527 \\
2,397\end{array}$ & $\begin{array}{l}4,213 \\
4,785\end{array}$ \\
\hline Totals.......... & 6,031 & 3,503 & Totals.......... & 10,924 & 8,998 \\
\hline
\end{tabular}

According to the above table the percentage of volume increase was 157 per cent in 19 years. The growth in this case, of course, was exaggerated because many trees just below 20 centimeters in diameter passed into the merchantable class which was calipered in the revision. Taking these figures, however, as correct, it means an average growth of 8.7 cubic meters per hectare per year for a forest which had been mismanaged in the past. According to the original working plan:

"The working group has been completely transformed in the course of a period. The stand formerly very broken, open, often formed of sparse groups of conifers or isolated trees as it existed in $\mathbf{1 8 9 1}$ has given place to a thrifty young selection forest sometimes even dense, which is rapidly beginning to suppress the broadleaf understory with which the conifers are still in mixture at certain points. It is to be regretted, however, that the small yield did not allow cutting over the entire working group by selection fellings during the period and that consequently several compartments are crowded with overmature and deformed trees."

In the second working group, the recovery (for average and old wood) was from 12,265 cubic meters to 27,452 cubic meters in 19 years; 124 per cent. In five compartments of the first working group, the growth averaged 8.7 cubic meters per hectare per year, and in 14 compartments of the second working group the same average rate of growth was maintained, varying from 4 to 11.5 cubic meters per hectare per year. It is interesting to note that the yield was formerly fixed at 157 cubic meters per year for the entire forest of 166.45 hectares. According to Schaeffer's revision of 1910, the entire forest was thrown into one working group. He figured the old wood at 16,048 cubic meters and the deficit of old wood was $\frac{32,802 \times 5}{8}$ or a total of 20,501 , meaning a deficit of 4,453 cubic meters. The average wood amounted to $16,754.2$, an excess, since $\frac{32,802 \times 3}{8}=a$ total of 12,301 . Therefore, in accordance with the procedures explained on page 234 , trees 0.35 meter in diameter were transferred to the old wood, thus justifying still further economy of yield. Since the rotation was fixed at 162 years, the yield under this formula would be 16,048 , the volume of the old wood divided by 54, one-third the rotation, would be 297.1 plus 1 per cent of the growth of the average wood (i.e. 1 per cent of 16,754 , or 167.5) making a total estimated cut of 464.6 which equals 1.41 per cent of the volume, or 3.2 cubic meters per hectare per year. In the working plan, Schaeffer pointed out that the growth, according to Pressler's formula, would have been 654.16 cubic meters per year. This working plan is an example of how the French are rehabilitating worn out forests; one-quarter of the 
theoretical cut is held in reserve to provide for such emergencies as windfall and other damages so that the actual cut is prescribed at 348 cubic meters per year, which is obviously much less than the actual growth. The working plan provides that the whole area be cut over by improvement fellings every 17 years.

\section{(7) COMMUNAL FOREST OF BURDIGNIN (HAUTE-SAVOIE)}

The working plan for the communal forest of Burdignin, written by Schaeffer in 1897, presents another interesting example of French yield regulation. This forest comprises 67.11 hectares, is situated at an altitude of 1,300 meters and the stand is composed of spruce, 80 per cent; fir, 18 per cent; beech, 1 per cent; Austrian pine and larch, 1 per cent. Schaeffer calls it a model of regularity especially as regards the second and third periodic blocks. The yield was formerly fixed at 136 cubic meters per year. A period of 18 years was found too short to get satisfactory and complete regeneration in the first periodic block. The yield from thinnings has been irregular. In 1881 it was 15 cubic meters; in 1882, 22 cubic meters; in 1890, 222 cubic meters; in 1891 and 1894, but 75 cubic meters. The rotation was 120 years and the diameter limit was 0.40 ; the period was fixed at 20 years in the 1897 working plan. The cut prescribed was 280 cubic meters by volume with the addition of the improvement fellings yield on $\mathbf{5 . 6 3}$ hectares each year. According to Schaeffer, care was to be taken not to open up the stand too fast and the thinnings had to aim at developing the stand without making sacrifices to regularize it. Trees without a future were removed, but he aimed at keeping the top cover complete. In the older stands the thinnings were essentially crown thinnings. (Par le haut.)

The following analysis of the stand was made in Schaeffer's working plan:

"To determine the yield, it is necessary to first divide the stand enumerated in three groups or classes (young wood, average wood, and old wood). We consider the conifers 16 inches and over in diameter 'old wood' and the beech 12 inches and over . . . the conifers 8 to 14 inches, and the beech 8 to 10 inches 'average wood,' and the trees 6 inches 'small wood.' This division has been made in the following table:

\begin{tabular}{|c|c|c|c|c|}
\hline \multirow{2}{*}{ Species } & \multicolumn{4}{|c|}{ Volumes } \\
\hline & Young wood & A verage wood & Old wood & Totals \\
\hline $\begin{array}{l}\text { Conifers.............. } \\
\text { Beech............ }\end{array}$ & $\begin{array}{c}405.10 \\
\ldots \ldots \ldots \ldots\end{array}$ & $\begin{array}{r}9,205.60 \\
91.80\end{array}$ & $\begin{array}{r}8,564.70 \\
87.10\end{array}$ & $\begin{array}{r}18,175.40 \\
178.90\end{array}$ \\
\hline Totals..... & 405.10 & $9,297.40$ & $8,651.80$ & $18,354.30$ \\
\hline
\end{tabular}

"It is evident from this table that the normal proportion of five to three which should exist between the large wood and the average wood is far from being attained. To obtain it one must transfer 2,567 cubic meters (or about two-thirds the conifers 14 inches in diameter) from the average wood class to the old wood. We consider this transfer justified because a 16-inch tree is considered merchantable in this region and most of the 14-inch stems will reach this size during the period. We, moreover, propose (to avoid any disaster) not to count the future growth of the old wood . . . prudence and moderation.

"The volume to be cut during the one-third of the rotation will then be: $8,651.8+$ $2,567=11,219$ cubic meters in round figures, when the yield will be: $\frac{11,219}{40}=280$ cubic meters.

"The thinnings are already ordered (September 18, 1880), by nine year cycles; they have given good results and we propose to continue them. Since the periodic blocks 
to be run over by thinnings are three in number, each will continue to form three felling areas whose average area will be: $\frac{17.02+16.79+16.86}{9}=\frac{50.67}{9}=5.63$ hectares.

"There are four periodic blocks; one is cut over for regeneration, and the other three are cut over for thinnings, etc."

\section{(8) STATE FOREST OF PARC-ET-ST. QUENTIN (OISE)}

The State forest of Parc-et-St. Quentin has had working plans made in 1869, 1884, and 1905. As a result of experience a rotation of 120 years was found too short, because of the large proportion of oak. It was, therefore, increased to 150 years. According to the most recent working plan, there are two classes of stands: (1) Regeneration areas over 100 years old; (2) under 100 years old, not under regeneration.

"One observes at once that, after this classification, the group of old wood will be totally deficient and that there exists a deficiency in the age sequences between the ripe wood and that which comes next."

According to the 1905 revision (page 47, original working plan):

"The yield of the principal felling areas will be obtained by dividing the volume of the stand in compartments 7, 8, and 9 (to be regenerated 1904 to 1923) by 20 . This volume amounts to $26,739.29$ cubic meters and the yield will be fixed at $\frac{26,739.29}{20}$ or 1,337 cubic meters. During the same period of 20 years the yield of the improvement fellings by area will cover $\frac{674.27 \text { hectares }}{10}$ or 67.43 hectares because the cutting cycle is 10 years."

Where there is difficulty in regeneration, the cuttings should be regulated according to seed crops rather than to the sequence of fellings as developed. According to the plan:

"The density of the seed fellings will be regulated so as to allow for the requirements of the species - oak and beech - which should be forced into the proper mixture, (about half and half). The existing understory must be completely removed above this size and under no pretext whatever should it be allowed to form part of the future stand. The seed fellings will be followed by secondary and final fellings laid out exclusively according to the cultural needs. The improvement cuttings should aim at the establishment of a high forest with a suitable mixture of species and as fully stocked as possible; they will be carried out by the use of regular normal thinnings, the removals limited to trees already dead or almost wholly so. . . . In the young stands the valuable species will be carefully freed, and in accordance with their needs the soft woods and species of secondary value will be sacrificed."

\section{(9) COMMUNAL FOREST OF THIEZ (HAUTE-SAVOIE) 2}

\section{PART I}

\section{Record of Management. - General Data}

Art. 1. - Name. - Communal Forest of Thiez.

Art. 2. - Area. - In 1866 the area of the forest was 152.7669 hectares; it was reduced to 119.51 hectares by the revised decree of January 31, 1872. A decree dated June 28,1889 , authorized the sale of 22.08 hectares and put the area under management at 97.43 hectares. Finally a new decree. April 11, 1900, reduced the area to 65.14 hectares.

Our recent survey gives an area of 61.54 hectares, divided as follows between the two cantons which compose the forest:

2 Savoie was formally ceded to France in 1860 and prior to this date communal forests were badly overcut and mismanaged. 


\begin{tabular}{|c|c|c|c|}
\hline Canton & Area & Blanks * & Forested \\
\hline $\begin{array}{l}\text { La Vuardaz } \ldots \ldots \ldots \ldots \ldots \ldots \ldots \ldots \ldots \ldots \ldots \ldots \ldots \ldots \ldots \ldots \ldots \ldots \ldots \ldots \ldots \ldots \\
\text { Le Péray. }\end{array}$ & $\begin{array}{l}26.74 \\
34.80 \\
\end{array}$ & $\begin{array}{l}1.70 \\
3.60\end{array}$ & $\begin{array}{l}25.04 \\
31.20 \\
\end{array}$ \\
\hline Totals $\ldots \ldots \ldots \ldots \ldots \ldots \ldots \ldots \ldots$ & 61.54 & 5.30 & 56.24 \\
\hline
\end{tabular}

* Most of the blanks are rocky and consequently could hardly be forested.

The disparity in area of 3.60 hectares $(65.14-61.54=3.60)$ is due to the inaccurate data upon which the original area computation was based; it has not been corrected until now.

Art. 3. - Boundaries. - Except bordering the Commune of Châtillon (HauteSavoie) a boundary established when the working plan for that forest was made, the boundaries were very indefinite. We have made a general survey of the boundary and have established corners for the two stands in accordance with the map of 1730 which is sufficiently accurate. Every corner and boundary rock marked with a cross has its numerical order carefully chiseled as given in the working-plan map. These 39 boundary marks are divided as follows: Le Péray, 18 (3 of these coincide with the numbers for the communal forest of Châtillon); La Vuardaz, 21; Total, 39.

Art. 4. - Rights and servitudes. - None.

Art. 5. - Topography and drainage. - Occupying the summit of Mt. Orsay ("Orchez" according to the army map) a point at which the range ends which separates the valleys of Giffre and Arje and dominates their heads, the forest therefore lies on north and south slopes. The extreme altitudes are 620 meters (lower part of the Péray Canton) and 1,346 meters (summit of Vuardaz), or an average of 980 meters. The slopes are often very steep and occasionally precipitous near the summit; within the forest there are cliffs 100 meters in height.

Art. 6. - Soil. - Despite its small area the forest stands on a number of different geological formations which can be classed as follows:

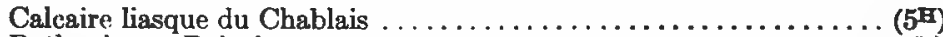

Bathonien et Bajocien. . . . . . . . . . . . . . . . .

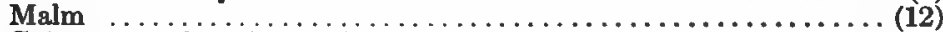

Crétacé supérieur dit couche rouge $\ldots \ldots \ldots \ldots \ldots \ldots \ldots \ldots \ldots \ldots \ldots \ldots \ldots \ldots \ldots \ldots$ (17)

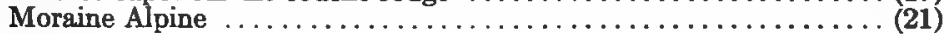

The figures enclosed in parentheses show approximately the area occupied by each (geologic) soil. Because of this diversity of mineral bases soils of very different character have resulted. Marls deep and fresh, occasionally actually wet, arid detritus, bare limestones or only slightly covered with a thin layer of humus are found side by side; the fertility itself is extremely variable. One must admit that the poor or mediocre areas are the rule rather than the exception and that the really rich soils are scarce.

Art. 7. - Climate. - Since the two stands are situated in different valleys it naturally follows that the climate is also dissimilar. On the one hand the Canton of Vuardaz, with a northern exposure, is in a rainy valley where the snow lies four months each year, while the vineyards still flourish just below in the Péray Canton.

Art. 8. - Stand. - The chief species are spruce, fir, Scotch pine, and beech. Spruce, which is easily the most important, varies a great deal. From the straight, cylindrical long-boled well-pruned tree 35 meters in height ( 115 feet!) in the well watered valley of Vuardaz, which one cannot help but admire, to the branchy unstable stem which clings to the rock on the Orsay peak. In the Péray Canton it is represented by sapling stands, dense and regular, but because of the dry soil and climate these do not 
appear to have much of a future. The fine quality of timber at the Vuardaz bridge makes it a prize for the lumberman; yet on the moist soils there seems to be a tendency to early decay. The fir perhaps is a more rapid grower, and notwithstanding that its wood is less sought after in the region, it is a valuable species because it is easy to regenerate. The Scotch pine, introduced artificially, when found in the Péray Canton in mixture with scattering larch, seems well suited to the situation; but the stock which has come in naturally, often very defective, has suffered a great deal from caterpillars and the wood has little value. The beech is quite important in the understory, but with the exception of a few poles, it is not represented in the young stands; yet, because of its cultural value, it ought to have a place in the mature stands. Its litter can alleviate the acidity of the humus produced under the spruce and also assists the natural regeneration of this latter species. The oak is at its extreme elevation and is not important, except in the rocky areas, where, with the maples (sycamore, etc.), it serves to protect the soil. One sees a few linden, service trees, and hazel, which have some value. To sum up, the importance of the species is shown by the following figures: Spruce, 62 per cent; fir, 2 per cent; pine, 11 per cent; oak, 10 per cent; beech, 10 per cent; miscellaneous, 5 per cent.

Art. 9. - Chief and accessory products. - The following table shows the amount and value of the products realized during the last 10 years:

\section{YIELD DURING THE LAST 10 YEARS}

WOOD PRODUCTS

\begin{tabular}{|c|c|c|c|c|c|c|c|c|c|c|c|c|c|c|}
\hline \multirow{3}{*}{ Years } & \multicolumn{4}{|c|}{ Regular fellings } & \multicolumn{4}{|c|}{ Extraordinary fellings } & \multirow{2}{*}{\multicolumn{2}{|c|}{$\begin{array}{l}\text { Emergency } \\
\text { wood }\end{array}$}} & \multirow{2}{*}{\multicolumn{2}{|c|}{$\begin{array}{l}\text { Windfall, } \\
\text { dead wood } \\
\text { and tres- } \\
\text { pass }\end{array}$}} & \multirow{2}{*}{\multicolumn{2}{|c|}{ Totals }} \\
\hline & \multicolumn{2}{|c|}{ Coppice } & \multicolumn{2}{|c|}{ High forest } & \multicolumn{2}{|c|}{$\begin{array}{l}\text { (Coppice) } \\
\text { Improve } \\
\text { ment }\end{array}$} & \multicolumn{2}{|c|}{ High forest } & & & & & & \\
\hline & $\begin{array}{l}\text { Vol- } \\
\text { ume, } \\
\text { m. c. }\end{array}$ & $\begin{array}{l}\text { Value, } \\
\text { francs }\end{array}$ & $\begin{array}{l}\text { Vol- } \\
\text { ume, } \\
\text { m.c. }\end{array}$ & $\begin{array}{l}\text { Value, } \\
\text { frances }\end{array}$ & $\begin{array}{l}\text { Vol- } \\
\text { ume, } \\
\text { m. c. }\end{array}$ & $\begin{array}{l}\text { Value, } \\
\text { francs }\end{array}$ & $\begin{array}{l}\text { Vol- } \\
\text { ume, } \\
\text { m.c. }\end{array}$ & $\begin{array}{l}\text { Value, } \\
\text { francs }\end{array}$ & \multicolumn{2}{|c|}{$\mid$\begin{tabular}{c|c} 
Vol- & Value, \\
ume, & francs \\
Im. c.
\end{tabular}} & $\begin{array}{l}\text { Vol- } \\
\text { ume, } \\
\text { m. c. }\end{array}$ & $\begin{array}{l}\text { Value, } \\
\text { francs }\end{array}$ & $\begin{array}{l}\text { Vol- } \\
\text { ume, } \\
\text { m.c. }\end{array}$ & $\begin{array}{l}\text { Value, } \\
\text { francs }\end{array}$ \\
\hline $1901 \ldots$ & ... & $\cdots$ & $\ldots$ & $\cdots$ & $\ldots$ & . & . & $\cdots$ & 2 & 20 & 30 & 375 & 32 & 395 \\
\hline $1902 \ldots$ & .... & ..... & $\ldots$ &. & & . & $\ldots$ & 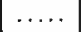 & 8 & 128 & 21 & 212 & 29 & 340 \\
\hline $1903 \ldots$ & ... & $\ldots \ldots$ & $\ldots$ & & .. & & & & 4 & 64 & 23 & 165 & 27 & 229 \\
\hline $1904 \ldots$ & ... & $\ldots .$. & $\ldots$ & & . & & $\ldots$ & 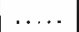 & 10 & 174 & 20 & 250 & 30 & 424 \\
\hline $1905 \ldots$ & . & & & & & & 136 & 1525 & 4 & 64 & 29 & 270 & 169 & 1859 \\
\hline $1906 \ldots$ & $\ldots$ & & & & & & $\cdots$ & $\ldots \ldots$ & 6 & 90 & 45 & 435 & 51 & 525 \\
\hline $1907 \ldots$ & $\ldots$ & $\ldots .$. & $\ldots$ & & .. & & & & 21 & 273 & 38 & 300 & 59 & 573 \\
\hline $1908 \ldots$ & .... & $\ldots \ldots$ & $\ldots$ & $\ldots \ldots$ & $\ldots$ & $\ldots \ldots$ & $\ldots$ & $\ldots \ldots$ & $\ldots$. & ..... & 1 & 20 & 1 & 20 \\
\hline $1909 \ldots$ & ... & ..... & $\ldots$ & $\ldots \ldots$ & 65 & 130 & $\ldots$ & $\ldots \ldots$ & $\ldots$. & $\cdots \cdots$ & 104 & 1237 & 169 & 1367 \\
\hline $1910 \ldots$ & & & $\ldots$ & $\ldots \ldots$ & $\ldots$ & $\ldots \ldots$ & 115 & 2290 & $\ldots$ & $\ldots \ldots$ & 17 & 175 & 132 & 2465 \\
\hline \multirow{2}{*}{\multicolumn{3}{|c|}{$\begin{array}{c}\text { Totals............. } \\
\text { Average annual .... }\end{array}$}} & $\ldots$ & $\ldots \ldots$ & 65 & 130 & 251 & 3815 & 55 & 813 & 328 & 3438 & 699 & 8197 \\
\hline & & & $\ldots$ & $\ldots \ldots$ & 6.5 & 13 & 25.1 & 381.5 & 5.5 & 81.3 & 32.8 & 343.9 & 69.8 & 819.7 \\
\hline \multicolumn{3}{|c|}{ Price per cubic meter } & $\ldots$ & .... & .... & 2 & ... & 15.20 & $\ldots$ & 14.8 & $\cdots$ & 10.5 & $\cdots$ & 11.7 \\
\hline
\end{tabular}


ACCESSORY PRODUCTS

\begin{tabular}{|c|c|c|c|c|c|c|c|}
\hline Years & $\begin{array}{c}\text { Extension } \\
\text { of cutting } \\
\text { period }\end{array}$ & $\begin{array}{c}\text { Miscel- } \\
\text { laneous } \\
\text { concegsions } \\
\text { (gprings, } \\
\text { rights of } \\
\text { way, } \\
\text { stone, } \\
\text { sand, etc.) }\end{array}$ & $\begin{array}{c}\text { Minor } \\
\text { products, } \\
\text { value of } \\
\text { day's labor }\end{array}$ & $\begin{array}{c}\text { Grazing, } \\
\text { value }\end{array}$ & $\begin{array}{l}\text { Hunt, } \\
\text { rental }\end{array}$ & $\begin{array}{l}\text { Trespass, } \\
\text { eivic } \\
\text { damages }\end{array}$ & Totals \\
\hline $1901 \ldots \ldots \ldots \ldots \ldots$ & $\ldots$. & 4 & 37.50 & $\ldots \ldots \ldots \ldots$ & . & 4.00 & 45.50 \\
\hline $1902 \ldots \ldots \ldots \ldots \ldots$ & .......... & $\ldots \ldots \ldots$ & 37.50 & $\ldots \ldots \ldots$ & $\ldots \ldots \ldots$ & .......... & 37.50 \\
\hline $1903 \ldots$ & & 3 & 37.50 & $\ldots \ldots \ldots$ & $\ldots \ldots$ & 13.80 & 40.50 \\
\hline $1904 \ldots \ldots \ldots \ldots \ldots$ & $\ldots$ & & 25.00 & $\ldots \ldots \ldots$ & $\ldots \ldots \ldots$ & $\ldots \ldots \ldots$ & 38.80 \\
\hline $1905 \ldots \ldots$ & $\ldots$ & $\ldots$ & 62.50 & $\ldots \ldots \ldots$ & 26 & $\ldots \ldots \ldots \ldots$ & 88.50 \\
\hline $1906 \ldots \ldots$ & .......... & $\ldots \ldots$ & 30.00 & .......... & 26 & 13.50 & 56.00 \\
\hline $1907 \ldots$ & & & 42.50 & & 26 & 93.00 & 82.00 \\
\hline $1908 \ldots$ & & & 35.00 & & 11 & 28.00 & 139.00 \\
\hline $1909 \ldots \ldots$ & $\ldots$ & $\ldots \ldots \ldots$ & 40.00 & & 11 & $\ldots \ldots \ldots$. & 79.00 \\
\hline $1910 \ldots \ldots$ & $\ldots \ldots \ldots$ & $\ldots \ldots \ldots$ & 40.00 & $\ldots \ldots \ldots$ & 11 & $\ldots \ldots \ldots$ & 51.00 \\
\hline Totals........... & $\ldots \ldots \ldots$ & 7 & 387.50 & $\ldots \ldots \ldots$ & 111 & 152.30 & 657.80 \\
\hline Average annual.. & $\ldots$ & 0.7 & 38.75 & $\ldots \ldots \ldots$ & 11.1 & 15.23 & 65.78 \\
\hline
\end{tabular}

Art. 10. - Roads, trails, and means of removal. - There are no regular roads in the forest (only a few trails traversing the stand), but at the bottom of each canton there is a mule trail. That part which borders the Canton of Vuardaz joins the national road No. 202; this enables the hauling of wood to the Taninges station (narrow gauge), 4.6 kilometers away. The area bordering the Péray Canton almost touches the main road from the pass of Chatillon to Bonneville via Marignier (P. L. M. station, 4 kilometers).

Art. 11. - Markets. - The fire wood is used locally, while the logs (owing to the railroads in each valley) have a wide market.

Art. 12. - Grazing, etc. - None.

Art. 13. - Patrol. - The patrol is done by two guards, one belonging to the Taninges ranger district, the other to Cluses. Their residences are at Taninges and Cluses.

\section{PART II}

\section{Chapter I. - Statement and Critical Review of Treatment in Force}

By a decision of the director, dated June 13, 1873, the forest of Thiez was divided into two working groups, one coppice, the other high forest. The coppice working group having been entirely disposed of since 1873 there is nothing to report. The high forest working group has been cut over during a period of 15 years by improvement cuttings amounting to 4.34 hectares each year. This period of 15 years ended in 1888 . Since this date the forest has only been cut under emergency fellings except for an improvement felling in 1909 of 8.68 hectares, and in two or three selection cuttings only windfall or overmature timber was removed. While the regular fellings have been few in number, the same cannot be said of the trespass cuttings, for almost all the stock of the Péray Canton has been cut by trespassers. It is essential to regulate the fellings and to determine a yield based upon an exact estimate of the forest's resources. This is the object of this work.

\section{Chapter II. - Basis of Proposed Management}

A conifer stand with such a small stock can only be treated by the selection system. We propose to put the entire area into a single working group of selection high forest. 


\section{PART III}

\section{Spectal Study of the Working GrodP}

Art. 1. - Compartments. - It has been laid out according to natural boundaries such as roads or ravines following current usage. Each compartment has been marked and designated with capital letters. Their area varies from 2.11 hectares to 8.46 hectares, an average of 5.28; this is in keeping with the size of the forest.

The forest description follows: (Sample given on pages 532 and 533).

Art. 2. - Exploitability, rotation, periods. -A tree 0.60 meter (23.6 inches d.b.h.) in diameter is best suited to the sale requirements. A smaller size would not be adapted to all uses, while a large size would make lumbering too difficult. We shall therefore adopt $\mathbf{0 . 6 0}$ meter as the exploitable size.

To reach this size a tree requires at least 140 years. If you glance over the curves inserted in the Appendix (page 528) it is evident that the spruce and fir take on an average 16 years to pass from one diameter class ( 2 inches) to another; it follows that to pass through the diameter classes from 6 inches to 24 inches takes 144 years. In fixing the rotation at this figure we are overlooking the length of time that a tree takes to pass from the understory, and recent studies have shown that this method of procedure is legitimate. It seems logical to choose 16 years as the period since it takes that length of time to pass from one diameter class to another.

Art. 3. - Regulation of felling. - The compartments A, B, C, D, E, F, G, I, L, and $M$ only carry a growing stock which can be inventoried. These are the only compartments to be cut over by selection cuttings based on volume. The compartments $\mathrm{H}$ and $\mathrm{K}$, stocked solely with young growth, will be run over by improvement cuttings based on area. On the formal request of the commune (which, while wishing to sell the principal cuttings, desires to provide for the residents a small right to gather hardwood fuel) these shall be filled by improvement cuttings in the compartments $C, D$, E, F, G, I, L, and M. The table below gives a résumé of these plans:

\begin{tabular}{|c|c|c|c|c|}
\hline Canton & Compartment & Area & Extent of selection & $\begin{array}{c}\text { Improvement } \\
\text { fellings }\end{array}$ \\
\hline \multirow[t]{2}{*}{ La Vuardaz. } & \multirow[t]{2}{*}{$\begin{array}{l}\mathbf{A} \\
\mathbf{B} \\
\mathbf{C} \\
\mathbf{D} \\
\mathbf{E} \\
\mathbf{F} \\
\mathbf{G} \\
\mathbf{H} \\
\mathbf{I} \\
\mathbf{K} \\
\mathbf{L} \\
\mathbf{M}\end{array}$} & $\begin{array}{l}6.11 \\
5.24 \\
2.17 \\
4.70 \\
2.95 \\
3.46 \\
2.11 \\
6.78 \\
7.74 \\
4.68 \\
7.14 \\
8.46\end{array}$ & $\begin{array}{l}6.11 \\
5.24 \\
2.17 \\
4.70 \\
2.95 \\
3.46 \\
2.11 \\
\dddot{7.74} \\
\ddot{7.14} \\
8.46 \\
\end{array}$ & $\begin{array}{l}\ldots . \\
\ddot{2} .17 \\
3.00 \\
1.00 \\
2.00 \\
1.00 \\
6.78 \\
7.74 \\
4.68 \\
7.14 \\
8.46\end{array}$ \\
\hline & & 61.54 & 50.08 & 43.97 \\
\hline
\end{tabular}

\section{A. - FELLINGS BY VOLUME}

Art. 4. - Determination of the yield. - The yield will be calculated in accordance with the method given in the circular of July 17, 1883, which consists in dividing the wood in three groups in accordance with their size: (1) The young wood whose diameter is less than one-third the exploitable size. (2) The average wood whose diameter is included between one-third and two-thirds this size. (3) The old wood whose diameter is more than two-thirds this size. 
If the volume of old wood and that of average wood are to each other as 5 is to 3 it is a normal proportion, and if not it is possible to decrease or even the difference by approximate transfers. Then the final volume of old wood plus its growth is divided by one-third the number of years in the rotation. The trees have been calipered by 2 -inch diameter classes, commencing with 8 inches, and the volumes figured with the volume table made by M. Algan (No. 11 for the fir and spruce and No. 5 for the pine and broadleaved trees).

The following table gives the division by groups and diameter classes:

\begin{tabular}{|c|c|c|c|c|c|c|}
\hline \multirow{2}{*}{$\begin{array}{c}\text { Diameters (d. b. h.) } \\
\text { centimeters }\end{array}$} & \multicolumn{3}{|c|}{ Volume of average wood } & \multicolumn{3}{|c|}{ Volume of old wood } \\
\hline & Spruce and fir & Pine & Total & Spruce and fir & Pine & Total \\
\hline $\begin{array}{l}20(7.8 \text { inches }) \ldots \\
25 \ldots \ldots \ldots \ldots \ldots \ldots \\
30 \ldots \ldots \ldots \ldots \ldots \\
35 \ldots \ldots \ldots \ldots \ldots\end{array}$ & $\begin{array}{l}348.4 \\
486.8 \\
523.2 \\
639.9\end{array}$ & $\begin{array}{l}7.6 \\
4.2 \\
5.7 \\
3.0\end{array}$ & $\begin{array}{l}356.0 \\
491.0 \\
528.9 \\
642.9\end{array}$ & $\begin{array}{l}\ldots \ldots \ldots \\
\cdots \ldots \ldots \\
\cdots \cdots \cdots \\
\cdots \cdots \\
\end{array}$ & $\begin{array}{l}\cdots \\
\cdots \\
\cdots \\
\cdots\end{array}$ & $\begin{array}{l}\ldots \ldots \ldots \\
\cdots \ldots \ldots \\
\cdots \ldots \ldots \\
\ldots \ldots \ldots \\
\end{array}$ \\
\hline $\begin{array}{l}40(15.7 \text { inches }) \\
45 \ldots \ldots \ldots \ldots \ldots \ldots \\
50 \ldots \ldots \ldots \ldots \ldots \\
55 \ldots \ldots \ldots \ldots \\
60 \text { (23.6 inches). }\end{array}$ & & $\begin{array}{l}\cdots \cdots \\
\cdots \\
\cdots \\
\cdots \\
\cdots\end{array}$ & 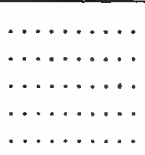 & $\begin{array}{l}895.2 \\
684.8 \\
399.0 \\
249.6 \\
160.0\end{array}$ & $\begin{array}{l}2.8 \\
\cdots \\
\cdots \\
\cdots\end{array}$ & $\begin{array}{l}898.0 \\
684.8 \\
399.0 \\
249.6 \\
160.0\end{array}$ \\
\hline $\begin{array}{l}65 \ldots \ldots \ldots \ldots \ldots \ldots \\
70 \ldots \ldots \ldots \ldots \ldots \\
75 \ldots \ldots \ldots \\
80(31.5 \text { inches })\end{array}$ & $\begin{array}{l}\ldots \ldots \cdots \cdots \\
\cdots \ldots \cdots \cdots \\
\cdots \cdots \cdots \cdots \\
\cdots \cdots \cdots\end{array}$ & $\begin{array}{l}\cdots \\
\cdots \\
\cdots \\
\cdots\end{array}$ & 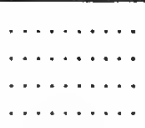 & $\begin{array}{l}72.2 \\
36.0 \\
20.8 \\
18.0\end{array}$ & $\begin{array}{l}\cdots \\
\cdots \\
\cdots \\
\cdots\end{array}$ & $\begin{array}{l}72.2 \\
36.0 \\
20.8 \\
18.0\end{array}$ \\
\hline Totals.. & $1,998.3$ & 20.5 & $2,018.8$ & $2,535.6$ & 2.8 & $2,538.4$ \\
\hline
\end{tabular}

The normal proportion should be:

$$
\left.\begin{array}{l}
\text { Old wood } 4,557.2 \times 5 / 8=2,848.3 \\
\text { Average wood } 4,557.2 \times 3 / 8=1,708.9
\end{array}\right\} 4,557.2 .
$$

For the transfer as prescribed by the method the only change which is justified is by the abundance of overmature timber in the lower diameter classes which means that the yield would be:

$$
P=\frac{2,848.3}{48}=59 \text { cubic meters. }
$$

But on the other hand in this forest the growth cannot be overlooked (see table of growth per cent in the Appendix) and we intend to count that of the old wood during half of the period (conservative estimate of growth at 1 per cent per year). The yield will thus become:

$$
P=\frac{2,848.3+{ }_{\mathrm{I}}{ }_{\mathrm{T} \sigma} \times 24 \times 2,848.2}{48}=73.58 \text { or } 74 \text { in round figures. }
$$

This yield, which corresponds to 1.62 per cent of the calipered material and is 1.6 cubic meters per hectare per year for the forested area, is not too large but fully provides for the small growing stock (and the consequent necessity for economy).

$$
\text { B. - AREA FELLINGS }
$$

The area to be cut over by improvement cuttings being 43.97 hectares, the yield will be:

$$
P=\frac{43.97}{16}=2.75 \text { hectares. }
$$




\section{A. - FELLINGS BY VOLUME}

Art. 5. - Method of getting the yield. - The principal fellings are all for sale, and since the commune actually needs all its resources, it also desires that no reserve should be made, but that the whole yield should be auctioned each year. This request does not seem to be contrary to the spirit of the law and we believe it is correct. If the principal yield were entirely reserved each year the commune would ask for an emergency felling and the result would be the same.

\section{B. - AREA FELLINGS}

The improvement cuttings, because of the necessity for special firewood allowances, will form two distinct felling areas, each located at the nearest hamlet. The cutting will then be worked in two lots:

The first for special firewood allowances . . . in compartments $\mathrm{H}, \mathrm{I}, \mathrm{K}, \mathrm{L}$, and $M$ (average area 2.18 hectares). The second for special firewood allowances . . . in the compartments C, D, E, F, and G (average area 0.57 hectare). However, since this second lot is so small it will only be worked every two years and its area will be 1.14 hectares.

\section{A. - FELLINGS BY VOLUME}

Art. 6. - Location of fellings for the first period, 1911-1926. - The selection fellings will be marked one after another and will cut over the compartments alphabetically. No division will be left until it has been entirely cut over.

The following table gives for each compartment the estimated yield. Since the windfalls which may take place during the period must be counted (against the yield) it is recommended especially at the start to keep well below the (yield) figures given:

\begin{tabular}{|c|c|c|c|c|c|}
\hline Canton & Compartment & Area & Growing stock & Per cent to cut* & Estimated yield \\
\hline $\begin{array}{l}\text { La Vuardaz..... } \\
\text { Le Péray........ }\end{array}$ & $\begin{array}{l}\mathbf{A} \\
\mathbf{B} \\
\mathbf{C} \\
\mathbf{D} \\
\mathbf{E} \\
\mathbf{F} \\
\mathbf{G} \\
\mathbf{I} \\
\mathbf{L} \\
\mathbf{M}\end{array}$ & $\begin{array}{l}6.11 \\
5.24 \\
2.17 \\
4.70 \\
2.95 \\
3.46 \\
2.11 \\
7.74 \\
7.14 \\
8.46\end{array}$ & $\begin{array}{r}741 \\
1,164 \\
254 \\
1,151 \\
464 \\
485 \\
52 \\
63 \\
121 \\
62 \\
\end{array}$ & $\begin{array}{l}22 \\
35 \\
30 \\
25 \\
22 \\
22 \\
40 \\
10 \\
10 \\
10\end{array}$ & $\begin{array}{r}163 \\
406 \\
76 \\
288 \\
100 \\
107 \\
20 \\
6 \\
12 \\
6 \\
\end{array}$ \\
\hline Totals....... & $\ldots \ldots$ & 50.08 & 4,557 & 26 & $1,184=74 \times 16$ \\
\hline
\end{tabular}

* In realizing each year 1.62 per cent of the total stand there will be cut during the period $16 \times 1.62=26$ per cent. This is the average per cent cut. We have varied it for each compartment in accordance with the cultural requirements.

\section{B. - FELLINGS BY AREA}

The table which follows shows the sequence and size of improvement fellings to mark each and every year in the first class of fellings and every two years in the second. The areas are somewhat unequal from one year to another; to assure an approximately sustained yield so far as practicable it was necessary to allot felling areas universely proportional to the abundance of broad-leaved trees in each of them, dividing up the compartments, however, as little as possible. 


\begin{tabular}{|c|c|c|c|c|c|c|}
\hline \multirow[b]{2}{*}{ Year of the felling } & \multirow[b]{2}{*}{$\begin{array}{l}\text { Serisl No. } \\
\text { of the cut }\end{array}$} & \multirow[b]{2}{*}{ Compartment } & \multicolumn{2}{|c|}{ Area } & \multicolumn{2}{|c|}{ Age of broadleaf trees } \\
\hline & & & $\begin{array}{l}\text { Of parts to } \\
\text { be cut over } \\
\text { esch year }\end{array}$ & $\begin{array}{l}\text { Of cutting } \\
\text { areas }\end{array}$ & In 1910 & $\begin{array}{l}\text { At time of } \\
\text { felling }\end{array}$ \\
\hline
\end{tabular}

Canton of Le Péray - (First series of cuttings)

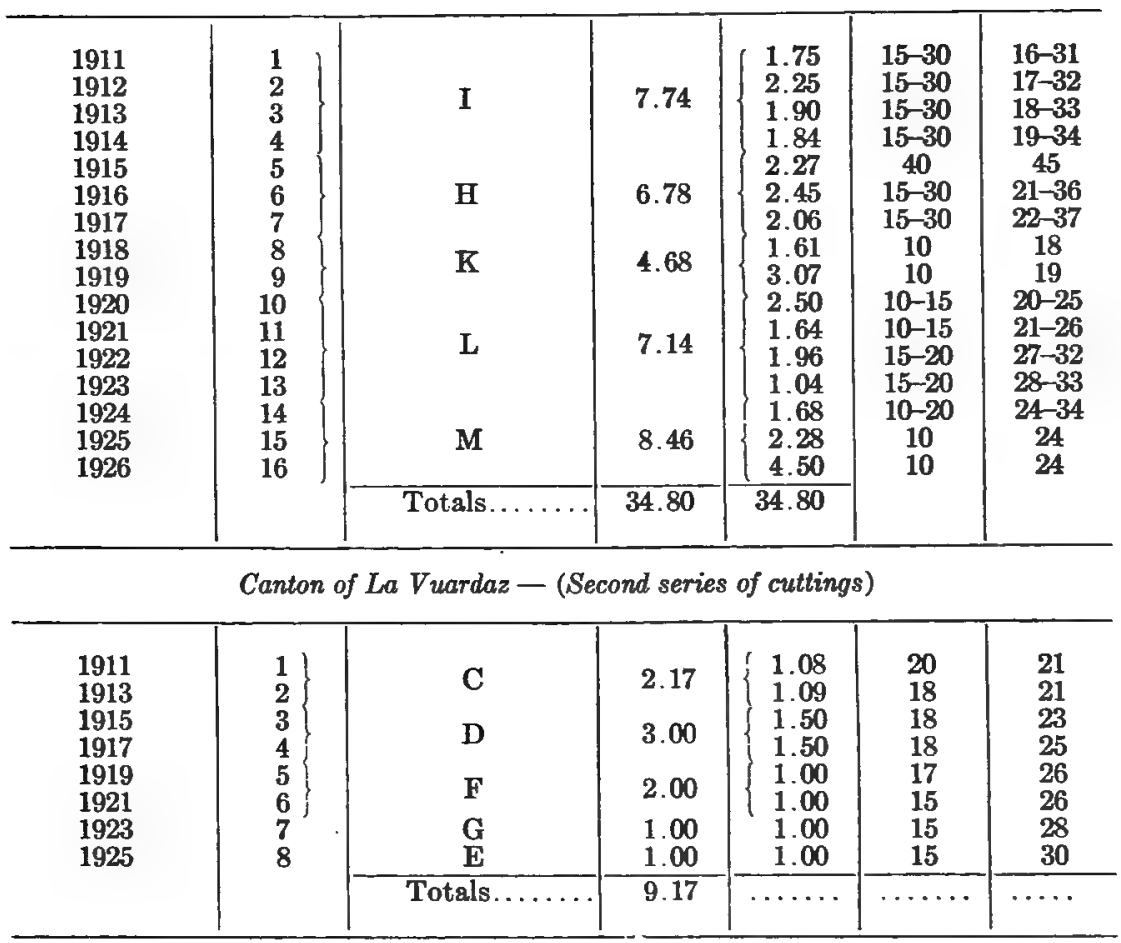

\section{A. - VOLUME FELLINGS}

Art. 7. - Application of the yield. - Cultural rules. - The fellings shall be on the whole entirely selection (in character) favoring (for removal) dry topped trees, those decayed or overmature of all diameter classes whose removal will fill an important part of the yield. Next cut trees which have reached or passed the exploitable size (23.6 inches or $60 \mathrm{c} . \mathrm{m}$. in diameter) and whose retention does not seem to be necessary in order to maintain the canopy. Do not forget that on the whole the growing stock is deficient and that all young trees which are sound and vigorous sbould in theory be retained; yet at the bottom of compartments A and B where there is a half-grown high forest, quite regular thinnings must be carried on in order to favor the development of the best stems.

\section{B. - AREA FELLINGS}

The aim of the improvement cuttings should be the creation of a mixed forest of conifers and broadleaves. In theory they should be exploited by cutting back (recepage); this cutting back shall be complete when it concerns the softwoods, but on the 
contrary with the hardwoods there should be reserved (1) all the trees with freed crowns and in good condition; (2) a certain number of stems chosen from those with the longest boles on the areas where the conifers are lacking. However, at the time of the regular fellings one can clean out the saplings where they are too dense by removing the dead trees or those clearly suppressed, although these last will be conserved, in theory.

Art. 8. - Deduction (from the yield). - The volume of conifers, from $20 \mathrm{~cm}$. (8 inches) up, cut in any felling whatever in the compartments calipered shall be counted against the yield.

\section{PART IV}

\section{Betperments}

General Map. - Compartment Map. - The topographic map was drawn on a scale of $\frac{1}{23 \%}$ which corresponds to the scale used in the former map of Savoie, then reduced to $\frac{1}{500}$ in order to obtain the complete map given in the Appendix. Twentymeter (66-foot) contours have been used. It is hoped that this map can be reproduced by the helographique process so that it can be sent to each agent as an example.

Management Divisions. - All compartments are bounded by natural lines, trails, or canyons; there are no ditches to open up. But in order to avoid all confusion it is advisable that the compartment letters be marked on the boundary trees. A method which has given excellent results consists in lightly scraping the bark so as to make a smooth square which will take two coats of white zinc on which the letter can be painted in red or blue.

Boundary Posts. - As has been seen, the boundary has been marked by posts and "crossed" rocks while the working plan data were collected, but it would be well to make this still plainer by opening up ditches or paths between the pillars or rocks. If the commune cannot afford this work along the entire boundary it would be a good plan to commence ditches on each side of corners pointing to the next ones.

Reforestation. - The removal of overmature material, especially in compartments B and C, will necessitate openings which must be restocked to enrich the soil. The best method consists in working seed spots about 2 meters apart upon which excess wild stock can be planted; the cultivation thus given the ground has the effect of mixing the soil with the acid humus, freely worked in, thus aiding the rooting of the seedling.

Communications. - It is chiefly outside the forest that means of communication are lacking, especially in the Canton of Vuardaz, but the study for road improvements below the stand at the hamlet of Bois and Châtillon is out of our hands.

Improvement Tax on the Sales. - To permit the execution of the improvements here enumerated as well as those found later on to be useful a tax of 3 per cent should be levied on all wood sales and allotted for expenditure to the local forest service.

Patrol. - The trespass (timber cutting) which has taken place and which still continues in the Canton of Péray requires vigorous measures. The isolation of this separate stand from the rest of the forest by a rocky ridge and the distance from the ranger station makes patrol difficult; to assure patrol it appears that coöperation will be necessary between the Canton of Bonneville and Taninges. It will not require too much work of the two districts to prevent the abuse of this wretched canton. It goes without saying that legal proceedings must always.be_pressed with the utmost_vigor. 


\section{PART V}

\section{Comparative Review of the Revenut Before and after the (proposed) Working Plan}

The average annual yield of the forest during the last 10 years (1901-1910) is as follows:

Wood products $(70 \mathrm{~m}$. c.) 820 francs; (minor) accessory products, 66 francs $=$ total of 886 francs. From this must be deducted: (1) cost of guard, 110 francs; (2) administrative costs, 41 francs; (3) taxes, 102 francs, or 253 francs, leaving a net revenue of 633 francs (equal to 80 cents per acre per year). The receipts to be realized after the application of the working plan proposed can, on the other hand, be valued as follows: Principal felling (74 m. c.) 962 francs; improvement cuttings ( 20 m. c. at 2 francs), 40 francs; (minor) accessory products, 66 franes, or a total of 1,068 francs; from which must be deducted: (1) cost of guard, 122 francs; (2) administrative costs, 50 francs; (3) taxes, 102 francs, or 274 francs costs, leaving a net revenue of 794 francs. This net revenue would thus be 161 franes more than the former, or a 25 per cent increase (about $\$ 1$ per acre per year).

(Signed) A. SchatfFer, Inspector of Waters and Forests, Chief of Management.

Chambéry, November 25, 1910. 
VOLUME TABLE *

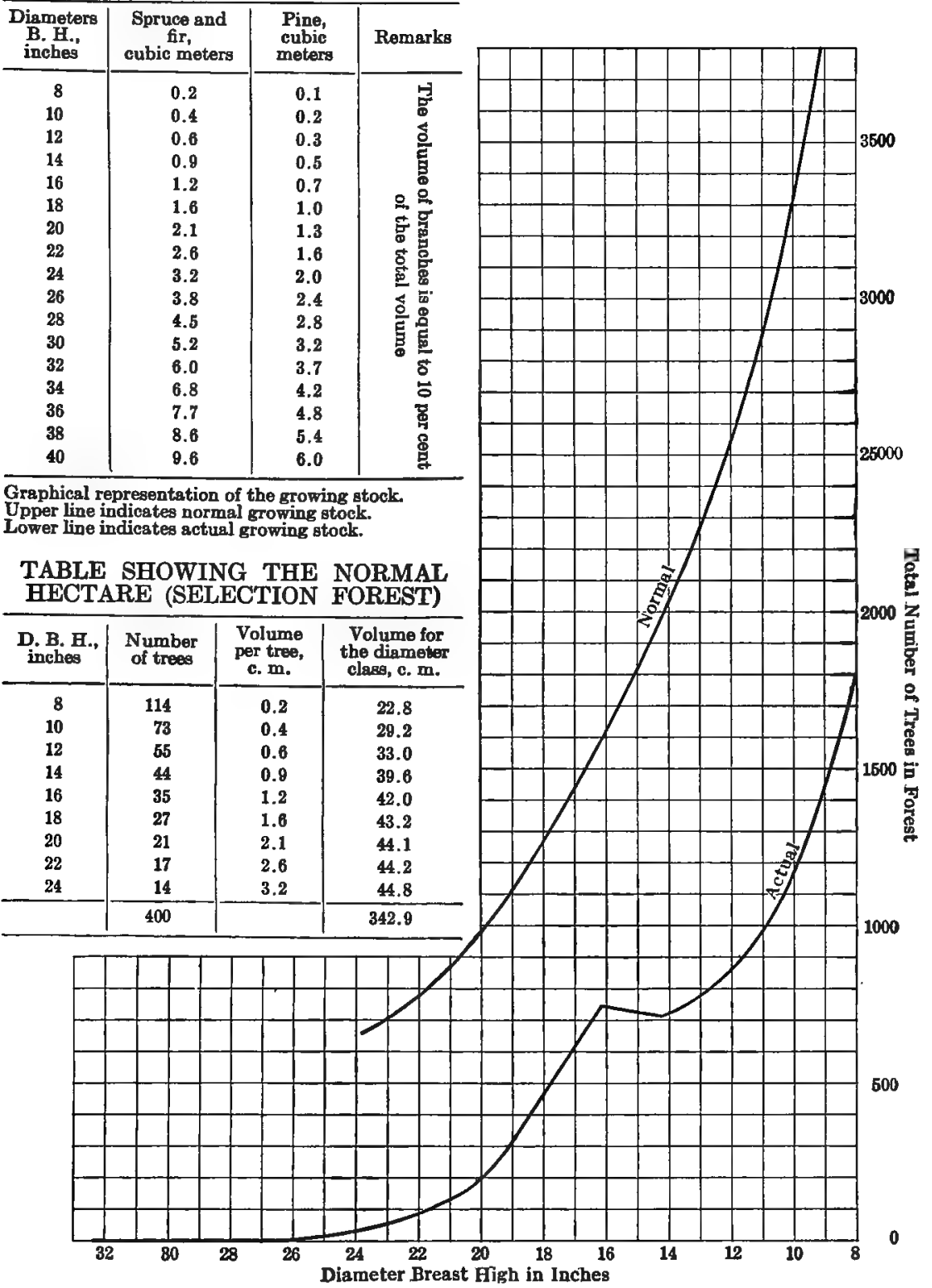

* In the original working plan the volumes for (a) the epruce, fir and (b) the pine were graphically shown by 2-inch diameter classes and cubic meters of volume. 
RESULTS OF BORINGS WITH PRESSLER'S INCREMENT BORER

Number of years to pass from one diameter class to another

\begin{tabular}{|c|c|c|c|c|c|c|c|c|c|c|c|c|}
\hline D. B. H., inches & 8 & 10 & 12 & 14 & 16 & 18 & 20 & 22 & 24 & 26 & 28 & 30 \\
\hline $\begin{array}{l}\text { Time in } \\
\text { years to } \\
\text { grow } \\
2 \text { inches }\end{array}$ & $\begin{array}{l}19 \\
17 \\
10 \\
11 \\
12\end{array}$ & $\begin{array}{r}11 \\
8\end{array}$ & $\begin{array}{c}40 \\
16 \\
\ldots \ldots\end{array}$ & $\begin{array}{r}14 \\
21 \\
8 \\
21 \\
28 \\
21 \\
10 \\
6\end{array}$ & $\begin{array}{r}17 \\
16 \\
7 \\
22 \\
25 \\
25 \\
10 \\
14 \\
17\end{array}$ & $\begin{array}{c}11 \\
17 \\
17 \\
\ldots \ldots \\
\cdots \cdots\end{array}$ & $\begin{array}{c}\mathbf{1 6} \\
\mathbf{5} \\
\cdots \cdots \\
\cdots \cdots \\
\cdots \cdots \\
\cdots \cdots \\
\cdots \cdots\end{array}$ & $\begin{array}{c}24 \\
8 \\
9 \\
9 \ldots \\
\ldots \ldots\end{array}$ & $\begin{array}{l}\cdots \\
\cdots \\
\cdots \\
\cdots\end{array}$ & $\begin{array}{c}\cdots \\
\cdots \\
\cdots \\
\cdots \\
\cdots \\
\cdots \\
\cdots \\
\cdots\end{array}$ & $\begin{array}{l}\cdots \\
\cdots \\
\cdots \\
\cdots \\
\cdots \\
\cdots \\
\end{array}$ & $\begin{array}{c}6 \\
\ldots \ldots \\
\cdots \\
\cdots \\
\cdots \\
\cdots \\
\cdots \\
\cdots\end{array}$ \\
\hline Totals.... & 69 & 19 & 56 & 129 & 153 & 45 & 21 & 41 & $\ldots$ & $\ldots$ & $\ldots$ & 6 \\
\hline Averages & $\overline{13.8}$ & $9 . \overline{5}$ & 28.0 & 16.1 & 17.0 & 15.0 & 10.5 & 13.6 & & & $\cdots$ & 6 \\
\hline
\end{tabular}

The 35 trees take in the aggregate 539 years to pass from one diameter class to another or an average of $\frac{539}{35}=15.4$; that is to say in 16 years all the stems should pass through one diameter class ( 2 inches); the length of the cutting period is therefore justified. The curve given below brings out this point even clearer:

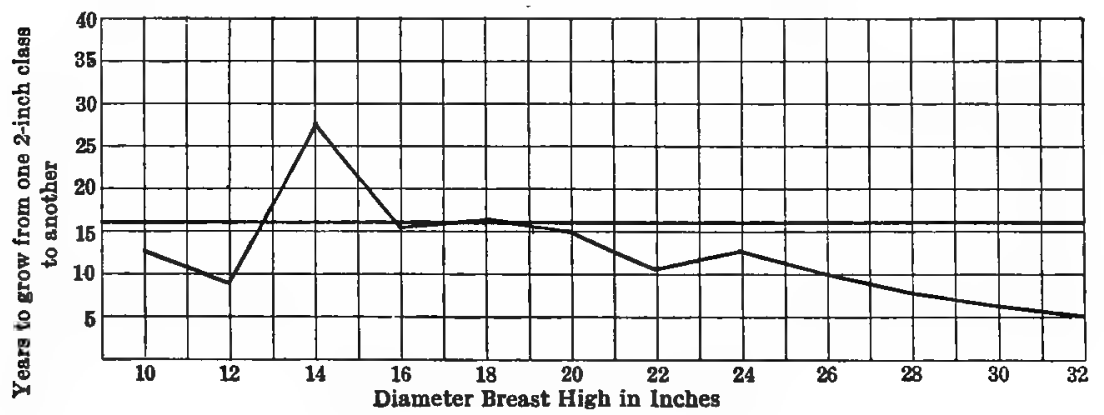


ORIGINAL WORKING PLAN DATA

AVERAGE GROWTH PER CENT BY DIAMETER CLASSES

\begin{tabular}{|c|c|c|c|c|c|c|c|c|c|c|c|c|}
\hline D. B. H., inches & 8 & 10 & 12 & 14 & 16 & 18 & 20 & 22 & 24 & 26 & 28 & 30 \\
\hline$\ldots$ & 2.86 & 2.67 & 0.53 & 2.28 & 1.67 & 1.78 & 1.14 & 0.61 & $\ldots$ & $\ldots$ & $\ldots$ & 2.67 \\
\hline$\ldots$. & 2.86 & 5. 33 & 1.67 & 1.43 & 2.00 & 1.27 & 4.00 & 1.82 & $\ldots$ & $\ldots$ & $\ldots$ & $\ldots$ \\
\hline$\ldots$ & 5.83 & $\ldots$ & $\ldots$ & 3.81 & 4.16 & 1.11 & $\ldots$ & 1.82 & $\ldots$ & $\ldots$ & $\ldots$. & $\ldots$ \\
\hline$\ldots$ & 3.67 & $\ldots$ & $\ldots$ & 1.04 & 1.11 & $\ldots$ & $\ldots$. & $\ldots$ & $\ldots$ & $\ldots$ & $\ldots$ & $\ldots$ \\
\hline .. & 4.00 & $\ldots$ & $\ldots$ & 1.43 & 0.83 & $\ldots$ & $\ldots$ & $\ldots$ & $\ldots$ & $\ldots$ & $\ldots$. & $\ldots$ \\
\hline$\ldots$ & $\ldots$. & $\ldots$ & $\ldots$ & 1.43 & 0.83 & $\ldots$ & $\ldots$ & $\ldots$ & $\ldots$ & $\ldots$ & $\ldots$. & $\ldots$ \\
\hline$\ldots$ & $\ldots$ & $\ldots$ & $\ldots$ & 2.86 & 2.50 & $\ldots$ & $\ldots$ & $\ldots$ & $\ldots$ & $\ldots$ & $\ldots$ & $\ldots$ \\
\hline$\ldots$ & $\ldots$ & $\ldots$ & $\ldots$ & 4.75 & 1.43 & $\ldots$ & $\ldots$ & $\ldots$ & $\ldots$ & $\ldots$ & $\ldots$ & $\ldots$ \\
\hline$\ldots$ & $\ldots$ & $\ldots$ & $\ldots$ & $\ldots$ & 2.00 & $\ldots$ & $\ldots$ & $\ldots$ & $\ldots$ & $\ldots$ & $\ldots$ & $\ldots$ \\
\hline Totals $\ldots \ldots \ldots \ldots$ & 19.22 & 8.00 & 2.20 & 19.03 & 16.53 & 4.16 & 5.14 & $\overline{4.25}$ & $\ldots$ & $\bar{\ldots}$ & $\ldots$ & 2.67 \\
\hline Averages. & 3.84 & 4.00 & $\overline{1.1}$ & 2.38 & 1.83 & 1.39 & $\overline{2.57}$ & $\overline{1.42}$ & $\cdots$ & $\cdots$ & $\bar{\ldots}$ & 2.67 \\
\hline
\end{tabular}

Evened off by curve.

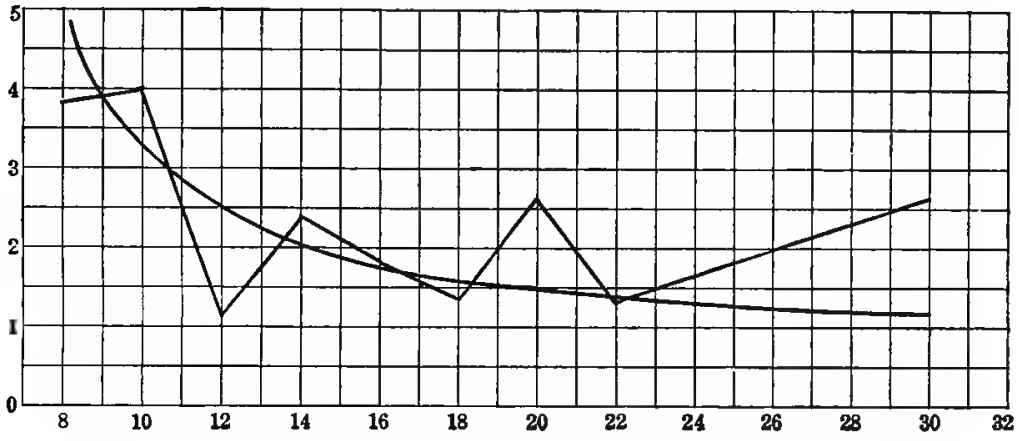


The table below gives the per cents evened off by a curve; by applying them to the volumes of the different diameter classes resulting from the valuation the probable growth of the forest as it stands is obtained:

\begin{tabular}{|c|c|c|c|}
\hline D. B. H., inches a & $\begin{array}{c}\text { Total volume in cubic } \\
\text { meters }\end{array}$ & $\begin{array}{l}\text { Growth per cent read from } \\
\text { curve }\end{array}$ & Growth in cubic meters \\
\hline $\begin{array}{r}8 \\
10 \\
12 \\
14 \\
16 \\
18 \\
20 \\
22 \\
24 \\
26 \\
28 \\
30 \\
32\end{array}$ & $\begin{array}{r}356 \\
491 \\
529 \\
643 \\
898 \\
685 \\
399 \\
255 \\
160 \\
72 \\
36 \\
21 \\
18 \\
4,558\end{array}$ & $\begin{array}{l}4.75 \\
3.25 \\
2.75 \\
2.0 \\
1.75 \\
1.62 \\
1.50 \\
1.32 \\
1.20 \\
1.15 \\
1.10 \\
1.05 \\
1.00\end{array}$ & $\begin{array}{r}16.9 \\
16.0 \\
14.5 \\
12.9 \\
15.7 \\
11.1 \\
6.0 \\
3.3 \\
1.9 \\
0.8 \\
0.4 \\
0.2 \\
0.2 \\
99.9\end{array}$ \\
\hline
\end{tabular}

a This column was not given in the original plan.

The average yearly growth per cent would equal $\frac{99.9}{4,558}=2.19$ per cent. It is therefore evident that in reducing the per cent to be cut to 1.62 a considerable saving will be made so essential to complete the (deficient) growing stock. 
ORIGINAL WORKING PLAN DATA

\begin{tabular}{|c|c|c|c|c|c|c|c|c|c|}
\hline & $\rightarrow$ & 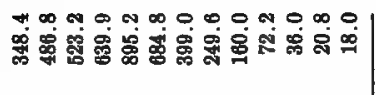 & 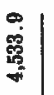 & $\vdots \vdots$ & 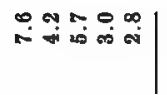 & $\ddot{\infty}$ & 永 & 象 \\
\hline & & $\infty+\infty$ & 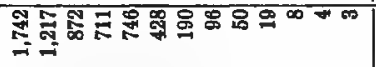 & 遂 & $:$ & ह & \$ั & 承 & 莺 \\
\hline & & 压 & 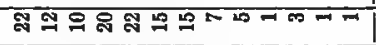 & $\not ̈$ & $\vdots 1$ & $\vdots \vdots \vdots \vdots \vdots$ & $\vdots 1$ & $\vdots 1$ & $\vdots$ \\
\hline & & $\infty$ & 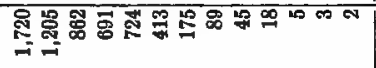 & 兽 & $\vdots$ & 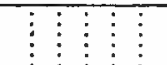 & $\vdots$ & $\vdots$ & $\vdots$ \\
\hline 옹 & & $>$ & 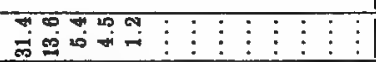 & $\overrightarrow{1}$ & $\vdots$ & बio & $\begin{array}{l}\cdot 1 \\
0 \\
0 \\
0\end{array}$ & $\begin{array}{l}-1 \\
0 \\
0\end{array}$ & ㅇ. \\
\hline$\stackrel{\theta}{\rightarrow}$ & $\Sigma \underset{\infty}{\infty}$ & $\infty$ & 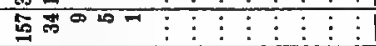 & $\$$ & $\vdots$ & $90 \infty-\vdots$ & 要 & 票 & ঞ̊ \\
\hline & \multirow{2}{*}{$\rightarrow \stackrel{\#}{二}$} & $>$ & 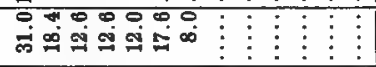 & @i & $\vdots$ & 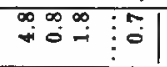 & $\vec{\infty}$ & ثิ่ & $\pi$ \\
\hline & & $\infty$ & 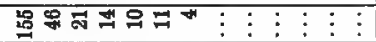 & $\overline{\mathrm{B}}$ & $\vdots 1$ & 果 & 8 & ब్లై & 桨 \\
\hline & \multirow{2}{*}{$r \underset{\infty}{8}$} & $>$ & 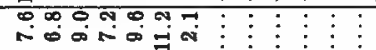 & 象 & $\vdots$ & 0 i & $\vec{a}$ & a & $\stackrel{0}{=}$ \\
\hline & & $\infty$ & 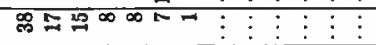 & \$ & $\vdots$ & कब्न काल & क्ष। & 品 & ב⿱⺈ \\
\hline & \multirow{4}{*}{ 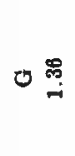 } & $>$ & 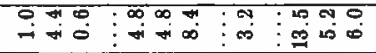 & $\sum_{i}^{\infty}$ & 吕 & $\bar{\vdots}$ & $\vdots$ & $\vdots$ & $\vdots$ \\
\hline & & $0 n+\infty$ & ${ }^{\infty} \exists^{-1} \vdots^{\text {巾 }}$ & में & 每 & $\vdots$ & $\bar{\vdots}$ & $\bar{\vdots}$ & $\vdots$ \\
\hline & & 压 & $-\sim \vdots \vdots \vdots \vdots^{-} \vdots^{-} \vdots^{\infty} \vdots^{-}$ & 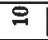 & $\bar{\vdots}$ & $\vdots \vdots$ & $\vdots$ & $\vdots$ & $\vdots$ \\
\hline & & $\infty$ & 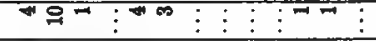 & A゙ & $\vdots 1$ & $\vdots \vdots$ & $\vdots$ & $\bar{\vdots}$ & $\vdots$ \\
\hline- & \multirow{4}{*}{ 化 } & $>$ & 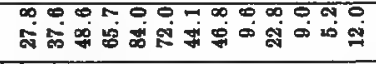 & 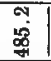 & 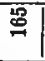 & $\vdots \vdots$ & $\vdots$ & 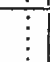 & \\
\hline & & $62+5$ & 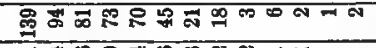 & 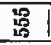 & $\underset{\sim}{\infty}$ & $\vdots \vdots$ & $\vdots$ & $\vdots$ & $\vdots$ \\
\hline & & $\Sigma_{1}$ & 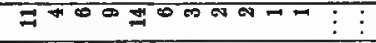 & 要 & & $\vdots \vdots$ & : & $\bar{\vdots}$ & : \\
\hline 3 & & $\infty$ & 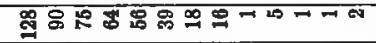 & 兽 & $:$ & $\vdots \vdots$ & $\vdots$ & $\vdots$ & $\vdots$ \\
\hline 至 & \multirow{4}{*}{ 闵 } & $>$ & 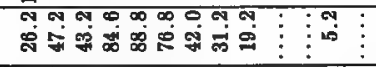 & 离 & $\vec{E}$ & $\vdots \vdots \vdots$ & $\vdots$ & $\vdots$ & \\
\hline & & $\infty+5$ & 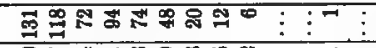 & $\begin{array}{ll}0 \\
0 \\
0\end{array}$ & बू & $\vdots \vdots \vdots \vdots$ & $\vdots$ & $\vdots$ & $\vdots$ \\
\hline & & 幽 & 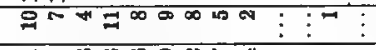 & 8 & $\vdots$ & $\vdots \vdots \vdots \vdots$ & $\vdots$ & $\vdots$ & \\
\hline & & $\infty$ & 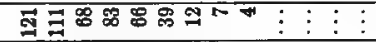 & $\overline{10}$ & $\vdots$ & $\vdots \vdots \vdots \vdots$ & $\vdots$ & $\vdots$ & \\
\hline 0 & \multirow{2}{*}{ 윰 } & $>$ & 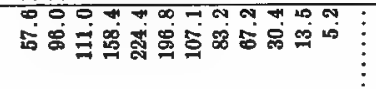 & $\stackrel{\infty}{\infty}$ & 事 & & & $\vdots$ & \\
\hline Z & & $\infty$ & 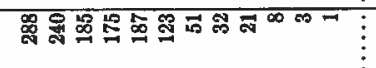 & 墨 & 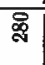 & & & $\vdots$ & \\
\hline & \multirow{2}{*}{$0 \underset{\text { क }}{5}$} & $>$ & 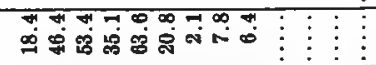 & 官 & פ্] & $\vdots$ & & $\begin{array}{l}\vdots \\
\vdots \\
\vdots\end{array}$ & \\
\hline & & on & 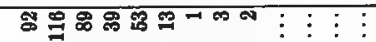 & $\frac{8}{8}$ & 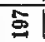 & $\vdots \vdots \vdots \vdots$ & $\bar{\vdots}$ & $\vdots$ & $\vdots$ \\
\hline \multirow{6}{*}{ 怼 } & \multirow{2}{*}{ m } & $\rightarrow$ & 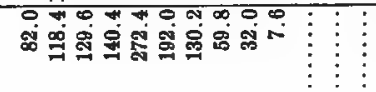 & 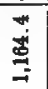 & สู้ & & & & \\
\hline & & $\infty$ & 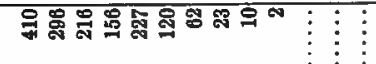 & 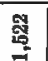 & $\overline{\bar{B}}$ & & & $\vdots$ & \\
\hline & \multirow{2}{*}{$4 \stackrel{0}{0}$} & $>$ & 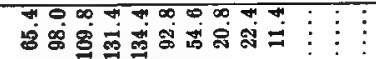 & F & ज्ञ & $\vdots \vdots \vdots \vdots$ & & $\bar{\vdots}$ & \\
\hline & & 葷 & 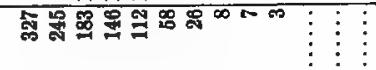 & $\stackrel{2}{Z}$ & 臯 & $:::$ & & $\vdots$ & \\
\hline & 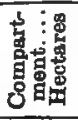 & 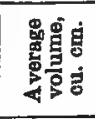 & ஸे & & $\begin{array}{l}\dot{g} \\
\stackrel{5}{5} \\
\stackrel{5}{8}\end{array}$ & 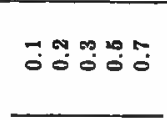 & & $\frac{\dot{m}}{\frac{m}{0}}$ & 悹 \\
\hline & & & 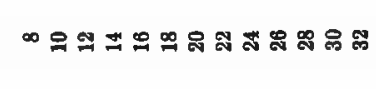 & $\begin{array}{l}\text { 唃 } \\
\text { 总 }\end{array}$ & 宽 & $\infty$ 유워 & 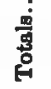 & 蔍 & $\begin{array}{l}\dot{s} \\
\dot{q}\end{array}$ \\
\hline
\end{tabular}


COMPARTMENT DESCRIPTIONS (SAMPLE)

\begin{tabular}{|c|c|c|c|c|c|c|}
\hline $\begin{array}{c}\text { Canton } \\
1\end{array}$ & $\begin{array}{l}\text { 5. } \\
\text { 量 } \\
\text { 总 } \\
8 \\
8 \\
2\end{array}$ & Area & $\begin{array}{l}\text { Situation - } \\
\text { slope, altitude, } \\
\text { aspect }\end{array}$ & 5 & Species & $\begin{array}{l}\text { Age } \\
7\end{array}$ \\
\hline La Vuardas. . & $\mathbf{A}$ & $\begin{array}{c}\text { Hectares } \\
6.11\end{array}$ & $\begin{array}{l}\text { Slope very } \\
\text { steep, eliffs, } \\
\text { north expo- } \\
\text { sure } \\
\text { Altitude } \\
850-1084 \mathrm{~m} \text {. }\end{array}$ & $\begin{array}{l}\text { Upper cretaceous red stratum } \\
\text { calcaire, marl. } \\
\text { Soil rocky and generally shal- } \\
\text { low. The rock formation } \\
\text { outcrops very frequently } \\
\text { Cover of moss and vegetable } \\
\text { litter }\end{array}$ & $\begin{array}{l}\text { Spruce, } 97 \text { per } \\
\text { cent } \\
\text { Beech and } \\
\text { others, } 3 \text { per } \\
\text { cent }\end{array}$ & $\begin{array}{l}\text { Age of } \\
\text { overstory } \\
100 \text { years }\end{array}$ \\
\hline La Vuardak. . & $\mathbf{B}$ & 5.24 & $\begin{array}{l}\text { Slope very } \\
\text { steep, facing } \\
\text { north and } \\
\text { northweest } \\
\text { Altitude } \\
\text { 850-1084 m. }\end{array}$ & $\begin{array}{l}\text { Opper cretaceous red stratum } \\
\text { Soil quite deep and solid but } \\
\text { impermeable, therefore some } \\
\text { root rot } \\
\text { Cover of grass, èpilobes }\end{array}$ & $\begin{array}{l}\text { Spruce, } 99 \text { per } \\
\text { cent; beech. } \\
1 \text { per cent }\end{array}$ & $\begin{array}{l}\text { Age of } \\
\text { overstory } \\
100 \text { years }\end{array}$ \\
\hline La Vuardas. . & $\mathbf{C}$ & 2.17 & $\begin{array}{l}\text { Slope eteep } \\
\text { to west and } \\
\text { nort h west } \\
\text { dominated } \\
\text { by a cliff } \\
\text { Altitude } \\
892-1045 \mathrm{~m} \text {. }\end{array}$ & $\begin{array}{l}\text { Same geologic base as above } \\
\text { but with marl. } \\
\text { Soil dry, rocky, and stony to } \\
\text { the south; rest like B }\end{array}$ & $\begin{array}{l}\text { Spruce, } 90 \text { per } \\
\text { cent; beech } \\
\text { and oak, } 10 \\
\text { per cent }\end{array}$ & $\begin{array}{l}\text { Age of } \\
\text { overstary } \\
100 \text { years } \\
\text { also 15-20 } \\
\text { year old } \\
\text { brosd- } \\
\text { leaved } \\
\text { treed }\end{array}$ \\
\hline Ia Vuardas. . & $\mathbf{D}$ & 4.70 & $\begin{array}{c}\text { Ridge with } \\
\text { rapid slope } \\
\text { facing north- } \\
\text { west and } \\
\text { west where it } \\
\text { is bounded } \\
\text { by a cliff } \\
\text { Altitude } \\
\text { 995-1171 m. }\end{array}$ & $\begin{array}{l}\text { Same as C in re. geology. } \\
\text { Soil dry, shallow, and rocky } \\
\text { toward the clift to the weat; } \\
\text { on remainder fresh and rich, } \\
\text { there is an abuadant cover } \\
\text { of ahrubs, briars, forns, } \\
\text { moss, etc. }\end{array}$ & $\begin{array}{l}\text { Spruce, } 90 \text { per } \\
\text { cent: beech } \\
\text { and brosd- } \\
\text { leaves, } 10 \\
\text { per cent }\end{array}$ & $\begin{array}{c}1 \text { to } 150 \\
\text { years for } \\
\text { the coni- } \\
\text { fers } \\
15 \text { to } 20 \\
\text { years for } \\
\text { the broad- } \\
\text { leaved } \\
\text { trees }\end{array}$ \\
\hline Total..... & $\bar{\cdots}$ & 18.22 & & & & \\
\hline
\end{tabular}




\section{COMPARTMENT DESCRIPTIONS (SAMPLE) - Continued}

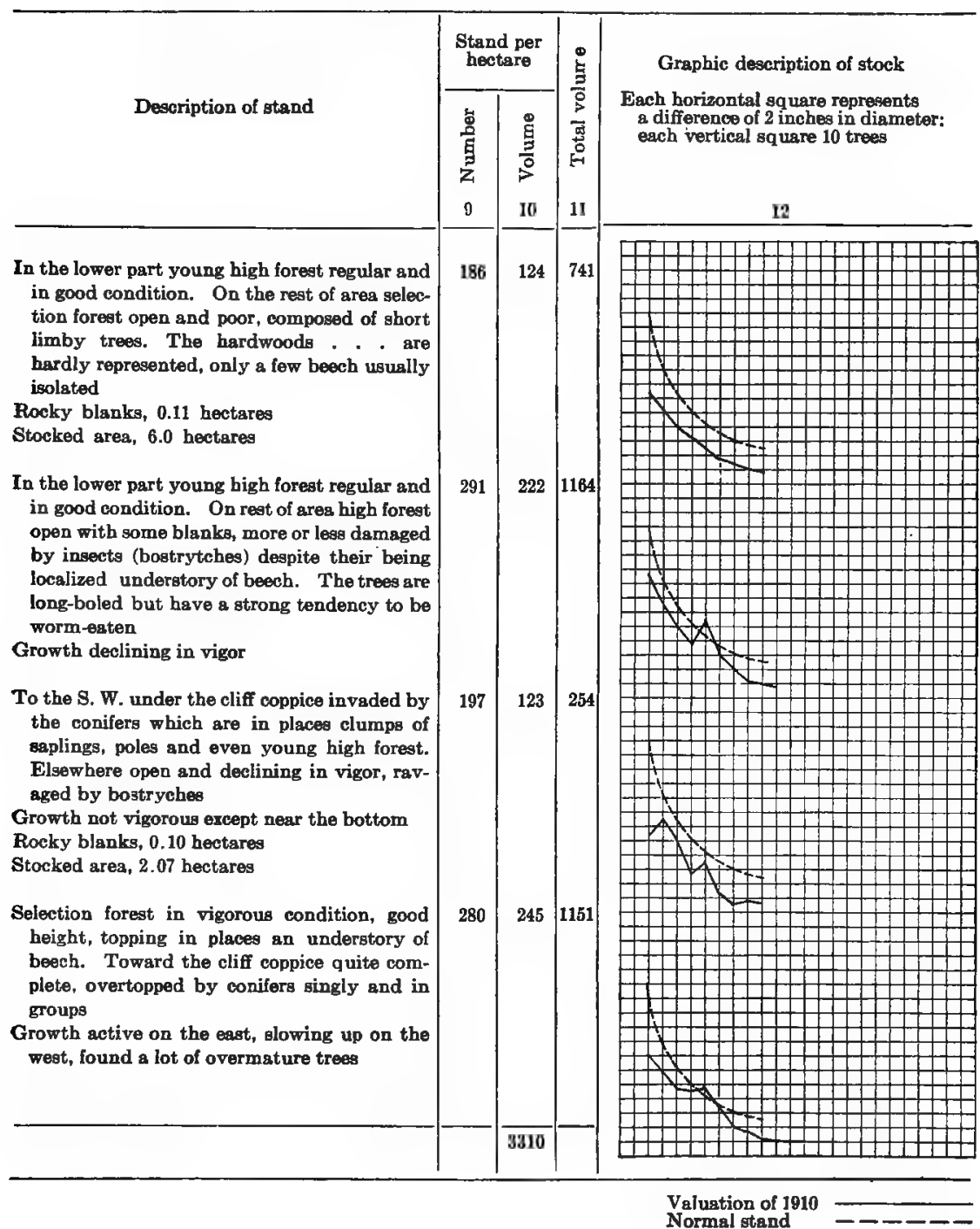




\section{APPENDIX L \\ MODEL INSURANCE CALCULATIONS OF DAMAGE BY FIRE 1}

Forest under working plan with an area of 80 hectares, treated in coppice-understandards with a rotation of 20 years divided into 20 felling areas with an average area on the ground of 4 hectares.

\section{1.- Object Insured}

(1) The coppice, composed of oak 0.3 ; beech 0.2 ; hornbeam 0.4 ; miscellaneous 0.1 ; whose ages vary from 1 to 20 years.

(2) The reserves, but only including the oak, the beech, and the miscellaneous trees with circumferences between 0.51 meters and 1.10 meters at 1.30 meters above the soil.

(3) (L'Ensouchement) root systems.

(4) Litter.

It is agreed that the rate of interest to be used in calculations shall be $3 \frac{2}{2}$ per cent.

\section{II.-Calculations of the Capital to be Insured}

(1) Coppice. The net average value of the stand 20 years old is 300 francs per hectare. The value per hectare capable of giving a revenue of 300 francs every 20 years is given at the rate of $3 \frac{1}{2}$ per cent:

$$
\begin{aligned}
& F=300 \times \frac{1}{(1035)} 20-1=(\text { By using the } 3 \text { d Cotta table) } \\
& F=300 \times 1.01=303 \text { francs. }
\end{aligned}
$$

From this value per hectare should be deducted the value $V$ per hectare calculated by the formula:

$V=303$ francs $\left(1.033^{n}-1\right)$, where ${ }^{n}=$ the age of the growing stock or, employing the first Cotta table,

$V^{1}$, or a value of a hectare aged one year $\ldots \ldots \ldots \ldots \ldots . .303 \times 0.03=9$ francs

$V^{10}$, or a value of a hectare aged 10 years $\ldots \ldots \ldots \ldots \ldots \ldots . \cdots \ldots 303 \times 0.41=124$ francs

$V^{20}$, or a value of a hectare aged 20 years $\ldots \ldots \ldots \ldots \ldots \ldots . \cdots \cdots \cdots+303 \times 0.99=300$ francs

Total .................................. $\overline{2,802}$ francs

In the example just given, each of the 20 felling areas with ages 1 to 20 years have a surface of 4 hectares. It therefore results that the total value of the coppice, that is to say, the amount to be insured, will be $2,802 \times 4=11,208$ francs, or, in round numbers, 11,200 francs.

(2) Reserve. The oak and beech with circumferences between 0.51 and 1.10 meters are divided into three classes according to the table which follows (resulting from former

\begin{tabular}{|c|c|c|}
\hline $\begin{array}{c}\text { Circumference class } \\
\text { (meters) }\end{array}$ & Species and value & $\begin{array}{l}\text { Total value, } \\
\text { francs }\end{array}$ \\
\hline $\begin{array}{l}0.51-0.70 \ldots \\
0.71-0.90 \ldots \\
0.91-1.10 \ldots\end{array}$ & 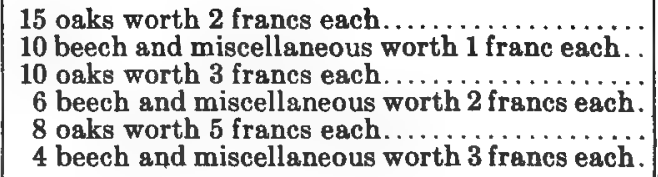 & $\begin{array}{l}30 \\
10 \\
30 \\
12 \\
40 \\
12\end{array}$ \\
\hline Total.... & 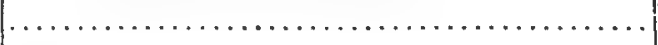 & 134 \\
\hline
\end{tabular}
stocktaking and valuation) indicates the composition and the average value per hectare:

${ }^{1}$ See p. 288 for discussion. 
The sum of 134 francs being the capital to insure to guarantee the reserves on one hectare, that corresponding to the whole forest will be $134 \times 80=10,720$ francs, or, in round figures, 19,700 francs.

(3) Roots. The cost of planting 1,000 plants may be estimated according to regional costs at:

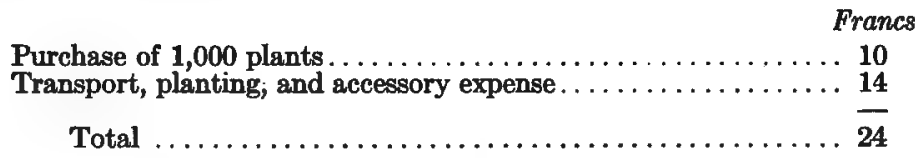

5,000 plants per hectare will be sufficient to reconstitute the forest supposedly entirely destroyed. It results, therefore, that the expense per hectare will be 24 francs $X$ $5=120$ francs and that for the 80 hectares of the forest, the capital to be insured in view of the guarantee will be 120 francs $\times 80=9,600$ francs.

(4) Litter. The necessary expense for covering the soil with 1 kilogram of azote can be valued locally as follows:

Francs

Purchase of manure yielding 1 kilogram of azote . . . . . . . 1.50

Transport, spreading, and necessary expense ...............50

Total.......................... 2.00

The average weight of the litter per hectare is 40 quintaux capable of furnishing 1 kilogram of azote per quintal or $\mathbf{4 0}$ kilograms of azote per hectare. It therefore follows that the expense per hectare will be 2 francs $\times 40=80$ francs and that for the 80 hectares of the forest the capital to be insured will be 80 francs $\times 80=6,400$ francs.

The total capital to be insured will then be:

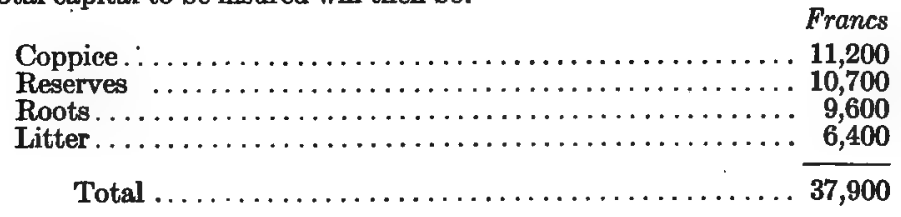

\section{III.- Calculations of the annual Insurance Rate}

(1) Charcoal is manufactured.

(2) The forest has no fire lines, divisions, or brooks capable of stopping fire.

These two factors increase the insurance risk each to the extent of 0.05 per cent or a total of 0.10 per cent, which gives a final figure of $0.50+0.10=0.60$ per cent. Applying this 0.60 per cent rate to the capital to be insured, it yields an annual rate to be paid of $37.9 \times 0.60=22.74$ franes.

A fire burns 3 hectares of the forest of which 2 hectares is coppice aged 8 years and 1 is hectare coppice aged 10 years -16 oaks and 60 beech and miscellaneous of circumferences between 0.51 and $\mathbf{1 . 1 0}$ are destroyed. Half the stumps have been killed by the fire. Two-thirds the litter is destroyed.

IV.- Calculation of the Damage Cadged

(1) Coppice. 2 hectares aged 8 years, worth $2 \times 97$ francs $=194$

1 hectare aged 10 years, worth $1 \times 125$ francs $=125$

Total ........................ 
Salvage and deduct. The cost of cutting back is compensated by the value of the products saved; therefore there is no salvage: Net $=319$ francs.

(2) Reserves. The trees destroyed according to circumferences at 1.30 above the soil are:

\begin{tabular}{|c|c|c|}
\hline Circumferences & & Francs \\
\hline $0.51-0.70$. & \multirow{4}{*}{ 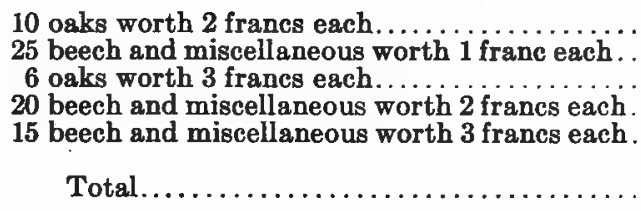 } & 20 \\
\hline & & $\begin{array}{l}25 \\
18\end{array}$ \\
\hline & & $\begin{array}{l}40 \\
45\end{array}$ \\
\hline & & 148 \\
\hline \multirow[t]{2}{*}{ Salvage to deduct. } & Actual value of the trees killed by fire... & 60 \\
\hline & Net. & 88 \\
\hline
\end{tabular}

(3) Roots. The amount necessary to replace half the roots per hectare is $120 \div 2$. This replacement being necessary on 3 hectares, there will be due for the damage to the root systems $\frac{120}{2} \times 3=180$ francs.

(4) Litter. The amount necessary to replace two-thirds the litter per hectare is $\frac{2 \times 80}{3}$ francs.

This replacement being necessary on 3 hectares there will be due for damage caused to the litter $\frac{2 \times 80}{3} \times 3=160$ francs.

The total damage caused will then be:

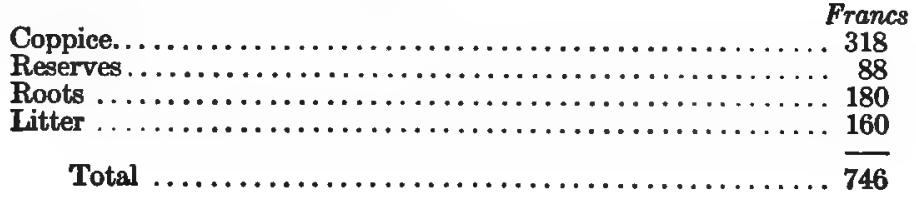




\section{INDEX}

Administration, costs, 57

Administrative education, 268

Adour, valley of the, 71

Agriculture, cultivable land, 27 staples of, 27

Aleppo and Scotch pine, selection fellings for, 87 pine, clear cutting, 72

Algerian code of 1908, 261

Algeria, special laws for, 261

Allied coöperation, $\mathbf{x}$

Alpine gorges, work done in, 8

Alps, land forests of the, 36 region, 422

size, 36

zone, 32

Alsace-Lorraine, forests of, 495 valley in, Frontispiece.

Amance, State forest of, 101

Amboise, forest of, 95, 323, 328

American Army, what it required, 337

Forest Engineers in France, 336

operations, French view of, 355

requirements, French difficultìes. in supplying, 356

woodsmen called to the colors, 338

Appraisal, a sample, 295

and estimate, 294

Appendixes, 360-536

Aqueducts and tunnels, 162

Arbor day celebrations, 19

Arc-et-Châteauvillain forest, 323

Area allotment by periods, 239

and age, 234

and topography, 25

burned over, 204

felling by, 255

in hectares, $x x i$

pure, 232

size of, to restore, 156

Areas, eroded, per cent, 145

Argon, forest of, 111

Avalanches, erosion, and floods, 23

frequent in the mountains, 158
Avalanches, protection against, 158

works to prevent, 255

Aude, sowing in the, 138

Badré, inspecteur, 76

Bagneris method of tapping, 107

Ball planting, 128

Ban d'Étival, fir stumpage prices, 313

Ban de Puy-Saint Pierre, forest of, 91

Barcelonette (Basses-Alpes), success of plants, 126

Bark, cork, 233 tannin, 92

Barrès Secondary School for Rangers, 124

Basses-Alpes, department of, 36

Beaufort, communal forest of, 109

Beech, 390 and oak forests, well-managed, 14 -oak stands.in northeast of France, 98 regeneration, irregularity of, 82 second important species, 41 selection coppice, 94 shelterwood for, 76 tolerant, 76

Benardeau, conservator of forests, 18

Betterments, 290

Biscarrosse, forest of, $7,172,189,191$

Bonnevaux, forest of, 87

Boppe, 71, 94, 106

Bremontier, a great engineer, 169, 173, 175

Bridge and Road Service, 176

Briot, conservator, Forest Service, 153

Broadleaves, area occupied by, 40

Broilliard, 23, 97

Calipering, rules for, 212 stands, 211

Carcans, forest of, 188, 191

Caterpillar tractors, 346

Cembric pine and larch, 33, 165

Central Plateau region, 426 zone, 33

Cette-Eygun, forest of, 83

Cévennes region, 427 
Chamonix forest, 229, 259

working plan, 248-250

Chapelle d'Huin, forest of, 87

Charcoal, burning, 204

Chévandier, Doctor, 142

Cleaning and freeing young stands, 106 meaning of, 105

Cleanings and thinnings, 71 when to make, 108

Climate, 26

Climatic and physical features, 25

Code, forest, xv

Colbert, the great conservationist, 221

Combre dune, sowing on the, 138

Commerce, 29

Communal forests, xiv

Compartment subdivision, 226

Conifers, area occupied by, 40

Coniferous stands, planting of, 130

Conservation, French attitude toward, 9 name of, xxi projects, private forests in, 9

Conservations, France proper divided into thirty-two, 273

Consumption of lumber, per capita, 16

Contractors, rights of, 299

Conversion, cost of, 103 the best known, 101, 103

Conversions, 54-57, 70, 100

Coöperation, allied, x

Coppice, 54, 57, 70

loss in large area in, 92

managed on short rotation, 92

of sessile oak, 92

selection treatment in, 94,233

simple, 93

stands, species found in French, 93

systems, 92,100

under conversion, acres of, 100

when not to cut, 93

with field crops, 94

with short rotation, 218

with standards, 487

Coppice-under-standards, 54, 57, 70, 93

classified, 97

four rules for improvement of, 96

(futaie claire), substitute, 98

inferior to high forest, 94

rotation for, 97

system, 100

Cordwood, how estimated, 208
Cordwood, prices, 306

sold by ton, 208

Corsica, 262 special laws for, 261

Cork bark, 233

Cost of conversion, 103

Costs, restocking blanks, 79

Cover and protection, 129

Crowns, thrifty, well-developed, 86

Cuif, in charge of research at Nancy, 101

Cut, regulation of, 231

systematizing the, 225

Cutting area, marking the, 254

and logging rules, 297

clear, 70, 82

cycles, length of, 227

cycles and rotations, 226

final, 188

period, 87,227

principles and methods of, 224

regulation of, 215

requirements imposed by the French, 353

saw timber, 201

systematic, beginning of, 218

systems of, 70, 232

Cuttings, improvement, 104, 105, 189

intermediate, 105

transformation, 103, 104

Dabat, M., 312

Damage by birds, 278

by frost, 281

by game, 279

by sunscald and drought, 282

from grazing, 280

from logging, 277

fungous, 280

insect, 278

prevention of, 275

snow, 282

windfall, 280

Dams, costly system of, 154

construction of, 157

log and dry stone, 155

masonry and rubble, 9

principal objects of, 157

technique of, 157

walls, drains, purpose of, 164

Daubrée, minister of agriculture, 23, 140

Deforestation, cause of, 18 
Deforestation, dangers of, 17

legislation against, 316

on mountain slopes, 6

obligation of the State, 18

Deforested countries, 17

De Gail, conservateur, 45, 279

De Lapasse, conservateur, xx, 22

Démontzey, 115, 141, 162

Department of Bouches-du-Rhone, 88

Departments, xxi, 47, 50 most heavily and least forested, 52

Devarennes, inspector, 60

Diameter limit by single trees, 233

Dijon hardwood belt, 'xviii

Dingy St. Clair, forest of, 244

Dinner, authority on forestation, 122, 130

District manager, duties of, 341

Drains, paved, at Bastan, 161

Drôme, basin of, 36 valley of, 167

Dune commission, 175

littoral, 180, 181

protection, at Lacaneau-Océan, 171

road, 183

the protective, 180

Dunes, 169

advance of, 172

and Landes, 262

area of French, 177

artificial, 181

artificial barrier, cost, 184

conditions of coast, 177, 179

cost and price data, 183

development of, 173

fixation and maintenance of, 180

high protective, 181

kinds of, causes, 171

maintenance of, 437

maritime, in France, 176

method of combatting, 6

reclamation of, 173

Dunning, valuation surveys by, 212

Durance, the basin of the, 36

Earth movements, causes of, 160

Economic needs and national traits, 1

Education, forestry, 275

Embrunais, larch forests of the, 36

Engineers, the American Forest, in France, 336

Ermenonville, forest of, 78
Erosion and precipitation, 147

avalanches, and floods, 23

corrective measures, 153

form of, 148

in the mountains, 140

not caused by grazing, 152

preventing further, 166

rocks and soils, 148

Estimates, ocular, 211

Eu-et-Aumale, forest of, 316

Expense and receipts, state forests, 203

Exotics rarely succeed, 44

Experiments recommended, 79

Felling areas, groups divided into, 88

cycles, 191

final, 74,231

"open" or "light," 74

Fellings, fir selection, 83

group, 70

improvement, 111

intermediate, 113, 189, 233

or thinnings, intermediate, 231

progressive (shelterwood system), 73

secondary, 74

selection, 70

Fence, to prevent damage from game, 75

Field crops, coppice with, 94

Final felling, 74

Fire, chief causes of, 284

damage intensive, 282

insurance calculations of damage by, 534

insurance in France, 288

lines, 287

preventive, chief, measures in France, 276

problem in forest of l'Estérel, 283

protection necessary, 276

Fir and spruce in mixture, shelterwood for, 82

average figure per acre for, 84

forest, $a, 332$

forests, money yield from, 320

or spruce, group selection for, 89

selection fellings, 83

shelterwood for, 80

silver, 41, 397

-spruce forests, 60

-spruce stands, rule for, 239

stands in the Jura, studies of, 60 
Flahaut, M., 141

Fishing and shooting, 262

Flood control in the Alps, 7

Floods, avalanches, and erosion, 23

Fontainebleau, forest of, 79

Forest acquisitions in the war zone, 352 acres of, State, communal, private, 34 agencies of France, coöperation with, 351

and land conservation, 6

and sawmill divorced, 14

and springs, 361

area, French possession of, 45

area in private ownership, 315

area, per cent of, 46

area, typical, 34

areas, 49

art and literature, 24

belts, important, 338

code, $\mathrm{xv}, 11$

code of 1827, 261

crop, 218, 226

description, example of the latest, 245 , 246

destruction, controlling, xxiv

devastation, State control of, 4

divisions, 29

education, where obtained, 274

engineers, accomplishment of, 348, 350

engineers, organization of, 338

enterprises, use of land for, 9

fires, laws dealing with, 4

growth, receding in the mountains, 141

high, 54-57, 93, 98

houses, 290

influences, 19

investment, 319, 320, 322

labor, wages paid, 13

land in the United States, 45

lands, confiscation of, 8

devastation of, 16

literature and art, 24

French, 448

management, 11, 224

name of, xxi

the normal, 231

officers, staff of, 12

ownership, 46

policy in the United States, 220, 221

preparedness in France, 337

private, owners, 45
Forest problems, 15

production, xxiv, 46

property as long-term investment, 322

regions, 25,29

regulating a, 225

regulation, beginning of, 218

high, 476

reserves, when established, 223

resources, intensive use of, 15

revenue, average, 184

roads, local, 63

selection, formula for management of in 84

school, Nancy, 101

soil, 67

species, important, 40

species, silvics of important, 387

statistical data, 45

state administration, xvii

system of cutting, 46

systems, high, 71

taxation, French, 267

the, from an economic viewpoint, 381

from a physical viewpoint, 381

from a social viewpoint, 381

troops loaned to French and British Armies, 357

type of, 99

versus farm crops, 13

Forest of Amance, 20

Amboise, 95

Amboise, how arquired, 327

Amboise, receipts and expenses, 329

Amboise, situation, 328

Argon, 111

Ban d'Etival, 508

Ban de Puy-Saint Pierre, 91

Beaufort, 109

Belle Vaux, 37

Biscarrosse, 172, 189, 191

Bonnevaux, 87

Burdignin, 516

Carcans, 188, 191

Cette-Eygun, 83

Chamonix, 260

Chapelle d'Huin, 87

Dingy St. Claire, 244

Ermenonville, 78

Fillinges, 515

Fontaineblesu, 79

Gérardmer, 80, 243 
Forest of Grande Chartreuse, 87

Grande Cóte, 500

Huit, 102

La Dôle, 32

La Gardiole, 126, 129

La Joux, 32, 60, 512

Lancanau, 188

Lardies, 512

L'Estérel, 233

La Teste, 188, 193

Levier, 62

Malmifait, 77, 112

Manigod, 39

Montargis, conversion in the, 102

Mont-Genèvre, 36

Mont Glore, 511

Moudon, 379

Ouhans, 61

Noirémont, 81

Parc-et-St. Quentin, 77, 517

Paridas, 75

Rambouillet, 79

Risol, 81

Risoux, 32

St. Antoine, 91

St. Martin d'Are, 87

St. Panerace, 89

St. Paul, 165

St. Point, 62

Thiez, 517

Thones-Ville, 109

Tignes, 90

Villarodin-Bourget, 85

Vuillecin, 103

$\mathrm{X}, 323,332$

Forestation, 182

and drainage practicable, 170

artificial, grazing disastrous to, 173

by communes, 147

by individuals, 147

divisions, 145

examples of, 164

methods, 130

obligatory, 115

optional, 115

practice, French, 138

Forester's golden rule, 66

Forestry a national art, 2

a poor investment for an individual, 335

as a commercial business, 14

as an investment, 317
Forestry education, 275

French, restrictions in cutting, 354

the war a vindication of, 358

in the Landes, 169

operations, geographical distribution, 340

private, its economic basis, 12

on its own merits, 15

real, in France, 268

section of the Expeditionary Force, 340, 858

-troops, a division of, 340

troops, spirit of, 349

Forests, action of, on springs, 363

area and topography, 25

communal and institution, 53

control of private, 5

dune, in public hands, 178

educational value of, 11

extent of the public, 10

famous recreation, 23

federal, two important, 36

fir, of France, 31

for indirect benefits, 323

for health, recreation, and beauty, 23

French, inroads upon, 356

regulations, 231,232

frontier, 262

functions of, 11

high, selection, 233

important private, 415

in conservation projects, 9

indirect benefits of, xxiv

influence of, $365,371,372$

in small holdings, 46

in the Alps, xxiii

Central Plateau, xxiii

Girondine, xxiii

Jura, sxiii

Provençale, xxiii

Pyrénées, xxiii, 38

Vosges, xxiii

legal status of, 2

most worth a visit, $x \times$

mountain, in detail, 34

yield, 35

national, alienations of; 10

of the United States, 220

oak, 69

of Alsace-Lorraine, 495

of France, communal, 11 
Forests, ownership of, 177

painters of, 24

plains, yield, 35

private, 53

bought by the A. E. F., 212

statistics on, 409

protection of, 140

public, statistics on, 409

purpose of, 11

scenic, treatment of, 91

selection, French government, 230

German viewpoint, 230

two schools, 107

special legal status of, 2

State, 52

as storehouses of heavy timber, $\mathrm{XV}$

checkered history of, 10

permanent, 7

tax exemption on, 6

the core of publicly owned, 9

Normandy, 22

rôle of, 17

value of, 17

three notable, 323

Vosges, 34, 220

France, private forestry in, 315

proper, divided into thirty-two conservations, 273

saved by her forests, xiv

stumpage prices in, 309

French coöperation, effectiveness of, 356

engineers, operations of, 153

forestry, German comment on, 469

impressions of, 1

public phases of, 2

forest literature, 448

forests and forestry, xxvi

forests, boundaries of all, 292

government, early negotiations with, 352

interest rates paid by, 317

selection forests, 230

instructions, 236

Jura mountains, 84

lumber grades, $\mathbf{3 1 0}$

mensuration, 206

national forest administration, 261

officials, ix

planting technique, 127

policy, 65, 114

regulation policy, broad aims of, 215
French silvies of aleppo pine, 407

beech, 390

cork oak, 395

European Jarch, 404

holm oak, 394

hornbeam, 393

maritime pine, 401

Norway spruce, 402

pedunculate oak, 387

Scotch pine, $\mathbf{4 0 0}$

sessile oak, 389

silver fir, 397

silviculture, 90

State forest roads, 291

system of planting, 129

terms and American equivalents, 224

views, an insight into, 17

working plan, 243

Fron, 119

Frost, forest cover prevents, 20

Frosts, spring, 80

Fuel, classification of, 300

supply service, special, 347

Fungus, root, 205

Galmiche, inspecteur, 95

Game, charge for shooting, 326

fence to prevent damage from, 75

Gard and Herrault, sowing in the, 137

Garnissage, 162

Gazin, 96

Gérardmer, fir sawtimber stumpage prices, State forest of, 313

forest of, 80,243

region, hardwood cordwood stumpage prices, 314

German comment on French forestry, 469

Gets, communal forest of, 39

Gironde, maritime pine, 57 sand wastes of the Landes and, 169

zone, 30

Glacial deposits, 149

Gneiss, slopes formed by, 149

Government, administrative departments, 29

regulation and working plans, 206

representative, 29

Grande Chartreuse, forest of, 89

Granites, slopes formed by, 149

Graphics, stand, what they represent, 214, 215 
Grazing betterment, the work of, 144 disastrous to artificial forestation, 173 forbidden, 91 grounds, reservation of, 143

law of 1882,144 regulation of, 142 trespass, prevent, 203

Ground, when to cultivate, 91

Group selection for larch, 89

Groups, working, 191 working, essential, 215 small working, 226

Gurnaud, 107 method, 241, 242

Hailstorms, 21

Hardwood cordwood, stumpage prices for, 314

fuel production of, 14

Haute-Dauphiné, forest of, 37 -Jura, 32

-Loire, stands in the, 137

-Marne, broadleaves, 56

-Savoie, 36

Henry, list of forests by, xxiii

Hérault and Gard, departments of the, 144

Hez-Froidemont, State forest of, 58

High forest, 54-57, 93

High forests, selection, 233

Highways, French, value of, 346

Hole-selection method, 88

Hornbeam, 41, 393

Huffel, 21, 36, 60, 70, 94, 98, 100, 361

Huit, the forest of; 102

Humidity and rainfall, 21

Implements, 69, 127

Improvement cuttings, 104, 105, 189 fellings, 111

Indo-China, special laws for, 261

Industries, development of machinery, 27

Influence of forests, 323, 373

Institutional forests, xvi

Interest rates paid by the French government, 317

Intermediate fellings, 113

Inundation of 1840,142

Inventory, a sample, 237

Isère, basin of, $\mathbf{3 6}$

Jacquot, 381
Jolyet, 42, 94, 105, 109

Jura, forests of the, 308 zone, 31

La Blanche forestation area, 424

Lacanau (Gironde) State forest, 188

Lafond, 180

La Gardiole, forest of, 126

Land, areable, 130, 131

barren, 131

bog and swamp, 131

brush and pasture, 131

exempt from taxation, 317

idle, America's problem, 16

in the United States forests, 45

mountain, reserved from use, 268

ownerships of, 173

reclaimed, cost of, 168

Landes and dunes, 262

and Gironde, sand wastes of the, 169

area, 170

drainage of, cost, 170

forestry in the, 169

local conditions, 172

maritime pine, 57

special betterments in the, 183

Lands, forestation of communal, 7 mountain, how governed, 263

Laporte, conservateur, 88

Larch, a light-demanding species, $83^{\circ}$ and cembric pine, 33

European, 404

forests of the Briançonnais, 36

group selection for, and other methods, 89

habitat, 41

pure, 90

where sown, 165

La Teste, forest of, 188, 193

Law of 1846, 142

1858,142

1860,142

1864,142

1876,142

1882,143

June 10, 1857, 263

June 18, 1859 (Guyot), 262

July 28, 1860, 263

April 4, 1882, 263

August 19, 1893, 283

violations of the, 5 
Laws dealing with forest fires, 4

Leaf litter, 69

L'Estérel, forest of, 233 topography of, 284

Legislation against deforestation, 316 abuses led to, 221 reference to, 268 summary of, 142, 261

Levier, statistics for, 62

Light burning never permitted, 284

Logging and cutting rules, 297 equipment and sawmills, 343 railways, 346

Loire river valley, 12 watershed, 18

Long-term sale, example of, 301

Lozère, Aveyron, and Corrèze, sowing in the, 137

Lumbering, strategy in military, 342

Lumber grades, French, 310 manufacture, 15 shortage, handicap of, 16 prices paid for manufactured, 304 transportation of, 342 winning the war with, 349

Lumberjacks as road builders, 339

Lumberjack units, the organization of, 339

Malmifait, forest of, working plan, 105, 112

Management, areas and systems of, 316 divisions, 225

objects of, 186

statistics, 54

subdivisions, 225

Manufactured lumber, prices paid for, 304

Maps issued for each State forest, 293

Maram grass, sand planted to, 178

Maritime pine, clear cutting of, 72 during improvement felling, 194

forests, management of, $\mathbf{1 8 6}$

forests, working plan for, 192

method of sowing, 182

shelterwood for, 78

yield of, 202

Martin, Doctor, of Tharandt, xiii

Mathieu, investigations by, at Nancy, 19

Maures and l'Estérel, 261, 262

Measure, units of, xvii, 207 units of, American, 48
Mensuration in working plans, 206

Meter, legal cubic, 207

Method, hole-selection, 88 rule-of-thumb, 211

Methods used to stop erosion, 165

Military rank, 274

Mill cuts, daily and monthly, 349

Minor products, 277, 278

Montargis, forest of, conservation in the, 102

Mont-de-Marsan inspection, 202, 203

Mont Dore (Puy-de-Dome), 151

Mont-Genèvre, forest of, 36

Motor trucks and caterpillars, 346

Moudon, forest of, 379

Mountain floods, efforts to check, 8 lands, 263

pine, where sown, 165

Mountains, control of erosion in, 140 divided into zones, 31

Names of reserves, $\cdot 95$

Nancy forest school, 66, 95

Natural regeneration, 65 vegetation, 148

Noirémont (Jura), fir forest of, 81

Nurseries at high altitudes, 123

fixed local, 122

flying, 122

location of, 122

permanent or central, 122

two sample, 124

Nursery practice, 123

Oak and beech forests, well-managed, 14

-beech stands in northeast of France, 98

shelterwood for, 76

clear cutting, 71

cork, 41, 395

holm, 41, 394

management of, 469

official price for, 311

pedunculate, 40, 387

sessile, 40, 389

coppice of, 92

shelterwood cuttings in, 73

standards, space for, 95

sprouting longevity, 92

volume of, 331

Oaks, the timber, 40 
Officers, thanks of author due to, ix, $x$ number of, in each grade, 270

Oise, broadleaves, 56

Organization, early, 268 modern, 272

of Forest Engineers, 338

Orne, broadleaves, 56

Owners, private, unwilling to repair damages, 267

Palisade, how built, 179

Parc-et-St. Quentin, forest of, 77

Parde, L., 78, 79

Parisian plateau, 76

Parisienne zone, 30

Paving channels, 162

Pay for subordinate force, 272

Penal code, 3

Periodic blocks, 240

Physical and climatic features, 25

Pine, aleppo, 41, 407

maritime, 41, 401

maritime, method of sowing, 178

Scoteh, 41, 400

Pitwood, average market price of, 312

Plains, zones, 30

Plans, management, 215

Plants, age of, 126

Plantations in holes (or spots), 127

Planting, 116

ball, 128

bush or clump method, 128

choice between sowing and, 115

cultivation and spacing, 125

methods, 167

so-called basket method, 128

the great aim of, 125

Plants used in reforestation, 408

Plateau of Bourgogne, 76

Lorraine, 76

Policy, French, 65

Nancy school, 66

Pontarlier, sale at, 297

Port of Clamecy, 314

Precipitation and erosion, 147

Pressler borings, 256

Pressler's increment borer, boring with, 528

Prévost, Marcel, of the French academy, $x \times v$

Price for commercial sales, average, 320
Price for oak, official, 311

of pitwood, average market, 312

sawtimber, 307

Prices, stumpage, 304

timber, average local, 306

Private forestry, conclusions, 334

examples of the best, 323

importance of, 13

in France, 315

forests as permanent investments, 333 returns from, 14

owner, restraining the, 316

ownership, trend of, 315

Production, amount of, 202

annual, 46, 47

Products, for military purposes, 28

resinous, yield of, 202

Property rights, infringement of, 5

Protection, 275

against rodents, heat, and wind, 136

and cover, 129

benches, 158

Protective measures, 204

Provençale zone, 30

Pruning of branches on trunks, 300

excessive, 278

when started, 189

Puy-de-Dome, seed spots in the, 137

Pyrénées-Orientales, species, 55

Pyrenees region, 428

sowing in the, 138

the forests of, 38

zone, 34

Railroads required to open fire lines, 283

Rainfall absorbed, 148

and humidity, 21

annual, 26, 88

where greatest, 141

outside and inside the forest, 367

Rains, damage from, 147

Rambouillet, forest of, 79

Rata ravine at Ubaye (Basses-Alpes), 166

Ravine de Roche Noire, 152

Receipts and expenses, State forests, 203

Reforestation areas, typical, 422

artificial, 114

expense, summary of, 146

methods of, 165

obligatory, 143

plants used in, 387 
Reforestation, policy and summary of, Rules for choice of calipering, 212 140

shrubs used in, 387

statistics of, 145

trees used in, 387

typical areas, 168

work, summary of, 146

Regeneration, assisting, cost, 79

by natural means, 114

care of stand after, 105

difficulty in, 77

natural, 65-67

of spruce in Alpine forests, 83

period, 76

Regions, reforestation, 168

Regulation, four essential kinds of, 224

intensive, 229.

of eutting, 215

Regulating the cut, method of, 232

Reorganization of 1882,269

Reserves, history of, 222

names of, 95

policy of, 222

Resin crops, 232

operations, specifications covering, 196

price of crude, 186

sales, clauses specified, 195

examples, 195

value of, 203

Revenue, average forest, 184

Rights of contractors, 299

Risol, forest of, 81

Road and bridge service, 176 dune, 183

Roads and trails, 290

French State forest, 291

Rock drains, 160

Rodents, how killed, 132

Root fungus, 205

Rotation, 252

coppice managed on short, 92

length of, 78, 228

method of 1883,234

Rotations and cutting cycles, 226

financial, computing, 229, 230

technical, 230

Royal domains, 10

Rule-of-thumb methods, 211

Rules, cultural, 86, 187, 254

for choice of standards, 96

reductions, standard, 207

Salaries to forest officers, 271, 325

Sale of felling areas, 445

Sales and traffic department, 342

on the stump, hardwood fuel, 311

procedure, general, 293

ratios between different methods, 307

resin, 195

Sample inventory, 237, 238

Sand dunes, fixing shifting, 177, 429 erosion, kinds of barriers against, 180

Savoie conifers, 54, 55 forests of the, 308

Sawmill capacity and output, 350 the flying, 344

hervy, 344

light, 344

Sawmills, American, operating during the war, 349

and logging equipment, 343

equipping the, 342

installed during the war, 341

kind of, 201

the man behind the, 339

Sawtimber, cutting, 201

minimum diameter of, 307

price of, 307

Schaeffer, A., 38, 106, 214, 260

Schists, mica and Paleozoic, slopes formed by, 149

Scotch and aleppo pine, selection felling for, 87

pine and spruce, planting of, 130 shelterwood for, 78

Secondary fellings, 74

Seed, amount of, to sow, 133, 134

control, rules for, 120

culturiral value of, 117

dangers to sown or planted, 132

felling, 73

required for test, 118

sown and planted, 117

test, germination, 119

testing, 118, 120

value, average, 117

Seeding, natural, 188

Seeds, length of time to germinate, 116

Seine, department of, 28

Selection fellings, classic, 82 
Selection, for Scotch and aleppo pine, 87

method, 68

system in broadleaf stands, 82

Service des Eaux et Forêts, 40

Servitudes and the use of minor products, 1 . 277

Sessile and pedunculate oak, 40

Shelterbelts for the fields, 115

Shelterwood cuttings in oak, 73

for beech, 76

fir, 80

and spruce in mixture, 82

maritime pine, 78

oak and beech, 76

Scotch pine, 78

spruce, 81

systems, $68,70,75,239$

Shipbuilding, iron first used for, 70

Shooting and fishing, 262

game, charge for, 326

Shrubs, the best to use, 129

used in reforestation, 408

Silver fir stands, xiii

Silvics of important forest species, 387

Silvicultural operations, 72

systems, 188

Silviculture, poor, 94

Snow damage, 282

Soil conditions, 67, 130

erosion, to prevent, 161

forest, 67

preparations, 68, 79

prepared and unprepared, 132

values, study of, 318

Soils, depth and character of, 68

which disintegrate, 148

Sowing, 116

and planting, choice between, 115

chief species, 135

continuous or broken strips, 132

cost of, 138

field, 132

may be broadcasted, 132

methods, summary of, 135

on unprepared soil, 133

season for, 135

seed-spot method, 129

short-cut methods, 133

stick method of, 167

time of, and amount of seed used in, 136
Sowing, without soil preparation, 133

Species and method to use, 130

calipered by compartments, 256

data, forest areas and, 50

exotic, 43

important, 25, 34, 40

in l'Estérel forest, 285

light-demanding, 81, 107

most important timber, 106

on an ideal plantation, 130

planted to correct erosion, 157

principal, xxi

qualities of, 97

quantity of seed to sow, 134

shade-enduring, 107

tapping other, 194

Specifications, utilization, logging, and local, 201

Springs, action of forests on, 363

and their origin, 361

French and Russian experiments, 22

in the forest, 22

Spruce a light-demanding species, 81,86

and fir in mixture, shelterwood for, 82

Scotch pine, planting of, 130

cones, 81

forest, thinned and unthinned, 111

natural regeneration of, 85

Norway, 41, 402

or fir, group selection for, 89

pole stand of, 109

regeneration of, in Alpine forests, 83

selection fellings, 84

shelterwood for, 81

stand in Savoie, study of, by Thiollier, 86

strip fellings, 72

suppressed, 103

Standard of timber analyzed, 302

Standards, 234

rules for choice of, 96

1R, 2R, 3R, 95

Stand graphics, 214, 216, 217

Stands, calipering, 211

ruined through careless selection, 95

the most notable, 33

young, cleaning and freeing, 106

State forest of Amance, 101

Ban d'Etival fir stumpage prices, 313

Gérardmer fir stumpage prices, 313

Tronçais oak stumpage prices, 313 
State forest, maps issued for each, 292 relations, 190

State forests, xiv, 52 expense for the management of, 60

Statistical data, forest, 45

Statistics, 176 acres reforested, 145 purchased, 145

analysis of general, 52

for Levier, 62

management, 54

of State and communal forests, 321

on private forests, 409 public forests, 409

St. Antoine, forest of, 91

Martin d'Arc, forest of, 87

Paul, forest of, 165

Stock, transplanted and untransplanted, 125

Stumpage prices, 304, 309, 310

rates on timber, 308

values, 12

Summary and forecast, financial, 255

Systems, coppice, 92

System, selection, in broadleaf stands, 82 shelterwood, 239

Tables, volume, 208

Tannin bark, 92

Tapping, effect of, 200

frequency of, 200

maritime pine, specifications for, 429

methods contrasted, French and American, 199

operations, 200

other species, 194

period, reduction in length of, 193

rules for, 433

scheme, new, 193

so-called exhaustive, 190

technique of, 199

tools for, French, 196

width and height of faces, 193

Tassey, 92, 269

Taxation, lands exempt from, 317

French forest, 267

Technique of tapping, 199

Temperature, average, 173

difference in, 20

in forests, effect on, 19

of the trees and surrounding air, 368
Testing seed, 118

Thalweg, collecting basin, 151

Thinnings and cleanings, 71

are profitable, 111

by tapping alive, how conducted, 189

efficient, 229

regular, 189

three main objects, 108

Thiollier, study of spruce stand in Savoie by, 86

Thones-Ville, communal forest of, 109

Tignes, communal forest of, 90

Timber acquired by timberland department, 343

amount of, at beginning of war, 337

analyzed, standard of, 302

average local prices, 306

best, in private hands, 187

committee, the interallied, 352

different sized, xviii

estimating a fair price for, 294

general rules, saile of, 297

how sold, 293

in modern warfare, 336

private clearing of, 263

requisition for, 268

restrictions upon the amount cut, 354

sale of, 293,303

regulations, 438

scouting France for, 353

shortage of home-grown, 1

supplies, French organization of, 351

stumpage rates on, 308

three main methods of selling, 295

warfare, heavy and light artillery in, $\mathbf{3 4 5}$

Timberland department, timber acquired by, 343

Tools, barrasquit d'espourga, 196

French turpentine, 196, 197

hapchot (bridon), 198

palette (or palinette), 198

place-crampon (pousse-crampon), 198

rasclet, 198

Topography of l'Estérel forest, 284

Torrent, control of, 168

definition of a, 149

gorges, formation of, 150

how controlled, 156

of St. Julien, corrective measures, 156

Torrents, 164

causes of, 151 
Torrents, damage caused by, 152 losses from, 153 where formed, 150

Trails and roads, 290

Transformation cuttings, 103, 104

Transportation, a war of, 337 equipment, 348

Transport problem, 345

Treatment, method of, xxi

Tree growth, to obtain the real, 241 planting, roadside, 115

Trees for each diameter class, number of, 99

how estimated by the A. E. F., 212, 213 used in reforestation, 407 market for, 301 reserved (standards), 96 time to plant, 126

Trespass, grazing, prevent, 203 regulations against, 204

Tronçais, oak saw timber, State forest of, 313

Tunnels and aqueducts, 162

Turpentine, barrel price, 185 permit, sample, 435 tools, French, 197

Type of forest, 99

Ubaye, basin of, 165

Units of measure, 207 American, 48

Valuation of growing stock, 531 surveys, by Dunning, 212

Vegetable cover, 68

Vegetation, natural, 148

Verdon-Supérieur area, 163

Villarodin-Bourget, forest of, 85

Volume of average wood, 235 old wood, 235

tables, 208, 209, 210, 212

yield by, 63

Vonne, broadleaves, 57

Vosges, conifers, 54 forests, 34, 220, 308

mountains, 12

zone, 31

Walls, protection, how built, 158 retaining, on a hillside, 159
Walls, snow, to turn snow slides, 160 to prevent avalanches, 159

War of transportation, a, 337 zone, forest acquisitions in the, 352

Water level, lower in forests, 21 power, 28

Waters and Forests Service, xix, 176, 268, 351

Wattle work, $155,156,162$ purpose of, 164 ravine stabilized by, 163

Weeds, cutting in clearance, 106

Windfall damage, 280 yields by, 80

Wind, shelterbelts against, 20

Winds, prevailing, 26

Wood, amount of, to cut, 11 average volume of, 235

fuel, cut by forest engineers, 347 production of, 347 special service, 348

need of, reduced, 19

old, average, young, 234 volume of, 235

products, specifications of, 201 shortage and high cost, 16

used by two million American soldiers 337

yield during twenty years, 251,252

Woodsmen, American, in France, 358

Working groups, 102 cultural rules for, 187

method of management, 191

protection, 187

8mall, 226

sustained yield for, 215

Working plan, application of the, 250

Chamonix, 248

data, original, 500

description, new methods of, Schaeffer, 244

discussion of, 244

features of, 253

flaws in, 260

for a maritime pine forest, 192

State forest of Carcans, 72

Malmifait, 105

of the forest of Malmifait, 77

report, outline, 247

scenic, the, 91

Working plans, 215, 243, 253 
Working plans, applicable to the United States, 219

difference between State and communal forest, 243,244

Government regulation, 206

mensuration in, 206

Schaeffer's simple rule, 244,245

theoretical need of, 219
Yield, allotting the, 254

by volume, 63

determination of, 253

relative, of timber and fuel, 93

regulation, Gurnaud method of, 241

Yields by windfall, 80

Zones, mountains, 31 


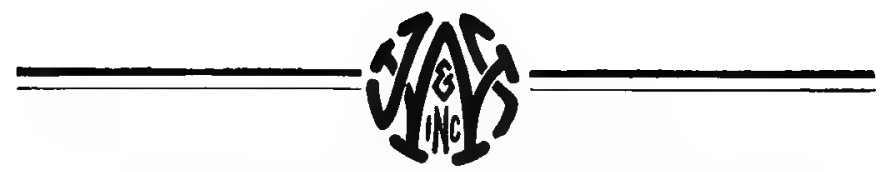

\section{Wiley Special Subject Catalogues}

For convenience a list of the Wiley Special Subject Catalogues, envelope size, has been printed. These are arranged in groups-each catalogue having a key symbol. (See special Subject List Below). To obtain any of these catalogues, send a postal using the key symbols of the Catalogues desired.

1-Agriculture. Animal Husbandry. Dairying. Industrial Canning and Preserving.

2-Architecture. Building. Concrete and Masonry.

3-Business Administration and Management. Law. Industrial Processes: Canning and Preserving; Oil and Gas Production; Paint; Printing; Sugar Manufacture; Textile.

\section{CHEMISTRY}

4a General; Analytical, Qualitative and Quantitative; Inorganic; Organic.

4b Electro- and Physical; Food and Water; Industrial; Medical and Pharmaceutical; Sugar.

\section{CIVIL ENGINEERING}

5a Unclassified and Structural Engineering.

5b Materials and Mechanics of Construction, including; Cement and Concrete; Excavation and Earthwork; Foundations; Masonry.

5c Railroads; Surveying.

5d Dams; Hydraulic Engineering; Pumping and Hydraulics; Irrigation Engineering; River and Harbor Engineering; Water Supply. 


\section{CIVIL ENGINEERING-Continued}

5e Highways; Municipal Engineering; Sanitary Engineering; Water Supply. Forestry. Horticulture, Botany and Landscape Gardening.

6-Design. Decoration. 'Drawing: General; Descriptive Geometry; Kinematics; Mechanical.

\section{ELECTRICAI ENGINEERING-PHYSICS}

7-General and Unclassified; Batteries; Central Station Practice; Distribution and Transmission; Dynamo-Electro Machinery; Electro-Chemistry and Metallurgy; Measuring Instruments and Miscellaneous Apparatus.

8-Astronomy. Meteorology. Explosives. Marine and Naval Engineering. Military. Miscellaneous Books.

\section{MATHEMATICS}

9-General; Algebra; Analytic and Plane Geometry; Calculus; Trigonometry; Vector Analysis.

\section{MECHANICAL ENGINEERING}

10a General and Unclassified; Foundry Practice; Shop Practice.

10b Gas Power and Internal Combustion Engines; Heating and Ventilation; Refrigeration.

10c Machine Design and Mechanism; Power Transmission; Steam Power and Power Plants; Thermodynamics and Heat Power.

11-Mechanics.

12-Medicine. Pharmacy. Medical and Pharmaceutical Chemistry. Sanitary Science and Engineering. Bacteriology and Biology.

\section{MINING ENGINEERING}

13-General; Assaying; Excavation, Earthwork, Tunneling, Etc.; Explosives; Geology; Metallurgy; Mineralogy; Prospecting; Ventilation.

14-Food and Water. Sanitation. Landscape Gardening. Design and Decoration. Housing, House Painting. 







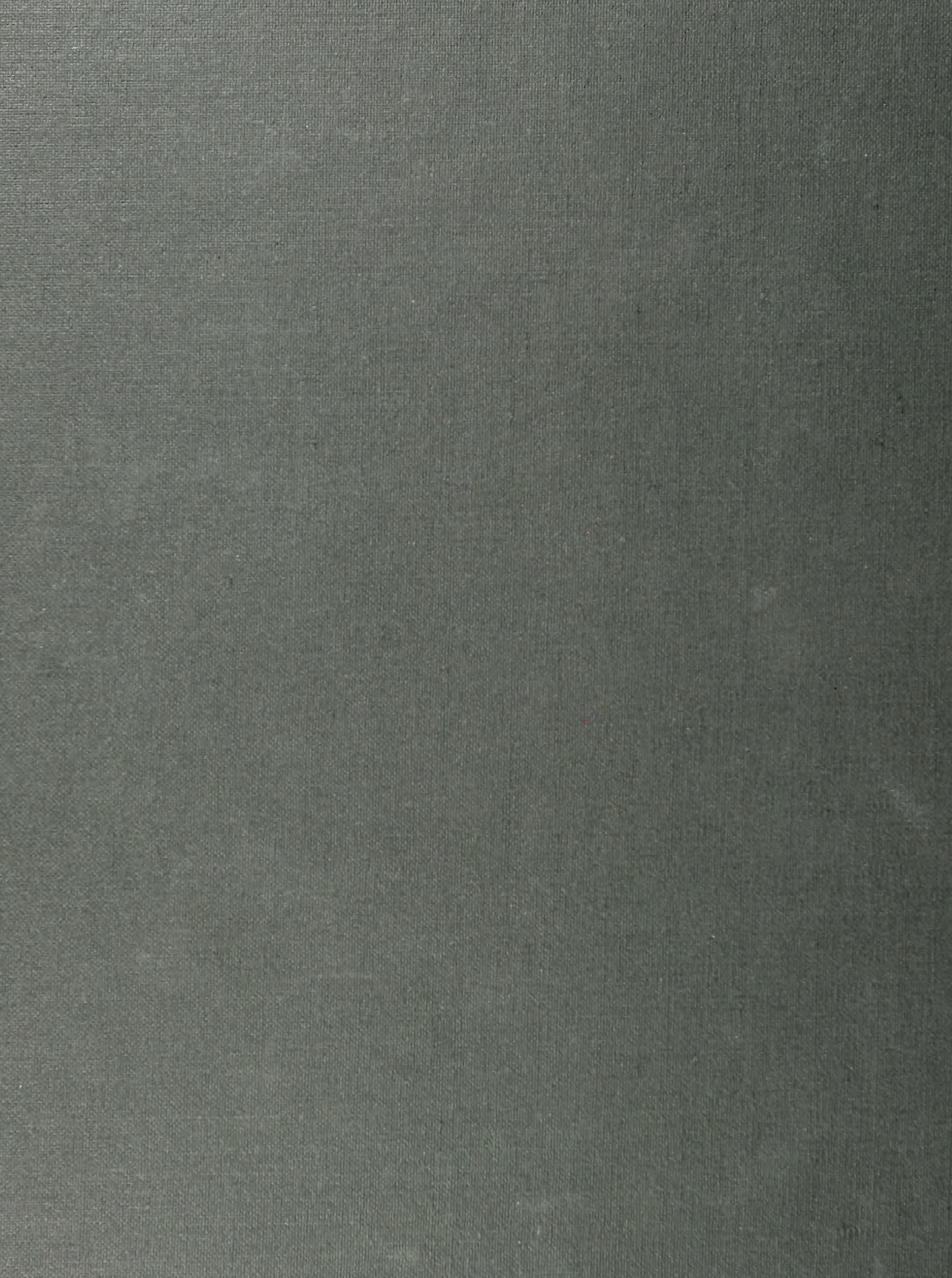

